Universidad deValladolid

PROGRAMA DE DOCTORADO EN EUROPA Y MUNDO

ATLÁNTICO: PODER, CULTURA Y SOCIEDAD

TESIS DOCTORAL:

\title{
SISTEMA CONTABLE Y ORGANIZATIVO DE LAS CONCESIONARIAS FERROVIARIAS ESPAÑOLAS: NORTE (1900-1924)
}

Presentada por Miguel Ángel Villacorta Hernández

Para optar al grado de Doctor por la Universidad de Valladolid

Instituto Universitario de Historia Simancas

Dirigida por:

Pedro Pablo Ortúñez Goicolea 


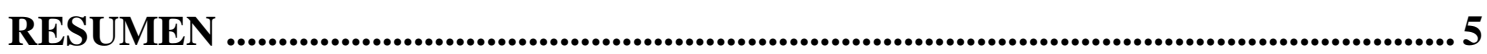

CAPÍTULO PRIMERO.- MARCO CONCEPTUAL DE LA INVESTIGACIÓN .. 6

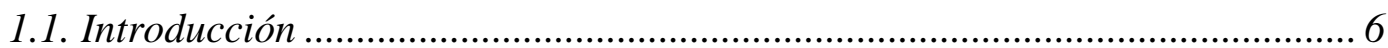

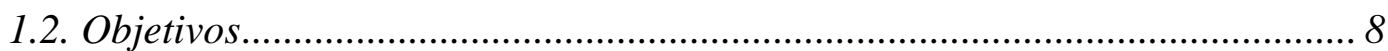

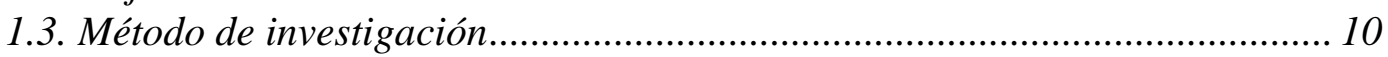

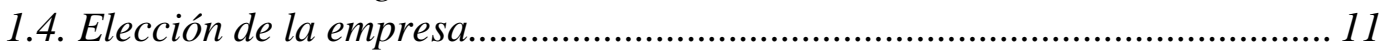

1.5. Elección de la dimensión temporal ............................................................... 12

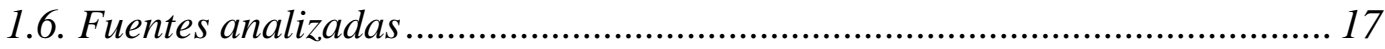

CAPÍTULO SEGUNDO.- AVANCES ORGANIZATIVOS Y CONTABLES EN

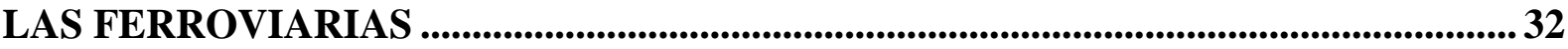

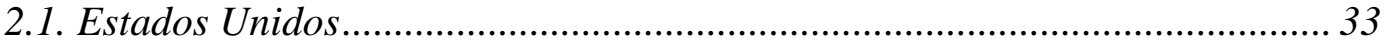

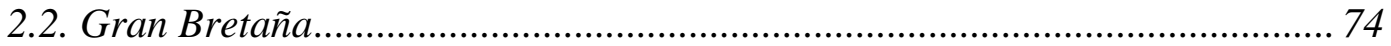

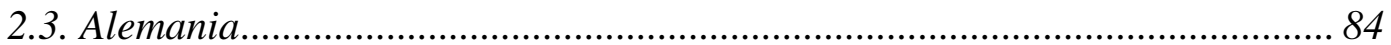

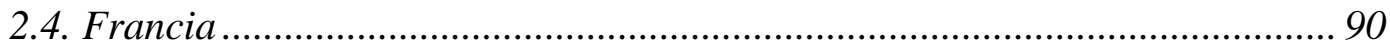

CAPÍTULO TERCERO.- EL FERROCARRIL ESPAÑOL EN LA ÉPOCA DE

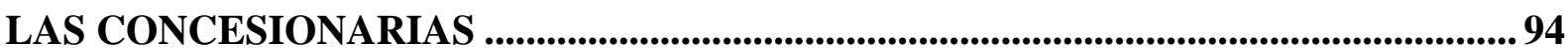

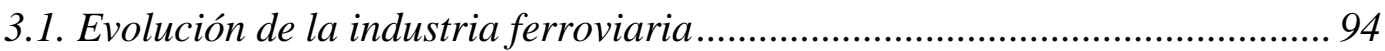

3.2. Problema ferroviario................................................................................. 103

3.3 Desequilibrios en la estructura financiera de las compañías ferroviarias... 120

3.4. Intervención de la Dictadura de Primo de Rivera. Auditoría externa......... 155

3.5. Legislación Mercantil y contable aplicable a las ferroviarias .................... 217

3.6. Regulación interna de las compañías .......................................................... 236

3.7. Práctica contable propuesta por los expertos.............................................. 253

3.8. Informes Anuales de las compañías ferroviarias ..................................... 279

3.9. Compañía de Caminos de Hierro del Norte de España (NORTE)............... 289

CAPÍTULO CUARTO.- MODELO ORGANIZATIVO DE NORTE .................... 299

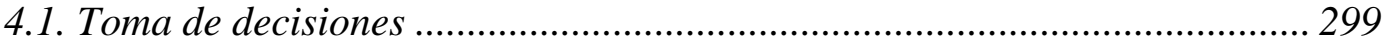

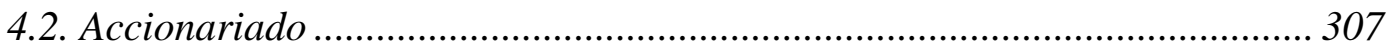

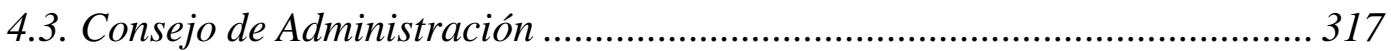

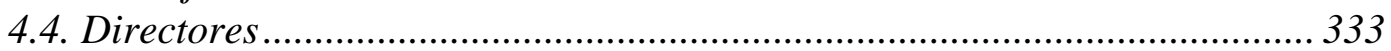

4.5. Resto de trabajadores.............................................................................. 349

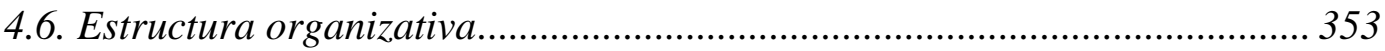

CAPÍTULO CINCO.- SISTEMA DE INFORMACIÓN CONTABLE DE NORTE 373

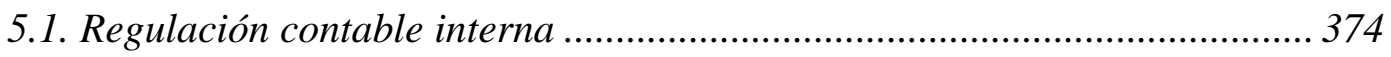

5.2. Documentos contables distintos del Informe Anual ................................... 380

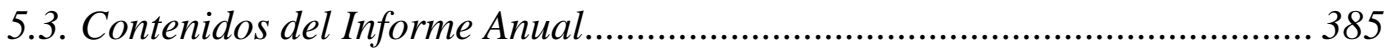

5.3.1. Memoria del Consejo de Administración .................................................. 389

5.3.2. Proyecto de Resoluciones de la Junta General ...................................... 415 
5.3.3. Cuentas del ejercicio.

5.4. Indicadores que acompañan a los Informes Anuales................................. 467

5.5. Valoración crítica del Informe Anual ...................................................... 472

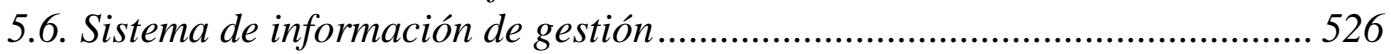

5.7. Valoración crítica del sistema de contabilidad de gestión ........................... 548

CAPÍTULO SEXTO.- ACUERDOS DE OLIGOPOLIO Y FUSIÓN ENTRE NORTE Y MZA 552

6.1. Principal competidor de NORTE: MZA ................................................... 552

6.2. Comparación económico-financiera entre MZA y NORTE ........................ 562

6.3. Relación competencial entre MZA y NORTE ........................................... 582

6.4. Enfrentamiento inicial de MZA-NORTE ........................................................ 583

6.5. Convenio de tarifas MZA-NORTE en 1870................................................ 587

6.6. Acuerdo de la distancia más corta MZA-NORTE de 1875 ......................... 588

6.7. Convenio de reparto de tráfico NORTE-MZA-TBF en 1896 ........................ 589

6.8. Intento de fusión NORTE-MZA de 1904 ...................................................... 590

6.9. Convenio "Sindicatura general de productos" NORTE-MZA: Comisión

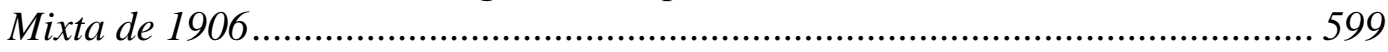

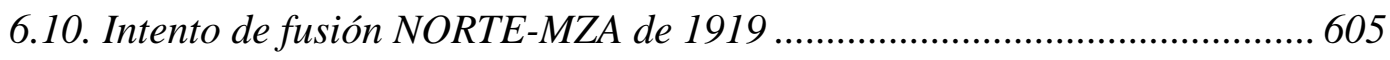

6.11. Establecimiento de tres oligopolios en 1923. Posterior intento de fusión

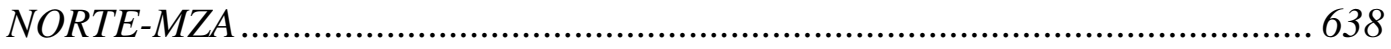

6.12. Intento de fusión NORTE-MZA de 1931 ..................................................... 643

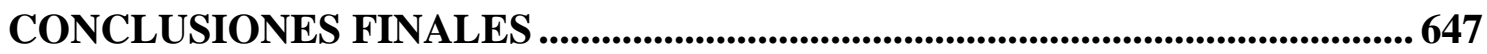

BASE DOCUMENTAL Y BIBLIOGRÁFICA .................................................665

Expedientes de Archivo (Archivo Histórico Ferroviario)....................................66 665

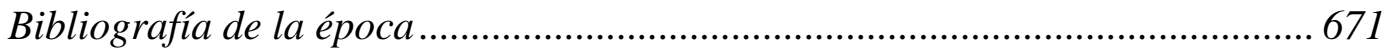

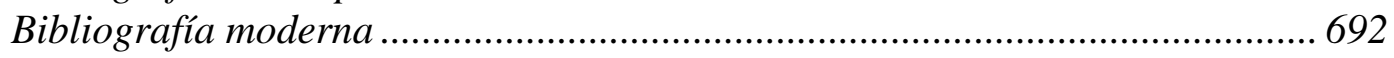




\section{RESUMEN}

El sector ferroviario español ha sido prolíficamente estudiado desde diversos ámbitos, debido al importante papel que ha desempeñado en su contribución al progreso económico. Sin embargo, los aspectos de organización y gestión empresarial, por un lado, y contable, por otro, de las compañías ferroviarias han sido relativamente poco tratados, cuestión ciertamente paradójica si tenemos en cuenta la aportación del sector al desarrollo de la ciencia empresarial y contable.

La empresa analizada en esta investigación es la mayor sociedad privada de España: La Compañía de los Caminos de Hierro del Norte de España (NORTE). El objetivo fundamental es analizar su información contable desde el punto de vista cuantitativo y cualitativo, y su estructura organizativa desde diferentes puntos de vista y de forma dinámica.

La estructura de la investigación es la siguiente. Tras un capítulo inicial donde se establecen los objetivos y métodos de la investigación, en el capítulo segundo se analizan los avances organizativos de gestión y contables en los países más influyentes en el sector, mientras que en el tercero se hace una semblanza histórica del sector del ferrocarril en España. El cuerpo de trabajo lo constituye el apartado cuarto donde se analiza el sistema organizativo y gestión de la empresa NORTE, y el quinto donde se realiza un análisis de su sistema contable. El trabajo se cierra con una valoración crítica de los acuerdos de colaboración y de gestión, y los fallidos intentos de fusión, entre MZA y NORTE.

La principal conclusión del trabajo es que la situación económico-financiera de la empresa hubiera mejorado si se hubieran financiado con acciones privilegiadas más que con la emisión de empréstitos (escenario contrafactual). Por otro lado, NORTE fue una de las primeras sobre las que se realizaron auditorías de estados financieros y en las que se desarrolló un sistema contable completo. La última conclusión es que la documentación de la empresa ofrece una forma de codificación muy sistemática ofreciendo unos registros contables con alto nivel informativo.

PALABRAS CLAVE: Historia, Ferrocarril, Contabilidad, Gestión, NORTE, MZA. 


\section{CAPÍTULO PRIMERO.- MARCO CONCEPTUAL DE LA INVESTIGACIÓN}

\subsection{Introducción}

El 31 de julio de 2013 se liberalizó el tráfico ferroviario privado de personas en España, de forma que desde ese momento desapareció el monopolio estatal del sector y comienzan a competir empresas públicas y privadas. La Red Nacional de los Ferrocarriles Españoles (RENFE) fue una empresa estatal española que se encargó del transporte de pasajeros y mercancías por la red nacional ferroviaria de ancho ibérico desde su creación el 24 de enero de 1941 a su disolución el 31 de diciembre de $2013^{1}$. Únicamente en esos 62 años existió en España una empresa pública que mantuvo el monopolio de toda la red ferroviaria de ancho ibérico ${ }^{2}$, por el contrario, un periodo de tiempo más extenso, desde el primer ferrocarril en 1847 hasta 1941, y a partir de 2013, las compañías ferroviarias han sido y son privadas. Por todo ello, el estudio de las compañías ferroviarias privadas es una forma de estudiar el pasado y el futuro.

Las primeras empresas industriales modernas $^{3}$ se originaron en el sector ferroviario. Las grandes corporaciones ferroviarias estaban constituidas por grandes capitales, innovadoras tanto desde el punto de vista (a) tecnológico, (b) laboral, (c) operativo como (d) organizativo.

Las ferroviarias tenían un gran despliegue tecnológico, con una elevada proporción de costes fijos sobre los costes totales.

Hasta la construcción de la red ferroviaria, ninguna otra empresa había tenido que seleccionar y dirigir un número tan elevado ${ }^{4}$ y diversificado de hombres. Las ferroviarias fueron las primeras que tuvieron un gran tamaño, con una plantilla enorme y con diferentes cualificaciones y perfiles. La necesidad de gestionar enormes y complejos flujos de carga y pasajeros, requirió gran número de trabajadores y establecimientos repartidos por una amplia geografía.

Tampoco hasta ese momento ninguna compañía había necesitado definir con tanto detalle normas de actividad para garantizar la seguridad de trabajadores y viajeros (Chandler, 1965:

\footnotetext{
1 A partir del 31 de diciembre de 2013, RENFE se dividió en dos entidades: ADIF, ente gestor de las infraestructuras ferroviarias españolas, y Renfe Operadora, compañía que se quedó con la explotación de los ferrocarriles de titularidad pública.

${ }^{2}$ Nos referimos a red de ancho convencional toda la red salvo la de vía estrecha. La primera se nacionalizó en RENFE, la segunda se agrupó posteriormente en FEVE.

${ }^{3}$ En palabras de Chandler (1977: 190) fueron "las primeras estructuras organizativas de tipo moderno".

${ }^{4}$ La empresa de mayor tamaño del mundo, la estadounidense Pennsylvania Railroad (EEUU), empleaba en 1890 a más de 110.000 trabajadores (Vidal Olivares: 1997). En los años 1880 la Great Western Railways, una de las cuatro grandes británicas, ocupaba más de 40.000 empleados, cifra que se elevó a 75.344 en 1919 y superó los 100.000 en 1923 (Savage, 2000: 70). En 1918, la francesa Compagnie des Chemins de Fer du Nord, propiedad de los Rothschild, daba empleo a 34.556 ferroviarios (Annuaire des Chemins de Fer et des Tramways, 1920).
} 
97; Lummis; 1994: 64). Del mismo modo, no habían existido anteriormente empresas con tantas unidades operativas diferentes y una especializada organización jerarquizada de ejecutivos asalariados (Chandler, 1987: 75). Las personas que dirigían estos gigantes económicos se convirtieron en el primer grupo de gerentes o ejecutivos modernos profesionalizados ${ }^{5}$.

Su tamaño, alto nivel tecnológico, complejidad y volumen de información, así como la extensión geográfica de sus actividades, les supuso enfrentarse a muchos problemas organizativos nuevos. La existencia de este alto grado de dificultad de la gestión interna del ferrocarril sin precedentes, obligó a buscar nuevas estructuras de gestión empresarial ${ }^{6}$ y de procedimientos de la organización ${ }^{7}$. La gestión adecuada de todo lo anterior obligó a crear en las grandes compañías ferroviarias nuevos hábitos de gestión y contabilidad que dieron lugar al nacimiento de la empresa moderna burocratizada.

Los orígenes de la empresa corporativa y de la gestión moderna estuvieron asociados al desarrollo de las grandes ferroviarias ${ }^{8}$; esto fue así en Estados Unidos, donde el proceso fue anterior y más acentuado, pero también en Europa, aunque con características específicas según los diferentes tamaños y estilos nacionales. España no constituyó ninguna excepción al respecto, aunque el predominio de una estructura empresarial "de corte netamente familiar" (Vidal Olivares: 1996) hizo que los nuevos métodos de gestión y los sistemas contables llegaran con retraso y menor intensidad.

La historiografía económica ha demostrado que el ferrocarril fue una de las industrias que más notablemente contribuyó a la modernización de España; la importancia del sector se deriva de que afecta a la economía de toda la nación y al desarrollo de su comercio. De las diez empresas más grandes de España, a finales del siglo XIX, seis pertenecían al sector de transporte ferroviario, representando más del $71 \%$ del total de los activos?.

Esta investigación se puede encuadrar dentro de la "Historia de la información contable", y dentro de ella se ha elegido estudiar a las ferroviarias privadas porque eran las empresas más importantes de la época, tanto en España como en Europa. Para estudiar la Historia Económica es una herramienta muy válida la Historia de la contabilidad ${ }^{10}$. La "Historia de la

\footnotetext{
${ }^{5}$ Fue en ellos, pues, donde la "mano visible" de las nuevas formas de gestión empresarial, de Chandler (1987), apareció por primera vez. Una versión crítica de esta teoría fue escrita por Channon (1996).

${ }^{6}$ Vidal Olivares (1997) adelantó que las ferroviarias presentaban un alto grado de dificultad en su gestión interna, sin precedentes históricos hasta ese momento, lo que en su opinión obligó a las compañías ferroviarias a iniciar una búsqueda de nuevas estructuras de gestión empresarial.

${ }^{7}$ El sector del transporte ferroviario fue el primero en desarrollar las formas organizativas típicas de las grandes corporaciones que hoy conocemos y que Chandler (1964) calificó como Big Business debido al tamaño, la complejidad de su organización y el elevado porcentaje de costes fijos de su estructura.

${ }^{8}$ En los siglos XIX y primer tercio del siglo XX, las grandes empresas, tanto estadounidenses (Chandler, 1987) como europeas (Caron, 1973; Gourvish, 1973), eran abrumadoramente ferroviarias.

${ }^{9}$ Datos tomados de Carreras y Tafunell (1993).

${ }^{10}$ En la actualidad destaca "la vigencia de los caminos de acercamiento y colaboración entre las disciplinas de la Historia de la Contabilidad y la Historia Económica” (Hernández: 1998).
} 
información contable" es una especialidad de la Historia de la Contabilidad cuya finalidad primaria es extraer todos los conocimientos que puedan obtenerse a partir de los libros de cuentas y de la documentación contable en general, trascendiendo de esta forma la Historia de la Contabilidad, de la que deviene, "para convertirse en una vía privilegiada de carácter metodológico que permita aproximarse a cualquier índole de investigación histórica" (Hernández: 2011).

La contabilidad moderna apareció en las compañías ferroviarias a mediados del siglo XIX, inicialmente en las estadounidenses, y posteriormente en las europeas ${ }^{11}$. No parecen suficientes los estudios que han abordado el examen de la contabilidad, por lo que el presente trabajo intenta contribuir al impulso de esta línea de investigación concerniente al ferrocarril español. Merece la pena realizar nuevas aportaciones desde la perspectiva histórica contable de principios de siglo XX, dado que fue en ese momento cuando "comenzaron a desarrollarse los conceptos que configuraron la contabilidad moderna” (Hernández: 1996).

\subsection{Objetivos}

La opinión pública española -ni más ni menos que en Francia o Inglaterra- recelaba de las cuentas que publicaban año tras año las concesionarias. Pensaba que no reflejaban la situación real, sino que se trataba de cálculos interesados, detrás de los que se escondían cuantiosos beneficios de los que eran partícipes muchos políticos situados en los Consejos de administración y favorecían sin ningún tipo de pudor los intereses ferroviarios. En esta investigación se intentará evaluar la calidad de los registros contables de la principal empresa privada española del siglo XIX y primera mitad del siglo XX: La Compañía de los Caminos de Hierro del NORTE de España (NORTE).

El primer objetivo del trabajo es identificar cómo se resolvieron, en la principal empresa ferroviaria española, los interrogantes fundamentales que se observan de la utilización de la contabilidad por parte de las empresas foráneas:

1. Calidad de los datos publicados y divulgados en la información derivada de la contabilidad externa. En este punto es necesario identificar los contenidos de los estados financieros. Dentro de ello, adquiere enorme importancia identificar si se busca una uniformidad en la presentación y elaboración de los estados financieros, tanto desde el punto de vista temporal como interempresarial. Por último, es necesario indagar si sirven para ofrecer unos datos fiables que permitan a la compañía revelar la información necesaria para obtener recursos de los proveedores de financiación del mercado de capitales.

2. Características de los instrumentos financieros que sirven para obtener los recursos de las empresas ferroviarias, e identificación del nivel de innovación financiera de estos productos.

3. Calidad de las estadísticas ferroviarias utilizadas.

\footnotetext{
${ }^{11}$ La idea de que el desarrollo de la contabilidad moderna le debe mucho a las ferroviarias fue aportada por Chandler (1965: 97) y posteriormente corroborada para el caso español por Valdaliso y López (2000: 245-246).
} 
4. Establecimiento de herramientas de planificación y control, por medio de presupuestos y cálculo de desviaciones.

5. Nivel de utilización de los indicadores elaborados por la empresa para ayudar a la toma de decisiones.

Dentro de este objetivo, es imprescindible indagar sobre si los sistemas información contable de la compañía diferencian entre contabilidad de gestión y financiera. La contabilidad financiera o externa, abarca la elaboración de las cuentas anuales que la empresa prepara para informar a accionistas, intermediarios financieros y Hacienda. La contabilidad de gestión o interna, integrada por datos de costes, presupuestos y otros indicadores, es una herramienta estratégica para tomar decisiones de gestión, por ejemplo: precios de venta de productos, descuentos a realizar a clientes, eliminación o potenciación de productos, retribución variable para empleados y medidas de reducción de gastos.

El segundo objetivo consiste en analizar si la compañía realizó maniobras de manipulación contable. La normativa contable tiene un gran número de operaciones que pueden contabilizarse de varias formas y muchas de ellas admiten valoraciones subjetivas. La manipulación contable consiste en gestionar los criterios contables con el objetivo de que las cuentas expresen la imagen que interesa a la empresa. Para ver si una empresa está gestionando los criterios contables de forma interesada, es útil revisar las estimaciones, entre ellas las de amortizaciones o deterioros por morosidad; además, es necesario observar si han existido cambios en los criterios contables, lo cual puede ser un indicio de manipulación (salvo que estén convenientemente motivados y/o justificados); otra técnica es comparar los criterios que utiliza una empresa con los de sus competidores.

El tercer objetivo consiste en observar si NORTE posee una estructura organizativa adecuada y compatible con su sistema informativo, que favorezca la toma de decisiones. El modelo organizativo y el sistema de información están directamente relacionados: el modelo organizativo se diseña con una unidad de decisión que permita un control de la gestión, y eso sólo es posible de realizar con un sistema informativo que facilite dicho control y la toma de decisiones; el modelo contable facilita dicho proceso, dado que pretende elaborar documentos que permitan obtener información útil para la toma de decisiones a nivel interno. En concreto, es necesario identificar si la estructura organizativa de NORTE fue establecida bajo la influencia de los modelos de gestión estadounidenses, más adelantados, o se basaba en los europeos continentales más retrasados e ineficientes.

El cuarto objetivo es observar la situación económico-financiera de las empresas NORTE y MZA en el periodo 1900-1924. Es imprescindible analizar la situación real de las principales empresas ferroviarias de la época, pues la legislación para regular la red ferroviaria no se entiende fuera del contexto de las dificultades económicas que comenzaron a padecer las compañías ferroviarias coincidiendo con la I Guerra Mundial, y que desencadenaron las propuestas de reversión de las concesiones al Estado, previo rescate. 
El quinto y último objetivo consiste en analizar las razones por las que no se produjo la fusión entre NORTE y MZA. Esta tarea se realiza en último lugar, porque es imprescindible haber conocido la situación económico-financiera de ambas compañías y si sus registros contables son fiables, relevantes y si sobre ellos se han realizado procedimientos de contabilidad creativa.

Toda esta investigación requiere la comparación temporal de datos contables, para la que se han realizado diversos análisis, cuadros y estadísticas, en los cuales ha sido necesario corregir la inflación. Para corregir el efecto de las variaciones en los precios, todos los valores monetarios han sido referidos al año base 1913 utilizando los índices de coste de la vida que aparecen en las tablas del trabajo de Ballesteros (1997: 363-395) ${ }^{12}$.

\subsection{Método de investigación}

El método de investigación elegido es el análisis del caso histórico de NORTE, a través del estudio longitudinal de la empresa en el periodo 1900-1924, y el uso de fuentes primarias y secundarias.

La técnica del análisis del caso histórico ha sido anteriormente utilizada en trabajos sobre el modelo contable de las ferroviarias. Así se estudió, entre otras, en las empresas británicas Liverpool \& Manchester Railway (Pollins: 1952a; 1952b; 1956) y Eastern Counties Railway (Mc Cartney y Arnold: 2000), en las empresas estadounidenses East \& West Railway (Greene: 1892), Baltimore \& Ohio Railroad (Previts y Samson: 2000), Louisville \& Nashville Railroad y Union Pacific Railroad (Heier: 2009; 2010) y en la empresa española MZA (Benito Barroso: 2015) (Santos Cabalgante: 2015) (Luján: 2015).

Esta investigación es un estudio descriptivo, y a su vez, de carácter explicativo, ante el análisis de las variaciones en el sistema informativo y en el modelo organizativo y las causas que han podido originar dichas variaciones. Presenta un enfoque positivo en la descripción del modelo contable y organizativo, pero también interpretativo en el análisis.

El modelo contable de NORTE se forma, por un lado, a través de la interacción entre la legislación de obras públicas, la legislación mercantil, y las disposiciones normativas emanadas de la propia organización de la empresa; y por otro, a través del proceso de toma de decisiones, la estructura de los diferentes órganos de gestión, el proceso de gestión ferroviaria, los procedimientos de verificación de la información contable y la estadística utilizada para gestionar adecuadamente.

\footnotetext{
${ }^{12}$ Martínez Vara (2004: 112) hizo un comentario sobre los índices de precios en relación con su aplicación a las ferroviarias.
} 
Por esta razón, para estudiar el modelo contable de NORTE en el capítulo quinto, es imprescindible observar anteriormente dos dimensiones: por un lado el conjunto de normas y disposiciones (capítulo tercero), y por el otro, observar la estructura organizativa de la organización (capítulo cuarto).

Las tareas a realizar son:

- Recopilación de la legislación externa e interna para el periodo 1900-1924, de aplicación a las ferroviarias españolas y, además, identificación y análisis de los aspectos de carácter contable incluidos en las anteriores disposiciones, que pudieran configurar el modelo normativo contable en dicho periodo.

- Análisis de los Informes Anuales emitidos por NORTE.

- Estudio de las Actas de las reuniones del Consejo de Administración, del Comité de París, y de las Juntas Generales de Accionistas. De estos textos se obtiene información sobre el modelo de gestión desarrollado por estos órganos en relación a la toma de decisiones, la estructura organizativa, el proceso de toma de decisiones y la política contable.

- Análisis de las Actas de la Comisión Mixta NORTE-MZA, pues este organismo fue el que gobernó ambas compañías desde entonces.

\subsection{Elección de la empresa}

La investigación se centra en la Compañía de los Caminos de Hierro del Norte de España (NORTE) porque es la empresa española con mayor dimensión de la época, tanto por el peso de sus activos, como por la mano de obra empleada. Además, su indiscutible relevancia en el panorama de los ferrocarriles europeos, permite observar la situación de las grandes empresas europeas en esa época. NORTE llego a ser la empresa privada más importante de España, y la décima de toda Europa ${ }^{13}$, por volumen de $\operatorname{activos}^{14}$ y por número de empleados, llegando a tener veinte mil trabajadores ${ }^{15}$. Hasta entonces ninguna otra compañía española había tenido que seleccionar y dirigir un número tan elevado y diversificado de personas con normas de actividad definidas tan claramente ${ }^{16}$.

El estudio de NORTE debe realizarse conjuntamente con el de la Compañía de Madrid a Zaragoza y Alicante (MZA). En primer lugar porque ambas eran, con diferencia, las dos de mayor tamaño del sector, e incluso fueron las mayores privadas españolas hasta que llegaron

\footnotetext{
${ }^{13}$ Otra cosa bien distinta es el análisis desde el punto de la rentabilidad financiera, pues NORTE formó parte siempre del furgón de cola junto con MZA y Andaluces (Tafunell, 2000: 96-97).

${ }^{14}$ Por volumen de activos, NORTE pasó de ser la decimoctava empresa de Europa en 1890 a ser la décima del continente a partir de 1917 (Carreras y Tafunell, 1993: 127-174; 1996: 77; 1997: 277-304) (Carreras: 1999: 39). Las mismas citas muestran como MZA pasó de ser la decimonovena a ser la undécima de Europa en los mismos años, siempre siguiendo los pasos por detrás de NORTE, pero muy cerca.

${ }^{15}$ El empleo dentro del sector ferroviario español era en 1917 de sesenta mil operarios (Ballesteros y Martínez Vara: 2001a). Ballesteros y Martínez Vara ofrecen series del total del empleo ferroviario entre 1893 y 1935, y también desglosado por compañías, entre ellas NORTE.

${ }^{16}$ Muy interesante es la aplicación de la teoría del capital humano a la construcción y explotación de las redes fue realizado por Martínez Vara y Ramos (2015b).
} 
los procesos de privatización y de fusiones continúas de finales del siglo XX. Ambas suponían el $63,41 \%$ de las líneas explotadas ${ }^{17}$, por lo que se puede inferir que estudiando las dos conjuntamente, se analiza gran parte del sector. En segundo lugar porque ambas empresas alcanzaron muchos acuerdos: cuatro oligopolísticos de gestión para luchar contra el mercado y el Estado, uno en el que se alcanzó una dirección unificada desde 1906, e incluso estuvieron muy cerca de fusionarse en tres ocasiones.

La elección de NORTE tiene una ventaja adicional, pues ofrece Informes Anuales de muy alta calidad. Esta documentación proporcionaba mucha información, mostrando riquísimas explicaciones acerca del contenido del balance y cuenta de pérdidas y ganancias, además de presentar de forma desglosada las cuentas de explotación de cada una de sus líneas, y todo ello completado con una batería de datos estadísticos útiles para la gestión y evaluación del comportamiento de la compañía.

\subsection{Elección de la dimensión temporal}

El periodo elegido para el estudio es el tramo del siglo XX que transcurre hasta el Estatuto de 12 de julio de 1924, en el que comienza la nacionalización de la compañía y el sector. El periodo es breve pero con una enorme sucesión de acontecimientos, que determinaron el devenir de NORTE, y de todo el sector ferroviario español.

Este periodo 1900-1923 coincide con dos épocas de la historiografía política española (Tusell, 1990: 39-222): la época regeneracionista "revolución desde arriba" (1902-1914) y la crisis del parlamentarismo (1914-1923).

El intervalo elegido debe ser contrastado con la parcelación dada por otros autores que han analizado la legislación ferroviaria en nuestro país. Gómez Mendoza (1989a: 46-50) perfiló tres etapas en el sector ferroviario español: una primera fase de indecisión y especulación hasta 1854, otra segunda de planificación y construcción general, entre $1855-1913^{18}$, y finalmente, la tercera, de nacionalización de la red viaria, entre 1914 y 1936.

\footnotetext{
${ }^{17}$ En 1923, MZA explotaba 3.663 kilómetros -2.944 de la Antigua Red y 719 de la Red Catalana- (De la Torre, 1923: 101; MZA, 1924: 4). En 1923, NORTE explotaba 3.692 kilómetros (De la Torre, 1923: 65; NORTE, 1924: 5). En ese mismo ejercicio económico, en España existían 11.599 kilómetros de vía normal -11.559 a vapor y 40 eléctricos- (De la Torre, 1923: 62). El porcentaje de 63,41\% ha sido calculado por el cociente 7.355/11.599. Tedde (1978: 11) va más lejos cuando afirma que ambas compañías constituían el $90 \%$ del tendido ferroviario con tráfico con cierta intensidad.

${ }^{18}$ Paradójicamente, en la etapa denominada de planificación y construcción por Gómez Mendoza (1989a: 4650), la característica fundamental es que existe una disminución en el periodo de construcción; "tras la euforia constructora del ferrocarril entre 1855-1866, que alcanzó el ritmo de $430 \mathrm{~km} / a \tilde{n} o$, se estanca en el periodo inmediato superior para relanzarse, aunque más pausadamente, entre 1873-1896, con una media anual de 230 $\mathrm{km}$. Durante el primer tercio del siglo X, las construcciones cayeron hasta $30 \mathrm{~km}$ anuales" (Montenegro Duque, 1991, tomo 12: 320).
} 
Por su parte, Tedde (1978: 105-243) realizó sus estudios dividiendo la vida de las grandes compañías ferroviarias españolas en cuatro fases: creación (1865-1874), expansión (18751900), afirmación (1900-1919) e institucionalización (1920-1936).

Nuestro criterio es mantener las cuatro fases de Tedde, pero variando la fase de expansión y afirmación, alargándola hasta el año $1923^{19}$. De esta forma, concedemos al Estatuto Ferroviario la importancia máxima, por ser el comienzo de la nacionalización de las compañías. Con nuestro criterio, se divide la vida de las grandes compañías en cuatro fases:

- Fase de creación de las compañías (1865-1874)

- Fase de expansión de las compañías (1875-1900)

- Fase de afirmación de las compañías (1900-1923)

- Fase de institucionalización de las compañías (1924-1941) ${ }^{20}$.

Así, en este trabajo se estudiará la fase de afirmación de las compañías ferroviarias españolas.

El periodo comienza en el 1900 que marca el cambio de siglo, y termina con la dictadura de Primo de Rivera, que influyó enormemente sobre la política ferroviaria. Este periodo deja fuera el periodo posterior a la creación del "Consejo Superior de Ferrocarriles" y a la vigencia del "Estatuto Ferroviario" de 1924.

La razón fundamental para elegir el inicio del periodo en el año 1900 es porque en ese momento NORTE tenía prácticamente consolidada su red. Tras el periodo de construcción y ampliación a través de adquisiciones, la empresa tenía un total de $3.656 \mathrm{~km}$ en explotación ${ }^{21}$, por el contrario, con posterioridad a 1925 tan sólo entraron en servicio $70 \mathrm{~km}$ más, correspondientes a la concesión de la línea Huesca-Canfranc. Su principal competidor -MZAtampoco varió su extensión ni su implantación geográfica desde 1900 (Ortúñez, 1999b: 274).

El periodo 1900-1924 está caracterizado por la estabilidad en la longitud de red ferroviaria construida. En 1900 se había concluido la etapa de construcción de las redes y las anexiones

\footnotetext{
${ }^{19}$ La definición de este periodo es concordante con un autor, y cercano a otros. De Benito (1935: 39) realizó una división de la legislación ferroviaria española en cinco periodos: 1844-1855, 1855-1868, 1868-1877, 1877-1924 y 1924-1936. Por su parte, Bentabol et al. (2011: 5) amplían la fase de “institucionalización” hasta el año 1925. Estos autores reconocieron el periodo 1900-1925, incluso lo descompusieron en tres etapas diferenciadas, consecuencia de las diferentes condiciones existente en cada momento: $1^{\text {a }}$ Etapa (1900-1913): "Fase de afirmación", 2 a Etapa (1914-1920): "Fase del problema ferroviario" y $3^{\text {a }}$ Etapa (1921-1925): "Fase de institucionalización".

${ }^{20}$ El último periodo se amplía hasta 1941, no obstante es necesario destacar que, a partir de 1936, en el que comienza la guerra civil, la actividad de las ferroviarias no tiene la continuidad que había tenido hasta ese momento, para poder considerarla un periodo homogéneo.

${ }^{21}$ En 1900, la Compañía NORTE detenta "una red total de 3.656 kilómetros, seis más que las líneas controladas por la Compañía MZA” (Comín, et al., 1998: 164).
} 
en MZA y NORTE, tanto que en esa fecha estaba construido el 90\% de los kilómetros de la red ferroviaria española ${ }^{22}$.

Hasta 1900, las compañías ferroviarias habían llevado a cabo multitud de fusiones y adquisiciones, sin embargo, en el periodo 1900-1924 la red ferroviaria de las grandes compañías varió poco, tanto en extensión como en implantación geográfica ${ }^{23}$. A partir del comienzo de siglo, se produjo un importante cambio en la política ferroviaria: el Estado creía más adecuado obtener mayor rendimiento a la red establecida sin necesidad de ampliar el tendido ferroviario ${ }^{24}$. Por el contrario, el Estado alentó las fusiones, adquisiciones de empresas, absorciones, unificaciones de empresas y de material. La razón de esta nueva situación $^{25}$, en la que no se construía, sino que se intentaba aprovechar al máximo lo ya existente, era que las nuevas construcciones formarían parte de la "Cuenta de primer establecimiento", y ésta debía estar subvencionada por el Estado, por lo que si el Estado quería más red, o subvencionaba su construcción, o se adjudicaba la capacidad para construir nuevas líneas como hará con el Estatuto de 1924.

Analizando la legislación ferroviaria española, necesariamente debe terminar un periodo en 1923, porque el "Estatuto Ferroviario" de 1924 modifica y reordena el sector ferroviario español. El régimen derivado del Estatuto, impuesto tras el golpe de Estado de Primo de Rivera, acentuó la intervención del Estado, hasta entonces casi inexistente. A partir del Estatuto de 1924 numerosas facultades que podían ejercitar las empresas pasan a un organismo oficial: el Consejo Superior de Ferrocarriles. Tanto es así, que se puede afirmar que la promulgación del "Estatuto Ferroviario" de 1924 creó un nuevo modelo ferroviario para España. Con él comienza la fase de "institucionalización" de los ferrocarriles, que desembocó en la nacionalización de las compañías en 1941 bajo la tutela de RENFE ${ }^{26}$. Durante la Dictadura de Miguel Primo de Rivera se articuló "una tupida malla protectora de la industria nacional" (García Delgado et al. 1976: 76) en la que destacan tres puntos: intervencionismo estatal, aumento de la concentración económica y proliferación de prácticas monopolistas. La tendencia a la concentración empresarial era coherente con la admiración que sentía Primo de Rivera por el nacionalismo económico y su predilección por la gran empresa, especialmente, por las monopolistas. Consecuencia lógica de esta protección, fue el

\footnotetext{
22 "A comienzos del siglo XX se encontraban construidos aproximadamente el 90\% de los kilómetros de la red ferroviaria que posteriormente se integrarían en Renfe en 1941, y que básicamente son los que han llegado hasta nuestros días" (Bentabol et al., 2011: 4).

${ }^{23}$ Diversos autores han reconocido que NORTE y MZA modificaron muy poco sus redes arborescentes a partir de 1900: Cordero y Menéndez (1978: 182), Gómez Mendoza (1989a: 54), Tortella (1994: 108) y Ortúñez (1999b: 274-275).

${ }^{24}$ Entonces, "las compañías ferroviarias ya no centraban su atención en la expansión de sus líneas, sino en la rentabilización de los servicios que prestaban” (Muñoz Rubio, 1995: 73).

${ }^{25}$ Esta justificación ya fue dada por Ortúñez (1999b: 274).

${ }^{26}$ La Junta general extraordinaria de accionistas de 4 de octubre de 1924 acordó el ingreso de NORTE en el nuevo régimen ferroviario, solicitándolo el 10 de octubre de 1924. Desde ese momento, la compañía tendría que aceptar las obligaciones y limitaciones que le imponía el nuevo régimen ferroviario, perdiendo su libertad de acción, al entrar en "una verdadera asociación con el Estado" (NORTE, 1940: 515).
} 
gran número de absorciones y fusiones empresariales que se produjeron a lo largo del Directorio Militar, frecuentemente mediante ofertas de adquisición de acciones.

Para el caso concreto de MZA y NORTE, el periodo linda, por un lado, con el 1900 que marca la conclusión de la etapa de anexiones tanto para NORTE como para MZA, y la aprobación por la Junta General de NORTE celebrada el 31 de mayo de 1900 del convenio con los obligacionistas. Además, en este periodo se incluyen los dos principales intentos de fusión entre NORTE y MZA, que se produjeron en 1904 y en 1919.

Como el Estado, por su propio interés, alentó las fusiones, absorciones, unificaciones de empresas y adquisiciones de empresas de todos los sectores, llama tanto la atención que no hubiera más fusiones de empresas ferroviarias en este periodo 1900-1923, y en concreto la más natural, la de NORTE con MZA.

La historia de la competencia empresarial entre ambas empresas puede dividirse en tres etapas (cuadro 1). Entre 1855-1873 son dos de las compañías de mayor envergadura financiera y del negocio, pero con parecido comportamiento en el mercado que otras sociedades ferroviarias españolas. Entre 1874 y 1905, la estrategia expansionista de NORTE y MZA llegó a plantear abiertamente un conflicto comercial entre ambas para contralar el tráfico. A partir de 1906, NORTE y MZA, consagran el régimen de duopolio con reparto de beneficios, y comienza un proceso de integración entre ambas compañías.

\section{Cuadro 1. Fases de la relación entre MZA y NORTE}

\begin{tabular}{|c|c|c|}
\hline ETAPA & & \multicolumn{1}{c|}{ TIPO DE RELACIÓN } \\
\hline 1855-1873 & - Compañías de mayor envergadura financiera que otras sociedades \\
& - Con parecido comportamiento en el mercado \\
\hline 1874-1905 & - Ambas presentan una estrategia expansionista \\
& - Conflicto entre ambas compañías para controlar el tráfico \\
\hline 1906-1941 & - Ralentización en la construcción de la red \\
& - Proceso de integración \\
& - Régimen de duopolio con reparto de beneficios entre ambas \\
& - Cada vez mayor intervención del Estado \\
\hline
\end{tabular}

Fuente elaboración propia

Desde el punto de vista contable puede dividirse la historia de NORTE en tres etapas, si clasificamos en función del texto que regula su contabilidad (cuadro 2). En el periodo 19001924, las compañías tienen una regulación interna para llevar su contabilidad, sin que hubiera una normalización expresa de la legislación contable para empresas ferroviarias. Entre todas las regulaciones internas destaca la publicada por la empresa NORTE el 30 de septiembre de 1900 -La "Instrucción General Número 1 sobre la Organización de los Servicios de la Compañía de los Caminos de Hierro del Norte de España"-, que hace referencia a las 
actividades relacionadas con la contabilidad de la compañía. Hasta que entró en vigor el Estatuto ferroviario de 1924, que incluía leyes concretas en el ámbito contable (incluida una clasificación uniforme de ingresos, gastos y cargas), la regulación interna fue la guía de los usos contables de las compañías. Sin embargo, hasta el momento de la elaboración de esta clasificación uniforme, las empresas homogeneizaron voluntariamente con su propia regulación.

El "Estatuto Ferroviario" creó las bases para tener una normalización contable para las empresas ferroviarias, tanto que podemos afirmar que es la primera regulación de la contabilidad ferroviaria en España. Desde la implantación del Estatuto ferroviario en 1924, el Consejo Superior de Ferrocarriles acordará la adopción por todas las empresas de una clasificación uniforme de sus ingresos, gastos y cargas., estableciendo las bases para que todas las empresas concesionarias tuvieran una clasificación uniforme de sus ingresos, gastos y cargas de manera que cada uno de los conceptos parciales comprendidos en estos tres epígrafes se correspondan exactamente en las contabilidades de aquéllas a fin de evitar las dificultades a que daría lugar la diversidad de criterio en las referidas clasificaciones. De igual forma, en el Estatuto ferroviario se encomienda la realización por parte del Estado, y posterior aplicación por las empresas, de una distinción y determinación de los gastos de primer establecimiento y de explotación, así como para acomodar a modelos uniformes las cuentas anuales, las estadísticas del tráfico y los demás datos.

Por si fuera poco, en 1923, se realizó la primera auditoría externa de estados financieros en España. Nos referimos a la revisión de las grandes compañías ferroviarias realizadas por la "Comisión Investigadora de la Situación Económica de las Empresas de Ferrocarriles".

\section{Cuadro 2. Fases de contabilización de NORTE}

\begin{tabular}{|l|r|l|}
\hline ETAPA & \multicolumn{2}{|c|}{ TEXTO QUE REGULA LA CONTABILIDAD DE NORTE } \\
\hline 1855-1899 & $\bullet$ & Usos y costumbres de la compañía \\
\hline $1900-1923$ & $\bullet$ & $\begin{array}{l}\text { Instrucción General Número 1 sobre la Organización de los Servicios } \\
\text { de la Compañía de los Caminos de Hierro del NORTE de España }\end{array}$ \\
\hline 1924-1941 & $\bullet$ & Estatuto ferroviario y legislación contable posterior \\
\hline
\end{tabular}

Fuente elaboración propia

En definitiva, uno de los periodos más interesantes para el estudio de NORTE es el que transcurre entre 1900 y 1923, tanto por la estabilidad de la red, como por la relación empresarial entre MZA y NORTE, y por su relevancia desde el punto de vista de la contabilidad y de la auditoría. 


\subsection{Fuentes analizadas}

La fuente principal son los diversos documentos referidos al tema que se conservan en el Archivo Histórico Ferroviario (AHF) de la Fundación de Ferrocarriles Españoles con sede en Madrid.

En la investigación se ha realizado un análisis, tanto de fuentes primarias, compuestas por la legislación, documentación y correspondencia emitida por la compañía NORTE y MZA, como por las fuentes secundarias escritas por autores y organizaciones.

Las dos grandes empresas privadas españolas generaron un abundante legado documental que propician investigaciones. El único inconveniente para su estudio se deriva de que durante la guerra civil tenían situadas sus oficinas centrales en Madrid, lo que hizo que el asedio provocara la desaparición de archivos y de documentación valiosísima ${ }^{27}$. La diferencia entre ambas compañías es que los documentos almacenados en las oficinas centrales de MZA de la Avenida Ciudad de Barcelona han llegado a los archivos públicos actuales, mientras que parte de la documentación de NORTE en su sede de la estación del Norte (Principe Pío) se ha perdido o está oculta. La mayoría de documentos de NORTE nos han llegado por los archivos orginarios de MZA; esto ha provocado que hayan proliferado trabajos sobre la segunda y mucho menos sobre la primera.

La principal documentación en la que se basa el trabajo está constituida por las fuentes de carácter interno de las ferroviarias NORTE y MZA: Estatutos de las sociedades, Informes anuales, Actas de las reuniones del Consejo de Administración de las compañías, Actas de los diversos Comités, Actas del organismo conjunto que gobernó NORTE y MZA desde 1906 y las cartas comerciales y personales entre ambas compañías.

Respecto a las fuentes secundarias, en el trabajo se analizan fuentes de la época de las concesionarias privadas del ferrocarril, pero además, también se observan los resultados de las investigaciones posteriores sobre el ferrocarril en general, y sobre su organización, gestión y contabilidad en particular,

Las fuentes de la investigación de la época se caracterizan por su atomización y dispersión, al materializarse en un alto número de tipologías -documentos de archivo, libros, publicaciones periódicas, prensa, folletos, revistas especializadas, etc.-, repercutiendo así negativamente en la investigación. También poseen interés los manuales que las compañías difundieron y la acogida y valoración que de ellos hizo la literatura de la época. El estudio se completa con los manuales de contabilidad encontrados en la Biblioteca de la Escuela de Caminos, el resto de

\footnotetext{
${ }^{27}$ Sobre la desaparición de parte de la documentación véase NORTE (1940: 7). En esta monografía, el Director de la compañía Marquina afirma en la "exposición" introductoria que pretende hacer una "recopilación de la documentación oficial que dio origen a NORTE y de la que últimamente dio lugar a la ampliación y actuación, con el mayor acopio posible de los datos que puedan tener algún valor para la reconstrucción del historial de nuestra compañía". Todo esto parte de que se había perdido el grueso de la documentación durante la guerra civil.
} 
documentos de historia económica y contable situados en la Biblioteca de la Fundación de Ferrocarriles y las fuentes hemerográficas (Revista de Obras Públicas y Gaceta de los Caminos de Hierro, principalmente).

\subsubsection{Documentación social de las compañías}

El Archivo Histórico Ferroviario (AHF) de la Fundación de Ferrocarriles Españoles conserva los Estatutos y las Actas de los Consejos y Comités que gobernaban las sociedades MZA y NORTE. Además de esta vasta documentación, se ha analizado la correspondencia postal entre los diferentes cargos y organismos de estas dos sociedades, y de algún sujeto u organismo de la compañía con terceras personas físicas y jurídicas.

Uno de los mayores esfuerzos de esta investigación es haber analizado la documentación social de NORTE: Libros de Actas del Consejo de Administración y de los Comités de París, Madrid y Barcelona (AHF - L-0356 a L-0368). Esta información social es fundamental para conocer la estructura organizativa y el sistema de información de NORTE.

La aportación más novedosa del trabajo es la Consulta de las Actas del Comité de Madrid de NORTE (también denominado Ejecutivo o de Dirección).La Serie E (Fondo Norte) del AHF está compuesta por 456 expedientes relativos a la compañía del NORTE, entre la que destaca para esta investigación las copias de las Actas de las sesiones celebradas por el Comité de Madrid de la Compañía del Norte. La otra gran novedad es el análisis de los cinco Libros de Actas del organismo conjunto que gobernó NORTE y MZA desde 1906 (AHF - L-04540458).

NORTE cuenta con una notable representación documental en el AHF. La documentación más significativa proporcionada por NORTE se debe, fundamentalmente, a la generada por sus principales órganos de gobierno: 25 libros de actas, copias y relación de asistentes a las reuniones de su Consejo de Administración; 36 cajas de expedientes de su Secretaría General relativos a las juntas de accionistas, personal de altos cargos, personal y correspondencia de la propia Secretaría del Consejo de Administración; 50 libros de actas y 21 cajas de expedientes del Comité de Madrid, así como 3 libros de correspondencia y 6 de registro de su Secretaría; 5 libros de actas y 1 de la Secretaría del Comité de Barcelona; y el conjunto de las Actas de las reuniones del Comité de París (Compagnie des Chemins de Fer du Nord de l'Espagne, Procès verbaux des séances tenues par la reunión de Paris). Descendiendo en el organigrama de NORTE cabe referir, también, un conjunto notorio de expedientes sobre cuestiones del Servicio de Personal, del Servicio de lo Contencioso, de las divisiones de Material y Tracción y Vías y Obras y de la Cooperativa de Ferroviarios y del Consejo Superior de Ferrocarriles.

En el AHF también puede consultarse la documentación social de MZA: Libros de Actas del Consejo de Administración y de los Comités de París, Madrid y Barcelona. La más destacable son los apéndices de los Informes Anuales de MZA, donde se reproducen muchos documentos internos de la empresa (acuerdos, circulares, informes, proyectos y comunicados). Respecto a los datos presupuestados de MZA, existen 151 libros de 
presupuestos de la red antigua (AHF - L-0045 a L-0195), 63 libros de presupuestos de la red catalana (AHF - L-0196 a L-0257; años 1912-1935), 11 libros de presupuestos de la red catalana y red antigua de la compañía MZA (AHF - L-0258 a L-0268; año 1936), 9 libros de resúmenes de presupuestos de la red catalana y red antigua (AHF - L-0269 a L-0277; años 1919-1935), 6 libros de notas anexas a los presupuestos (AHF - L-0278 a L-0283; años 1919, 1921, 1927-1934, 1936), AHF - L-0790 a L-0797, (años 1919-1935), 8 Libros de resúmenes de los Presupuestos de la Red Catalana y la Red Antigua (AHF - L-0790 a L-0797; años 1919-1935), 12 Libros de Presupuestos de la Red Antigua (AHF - L-0798 a L-0809; años 1910-1935), 6 Libros de Presupuestos de la Red Catalana (AHF - L-0810 a L-0815; años 1912-1935) y 5 Libros de notas anexas a los presupuestos (AHF - L-0816 a L-0820; años 1919, 1921, 1927-1934, 1936).

Desde el punto de vista de la gestión, el elemento clave de esta estructura empresarial eran los directivos, quienes mantuvieron una alta movilidad en sus puestos y frecuentes cambios entre empresas, teniendo como objetivo alcanzar los puestos de mayor prestigio en las principales compañías del país. Para analizar el papel y movilidad de los directivos de NORTE se han consultado los Libros de Actas de los Consejos de administración, los Informes Anuales, la documentación relativa a las Juntas de accionistas y los expedientes de altos cargos de NORTE custodiados en el AHF. Incluidos en la serie de la "Secretaría General de la Dirección NORTE" están los 128 expedientes sobre personal de altos cargos donde se hace referencia a los nombramientos, dimisiones, ceses y fallecimientos de los administradores de la empresa entre 1859 y 1937. Para analizar los directivos de MZA existen en la serie "Secretaría General de MZA" más de 20 expedientes, que, aunque con menor contenido informativo que los de NORTE, también aluden a los nombramientos, dimisiones y ceses de altos cargos.

\subsubsection{Documentación contable de las compañías}

Dentro de las fuentes de las propias empresas, en esta investigación se ha analizado la documentación contable de las compañías, concepto ámplio que incluye un conjunto de diversos documentos: Informes anuales, libros de presupuestos, expedientes e informes.

La información más importante es la del Informe Anual ("Memorias anuales de los Consejos de administración" en la denominación más frecuente entre las empresas de la época) en las que, tras un breve preámbulo, se daba a los accionistas información periódica razonada de las vicisitudes experimentadas por los distintos servicios, resaltando los aspectos más destacados $^{28}$. En los apéndices del Informe Anual se reproducían cualquier tipo de texto que los gerentes consideraban de interés: instancias, propuestas, decretos, leyes y circulares internas. El acopio de información contenida en el Informe Anual es extraordinario y reviste gran interés tanto desde el punto de vista cuantitativo como cualitativo. Por suerte, el AHF

\footnotetext{
${ }^{28}$ Los Informes Anuales de las empresas ferroviarias pueden ser consultadas en la Biblioteca Ferroviaria del Museo del Ferrocarril de Madrid signatura A01. También en su catálogo en línea: http://www.docutren.com/Biblioteca/index.asp.
} 
dispone de todos los Informes anuales de MZA y NORTE, excelentemente conservados; siendo su grado de meticulosidad muy elevado.

Respecto a la información contable previsional, entre las fuentes primarias del AHF pueden consultarse los 272 "Libros de Presupuestos" (1910-1936) de MZA $^{29}$. Estos libros terminaban con resúmenes que sirvieron para confeccionar, entre 1915 y 1936, un libro anual independiente ${ }^{30}$.

En NORTE se ha conservado un número menor de "Libros de Presupuestos" (1916-1920) ${ }^{31}$, aunque en esta investigación hemos obtenido los datos presupuestados de forma indirecta de los datos expuestos en los Informes Anuales y en el Libro de Actas del Consejo de Administración.

\subsubsection{Trabajos recopilatorios publicados por NORTE}

NORTE presenta su información contable directamente en dos fuentes: los regulares y periódicos Informes Anuales, y los excepcionales documentos que agregan información de varios años, y que también reúne y pública NORTE.

La compañía publicó cuatro documentos recopilatorios. El primero de ellos es la recopilación legislativa específicamente relacionada con la sociedad en 1857, todavía en francés, que recibió el título: "Recueil de pièces officielles" (Chemin de Fer du Nord de L'Espagne, 1857: 1-51). En él se puede encontrar información sobre la Ley de ferrocarriles de 1855; la aprobación de la adjudicación del ferrocarril de Valladolid a Burgos con pliego de condiciones y tarifas; la Ley de concesión del ferrocarril de Alar a Dueñas, con pliego de condiciones y tarifas; el Acta de concesión del ferrocarril de Madrid a Valladolid, y de Burgos a la frontera francesa; y la Ley general que crea la línea de Madrid a Irún.

El segundo es "Titulación oficial de la Compañía de los Caminos de Hierro del Norte de España", elaborada el 1 de enero de 1879. En este documento NORTE (1879: 1-272) vuelve a realizar una recopilación legislativa relacionada con la empresa, pero esta vez la amplia al incorporar información sobre concesiones, estatutos, regulación interna, obligaciones y las líneas que la componen ${ }^{32}$.

\footnotetext{
29 AHF, L-0045 a L-0195 y AHF, L-0798 a L-0809, (años 1910-1935) Libros de Presupuestos de la Red Antigua; AHF, L-0196 a L-0257 y AHF, L-0810 a L-0815, (años 1912-1935) Libros de Presupuestos de la Red Catalana; AHF L-0258 a L-0268, (año 1936) Libro de Presupuestos de la Red Antigua y Red Catalana (11 tomos) y AHF, L-0278 a L-0283 y AHF, L-0816 a L-0820, (años 1919, 1921, 1927-1934, 1936) Libros de notas anexas a los presupuestos.

${ }^{30}$ AHF, L-0269 a L-0277 y AHF, L-0790 a L-0797, (años 1919-1935) Libros de resúmenes de los Presupuestos de la Red Antigua y Red Catalana.

${ }^{31}$ AHF, W-0052-004 "Libros de Presupuestos" (año 1916) y AHF, W-0043-002 "Libros de Presupuestos" (año 1917); AHF, W-0043-003 "Libros de Presupuestos" (año 1918); AHF, W-0043-004 "Libros de Presupuestos" (año 1919); AHF, W-0043-005 "Libros de Presupuestos" (año 1920).

${ }^{32}$ El documento está organizado en las siguientes partes:

- Líneas primitivas de la Compañía: línea de Madrid a Irún; línea de Alar a Dueñas (Venta de Baños).
} 
En 1916, la empresa publicó “Compañía del Norte y su personal: datos y cifras que es imprescindible conocer para juzgar con acierto el Problema Ferroviario" "33, que reúne el conjunto de argumentaciones de la empresa frente al Estado para intentar recibir más ayudas, apoyándose en una exposición de numerosas cifras.

Pero, sin duda, la obra más importante es "Compañía de los Caminos de Hierro del NORTE de España (1859-1939). Historia, Actuación, Ingresos, Gastos y Balance”, publicada en 1940 por la propia empresa en dos tomos (NORTE: 1940). El prólogo fue realizado por el que fuera su último director, y sin duda el director más representativo de toda la historia de la compañía, Francisco Javier Marquina, quien fue, asimismo, su redactor principal en estrecha colaboración con el ingeniero P. Aza y Díaz.

En la "exposición" introductoria, Marquina afirma que pretende hacer una "recopilación de la documentación oficial" de NORTE (1940: Prólogo, 8). En concreto, "los datos, cifras y conceptos" con los que la monografía fue escrita se basa en: la información obtenida de los documentos contables de NORTE ("oficiales" según su denominación), "en disposiciones ministeriales con ella relacionados" y "en la valiosísima Historie de la Compagnie, redactada por Péreire" 34 .

Los autores, más que investigar, se habrían limitado -añade Marquina- a "redactar unos brevísimos comentarios y a la labor mecánica de copiar y extractar cifras, datos y párrafos oficiales" (NORTE, 1940: Prólogo, 8), de los que lamentablemente casi nunca señalan su procedencia. No es cierto que su trabajo se limitase exclusivamente a ello, ya que elabora de nuevo los datos, incluso, en algunas partidas, los reclasifica y ordena de forma diferente a cómo aparecen en los Informes Anuales. Además, los comentarios no fueron tan breves.

La voluminosa obra recoge gran cantidad de información contable de NORTE: en el Tomo I "Textos y Gráficos", mientras que en el Tomo II "Cuadros Estadísticos". El primero de los tomos es una descripción pormenorizada de la compañía desde los orígenes, incluyendo el tiempo de la Guerra civil. En este primer tomo destaca la gran cantidad de información literal

- Líneas adquiridas por la Compañía con posterioridad a la fecha de constitución de la misma: línea de Alar a Santander; Quintanilla a Barruelo; de Barcelona a Zaragoza; de Tardienta a Huesca; de Zaragoza a Alsasua.

- Fusión de las Compañías de los Ferro-carriles de Zaragoza a Barcelona y de Zaragoza a Pamplona.

- Convenio entre la Compañía de Zaragoza a Pamplona y Barcelona y sus acreedores.

- Fusión de la Compañía de los ferro-carriles de Zaragoza a Pamplona y Barcelona con la del NORTE.

- Contrato celebrado por la Compañía del NORTE con los obligacionistas y tenedores de bonos sin interés de la Compañía de los ferrocarriles de Zaragoza a Pamplona y Barcelona.

- Línea de Tudela a Bilbao. Convenio entre la Compañía de Bilbao y sus acreedores. Adquisición de la línea de Tudela a Bilbao por la Compañía de los Caminos de Hierro del NORTE de España.

- Ley y estatutos de la Compañía de los Caminos de Hierro del NORTE de España.

${ }^{33}$ AHF, S-0050-016. "Compañía del Norte y su personal: datos y cifras que es preciso conocer para juzgar con acierto el Problema Ferroviario".

${ }^{34}$ En la "exposición" introductoria, Marquina escribe que "para explicar el origen y primeras actuaciones de la compañía se valió de una Historie du la Compagnie, redactada por M. Péreire". No ha sido posible localizar este libro. 
que permite comprender la práctica empresarial de la concesionaria ${ }^{35}$. No obstante, lo que confiere a la obra un incuestionable valor es la gran cantidad de datos estadísticos contenida en el tomo segundo.

Este documento de NORTE es una fuente que, de forma homogénea, continuada y sin lagunas, cubre todo el período analizado y permite obtener una visión de conjunto de la evolución de los gastos. Además, las cifras de gastos de la explotación aparecen desagregadas por servicios: Administración Central y Dirección, Explotación, Material y Tracción, Vía y Obras.

\subsubsection{Trabajos recopilatorios publicados por MZA}

Para la historia empresarial es relevante la monografía de MZA "Reseña Histórica de su constitución y desarrollo. Actuación de la Compañía durante los últimos veinte años, 19131931". Para la elaboración de esta documentación, realizada en 1933, tuvo mucha importancia el director más representativo de MZA, Eduardo Maristany.

Al igual que en la monografía de NORTE de 1940, son importantes, tanto los contenidos de información literal que permiten comprender la práctica empresarial, como el enorme acopio estadístico que contienen.

Con la publicación de este documento, siete años antes al de NORTE, los directivos buscaban que se reconociera a la compañía los esfuerzos realizados "en el orden técnico y organizativo". Consideraron igualmente "interesante, útil y provechoso comenzar por hacer una reseña histórica", donde se expusiera todo lo referente a la formación de la compañía, construcción de las líneas, adquisiciones y fusiones habidas.

La información estadística aparece ubicada sobre todo en los "anexos" (18 cuadros estadísticos y 41 gráficos).

\subsubsection{Trabajos recopilatorios publicados conjuntamente por NORTE y MZA}

En los años que precedieron a la nacionalización de la red de ancho convencional, la situación de las ferroviarias empeoró. A los viejos problemas se añadían la competencia de la carretera y la creciente inestabilidad política y social. La crisis económica llegó en ese momento a cuestionar la viabilidad del modelo de ferrocarril y sus posibles alternativas futuras (fenómeno que se denominó problema ferroviario). En este contexto, empresas y gobierno tratarán de publicitar su posición a través de todos los medios a su alcance: prensa diaria, revistas especializadas, folletos y libros. NORTE y MZA, ya muy unidas en ese momento, tomaron frente común y publicaron trabajos para ofrecer su interpretación y solucionario del problema ferroviario.

\footnotetext{
${ }^{35}$ Particularmente útil para este trabajo ha resultado la tercera parte del tomo I: "Actuación de la Compañía desde 1914 a 1936" (NORTE, 1940: I, 212-310).
} 
De entre los folletos, los más significativos son tres que fueron publicados conjuntamente por NORTE y MZA en 1932, 1933 y 1934, respectivamente: "El Problema Ferroviario. Estudios realizados y medidas adoptadas en España para intentar su resolución, 1918-1932" (NORTE y MZA: 1932), "El Problema de los Ferrocarriles Españoles: antecedentes, datos, soluciones" (NORTE y MZA: 1933) y "La ordenación ferroviaria: documentos parlamentarios" (NORTE y MZA: 1934).

El primero es una magnífica recopilación de documentos, didácticamente secuencializados. En el segundo libro, redactado en un lenguaje sencillo y claro, las dos grandes compañías explican su interpretación del problema ferroviario. En la primera parte se autoexoneran de toda responsabilidad ${ }^{36}$ y en la segunda exponen su particular visión del problema ferroviario y dan claves para resolverlo. El tercer libro reúne las normas y proyectos de normas desarrolladas parlamentariamente y gubernamentalmente para intentar resolver el problema.

\subsubsection{Informes oficiales}

Especial importancia tienen las normativas legislativas y ministeriales relacionadas con el ferrocarril $^{37}$.

Además de las disposiciones legales, una parte de la información utilizada en esta investigación procede de los registros y publicaciones, oficiales y semioficiales. Entre ellas destacan las "Memorias, Anuarios y Estadísticas de Obras Públicas", publicadas y presentadas por la Dirección General del mismo nombre, el "Anuario de los Ferrocarriles Españoles", de Enrique de la Torre (1892-1935), el "Anuario Financiero y de Sociedades Anónimas", el "Instituto Geográfico", la "Gaceta de los Caminos Hierro" (GCH), la portuguesa Gazeta dos Caminhos de Ferro y, sobre todo, "Elementos para el estudio del problema ferroviario en España", el magno trabajo de recopilación en seis tomos mandado realizar por Cambó (1918-1921) ${ }^{38}$, y su continuación "Antecedentes y datos para el estudios del problema ferroviario" (Peña y Pérez: 1940, tomo I).

El “Anuario de Ferrocarriles Españoles" (1893-1935) 39 de Francisco de la Torre está formado por cuarenta y dos volúmenes (De la Torre: 1893-1935). Su importancia se deriva de que el Estado recomendó a las compañías de ferrocarril el envío de los datos a los editores de la

\footnotetext{
${ }^{36}$ La afirmación de que las dos grandes no tenían responsabilidad en la situación creada no es compartida por muchos sindicalistas y políticos como el socialista Gómez (1936), antiguo trabajador de los talleres de NORTE en Valladolid.

37 En la Biblioteca Ferroviaria de la FFE, se conserva la colección bibliográfica más completa sobre disposiciones y normativas ferroviarias, consultable a través del portal: "www.docutren.com".

${ }^{38}$ Los tres primeros tomos se publicaron en 1918, el cuarto y quinto en 1920 y el sexto en 1921 . Los tres últimos se refieren a las políticas ferroviarias de otros países.

${ }^{39}$ Un análisis detallado de su estructura puede observarse en Ballesteros y Martínez Vara (2001a).
} 
recopilación anual ${ }^{40}$. La información recogida en él es fundamental para observar la estructura organizativa y de gestión de todas las ferroviarias.

"Elementos para el estudio del problema ferroviario en España" es la obra que más influyó en la literatura ferroviaria en España ${ }^{41}$. El trabajo fue ordenado por Francisco Cambó ${ }^{42}$ en 1918 , y publicado por el Ministerio de Fomento (Cambó, 1918-1921). Toma los datos de los Informes Anuales que anualmente publicaban las empresas ${ }^{43}$. En el tomo IV se reproducen multitud de textos jurídicos, así como diversas notas e informes de las dos grandes concesionarias, NORTE y MZA. La obra de Cambó resulta imprescindible para comprender el llamado Problema Ferroviario.

En 1940 se publicó “Antecedentes y datos para el estudio del problema ferroviario", un trabajo realizado por la Junta Superior de Ferrocarriles, dependiente del Ministerio de Obras Públicas (Peña y Pérez: 1940). Es una magnífica recopilación de documentos legislativos, proyectos y estadísticas, dirigida por el ingeniero y ministro de Obras Públicas, Alfonso Peña Bobeuf, y por el entonces Director General de Ferrocarriles, Gregorio Pérez Conesa, que imitaba el informe de Cambó, del que se puede considerar una continuación. En su tomo IV se incluyen, por un lado, las cifras contables de las cinco principales compañías por servicios entre 1929 y 1935 y, por el otro, los datos de todas las compañías españolas en el periodo 1913-1939, pero exclusivamente de los Resultados de explotación, eso sí desagregados. También es interesante en este capítulo las "Statistique Internationale des Chemins de Fer", publicadas por la Unión Internacional de los Ferrocarriles (UIC), donde se analizan de modo comparativo diferentes compañías y empresas ferroviarias de Europa desde $1928^{44}$.

\footnotetext{
${ }^{40}$ En la Real Orden de 10 de diciembre de 1894 se recomienda a las compañías de ferrocarril el envío de los datos, en virtud del dictamen emitido por la Sección tercera de la Junta Consultiva de Caminos, Canales y Puertos, en 19 de septiembre de 1894.

${ }^{41}$ En 1918 Francisco Cambó asume durante ocho meses, de marzo a septiembre, el cargo de ministro de Fomento. Cambó desarrolló una política ferroviaria que encaró el problema con bases documentadas para llegar a una solución. Se propuso hacer un estudio previo que daría lugar a su Proyecto de Ley de Bases, que contemplaba la nacionalización de los ferrocarriles y la explotación por compañías privadas bajo el control de una comisión ferroviaria. Ese trabajo de análisis fue desarrollado por una comisión compuesta por miembros que pertenecían al mundo académico del derecho, a la ingeniería civil y a la militar, y a la administración del Estado. Cambó aparece como director del estudio. La obra consta de seis volúmenes. Originalmente tenían que haber sido cinco, pero el estallido de la Guerra Mundial alteró el plan de publicación. Los dos primeros tomos se publicaron en 1918, la guerra retrasó la publicación de los tomos cuarto y quinto a 1920. El impacto en los ferrocarriles europeos de la guerra provocó la publicación de un sexto tomo, no previsto, para actualizar y completar la información en 1921.

${ }^{42}$ Cambó explicó su visión del problema ferroviario en numerosos foros, siendo sus intervenciones reproducidas a menudo por los periódicos y revistas de la época. Una de estas revistas fue la "Revista de Economía y Hacienda", cuyo director, D. Ríu, no ocultó su simpatía por Cambó y su proyecto. También se pueden encontrar entrevistas con Cambó en la GCH y la "España Económica y Financiera". La "Revista de Obras Públicas" publicó muchos fragmentos de Elementos.

${ }^{43}$ Cambó (1921:6) explicita que "Elementos para el estudio del problema ferroviario en España" toma la información de las Memorias.

${ }^{44}$ Una ampliación de todas estas fuentes puede observarse en Martínez Vara (2003c: 108).
} 
En los apéndices del "Anuario de Ferrocarriles" de la Torre y en las monografías de Cambó y de "Antecedentes y datos para el estudio del problema ferroviario de la Junta Superior de Ferrocarriles" se incluyen documentos de muy diversa naturaleza sobre el tema ferroviario: instancias, propuestas, decretos, leyes y circulares internas.

\subsubsection{Monografias sobre el ferrocarril}

Con el cambio de siglo, y, sobre todo, a partir de la I Guerra Mundial, los trabajos de historia económica sobre el ferrocarril ganaron en rigor, incorporaron en su análisis la variable tiempo y los enfoques se hicieron más plurales, enfatizándose los aspectos jurídicos, técnicos, económicos y sociales.

Las tres obras que mejor simbolizan este progreso son: "Tratado de Ferrocarriles" de Rahola (1914-1923), "Railways of Spain" de Boag (1923) y "Estudios económicos" de Jiménez Ontiveros (1940).

El "Tratado de ferrocarriles" de Rahola ${ }^{45}$ (1914-1923) está compuesto por seis tomos:

Tomo I: Vía y obras (1914): construcción y mantenimiento de la vía.

Tomo II: Material de Transporte (1914): disposición de los vehículos, ensambles y aleaciones, suspensión, construcción de cajas, pintura, alumbrado, calefacción y ventilación.

Tomo III: Tracción vapor (1915): componentes, funcionamiento y mantenimiento de las locomotoras, calderas, vehículos y ténderes.

Tomo IV: Estaciones (1916): construcción, instalaciones de señalización, seguridad y telecomunicaciones, formación y marcha de los trenes.

Tomo V: Servicios Comerciales (1918): régimen administrativo, tarifas, contabilidad, intervención y estadística y servicios varios (sanitario, cooperativas...).

Tomo VI: Tracción eléctrica (1923): material motor, remolcado y sistemas de tracción. Tiene un capítulo dedicado a los ferrocarriles especiales: subterráneos, aéreos, de fuertes rampas y mineros.

La importancia del libro Railways of Spain de Boag $(1923)^{46}$, publicado por The Railway Gazette, es que fue uno de los escasos estudios monográficos elaborados en el exterior con cierto rigor sobre el origen y funcionamiento de nuestro ferrocarril hasta la década de $1920^{47}$.

Coincidiendo con el libro de Marquina y con "Antecedentes y datos para el estudio del problema ferroviario", vió la luz también en 1940 otra importante obra: "Estudios económicos. Transportes por ferrocarril. Principios fundamentales de economía industrial.

\footnotetext{
${ }^{45} \mathrm{~S}$. Rahola era ingeniero directivo del ferrocarril de Madrid a Cáceres y Portugal y Andaluces.

${ }^{46}$ George L. Boag nació en Manchester en 1873, y se educó en Londres. Fue director del pequeño ferrocarril minero Lorca-Baza y Diputación de Almedricos a Águilas (LBA), perteneciente a la compañía británica The Great Southern of Spain Railway Company. Boag era, asimismo, corresponsal en España de The Railway Gazette, una de las publicaciones periódicas del sector más prestigiosas e influyentes del momento.

${ }^{47}$ Fue la segunda obra extranjera referida específicamente al sector ferroviario en España. La primera fue $D e$ $l$ ' 'Éspagne et ses chemins de fer, del político internacionalista francés A.M.N. Villiaumé (1861). Muy posterior a ellos se encuentra el trabajo del italiano Fratta (1936).
} 
Política y economía ferroviaria. Electrificación de ferrocarriles-dieselización, Coordinación de transportes. Revisión de tarifas". Su autor es el abogado e ingeniero de caminos F. Jiménez Ontiveros, quien dirigía la Quinta Jefatura de Estudios y Construcción de Ferrocarriles. El libro contribuye al conocimiento de la crisis estructural de las ferroviarias. Además, Jiménez Ontiveros (1940: 348-390) se adelantó al futuro del sector ferroviario; pues entendió que en la medida que se trataban de servicios públicos, la política del Estado en esta materia había de ser "intervencionista" 48 . Para solucionar de forma definitiva el problema ferroviario, el autor propuso establecer una única sociedad pública, la "Compañía Explotadora de los Ferrocarriles Españoles", dirigida por órganos que tuvieran su propia responsabilidad en lo administrativo, pero dependiente del Estado en lo concerniente al interés nacional. La fórmula tenía muchos rasgos comunes con lo que será RENFE, el monopolio estatal, creado en la Dictadura franquista.

\subsubsection{Publicaciones periódicas especializadas en el tema del ferrocarril}

También es necesario analizar las principales publicaciones periódicas especializadas. Tras unas primeras publicaciones con carácter testimonial, rápidamente nacieron otras, desde el sector o próximas a él, con gran importancia, y cada vez con mayor interés y mejor exposición ${ }^{49}$ :

- El Semanario de Agricultura y Artes ${ }^{50}$

- Boletín Oficial de Caminos, Canales y Puertos

- La Antorcha ${ }^{51}$

- El Ferrocarril de Pontevedra

- El Despertador Montañés

- Revista de Obras Públicas ${ }^{52}$

- Gaceta de los Caminos de Hierro ${ }^{53}$

\footnotetext{
${ }^{48}$ El concepto de "intervencionismo" se manejaba, en aquellas fechas, como sinónimo de "estatificación" y "nacionalización" de las redes (Martínez Vara y de los Cobos: 2009).

${ }^{49}$ Un magnifico estudio de las principales publicaciones periódicas especializadas fue realizado por Martínez Vara y de los Cobos (2009).

${ }^{50}$ El Semanario de Agricultura y Artes, editado en Londres por el español M. Calero y Portocarrero (1829-1931) fue la primera publicación periódica especializada que trató los asuntos ferroviarios en lengua española.

${ }^{51}$ La Antorcha fue publicada por M. Cubí Soler, a raíz de la inauguración del ferrocarril Mataró a Barcelona, y el quincenal Los Ferro-carriles, de D. J. De Meniolagoitia (subdirector del ferrocarril Madrid a Aranjuez).

${ }_{52}$ La Revista de Obras Públicas nació ligada directamente al Cuerpo de Ingenieros de Caminos, Canales y Puertos y a su Escuela, y mostró, desde el primer momento, su fascinación por el nuevo y revolucionario medio de tracción y por los postulados liberales. Hubo años en que coincidieron dentro del Comité de Redacción nombres tan ilustres como Práxedes Mateo Sagasta, Eduardo Saavedra o el economista Gabriel Rodríguez. (Ramos Gorostiza y Martínez Vara, 2008).

${ }^{53}$ El semanario Gaceta de los Caminos de Hierro fue fundado 1856 en Madrid por el periodista y economista liberal F. J. de Bona. En sus páginas se trataron las cuestiones más candentes de cada momento: sistema de concesiones, carácter de servicio público, fijación de las tarifas por el Estado, subvenciones, ancho de vía o estructura de la red y problema ferroviario. En 1921 falleció J. Eloy de Bona Cortezo, tercero de la saga de los Bona, haciéndose cargo de la dirección técnica el ingeniero militar A. Riera y Gallo, primero, y Enrique de la Torre, después (Martínez Vara y de los Cobos: 2009).
} 
- Revista Peninsular-Ultramarina de Caminos de Hierro, Telégrafos, Navegación e Industria $^{54}$

- Anuario de los Ferrocarriles ${ }^{55}$

- Madrid Científico ${ }^{56}$

- Los Transportes Férreos ${ }^{57}$ y

- Ferrocarriles y Tranvías ${ }^{58}$.

\subsubsection{Publicaciones periódicas de otros sectores}

El ferrocarril estuvo igualmente muy presente en otros medios más generales como la Revista Minera, Metalúrgica y de Ingeniería, Revista ilustrada de Banca, Ferrocarriles, Industria y Seguros, la Revista Minera: científica, industrial y mercantil ${ }^{59}$, El Economista, España Económica y Financiera ${ }^{60}$, El Financiero, Revista de Economía y Hacienda, Revista Nacional de Economía ${ }^{61}$, Memorial de Ingenieros del Ejército, El Ingeniero Industrial, Revista de Montes, El Progreso Agrícola y Pecuario y, por último, Ingeniería y Construcción.

\footnotetext{
${ }^{54}$ La Revista Peninsular-Ultramarina de Caminos de Hierro, Telégrafos, Navegación e Industria apareció en 1856, al mismo tiempo que la Gaceta de los Caminos de Hierro, y desapareció en 1863. Su periodicidad fue al principio quincenal, aunque más tarde se convirtió en semanario.

${ }^{55}$ El Anuario de los Ferrocarriles comenzó a publicarse en 1893 cuando ya se había diseñada la red y estaban construidas las principales arterias. Su creador, Enrique de la Torre, era Jefe de la Sección de tasas en el Servicio de Intervención y estadística de NORTE, y posteriormente fue director de la GCH. El Anuario reúne gran cantidad de información, cuantitativa, pero también de carácter cualitativo, muy heterogénea por cierto. Gracias a él "se puede conocer, año a año, el volumen de trabajo fijo en el sector y el diseño organizativo de cada empresa, con los nombres de los a la sazón titulares de los puestos de responsabilidad" (Ballesteros y Martínez Vara, 2001a: 636-678).

56 "Madrid Científico" se fundó en 1897 a instancias del polifacético ingeniero de caminos F. Granadino, como contrapunto de la Revista de Obras Públicas, cuyo nivel era cada vez más bajo. Llevaba incorporado un suplemento titulado "El Ingeniero", donde el tema ferroviario era uno de los más socorridos. "Mantuvo un tono científico muy digno hasta su desaparición en 1936" (Martínez Vara y de los Cobos: 2009).

${ }^{57}$ Los Transportes Férreos era una publicación comercial de ferrocarriles. Apareció en Barcelona a finales de XIX, trasladándose a Madrid en agosto de 1903. Coincidió con Los Transportes. Revista de Ferrocarriles, Tranvías y Transportes por Carretera, que era el órgano oficial de los Propietarios de Vagones de España. Pese a su carácter empresarial, este medio ofreció a sus lectores noticias muy variadas de todo lo concerniente al mundo ferroviario. "Aunque mejoró con el paso de los años, las informaciones que ofrece son pobres, y no hay rúbricas" (Martínez Vara y de los Cobos: 2009).

${ }^{58}$ Cuando desaparece Gaceta de los Caminos de Hierro, su lugar es ocupado por Ferrocarriles y Tranvías (19311951). Alcanzó un nivel científico bastante respetable (Cabanes y Letón, 2003). Fue durante los años de la II República uno de los foros de debate más importantes a propósito del problema ferroviario.

${ }^{59}$ La Revista Minera dispuso de varias firmas de gran calado intelectual como Román Oriol o Juan Gómez Hemas (Chastagnaret: 1975).

${ }^{60}$ Es una de las fuentes hemerográficas con más informaciones teóricas y aplicadas, en especial tras la Gran Guerra. Dedicó atención especial a los distintos proyectos de ordenación ferroviaria y criticó con dureza la política social durante la II República. Su fundador, Rogelio Madariaga y Castro, mantuvo excelentes relaciones con las grandes compañías, en particular con E. Maristany (Martínez Vara y de los Cobos: 2009).

${ }^{61}$ La cuasi-regeneracionista Revista Nacional de Economía fue, desde su fundación en 1916 por Emilio Riu hasta su fin en 1935, uno de los medios que más espacio dedicó al asunto ferroviario, con colaboraciones teóricas y aplicadas de un amplio elenco de firmas: Eloy L. André, J. Martínez de la Fuente, J. Bores Romero, B. Vives, Pedro M. González Quijano, Pedro Barthe, etc. (Martínez Vara y de los Cobos: 2009).
} 


\subsubsection{Publicaciones periódicas europeas especializadas en el tema del ferrocarril}

El tema de los ferrocarriles españoles fue también, a menudo, noticia fuera de España, como lo demuestra la atención que le prestaron, entre otros, la revista francesa Revue Générale des Chemins de Fer ${ }^{62}$, la portuguesa Gazeta dos Caminhos de Ferro y el semanario británico The Railway Gazette ${ }^{63}$.

\subsubsection{Grandes diarios nacionales}

Las noticias sobre el tema del ferrocarril son frecuentes en los periódicos de la época, principalmente: ABC, La Época, El Debate, El Sol ${ }^{64}$, El Imparcial y La Ilustración Española y Americana.

\subsubsection{Anuarios y Estadísticas privadas}

Además de los Informes Anuales de las propias empresas, también diferentes anuarios y recopilaciones de estadísticas privadas aportan cifras sobre el sector: el Anuario Estadístico de España, el Anuario General de España (Bailly-Bailliere), las Estadísticas de Obras Públicas, publicadas por la Dirección General del mismo nombre, el Anuario Financiero y de Sociedades Anónimas y el Instituto Geográfico y Estadístico.

\subsubsection{Manuales de contabilidad}

Una de las fuentes obligatorias para conocer la contabilidad de la época son los diferentes manuales y apuntes de la época utilizados en la Escuela de Caminos. El estudio de la contabilidad era uno de los puntos fuertes de la carrera ya que se presuponía que eran los ingenieros quienes habrían de dirigir las compañías, como de hecho sucedió (además de conocimientos en contabilidad también se impartían de derecho mercantil y administrativo). Los más destacados son los trabajos del Ingeniero de Caminos, Canales y Puertos Domingo Mendizábal Fernández (1920a; 1920b; 1924) ${ }^{65}$, Carlos de Orduña y Zarauz, y el profesor de la Escuela de Caminos Federico Reparaz $(1934)^{66}$. Por su parte, Martín Rodríguez $(2006 ; 2007)$ publicó un buen estudio sobre la asignatura de Economía Política en la Escuela de Caminos

\footnotetext{
${ }^{62}$ Coincidente con las inversiones exteriores se produjo en España una colonización cultural. Al principio el influjo de Francia, de donde vino la mayor parte de las inversiones, resultó abrumador. La prensa gala tenía, además, la ventaja añadida de que el grueso de la documentación primigenia estaba en francés.

${ }^{63}$ En Gran Bretaña las referencias a España fueron cada vez más frecuentes por parte del prestigioso semanario The Railway Gazette.

${ }^{64}$ En el periódico El Sol participaba frecuentemente L. Olariaga. Un buen compendio de su pensamiento al respecto, puede localizarse en Olariaga (1921: 243).

${ }^{65}$ Mendizábal, además de profesor de contabilidad de dicho centro, fue directivo de MZA. Cuando fue Director del servicio de Material y Tracción de MZA, de él dependía el Taller Central (Martínez Vara, 2007).

${ }^{66}$ Reparaz fue profesor de Economía Política de la Escuela de Caminos, y posteriormente fue el primer Secretario General de RENFE.
} 
entre 1855 y 1936, siendo su consulta fundamental. Siempre dejando claro que los textos españoles distaban mucho de los excelentes manuales escritos en Estados Unidos.

A esto hay que añadir los manuales de contabilidad, dirigidos para todos los sectores, pero que ofrece un capítulo específico para la contabilidad de las ferroviarias, como el de Jesús de Aragón (1942: Libro Noveno).

Además, existieron trabajos publicados en las revistas especializadas de la época sobre algún aspecto de la contabilidad de las ferroviarias españolas, entre ellos destacan los realizados por Pelayo (1871a; 1871b) sobre la contabilidad del material durante el periodo de su construcción.

\subsubsection{Investigaciones posteriores sobre la historia ferroviaria}

Los estudios históricos que en todos los países industrializados se han venido publicando para avanzar en el conocimiento del sector ferroviario desde distintas perspectivas son muy numerosos, debido a la importancia del ferrocarril en el desarrollo económico de los países. En este sentido, abundan los trabajos de dicho sector circunscritos al área de la Historia Económica en España. Sin embargo, no son tantos los que han abordado el estudio de los modelos de gestión y el examen de la contabilidad de las compañías ferroviarias.

Muchos investigadores han centrado su atención en la historia del ferrocarril, ya sea como objeto de investigación principal o como referente inevitable en un análisis más general, tanto en términos cualitativos y cuantitativos. La importancia de los cambios e innovaciones llevados a cabo desde el comienzo del ferrocarril han sido analizadas por los historiadores económicos como Fogel (1964), Gourvish (1980), Caron (1973), O’Brien (1983) y Chandler (1987).

También el ferrocarril español es, como en casi todas partes, uno de los sectores más estudiados; por sólo mencionar algunos nombres Tortella (1973), Nadal i Oller (1975), Anes Álvarez (1978: 355-512), Artola (1978: 341-453), Cordero y Menéndez (1978: 163-341), Anes (1978: 355-512), Tedde de Lorca (1978; 1996), Gómez Mendoza (1982), Muñoz Rubio (1995), Comín, et al. (1998: 367-410), Comin (1998: 255-272), Muñoz Rubio y Vidal Olivares (2001), Herranz (2004), Cuéllar (2007a) y Herranz (2008). La mayoría de estos autores españoles han tratado con mucha profundidad aspectos que aquí dejamos a un lado: el origen y desarrollo de la red, el crecimiento de las compañías, las relaciones de éstas con el Gobierno, y asuntos tan específicos como enlaces y perfiles de las líneas (marcados por la complicada orografía del país), el ancho de vía ${ }^{67}$ o la estructura radial de la red ${ }^{68}$. Estos autores han dejado estos temas inmejorablemente tratados.

\footnotetext{
${ }^{67}$ Para observar los argumentos a favor o en contra del ancho de vía ibérico o el de 2,10 metros con la que en 1836 Brunel construyó el Great Western Railway véase Cordero y Menéndez (1978: 185). El ancho de vía ibérico de 6 pies castellanos (1,67 metros) fue establecido por la Real Orden de 1988, de acuerdo con el Informe de la Comisión de ingenieros. El ancho ibérico no fue adoptado por exigencias de los militares -como a veces se escribe- sino porque así lo aconsejaban los autores del "Informe Subercase", basándose en razones técnicas y
} 
Un aspecto característico de esta investigación es la perspectiva comparada de NORTE con MZA; anteriormente esto había sido realizado por Tedde (1978: cap. 1), Cordero y Menéndez (1978: 163-338), Comin, et al. (1998), Ortúñez (1999a) (1999b), Vidal y Ortúñez (2002) y de los Cobos y Martínez Vara (2009).

El mejor análisis económico de ambas compañías fue realizado por Tedde (1978). La presente investigación lo continúa cuarenta años después, pero centrando el análisis en la información contable, en la estructura organizativa de la empresa y en las decisiones internas de gestión.

\subsubsection{Investigaciones posteriores sobre la estructura de la propiedad, la organización y la gestión de las ferroviarias}

A pesar de que el ferrocarril español es uno de los sectores más estudiados, la estructura de la propiedad, la organización y la gestión, por un lado, y los criterios de contabilización y registros contables, por otro, son asuntos de los que más se desconoce aún.

Los historiadores han dedicado al tema ferroviario una atención preferente y han polemizado entre ellos sobre los más diversos temas. Ahora bien, en esta eclosión de trabajos no ha habido, hasta ahora, espacio suficiente para la gestión. Respecto a la estructura de la propiedad, de la organización, de las modernas formas de gestión empresarial y la formación de los directivos, se ha ocupado casi exclusivamente Vidal Olivares (1995a; 1995b; 1996; 1997; 1999); sus estudios se ocupan tanto de la gran empresa ferroviaria en general, como de la Compañía de los Caminos de Hierro del Norte de España en particular. La estructura organizativa de MZA fue estudiada por Ortúñez (1993) y Santos; Santos y Fidalgo (2011a).

\subsubsection{Investigaciones posteriores sobre la contabilidad de los ferrocarriles}

Los estudios sobre la contabilidad de las compañías ferroviarias han sido más frecuentes que sobre la estructura organizativa y de gestión. Esto se debe a que entre los investigadores está consensuado el pensamiento de que la contabilidad moderna le debe mucho a las ferroviarias.

\footnotetext{
económicas. La recomendación equivalía a tener un ancho de vía sólo igual al utilizado por Portugal, y por tanto diferente al del resto de países europeos; según estos autores, para el desarrollo de las técnicas de la época, era más adecuada una separación mayor de los carriles, pues permitiría usar locomotoras más potentes, lo que era recomendable en un país montañoso como España. Otra cosa es que el motivo técnico fuese apoyado por el estamento militar, en el que estaba extendida la idea de que un ancho de vía diferente dificultaría una hipotética invasión del país por ejércitos extranjeros. Lo que es indudable es que la medida -muy criticada a lo largo de la historia- tuvo posteriores repercusiones negativas en las relaciones internacionales de nuestro ferrocarril.

${ }^{68}$ Para el directivo británico G. L. Boag (1923), la estructura radial de la red era la que mejor se ajustaba a los flujos del tráfico pues en la periferia se encontraban los mayores núcleos urbanos. Barquín (2016: 313) muestra como la red de carreteras era más radial que la de ferrocarriles, pues algunas líneas ferroviarias estaban ausentes de las rutas principales y otras daban grandes rodeos hasta llegar a su destino. El mismo autor afirma que los graves errores en el diseño de la red se debieron en parte a que la política de subvenciones primó el tendido de railes frente a la realización de las grandes infraestructuras, como túneles y puentes.
} 
En el plano internacional destacan las contribuciones a la contabilidad financiera de Edwards (1985; 1986b) sobre el origen y evolución del sistema de partida doble en las ferroviarias, de Brief (1966) y Edwards (1986a; 1986b) sobre los procedimientos de amortización que se practicaron en las ferroviarias inglesas, de Edwards (1989) acerca de la valoración de los inmovilizados, y por último, de Richard (2006: 2) sobre la importancia de los costes históricos en el registro de las ferroviarias de la Europa continental. Por otro lado, Heier (2000) analizó la contabilidad de gestión de las ferroviarias.

Destacables son los trabajos sobre las prácticas contables de las ferroviarias realizadas por Glynn (1984) acerca de las empresas británicas durante el siglo XIX y principios del XX, Pollins (1952a; 1952b; 1956) y Heier (2009) de las estadounidenses durante el siglo XIX, Lardner (1850) de las europeas y norteamericanas del siglo XIX y Lemarchchand (1993; 1994) de las francesas del siglo XIX.

Entre los trabajos que analizan la contabilidad de las compañías ferroviarias españolas, en general, se deben citar los de Montoya (2011) y Montoya y Guzmán (2011b; 2012). Por su parte la empresa MZA fue analizada por Fidalgo y Miranda (2006), Villacorta y Martínez (2009), Santos et al. (2011a; 2011b; 2012), Fidalgo et al. (2015) y Benito (2015; 2017); Andaluces por Blasco et al. $(2014 ; 2015)$; El Ferrocarril de Asturias, Galicia y León por Montoya y Guzmán $\left(2011\right.$ b; 2012); y la contabilización de un subconstratista ${ }^{69}$ de un tramo de Madrid-Valladolid por parte de Rodríguez (2012). La principal empresa estudio de esta investigación, NORTE, fue analizada anteriormente por Montoya y Guzmán (2011a) y Bentabol et al. (2011).

\footnotetext{
${ }^{69}$ En ocasiones, las construcciones se subcontrataban a empresarios constructores por parte de la compañía titular de la concesión.
} 


\section{CAPÍTULO SEGUNDO.- AVANCES ORGANIZATIVOS Y CONTABLES EN LAS FERROVIARIAS}

El ferrocarril proporcionó la tecnología de transportar un volumen de bienes sin precedentes a una velocidad nunca vista, y además de hacerlo de un modo programado, no en términos de semanas o meses, sino de días e incluso horas.

Las empresas de ferrocarriles pueden compararse con grandes grupos industriales cuyas sucursales son las distintas estaciones establecidas en sus líneas, y "los corresponsales pueden asimilarse a las demás compañías con las que combinan los servicios" (Torrents y Monner, 1885: 531).

Los sistemas ferroviarios de los países desarrollados comparten cuatro rasgos característicos: el interés y participación del Estado desde los primeros momentos, el surgimiento de las primeras instituciones corporativas de la historia, la consecución casi inmediata de la mayoría del mercado del transporte y, por último, la posterior pérdida de una gran parte del volumen de transporte por la competencia del transporte por carretera.

En el segundo capítulo analizamos la evolución del ferrocarril en los países que más lo desarrollaron -Estados Unidos, Reino Unido, Alemania y Francia-, incidiendo sobre cuatro aspectos:

- Nivel de separación de la propiedad y la gestión; aspecto fundamental porque es posible advertir que progresivamente se han reforzado los poderes de los management a costa del poder asambleario, con la supuesta finalidad de lograr una mayor eficiencia en la toma de las decisiones.

- Desarrollo del sistema de información administrativo-contable.

- Modo de financiar las necesidades de recursos.

- Nivel de descentralización, pasando de un sistema Departamental centralizado a un sistema Divisional, con una diferenciación entre línea y staff.

A lo largo de la historia ferroviaria, es posible identificar dos modelos de organización: "Modelo departamental centralizado" y "Modelo científico"70. En todos los países existió una evolución del "Modelo departamental centralizado" al "Modelo científico", aunque con diferentes tiempos y velocidades.

\footnotetext{
${ }^{70}$ Al modelo más avanzado no le denominamos "chandleriano", porque en ese caso "sólo tendría validez en Estados Unidos" (Vidal Olivares, 1997: 48). El modelo "chandleriano" se caracteriza por la relación secuencial: compañías ferroviarias-organización científica de la gestión-formación de directivos-gran empresa corporativacrecimiento industrial basado en la gran empresa multidivisional. El "Modelo científico" sólo comparte dos rasgos con el "chandleriano": organización científica de la gestión y esquema organizativo multidivisional. Además no es secuencial, pues en otros países tuvo un orden distinto a como fue en Estados Unidos; en algunas empresas del resto de países tuvo una evaluación diferente incorporando el segundo rasgo antes que el primero.
} 
El "Modelo departamental centralizado" era típico de la Europa continental, sobre todo de Francia, y llegó a España por las empresas matrices francesas a mediados del siglo XIX cuando se constituyeron las compañías españolas, muchas veces filiales de aquellas. Sus características fundamentales son la centralización en la toma de decisiones y la división de la empresa en departamentos.

El "Modelo científico", originario del mundo anglosajón, está caracterizado por dos rasgos: organización científica de la gestión y esquema organizativo multidivisional. La organización científica de la gestión consiste en la recopilación de estadísticas e informes para la toma de decisiones, en la elaboración de un sistema de control contable para racionalizar los gastos y mejorar los beneficios y en la adopción de métodos estadísticos complejos para la toma de decisiones. Por su parte, el esquema organizativo multidivisional se aplica cuando una empresa crece, se diversifica e incrementa su complejidad. Con este modelo, la empresa se divide en unidades organizativas que funcionan de forma casi autónoma estando coordinadas por una dirección central. Cada subunidad se asemeja a empresas independientes que son coordinadas y controladas por la dirección general.

\subsection{Estados Unidos}

La extensión geográfica de Estados Unidos, unida a la gran distancia entre los centros urbanos, produjo la necesidad de construir una longitud férrea mucho mayor que en el resto de países industriales ${ }^{71}$. El funcionamiento eficiente de esta infraestructura requería una serie de innovaciones, tanto tecnológicas, como organizativas y contables.

\subsubsection{Diferencias entre la organización y gestión de los ferrocarriles estadounidenses y españoles en el periodo 1900-1924}

En el periodo 1900-1924 existían diferencias tecnológicas entre los ferrocarriles estadounidenses y españoles ${ }^{72}$, derivadas de su trazado, inmovilizados y equipamientos:

\footnotetext{
${ }^{71}$ Cuando transcurría el año 1860, en Estados Unidos se habían construido 30.000 millas de vías férreas cuando en Gran Bretaña se habían construido poco más de 9.000, mientras que en 1880, las cifras eran de 93.292 para Estados Unidos, 15.563 para Gran Bretaña, 21.000 en Alemania y 14.500 en Francia En 1910 eran los siguientes: 240.000 en Estados Unidos, 20.000 en Gran Bretaña, 38.000 en Alemania y 25.200 en Francia. Estos datos fueron aportados por Chandler (1990: 84).

${ }^{72}$ Para comparar los rasgos característicos de los ferrocarriles estadounidenses y españoles en el periodo 19001924, la mejor fuente es acudir a los escritos de Maristany tras asistir al VII Congreso Internacional de Ferrocarriles celebrado en Washington. Aunque acabara de acceder a la Dirección de MZA, Maristany era ya en estos momentos un personaje muy conocido fuera y dentro del país por haber realizado, en su época de TBF, una obra compleja de ingeniería, el túnel de Argentaria de cuatro kilómetros, que le granjeó "un gran prestigio internacional" (Martínez Vara, 2011: 93). A su regreso, escribió un libro que tuvo gran resonancia, titulado "Impresiones de un viaje a Estados Unidos", donde Maristany (1905) detallaba sus observaciones respecto de la construcción y explotación de los ferrocarriles estadounidenses, cuya forma de explotación y gestión admira. El libro fue reproducido al año siguiente por la Revista de Obras Públicas (Maristany, 1906a, 1906b; 1906c). No fue el único caso en el que Maristany demostró conocer muy bien lo que sucedía en otros países. En 1911 realizó un extenso y meticuloso estudio comparativo sobre los conflictos ferroviarios en diferentes países (Maristany:
} 
mayor flexibilidad, gracias al empleo de las curvas de pequeño radio; mayor estabilidad de la vía, a causa del superior número de buenas traviesas sobre las que se asentaba; mayor suavidad del movimiento del material móvil, debida a los bogies que tenían los coches y vagones de tipo americano y, por último, mayor confianza en los trenes, debido al freno automatico por aire comprimido.

A estas diferencias hay que unir otras cinco, derivadas de la organización y gestión de los ferrocarriles: la financiación en Estados Unidos estaba basado en acciones, con gran importancia de las privilegiadas, además, muchas de estas acciones eran cotizadas, que eran rasgos no frecuentes en las ferroviarias europeas de la época, en tercer lugar existía una diferente concepción del poder respecto a lo usual en las ferroviarias europeas continentales de la época, pues el poder residía en el Consejo de Administración más que en la Junta de Accionistas, en cuarto lugar, utilizaban modelos organizativos y de gestión muy desarrollados, y además existía una decidida aplicación de la Organización Científica del Trabajo en los talleres, y por último, existía una influencia de los militares en la formación de los directivos y en la organización de las empresas.

\section{a) Capital basado en acciones, con gran importancia de las privilegiadas}

En Estados Unidos la financiación con acciones estaba equilibrada con los empréstitos, lo cual se parecía a lo que acontecía en Inglaterra. Ello difiere de lo que ocurría en España, Francia y el resto de países europeos continentales, en las que existía un notable predominio de los empréstitos sobre el capital (Maristany, 1906c: 55).

En Europa continental existía un único modelo de obligaciones, ya sea de carácter personal, como en Francia, o de carácter hipotecario, como en España. Por el contrario, en Estados Unidos las principales compañías poseían cuatro tipos: obligaciones hipotecarias similares a las que financiaban los ferrocarriles españoles (lo que suponían alrededor del 80\%); obligaciones diversas, formadas por un gran número de clases; obligaciones que tenían como única garantía el material móvil de la compañía; y por último, unas obligaciones cuyo único "seguro es el beneficio líquido de la compañía" (Maristany, 1906c: 56), puesto que sólo serán atendidas después de haber satisfecho todas las cargas, lo cual les confiere similitudes con las acciones privilegiadas sin derecho a voto.

También existían diferencias en la amortización de las obligaciones. En la Europa continental las concesiones del ferrocarril eran concedidas por un tiempo determinado. Para amortizarla periódicamente se utilizaban anualidades, cuadros prefijados en la emisión o sorteos. Por el contrario, en Estados Unidos las concesiones eran a perpetuidad, por lo que al no existir una necesidad de amortización progresiva, no se utilizan estos métodos. Cuando se realizaba una emisión de empréstitos, el único compromiso que se adquiría era que la emisión estuviera amortizada en ese momento. Durante ese periodo se iba constituyendo un fondo de rescate

1911). En 1925, Maristany publicó en la Revista de Obras Públicas, un largo artículo donde compara el régimen ferroviario de Francia, EE. UU. y Gran Bretaña con el español tras la aprobación del Estatuto (Maristany: 1925). 
para que al finalizar la vida del empréstito la emisión estuviese totalmente amortizada (Maristany, 1906c: 56).

Respecto a las clases de acciones, el capital de las compañías estadounidenses -e inglesasestaba formado tanto por acciones ordinarias como privilegiadas, lo cual difiere mucho de lo que sucedía en la Europa continental, donde se financiaba casi exclusivamente por acciones ordinarias $^{73}$.

\section{b) Gran parte de las acciones eran cotizadas}

Las ferroviarias estadounidenses fueron las primeras empresas financiadas por los instrumentos financieros modernos (Chandler, 1965: partes II, IV, V y VI).

Las sociedades ferroviarias contribuyeron a la centralización del mercado de capitales estadounidenses en la ciudad de New York en la década que comenzó en 1850 (Chandler, 1977: 179). Y así continuó en los años posteriores. En el periodo 1890-1900, los títulos de Wall Street se utilizaron casi exclusivamente para financiar los ferrocarriles, tanto es así que casi todos los valores negociados en la Bolsa de Nueva York eran de ferrocarriles y de empresas estrechamente vinculadas a ellas.

Otra parte de la financiación de los ferrocarriles en el siglo XIX se realizó por medio de los grandes bancos de inversión como J.P Morgan, Kuhn Loeb, Lee Higginson, Kidder Peabody y Wislow Lanier (Chandler, 1990: 91).

\section{c) Diferente concepción del poder}

En Estados Unidos el poder claramente estaba en los Consejos de Administración, y especialmente en sus presidentes y vicepresidentes. Ellos podían tomar ciertas decisiones sin necesidad de acuerdos con los accionistas: fijar dividendos, emitir empréstitos, aumentar o disminuir capital social, e incluso adquirir líneas o fusionar las suyas (Maristany, 1906c: 56). Todas estas decisiones en Europa, por lo menos aparentemente, era de incumbencia exclusiva de la Junta General de Accionistas.

En esa época, el presidente del Consejo de Administración, poseía el poder ejecutivo, pero también el poder legislativo representado por la Junta General de Accionistas. Esto era más práctico, aunque "chocaba con la separación de poderes de la cultura europea" (Maristany, 1906b: 25).

En Estados Unidos había varios consejeros o administradores, denominados vicepresidentes, que eran los verdaderos directores de los principales servicios del ferrocarril, y que desempeñaban un papel verdaderamente activo. El Consejo de Administración era más bien

\footnotetext{
${ }^{73}$ El hecho de que las empresas ferroviarias de Estados Unidos de América y el Reino Unido de la Gran Bretaña se financian mayoritariamente de acciones ordinarias y privilegiadas, mientras que las de la Europa continental por acciones ordinarias, es señalado por Maristany (1906a: 2-6; 1906c: 55) y Morrison y Wilhelm (2007: 176).
} 
una reunión de directores que administraban y dirigían todos los asuntos del ferrocarril bajo las órdenes del presidente que hacía las veces de Director general, y que en palabras de Maristany (1906b: 25), era un "verdadero dictador de la compañía". No existía por tanto la separación que existía en Europa entre el Consejo de Administración y la Dirección de las compañías. En Europa el Consejo desempeñaba una función más pasiva, de inspección, consejo o alta dirección, pero no ejecutaba; frente a ello, en Estados Unidos, el Consejo hacía las dos cosas a la vez (Maristany, 1906b: 25).

\section{d) Modelos organizativos y de gestión muy desarrollados}

En Europa, el servicio financiero se limitaba a las operaciones de pago de cupones, amortizaciones, renovaciones de las hojas de cupones y similares. Por su parte, en Estados Unidos era frecuente que las compañías hicieran operaciones de compraventa especulativa en bolsa con acciones de otras empresas, e incluso, "con las propias acciones y obligaciones que tienen en cartera" (Maristany, 1906b: 25). Las empresas consideraban esto como un medio de preparar la absorción de otras líneas o la fusión con otras compañías.

Las empresas estadounidenses estaban organizadas de forma que los servicios comerciales y financieros -incluído el servicio de contabilidad, caja e intervención de productos- estaban exageradamente centralizados en manos de los trabajadores que manejaban el dinero. Por el contrario, los servicios llamados técnicos estaban muy descentralizados e incluso algunos empleados tenían campo libre para sus iniciativas, teniendo "gran responsabilidad de sus actos" (Maristany, 1906b: 26), existiendo sobre ellos un "menor número de reglamentaciones" (Maristany, 1906c: 60).

En los ferrocarriles estadounidenses se da mucha más libertad a la explotación comercial, en manos del presidente (Maristany, 1906c: 60), y teniendo por debajo un gran número de agentes que negociaban el transporte como cualquier comisionista de empresas comerciales.

Las compañías estadounidenses no presentaban una organización uniforme de los servicios (Maristany, 1906b: 25), como resultaban de una aglomeración constante y progresiva de redes pequeñas mantenían cierta autonomía. Así también lo hizo MZA al fusionarse con TBF, todo lo contrario que hizo NORTE con sus fusiones. No es el único elemento en que MZA coincide con los ferrocarriles estadounidenses, pues ambos circulan por la derecha, mientras que NORTE y la mayoría de compañías europeas circulan por la izquierda (Maristany, 1906b: 28).

En igualdad de condiciones, las compañías estadounidenses tenían la mitad de empleados por kilómetro de línea que los europeos ${ }^{74}$. De todos los servicios, el de Movimiento era el que presentaba más escasez de personal. Maristany (1906b: 26) describió como en las estaciones intermedias apenas había jefes de estación, ni guardagujas ni mozos. Esto se debe a que el personal de los trenes era el encargado de la seguridad de la marcha. Por tanto, en Estados

\footnotetext{
${ }^{74}$ Maristany (1906b: 26) afirmaba que las grandes redes europeas presentan entre 8 y 10 empleados por kilómetro, frente a los 4 o 5 por kilómetro en Estados Unidos.
} 
Unidos el personal de los trenes era más numeroso que en Europa, mientras que el personal de las estaciones es más reducido en Estados Unidos ${ }^{75}$.

\section{e) Aplicación de la Organización Científica del Trabajo en los talleres}

La expresión Organización Científica del Trabajo equivale al concepto en idioma inglés scientific management (o scientific administration). Es el conjunto de técnicas cuyo objeto es la racionalización del trabajo para el logro de una Dirección más eficaz (Instituto Nacional de Racionalización del Trabajo, 1962: 55).

En los primeros años del siglo XX, muchas empresas de Norteamérica iniciaron con éxito en sus fábricas la reorganización del trabajo siguiendo los criterios establecidos por los expertos en eficiencia. El concepto de eficiencia se resume en la búsqueda del máximo rendimiento producido en el menor tiempo posible, lo que significaba el culto al menor consumo posible de energía, trabajo y capital durante el proceso de producción. El medio para conseguirlo pasaba indefectiblemente por la racionalización de los procesos productivos. Entre los expertos en eficiencia destacan Carl G. Barth, H.K. Hathaway, Stanford E. Thompson, Frank B. Gilberth, Henry L. Gantt, Morris L. Cooke y, el más relevante, Frederick W. Taylor. Todos ellos eran ingenieros descontentos con los métodos de dirección de las empresas tradicionales en un momento de gran avance tecnológico.

El término, acuñado por Taylor y sus seguidores, scientific management es la plasmación empírica de esa preocupación por utilizar racionalmente los recursos humanos y aprovechar al máximo el tiempo y la energía, mediante un conjunto de reglas basadas en la experiencia para la dirección de fábricas y talleres, entre las que se incluyen desde la disposición de los locales e instalación de maquinaria hasta los principios de contabilidad para calcular el coste y determinar la amortización. Taylor sostenía que con su sistema crecían los beneficios, aumentaba la productividad y desaparecían las divisiones de clase $\mathrm{y}$, con ellas, los conflictos laborales, pues él pensaba que los verdaderos intereses de asalariados y patronos eran idénticos.

Taylor realizó experimentos de métodos de control de costes y tiempos de producción, los cuales se convirtieron en "fuente de inspiración" (Nelson, 1992: 9) para quienes equiparaban el progreso industrial y social con el aumento de la eficiencia. Taylor publicó dos obras fundamentales: Shop Management (1903) y The Principles of Scientific Management (1911). En la primera, se centró en las técnicas de racionalización del trabajo a través del estudio de tiempos y movimientos y en sistemas de pagos por rendimiento a los trabajadores. En la segunda, analizó que dicha racionalización debía ir acompañada de una estructura general de la empresa, un sistema de organización científica del trabajo que hiciera coherente la aplicación de sus nuevos principios.

\footnotetext{
${ }^{75}$ Esta diferencia es descrita detalladamente por Maristany (1906b: 26).
} 
La Organización Científica del Trabajo se introdujo muy pronto en las empresas industriales norteamericanas. Cuando Taylor muere, en 1915, la Organización Científica del Trabajo se había convertido en realidad en unas 200 empresas norteamericanas, y seguiría extendiéndose a toda la economía a lo largo del periodo de entreguerras y durante los años de la Segunda Guerra Mundial (Martínez Vara y de los Cobos, 2014, 79). Sin embargo, en la industria ferroviaria su implantación fue limitada a los grandes talleres de construcción de material ferroviario y, en menor medida, a los grandes talleres de reparación de material rodante dependientes de las compañías ferroviarias (Martínez Vara y Ramos, 2015a: 84).

La primera gran experiencia en los talleres ferroviarios fue llevada a cabo en Topeka (Kansas) por Harrington Emerson, discípulo y colaborador de Taylor. En 1904, el Atchison, Topeka and Santa Fe Railway le contrató para introducir en dichos talleres -que eran los mayores de la red- el scientific management ${ }^{76}$. Con ello, la compañía buscaba, sin incrementar la inversión, reducir los costes de reparación, aumentar la eficiencia de los equipos y del trabajo. Emerson presentó un plan completo de "gestión científica" que suponía: un incremento de la especialización y la estandarización; la centralización de los equipos y de las grandes reparaciones; un nuevo método de retribución que combinaba el salario por hora con un bonus basado en los estudios de tiempos (que sería muy criticado por trabajadores y sindicatos hasta su desaparición en 1918); y un sistema programado de reparaciones.

La segunda experiencia significativa en los talleres ferroviarios fue llevada a cabo por otro discípulo de Taylor: Henry Laurence Gantt en los talleres de la Canadian Pacific.

La tercera gran experiencia en los talleres ferroviarios fue realizada por Henry Ford en 1921. Para entonces Ford ya había puesto en marcha en Detroit el sistema de ensamblaje de su automóvil modelo T. Ford por medio de la Organización Científica del Trabajo: control de tiempos y movimientos, estandarización de herramientas y condiciones laborales, división del trabajo, separación de la concepción y dirección de la ejecución de las tareas, selección científica de las plantillas y formación de acuerdo con bases científicas ${ }^{77}$. En 1921, Ford se hará cargo del Detroit, Toledo and Ironton Railroad al que aplicará las mismas técnicas.

En Europa, la difusión del taylorismo fue hasta entonces un fenómeno aislado, pues no se habían dado las condiciones idóneas para ello. El primer ingeniero europeo que aplicó las ideas y técnicas tayloristas fue el francés Marcel Bloch, jefe del servicio de Material y de los Talleres del Ferrocarril París-Orleáns. Tras un viaje a Estados Unidos, aplicó métodos tayloristas en los talleres de Tours y Périgueux desde 1912, llevando a cabo incluso una reforma de la contabilidad (Caron, 2003: 203). En los años treinta, su aplicación ya se había generalizado en los talleres franceses de reparación de material móvil y motor ${ }^{78}$.

\footnotetext{
${ }^{76}$ La experiencia de Topeka fue analizada por Graves (1981: 124-131).

${ }^{77}$ La aplicación de la Organización científica del trabajo sobre las fábricas de Ford es analizada por Valdaliso y López (2009: 314).

${ }^{78}$ Así lo expuso en un meticuloso informe la comisión española de expertos de NORTE que, en el transcurso de 1933, visitó para su estudio diversos establecimientos de las ferroviarias francesas, entre ellas, Epernay, Hellemmes, Oullins, Tours y Perigueux (Martínez Vara y Ramos, 2015a: 87).
} 
Al igual que en Estados Unidos y Francia, en España la racionalización del trabajo en los ferrocarriles no fue fruto de una decisión concreta, sino el resultado de un proceso acumulativo que se fue desarrollando con el paso del tiempo (Martínez Vara y Ramos, 2015a: 106). En España no hubo retraso en la divulgación de la idea ${ }^{79}$, pero sí un gran retraso en la materialización práctica de los principios de la administración científica del trabajo al sector ferroviario, con especial atención al caso de los talleres de grandes reparaciones. Tanto que se puede afirmar que antes de 1939, el scientific management en España fue más teórico que práctico (Mallart, 1942: 76).

Para analizar los factores que impidieron la adopción y el desarrollo del scientific management en España es necesario distinguir entre los que hubo hasta la I Guerra Mundial y los que hubo después de ella. En los primeros años de siglo XX, existía un relativo atraso económico y tecnológico del país (Martínez Vara y de los Cobos, 2014: 95); con predominio de empresas de pequeño tamaño, con estructuras organizativas atrasadas y una gestión poco profesionalizada (Carreras y Tafunell, 1993) (Fernández Gómez, 1996: 470) (Martínez Vara y Cobos, 2014: 82, 95) (Martínez Vara y Ramos, 2015a: 81); un reducido número de ingenieros en relación con la población (Guillén, 1994, pp. 165-167); y, por último, la oposición de parte de los trabajadores (Ibáñez Ortega, 2011). A estos factores, hay que añadir que la difícil situación económica de las empresas ferroviarias al final de la I Guerra Mundial no era propicia para ensayar nuevos métodos de gestión que aumentaran la eficiencia: sobre todo porque al estar próximas el vencimiento de las concesiones, estaban acuciadas por una alarmante falta de inversiones (Tedde, 1978: 210-231; Comín, et al., 1998: 355-367); presentaban una conflictividad laboral preocupante (Plaza: 2012); y por último, los resultados de la explotación eran muy malos, debido al incremento de los costes laborales y al elevado nivel de los precios del combustible. Por todo ello, los gerentes españoles no tuvieron mucho margen de actuación a la hora de ensayar unos métodos que implicaban inversiones fuertes.

La primera experiencia divulgativa para incorporar estas medidas en España tuvo como pionero a un ingeniero de la compañía NORTE. Vicente Burgaleta (1917) escribió un artículo decisivo para el desarrollo de la idea en España ${ }^{80}$, en un momento en que el contexto general

\footnotetext{
${ }^{79}$ Respecto a la cuestión de la recepción y divulgación de los principios de la organización científica del trabajo en España, hay un consenso bastante generalizado en considerar que tuvo lugar prácticamente al mismo tiempo que en los países más industrializados (Martínez Vara y Ramos, 2015a: 3).

${ }^{80}$ Vicente Burgaleta, hijo del que fuera jefe de Tracción en NORTE y profesor de Mecánica Racional en la Escuela Central de Ingenieros Industriales, formó parte de la primera promoción (1913) de ICAI (Universidad de Comillas), con cuyo fundador, J.A. Pérez del Pulgar, realizó alguna publicación a propósito de la presencia de A. Einstein en España, cuyas teorías admiraba. Como accionista de NORTE intervino en la junta de accionistas de 1923, acusando con dureza a los directivos de ser los responsables de los malos resultados económicos [Archivo Histórico Ferroviario (AHF), S/15/44 bis]. En 1926 fue nombrado presidente de la Comisión de reforma de la enseñanza Industrial por el ministro de Trabajo E. Aunós. En 1927 emigró a Bolivia, donde fue jefe de tracción e ingeniero jefe de Vías y Obras del Ferrocarril a los Yungas, llegó a ingeniero-director de Teléfonos Automáticos de La Paz. Simultáneamente, desarrolló su trabajo en la Universidad Mayor de San Andrés, donde enseñó varias materias en la Escuela de Ingeniería Civil (que también dirigió) y en la Facultad de Ciencias Económicas y Financieras. Estas referencias aparecen en el trabajo de Martínez Vara y de los Cobos (2014: 84). La paradoja es que fue uno de los pioneros de la OCT en 1917, y sin embargo, pasó a ser desterrado en 1926.
} 
del país era muy relevante. La Gran Guerra había provocado una espiral inflacionista a la que siguió una enorme conflictividad social que tuvo uno de sus epicentros en NORTE, concretamente en el servicio de Material y Tracción, del que Burgaleta era inspector. Él pensaba que el conflicto entre empresa y sindicatos tenía su origen en la falta de estímulo para el trabajo, que se había originado por una defectuosa organización y remuneración del mismo, a la vez que por una relajación disciplinaria. Para el autor, la única solución para estimular directa o indirectamente a los trabajadores era "entrar de lleno en la organización científica del trabajo" (Burgaleta: 1917). En su opinión, muchos ingenieros ferroviarios habían oído hablar de los métodos de Taylor, pero muy pocos los habían comprendido en profundidad y menos aún los habían tratado de aplicar. El autor estableció las normas generales que debían implementarse en los talleres ferroviarios "para desarrollar en el obrero la confianza en sí mismo y estimularse en su trabajo" (Burgaleta: 1917): medición de tiempos y descomposición de tareas, tarificación de las diversas operaciones elementales, establecimiento de un jornal mínimo que solo remunerase la presencia, haciendo depender del trabajo efectuado el resto, elección del personal apropiado, contabilidad rigurosa, desaparición del trabajo por equipos, etc. (Martínez Vara y Ramos, 2015a: 91). Estas medidas eran "una reproducción mimética de las recetas tayloristas" (Martínez Vara y de los Cobos, 2014: 85).

El año siguiente, del 20 al 27 de enero de 1918, se celebró la Asamblea Nacional de Ferrocarriles. En una Ponencia, Burgaleta (1918) establecía las tres medidas para evitar, de una vez por todas, las enormes coacciones y amenazas realizadas por los sindicatos en 1916 y 1917 contra la empresa NORTE. La primera era dotar al personal del ferrocarril de la instrucción social y profesional adecuada. La segunda era confiar las inspecciones únicamente a técnicos de gran cultura económica y social. Por último, y más importante, adoptar los métodos Taylor en la organización del trabajo, tanto en lo referente a útiles y mecanismos como en lo tocante a la contabilidad y remuneración del trabajo, "tendiendo siempre a que el obrero perciba directa e inmediatamente los beneficios de su esfuerzo individual" y relegando el trabajo por equipos a los casos en que sea estrictamente indispensable ${ }^{81}$.

El primer intento relevante ${ }^{82}$ de realizar una experiencia práctica sobre los talleres ferroviarios fue la realizada por D. Mendizábal en 1924, en el recién creado, por parte de MZA, Taller de Material Fijo de Villaverde Bajo, dependiente del Servicio de Vía y Obras y conocido como Taller Central o Taller de Puentes. Fue en este establecimiento, dotado de unas instalaciones y unos equipamientos modélicos, donde primero comenzaron las prácticas tayloristas en los talleres ferroviarios españoles (Martínez Vara y de los Cobos: 2007a). Mendizábal sabía -y así se lo había manifestado ese mismo año al que era su director, Juan Abarca- que el éxito del taller no dependía sólo de que se dotase de unos equipamientos modernos, sino también de

\footnotetext{
${ }^{81}$ Gaceta de los Caminos de Hierro, 1918, $\mathrm{n}^{\circ}$ 3158. Las conclusiones de todos los ponentes pueden observarse en Asamblea Nacional de Ferrocarriles (1918a).

82 Anteriormente encontramos las experiencias realizadas por Arturo Soria en los talleres de la empresa tranviaria de Ciudad Lineal (Madrid), las llevadas a cabo por L. Leprè- vost en los talleres Hamsa (Barcelona) y por último las diseñadas por A. Layret Foix en los de la Maquinista Terrestre y Marítima (Barcelona). Estas experiencias son descritas por Martínez Vara y de los Cobos $(2014,82)$, quienes también incluyen la realizada por M. Porrmann en los talleres de loza de La Cartuja de los Pickman (Sevilla).
} 
que el personal se organizara de acuerdo con "las teorías modernas" sobre dirección de empresas industriales ${ }^{83}$.

La segunda gran materialización práctica fue realizada en los Talleres Generales de Atocha de RENFE en Madrid, en la Sección de reparación de vagones. El ingeniero industrial y director de los Talleres de Atocha, Eduardo Labrandero intentó establecer una cadena de montaje en la reparación de vagones. Él mismo indica que es la primera experiencia de este tipo en España (Labrandero, 1945: 478-488). Con las medidas establecidas, pasaron de tres unidades reparadas al día a cinco.

\section{f) Influencia militar en la formación de los directivos y en la organización de las empresas}

Al igual que ocurrió en Europa, la dirección de las empresas ferroviarias fue asumida por ingenieros (Chandler, 1965b, 16-40), que tenían una sólida experiencia en la construcción de líneas ferroviarias. La peculiaridad más destacable en Estados Unidos es que el modelo militar influyó en el management moderno, tanto es así que los ingenieros de West Point fueron los primeros que se dedicaron a la gestión de las empresas ferroviarias ${ }^{84}$.

La autoridad lineal, por ejemplo, tiene sus orígenes en la organización militar de los ejércitos de la antigüedad y en la época medieval. El principio de unidad de mando, según el cual cada subordinado sólo puede tener un superior -fundamental para la función de la dirección-, es el núcleo central de todas las organizaciones militares. La escala jerárquica, es decir, la escala de niveles de mando de acuerdo con el grado de autoridad y de responsabilidad, es un elemento característico de la organización militar, utilizado en otras organizaciones. Con el paso del tiempo, la ampliación gradual de la escala de mando trajo también la correspondiente ampliación de grado de autoridad delegada: a medida que el volumen de las operaciones militares aumentaba, crecía también la necesidad de delegar autoridad en los niveles más bajos de la organización militar. En la época de Napoleón, el general, al dirigir su ejército, tenía la responsabilidad de vigilar la totalidad del campo de batalla. No obstante, con la aparición de batallas de mayor alcance, el comando de las operaciones de guerra exigió nuevos principios de organización, lo que condujo a una planificación y un control centralizado paralelo a las operaciones descentralizadas. Se pasó, entonces, de la centralización del mando a la descentralización de la ejecución. Otra aportación de la organización militar es el uso de algunos conceptos originados en ese ambiente: estrategia, tácticas, operaciones, reclutamiento y logística ${ }^{85}$.

\subsubsection{Avances en la estructura organizativa}

La empresa moderna, caracterizada por la formación de una cultura de gestión y organización empresarial, así como de aspectos comerciales y financieros (López Pita et al., 1995: 2-10)

\footnotetext{
${ }^{83}$ AHF C/661/2: Carta de Mendizábal al director del taller J. Abarca. 1924.

${ }^{84}$ Chandler $(1977,188)$ analiza la influencia de los ingenieros civiles militares en la gestión del ferrocarril.

${ }^{85}$ Incluso, Lyndall Urwich (1891-1983) afirma que el concepto de staff se basa en la organización militar (Urwich: 1943).
} 
surgió en Estados Unidos, antes del comienzo de la Guerra Civil (Chandler, 1977: 166). Las cualidades de estas empresas quedaron plasmadas en los estudios teóricos de Alfred D. Chandler, Jr. (1977), que se han denominado "moderna estructura de Chandler" o "estructura chandleriana".

Las ferroviarias fueron las primeras sociedades que implantaron la estructura de Chandler ${ }^{86}$, en parte porque estas empresas tenían la estructura empresarial más adecuada para su aplicación en esa época y además porque era la industria sobre la que el autor más había trabajado sus ideas téoricas. Esto último se debe a que Chandler usó los papeles de su bisabuelo Henry Varnum Poor $^{87}$, un destacado analista de la industria ferroviaria, editor de la American Railroad Journal, y fundador de Standard \& Poor's, como base para su tesis doctoral $^{88}$.

A causa de la complejidad de sus operaciones, las ferroviarias constituyeron las primeras empresas gerenciales de Estados Unidos. En las empresas más grandes, los directores -que no poseían apenas acciones- tomaban las decisiones operativas. En la medida que crecían las empresas, estos directores vinieron a desempeñar un papel fundamental en la estrategia de su crecimiento y en la defensa de la compañía frente a la competencia.

Los directores dividieron sus operaciones en grupos operativos más pequeños y nombraron directivos de nivel medio para supervisar, controlar y coordinar las actividades funcionales de cada división. Dentro de esta estructura fue fundamental el sistema de información que permitía contabilizar las miles de transacciones económicas y financieras diarias que se producían en la organización.

Las ferroviarias fueran las primeras empresas modernas con elevados costes fijos, pues el coste de construcción y equipamiento de los ferrocarriles fue mucho más elevado que el acometido por los negocios empresariales anteriores. Derivada de esta estructura de costes, fueron pioneras en que la utilización de la capacidad de la empresa fuese una variable fundamental para alcanzar los necesarios niveles de rentabilidad y solvencia financiera.

El sector ferroviario fue el primero en crear medios para gestionar los grandes volúmenes de datos, recursos y personal que debía manejar. Fue también pionero en la formación de un grupo de directivos y en la creación de estructuras organizativas descentralizadas que posteriormente fueron adoptadas por las grandes empresas de otros sectores ${ }^{89}$.

\footnotetext{
86 "Fue en los ferrocarriles donde la mano visible de Chandler de las nuevas formas de gestión empresarial aparecieron por primera vez" (Porter, 1999: 111).

${ }^{87}$ Henry Varnum Poor (1812-1905) era un financiero de Wall Street, que fue posteriormente uno de los fundadores de Standard \& Poor. Además, era el director de la American Railroad Journal desde su fundación en 1854 (Chandler: 1952).

88 "Alfred Chandler", The Economist, 17 de mayo de 2007 (http://www.economist.com/node/9184105).

${ }^{89}$ Según Chandler (1990: 86), durante los años cincuenta del siglo XIX, los ferrocarriles estadounidenses se convirtieron en los pioneros de la dirección moderna.
} 
La utilización de una estructura organizativa fue dinámica, pudiendo identificar diferentes etapas a lo largo del tiempo que varían en función de dos variables. Por un lado, entre una organización centralizada y otra descentralizada. Por otro lado, entre una estructura departamental y "una distinción entre línea y staff", considerando que los componentes de la autoridad de línea son los responsables directos de la realización de los objetivos, mientras que los de staff ayudan a los de línea a lograr los objetivos eficientemente.

Teniendo en cuenta ambos factores, es posible diferenciar varias etapas en el ferrocarril estadounidense del siglo $\mathrm{XIX}^{90}$. La década de 1850 fue una época de construcción y de aprendizaje en la gestión de los ferrocarriles. Las décadas de 1860 y 1870 fueron un periodo de coordinación y competencia por los movimientos del tráfico de larga distancia. Finalmente, las de 1880 y 1890 fueron los años de creación de las redes ferroviarias.

Las ferroviarias estadounidenses fueron las primeras compañías que se administraban por medio de extensas jerarquías, y las primeras en competir en modo de oligopolio moderno.

La gestión de las empresas ferroviarias hizo imprescindible la creación de métodos de control y coordinación del tráfico para lo que se formularon procedimientos administrativos internos de comunicación y de información, desarrollados por directivos asalariados que solían ser ingenieros de caminos.

En la década de 1850 las redes ferroviarias llegaron a una dimensión tal que fue necesario dividirlas en divisiones operativas de carácter geográfico, cuyas actividades serían coordinadas desde la oficina central.

Para el funcionamiento de esta estructura había que determinar las responsabilidades concretas de cada directivo y establecer unas líneas sólidas de autoridad y comunicación; estas innovaciones dieron lugar al nacimiento del concepto de staff. A su vez hubo que crear unos principios generales de administración y de circulación interna de la información.

En cada división geográfica había un superintendente que gozaba de una delegación de autoridad expresa del superintendente general, estableciéndose unas líneas de autoridad que iban de arriba a abajo y que al mismo tiempo servían de líneas de información. Por otra parte aparecieron en la oficina central una serie de ejecutivos funcionales cuya misión era elaborar los procedimientos por los que debe funcionar la empresa.

Las ferroviarias fueron las primeras que necesitaron un gran número de directivos asalariados y los primeros en tener una oficina central, gestionada por mandos intermedios, y dirigida por altos directivos que dependían de un Consejo de Administración. Fueron las primeras en establecer una gran estructura organizativa interna con líneas de responsabilidad, de autoridad y de comunicación entre la sede central, las oficinas de los departamentos y las unidades

\footnotetext{
${ }^{90}$ Esta clasificación es concordante con lo afirmado por Chandler (1990: 86).
} 
operativas claramente definidas. Y fueron las primeras en desarrollar flujos financieros y estadísticos para controlar y evaluar el trabajo de los numerosos directivos.

Las necesidades de seguridad, y más tarde de eficiencia, llevaron al establecimiento de una jerarquía administrativa, cuyos deberes quedaron definidos pormenorizadamente en manuales de organización y en organigramas ${ }^{91}$.

Una vez que cada gran vía férrea se había financiado, construido y puesto en funcionamiento, el reto era gestionarla correctamente. No se podía transportar un gran volumen de tráfico de forma eficiente sin la existencia de directivos, sin el diseño de unos procedimientos administrativos internos y sin la comunicación de la información interna.

Ninguna otra empresa hasta entonces había requerido tanta coordinación, planificación y control, ni ninguna antes había manejado tanta información financiera ni tan variada.

En las ferroviarias estadounidenses se pudo observar que el poder dejaba de estar en manos de los accionistas para pasar a ser de los directivos. Hasta la irrupción de estas empresas se aceptaba masivamente la idea de que el conjunto de accionistas reunidos en las juntas generales de accionistas constituían la fuente del poder en la sociedad anónima, que podía ser ejercido directamente, o bien delegado en otros órganos en la medida que fuese conveniente por razones prácticas. Este esquema funcional tradicional fue avasallado por la estructura empresarial de la gran sociedad anónima. La dispersión accionarial, como instrumento para la acumulación de capitales, provocó la separación entre la propiedad del capital y la gestión de la gran sociedad anónima. La dispersión del accionariado trasladó el poder de decisión del órgano tradicional de gobierno -la Junta General de Accionista- hacia el órgano de administración, formado por directivos profesionales con iniciativas e intereses particulares. El principal hecho económico que provocó las modificaciones en la estructura de poder de las empresas fue la relevancia que adquirió en Estados Unidos el mercado de capitales como fuente de financiación de las empresas a principios del siglo XX -sobre todo en la bolsa de New York-. La perspectiva del mercado de capitales constituyó una nueva forma de entender la empresa. El accionista de una sociedad cotizada fue considerado más como partícipe del mercado de capitales que como miembro de una agrupación de accionistas.

\subsubsection{Modelos de estructura organizativa}

Identificamos tres etapas en la estructura organizativa de las sociedades: hasta 1850 hubo una estructura centralizada, entre 1850 y 1900 existió una descentralización, y por último, de 1900 en adelante se volvió a recurrir a una estructura centralizada.

Hasta la década de 1850, los mandos medios y los altos directivos asalariados habían desarrollado los métodos organizativos y contables que permitían a sus empresas coordinar y

\footnotetext{
${ }^{91}$ Chandler (1977: 167) ofrece un organigrama tipo de un gran ferrocarril en la década de 1870 . No ofrece información de ninguna empresa en concreto, pero recoge las diferentes innovaciones producidas en las ferroviarias estadounidenses hasta ese momento.
} 
controlar el gran volumen de tráfico que circulaba a una velocidad y con una regularidad desconocida hasta entonces ${ }^{92}$. Un reducido número de grandes empresas, administradas por directivos, sustituyó a un gran número de pequeñas empresas individuales.

En las Convenciones y Congresos ferroviarios de la década de 1850, los presidentes y superintendentes generales adoptaron el principio de cobrar según el valor del producto que se transportaba y no en función del coste real del transporte. Los Congresos realizaron clasificaciones de las mercancías en cuatro grupos, y los agentes de mercancías de cada ferrocarril fijaban las tarifas de cada artículo transportado.

El management ferroviario científico se creó en Estados Unidos por la aplicación de principios de gestión elaborados por algunos directivos del negocio ferroviario en el periodo 1842-1900. Poco a poco, los principios del management científico se fueron imponiendo generalizadamente en la mayoría de las empresas ferroviarias.

En las primeras líneas ferroviarias era posible una dirección de tipo personal, ya sea de presidente o administrador. Ejemplos de estas estructuras personalistas son las que aparecen en las empresas ferroviarias en el entorno de New York, Boston y Philadelphia ${ }^{93}$ en los años 1830-1840. En estos primeros ferrocarriles, la dirección del personal era fácil, ya que el superintendente y sus ayudantes trabajaban en la misma oficina. Al igual que en las fábricas textiles de la época, el superintendente conversaba semanalmente con el treasurer (tesorero), con el presidente e, incluso, con el Consejo de Administración (Chandler, 1977: 150).

Sin embargo, entre 1842-1870 fue imprescindible realizar innovaciones significativas en la gestión de la empresa. Las innovaciones se produjeron en ese momento por dos razones. La primera es que a partir de ese momento existía una real separación entre la propiedad y gestión ${ }^{94}$. Pero sobre todo, la razón fundamental para que se realizasen las innovaciones es que empezaba a ser imposible organizar de forma sencilla las estructuras cada vez más complejas $^{95}$.

Las más importantes propuestas históricas de innovación en el management ferroviario fueron cinco (cuadro 3) ${ }^{96}$. La primera gran planificación estructural y organizativa fue realizada por

\footnotetext{
${ }^{92}$ Para Chandler $(1977,185)$ el hecho más representativo es la reducción del tiempo de viaje y de transbordos para transportar una persona o una mercancía. Pone como ejemplo el viaje de Philadelphia a Chicago, que pasa de nueve semanas y nueve transbordos en 1849, a un único embarque y tres días, en 1859.

${ }^{93}$ Chandler (1954: 248-263) analiza con detalle la ferroviaria New England en los años 1830-1850 para ejemplificar esta estructura.

${ }^{94}$ Lo cual se manifestó en que "el peso de los Consejos de Administración determinaba la imposición a los gestores ferroviarios, casi todos técnicos y especialmente ingenieros, de métodos y formas de administración propios del mundo de las finanzas" (Vidal Olivares, 1997: 12).

95 A final de 1890, únicamente 30 compañías controlaban las 2/3 partes del total de líneas existentes en Estados Unidos, parte de las cuales habían sido financiadas por bancos de inversión, lo que terminó reforzando el poder de los intereses financieros sobre los técnicos en la gestión (Chandler, 1977: 251-269).

${ }^{96}$ Los pioneros del management moderno son estas cinco figuras más otras dos: John B. Jervis de la Michigan Southern, y George C. McClellan de la Illinois Central. Todos ellos eran ingenieros civiles con una sólida
} 
la Western Railroad, cuando era su director George Washington Whistler, quien estableció los principios directivos para la organización, y además, una estructura organizativa integrada por tres tipos de actividad funcional basada en una división geográfica (Salsbury, 1967: 182-184).

La segunda, realizada por Benjamin Henry Latrobe II, de la Baltimore and Ohio Railroad Company, se centró en la exigencia de una contabilidad financiera y una contabilidad de gestión.

La tercera es la llevada a cabo por Daniel Craig Mc Callum, Superintendente general de la New York \& Erie Rail Road Company, desde 1855. Su aportación se basa en mejorar los resultados por medio de una adecuada organización interna del personal y de la información que maneja.

En cuarto lugar, son destacables las innovaciones realizadas en la Pennsylvania Railroad Company $^{97}$, por el ingeniero y financiero John Edgar Thomson, aunque también fue importante, el ingeniero de la construcción del ferrocarril (también ingeniero civil) y ejecutivo de la compañía Herman Haupt. En 1857, en esta compañía se estableció una estructura de empresa de carácter divisional, en la que se instauró la forma de organización descentralizada en divisiones tipo línea y staff.

Por último, es necesario desatacar las innovaciones de gestión en materia de reestructuración interna realizadas por Charles Parkins en la Chicago, Burlington and Quincy Railroad, a partir de 1885. La empresa adoptó la estructura descentralizada multidivisional de la Pennsylvania dividiendo la empresa en cuatro divisiones operativas de carácter autónomo.

experiencia en la construcción de las líneas ferroviarias, y posteriormente tomaron las riendas de la dirección de su respectiva sociedad ferroviaria. Estas figuras son analizadas por Chandler (1965b: 16-40).

${ }^{97}$ La Pennsylvania Railroad Company fue una de las empresas sobre las que Maristany (1906a: 4) contó sus experiencias tras su viaje a Estados Unidos. 


\section{Cuadro 3. Principales aportaciones organizativas en el siglo XIX en Estados Unidos}

\begin{tabular}{|c|c|c|c|}
\hline EMPRESA & PERSONA & $\begin{array}{l}\text { AÑO DE } \\
\text { COMIENZO DE } \\
\text { LA } \\
\text { INNOVACIÓN }\end{array}$ & INNOVACIONES FUNDAMENTALES \\
\hline Western Railroad & $\begin{array}{l}\text { George Washington } \\
\text { Whistler (1800-1849) }\end{array}$ & 1842 & $\begin{array}{l}\text { Primera gran planificación estructural y organizativa } \\
\text { Estableció los principios directivos para la organización } \\
\text { Estructura organizativa integrada por tres tipos de } \\
\text { actividad funcional basada en una división geográfica }\end{array}$ \\
\hline $\begin{array}{l}\text { Baltimore and Ohio } \\
\text { Railroad Company }\end{array}$ & $\begin{array}{l}\text { Benjamin Henry Latrobe } \\
\text { II (1806-1878) }\end{array}$ & 1845 & $\begin{array}{l}\text { Instauró una contabilidad financiera y una contabilidad } \\
\text { de gestión }\end{array}$ \\
\hline $\begin{array}{l}\text { New York \& Erie } \\
\text { Rail Road Company }\end{array}$ & $\begin{array}{l}\text { Daniel Craig Mc Callum } \\
(1815-1878)\end{array}$ & 1853 & $\begin{array}{l}\text { Mejoró la organización interna } \\
\text { Realizó uno de los primeros organigramas } \\
\text { Organizó la estructura administrativa con el objeto de } \\
\text { asegurar una contabilización y control más precisos de } \\
\text { los gastos, y una valoración más efectiva de los hombres } \\
\text { y de los directivos } \\
\text { Definió de forma muy concreta las líneas de autoridad y } \\
\text { de responsabilidad. } \\
\text { Perfeccionó la circulación de la información interna } \\
\text { Formuló los principios generales organizativos y de la } \\
\text { administración } \\
\text { Desarrolló sistemas para utilizar los datos generados } \\
\text { internamente como instrumentos prácticos de gestión }\end{array}$ \\
\hline $\begin{array}{l}\text { Pennsylvania } \\
\text { Railroad Company }\end{array}$ & $\begin{array}{l}\text { John Edgar Thomson } \\
(1808-1874) \\
\text { Herman Haupt (1817- } \\
1905)\end{array}$ & 1857 & $\begin{array}{l}\text { Elaboró la forma de organización descentralizada en } \\
\text { divisiones tipo línea y staff }\end{array}$ \\
\hline $\begin{array}{l}\text { Chicago Burlington } \\
\text { \& Quincy Railroad }\end{array}$ & $\begin{array}{l}\text { Charles Elliott Perkins } \\
(1840-1907)\end{array}$ & 1885 & $\begin{array}{l}\text { Estableció una estructura descentralizada en cuatro } \\
\text { divisiones operativas autónomas dentro del esquema } \\
\text { multidivisional }\end{array}$ \\
\hline
\end{tabular}

Fuente: Elaboración propia

Las estructuras son cada vez más complejas, por lo que la Western intentó mejorarla ante las dificultades de organizar la empresa de forma tan sencilla. Este hecho fue precipitado, además, por una serie de accidentes "achacables a las deficiencias de coordinación de la Western" (Salsbury, 1967: 182-184). Ante ambos hechos, la Western elaboró un Informe para intentar evitar colisiones y dirigir mejor a los empleados ${ }^{98}$. La nueva estructura organizativa consistía en situar a tres grupos de directivos funcionales en cada una de las tres divisiones operativas, geográficamente separadas y la creación de unas oficinas centrales en Springfield para controlar y coordinar las actividades de los tres directivos. Cada división contaba con un director adjunto de transportes (que luego se llamó superintendente de división), un jefe de

\footnotetext{
${ }^{98}$ El objetivo expreso del Informe de la Western era "trazar líneas sólidas de autoridad y de comunicación para la administración, el mantenimiento y el funcionamiento del ferrocarril” (Salsbury, 1967: 186-187).
} 
vía y un mecánico o capataz, encargado del depósito de locomotoras y de los talleres. El superintendente era responsable del funcionamiento del ferrocarril ante el presidente y los miembros del consejo. La Western fue la primera empresa estadounidense que funcionaba por medio de una estructura administrativa formal dirigida por ejecutivos asalariados.

Latrobe establecío una estructura similar a la de la Western con dos actividades funcionales y con el superintendente como figura clave. Latrobe estableció una serie de reglas: "Los objetivos consistían en acercar la supervisión y la dirección general de todos los departamentos a sus deberes $\mathrm{y}$, mediante una división del trabajo asegurar una aplicación directa de los poderes de supervisión a los elementos que se encuentren directamente a su cargo y, en general, llevar de una manera más precisa y responsable el departamento de contabilidad" (Baltimore \& Ohio Rail-Road Company, 1847b: 13). Dividió las funciones de la empresa en dos actividades básicas: el funcionamiento del ferrocarril, y el desembolso de dinero (Baltimore \& Ohio Rail-Road Company: 1847a). Latrobe consideraba que esta segunda función es mucho más compleja en las ferroviarias que en el resto de empresas, donde sólo el director de la fábrica o el oficinista se encargaba del dinero; por el contrario en un gran ferrocarril muchas personas manejaban todos los días grandes sumas de dinero (revisores, jefes de estación, jefes de compras, encargados de talleres, de depósitos de locomotoras, etc.).

La Baltimore \& Ohio centralizaba en el treasurer (tesorero) la responsabilidad financiera total, dedicándose a partir de entonces a supervisar las transacciones internas, pero también las externas, como por ejemplo la toma de decisiones ordinarias con acciones y obligaciones.

Dependiente del anterior, se situaba otra persona física -secretary (secretario)- que se ocupaba de las operaciones internas, incluída la inspección del dinero manejado por el personal. Este sujeto inspeccionaba todas las cuentas de pasajeros y mercancías y supervisaba a todos los que manejaban fondos de la empresa.

Dependiente a su vez del anterior se situaba el chief clerk (oficinista jefe), encargado de elaborar y verificar las cuentas (Baltimore \& Ohio Rail-Road Company, 1847a: 3). Además, empezó a producir documentos diarios donde se comparaba el trabajo efectuado por el ferrocarril y los ingresos obtenidos. Las cifras diarias se resumían, a su vez, en informes mensuales, que ofrecían numerosos datos. Los informes mensuales se convirtieron en herramienta de gestión y en controles de honestidad y competencia de los empleados (Baltimore \& Ohio Rail-Road Company, 1847a: 3). Estos detallaban las transacciones financieras, pero no estaban tan organizados como para permitir conocer el análisis de los costes ocasionados por la actividad ferroviaria.

Cuando en la década de 1850 otras grandes líneas se pusieron en funcionamiento, crearon estructuras similares a la Western. No obstante, estas estructuras no eran del todo óptimas si las comparamos con las empresas medianas con una organización más simple. Los costes crecientes de transportar las mercancías aumentaban los problemas para dirigir eficientemente estas líneas más largas. En las grandes líneas, los gastos de explotación por milla eran más 
altos que los de las líneas medianas. Daniel Craig Mc Callum (1815-1878), nombrado superintendente general de la New York \& Erie Rail Road Company en 1855, consideró que este hecho tenía su origen en una organización interna inadecuada: "Un superintendente de una empresa mediana puede ocuparse personalmente de los negocios, así como visitar la línea para dirigir los detalles, conoce de cerca a sus empleados,... En la gestión de una empresa grande las cosas son bien diferentes. Cualquier sistema que pudiera aplicarse a un ferrocarril pequeño sería inadecuado a las necesidades de uno grande; estoy completamente convencido que el verdadero secreto del fracaso de las grandes ferrocarriles reside en la carencia de un sistema de organización" (Mc Callum: 1856). El poder de los superintendentes incluía el control sobre la contratación y el despido de empleados, aunque sujeto al veto de la alta dirección.

Mc Callum ${ }^{99}$ dibujó un gráfico detallado, que supone uno de los primeros organigramas de una empresa estadounidense (Chandler, 1956: 147-148).

En otoño de 1853, el Consejo de Administración de la New York \& Erie Rail Road Company intentó organizar la estructura administrativa con el objeto de asegurar una contabilización y control más precisos de los gastos, y una valoración más efectiva de los empleados y de los directivos. Los miembros del Consejo esperaban conseguir este objetivo realizando unas "comparaciones con los gastos de las diferentes operaciones con las de ferrocarriles semejantes y con las diversas divisiones del mismo ferrocarril; y controlar los gastos de los distintos revisores, maquinistas, etc." (New York \& Erie Rail Road Company, 1853: 47-48).

Mc Callum adoptó una estructura similar a la de la Western, aunque definió de forma más precisa las líneas de autoridad y de responsabilidad. Las mayores aportaciones de este directivo fueron dos. Por un lado, perfeccionar la circulación de la información interna, tan esencial para los altos directivos y mandos intermedios en su cometido de controlar y evaluar el rendimiento de cada responsable. Por el otro, la de formular los principios generales de la administración.

Mc Callum intentó mejorar la exactitud de la información y la regularidad y rapidez con la que circulaba. Los informes eran más pormenorizados que los de la Baltimore\&Ohio. Los informes sobre el funcionamiento de la vía férrea y la causa de los retrasos eran efectuados cada hora, cada día y cada mes. El telégrafo se convirtió en algo más que un medio para

\footnotetext{
${ }^{99}$ La revista American Railroad Journal, cuyo director era desde su fundación en 1854 Henry Varnum Poor, dedicó mucho espacio a las innovaciones en la estructura y en los principios y procedimientos administrativos de Mc Callum. El citado Poor partía del convencimiento de que el fracaso de las pequeñas empresas del ferrocarril de la época se basaba en los fallos en la administración y operatividad de la compañía más que en las bajas tarifas recibidas, que era el argumento que ellas defendían. En su opinión, sólo con la aplicación de la teoría del management, basándose en los conocimientos empíricos que ingenieros como Mc Callum estaban desarrollando, se podía contribuir al diseño de estrategias empresariales exitosas. Poor defendía que la eficiencia en la gestión descansaba en tres principios: organización, para conseguir una división interna del trabajo; comunicación, para crear sistemáticamente un flujo de información acerca de las tareas llevadas a cabo en las diferentes líneas; e información, que consistía en el análisis continuo de todos los informes relativos al trabajo realizado.
} 
mejorar la seguridad de los trenes, para Mc Callum era un dispositivo para garantizar la coordinación y la evaluación efectiva de las unidades a su cargo.

El sistema se basaba en los informes diarios que obligatoriamente rellenaban los revisores, agentes e ingenieros. Estos informes se convertían en estadillos mensuales que eran complementados con información adicional proporcionada por los directivos de las divisiones y los jefes de departamentos funcionales. Toda esta información era entregada a los superintendentes de división y al superintendente general. Los contenidos de esta información eran tanto de movimiento físico de trenes y tráfico como de naturaleza económica, para entender y controlar los costes y para fijar las tarifas, por ejemplo, millas recorridas, trabajos realizados, costes de reparación o gastos de explotación incurridos. Por esta razón, permitía la comparación del trabajo entre las distintas unidades operativas de la empresa e incluso con el resto de empresas ferroviarias.

Las innovaciones organizativas de Mc Callum aumentaron la eficiencia de la New York \& $E_{r i e}{ }^{100}$, al tiempo que redujeron el número de trabajadores (Poor, 1854: 549). Ningún hombre de negocios había mostrado tanta preocupación hasta ese momento por la teoría y principios organizativos, pero sobre todo, nadie había desarrollado sistemas para utilizar los datos generados internamente como instrumentos prácticos de gestión ${ }^{101}$.

Mc Callum (1855) define los siguientes principios generales de la administración:

- Establecer una división adecuada de las responsabilidades

- Otorgar el poder suficiente para permitir que lo anterior se lleve a cabo en su totalidad y para que la autoridad sea proporcional a la responsabilidad

- Establecer medios que permitan saber si tales responsabilidades se cumplen

- Informar rápidamente acerca de todas las negligencias ocurridas, con el fin de que los errores puedan corregirse inmediatamente

- Obtener dicha información por medio de informes y comprobaciones diarias, que no molesten a los directivos ni reduzcan su influencia sobre los subordinados

- Adoptar un sistema que no sólo permita al superintendente general detectar errores inmediatamente, sino también descubrir al culpable.

John Edgar Thomson (1808-1874) de la Pennsylvania Railroad Company ${ }^{102}$ elaboró en 1857 la forma de organización descentralizada en divisiones tipo línea y staff, donde la línea se centra en la función fundamental de la empresa -la producción-, mientras que el staff se

\footnotetext{
${ }^{100}$ Estas innovaciones en la estructura y en los principios y procedimientos administrativos de Mc Callum fueron probados en un principio en la Erie, aunque donde se debe valorar realmente su aplicación y validez es en la implantación en la Pennsylvania.

${ }^{101}$ Chandler (1977: 162) apoya estas ideas comparándolas con los escritos de Montgomery sobre las órdenes de los propietarios de las plantaciones y con lo escrito por Pollard en su obra Genesis of Modern Management. En ninguno de los dos se hace referencia al control, disciplina y evaluación de los directivos frente a los empleados. La importancia y novedad de las ideas de Mc Callum es clara.

${ }^{102}$ La Pennsylvania Railroad era la compañía con más trabajadores del mundo; empleaba en la década de 1890 a más de 110.000 trabajadores. Además, su administración era considerada "la mejor del país" (Van Oss, 1893: 235).
} 
dedica a la asistencia y a la consultoría. La estructura línea-staff permite alcanzar los objetivos básicos de la organización, estableciendo que los órganos de línea son los responsables de la consecución de dichos objetivos, mientras que los órganos de staff son el apoyo, ayuda y asesoría para la organización lineal.

Para gestionar la organización, los directivos instrumentaron un sistema de administración constituido por una diferenciación de la plantilla en empleados de línea y empleados de staff. Los directores responsables del movimiento de trenes eran empleados de línea, pues actuaban en línea de autoridad desde el presidente hasta el director general, al superintendente general y al superintendente de la división. Los directores responsables de otras funciones, como el departamento financiero, formaban parte del staff. Los empleados de línea dirigían el movimiento de hombres y trenes, los directivos staff fijaban las normas y las políticas de sus departamentos funcionales.

Una vez tomada la decisión, los directores generales supervisaban, evaluaban y coordinaban las actividades diarias de su administración territorial. Los directores y supervisados trabajaban en estrecha colaboración para confeccionar las tarifas (Pennsylvania Railroad Company, 1873: 14). Los directivos (primer nivel de administración) nombraban al personal directivo de cada una de sus divisiones. En cada una de las divisiones, los directores generales (segundo nivel de administración) eran los responsables del rendimiento financiero, siempre dentro de la política general de la compañía. Las obligaciones de los superintendentes generales (tercer nivel de administración) que dependían del director general suponían "una supervisión continuada más que una dirección independiente"103. Por último, los superintendentes de división (cuarto nivel de administración) se dedicaban a la circulación cotidiana de trenes y tráfico. En todos los niveles existía la distinción entre la línea y el staff (Pennsylvania Railroad Company, 1873: 16, 17 y 20; 1881: 26).

La estructura de la Pennsylvania era descentralizada, con redes autónomas responsables de las actividades cotidianas y una oficina central para supervisar y planificar a largo plazo. Los altos directivos tenían sus despachos en la oficina central de la compañía en Philadelphia. El presidente y los tres vicepresidentes eran responsables de coordinar y evaluar el funcionamiento de las tres redes autónomas, y de planificar y asignar los recursos para la red en su conjunto ${ }^{104}$.

Chicago Burlington \& Quincy Railroad adoptó la estructura descentralizada de la Pennsylvania. Estableció cuatro divisiones operativas autónomas. Cada una tenía sus departamentos de transporte, de tráfico, jurídico, de contabilidad y de compras. Sólo los departamentos de contabilidad y de compras tenían contacto directo con la oficina central. Los otros tres departamentos dependían directamente del director general encargado de la división. El vicepresidente tercero tenía la tarea de supervisar la situación financiera, para ello

\footnotetext{
${ }^{103}$ Estas palabras están tomadas de "Historical development of the organization of the Pennsylvania Railroad", Railroad Gazette, 1882, pp. 766 y ss. Reeditado por Jenks (1961: 174).

${ }^{104}$ La Pennsylvania había creado una estructura que permitía a los altos directivos, trabajando en grupo, evaluar coordinar y asignar recursos a toda la red (Chandler, 1977: 273).
} 
obtenía informes periódicos de los libros de contabilidad y pasaba una comunicación trimestral al presidente.

En los años posteriores a la Guerra Civil, la estructura de la Pennsylvania fue utilizada, con modificaciones, por las líneas ferroviarias estadounidenses que llevaban mucho tráfico a larga distancia (la Michigan Central, la Michigan Southern y la Chicago Burlington \& Quincy Railroad). Sin embargo, no todas las ferroviarias utilizaron esta estructura divisional descentralizada, pues coexistió con una estructura "departamental", en las que el presidente y superintendente general no delegaban su autoridad, sino que los directivos de las divisiones geográficas (transporte, material motor, mantenimiento de vías, pasajeros, mercancías y contabilidad) dependían directamente de sus superiores de la oficina central. La estructura "departamental" fue utilizada por las ferroviarias estadounidenses con tráfico local y que no prestaron mucha atención a los problemas de organización, como la New York Central. Esta estructura era muy similar a la implantada por las ferroviarias europeas de la época ${ }^{105}$.

En la década de 1880, las grandes sociedades ferroviarias presentaban un organigrama muy homogéneo $^{106}$. El Board of Directors tenía mando directo sobre el President bajo el cual existe tres Vicepresidents (Finanzas, Transporte y Tráfico). El vicepresidente de Finanzas controlaba dos personas (Treasurer y Comptroller) sobre las que dependían todos los contables de la empresa.

En las décadas de 1880-1900 aparecen nuevos modelos de relaciones entre las empresas ferroviarias que modifican, a su vez, la estructura organizativa y contable de las ferroviarias. Las nuevas estructuras organizativas estaban caracterizadas por la interacción de los tres tipos de hombres de negocios: los inversores, los directivos (directores) y los especuladores.

Los altos directivos tomaban las decisiones relativas a la política básica y a la estrategia de crecimiento del ferrocarril. Entre otros asuntos, fijaban los objetivos a largo plazo y asignaban los recursos de hombres, dinero y material móvil necesarios para llevar a cabo estos fines. Además, establecían alianzas con las líneas rivales, además, decidían cuándo unirse y por cuanto tiempo.

Los altos directivos incluían a dos tipos de hombre de negocios diferentes: el directivo que había hecho su carrera en los ferrocarriles y el empresario o financiero que había invertido en ellos. El presidente y el tesorero solían ser inversores o representantes de éstos, mientras que el director general y los jefes de departamento de transporte y de tráfico eran siempre directivos profesionales ${ }^{107}$.

\footnotetext{
${ }^{105}$ La organización departamental de los ferrocarriles británicos fue descrita por Morris (1920, cap. 6).

${ }^{106}$ Chandler (1977: 204) describe el organigrama de las grandes sociedades ferroviarias en la década de 1880.

107 Cochran (1953: Appendix) resume la vida profesional de 60 presidentes de compañías ferroviarias. En la década de 1850 la mayoría de los presidentes eran accionistas o representantes de los accionistas designados sin escalar la jerarquía administrativa, y en la de 1890 la mayoría eran directivos profesionales que habían pasado toda su vida activa como ejecutivos de los ferrocarriles.
} 
La política y la estrategia decidida por los altos directivos requería la aprobación del Consejo de Administración, en especial de su presidente. Los miembros del Consejo -empresarios con éxito- trabajaban en el ferrocarril a tiempo parcial, eran casi siempre, o grandes inversores, o sus portavoces.

Los objetivos de estos dos grupos no eran siempre los mismos. Los directivos, que casi nunca poseían acciones, cuidaban de la buena marcha y del crecimiento a largo plazo de la organización en la que trabajaban desde que comenzaron su vida laboral; normalmente preferían reducir dividendos para garantizar la estabilidad a largo plazo. Por el contrario, los representantes de los inversores daban prioridad al mantenimiento de los dividendos que les asegurara una tasa de rendimiento de las inversores razonable y continua; por supuesto, los inversores eran reacios a gastar grandes cantidades en ampliar las instalaciones del ferrocarril.

El tipo de inversores cuyos representantes eran miembros del Consejo y llegaban a ser presidentes y tesoreros cambiaron con el tiempo. En la década de 1850 los inversores eran comerciantes, agricultores o fabricantes que fomentaron y financiaron los ferrocarriles para mejorar la fortuna de su ciudad o región. A medida que los ferrocarriles aumentaban de tamaño y demandaban más capitales, los capitales locales tenían que complementarse con fondos de todo el país; en este entorno los Consejos empezaron a representar a los inversores que aportaban este capital.

Posteriormente apareció otro tipo de hombre de negocios: los especuladores. Eran miembros de los Consejos de Administración, o ejercían de presidentes o tesoreros. Los especuladores diferían de directivos e inversores en que no tenían intereses a largo plazo, pues no esperaban ganarse la vida laboral con un salario de por vida, ni recibir unos ingresos con la prestación de unos servicios. Sus beneficios eran obtenidos de las actividades auxiliares (como la construcción o las compañías de transporte rápido de mercancías), pero sobre todo de la manipulación del precio de los valores ferroviarios. Esta especulación se pudo realizar gracias a la centralización e institucionalización del mercado de capitales en la década de 1850 en Wall Street, acontecida porque fue posible comprar y vender grandes paquetes de acciones, controlar las líneas férreas y manipular sus títulos por medio de la posibilidad de transferir de forma masiva los títulos.

La estrategia de los ferrocarriles estaba determinada por la interacción de los tres tipos de hombres de negocios: los inversores y los directivos acordaban una estrategia; los directivos la planificaban y la llevaban a cabo; por su parte, los especuladores eran quienes convencían a los inversores para que los directivos emprendieran dicha estrategia.

Las estrategias derivadas de especuladores, inversores y directivos facilitaron el proceso de crecimiento de las primeras empresas modernas. Permitieron la constitución de empresas gigantes (con muchísimo capital y personal) que fusionaron e interiorizaron la propiedad, el personal y las actividades de una serie de grandes empresas ${ }^{108}$.

\footnotetext{
${ }^{108}$ Las redes no se crearon para reducir los costes o para incrementar los beneficios. Las estrategias tampoco se emprendieron para satisfacer ninguna necesidad o para aprovechar las oportunidades que se derivaron de la
} 
En la década de 1880 los directivos utilizaron a los especuladores con el fin de obtener el apoyo de inversores reacios a gastar los fondos necesarios para la creación de las redes ferroviarias. Por ello, hicieron alianzas con bancos de inversión como J.P Morgan \& Company, Kuhn, Loeb \& Company o Drexler \& Company. Únicamente estas empresas bancarias contaban con los medios y las conexiones para atraer las enormes sumas de capital que se necesitaban ${ }^{109}$.

En aquellos ferrocarriles financiados por los bancos de inversión (la mayoría de las grandes redes ferroviarias), los presidentes eran directivos experimentados. Los directivos tenían una autonomía completa en materia de operaciones, mientras que el Consejo conservaba la vigilancia en asuntos financieros, incluyendo la política de dividendos y la asignación de recursos financieros. Los miembros de los bancos de inversión presidían los Consejos.

Los bancos de inversión iniciaron reformas financieras y administrativas. Con respecto a las finanzas disminuyeron las cargas fijas de la deuda, al convertir las obligaciones en acciones privilegiadas. En la reorganización administrativa, los banqueros adoptaron la estructura centralizada, como tenía la Illinois, en lugar de la descentralizada característica de la Pennsylvania y de la Burlington.

La Illinois concentró en Chicago todas las decisiones relativas al tráfico, al transporte y a las finanzas. Como la mayoría de los miembros del Consejo vivían en New York y se dedicaban a otros negocios, tenían poco tiempo para examinar las actividades pasadas o planificar las futuras. Los financieros del banco de inversión preferían esta estructura porque la concentración en Chicago facilitaba las consultas por parte de los directivos y permitía que los miembros del Consejo que residían en New York contactaran más fácilmente con ellos.

A comienzos del siglo $\mathrm{XX}$, todas las grandes compañías volvieron a una estructura centralizada. Pero en este tiempo no hubo tanto consenso con la estructura a utilizar. Aunque algunos abandonaron la organización divisional, con su diferenciación entre línea y staff, y adoptaron la organización departamental, la mayoría continuaron utilizando la organización tipo línea y staff para garantizar la coordinación eficaz de la circulación de trenes y de tráfico.

El declive de los ferrocarriles en Estados Unidos llegó en la década de 1920. Las razones de ello fueron las siguientes (Morris, 1973): el bajo nivel de los directivos contratados; la incorporación masiva de personas procedentes del comercio y de la administración más simple frente a los graduados universitarios; el hecho de que los ingenieros dejaran de tener protagonismo en las compañías para dejar paso a los juristas en los niveles más altos de

mejora de la coordinación administrativa. En la década de 1880, la red de ferrocarriles estadounidenses ya había conseguido dicha coordinación gracias a la cooperación entre las empresas. El motivo de la creación de las redes fue defensivo: asegurar un flujo continuado de mercancías y pasajeros a través de las instalaciones de los ferrocarriles mediante un control total de las conexiones (Chandler, 1977: 220).

${ }^{109}$ Debido a esto, en la década de 1880 se "tendieron 75.000 millas de vías en Estados Unidos, con mucho, la mayor cantidad de millas construida jamás en ninguna década y en ninguna parte del mundo" (Dagget, 1908: V). 
responsabilidad de las empresas; y una burocracia demasiado jerarquizada en la que la antigüedad primaba como método de ascenso fundamental.

\subsubsection{Avances en la estructura contable}

En el siglo XIX, a raíz de las grandes necesidades de financiación con el proceso de industrialización, se produce a nivel mundial una evolución significativa en el suministro de información contable externa debido fundamentalmente a las necesidades de los inversores y financiadores.

El éxito en la organización y gestión del ferrocarril de New York \& Erie de Mc Callum se basaba en la confección de estadísticas internas como medio fundamental para aplicar una dirección científica del negocio ferroviario. Los primeros gestores de las compañías del ferrocarril en Estados Unidos se sirvieron de la estadística y la contabilidad para conocer los costes operativos de las compañías y establecer las tarifas adecuadas para mercancías y pasajeros ${ }^{110}$. De este modo se rompía el viejo planteamiento según el cual sólo se podían obtener altos beneficios si las tarifas eran elevadas, planteamiento ampliamente aceptado entre las primeras compañías estadounidenses ${ }^{111}$.

Al contrario que las innovaciones estructurales, las innovaciones contables no vinieron de las necesidades de volumen físico de las actividades, llegaron para mejorar la eficiencia de las empresas que voluntariamente las aplicaron. Hasta la irrupción de las ferroviarias estadounidenses ninguna otra empresa había tenido que dirigir un número tan grande de hombres y oficinas diseminados por extensas zonas geográficas. Por esta razón, para poder funcionar, deberían organizarse en departamentos funcionales y tener un flujo continuado de información interna. Sin embargo, las innovaciones en contabilidad y control fueron más allá de las simples necesidades. Las líneas férreas podían haber funcionado sin auditores internos y sin desarrollar los procedimientos de contabilidad financiera, de capital y de costes, concebidos por Mc Callum, Thomson y Fink. Es más, muchas funcionaron sin ellas, en concreto, la mayoría de las ferroviarias estadounidenses pequeñas, pero también bastantes de las grandes. No obstante, las empresas que las aplicaron aumentaron la eficiencia y productividad.

Las innovaciones en los procedimientos administrativos, organizativos y de contabilidad de las décadas de 1850 y 1860, que se convirtieron en prácticas habituales en las de 1870 y 1880 , permitieron una utilización más intensiva del material disponible y un reparto más rápido de los productos, al proporcionar un control más efectivo sobre las operaciones del ferrocarril.

En Estados Unidos, la empresa que gestionaba la primera línea de ferrocarril ya utilizaba la partida doble y desde entonces todas las empresas ferroviarias han basado sus registros en este

\footnotetext{
110 "La estadística y la contabilidad fueron convirtiéndose en la piedra angular sobre la que se edificó el management moderno" (Vidal Olivares, 1997: 10).

${ }^{111}$ Según Vidal Olivares (1997: 11), el viejo planteamiento según el cual sólo se podían obtener altos beneficios si las tarifas eran elevadas, no fue superado nunca por las empresas privadas españolas.
} 
método (Knight y Latrobe, 1838: 4 y 13-19). Los accionistas representados en el consejo de la Boston \& Worcester Railroad en 1831 afirman que se llevan las cuentas "en un estilo estrictamente mercantil, según el método italiano de contabilidad por partida doble" (Kirkland, 1948a: 338).

El volumen de transacciones financieras, de tráfico y de pasajeros realizados por el gran ferrocarril, llevó a los directivos a sentar las bases de una moderna contabilidad de empresas. Los métodos originados en la década de 1850, y perfeccionadas en los años siguientes para las ferroviarias, fueron adoptados por las grandes empresas industriales de la década de 1880, y continuaron siendo las técnicas de contabilidad básicas utilizadas en la empresa estadounidense de cualquier sector hasta bien entrado el siglo $\mathrm{XX}^{112}$. A partir de estas innovaciones se produjo un enorme interés sobre los métodos de contabilidad ${ }^{113}$.

Las nuevas prácticas contables se dividieron en tres categorías: contabilidad externa (incluido el análisis económico y financiero), de capital y de gestión.

La disciplina contable debe dar respuesta a las necesidades de información financiera derivadas de la actividad económica desplegada por la empresa. Respecto a la contabilidad externa, que permite el análisis económico financiero, tanto temporal como interempresarial, la doctrina progresó pronto, pues de inmediato los organismos crearon listados de cuentas. No obstante, los verdaderos protagonistas fueron las propias empresas, con su diseño de su sistema contable, a partir de lo establecido por la doctrina y sobre todo por los organismos de la época.

Los organismos de normalización contable fueron muy importantes en esa época en Estados Unidos, todo lo contrario que en España, donde o no existieron o no fueron relevantes.

La Convention of Railroad Commissioners, celebrada en Saratoga el 10 de junio de 1879, fue una reunión de comisionados estatales de ferrocarriles que pretendían establecer métodos de contabilidad uniformes ${ }^{114}$ para todos los ferrocarriles estadounidenses. El modelo de contabilidad recomendado por la Convención se encuentra en un apéndice del documento que refleja las actas y conclusiones (Convention of Railroad Commissioners, 1879: appendix IX, $\mathrm{n}^{\circ}$ 21). El modelo propuesto en esta reunión se basaba en tres documentos: "Esquema general", "Análisis de ingresos y gastos" y "Activos y pasivos".

El "Esquema general" es un documento presentado en una única columna, donde se resumen los componentes detallados de gastos e ingresos obtenidos del segundo documento: "Análisis

\footnotetext{
${ }^{112}$ Las grandes empresas industriales sólo modificaron los métodos de contabilidad ideados por los ferrocarriles, sobre todo la referida a la contabilidad de gestión, a mediados del siglo XIX, y esto lo hicieron "porque sus actividades eran muy distintas a las del transporte" (Chandler, 1977: 182).

${ }^{113}$ Las revistas dedicadas a la industria del ferrocarril, especialmente American Railroad Journal, de Henry Varnum Poor, y las revistas financieras, como Banker's magazine o Commercial and Finance Chronicle, publicaron, en esa época, numerosos artículos y editoriales sobre la contabilidad ferroviaria.

${ }^{114}$ Los antecedentes a favor de una contabilidad uniforme que dió lugar a esta reunión puede observarse en Kirkland (1948b: 335-339).
} 
de ingresos y gastos". El "Esquema general" parte de los "ingresos totales", a los que se les resta una partida denominada "gastos totales, incluyendo impuestos", en los que extrañamente no están incluidos ni los arrendamientos ni los gastos financieros. La diferencia entre "ingresos totales" menos "gastos totales, incluyendo impuestos" constituyen los "ingresos netos". A esta partida se le restan los arrendamientos y los gastos financieros de la deuda para llegar al saldo de pérdidas y ganancias. En este mismo documento, pero en un epígrafe separado del resto aparece el título más importante y significativo del modelo propuesto: "Cargos y abonos en la cuenta de propiedad durante el año". En este apartado se incluyen dos conceptos. En primer lugar, las reparaciones y renovaciones, que se cargaban en los gastos de explotación y no en las cuentas de capital. Solamente se cargaba un gasto en las cuentas de neto cuando las instalaciones antiguas incrementaban el valor de la propiedad por encima del coste de renovar las estructuras originales; en estos casos, se cargaba la diferencia. En segundo lugar se registran los cambios en el valor de los bienes inmuebles y de otras propiedades pertenecientes a la compañía.

El estado denominado "Análisis de ingresos y gastos" está formado por una única columna que recoge los listados detallados, primero de los ingresos y luego de los gastos, con una suma al final de cada uno de los conceptos. En los ingresos se diferencian entre larga distancia y locales, y esto se hace tanto de pasajeros como de mercancías. En los gastos se detallan los impuestos, las reparaciones, las sustituciones, los gastos de mantenimiento y los gastos excepcionales como daños a la propiedad, y pérdidas de mercancías y equipajes; todos los gastos excepto arrendamientos y gastos financieros; se incluyen todos los gastos excepto arrendamientos y gastos financieros.

El estado "Activos y pasivos" ofrece la información de las masas patrimoniales. Los activos están expresados sin ningún criterio temporal, es decir no indica si son de corto y de largo plazo, o si son corrientes y no corrientes. Los activos están divididos en cinco títulos con subapartados en los dos últimos: cuenta de construcción, cuenta de material móvil, otras inversiones, partidas en efectivo y otros activos. Los pasivos están divididos en cuatro títulos, teniendo subapartados únicamente el tercero: capital, deuda consolidada, deuda flotante y cuenta de ingresos o pérdidas y ganancias. Al final de estos cuatro elementos se recoge la suma de pasivos. En los pasivos sí se realiza una clasificación temporal; pues separa el capital del resto de la financiación ajena, que está dividida en deuda a largo plazo ("consolidada" para Convention), y de corto plazo ("flotante" para Convention), por último incorpora el saldo del resultado del ejercicio. No recoge una partida de patrimonio neto, pero al incluir capital y resultados, podemos realizar una comparación interempresarial. No aparece ninguna partida, título o apartado para recoger las reservas. Después de la suma de pasivos se incluye un apartado separado denominado "Pasivos ciertos o imprevistos no incluidos en el balance" que recoge las obligaciones garantizadas por la campaña o las cargas sobre sus ferrocarriles, los intereses vencidos sobre ellas y, por último, otros pasivos distintos de los anteriores. 
Por otro lado, desde 1900 Interstate Commerce Commission (1900; 1908a; 1908b; 1909; $1910 ; 1911 ; 1913 ; 1914 \mathrm{a} ; 1914 \mathrm{~b} ; 1915 ; 1930)$ iban estableciendo listados completo y detallados de todas las cuentas, tanto de activo, pasivo, ingreso y gasto ${ }^{115}$.

Posteriormente, tomó el relevo la Association of American Railroads (1951), creando un listado de cuentas más sistemático y detallado. Este organismo separó las cuentas en ingresos (grupo 7), gastos (grupo 5) y todas las de balance (grupo 1, 2, 3, 4 y 6). Además, como novedad, establece subcuentas o cuentas de desglose, estableciendo cuentas intermedias (por ejemplo 702 1/2). También instauró una diferenciación de cuentas entre grandes y pequeñas empresas, estableciendo diferente listado para los grandes y pequeños transportistas (large carriers o small carriers). Por último, realizó una diferencia en el balance entre largo y corto plazo, apareciendo el concepto de activo o pasivo corriente. El lado del activo (asset side) se divide entre Investments, Current assets, Deferred assets, Unadjusted debits. El lado del pasivo (liability side) se divide en: Stock, Long Term debt, Current liabilities, Deferred liabilities, Unadjusted credits, Surplus.

Aunque los organismos tuvieron mucha importancia, las innovaciones de la contabilidad financiera estuvieron originadas de la práctica empresarial. Para satisfacer las necesidades informativas de las primeras empresas modernas, los directivos de los grandes ferrocarriles estadounidenses de las décadas de 1850 y 1860 inventaron gran parte de las técnicas básicas de la contabilidad financiera actual. Los directivos que realizaron las contribuciones más significativas fueron Latrone, Mc Callum, pero sobre todo J. Edgar Thomson y el resto de responsables de la Pennsylvania Railroad.

La contabilidad externa requería de la codificación de los datos registrados de las miles de transacciones realizadas por las grandes empresas ferroviarias, con el objetivo de elaborar el balance, por un lado, y permitir un análisis del rendimiento financiero, por otro ${ }^{116}$. La codificación de estas empresas ferroviarias era mucho más compleja, que las del resto de industrias que habían existido hasta el momento. La única que podría asemejarse era la textil, pero las comparaciones eran concluyentes: la mayor fábrica textil poseía, como mucho, seis grupos de cuentas, mientras que la Pennsylvania tenía en el año 1857, en el que Thomson reorganizó el departamento de contabilidad, 144 grupos básicos de anotaciones contables. De estas cuentas, 33 pertenecían a la oficina de pasajeros, 2 a las mercancías, 26 a la de materia motor, 9 a la oficina de mantenimiento de vagones, 22 a la de mantenimiento de vías, 21 a construcción y materiales y 8 a gastos generales ${ }^{117}$. Otra diferencia significativa es que en la industria textil sólo se confeccionaban los informes semestralmente, mientras que las de la Pennsylvania se realizaban mensualmente, y el interventor las enviaba, de forma impresa, al

\footnotetext{
${ }^{115}$ Como comparación, White (1925) estableció un listado de cuentas para ingresos y gastos.

116 Aunque el análisis económico-financiero es un concepto más amplio, que incluye el estudio de otros parámetros, fundamentalmente la solvencia y la liquidez, en estos primeros años las ferroviarias se limitaron a analizar la rentabilidad.

${ }^{117}$ La codificación de cuentas de la Pennsylvania puede observarse directamente en la documentación de la compañía (Pennsylvania Railroad Company, 1851: 60-61; 1852: 103-104; 1856:74-75). Un análisis de ellas fue realizada por Wilson (2010).
} 
Consejo de Administración a la mitad del mes siguiente. Los totales de informes mensuales se consolidaban al final del ejercicio contable en la memoria anual.

En 1851, el Informe Anual de la Pennsylvania mostraba el número de pasajeros que habían entrado al mes en cada estación, así como las toneladas de mercancías transportadas, diferenciando las transportadas localmente de las de larga distancia (Pennsylvania Railroad Company: 1851: 60-61).

Las grandes ferroviarias establecieron grandes departamentos de intervención, en los que se incluía un gran número de contables y de auditores internos.

Los miembros del Consejo de Administración y los inversores hicieron uso de los datos existentes en los informes anuales y en el resto de información derivada del departamento de intervención para evaluar el rendimiento. A finales de la década de 1850, la "ratio de partidas de ingresos frente a gastos", era la manera más utilizada para juzgar los resultados financieros. Las pérdidas y ganancias no eran suficientes por sí solas. Las ganancias tenían que compararse con el volumen de negocio. Un mejor indicador era la ratio que comparaba los ingresos y los gastos de un ferrocarril, es decir el porcentaje de los ingresos brutos que habían sido necesarios para cubrir los gastos de explotación ${ }^{118}$.

Al igual que ocurría con la codificación de la contabilidad externa, la contabilidad del capital de las empresas ferroviarias no tenían precedentes. Ningún tipo de empresa había prestado tanta atención a la contabilidad del capital, sin duda porque ningún otro tipo de empresa privada había realizado nunca inversiones tan grandes en capital, instalaciones y equipo.

En la década de 1850, los directivos del ferrocarril, los accionistas y los periodistas dedicaron mucho tiempo a establecer con claridad la distinción entre la cuenta de capital (también denominada de construcción) y la cuenta de explotación ${ }^{119}$. El origen de esta discusión es que los directivos podían aparentar que estaban obteniendo unos beneficios que no estaban ganando en realidad, cargando los gastos de explotación en las cuentas de construcción. Esto lo hacían para intentar aumentar las posibilidades de la empresa de conseguir fondos para completar o continuar la construcción. Con estas discusiones públicas, comenzaba la atención de la literatura financiera sobre la contabilidad creativa.

Una vez que se terminaba un ferrocarril, y que se cerraba la cuenta de construcción, su cuantía total se registraba en el activo del balance como una cuenta de capital o de propiedad.

Una vez activado surgía el problema de cómo determinar la depreciación de los activos de capital del ferrocarril (en estos años se intentaba registrar la depreciación por uso e incluso por la obsolescencia, no se tenía en cuenta aún el desuso). Este factor era fundamental en las

\footnotetext{
${ }^{118}$ El empleo de la "ratio de partidas de ingresos frente a gastos" en la década de 1850 se puede analizar en Chandler (1956: 139), mientras que la aplicación en el siglo XX se encuentra en Rippley (1915: 112-115).

${ }^{119}$ Estas ideas son compartidas por Kirkland (1948a: 340-344; 1948b: 332-335).
} 
ferroviarias, porque sus activos tenían mucho más valor que los de las fábricas de otras industrias, y encima se depreciaban a mayor velocidad. Para calcular la depreciación, las primeras líneas ferroviarias, como la Boston\&Worcester, comenzaron empleando los procedimientos de cálculo de las fábricas textiles. Incorporaron cantidades en los fondos de imprevistos o en las cuentas de pérdidas y ganancias con el objeto de tenerlo disponible para reparaciones costosas o para comprar nuevos equipos.

Sin embargo, en la década de 1850 los ejecutivos de los nuevos grandes ferrocarriles empezaron a considerar la depreciación como un gasto de explotación, y lo hicieron cargando las reparaciones y las renovaciones en las cuentas de explotación. La Pennsylvania Railroad Company explica que realizaba esta operativa de cargar las reparaciones y las renovaciones en los gastos de explotación "para que la cuenta de capital continúe reflejando el verdadero valor de los activos de capital", ya sean vagones, locomotoras, pero también carriles, traviesas y puentes (Pennsylvania Railroad Company, 1852: 15). Este procedimiento evitó el complejo problema de determinar la depreciación, pero no garantizó la disponibilidad de fondos para cuantiosas renovaciones y reparaciones ${ }^{120}$.

La Pennsylvania Railroad Company también fue pionera en la dotación de una reserva antes del reparto de dividendos, y en instaurar un principio de prudencia que rigiera los registros de la empresa para evitar una posible descapitalización de la empresa frente a terceros: "Si la compañía había declarado dividendos con cargo a sus beneficios, sería prudente llevar una parte de éstos a un fondo de reserva" (Pennsylvania Railroad Company, 1856: 12).

Tras saldar los ingresos con los gastos, la compañía deducía impuestos, intereses y otras cargas y luego fijaba los dividendos al 6\%. El saldo excedente iba a un "fondo de imprevistos" (Pennsylvania Railroad Company, 1856: 12). Estas cuentas eran utilizadas para satisfacer demandas anticipadas de reparaciones y renovaciones de vías y materiales hasta 1866. En 1866 se dejó de utilizar las cuentas de imprevistos independientes, a partir de ese momento se mantuvo simplemente la cuenta de excedentes suficientemente dotadas para acometer estas reparaciones y renovaciones.

Hasta la década de 1870 , este tipo de contabilidad de renovaciones ${ }^{121}$ será la forma estándar de la contabilidad de capital utilizada por los ferrocarriles estadounidenses (Chandler, 1977: 172). Las reparaciones y renovaciones se cargaban en los gastos de explotación y no en las cuentas de capital o propiedad. Las dos cuentas -una para la construcción y otra para el material móvil- se alteraban únicamente cuando se añadían nuevas instalaciones o cuando se dejaban de utilizar algunas ya existentes. El procedimiento fue definido del siguiente modo: "No se debe cargar ningún gasto en las cuentas de propiedad, excepto en caso de un aumento real en la construcción, en los materiales y en la propiedad, a menos que se haga en instalaciones antiguas de forma que incremente claramente el valor de la propiedad por encima del coste de renovar las estructuras originales. En estos casos, sólo se debe cargar la

\footnotetext{
${ }^{120}$ En las ferroviarias estadounidenses no se mantenían fondos de reserva para las renovaciones y las reparaciones, al igual que ocurría en las empresas originadas en la revolución industrial inglesa.

${ }^{121}$ El método de contabilidad de renovaciones fue descrito con detalle por Brief (1966: 1-23; 1968: 21$)$.
} 
cuantía del coste diferencial, y se debe especificar la cantidad asignada a la antigua instalación" (Convention of Railroad Commissioners: 1879).

Cargando las reparaciones y las renovaciones en los gastos de explotación, el valor de la propiedad se mantenía teóricamente inalterado. El método de contabilidad de renovaciones suponía que el beneficio se calculaba por diferencia entre los ingresos y los gastos de explotación, y no como la tasa de rendimiento sobre la inversión en activos reales ${ }^{122}$.

El método de contabilidad de renovaciones presentaba dos inconvenientes. En primer lugar, la utilización de la contabilidad de renovaciones imposibilitó conocer cuanto capital se había invertido en instalaciones y material móvil, pues parte de los costes de capital se habían absorbido como gastos de explotación. De esta forma, la ratio de partidas de ingresos frente a gastos se convirtió en el instrumento básico para analizar el rendimiento financiero de las compañías ferroviarias en lugar de la tasa de rendimiento sobre la inversión en activos reales, pues este último dato no se podía calcular. En segundo lugar, este método de determinar la depreciación suponía asimismo que la contabilidad exageraba los gastos de explotación e infravaloraba el consumo de capital ${ }^{123}$.

Mientras que las innovaciones en la contabilidad financiera y de capital se produjeron en el periodo 1850-1870, las innovaciones en la contabilidad de gestión se produjeron desde 1840 en el cálculo y análisis de los costes, y desde 1881 en la planificación y el control en las ferrovías estadounidenses. La mayor innovación contable es el paso de la teneduría de libros a la contabilidad como instrumento de la dirección empresarial, y este no se produjo en las empresas británicas durante la Revolución Industrial, porque era tan alto el margen de beneficio -tanto que les convertía en una posición cuasimonopolista-, que ellos no consideraron necesario desarrollar un sofisticado sistema de contabilidad de gestión (Pollard, 1965: 325). Fueron, sin embargo, las ferroviarias estadounidenses las que desarrollaron un interés por la contabilidad de gestión a medidados del siglo XIX, cuando se enfrentaron a la necesidad de realizar grandes inversiones en capital, instalaciones y equipo.

Los Directivos ferroviarios como Charles Ellet (en los años cuarenta del siglo XIX), Daniel C. Mc Callum (en los años cincuenta del siglo XIX) y Albert Fink y J. Edgar Thompson (en los sesenta del siglo XIX) idearon los sistemas de contabilidad y de información necesarios para controlar el movimiento de los trenes y el tráfico, dar cuenta de los fondos gestionados y determinar los beneficios y pérdidas de las diversas unidades operativas y de la empresa en su conjunto. Estos sistemas proporcionaron las técnicas básicas utilizadas por los fundadores de las primeras compañías ferroviarias para crear sus sistemas de control interno y contabilidad.

\footnotetext{
${ }^{122}$ Lógicamente el beneficio no se podía relacionar con los activos reales por medio del cálculo de una tasa de rendimiento entre los beneficios y los activos reales.

${ }^{123}$ Brief (1968: 21) afirmó que "con el tiempo, la contabilidad de renovaciones subestima el consumo de capital".
} 
En la década de 1840, el ingeniero de caminos Charles Ellet realizó una descripción detallada de los costes ferroviarios que publicó en American Railroad Journal ${ }^{124}$.

En la década de 1850 destacó Mc Callum, quien hizo hincapié en la necesidad de generar datos de costes comparativos en cada una de las divisiones operativas de un gran ferrocarril. Su mayor aportación fue la emisión de una serie de recomendaciones para la realización de cuentas detalladas por divisiones $^{125}$.

No fue hasta la década de 1860 cuando la contabilidad de costes se convirtió en instrumento básico en la dirección de los ferrocarriles, sobre todo por las aportaciones de Albert Fink ${ }^{126}$ en el Lousville \& Nashville Railroad en 1874. El objetivo de Fink era determinar con mayor precisión la medida básica del coste unitario: "la tonelada/milla". El primer paso para la obtención de costes exactos de transportar una tonelada por una milla en cada una de las divisiones fue organizar sus datos financieros y estadísticos recopilados por los departamentos de contabilidad y de transporte (Fink, 1875: 47-48). Consolidó algunas de las cuentas existentes y subdividió otras. Su aportación más novedosa fue clasificar las cuentas existentes según la naturaleza de los costes y no según los departamentos en los que se llevaban a cabo las funciones.

Los cuadros 4-6 muestran como Fink reorganizó los 70 grupos de cuentas ${ }^{127}$ en cuatro categorías: "Mantenimiento de vías y administración central", "Costes de estación por tren/milla", "Costes de circulación por tren/milla" y "Cargos en concepto de interés". Las cuentas de estas categorías se determinaban para cada división sobre la base de las millas recorridas.

\footnotetext{
${ }^{124}$ Chandler (1977: 177) analizó los costes ferroviarios diseñados por Charles Ellet.

125 Según el autor, la comparación de las cuentas por divisiones permitirá a los directivos llevar "sus asuntos con la mayor economía, e indicará sin confusión la capacidad y la competencia relativa de cada uno de ellos para desempeñar el puesto que ocupa. Será útil para señalar los excesos en el coste de dirigir las divisiones, al comparar los detalles" (Mc Callum, 1855: 107).

${ }^{126}$ Fink (1827-1897) nació en Lauterbach, Hesse, Alemania, estudió arquitectura e ingeniería de caminos en la Escuela Politécnica de Darmstadt, y se graduó en 1848. En 1849 emigró a los Estados Unidos. Pronto encontró trabajo en el ferrocarril de Baltimore and Ohio Railroad Company como dibujante, y se convirtió en asistente del jefe de la oficina de Benjamin H. Latrobe. En este cargo, supervisó el diseño y construcción de edificios y puentes. Dejó el ferrocarril de Baltimore y de Ohio en 1857 para convertirse en el asistente de George McLeod, ingeniero jefe del ferrocarril de Lousville \& Nashville Railroad. Fink avanzó rápidamente en el Louisville \& Nashville, hasta convertirse en ingeniero jefe (Faust, 1909: 80-81) En 1865, fue nombrado gerente general, y en 1870, elegido vicepresidente (Dictionary of American Biography, vol. VI: 387-388). La crisis financiera de 1873 llevó a Fink a estudiar el coste del transporte, y posteriormente publicó un texto sobre el tema, conocido como "El Informe Fink en los costes de transporte" (Fink: 1875).

${ }^{127}$ Son 71 cuentas $(28$ de la primera +10 de la segunda +32 de la tercera +1 de la cuarta), habiendo una semisuma al final de cada una de las cuatro categorías y una suma total al final. Notar que el indicador 29 que es una semisuma está dividida en dos: 29 y 29 1/2. Por tanto Fink establece 76 epígrafes: las 71 cuentas (epígrafes número 1-28, 30-39, 41-73), las 4 semisumas (epígrafes número 29. 29 1⁄2, 40 y 74) y la suma final (epígrafe número 75). Además de estas semisumas de cada una de las categorías, el listado está plagado de indicadores que realmente son sumas pero que poseen una capacidad de gestión como para considerarlas simultáneamente indicador: $10,34,35,39,47,54$ y 73. Del mismo modo, hay indicadores que tienen el origen en una semisuma pero referenciada al cociente de las millas de vía: 14, 20 y 28.
} 
Cuadro 4. Clasificación de los gastos de "Mantenimiento de vías y administración central" de Fink

\begin{tabular}{|l|}
\hline 1. Reparación de vías \\
\hline 2. Balasto \\
\hline 3. Cunetas \\
\hline 4. Alcantarillas y cercas para el ganado \\
\hline 5. Reparaciones extraordinarias: corrimientos, etc. \\
\hline 6. Reparaciones de tolvas y vagones basculantes \\
\hline 7. Reparaciones de herramientas para construir vías \\
\hline 8. Vigilantes de vías \\
\hline 9. Gastos generales del departamento de vías \\
\hline 10. Total \\
\hline 11. Sustitución de traviesas: valor \\
\hline 12. Trabajo a sustituir las traviesas \\
\hline 13. Gastos de transportar las traviesas \\
\hline 14. Coste total de las traviesas por milla de vía \\
\hline 15. Reparaciones en las superestructuras de los puentes \\
\hline 16. Vigilantes de puentes \\
\hline 17. Reparaciones de los talleres \\
\hline 18. Reparaciones de los depósitos de aguas \\
\hline 19. Reparaciones de las casa de tramo \\
\hline 20. Coste total de las reparaciones de puentes y edificios por milla de \\
\hline vía \\
\hline 21. Administración central y gastos generales del departamento de \\
\hline operaciones \\
\hline 22. Publicidad y captación de pasajeros y mercancías \\
\hline 23. Seguros y gastos \\
\hline 24. Cuentas e arrendamientos \\
\hline 25. Total por milla de vía \\
\hline 26. Salarios de los directivos \\
\hline 27. Seguros, impuestos y gastos generales \\
\hline 28. Total por milla de vía \\
\hline 29. Coste total por milla de vía del mantenimiento de la total por tren/milla del mantenimiento de la vía y los \\
\hline \\
\hline
\end{tabular}

Fuente: Flink (1875)

En la categoría "Mantenimiento de vías y administración central" se recogen 28 grupos de cuentas en los que los costes no varían en función del volumen del tráfico. Los contenidos son 
las partidas que se ocupan del mantenimiento de las vías, edificios y la administración central o gastos generales.

Cuadro 5. Clasificación de los gastos de "Costes de estación por tren/milla" de Fink

\begin{tabular}{|l|}
\hline 30. Trabajo de cargar y descargar las mercancías \\
\hline 31. Agentes y oficinistas \\
\hline 32. Gastos generales de las estaciones: luces, combustibles, etc. \\
\hline 33. Vigilantes y guardagujas \\
\hline 34. Gastos de cambiar la vía \\
\hline Reparaciones de locomotoras \\
\hline Salarios de mecánicos y bomberos \\
\hline Gastos del depósito de locomotoras \\
\hline Gastos generales y de supervisión \\
\hline Aceite y borra de algodón \\
\hline Abastecimiento de agua \\
\hline Combustible \\
\hline 35. Total por tren/milla \\
\hline 36. Material de oficina e imprenta \\
\hline 37. Gastos de telégrafo \\
\hline 38. Reparaciones del depósito de locomotoras \\
\hline 39. Total por tren/milla \\
\hline 40. Gastos totales de estación por tren/milla \\
\hline
\end{tabular}

Fuente: Flink (1875)

En la categoría "Costes de estación por tren/milla" se incluyen diez grupos de cuentas que variaban con el volumen de mercancías, pero no con la longitud del ferrocarril o con las millas recorridas. Eran costes incurridos en las estaciones para mantener una fuerza laboral para recibir y expedir mercancías y posibilitar en sentido amplio el transporte de personas. 
Cuadro 6. Clasificación de los gastos de "Costes de circulación por tren/milla" de Fink

\begin{tabular}{|l|}
\hline 41. Reparaciones de la vía \\
\hline 42. Costes de sustitución del carruaje: valor \\
\hline 43. Trabajo de sustituir el carruaje \\
\hline 44. Gastos de transportar los carriles \\
\hline 45. Bridas \\
\hline 46. Agujas \\
\hline 47. Gastos totales de reparar la vía y de sustituir el carruaje por \\
tren/milla \\
\hline 48. Reparaciones de locomotoras \\
\hline 49. Aceite y borra de algodón utilizados en las locomotoras \\
\hline 50. Vigilancia y limpieza \\
\hline 51. Combustible utilizado en el depósito de locomotoras \\
\hline 52. Gastos generales y de supervisión del depósito de locomotoras \\
\hline 53. Salarios de mecánicos y bomberos \\
\hline 54. Gastos totales de las locomotoras por tren/milla \\
\hline 55. Revisores y guardafrenos \\
\hline 56. Reparaciones de los vagones de pasajeros \\
\hline 57. Reparaciones de los coches cama \\
\hline 58. Reparaciones del os vagones de mercancías \\
\hline 59. Aceite y borra de algodón utilizados en los vagones \\
\hline 60. Labores de engrase e inspección de vagones \\
\hline 61. Gastos de trenes \\
\hline 62. Gastos totales de los trenes por tren/milla \\
\hline 63. Combustibles utilizados por las locomotoras \\
\hline 64. Abastecimiento de agua \\
\hline 65. Gastos totales de combustible y agua por tren/milla \\
\hline 66. Daños a mercancías y pérdidas de equipajes \\
\hline 67. Daños a existencias \\
\hline 68. Cuenta de accidentes \\
\hline 69. Daños a personas \\
\hline 70. Gratificación a los empleados \\
\hline 71. Vallas quemadas \\
\hline 72. Gastos legales \\
\hline 73. Total por tren/milla \\
\hline 74. Costes totales de circulación por tren/milla \\
\hline
\end{tabular}

Fuente: Flink (1875) 
En la categoría "Costes de circulación por tren/milla" se recogen 32 grupos de cuentas en las que los costes dependían del número de trenes que estaban en funcionamiento ${ }^{128}$.

Tras el listado de los gastos de las tres categorías se ubicaba un indicador más "75. Total de mantenimiento y de la circulación por tren/milla", donde se agrupaban todos los gastos de explotación como suma de las tres primeras categorías.

La última categoría, "Cargos en concepto de interés", estaba ubicada fuera de los gastos de explotación, al interpretarse que no tenía relación con el tráfico transportado o los trenes en circulación. Estos cargos sólo aumentaban cuando la expansión del negocio demandaba nuevas construcciones y una ampliación de la deuda.

Además de estas partidas de gastos, el autor requiere de información adicional para realizar los cálculos correctos de la estimación del coste de transporte por ferrocarril: media de toneladas de mercancías transportadas en tren por milla de viaje de ida y vuelta, distancia media del transporte, número de millas recorridas anualmente por los trenes de mercancías y de pasajeros, coste de ferrocarril, tipo de interés y número total de toneladas de mercancías acarreadas durante un año por milla de vía.

A continuación se describe la fórmula empleada por Fink (1875: 47-48) para transformar los 70 grupos de cuentas en costes por tonelada/milla.

El resultado se obtiene de la suma de cuatro términos matemáticos. "Coste total por tonelada / milla" = "Costes de circulación por tonelada / milla" + "Costes de estación por tonelada / milla" + "Mantenimiento de la vía por tonelada / milla" + "Intereses por tonelada / milla".

\footnotetext{
${ }^{128}$ Fink (1875: 47) y Chandler (1977: 177) restan importancia a esta categoría porque los costes no variaban con el volumen de negocio debido a que los trenes rara vez circulaban completamente cargados. Sin embargo la clasificación de Fink, y no sus comentarios, tenían razón. Existen costes que se incurren por el número de viajes realizados por cada circulación de tren, independientemente de su nivel de ocupación.
} 
Cuadro 7. Fórmula para averiguar el coste del transporte ferroviario por tonelada/milla

$\frac{\text { Costes de circulación por tren/milla(partidas } 41 \text { a 74) }}{\text { Número medio de toneladas de mercancías en cada tren }}=$ Costes de circulación por tonelada / milla

Costes de manipulación de las mercancías en la estación de expedición

+en la estación de recepción (partidas 30 a 40)

Longitud del trayecto

$=$ Costes de estación por tonelada / milla

Costes de mantenimiento de la vía

por milla y por año

(partidas 1 a 29)

$x \frac{\text { Millas totales recorridas por los trenes de mercancías por año }}{\text { Trenes }}$ Trenes de pasajeros y de mercancías por año

Número medio de toneladas de mercancías trasportadas por milla de vía y por año

= Mantenimiento de la vía por tonelada / milla

Número de millas recorridas

por los trenes de mercancías

Costes de la vía por milla $\mathrm{x} \frac{\text { Interés anual de mercancías por año }}{100} \times \frac{\text { por año }}{\text { Número de millas de los }}$ trenes de pasajeros y de mercancías por año

Número de millas de los trenes de pasajeros y de mercancías por año

$=$ Intereses por tonelada / milla

Fuente Fink (1975: 47-48) 
Los "Costes de circulación por tonelada / milla" se obtiene por el cociente de Costes de circulación por tren/milla" (tercera categoría) dividida entre el "Número medio de toneladas de mercancías en cada tren".

Los "Costes de estación por tonelada / milla" se calculan por el cociente "Costes de manipulación de las mercancías en la estación de expedición más en la estación de recepción" (segunda categoría), dividido entre la "Longitud de trayecto".

El "Mantenimiento de la vía por tonelada / milla" se obtiene por el cociente de dos términos estando el numerador formado por dos términos. El numerador es el producto de "Costes de mantenimiento de la vía por milla y por año" (primera categoría) por las "Millas totales recorridas por los trenes de mercancías por año" partido entre los "trenes de pasajeros y de mercancías por año". El denominador es el "Número medio de toneladas de mercancías transportadas por milla de vía y por año".

El "Intereses por tonelada / milla" se calcula por el cociente de dos términos, estando el numerador formado por tres términos. El numerador es el producto de "Costes de la vía por milla", por "Interés anual de mercancías por año" partido\%, y por "Número de millas recorridas por los trenes de mercancías por año" partido por el "Número de millas de los trenes de pasajeros y de mercancías por año". El denominador es el "Número medio de toneladas de mercancías transportadas por milla de vía y por año".

Por tanto, para calcular el coste del transporte ferroviario por tonelada/milla se suman los resultantes de las cuatro sumatorios anteriores: "Costes de circulación por tonelada / milla" + Mantenimiento de la vía por tonelada / milla" + "Intereses por tonelada / milla" + "Intereses por tonelada / milla".

Para Fink, el análisis de los costes era fundamental para confeccionar las tarifas. El mero conocimiento de los "costes medios totales por tonelada / milla" no tenía valor ya que nunca se transportaban mercancías en condiciones medias. Si las tarifas deben basarse en los costes, entonces las mercancías deben clasificarse según las circunstancias que afecten al coste de transporte y obtener el coste de cada mercancía por separado ${ }^{129}$. Siempre teniendo en cuenta que los costes sólo eran un factor más en los cálculos que determinaban las tarifas.

A partir de Fink, la ratio "coste por tonelada/milla" fue el criterio para que los directivos controlaran y evaluaran a sus subordinados, y no las ganancias, los ingresos netos o la ratio "ingresos frente a gastos".

La tarea de planificación y control utilizando presupuestos era generalizada en 1881 (Haines, 1897: 159-167). Cuando los bancos de inversión entraron en los ferrocarriles, pidieron a sus directivos propuestos unos presupuestos de las operaciones.

\footnotetext{
${ }^{129}$ Estas conclusiones de Fink nos han llegado a través de las citas de Chandler (1965a: 115).
} 
La productividad del ferrocarril se deterioró desde el año 1910. Esto fue relacionado por Thompson (1991: 1-10) con la ineficacia en el cálculo de los costes. Según él la disminución de la productividad se debió, entre otras cosas, al fracaso de los directivos en conocer la cuantía de los costes de cada uno de los servicios que las compañías ofrecían, además de ignorar si cada uno de ellos, tomados individualmente dentro de las empresas, arrojaba o no beneficios $^{130}$.

El primer tercio del siglo $\mathrm{XX}$ es un periodo de minoración del poder de innovación en la gestión de las compañías ferroviarias. Las empresas empezaron a experimentar un deterioro en sus prácticas contables, "en parte por los propios defectos introducidos en la contabilidad interna por la estandarización de métodos a que obligaba la Interstate Commerce Commision a todas las compañías desde 1887, pero sobre todo por la fosilización de las prácticas de gestión administrativa" (Vidal Olivares, 1997: 15). La contabilidad interna fue progresivamente más pasiva y ello no permitía adelantarse, prever los resultados de la explotación; "se convertía, de ese modo, en un instrumento sin virtualidades para la toma de decisiones, dejando de ser un herramienta de administración y gestión efectiva" (Salsbury, 1977: 48-49).

En el periodo 1900-1923, la contabilidad de gestión de las empresas ferroviarias estadounidenses estaba caracterizada por el desarrollo del modelo de costes estándar. En ese mismo periodo era habitual la asignación de los costes indirectos a los productos y la utilización de los indicadores de costes de forma continuada. La gran novedad de esta época es la creación de novedosos indicadores para la asignación de los recursos a las distintas divisiones. Sin embargo, hubo que esperar hasta la década de 1960 para generalizar el objetivo del usuario de la contabilidad de gestión, y la generalización del Modelo de Costes Variables.

\subsubsection{Financiación con clases de acciones}

Las acciones pueden otorgar derechos diferentes. Las acciones que tengan el mismo contenido de derechos constituyen una misma clase de acción. Cuando dentro de una clase se constituyan varias series, todas las que integren una serie tienen igual valor nominal.

La primera empresa que emitió clases de acciones en Estados Unidos fue la Baltimore and Ohio Railroad Company cuando autorizó en sus estatutos sociales la emisión de acciones privilegiadas en 1836. No obstante, no se generalizó su emisión hasta finales del siglo XIX, cuando se promulgaron las leyes de sociedades de los distintos estados de la Unión (Evans, 1931: 56-62) (Friedman, 1973: 446-449). El final del siglo XIX fue el momento de más éxito, existiendo numerosas emisiones, sobre todo entre las empresas de ferrocarriles y de provisión de servicios públicos (Ripley, 1912: 37-43) (Evans, 1931: 56-62). Esta situación se mantuvo hasta 1928, cuando la emisión de acciones privilegiadas suponía el $20 \%$ del total de todas las acciones emitidas (Depenbrock, 1975: 21-23).

\footnotetext{
130 “Aún a pesar de que las evidencias estadísticas pusieron de manifiesto los errores de cálculo en las estrategias tomadas, éstas se mantuvieron invariables" (Thompson, 1991: 1-10).
} 
En el siglo XX la utilización de las clases de acciones, sobre todo por stock corporations ${ }^{131}$, ha sido y es una práctica habitual. Las acciones privilegiadas han sido utilizadas frecuentemente en Estados Unidos como "mecanismo de holdings financieros (trust)" (Ripley, 1912: 37-43) (Evans, 1931: 56-62) (Depenbrock, 1975: 21) (Peñas Moyano, 2008: 293) en compañías de ferrocarriles que, saneadas bajo la Bankruptcy $A c t^{132}$, recurren a estas acciones para estructurar su nueva dotación de capital ${ }^{133}$.

La principal característica legislativa de Estados Unidos es que existe un Derecho de sociedades por acciones organizado en un doble nivel: estatal y federal. Esto supone que existe distinta regulación en cada uno de los estados que conforman la Unión (Grosso, 1999: 318) (Olavo, 1993: 106 y 107) $)^{134}$.

La otra característica es que Estados Unidos se basa en la teoría contractualista del Derecho. Frente a la visión imperativa del Derecho continental europeo (Mattei, 2003: 615 y 617), en Estados Unidos estaba vigente la teoría contractualista ${ }^{135}$ del derecho, la cual presenta un rasgo característico. El Derecho societario se separa de las normas imperativas, a favor de la dimensión dispositiva (default) del Derecho, de tal modo, que busca un Derecho opcional antes que imperativo, facilitador antes que limitativo, competitivo antes que jerárquico. Ambos rasgos tienen una influencia directa en la práctica societaria estadounidense de las clases de acciones. En primer lugar, la prevalencia de las normas de derecho facultativo sobre las de derecho imperativo ofrece una gran flexibilidad para modular las clases de acciones, ofreciendo alternativas que pueden ajustarse más a las demandas de potenciales inversores. En segundo lugar, es muy frecuente la utilización de la cláusula estatutaria conocida como blank stock clauses, por la cual se atribuye a los administradores de la entidad, en el momento de la emisión, acciones especiales denominadas blank stocks, por las que se atribuye el poder para

\footnotetext{
131 Por ejemplo, el 31 de diciembre de 1994, estaban emitidos más de 125 billones de dólares en acciones privilegiadas por compañías americanas cotizadas en mercados bursátiles (Mitchell, 1996: 443).

$132 \mathrm{http} / / /$ statutes.agc.gov.sg/non_version/cgi-bin/cgi_retrieve.pl?actno=REVED-20.

${ }^{133}$ También se utilizaron en la reorganización de servicios públicos para reembolsar obligaciones. En la década de 1930 a 1940, el gobierno estadounidense utilizó los fondos públicos y la legislación para subvencionar la producción con pérdidas. La Reconstruction Finance Corporation de 1932 permitió prestar capital a los bancos, compañías de seguros y cajas de crédito agrícola. La Emergency Banking Relief Act de 1933 autorizó al Tesoro a nombrar un administrador en los bancos con dificultades. Por último, el Estado adquirió acciones privilegiadas de los bancos y creó instituciones de crédito público: Federal Land Banks (agricultura), Home Loan Banks (vivienda), Federal Farm Mortage Corporation (créditos hipotecarios) y Export-Import Bank (exportación e importación). Todas estas medidas legislativas pueden observarse en Sagredo (2001: 186-188).

${ }^{134}$ La primera fuente jurídica escrita en Estados Unidos es la Constitución Federal aprobada en 1787. En ella se regulan la estructura política y el sistema jurídico estadounidense, arbitrándose una distribución de poderes y, en consecuencia, de competencias legislativas entre el Estado Federal y los distintos estados de la Unión. Según la décima enmienda, los Estados son competentes para todo aquello que no haya sido expresamente atribuido al Estado Federal. La disciplina federal se ocupa del control de los mercados financieros, regulación del comercio y el establecimiento de los impuestos federales. La competencia en materia de organización y funcionamiento de las sociedades corresponde a los distintos estados (Guerra Martín, 2003: 45 y 46).

${ }^{135}$ Estas diferencias están matizadas en el siglo XXI, pues existe un cuestionamiento del modelo contractualista de la sociedad por acciones en los Estados Unidos de América (Mattei, 2003: 615 y ss.) (Rossi y Stabilini, 2003: 2 y 11-16).
} 
determinar las características, tanto administrativas como económicas de estas acciones, sin necesidad de tener que proceder a la modificación de los estatutos sociales (Peñas Moyano, 2008: 359). Estas blank stock, no previstas en los articles of incorporation, "son muy atractivas para el board of directors" (Vargas, 1964: 160) (Cary y Eisenberg, 1995: 1988) pues permite establecer sus términos teniendo en cuenta las necesidades económicas de cada momento concreto, evitando así los procedimientos de modificación de los articles. La posibilidad de emitir estas acciones supone una praxis flexible y la concesión de un amplio poder a los management en la emisión de clases de acciones.

En el tema de las clases de acciones, la praxis del mercado financiero estadounidense presenta dos peculiaridades respecto al resto de mercados. De un lado, posee una gran cantidad de acciones postergadas o de fundador ${ }^{136}$ suscritas por los promotores. De otro lado, el derecho de voto nunca se ha considerado esencial, por lo que nada se opone al reconocimiento de acciones de voto plural ${ }^{137}$ o privadas del derecho de voto ${ }^{138}$. Las acciones de voto plural no han logrado un gran auge ${ }^{139}$, al contrario que las acciones sin voto, que han tenido un éxito sin parangón en cualquier otro mercado. El recurso de las acciones sin voto (non voting stock) posee una absoluta libertad de configuración ${ }^{140}$; esta flexibilidad, frente a la rigidez continental, ha hecho que sea en Estados Unidos donde mayor éxito tuvieron las acciones sin voto (Bergerman, 1928: 445-448) (Dood y Baker, 1951: 301) (Farrar, 1991: 221) (Levine, 1976: 460) (Pennington, 2001: 225) ${ }^{141}$.

\footnotetext{
${ }^{136}$ En el ordenamiento español, las "acciones de fundador" nunca podrían ser calificadas jurídicamente como acciones. Se podrá denominar bonos de fundador, pero nunca acciones. Es un error considerarlas "acciones preferentes de fundador", como realizó la Sentencia 4784/1979, de 23 de junio de 1979, del Tribunal Supremo. Sala de lo Civil. Madrid (Sección $1^{\mathrm{a}}$ ).

${ }^{137}$ Toda clase puede tener atribuido un voto múltiple [s. 6.01 (c) (1) MBCA y s. 7.21 (a) MBCA].

138 Toda clase puede no atribuir a sus titulares el derecho de voto, salvo en los casos en los que la MBCA disponga otra cosa [s. 6.01 (c) (1) MBCA].

${ }^{139}$ Las acciones de voto plural no han gozado de gran predicamento en la praxis societaria estadounidense (Cincotti y Nieddu, 2003: 681/II). La razón radica en la existencia de otras fórmulas, como la absoluta libertad de configuración de las acciones sin voto o las acciones con distintos valores nominales o sin valor nominal (Olavo, 1993: 108) (Campuzano, 2000: 73).

${ }^{140}$ La jurisprudencia apoya la totalidad libertad para establecer los derechos de cada clase. Una Sentencia permite la emisión de acciones sin derecho a dividendo alguno, rescatable en cualquier momento por el valor nominal si tiene cuatro de los cinco votos de los administradores, y que en caso de liquidación sólo recibe el valor nominal. La justificación para permitirlo es que si las leyes conceden libertad prácticamente absoluta para determinar el contenido de las clases de acciones, entonces trazar la línea divisoria entre lo que está permitido, y lo que no está, parece imposible. Vid. Sentencia del caso Lehrman versus Cohe (Corte Suprema del Estado de Delaware, 1966). Otra Sentencia considera válida una categoría de acciones en la que, con el objeto de preservar el control familiar de una entidad, cada accionista poseía de diez votos por cada acción poseída. Vid. Sentencia del caso Williams versus Geier (Corte Suprema del Estado de Delaware, 1977).

${ }^{141} \mathrm{La}$ emisión de acciones sin voto llegó a ser, en algunos casos, abusiva; por ejemplo "la sociedad industrial Rayon emitió 600.000 acciones, de las cuales sólo 2.000 tenían derecho a voto" (Ripley, 1972: 123). Estos escándalos tuvieron como respuesta una serie de leyes que intentaron disminuir el número de acciones sin voto, guiándose por el principio de "one share, one vote"; las principales normativas al respecto son dos: Public Utility Holding Company Act de 1935 e Investment Company Act de 1940.
} 
La figura acciones rescatables apareció por primera vez legislada en Estados Unidos en la Corporate Law del año 1836, aunque no existió una utilización masiva hasta la segunda década del siglo XX (Model Business Corporation Act de 1946; MBCA Annotated, vol. I, section 6.01.).

\subsubsection{Avances en la auditoría y revisión de estados contables}

Los primeros antecedentes de la auditoría son muy antiguos ${ }^{142}$, porque la profesión auditora, entendida como actividad de control de la actividad económico-financiera, surge en el momento en que la propiedad de los recursos financieros o fuentes de financiación y la responsabilidad de la asignación de los mismos a usos productivos no se encuentra en manos de la misma persona, es decir cuando se produce una separación entre propiedad y gestión (Suárez Suárez, 1991: 12).

Aunque en la Edad Antigua (Babilonia, Egipto y Persia) podemos encontrar actos que podrían corresponder con una auditoría interna ${ }^{143}$, la auditoría externa, como actividad profesional independiente, aparece en la Edad Media en Italia.

En la Edad Media existían personas encargadas de oír las rendiciones de cuentas o justificación de los gastos efectuados por funcionarios y agentes, de aquí que algunos autores (Álvarez López, 1991, 49) (Sánchez Fernández de Valderrama, 1996, 36) (Alvarado Riquelme, 1998: 13) consideren que el término auditoría proviene del verbo audire ${ }^{144}$. Los primeros documentos escritos que acreditan la existencia de auditorías externas tienen como objeto organismos públicos, entre ellos destaca el acuerdo realizado en 1164 entre el Cabildo Catedralicio de Milán y el revisor contable Giovani Donnolo; más tarde, en el siglo XIII, está documentado la actuación del revisor contable y matemático Leonardo Fibonacci sobre el Municipio de Pisa (Gironella, 1978: 61) (Alvarado Riquelme, 1998: 103). En 1581 se funda en Italia "Il Collegio Dei Raxonati", la primera asociación de revisores contables o auditores

\footnotetext{
${ }^{142}$ Las primeras manifestaciones de auditorías se ubican muy lejanas en el tiempo, tanto que autores han llegado a afirmar "que es tan antigua como la propia historia de la humanidad" (Jiménez Caraballo, 2011: 1-2).

${ }^{143}$ La revisión de cuentas tiene algunos antecedentes muy remotos, como el caso descrito en uno de los papiros de Zenón, encontrados en Egipto en 1951. En el año 254 AC, Apolunios, ministro de finanzas del rey Filadelfo, de la dinastía de los Ptolomeos de Egipto, contrariado por haberse pagado de su caja siete talentos de plata sin su autorización, ordenó fuesen comprobadas las cuentas de Aristeo, uno de los tesoreros y las del mayordomo Artemidoro. Esta orden se extendió a Zenón, administrador de todos sus intereses y jefe de Contabilidad para que preparase sus cuentas para ser inspeccionadas por Pythen, banquero del estado (Chatfield y Vangermeersch, 1996: 237) (Jiménez Caraballo, 2011: 1-2).

${ }^{144}$ La función de la auditoría, surge, debido a que los grandes señores se hacían acompañar de hombres de su entera confianza que sabían escribir y su principal función consistía en escuchar lo tratado y ponerlo por escrito. De ahí, que por su actividad de "oír", se derivó hacia la de "oidor" y dadas las funciones de este oidor que se referían a la revisión del cumplimiento de los pactos, acuerdos y las cuentas de sus señores, con el tiempo el termino se convirtió en "auditor". En la Europa Feudal esta profesión comenzó a precisarse más, llegando a identificarse las funciones con el cargo y así nació el auditor. Esta actividad auditora como acto de control del desarrollo económico financiero de cualquier institución, surge en el momento mismo en que la propiedad de unos recursos financieros y la responsabilidad de asignar estos a sus productivos, ya no están en manos de una misma y única persona, como ocurre en cualquier institución de cierto tamaño y complejidad.
} 
independientes (Alvarado Riquelme, 1998: 103). En 1658 se crea en Milán y Bolonia la "Academia dei Ragioneri". En el año 1793 se constituye en Milán el segundo "Colegio de revisores contables", cuyo propósito primordial era detectar errores e irregularidades en la llevanza de la contabilidad (Alvarado Riquelme, 1998: 103).

Los auditores internos existen en las ferroviarias estadounidenses desde 1847, momento en el que Latrobe estableció en la Baltimore \& Ohio la figura de chief clerk, encargado de elaborar y verificar las cuentas (Baltimore \& Ohio Rail-Road, 1847a: 3).

Las empresas ferroviarias tuvieron la necesidad de instaurar auditores externos desde la década de 1840.

Chandler (1977: 170) une el primer indicio del reconocimiento de la necesidad de revisión externa a la distinción entre la cuenta de construcción o de capital y la cuenta de explotación. Al cargar los costes de construcción en las cuentas de explotación, los inversores en ferrocarril se beneficiaban a expensas de sus usuarios. Por esta razón, reformadores de las vías férreas tales como Henry Varnum Poor ${ }^{145}$, fundador de Standard \& Poor y director de la American Railroad Journal, en la década de 1850, y Charles Francis Adams, el presidente de la Massachusetts Railroad Commission, en las décadas de 1860 y 1870, pidieron reiteradamente a sus directivos que delimitaran exactamente los dos grupos de cuentas: la cuenta de construcción o de capital y la cuenta de explotación. Para comprobar que habían sido separadas correctamente, los reformadores propusieron que personas independientes, ya fueran grupos de inversores o comisiones ferroviarias o legislativas, tuvieran la oportunidad de revisar los libros de contabilidad de las empresas.

Morgan y los otros banqueros de bancos de inversión contrataron a un censor jurado de cuentas independiente que aportara un punto de vista externo sobre la contabilidad financiera y de capital de la compañía. No obstante no hicieron auditoría sobre los costes y las estadísticas de explotación (Chandler, 1977: 170).

Para las empresas del resto de sectores de Estados Unidos, la necesidad de tener un auditor externo surgió más tarde, ya en el siglo $\mathrm{XX}^{146}$, tomando gran importancia a partir del hundimiento de la Bolsa de Nueva York en 1929. Desde el 1 de julio de 1933 se exigió a las sociedades que cotizaban en este mercado bursátil la obligación de adjuntar a los Estados Financieros un Informe de Auditoría independiente.

\footnotetext{
${ }^{145}$ Henry Varnum Poor era bisaubuelo de Chandler.

${ }^{146}$ A pesar de que en el momento actual el protagonismo indiscutible en materia de auditoría corresponde a los Estados Unidos, los primeros pronunciamientos doctrinales y normativos tienen su origen en el Reino Unido (especialmente por galeses y escoceses). Situación aún más importante si cabe, al constatar que las primeras auditorías de empresas norteamericanas fueron realizadas por profesionales británicos.
} 


\subsection{Gran Bretaña}

Como la mayoría de los países, incluída España, los ferrocarriles británicos fueron planificados, promovidos, construidos y explotados por empresas privadas hasta su nacionalización en 1947 (Gourvish, 1999: 57).

Gran Bretaña fue el país que desarrolló por primera vez la tecnología ferroviaria. No obstante, el impacto del ferrocarril en los procesos de producción y distribución fue menor en Gran Bretaña que en Estados Unidos pues empezó a industrializarse mucho antes que la aparición del ferrocarril, además el área geográfica es mucho menor que en Estados Unidos, y sus redes marítimas, fluviales y terrestres estaban mucho más desarrolladas. A pesar de ello, el volumen transportado por kilómetro era mucho mayor que en Estados Unidos. Eso sí, las compañías ferroviarias británicas fueron, con mucho, las mayores empresas de Gran Bretaña durante el siglo XIX (Chandler, 1990: 402).

Las inversiones para la construcción de ferrocarril tuvieron un menor impacto sobre las instituciones financieras existentes que lo que ocurrió en Estados Unidos y Alemania, pues las ferroviarias británicas pudieron financiarse exclusivamente con el capital local, y con las instituciones del mercado monetario existentes (que era el mercado de capitales más sofisticado del mundo en ese momento).

\subsubsection{Avances en la estructura organizativa}

Los directivos de los ferrocarriles británicos tenían una menor motivación para introducir nuevos métodos de organización y de control interno. Por ello, los ferrocarriles británicos no proporcionaron modelos para la dirección industrial como lo hicieron los ferrocarriles estadounidenses $^{147}$.

A mediados de la década de 1890, la London and North Western Railway (L\&NWR) contrató a nuevos directivos universitarios. Con ellos reorganizó los esquemas organizativos de la compañía a lo largo del periodo 1891-1902. Cambió un modelo organizativo sencillo, basado en departamentos en línea, por un organigrama complejo, de carácter multidivisional y estructurado por zonas.

Las actividades de las compañías ferroviarias dieron lugar a la creación en Gran Bretaña de las primeras jerarquías directivas con niveles de dirección bajos, medios y altos (Gourvish, 1972: 265-267; 1980: 10-11).

Cada vez en mayor medida, la toma de decisiones descansaba en directivos mejor reclutados y formados (Irving, 1976: 250-266). La profesionalidad y conocimiento de estos directivos era tan valorada, que era frecuente que muchos directivos de la compañía, se integraran en los

\footnotetext{
147 Tanto es así que Irving (1976: 213-218 y 254-256) describe cómo, a finales del siglo XIX, los directivos británicos viajaban a Estados Unidos para aprender los métodos y técnicas de organización y de dirección estadounidenses.
} 
Consejos de Administración de esa ferroviaria, otras ferroviarias, o incluso de otro tipo de empresas, aportando sus conocimientos en el management, a la hora de plantear estrategias de expansión o de gestión (Gourvish, 1986: 185-204).

\subsubsection{Innovaciones contables}

Durante el periodo 1820-1845, las empresas tuvieron muchos problemas operativos, causados por la baja eficiencia, por el uso de sistemas contables inadecuados, por tener una actitud dubitativa para aplicar la contabilidad de costes y por la baja cualificación del personal de gestión $^{148}$.

La aprobación de la Railway Clauses Consolidation Act en 1845 impuso tarifas bajas y supuso un impulso para la unión de diferentes líneas, dando lugar a empresas de mayores dimensiones que debían aumentar su nivel de eficiencia (Dyos y Aldcroft, 1974: 133-154) (Gourvish, 1980: 49-51). Eran empresas con un número cada vez mayor de trabajadores y con una alta proporción de costes fijos, lo que obligaba a mejorar los modelos de gestión.

En el periodo 1845-1855 aparecieron con fuerza los ejecutivos (como Huish) que conocían los medios financieros y eran capaces de integrar los principios de la contabilidad y su experiencia práctica en los negocios ferroviarios. Todos ellos eran gestores asalariados, ni propietarios, ni socios ni accionistas, lo que suponía un cambio fundamental en la estructura empresarial británica: la separación entre propiedad y gestión.

El capitán Mark Huish, ocupó el cargo de general manager de la London and North Western Railway (L\&NWR) desde 1846. Tres fueron sus logros más importantes: introdujo la contabilidad de costes en todos los servicios de la empresa, creó un departamento nuevo para recopilar y controlar estadísticamente el tráfico y, por último, mejoró los métodos de cálculo de la depreciación de las instalaciones fijas y el material móvil ${ }^{149}$.

Desde 1850, algunas ferroviarias británicas establecieron una incipiente medida de planificación y control por medio de presupuestos, diferenciando, desde los primeros años de andadura ferroviaria, los gastos previsionales y realizados (Lardner, 1850: 194). Las empresas ferroviarias de la época fueron conscientes de la importancia del estado de ingresos y gastos para tomar decisiones (Lardner, 1850: 195), la necesidad de calcular el coste de cada uno de las personas y/u objetos transportados (Lardner, 1850: 196) y la subjetividad que conlleva este cálculo al existir costes indirectos (Lardner, 1850: 190). Las empresas realizaron una clasificación de los costes en función de las divisiones físicas (departamentos) en que se divide la empresa (Lardner, 1850: 200).

Más adelante, entre 1902 y 1914, la London and North Western Railway (L\&NWR) introdujo medidas de contabilidad para reducir los costes y aumentar el control sobre las diferentes partes de la empresa. Fundamentalmente, se incidió en la mejora de la elaboración de

\footnotetext{
${ }^{148}$ El origen de estas causas es analizada por Vidal Olivares (1997: 18).

${ }^{149}$ La actuación de Mark Huish fue estudiada por Gourvish (1970; 1972).
} 
estadísticas y los métodos contables de la compañía, con el objetivo de reducir los costes y facilitar la toma de decisiones (Irving, 1976: 213-227 y 250-266).

Desde que surge la British Railway en 1949 existía "un alto nivel de capacidad y habilidad en la gestión" (Gourvish, 1999: 61). Por ejemplo, utilizaban el método de valoración de inversiones basado en el valor actualizado de los flujos de caja futuros que previsiblemente se van a obtener (Discounted cash flow).

\subsubsection{Contabilidad de gestión}

Para analizar los indicadores de gestión de las empresas ferroviarias británicas de la época la mejor opción es estudiar lo escrito por George L. Boag ${ }^{150}$ en su libro Manual of Railway Statistics, editado por The Railway Gazette News en 1912. Manual of Railway Statistics analiza la elección más adecuada de un tipo u otro de promedio estadístico, que era el punto central del libro y objeto de una gran preocupación en Gran Bretaña y su imperio.

Manual of Railway Statistics ${ }^{151}$ suministró a los directivos un compendio asequible de los tipos de medidas de carácter estadístico habituales dentro el sector. Con la disponibilidad de buenas estadísticas, los ejecutivos podrían saber -creía el autor- si la compañía estaba o no bien gestionada. Representaban, por tanto, un excelente medio de control. Pero para que cumpliesen semejante cometido éstas debían ser, por encima de todo, uniformes, lo que no sucedía en Gran Bretaña, cargando las empresas diferentes valores de gasto a las mismas partidas contables. Así los resultados entre ellas no siempre eran homogéneos, lo que era un problema muy serio. Tampoco eran comparables con los de sus homólogas de Europa. El

\footnotetext{
${ }^{150}$ En 1907, viene a trabajar a España como Sub-Director del ferrocarril minero Lorca-Baza y Diputación de Almedricos a Águilas (LBA), perteneciente a la sociedad británica The Great Southern of Spain Railways Company, donde conoce la idiosincrasia de la industria ferroviaria española. En 1913 es nombrado Director General, puesto que mantuvo hasta su jubilación en febrero de 1936. Cuando Boag se jubila, la situación de la compañía era desastrosa, pues desde el ejercicio 1931 los saldos de las cuentas de explotación arrojaban saldos negativos.

The Great Southern of Spain Railways Company Limited se constituyó en Londres el 20 de octubre de 1885, y llegó a conseguir las líneas Lorca-Granada y Lorca al puerto de Águilas. Tenía su sede social en Londres y allí se reunía el Consejo de Administración. Cuando llegó Boag a España en 1907, LBA explotaba 133 kilómetros de la línea Lorca-Baza (antigua concesión del ferrocarril Murcia a Granada) más 33 kilómetros correspondientes al ramal de Diputación de Almedricos al Puerto de Águilas. La actividad fundamental de LBA entre 1909 y 1932 consistió en el porte del mineral de hierro hasta el embarcadero de El Hornillo (Gris, 2005), construido en 1906 por G. Gillman Bovet, y cuya explotación pertenecía a otra empresa, The Hornillo Company Limited (Gris, 2003). El nombramiento de Boag coincidió con uno de los escasos momentos dulces de la compañía, debido al aumento de tonelaje del mineral de hierro y a la absorción del Hornillo por The Southern.

${ }^{151}$ El libro recibió muchos elogios, entre los que destaca una extensa recensión aparecida en Journal of the Royal Statistical Society y firmada por W. M.A (Vol. 76, No. 1, pp. 117-119). También se hizo eco de la publicación The Railway Gazette (30 de agosto de 1912, p. 237), con un amplio comentario sin rúbrica. Es un libro singular, sin pretensión alguna de originalidad, pero muy útil. Por encima de todo, se trata -confiesa el propio Boag- de la obra de un "ferroviario" que quiere ayudar a todos sus "colegas" (gerentes), en especial a aquellos que se encontraban en lugares y países recónditos donde la información "era muy escasa", poniendo a su disposición, sintetizada, la vasta experiencia acumulada en su particular trayectoria (Gran Bretaña, Argentina, Guinea y España).
} 
autor tiene predilección por el sistema ton y passenger-mile (toneladas/viajero transportados sobre un kilómetro [milla] de distancia o toneladas kilométricas) pues -pensaba- ofrece información cuantitativa al respecto de los dos elementos fundamentales de la industria del transporte: el peso arrastrado y la distancia recorrida, siendo la base de muchos otros estadísticos. En Gran Bretaña este sistema sólo había sido adoptado por North Eastern (NER), pero existía un gran debate sobre la necesidad de uniformizar y homologar la praxis contable británica con la europea continental.

Las discrepancias producidas entre el sistema continental europeo y el británico son muy importantes para Boag, pues él trabaja en zonas alejadas de Gran Bretaña y se encuentra con problemas de comparabilidad entre las cuentas de las sociedades que maneja y las realizadas en Gran Bretaña; situación no expresada como problema por ningún autor hasta entonces. Él hizo una defensa del modelo utilizado en el continente, que es el que al final triunfa (salvo escasas excepciones, todas las sociedades ferroviarias británicas terminan adaptándolas). La importancia de la polémica puede observarse en que la discusión termina llegando al parlamento británico. Además, en el séptimo Congreso Internacional de Ferrocarriles de 1905, celebrado en Washington, hubo una sesión (número XIV) dedicada expresamente a contabilidad, donde se trataron los diferentes sistemas existentes y se habló de la necesidad de establecer criterios unificadores.

Manual of Railway Statistics está compuesto de cinco capítulos y tres apéndices. El primer capítulo desarrolla la importancia del uso de la estadística para la toma de decisiones ${ }^{152}$. El segundo capítulo es el fundamental, pues es donde analiza las estadísticas de tráfico, incidiendo en los ingresos. El tercero, denominado de estadística departamental, incide en los gastos, desarrollando la utilidad y forma de cálculo de indicadores útiles para la gestión: expenditure per mile, men per mile, engine-miles, engine-hours, gross-ton-mile-engine-hours, coal consumption per mile, expenditure per locomotive y cost of repairs per vehicle. El cuarto, sobre las estadísticas generales, posee dos aspectos fundamentales: 1) sus experiencias en la clasificación de los costes y en la asignación de los mismos a los distintos centros de costes, y 2) el detalle de las diferencias de presentación entre los sistemas estadísticos continentales y británicos, y las repercusiones de falta de comparabilidad entre ambos. El último capítulo desarrolla la utilidad de las gráficas y diagramas para la toma de decisiones, y de las máquinas para el cálculo de las estadísticas. Por su parte, el primer apéndice ofrece el Informe $n^{\circ} 1$ de la $8^{\text {a }}$ Sesión del Congreso Ferroviario realizado por Sir Thomas Rees Price ${ }^{153}$. El segundo apéndice desarrolla la información que debe ser incluida en los estados contables según las leyes de las compañías ferroviarias británicas vigentes en ese momento ${ }^{154}$, lo que supone una descripción detalladísima de las notas a incluir en la Memoria. El último apéndice

\footnotetext{
152 Al respecto, Boag acaba la obra recordando cosas tan sensatas como que disponer de la información estadística adecuada es una conditio sine qua non a la hora de tomar la solución oportuna. Los fallos que son obvios se notan enseguida y se pueden enmendar sobre la marcha, pero no sucede lo mismo cuando existe dejadez o desconocimiento de la unidad estadística pertinente.

${ }^{153}$ Publicado en Bulletin of the International Railway Congress Association, vol. XXIIII, n 12, December, 1909.

${ }^{154}$ The Railway Company Security Act 1866 y The Regulation of Railways Act 1868.
} 
incluye las reflexiones realizadas por Mr. Acworth, Sir George Paish y Mr. Peel sobre las cuentas de los ferrocarriles y de información estadística realizadas.

Las ideas fundamentales del libro, desarrolladas en el segundo capítulo, son las diferencias entre los modelos estadísticos utilizados en Gran Bretaña y en el resto del mundo ${ }^{155}$. En Gran Bretaña se utilizaba y se prefería el sistema train-mile $e^{156}$. Los ingresos y gastos de los estados contables de las empresas ferroviarias británicas están expresados en términos train-mile, y las cifras obtenidas al dividir el total de ingresos y gastos por el total de train-miles recorridos se utilizan para comparar los resultados de un período de trabajo con el mismo periodo del año anterior ${ }^{157}$. The total of the train-miles es el número de millas recorridas por todos los trenes, durante un período determinado. Puede ser utilizado de varias formas: puede ser tomado para cada tren separadamente, para cada sección, o separándolos entre servicios de pasajeros y de carga.

Frente a este método, se sitúa Ton and passenger-mileage ${ }^{158}$, cuyos máximos representantes son las ratios ton-miles y passenger-mile ${ }^{159}$. Ton mileage es el peso transportado (tonelaje) multiplicado por la distancia (millas) recorrida, mientras que ton-mile representa una tonelada transportada una milla ${ }^{160}$. En términos similares se define passenger-mileage, número de pasajeros transportados una milla ${ }^{161}$.

Prácticamente todas las ferroviarias del mundo fuera de las Islas británicas utilizan ton-mile statistics, incluida la East Indian Railway, la Grand Trunk Railway of Canada y prácticamente todas las ferroviarias de Argentina y Europa continental ${ }^{162}$.

Los responsables de los ferroviarios británicos se decantaban por el método train-mile: porque era más accesible, ya que el utilizado en Europa continental no estaba disponible hasta mucho después de que se hayan realizado las operaciones, porque era menos costosa su preparación y porque concedía menos información a los competidores (Boag, 1912: 8, 9 y 21).

\footnotetext{
${ }^{155}$ El método ton-mile statistics es prácticamente universal excepto en Gran Bretaña (Boag: 1912, 20).

${ }^{156}$ El método train-mile statistics es utilizado por todas las ferroviarias británicas, salvo la North-Eastern (NER). La compañía NER, constituida en 1854 por la fusión de cuatro empresas existentes, fue absorbida por London and North Eastern Railway en 1923. Su línea principal sobrevive hasta nuestros días como parte de la línea East Coast Main entre London y Edinburgh.

${ }^{157}$ Dentro del método, Boag $(1912,23)$ identifica diferentes formas de obtener los datos en Inglaterra y en la India.

${ }^{158}$ El método Ton-mile cost está desgranado con detalle en un libro de WOODLOCK (1940).

${ }^{159}$ Otros dos artículos habían defendido anteriormente la utilización de este método (Gibb: 1836) (Wedgewood, 1909).

${ }^{160}$ Diez toneladas transportadas diez millas equivale a cien toneladas transportadas una milla. Ambas cifras son expresadas 100 ton-miles $(10 \times 10=100 \times 1)$.

${ }^{161}$ Diez pasajeros transportados a una estación de diez millas de distancia equivalen a 100 passengers-miles $(10 \times 10=100)$.

${ }^{162}$ Recordemos que Boag desarrolló su actividad en Argentina y España.
} 
El método train-mile es solamente una unidad de distancia, porque no tenía en cuenta el peso de los trenes y no representaba el trabajo realizado. Boag ${ }^{163}$ se decantó por Ton and passenger-mileage, porque de todos los sistemas de medidas existentes era, en su opinión, el más sintético y universal, y también porque observa su capacidad para tomar decisiones en el futuro. Pero, sobre todo, cree que la aplicación generalizada de este sistema resolvería los problemas de comparabilidad que a él tanto le preocupaban.

Como elemento de comparación, observamos que el indicador de gestión más utilizado por las ferroviarias francesas ${ }^{164}$ es el equivalent ton-miles ${ }^{165}$.

\subsubsection{Regulación contable}

En los inicios del ferrocarril británico tuvo mucha importancia las legislaciones y regulaciones de los organismos contables, porque la normalización fue grande, por supuesto mucho más que en Estados Unidos ${ }^{166}$.

La normalización contable de las ferroviarias está integrada por la regulación contable general para todo tipo de empresas y la específica del sector.

Aplicable a todo tipo de empresas, "The Company Act 1844" 167 obligaba a utilizar un balance de situación, a pesar de que no se proporcionó un formato del mismo hasta "The Company Act 1956". Por su parte, "The Company Act 1929” obligaba a presentar una Cuenta de Pérdidas y Ganancias del Periodo ${ }^{168}$.

Por otro lado, "Regulation of Railways Act 1868" obligaba a las ferroviarias a rendir sus cuentas cada seis meses. Además, establecía que los apuntes debían realizarse por partida doble. Mucho antes, la doctrina ya venía recomendando que se publicasen las cuentas de las sociedades de responsabilidad limitada (Stuart Mill, 1848: 900-907).

Ante la insatisfactoria homogeneización de los registros contables de la Ley de 1868, en 1903 se crea un comité para unificar las prácticas: "Railway Companies'Association Committee". Este comité emitió diversos informes, siendo el principal el emitido en diciembre de 1905.

\footnotetext{
${ }^{163}$ Boag (1912: 21) es partidario de este método, pero cita argumentos de otros autores, fundamentalmente de Sir Alexander Rendel, que introdujo ton-mile statistics en la India en 1970.

${ }^{164}$ La utilización de este indicador en Francia es corroborada por Boag (1912: 9).

${ }^{165}$ Esta medida $\mathrm{D}=\mathrm{A} * \mathrm{~B} / \mathrm{C}$, siendo $\mathrm{D}$ equivalent ton-miles, " $\mathrm{A}$ " los ingresos totales de los paquetes, equipajes, correo y demás mercancías, "B" total de los bienes ton-miles y " $\mathrm{C}$ " mercancías totales recibidas.

${ }^{166}$ Glynn (1984) describe el modelo contable de las ferroviarias británicas en el periodo 1800-1911, señalando las principales disposiciones legislativas de aplicación a la información contable que debían publicar, así como, las limitaciones que presentaron dichos estados contables emitidos.

${ }^{167}$ En Companies Act 1844 aparece la expresión "true and correct" o "true and fair", relativos a los estados financieros, el antecedente del término "true and fair view” que surgíó por primera vez en Companies Act 1942.

${ }^{168}$ Todas estas regulaciones fueron estudiadas por Edwards (1981: 50).
} 
Posteriormente, en 1906, se creó el "Board of Trade Committee". Este comité emitió diversos documentos, siendo el fundamental el Blue Book de 1909, que contiene recomendaciones para la elaboración de la contabilidad. Las recomendaciones de este comité fueron incluidas en la Ley de $1911^{169}$.

La Ley "Railway Companies (Account and Returns) Act 1911" estableció que desde el uno de enero de 1913, cada compañía ferroviaria debe preparar anualmente estados financieros y que además, serían revisadas por auditores. Esta Ley deroga la obligación de ofrecer información cada seis meses establecida en la Regulation of Railways Act 1868. La ley de 1911 establece la obligación de depositar las cuentas anuales en el Board Trade. Además, obligaba a la empresa a permitir la copia de las cuentas por parte de cualquier accionista u obligacionista que lo solicitase. Los estados financieros ("Financial Accounts") están formados por tres documentos "Balance", "Ingresos y gastos" y "Capital". Lo más destacable del balance es que presenta la información en un orden distinto al actual: a la izquierda se presentan los pasivos mientras que a la derecha se recogen los activos. El más novedoso es el documento de Capital, que está formado por 9 cuadros. Además de la gran cantidad de información a incluir en los cuadros, destaca que la Ley de 1911 obliga a diferenciar el capital autorizado del emitido, que es el preludio de la concepción dual de capital.

La práctica británica realiza una distinción doble del capital (authorised capital e issued capital), lo que en esta investigación se denomina "concepción dual del capital", que es una figura típica del Reino Unido. El capital autorizado, nominal o registrado (authorised, nominal o registered capital) es el capital máximo que la sociedad puede emitir, aunque todavía puede no estar suscrito. El capital emitido o suscrito (issued capital) es el que está efectivamente emitido (suma del nominal de todas las acciones emitidas). El authorised capital está recogido en los estatutos (memorandum), mientras que el issued capital no aparece en estatutos, sin embargo es objeto de reflejo contable en el pasivo del balance, expresando una cifra de retención de las variaciones que pueda sufrir el patrimonio social ${ }^{170}$. Con todo ello, la cifra que aparece en los estatutos no coincide con el capital efectivamente suscrito, pues aquélla no muestra más que el número máximo de acciones que es posible emitir en la sociedad; por el contrario, el efectivo capital suscrito sólo aparece reflejado en la contabilidad de la sociedad emisora ${ }^{171}$.

"The Railways Act 1921" introdujo modificaciones en la forma de presentar los Estados financieros. En un primer momento fueron únicamente recomendadas, para posteriormente

\footnotetext{
${ }^{169}$ Newton (1930: 5) afirmó que las recomendaciones del Board of Trade Committee fueron incluidas en la Ley de 1911.

${ }^{170}$ El capital autorizado sólo puede modificarse previo acuerdo de la Junta de Socios y correspondiente modificación de estatutos que deberá estar inscrita en el Registro. Por su parte, el capital emitido es susceptible de ser modificado, dentro de los límites del capital autorizado, sin necesidad de una modificación estatutaria.

${ }^{171}$ Esto supone que el Derecho británico "no confía a la publicidad legal la función externa o de protección de terceros que en nuestro Derecho tiene anudado el capital social. En efecto, la previsión de una cifra de retención patrimonial -que habrá de coincidir con la expresada como issued capital- asegura su eficacia a través de previsiones de orden contable, pero al no aparecer en el memorando no goza de publicidad registral como tal, y por tanto, su variación no entraña necesariamente una modificación estatutaria” (García Cruces, 2002: 916).
} 
(27/12/1928) ser convertidas en obligatorias para todas las compañías ferroviarias. La principal es que el activo debe situarse en el lado izquierdo y el pasivo en el derecho.

\subsubsection{Financiación con clases de acciones}

La financiación del ferrocarril británico se realizó con instrumentos financieros, en un primer lugar con acciones ordinarias y obligaciones, y posteriormente con clases de acciones especialmente sin voto-, sin que fuese necesaria la intervención de los bancos de inversión como ocurrió en el mercado de capitales de New York.

Las acciones privilegiadas son conocidas en el Derecho británico desde principios del siglo XVII. Las primeras compañías que utilizaron las acciones preferentes fueron la Mine Adventurers 'Company desde el año 1698 y la East India Company desde el 1702 (Gower's, 1997: 350 y 351). Aunque su generalización en la práctica "se produce a lo largo de los siglos XVIII y XIX" (Gower's, 1997: 23).

Desde comienzos del siglo XIX prevalece, entre las empresas británicas, la emisión de acciones de una única clase ${ }^{172}$, de alto valor nominal. Esta tendencia varía a mediados del siglo XIX, al aumentar el número de pequeños accionistas que invierten en la sociedad pero que no desean participar en su gestión. La generalización de las clases de acciones se produce en el doble ámbito de los derechos de socio; no sólo se introducen diferencias en el plano de los derechos económicos, sino también con relación al derecho de voto que no se configura con carácter esencial. Se emiten así acciones privilegiadas con valor nominal menor, capaces de satisfacer simultáneamente las necesidades de accionistas centrados en la obtención de un rendimiento fijo, y de sociedades intentando aumentar capital sin el riesgo de una pérdida de control por parte de los accionistas existentes. De acuerdo con esta orientación, a partir de 1830, numerosas sociedades incorporan en sus estatutos tres tipos de clases de acciones: ordinarias (ordinary shares), preferentes (preferred shares) ${ }^{173}$ y subordinadas (deferred shares $)^{174}$.

La s. 75 The Companies Act 1845 reconoce la posibilidad de regular estatutoriamente el derecho de voto. Esto posibilitó "la emisión masiva de acciones sin voto y acciones de voto plural” (Peñas Moyano, 2008: 160).

\footnotetext{
${ }^{172}$ Durante la primera mitad del siglo XIX tuvo cierta virtualidad la rule of Law que establecía la necesidad de que los derechos derivados de las acciones fuesen idénticos; "A presumption of equality between shares" (Farrar y Hannigan, 1998: 226).

${ }^{173}$ Entre los sectores que utilizan masivamente acciones privilegiadas (preferred stock) destaca el de ferrocarril, de tal forma que "en 1849 el 66\% del capital social total de las compañías de ferrocarril británicas adoptaba la forma de preferred stock” (Kindleberger, 1993: 194).

${ }^{174}$ La utilización de estos tres tipos de clases de acciones puede observarse en: Farrar y Hannigan (1998: 226), Gower's (1997: 352), Tunc (1985, 90) y Pennington (2001: 205).
} 
La posibilidad de poder emitir tanto acciones privilegiadas como ordinarias, "se confiere, de forma general a todas las empresas, a partir de 1860" (Farrar y Hannigan, 1998: 221).

La creación de clases de acciones es contemplada expresamente en la Ley de 21 de diciembre de 1908. A estos efectos, la Ley distingue tres figuras. Acciones privilegiadas (preferred shares), caracterizadas por poseer un mayor derecho al dividendo, un derecho al reembolso anticipado o un derecho de voto múltiple ${ }^{175}$. Acciones ordinarias o diferidas (ordinary or deferred shares) que reciben dividendos solamente después del reparto efectuado a las privilegiadas ${ }^{176}$. Acciones de fundador (founder's shares) similares a los bonos del promotor y fundador del derecho continental ${ }^{177}$.

A partir de ese momento, la posibilidad de crear clases de acciones ${ }^{178}$ siempre se ha contemplado en la legislación mercantil británica (Gower's, 1997: 48-53) (Mc Gee, 1999: 69) (Hannigan, 2003: 389).

El Derecho británico consagra un principio de libertad de emisión de clases de acciones, admitiendo la creación de acciones ordinarias (ordinary shares) ${ }^{179}$, privilegiadas (preferred shares $)^{180}$, postergadas (deferred shares) ${ }^{181}$, de fundador (founder's shares), de oro (golden shares) ${ }^{182}$, atribuidas a los empleados (employees' shares) ${ }^{183}$, convertibles (convertible shares ${ }^{184}$, rescatables (redeemable shares), sin voto (non voting shares) ${ }^{185}$ y otras clases de

\footnotetext{
${ }^{175}$ La creación de acciones de voto plural se admiten con dos requisitos: (i) doble deliberación con acuerdo favorable de la junta general de accionistas y (ii) ratificación de los accionistas lesionados en dos reuniones sucesivas y por mayoría de las tres cuartas partes del capital y mitad de socios. Ley de 21 de diciembre de 1908, artículo 45 y 69. El número de emisiones con derecho de voto múltiple fue escasa, al no concurrir en el Reino Unido las circunstancias que en Alemania y Francia, produjeron el espectacular desarrollo de las acciones de voto plural.

${ }^{176}$ Ley de 21 de diciembre de 1908, artículo 45-56.

${ }^{177}$ Ley de 21 de diciembre de 1908, artículo 37 y 38.

178 A estos efectos, The Companies Act 2006 define lo que debe entenderse por clase de acciones (class of shares): "las acciones son de una clase si los derechos vinculados a las mismas son uniformes en todos los aspectos" [The Companies Act 2006, sección 629 (1)].

${ }^{179}$ Un análisis de las preferred stocks emitidas en Inglaterra puede observarse en Peñas Moyano (2008: 105114).

${ }^{180}$ Una descripción de las ordinary shares emitidas por empresas inglesas se encuentra en Peñas Moyano (2008: 115-146).

${ }^{181}$ Un estudio de las acciones postergadas (deferred shares) emitidas en el Reino Unido puede observarse en Pennington (2001: 219), Cain (1965: 128), Grier (1998: 151) y Ferrán (1999. 320). También pueden encontrarse, en el Reino Unido, acciones con distinto valor nominal y con el mismo poder de voto (Sentencia Greenhalgh versus Ardenne Cinemas Limited: 1946).

${ }^{182}$ Esto puede observarse en Ferrán (1999: 333) y Farrar y Hannigan (1998: 231).

${ }^{183}$ Ello puede observarse en Morse (1983: 221 y 222), Tunc (1985: 94), Gower'S (1997: 320) y Lorry y Watson (2001: 136 y 137).

${ }^{184}$ Esta idea es recogida por Lorry y Watson (2001: 136) y Farrar y Hannigan (1998: 23).

185 Esto puede observarse en Gower's (1997: 303), Tunc (1985: 92 y 93), Morse (1983: 221 y 222) y Grier (1998: 151).
} 
acciones caracterizadas por una diversa atribución del derecho de voto (contingent voting, disproportionale voting, voting debt securities y ordinary non voting shares $)^{186}$.

\subsubsection{Avances en la auditoría y revisión de cuentas}

En el Reino Unido, los primeros antecedentes de auditoría se encuentran en los entes públicos: el ayuntamiento de Londres en 1299 y la Corona Británica en 1324 (Vicent Chulia, 2004: 190).

George Watson, fue el primer contador que ofreció al público sus servicios como auditor en el año 1645 en Escocia (Brown, 1968: 156) (Littleton, 1966: 82) (Jiménez Caraballo, 2011: 2). En el año 1799 había varias firmas de contadores públicos que ejercían en Inglaterra la auditoría, lo que más tarde da lugar a la creación de varias asociaciones de la nueva profesión, siendo la primera la que se forma en Escocia en el año 1854 (Brown, 1968: 156) (Littleton, 1966: 82).

La primera referencia legislativa a la auditoría externa en los ferrocarriles se localiza en el Reino Unido, en concreto en la Great Western Railway's Act de 1835 se permite que sus Estados Financieros, incluso los intermedios, sean revisados por sujetos ajenos a ella, siempre que sean accionistas.

Esta potestad para las empresas del sector ferrocarril se generaliza al conjunto de sectores en la ley de sociedades anónimas, Joint Stock Companies Act de 1844, donde se permite que uno o más accionistas revisen los registros contables de las empresas ${ }^{187}$. Esta es la primera referencia legal a la revisión de sus propios socios para las sociedades de todos los sectores; anterior al primer referente legislativo de Francia en 1867, Italia en 1882 o Alemania en 1897.

Esta posibilidad también es incluida un año más tarde en The Companies Clauses Consolitation Act de 1845, permitiendo a los inversores-auditores revisar los libros de la sociedad y realizar preguntas a los empleados. Estos auditores no podían ejercer en la compañía ningún cargo, ni poseer en ella otros intereses que los que les correponde como accionistas. Estos pioneros Informes de Auditoría eran entregados, junto con los Balances, a los accionistas diez días antes de celebrarse las juntas de accionistas.

The Companies Act de 1855-1856 elimina la obligatoriedad de que los revisores fuesen accionistas de la empresa, facilitando, por primera vez, la contratación de sujetos ajenos a la sociedad en calidad de auditores externos. Además, se expone la primera situación en la que es obligatorio el nombramiento de un auditor, pues con la intención de ofrecer una garantía adicional para la protección de los accionistas, la Ley establece que las sociedades que no

\footnotetext{
${ }^{186}$ Aunque la legislación establece estas alternativas de creación de clases de acciones, la doctrina británica reconoce la posibilidad de emitir clases de acciones con otros perfiles, como las acciones con voto plural (Gower's, 1997: 303).

${ }^{187}$ La Ley de 1844 obligaba a las "Unicorporated Companies", aquellas formadas por más de treinta miembros, a inscribirse en el Registro Mercantil, siempre que estuvieran dedicadas a fines lucrativos.
} 
tengan nombrado un auditor deben hacerlo obligatoriamente si lo solicita el $20 \%$ de sus accionistas.

The Companies Act de 1862 describe con más detalle la tarea del auditor, y por primera vez establece un modelo de Informe de Auditoría.

The Companies Act de 1879 impuso a las sociedades bancarias la obligación de someter anualmente sus cuentas a la revisión de un Censor.

En 1880 se constituyó el Institute of Chartered Accountants in England \& Wales (ICAEW).

En 1895, The Davey Committee recomienda la revisión anual de los Estados Financieros para todas las empresas legalmente constituidas. Este documento es fundamental para entender la realidad actual, donde la legislación del Reino Unido e Irlanda, al contrario de lo establecido en la VII Directiva Europea, obliga a auditar a todas sus empresas, independientemente de su tamaño.

Posteriormente, The Companies Act de 1900 también incorporó la recomendación de auditarse a todas las sociedades, tengan el tamaño que tengan. Sin embargo, a pesar de recoger la recomendación, la citada Ley de 1900 no obliga a las empresas a nombrar un censor.

The Companies Act de 1907 es la primera legislación del mundo que requiere una auditoría externa obligatoria de forma masiva, pues obliga a todas las empresas que cotizan en bolsa a presentar un informe del auditor que exprese una opinión sobre los libros contables.

La Ley "Railway Companies (Account and Returns) Act 1911" estableció que desde el uno de enero de 1913, cada compañía ferroviaria debe preparar anualmente estados financieros y que además, serían revisadas por auditores.

The Companies Act de 1929 amplía aún más las operaciones que requieren la actuación del auditor externo obligatorio, al incluir, la revisión de los folletos de emisión de las nuevas emisiones de acciones.

\subsection{Alemania}

Alemania fue el país -junto con Bélgica- donde se implantó el primer sistema ferroviario del continente europeo en 1835.

El impacto del ferrocarril en Alemania fue mucho mayor que en Gran Bretaña porque las distancias eran mayores, el relieve más accidentado y las áreas accesibles por vía acuática eran más limitadas. 


\subsubsection{Avances en la estructura organizativa}

El político alemán List fue el primero que propuso en 1841 un sistema nacional de ferrocarriles (Nipperdey, 1996: 165). Esta medida fue finalmente establecida en Alemania en 1879, después de la unificación política de 1870, mucho más pronto que en el resto de países.

La temprana estatalización de la red provocó un impacto del management ferroviario con unos rasgos distintos al del resto de Europa. El principal es que no se produjo la separación entre propiedad y gestión.

Esta situación cambió parcialmente con la intervención de los aliados en la década de 1920, al incluir entre los objetivos de gestión, una mayor profesionalidad del management, aplicando criterios netamente privados (Mierzewski, 1993; 1990).

\subsubsection{Regulación contable}

Las Leyes contables de las empresas ferroviarias fueron fundamentales para establecer una regulación contable aplicable a todas las sociedades anónimas. La primera ley de ferrocarriles (Eisenbahngesetz) fue promulgada en 1838 cuando no había aún en Prusia regulación para el conjunto de las sociedades anónimas (Richard, 2006: 9).

\subsubsection{Financiación con clases de acciones}

Hasta que Bismarck se embarcó en su política de nacionalización, la mayoría de los ferrocarriles alemanes, particularmente los de Prusia, fueron construidos y administrados por sociedades privadas. El capital en estos primeros momentos se captó a nivel local en mucha mayor medida que en el Estados Unidos y Gran Bretaña; procedía de comerciantes, fabricantes, banqueros y de terratenientes ubicados cerca de las líneas férreas.

El posterior crecimiento del ferrocarril en el periodo 1850-1870, generó una demanda enorme (al igual que ocurría en Estados Unidos), lo que estimuló la creación de un intermediario financiero nuevo, el Kreditbank, un banco que suministraba capital a escala nacional e internacional. Unos cuantos intermediarios financieros, los Grossbanken (grandes bancos), dominaron las finanzas alemanas desde entonces. Según Riesser (1911: 48), estos Grossbanken combinaban en una única empresa las actividades de un banco comercial, de un banco de inversión, de un banco de desarrollo y de una sociedad de inversión. Los Grossbanken, al igual que ocurrió con los bancos de inversión estadounidenses ${ }^{188}$, fueron los instrumentos que hicieron posible la rápida acumulación de capitales en una escala suficientemente grande para financiar la construcción de la nuevas infraestructuras de comunicación, en términos que ahora se denominarían capital de riesgo. En esa época aparecieron un gran número de estos bancos: Abraham Schaaffhausen en 1849, Disconto-

${ }^{188}$ Los Grossbanken eran mayores que los bancos de inversión estadounidenses en términos de activos y personal. 
Gesellschaft en 1851, Bank für Handel und Industrie en 1853 y el Berliner HandelsGesellschaft en 1856.

Los bancos alemanes desempeñaron un papel importante en la financiación de las empresas ferroviarias e industriales (mucho más que los estadounidenses), por esta razón los banqueros alemanes tuvieron oportunidad de participar en la toma de decisiones de alto nivel. Por un lado, formaron parte de los consejos de supervisión de las empresas, tuvieron una intervención significativa en las decisiones de inversión, en la selección de directivos y en el establecimiento de procedimientos administrativos (Cleveland y Huertas: 1985). Como los bancos controlaban muchas acciones por cuenta propia y también votaban por delegación de muchos inversores, que tenían medios legales y administrativos más fuertes para supervisar la auditoría interna, los procedimientos contables y la financiación externa, que los representantes de las instituciones financieras en los consejos de administración de las compañías estadounidenses (Seidenzahl: 1970).

El Derecho positivo de las sociedades por acciones de los países germánicos, al contrario que los países anglosajones, ha dispuesto "un sistema cerrado de clases de acciones" (Campuzano Laguillo, 2000: 55-59), en el que las categorías de acciones posibles utilizables por el emisor son un número predeterminado y escaso, que son tipificadas normativamente ${ }^{189}$.

En el ámbito del derecho continental europeo, el siglo XIX marca el inicio del reconocimiento legal de las clases de acciones, movimiento en el que es pionero el Derecho alemán ${ }^{190}$. Desde 1840, se emiten en Alemania ${ }^{191}$ acciones prioritarias (Prioritätsaktien), precursoras de las acciones privilegiadas (Vorzugsaktien).

La utilización de acciones prioritarias (Prioritätsaktien) para financiarse tiene su origen, al igual que en Estados Unidos ${ }^{192}$, en las necesidades financieras de las sociedades de

\footnotetext{
${ }^{189}$ A este sistema cerrado se le denomina "principio de tipicidad", concepto según el cual no se pueden crear emisiones distintas de las tipificadas por el legislador. El derecho mercantil alemán ofrece opciones multiples en la creación de los estatutos de una sociedad de capital en el ámbito de la SRL $(\mathrm{GmbH})$, apoyándose en el principio dispositivo. En la SA $(A G)$ rige el principio opuesto, el principio de oficiliadad (ausencia de poder dispositivo).

${ }^{190}$ En el mosaico de estados alemanes antes de su unificación bajo el II Reich (en 1871), coexistieron en la parte occidental de Alemania, estados influidos por la legislación mercantil francesa (Renania y Westfalia) y también anglosajona (Hamburgo y Bremen). Por ello, quizás sería más exacto referirse al modelo prusiano en lugar del alemán, una expresión quizás demasiado generalista desde un punto de vista histórico.

${ }^{191}$ En esta época, Alemania está formado por un conjunto de estados, en el que el principal es Prusia. La Revolución de marzo de 1848 conduce a la creación del primer Parlamento alemán que elabora una primera constitución, pero fracasa con la unificación nacional porque los monarcas recuperan el control. El Imperio alemán se funda el 18 de enero de 1871 tras la victoria de Prusia en la Guerra franco-prusiana y se consigue la unificación de los diferentes estados alemanes en torno a Prusia, excluyendo a Austria. Así Prusia se convierte en Alemania, bajo el liderazgo del canciller Otto von Bismarck, quien será el artífice de la unificación. De esta forma, el país fue unificado, como un moderno estado-nación. A partir de este punto, y hasta el fin de la Primera Guerra Mundial, la historia de Alemania y la historia de Prusia se confunden.

${ }^{192}$ En el conjunto de los estados alemanes (y sobre todo en Prusia), la mayor parte de la red ferroviaria fue construida por el Estado y los pocos ferrocarriles emprendidos por la iniciativa privada no tardaron en ser
} 
ferrocarriles ${ }^{193}$. Era la época en que estaba vigente la Ley prusiana de sociedades por acciones de 8 de noviembre de 1843, para todo tipo de sociedades, y la Ley de ferrocarriles prusiana de 3 de noviembre de 1838, para regular las sociedades dedicadas a la explotación del ferrocarril. Ninguna de las dos leyes recogían la posibilidad de emitir acciones prioritarias (Prioritätsaktien), pero las empresas de ferrocarriles las emitían.

Las Prioritätsaktien se regularon por primera vez en la Aktiennovelle de 18 de julio de 1884, siendo el primer Derecho continental europeo en regular la figura de las categorías de acciones. La Aktiennovelle permite la creación de acciones prioritarias en el ámbito de los derechos patrimoniales, pero prohíbe las diferencias sobre los derechos políticos ${ }^{194}$. Las empresas que querían acogerse a ellas no podían emitir acciones que alterasen la proporcionalidad entre el valor nominal de la acción y el derecho de voto, opción que consagra la igualdad del derecho de voto de todos los accionistas de la sociedad anónima.

La Handelsgesetzbuch (HGB) de 10 de mayo de 1897 regula las acciones privilegiadas y las acciones de voto plural. El $\S 185$ de HGB autoriza la creación de derechos diferentes en cada clase de acciones, lo que supone la aparición de las acciones privilegiadas (Vorzugsaktien) ${ }^{195}$. Por su parte, el $\S 252$ de HGB, a diferencia de lo que sucedía en la Aktiennovelle de 1884, permitía la emisión de acciones de voto plural (Mehrstimmrechtsaktien) ${ }^{196}$. Cada acción concede un voto, pero se admiten clases de acciones que atribuyan un voto más elevado. Existen dos límites para la emisión de acciones con voto plural. El primero es que para su emisión no es suficiente la diferenciación en el derecho de voto, sino que se exige también que posean algún privilegio de naturaleza económica ${ }^{197}$. El segundo es que toda acción debe disponer de, al menos un voto, en la asamblea general de accionistas, lo que impide la posibilidad de emitir acciones sin voto (aktien ohne sitmmrecht).

La utilización de las clases de acciones en el mercado alemán "fue escaso hasta el término de la primera guerra mundial, momento a partir del cual comienzan a utilizarse mucho más" (Kübler, 1998: 45), incentivadas por el entorno económico de ese momento. De un lado, al

nacionalizados. Ello constituye una gran diferencia en relación a países como el Reino Unido o Estados Unidos, donde la inversión de fondos públicos en la construcción de la red ferroviaria fue irrelevante.

${ }^{193}$ La idea de que, en Alemania, la utilización de acciones prioritarias (Prioritätsaktien) para financiarse tiene su origen en las necesidades financieras de las sociedades de ferrocarriles puede observarse en: Bekker (1871: 712), Auerbach (1873: 50), Lehman (1964: 77), Zöllner (1984: 223) y Siebel (1997: 642-648).

${ }^{194}$ La Aktiennovelle de 11 de julio de 1870 había establecido que el derecho de voto constituía un derecho mínimo para todo accionista, debiendo ser éste idéntico para todos los socios. Esto supuso que cuando la Aktiennovelle de 18 de julio de 1884, reguló las categorías de acciones con las Prioritätsaktien, éstas podían tener privilegios en el reparto de ganancias y en el reparto de la cuota de liquidación, pero no en los derechos políticos.

${ }^{195}$ El $\S 185$ de HGB señalaba que "el contrato social podrá fijar determinados derechos para ciertas acciones, especialmente en lo que se refiere al reparto de ganancias".

${ }^{196} \mathrm{El} \S 252$ Inc. $2^{\circ}$ de HGB establece que "si se emitieran varias categorías de acciones, el contrato social podrá determinar la importancia y extensión del voto para cada clase".

${ }^{197}$ Como ejemplo de esta especialidad, la Ley recoge las ventajas en las ganancias y en la cuota de liquidación. Cfr. Handelsgesetzbuch, 1897, § 252. 
final de la contienda, Alemania se queda inmersa en una profunda crisis monetaria. Del otro, coincide un importante crecimiento del tráfico comercial y una resurrección de la industria, fenómenos ambos que vienen acompañados de una masiva afluencia de capital extranjero. En este contexto, a lo largo de la posguerra alemana, se emiten, tanto acciones con un derecho preferente sobre el dividendo "con una finalidad de saneamiento y recuperación económica" (Schmulewitz, 1927: 29), como acciones de voto plural "con el objetivo de evitar una invasión de capital extranjero que se haga con el control de la economía" (Depenbrock, 1975: 28).

La desventajosa situación de la moneda alemana posibilitó que los extranjeros pudieran utilizar su propia moneda como medio de pago en la adquisición de acciones alemanas en condiciones favorables. Las acciones de voto plural, raramente utilizadas con anterioridad, crecen espectacularmente. Son numerosas las sociedades que en este período emiten acciones de voto privilegiado reservadas a suscriptores nacionales, permitiendo únicamente a los inversores extranjeros la suscripción de acciones con un único voto por acción ${ }^{198}$. A través del mayor peso del derecho de voto de las acciones poseídas por accionistas alemanes, se asegura la estabilidad en la dirección de la empresa, y se permite que este círculo pueda luchar contra las tentativas de adquisición externa, conservando su influencia sobre los socios.

Las acciones de voto plural se extienden al mercado del oro merced al Decreto Goldmarkbilanzverordnung (1923: 27-32).

En el JuristenTag, que examina la reforma del Derecho de acciones, la Comisión propone en su informe, publicado en 1928, que el derecho de voto de las acciones pueda ser limitado o excluido. Esta propuesta adquiere gran difusión con el argumento de que la creación de esta clase de acciones permite obtener financiación preservando, dentro de la sociedad, las relaciones preexistentes de mayoría. Esta propuesta, unida a los Proyectos del Gobierno de reforma del Derecho de acciones de 1930 y 1931, que prevén y regulan la creación de acciones sin voto, da comienzo a una polémica. Por una parte, quienes defienden la conveniencia de admitir la emisión de acciones sin voto en el Derecho alemán, aduciendo razones para incentivar la financiación y la posibilidad de preservar las mayorías existentes en la sociedad. Por otra parte, quienes se pronuncian en contra de la creación de esta figura, argumentando que el principio de que todas las acciones posean un voto forma parte de los pilares básicos del Derecho de acciones alemán; además afirman que el argumento sobre que el accionista no da valor al derecho de voto no basta para justificar esta medida. Las reticencias a la introducción de las acciones sin voto tienen como resultado el rechazo de su reconocimiento legal, aunque su oposición únicamente servirá para demorar su admisión, que se produciría, definitivamente, en la Aktiengesetz de 1937.

La Aktiengesetz de 30 de enero de 1937 afianza la posibilidad de crear categorías de acciones en el ámbito de los derechos patrimoniales del socio. Asimismo modifica, sustancialmente,

\footnotetext{
198 "De esta forma, se garantizaba la mayoría de votos -y con ella la dominación de la empresa- a pesar de la pérdida de la mayoría de capital” (Kübler, 1998: 45).
} 
las reglas para la emisión de acciones con diferenciación en el derecho de voto. Por un lado, la emisión de acciones de voto plural se limita a supuestos excepcionales; únicamente el Ministerio de Economía puede autorizar su emisión cuando lo aconsejen las necesidades de la empresa y los intereses de la economía nacional (Von Caemmerer, 1967: 167). Por otro lado, este texto admite (Aktiengesetz, 1937: § 12.2) y regula (Aktiengesetz, 1937: §§ 115-117), la creación de acciones sin voto (vorzugsaktien ohne stimmrecht) como medio de obtención de capital por primera vez en un Derecho societario europeo continental (Porfirio, 1991: 109). La emisión de acciones sin voto se limita cuantitativamente y se somete al cumplimiento de determinadas condiciones. El $§ 115.2$ de la Aktiengesetz de 1937 establece que las acciones sin voto no pueden superar un tercio del capital social del emisor. Las acciones sin voto privan de este derecho a su titular a cambio del reconocimiento de ventajas patrimoniales. El $\S 117.4$ de la Aktiengesetz de 1937 establece que los titulares de acciones sin voto que no reciban sus privilegios económicos, recuperarán el derecho de voto ${ }^{199}$.

Las variaciones producidas en la legislación mercantil alemana sobre el privilegio del derecho de voto quedan resumidas en las siguientes líneas. La Aktiennovelle de 1884 no permite ni las acciones sin voto, ni las acciones con voto plural. La Handelsgesetzbuch de 1897 no permite las acciones sin voto, pero sí permite la emisión de acciones con voto plural. La única condición para ello es que las acciones con voto plural tengan privilegios económicos, es decir que no se limite únicamente a potenciar los derechos políticos. La Aktiengesetz de 1937 permite la emisión de las acciones sin voto y las acciones con voto plural. La condición en esta legislación es que la emisión de voto plural esté autorizada por el Reich, cuando lo aconsejen las necesidades de la empresa y los intereses de la economía nacional.

Por otro lado, aunque el Derecho positivo alemán casi no reguló los híbridos financieros que no tienen la consideración jurídica de clases de acciones, sin embargo, la práctica de los negocios instauró el bono de disfrute como un mecanismo para compensar financieramente las acciones que se amortizaban por el nominal. La figura fue definida por la práctica como un crédito participativo que no incorporaba el voto y que se representaba en un título (Genusschein). Aunque esta compensación era la finalidad inicial de esta figura, posteriormente, se utilizó para los más diversos propósitos: como bono de disfrute con ocasión de amortización de acciones, como mecanismo para remunerar a los fundadores, como instrumento para retribuir participativamente a los trabajadores (y directivos) o como técnica financiera de fortalecimiento de recursos propios. Las emisiones de estos títulos se iniciaron en las sociedades concesionarias de ferrocarril, aunque posteriormente se amplió su utilización a un gran número de sectores.

\footnotetext{
${ }^{199}$ Durante este tiempo, el número de emisiones de acciones sin voto fue escaso. "Las pocas que se emitieron fueron realizadas por empresas familiares y por sociedades públicas, que necesitaban financiación y no querían perder poder en la administración de las sociedades" (Porfirio, 1991: 109).
} 


\subsection{Francia}

\subsubsection{Avances en la estructura organizativa}

Es posible hablar de un "Modelo departamental centralizado", nacido y desarrollado en Francia, donde todas las grandes empresas de ferrocarriles francesas empezaron su andadura con este modelo de gestión organizativa. Todas estaban compuestas por un Consejo de Administración y un Comité de Dirección. El Comité de Dirección estaba compuesto por el Director General (que era un directivo asalariado) y por el presidente y vicepresidente del Consejo de Administración.

El reconocimiento de un "Modelo centralizado francés" parte de la idea de que en Francia hubo una tendencia mucho mayor que en el resto de países, a que todas las empresas tomasen las decisiones de forma centralizada. El origen de este rasgo distintivo puede estar en que la Administración francesa consideró como fundamental el carácter estratégico y defensivo del ferrocarril, y por tanto en los Consejos de Administración como en los puestos directivos se situaran muchos militares. Esto ocurrió sobre todo en los primeros años de construcción ferroviaria, pero fue una realidad hasta mediados del siglo XX. Por influencia de los militares se establecieron criterios jerárquicos y especialmente militares (Ribeill: 1977) (Caron: 1989).

No obstante, aunque todas las empresas francesas de ferrocarriles tuvieron en sus orígenes el mismo modelo de gestión organizativa, es posible diferenciar dos evoluciones en función del organismo que detente en mayor medida el poder. Existieron dos versiones de esta centralización: una "inmovilista", representada por Midi, y otra "evolutiva" representativa de Nord.

En la compañía Midi, el Consejo de Administración no dejó de ejercer el poder de decisión de forma centralizada, aunque el Director General también tuviese cierta capacidad de emprender iniciativas, apoyado por un amplio grupo de directivos ${ }^{200}$. El organismo esencial de esta empresa era el Consejo de Administración, que tomaba las decisiones de forma centralizada, con poca presencia de ingenieros, pero plagado fundamentalmente de tres agrupaciones de personas: la gran banca francesa, los altos funcionarios de la Administración y los inversores regionales. El sistema prácticamente no tuvo modificaciones sustanciales a lo largo de la existencia de la compañía.

En el resto de empresas francesas se puede observar una evolución, de un comienzo centralizado se fue pasando a un sistema multidivisional. De entre todas las empresas destaca la Compagnie des Chemins de Fer du Nord (Nord) ${ }^{201}$.

Nord también estaba compuesto por un Consejo de Administración y un Comité de Dirección (formado por el Director General, el presidente y el vicepresidente del Consejo de

\footnotetext{
${ }^{200}$ Midi fue estudiada por Bouneau (1995: 839-893).

${ }^{201}$ De la compañía Nord conocemos mucho porque fue detalladamente estudiada por Caron $(1973 ; 1981 ; 1989$; 1997; 2005).
} 
Administración). La diferencia con el anterior, es que en Nord el poder estaba en el Comité de Dirección, que tomaba las decisiones de forma centralizada.

El Comité de Dirección de Nord gozaba de una importante concentración de poder, siendo el Consejo de Administración únicamente un órgano de discusión de las estrategias y directrices surgidas del Comité de Dirección. La concentración de poder se dio en todo momento, aunque dependiendo del diferente órgano de poder que lo ostentaba se diferencian tres etapas: etapa de formación aproximadamente hasta 1870, etapa de consolidación (1870-1880) y, la última etapa, a partir de 1880.

En la etapa de formación de Nord, que se produjo hasta 1870, la empresa estaba dividida en divisiones, aunque siempre prevalecía la División de Explotación, que era la que concentraba los aspectos fundamentales de la gestión de la empresa. El Comité de Dirección estaba eventualmente asesorado en su misión de control de servicio por una Comisión de Contabilidad, que era la que definía las técnicas contables y la política financiera de la empresa. Los signos característicos de este sistema son la centralización de la información y la aplicación del criterio de autoridad.

A partir de 1870, Nord entra en su etapa de consolidación en el mercado francés. En esta etapa se produjeron cambios en el seno de la compañía motivados por el ascenso de una nueva generación de técnicos y directivos que consolidaron un mayor grado de autonomía en las decisiones. Los Directivos frenaron el proceso de concentración de poder acumulado por el Director General, que había caracterizado la etapa de formación, consiguiendo que la gestión interna pasase enteramente a manos de los ingenieros los cuales, junto al Comité de Dirección, fueron tomando cada vez más decisiones de forma autónoma. Con el aumento del poder de los ingenieros, los mecanismos de decisión se modificaron, al producirse una descentralización y un reparto de poderes que evolucionaron buscando tres objetivos: especializar los servicios, reforzar la independencia de cada uno de ellos y aumentar la coordinación general mediante comisiones que canalizasen la información entre todas las divisiones operativas de la compañía. Estas prácticas, centradas en el creciente poder de los directivos asalariados, se asemejan a las que los ferrocarriles estadounidenses y británicos estaban adoptando por las mismas fechas (Vidal Olivares, 1997: 31). Frente a la presión de los miembros del Consejo de Administración, los ingenieros respondieron realizando innovaciones en la gestión.

A partir de 1880, hubo un cierto equilibrio en el poder de la gestión entre el Comité de Dirección y los diferentes jefes de División. A su vez, el Consejo de Administración terminó convirtiéndose en un órgano protocolario. Al igual que en Midi, en el Consejo figuraban los intereses bancarios, la alta Administración francesa y los intereses regionales. Frente a un Consejo de Administración sin casi poder, los ingenieros fueron desarrollando cada vez más la organización de la compañía, jerarquizándola e introduciendo criterios corporativos sobre los que cimentar los objetivos de máxima eficiencia. 
La importancia de los Directivos de las empresas ferroviarias francesas, no sólo se observa en el protagonismo en su país, sino que también es destacable su movilidad pues trabajaron en empresas de Austria, España y Rusia, donde propagaron sus conocimientos.

\subsubsection{Financiación con clases de acciones privilegiadas}

La utilización generalizada de las clases de acciones en Francia no se produjo hasta el siglo $\mathrm{XX}$, cuando las sociedades de capital optaron por diseñar estructuras más complejas, lo que favoreció su reconocimiento legislativo, ya que "era necesario dotarlas de un marco jurídico propio" (Danos, 1922: 19) (Cordonnier, 1924: 5). Inspiradas en la legislación alemana, la Ley francesa de 9 de julio de 1902 autorizó la emisión de acciones que confirieran privilegios a sus titulares, salvo que los estatutos lo prohibieran directa y expresamente ${ }^{202}$. Así aparecen reguladas por primera vez las actions de priorité o actions privilégiés, acciones que disfrutan de ventajas sobre el resto de acciones: ya sea porque confieren derechos de preferencia sobre los beneficios y/o el activo social, o porque establecen privilegios sobre el voto. Las Leyes de 16 de noviembre de 1903 y 22 de noviembre de 1913 también autorizaron la emisión de acciones que confirieran privilegios económicos o sobre el derecho a voto a sus titulares, salvo que los estatutos lo prohibieran.

Desde 1902 hasta 1925 se produce, por un lado, "el afianzamiento de las acciones que atribuyen ventajas patrimoniales a sus titulares, y por otro lado, un número escaso de emisiones de acciones que reconocen privilegios sobre el derecho de voto" (Hamel; Lagaboe; Jauffret, 1980: 242). Durante los años 1925 y 1926, con la caída del franco, se produce una avalancha de acciones de voto plural; ante esta situación, comienza una continua y acusada censura doctrinal a las acciones de voto plural (Danos, 1922: 26-27 y 31-34) (Thaller, 1930: 380) (Hamel; Lagaboe; Jauffret, 1980: 242). A estas críticas responde la Ley de 26 de abril de 1930 que, basándose en el principio de proporcionalidad entre el valor nominal de la acción y el derecho de voto, prohíbe la emisión de nuevas acciones de voto plural.

La Ley de 13 de noviembre de 1933 hace extensiva la prohibición a las acciones ya existentes, pues fija un plazo de dos años para la adaptación de aquellas acciones de voto plural que, creadas con anterioridad a 1930, sobrevivían aún en la práctica. La Ley de 13 de noviembre de 1933 prohíbe la existencia de cualquier acción que implique una desproporción entre poder de voto y valor nominal. La única excepción contemplada expresamente es la referida a la posible concesión de un voto doble a los titulares de acciones nominativas que se encuentren íntegramente desembolsadas, siempre y cuando se hubieran realizado dos años antes. Con ello, la Ley de 13 de noviembre de 1933 establece un sistema intermedio conciliador entre adversarios y partidarios del voto plural (Pottier, 1934: 30 y 172) (Gaillard, 1938: 5). Se refrenda la exigencia de proporcionalidad entre el derecho de voto y la cuota de capital social representada por cada acción, ya introducida en la Ley de 26 de abril de 1930, y a la que en noviembre de 1933 se le confiere carácter retroactivo, pero se admite la posibilidad de atribuir

\footnotetext{
${ }^{202}$ La Ley francesa de 9 de julio de 1902 modificó el Código de Comercio estableciendo que "salvo disposición contraria de los estatutos, la sociedad puede crear acciones privilegiadas, investidas del derecho de participar antes que las otras acciones en la repartición de los beneficios, o en la distribución del activo social".
} 
un voto doble a las acciones nominativas que cumplan dos condiciones: íntegramente desembolsadas y emitidas dos años antes.

Por tanto, es posible detallar las posibles figuras permitidas en cada legislación francesa. La Ley de 9 de julio de 1902, la Ley de 16 de noviembre de 1903, la Ley de 22 de noviembre de 1913, la Ley de 26 de abril de 1930 y la Ley de 13 de noviembre de 1933 admiten dos clases de acciones: Actions de priorité y Actions privilégiées. Respecto a las variaciones producidas en la legislación mercantil francesa sobre el privilegio del voto, la Ley de 9 de julio de 1902, Ley de 16 de noviembre de 1903 y la Ley de 22 de noviembre de 1913 permiten la emisión de acciones sin voto y acciones con voto plural. Por el contrario, la Ley de 26 de abril de 1930 no admite la emisión de acciones sin voto ni con voto plural. La Ley de 13 de noviembre de 1933 no autoriza la emisión de acciones sin voto ni las acciones con voto plural como criterio general, pero posibilita la emisión de ambas figuras en determinadas situaciones. 


\section{CAPÍTULO TERCERO.- EL FERROCARRIL ESPAÑOL EN LA ÉPOCA DE LAS CONCESIONARIAS}

La gran empresa en España tuvo matices distintos a los de Estados Unidos y el resto de países europeos. Antes de la Guerra Civil española prácticamente sólo hubo empresas de gran tamaño en el sector público. Las únicas excepciones de grandes empresas privadas antes del periodo guerracivilista fueron las ferroviarias; siendo las dos más importantes NORTE y MZA.

\subsection{Evolución de la industria ferroviaria}

En España, las compañías ferroviarias fueron las empresas líderes por tamaño entre 1850 y 1935 (Carreras y Tafunell, 1993: 147).

El primer ferrocarril en el mundo se abrió al servicio público en Inglaterra en 1825 (StocktonDarlinghton $)^{203}$. Por su parte, el primer ferrocarril español fue el de La Habana-Güines abierta en la Cuba española en 1837, mientras que la primera línea ferroviaria peninsular ${ }^{204}$ fue el primer tramo del ferrocarril de la línea de Barcelona-Mataró ${ }^{205}$ abierto al público el 28 octubre de $1848^{206}$.

\footnotetext{
${ }^{203}$ En el año 1802, los ingleses Richard Trevithick y Andrew Vivian patentaron una locomotora a vapor de adherencia que se desplazaba sobre rieles por medio de un engranaje. Esta puede considerarse como la fecha de aparición del ferrocarril (Alliende: 1993).

${ }^{204}$ Anteriormente hubo una fallida tentativa de construcción de una línea para unir Jerez y el Puerto de Santa María. La construcción de esta línea se realizó finalmente en 1858. La construcción de esta línea puede consultarse en Castañeda (1946: 12-17).

${ }^{205} \mathrm{La}$ "Escritura de la sociedad y el reglamento de la compañáa del Camino de Hierro de Barcelona a Mataró y vice-versa" fue publicada en 1845 (Compañía del Camino de Hierro de Barcelona a Mataró, 1845: 1-16).

${ }^{206}$ La línea de Barcelona-Mataró fue otorgada provisionalmente a José María Roca por Real Orden de 23 de agosto de 1843. Posteriormente fue incorporada a TBF y luego a MZA.
} 


\section{Cuadro 8. Desarrollo cronológico del ferrocarril en España}

\begin{tabular}{|c|c|c|}
\hline Periodo & $\begin{array}{l}\text { Kms. } \\
\text { construidos }\end{array}$ & Descripción \\
\hline 1840-1855 & 440 & $\begin{array}{l}\text { Experimentación e iniciación al amparo de la Real Orden de } 31 \text { de } \\
\text { diciembre de 1844, basada en el Informe Subercase }\end{array}$ \\
\hline 1856-1865 & 5.000 & Periodo de gran expansión bajo la Ley Ferroviaria de 1855 \\
\hline 1866-1870 & 350 & $\begin{array}{l}\text { Crisis económica de } 1866 \text { e inestabilidad política del Sexenio Democrático: } \\
\text { nueva Ley Ferroviaria de } 1869 \text { de carácter liberal }\end{array}$ \\
\hline 1873-1896 & 5.300 & Segunda expansión y concentración de compañías bajo la Ley de 1877 \\
\hline 1896-1936 & 1.450 & $\begin{array}{l}\text { Conclusión de la red: inicio del Problema Ferroviario y de los procesos de } \\
\text { nacionalización }\end{array}$ \\
\hline Desde 1941 & 3.050 & $\begin{array}{l}\text { Nacionalización del ferrocarril en 1941: RENFE. Reconstrucción y } \\
\text { electrificación bajo la competencia de carretera y avión }\end{array}$ \\
\hline Total & 15.600 & \\
\hline
\end{tabular}

Fuente: Elaboración propia a partir de Montoya (2010b: 58-59), Herranz (2008: 36), de Bustelo (1994: 260) y Gómez Mendoza (1989: 282).

El cuadro 8 analiza el desarrollo del ferrocarril en España. La situación de España en materia de construcciones ferroviarias era, a mediados del siglo XIX, "de alarmante retraso" (Carreras y Tafunell, 1993: 127-147). Las razones por las que se retrasó la construcción de la red fueron: la Guerra Carlista, las condiciones geográficas adversas, el escaso desarrollo económico y social del país, la caótica situación de la Hacienda, la falta de capitales, el reducido mercado interior, y la ineficacia de los gobiernos ${ }^{207}$.

El ritmo de construcción fue lento hasta el Bienio Progresista (1854-1856), cuando se aceleró. En 1854 el número de kilómetros no superaba los 350 kilómetros, mientras que en 1855 alcanzó los 440 kilómetros ${ }^{208}$. Una cifra muy alejada de los construidos en los principales países europeos, por ejemplo ${ }^{209}$ en 1850 Gran Bretaña disponía de 9.757 kilómetros, Francia 2.915 y Alemania 5.857.

La verdadera aceleración en el ritmo de construcción se produjo después de la aprobación de la Ley General de Ferrocarriles de 3 de junio de 1855 (Page: 1882-1883). Esta Ley cambió totalmente el panorama y supuso el inicio de un ciclo inversor expansivo; además, con esta Ley se crearon las dos ferroviarias españolas más importantes: MZA (1857) y NORTE (1858). La construcción de la red fue financiada en su mayor parte por capital exterior, lo que no debe hacer olvidar el papel decisivo también desempeñado por la ayuda estatal ${ }^{210}$.

\footnotetext{
${ }^{207}$ La ineficacia de los gobiernos es analizada por Tortella (1973: 165-168).

${ }^{208}$ Los datos de kilómetros de red construidos en esos momentos en España fueron expuestos por Gómez Mendoza (1989: 282).

${ }^{209}$ Los kilómetros de red construidos en Gran Bretaña, Francia y Alemania son tomados de Fontana (2003: 271).

${ }^{210}$ El poder político condicionó, como en los demás países, el proceso de construcción de la red (Villacorta y Martínez, 2009: 18).
} 
Con la crisis general iniciada en 1866, se paralizó la actividad constructora, dando lugar al tejido básico de la red ferroviaria española ${ }^{211}$. Dos eran las características de la red ferroviaria española: ejes radiales partiendo de Madrid $^{212}$ y la adopción de un ancho de vía propio, pero uniforme para todo el país, que difería del que se terminaría imponiendo en el resto de Europa $^{213}$.

La actividad constructora estuvo paralizada hasta 1875, cuando se reanudó, aunque a un ritmo más lento. No obstante, el escaso nivel constructor coincidió con una fuerte emisión de empréstitos. El fuerte aumento del número de obligaciones emitidas por las ferroviarias en el periodo 1873-1875 no coincidió con los años de mayor expansión en la construcción de la red, por lo que es posible inferir que las ferroviarias pasaron por apuros financieros, en parte "provocados por el pago de intereses y amortización de obligaciones emitidas anteriormente" (Costa, 1983: 163).

Los intereses constituían una importante salida de capital fuera de España, ya que la mayoría de los tenedores de títulos los habían adquirido en el mercado bursátil parisino. Según Costa (1983: 157) "el 60 de las obligaciones ferroviarias se habían negociado en la Bolsa de París". Hay que tener en cuenta, que estos datos deben ser ajustados por los españoles que vivían fuera de España, porque parte de estos títulos fueron adquiridos por ellos.

La década de 1930 fue negativa para las compañías ferroviarias, al igual que para el resto de la economía española. Se suspendieron las inversiones en capital físico y las empresas no estuvieron en condiciones de realizarlas. La crisis ferroviaria se agravó por el descenso de los ingresos debido a la crisis internacional, por la competencia de los vehículos de motor de explosión y por "el incremento de los gastos de explotación” (Tedde: 1978). La Guerra Civil

\footnotetext{
${ }^{211}$ Hacia el norte, a través de Valladolid y Burgos, hasta San Sebastián e Irún; hacia el noreste, a través de Zaragoza y Lérida, hasta Barcelona y Gerona; hacia el este, a través de Alcázar de San Juan y Albacete, hasta Murcia y Cartagena, en un primer apéndice, hasta Alicante, y hasta Valencia y Castellón. Sólo quedan incompletos los ejes sur, a través del paso de Despeñaperros, hasta el valle del Guadalquivir y toda la Baja Andalucía, y al oeste, a través de Ciudad Real, a Badajoz y la frontera portuguesa, pero estaban en condiciones de abrirse al servicio en los años siguientes. Además se han trazado y casi completado dos ejes transversales de gran dinamismo económico, el del valle del Ebro que ponía en comunicación las dos regiones más industrializadas de España, Cataluña y País Vasco, y el eje litoral mediterráneo, desde Valencia a Barcelona que tendrá su continuidad hacia el norte a la frontera francesa, a través del paso de Portbou. Galicia, Asturias, el norte de Extremadura y todo el Sureste.

${ }^{212} \mathrm{Al}$ concluir 1865 estaban, como indica Tedde (1996: 265), "terminadas las cinco direcciones del ferrocarril en un sentido radial: de Madrid a Francia; de Madrid a Santander, según la misma línea anterior, con una ramificación a partir de Venta de Baños; de Madrid a Barcelona por Zaragoza; de Madrid a Alicante, y de Madrid a Andalucía, con ramales hacia Cádiz y Málaga, a partir de Córdoba. Además, en esa misma fecha, se había concluido una larga línea que bordeaba el litoral mediterráneo, desde Barcelona a Alicante, y un tendido que enlazaba el País Vasco -Bilbao y San Sebastián- con Cataluña, pasando por Alsasua, Pamplona y Zaragoza". ${ }^{213}$ El establecimiento de la estructura radial y el ancho de vía propio fueron objeto de un intenso debate posterior sobre el acierto o no de las mismas. Una valoración crítica sobre el acierto del establecimiento de ambas características fue realizada por Cordero y Menéndez (1978: 185) y Muñoz Rubio y Vidal Olivares (2001).
} 
hizo irreversible la nacionalización ${ }^{214}$ en 1941 de unas empresas que hacía tiempo estaban en quiebra técnica $^{215}$.

Del total de los $15.600 \mathrm{Kms}$. de la red nacional de ferrocarriles que existen en la actualidad, 13.500 Kms. son de vía ancha o "ancho RENFE" de separación entre raíles de 1,672 metros ( 2 varas castellanas $=6$ pies), aunque en la actualidad la red en servicio de RENFE es de $12.500 \mathrm{Kms}$. al haber sido cerrados al tráfico ferroviario $1.000 \mathrm{Kms}$. por resultar antieconómica su utilización. Las restantes $2.100 \mathrm{~km}$. son de vía estrecha, normalmente con una separación entre raíles de un metro, de los que $1.600 \mathrm{Kms}$. corresponderían a la empresa pública Ferrocarriles de Vía Estrecha (FEVE). El resto de líneas, mayoritariamente propiedad de compañías mineras privadas, se encuentran en la actualidad fuera de servicio o explotadas por las respectivas Comunidades Autónomas.

Los rasgos fundamentales de la explotación ferroviaria en España -analizados a continuación-, son la propiedad pública de la red, el alto nivel de inversión extranjera, la alta concentración de la industria y la mayoritaria financiación ajena.

\subsubsection{Propiedad pública de la red}

Entre 1847 y 1941, el sector estuvo caracterizado porque el ferrocarril era de titularidad pública, mientras que la construcción primero y la explotación después, se encomendaba a las empresas concesionarias.

Las dificultades financieras de la Hacienda Pública española, fue la causante de que determinadas actividades económicas, como el ferrocarril, se confiaran en régimen de concesión a empresarios privados (Ortúñez, 2008: 142) (Ortúñez y Vidal, 2000: 123-135).

La fórmula de la concesión ${ }^{216}$ de obras públicas y de servicios públicos es la transferencia de funciones y poderes de la administración a los particulares. Sin embargo, el Estado mantuvo en todo momento una fuerte protección económica sobre los concesionarios, por medio de cuatro métodos: franquicias arancelarias, compensaciones de déficit industrial, exenciones tributarias y anticipos no reintegrables.

\footnotetext{
${ }^{214}$ La nacionalización se llevó a cabo por medio de la Ley de Ordenación Ferroviaria de 1941.

${ }^{215}$ Que las compañías llevaban tiempo en quiebra técnica es contrastado por Comín, et al. (1998: 367).

${ }^{216}$ La concesión es la forma paradigmática de la gestión indirecta de los servicios públicos. Consiste en la transferencia al gestor indirecto (sujeto privado) de facultades originariamente administrativas. En ella, el empresario gestionará el servicio a su propio riesgo y ventura. Las concesiones de ferrocarriles "son contratos bilaterales, otorgados entre el Estado y las concesionarios, obligatorios para ambas partes, y que, si bien derivan de la ley de concesión, no se perfeccionan en realidad, ni se consuman, hasta el otorgamiento de la escritura pública, verdadero título inscribible, que es, por decirlo así, la forma definitiva de la relación jurídica por la cual el Gobierno ejecuta la Ley y el concesionario se compromete a verificar las obras y a explotar la concesión, en las condiciones prefijadas" (NORTE, 1940: 583).
} 
Como la Hacienda pública española no tenía capacidad para construir y explotar el tráfico ferroviario, las concesiones se financiaron con inversiones de entidades privadas extranjeras que llegaron de la mano de la banca internacional.

En el siglo XIX existía la idea de que los ferrocarriles eran un servicio público, y que la sociedad mejoraría si este bien público alcanzaba a gran parte del territorio. Por ello, el Estado se implicó en garantizar la construcción de líneas, aunque lo hizo sin la eficiencia necesaria. La intervención pública no fue capaz de garantizar unos niveles mínimos de rentabilidad para las empresas, ni unos dividendos aceptables para los accionistas, ni una calidad mínima de servicios prestados a los usuarios.

Los gobiernos emitían las legislaciones ferroviarias, a veces lesionando los derechos e intereses que deberían proteger: los intereses públicos. Las leyes las hacían los políticos de la época - en muchos casos corruptos- pero presionados e influenciados por los administradores de las compañías, que frecuentemente habían ocupado, o peor ocupaban simultáneamente, puestos en la administración política de la nación.

El procedimiento de construcción y explotación del ferrocarril debía ser racional, sin embargo, desafortunadamente los intereses privados se impusieron a los intereses públicos. Mientras que en el resto de industrias la planificación sí fue racional, en materia ferroviaria no; en parte porque las familias francesas se impusieron a la oligarquía española, y plantearon la cuestión como materia financiera, al igual que habían hecho en Francia y en media Europa.

\subsubsection{Alto nivel de inversión extranjera}

El proceso de construcción de la red requirió una movilización de capital tan enorme "que hubiera sido imposible lograrse sólo en los estrechos mercados financieros domésticos" (Tedde, 1978: 29-46), y con la ayuda del Estado a través de subvenciones y dispensas fiscales.

La falta de recursos interiores para llevar a cabo la construcción de la red ferroviaria provocó que únicamente las compañías vinculadas a los círculos financieros franceses pudieran protagonizar un continuado proceso de concentración empresarial, acaparando las líneas más rentables.

Gracias a la Ley de 1855, España se convirtió en un territorio atractivo para los inversores europeos. A pesar de las facilidades que daba la citada Ley, de no haber existido la traslación a España de la competencia francesa entre los Rothschild y los Péreire, las líneas ferroviarias se hubieran seguido construyendo a un ritmo muy lento.

Francia fue el país más importante en la construcción en España. Cierto es que también acudió el capital belga (Central de Aragón) y británico (Ferrocarril de Tudela a Bilbao) -que eran los dos países con más alta concentración fabril-, pero "su cuantía no es comparable a la aportación francesa" (Boag: 1923); en el caso británico la inversión se centró preferentemente 
en sociedades interesadas en la actividad minera, más que en servicio ferroviario propiamente dicho $^{217}$.

Francia, a través de sucursales de sus grandes entidades financieras, fue el gran proveedor, no sólo de recursos financieros, sino también de recursos técnicos y de capital humano, fundamentalmente durante los primeros años ${ }^{218}$. La competición que ya existía en el país galo entre las familias Péreire y Rothschild se trasladó a España. Los Péreire [Sociedad General del Crédito Mobiliario Español ${ }^{219}$, reflejo de la francesa Societé Genérale de Crédit Mobilier] y los Rothschild [Sociedad Española Mercantil e Industrial] pujaron por el control del negocio ferroviario $^{220}$. Sin embargo, ni los Rothschild, ni mucho menos los Péreire, obtuvieron las rentabilidades esperadas de estas inversiones. Casi parecía más que invertían en ciertas líneas, para que no lo hiciese su familia competidora.

En el primer momento (1854-1856), los Rothschild ganaron la partida a los Péreire en España, pues consiguieron el doble de kilómetros de ferrocarril que su rival ${ }^{221}$. Además, tomaron la

${ }^{217}$ El ingeniero británico G. Higgin (1886: 114) dio dos razones por las que no se invirtió más capital británico. El primero es el cierre de la bolsa de Londres a las empresas españolas. La aversión a los títulos españoles en el mercado londinense fue recogida por The Economist en su edición del 24 abril 1869. El segundo es el sistema de subvenciones, que no gustó a los financieros de la City. Los capitalistas ingleses exigían garantías de intereses, mientras que el Gobierno español consideró preferible un compromiso fijo antes que una deuda cuyo alcance le resultaba desconocido. Otro factor, apuntado por Platt (1983), es que el capital británico fue escaso en los ferrocarriles españoles por los efectos de la desfavorable conversión de la Deuda Nacional de 1851, realizada por Bravo Murillo.

${ }^{218}$ El origen del capital francés en España fue la contrapartida a la tramitación de la Ley de Sociedades de Crédito realizada -en el primer trimestre de 1856- por el ministro de Hacienda español Bruil para permitir la entrada del capital de los tres grandes grupos franceses: Péreire, Rothschild y Prost. Juan Faustino Bruil y Olliarburu (Zaragoza, 1810-1878) fue un banquero y comerciante español. Miembro del Partido Progresista y muy vinculado a Baldomero Espartero. Fue nombrado, por Leopoldo O'Donnell, ministro de Hacienda en sustitución de Pascual Madoz en junio de 1855. Influido por el modelo inglés, inició reformas legislativas para el establecimiento de mejores sistemas financieros privados que impulsaran la economía. Aprobó la primera Ley de sociedades anónimas de préstamo y crédito que permitiría la entrada de capitales extranjeros para la financiación de proyectos en España. A nivel privado esbozó el proyecto del ferrocarril a Canfranc para dar salida a Aragón hacia Francia. Ver datos de su biografía en Rull (1991: 166).

${ }^{219}$ La Sociedad General de Crédito Mobiliario Español fue una sociedad bancaria de capital francés que, impulsada por Isaac Péreire, se constituyó en Madrid el 28 de enero de 1856 al amparo de la nueva Ley de Sociedades de Crédito. Tras la crisis de 1898, las reformas financieras de Raimundo Fernández Villaverde de 1900 y la repatriación de los capitales de las antiguas colonias americanas, los accionistas deciden liquidar la sociedad y fundar una nueva, el Banco Español de Crédito (BANESTO), creado el 1 de mayo de 1902 con un capital social de 20 millones de pesetas representado por 80.000 acciones con un valor nominal de 250 pesetas. El promotor del BANESTO fue un grupo francés presidido por Gustavo Péreire; a esta iniciativa se unieron Cayetano Sánchez Bustillo y León Cocagne (subdirector del Banco Hipotecario de España) en representación de un conjunto de inversores españoles. La primera sede se ubicó en el Paseo de Recoletos de Madrid.

${ }^{220}$ Los hermanos Péreire y los Rothschild decidieron constituir NORTE y MZA, independiente de la Sociedad General de Crédito Mobiliario Español y la Sociedad General de Crédito Mobiliario Español, que se ocupasen, tan sólo de la construcción y administración de las líneas ferroviarias.

${ }^{221}$ Este empuje inicial se basó en la estrategia expresada por James Rothschild: "quien construya las primeras líneas obtendrá los grandes negocios en España": Vid. Carta de James Rothschild a Weisweiller y Baues, 16 de febrero de 1856, Archivos Rothschild Paris (Centre des Archives du Monde du Trabail; Roubaix) 132AQ728. Esta carta fue estudiada por López Morell (2005: 172). 
delantera al crear un Banco local, la Sociedad Española Mercantil e Industrial, a cargo de dos representantes en España: Weisweller y Baüer. Junto a ellos, también desembarcan en España el Conde de Morny y varios administradores franceses del Chemin de Fer du Grand Central. Más adelante los Péreire recondujeron la situación, incrementando la competencia y creando una entidad filial en España -la Sociedad General del Crédito Mobiliario Español-, para competir con la Sociedad Española Mercantil e Industrial de los Rothschild.

Las dos ferroviarias más importantes formadas en España tras la Ley General de Ferrocarriles de 1855 -MZA (1857) y NORTE (1858)- estaban participadas mayoritariamente por inversiones francesas: la primera por el grupo de empresas Morny-Rothschild y la segunda por el consorcio Péreire. Más tarde se le uniría la Compañía de los Ferrocarriles Andaluces (1869), de los banqueros galos Prost-Guilhou ${ }^{222}$.

Entre 1855 y 1890, la inversión realizada en el ferrocarril español, cuando ya se había construido casi la totalidad de la red española, fue de 3.750 millones de pesetas (Comín: 1999). Un $56 \%$ de esta inversión procedería del exterior, un $18 \%$ correspondería a las subvenciones estatales y el $26 \%$ restante sería aportado por los inversores nacionales (Comín, 1999: 265).

A principios del siglo XX, la mitad del capital de las tres compañías mencionadas era aún de origen francés (Boag, 1923: capítulo I). En NORTE la influencia del grupo Péreire cayó en picado en los inicios de 1920. En MZA, sin embargo, y pese al aumento de capital español, las directrices generales en la década de 1920 se seguían dictando mayoritariamente desde París.

\subsubsection{Alta concentración}

El mercado ferroviario estuvo caracterizado por su gran segmentación, controlado por cuatro empresas, que actuaron como auténticos monopolios en sus áreas.

A finales del siglo XIX, tres empresas - NORTE, MZA y Compañía de los Ferrocarriles Andaluces (ANDALUCES)- concentraban el 75\% de los kilómetros de explotación de vía ancha en España. Este porcentaje se mantuvo así hasta 1935 (Anes, 1978: 485-486).

En 1913, las dos grandes, NORTE y MZA, controlaban el 64\% de todo el tendido, y en torno al 80\% si se incluyen ANDALUCES y la Compañía de los Ferrocarriles de Madrid a Cáceres y Portugal (MCP) $)^{223}$.

\footnotetext{
${ }^{222}$ Un ilustrativo cuadro comparativo por países y sectores del capital extranjero invertido en España entre 1851 y 1914 es incluido por Castro Balaguer (2007: 89). Para la financiación de las compañías ferroviarias ver Tedde (1978: 29-46) y Comín, et al. (1998).

${ }^{223}$ En 1913 el tendido alcanzaba los 11.379 kilómetros de vía de ancho ibérico y 3.524 kilómetros de red de ancho métrico. Datos tomados de Boag (1923: 6).
} 
El Cuadro 9 recoge los principales datos de las sociedades ferroviarias existentes al inicio del siglo $\mathrm{XX}$.

Cuadro 9. Compañías ferroviarias españolas al comienzo del siglo XX

\begin{tabular}{|c|c|c|c|c|}
\hline Compañía & $\begin{array}{l}\text { Año } \\
\text { constitución }\end{array}$ & $\begin{array}{l}\text { Entrada en } \\
\text { servicio }\end{array}$ & $\begin{array}{l}\text { Kms. Red } \\
\text { a 1/1/1900 }\end{array}$ & $\begin{array}{l}\text { Año } \\
\text { extinción }\end{array}$ \\
\hline $\begin{array}{l}\text { Compañía de los Ferrocarriles de Madrid a } \\
\text { Zaragoza y a Alicante (MZA) }\end{array}$ & 1856 & 1856 & 3679 & 1941 (RENFE) \\
\hline $\begin{array}{l}\text { Compañía de los Caminos de Hierro del Norte de } \\
\text { España (NORTE) }\end{array}$ & 1858 & 1856 & 3650 & 1941 (RENFE) \\
\hline Ferrocarriles Andaluces (ANDALUCES) & 1877 & 1877 & 3672 & 1941 (RENFE) \\
\hline $\begin{array}{l}\text { Compañía de Explotación de los Ferrocarriles de } \\
\text { Madrid a Cáceres y Portugal y del Oeste de } \\
\text { España (MCPO) }\end{array}$ & 1894 & 1894 & 1072 & 1941 (RENFE) \\
\hline $\begin{array}{l}\text { Compañía de los Caminos de Hierro del Sur de } \\
\text { España (SUR) }\end{array}$ & 1888 & 1899 & 299 & 1929 (ANDALUCES) \\
\hline Compañía del Ferrocarril Central de Aragón & 1894 & 1902 & 246 & 1941 (RENFE) \\
\hline $\begin{array}{l}\text { Compañía del Ferrocarril de Medina del Campo } \\
\text { a Zamora y de Orense a Vigo (MZOV) }\end{array}$ & 1880 & 1885 & 55 & 1928 (OESTE) \\
\hline $\begin{array}{l}\text { Compañía del Ferrocarril de Salamanca a la } \\
\text { Frontera Portuguesa (SFP) }\end{array}$ & 1885 & 1887 & 77 & 1927 (NORTE) \\
\hline Compañía del Ferrocarril de Zafra a Huelva & 1884 & 1889 & 364 & 1941 (RENFE) \\
\hline Ferrocarril de Lorca á Baza y Águilas (LBA) & 1885 & 1885 & & 1941 (RENFE) \\
\hline $\begin{array}{l}\text { Compañía del Ferrocarril de Torralba } \\
\text { a Soria (TS) }\end{array}$ & 1887 & 1892 & 94 & 1941 (RENFE) \\
\hline $\begin{array}{l}\text { Compañía del Ferrocarriles de Medina del } \\
\text { Campo a Salamanca (MCS) }\end{array}$ & 1871 & 1877 & 77 & 1928 (OESTE) \\
\hline $\begin{array}{l}\text { Sociedad del Ferrocarril Compostelano de la } \\
\text { Infanta Isabel al Puerto de Carril (PCS) }\end{array}$ & 1863 & 1899 & 73 & 1928 (OESTE) \\
\hline $\begin{array}{l}\text { Sociedad del Ferrocarril de Alcantarilla } \\
\text { a Lorca (AL) }\end{array}$ & 1900 & 1900 & 55 & 1941 (RENFE) \\
\hline $\begin{array}{l}\text { Sociedad de los Ferrocarriles de Valencia y } \\
\text { Aragón (VA) }\end{array}$ & 1876 & 1890 & 31 & 1941 (RENFE) \\
\hline $\begin{array}{l}\text { Compañía del Ferrocarril de Bilbao a Portugalete } \\
\text { (PORTUG) }\end{array}$ & 1884 & 1888 & 17 & 1941 (RENFE) \\
\hline $\begin{array}{l}\text { Compañía del Ferrocarril de Mollet a Caldas de } \\
\text { Montbuí (MCA) }\end{array}$ & 1901 & 1901 & 15 & 1941 (RENFE) \\
\hline Ferrocarril de Triano (TRIANO) & 1859 & 1890 & 13 & 1941 (RENFE) \\
\hline
\end{tabular}

Fuente: Elaboración propia

\subsubsection{Mayoritaria financiación ajena}

Un aspecto fundamental de las ferroviarias es su estructura financiera. Destaca el profundo desequilibrio entre el capital representado por el capital externo respecto al capital propio ${ }^{224}$.

\footnotetext{
${ }^{224}$ En el II Congreso de Economía Nacional, dentro de la sección sexta, dedicada a "Los transportes ferroviarios y situación de la red española en su aspecto financiero", Gari Gimeno expuso un cuadro en el que comparaba el peso de las cargas financieras, tanto de las compañías francesas Norte, Orleáns, PLM y Este, como de los
} 
El profundo desequilibrio financiero entre los recursos ajenos respecto al capital propio generó costes financieros desorbitados. En las tres empresas más grandes -NORTE, MZA y ANDALUCES- las acciones sólo representaban entre un tercio y un cuarto de las obligaciones.

La financiación se realizó mayoritariamente mediante la emisión de obligaciones porque permitía generar ingentes recursos sin perder el control de las empresas creadas. La elección de esta alternativa de financiación tiene su origen en la política expansiva llevada a cabo por esas empresas, pues, en su empeño por expandirse, evitar la competencia y conseguir economías de escala, se hicieron con líneas sobrecapitalizadas y con grandes deudas acumuladas.

Este desequilibrio financiero frustró las expectativas de rentabilidad desde el comienzo de la explotación de la industria. Esta deficiencia financiera se convirtió en un problema insalvable que nunca consiguieron solucionar las ferroviarias ${ }^{225}$, principalmente porque generaron costes financieros desorbitados. De ahí que, aunque aumentaran los ingresos corrientes por el incremento del kilometraje y de la facturación, y aunque permanecieran bajos los gastos de explotación $^{226}$ (generando coeficientes de explotación 227 favorables), no mejoraron los beneficios. En este contexto las compañías pagaron mínimos dividendos a los accionistas, e incluso a veces no los entregaron, como sucedió, por ejemplo, en los últimos años del siglo XIX, al coincidir con la crisis agraria. Esto supuso un círculo vicioso; al no dar dividendos pocos querían ser accionistas y tenían que emitir más obligaciones. Las dificultades de obtener financiación barata, provocó que a las ferroviarias españolas les resultara muy difícil renovar -y modernizar- el material fijo y rodante como requería el tráfico creciente, particularmente tras la Gran Guerra. Este era el problema estructural al que se refería Cambó (1918-1921; 1921), que fue denominado en la época, de forma generalizada, por su expresión Problema Ferroviario ${ }^{228}$, y que nosotros denominamos problema ferroviario en sentido amplio.

\footnotetext{
ferrocarriles suizos, con las españolas Andaluces, MZA y NORTE en 1913. Los niveles de endeudamiento eran similares en ambos países (AHF, C-0002-0004).

${ }^{225}$ Ya en una fecha tan temprana como 1861, Villiaumé (1861: 134-135) advertía al gobierno español del peligro que conllevaba que las empresas abusaran de este tipo de financiación.

${ }^{226}$ Los gastos unitarios de explotación de las dos grandes eran "cerca del 40\%" (NORTE y MZA, 1933: 143).

${ }^{227}$ El coeficiente de explotación (proporción de ingresos absorbidos por los gastos de explotación) es un índice de eficiencia de la gestión empresarial. Las dos grandes -NORTE y MZA- superaron con nota este coeficiente pues, entre 1900 y 1917, se hallaban entre los más bajos de Europa (André, 1919: 375-376). Esto no cambió en los años siguientes, donde el coeficiente de explotación de las dos grandes, se situaba en torno al $75 \%$, lo cual era "plenamente satisfactorio" (NORTE y MZA, 1933: 143).

${ }^{228}$ El periodo más representativo de la gran crisis que afectó de forma muy directa a las compañías ferroviarias, y que es conocida como el problema ferroviario, se sitúan entre 1914 y 1924. La citada crisis supuso, para las compañías de ferrocarriles, unas dificultades que muchas no consiguieron salvar, y las que lo lograron quedaron económicamente muy perjudicadas.
} 


\subsection{Problema ferroviario}

\subsubsection{Conceptualización del problema ferroviario}

El problema ferroviario fue vinculado mayoritariamente a la I Guerra Mundial; no obstante, realmente la guerra lo agravó, pero es un problema anterior. Identificamos dos interpretaciones del problema ferroviario: "en sentido estricto" y "en sentido amplio".

Cuando se discutía sobre el futuro de las empresas ferroviarias (1914-1924), a todo el proceso de aumento de costes derivados de la I Guerra Mundial se le denominó problema ferroviario (problema ferroviario en sentido estricto a efectos de esta investigación). Pero puede existir otra interpretación (problema ferroviario en sentido amplio o problema ferroviario según Cambó), que es anterior en el tiempo. Según esta segunda interpretación, el problema de los costes elevados tiene su origen en la mala estructura financiera, basada sobremanera en la financiación ajena, sobre todo con empréstitos, y poca en la financiación basada en acciones. Las acciones remuneran con unos dividendos, que pueden ser no entregados a los accionistas si los resultados no son buenos, mientras que los empréstitos remuneran a los obligacionistas independientemente de la marcha de la empresa.

Aunque sin recibir estas denominaciones, la doctrina ya trabajó sobre las dos interpretaciones del término problema ferroviario (en sentido estricto y en sentido amplio). Muchos autores consideran que el problema ferroviario es un fenómeno que normalmente se circunscribe, o al menos tiene su origen, al periodo de la I Guerra Mundial ${ }^{229}$. Por su parte, para otros autores, el problema ferroviario no fue un efecto de la guerra sino que deriva del modelo de financiación elegido ${ }^{230}$. Para estos últimos, el problema ferroviario era anterior a la I Guerra Mundial, lo cual está respaldado por dos ideas. En primer lugar, desde mucho antes de que estallara el conflicto ya existieron propuestas para solucionarlo. En segundo lugar, las ferroviarias eran conscientes de su estructura financiera desequilibrada mucho antes de la I Guerra Mundial; por ejemplo, así quedó claro en la "Exposición y proyecto de garantía de interés por el Estado a los ferrocarriles"231 celebrada en febrero de 1866.

El problema ferroviario en sentido amplio no surgió durante la I Guerra Mundial, sino que deriva del modelo financiero elegido (endeudamiento externo) por las concesionarias, un error agravado por las consecuencias de la contienda, el rígido sistema tarifario derivado de la política estatal, la crisis económica internacional (y nacional) y la inestabilidad política

\footnotetext{
${ }^{229}$ Así lo entienden la mayoría de los autores que proponen soluciones para corregirlo: Ortuño (1920), de la Cierva (1921) y Maura (1922).

${ }^{230}$ González Quijano (1917), Cambó (1918-1921; 1921), Boag (1923) y Jiménez Ontiveros (1940) advirtieron que el problema ferroviario no fue un efecto de la Gran Guerra sino que deriva de su modelo de financiación.

${ }^{231}$ La Revista de Obras Públicas se mostró especialmente crítica con la "Exposición y proyecto de garantía de interés por el Estado a los ferrocarriles", elaborada por la "Comisión Central de Ferrocarriles" que, "ante la negativa situación padecida por las empresas férreas, solicitaba la protección por parte del gobierno". Por el contrario, la Exposición estuvo avalada por las firmas de destacados dirigentes políticos, y defendida por otros medios como la Gaceta de los Caminos de Hierro que reprodujo el texto (25 de febrero de 1866), y por determinados autores como Reynals (1866). Estos apoyos son descritos por Mateo del Peral (1978, 148-149).
} 
interior. Por todo ello, en España se acabará haciendo lo mismo que en los demás países europeos: tras un progresivo aumento del intervencionismo estatal, la red se nacionaliza (Ley de Ordenación Ferroviaria de 1941).

El problema ferroviario en sentido estricto se circunscribe al proceso de aumento de costes derivados de la I Guerra Mundial ${ }^{232}$, por lo que exclusivamente se limita al periodo 19141924. La Guerra mundial supuso para las ferroviarias españolas serios apuros financieros que las colocaron al borde del colapso. Entre 1914 y 1918, los ingresos aumentaron debido al incremento del tráfico, pero aumentaron mucho más los costes de la explotación, lo que acabó con el que había sido hasta entonces uno de los principales supuestos característicos del sistema ferroviario español: costes de explotación bajos y coeficientes muy favorables. En ese periodo, los costes de explotación de las compañías, hasta entonces bajos, se dispararon y las cargas financieras, principales responsables de la casi siempre escasa rentabilidad de unas empresas demasiado apalancadas, no disminuyeron.

La subida generalizada de costes afectó fundamentalmente a dos rúbricas: por un lado, el aumento del precio del combustible, circunstancia que se agravó con la pérdida de calidad, lo que ocasionó un mayor consumo derivado de las dificultades de la importación; y por el otro, el incremento de los salarios, provocados por las continuas reivindicaciones sociales, que vinieron a materializarse, entre otras, con el establecimiento de la jornada máxima de ocho horas.

Con la Guerra empezaron a aumentar el precio de todas las materias primas. Como no podía aprovisionarse de los países europeos, las ferroviarias se vieron obligadas a comprar productos más caros en España. El primero de los inputs que elevó su precio con la contienda fue el carbón por el cese de las importaciones. Además, en el carbón había otro problema adicional, pues el sucedáneo nacional además de más caro, era de peor calidad. Al no poder adquirir el carbón de Gales, se tuvo que comprar el peninsular menos eficiente y que produjo un número mayor de averías y problemas con las máquinas. También se dispararon los precios de las materias utilizadas en la explotación y los gastos de reparación. La red y el parque móvil se resintieron por la intensidad del uso y "se multiplicaron los litigios contra las empresas" (Boag: 1923), y en consecuencia, los gastos. La consecuencia de todo ello fue un aumento de costes en las cuentas anuales de los años sucesivos, incrementando tanto los gastos de primer establecimiento como los de explotación.

La situación económica de las ferroviarias se agravó con los problemas sociales. La población española reclamó un mayor salario, lo que provocó un incremento en los costes salariales. Los costes aumentaron aún más cuando se impuso la obligación de que los trabajadores no sobrepasaran las ocho horas.

\footnotetext{
${ }^{232}$ Entre 1906 y 1913, las grandes empresas ferroviarias habían conocido los mejores años de la explotación, incluso habían podido repartir más dividendos que nunca a sus accionistas (Ortúñez, 1999a: 97) (Pascual, 2000: 33) (Ortúñez, 2008: 145). Sin embargo, la Guerra alteró por completo el sistema e incrementó fuertemente los costes de explotación. La profunda crisis financiera que siguió fue el desencadenante de las actuaciones del Estado en la regulación del sector y su intervención en las compañías.
} 
Los aumentos de los costes se unieron a otros condicionantes que provocaron una espiral de efectos negativos. La saturación del tráfico durante la Gran Guerra puso de manifiesto la incapacidad del ferrocarril español para satisfacer la demanda; pero además, la intensificación del tráfico provocó un profundo desgaste en la red ferroviaria española. A esta deficiencia estructural vino a sumarse una importante dificultad coyuntural. La falta de abastecimiento de energía, materias primas y otros productos necesarios, y el encarecimiento del mercado interior, provocado por la I Guerra Mundial, obligaron a las compañías a subir las tarifas del servicio ferroviario. Esta subida produjo duras protestas. La Ley Alba de 1916 trató de contener esta elevación de tarifas (García Delgado, 1989: 251-363), poniendo en situación límite a varias compañías y abriendo una verdadera crisis ferroviaria (La Parra, 2004: 320).

En esta situación, las compañías recurrieron al Estado para obtener los recursos financieros con los que poder hacer frente al incremento de los costes laborales, reparar y mejorar la maltrecha red y comprar material fijo y rodante. El Estado se encontró en la tesitura de que si quería garantizar un servicio público, que se consideraba imprescindible y con gran impacto en la opinión pública, no le quedaba más opción que auxiliarlas ${ }^{233}$.

Para cualquiera de las dos interpretaciones, comenzó a planificarse una serie de propuestas para intentar solucionar el problema ferroviario.

\subsubsection{Soluciones propuestas al problema ferroviario}

Hasta 1914 el Estado se había limitado a establecer las reglas del sistema ferroviario y a tratar de garantizar que las empresas privadas concesionarias ofertaran un servicio público en condiciones óptimas para los usuarios. A partir de entonces, comenzó un proceso de injerencia cada vez mayor del Estado para resolver el problema ferroviario.

El problema ferroviario generó un enconado y duradero debate y una multitud de posibles soluciones (cuadro 10). Una alternativa hubiera sido el proceso de nacionalización de la industria de material ferroviario para tratar de evitar la carestía y escasez de productos importados. La otra salida, la que finalmente se implantó, fue la propuesta de Cambó de nacionalizar la red férrea concediendo la explotación a las compañías ya establecidas mediante un consorcio con el Estado ${ }^{234}$.

\footnotetext{
${ }^{233}$ Artola (1978: 409-445) fue el primero en analizar la cuestión política del período.

${ }^{234}$ La prensa de la época abogaba desde hacía tiempo sobre la necesidad de anular las concesiones y nacionalizar la red, como estaban realizando algunos países europeos (Marraco, 1922: 10).
} 


\section{Cuadro 10. Resumen de los intentos de solución al problema ferroviario 1900-1924}

\begin{tabular}{|c|c|c|c|c|c|c|}
\hline & $\begin{array}{l}\text { Legislación } \\
\text { vigente en } 1900\end{array}$ & $\begin{array}{l}\text { Proyecto } \\
\text { Cambó (1918- } \\
\text { 1919) }\end{array}$ & $\begin{array}{l}\text { Proyecto } \\
\text { Ortuño (1920) }\end{array}$ & $\begin{array}{l}\text { Proyecto de la } \\
\text { Cierva (1921) }\end{array}$ & $\begin{array}{l}\text { Proyecto } \\
\text { Maura (1922) }\end{array}$ & $\begin{array}{l}\text { Estatuto } \\
\text { Ferroviario (1924) }\end{array}$ \\
\hline Régimen legal & $\begin{array}{l}\text { Empresas } \\
\text { privadas } \\
\text { Ley general de } \\
1877 \text { para } \\
\text { concesiones. } \\
\text { Continúan } \\
\text { vigentes preceptos } \\
\text { de la Ley } 1855- \\
1856\end{array}$ & $\begin{array}{l}\text { Nacionalización } \\
\text { Rescate } \\
\text { Arriendos a } \\
\text { compañías } \\
\text { privadas }\end{array}$ & $\begin{array}{l}\text { Mantenimiento } \\
\text { de la legislación }\end{array}$ & $\begin{array}{l}\text { Consorcio entre } \\
\text { el Estado y las } \\
\text { compañías }\end{array}$ & $\begin{array}{l}\text { Comunidades } \\
\text { Reversión } \\
\text { anticipada } \\
\text { prevista, previa } \\
\text { indemnización a } \\
\text { las compañías }\end{array}$ & $\begin{array}{l}\text { Consorcio y } \\
\text { auxilios del Estado }\end{array}$ \\
\hline $\begin{array}{l}\text { Régimen } \\
\text { económico }\end{array}$ & $\begin{array}{l}\text { El ferrocarril debe } \\
\text { bastarse a sí } \\
\text { mismo } \\
\text { Las tarifas tienen } \\
\text { un tope máximo. } \\
\text { Son revisables } \\
\text { cada cinco años. } \\
\text { Pueden ser } \\
\text { reducidas por el } \\
\text { Estado previa } \\
\text { indemnización } \\
\\
\text { Déficit a cargo } \\
\text { compañía. Tarifas } \\
\text { generales y } \\
\text { especiales }\end{array}$ & $\begin{array}{l}\text { Mantenimiento } \\
\text { de la situación } \\
\text { vigente en } 1900\end{array}$ & $\begin{array}{l}\text { Se preveía que } \\
\text { las tarifas } \\
\text { pudieran } \\
\text { elevarse por } \\
\text { encima de los } \\
\text { tipo máximos } \\
\text { legales } \\
\text { Determinación } \\
\text { de las nuevas } \\
\text { tarifas por } \\
\text { Comisión }\end{array}$ & $\begin{array}{l}\text { Las tarifas } \\
\text { deberían cubrir } \\
\text { todos los gastos } \\
\text { de explotación, } \\
\text { cargas, } \\
\text { pensiones, } \\
\text { dividendo fijo } \\
\text { de las acciones } \\
\text { y primas de } \\
\text { gestión y } \\
\text { personal }\end{array}$ & $\begin{array}{l}\text { El ferrocarril } \\
\text { debe bastarse a } \\
\text { sí mismo } \\
\text { Las tarifas } \\
\text { deberían cubrir } \\
\text { todos los gastos } \\
\text { de explotación, } \\
\text { cargas, } \\
\text { pensiones, y } \\
\text { primas de } \\
\text { gestión y } \\
\text { personal }\end{array}$ & $\begin{array}{l}\text { El ferrocarril debe } \\
\text { bastarse a sí mismo } \\
\text { (Base } 11^{\mathrm{a}} \text { ) } \\
\text { Tarifas con cálculo } \\
\text { previo (Base } 10^{\mathrm{a}} \text { ) }\end{array}$ \\
\hline $\begin{array}{l}\text { Régimen } \\
\text { financiero }\end{array}$ & $\begin{array}{l}\text { Las compañías } \\
\text { pueden emitir } \\
\text { empréstitos (arts. } \\
\text { 184-193 Código } \\
\text { de Comercio } \\
\text { 1885) }\end{array}$ & $\begin{array}{l}\text { Cuestión } \\
\text { financiera a } \\
\text { cargo del } \\
\text { Estado } \\
\text { La incapacidad } \\
\text { financiera de las } \\
\text { compañías sería } \\
\text { suplida por el } \\
\text { Estado }\end{array}$ & $\begin{array}{l}\text { Las compañías } \\
\text { podrían emitir } \\
\text { empréstitos por } \\
\text { un plazo mayor } \\
\text { que el fin de las } \\
\text { concesiones } \\
\text { Las obras de } \\
\text { ampliación y } \\
\text { mejora serían a } \\
\text { cargo de las } \\
\text { compañías; las } \\
\text { líneas nuevas al } \\
\text { Estado } \\
\text { Deuda Especial } \\
\text { Ferroviaria }\end{array}$ & $\begin{array}{l}\text { Mantenimiento } \\
\text { de la situación } \\
\text { vigente en } 1900\end{array}$ & $\begin{array}{l}\text { "Deuda especial } \\
\text { ferroviaria" } \\
\text { para atender a } \\
\text { los gastos de } \\
\text { ampliación de } \\
\text { instalaciones }\end{array}$ & $\begin{array}{l}\text { La adquisición de } \\
\text { material y obras de } \\
\text { ampliación y } \\
\text { mejora son pagadas } \\
\text { por el Estado } \\
\text { "Caja Ferroviaria" } \\
\text { "Deuda especial } \\
\text { ferroviaria" (Base } \\
3^{\mathrm{a}}, 4^{\mathrm{a}}, 5^{\mathrm{a}} \text { y } 9^{\mathrm{a}} \text { ) }\end{array}$ \\
\hline $\begin{array}{l}\text { Gestión, } \\
\text { Dirección, } \\
\text { Control e } \\
\text { Inspección }\end{array}$ & $\begin{array}{l}\text { Gestión autónoma } \\
\text { de las compañías } \\
\text { La Ley de } 1877 \\
\text { concede a las } \\
\text { compañías la } \\
\text { administración o } \\
\text { explotación (cap. } \\
\text { 7), con } \\
\text { limitaciones sobre } \\
\text { tarifas, vigilancia } \\
\text { e intervención } \\
\text { La vigilancia } \\
\text { sobre la }\end{array}$ & $\begin{array}{l}\text { Después del } \\
\text { rescate, las } \\
\text { compañías } \\
\text { arrendatarias de } \\
\text { las redes } \\
\text { explotarían en } \\
\text { gestión } \\
\text { autónoma }\end{array}$ & $\begin{array}{l}\text { Gestión } \\
\text { autónoma de las } \\
\text { compañías }\end{array}$ & $\begin{array}{l}\text { Este proyecto } \\
\text { no se decanta } \\
\text { sobre quién } \\
\text { debe } \\
\text { administrar: el } \\
\text { Estado o las } \\
\text { compañías }\end{array}$ & $\begin{array}{l}\text { Gestión de las } \\
\text { compañías no } \\
\text { autónomas, en } \\
\text { régimen de } \\
\text { comunidades } \\
\text { La intervención } \\
\text { del Estado se } \\
\text { ejercería por el } \\
\text { "Consejo } \\
\text { Superior } \\
\text { Ferroviario", } \\
\text { con plenitud de } \\
\text { poderes y } \\
\text { amplias }\end{array}$ & $\begin{array}{l}\text { Gestión autónoma } \\
\text { de las compañías } \\
\text { La intervención del } \\
\text { Estado en la } \\
\text { explotación se } \\
\text { ejerce por el } \\
\text { "Consejo Superior } \\
\text { de Ferrocarriles" y } \\
\text { la Dirección } \\
\text { General de } \\
\text { Ferrocarriles (Base } \\
9^{a} \text { ) }\end{array}$ \\
\hline
\end{tabular}




\begin{tabular}{|c|c|c|c|c|c|c|}
\hline & $\begin{array}{l}\text { explotación } \\
\text { corresponde al } \\
\text { gobierno (cap. 9) }\end{array}$ & & & & atribuciones & \\
\hline $\begin{array}{l}\text { Superávits y } \\
\text { déficits. } \\
\text { Aportaciones } \\
\text { del Estado y } \\
\text { auxilios }\end{array}$ & $\begin{array}{l}\text { Hasta 1924, el } \\
\text { Estado auxilió a } \\
\text { las compañías con } \\
\text { franquicias, } \\
\text { subvenciones y } \\
\text { anticipos } \\
\text { reintegrables }\end{array}$ & $\begin{array}{l}\text { Si se produce } \\
\text { déficit, correría } \\
\text { a cargo del } \\
\text { Estado }\end{array}$ & $\begin{array}{l}\text { La Deuda } \\
\text { Especial } \\
\text { Ferroviaria para } \\
\text { atender a las } \\
\text { nuevas } \\
\text { construcciones, } \\
\text { es lo único que } \\
\text { podría constituir } \\
\text { aportaciones del } \\
\text { Estado. Los } \\
\text { demás gastos } \\
\text { serían cubiertos } \\
\text { por las } \\
\text { emisiones de } \\
\text { obligaciones de } \\
\text { las compañías } \\
\text { en un plazo } \\
\text { mayor que el fin } \\
\text { de las } \\
\text { concesiones }\end{array}$ & $\begin{array}{l}\text { El déficit } \\
\text { correría a cargo } \\
\text { de las dos partes } \\
\text { contratantes } \\
\text { Las } \\
\text { aportaciones del } \\
\text { Estado estarían } \\
\text { constituidas por } \\
\text { el importe de } \\
\text { los anticipos } \\
\text { realizados a las } \\
\text { compañías, las } \\
\text { subvenciones } \\
\text { del Estado y la } \\
\text { construcción de } \\
\text { nuevas líneas. } \\
\text { El capital del } \\
\text { Estado } \\
\text { percibiría un } \\
2 \% \text { de interés } \\
\text { El superávit, si } \\
\text { lo hubiese, } \\
\text { corresponde a } \\
\text { parte iguales } \\
\text { con las } \\
\text { compañías }\end{array}$ & $\begin{array}{l}\text { Supone que la } \\
\text { variación de } \\
\text { tarifas cubriría } \\
\text { todas las } \\
\text { necesidades del } \\
\text { ferrocarril, } \\
\text { incluso el } \\
\text { interés del } \\
\text { capital aportado } \\
\text { por el Estado } \\
\text { La prima de } \\
\text { gestión a las } \\
\text { compañías sería } \\
\text { anterior y } \\
\text { preferente a la } \\
\text { participación } \\
\text { del Estado }\end{array}$ & 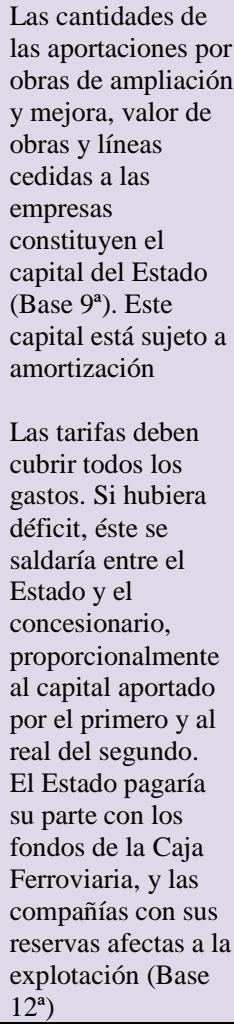 \\
\hline $\begin{array}{l}\text { Rescate, } \\
\text { Reversión, } \\
\text { Caducidad e } \\
\text { Incautación }\end{array}$ & $\begin{array}{l}\text { La Ley de } 1877 \\
\text { especifica los } \\
\text { casos de } \\
\text { caducidad (arts. } \\
\text { 32, 33, } 34 \text { y 53). } \\
\text { La adquisición } \\
\text { anticipada estaba } \\
\text { regulada en la Ley } \\
\text { de } 1856 \text { (art. 31) }\end{array}$ & $\begin{array}{l}\text { Todas las redes } \\
\text { habrían de ser } \\
\text { rescatadas } \\
\text { anticipadamente } \\
\text {, previa } \\
\text { indemnización } \\
\text { del Estado }\end{array}$ & $\begin{array}{l}\text { Mantenimiento } \\
\text { de la situación } \\
\text { vigente en } 1900\end{array}$ & $\begin{array}{l}\text { El Estado } \\
\text { podría anticipar } \\
\text { la fecha de la } \\
\text { reversión, } \\
\text { adquiriendo las } \\
\text { acciones de las } \\
\text { compañías, } \\
\text { capitalizando al } \\
5 \% \text { los } \\
\text { dividendos } \\
\text { obtenidos } \\
\text { durante los diez } \\
\text { últimos años }\end{array}$ & $\begin{array}{l}\text { El importe del } \\
\text { valor de las } \\
\text { concesiones, al } \\
\text { adelantar la } \\
\text { fecha de la } \\
\text { reversión, sería } \\
\text { pagado a los } \\
\text { concesionarios } \\
\text { mediante un } \\
\text { cálculo } \\
\text { efectuado por el } \\
\text { Consejo } \\
\text { Superior } \\
\text { Ferroviario }\end{array}$ & $\begin{array}{l}\text { Quedan sujetos a } \\
\text { reversión, al final } \\
\text { de las concesiones, } \\
\text { el valor real del } \\
\text { establecimiento de } \\
\text { los concesionarios } \\
\left(\text { Base } 9^{\mathrm{a}}\right) \\
\text { El rescate } \\
\text { anticipado tendría } \\
\text { como base un } \\
\text { cálculo por abono } \\
\text { de una anualidad } \\
\text { por el tiempo que } \\
\text { reste de concesión } \\
\left(\text { Base } 14^{\mathrm{a}} \text { ) }\right.\end{array}$ \\
\hline
\end{tabular}

Fuente: Elaboración propia con adaptación parcial de Jiménez Ontiveros (1940: 201)

En el cuadro anterior podría haberse incluido también el Proyecto de Ley presentado por el ministro de Fomento Argüelles al Senado el 4 de abril de 1922. Por claridad se ha decidido no incluirlo porque simplemente reproduce el de Maura. 


\subsubsection{Cambó}

Francisco Cambó asumió durante ocho meses -de marzo a septiembre de 1918- el cargo de ministro de Fomento. En su efímero paso por el Ministerio, Cambó fue partidario de coordinar y armonizar el interés privado con el público ${ }^{235}$ para intentar resolver la crisis ferroviaria.

Cambó intentó alcanzar soluciones para el problema ferroviario, encabezando la elaboración de tres documentos: la publicación de la obra "Elementos para el estudio del problema ferroviaria en España", la publicación de la conferencia en el Instituto de Ingenieros Civiles y la emisión del "Proyecto de Ley de Bases para la retrocesión de los ferrocarriles, estructuración y explotación posterior".

En la obra que él coordinó -y en la que aparece como director del estudio ${ }^{236}$ - "Elementos para el estudio del problema ferroviaria en España" (Cambó: 1918-1921), expuso la tesis de que el Estado había de asumir de una u otra forma la carga del mantenimiento de los ferrocarriles como único medio de ampliar y renovar la red. Ese trabajo fue desarrollado por una comisión compuesta por miembros que pertenecían al mundo académico del derecho, a la ingeniería civil y a la militar, y a la administración del Estado. La obra sigue siendo un referente para la historia ferroviaria española ${ }^{237}$.

El libro detalló dos propuestas. La primera es la nacionalización completa de la red de ancho ibérico, previo rescate de las compañías; proponía ceder temporalmente el arriendo de la

\footnotetext{
${ }^{235}$ Durante esa época existía entre los políticos la idea de nacionalización como solución al problema ferroviario. Dos meses antes de acceder Cambó al Ministerio de Fomento, en enero 1918, se celebró la Asamblea Nacional de Ferrocarriles a la que concurrieron representaciones de muy diversas entidades económicas del país, alarmadas porque las ferroviarias tenían una situación tan crítica que perjudicaba a la economía nacional, así al menos se transmitió a la opinión pública. En la primera de las seis secciones, dedicada a "Cuestiones Generales de Política Ferroviaria”, se oyeron voces de notables políticos (Calbetón, Vizconde de Eza, Ventosa,...) a favor de incrementar la intervención del Estado, llegando a propugnar en algún caso una estatificación y gradual nacionalización del servicio. También en la sección quinta, dedicada a "Cuestiones técnicas", se habló de la nacionalización, pero en este caso de la industria ferroviaria (J. M Z Zumalacárregui, F. Averly,...). La situación se repetiría, un año después, en el Primer Congreso Nacional de Ingeniería (1918), donde hubo abundantes reflexiones sobre las facultades que tiene el Estado para intervenir en la administración de los ferrocarriles explotados por empresas concesionarias (Azcárate y Flórez: 1917).

${ }^{236}$ La obra consta de 6 volúmenes. Originalmente tenían que haber sido cinco, pero el estallido de la Guerra Mundial alteró el plan de publicación. Los dos primeros tomos se publicaron en 1918, la guerra retrasó la publicación de los tomos cuarto y quinto a 1920. El impacto en los ferrocarriles europeos de la Guerra provocó la publicación de un sexto tomo, no previsto, para actualizar y completar la información en 1921, con apéndices, como "Los ferrocarriles del mundo ante la última guerra y el comienzo de la post-guerra". La obra incluye gráficos a color, tablas y varios mapas desplegables. El primer tomo está dedicado a la historia de la legislación ferroviaria española y las concesiones de líneas; el segundo al desarrollo de la explotación y al tráfico, capital y datos históricos de cada una de las compañías; el tomo tercero a los ferrocarriles secundarios y estratégicos; el cuarto y el quinto, a la política ferroviaria de diversas naciones y datos estadísticos de ferrocarriles; y el último tomo recoge los apéndices de actualización, y el epílogo.

${ }^{237}$ Las soluciones al problema ferroviario expuesto por Cambó en su trabajo "Elementos para el estudio del problema ferroviario en España", supuso la idea inicial del rescate de toda la red española, concentrando su actuación en cuatro grandes redes, que serían explotadas por empresas privadas.
} 
explotación a las actuales o a otras compañías privadas ${ }^{238}$, bajo el control de una comisión ferroviaria. Esta alternativa es la contraria a la que se hizo en el siglo XIX, cargar sobre el Estado las inversiones ferroviarias, dejando a las compañías privadas el rentable negocio de la explotación. El autor consideraba que esta propuesta imponía un enorme desembolso al Estado sin contrapartida. La segunda propuesta fue el establecimiento de tarifas subvencionadas por parte del Estado.

Con independencia de la retórica a favor y en contra de la nacionalización, tres afirmaciones de la obra son ciertas. La primera es que en el periodo que constituye el final de la Gran Guerra, las compañías, que se encuentran ahogadas económicamente, ofrecían un mal servicio y no se vislumbran perspectivas de mejora a corto, medio y largo plazo. La segunda es que el Estado no disponía del capital humano suficiente para emprender una nacionalización completa. La tercera es que el Estado también carecía de los recursos financieros necesarios para emprender una nacionalización completa. De atravesar las arcas públicas por una situación más saneada, el Estado podría emitir títulos de deuda pública y cambiarlos por acciones y bonos ferroviarios en manos de propietarios privados; es poco probable que los propietarios de acciones o de bonos se opusieran seriamente a un intercambio de sus valores ferroviarios por títulos del gobierno. Sí podía, entre tanto y como solución coyuntural, permitir a las compañías elevar el precio del transporte para así hacer frente a los gastos de explotación y financieros, ocupándose el Estado de: construir nuevas líneas y operarlas; realizar o, en su defecto, subsidiar los procesos de electrificación; establecer doble vía en los trayectos más concurridos; y hacerse con las pequeñas líneas fracasadas, explotándolas por medio de un cuerpo de funcionarios, que podrían adiestrarse de cara al futuro o cederlas en "leasing" a la explotación de las grandes compañías.

En febrero de 1921, Cambó pronunció una conferencia en el Instituto de Ingenieros Civiles sobre el problema ferroviario. La conferencia fue reproducida por el propio Instituto (Cambó: 1921) y por la Revista de Obras Públicas ( $n^{\circ} 2349$ ). En la conferencia abogaba por el rescate por parte del Estado de las concesiones pertenecientes a las compañías. Tras el rescate de las líneas por parte del Estado, se dividiría toda la red en cuatro grandes explotaciones, según más conviniera geográficamente ${ }^{239}$ y según las corrientes del tráfico; la explotación de estas grandes redes agrupadas sería, bien por el Estado, o bien por el arrendamiento a compañías $\operatorname{privadas}^{240}$

El gobierno, dándose cuenta de la crítica situación de las ferroviarias, presentó a las Cortes el 22 de octubre de 1918, por medio del ministro de Fomento Cambó, El "Proyecto de Ley de Bases para la retrocesión de los ferrocarriles, estructuración y explotación posterior" ${ }^{241}$. El

\footnotetext{
${ }^{238}$ Cambó preveía el rescate por redes completas y fijaba la anualidad en función del producto neto de los cuatro mejores años del último quinquenio.

${ }^{239}$ La división posterior de todas la red en cuatro grandes explotaciones, no es la única idea del gobierno Cambó que fue posteriormente retomada, también la constitución de una Comisión Ferroviaria.

${ }^{240} \mathrm{La}$ interpretación de estas propuestas por parte de las dos principales concesionarias puede observarse en NORTE y MZA (1932: 17).

${ }^{241}$ El "Proyecto de Ley de Bases" fue muy reflexionado y elaborado, como muestra que tuvo seis anteproyectos de ley.
} 
Proyecto autorizaba por primera vez en la historia la subida de tarifas por encima del máximo legal, en concreto el $15 \%$, en las bases de percepción por unidad y kilómetro establecidas como máximas en las distintas concesiones, dando facultad al ministro para aprobar las nuevas tarifas de viajeros y mercancías que, dentro del expresado aumento, presentasen las compañías.

El "Proyecto de Ley de Bases" consistía esencialmente en el rescate por el Estado de las concesiones pertenecientes a las compañías; en la división después de toda la red española en cuatro grandes explotaciones, según aconsejaba su mejor agrupación geográfica y las corrientes del tráfico, y en la explotación de estas grandes redes agrupadas, bien por el Estado, o bien por arrendamiento a compañías privadas. El "Proyecto de Ley de Bases" se basa en la primera alternativa para solucionar el problema ferroviario ofrecida por Cambó en "Elementos para el estudio del problema ferroviaria en España", pues promovía la nacionalización de la propiedad de los ferrocarriles manteniendo la explotación en manos de las compañías, aunque sometiéndolas al control de una Comisión ferroviaria, que fuera prestigiosa para que pudiera permanecer inalterable a las presiones de los gobiernos.

Al discutirse este Proyecto de Ley en el Senado, se modificó su texto, limitando la aplicación del $15 \%$ a las tarifas que estuvieran en vigor, criterio que luego fue mantenido por la Comisión dictaminadora del Congreso el 16 de diciembre de 1918. El ministro de Fomento Marques de Cortina ${ }^{242}$ publicó el Real Decreto de 26 de diciembre de 1918 que reproducía lo aprobado en el Senado y luego adaptado en el Congreso, salvo unas medida lesivas para los intereses de las compañías: como la de que los ingresos que proporcionara la elevación del $15 \%$ sería computable a los efectos de la posible reversión anticipada al Estado, y la obligación de suspender este aumento siempre que, surgiendo un conflicto entre el personal y las empresas, no aceptarán éstas el fallo del gobierno, o en su nombre, el del Instituto de Reformas Sociales. Aún así, las cuatro principales compañías elevaron una instancia al ministro de Fomento, el 31 de diciembre de 1918, en la cual hacían constar las manifestaciones y reservas que se presuponía por parte de las mismas la aceptación obligada del Real Decreto de 26 de diciembre de 1918, único medio de salvación que le ofrecía el Estado. Finalmente, todas las empresas aceptaron el Real Decreto. NORTE lo aceptó el 1 de enero de 1919.

El Real Decreto de 26 de diciembre de 1918 estableció que las bases de percepción por unidad y kilómetro podían ser proporcionalmente aumentadas para todos sus efectos hasta un $15 \%$ como máximo, aunque, en consecuencia de estos aumentos, excediesen de las establecidas como máximas legales de las distintas concesiones de ferrocarriles (artículo 1 del Real Decreto de 26 de diciembre de 1918). Las compañías deberían llevar una cuenta especial

\footnotetext{
${ }^{242}$ El ministro de Fomento José Gómez Acebo y Cortina (Marques de Cortina) escribió en el Preámbulo del Real Decreto de 26 de diciembre de 1918 que "el hecho de implantar medida tan importante por acto del Poder ejecutivo obedecía a la necesidad imperativa y agobiante de solucionar la situación del personal obrero, la que no se resolvería, ni podría resolverse, si no se evitaba, al mismo tiempo, la quiebra de las compañías".
} 
de lo que ingresase como consecuencia de los aumentos de tarifa ${ }^{243}$. El ingreso no sería nunca computado para aumentar el producto líquido a los efectos de la posible reversión anticipada de las líneas al estado (art. 3 del Real Decreto de 26 de diciembre de 1918). El aumento quedaría sin efecto: cuando el precio del carbón no excediera del 50\% del que tenía en 1913; cuando los productos netos de la mitad de la red ferroviaria española alcanzasen a los del 1913; o en todo caso, al finalizar el tercer año a contar del 11 de noviembre de 1918 -fecha en que finaliza la I Guerra Mundial- (art. 4 del Real Decreto de 26 de diciembre de 1918).

Cambó fue el primero en comprender el problema en toda su dimensión y en idear una solución definitiva. Realizó un acertado estudio del problema, pero sin enjuiciar debidamente la perspectiva futura de la cuestión. El autor erró cuando determinó una falta de capacidad del tráfico, cuando lo que ocurrió más tarde fue una falta de tráfico.

\subsubsection{Ortuño}

El 15 de abril de 1920, el ministro de Fomento Ortuño elaboró unas Bases que respetaba en todo lo posible la legislación vigente. Este documento daba importancia a la cuestión económica (tarifas) y a la financiera (emisión de empréstitos a plazo de amortización superior al de las concesiones).

Su aplicación hubiera significado un aumento de tarifas en la medida necesaria para cubrir los gastos de explotación y los financieros de las compañías, así como para atender el servicio de los nuevos empréstitos que se suscribiesen para la modernización de la red.

Las Bases de Ortuño no tuvieron ninguna incidencia parlamentaria. El principal discordante con el aumento de tarifas era Juan de la Cierva (1920a; 1920b), que abogaba por la nacionalización, pero sin aumentar las tarifas ${ }^{244}$.

\subsubsection{Juan de la Cierva}

En marzo de 1921, el ministro de Fomento Juan de la Cierva inició un nuevo estudio del problema y expuso sus ideas sobre el mismo para buscar una solución. La posición del ministro era promover la nacionalización sin aumentar las tarifas (Juan de la Cierva, 1920a; 1920b).

Para buscar una solución al problema ferroviario, convocó reuniones con representantes de las compañías y las solicitó un gran número de informes sobre la explotación, acciones, obligaciones, reservas y rescate (NORTE, 1940: 244). Entre estas medidas, el ministro cursó a

\footnotetext{
${ }^{243}$ La subida de tarifas que se promulgó por Decreto de 26 de diciembre de 1918 estaba condicionada a determinados supuestos, los principales eran que le reconocía una vigencia de tres años, y que las compañías tendrían que llevar una cuenta especial de estos ingresos que no podrían aumentar el producto líquido a los efectos de una revisión anticipada. En caso de producirse estas condiciones se volvería a las anteriores tarifas.

${ }^{244}$ Artola (1978: 419) considera como "enemigo declarado de los concesionarios de ferrocarriles" a Juan de la Cierva, que llegó a ser ministro de Fomento.
} 
las compañías un cuestionario, en cuyo planteamiento se ponía de manifiesto la intención de nacionalizar la red y hacerlo a un coste bajo ${ }^{245}$.

El 15 de marzo de 1921, el ministro sintetizó sus ideas ${ }^{246}$ :

- Que no convenía la nacionalización inmediata, pero se debía preparar las cosas para facilitarla en el porvenir.

- Que las tarifas debería estar en manos del Estado, por el interés público.

- Que procedía establecer una coordinación entre el Estado y las compañías para explotar y mejorar las redes

- Que la elevación de tarifas debería hacerse sólo en lo indispensable.

- Que era preciso construir nuevos ferrocarriles complementarios a los existentes entonces.

El ministro de Fomento Juan de la Cierva promovió la Real Orden publicada el 10 de abril de 1921, la cual estableció cuatro medidas muy importantes. En primer lugar, dio carácter de permanencia a los anticipos que el Estado daba a las compañías ferroviarias. En segundo lugar, recomendó a las compañías incorporar los pluses -que percibían los empleados con cargo a las compañías y al anticipo del Estado- a los haberes ${ }^{247}$, a fin de que los nuevos sueldos sirvieran de regulador para el cálculo de los derechos pasivos; lo cual fue realizado por las compañías seguidamente ${ }^{248}$. En tercer lugar, el Estado se comprometía a seguir facilitando el segundo plus que, con cargo al anticipo, percibía el personal hasta que se estableciera el régimen ferroviario. Por último, y lo más importante, establecía la concesión de un segundo plus, incluso, en el caso de que la situación económica de las compañías, antes de establecer dicho régimen, no permitiera el pago del primer plus que venían satisfaciendo desde 1919 con sus propios recursos; es decir, el Gobierno ampliaría el anticipo hasta cubrir también el pago de estas atenciones (artículo 2).

Una vez realizado todo ello ${ }^{249}$, Juan de la Cierva presentó el 13 de mayo de 1921 el "Proyecto de Ley sobre Transportes, Obras Públicas y Fomento de la Riqueza Nacional”"250, que

\footnotetext{
${ }^{245}$ En febrero de 1921, cuando se discutía el proyecto de ordenación ferroviaria de Juan de la Cierva, se publicó el panfleto "Una solución al problema ferroviario", cuyo autor era F. Martínez Ramírez (1920), director del ferrocarril Aramasilla-Tomelloso y secretario de Melquiades Álvarez. Para solucionar el problema ferroviario, Martínez Ramírez proponía que el Banco de España emitiese billetes de ferrocarriles por un valor aproximado de mil millones de pesetas, reintegrable por las compañías en 30 años. Así -añadía Martínez Ramírez- se evitaría la subida de tarifas. Más que solución, a Boag le parecía un disparate ("El Boletín" de febrero de 1920; "El Boletín" de marzo de 1920). La emisión afectaría muy negativamente al crédito del país pues "la sobreproducción del dinero tendría como efecto la pérdida del poder adquisitivo".

${ }^{246}$ Estas ideas son valoradas por NORTE y MZA (1932: 28).

${ }^{247}$ La repercusión de los aumentos de haber en los derechos pasivos quedaba a cargo de las compañías.

${ }^{248}$ Cómo quedó escrito en la Real Orden de 10 de abril de 1921 "En las Conferencias celebradas por el Ministerio con los directores y representantes de las compañías ferroviarias, las compañías acordaron la incorporación de los pluses al sueldo, como les venía pidiendo el Ministerio”.

${ }^{249}$ Las compañías se quejaron que para llegar a la autorización de presentación a las Cortes del Proyecto de Ley de 13 de mayo, las empresas tuvieron que contestar infinidad de cuestionarios, solicitándoles toda clase de datos, respecto a la explotación, acciones, obligaciones, reservas, etc. (NORTE y MZA, 1932: 28-32).
} 
"significó un importante paso adelante en la línea del pensamiento nacionalista del capitalismo español" (Malo y Guillén: 2006). Proponía el establecimiento de un "consorcio" entre las compañías y el Estado, las primeras suministrarían el capital, y el segundo las cantidades transferidas en concepto de anticipos y las que en lo sucesivo requirieran la construcción de nuevas líneas. El Proyecto proponía la creación de un "Consejo Superior de Ferrocarriles", un organismo intervencionista que dependería del Ministerio de Fomento para intervenir, fiscalizar y asesorar a los distintos gobiernos en la materia. Las tarifas deberían cubrir los gastos, cargas y pensiones más un dividendo fijo y una prima de buena gestión.

Las discusiones sobre el tema ferrocarril, estaban recogidas en veinte Bases. La Base segunda establecía un Consorcio entre el Estado y las compañías, interviniendo los funcionarios del Estado en la explotación, formando parte de los Consejos de Administración. El Proyecto pretendía transferir las decisiones fundamentales (obras, salarios y tarifas) a un "Consejo Superior de Ferrocarriles", en el que los delegados de las compañías serían minoritarios, en tanto una "Caja Especial de Valores Ferroviarios" se haría cargo de las operaciones financieras decididas en el Consejo (emisión y negociación de Deuda especial del Estado, contabilidad de anticipos, etc.). La fórmula suponía dejar la gestión a las compañías, limitar sus ganancias y arrebatarles su capacidad de decisión "al tiempo que se mantenía sobre ellas una constante amenaza de expropiación” (Artola, 1978: 421).

La base duodécima del "Proyecto de Ley sobre Transportes, Obras Públicas y Fomento de la Riqueza Nacional" de 1921, denominada "Del régimen de contabilidad", establecía que "al tiempo de ser promulgada esta ley, un Real Decreto establecerá las reglas de contabilidad que deberán ser rigurosamente guardadas a fin de que se mantenga en todo tiempo distinta y clara la cuenta y razón de ingresos y gastos concernientes a ferrocarriles, y también para preservar de eventuales complicaciones y anormalidades el servicio financiero de los mismos. Se dará cuenta en las Cortes del mencionado Real Decreto y, transcurridos sesenta días sin haber sido modificado o con las enmiendas que en él se introduzcan, no podrá ser alterado sino por una ley". Este es el primer intento conocido de regular una adaptación sectorial de la contabilidad ferroviaria.

El Proyecto de la Cierva era un proyecto político y además no definía quién debía encargarse de $\operatorname{administrar}^{251}$. En las discusiones parlamentarias sobre el tema ferrocarril participaron Cambó y Maura ${ }^{252}$, los cuales desmontaron el proyecto presentado por de la Cierva ${ }^{253}$. En gran medida, el proyecto fracasó por la feroz oposición de Cambó y Maura.

\footnotetext{
${ }^{250}$ Las bases del Proyecto de Juan de la Cierva aparecen comentados desde su punto de vista por NORTE y MZA (1932: 28-32).

${ }^{251}$ Las intervenciones de Maura en el Congreso los días 15, 16 y 17 de junio de 1921 dejaron claro que el sistema de Cambó de hacer inmediatamente el rescate y luego entregar a la explotación a compañías privadas, divergía sólo del proyecto de Cierva en que éste aplazaba el rescate, "administrando entre tanto las líneas las compañías concesionarias" (NORTE y MZA, 1932: 30).

${ }^{252}$ Los discursos de Juan de la Cierva, Maura y Cambó quedaron reflejados en NORTE y MZA (1934).

${ }^{253}$ Intervenciones en el Congreso Sesiones de los días 15, 16 y 17 de junio de 1921.
} 
Para Cambó, el Proyecto de Juan de la Cierva no aportaba ninguna de las ventajas, aunque sí contenía todos los inconvenientes de los "sistemas-tipo que regían en el mundo" (NORTE y MZA, 1932: 30-33).

Las intervenciones de Maura en el Congreso ${ }^{254}$ fueron muy relevantes porque establecieron las bases fundamentales que después sirvieron para la redacción del Proyecto de ordenación Ferroviaria, que a su vez dio origen al Estatuto Ferroviario del año 1924. Maura consideró que la impotencia de las compañías en ese momento era un vicio congénito del sistema por menguar su potencia económica según se acercaba el final del usufructo. Para Maura el procedimiento de Consorcio concebido por de la Cierva era impracticable. Además si el Estado era un accionista, la soberanía de la junta de accionistas, ya no pertenecía a los accionistas; igualmente el Consejo no era tampoco la delegación de los mismos por estar intervenido por el Estado, pudiendo considerarse la compañía como medio liquidada; además, como a los accionistas se les daba un dividendo fijo, se les sustraía del estímulo de la vida industrial, desapareciendo "todo móvil de lucro, que para el primer artículo del Código de Comercio, es el emblema de la vida industrial y económica"255. Maura no admitía "el Consorcio entre una compañía de intereses privados, íntimamente atenida al interés privado, y el Estado, necesariamente preocupado de cosas totalmente diversas, acaso opuestas al interés privado" 256 .

\subsubsection{Maura}

Un año después, en $1922^{257}$, se presentó el "Proyecto de Ordenación Ferroviaria",258. Aunque el Proyecto se presentó sin firma que lo refrendara, su paternidad debe atribuirse a Maura ${ }^{259}$, asesorado por Flores de Lemus. El Proyecto de Maura ${ }^{260}$ parte de la idea que el Estado debía seguir siendo propietario de las líneas, y que las compañías debían seguir disfrutando del usufructo temporal, pues el Estado no debía quitar el usufructo a los usufructuarios. Los principios esenciales que a juicio de Maura debían presidir la ordenación del problema

\footnotetext{
${ }^{254}$ Las ideas de Maura pueden observarse en NORTE y MZA (1932: 28-32).

${ }^{255}$ Intervención de Maura en el Congreso. Sesión de 21 de junio de 1921.

${ }^{256}$ Intervención de Maura en el Congreso. Sesión de 21 de junio de 1921.

${ }^{257}$ Tras el fracaso de Annual se formó un nuevo gobierno de concentración nacional, presidido por Maura, y del que, paradójicamente, formaron parte Cambó y Juan de la Cierva. Maura encargó al prestigioso economista A. Flores de Lemus la elaboración de un proyecto alternativo (Damas Rico, 1976). Maura pretendía con el Proyecto de Ordenación Ferroviaria solucionar el problema, armonizando las diversas tendencias de sus ministros: Cambó y Cierva.

${ }^{258}$ La Comisión del Congreso no llegó a emitir su informe, este proyecto no llegó a tomar estado parlamentario hasta que a primeros de abril, después de una crisis política, presentó Arguelles al Senado, como ministro de Fomento, un nuevo proyecto de Ordenación Ferroviaria calcado al atribuido a Maura.

${ }^{259}$ NORTE y MZA (1932: 35) asumen que el Proyecto está realizado por Maura, aunque él no lo firme.

${ }^{260}$ Antonio Maura y Montaner (1853-1925) fue un importante político liberal que hizo trasvase, a principios del siglo XX, al conservadurismo. Entre 1818 y 1922 presidió varios gobiernos, reclamado por el Rey para formarlos una y otra vez, como cabeza de un movimiento político que llevaría su nombre, el Maurismo. Éste, a su vez, contaba con dos ramos: una tendencia parlamentaria, que modernizando su conservadurismo y adaptándolo a la política de masas propugnaba una "revolución desde arriba", y otra tendencia profascistas, que encarnaban las "Juventudes Mauristas".
} 
ferroviario era constituir una comunidad de explotación (comunidad de bienes) entre el Estado y las compañías ${ }^{261}$, administrado con arreglo a las normas propuestas por un Consejo Superior Ferroviario. Para él, la solución está en la utilización de un concepto jurídico de la explotación basado en concesiones temporales, usufructo y fideicomiso, que fue la base de todos los proyectos que se formularon posteriormente.

El Proyecto propone constituir el Consejo Superior de Ferrocarriles como organismo autónomo para dirimir la discordia entre el Estado y las compañías. Para Maura las tarifas deberían ser suficientes para cubrir los gastos de explotación, las cargas financieras, pensiones de retiro y la remuneración del capital de las compañías. Para él, el dividendo del accionista "no debía ser seguro ni fijo, pero si cierto, puesto que al capital que actúa en la producción hay que reconocerle un rendimiento" 262 .

Las empresas ferroviarias se quejaron de que no tuvieron participación en la elaboración de este Proyecto de Ordenación Ferroviaria ${ }^{263}$. Las compañías pensaban que no intervinieron nada, ni siquiera con carácter informativo ni con aportación de datos a la preparación de este proyecto $^{264}$, por parecerle a Maura contraproducente negociar con tantas entidades que tenía situaciones tan diversas, pero sobre todo por temor a "entenderse con algunas y rendirse a la imposibilidad de aplicar a las demás el mismo trato" (NORTE y MZA, 1932: 35).

Existía un error en el Proyecto de Maura, al entender que las compañías y el Estado podían deliberar de tú a tú, y que el organismo Consejo Superior de Ferrocarriles podía dirimir la discordia sin que el Estado acabara por imponerse ${ }^{265}$. Además, Maura no analizó la realidad económica del sistema; intentaba mejorar la solución mientras durasen las concesiones, aunque no proponía un régimen definitivo para el futuro.

Realmente el régimen de comunidad de bienes entre el Estado y las concesionarias, era una forma más desarrollada de denominar al Consorcio propuesto por de la Cierva. El Proyecto de Ordenación Ferroviaria de Maura tampoco se convirtió en Ley, al ser rechazada en el Congreso.

\subsubsection{Estatuto Ferroviario}

El 13 de septiembre de 1923 tiene lugar el golpe de Estado del General Primo de Rivera, con el que se abre la puerta a una nueva etapa, marcada por el nacionalismo y el intervencionismo.

\footnotetext{
${ }^{261}$ Para Maura la comunidad debe tener un alcance jurídico concreto: "debe ser de explotación, en los productos y nada más" (Intervención de Maura en el Congreso. Sesión de 21 de junio de 1921).

${ }^{262}$ Intervención de Maura en el Congreso. Sesión de 21 de junio de 1921.

${ }^{263}$ Las críticas de las compañías a esta propuesta fueron abundantes, quedando recogidas por NORTE y MZA (1932: 32 y 35-41).

${ }^{264}$ Las ferroviarias no tuvieron la menor participación en la elaboración; según NORTE (1940: 246) las empresas ferroviarias fueron sorprendidos por la publicación de este Proyecto de Ordenación Ferroviaria.

${ }^{265}$ Esta idea fue incluida por Boag (1923), quien señala con ironía que "es difícil imaginar cómo el Estado puede cumplir el doble papel de socio y guardián del interés público”.
} 
La Dictadura intentó solucionar sin dilación el problema ferroviario. El nuevo proyecto, muy parecido al de Maura ${ }^{266}$, acabó de redactarse a principios de 1924 y se aprobó en julio de ese año; con la denominación "Decreto de 12 de julio de 1924 relativo al Régimen Ferroviario", conociéndose como "Estatuto Ferroviario".

De las tres posibles soluciones -estatificación, régimen de empresa privada y régimen de comunidad- el Estatuto se decantó por la última. Preveía la constitución de un consorcio o coparticipación entre el Estado y aquellas compañías que voluntariamente aceptasen el convenio. Uno de los aspectos más importantes del nuevo régimen es la provisión de capital con garantía del Estado, el único objetivo que la Dictadura cumplió satisfactoriamente. Por el contrario, en la cuestión de tarifas, estructuración de la red y unificación de material y contabilidad apenas hubo mejoras.

Los proyectos para resolver el problema ferroviario que se habían sucedido en los años anteriores fueron paliativos para salir del paso, hasta que llegó el Estatuto de 1924, que introducía un nuevo orden al ferrocarril en España. El nuevo régimen ferroviario, creado por el Estatuto de 1924, estableció que el Estado es quien construye las nuevas líneas y concede auxilio financiero a las compañías para la mejora de las que tiene en explotación.

El Estatuto Ferroviario, que tiende a un régimen de nacionalización ${ }^{267}$, define un consorcio no comunidad- entre el Estado y las compañías, respetando íntegramente la gestión de las compañías.

En la Exposición del Estatuto Ferroviario de 1924 aparece el objetivo del nuevo Régimen Ferroviario. Del estudio económico-financiero efectuado se dedujo la necesidad de que las soluciones que se habían de proponer tuvieran la flexibilidad suficiente para que pudieran aplicarse a las distintas empresas de ferrocarriles. Admite que, con el nuevo régimen, no es posible pretender que un negocio ferroviario, esencialmente ruinoso, se convierta en bueno; lo único que se puede aspirar es a que, interviniendo el Estado, se mejorasen los servicios, se ordenasen las explotaciones para la construcción de obras que los concesionarios por sí solos no podrían acometer, y se armonizase el precio del transporte dentro de límites equitativos. "Pero si con las mejoras, con buenos servicios de explotación, con medidas indirectas de gobierno y con tarifas adecuadas, el negocio no prospera, será porque el ferrocarril no responda a una verdadera necesidad comercial, porque se ha querido obtener una subvención y no organizar un transporte, y en estas condiciones el Estado no debe intervenir, dejando a las empresas dentro de sus concesiones" (Estatuto Ferroviario, 1924: Exposición).

\footnotetext{
${ }^{266}$ The Railways Gazette, 5 de septiembre de 1924 (“The New Spanish Law)" de 1924, pp. 306-307. Es posible encontrar una visión desde las dos grandes empresas: NORTE y MZA $(1932 ; 1934)$.

${ }^{267}$ En octubre de 1930, desaparecida ya la Dictadura, los redactores de "El Boletín" le preguntaron a Boag (1923) sobre lo que pensaba del futuro del ferrocarril español. Esta fue su respuesta: "El futuro de los ferrocarriles españoles, como en otras naciones, creo verlo con toda claridad, afirmando, que bien pronto han de pasar a posesión del Estado, anticipándose la reversión de las concesiones, sin que por este hecho sea más beneficiosa la explotación, por lo menos en algunos lustros, encargándose de ella una o varias grandes corporaciones". Era una premonición que no tardó en convertirse en realidad.
} 
Para estos casos especiales se precisa una previa intervención práctica del Estado que defina la situación real de cada concesionario, las modificaciones que en su caso deban introducirse en los servicios y en la administración y determine hasta qué límite debe llegar el auxilio del Estado, dejando siempre a salvo los derechos adquiridos de las empresas.

El nuevo régimen no se impone a las empresas, sino que se las deja libertad para acogerse a sus beneficios. Para la implantación del nuevo régimen se considera como base principal la agrupación de las líneas existentes y futuras, para llevarla a cabo, por cuanto con ello se resolverían muchas dificultades derivadas del problema ferroviario, porque se disminuirían los gastos generales y de administración, así como los de personal, por el mejor aprovechamiento de éste; se simplificaría la explotación unificando criterios; se facilitaría la ordenación de tarifas, de modo que el tráfico pueda utilizar las líneas de más corto recorrido por supresión de competencias; permitiría la unificación de Reglamentos para el personal, facilitando la solución de los problemas sociales; se obtendría una mejor distribución del tráfico en bien del servicio público; mejor utilización del material móvil, facilitando su unificación, que redundaría en beneficio de la fabricación nacional; se simplificarían igualmente las relaciones entre las empresas y el Estado.

La primera decisión del Estatuto Ferroviario consistió en abrir un período de información pública sobre el tema y reactivar el "Consejo Superior Ferroviario" (que había sido creado por el Real Decreto de 15 de marzo de 1922), aunque cambiando su denominación a "Consejo Superior de Ferrocarriles" 268 como organismo consultivo al que se le otorgarán nuevas atribuciones en la línea de su homónimo francés.

El 30 de enero de 1924 se creó el "Consejo Superior de Ferrocarriles", para regular e inspeccionar la gestión ferroviaria de las empresas. Las facultades del Consejo Superior de Ferrocarriles fueron potenciadas en el Estatuto, donde se le reconocía la misión de ser órgano de enlace entre el gobierno y las empresas. Entre las atribuciones que le asignó el Estatuto, destaca las de definir las características de la red, es decir, proponer las ampliaciones y las tareas de mejora que pudieran llevarse a cabo; la fijación de las tarifas; el estudio y la realización de las operaciones de rescate e incluso podía llegar, temporalmente, a intervenir en la gestión de las compañías.

La intervención que el Estado deba realizar, será ejercida por el Consejo Superior de Ferrocarriles, organismo mixto de máxima autoridad, en el que están representados todos los intereses públicos ${ }^{269}$. De esta forma, se encamina a la total nacionalización de los ferrocarriles, que constituiría la base fundamental de la nueva organización ferroviaria.

\footnotetext{
${ }^{268}$ El Consejo Superior de Ferrocarriles fue el heredero del Consejo Superior Ferroviario. El Decreto-Ley de 30 de enero de 1924 cambiaba su nombre y concedía participación a los trabajadores y a la minería a través de la concesión de un representante (The Railways Gazette, 8 de febrero de 1924, p. 160; 18 de abril de 1924).

${ }^{269}$ La trascendencia del Consejo Superior de Ferrocarriles puede observarse en Ortúñez (2008: 141-168).
} 
La intervención de dicho organismo debe estar limitada única y exclusivamente por la necesidad de no perturbar la gestión de las empresas; pero dentro de esa limitación, como el Estado facilita capital y autoriza las tarifas necesarias, es preciso que pueda llegar, con su inspección y autoridad, dentro de los organismos ferroviarios técnicos y administrativos de las empresas, hasta donde sea preciso para garantir al Estado que los servicios se realizan en buenas condiciones de rendimiento y que todas las inversiones de capital están perfectamente justificadas.

Para satisfacer las necesidades del tráfico nacional, es indispensable desarrollar un programa de obras y de adquisiciones de material, y otro de construcción de líneas nuevas. Dada la situación financiera de las empresas y la vida avanzada que llevan dentro del periodo de sus concesiones, hay que prescindir de que ellas, salvo en casos justificados, adquieran el dinero para la realización de las referidas obras, y por tanto, debe ser el Estado quien facilite los capitales necesarios para cuantos desembolsos implique la implantación del nuevo régimen, proponiendo para ello la creación de una Deuda especial ferroviaria, cuyos productos habrán de ingresar en una caja especial llamada "Caja Ferroviaria del Estado". Esta Caja deberá nutrirse con los recursos que se puedan obtener de la consignación anual que se incluya en los Presupuestos generales, con los excesos de productos de determinados impuestos, a fin de facilitar la realización de dichas obras, dotando al Estado de un medio indirecto de obtener el interés y amortización de los capitales que preste a los concesionarios, sin gravar la tarifa, considerando justo que entren en esa Caja determinados ingresos de productos e impuestos que correspondan al Estado, porque es natural que en un período de construcción de intensa renovación de los ferrocarriles aquél no se lucre, sino que se limite a no perder, en relación con lo que le corresponda por el capital que haya prestado.

La Base octava del "Estatuto ferroviario" establecía que el metálico facilitado por el Estado no se considerará como "anticipo", sino como "aportación". Ni los inmuebles ni el material fijo y móvil cedidos por el Estado, se computarán por su valor real actual en el momento de la cesión, sino por su valor de coste; y no se les aplicará coeficiente alguno de amortización por demérito de tiempo y servicio. En el capital del Estado sujeto a amortización no se incluirán las líneas que hayan revertido al mismo, libres de cargas.

El Estatuto ferroviario trajo cuatro efectos. Por un lado, aumentaron las facultades fiscalizadoras de la administración y el control e intervención del Estado sobre las ferroviarias. Por otro, se estableció una aportación de capitales por el Estado para hacer posible la mejora de las redes. En tercer lugar, propició la Caja Ferroviaria que se nutriría, a parte de las consignaciones presupuestarias, con la emisión de Deuda Ferroviaria. Por último, estableció una nueva legislación en la que se incluían normas para un posible rescate de las líneas por el Estado.

El Estatuto no se limitó a los conceptos jurídicos, sino que se ocupó de la realidad económica del sistema y de las dificultades financieras de las compañías. Esta Ley -no cumplida en la práctica íntegramente- tenía indudable acierto, y de haberse aplicado convenientemente "podría haber encauzado el problema ferroviario hacia otros derroteros si nuevos hechos de 
naturaleza económica, como la competencia de la carretera y la crisis general, con la disminución de tráfico, no hubieran puesto de manifiesto la absoluta necesidad de acudir a nuevas figuras de Derecho" (Jiménez Ontiveros, 1940: 284-285).

\subsubsection{Evaluación de las propuestas de solución}

En todas las propuestas de solución, los autores culpabilizan del problema, de una u otra forma, a las empresas, pero ellas no fueron las únicas responsables, también fueron responsables el propio Estado, la cultura y sociedad de la época, y los modelos de gestión heredados de Francia.

Una vez analizadas todas las propuestas, es necesario destacar que las relaciones del Estado representante de la colectividad nacional- con las compañías de ferrocarriles fueron un problema complejo y difícil ${ }^{270}$.

También fue culpable el Estado, que no se limitó a fijar las reglas del juego, sino que con el sistema de ayudas, garantías y subvenciones, de un lado, y la fórmula concesional, del otro, influyó en la captación y canalización de las inversiones para el negocio ferroviario ${ }^{271}$. Las empresas recibieron dos tipos de subvenciones: una cantidad proporcional al presupuesto de la obra, y otra que aseguraría un rendimiento al capital de las acciones desembolsado en tanto que no comenzase la explotación comercial. El otorgamiento de ambos tipos de subvenciones, hizo que, para muchos especuladores, el negocio ferroviario residiese más en la propia construcción de la red que en la posterior rentabilidad de la explotación.

Las propuestas no tuvieron en cuenta que el problema ferroviario también tenía su origen en aspectos ajenos a empresas españolas y el Estado. Por un lado, el nivel cultural de la sociedad española era inferior al de las naciones centroeuropeas (Marraco, 1922: 10), lo que dificultaba conseguir un capital humano adecuado y una clientela con posibilidades y cultura de ocio. Por el otro, los informes técnicos que dieron al Estado sus funcionarios dejaban claro que el modelo debía ser racional y que los intereses privados nunca debían sobreponerse a los intereses públicos. Así ocurrió con las otras vías de comunicación y con el resto de industrias. Sin embargo, en materia ferroviaria nos perdió la vecindad con Francia; allí se había

\footnotetext{
${ }^{270}$ En 1887 decía Arthur Raffalovich que no había problema más complejo y difícil que el de las relaciones del Estado representante de la colectividad de intereses nacionales, con las compañías de ferrocarriles, que a cambio de sacrificios más o menos considerables se habían provisto de un monopolio industrial. La cita de Arthur Raffalovich se encuentra en el prólogo a la traducción del libro de Hadley "El transporte por ferrocarril".

${ }^{271}$ La concesión ferroviaria es un acto jurídico por el que el Estado confirma a unos sujetos determinados el derecho que éstos tienen de construir o explotar un ferrocarril, en un periodo de tiempo dado. En este sistema de concesiones, la titularidad del ferrocarril se concede al Estado, mientras que la propiedad y la gestión se otorga a las sociedades ferroviarias. Este sistema se estableció por la incapacidad del Estado para movilizar los recursos necesarios para llevar a cabo la construcción y explotación de la red. De ahí que todos los cauces legales se arbitraron para hacer posible la captación de capitales privados, en gran parte provenientes del extranjero, al decretar la libre circulación de capital y las ayudas a las empresas en momentos de crisis con las garantías del interés de las deudas, incluidas las de los empréstitos. Que el sistema español de concesiones por 99 años con subvenciones no resultó beneficioso para el país lo demuestra la existencia del problema ferroviario.
} 
planteado la cuestión como materia financiera, y las familias francesas se impusieron a la "torpe e impotente" (Marraco, 1922: 10) oligarquía española.

Pero los fallos de las empresas españolas, del Estado, de la cultura y de los modelos de gestión heredados de Francia son problemas estructurales desde el origen, de ninguna manera, pueden considerarse que tienen su origen en la I Guerra Mundial. La Gran Guerra sólo supuso un agravamiento de la situación.

Aunque el modelo ferroviario era deficiente, las empresas ferroviarias podrían haber intentado mejorar su gestión, sin tener que esperar la resolución del modelo por parte del Estado. La solución del problema ferroviario podría haber sido aliviado por las propias empresas del ferrocarril con medidas económicas que hubieran mejorado su estructura financiera. Como el mercado de capitales no admitía la absorción de mayores capitales en forma de acciones ordinarias, debería haber emitido clases de acciones, en forma de acciones preferentes, privilegiadas, sin voto o rescatables, de forma que hubieran evitado emitir nuevos empréstitos.

\subsection{Desequilibrios en la estructura financiera de las compañías ferroviarias}

El sector ferroviario es una industria muy intensiva en capital y gestión, que genera fuertes externalidades. Su construcción, puesta en servicio y explotación requieren una acertada planificación temporal, importantísimas inversiones iniciales que suponen largos periodos de amortización. Estas características ocasionan a las empresas crecientes dificultades de acceso a los recursos financieros, "con la consecuente complicación para mantener en el tiempo la confianza de los inversores" (Ortúñez, 2016a: 81).

\subsubsection{Origen de la financiación por medio de emisiones}

El origen del problema ferroviario no fue la I Guerra Mundial, sino la estructura financiera de las ferroviarias españolas desde el origen; esto es compartido por Cambó (1921). Su estructura financiera era altamente endeudada, financiada mayoritariamente por emisión de empréstitos, y con poco peso relativo de la emisión de acciones dentro de la masa de pasivo. La razón de decantarse por los empréstitos era el temor de las empresas de que el mercado financiero en ese momento no absorbiera un número mayor de emisiones de acciones porque los inversores potenciales no quisieran arriesgarse a contratar más acciones ordinarias.

Los problemas del sistema de concesiones se acentúan cuando se acerca el vencimiento, cuando arrecían las dificultades económicas o cuando no había libertad para fijar las tarifas. Durante muchos periodos de su actividad, en las empresas concesionarias españolas han coincidido los tres hechos al mismo tiempo.

Las ferroviarias españolas surgieron al amparo de la Ley General de Ferrocarriles de 1855, y en virtud de ella formaron su capital inicial emitiendo acciones. Sin embargo, a medio y largo plazo las dificultades de financiación surgidas durante la segunda mitad del siglo XIX, debido 
a la crisis financieras y los problemas derivados de la explotación, provocaron que, las sociedades ferroviarias recurriesen a la seguridad que representaban los empréstitos, teniendo en cuenta que el gobierno español garantizaba el interés de las emisiones. Sin embargo, esta financiación tuvo un inconveniente claro, la alta remuneración que las compañías tuvieron que pagar periódicamente a los obligacionistas consumió buena parte de los ingresos generados por la explotación, mientras que los fondos obtenidos con estas emisiones se mostraron cada vez menos rentables "por el reiterado abuso de las emisiones y el quebranto con que se llevaron a cabo" (Vidal Olivares, 1998: 61).

El denominador común en las prácticas financieras de las compañías de ferrocarril en España fue no ampliar excesivamente el capital en forma de acciones por los problemas de colocación de la renta variable en los mercados. Por ello se acudió más a los recursos ajenos por medio de la emisión de obligaciones, en vez de ampliar el capital en forma de acciones. Para Tedde (1978: 35) este hecho tenía su origen en que en el mercado francés -gran aportador de la financiación del ferrocarril español- había más ahorradores dispuestos a invertir en títulos de una rentabilidad segura, aunque limitada, que en participar de los riesgos de la propiedad. Aunque esto es cierto, también puede haber otra justificación, pues la emisión de empréstitos permitía, a las poderosas familias que iniciaron la concesión, no perder el control de las compañías $^{272}$.

Las emisiones de empréstitos de cada ferroviaria tuvieron que competir con el resto de obligaciones de compañías ferroviarias, pero también con las emisiones de sociedades de otros sectores, y a partir de final del siglo XIX, con una nueva emisión de obligaciones para financiar al Estado: la emisión del empréstito del Decreto de 3 de noviembre de 1896. Este empréstito, creado para financiar la insurrección de la provincia cuabana de Santa Clara, tuvo una suscripción previa de 600 millones. Entre los inversores que eligieron el empréstito denominado "nacional"- destacan los 14 millones de la familia Urquijo, 13 de la compañía Transatlántica y 10 de la Condesa de Bornos ${ }^{273}$. Es de suponer que si no hubiera existido este empréstito nacional, gran parte de estos fondos hubieran ido a parar a la suscripción de los bonos de las ferroviarias.

A principios del siglo XX se produjo un incremento de los ya altos costes financieros, a raíz de la devaluación de la peseta. La importancia de este hecho es que en 1900 una gran parte de su financiación estaba constituida por obligaciones, y de ellas su mayoría estaba colocada en el mercado francés, teniendo que pagarse los intereses y amortización en francos. La depreciación de la peseta respecto a la divisa francesa alcanzó, en los años noventa del siglo XIX, un 23\% (Tedde, 1978: 38-42). Con el nuevo siglo, y gracias a las medidas estabilizadoras del ministro de Hacienda Fernández Villaverde, estos quebrantos por el cambio de moneda fueron cayendo hasta resultar insignificantes antes de la Gran Guerra (Comín, et. al., 1998: 203-204).

\footnotetext{
${ }^{272}$ Mediante la emisión de obligaciones, las ferroviarias se aseguraron el control de sus empresas y la pérdida de valor de sus acciones (Casares: 1973; Anes: 1978 y Tedde: 1978).

${ }^{273}$ Los detalles de esta emisión pueden observarse en tres publicaciones: El Imparcial, 15 de noviembre de 1896, p. 3; La Ilustración Española y Americana, pp, 2-3; y El Imparcial, 16 de noviembre de 1896, pp. 3-4.
} 
La principal herramienta que el regulador había establecido para controlar el sector, era el de reservarse la autorización para que las compañías pudieran incrementar las tarifas. Con el incremento de los costes, las compañías necesitaban que el Estado les autorizara tal subida, pero éste se negó sistemáticamente. Tan sólo accedió a un aumento en diciembre de 1918, que no alcanzó las proporciones que las compañías habían solicitado. El problema de la insuficiencia de los ingresos respecto a los costes no se resolvió, pero el Estado se negó a autorizar nuevos aumentos tarifarios y abrió la puerta al sistema de anticipos -adelantos de fondos- en 1920. Los dos anticipos autorizados por parte del Estado en 1920 y prorrogados después eran, en realidad, préstamos: el primero, para financiar el coste del aumento de los salarios de los trabajadores, sin intereses; y, el segundo, para adquirir material móvil y de tracción, con un interés anual del 5 por 100 a devolver en veinte años. La cuantía de ambos anticipos fue insuficiente, lo que provocó la necesidad de buscar financiación en el mercado de capitales; el coste de esta financiación fue muy alto, lo que complicó su estructura financiera.

NORTE no fue ajena al predominio de las obligaciones respecto a las acciones. Las anexiones de las distintas compañías que propiciaron la expansión de NORTE se financiaron con cargo a préstamos, con las propias reservas de la empresa y, fundamentalmente, mediante la emisión de nuevos empréstitos hipotecarios.

En los orígenes de NORTE, existía una alta motivación para buscar financiación en el mercado de capitales por medio de acciones. Esto puede observarse en el documento de anuncio de emisión de acciones, con formulario adjunto de petición de acciones incluido "Camino de Hierro del Norte de España a Madrid. Primera sección de Avilés a León" (NORTE, 1845: 1-2).

No obstante, aunque NORTE buscó al principio la financiación por medio de acciones, a medida que trascurría la vida de la compañía, en verdad se financió más con obligaciones que con acciones. Este era el problema estructural más importante de NORTE a pesar de que ella no lo veía así; la propia empresa afirmaba que colocar los empréstitos "da confianza en la marcha y prosperidad de la empresa" (NORTE, 1923b: 46).

El cuadro 11 refleja la estructura financiera de NORTE y MZA durante el periodo estudiado, diferenciando los tipos de deuda, ordenada quinquenalmente. Dentro del intervalo temporal es muy representativa, la estructura de capital del año 1913, pues el 26\% de la financiación por medio de valores negociables estaba constituida por obligaciones en Gran Bretaña, mientras que en Francia alcanzaría el 91\% (Caron, 1981: 108). En España, para esas mismas fechas, NORTE (1914) estaba en torno al 76,9\% y en MZA (1914) al 76,4\%, porcentajes que se incrementarían años más tarde. 
Cuadro 11. Estructura financiera de NORTE y MZA

\begin{tabular}{|l|l|l|l|l|l|l|}
\hline AÑO & \multicolumn{3}{|c|}{ NORTE } & \multicolumn{3}{c|}{ MZA } \\
\hline & NETO & OBLIGACIONES & $\begin{array}{l}\text { OTRAS } \\
\text { DEUDAS }\end{array}$ & NETO & OBLIGACIONES & $\begin{array}{l}\text { OTRAS } \\
\text { DEUDAS }\end{array}$ \\
\hline 1900 & 401.913 .506 & 751.546 .011 & 69.994 .598 & 341.805 .241 & 679.227 .474 & 47.919 .571 \\
\hline 1905 & 427.255 .787 & 784.161 .721 & 57.421 .991 & 346.115 .314 & 710.713 .781 & 47.916 .626 \\
\hline 1910 & 446.488 .413 & 793.318 .563 & 86.564 .813 & 380.853 .726 & 728.977 .680 & 51.630 .166 \\
\hline 1915 & 541.721 .078 & 850.473 .334 & 44.410 .827 & 431.298 .406 & 788.021 .665 & 55.052 .263 \\
\hline 1920 & 549.946 .979 & 973.340 .318 & 80.761 .853 & 460.905 .116 & 848.909 .953 & 103.703 .632 \\
\hline 1925 & 584.206 .651 & 1.205 .831 .843 & 342.934 .142 & 163.930 .413 & 1.122 .059 .741 & 184.670 .140 \\
\hline
\end{tabular}

Fuente: Elaboración propia con adaptación parcial Ortúñez (2016b: 270)

El problema de los costes elevados de NORTE tiene su origen en la mala estructura financiera, basada sobremanera en la financiación ajena, sobre todo con empréstitos, y poca en la financiación basada en acciones. Las acciones remuneran con dividendos, que pueden ser no entregados a los accionistas si los resultados no son buenos, mientras que los empréstitos remuneran a los obligacionistas independientemente de la marcha de la empresa.

La estructura financiera de NORTE, muy sesgada hacia los recursos ajenos, sobre todo con obligaciones, tuvo como repercusión que las cargas financieras fueron muy voluminosas, impidiendo que los resultados contables fueran positivos durante muchos años. Esto fue más acusado cuando la peseta se depreciaba, ya que los intereses había que pagarlos en francos, porque las obligaciones se emitieron mayoritariamente en París (Comín, et. al., 1998: 203204).

\subsubsection{Posible solución: Financiación con clases de acciones}

La financiación con clases de acciones hubiera resuelto, o al menos atenuado, los tres principales problemas de las ferroviarias concesionarias españolas.

En primer lugar, las concesionarias españolas tenían una alta financiación con recursos ajenos, fundamentalmente obligaciones, lo que provocaba una estructura económicofinanciera caracterizada por un alto nivel de endeudamiento. A las concesionarias les costaba captar fondos de los accionistas; el ferrocarril "proporcionó beneficios sensiblemente inferiores a los ofrecidos por otras alternativas de inversión" (Tedde: 1978: 235), y que durante largos periodos no remuneró en absoluto a sus propietarios. Ante la necesidad de captar fondos, el único camino era aumentar sus deudas, algunas bancarias, pero sobre todo por medio de empréstitos. Si las compañías hubieran utilizado acciones privilegiadas u otra clase de acciones, éstas hubieran sido contabilizadas en los recursos propios. De esta forma, la situación económica financiera hubiera sido la misma, pero la apariencia hubiera sido la de un endeudamiento menor.

En segundo lugar, y unido al anterior problema, la financiación con empréstitos ofrecía una remuneración alta, insostenible para las empresas a largo plazo. El inversor español estaba 
poco motivado en invertir en sectores de elevado riesgo, como era la construcción de vías ferroviarias, por lo que las empresas debieron remunerar mucho a los obligacionistas. El Estado se reservó la competencia para fijar las tarifas máximas con el fin de que los usuarios pagasen precios asequibles, pero esto impidió que las empresas obtuvieran grandes beneficios. Los problemas se agravaron cuando los costes de explotación crecieron de forma brusca. En ese momento comenzó poco a poco la intervención del Estado y la necesidad de mayores recursos para las empresas que no procedían de las tarifas, ante las sucesivas negativas de los gobiernos para aumentarlas ${ }^{274}$, aunque el Estado sí concedió más ayudas de otro tipo. Las concesionarias podrían haber ofrecido a los mercados de capitales otras ventajas que no fuese la remuneración -como ventajas en el voto o privilegios en el derecho a obtener una mayor cuota de liquidación-, de forma que hubiera podido soportar una remuneración moderada, aunque esto hubiera supuesto alguna otra contraprestación.

Pero, además, había otro tercer problema: la disminución de la potencia económica de las compañías, según se acercaba al término del usufructo. Esta peculiaridad podría haber sido solucionada con la financiación por medio de acciones rescatables.

Por tanto, la solución a los tres problemas podría haber sido realizar emisiones normalizadas, pero no de empréstitos, sino de acciones con alguna diferenciación en los derechos que concedían a los titulares, respecto a los títulos ordinarios.

\subsubsection{Diferenciación de los privilegios}

Las acciones (también las participaciones sociales) pueden otorgar derechos diferentes. Las acciones que tengan el mismo contenido de derechos constituyen una misma clase de acción.

La diferenciación de emisiones en clases, aunque menos utilizada en el mercado financiero, es la terminología adecuada. No es conveniente denominar acciones privilegiadas a las clases con mayor número de derechos respecto a una clase existente, ya que, si posteriormente se realiza una nueva emisión, el privilegio de la anterior emisión podría ser ahora un derecho inferior frente a la nueva. Además, no en todos los casos resulta fácil a un observador decidir cuándo se encuentra ante acciones privilegiadas en términos absolutos o ante emisiones con una ventaja en un derecho y una desventaja en otro. Por ejemplo, las acciones sin voto constituyen una clase de acciones, incluso podrían denominarse acciones especiales (de la Cuesta, 1973: 913-928) (Aguilera, 1994: 159), si se acepta a otra emisión de acciones previa como ordinaria, pero difícilmente podría entenderse siempre como acciones privilegiadas o preferentes, pues las posibles ventajas económicas son ensombrecidas por la pérdida de voto. Otro ejemplo son las acciones rescatables, que sólo pueden ser consideradas privilegiadas si la posibilidad de rescate es dejada a voluntad del accionista, pero nunca si el rescate es a

\footnotetext{
${ }^{274}$ A lo largo del periodo de estudio sólo hubo un aumento de tarifas, a finales de 1918, que significó un aumento del $15 \%$ sobre las tarifas que se estaban aplicando, no sobre las máximas.
} 
voluntad del emisor ${ }^{275}$. Por esta razón, parece más conveniente hablar de emisiones especiales $^{276}$ en vez de privilegiadas o preferentes ${ }^{277}$ y, aún mejor, de diferentes clases. El término clases de acciones sólo requiere que dos emisiones tengan derechos diferentes, en contraposición a la consideración de privilegiadas, que precisa considerar a una de las emisiones como ordinaria o normal.

Respecto a la regulación legal de las clases de acciones, el Código de Comercio de 1885 no los reguló. La primera vez que se planifica su regulación es el Proyecto de Reforma de 19 de agosto de 1926, que permite emitir acciones privilegiadas sobre los derechos económicos del socio, siempre que se respeten cuatro límites. En primer lugar, la validez de la emisión se condiciona a la observancia de las formalidades establecidas para la reforma de la constitución social. En segundo lugar, el privilegio reconocido a los titulares de acciones preferentes no puede suponer la totalidad de los beneficios. En tercer lugar, no puede suprimirse el derecho de fiscalización inherente a la cualidad de socio que tengan los titulares de acciones ordinarias. Por último, el legislador admite la creación de clases de acciones en el ámbito de los derechos patrimoniales, pero rechaza la diversidad en el plano de los derechos políticos incluido el derecho de voto ${ }^{278}$.

Por tanto, en el periodo de estudio de esta investigación no estaba prevista legislativamente la emisión de acciones privilegiadas, pero tampoco prohibidas, por lo que podrían haberlos emitido (como así lo hicieron algunas). Esto hubiera mejorado su estructura económicofinanciera. Si los concesionarios hubieran concedido estos privilegios, los inversores los hubieran adquirido, y los primeros no hubieran tenido que emitir tantas obligaciones. Por

\footnotetext{
${ }^{275} \mathrm{Si}$ el rescate está definido de otra forma, "es difícil considerarlo como un privilegio" (Peñas Moyano, 2008: 359).

${ }^{276} \mathrm{Al}$ margen de los términos legales de clases de acciones y acciones privilegiadas, la doctrina (Garrigues, 1976: 453) (Garrigues y Uría, 1958: 425) (de la Cuesta, 1973: 159) (Sánchez Andrés, 1994: 292) ha utilizado la expresión acciones especiales para referirse a las acciones que posen una especialidad en el contenido de sus derechos, siendo por tanto un término más amplio que el concepto de acción privilegiada, pues abarca cualquier especialidad -tanto positiva como negativa- referida al contenido de los derechos atribuidos por la posición de socio.

${ }^{277}$ Normalmente las acciones preferentes se equiparan a las acciones privilegiadas. La razón de generalizar el uso indistinto de los dos términos es que, ambos términos ofrecen, en la mayoría de los casos, ventajas de contenido económico. El término acciones preferentes debe reservarse a las que tengan una preferencia temporal en el derecho de recibir el beneficio, y el término acciones privilegiadas debe ser utilizado para las que concedan ese derecho o cualquier otra ventaja, ya sea en los derechos económicos o políticos. Como las principales ventajas se dan en el derecho económico o patrimonial, las acciones privilegiadas serán normalmente las que concedan un derecho al dividendo acumulativo, fijo, mínimo, mixto, diferido o preferente en el tiempo.

${ }^{278}$ El Proyecto de reforma de 1926 rechaza la introducción de desigualdades en la atribución de derechos políticos del socio, y más en concreto, del derecho de voto. Según el texto, el derecho de voto posee carácter esencial, de modo que no sólo debe concederse a todos los accionistas, sino que, además, ha de atribuirse en igual medida a todos ellos. La declaración de igualdad de voto de las acciones, cualquiera que sea su denominación y clase, supone la prohibición de emitir acciones sin voto y acciones de voto plural.
} 
tanto, es imprescindible analizar la posible diferenciación de los derechos que pueden ser privilegiados.

Las acciones privilegiadas pueden clasificarse atendiendo a la naturaleza de privilegio que conceden a sus titulares. Según este criterio, las emisiones pueden clasificarse en cinco grupos de privilegios: económicos, administrativos, económicos-administrativos, sujetos a condición o plazo y combinados. Pertenecen al primer grupo aquellas que conceden ventajas económicas, ya sea sobre los beneficios sociales, ya sea sobre la cuota de liquidación; al segundo grupo pertenecen aquellas acciones que permiten una intervención superior en las funciones administrativas de la sociedad; el tercero incluye la diferenciación en el derecho de suscripción preferente; en el cuarto se incluyen las acciones convertibles y las acciones rescatables; y el último engloba a las emisiones con mezcla de los anteriores privilegios.

\section{a) Privilegios económicos}

Las acciones con privilegios de orden pecuniario pueden dividirse en:

a.1) Acciones con privilegios en el reparto de los beneficios.

口 Dividendo preferente;

口 Dividendo fijo;

- Derecho a obtener preferentemente un primer dividendo, igualándose después, a las ordinarias;

a Dividendo prioritario acumulativo o recuperable;

- Privilegio sobre los beneficios, en razón de su valor nominar inferior;

- Derecho a un porcentaje mayor en los beneficios sociales.

a.2) Acciones con privilegios sobre la cuota de liquidación, es decir sobre el activo social disponible al liquidarse la sociedad.

- Derecho de reembolsarse preferentemente a las ordinarias, del capital nominal que representan;

- Derecho a cobrar, contra dicho activo, los dividendos atrasados que se les adeuden, si su privilegio es acumulativo;

口 Derecho a ser reembolsadas con una prima especial prioritaria.

\section{a.1) Privilegios en el reparto de los beneficios}

Las acciones privilegiadas con dividendo prioritario son aquellas que confieren a su poseedor el derecho de obtener un dividendo mayor que las ordinarias. 
Dentro de ellas diferenciamos las que tienen un dividendo privilegiado "absoluto" porque tendrán un dividendo adicional mayor siempre ${ }^{279}$, y las que tendrán un posible dividendo mayor ("relativo") porque depende de la cuantía de la cifra de resultados contables ${ }^{280}$.

El cálculo de la remuneración puede ser muy diversa: puede ser fija, variable en función de los beneficios, variable en función del valor de cotización del emisor o, incluso, variable en función de los rendimientos de un determinado sector ${ }^{281}$.

Las acciones privilegiadas con dividendo preferente son aquellas que confieren a su poseedor el derecho de obtener el dividendo antes que las acciones ordinarias. La preferencia está en el momento de recibir el dividendo, no en la cantidad ${ }^{282}$.

\footnotetext{
${ }^{279}$ En España han emitido acciones privilegiadas cinco sociedades relacionadas con el ferrocarril: la "Compañía del Ferrocarril de Madrid a Aragón", la Société Générale de Tramways de Madrid et d'Espagne (SGTME), la "Compañía de los Caminos de Hierro del Norte de España", "Construcciones y Ferrocarriles S.A." y Canal Metro Madrid. Entre los medios absolutos para privilegiar una emisión destacan la remuneración fija, por ejemplo, el 22 de julio de 1.918, la "Compañía de los Caminos de Hierro del Norte de España" emitió acciones al portador con un interés fijo del 3\% sobre el valor nominal. Como el valor nominal era de 500 pesetas, el interés anual era de 15 pesetas (3\%500).

${ }^{280}$ Dentro de estos últimos dividendos privilegiados "relativos" destacamos el dividendo adicional, una figura legislada actualmente en España para las acciones sin voto. En España, una única sociedad ferroviaria emitió acciones con derecho a un dividendo adicional: la empresa "Ferrocarriles de Cataluña S.A.". La empresa "Ferrocarriles de Cataluña S.A." realizó siete aumentos de capital de acciones preferentes de 500 pesetas de valor nominal, las cuales tenían un derecho a un dividendo adicional no acumulativo del 5\%. La otra sociedad que emitió este tipo de títulos es la Compañía española de viviendas de alquiler (CEVASA). Esta compañía admitió a cotización 12.737 acciones privilegiadas de 1.000 pesetas de valor nominal. Las acciones eran preferentes con derecho a percibir un dividendo de hasta el 7,5\% de su valor nominal con carácter fijo y preferente a las ordinarias. Ambas emisiones de dividendo preferente también tenían derecho a recibir el dividendo de las acciones ordinarias, por lo que es posible expresar que poseían el dividendo adicional, característico de las acciones sin voto actuales (hay que tener en cuenta que las acciones sin voto no estaban reguladas en España en el momento de la emisión de estas acciones privilegiadas).

${ }^{281}$ Las posibilidades de crear clases de acciones con privilegios en los derechos sobre el beneficio son ilimitadas. A las clásicas formas de calcular la base del privilegio, sobre los beneficios, valor nominal o cotización de la propia empresa emisora, se unen otras que amplían y enriquecen el catálogo de instrumentos financieros jurídicos disponibles por los inversores. Por ejemplo, destacamos las acciones procedentes del Derecho societario estadounidense conocidas como tracking stocks, lettered stocks, targeted stocks o alphabet stocks, caracterizadas porque atribuyen a sus titulares derechos económicos vinculados a los resultados de la actividad social de un determinado sector. Esta clase de acciones tomó un impulso tras la Reforma del Derecho italiano de 2003, pues es posible emitir azioni correlate con estas características (Codice Civile, artículo 2350, párs. 2 y 3).

${ }^{282}$ Las acciones preferentes son las acciones privilegiadas más frecuentes. En el ámbito ferroviario destacan la "Compañía de los Ferrocarriles Económicos de Villena a Alcoy y Yecla", Barcelona Traction Light and Power Company Limited y la "Compañía General de Ferrocarriles Catalanes, S.A.". La "Compañía de los Ferrocarriles Económicos de Villena a Alcoy y Yecla" emitió acciones preferentes el 3 de diciembre de 1910. El capital social total, tras su emisión, fue de 13.015.000 pesetas, formadas por 27.400 acciones al portador de 475 pesetas de valor nominal. La Barcelona Traction Light and Power Company Limited emitió en 1914 acciones preferentes de 100 dólares oro al 7\% no acumulativo. La "Compañía General de Ferrocarriles Catalanes, S.A." emitió acciones preferentes el 27 de mayo de 1963 con la denominación "Acciones preferentes serie A" y "Acciones preferentes serie B". Las acciones preferentes de la Serie B tienen un derecho a un dividendo no acumulativo del $4 \%$.
} 
Cuando existen acciones privilegiadas con dividendo preferente se procede a retirar, en primer lugar, de los beneficios sociales la cantidad necesaria para distribuir entre los titulares un dividendo determinado en los estatutos (por ejemplo un tanto \% anual sobre su valor nominal); hecha esta operación, y si los beneficios lo permiten, se distribuye a las acciones ordinarias un dividendo igual al que le correspondió a las privilegiadas; finalmente, si queda un saldo restante, se reparte entre el resto de acciones, sin distinción ni preferencia.

La modalidad de acciones privilegiadas con un dividendo fijo consiste en que la sociedad reconoce a sus titulares el derecho preferente a un dividendo fijo determinado (un tanto\% anual sobre su valor nominal), y que deberá pagarse a sus titulares con anterioridad a todo reparto a las acciones ordinarias, pero estableciéndose que el excedente de los beneficios será distribuido exclusivamente entre las acciones ordinarias ${ }^{283}$.

Las acciones privilegiadas que conceden preferentemente un primer dividendo igualándose después a las ordinarias gozan u obtienen un dividendo fijo, determinado en los estatutos; efectuado este reparto, el excedente de los beneficios si existe, se distribuye por partes iguales entre todas las acciones, ordinarias y privilegiadas. En este caso, el privilegio es más pronunciado a favor de los titulares, pues siempre obtendrán un dividendo superior al que se distribuye a los inversores en acciones ordinarias ${ }^{284}$.

Las acciones privilegiadas con dividendo prioritario acumulativo o recuperable aseguran a sus titulares el cobro de sus dividendos en el caso que los ejercicios no arrojen beneficios, es decir los dividendos no satisfechos se van trasladando por acumulación a los ejercicios posteriores, de manera que el titular puede ir recuperándolos en los ejercicios con beneficios. Para los titulares de acciones que posean este derecho, su utilidad consiste en la seguridad de que obtendrá finalmente su dividendo.

La ventaja de las acciones privilegiadas con privilegio sobre los beneficios, en razón de su valor nominal inferior, resulta del hecho de que entran a gozar de los mismos derechos en el reparto que las acciones de mayor valor nominal. Su emisión requiere que se disponga en los estatutos que, sin perjuicio de su distinto valor nominal, todas las acciones gozarán de igual derecho en el reparto de los dividendos, considerando a todas las acciones como si fuesen iguales. Existe un privilegio en cuanto a distintas proporciones de capital le van a corresponder idénticos dividendos ${ }^{285}$.

En las acciones privilegiadas con derecho a un porcentaje mayor en los beneficios sociales, la sociedad atribuye a las acciones privilegiadas un tanto \% mayor en los dividendos que se van a

\footnotetext{
${ }^{283}$ Este tipo de acciones privilegiadas es muy poco frecuente, entre los pocos ejemplos encontrados está la sociedad salvadoreña "Metrocentro, sociedad anónima de capital variable". Metrocentro: Annual Report 2015, 2014.

${ }^{284}$ Un ejemplo de este privilegio es el dividendo adicional de las actuales acciones sin voto en España.

${ }^{285}$ Por ejemplo, una acción de valor 20 euros y otra de 10 euros obtendrán un mismo dividendo.
} 
repartir ${ }^{286}$. En este caso, no existe un dividendo fijo, ni tampoco preferencia temporal, sino un privilegio en cuanto que las acciones privilegiadas van a percibir mayor cantidad que los ordinarios.

\section{a.2) Privilegios en la cuota de liquidación}

El privilegio de las acciones privilegiadas reembolsables preferentemente consiste en que sus poseedores reciben, en caso de liquidación de la sociedad de capital, el valor de su aportación en un momento anterior al de recepción por parte del resto de titulares.

Las acciones privilegiadas que gozan del derecho a cobrar contra el activo social, los dividendos atrasados que se les adeuden, si su privilegio es acumulativo, otorgan a sus titulares el derecho de cobrar los dividendos adeudados del activo social líquido cuando su privilegio es acumulativo. Esta modalidad de acciones privilegiadas es desaconsejable para el resto de clases de acciones, pues se puede presentar el caso que la acumulación de dividendos, llegue a aumentar en tal forma, que abarque por entero el activo repartible, perjudicando al resto de acciones que verían desaparecer uno de sus derechos esenciales.

El privilegio de las acciones privilegiadas con el derecho de ser reembolsadas con una prima especial prioritaria consiste en que gozan del derecho a una prima, que debe ser pagada preferentemente, en el momento de efectuarse el reembolso de esas acciones ${ }^{287}$.

En el supuesto de que una sociedad emita acciones privilegiadas que acrediten los tres privilegios antes expuestos y se produzca su liquidación, el activo distribuible deberá ser repartido de la siguiente forma: primeramente, se pagarán los dividendos acumulados que se adeuden; luego se reembolsarán de su valor nominal y prima correspondiente las acciones privilegiadas que gocen de esos derechos; a continuación, si aún resta activos, se procederá a reembolsar el valor nominal del resto de acciones; finalmente, si hubiera todavía saldo, este deberá prorratearse entre todos los titulares, sin distinción alguna de clases. El orden señalado es susceptible de cambiar de acuerdo a la extensísima variedad que puede adoptar la ordenación de las preferencias sobre el activo social.

\section{b) Privilegios administrativos}

Las acciones que confieren privilegios de orden administrativo pueden ser clasificadas en tres agrupaciones:

口 Voto privilegiado;

- Derecho para designar la mayoría de los miembros del consejo de administración;

- Derecho a nombrar la mayoría de liquidadores.

\footnotetext{
${ }^{286}$ Por ejemplo, el $60 \%$ de los beneficios para los titulares de acciones privilegiadas con este derecho y el resto a los de la emisión ordinaria.

${ }^{287}$ Por ejemplo, puede estipularse que las acciones privilegiadas con un valor nominal de diez euros, serán reembolsadas preferentemente por un valor de cincuenta euros ganando, de esa forma, una prima de reembolso de cuarenta euros por acción.
} 
Las acciones con voto privilegiado pueden definirse como las que tienen un derecho de voto superior al de otras, con relación a la cuota del capital que ellas representan. Las acciones con voto privilegiado confieren a su poseedor un derecho de voto más elevado que el atribuido a las ordinarias. Las acciones con voto privilegiado han recibido un gran número de denominaciones: de voto plural, de voto desigual, de voto acumulativo, de voto múltiple, de voto preferencial, de voto superior, de voto mayor, de dirección, de gestión, de control, de protección, de comando o predominante ${ }^{288}$.

Las acciones privilegiadas con derecho a nombrar la mayoría de miembros del Consejo de Administración ${ }^{289}$ confieren a sus poseedores el derecho a nombrar la mayoría de los miembros de la Junta Directiva ${ }^{290}$.

Otro privilegio es la concesión a sus poseedores del derecho a nombrar la mayoría de los liquidadores $^{291}$. Por la importancia de la función que desempeñan los liquidadores, las acciones privilegiadas que gocen del privilegio de designar la mayoría de liquidadores pueden ser muy valoradas por el mercado.

\section{c) Derechos económicos-administrativos}

Pueden existir acciones privilegiadas con ventajas en el derecho preferente para suscribir las acciones nuevas en los aumentos de capital o en emisión de obligaciones convertibles en acciones. Son mixtos los derechos con trascendencia económica y política simultáneamente. El único derecho, con carácter mixto, que pueden poseer los titulares de acciones es el derecho de suscripción preferente. La sociedad de capital, al proceder a aumentar su capital, emitiendo acciones nuevas, puede ofrecerlas al público, o reservarlas para los antiguos

\footnotetext{
${ }^{288}$ La emisión de acciones con voto plural (Multiple Voting Shares) solamente ha estado permitida, en algún momento del tiempo, en Argentina, Chile, Colombia, Estados Unidos y Reino Unido. Sin embargo, sí ha sido, y es, muy frecuente la emisión de acciones sin voto en muchos países. En España, sólo está vigente actualmente una emisión de acciones con voto plural, la de Amadeus, y dos de acciones sin voto, la británica Jazztel y la italiana "Reno de Medici S.p.A.", todas ellas con domicilio social fuera de España, aunque realizan su actividad empresarial en nuestro país.

${ }^{289}$ Gracias a este privilegio si una sociedad anónima tiene, por ejemplo, siete directivos, los titulares de las acciones privilegiadas están facultados para elegir cuatro, eligiendo los otros tres, el resto de accionistas.

${ }^{290}$ En los Derechos societarios anglosajones, el derecho a nombrar la mayoría de miembros del Consejo de Administración supone la generación de una clase de acciones, sin embargo, en los Derechos continentales europeos no. Esta particularidad ha sido señalada por la doctrina como la, prácticamente, única diferencia entre las dos zonas (Peñas Moyano, 2008: 427).

${ }^{291} \mathrm{Al}$ disolverse la sociedad anónima debe procederse a designar la comisión liquidadora que se encargará de realizar el activo y pasivo de la sociedad y de proceder a efectuar la partición de los bienes entre los socios. El liquidador es, al igual que el administrador, un mandatario de la sociedad, y sus funciones, jurídicamente hablando, son idénticas a las de los administradores, pues representan a la sociedad tanto frente los terceros, como ante los socios mismos, al mismo tiempo que están facultados para dirigir los negocios sociales pendientes. Los socios estarán interesados en designar liquidadores de su confianza, protegiendo sus aportaciones, y también, sus preferencias sobre el activo repartible.
} 
accionistas, a fin de compensarles por el efecto dilución que, como resultado de la nueva emisión, experimentarían las acciones antiguas.

El privilegio se deriva de que es posible diferenciar su ejercicio limitando a que el titular ordinario podrá tener el derecho preferente de suscribir las acciones nuevas ordinarias, pero no privilegiadas. Este tipo de acciones confieren a sus titulares la ventaja de evitar la posibilidad que las nuevas emisiones caigan en manos de competidores, de manera que éstos llegaran a dominar la sociedad y que, en consecuencia, se produzcan variaciones en la dirección de la compañía por la formación de nuevas mayorías, gracias a los votos que confieren las nuevas acciones.

\section{d) Sujetos a condición o plazo}

En cuanto a su extinción, tomando en cuenta la duración del privilegio, las acciones privilegiadas se pueden dividir entre las que posean privilegios definitivos, es decir para toda la vida de la sociedad; y las que posean privilegios transitorios, es decir sujetos a condición o plazo.

En las acciones con privilegios definitivos, los especiales derechos pueden ser ejercidos por sus titulares durante toda la vida de la sociedad y terminan al extinguirse ésta.

También pueden existir acciones con privilegios transitorios, sujetos a condición o plazo. Partiendo de la base que las acciones privilegiadas no constituyen una institución permanente dentro del régimen de las sociedades de capital, es perfectamente comprensible que los privilegios que otorgan, puedan sujetarse a plazo o condición ${ }^{292}$. Respecto de la condición para que deje de operar el privilegio, se pueden señalar, como ejemplos, los siguientes: transferencia de las acciones privilegiadas a terceros no contemplados en el pacto social, supresión de privilegio mediante acuerdo de una mayoría de socios preestablecida y extinción del privilegio mediante un sistema de rescate, que consiste en ir rescatándolas paulatinamente.

Entre las acciones con privilegios transitorios, sujetos a condición o plazo, destacan dos tipos que conceptualmente tienen implícita una posible fecha de extinción o modificación: las convertibles y las rescatables ${ }^{293}$.

Las acciones convertibles conceden al emisor, titular, ambos, ante una fecha o ante un hecho preestablecido, el derecho a convertirse en otra clase de acciones, o incluso unas

\footnotetext{
${ }^{292}$ La temporalidad de los privilegios puede regularse en el pacto social de cada sociedad. Con relación al plazo del privilegio, la sociedad puede indicar en sus estatutos que los privilegios conferidos por las acciones privilegiadas regirán por un plazo de tres, cinco, diez años, etc., a partir de su emisión.

${ }^{293}$ Estos privilegios transitorios, sujetos a condición o plazo, son también opcionales o relativos, porque pueden ser ejercidos por el inversor o no, porque, dependiendo de la evolución de la economía, les pueden ser más o menos rentables (o incluso nada, y entonces no lo ejercitarían). Por esta razón, deberían ser consideradas una diferenciación más que un privilegio.
} 
obligaciones $^{294}$, en unas condiciones determinadas ${ }^{295}$. Las acciones con derecho a conversión pueden tener muy diversas características, atendiendo al periodo en que es posible la conversión, el número de acciones comunes emitidas por cada acción o participación convertible y si necesita pago en metálico para su conversión (Hartman, Harper, Knoblet y Reckers, 1997: 959). La conversión se realiza en función de la "tasa de conversión", proporción que indica el número de acciones ordinarias que corresponden a cada una de las privilegiadas. La "tasa de conversión" puede estar previamente fijada en el contrato de las acciones, o puede estar establecida en función del valor de mercado de las ordinarias y privilegiadas en el momento de la conversión.

Las acciones ${ }^{296}$ rescatables son las emisiones que conceden al emisor, titular, ambos, ante una fecha o ante un hecho, el derecho a ser rescatadas con unas condiciones determinadas ${ }^{297}$.

La denominación "rescatable", utilizada en la legislación española, es la consideración del fenómeno de amortización desde la perspectiva de la sociedad emisora. Antes de su inclusión en el Derecho positivo, no eran normalmente denominadas como acciones rescatables, por el mercado y la doctrina; la nomenclatura más común era la de acciones "redimibles", en menor medida "redimidas" 298 . Aunque la figura fue recogida anteriormente por la Segunda Directiva, la Ley de Reforma de la Ley del Mercado de Valores (LRLMV) ${ }^{299}$ de 1998 fue el texto que incorporó por primera vez las acciones rescatables en España.

Aunque con poca presencia, la institución de las rescatables no era desconocida en el mercado financiero español antes de su incorporación en la Unión Europea y en el Anteproyecto de Ley de 1987 de España. No faltan, en la práctica societaria del siglo XX, ejemplos de acciones rescatables en sociedades españolas, fundamentalmente, en ejecución de una específica cláusula estatutaria de rescate ${ }^{300}$.

Los primeros ejemplos de acciones rescatables aparecen en empresas concesionarias. Las sociedades que explotaban una concesión de obra o un servicio público regulaban estatutariamente la amortización de sus acciones durante la vida de la sociedad. La

\footnotetext{
${ }^{294}$ Lorry y Watson (2001: 136), Farrar y Hannigan (1998: 23) y Pennington (2001: 215 y 216).

295 Aunque las acciones convertibles son frecuentes en muchos países, sobre todo Estados Unidos, sólo han existido dos emisiones convertibles en España (la realizada por Abertis y por el Banco Guipuzcoano), y otra de una empresa italiana (Reno de Medici) que cotiza en las bolsas españolas.

${ }^{296}$ En España está limitada la posibilidad a que existan acciones rescatables, y no participaciones rescatables, porque de forma clara el legislador español establece que sólo las podrán emitir las sociedades anónimas.

${ }^{297}$ En los Derechos estadounidense y británico, las acciones rescatables tienen además privilegios en derechos económicos, pero no por imposición legal, sino "como modo normal de aparecer en el mercado" (Peñas Moyano, 2008: 437). El mismo autor afirma que en los ordenamientos societarios anglosajones, las acciones rescatables forman una clase.

${ }^{298}$ Las acciones rescatables son la misma figura que fue designada como "redimibles" por Fernández del Pozo (1990: 1164-1171), que fue el primer autor español que estudió detenidamente la figura.

${ }^{299}$ Disposición Adicional decimoquinta de la Ley 37/1998, de 16 de noviembre.

300 A pesar de que hasta 1998 no están legisladas las acciones rescatables en España, algunas empresas las emitieron con anterioridad a esa fecha. En el sector ferroviario destaca la Compañía General de Ferrocarriles (hoja número 12.859 del Registro Mercantil de Barcelona).
} 
racionalidad de la amortización estatutaria se fundamentaba en la presunta existencia de necesidades decrecientes de capital. Al finalizar la concesión, que tenía un plazo determinado, los bienes y derechos afectos a la explotación revertían a la administración cedente (o a un tercero). En esta situación, los gestores establecían las correspondientes previsiones de amortización de los recursos propios.

La práctica empezó a generalizarse con la introducción en nuestro país de sociedades de economía mixta que, con participación de accionistas privados, tenían por objeto la ejecución de obras de interés público o la explotación de un servicio público. En este ámbito, una sociedad que explotaba una concesión administrativa o un servicio público, se constituía en "régimen de economía mixta" con participación privada y pública. Como el derecho concesional era temporal, la práctica más usual consistía en la previsión estatutaria de amortización del capital privado antes de una determinada fecha ${ }^{301}$. Mediante la amortización de los capitales privados se articulaba la reversión al Estado o a la entidad pública de la concesión o del servicio ${ }^{302}$. No faltan ejemplos en los diferentes niveles de ordenación territorial del Estado, aunque la práctica acabó siendo frecuente en las sociedades municipales que explotaban, en régimen de economía mixta, ciertos servicios públicos municipales ${ }^{303}$.

\section{e) Privilegios combinados}

Las acciones con privilegios combinados aglutinan para sus titulares, varios de los privilegios antes mencionados, tales como: voto privilegiado, dividendo prioritario, reembolso preferente, rescate, etc. Mientras que en Estados Unidos lo usual es que existan combinación de privilegios, en España se han producido pocas emisiones con una combinación de privilegios, y las realizadas, aunque cotizan en el mercado bursátil español, tienen su origen en Brasil $^{304}$.

\footnotetext{
301 Normalmente, el derecho concesional tenía una duración de 50 ó 99 años. La Compañía General de Ferrocarriles, citada anteriormente, tiene un periodo máximo de concesión de 99 años. Esta autoregulación era concordante con la vigente en ese momento, Ley General de Ferro-carriles de 23 de noviembre de 1987, Capítulo, II: "La concesión de las líneas de servicios y general se otorgarán por término de 99 años cuando más" (artículo 22).

${ }^{302}$ En la jurisprudencia es muy interesante la Sentencia del Tribunal Supremo de 21 de marzo de 1986 sobre la «Empresa mixta de servicios funerarios de Madrid». Ver comentarios sobre ella realizados por Velasco San Pedro (1986: 3577-3590).

303 "Desde la Ley municipal de la II República, las sociedades mixtas locales constituyeron el marco en el que nació la amortización estatutaria" (Montoya Martin, 1996: 217).

${ }^{304}$ Aracruz Celusose tiene una emisión de acciones privilegiadas, sin voto y convertibles simultáneamente, Bradesco tiene una emisión de acciones con privilegios en la cuota de liquidación y sin voto, Bradespar emitió acciones con privilegios económicos y sin voto simultáneamente, Braskem tiene una emisión de acciones privilegiadas, sin voto y convertibles simultáneamente, Copel se financia con una emisión de acciones privilegiadas, sin voto y convertibles simultáneamente, Eletrobras posee una emisión de acciones con privilegios en el derecho al beneficio, en la cuota de liquidación y sin voto, Net Serviços tiene una emisión de acciones con privilegios en el derecho al beneficio, en la cuota de liquidación y sin voto, Petrobras se financia con una emisión de acciones con privilegios en el derecho a recibir beneficios, en la cuota de liquidación y sin voto, Sadia posee una emisión de acciones con privilegios en el derecho a recibir beneficios, en la cuota de liquidación y sin voto, Suzano Papel e Celulose tiene una emisión de acciones con privilegios en el derecho a recibir beneficios, en la cuota de liquidación y sin voto, Suzano Petroquímica posee acciones con privilegios en el
} 


\subsubsection{Utilización de acciones privilegiadas en compañías españolas relacionadas con el ferrocarril}

Respecto a las empresas analizadas en esta investigación, NORTE emitió acciones con una remuneración fija, pero solamente una emisión, mientras que MZA no se financió nunca con emisiones de acciones privilegiadas.

Del conjunto de empresas relacionadas con el ferrocarril en España, sólo once han emitido clases de acciones diferentes a las acciones ordinarias, aunque una de ellas realizó dos emisiones distintas, por lo que existieron doce emisiones. Cuatro sociedades emitieron acciones privilegiadas, siete empresas emitieron acciones preferentes y una compañía emitió acciones rescatables. Las compañías españolas relacionadas con el ferrocarril que emitieron clases de acciones aparecen detalladas en el cuadro 12.

Cuadro 12. Clases de acciones en compañías españolas relacionadas con el ferrocarril

\begin{tabular}{|l|l|}
\hline \multicolumn{1}{|c|}{$\begin{array}{c}\text { TIPO DE } \\
\text { PRIVILEGIO }\end{array}$} & \multicolumn{1}{|c|}{ EMPRESA } \\
\hline Privilegiadas & $\begin{array}{l}\text { NORTE, Compañía del ferrocarril de Madrid a Aragón, Construcciones y } \\
\text { Ferrocarriles, SGTME }\end{array}$ \\
\hline Preferentes & $\begin{array}{l}\text { CGFC, Villena a Alcoy y Yecla, Barcelona Traction, Ferrocarril de } \\
\text { Cataluña, Compañía General de Ferrocarril, MPDR, Compañía del } \\
\text { Ferrocarril Central de Aragón }\end{array}$ \\
\hline Rescatables & Compañía General del Ferrocarril \\
\hline
\end{tabular}

Fuente: Elaboración propia

El 22 de julio de 1.918, NORTE emitió acciones al portador con un interés fijo del 3\% sobre el valor nominal. Como el valor nominal era de 500 pesetas, el interés anual era de 15 pesetas $(3 \% * 500)$.

La "Compañía del Ferrocarril de Madrid a Aragón”, constituida en 1895 y adquirida por una OPA por NORTE en septiembre de 1924, utilizaba para financiarse obligaciones simples y

derecho a recibir beneficios, en la cuota de liquidación y sin voto y, por último, Vale do Rio tiene su capital formado, entre otras, por acciones con privilegios en el derecho a recibir beneficios, en la cuota de liquidación y sin voto. 
acciones privilegiadas $^{305}$. La operación más novedosa es que en el año 1933 realizó un canje de obligaciones por acciones privilegiadas ${ }^{306}$.

La empresa barcelonesa "Construcciones y Ferrocarriles S.A.” realizó, el 7 de marzo de 1919, un aumento de capital de 4.000 acciones de 500 pesetas de valor nominal, 2.000 de ellas ordinarias y las otras 2.000 privilegiadas.

La Société Générale de Tramways de Madrid et d'Espagne (SGTME) fue una sociedad belga, con domicilio en Bruselas. La SGTME se constituyó en 1886 y se centró en la explotación de los Tranvías del Norte de Madrid. Su capital inicial estaba formado por 10.000 acciones ordinarias (sin valor nominal) y otras tantas privilegiadas, cada una de estas últimas con un valor inicial de 250 francos; en 1906 ambas quedaron sin valor nominal. Los principales capitalistas fueron Barbanson, Bourson, Dansette, Otlet y Peemans, que aportaron, a cambio de 9.500 acciones privilegiadas y otras tantas ordinarias, 5.000 acciones de Tranvías del Norte de Madrid. Las aportaciones no dinerarias de trenes y tranvías era una operación, bastante frecuente entre empresas de servicios públicos de la época.

La “Compañía General de Ferrocarriles Catalanes, S.A.” (CGFC) se fundó en Barcelona el 14 de julio de 1919 y estuvo en funcionamiento hasta 1977. Dicha compañía tenía un capital social de 15 millones de pesetas repartido en 30.000 acciones, que estaba participaba mayoritariamente por capital belga. Tras comenzar los trabajos en el tramo Martorell-Manresa Alta para unir las diferentes concesiones, fue absorbiendo las diferentes compañías que integraban la red: la Compañía de los Caminos de Hierro del Nordeste de España el 10 de septiembre de 1920, la Compañía del Ferrocarril Central Catalán el 19 de noviembre de 1921, y la línea de ferrocarril minero de via métrica entre Manresa y Suria, propiedad de la multinacional Solvay, el 16 de octubre de 1922. La Solvay suscribió íntegramente una ampliación de capital de 10 millones de pesetas realizada por la CGFC en 1921. La compañía emitió acciones preferentes el 27 de mayo de 1963 con la denominación "Acciones preferentes serie A" y "Acciones preferentes serie B". En total, el capital social de 89.954.500 estaba formado íntegramente por 179.909 acciones al portador: 74.000 acciones ordinarias,

\footnotetext{
${ }^{305}$ La compra de la "Compañía del Ferrocarril de Madrid a Aragón" por NORTE, en septiembre de 1924, por medio de una OPA, fue gestionada por Venancio Echevarría, Consejero de NORTE e importante ejecutivo bancario bilbaíno.

306 "En ejecución de lo establecido en la cláusula 5. a del Convenio aprobado por los señores Obligacionistas en las Juntas generales de las Asociaciones Civiles de Obligacionistas de Madrid a-Vaciamadrid y Arganda y de Arganda a Colmenar, con ramal de Morata a Orusco y de Orusco a Alocén, celebradas los días 20 de diciembre de 1932 y 7 de enero de 1933, respectivamente y sancionado por auto del Juzgado de 1.a Instancia número 13 de Madrid, fecha 14 de febrero de 1933, el Consejo de Administración de esta Compañía ha acordado llevar a efecto el reparto, entre los tenedores de las Obligaciones citadas, de las 3.182 acciones privilegiadas cedidas gratuitamente por un grupo de accionistas, con dicho objeto. La entrega de los títulos de las acciones privilegiadas, a razón de una por cada diez Obligaciones de la misma serie, despreciando las fracciones, se hará mediante presentación de los correspondientes títulos bajo factura en el Banco Internacional de Industria y Comercio, de Madrid y sus Sucursales; en el Banco Urquijo, de Madrid y sus Sucursales; en la Banca Marsans, de Barcelona; en el Banco de Valencia, de Valencia y sus Sucursales, y en las oficinas de la Compañia, Estación del Niño Jesús", a partir del día 1 de marzo de 1934 (La Vanguardía Española, 14 de febrero de 1934, p. 14).
} 
109.303 acciones preferentes de la serie A y 35.303 acciones de la serie B. Las acciones preferentes de la Serie B tienen un derecho a un dividendo no acumulativo del $4 \%$.

La "Compañía de los Ferrocarriles Económicos de Villena a Alcoy y Yecla" estuvo en funcionamiento desde 1909 hasta 1965. La empresa emitió acciones preferentes el 3 de diciembre de 1910. El capital social total, tras su emisión, fue de 13.015.000 pesetas, formadas por 27.400 acciones al portador de 475 pesetas de valor nominal.

El grupo canadiense Barcelona Traction Light and Power Company Limited, se constituyó en Toronto en septiembre de 1911. Uno de los primeros movimientos de la compañía fue la adquisición de la sociedad Tranvías de Barcelona. La empresa emitió en 1914 acciones preferentes de 100 dólares oro al $7 \%$ no acumulativo.

La empresa "Ferrocarriles de Cataluña S.A." tenía fuertes intereses y capital procedente de Estados Unidos relacionados con la electrificación industrial de Cataluña (Riegos y fuerzas del Ebro S.A.). La sociedad Ferrocarriles de Cataluña S.A. fue constituida el 1 de abril de 1912, emitiendo acciones preferentes de 500 pesetas de valor nominal, con un capital de 12 millones de pesetas. A lo largo de la vida de la empresa se realizaron siete aumentos de capital de acciones preferentes de 500 pesetas de valor nominal: el 7 de marzo de 1919, el 1 de mayo de 1941, el 30 de enero de 1943, el 22 de febrero de 1944, el 24 de junio de 1963, el 27 de mayo de 1968, el 14 de abril de 1969 y el 1 de mayo de 1969. El 27 de mayo de 1968, se realizó la mayor ampliación de capital de su historia, al emitir 270.000 acciones preferentes de 500 pesetas de valor nominal. Los valores de "Ferrocarriles Cataluña preferente" cotizaron en la Bolsa de Barcelona. Las acciones preferentes tenían un derecho a un dividendo adicional no acumulativo del 5\%. Desde que se emitieron las acciones preferentes, los dividendos a cuenta eran diferenciados para las dos clases de acciones ${ }^{307}$ e incluso algunos dividendos a cuenta se entregan sólo a las acciones preferentes y no a las ordinarias ${ }^{308}$.

\footnotetext{
${ }^{307}$ El primer dividendo a cuenta diferenciado de Ferrocarriles de Cataluña, S. A. se aprobó el 28 de marzo de 1960. Por mediación del Banco Central y del Banco de Santander, en Madrid y Barcelona, se hizo efectivo el siguiente dividendo por el ejercicio de 1959: acciones preferentes 25 pesetas y acciones ordinarias 22,50 pesetas (La Vanguardia Española, Barcelona, 30 de marzo de 1960, p. 8). La segunda se realizó el ejercicio contable siguiente, pues el día 1 de abril de 1961, y por mediación del Banco Central y del Banco de Santander, en Madrid y Barcelona, se hizo efectivo el siguiente dividendo por el ejercicio de 1960: acciones preferentes por importe de 25 Pesetas como complemento al dividendo abonado a cuenta y acciones ordinarias por importe de 22 '50 pesetas (La Vanguardia Española, Barcelona, 21 de marzo de 1961, p. 10). El tercer dividendo a cuenta diferenciado se acordó el 10 de octubre de 1966 (en Madrid y Barcelona, por mediación del Banco Central y del Banco de Santander); el importe líquido del expresado cupón es de 20 pesetas para las acciones preferentes y 10 pesetas para las ordinarias (La Vanguardia Española, Barcelona, 11 de octubre de 1966, p. 12). Otro dividendo diferenciado se hizo efectivo a partir del día 1 de octubre de 1968, en Madrid y Barcelona, por mediación del Banco Central y del Banco de Santander: acciones preferentes, por un importe 20 pesetas y acciones ordinarias, por un importe líquido de 10 pesetas (La Vanguardia Española, Barcelona, 21 de septiembre de 1968, p. 11).

${ }^{308}$ El 1 de octubre de 1954, el Consejo de Administración de la compañía acordó repartir a las acciones preferentes un dividendo de un $4 \%$ neto, a cuenta de los beneficios del ejercicio 1954 (La Vanguardia Española, Barcelona, 1 de octubre de 1954, p. 8).
} 
La construcción de la línea de Ávila a Salamanca había sido otorgada de modo provisional en 1883 a Manuel González y García Franco. Una vez conseguida la concesión definitiva en enero de 1888, ésta fue traspasada a una sociedad británica, The Madrid and Portugal Direct Railway (Avila and Salamanca) Limited (MPDR), que había sido constituida en el mes de noviembre de 1887. Con esa razón social tan ambiciosa se presumían grandes logros, aunque en realidad sólo se pudieron construir 40 kilómetros entre la capital salmantina y la ciudad de Peñaranda de Bracamonte, terminada en 1894. El capital nominal inicial fue de 600.000 libras, escaso si tenemos en cuenta que el coste previsto para la construcción completa de la línea fue de 900.000 libras. El capital fue dividido en tres tipos de títulos: 15.000 ordinarias de 10 libras cada una, de las que sólo se contrataron 5.007 acciones; otras 200.000 de primera preferencia de 1 libra, con una respuesta también insuficiente de 106.526 acciones colocadas; y, por último, otras 150.000 acciones de segunda preferencia, también de 1 libra, con 100.010 respaldadas.

La Compañía del Ferrocarril Central de Aragón se constituyó en 1895 para explotar la concesión de la línea de Calatayud al Grao de Valencia otorgada el 3 de mayo del mismo año, y cuya construcción se terminó en 1901 (Wais: 1948). Tenía una longitud de 295 Kms y contaba con una red de 34 estaciones y algunos apeaderos, sitos en las provincias de Zaragoza, Teruel, Castellón y Valencia. A este largo recorrido se unió posteriormente la línea de Camín Real a Zaragoza de 123 Kms. Según datos del balance de 1925, el capital social "tenía una fuerte presencia belga, acompañado de capital español". El capital por acciones estaba dividido entre ordinarias y privilegiadas. Las acciones privilegiadas fueron contabilizadas por importe de 10.000 .000 pesetas.

La Compañía General de Ferrocarriles, S.A. (hoja número 12.859 del Registro Mercantil de Barcelona) que poseía en el pasivo del Balance emisiones de obligaciones hipotecarias realizadas en 1919, 1920, 1922 y 1924, alcanzó un acuerdo con sus acreedores para resolver su crisis financiera ${ }^{309}$. El saneamiento consistía en involucrar a los obligacionistas en la marcha de la sociedad mediante su conversión en accionistas y mediante su representación en el Consejo de Administración. Para ello se procedió a la supresión de los privilegios de que gozaban las acciones ya existentes que se convirtieron en acciones ordinarias, y a una fortísima ampliación de capital $^{310}$. En virtud de la ampliación, las nuevas acciones de la Compañía General de Ferrocarriles, S.A. se entregaron a los antiguos obligacionistas en la relación siguiente: por cada dos obligaciones poseídas se entregaron dos nuevas acciones preferentes serie A y una nueva acción preferente serie B, todas ellas enteramente liberadas. Los obligacionistas privilegiados pasaron a convertirse en accionistas privilegiados (titulares de acciones de la serie A con derecho al cobro de un dividendo de hasta el 5\% no acumulativo sobre el producto líquido de cada ejercicio y de la serie B con un segundo privilegio de hasta el $4 \%$ no acumulativo una vez retribuida las de la serie A prioritaria). Al objeto de asimilar la posición de obligacionistas a la nueva situación en cuanto a la duración del derecho, se les

\footnotetext{
${ }^{309}$ Decreto aprobatorio del Convenio de saneamiento financiero número 2968 de 15 de noviembre de 1962 , publicado en el B.O.E. el 24 de noviembre de 1962.

${ }^{310}$ Expediente de revalorización y reversión de líneas resuelto por el Ministerio de Obras Públicas por Orden de 28 de septiembre de 1960.
} 
entregaron acciones serie B rescatables: una vez satisfecha la doble atención retributiva privilegiada, debería destinarse el cincuenta \% del remanente como mínimo a la amortización de las acciones preferentes serie B por sorteo y a la par, efectuándose dicha amortización por múltiplos de quinientas mil pesetas y destinándose las fracciones inferiores a esta cifra a un fondo para engrosar la amortización del año o años siguientes.

En este apartado hemos analizado la utilización de clases de acciones en las empresas ferroviarias españolas. Una vez realizado el estudio empírico hemos podido obtener que únicamente once empresas de ferrocarriles españolas utilizaron clases de acciones, realizando en total doce emisiones (una empresa emitió dos clases diferentes: una privilegiadas y otra rescatables). Todas las modalidades de privilegiadas podrían ser útiles para todas las compañías ferroviarias de la época, pero en concreto, como veremos a continuación, las rescatables podrían haber mejorado la estructura financiera.

\subsubsection{Motivaciones para emitir clases de acciones}

Una vez constatada la poca utilización de las acciones privilegiadas por parte de las ferroviarias españolas, es necesario indagar para intentar conocer las posibles razones que pueden provocar la poca iniciativa de los emisores españoles a la hora de acudir a una financiación mediante la diferenciación de las clases de acciones. Para ello analizamos las motivaciones para emitir estos títulos a nivel internacional.

Identificamos cinco razones para emitir acciones privilegiadas: defensiva, fiscal, legal, estratégica y financiera.

La primera motivación para emitir clases de acciones puede ser legal. Entre las razones de tipo legal destaca la que se produce en la legislación de Estados Unidos, donde las empresas de servicios públicos de electricidad están obligadas a que la deuda no exceda del $60 \%$ de su pasivo (IEA/DOE: 2007). Esta situación obliga a las empresas de sectores regulados a utilizar emisiones de acciones, y en muchas ocasiones, las empresas eligen acciones privilegiadas porque son permitidas y se asemejan económicamente a las deudas. En España no existen tales limitaciones sobre la estructura de capital de las empresas eléctricas ni ferroviarias, sin embargo, sí las hay en el sector de los intermediarios financieros. Los bancos y cajas de ahorros españolas también presentan limitaciones cuantitativas respecto al porcentaje de deuda que debe poseer respecto al total del pasivo. Derivado de este hecho, la utilización de recursos propios con algunas características de deuda es atractivo instrumento de financiación por los intermediarios financieros.

La emisión de clases de acciones también puede tener una motivación fiscal. En algunos países, la inversión en acciones privilegiadas posee una serie de ventajas fiscales respecto a la inversión en acciones ordinarias. Este proceso es observable, sobre todo, en Estados Unidos, 
donde los dividendos de acciones privilegiadas estuvieron exentos de impuestos en un $80 \%$.

En tercer lugar, la emisión de estos títulos puede tener una motivación defensiva. Las clases de acciones pueden configurarse como un procedimiento de defensa de las relaciones de poder preexistentes en la sociedad (Reckkinger, 1983, 216). La estratificación del capital en emisiones con diferentes derechos es utilizada, sobre todo en el mercado estadounidense, en situaciones en las que una compañía se encuentra ante la necesidad de disponer de una cierta capacidad de maniobra para poder defenderse de supuestas agresiones por parte de terceros, interesados en conseguir posiciones de control a través de maniobras en el mercado financiero (por ejemplo, OPAS).

En cuarto lugar, existen razones de tipo estratégico para emitir acciones privilegiadas, ya que éstas pueden ser utilizadas como un método de financiación útil en el caso de encontrarse en tres situaciones: en fusiones (Brealey, Myers y Marus, 1996: 363), en la adquisición de una filial, por medio de la emisión de acciones privilegiadas por la sociedad adquirente, para entregárselas a los accionistas de la filial como parte del precio de compra (Houston y Houston, 1991: 49) y, por último, en situaciones en las que la evolución de la empresa es negativa, porque en este caso es preferible emitir acciones privilegiadas en vez de deuda, debido a que el impago de los dividendos de las acciones privilegiadas no puede ser causa para ser declarado en quiebra (Brändel, 1992: 247) (Ross, Westerfield y Jaffe, 1997: 426).

La quinta y última causa para emitir acciones privilegiadas tiene carácter financiero, ya que su diseño tiene como objetivo hacer más atractiva la emisión de acciones para que los inversores potenciales elijan la opción de invertir en la empresa frente a los títulos de otras entidades. Con la emisión de acciones con derechos y privilegios variados, la compañía puede llegar a una gama mayor de inversores, incidiendo en un ajuste del coste efectivo de los títulos, teniendo en cuenta los condicionantes de mercado y la fiscalidad ${ }^{312}$.

Como instrumento de financiación, las clases de acciones resultan útiles para dos momentos de la evolución de la empresa. Por un lado, permite luchar contra la escasez de disponibilidades financieras; una empresa amenazada por una crisis difícilmente va a conseguir que los potenciales inversores suscriban sus acciones, sin embargo, puede captar nuevos fondos si ofrecen ventajas a los suscriptores. Por el otro, las clases de acciones son un instrumento válido para lograr la expansión de las actividades de la empresa.

En ambos casos, la idoneidad de las clases de acciones como instrumento de financiación pasa por la atribución al inversor de preferencias que incentiven la suscripción, y, a estos

\footnotetext{
${ }^{311}$ La motivación fiscal para emitir acciones privilegiadas puede ser observada en Wall Street Journal (1988, 2), Houston y Houston (1991, 49), Collins y Shackelford (1992, 105), Outslay (1992, 125), Brealey, Myers y Marus (1996, 364), White, Sondhi y Dov (1997, 495), Patterson (1997, 137), Ross, Westerfield y Jaffe (1997, 424), Van Horne (1997, 393) e Ingram y Baldwin (1998, 311).

${ }^{312}$ La motivación financiera a la hora de emitir clases de acciones puede ser observada en Cremades (1986, 3738), Campobasso (1993, 225), Ventura $(1982,1412)$, Beltrán $(1994,199)$ y Tapia $(1994,638)$.
} 
efectos, “(...) resultan idóneas tanto las clases de acciones con una diversidad en derechos patrimoniales como en derechos administrativos" (Beltrán, 1994: 200). En efecto, para lograr que una sociedad obtenga nuevas aportaciones cuando se encuentra en una situación en la que es difícil atraer a los inversores, pueden emitirse tanto clases de acciones con diferenciación en los derechos patrimoniales (una de ellas son las preferentes) como clases de acciones con diferenciación en otro tipo de derechos (como rescatables o acciones sin voto).

Las acciones privilegiadas son producto de la ingeniería financiera. Las acciones, como todos los productos y servicios que se pretenden colocar en el mercado financiero por las empresas, son susceptibles de diversificación al objeto de alcanzar mercados con necesidades específicas y susceptibles de políticas de oferta discriminatorias o de segmentación del mercado. Como las preferencias de los inversores no son idénticas, es posible que la segmentación de los mercados permita penetrar de manera más eficiente en aquellos «nichos de mercado» caracterizados por ciertos rasgos diferenciales en cuanto a preferencia o aversión respecto del riesgo, de la liquidez y de la rentabilidad. Es posible que una sociedad coseche un mayor éxito si configura su producto en el mercado de manera atractiva a cierto sector del público objetivo inversor.

Pues bien, aunque hemos identificado cinco motivaciones ${ }^{313}$ para emitir clases de acciones en el ámbito internacional ${ }^{314}$, las empresas ferroviarias españolas sólo pueden haber tenido tres: la defensiva, la estratégica y la financiera. Esta es la principal razón que explica porque las empresas españolas han emitido menos clases de acciones que las domiciliadas en otros países.

\subsubsection{Ventajas de las clases de acciones}

Aunque las empresas ferroviarias españolas tuvieran menos motivaciones que sus iguales en el panorama internacional, no realizar estas emisiones impedieron aprovechar muchas ventajas que hubieran cambiado su estructura financiera. En este apartado analizaremos las ventajas de las clases de acciones en general, y de cada una de las figuras en particular.

Las acciones privilegiadas son un buen medio de financiación para empresas que desean autonomía de los poderes fácticos ya establecidos: acreedores y accionistas ordinarios.

La emisión de privilegiadas permite al emisor la flexibilización frente a otras fuentes financieras, como por ejemplo las deudas bancarias y las acciones ordinarias. Con la emisión de clases de acciones se amplían las posibilidades de financiar la empresa con acciones. Esto

\footnotetext{
${ }^{313}$ La consecución de los objetivos anteriores justifica la mayor parte de las emisiones de clases de acciones, sin embargo, no es necesario que el fin perseguido se encuentre definido explícitamente en la emisión. Una clase de acciones emitida en su origen con una finalidad protectora de las relaciones de poder preexistentes, puede convertirse en un eficaz instrumento de financiación de la sociedad, y viceversa. A esto hay que añadir que no siempre es posible separar radicalmente los objetivos de una emisión de clases de acciones, por el contrario, “(...) cuando una sociedad crea clases de acciones lo habitual es que lo haga atendiendo, simultáneamente, a razones financieras y de protección de las relaciones de poder preexistentes” (Sánchez: 1992, 2498).

${ }^{314}$ Por ejemplo, en Estados Unidos se dan las cinco finalidades.
} 
concede dos ventajas. Por un lado, proporciona una mayor autonomía del control que pueden ejercer en la empresa los acreedores, fruto de un excesivo endeudamiento. Por el otro, el aumento de financiación en acciones reduciría (y, por tanto, mejoraría) la ratio de endeudamiento $^{315}$ de la empresa, mejorando los indicadores de solvencia, lo que permite la captación posterior de nueva financiación ajena a menor coste.

Las acciones privilegiadas, al tener naturaleza jurídica de acciones, pueden ser un buen medio para las empresas para cubrir sus niveles de recursos propios frente a los niveles de deudas. La principal ventaja de la emisión de clases de acciones respecto a otras figuras es que pueden configurar las acciones para que tengan las características económicas de una deuda, pero siempre serán acciones a efectos jurídicos. Esta ventaja podría haber sido muy importante para las empresas ferroviarias que estuvieron muy endeudadas y necesitaron aún más financiación, porque hubieran podido conseguir recursos cuando tenían difícil el acceso a la financiación bancaria, por tener niveles de endeudamiento altos (cuadro 13).

\section{Cuadro 13. Nivel de endeudamiento de NORTE}

\begin{tabular}{|l|l|l|l|l|l|}
\hline & & & & & \\
& & & & & $\begin{array}{l}\text { TOTAL } \\
\text { DEUDAS } \\
\text { TOTAL } \\
\text { ACTIVO }\end{array}$ \\
\hline 1913 & $817.262 .586,12$ & $42.360 .015,10$ & $859.622 .601,22$ & $1.461 .684 .114,30$ & 0,58810422 \\
\hline 1914 & $840.839 .171,49$ & $42.483 .357,06$ & $883.322 .528,55$ & $1.488 .828 .256,83$ & 0,59330049 \\
\hline 1915 & $850.473 .334,54$ & $44.410 .827,30$ & $894.884 .161,84$ & $1.515 .576 .154,17$ & 0,59045806 \\
\hline 1916 & $903.387 .278,11$ & $46.284 .898,76$ & $949.672 .176,87$ & $1.627 .414 .720,61$ & 0,58354651 \\
\hline 1917 & $973.299 .421,04$ & $57.218 .620,13$ & $1.030 .518 .041,17$ & $1.694 .393 .030,26$ & 0,60819304 \\
\hline 1918 & $973.311 .866,04$ & $61.411 .718,60$ & $1.034 .711 .139,64$ & $1.687 .302 .400,50$ & 0,61323396 \\
\hline 1919 & $973.324 .121,04$ & $50.336 .591,40$ & $1.023 .648 .457,44$ & $1.669 .858 .004,76$ & 0,61301527 \\
\hline 1920 & $973.340 .318,54$ & $80.778 .050,80$ & $1.054 .102 .171,84$ & $1.720 .588 .628,56$ & 0,61264044 \\
\hline 1921 & $973.365 .968,54$ & $139.669 .274,78$ & $1.113 .035 .243,32$ & $1.825 .118 .576,89$ & 0,60984270 \\
\hline 1922 & $1.070 .262 .607,88$ & $214.703 .527,76$ & $1.284 .966 .135,64$ & $2.082 .418 .971,70$ & 0,61705457 \\
\hline 1923 & $1.114 .785 .598,17$ & $287.562 .587,87$ & $1.402 .348 .186,04$ & $2.249 .320 .738,63$ & 0,62345408 \\
\hline 1924 & $1.203 .602 .830,72$ & $311.236 .730,88$ & $1.514 .839 .561,60$ & $2.444 .461 .812,56$ & 0,61970269 \\
\hline
\end{tabular}

Fuente: Elaboración propia a partir de los datos de Ortúñez (1999a: 32)

La gerencia debe tener en cuenta si la empresa se encuentra en una época de expansión o recesión; en tiempos de recesión es preferible usar una mayor proporción de neto, mientras que en momentos de expansión se puede emplear sin peligro, y con mayor provecho, una mayor proporción de pasivo exigible.

Las acciones privilegiadas presentaban una ventaja superlativa para los tiempos de crisis. La financiación de deudas y empréstitos debe ser remunerada obligatoriamente, tanto si existen beneficios o pérdidas contables en el ejercicio. Por el contrario, por las acciones, no deben entregarse dividendos si existen pérdidas, sólo deben realizarse en los ejercicios contables con

\footnotetext{
${ }^{315}$ La ratio de endeudamiento equivale al cociente entre los recursos ajenos y los recursos propios.
} 
beneficios; pero incluso, si la empresa obtiene resultados positivos, pero prevé una posible mala situación económica futura, no tiene ninguna obligación legal para entregar esos dividendos. De esta forma, al utilizar las privilegiadas las ferroviarias podrían no haberse desprendido de unos recursos que pueden ser vitales en un momento posterior ${ }^{316}$.

\subsubsection{Ventajas de las acciones sin voto}

El fundamento para su creación es que en las grandes sociedades anónimas resulta imposible reunir en junta general a todos los socios y, además, existe un desinterés de los pequeños accionistas en la marcha de la gestión social. Las acciones sin derecho de voto dan respuesta a los nuevos intereses de ese sector accionarial.

La principal motivación para emitir acciones sin voto es financiera, pues la empresa emisora de estas acciones busca inversores potenciales que le proporcionen los recursos que necesita. Cuando el mercado se encuentra en situación de saturación, por el gran número de alternativas de inversión que ofrece, las empresas emisoras identifican las características de un perfil de accionista denominado "de ahorro", con unas necesidades específicas, y emiten acciones sin voto para absorber sus recursos. Esta idea se basa en que sólo una parte del accionariado (accionistas de control) se interesa por la gestión social, mientras que el resto es atraído únicamente por el rendimiento patrimonial de los títulos (accionistas de ahorro) ${ }^{317}$.

El marketing financiero genera soluciones a problemas del mercado y las empresas que lo componen. Esto ocurre con la doble estructuración de capital (dual capitalization) entendida como la financiación por medio de varios tipos de acciones con diversas características para obtener la mejor estrategia de riesgo y rentabilidad ${ }^{318}$. La doble estructuración de capital responde a la solución eficiente del problema típico de la dispersión del accionariado con los dos extremos de la balanza societaria: por un lado, los accionistas de control, y por el otro los accionistas inversores que representan el "capital flotante". De esta forma, la financiación mediante acciones sin voto tiene un fuerte atractivo para los inversores que están dispuestos a

\footnotetext{
316 Respecto al caso concreto de las acciones privilegiadas más comunes, las que privilegian derechos económicos, pueden tener unas finalidades adicionales. Las acciones con una preferencia en derechos económicos pueden incentivar la suscripción cuando la situación del mercado de capitales no permita una colocación rápida y ventajosa de nuevas acciones ordinarias. Ante la prohibición de emisión de nuevas acciones por debajo del valor nominal, si la cotización bursátil de las acciones es especialmente baja, cerca del valor nominal, sólo es posible una nueva emisión de acciones ligeramente por encima o, incluso, por el valor de cotización. Ello supondría que la sociedad absorbería un capital propio muy caro, porque si la cotización de la emisión sube, los costes reales del capital descienden. Para evitar esto y, a la vez, asegurar una colocación ventajosa en el mercado de acciones con una cotización aceptable, se ofrece como fórmula la acción privilegiada en derechos económicos, “(...) donde el privilegio en derechos económicos funciona como incentivo" (Donaldson, 1962, 124-126).

${ }^{317} \mathrm{La}$ motivación inicial de las acciones sin voto parece que es satisfacer las necesidades de los pequeños inversores interesados únicamente por la rentabilidad económica de su inversor, y no tanto por participar en la gestión de la sociedad. No obstante, parte de la doctrina (Kriebel: 1963, 175) estima que a quien realmente interesa la existencia de tales acciones es a los grupos de poder de las sociedades emisoras.

${ }^{318}$ El concepto de dual capitalization ha sido analizado, entre otros, por Simmons (1987, 106-125) y Gordon (1988, 10).
} 
cambiar dividendo por voto, porque pueden ser un instrumento para edificar un determinado equilibrio societario de poderes.

Además de ser derivado de la innovación financiera y del marketing financiero, existen otras situaciones específicas en las que puede ser adecuada la emisión de acciones sin voto: procesos de reorganización empresarial, reconversión o industrialización, conservación del control público de las sociedades estatales y recapitalización sin riesgos de la pérdida de control familiar o grupal. Respecto a esto último, la OPA (Oferta Pública de Adquisición de acciones o takeover bid) es una operación dirigida a la adquisición de un determinado volumen de acciones, admitidos a negociación en una bolsa de valores, que directa o indirectamente pueden dar derecho a su suscripción o adquisición, para de esta forma, llegar a alcanzar una participación significativa en el capital de una sociedad. La emisión de acciones sin voto es, para la empresa emisora, una garantía de protección frente a una posible OPA futura, porque las acciones sin voto no puedan agruparse para designar a los administradores por el sistema proporcional ${ }^{319}$.

\subsubsection{Ventajas de las acciones rescatables}

Una de las razones por las que se utilizaron acciones rescatables en el mercado financiero internacional es porque la financiación con acciones ordinarias presentaba problemas para el emisor. Las ordinarias son, para la empresa emisora, instrumentos que conceden muchos derechos a los titulares, lo que puede pasar factura en tiempos de dificultad, por ser muy cara su posterior reestructuración. Ante esta situación, parece razonable configurar parte del capital con carácter temporal y facultades transitorias.

Las emisiones de acciones rescatables pueden tener diversas razones por las que pueden ser utilizadas: para la reestructuración financiera de su capital, para sanear una compañía o para reorganizar su capital permanente por razones estratégicas. Las estrategias financieras pueden tener dos orientaciones: la conversión de capitales propios en capitales ajenos para aprovechar el efecto apalancamiento o la transformación de los acreedores en accionistas. El efecto palanca o apalancamiento (l'effet de levier) explica cómo, en períodos de inflación, la rentabilidad de las compañías podría mejorar (o al menos no empeorar) si las inversiones se financian recurriendo a capitales ajenos más que a capitales propios, y viceversa (Cozian y Viander, 1992: 109). Al servicio de esta transición entre períodos inflacionarios y no inflacionarios, entre tasas de interés altas y bajas, podrían situarse aquellas fórmulas de capitalización reversible o con carácter no permanente ${ }^{320}$.

\footnotetext{
319 La regulación de las OPAS está diseñada para proteger a los titulares de acciones ordinarias, pero no especifica el tratamiento de las acciones sin voto. Sólo en el caso concreto de las OPAS de exclusión de bolsa, la oferta debe extenderse a todas las acciones. El atractivo de las acciones sin voto es inversamente proporcional a la probabilidad de cambios en la estructura de propiedad.

${ }^{320}$ Según Sánchez Andrés $(1999,49)$, las rescatables permiten "(...) a la sociedad refinanciarse a menor coste cuando descienden los tipos de interés, sin los inconvenientes de recurrir a sucesivas emisiones de deuda, mediante procesos permanentes de ida y vuelta".
} 
Además, es necesario destacar que las acciones rescatables son instrumentos de financiación con costes inferiores a otras fuentes de financiación temporales, como la emisión de empréstitos.

Las acciones rescatables permiten introducir un alto grado de flexibilidad, siendo útiles para hacer frente a las necesidades coyunturales. La creación de unas acciones privilegiadas con un precio de rescate por encima del precio de emisión proporciona flexibilidad a la compañía, ya que sin el establecimiento de una característica de rescate en las acciones privilegiadas la corporación únicamente podría retirar la emisión mediante un método más caro: comprar las acciones en el mercado abierto.

\subsubsection{Utilidad de las emisiones de acciones rescatables}

Es posible identificar siete posibles finalidades para emitir las acciones rescatables: necesidades financieras, sociedades con necesidades decrecientes de capital, desinversión de capital-riesgo, cobertura financiera de los planes de opciones, táctica defensiva frente a las OPAS, control por parte de las mayorías accionariales y reestructuración financiera.

\subsubsection{Necesidades financieras}

Con la inclusión de este híbrido financiero ${ }^{321}$ en el mercado se intenta satisfacer simultáneamente las necesidades de inversión de los accionistas y las necesidades de financiación de las sociedades emisoras.

El mercado financiero ha producido un conjunto de productos con características mixtas entre la inversión en renta fija y en renta variable. Este proceso es debido a la búsqueda, por parte del tejido empresarial, de recursos, no sólo en intermediarios financieros, sino también en ahorradores individuales. Para poder conseguir esta financiación, el mercado financiero debe generar productos de características distintas que permitan diversificar su oferta y llegar a un número mayor de inversores individuales. El proceso de segmentación de la oferta financiera ofrece como resultado emisiones con las más variadas características, entre ellas, valores de renta fija indexados, valores de renta variable garantizados, fondos de inversión, obligaciones convertibles y warrants. Las acciones rescatables nacieron para ampliar aún más el abanico de oferta financiera del mercado, concediendo, a las empresas emisoras, una nueva forma de financiación transitoria y, al accionista, una forma de invertir a plazo determinado.

La existencia de acciones rescatables tienen sentido en el mercado financiero porque la financiación con acciones ordinarias presenta problemas para el emisor. Las ordinarias son, para la empresa emisora, instrumentos que conceden muchos derechos a los titulares, lo que puede ser nefasto en tiempos de dificultad. Ante esta situación, es razonable configurar parte del capital con vida temporal y facultades transitorias.

\footnotetext{
${ }^{321}$ Las acciones rescatables son el más representativo ejemplo de híbrido de deuda, en sentido contrario, la financiación subordinada representa el modelo de híbrido de capital.
} 
Las acciones rescatables son productos de la ingeniería financiera. Las acciones -como todos los productos que se pretenden colocar en el mercado por las empresas-, son susceptibles de diversificación al objeto de alcanzar mercados con necesidades específicas de políticas de oferta discriminatorias o de segmentación del mercado. Como las preferencias de los inversores no son idénticas, es posible que la segmentación de los mercados permita penetrar de manera más eficiente en aquellos "nichos de mercado" caracterizados por ciertos rasgos diferenciales en cuanto a preferencia o aversión respecto del riesgo, de la liquidez y de la rentabilidad. Una sociedad cosechará un mayor éxito si configura su producto en el mercado de manera atractiva a cierto sector del público-objetivo inversor.

El derecho de rescate dota al instrumento financiero de la versatilidad de las opciones financieras. Cuando el rescate es un derecho del emisor, las rescatables tienen una estructura análoga a las call options: su emisión permite a la sociedad un margen de flexibilidad en la reestructuración financiera de sus recursos propios. En caso de una fuerte caída de los tipos de interés o de una mejora del "rating de solvencia" del emisor (que suponen un abaratamiento de las condiciones de financiación), la sociedad puede utilizar el rescate para refinanciarse con la amortización de las rescatables. Cuando el rescate es a voluntad del accionista, las acciones funcionan de manera análoga a una put option lo que incrementa la liquidez del instrumento. Con un determinado precio de rescate establecido, el accionista podrá cobrar un precio superior al de cotización.

Las acciones rescatables nacen como instrumento de financiación, pero su emisión no dependerá únicamente de la estructura de la sociedad emisora, sino también de las motivaciones de inversión de los accionistas y de las necesidades de financiación del emisor.

Desde el punto de vista de la empresa emisora, la gerencia debe tener en cuenta si la empresa se encuentra en una época de expansión o recesión. En tiempos de recesión es preferible usar un mayor porcentaje de neto, mientras que en momentos de expansión se puede emplear sin peligro, y con mayor provecho, una mayor proporción de pasivo exigible.

La principal ventaja de la emisión de rescatables para el accionista es que, sin renunciar a la calificación de acciones, consigue limitar su horizonte temporal de inversión. Son especialmente atractivos para inversores con aversión al riesgo, ya que frecuentemente tienen garantizado al menos el valor nominal de las inversiones.

Además de los incentivos y desincentivos generales para el emisor e inversor, es necesario realizar un análisis sobre el sujeto que tiene la opción de ejercer el derecho de rescate. Si el derecho de rescate pertenece a los inversores, éstos poseen una ventaja ya que les permite elegir el horizonte de inversión más adecuado; por el contrario, si el derecho de rescate pertenece al emisor, el inversor tendrá una indeterminación en la duración de su inversión. 
La principal ventaja para el inversor, si posee el derecho de rescate, es que adquiere un título que compensa la carencia de un mercado secundario, protestándole para desinvertir de forma ágil y sencilla. El socio, adquiriendo estos valores, consigue limitar su horizonte temporal de inversión sin renunciar a los derechos políticos y económicos de todas las acciones, obteniendo una inversión con una rentabilidad financiero-fiscal superior a la ofrecida por la renta fija; por lo tanto, son una fuente de financiación idónea para aquellos inversores que buscan una rentabilidad menos volátil y más segura que la ofrecida por las acciones ordinarias.

Por su parte, la principal ventaja, para el emisor, de las rescatables a opción del emisor ${ }^{322}$ frente a las ordinarias es que, al tener la posibilidad de rescate, permite al emisor modificar su política financiera en cualquier momento, atendiendo para ello a la evolución que observe en el mercado en cuanto a los costes financieros de la deuda. Además, la posesión de acciones rescatables a opción del emisor permite una refinanciación más barata a través del ejercicio de rescate y de una nueva emisión de acciones.

El principal inconveniente, para el emisor, de las rescatables a opción del inversor es que los accionistas pueden exigir el rescate en el momento que deseen, lo que puede perjudicar los intereses del emisor. El rescate puede darse cuando los tipos de interés de otras inversiones tiendan a ser mayores, lo que conlleva la pérdida de esa financiación y la obligación de autofinanciarse o buscar financiación a tipos más altos. Ante este hecho, la empresa está obligada a reducir capital, lo que aumentaría (y, por tanto, empeoraría), la ratio de endeudamiento (recursos ajenos/recursos propios) de la empresa, empeorando los indicadores de solvencia; esta situación obliga a la captación posterior de nueva financiación ajena a menor coste, o si no se quiere captar más recursos provoca un inevitable desprestigio de la empresa frente a acreedores. Tras lo anterior podemos afirmar que las rescatables a opción del inversor son válidas para ser utilizadas en empresas poco endeudadas, mientras que no es aconsejable en empresas excesivamente endeudadas ${ }^{323}$.

Teniendo en cuenta que para que se produzca una emisión debe interesar a las empresas emisoras y a los futuros inversores, las emisiones más probables desde el punto de vista financiero son las acciones rescatables que a su vez sean privilegiadas en el derecho al beneficio y sin voto; privilegiadas en el derecho al beneficio para que la rentabilidad de estas acciones sea percibida como un aliciente para los futuros inversores; sin voto para que la gestión de la empresa no se vea influenciada por la participación en la junta general de los nuevos accionistas temporales.

\footnotetext{
${ }^{322}$ Estas afirmaciones también se puede ampliar a las emisiones que tengan derecho de rescate a opción conjunta del emisor e inversor.

${ }^{323}$ Cotton (1995: 287) desarrolla la idea de que las acciones rescatables a opción del inversor son adecuadas para empresas poco endeudadas, pero no para las excesivamente endeudadas.
} 


\subsubsection{Capital-Riesgo}

Además de las anteriores, existen otras empresas cuya naturaleza hace recomendable la inversión en recursos propios por un tiempo limitado: las sociedades y fondos de capital riesgo. Por su propia naturaleza, este tipo de entidades invierten sus recursos financieros en capitales de riesgo y por un determinado período, terminado el cual deben liquidar su inversión. El mecanismo de las rescatables puede ser utilizado para estos fines. La doctrina (Yanes, 2004: 61) así lo ha reconocido, aunque no ha existido en España hasta el momento ninguna emisión que tenga esta finalidad. De todas formas, la cláusula de rescate podría ser utilizada siempre que el inversor, por razones de lo establecido en su estatuto o por razones derivadas de las diferentes legislaciones, deba tener limitada en el tiempo la inversión en recursos propios.

El capital riesgo (venture capital) es una actividad financiera que trata de proporcionar recursos a empresas "de riesgo" ${ }^{324}$, a medio y largo plazo y sin vocación de permanencia ilimitada. Los inversores, que pueden ser tanto públicos como privados, toman participaciones en las empresas a cambio de facilitar financiación y ofrecer apoyo gerencial y asesoramiento empresarial. Sus objetivos son obtener plusvalías, si se trata de inversores privados, y favorecer al tejido empresarial, si son públicos ${ }^{325}$.

Pues bien, la rescatabilidad podría contribuir a cumplir una función dentro del ámbito de la inversión ocasional y no periódica del capital-riesgo. Como el capital-riesgo es una actividad financiera sin vocación de permanencia ilimitada, a empresas que presentan dificultades para acceder a otras fuentes de financiación, la participación en ellas nunca será permanente. Las tomas de participación por las entidades de capital-riesgo han de tener necesariamente vigencia temporal, aspecto bajo el cual cobran especial interés las cuestiones relacionadas con los procedimientos adecuados para articular la desinversión de estas entidades y realizar la plusvalía que retribuya el riesgo recuperando la liquidez necesaria para acometer nuevas tomas de participación en otras empresas. Entre estos procedimientos se encuentran (aparte de los pactos de recompra de las participaciones minoritarias de las entidades por parte de los socios mayoritarios y estables de las participadas) las acciones rescatables ${ }^{326}$.

\subsubsection{Cobertura financiera de planes de opciones}

Uno de los usos principales de las acciones rescatables, en la actualidad, es la cobertura financiera de planes de opciones a favor de empleados y directivos. Las acciones rescatables se utilizan en compañías que dispongan de un plan de opciones sobre compra de acciones,

\footnotetext{
${ }^{324}$ Se consideran empresas "de riesgo" las que presentan dificultades para obtener otro tipo de financiación.

${ }^{325}$ En España, las entidades de capital riesgo pueden adoptar dos formas jurídicas: Sociedades de Capital Riesgo (SCR) o Fondos de Capital Riesgo (FCR). Las Sociedades Gestoras de Entidades de Capital Riesgo (SGECR) son sociedades anónimas responsables de administrar y gestionar los activos de las SCR así como los FCR.

${ }^{326}$ Las acciones rescatables son calificadas por la doctrina como "una vía societaria capaz de salvar las dificultades (...) y apta para facilitar las operaciones de desinversión” (Yanes, 2004: 61).
} 
como forma de remuneración a sus directivos y trabajadores, actuando la emisión de acciones rescatables como cobertura ${ }^{327}$.

Las sociedades que tengan la intención de poner en marcha un plan de opciones como mecanismo adicional de retribución para sus empleados o los de sociedades de su grupo, podrán financiarlo a través de una ampliación de capital de acciones rescatables ${ }^{328}$.

El esquema que siguen las sociedades que optan por esta posibilidad consiste en colocar entre el emisor y los destinatarios finales del plan de opciones sobre acciones, una entidad financiera interpuesta que suscriba la totalidad de los valores, a la vez que administra y gestiona la integración diferida en el tiempo de los que ejercitan las stock options. La rescatabilidad de las acciones funciona en todos los casos como garantía de las relaciones entre la entidad emisora y la suscriptora, configurándose su desaparición cuando se ejecute definitivamente el plan de opciones sobre acciones a través del ejercicio de las opciones por los beneficiarios. A su vez, en aquellos casos en los que la cobertura del plan de opciones sobre acciones por medio de acciones rescatables deje de ser necesaria o existan acciones tras la finalización del plan de opciones sobre acciones, la previsión del rescate se configura como una posibilidad ejercitable por la entidad suscriptora de las acciones, que "le permite a ésta recuperar la inversión realizada a través de la percepción del contravalor del rescate" (Chamorro, 2009: 43).

La entidad financiera, tenedora de las acciones, tiene concedido, en exclusiva, el derecho de ejercer el rescate. En el supuesto que los empleados beneficiarios del plan de opciones ejerzan las mismas, la entidad financiera suscriptora se compromete a no ejercitar el rescate de las acciones que les correspondiesen y, por el contrario, a instar de la entidad emisora la conversión de las acciones rescatables en acciones ordinarias, para su posterior entrega a los beneficiarios del plan que hubiesen ejercitado sus opciones. Una vez que la entidad financiera sea titular de las acciones ordinarias convertidas, transmitirá por cuenta de la sociedad emisora dichas acciones al personal de la sociedad beneficiaria del plan de opciones que hubiese ejercitado las mismas. Éstas se liquidarán mediante la entrega de las acciones a los trabajadores, contra el pago por éstos del precio de ejercicio de las opciones, las cuales se conceden a los beneficiarios con carácter gratuito y sin que su aceptación suponga coste o desembolso alguno. Por el contrario, en el caso en el que durante la vida del plan de opciones, la cobertura del mismo a través de las acciones rescatables dejase de ser total o parcialmente necesaria, la entidad suscriptora de la emisión procederá a ejercer el rescate sobre las acciones de las que sea titular y que supongan un exceso de cobertura, por el precio de rescate acordado en la emisión. De este modo, la entidad financiera interpuesta podrá recobrar el desembolso que realizó para efectuar la suscripción de las acciones. Las acciones rescatadas serán, entonces, amortizadas previo pago del precio de rescate acordado en la emisión. Alternativamente, al vencimiento del plan de opciones, las acciones rescatables pueden ser

\footnotetext{
327 Ante la masiva utilización de esta finalidad por parte de las empresas, la doctrina la ha desarrollado ampliamente (Yanes, 2004: 72-75) (Chamorro, 2009: 165-170).

328 Así se ha utilizado en las emisiones realizadas por Agbar, Indra, Prisa y Sogecable.
} 
convertidas en acciones ordinarias, "si esto resulta más conveniente a los intereses de la sociedad" (Chamorro, 2009: 43).

\subsubsection{Táctica defensiva frente a las OPAS}

La rescatabilidad podría utilizarse como táctica defensiva frente a las $\operatorname{OPAS}^{329}$, aunque en España ninguna compañía la haya utilizado. La oferta pública de adquisición de acciones (OPA) tiene lugar obligatoriamente cuando un accionista (bidder) desea poseer más del $25 \%$ de las acciones de una empresa (targer) que cotiza en un mercado de valores. La OPA especifica el número máximo y mínimo de acciones que se desea alcanzar y el precio que se ofrece pagar por ellas. Si el equipo directivo de la empresa está a favor de la OPA, y recomienda a los accionistas que vendan sus acciones al oferente, se llama amistosa; si no está a favor, recibe la denominación de hostil.

La rescatabilidad puede funcionar como mecanismo adecuado para fortalecer la posición del grupo de control ante la formulación de OPAS hostiles de dos formas: (i) porque la amortización de acciones subsiguiente del rescate modifica a favor de aquel grupo las proporciones de participación en el capital, incrementando su peso relativo en el accionariado o, (ii) porque la amortización permite retirar del mercado acciones, que en otro caso, podrían ser adquiridas por el oferente hostil ${ }^{330}$.

Para que funcione la protección es necesario definir una determinada poison pill $^{331}$, que disuada al bidder de la toma de control prevista, por el costo excesivo que entrañaría. Por ejemplo: (i) emisión de acciones rescatables con previsión de amortización automática y

\footnotetext{
${ }^{329}$ Así lo han expuesto Calvosa (1995: 21), Estevan de Quesada (2002: 138), García-Cruces (2002: 921), Yanes (2004: 62-64) y Chamorro (2007: 158-165).

330 "El rescate podría entonces funcionar como medida defensiva que frenara o anulara completamente el ataque del bidder frente a la sociedad targer" (Garrido, 1991: 367). Esto es ampliado por García-Cruces (2002: 921), "el carácter rescatable de las acciones puede ser utilizado como una idónea medida anti-OPA. Así bastaría con que el rescate -y, en su caso, el devengo de la redemption premium o prima- se sujetaran a la condición de la formulación de una oferta pública de adquisición de acciones de carácter hostil o, si se prefiriera disimular tal condición, a la voluntad del tenedor de las propias acciones rescatables".

${ }^{331}$ La técnica conocida como poison pill ha estado muy relacionada en la práctica estadounidense con las blank shares. El procedimiento habitual es que los articles of incorporation establecen la creación de una class of shares sin fijar paralelamente ninguna estipulación sustantiva respecto a las mismas, o estableciendo sólo algunas disposiciones muy generales. Estos articles autorizan al board of directors a la creación de varias series integrantes de aquella clase no definida, estableciendo ya su contenido jurídico particularizado, las cuales podrán ser puestas en el mercado en fechas diversas, dependiendo de las necesidades del mismo. Estas blank shares, denominadas así por no estar previstas en los articles of incorporation, resultan muy interesantes, al permitir establecer al board of directors sus términos teniendo en cuenta las necesidades económicas de cada momento en concreto, "evitando los engorrosos procedimientos de modificación de los articles" (Vargas, 1964: 160) (Cary y Eisenberg, 1995: 1988). "La técnica poison pill consiste en la creación por el board of directors, sobre la base de la autorización establecida en los articles of incorporation, de una o más series de acciones privilegiadas cuya operatividad depende de hechos externos, tales como la adquisición de un elevado porcentaje de las acciones con voto de la corporation por parte de un tercero agresor" (Hamilton, 1996: 209 y 210). Ante tal evento, "la poison pill es puesta en marcha, con lo que un montante importante de nuevas acciones van a parar a los accionistas antiguos, y no al agresor, para hacer así inoperativa la OPA” (Peñas Moyano, 2008: 315 y 316).
} 
prima de rescate ventajosa en caso de amenaza de OPA o sustitución efectiva en el control corporativo a consecuencia de su éxito; (ii) emisión de rescatables con cláusula de conversión automática en ordinarias en los mismos casos o; (iii) contemporánea o inmediata ejecución de un aumento de capital con emisión de rescatables, que no sólo diluyera el porcentaje de participación que pretenda o haya tomado el bidder, sino que aumentará también el coste de su adquisición ${ }^{332}$.

Esta finalidad ha sido utilizada en Estados Unidos. En este país las rescatables han estado relacionadas con Mergers and Acquisition (fusiones y adquisiciones por medio de OPAs) de dos formas. En primer lugar, es usual que "el factor desencadenante del rescate sea la preparación de una OPA hostil” (Hamilton, 1996: 521). En segundo lugar, la conversión de la rescatable en ordinaria puede usarse como poison pill, de tal forma que su rescate disminuyera también los recursos que el adquirente hostil va a encontrar en la sociedad y "puede hacer antieconómico el precio pagado por ella" (Cary y Eisenberg, 1988: 521).

\subsubsection{Control por parte de las mayorías accionariales}

La rescatabilidad tiene utilidad en las operaciones de exclusión de la minoría accionarial, conocidas como minority freezeouts ${ }^{333}$. En concreto, a la atribución a los administradores o a la mayoría del capital social de un poder corporativo de control del accionariado permitiría la eliminación de la minoría accionarial o la reducción, a una medida insignificante, de su capacidad de influencia corporativa. Los freezeouts, squeezeouts o takeouts ${ }^{334}$ son las herramientas utilizadas en reestructuraciones corporativas, por vías fundamentalmente de fusión y escisión, que (i) unas veces consiguen la eliminación de la minoría y (ii) otras domestican al grupo disidente.

En los primeros casos, que son los que interesan en el estudio de las acciones rescatables, los freezeouts sirven a las reestructuraciones de capital con reducción de la base accionarial por eliminación inconsentida de la minoría. Esta eliminación permitiría al adquirente del paquete de control apropiarse de una parte sustanciosa de las ganancias derivadas de la adquisición misma, pero además, posibilitaría eliminar los problemas ligados a los conflictos de intereses entre sociedad controlada y sociedad de control, los costes de agencia cuando la reducción de

\footnotetext{
332 Sería suficiente la mera recompra de todas las rescatables emitidas con objeto no sólo de modificar la composición del accionariado (hasta una cuarta parte del capital social) y la correlación de fuerzas en la Junta General, sino de reducir el volumen de acciones flotantes en el mercado y restringir las posibilidades de que el oferente se haga con un alto porcentaje de participación corporativa, sobre todo si el grupo que ostenta la titularidad de aquéllas se encuentra tan escasamente fidelizado al núcleo estable de accionistas que sus acciones serían presa fácil en el plan de toma de control (weak hands o pequeños ahorradores).

333 "La rescatabilidad podría presentar utilidad en las operaciones de exclusión (o de mero sometimiento) de la minoría accionarial, conocidas como minority freezeouts" (Paz Ares, 2002: 54).

${ }^{334}$ La operación de squeezeouts es una institución típicamente estadounidense, que significa una claudicación del Derecho de sociedades por acciones al Derecho del mercado de capitales, al suponer la posibilidad de que parte de los socios puedan ser excluidos de la entidad por acciones sin causa justificada, aunque sea enmarcado dentro de un procedimiento estrictamente regulado.
} 
la base accionarial va acompañada de la exclusión de la cotización de las acciones de la minoría, y en general, los costes atribuibles a la propiedad difusa de la empresa.

Las acciones rescatables se han utilizado como una medida eficaz en el control corporativo en Estados Unidos ${ }^{335}$ y Países Bajos ${ }^{336}$, aunque todavía en España no realizó ninguna emisión con esta finalidad ${ }^{337}$.

\subsubsection{Reestructuración financiera}

Dentro de este apartado, se incluye el conjunto de posibles finalidades por las que pueden ser utilizadas las emisiones de acciones rescatables para la reestructuración financiera de su capital.

La reestructuración financiera del capital puede utilizarse para sanear una compañía o para reorganizar su capital permanente por razones estratégicas. Las estrategias financieras pueden tener dos orientaciones divergentes: la conversión de capitales propios en capitales ajenos para aprovechar el efecto apalancamiento o la transformación de los acreedores en accionistas.

Aunque sí tenemos ejemplos de dos compañías españolas que han realizado emisiones con motivaciones de saneamiento y reorganización financiera, no existen emisiones relacionadas con los casos específicos de joint venture ni de préstamos participativos. Dentro de la reorganización financiera, una sociedad transformó los acreedores en accionistas, mientras que no han aparecido ejemplos en sentido contrario (la conversión de capitales propios en capitales ajenos para aprovechar el efecto apalancamiento).

Antes de la incorporación de las acciones rescatables a la legislación española en 1998, la finalidad de la emisión de Compañía General de Ferrocarriles fue atender a la reestructuración financiera de la compañía convirtiendo en accionistas a parte de los acreedores.

La Compañía General de Ferrocarriles, S.A. (hoja número 12.859 del Registro Mercantil de Barcelona), que tenía emitidas obligaciones hipotecarias realizadas de los años 1919, 1920, 1922 y 1924, alcanzó un acuerdo con sus acreedores para resolver su crisis financiera (Decreto aprobatorio del Convenio de saneamiento financiero número 2968 de 15 de noviembre de 1962, publicado en el BOE el 24 de noviembre de 1962). El saneamiento consistía en involucrar a los obligacionistas en la marcha de la sociedad mediante su conversión en accionistas y mediante su representación en el Consejo de Administración. Para ello se suprimieron los privilegios de las acciones ya existentes que se convirtieron en acciones ordinarias, y a una fortísima ampliación de capital (Expediente de revalorización y

\footnotetext{
335 Esta función es resuelta por las denominadas acciones rescatables utilizadas para casos de fusión (Redeemable-preferred Mergers). Esta figura es descrita por Paz Ares (2002: 54).

${ }^{336}$ Puede observarse su utilización en los Países Bajos en Schuit (1998: 47).

${ }^{337}$ No obstante, la doctrina española ha atisbado esta finalidad y por eso la desarrolla con detalle en sus monografías (Yanes Yanes, 2004: 64-68).
} 
reversión de líneas, resuelto por el Ministerio de Obras Públicas por Orden de 28 de septiembre de 1960). En virtud de la ampliación, las nuevas acciones se entregaron a los antiguos obligacionistas: por cada dos obligaciones se entregaron dos nuevas acciones preferentes, serie A y una nueva acción preferente serie $\mathrm{B}$, todas ellas totalmente liberadas. Los obligacionistas privilegiados pasaron a convertirse en accionistas privilegiados (titulares de acciones de la serie A con derecho al cobro de un dividendo de hasta el 5\% no acumulativo sobre el producto líquido de cada ejercicio y de la serie B con un segundo privilegio de hasta el $4 \%$ no acumulativo una vez retribuidas las de la serie A prioritaria). Al objeto de asimilar la posición de obligacionistas a la nueva situación en cuanto a la duración del derecho, se les entregaron acciones serie B rescatables.

Tras la entrada en vigor de la LRLMV en 1998, Campofrío realizó una emisión de rescatables como mecanismo de reorganización financiera. Con la emisión, Campofrío Alimentación trataba de financiar la compleja operación de adquisición de las acciones del Grupo Navidul, en posesión de los accionistas de esta última sociedad. A tal fin se entregaron a los accionistas del Grupo Navidul, y en pago parcial de las acciones transferidas a Campofrío, acciones de nueva emisión de la adquirente con la naturaleza de rescatables. La rescatabilidad buscaba garantizar a los accionistas de Navidul un incremento patrimonial mínimo de la compañía adquirente y de la inversión en ella tras la adquisición. El contenido del derecho de rescate consistía en la atribución a los titulares de las acciones rescatables y viejos accionistas de la compañía comprada, Grupo Navidul, de la posibilidad de percibir en metálico la diferencia entre el precio de cotización en bolsa de las acciones de Campofrío en determinada fecha y la cantidad de 15,05 euros por acción que se establecía como precio base de rescate. La finalidad del mecanismo de rescate a opción exclusiva de los tenedores es que representara una garantía de los nuevos socios de "Campofrío" frente a una posible caída de la cotización bursátil de las acciones ordinarias por debajo de un precio base asignado a la acción rescatable en el momento de su emisión, y que era el resultado de la valoración de las acciones de "Campofrío" tras la integración de negocios y actividades con "Navidul". La compleja operación realizada en Campofrío pudo haberse llevado a cabo sin haber utilizado la figura de las acciones rescatables, en concreto por medio de la emisión de acciones ordinarias con un pacto de recompra.

\subsubsection{Empresas con necesidades decrecientes de financiación}

Las acciones rescatables son muy útiles en las empresas con necesidades decrecientes de financiación. Las acciones rescatables son perfectas para atender a las peculiaridades de las empresas que requerían menos recursos en plazos predecibles, ya sean denominándolas "sociedades con patrimonio perecedero"338 o "sociedades con necesidad decreciente de capital"339.

\footnotetext{
${ }^{338}$ Sentencia del Tribunal Supremo del 21 de marzo de 1986.

339 Cosack (1904: 175), Gay de Montellá (1948: 192), Garrigues (1976: 310), Sánchez Andrés (1987: 370), Fernández del Pozo (1990: 1165), García Fronti y Navazo (2000: 8).
} 
En estas compañías, su propio objeto social hace necesaria una restitución paulatina de la inversión, realizada mediante el reembolso de las acciones emitidas. Las empresas de esta naturaleza tienen unas características específicas, pues deben poseer una concreta y cierta necesidad decreciente de recursos, y poder determinar los plazos y las cuantías que permitan establecer un plan de amortización prefijado ${ }^{340}$.

Las sociedades con necesidades decrecientes de capital son las que cumplen tres requisitos. Primero, en el momento inicial de su actividad necesitan una fuerte inversión y captación de recursos. Segundo, tales necesidades decrecen con el paso del tiempo. Y tercero, es posible determinar, de antemano, las anteriores dos situaciones.

La noción de sociedades con necesidades de capital decreciente es un concepto amplio que engloba empresas con diversas naturalezas:

- Empresas cuya explotación total o parcial está limitada temporalmente, como las constructoras de determinadas obras públicas, aeropuertos, carreteras, ferrocarriles, pantanos y puertos ${ }^{341}$.

- Sociedades que explotan proyectos de inversión que se suceden en el tiempo y que no quieren o no pueden crecer $^{342}$.

- Empresas de explotación de objetivos agotables después de cierto tiempo, como la explotación de minas, yacimientos o bosques ${ }^{343}$.

- Compañías concesionarias cuyas instalaciones deben revertir al Estado al finalizar la concesión de servicios públicos ${ }^{344}$.

- Inmobiliarias cuyo objetivo se limita a la promoción y venta de varias fincas, sin que con el beneficio se adquieran nuevos bienes o se persiga la reinversión, sino que se destine al reembolso por la vía de amortización de capital ${ }^{345}$.

- Entidades que explotan eventos culturales y deportivos puntuales, como Exposiciones Universales, campeonatos deportivos u Olimpiadas.

Sólo una emisión de acciones rescatables de todas las realizadas hasta el momento en España, presenta la finalidad de satisfacer las necesidades decrecientes de capital: la realizada por la Sociedad de Aparcamientos de Tarrasa ${ }^{346}$.

\footnotetext{
${ }^{340}$ Uno de los primeros autores que desarrolla el interés de la emisión de rescatables en aquellos casos en que sea relativamente posible prever necesidades decrecientes de capital, es Garrigues (1952). Posteriormente, el autor define a estas empresas como "una cierta especie de sociedades en las que sería posible predecir de antemano la restitución paulatina de la inversión en recursos propios realizada” (Garrigues, 1976: 310).

${ }^{341}$ Gay de Montellá (1948: 192) y Chamorro (2007: 155).

342 Fernández del Pozo (1990: 1165; 1992: 251), Alonso Ledesma (1999: 29), García-Cruces (2002: 919) y García-Cruces (1999: 1949).

343 Gay de Montellá (1948: 192), García Fronti y Navazo (2000: 8), Chamorro (2007: 155), Alonso Ledesma (1999: 29), García-Cruces (199: 1949; 2002: 919).

344 Gay de Montellá (1948: 192), Sánchez Andrés (1987: 370). Pérez de la Cruz Blanco (1971: 46) y Chamorro (2007: 155).

${ }^{345}$ Cosack (1904: 175).

${ }^{346}$ La Sociedad de Aparcamientos de Tarrasa era una empresa mixta de capital (parte capital público, parte capital privado), cuyo objeto social era la construcción y explotación de un aparcamiento para vehículos en la
} 
Para el caso concreto de compañías concesionarias cuyas instalaciones deben revertir al Estado al finalizar la concesión de servicios públicos, sí es posible encontrar ejemplos de empresas concesionarias con necesidades decrecientes de capital, aunque no tienen porqué necesariamente tener todas las concesionarias la citada condición. En las sociedades concesionarias de obras o servicios públicos ${ }^{347}$, los socios deben recuperar el valor de las acciones antes de que los elementos patrimoniales reviertan y los activos no corrientes pasen a la entidad concedente. Sin embargo, no es cierto que la pura existencia de un título concesional con duración limitada obligue a amortizar las acciones de la sociedad cuyo objeto es la explotación de la concesión. La duración temporal de la concesión suele traducirse en la reversión de los activos afectos, en buen estado de explotación, y generalmente a un precio nulo o simbólico ${ }^{348}$, pero ese rescate del capital privado no viene exigido por la reversión de los activos, sino por el estatuto de las sociedades públicas de economía mixta ${ }^{349}$.

Las sociedades concesionarias de obras o servicios públicos en España han estado históricamente dedicadas al sector minero y sobre todo ferroviario. Los principales ejemplos de empresas concesionarias españolas se encuentran en las compañías privadas ferroviarias que todas funcionaron con el sistema de concesión hasta su nacionalización y creación de RENFE. Entre ellas, Compañía de los Caminos de Hierro del Norte de España (NORTE), Compañía de los Ferrocarriles de Madrid a Zaragoza y Alicante (MZA), Compañía de Ferrocarriles de Tarragona a Barcelona y Francia, Compañía de los Ferrocarriles Andaluces, Compañía de los Ferrocarriles de Madrid a Cáceres y Portugal, Compañía Nacional de los Ferrocarriles del Oeste de España, Compañía de los Caminos de Hierro del Sur de España, Compañía de los Caminos de Hierro de Granada (Baza-Guadix), The Great Southern of Spain Railway Company (Compañía de los Ferrocarriles de Lorca a Baza y Águilas) y Compañía del Ferrocarril Santander-Mediterráneo. El sistema de concesión provocó que las ferroviarias

Plaza del Doctor Robert de la ciudad de Tarrasa. La duración de la sociedad era de cincuenta años a contar desde la fecha de inscripción en el Registro Mercantil. El capital social era de 131 millones (1.000 pesetas de valor nominal) dividido en dos clases: A (suscritas por el ayuntamiento) y B (suscritas por accionistas privados). De conformidad con lo establecido en el artículo 248.4 de la Ley municipal y de Régimen Local de Cataluña y en el artículo 111.3 del Reglamento de Servicios de las Corporaciones Locales, las acciones de la clase B serían amortizadas a lo largo de toda la vida de la sociedad, para lo cual se preveía la dotación de una reserva de amortización. En caso de que, por no existir beneficio, no hubiera podido formarse la reserva indicada o sólo pudiera haberse formado en parte, el rescate de las acciones se realizaría o bien con cargo a nuevas aportaciones o mediante la reducción de capital cumpliendo con los requisitos establecidos en la Ley. La reserva se materializaría en valores con alta seguridad, principalmente valores públicos de renta fija, cuyo rendimiento sería ingresado en el fondo de reserva.

${ }^{347}$ La concesión, como técnica de gestión indirecta del servicio público, se caracteriza por ser temporal. El título concesional debe fijar un plazo definido que no podrá exceder de 99 años, según el artículo 64 de la Ley de Contratos del Estado y el artículo 22 de la Ley General de Ferro-carriles de 23 de noviembre de 1987, o de 50 años, según el Reglamento de Servicios de las Corporaciones Locales de 1955.

${ }^{348}$ El estatuto concesional incluye una cláusula de rescate de las acciones como solía ser frecuente en las empresas públicas municipales de economía mixta y respecto del capital privado (Fernández del Pozo, 1992: 248).

${ }^{349}$ El ejemplo típico del rescate de capital privado es el artículo 111 del Reglamento de Servicios de las Corporaciones Locales de 1955 y el artículo 289 del Reglamento de obras, actividades y servicios de los entes locales de Cataluña aprobado por Decreto 1791/1995, de 13 de junio. 
españolas intentaban invertir cada vez menos cantidades según iba llegando el final del periodo de concesión, sin embargo, en realidad las necesidades de inversión del negocio no eran decrecientes y el gasto corriente tampoco.

NORTE nunca emitió acciones rescatables, lo cual hubiera mejorado su estructura financiera, pero tuvo un intento de amortizar las acciones ordinarias. El presidente de la compañía dio cuenta al Consejo de la carta que le había dirigido el Administrador Garate sometiendo a su examen un proyecto muy detallado para poder efectuar la amortización de las acciones de la compañía, de forma que quedasen totalmente reembolsadas antes de revertir al Estado la últimas de las líneas que hubieran de entregar. El Consejo consideró una propuesta muy interesante y acordó que pasase a estudiarla el Comité Ejecutivo, con el fin de que pudiera exponer al Consejo su opinión tras el estudio (Acta $\mathrm{n}^{\circ} 911$ del Libro de actas del Consejo de Administración de NORTE: 27 de noviembre de 1920, Apartado III.5).

\subsection{Intervención de la Dictadura de Primo de Rivera. Auditoría externa}

La motivación del apartado es indagar sobre los orígenes de la auditoría obligatoria legal en España. Uno de los primeros intentos de realizar una auditoría es la revisión de las cuentas de las ferroviarias realizada por el gobierno militar de Primo de Rivera en 1923 sobre NORTE y MZA.

Es difícil afirmar que esta revisión fue la primera auditoría en España, porque, por un lado, es controvertido identificar las cualidades que debe tener una revisión de estados contables para tener la calificación de auditoría y, por otro lado, porque siempre pueden aparecer noticias de otra revisión desconocida hasta el momento en otro sector, o incluso en el mismo, que haga replantearnos la novedad absoluta de esta revisión. Sin embargo, esta revisión tiene una enorme importancia entre los incipientes esfuerzos de revisión de los estados contables, tanto por su meticulosidad y calidad, como por su importancia para el futuro de la contabilidad y la auditoría.

La revisión gubernamental de las cuentas de las concesionarias del ferrocarril tuvo un papel político innegable. Tanto que se plantea el interrogante de saber si la revisión tenía una motivación de conocer la situación económico-financiera de las compañías, o si en realidad fue un instrumento político para argumentar, por parte del Gobierno, la necesidad de que los anticipos -que el Estado llevaba abonando a las compañías desde hace varios años- dejaran de entregarse, principalmente, por la escasez de fondos en las arcas públicas en ese momento. La conclusión es que fue más un instrumento político que de validación de la situación económica, aunque el nivel de calidad de la revisión es elevado para el momento en que se realizó.

Mientras que han existido multitud de estudios dedicados a analizar la contabilidad de las compañías ferroviarias, sobre el tema de la auditoría de las empresas ferroviarias no ha existido hasta ahora apenas trabajos. 


\subsubsection{Origen de la auditoría en España}

Desde que existen estados financieros, hubo revisiones de estos documentos, pues siempre han existido personas con interés de conocer si la información contable incluida en los estados financieros cumplía las cualidades exigidas. Otro aspecto distinto es identificar cuándo la auditoría se institucionalizó como profesión, y cuándo se convirtió en obligatoria.

En España la auditoría profesionalizada y obligatoria llegó más tarde que en otros países ${ }^{350}$. El legislador español tardó en regular la actividad para el conjunto de sectores.

El sector ferroviario español fue el primero con antecedentes regulatorios destacables. Eso sí, con una variación respecto a lo establecido en el mundo anglosajón; hasta 1926, no se pensó en una revisión que beneficiara a los accionistas, sino en una fiscalización pública. Esta fiscalización era realizada por sujetos diferentes: el gobierno civil, expertos delegados del gobierno, funcionarios públicos ${ }^{351}$ y el cuerpo de contadores.

Los Códigos de Comercio de 1829 y 1885 fueron elaborados pensando en un tráfico entre pequeños comerciantes, por lo que no se plantearon regular la actividad de la revisión de cuentas. Posteriormente, la auditoría se intentó regular en tres ocasiones, aunque hasta 1951 nunca llego a convertirse en Ley.

En el artículo 34 del Real Decreto 17/1848, sobre compañías mercantiles por acciones, se establecían normas para la inspección de la contabilidad del conjunto de sectores. Por el contrario, la Ley de 11 de julio de 1856 sobre constitución de las compañías concesionarias de ferrocarriles es una ley específica para el sector ferroviario. En su artículo 11 se recoge que las compañías estarán obligadas a presentar al Gobierno, por medio del gobernador civil, un balance demostrativo y calificado de todo su haber activo y pasivo, que se debe publicar en la Gaceta; y siempre que el Gobierno lo pidiere remitirán por el mismo conducto estados que den pleno conocimiento de sus operaciones, así como las demás noticias y detalles relativos a los gastos e ingresos de la empresa. El Gobierno podrá además examinar, siempre que lo estime conveniente, la contabilidad y administración de las compañías, y comprobar sus existencias, nombrando a este efecto delegados retribuidos por las mismas sociedades, a quienes sus respectivos directores-gerentes o administradores tendrán obligación de presentar cuantos libros, datos, valores y documentos les fueren por estos pedidos y existieren o debiesen existir en sus oficinas.

La Real Orden de 12 de diciembre de 1857 (art. 14) y el Reglamento para el ejercicio de las funciones que corresponden á los gobernadores de provincia y delegados especiales del Gobierno cerca de las Compañías mercantiles por acciones de 12 de diciembre de 1857, establecieron que el Gobierno Civil exigirá copia de los balances generales comprobándolos con los libros de contabilidad.

\footnotetext{
${ }^{350}$ En España la auditoría "no surge como profesión hasta la década de 1960” (Fernández Peña, 1985: 427).

${ }^{351}$ Real Decreto de Creación de las Comisiones para examinar la contabilidad de las empresas e informar acerca de la situación económica de las mismas, 20 de octubre de 1923.
} 
El Proyecto de Ley sobre Inspección de Bancos y Sociedades Anónimas, presentada a las Cortes el 22 de octubre de 1910 por el ministro de Fomento Fermín Calbetón, establecía la inspección o censura de cuentas realizada por un cuerpo de contadores.

No existió un desarrollo explícito de la figura del censor de cuentas hasta la creación del "Instituto de Contadores Públicos de España” en 1912 (Alvarado Riquelme, 1998: 197) ${ }^{352}$.

El Proyecto de Reforma del Libro II del Código de Comercio, elaborado en 1926 por la Comisión General de Codificación, instauró tres medidas: (a) el artículo 88 reconocía a los socios el derecho a examinar la administración social, (b) el artículo 90 admitía que los socios pudieran valerse de revisores técnicos, conocedores de la contabilidad, para comprobar el balance y, por último, (c) los artículos 121 y 122 contemplaban el nombramiento de un Comité de Vigilancia, que debía examinar los libros contables y demás documentos, y redactar un informe dirigido a la Junta General en relación a la situación económica y patrimonial de la sociedad. En 1928, durante la presidencia de Primo de Rivera; el Ministerio de Trabajo, Comercio y Turismo elaboró un Real Decreto-Ley que encomendaba la actividad de auditoría a un cuerpo autónomo formado por expertos en contabilidad con título expedido por las Escuelas de Comercio ${ }^{353}$. Por fin, la primera legislación española que entró en vigor sobre censura de cuentas fue el artículo 108 de la Ley de Régimen Jurídico de las Sociedades Anónimas de 17 de julio de 1951, al regular la figura del "accionista censor de cuentas".

Tanto el Real Decreto 7/64, de 30 de abril, como el Reglamento de la Bolsa de Comercio aprobado por el Decreto 1506/1967, de 30 de junio, establecían que las empresas con valores admitidos a cotización, estaban obligadas a suministrar a la "Junta Sindical de la Bolsa", balances y cuentas de pérdidas y ganancias certificadas por técnicos titulados, miembros del Instituto de Censores Jurados de Cuentas.

Hasta este punto de la investigación, el término revisión de estados financieros y auditoría ha sido utilizado indistintamente sin ninguna diferenciación. Pero ahora pretendemos diferenciar ambos términos, para lo cual se identifican las cualidades que debe tener una revisión para ser considerada una auditoría externa de las cuentas anuales realizada de forma obligatoria por mandato legal.

Esta investigación parte de la idea ${ }^{354}$ de que una revisión debe ser considerada auditoría externa de cuentas anuales cuando cumpla tres requisitos ${ }^{355}$ : qué sea elaborada con arreglo al

\footnotetext{
352 En 1927 nace el Colegio de Contadores Públicos de Bilbao, y en 1936 los Institutos de Contadores Públicos de Madrid, Barcelona y Vigo.

${ }^{353}$ Estos tres intentos legislativos que no llevaron a ser Ley fueron analizados por Arana (1976) y Fernández Peña (1989: 477). Alvarado Riquelme (1998: 197) considera a estos intentos "como eco de lo que empezaba a ser una demanda social".

${ }^{354}$ No existe entre la doctrina una enumeración de requisitos más adecuada que ésta.

${ }^{355} \mathrm{La}$ diferenciación terminológica entre revisión de estados financieros y auditoría no es lo importante, lo fundamental son las cualidades que presenta esta revisión. Sin ir más lejos, la revisión objeto de esta
} 
marco normativo de información financiera, qué sea completa y qué tenga por objeto la emisión de un informe ${ }^{356}$. Para realizar un listado de características de una auditoría externa de cuentas anuales debe incluirse otra cualidad más: que sea externa, para diferenciarla de la auditoría interna. Una auditoría externa obligatoria y legal de cuentas anuales debe incluir dos características más: por un lado que sea obligatoria, para diferenciarla de la voluntaria, en la que no tendría obligación de realizarla, y, por otro lado, que la obligatoriedad tenga su origen en un mandato legal.

A efectos de esta investigación -lo cual es únicamente una opinión- una revisión contable debe ser considerada como una auditoría externa legal de las cuentas anuales de las empresas de un sector cuando cumpla las seis cualidades siguientes:

- Elaborados en función del marco normativo de información financiera vigente en ese momento.

- Completa, tanto del balance como del resto de componentes que formen en cada momento los estados financieros.

- Tenga por objeto la emisión de un informe con los resultados de la revisión.

- Externa, es decir realizada por personas ajenas a la empresa, para diferenciarla de una auditoría interna.

- Obligatoria, para diferenciarla de una voluntaria sin obligación de ser realizada.

- Legal u obligatoria por mandato legal, para diferenciarla de una obligación autoimpuesta por la empresa ya sea estatutariamente o por la junta de socios.

Las primeras empresas privadas españolas ${ }^{357}$ que realizaron una revisión de estados financieros con esas características fueron las concesionarias del ferrocarril ${ }^{358}$.

investigación, nunca recibió la denominación de auditoría por parte de los miembros de las Comisiones investigadoras de MZA y NORTE.

${ }^{356}$ Estos requisitos son concordantes con la legislación vigente en España sobre la actividad auditora, regulada en: art. 263-271, Real Decreto Legislativo 1/2010, de 2 de julio, por el que se aprueba la Ley de Sociedades de Capital (LSC), arts. 1-2 del Real Decreto Legislativo 1/2011, de 1 de julio, por el que se aprueba el texto refundido de la Ley de Auditoría de Cuentas (LAC) y arts. 1-4 Real Decreto 1517/2011, de 31 de octubre, por el que se aprueba el Reglamento que desarrolla el texto refundido de la Ley de Auditoría de Cuentas, aprobado por el Real Decreto Legislativo 1/2011, de 1 de julio (RAC). El art. 1.2 LAC establece que la auditoría de cuentas es la actividad consistente en la revisión y verificación de las cuentas anuales, así como de otros estados financieros o documentos contables, elaborados con arreglo al marco normativo de información financiera que resulte de aplicación, siempre que dicha actividad tenga por objeto la emisión de un informe sobre la fiabilidad de dichos documentos que pueda tener efectos frente a terceros. Los arts. 1.3. del LAC y 4.1. del RAC establecen que la auditoría de las cuentas anuales consistirá en verificar dichas cuentas a efectos de dictaminar si expresan la imagen fiel del patrimonio, de la situación financiera y de los resultados de la entidad auditada, de acuerdo con el marco normativo de información financiera que resulte de aplicación. El art. 2. del RAC establece dos modalidades de auditoría de cuentas, en función de los estados financieros o documentos contables objeto de examen: a) Auditoría de cuentas anuales, y b) Auditoría de otros estados financieros o documentos contables.

${ }^{357}$ A la hora de realizar esta investigación no nos consta que exista una auditoría externa de cuentas anuales con anterioridad a esa fecha. No obstante, es posible que sí exista en otro sector empresarial alguna revisión en España, en un momento anterior, que cumpla los requisitos establecidos para ello.

${ }^{358}$ Con anterioridad, las únicas revisiones relevantes son las que realizaban para todo tipo de empresas, la "Inspección Pericial de utilidades del Estado". Este organismo estaba compuesto por reconocidos profesionales mercantiles. Realizaba una revisión de tipo fiscal para identificar si los datos empresariales son adecuados para 
Hasta que no se reguló una específica revisión de estados financieros realizada por un ente externo, a las concesionarias del ferrocarril le eran aplicables lo regulado para todas las sociedades por acciones. Como hemos visto, desde 1856 existían diferentes disposiciones legislativas que obligaban a las ferroviarias a presentar periódicamente la documentación contable a los gobernadores de las provincias -o delegados especiales nombrados al efectopara someterla a la correspondiente inspección mercantil y/o administrativa.

El primer intento de instaurar una revisión de la contabilidad en las concesionarias del ferrocarril se dio en el Proyecto de Ley de 30 de diciembre de 1919, texto que fue aprobado en el Senado el 14 de enero de 1920, aunque fue paralizada su discusión en el Congreso. El Proyecto de Ley de 30 de diciembre de 1919 obligaba a las empresas ferroviarias a llevar una cuenta especial de los ingresos suplementarios que obtuvieran, la cual sería intervenida por delegados del Ministerio de Fomento, lo mismo que todos los demás gastos e ingresos de las empresas; quedando asimismo obligadas éstas a someterse a los fallos arbitrales del Gobierno, previo informe del Instituto de Reformas Sociales, en las cuestiones que surgieran con el personal y en las que pudieran derivarse sobre las mejoras a otorgar con los recursos procedentes del aumento de tarifas.

El segundo intento -considerado en esta investigación como la verdadera primera auditoría legal externa de las cuentas de las empresas de un sector- se dio casi cuatro años más tarde con la creación de comisiones investigadoras de la contabilidad de las compañías concesionarias del ferrocarril a partir de la aprobación de la Real Orden de 20 de octubre de 1923 para realizar revisiones en las cuentas de MZA y NORTE ${ }^{359}$. Esta revisión cumplía las seis características requeridas: estaba elaborada en función del marco normativo de información financiera vigente en ese momento, era completa ${ }^{360}$, tenía por objeto la emisión de un informe con los resultados de la revisión externa, obligatoria, y derivada de un mandato legal.

Pero además, esta auditoría cumplía una característica deseable: era generalizada. Una revisión con estas características implica que no se aplica a una única empresa, sino que se realizaba a un considerable número de empresas de un sector, o de un tamaño determinado dentro del conjunto de los sectores. La evaluación de este requisito pretende diferenciar una deseable revisión de la mayoría de empresas de un sector de una revisión unilateral aplicada a

realizar la liquidación del impuesto sobre sociedades, sin que pueda considerarse una auditoría contable del conjunto de los estados financieros, pero ni tan siquiera una revisión contable.

También son antecedentes las inspecciones realizadas por el Tesoro para exigir la satisfacción del importe de los gastos de inspección no reclamados desde 1986 (Real Decreto de 29 de diciembre de 1866).

${ }^{359}$ Real Decreto de Creación de las Comisiones para examinar la contabilidad de las empresas e informar acerca de la situación económica de las mismas, 20 de octubre de 1923.

${ }^{360}$ La Comisión pretendía que la revisión fuera completa. El Informe relativo a la Compañía NORTE era un análisis completo pues fue el primero que realizó una revisión del balance, de la cuenta de resultados y de las estadísticas incluidas en la memoria. Por el contrario, el realizado para MZA se limitó al balance. Seguramente, la Comisión observó mejor situación económico-financiera en el balance de MZA y consideró suficiene su análisis. 
una única empresa. Pueden existir dudas sobre la generalización de esta auditoría pues sólo se aplicó a dos empresas. No obstante, MZA y NORTE eran, con diferencia, las dos de mayor tamaño del sector. Como suponían el $63,41 \%$ de las líneas explotadas ${ }^{361}$ es posible inferir que gran parte del sector fue revisado. De este modo debe considerarse, pues el resto del sector estaba atomizado, y así lo entendió también implícitamente la Real Orden al limitarse a revisar únicamente ambas empresas.

Por tanto, al cumplir los seis requisitos podemos afirmar que las revisiones de MZA y NORTE fueron las primeras auditorías de cuentas anuales externas obligatorias por mandato legal realizadas en España; y estas revisiones, además, se realizaron por primera vez para la mayoría de empresas de un sector en nuestro país.

\subsubsection{Creación de comisiones investigadoras de la contabilidad de las compañías}

El General Primo de Rivera ordenó las primeras revisiones de estados financieros de las más representativas empresas de un sector en España: las empresas ferroviarias. Estas revisiones no fueron periódicas; fueron puntuales porque sólo se hicieron en el año 1923 con la intención de conocer la situación económica de las empresas para intentar resolver el problema ferroviario $^{362}$. El dictador concedió la máxima importancia a este problema, pues a los 27 días de tomar el poder, comenzó a tomar medidas para recabar información con la intención de resolverlo, y a los 40 días mandó crear unas Comisiones que realizaran una revisión de la situación económica-financiera de las compañías.

El 13 de septiembre 1923 tiene lugar el pronunciamiento del golpe de Estado del General Primo de Rivera y, dos días después, comienza el Directorio Militar, integrado por el propio Dictador más otros nueve militares. De los asuntos ferroviarios se ocupó el General de Brigada A. Mayandía Gómez, perteneciente al cuerpo de Ingenieros del ejército ${ }^{363}$.

Desde el primer momento, el Directorio creyó necesario replantear el tema ferroviario para lo que comenzó (con las Reales Ordenes de 10 de octubre de 1923) por abrir una información

\footnotetext{
${ }^{361}$ En 1923, MZA explotaba 3.663 kilómetros -2.944 de la Antigua Red y 719 de la Red Catalana- (De la Torre, 1923: 101) (MZA, 1924: 4). En 1923, NORTE explotaba 3.692 kilómetros (De la Torre, 1923: 65) (NORTE, 1924: 5). En ese mismo ejercicio económico, en España existían 11599 kilómetros de vía normal -11.559 a vapor y 40 eléctricos- (De la Torre, 1923: 62). El porcentaje de 63,41\% ha sido calculado por el cociente 7.355/11.599.

${ }^{362}$ La segunda auditoría legal externa de las cuentas de las empresas de un sector, fue establecida en la Real Orden de Fomento de 28 de septiembre de 1925 para evaluar si procedía o no la devolución de los anticipos. Y también fue para el sector ferroviario

${ }^{363}$ Varios miembros del cuerpo de Ingenieros del ejército habían intervenido de forma muy activa en la Asamblea Nacional de Ferrocarriles celebrada a fines de 1918. El capitán R. Marín del Campo y Peñalver presentó una ponencia titulada "Divorcio existente entre algunas empresas de ferrocarriles y sus empleados. Sus efectos, causas y remedio" (AHF S/35/92-5). El coronel Juan Avilés y el comandante Joaquín Aramburu propusieron, asimismo, unificar el ancho de vía, aumentar la capacidad de transporte y reorganizarlas por si se producía un conflicto bélico (AHF S/58/44).
} 
pública, requiriendo la presentación de escritos conteniendo las propuestas para mejorar el régimen ferroviario ${ }^{364}$.

Las Reales Órdenes de 10 de octubre de 1923 estaban compuestas por tres textos legales que entraron en vigor en esa fecha: la Real Orden Circular firmada por Primo de Rivera (en su cargo de presidente del Directorio Militar), la Real Orden firmada por Primo de Rivera (en su cargo de Jefe del despacho del Ministerio de Fomento) y la Real Orden firmada por José Vicente Arche (vicepresidente del Consejo Superior Ferroviario).

La Real Orden Circular de 10 de octubre de 1923 firmada por Primo de Rivera (en su cargo de presidente del Directorio Militar) abrió un periodo de información para recoger el sentir no sólo de las concesionarias, sino también de las diferentes corporaciones, asociaciones, empresas e incluso particulares. El trámite establecido en este documento se cumplió cuando la Dirección General de Obras Públicas envió un cuestionario a las corporaciones, asociaciones, empresas y particulares, donde se pedían ${ }^{365}$ propuestas para mejorar el régimen ferroviario.

La Real Orden firmada por Primo de Rivera (en su cargo de Jefe del despacho del Ministerio de Fomento) estableció la extraordinaria urgencia de las cuestiones pendientes de los ferrocarriles públicos. Por esta razón, el presidente del Directorio Militar dispuso que los vocales que integraban los Consejos Superiores de Obras Públicas y Ferroviario, dieran absoluta prioridad a los trabajos a realizar.

La Real Orden firmada por José Vicente Arche (vicepresidente del Consejo Superior Ferroviario) dispuso que los vocales que integraban el Consejo Superior Ferroviario deberían entregar en veinte días un documento que incluyera la formulación de un proyecto de bases para el régimen ferroviario.

Las compañías ferroviarias acudieron a la información pública abierta por el Directorio militar en las Reales Órdenes de 10 de octubre de 1923. NORTE y MZA cumplieron con ello, elaborando dos informes por separado y una ponencia en común ${ }^{366}$.

En los informes por separado, las empresas reivindicaban el carácter privado de la empresa ferroviaria e instaban al Estado a que aceptara -y respetara- el principio de que los ferrocarriles "deben bastarse a sí mismos"367.

\footnotetext{
${ }^{364}$ Las Reales Órdenes de 10 de octubre de 1923 son el mejor reflejo de la importancia que, desde los primeros momentos de su actuación, concedió el Directorio Militar al problema de los Ferrocarriles. El problema ferroviario entró ahora, según Artola (1978: 422), en su fase resolutiva.

${ }^{365}$ Los escritos se debían entregar en la Presidencia del Consejo de Ministros en sobres cerrados escritos por una sola cara del papel, con una extensión no superior a seis hojas tamaño folio corriente.

366 AHF P/113/254 y P/126/229. El informe conjunto ha sido analizado por Artola (1978: 423-423) у posteriormente por Ortúñez (1999a: 182-183), quien considera que las propuestas fueron bastante respetadas en la redacción del Estatuto de 1924.
} 
Las compañías NORTE y MZA presentaron conjuntamente, el 2 de noviembre de 1923, un Informe denominado "Principios esenciales en que se inspira el adjunto Proyecto de Bases para un régimen ferroviario" 368 .

En el Informe conjunto, ambas empresas reconocían tres sistemas de explotación: estatificación (es decir explotación por el Estado), absoluta libertad de las concesionarias y el de las concesiones intervenidas por el Estado. Los dos primeros métodos fueron totalmente desechados por ir en contra de la experiencia internacional de Francia, Inglaterra y Estados Unidos, y en el primer caso, además, porque el Estado no podría asumirlo. Sin embargo, se deja la puerta a una estatificación futura cuando las dos compañías afirman que "conviene prever la posibilidad de un rescate total en su día, pero disponiendo las cosas de modo que pueda hacerse con relativa sencillez y sin los inconvenientes casi insuperables que ofrece la legislación actual". Concluyen las dos ferroviarias que el sistema más adecuado en ese momento era el de concesiones con la adecuada y pertinente intervención del Estado, es decir, continuar con el sistema de explotación que existía hasta esa fecha ${ }^{369}$.

Teniendo en cuenta lo anterior, las dos compañías establecieron las bases de un Proyecto de nuevo régimen ferroviario, basándose en cinco aspectos:

- Las grandes compañías existentes deben ser conservadas, sin la formación de redes más amplias ni la segregación de líneas (como no podía ser de otro modo al ser afirmado "por las dos grandes").

- El nuevo régimen debe ser aceptado de forma voluntaria por parte de las compañías, solicitando que no fuese obligatorio.

- Las tarifas que se apliquen deben ser tales que los productos obtenidos basten para cubrir todos los gastos de explotación (incluyendo los de personal producidos por la aplicación de la jornada de ocho horas), pensiones, cargas financieras de toda clase, impuestos, amortizaciones, reservas de previsión e interés y reembolso de capital $^{370}$.

\footnotetext{
${ }^{367}$ El principio fundamental generalmente admitido de que los ferrocarriles se bastasen "por sí mismos" significa [es un eufemismo] para NORTE y MZA (932: 49) que las tarifas fuesen lo suficientemente altas para atender todos los gastos que consideraban las empresas.

368 Este documento, como no podía ser de otro modo, velaba por los intereses de las grandes compañías, separándose voluntariamente de la solución de los problemas de las empresas pequeñas. El informe y comentarios sobre él puede observarse en NORTE y MZA (1932: 48-49).

369 Según NORTE y MZA (1932: 48) era muy peligroso ensayar en España el sistema de Consorcio o Comunidad en el cual el Estado se asociara a las compañías para la explotación en común del negocio, según se había propugnado en los dos últimos Proyectos de Ley (Consorcio de la Cierva de 1921 y Comunidad de Maura de 1922). La asociación con el Estado equivaldría, a su juicio, a sumar cantidades heterogéneas, anulándose el ventajoso estímulo de la gestión industrial pura. También estimaban las empresas que no convenía al Estado multiplicar sus actividades interviniendo en estos negocios precisamente cuando el Directorio preconizaba medidas de descentralización de la Administración del Estado para simplificarla, opinando que la inspección y la defensa del interés público sería más eficaz por intervención fiscalizadora del Estado que con su participación directa en el negocio.

${ }^{370} \mathrm{El}$ hecho de que las tarifas fuesen necesarias para atender a estos gastos, fue considerado por las empresas como "el principio fundamental generalmente admitido de que los ferrocarriles se bastasen por sí mismos" (NORTE y MZA, 1932: 49).
} 
- Las compañías rechazaron por errónea la teoría de que cualquier recargo de las tarifas encarece la vida en proporciones sensibles, ya que estaba demostrado que el coste del transporte influye en un tanto \% muy reducido en los artículos vendidos al menudeo, y por lo tanto el coeficiente de recargo ha de tener una influencia mínima. Para las compañías es indispensable que se mantenga el principio de que el coeficiente de recargo variable sea único para todas las mercaderías.

- Las condiciones de rescate global del conjunto de líneas explotadas por cada compañía deben ser establecidas, simplificando el procedimiento para el supuesto en que el Estado conviniera hacerlo. Para ello se debe establecer una fecha media de reversión de todas las líneas de cada red en forma equitativa, y la anualidad de rescate será la que corresponda al producto medio neto obtenido por el quinquenio anterior a la reversión. Teniendo en cuenta que el establecimiento de las tarifas no depende de la compañía, el producto medio neto que sirve de base a la fijación de la anualidad no podrá ser inferior al obtenido en el quinquenio anterior a la guerra.

Las compañías, por su parte, se comprometían a cuatro hechos. En primer lugar, a una limitación de beneficios establecida en base de la media obtenida en el quinquenio anterior a la guerra, aparte de la prima de un buen servicio que se establezca. En segundo lugar, a conceder la jornada legal a sus agentes con las condiciones que establezca el Consejo Superior Ferroviario para los agentes que aún no la disfrutan, y a la creación de Tribunales arbitrales para resolver las diferencias que puedan presentarse entre las compañías y el personal. En tercer lugar, a presentarse al rescate de la totalidad de sus líneas, cualquiera que sea la legislación por la que fueron concedidas, con arreglo a las normas que se establezcan. Por último, a realizar las obras y adquisiciones de material que se concierten con el Estado.

Aunque importantes fueron las Reales Órdenes de 10 de octubre de 1923, la norma más transcendental fue emitida diez días más tarde: el Real Decreto de Creación de las Comisiones para examinar la contabilidad de las empresas e informar acerca de la situación económica de las mismas, 20 de octubre de 1923.

El Real Decreto de 20 de octubre de 1923, elaborado por el Directorio Militar de Primo de Rivera, sorprendió a las empresas porque se emitió justo antes de que llegara toda la información solicitada a las empresas por medio de las Reales Órdenes de 10 de octubre de 1923.

El Real Decreto de 20 de octubre de 1923 ordenó al Ministerio de Fomento la constitución de Comisiones $^{371}$, dependientes de la Dirección General de Obras Públicas. Las Comisiones se crearon por la Real Orden del Departamento de Fomento de 21 de octubre de 1923, en virtud de lo establecido en el Real Decreto de 20 de octubre de 1923. Las Comisiones investigadoras explicitaron que su objetivo era "examinar la contabilidad de las compañías concesionarias de

\footnotetext{
${ }^{371}$ Las Comisiones debían estar constituidas dentro del plazo de ocho días a partir de la publicación de la Real Orden de 20 de octubre de 1923.
} 
ferrocarriles de servicio general y de uso público e informar acerca de la situación económica de las mismas".

El artículo 1 del Real Decreto de 20 de octubre de 1923 establece que tales Comisiones estarían compuestas por "uno o dos ingenieros de Caminos o militares", un interventor de ferrocarriles y un perito contable, todos ellos funcionarios públicos ${ }^{372}$.

Concluidos los exámenes, las Comisiones deberían informar al Gobierno sobre la situación económica real de cada empresa.

Para realizar el Informe, las Comisiones deberían analizar los inventarios y balances de las empresas. Las Comisiones "examinarán, comprobarán y comentarán cuanto figure en el Activo y Pasivo de cada empresa", y estimen indispensable conocer a fondo, para juzgar su estado económico. Dentro del Informe, las Comisiones deben señalar las reservas constituidas con cargo a los productos netos de las explotaciones y, en su caso, las inversiones especiales realizadas de las mismas.

Como anejos a dichos Informes se incluirán estados diversos con los datos siguientes, tras realizar las oportunas comprobaciones ${ }^{373}$ :

a) Los ingresos de las empresas como productos de todas clases de las líneas.

b) Los gastos de las explotaciones de las líneas, cuidando muy especialmente de que en ellos no se comprendan más que los que técnica y racionalmente correspondan.

c) Los gastos generales de Consejos de Administración y otros semejantes.

d) Los gastos que representen las cargas financieras.

e) Los gastos representativos de los dividendos repartidos a los accionistas.

Para elaborar la documentación, las respectivas Comisiones solicitaron de las empresas que, "a la mayor brevedad" y "con el mayor detalle", las compañías remitieran a cada Comisión, por cuadriplicado, las cuentas de explotación y las cargas financieras correspondientes a los ejercicios 1913, 1919, 1922 y primeros meses de 1923, así como los balances de situación, inventarios de material y propuestas de obras, instalaciones y adquisición de material móvil y de tracción que consideraran necesarios. Las Comisiones no justifican porqué se solicita la información de estos ejercicios, y no los periodos 1914-1918 y 1920-1921. El primero de estos periodos se excluye por una razón obvia, porque aconteció la I Guerra Mundial y este hecho altera cualquier análisis. Es de suponer que se excluye el segundo periodo porque la Comisión prefiere detenerse en el ejercicio 1922 y los primeros meses de 1923 para centrarse en los veinte meses más cercanos a la revisión de estados financieros.

En cumplimiento de la Real Orden de 20 de octubre de 1923, la Real Orden del Departamento de Fomento de fecha 21 de octubre de 1923 constituyó la "Primera Comisión investigadora de

\footnotetext{
${ }^{372}$ Real Decreto de Creación de las Comisiones para examinar la contabilidad de las empresas e informar acerca de la situación económica de las mismas, 20 de octubre de 1923.

${ }^{373}$ Por esta razón, hemos comentado que la Comisión pretendía realizar un análisis completo, porque para cada empresa querían analizar balance (“activo y pasivo"), pero también la cuenta de resultados.
} 
la situación económica de las empresas del ferrocarril" que analizó NORTE, mientras que la "Segunda Comisión investigadora de la situación económica de las empresas del ferrocarril" revisó las cuentas de MZA. La auditoría se limitó a ellas porque en ese momento ambas constituían casi dos tercios de toda la red de ancho ibérico.

Ambas Comisiones reclamaron, el 30 de octubre de 1923, a las compañías NORTE y MZA, una batería de detalladas informaciones.

Cumpliendo la brevedad exigida, entre el 2 y el 6 de noviembre de 1923, las compañías, NORTE $^{374}$ y MZA ${ }^{375}$, enviaron toda la información solicitada.

El 29 de noviembre de 1923, fechado en Madrid, la Comisión encargada de analizar NORTE $^{376}$ y la encargada de revisar MZA ${ }^{377}$ emitieron sendas conclusiones basadas en los documentos elaborados por las compañías.

El 6 de diciembre de $1923^{378}$, la Dirección de NORTE ${ }^{379}$ y MZA ${ }^{380}$ contestan al "informe y documentos complementarios" del Informe realizado por la Comisión.

Los puntos comunes de fricción entre los documentos de MZA y NORTE, frente al Informe de la Comisión ${ }^{381}$, son: la constitución de las reservas por parte de las compañías, el reparto de dividendos a los accionistas, la clasificación de cuentas de primer establecimiento o costes de explotación de obras realizadas, y la supresión o no de los anticipos para el personal.

La realización de todos estos pasos, permitieron la emisión de un Informe ${ }^{382}$, por parte del Consejo Superior Ferroviario, en el que se proponían los principios en los que debe fundamentarse el nuevo régimen ferroviario; este informe fue comunicado a las compañías el 2 de noviembre de 1923. El 14 de enero de 1924 se formuló, por el General Mayandía, el proyecto definitivo, que sirvió de base para la discusión en el Consejo Superior Ferroviario y que fue el germen del Estatuto Ferroviario de 1924.

\footnotetext{
${ }^{374}$ El 6 de noviembre de 1923, la Dirección de NORTE ya había enviado el examen de su compañía. AHF P113-258-1: "Memoria sobre la situación económica de la Compañía NORTE” (Peña y Pérez, 1940, tomo. I, 89109).

${ }^{375}$ Tan sólo seis días después de recibir el oficio de la Segunda Comisión, que debía investigar las cuentas de MZA, Maristany (director de MZA) firmaba un oficio dirigido al presidente de la Segunda Comisión, en la que le informaba que "ya había enviado toda la información" (AHF P/113/257-1).

${ }^{376}$ AHF P-113-258-1: "Memoria sobre la situación económica de la Compañía NORTE” (Peña y Pérez, 1940, tomo I, 89-109).

377 AHF P/113/257-3: "Informe de la Comisión investigadora sobre la Compañía MZA".

${ }^{378}$ Sólo un mes después de enviar la información requerida.

379 AHF P-113-258-1: “Memoria sobre la situación económica de la Compañía NORTE” (Peña y Pérez, 1940, tomo I, 89-109).

${ }^{380}$ AHF P/113/257-3: "Informe de la Comisión investigadora sobre la Compañía MZA".

${ }^{381}$ Estos puntos de fricción entre los documentos han sido apuntados por Ortúñez (1999a: 186-187).

${ }^{382}$ El detalle del Informe, así como las observaciones e informaciones dadas por las compañías al proyecto de nuevo régimen puede leerse en NORTE y MZA (1932: Capítulo VIII).
} 


\subsubsection{Motivaciones del legislador para instaurar las auditorías}

El Directorio militar necesitaba diagnosticar la situación antes de configurar el nuevo régimen ferroviario.

Dos fueron las principales motivaciones del Directorio para establecer una auditoría de estados financieros sobre las ferroviarias: por un lado, resolver las dudas surgidas entre la ciudadanía y los diversos grupos de presión sobre el nivel de fiabilidad de las cuentas anuales $\mathrm{y}$, por el otro, el deseo del Directorio de eliminar los anticipos concedidos desde hace tiempo a las ferroviarias, principalmente, por la delicada situación de la Hacienda española.

\subsubsection{Dudas sobre la fiabilidad de las cuentas anuales}

Las dudas sobre la fiabilidad de las cuentas de las ferroviarias fueron observadas múltiples veces desde el gobierno, la prensa, los políticos y la opinión pública en general.

Las empresas ferroviarias chocaron casi siempre con las reticencias del gobierno de turno, que no acababan de creerse las cuentas que presentaban las concesionarias (Comín, et al., 1998: 289 y 299-300).

Martínez Aquerreta (1908) publicó un alegato contra las compañías a las que culpaba de manipulación sistemática de sus balances. Para que la obra no pasara desapercibida, mandó quinientos ejemplares a las Cortes y a los principales periódicos de la época.

Por su parte, la Gaceta de los Caminos de Hierro (8 de octubre de 1912) publicó que "cuando en ocasiones como la presente se han expuesto cifras representativas de la precaria situación de las compañías, casi todos dudaron de su actitud".

En un artículo en el periódico El Sol de 1920, Olariaga escribió que "El público español está habituado ya a que se acuse de la falta de exactitud cada vez que se habla de las compañías ferroviarias" ${ }^{, 383}$.

La opinión pública española recelaba de la fiabilidad de los estados financieros que publicaban anualmente las concesionarias. Se pensaba que no reflejaban la situación real, sino que se trataba de cálculos interesados, detrás de los que se escondían cuantiosos beneficios. Tanto dudaba la opinión pública de la fiabilidad de las cuentas de las ferroviarias, que reclamaba una intervención de los gobiernos. La reclamación de esta intervención residía en la gran cantidad de subvenciones recibidas por las compañías, apreciación compartida por bastantes personas que ocupaban altos cargos ${ }^{384}$.

\footnotetext{
383 "El público español está habituado ya a que se acuse de la falta de exactitud cada vez que se habla de las compañías ferroviarias, sin embargo (...) nuestras compañías se hallan en situación francamente satisfactoria" (Olariaga, L. El Sol, 22 de junio de 1920).

${ }^{384}$ El grupo Arnús-Gari reclamó una intervención coercitiva de los gobiernos en su ponencia a la Asamblea Nacional de Ferrocarriles de 1918. En su opinión, la ciudadanía lo reclamaba principalmente por las grandes
} 
En la Sesión del Congreso del viernes 26 de marzo de 1920, el diputado socialista A. Saborit preguntaba al Gobierno si tenía previsto algún tipo de intervención en los libros de contabilidad $^{385}$. El diputado exigió una inspección, con garantía parlamentaria, porque no se fiaba, en absoluto, de la ofrecida por las concesionarias.

La Comisión que investigó las cuentas de NORTE reconoció que la revisión se realizó en "estos tiempos en que con tanta profusión circulan insinuaciones y supuestos injuriosos"386.

Es comprensible el alivio que produjo a las ferroviarias la buena valoración que de ellas realizaron las Comisiones. La Comisión que investigó sus cuentas de NORTE expresó que sus estados financieros respondían "a la verdad de los hechos contables"387. Por su parte, la Comisión que analizó MZA consideró que la contabilidad de la compañía era "buena, clara, aceptable y hasta previsora" y valoraba como "saludable" en líneas generales la situación económica $^{388}$.

La credibilidad de las ferroviarias siguió estando bajo mínimos después de la auditoría de 1923, como lo demuestra que en 1932 se autorizara una nueva inspección económica y financiera (Orden del Ministerio de Obras Públicas de 3 de enero de 1932) por miembros del Cuerpo Pericial de Contabilidad del Estado para comprobar de nuevo "si era exacto que la aguda crisis que las compañías sufren les imposibilita para atender las reclamaciones de aumentos de sus agentes y obreros" (MZA, 1932: 26). Una medida que fue celebrada por la Asociación de Accionistas y Obligacionistas de Ferrocarriles "ya que así se conocerá de manera oficial la realidad de la situación de las empresas" (MZA, 1933: 209-210).

\subsubsection{Dudas sobre si deben continuar los anticipos}

El Decreto de creación de las Comisiones hace referencia explícita a los anticipos, refiriéndose a ellos como "los auxilios que vienen recibiendo del Estado, no previstos en las leyes generales de Ferrocarriles ni en los pliegos de condiciones particulares de las concesiones respectivas" 389 .

subvenciones recibidas por las compañías, apreciación compartida por bastantes "personas que ocupan altos cargos" (AHF S/35/92).

385 Congreso de los Diputados. Extracto Oficial n ${ }^{\circ} 95$.

${ }^{386}$ Peña y Pérez (1940, tomo I, Memoria sobre la situación económica de la Compañía de los Caminos de Hierro del NORTE de España, 89-109)

${ }^{387}$ Peña y Pérez (1940, tomo I, Memoria sobre la situación económica de la Compañía de los Caminos de Hierro del NORTE de España, 89-109).

${ }^{388}$ La Comisión que analizó MZA consideró que la contabilidad de la compañía era "buena, clara, aceptable y hasta previsora" y valoraba como "saludable" en líneas generales la situación económica, lo que le había permitido repartir un dividendo de 22 pesetas en 1922. Sorprende la valoración de la Comisión, cuando al final de informe, señalaba que sin el anticipo se hubiera registrado déficit. AHF P/113/257-3: "Informe de la Comisión investigadora sobre la Compañía MZA".

${ }^{389}$ Real Decreto de Creación de las Comisiones para examinar la contabilidad de las empresas e informar acerca de la situación económica de las mismas, 20 de octubre de 1923. 
El Informe de la Segunda Comisión que revisó las cuentas de MZA señaló que comprendía las razones que llevaron a la Administración a autorizar los anticipos de personal pero, sin embargo, creía que le faltó "previsión" al concederle a MZA "un montante excesivo" (AHF P-113-257-4).

El tema de los anticipos es clave para hacer una correcta lectura del pensamiento de los hombres de la Dictadura, incluido el propio Primo de Rivera. La opinión de políticos y sindicatos, era que las compañías manipulaban los datos, exagerando los gastos de personal para seguir obteniendo los anticipos.

Es posible identificar tres grupos principales de anticipos: (1) Anticipos para adquisición de material móvil y motor, (2) Anticipos especiales, y (3) Anticipos concedidos para realizar mejoras en los haberes del personal.

La primera clase de anticipos son los que tienen como finalidad la adquisición de material móvil y motor. El Real Decreto del Ministerio de Fomento de 15 de octubre de $1920^{390}$ autorizó a este Ministerio a realizar anticipos en metálico a los concesionarios que habrían de destinarse a la adquisición del material móvil y de tracción. Los productores nacionales de material móvil y de tracción tendrían preferencias sobre los extranjeros a la hora de hacer los suministros dentro del margen de protección establecido por la Ley de 14 de febrero de 1907.

Estos anticipos habrían de ser desembolsados en el plazo de veinte años, devengado el 5\% de interés y comenzando los reintegros anuales a los doce meses de efectuada la entrega de cada una de las cantidades.

Esta medida estaba pensada para ser muy relevante y con efectos positivos sobre el tejido industrial español, porque supondría una medida potencialmente reactivadora de la actividad económica al incorporar unas grandes cantidades de capitales para los productores de materiales españoles. No obstante, a las compañías ferroviarias no les terminaba de gustar porque sospechaban que al limitar sus posibilidades de adquisición a los proveedores nacionales, éstos establecerían unos precios poco competitivos, lo que supondría algo parecido a una entrega de dinero del Estado a los proveedores de material sin que las compañías ferroviarias pudieran disfrutar de ello. Además, las compañías no estaban conformes con el tratamiento establecido, porque no coincidió con la inicial declaración ministerial. Según admitían las concesionarias, el Real Decreto de 15 de octubre de 1920 el Estado les concedió "sencillamente un préstamo de más de un $8 \%$ anual de intereses" (NORTE y MZA, 1932: anejo 14).

\footnotetext{
${ }^{390}$ El texto del Real Decreto del Ministerio de Fomento de 15 de octubre de 1920 puede observarse en NORTE y MZA (1932: anejo 14). El Consejo de Administración debate sobre el Real Decreto del Ministerio de Fomento de 15 de octubre de 1920 para hacer a las concesionarias de ferrocarril anticipos en metálico que habrán de destinarse a la adquisición de material móvil y de tracción. En el Consejo se explica que las cuatro principales compañías se habían reunido y habían afirmado que "se consideraba grandemente lesivo para los intereses de las compañías las condiciones para el reintegro al Estado de los anticipos, puesto que con ellas se grava su futura situación financiera durante 20 años" (Acta n 906 del Libro de actas del Consejo de Administración de NORTE: 29 de octubre de 1920, Apartado I).
} 
La única petición de las compañías aceptada por el Gobierno fue que en caso de la reversión anticipada de las líneas al Estado, las compañías quedarán liberadas de la obligación de satisfacer al Estado las anualidades de reintegro del anticipo ${ }^{391}$.

El segundo tipo son los anticipos especiales. Son anticipos otorgados por el Estado, en diversas ocasiones en que alguna circunstancia lo aconsejó. Fueron concedidos con arreglo a distintas condiciones estipuladas en las disposiciones ministeriales; entre ellos destacan tres:

- El concedido a NORTE para la electrificación en la Rampa de Pajares

- El facilitado para la concesión de la línea del ferrocarril metropolitano de Barcelona, comprendida entre la estación de NORTE y la plaza de Cataluña, del cual se considera como auxilio a fondo perdido la cantidad de 75.000 pesetas por kilómetro, reintegrándose el resto del anticipo, que asciende hasta el 50\% del importe medio del presupuesto de contrata cuando el tráfico rebase un cierto límite fijado en el Real Decreto-Ley de 29 de abril de 1927.

- Los otorgados a diversas compañías, entre otras NORTE, en concepto de préstamo para pago de atrasos por exceso de jornada de ocho horas.

La tercera clase son los anticipos concedidos para conceder mejoras de los haberes del personal, que son el objeto de este apartado.

Dentro de las ayudas financieras del Estado, destacan los "anticipos reintegrables sin interés" otorgados por el Estado a las ferroviarias entre 1920 y 1926 (a partir de la R. O. de 23 de marzo de 1920) para hacer frente a los incrementos salariales. Estos anticipos fueron el centro de la discusión, debate y análisis que se produjo cuando el Directorio Militar decidió en 1923 nombrar Comisiones de funcionarios para la inspección de la contabilidad de las dos principales ferroviarias españolas, NORTE y MZA.

Para entender correctamente esta primera auditoría, es necesario encuadrar el proceso que llevó a ello y las motivaciones del gobierno de la Dictadura para realizarla, que fundamentalmente era eliminar el pago del anticipo por la mala situación del Erario Público de la época.

En las grandes empresas, sobre todo en NORTE, se sucedían las reivindicaciones económicas, las peticiones de mejora del personal y las luchas sociales que tanto auge había de adquirir en fechas posteriores. En 1909 empezó la Casa del Pueblo de Madrid en su labor de organización del personal, tanto obrero como administrativo, de las compañías de ferrocarriles. En NORTE, los movimientos reivindicativos fueron realizados por la sección sindical de NORTE de la Federación Nacional de Ferroviarios Españoles.

\footnotetext{
${ }^{391}$ La aceptación de esta solicitud puede observarse en los Reales Decretos de 14 de febrero de 1921, que adjudicaba a diversos constructores el suministro de locomotoras para las compañías MZA, MCP, Andaluces, MS y MZOV (Gaceta de los Caminos de Hierro: 15 de febrero de 1921).
} 
En la reunión que mantuvo el Gobierno el 27 de septiembre de 1912 con las cuatro grandes (NORTE, MZA, Andaluces y MCP) a propósito de la convocatoria de huelga general ferroviaria, estas adujeron falta de medios para atender las demandas de los empleados. El presidente del Gobierno, José de Canalejas, respondió que él estaba de acuerdo, pero la opinión pública no (Juez, 1992: 481-482).

La confrontación laboral se agravó con el conato de huelga general de 1 al 6 de octubre de 1912 y, sobre todo, desde el inicio de la espiral inflacionista de 1914. Los empleados demandaban compensaciones que atenuasen el creciente distanciamiento que se estaba produciendo entre el coste de la vida, en creciente alza, y el poder adquisitivo de los salarios.

Las discrepancias entre la sección sindical de NORTE de la Federación Nacional de Ferroviarios Españoles y la empresa desembocaron en la huelga de los días 12 al 20 de julio de 1916, resuelta gracias a una decisión arbitral. El 10 de agosto de 1916 se emitió el Decreto que refrendaba el laudo dictado por su presidente G. de Azcárate, consistente en la concesión de una mejora salarial equivalente a una gratificación especial, la imposición a las empresas del reconocimiento de las asociaciones y sindicatos libremente constituidos en los servicios públicos y la negociación como la vía adecuada para resolver los conflictos.

El año siguiente arreciaron las protestas y exigencias de los trabajadores, desembocando en la polémica huelga del 11 al 17 de agosto de 1917 en la que hubo muchos actos de sabotaje ${ }^{392}$. Las compañías concedieron otras dos gratificaciones: una en 1917 y la otra en 1918. A estas alturas, las finanzas de las empresas presentaban un estado lamentable. Para los directivos, la solución coyuntural pasaba por reducir los costes de explotación y porque el Estado revisara al alza las tarifas. Argumentaban que, de no hacerse, las empresas no podrían renovar equipos e instalaciones ni retribuir dignamente al personal. El Estado se había reservado la competencia de fijar las "tarifas máximas" al objeto de que los consumidores no pagaran precios abusivos por el servicio. Con esto, el gobierno intentaba "proteger al público" frente al eventual abuso de las empresas. Visto desde el momento actual, si se hubiesen revisado las tarifas legales las protestas se hubieran atenuado, al menos en la parte promovida por las compañías; por ello parece un error que no se hubiesen revisado aún las tarifas legales cuando la ley facultaba a los gobiernos para hacerlo cada cinco años, sin tener que pasar por el Parlamento.

Al acabar la primera Guerra Mundial, los problemas se acrecentaron. Las compañías se encontraron sin recursos e inmersas en la más grave crisis de toda su existencia. Los contemporáneos la denominaron Problema Ferroviario y la esencia no era otra que el desequilibrio entre ingresos y gastos ${ }^{393}$. Si el Estado quería garantizar un servicio público, que consideraba imprescindible, no le quedaba otra opción que permitir la subida de tarifas y, si no alcanzaba, auxiliar económicamente a las compañías de manera temporal. Y eso es lo que hizo en 1918 permitiendo el recargo del 15\%, en 1920 con los "anticipos reintegrables", y en 1926 invirtiendo directamente en infraestructura. Sólo así pudieron hacer frente al incremento de los

\footnotetext{
${ }^{392}$ En total hubo cuatro huelgas ferroviarias hasta el Estatuto Ferroviario: del 1-6 de octubre de 1912, del 12-20 de julio de 1916, del 11-17 de agosto de 1917 y del 23-24 de marzo de 1920.

${ }^{393}$ El problema era también jurídico, pero en este caso confluyen los problemas económicos, jurídicos y otros.
} 
costes de personal, renovar el material necesario en la explotación y mejorar la infraestructura. La contrapartida fue una mayor injerencia del Estado en las compañías privadas, que condicionó su gestión.

Los gerentes de NORTE y MZA sólo barajaban la solución de que el Estado revisara al alza las tarifas, de manera que cubrieran gastos de explotación, cargas financieras y una remuneración "razonable" del capital. Argumentaban, que si no había elevación, la empresa no podría renovar los equipos e instalaciones ferroviarias por falta de recursos. La pretensión de trasladar el aumento de los costes a los precios chocó con la oposición de prácticamente todos los sectores sociales interesados en el transporte barato; el recargo de las tarifas existentes [replicaban] tendría un efecto multiplicador sobre unos precios ya de por sí desenfrenados. El posible aumento de tarifas chocó siempre con la negativa de la Sociedad (cámaras de comercio, círculos mercantiles, asociaciones de agricultores y de ganaderos), que exigía un servicio más barato $^{394}$. Estas reticencias se repitieron antes de 1918, y en las peticiones oficiales de las ferroviarias de diciembre de $1918^{395}$, julio de 1919 y noviembre de 1919.

El 26 de diciembre de 1918, el ministro J. Gómez Acebo, Marqués de Cortina, en medio de una gran polémica, autorizó - Real Decreto de 26 de diciembre de $1918^{396}$ - un recargo máximo del $15 \%$ sobre las tarifas existentes, lo que permitiría a las ferroviarias conceder a sus trabajadores, con efectividad desde enero de 1919, una nueva gratificación y un plus extraordinario ${ }^{397}$. En el Preámbulo de este Decreto (Decreto del Marqués de Cortina) ${ }^{398}$, se estableció que se tomaba esta medida "para resolver la situación absolutamente insostenible del personal obrero" y "evitar la ruina financiera de las compañías". A cambio obligó a las empresas a llevar una cuenta especial donde se recogieran los ingresos fruto de este aumento; esto obligaba a las concesionarias a contabilizar de forma independiente los ingresos provenientes de esta subida con el objeto de no computarlos como productos líquidos en un futuro rescate ${ }^{399}$.

\footnotetext{
${ }^{394}$ Cambó (1918-1921, tomo VI: 240) lo explicó de forma clara: “Todo se reduce, en realidad, a que quienes se sirven de ferrocarril tienen la aspiración, muy humana (...) de que el transporte les resulte lo más económico posible; y que quienes han colocado sus capitales en la industria ferroviaria ansían una remuneración, por lo menos equivalente a la que se obtiene en las demás industrias".

${ }^{395}$ En ese momento las compañías estaban librando una dura batalla con el gobierno y los representantes de los consumidores (cámaras de comercio, círculos mercantiles y asociaciones de agricultores y ganaderos) para lograr trasladar el incremento de los costes a los precios; argumentaban que, mientras aquéllos se habían disparado, las tarifas permanecían estacionarias, lo que no sucedía en ningún país europeo (Ramos Gorostiza y Martínez Vara, 2008: 26).

${ }^{396}$ Previamente, el 22 de octubre de 1918 había presentado Cambó un proyecto de ley, autorizando la subida de tarifas (el 15\%), pero, como el 16 de diciembre se suspendieron las sesiones de las Cortes, el Gobierno recurrió al procedimiento al que se debía haber recurrido mucho antes pues lo permitía el marco legal.

${ }^{397}$ Ceballos Teresi (1915a: 23; 1915b: 112; 1917: 64), Madariaga (1913: 94; 1923: 1105-1106), Andrade (1919), "El Boletín" de febrero de 1920, "El Boletín" de marzo de 1920 y Boag (1923).

${ }^{398}$ El texto completo puede encontrarse en Cambó (1918-1921, tomo VI, 226-227).

${ }^{399}$ Para el ministro de Fomento Ortuño (1920b) "este fue un paso [decisivo] (...) en el sentido de la intervención del Estado en la gestión económica de las Compañías". Muñoz Rubio y Vidal Olivares (2001) consideran que la medida de obligar a las concesionarias a contabilizar de forma independiente los ingresos provenientes de esta subida tuvo enorme trascendencia, pues significó que el Estado se estaba convirtiendo, por la vía de los hechos, en socio de ellas.
} 
Esta elevación de tarifas fue considerada, por las concesionarias, como insuficiente para soportar los gastos de personal a causa del aumento de haberes y la implantación de la jornada de ocho horas de 1919 (NORTE y MZA, 1932: 19).

La elevación de tarifas del 15\%, autorizada por Real Decreto de 26 de diciembre de 1918 fue prorrogada sucesivamente. Como no se había cumplido los supuestos de suspensión anticipada (disminución del precio de carbón por debajo del 50\% que tenía en 1913, y cuando los productos netos alcanzasen los obtenidos en ese año), concluyó al transcurrir tres años después del 11 de noviembre de 1918. El 10 de noviembre de 1921 se aprobó un Real Decreto que prorrogaba la elevación de tarifas, hasta que una Ley aprobada por las Cortes regulara el régimen ferroviario, o hasta el plazo máximo de un mes. Transcurrido el plazo de un mes sin haberse resuelto nada sobre el régimen ferroviario, el Real Decreto de 9 de noviembre de $1922^{400}$ lo prorrogó por tres meses siempre que no se aprobara un nuevo régimen ferroviario con una Ley emitida por las Cortes. El Real Decreto de 10 de mayo de 1923 concedió otra prórroga de tres meses, y el Real Decreto de 8 de agosto de 1923 concedió otra prórroga de tres meses más. Posteriormente, estando sin resolver el problema, el Real Decreto de 3 de noviembre de 1923, emitido por el Gobierno de la dictadura del General Primo de Rivera, amplió el plazo de vigencia del 15\% hasta el 1 de enero de 1924. El Real Decreto de 28 de diciembre de 1923 lo amplió de nuevo hasta el 1 de febrero de 1924.

La elevación de tarifas del $15 \%$ sobre las existentes era muy inferior de lo que las concesionarias deseaban (solicitaban un $25 \%^{401}$ ), no obstante permitió a las compañías "salir de una situación difícil" "402, evitando una crisis financiera, y de paso aceptar nuevos incrementos salariales, concediendo a los agentes un nuevo plus extraordinario que osciló entre el 20 y $35 \%$ de los haberes según el nivel de ingresos. Estos incrementos compensaron, sólo en parte, la espiral inflacionista; el deterioro del poder adquisitivo siguió en aumento y también las protestas de los empleados.

Los gestores tropezaron con un nuevo obstáculo: la implantación de la jornada de ocho horas diarias, o cuarenta y ocho semanales ${ }^{403}$, establecido en el R.D. de 3 de abril de 1919; hasta entonces había sido de diez como media. La medida debía entrar en vigor el 1 de octubre de 1919 en unos casos, y a partir de 1920 en otros ${ }^{404}$. Trajo consigo un incremento inmediato del salario/hora en los servicios donde se implantó y obligó a las concesionarias a contratar más trabajadores y a aumentar el número de horas extraordinarias.

\footnotetext{
${ }^{400}$ El texto del Real Decreto de 9 de noviembre de 1922 puede observarse en NORTE y MZA (1932, Anejo 6).

${ }^{401}$ Como resaltó de inmediato la Gaceta de los Caminos de Hierro (Gaceta de los Caminos de Hierro, 1 de enero de 1919), que debe ser considerado como el portavoz de los intereses ferroviarios.

402 "El Estado y los ferrocarriles", en Revista de Economía y Hacienda. El texto fue reproducido en la Gaceta de los Caminos de Hierro del 8 de abril de 1919.

403 Esta medida es consecuencia del Convenio Internacional de Washington, ratificado provisionalmente en España, por el R.D. de 24 de mayo de 1918.

${ }^{404}$ Los efectos de la entrada en vigor de la implantación de la jornada de ocho horas diarias, o cuarenta y ocho semanales fue estudiada por Soto Carmona (1989: 610-623; 1992: 53-76) y Juez (2000: 155-159 y 210-213).
} 
La situación de las compañías había empeorado con la aprobación de la jornada de ocho horas. Para hacer frente al incremento de los costes que su implantación requería, NORTE y MZA solicitaron del Gobierno un incremento tarifario.

Por esta razón, NORTE y MZA solicitaron una nueva elevación de tarifas del 50\% en julio de 1919 al ministro de Fomento Ángel Ossorio y Gallardo, sin que fuera aprobada como Ley.

El 30 de noviembre de 1919, las cuatro grandes -NORTE, MZA, Andaluces y MCP- elevaron una "Exposición" 405 , por medio de una instancia al presidente del Consejo de Ministros Joaquín Sánchez de Toca ${ }^{406}$, solicitando que se elevaran de nuevo un 35\% (elevando el actual aumento del $15 \%$ hasta el 50), que entrará en vigor el 1 de enero de 1920. Esta propuesta tampoco fue aprobada como Ley, aunque al menos sí llegó a las Cortes. Las cuatro concesionarias más importantes entendieron que, con sólo el aumento de tarifas del 15\% era imposible hacer frente al alza de los costes que suponía la instauración de la nueva jornada legal y atender las nuevas demandas del personal. Las compañías, que consideraban imprescindible para evitar la quiebra la subida de tarifas del $35 \%{ }^{407}$, calculaban que la jornada de ocho horas supondría para NORTE un incremento de gastos de 18 millones y de 22,5 millones para $\mathrm{MZA}^{408}$. La argumentación de las cuatro grandes ferroviarias se completaba con la idea de que es necesario que quien utiliza el ferrocarril "sufrague por el servicio recibido la remuneración que corresponda a su coste efectivo" ${ }^{409}$.

La "Exposición" (NORTE, MZA, Andaluces y MCP: 1919) tuvo una buena acogida en el ministro de Fomento Gimeno, que presentó al Senado un proyecto de subida según la naturaleza del servicio, que se acercaba mucho al 50\%. El Proyecto de Ley de 30 de diciembre de 1919, autorizaba una elevación de las tarifas, hasta el 50\% para los viajeros de primera clase; el $48 \%$ para los de segunda; el $45 \%$ para los de tercera, y el 50\% para todas las mercancías. El Proyecto de Ley fue aprobado por el Senado el 14 de enero de 1920. En el Preámbulo del Proyecto de Ley, el Gobierno reconoce que la solución sería una "buena reforma", pero las "circunstancias del momento" sólo permiten parches, en su dialéctica "medidas provisionales". El Gobierno la presentó a las Cortes en forma de Proyecto de Ley, pero fue allí paralizada por las fuertes resistencias ${ }^{410}$, sobre todo de Juan de la Cierva. Llegó la disolución de la Cámara sin que se tomara ninguna decisión.

\footnotetext{
405 NORTE, MZA, Andaluces y MCP (1919).

${ }^{406}$ El texto completo de la instancia se encuentra en el apéndice de la memoria correspondiente al ejercicio contable 1919 (MZA, 1920:14).

${ }^{407}$ Los nuevos proyectos de elevación de tarifas, las peticiones del personal, las huelgas y las concesiones de los anticipos del Estado para las mejoras de los haberes a aparecen comentados desde su punto de vista por NORTE y MZA (1932: 19-21).

${ }^{408}$ El planteamiento de las grandes concesionarias puede observarse en el informe que remitieron en noviembre de 1919 (NORTE, MZA, Andaluces y MCP: 1919), donde se hacía un cálculo pormenorizado del incremento de los costes entre 1914 y 1919.

${ }^{409}$ Memoria MZA año 1919 (MZA, 1920:14).

${ }^{410}$ AHF P/58/35, AHF P/59/45, AHF P/59/46, AHF P/59/61, AHF P/59/67, AHF P/60/78.
} 
La ocasión fue aprovechada enseguida por los trabajadores quienes exigieron a las empresas nuevos incrementos remunerativos, que éstas aceptaron ${ }^{411}$. Pero, como el proyecto de ley acabó encallando en el Congreso, los trabajadores amenazaron con recurrir a la huelga en caso de no ser atendidas sus demandas, lo que acabarían haciendo el 23 de marzo de $1920^{412}$. Detrás de la huelga es probable que estuvieran las empresas ferroviarias, así al menos lo sospechaba la oposición al Gobierno con manifestaciones como estas: "las ferroviarias estaban detrás del conflicto" para, de este modo, "desbloquear el proyecto de ley sobre el nuevo recargo de tarifas" ${ }^{413}$; "han provocado la huelga los representantes del capitalismo, los directores de las compañías, los administradores, los Consejeros de Administración de esas compañías"414; "se trata de una huelga que las compañías venían preparando desde hace tiempo para así obtener el aumento de las tarifas ferroviarias" "415; y "responsabilizó de forma directa al personal superior del cierre de oficinas, talleres y estaciones ${ }^{416}$.

La situación del Gobierno era difícil: se juntó la paralización del Proyecto de ley en el Congreso, con las exigencias de los trabajadores sobre empresarios y Gobierno. Para atenuar esta situación, el Gobierno, por medio de la Real Orden de la Presidencia de 23 de marzo de $1920^{417}$, decide conceder unos anticipos del Estado a las compañías, con carácter reintegrable y sin interés, por las cantidades a que ascendieran durante un mes la mejora de los haberes prometidos. El Gobierno decidió asumir el incremento que suponían las nuevas mejoras, anticipando para ello, por el plazo de un mes (luego, a partir de la Real Orden de 29 de abril

\footnotetext{
${ }^{411}$ Mientras se discutía en las Cortes, los empleados exigieron a las empresas que definieran la cuantía de las mejoras y aclararan las escalas a aplicar en el supuesto de que el proyecto se convirtiera en decreto. Posteriormente los trabajadores exigieron, con huelga incluida el 23 de marzo de 1920, la percepción inmediata de la prometida mejora en base a la hipotética subida de tarifas.

${ }^{412}$ La huelga sólo duró un día, pero se vio envuelta en una fuerte polémica que salpicó a todos: protagonistas, sindicatos, medios de comunicación y Parlamento (Martínez Vara y de los Cobos, 2007a). La redacción de "El Boletín" hubo de salir al paso, en una excusación delatadora: "ninguno pudo advertir en el Director de la Compañía deseos de huelga ni, menos aún, ser coaccionado para que abandonase el trabajo". En cualquier caso, fuera inducida, o simplemente consentida, la huelga [añadía la redacción] tuvo "la virtud de hacer que nuestros gobernantes fijen su atención en el problema ferroviario, y adviertan que su solución es inaplazable" (El Boletín, "El aumento de tarifas y de sueldos", mayo de 1920). El anticipo, concluía, "sólo es un compás de espera" (El Boletín, marzo de 1920, pp. 30-33).

${ }^{413}$ Intervenciones de J. de la Cierva, R. Castrovido, J. Salvatella, J. M. Pedregal, M. Domingo y A. Saborit en las Sesiones del 23 y 24 de marzo de 1920 en la Sesión celebrada en el Congreso de los Diputados el miércoles 24 de marzo de 1920, legislatura 1919-1920 (Diario de las Sesiones de Cortes en el Congreso de los Diputados, $\mathrm{n}^{\circ}$ 93 y 94$)$, pp. 5331-5346.

${ }^{414}$ Intervención de J. de la Cierva en la Sesión celebrada en el Congreso de los Diputados el martes 23 de marzo de 1920, legislatura 1919-1920 (Diario de las Sesiones de Cortes en el Congreso de los Diputados, $\mathrm{n}^{\circ}$ 92), pp. 5121-5122.

${ }^{415}$ Intervención de M. Domingo en la Sesión celebrada en el Congreso de los Diputados el miércoles 24 de marzo de 1920, legislatura 1919-1920 (Diario de las Sesiones de Cortes en el Congreso de los Diputados, $\mathrm{n}^{\circ}$ 93), pp. 5331-5340.

${ }^{16}$ Intervención de A. Saborit en la Sesión celebrada en el Congreso de los Diputados el miércoles 24 de marzo de 1920, legislatura 1919-1920 (Diario de las Sesiones de Cortes en el Congreso de los Diputados, $\mathrm{n}^{\circ}$ 93), pp. 5339-5346.

${ }^{417}$ El texto de la R.O. de 23 de marzo de 1920 y prórrogas de la misma pueden observarse en Peña y Pérez (1940, tomo I: 20-21; tomo II: 99-104); Cambó (1918-1921, vol. VI: 242-243) y NORTE y MZA (1932, Anejos 2-4: 51-56).
} 
de 1920, será reiteradamente prorrogado "hasta que hubiera una solución definitiva acerca del

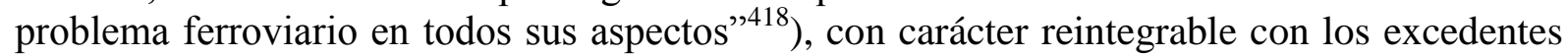
obtenidos por las compañías cuando fueran superiores a los de 1913 y sin interés las cantidades requeridas (Peña y Pérez, 1940, tomo I: 20-26 y 40-43; tomo II, 99-104). Con cargo a este anticipo, y desde marzo de 1920, se concedió, pues, al personal un segundo plus a añadir al anterior. Al final, el incremento de los haberes nominales con referencia a 1913 representó una elevación aproximada del 133 más\% para los sueldos inferiores y entre un 60 y 75 para los más elevados. El incremento final con respecto a 1913, sumados todos los conceptos, osciló entre un máximo del $115 \%$ y un mínimo de $60 \%$. Con ello, las rentas de los empleados ferroviarios no sólo se habían recuperado sino que quizás, en términos reales, habían mejorado respecto del período prebélico.

Meses después, en octubre de 1920, el Estado concedió nuevos anticipos amortizables, en este caso con interés, para la adquisición de material móvil y de tracción. La contrapartida fue, claro está, una mayor injerencia del Estado. En estos momentos, el Estado español era ya uno de los más intervencionistas del mundo ${ }^{419}$. De ahí a plantear abiertamente la nacionalización en el Parlamento sólo había un corto trecho.

Todos los incrementos habidos desde 1915 fueron normalizados y consolidados en la R. O. de 10 de abril $1921^{420}$. Esta Real Orden, aprobada por el ministro de Fomento Cierva, dio carácter de permanencia a los anticipos y propuso la consiguiente repercusión "en los derechos pasivos", lo que hicieron las compañías. Teniendo en cuenta que en los mismos años el coste de la vida subió $100,97 \%$ en el sector, los agentes de categorías más bajas, que constituían la mayoría de los empleados, consiguieron e incluso mejoraron el poder adquisitivo perdido durante el ciclo bélico ${ }^{421}$.

Los anticipos se devolvieron tarde y en poca cantidad ${ }^{422}$. A medio plazo, los anticipos permitieron a las concesionarias cerrar los ejercicios sin pérdidas ${ }^{423}$. La oposición política consideró que los anticipos fueron muy provechosos para las compañías, e incluso manifestó su total repulsa al sistema de anticipos por beneficiar a las ferroviarias ${ }^{424}$. Por su parte, el

\footnotetext{
${ }^{418}$ El texto de la R.O. de 29 de abril de 1920 pueden observarse en NORTE y MZA (1932, Anejo 3).

${ }^{419}$ Esta opinión es recogida por Boag (1923).

${ }^{420}$ El texto de la R.O. de 10 de abril de 1921 pueden observarse en NORTE y MZA (1932, Anejo 4).

${ }^{421}$ Los datos del coste de la vida y la recuperación del poder adquisitivo es tomado de Martínez Vara (2003; 2006).

${ }^{422}$ El importe recibido de los anticipos para el pago del personal ascendió a 160.029.029 pesetas, de los que se devolvieron 954.231 en 1928 y 1.024 .799 en 1929 (NORTE, 1940: I, 435). Para poder levantar nuevas instalaciones, construir dobles vías, reparar las existentes o simplemente reemplazar el material motor móvil y de tracción desgastado las concesionarias hubieron de aceptar también -R.O. de 15 de octubre de 1920- anticipos reintegrables con un plazo de 20 años de amortización y al 5\% de interés (NORTE, 1940: II, Cuadro 22).

${ }^{423}$ En septiembre de 1925 se acuerda la inspección de la contabilidad de las compañías para deducir si procedía o no la devolución (NORTE y MZA, 1932, Anejo n 11-13: 75-80).

${ }^{424}$ Intervenciones de J. de la Cierva, R. Castrovido, J. Salvatella, J. M. Pedregal, M. Domingo y A. Saborit en las Sesiones del 23 y 24 de marzo de 1920 en el Congreso de los Diputados (Extracto Oficial, no 92 y 93), pp 878880; pp. 5230-5241.
} 
Estado sólo esperaba la oportunidad de revocarla y librar así a la exhausta Hacienda de una carga que se consideraba fuera de lugar (Martínez Vara y de los Cobos, 2007b: 327).

Los anticipos eran una medida provisional que las compañías aceptaron a regañadientes, pero que no deseaban, y así lo manifestaron desde el primer momento, pues creían, con razón, que, aparte de suponer una deuda ${ }^{425}$, terminaría suponiendo una mayor injerencia del Estado en sus asuntos. Fueron una mala solución transitoria con la que el Gobierno solventó dos problemas puntuales: contentar a los empleados, acabando con la huelga, por un lado, y retrasar la enojosa decisión de subir las tarifas hasta tanto no se resolviese definitivamente el problema ${ }^{426}$, por otro. No hubo solución definitiva y, así, se fueron sucediendo mensualmente las órdenes para prolongarlos hasta su supresión en $1926^{427}$.

El Real Decreto de 9 de noviembre de 1922 prorrogó el anticipo del Estado para haberes del personal. Este anticipo fue concedido por un mes por la Real Orden de 23 de marzo de 1920 y luego prorrogado por la Real Orden de 29 de abril de 1920 para meses sucesivos hasta que se solucionara el problema. La Real Orden de 29 de abril de 1920 se basaba en la Ley de Subsistencia de 11 de noviembre de 1916, y ésta perdía su vigor el 11 de noviembre de 1921, hubo de prorrogarse por un año, por Real Decreto de la Presidencia de 14 de noviembre de 1921. Transcurrido este plazo, y continuando sin resolver el problema, fue preciso conceder una nueva prórroga por Real Decreto de 9 de noviembre de 1922. Posteriormente, estando sin resolver el problema, el 7 de noviembre de 1923, el Gobierno de la dictadura del General Primo de Rivera amplió el plazo de vigencia hasta el 1 de enero de 1924. El Real Decreto de 28 de diciembre de 1923 lo amplió de nuevo hasta el 1 de febrero de 1924.

Como el Proyecto de Ordenación Ferroviaria no tomaba estado parlamentario, el Gobierno emitió el Real Decreto 15 de marzo de 1922, firmado por el entonces ministro de Fomento Arguelles, un nuevo Proyecto de Ordenación Ferroviaria, que era calcado al atribuido a Maura. A partir de él se crea el Consejo Superior Ferroviario ${ }^{428}$, sin duda influido porque se había creado en Francia un organismo similar ${ }^{429}$.

\footnotetext{
${ }^{425}$ En sendos escritos remitidos al Presidente del Consejo de Ministros el 24 de junio y el 30 de noviembre de 1920, las cuatro grandes -NORTE, MZA, Andaluces y MCP- expresaron su enojo por el retraso a la hora de implementar la prometida subida tarifaria, lo que significa -le recuerdan al Presidente- un aumento de la deuda y una carga innecesaria para la Hacienda (MZA, 1921, Memoria, Apéndice 2: 47-50).

${ }^{426}$ E. Ocharán, presidente del Banco de Vizcaya y consejero de NORTE, lo expresó con claridad en una entrevista: "Los anticipos reintegrables o los préstamos que pueden hacerse no solucionan el problema ni remedian nada, en definitiva. Pudieron satisfacer una necesidad circunstancial, evitando un paro de funestísimas consecuencias. El anticipo fue un zurcido oportuno, pero nada más". Lo que se debía hacer, en su opinión, era "subir inmediatamente las tarifas" (El Liberal de Bilbao el 10 de julio de 1920).

${ }^{427}$ AHF, C/108/235: "Reales Ordenes autorizando las prórrogas de anticipos".

${ }^{428}$ El Estatuto provisional del Consejo Superior Ferroviario fue aprobado por la Real Orden de 27 de marzo de 1922. En él aparece que está formado por quince vocales: seis de las compañías, seis del estado y tres representantes de intereses mercantiles, agrícolas e industriales.

${ }^{429}$ Este "Consejo Superior de Ferrocarriles" francés sustituyó al extinto "Comité consultivo" hasta entonces vigente, disposición que apareció en el "Journal Officiel" de 15 de febrero de 1922, es decir un mes antes de la creación del "Consejo Superior de Ferrocarriles" español.
} 
Al final de marzo de 1922, el Gobierno de Sánchez Guerra presentó a las Cortes un Proyecto de Ley denominado "Fórmula económica", que se arbitró para prorrogar los presupuestos del estado hasta 30 de junio, en la cual, con el fin de suprimir los anticipos que el Tesoro venía haciendo a las ferroviarias para la mejora de haberes y jornales de sus agentes, se facultaba al Gobierno, en su artículo 6, para acordar, previo Informe del Consejo Superior Ferroviario, la elevación de tarifas, como máximo, en el tanto\% necesario para aquella compensación, llevando las empresas una cuenta especial de los mayores ingresos que esta elevación produjera, que corresponderían íntegramente al Estado, siendo intervenida dicha cuenta por éste. Tal régimen de elevación subsistiría hasta el establecimiento de un nuevo régimen general ferroviario, o hasta que hubieran desaparecido los anticipos. Este Proyecto se convierte en Ley en el Real Decreto de 1 de abril de $1922^{430}$. En esta Ley aparece que el Consejo Superior estudiara el aumento de tarifas. Las compañías pedían un aumento del 15\%, mientras que el Estado, por medio del Consejo Superior Ferroviario (Real Orden de 6 de junio de 1922), propuso un aumento de un 13,5\%. La decisión del Consejo Superior Ferroviario fue rechazada por el ministro.

El Gobierno presentó al Senado un nuevo Proyecto de Ordenación Ferroviario, redactado por el entonces ministro Arguelles ${ }^{431}$. El texto de Arguelles tenía pocas diferencias con la Ordenación Ferroviaria de Maura, aunque una de ellas, importante, porque incluía la necesidad de emitir normas de contabilidad para los ferrocarriles ${ }^{432}$. Después de aprobado en el Senado, con ligeras variaciones, fue discutido y aprobado por el Congreso de 12 de junio de 1922; sin embargo, su articulado no fue aprobado por un cambio de gobierno (dejó el poder Sánchez Guerra). El nuevo Gobierno, presidido por el Marques de Alhucemas y siendo ministro de Fomento Gasset, comenzó la preparación de un nuevo Proyecto de Ordenación Ferroviaria, que tampoco llegó a entrar en vigor. Este gobierno, al igual que su predecesor, tampoco autorizó la elevación de tarifas.

La solución definitiva debería haber llegado con la aprobación del Estatuto Ferroviario en julio de 1924 en la época del Directorio Militar. El Estado se haría cargo, a través de la Caja Ferroviaria del Estado ${ }^{433}$, de las inversiones en material móvil y de la construcción de nuevas líneas, y con los incrementos de las tarifas revisables periódicamente se absorberían los gastos de la explotación, incluido el coste de oportunidad del capital invertido, y las cargas financieras

\footnotetext{
${ }^{430}$ Esta fórmula solo resolvía una parte del problema, la relativa del personal y esto de un modo provisional y cuya finalidad evidente era descargar al Estado del pago de los anticipos.

${ }^{431}$ Tras la información pública abierta por la Comisión del Senado, las cuatro grandes ferroviarias presentaron un único Informe, en el cual figuraban todas las principales observaciones, que eran muy similares a las que hicieron constar respecto al Proyecto de Ley de Maura. Las empresas se quejaron de que tampoco ahora fueron tenidas en cuenta por el dictamen de la Comisión (NORTE y MZA, 1932: 44).

${ }^{432}$ Las bases $3^{\mathrm{a}}, 4^{\mathrm{a}}$ y $5^{\mathrm{a}}$ del Consejo Superior, atribuciones, delegaciones y forma de ejercitar las facultades, quedaron reducidas a la base $3^{\mathrm{a}}$ del Proyecto Arguelles, añadiéndose una base $12^{\mathrm{a}}$ estableciendo que "por Real Decreto se fijarían reglas de contabilidad para todo lo referente a ferrocarriles".

${ }^{433}$ La Caja Ferroviaria del Estado fue un organismo autónomo autorizado a emitir deuda con el respaldo del aval del Estado. Como las inversiones realizadas por este organismo fueron incapaces de generar los recursos para amortizar las emisiones, la deuda ferroviaria tuvo que ser incorporada al Estado en los años treinta. Estuvo vigente entre agosto de 1925 y septiembre de 1930. Las funciones de la Caja Ferroviaria son reguladas por las bases IV y V del Real Decreto-Ley de 12 de julio de 1924 y el Real Decreto-Ley de 4 de agosto de 1924.
} 
y pensiones. Las concesionarias creían que el nuevo régimen suponía una asociación empresarial con el Estado, que, "además de socio, era su regulador" (Comín, et al., 1998: 360). Hasta que no se implantase plenamente el nuevo régimen ferroviario, se concederían transitoriamente unos créditos estatales a las compañías, a fin de compensar los incrementos en los costes, debido, sobre todo, a las nuevas necesidades de política laboral. La realidad fue muy otra. El Estatuto de 1924 no se puso en vigor de forma íntegra, se redujeron los créditos y las compañías agravaron la crisis pues por sí solas no podían soportar los costes de personal y la necesaria adquisición de material móvil y de tracción (Tedde, 1978: 210-216; Ortúñez, 1999a: 205-218).

En definitiva, la idea subyacente del Gobierno al establecer la auditoría era su deseo de eliminar el anticipo, lo que conllevaba inexorablemente la reducción de los gastos laborales de explotación. A tal efecto, ambas Comisiones desplegaron todo tipo de argumentaciones para conseguirlo. Las compañías no querían su derogación, lo que produjo incluso la paradoja de que se convirtieran circunstancialmente en defensores de los derechos de los trabajadores $^{434}$.

El Gobierno y las ferroviarias utilizaron argumentos encontrados en defensa de sus respectivos intereses: por un lado el Directorio militar propone eliminar los anticipos por innecesarios, exonerando de esta carga a la débil Hacienda, por otro lado las concesionarias pretenden mantener los anticipos mientras que no se arbitrara una subida de tarifas que las permitiera no depender del Estado.

Las Comisiones recriminaron a las empresas, especialmente a NORTE, haber incurrido en dos grandes defectos que elevaban en exceso los gastos de personal: tener plantillas sobredimensionadas y abonar sueldos demasiado elevados en relación con los trabajadores de otras industrias y funcionarios públicos ${ }^{435}$. Las empresas negaron que el número de empleados fuese excesivo y que estuvieran mejor pagados que los de otras industrias. Este argumento era contrario a los que hubiera utilizado si no estuviera en juego en ese momento el mantenimiento del anticipo, por ejemplo en una negociación con los representantes sindicales. Los argumentos de las empresas cambian respecto a los que utiliza normalmente porque temen perder los anticipos cuando aún no se había determinado cómo sería el nuevo régimen ferroviario tantas veces prometido. Esto puede observarse tanto en NORTE como en MZA.

\footnotetext{
${ }^{434}$ La coincidencia entre intereses de la patronal ferroviaria y los derechos de los trabajadores puede verse tanto en NORTE como en MZA. Para NORTE véase AHF P-113-258-3: "Contestación de la Compañía al informe redactado por la Comisión”; para MZA véase AHF P-113-257-5: “Observaciones que a la Compañía MZA ha sugerido el informe redactado por la Comisión investigadora”. Ambos se encuentran en Pérez y Peña (1940: vol. I, 110-119).

${ }^{435}$ Sobre este último aspecto, la Primera Comisión recalcaba que mientras que el Estado y las demás empresas fuera del sector ferroviario dejaron en suspenso la paga extraordinaria que se estableció en el ámbito general en 1918 para compensar el incremento del índice del coste de la vida, NORTE la seguía abonando a sus empleados. Para la Comisión era un contrasentido que NORTE requiriera de los anticipos para hacerla efectiva y sus empleados se hallaban entre los trabajadores, de sector público o privado, mejor retribuidos del mundo laboral.
} 
NORTE argumentaba que si "mantenía esos gastos de personal (...) era porque los encontraba absolutamente indispensables" (Peña y Pérez, 1940, tomo I: 29). Estos argumentos eran distintos a los que utilizaban normalmente para evitar mejoras en las condiciones laborales. El 30 de octubre de 1912, Boix remitió al ministro de Fomento sendos informes solicitados por el Gobierno, uno sobre las peticiones formuladas por el Congreso Ferroviario, que acababa de celebrarse (incremento de los salarios, disminución de la jornada laboral y eliminación de abusos), y el otro detallando las "instituciones establecidas por la Compañía a favor de su personal" (AHF- S-190-72). En ellos, Boix calificó como "disparatadas" por su enorme coste las peticiones del personal; rechazó por "arbitrario" e "improcedente", el procedimiento de "exigirlas" (amenaza de huelga); señaló que el personal ferroviario, y muy en particular el de su red, estaba bien retribuido, tenía garantizado el puesto de trabajo y disfrutaba de otras muchas "ventajas" desconocidas aún en el resto de las industrias. Estos argumentos son los que utilizaron más tarde las Comisiones.

Para MZA, las "ventajas" de los ferroviarios eran "menores a las de los militares", además los agentes "no estaban suficientemente retribuidos", por lo que el coste de la vida no permitiría realizarlo sin grave quebranto para el personal, y las alusiones de la Comisión a las rebajas salariales habidas en otros países no tenían sentido aquí porque "no se había experimentado en España similares bajadas de precios"436. Maristany escribió que "las compañías ferroviarias, a propósito del tema de la huelga, están moralmente obligadas a mejorar la situación de sus agentes, que en buena parte apenas ganan lo necesario para atender el sustento suyo y de sus familias"437. Más adelante afirmaría que el aumento de las retribuciones no sólo era "un deber moral" sino que constituye el mejor antídoto frente a la conflictividad social y el avance de las "ideas revolucionarias" ${ }^{338}$. Estos razonamientos son matizados en las ideas que usualmente manejaba Maristany. El carácter de servicio público y su buen funcionamiento sirve al director de MZA de argumento para justificar la no intromisión de cualquier agente en los asuntos internos de la empresa. Por ello, Maristany siempre se opuso a que, en un servicio público de la trascendencia del ferroviario, existiera "libertad de huelga" y se permitieran "asociaciones y sindicatos"439.

Las Comisiones concluyeron que en el momento de realizar la auditoría dichos anticipos suponían una carga tan innecesaria como gratuita para las arcas de Estado, pues ambas empresas disponían de los medios suficientes para afrontar los costes laborales ${ }^{440}$. Si no sucedía así era porque ambas concesionarias abonaban a sus empleados y directivos más de lo que en realidad deberían. NORTE y MZA consideraban, en cambio, que, en tanto no se arbitrara una solución definitiva al Problema Ferroviario, su aportación resultaba

\footnotetext{
${ }^{436}$ Puede observarse en AHF P-113-257-5 y en AHF P-113-257-6.

${ }^{437}$ Carta de Maristany (director de MZA) a R. Lisle (Comité de París) en noviembre de 1910.

${ }^{438}$ AHF S-181-1: "Nota sobre huelgas de agentes empleados en Ferrocarriles".

${ }^{439}$ Estas referencias aparecen en el trabajo de Martínez Vara y de los Cobos (2007b: 334).

${ }^{440}$ La idea de que las compañías disponían de los medios suficientes para afrontar los costes laborales es emitida por las Comisiones. Seguramente las cantidades que llegaron vía anticipos eran imprescindibles, otra cosa es cómo tenían que entrar esos capitales en las empresas.
} 
imprescindible si en verdad se quería mantener el actual nivel salarial de los agentes, nivel que, por otro lado, “estimaban justo” (Martínez Vara y de los Cobos, 2007b: 320).

La otra alternativa posible era que los anticipos fuesen necesarios porque la gestión de las empresas era muy deficiente. Esto pudo ocurrir en NORTE, así al menos, se planteó en la Junta General de Accionistas. El accionista $-y$ trabajador- de NORTE, Burgaleta ${ }^{441}$, intervino en la junta de accionistas de 1923, acusando con dureza a los directivos de ser los responsables de los malos resultados económicos (AHF-S-15-44 bis); la respuesta de la empresa (NORTE: 1923), por medio de su director Boix, fue igual de dura. Burgaleta afirmó que en 1923 se estaba asistiendo "al derrumbramiento de la compañía NORTE, porque de derrumbamiento debe calificarse el hecho de que con 300 millones de ingresos, tengamos que recurrir a los anticipos del Estado para el pago de nuestro personal" ${ }^{\text {"442 }}$.

En los apartados siguientes se analizan los contenidos incluidos en cada una de las Comisiones derivadas de la Real Orden de 20 de octubre de 1923, designadas por el Directorio Militar para investigar la contabilidad de las compañías NORTE y MZA. Además de la descripción de la documentación, se realizará un análisis e interpretación de la misma para evaluar su calidad y relevancia. El cuadro 14 recoge la denominación y documentos de cada una de las Comisiones, especificando su finalidad y componentes.

\footnotetext{
${ }^{441}$ Vicente Burgaleta, hijo del que fuera jefe de también de Tracción en la misma compañía y profesor de Mecánica Racional en la Escuela Central de Ingenieros Industriales, formó parte de la primera promoción (1913) de ICAI (Universidad de Comillas). Burgaleta era inspector del servicio de Material y Tracción de NORTE cuando tuvieron lugar en dicha empresa las huelgas de 1916 y 1917, que tanta desafección produjeron hacia los trabajadores y sindicatos por parte de los gestores.

${ }^{442}$ AHF, S-15-44bis Discurso pronunciado por el accionista Burgaleta en la junta general celebrada el 19 de mayo de 1923: formuladas por encargo del Consejo de Administración y acordada por este su publicación, Compañía de los Caminos de Hierro del Norte de España, 19 de mayo de 1923, Madrid: Norte.
} 
Cuadro 14. Denominación y contenidos de los documentos de cada una de las Comisiones derivadas de la Real Orden de 20 de octubre de 1923

\begin{tabular}{|c|c|c|c|c|}
\hline & DENOMINACIÓN & DOCUMENTOS & OВJETO & COMPONENTES \\
\hline \multirow{3}{*}{$\begin{array}{l}\text { Comisión } \\
\text { especial } \\
\text { designada por } \\
\text { el Directorio } \\
\text { Militar para } \\
\text { investigar la } \\
\text { contabilidad } \\
\text { de la } \\
\text { "Compañía } \\
\text { del NORTE" } \\
\text { de noviembre } \\
\text { de } 1923\end{array}$} & \multirow{3}{*}{$\begin{array}{l}\text { "Primera Comisión } \\
\text { investigadora de la } \\
\text { situación económica de } \\
\text { las empresas del } \\
\text { ferrocarril" }\end{array}$} & $\begin{array}{l}\text { Memoria sobre la } \\
\text { situación económica } \\
\text { de la Compañía de los } \\
\text { Caminos de Hierro } \\
\text { del Norte de España }\end{array}$ & $\begin{array}{l}\text { Análisis de la } \\
\text { cuenta de la } \\
\text { explotación de } \\
\text { NORTE }\end{array}$ & $\begin{array}{l}\text { Introducción } \\
\text { Análisis de la Cuenta de } \\
\text { explotación } \\
\text { Resumen } \\
\text { Conclusiones }\end{array}$ \\
\hline & & $\begin{array}{l}\text { Examen del activo y } \\
\text { pasivo del balance de } \\
\text { la Compañía de los } \\
\text { Caminos de Hierro } \\
\text { del Norte de España } \\
\text { del año } 1922 \\
\end{array}$ & $\begin{array}{l}\text { Análisis del } \\
\text { balance de } \\
\text { situación de } \\
\text { NORTE }\end{array}$ & \\
\hline & & $\begin{array}{l}\text { Contestación de la } \\
\text { Compañía Norte al } \\
\text { Informe relativo a la } \\
\text { Comisión }\end{array}$ & $\begin{array}{l}\text { Contestación } \\
\text { de NORTE al } \\
\text { Informe } \\
\text { relativo a la } \\
\text { Primera } \\
\text { Comisión }\end{array}$ & $\begin{array}{l}\text { Introducción } \\
\text { I. Verdadero concepto del } \\
\text { anticipo y correcta forma } \\
\text { de su contabilización } \\
\text { II. Reparos del Informe a } \\
\text { las diversas partidas que } \\
\text { componen las cuentas de } \\
\text { explotación } \\
\text { III. Previsión de los } \\
\text { resultados del año } 1923 \\
\text { IV: Pronósticos para } \\
\text { ejercicios posteriores } \\
\text { V. Materialización de las } \\
\text { reservas } \\
\text { VI. Examen de las } \\
\text { conclusiones }\end{array}$ \\
\hline \multirow{2}{*}{$\begin{array}{l}\text { Comisión } \\
\text { especial } \\
\text { designada por } \\
\text { el Directorio } \\
\text { Militar para } \\
\text { investigar la } \\
\text { contabilidad } \\
\text { de la } \\
\text { "Compañía } \\
\text { del MZA" de } \\
\text { noviembre de } \\
\text { 1923 }\end{array}$} & \multirow{2}{*}{$\begin{array}{l}\text { "Segunda Comisión } \\
\text { investigadora de la } \\
\text { situación económica de } \\
\text { las empresas del } \\
\text { ferrocarril" }\end{array}$} & $\begin{array}{l}\text { Informe relativo a la } \\
\text { Compañía MZA } \\
\text { realizado por la } \\
\text { "Segunda Comisión } \\
\text { investigadora de la } \\
\text { situación económica } \\
\text { de las empresas del } \\
\text { ferrocarril" }\end{array}$ & $\begin{array}{l}\text { Análisis del } \\
\text { balance y de la } \\
\text { cuenta de la } \\
\text { explotación de } \\
\text { MZA }\end{array}$ & $\begin{array}{l}\text { Ámbito de la revisión } \\
\text { Opinión } \\
\text { Conclusiones }\end{array}$ \\
\hline & & $\begin{array}{l}\text { Observaciones de la } \\
\text { Compañía MZA al } \\
\text { Informe relativo a la } \\
\text { Compañía MZA }\end{array}$ & $\begin{array}{l}\text { Contestación } \\
\text { de MZA al } \\
\text { Informe } \\
\text { relativo a la } \\
\text { Segunda } \\
\text { Comisión } \\
\end{array}$ & \\
\hline
\end{tabular}

Fuente: Elaboración propia 


\subsubsection{Informe relativo a la Compañía NORTE}

La Real Orden del Departamento de Fomento de fecha 21 de octubre de 1923 constituyó la "Primera Comisión investigadora de la situación económica de las empresas del ferrocarril". Esta Comisión reclamó, el 29 de octubre de 1923, a la Compañía NORTE “cuantos antecedentes fuesen necesarios para conocer la extensión y circunstancias de las líneas explotadas por la Compañía, el detalle de los ingresos y gastos durante el periodo de 19131919 a 1922 y nueve primeros meses de 1923 y aquellos otros que nos diesen a conocer exactamente la valoración de todas las partidas que constituyen el activo de la compañía, así como los créditos representados por el pasivo".

La Comisión especial designada por el Directorio Militar para investigar la contabilidad de NORTE elaboró dos documentos en noviembre de 1923: "Memoria sobre la situación económica de la Compañía de los Caminos de Hierro del NORTE de España" y "Examen del activo y pasivo del balance de la Compañía de los Caminos de Hierro del NORTE de España del año $1922^{, 443}$.

El primer documento se centra en el análisis de la cuenta de la explotación de NORTE, dejando el estudio del balance de situación para el segundo.

\subsubsection{Memoria sobre la situación económica de la Compañía de los Caminos de Hierro del NORTE de España}

El 29 de noviembre de 1923, la "Primera Comisión investigadora de la situación económica de las empresas del ferrocarril" emitió el documento denominado "Memoria sobre la situación económica de la Compañía de los Caminos de Hierro del NORTE de España", firmado en Madrid por José García de los Ríos, Antonio Herbella, Pedro Gárate y Fernando García Bermúdez ${ }^{444}$.

El documento estaba compuesto por cuatro componentes: Introducción ${ }^{445}$, Análisis de la Cuenta de explotación, Resumen y Conclusiones ${ }^{446}$.

\footnotetext{
${ }^{443}$ Peña y Pérez (1940: tomo I, 89-109).

${ }^{444}$ AHF P-113-258-1: "Memoria sobre la situación económica de la Compañía NORTE".

${ }^{445} \mathrm{La}$ Introducción es el único componente del documento que no aparece con un título para diferenciarlo. Además no tiene esta denominación en ningún lugar del documento. No obstante, parece un prefacio o introducción clara. El resto de componentes sí están separados por un título escrito en mayúscula al principio de cada componente, dejando un apartado claramente diferenciado. La introducción también está diferenciada por exclusión del resto de componentes.

${ }^{446}$ Para acompañar el estudio de los datos y apoyar las recomendaciones de la Comisión, el Informe ofrecía ocho gráficos: Número 1. Gráfico de los gastos de administración y dirección. Años 1913-1922. Número 2. Gráfico de los gastos por reclamaciones e investigación. Años 1913-1922. Número 3. Gráfico de los gastos por tráfico e intervención de la cobranza. Años 1913-1922. Número 4. Gráfico de los gastos de explotación. Años 1913-1922. Número 5. Gráfico de los gastos de material y tracción. Años 1913-1922. Número 6. Gráfico de los gastos de vías y obras. Años 1913-1922. Número 7. Gráfico por cargas financieras. Años 1913-1922. Número 8. Gráfico general de ingresos y gastos, de reservas constituidas y de dividendos repartidos. Años 1913-1922.
} 


\section{a) Introducción}

En la introducción de este documento se incorporó el alcance del trabajo de revisión y los puntos clave del análisis.

El alcance del trabajo de revisión se establecía de la siguiente forma: "todos los documentos y libros de contabilidad que ha sido preciso consultar y comprobar para hacer un minucioso estudio del funcionamiento de la empresa, comprobando los resultados que ofrecen sus balances publicados, examinando la documentación necesaria para cerciorarse de la exactitud con que son llevados a los libros principales y adquiriendo la seguridad de que las cifras contenidas en los balances y en las cuentas generales de explotación responden a la verdad de los hechos contables".

Asimismo, en la introducción de la "Memoria sobre la situación económica de la Compañía de los Caminos de Hierro del NORTE de España" se establecen las materias claves y partidas más sensibles de la compañía para realizar un análisis lo más adecuado posible. Dentro de los objetivos de la revisión, la Comisión observó como fundamental el estudio del criterio de la compañía para la clasificación de las obras en las vías y edificios al servicio de la explotación, punto esencial para determinar las cantidades que deban cargarse a la cuenta de primer establecimiento -aumentando la cifra de activo de la compañía-, o que deben considerarse como gastos de explotación.

La Comisión fijó su atención en la extraordinaria elevación de las cifras dedicadas por NORTE a la "recomposición del material móvil" y a la renovación de vías. La Comisión, tras el estudio y causas que lo motivaron, obtuvo como consecuencia la necesidad de reducir ese gasto de explotación.

Del mismo modo, y juzgándolo como un dato indispensable para conocer la situación económica de la compañía en el presente y para el futuro, la Comisión elaboró los cuadros de vencimiento de todas las cargas de la compañía, tanto financieras como en relación con los anticipos reintegrables del Estado para adquisición de material móvil.

Para la Comisión, los gastos que más influían en el resultado de explotación son el número y retribuciones de los agentes. Por ello, la Comisión estudió las variaciones que en el periodo estudiado experimentó el personal de todas las clases y las retribuciones que por todos los conceptos le correspondieron, uniendo al Informe los estados que lo ponen de manifiesto.

La Comisión estudió las causas que permitieron el aumento de los productos de la explotación.

De la misma forma, la Comisión estudió detalladamente cada una de las partidas que integran los gastos de la explotación. Con este objeto, la Comisión encontró acertada la repartición de los gastos, llevando a la partida de gastos de primer establecimiento los que corresponden a la 
mejora o ampliación de servicios o locales, y dejando en los de explotación los de renovación o sustitución "de lo ya existente" $"$ "477.

\section{b) Análisis de la Cuenta de la explotación}

En el apartado Cuenta de la explotación se analizan sus datos, diferenciando los apartados en que se divide este estado contable en la empresa: Pronósticos para futuras cuentas anuales, Ingresos, Gastos, Reclamaciones e investigaciones, Explotación, Material y tracción, Vía y obras, Cargas de explotación, Amortización de material, Personal, Paga extraordinaria, Sueldos y Ampliaciones de obras, de material y de instalaciones.

La Primera Comisión resultó muy crítica con NORTE. Cuestionó, sobre todo, la forma de contabilizar los anticipos del personal. La Comisión consideró como inadecuado el registro del anticipo del Estado ya que NORTE no lo registraba como un gasto de personal; esto hacía que las cuentas de NORTE tuvieran unos gastos de explotación menores a los que acontecían realmente en cada periodo.

La Comisión recriminó a NORTE haber incurrido en dos grandes defectos que elevaban en exceso los gastos de personal: tener plantillas sobredimensionadas y abonar sueldos demasiado elevados en relación con los trabajadores de otras industrias y funcionarios públicos. Según la Comisión, en los años anteriores, NORTE no había conseguido evitar los "vicios y corruptelas de la Sociedad en que desarrollaba sus negocios", uno de los cuales, si no el principal, fue "aumentar su personal burocrático" 448 en una proporción que no guardaba relación con el aumento del tráfico, tanto de viajeros como de toneladas-kilómetros transportados. La Comisión recomendó una "revisión de las plantillas y de su asignación" compensando de esta forma parte del efecto derivado de la jornada de ocho horas en el personal obrero $^{449}$.

La otra discrepancia se dio en la paga extraordinaria que se estableció en el ámbito general en 1918 para compensar el incremento del índice del coste de la vida. Mientras que el Estado y las demás empresas fuera del sector ferroviario dejaron en suspenso esta paga extraordinaria, NORTE la seguía abonando a sus empleados. Para la Comisión esto era un contrasentido, pues la empresa requería de los anticipos para hacerla efectiva y sus empleados se hallaban entre los trabajadores, de sector público o privado, mejor retribuidos del mundo laboral. Además, NORTE la seguía abonando, no en la proporción de la primera paga concedida, que se reguló por los antiguos sueldos, sino que se reguló por todo el valor actual con sus

\footnotetext{
${ }^{447}$ AHF P-113-258-1: "Memoria sobre la situación económica de la Compañía de los Caminos de Hierro del NORTE de España", Primera Comisión investigadora de la situación económica de las empresas de ferrocarriles, 29 de noviembre de 1923: Apartado "Personal".

448 AHF P-113-258-1: "Memoria sobre la situación económica de la Compañía de los Caminos de Hierro del NORTE de España", Primera Comisión investigadora de la situación económica de las empresas de ferrocarriles, 29 de noviembre de 1923: Apartado "Personal".

449 AHF P-113-258-1: "Memoria sobre la situación económica de la Compañía de los Caminos de Hierro del NORTE de España", Primera Comisión investigadora de la situación económica de las empresas de ferrocarriles, 29 de noviembre de 1923: Apartado "Personal".
} 
respectivos aumentos, es decir que para los empleados de todas clases y categorías de NORTE, el año de haberes constaba de trece meses. La Comisión entendió que esta medida sería muy adecuada si la paga fuera un premio a la actividad o un estímulo al trabajo, pues de esta forma se conseguiría la participación de los obreros en los beneficios. Si se produjese esta unión entre el capital y el trabajo, la medida estaría justificada como una ventaja que la empresa, con sus propios fondos, otorga a sus empleados. Sin embargo, no resulta justificada la medida si para conceder la paga extraordinaria hay que acudir a los anticipos del Estado. De esta forma, deja de ser un estímulo al trabajo, perdiendo el carácter de premio y convirtiéndose en un privilegio arbitrario, cuando para otorgarlo hay que recurrir a fondos del Estado, quien por el contrario no lo concedía a sus propios empleados ${ }^{450}$.

Cuando se autorizó la elevación de tarifas en un 15\%, NORTE realizó un aumento de sueldos. El sueldo variable de los trabajadores de NORTE en el periodo 1918-1922 aumentó entre un 20 a un 35\%. Esto provocó que los empleados de NORTE tuvieran unos sueldos superiores a los de las empresas similares y también a los trabajadores del propio Estado. A esto hay que añadir el aumento simultáneo de las indemnizaciones por salidas.

La afirmación realizada por la Comisión de que los empleados de NORTE tenían unos sueldos superiores a los de las empresas similares y también a los trabajadores del Estado fue reconocida por la propia empresa (NORTE, 1922b: 60) para justificar que los problemas laborales, que fueron muchos (tensiones, huelgas y movilizaciones) no tenía sentido ni justificación. Sin embargo, es posible matizar hoy que las subidas salariales entre el 20 y $35 \%$ fueron bastante generales en ese periodo en las diferentes empresas. Es verdad que la compañía siempre pagó mejor a sus empleados, pero por supuesto eso no significa ni que los salarios fueran demasiado elevados ni que fueran los únicos responsables de la mala situación económica. Lo fue, tanto o más, la subida del precio del carbón y la sobreexplotación de un material insuficientemente renovado.

Al solicitar posteriormente NORTE una nueva elevación de las tarifas hasta el 50\%, ofrece a sus empleados otro aumento de sueldo, que sumado al primitivo lo elevan a una proporción variable de 60 a $115 \%$. Denegada la segunda autorización de aumento de tarifas y "ante la manifestación de que la situación de los empleados era angustiosa, (...) acudió al Estado con el anticipo de fondos para ello (más de 31 millones anuales)". La Comisión consideró, que igual que el Estado disminuyó los sueldos de sus trabajadores, NORTE debía continuar esa prudente conducta ${ }^{451}$.

\footnotetext{
${ }^{450}$ La Comisión propone que "se estimule a los agentes a conseguirla a expensas de su trabajo, concédase en forma de prima de beneficios al que realmente lo merezca, tasando preliminarmente la obra por lo que a los talleres se refiere, justipreciando el ahorro después, que debe ir íntegro al que lo produzca, y de esta manera el premio será justo, moral y equitativo y no recargará, como ahora sucede el gasto de explotación" (AHF P-113258-1: "Memoria sobre la situación económica de la Compañía de los Caminos de Hierro del NORTE de España", Primera Comisión investigadora de la situación económica de las empresas de ferrocarriles, 29 de noviembre de 1923: Apartado "Paga extraordinaria").

${ }^{451}$ AHF P-113-258-1: "Memoria sobre la situación económica de la Compañía de los Caminos de Hierro del NORTE de España", Primera Comisión investigadora de la situación económica de las empresas de ferrocarriles, 29 de noviembre de 1923: Apartado "Sueldos".
} 


\section{c) $\underline{\text { Resumen }}$}

Una vez realizado el examen de las partidas de ingresos y gastos, y teniendo en cuenta los datos de los nueve meses de 1923, la Comisión adelanta el resultado de la "Liquidación probable del año 1923", que pone de manifiesto la situación de la compañía el 31 de diciembre de 1923. En ella se observa la diferencia cuantitativa de incluir el anticipo del Estado entre los gastos y de no incluirlo (cuadro 15). 
Cuadro 15. Liquidación Probable del año 1923

\begin{tabular}{|l|l|l|}
\hline LIQUIDACIÓN PROBABLE DEL AÑO 1923 & $\begin{array}{l}\text { Gastos con exclusión de los } \\
\text { suplidos por el anticipo del } \\
\text { Estado }\end{array}$ & $\begin{array}{l}\text { Gastos con inclusión de } \\
\text { los suplidos por el } \\
\text { anticipo del Estado } \\
\text { Pesetas }\end{array}$ \\
\hline Administración central & 3.003 .000 & 3.003 .000 \\
\hline Dirección & 2.208 .000 & 2.208 .000 \\
\hline Reclamación e investigaciones & 6.424 .000 & 6.424 .000 \\
\hline Tráfico & 918.000 & 918.000 \\
\hline Intervención de la cobranza & 3.852 .000 & 3.852 .000 \\
\hline Explotación & 49.006 .000 & 49.006 .000 \\
\hline Material y Tracción & 104.887 .000 & 104.887 .000 \\
\hline Vía y obras & 27.882 .000 & 27.882 .000 \\
\hline $\begin{array}{l}\text { Diferencia entre haberes suplementarios } \\
\text { abonados al personal y anticipo recibido del } \\
\text { Estado }\end{array}$ & 2.286 .000 & 2.286 .000 \\
\hline Gastos de explotación & & \\
\hline Pensiones al personal & $\mathbf{2 0 0 . 4 6 6 . 0 0 0}$ & $\mathbf{2 0 0 . 4 6 6 . 0 0 0}$ \\
\hline & 3.100 .000 & 3.100 .000 \\
\hline CARGAS DE LA EXPLOTACIÓN & & \\
\hline Intereses y amortización de obligaciones & 67.650 .000 & \\
\hline Intereses y amortización anticipo material & 4.084 .000 & 67.650 .000 \\
\hline Varios & 1.766 .000 & 4.084 .000 \\
\hline & & 1.766 .000 \\
\hline Total de gastos & $\mathbf{2 7 6 . 8 6 6 . 0 0 0}$ & \\
\hline Anticipo del Estado para personal & - & $\mathbf{2 7 6 . 8 6 6 . 0 0 0}$ \\
\hline INGRESOS DE LA EXPLOTACIÓN & $\mathbf{3 1 2 . 0 0 0 . 0 0 0}$ & 31.200 .000 \\
\hline Excedente de productos 1923 & $\mathbf{3 5 . 1 3 4 . 0 0 0}$ & $\mathbf{3 1 2 . 0 0 0 . 0 0 0}$ \\
\hline & & $\mathbf{3 . 9 3 4 . 0 0 0}$ \\
\hline
\end{tabular}

Fuente: AHF P-113-258-1. "Memoria sobre la situación económica de la Compañía de los Caminos de Hierro del NORTE de España", Primera Comisión investigadora de la situación económica de las empresas de ferrocarriles, 29 de noviembre de 1923: Apartado "Resumen".

\section{d) Conclusiones}

El documento "Memoria sobre la situación económica de la Compañía de los Caminos de Hierro del NORTE de España", elaborado por la "Primera Comisión investigadora de la situación económica de las empresas de ferrocarriles, 29 de noviembre de 1923" finaliza con una enumeración de diez conclusiones obtenidas por la Comisión, en las que sintetiza la evolución previsible de la sociedad NORTE y una serie de recomendaciones para mejorar su rentabilidad y solvencia. 
Estas conclusiones serán rebatidas una a una por el documento de contestación de la empresa NORTE a la Comisión: "Contestación de la Compañía NORTE al Informe relativo a la Comisión".

Las conclusiones son las siguientes:

1. Que con las cifras de recaudación ordinaria, sin incluir la correspondiente al producto del 15\% aumentado en las tarifas, NORTE no puede satisfacer el gasto de la explotación y sus cargas.

2. Que de exceder los productos líquidos en el año 1923, de los alcanzados en 1913, como parece que ocurre, la compañía quedará obligada, en cumplimiento de lo dispuesto en el apartado $2^{\circ}$ de la Real Orden de 23 de marzo de 1920, al reintegro al Estado de los 12.823.000 en lo que excede.

3. Teniendo en cuenta que el resultado de la primera columna de la cuenta lleva a las conclusiones apuntadas en el párrafo 2, más ajustadas a la verdad, con la sola aplicación de las medidas de economía que se indican al tratar el personal, con sus propios recursos podía haber atendido la compañía a todas sus obligaciones actuales sin necesitar el anticipo del Estado.

4. Que dado el crecimiento progresivo de los ingresos y las economías que se imponen en los gastos, se puede esperar para el año 1924 y siguientes mayores beneficios y, por lo tanto, se debe suprimir totalmente los anticipos del Estado para el personal. Observándolo desde el momento actual, este es el aspecto fundamental porque, con toda seguridad, es lo que realmente buscaba el Estado con la revisión de los estados financieros.

5. Que si bien en los años 1917 a 1921 pudo ser crítica la situación de la compañía y encontrarse metida de lleno en el llamado problema ferroviario, con el aumento concedido del $15 \%$ en las tarifas, los préstamos del Estado para comprar material móvil de todas las clases, el también ventajoso adelanto para la electrificación del ramal de Pajares y la bajada de precio de carbones y materiales, han variado su situación en forma que la permiten hoy atender en condiciones normales a sus obligaciones formales. Desde un análisis realizado en el momento actual, esta conclusión de la Comisión no tiene mucho fundamento. Además, es cierto que el precio del carbón bajó, pero poco; el precio siguió siendo elevado.

6. Que si bien la compañía puede satisfacer con sus propios recursos los gastos de explotación y cargas actuales, es dudoso que pueda repartir dividendos en años sucesivos a sus accionistas en la cuantía acostumbrada, y mucho menos atender a nuevos gastos en la emisión de obligaciones. En nuestra opinión, este análisis de la Comisión sí es correcto y certero -aunque sin futuras emisiones de acciones y obligaciones se originarían evidentes problemas de financiación futura-.

7. Que aunque los recursos de la compañía aumentasen hasta el punto que el saldo de la explotación llegase a ser igual o superior al de 1913, no por eso se habría aumentado su capacidad financiera para emitir capitales con que ampliar las obras de primer establecimiento superiores a los 400 millones proyectados, pues la fecha de reversión de las líneas más importantes y las cargas que sobre ellas pesan no permitirá a la compañía con su sola garantía adquirir los capitales necesarios para ampliar tales 
obras al límite que las necesidades del tráfico pueden exigir en un porvenir más o menos próximo.

8. Que la adquisición de capitales para realizar las obras de ampliación y nuevas instalaciones que la compañía tiene en proyecto, sería muy onerosa hacerla con sus propios medios [sería imposible] y con su sola garantía, y por ello la Comisión entiende que debe el Estado facilitar el capital necesario para la ejecución de las que solicite la primera y acuerde el Gobierno, mediante la debida justificación e inspección de las obras, entregando a la compañía en forma de anticipo reintegrable los importes de las certificaciones de obras ejecutadas que periódicamente extienda la entidad inspectora. Estos anticipos se reintegrarán por la compañía por anualidades calculadas al interés del 5\% anual, en un periodo de sesenta años. Cuando se produzca la reversión o rescate de las líneas, estos anticipos quedarán totalmente cancelados.

9. Que el aumento de gastos para atender el pago por la nueva carga financiera, calculando el aumento de la deuda en los cinco primeros años en 55 millones anuales sería: en el primer año 2.876.500 pesetas, en el segundo año 5.753.000, en el tercer año 8.629.500, en el cuarto año 11.506.000 y en el quinto año14.272.500 pesetas.

10. Que el auxilio, de ser indispensable, no puede cifrarse, porque su necesidad dependerá del aumento de los ingresos y gastos de la compañía, mucho más teniendo en cuenta el crecimiento progresivo de los productos, originado por el mayor tráfico, que facilitará la utilización de las nuevas obras e instalaciones, que es de esperar lleguen a compensar las mayores cargas que su ejecución ocasionen. De todos modos, dado el escalonamiento del aumento de cargas, la deficiencia entre nuevos ingresos y nuevas cargas, no será apreciable sino en los últimos años de este ciclo, que es el momento más oportuno para fijar el modo de enjugar tal déficit.

Al finalizar las conclusiones, la Comisión hizo constar las muchas facilidades que había encontrado en la Dirección y alto personal de la compañía NORTE a la hora de realizar su trabajo.

\subsubsection{Examen del activo y pasivo del balance de la compañía de los Caminos de Hierro del NORTE de España del año 1922}

En la misma fecha y firmado en Madrid por los mismos expertos ${ }^{452}$, la "Primera Comisión investigadora de la situación económica de las empresas del ferrocarril" emitió el documento denominado "Examen del activo y pasivo del balance de la compañía de los Caminos de Hierro del NORTE de España del año 1922".

El documento comprueba la realidad de las partidas que constituyen el activo y pasivo del balance del año 1922. Tras el análisis de cada una de las partidas, la Comisión ofrece dos conclusiones y recomendaciones.

\footnotetext{
${ }^{452}$ Este documento fue elaborado por García de los Ríos, José; Herbella, Antonio; Garate, Pedro; García Bermúdez, Fernando y fechado en Madrid el 29 de noviembre de 1923.
} 
La Comisión afirma que del examen de las cifras que quedan expuestas se deduce "la solidez del activo de la compañía y, por tanto, la absoluta garantía del pasivo" ${ }^{\text {"453 }}$.

"Como consecuencia natural de los fines que tiene la compañía, y del carácter reversible al Estado del activo inmovilizado", la empresa debería constituir reservas que garantiasen para el futuro la amortización del capital ${ }^{454}$.

\subsubsection{Contestación de NORTE al Informe relativo a la Comisión}

Cuando NORTE recibió la Memoria de la Comisión Investigadora de la contabilidad de la misma, varios administradores estuvieron debatiendo sobre el Informe. En el debate, los administradores dejaron claro que si no se aceptaban por parte del Gobierno de la nación algunas de sus demandas contenidas en la contestación, o no se le concedía compensación por realizarlas, la compañía entraría en una difícil situación ${ }^{455}$. El Consejo de NORTE aprobó la respuesta que se debía dar a la Comisión. La respuesta fue amplia y meditada, pero no sólo por parte de los administradores, sino también tuvo en cuenta la opinión de los gerentes, abogados y contables de la compañía, que escrutaron a fondo todos los aspectos legales vigentes en ese momento para elaborar este documento.

El documento, denominado "Contestación de la Compañía de los Caminos de Hierro del Norte de España al Informe redactado por la Primera Comisión investigadora de la situación económica de las empresas de ferrocarriles nombrada por Real Orden de 20 de octubre de 1923", estaba compuesto por siete partes: Introducción ${ }^{456}$, "I. Verdadero concepto del anticipo y correcta forma de su contabilización", "II. Reparos del Informe a las diversas partidas que componen las cuentas de explotación”, "III. Previsión de los resultados del año 1923", "IV: Pronósticos para ejercicios posteriores", "V. Materialización de las reservas" y "VI. Examen de las conclusiones".

453 AHF P/113/258-2: "Examen del activo y pasivo del balance de la compañía de los Caminos de Hierro del NORTE de España del año 1922", Primera Comisión investigadora de la situación económica de las empresas de ferrocarriles, 29 de noviembre de 1923.

${ }^{454} \mathrm{La}$ empresa debería constituir reservas que garanticen la amortización del capital para el futuro, ya que "apenas se aplican a mantener los valores del primer establecimiento en el estado de conservación que exigen". AHF P-113/258-2: "Examen del activo y pasivo del balance de la compañía de los Caminos de Hierro del NORTE de España del año 1922”, Primera Comisión investigadora de la situación económica de las empresas de ferrocarriles, 29 de noviembre de 1923.

${ }^{455}$ Acta $\mathrm{n}^{\circ} 954$ del Libro de actas del Consejo de Administración de NORTE: 21 de diciembre de 1923, Apartado I.

${ }^{456}$ La Introducción es el único componente del documento que no aparece con un título para diferenciarlo. Además no tiene esta denominación en ningún lugar del documento. No obstante parece un prefacio o introducción clara. El resto de componentes sí están separados por un título escrito en mayúscula al principio de cada componente, dejando un apartado claramente diferenciado. La introducción también está diferenciada por exclusión del resto de componentes. 


\section{$\underline{\text { Introducción }}$}

La Introducción está formada por tres componentes: a) una nota de agradecimiento al trabajo de la Comisión y al reconocimiento de la opinión del Informe de la Comisión, b) las críticas al procedimiento de la revisión de las cuentas y c) la identificación de la principal motivación para realizar el Informe de la Comisión.

El Informe comienza con una nota de agradecimiento a la Comisión por la forma en que llevó su cometido. Además valora como muy positiva la opinión ofrecida por el alcance del trabajo de revisión de la Comisión, sobre la exactitud de todos los documentos y libros de contabilidad $^{457}$. Los gestores de NORTE conceden una gran importancia al reconocimiento de su honrada gestión, por estar "en tiempos de insinuaciones injuriosas de todo género para las personas que rigen la administración de las empresas ferroviarias"

En la Introducción también se incluye una crítica al procedimiento de la revisión de las cuentas establecido en el Real Decreto de 20 de octubre de 1923. La interpretación del Real Decreto realizada por la empresa NORTE $^{459}$ es que "tanto las Comisiones como las compañías deben someter sus informes a una entidad superior, especie de tribunal que examine, las alegaciones de unos y de otros, con absoluta igualdad". A la Compañía le extraña que en las instrucciones dadas por las Comisiones se dispusiera que ellas mismas pidan su respuesta a las empresas y que, después de recibirlas, formulen un nuevo escrito, sin dar conocimiento a las compañías ni opción de contestarlo. NORTE se compromete a entregar la respuesta directamente a la Comisión, pero considera como justo y procedente que las compañías reciban el escrito definitivo de las Comisiones para que ellas puedan oponer a sus conclusiones, las rectificaciones y argumentos que le sean pertinentes.

La Introducción culmina con la manifestación de la "idea de base" del Informe de la Comisión según la interpretación de NORTE. Para la empresa, el Informe de la Comisión tiene como eje de todo el trabajo la supresión del anticipo que el Estado facilita para complemento de haberes al personal. En opinión de la empresa, es normal que la Comisión compuesta de funcionarios no haya podido substraerse al sentir general, pues "por todos los lados se ha hablado que deben suprimirse" ${ }^{460}$. En nuestra opinión este análisis es correcto. La

\footnotetext{
${ }^{457}$ En la introducción del "Informe redactado por la Primera Comisión investigadora de la situación económica de las empresas de ferrocarriles" se establece el alcance del trabajo de revisión: "todos los documentos y libros de contabilidad que ha sido preciso consultar y comprobar para hacer un minucioso estudio del funcionamiento de la empresa, comprobando los resultados que ofrecen sus balances publicados, examinando la documentación necesaria para cerciorarse de la exactitud con que son llevados a los libros principales y adquiriendo la seguridad de que las cifras contenidas en los balances y en las cuentas generales de explotación responden a la verdad de los hechos contables".

458 AHF P-113-258-3: "Contestación de la Compañía de los Caminos de Hierro del NORTE de España al Informe redactado por la Primera Comisión investigadora de la situación económica de las empresas de ferrocarriles nombrada por Real Orden de 20 de octubre de 1923": Apartado "Introducción".

${ }^{459}$ NORTE entiende que su interpretación es compartida por la totalidad de las empresas ferroviarias.

${ }^{460}$ AHF P-113-258-3: "Contestación de la Compañía de los Caminos de Hierro del NORTE de España al Informe redactado por la Primera Comisión investigadora de la situación económica de las empresas de ferrocarriles nombrada por Real Orden de 20 de octubre de 1923": Apartado "Introducción".
} 
única puntualización que podemos hacer es que no es tanto por la opinión popular, ni por las presiones de agentes, sino más bien por las dificultades presupuestarias del Estado en el momento de la Dictadura militar.

\section{"I. Verdadero concepto del anticipo y correcta forma de su contabilización"}

El apartado "I. Verdadero concepto del anticipo y correcta forma de su contabilización" comienza indagando sobre las causas que dieron lugar a la concesión del anticipo para el personal. Aquí es donde la opinión de NORTE es más inconsistente, por interesada y sesgada. En el apartado se comienza señalando los argumentos del Informe de la Comisión. Los aumentos de haberes a que hace relación la Real Orden de 23 de marzo de 1920, confirmados por la Real Orden de 10 de abril de 1920, fueron prometidos por las compañías al personal para cuando los fondos existentes en su caja les permitiesen hacerlos efectivos, y el Estado, ejerciendo una función de banquero, no hizo más que ofrecer a las empresa que él les prestaría, a buena cuenta, lo que les faltase para su completo pago; es decir que "la concesión del Estado fue una sencilla operación de tesorería". De esta concepción del anticipo -añade NORTE- se deduce que siendo las compañías "las que se crearon a sí mismas, de una manera espontánea y definitiva" [en el momento actual sabemos no fue para nada espontánea], las cantidades totales pagadas por la elevación de haberes establecida en las Reales Órdenes antes mencionadas son verdaderos gastos de explotación a cargo de las empresas, no interviniendo en ellos el Estado sino para adelantar el dinero que faltara, con el mero carácter de prestamista. Para NORTE, esta concepción del anticipo es completamente equivocada. NORTE intenta demostrarlo con cuatro argumentos:

1. Con el texto de las disposiciones mencionadas.

2. Por los actos anteriores del Estado y de las compañías relacionadas con el asunto.

3. Con el examen de la situación en que las compañías se hallaban al tiempo de acordarse el anticipo.

4. Por los actos posteriores del Estado relacionados con la misma cuestión ${ }^{461}$.

En primer lugar, la Real Orden de 23 de marzo de 1920 expresó que, derivado de las perturbaciones económicas originadas por la Gran Guerra, existía en la fecha de emisión de la Real Orden la "necesidad inexcusable" de mejorar las remuneraciones de todos los que viven de sueldos y salarios y han creado dificultades graves a las empresas que no cuentan "con medios económicos suficientes para hacer efectivas dichas elevaciones ni tienen expedito el camino de aumentar en análoga proporción sus ingresos", contándose entre éstas, de un modo especial, por la magnitud de dichas dificultades y por la transcendencia del servicio que tienen encomendado, las empresas concesionarias de ferrocarriles ${ }^{462}$. Por ello, la Real Orden de 23

\footnotetext{
461 AHF P-113-258-3: “Contestación de la Compañía de los Caminos de Hierro del NORTE de España al Informe redactado por la Primera Comisión investigadora de la situación económica de las empresas de ferrocarriles nombrada por Real Orden de 20 de octubre de 1923": Apartado "Verdadero concepto del anticipo y correcta forma de su contabilización".

${ }^{462}$ La Ley denominada de Subsistencias de 11 de noviembre de 1916 prevé varios casos de intervención del Gobierno para facilitar los transportes y abastecer el mercado nacional, aún teniendo que satisfacer a las compañías ferroviarias indemnizaciones pecuniarias por consecuencia de las medidas que autorizan, y faculta, en cuanto al tráfico marítimo, para adoptar cuantas disposiciones estime necesarias para su regularización; pero no
} 
de marzo de 1920 estableció que, con cargo al crédito ilimitado, se autorice al ministro de Abastecimientos anticipar a las compañías ferroviarias las cantidades a que ascienden durante un mes los aumentos de haberes ofrecidos por las mismas a su personal para el día en que cuenten con los recursos necesarios al efecto; el reintegro de las cantidades anticipadas con tal objeto se verificará con el exceso que en los productos líquidos de ejercicios posteriores obtengan las compañías con relación al alcanzado en el ejercicio de 1913.

Para NORTE, nada hay en la Real Orden de 23 de marzo de 1920 que denote el carácter de préstamo simple que el Informe quiere señalar al anticipo. De la disposición se deduce que, no creyendo conveniente el Estado, "por razones políticas que no se expresan", autorizar la elevación de tarifas que las empresas tenían solicitada, tomó a su cargo totalmente el pago de su importe, hasta que por la resolución definitiva que se adoptara en el problema ferroviario, y que por hallarse sometido a las Cortes se estimaba de vigencia inmediata ${ }^{463}$, se dotase a las compañías "de una manera permanente" de los recursos necesarios para cubrir el aumento de gastos representado por la mejora de haberes ${ }^{464}$.

NORTE argumentó que a nadie podría ocurrírsele que, no permitiendo a NORTE aumentar sus gastos en más de 30 millones al año, porque con ello tendría un déficit de mucha consideración, podría ser una solución razonable del problema recurrir al préstamo para cubrir los déficits ${ }^{465}$.

Para NORTE la operación tenía otra finalidad. La carestía de la vida imponía aumentos de remuneración que todas las empresas libres habían llevado a efecto, pero que las compañías de ferrocarriles, aún reconociendo la justificación de la concesión, no podían acordar sin que una disposición oficial les permitiera poner en armonía el precio de venta de su producto con el precio de coste del mismo, es decir, elevar sus precios, como habían hecho ya en España todas las demás industrias y en el extranjero todas las ferroviarias. Eso es lo que quería NORTE, lo que no compartía ningún otro agente. El Estado, estimando justa la petición, pero no pudiendo acceder de momento a la elevación de las tarifas (la oposición era muy fuerte), aunque esperaban solucionar el problema en el plazo de días, tomó a su cargo todo el importe de la mejora de haberes solicitada.

prevé nominalmente el caso de necesitarse indemnizaciones o incautaciones para asegurar el tráfico ferroviario, por no haberse tenido presente esta forma posible de conflicto cuando la Ley fue redactada. AHF P-113-258-3: "Contestación de la Compañía de los Caminos de Hierro del NORTE de España al Informe redactado por la Primera Comisión investigadora de la situación económica de las empresas de ferrocarriles nombrada por Real Orden de 20 de octubre de 1923": Apartado "Verdadero concepto del anticipo y correcta forma de su contabilización".

${ }^{463}$ Así se explica que la concesión se hiciese sólo de un mes.

${ }^{464}$ AHF P-113-258-3: "Contestación de la Compañía de los Caminos de Hierro del NORTE de España al Informe redactado por la Primera Comisión investigadora de la situación económica de las empresas de ferrocarriles nombrada por Real Orden de 20 de octubre de 1923": Apartado "I. Verdadero concepto del anticipo y correcta forma de su contabilización".

465 AHF P-113-258-3: "Contestación de la Compañía de los Caminos de Hierro del NORTE de España al Informe redactado por la Primera Comisión investigadora de la situación económica de las empresas de ferrocarriles nombrada por Real Orden de 20 de octubre de 1923": Apartado "I. Verdadero concepto del anticipo y correcta forma de su contabilización". 
La Real Orden de 10 de abril de 1920 acordó la prórroga de lo establecido en la anterior disposición "hasta que recayera una solución definitiva acerca del problema en todos sus aspectos" con el fin de otorgar a las empresas ferroviarias medios económicos suficientes para hacer frente, entre otros extremos, "a la necesidad de mejorar las remuneraciones de sus empleados". Lo que las compañías querían era que se impusiera el principio de que fueran ellas, con sus propios ingresos, las que solventasen el problema. Esta reforma que proponían las ferroviarias suponía que el gobierno aprobara una subida espectacular de las tarifas, lo cual implicaba un coste social difícilmente asumible por el Estado.

NORTE concluye que en las Reales Órdenes queda claro que el régimen de anticipos sustituye al de otorgamientos a las empresas de los medios económicos necesarios para hacer frente, entre otras atenciones, a la mejora de haberes de su personal, siendo indudablemente que esos medios económicos permanentes son los ingresos en forma de elevación de tarifas.

En segundo lugar, la compañía intenta demostrar su interpretación sobre el anticipo, por medio de los actos anteriores del Estado y de las compañías relacionadas con el asunto, especialmente el Real Decreto de 26 de diciembre de 1918. En esa fecha, las compañías acuciadas por las reclamaciones de su personal solicitaron del Estado la autorización para elevar sus tarifas; el gobierno, estimando justa su petición, accedió a la elevación, aunque no en la cuantía en que habían solicitado. NORTE apunta que "para cubrir atenciones de carácter permanente, se autorizó, como era lógico, el medio de aumentar los ingresos normales de la empresa", y posteriormente se interroga sobre que, ante un hecho muy similar, "podía hacerse frente con un procedimiento dilatorio y circunstancial como sería el de un préstamo" 466 .

En tercer lugar, NORTE intenta justificar su posición con el examen de la situación en que las compañías se hallaban en el momento de acordarse el anticipo. Según NORTE ${ }^{467}$, al cerrar el ejercicio 1919, la compañía había tenido un excedente de productos de casi diez millones de pesetas, no obstante, no se hace referencia en las Reales Ordenes de concesión del anticipo ninguna alusión a él, como hubiese sido natural si el fin asignado a la concesión hubiese sido el de suplir la insuficiencia productiva de las líneas para cubrir el aumento de gastos que se establecía. Hubiese sido lógico que si el nuevo gasto se creaba a cargo de la compañía, la Real Orden facilitara solamente lo que fuese preciso para pagar la parte de él que no resultase cubierta por los ingresos propios de NORTE. No fue así, sino que en las disposiciones queda claro que el Estado entregaría para aquel mes (Real Orden de 23 de marzo de 1920) y después para lo sucesivo (Real Orden de 10 de abril de 1920), hasta la resolución del asunto, la cantidad total a que el aumento de gastos se eleve, dejando a la empresa en libertad de dar al

\footnotetext{
466 AHF P-113-258-3: “Contestación de la Compañía de los Caminos de Hierro del NORTE de España al Informe redactado por la Primera Comisión investigadora de la situación económica de las empresas de ferrocarriles nombrada por Real Orden de 20 de octubre de 1923": Apartado "I. Verdadero concepto del anticipo y correcta forma de su contabilización".

467 AHF P-113-258-3: “Contestación de la Compañía de los Caminos de Hierro del NORTE de España al Informe redactado por la Primera Comisión investigadora de la situación económica de las empresas de ferrocarriles nombrada por Real Orden de 20 de octubre de 1923": Apartado "I. Verdadero concepto del anticipo y correcta forma de su contabilización".
} 
saldo de las cuentas de explotación por los otros conceptos, en el año 1919 y en los posteriores, la aplicación determinada en sus estatutos. NORTE se vuelve a cuestionar sobre si es lógico pensar que se hubiera procedido de ese modo si se hubiese entendido que el nuevo gasto debía gravar directamente a la compañía y que al Estado correspondía solamente prestar el saldo no cubierto por los ingresos.

Por último, NORTE intenta justificar, con el análisis de tres actos posteriores del Estado relacionados con la misma cuestión, que el verdadero concepto del anticipo no es el de un préstamo, sino el de una colaboración del Estado en los gastos de las empresas. Evidentemente, esto es simplemente retórica, nunca se buscó una colaboración con el Estado.

La primera es la reiteración de cuarenta y tres entregas mensuales de igual importancia, sin hacer referencia alguna a que "fuera procedente su reducción, en relación con las posibilidades de pago directo por las empresas", bien claramente determina que la intención del Estado no ha sido nunca la de prestar dinero a las compañías en la cuantía necesaria para cubrir la insuficiencia de sus fondos disponibles para pagar el aumento de los gastos de personal representados por el plus, sino la de sufragar por sí mismos esos gastos en condiciones especiales de reembolso eventual, hasta que el problema ferroviario obtuviera una resolución completa y definitiva. En esos cuarenta y tres meses, las disponibilidades de las empresas aumentaron (tanto por emisiones de valores como por otros conceptos) y, sin embargo, el Estado no ha creído por ello extinguida la obligación que espontáneamente se había impuesto. "Y no lo ha creído extinguida porque el auxilio prometido a las empresas no fue una operación de tesorería, como parece dar a entender el informe, sino una colaboración, una verdadera sustitución en el pago de los gastos nuevos de personal, en razón a no concederle a ellos de momento los medios normales de satisfacerlos con sus propios ingresos" $"$. Este punto está la clave de todo el informe de NORTE: no había ninguna intención de devolver nada, como de hecho ocurrió.

La segunda está en el análisis de la Real Orden de 10 de abril de 1921, publicada un año después de la concesión del anticipo ${ }^{469}$. La Real Orden de 10 de abril de 1921 establece que:

- El plus concedido en 1920 se debe abonar con cargo al adelanto que hace el Estado.

- El Estado seguirá facilitando el adelanto con cargo del cual se paga el mencionado plus, hasta tanto que se establezca el nuevo régimen ferroviario.

- La repercusión del aumento de haber en los derechos pasivos será a cargo de las compañías. Desde luego, los trabajadores consideraron, desde el primer momento, que el anticipo constituía parte del salario.

\footnotetext{
468 AHF P-113-258-3: “Contestación de la Compañía de los Caminos de Hierro del NORTE de España al Informe redactado por la Primera Comisión investigadora de la situación económica de las empresas de ferrocarriles nombrada por Real Orden de 20 de octubre de 1923": Apartado "I. Verdadero concepto del anticipo y correcta forma de su contabilización".

469 En las Conferencias celebradas por el Ministerio con los directores y representantes de las compañías ferroviarias, las compañías acordaron la incorporación de los pluses al sueldo, como les venía pidiendo el Ministerio (Real Orden de 10 de abril de 1921).
} 
NORTE interpreta la Real Orden de 10 de abril de 1921 de forma muy discutible: "Si el plus se paga con cargo al adelanto del Estado, bien claro está que no es con cargo a las compañías, porque no puede ponerse a cargo de dos cuentas a la vez; si el Estado ha de seguir facilitando el adelanto hasta la resolución definitiva del asunto, bien claro está también que ello es independiente de las cuentas de las empresas por los otros conceptos"

La tercera es que, según NORTE, el Estado sancionó repetidamente el criterio, sustentado por la compañía, de que los pluses que se pagan con el anticipo no son a cargo de la compañía sino a cargo del adelanto del Estado. El argumento es que en las liquidaciones de los ejercicios de 1920, 1921 y 1922, formuladas sin comprender en los gastos de explotación los mencionados pluses, NORTE presentó beneficios que el Estado reconoció que eran procedentes sin haber dado principio al reembolso del anticipo, liquidando y percibiendo sobre ellos el impuesto de utilidades, así como ha percibido el mismo impuesto de utilidades sobre los dividendos repartidos. Para NORTE, esta actuación del Estado es una consagración completa y definitiva de su interpretación. Implícitamente está clamando por la necesidad de una auditoría de cuentas.

Por todo lo anterior, NORTE calificó su forma de presentar las cuentas, sin comprender en ellas como gasto el plus a cargo del adelanto del Estado, como "legal, lógica y correcta, bajo el punto de vista contable",470.

En la Real Orden de 23 de marzo de 1920 aparecía que el reintegro de las cantidades adelantadas por el Estado para el pago de haberes estaba sometido a la condición suspensiva de que, una vez concedidos a la compañía los medios normales de hacer frente a aquellos gastos, obtengan un beneficio superior al del año 1913, y sólo en la cuantía en que este beneficio al del año indicado.

Se estableció pues, para la compañía una obligación condicional de pagar, cuyo plazo y cuya cuantía son indeterminados. Podría ocurrir que la condición determinante del pago se cumpliese en seguida o tardase mucho tiempo en producirse, y que se realizase en grande o en pequeña cuantía. La indeterminación de estos dos elementos esenciales impide que pueda considerarse como un gasto hasta que se conozca el importe y la fecha. En opinión de NORTE, para que un gasto pueda estimarse legal necesita tener las dos condiciones de "real" y "exigible"; es decir de importe cierto y de vencimiento conocido. Si su importe no se conoce y no puede representarse por una cifra, no es posible contabilizarlo; no teniendo el carácter de exigible al contado o a plazo, podrá estimarse como una subvención, como una donación, pero no como un gasto. En nuestra opinión, es de destacar la debilidad del argumento sobre que no se conoce el importe y que éste no es exigible.

\footnotetext{
470 AHF P-113-258-3: “Contestación de la Compañía de los Caminos de Hierro del NORTE de España al Informe redactado por la Primera Comisión investigadora de la situación económica de las empresas de ferrocarriles nombrada por Real Orden de 20 de octubre de 1923": Apartado "I. Verdadero concepto del anticipo y correcta forma de su contabilización".
} 
NORTE considera que su forma de contabilización es lógica, pues en todas las disposiciones legales que rigen la operación se dice que "estos pagos se hacen con cargo al adelanto del Estado". No sería lógico, argumenta NORTE, que hallándose eso dispuesto, que "se diese cargo de ellos a la cuenta de explotación presentándose así déficits que no estarían de acuerdo con las disposiciones legales relativas a la cuestión",471.

Además, NORTE considera que su sistema es el más correcto, desde el punto de vista contable, porque no sería posible figurar en sus cuentas esos pagos como un gasto definitivo a cargo de la compañía, sin figurar en el pasivo, entre las cuentas acreedoras exigibles, el crédito a favor del Estado, y en el activo un déficit continuo y creciente que no sería exacto, puesto que el crédito del Estado contra la compañía no es exigible sino en las condiciones señaladas. De esta manera, tanto el activo como el pasivo estarían falseados, y no reflejarían "la verdad de los hechos contables" ${ }^{472}$. Visto desde el momento actual, NORTE alega que no pueda ser unos gastos porque no refleja un pasivo, pero no da razones para no registrar una deuda, cuando el tratamiento correcto es el de una deuda. Los argumentos anteriores para el gasto sí podrían utilizarla para ello.

NORTE se apoya también en la opinión de la "Inspección Pericial de utilidades del Estado", y en el dictamen de la Comisión para calcular si NORTE tiene que devolver algo al Estado por el anticipo. Ambas presentan la cuenta en la misma forma que lo hace la compañía.

\section{"II. Reparos del Informe a las diversas partidas que componen las cuentas de explotación"}

En el apartado "II. Reparos del Informe a las diversas partidas que componen las cuentas de explotación", NORTE intenta justificar las tres principales objeciones que la Comisión hizo a sus cuentas de explotación: (1) que el personal es excesivamente numeroso y está pagado en demasía, (2) que en las reparaciones del material móvil y de tracción, por alargarse demasiado la vida del mismo o por no haberse podido reparar a tiempo, se producen gastos de reparación que pueden estimarse extraordinarios y que no deben cargarse a la cuenta de explotación sino a las reservas, y (3) que en los conceptos de "Transformaciones con ampliaciones" y "Renovación de vía" se comprenden como gastos sumas que deberían también ser satisfechas por reservas.

1. Necesidad del número de agentes y justicia de su remuneración

NORTE describe los factores que han hecho aumentar el número de agentes y su remuneración:

- La implantación de la jornada de ocho horas.

\footnotetext{
${ }^{471}$ AHF P-113-258-3: “Contestación de la Compañía de los Caminos de Hierro del NORTE de España al Informe redactado por la Primera Comisión investigadora de la situación económica de las empresas de ferrocarriles nombrada por Real Orden de 20 de octubre de 1923": Apartado "I. Verdadero concepto del anticipo y correcta forma de su contabilización".

${ }^{472}$ La expresión "la verdad de los hechos contables" es un claro antecedente de fair value.
} 
- La reducción que universalmente ha tenido el coeficiente por hora del rendimiento medio del trabajo del obrero de todas las clases.

- La creación de nuevas estaciones, apeaderos y apartaderos.

- El descanso quinquenal remunerado a los agentes especialmente afectos a la circulación de trenes, que obliga a tener otros dispuestos para los reemplazos.

- La concesión de licencias temporales a agentes a quienes antes no se concedía o se concedían por un menor tiempo.

- El pago de las bajas por enfermedad hasta sesenta días (o noventa por gracia especial).

En opinión de la empresa, y en esto le asiste toda la razón, "si aumenta el número de agentes es porque lo encuentra absolutamente indispensable", porque preferiría ahorrar tanto en sueldos, como en los otros conceptos suplementarios de remuneración (pensiones, socorros, etc.).

NORTE reconoce que es posible que en algún servicio o en alguna dependencia haya en un momento dado algún agente en exceso, "porque en una organización de 35.000 hombres no puede tenerse en todos los sitios y en todos los momentos la medida justa"; pero ello, "que en conjunto no puede ser una cosa de mucha importancia", permite despachar los asuntos y realizar el trabajo aún en momentos de acumulación de éste, periodos de licencias temporales, época de enfermedades, etc.

Respecto a la remuneración, que el Informe califica como excesiva, NORTE advierte dos cosas. La primera es que el último aumento de salarios se hizo por disposición del Estado en las Reales Órdenes. La segunda es que la compañía recibe continuamente de su personal peticiones de mejora de remuneración, directamente por aumento de haber o indirectamente por pago de horas extraordinarias. Ambas argumentaciones de NORTE son indudablemente correctas.

El Informe de la "Primera Comisión investigadora de la situación económica de las empresas de ferrocarriles" tachó de improcedente el registro contable de la paga extraordinaria que NORTE satisface a su personal en el mes de abril de cada año. El Informe encuentra que si los fondos que se reparten como paga extraordinaria se distribuyeran en forma de participación en los beneficios, la operación "no sería censurable, sino digna de aplauso", y el premio así otorgado sería justo, moral y equitativo, y según dice al final del párrafo "no recargaría, como ahora sucede, los gastos de explotación".

Podemos afirmar que, en este argumento, NORTE también tenía razón. NORTE evalúa el registro contable de la paga extraordinaria del mes de abril por medio de sus antecedentes, en su concepto actual y en sus concepciones contables. En el periodo 1897-1917, la Compañía tenía establecidas unas primas llamadas "por buenos servicios", que se repartían anualmente a la mayor parte del personal de plantilla [en nuestra opinión esto no era verdad, sólo era a una parte del personal], en relación con los productos líquidos de la explotación (diferencia entre productos y gastos). Los empleados de plantilla que no participaban de las primas [que en nuestra opinión eran la mayoría, y no desde 1897] cobraban dos gratificaciones semestrales, 
equivalentes entre las dos a una mensualidad de su sueldo. El coeficiente de reparto de las primas era, por término medio, del 17 al 20\% del sueldo anual. Este argumento es matizable porque hasta la Gran Guerra esto suponía realmente poco.

Al producirse el encarecimiento de la vida, la compañía, para suplir la insuficiencia de los haberes, concedió al personal gratificaciones generales extensivas así al personal de plantilla como a jornal, puesto que a todos alcanzaban las consecuencias de la carestía, suprimiendo las llamadas primas "por buenos servicios". Así ocurrió en los años 1918 y 1919, hasta que acordada por el Estado la concesión del segundo plus (abril de 1920), en la misma Circular en que esta concesión se acordaba al personal se le ofreció (de acuerdo oficioso con el Gobierno) que se pagaría una mensualidad extraordinaria en abril de cada año, computándose el haber para estos efectos, con el aumento de los dos pluses y tomándose el importe total de ella a su cargo por la compañía.

Debe advertirse que para todo el personal de plantilla la paga extraordinaria, aún así calculada, es inferior a la prima "por buenos servicios" que antes percibía, siendo para algunas categorías superiores, de bastante importancia la diferencia.

La paga extraordinaria es una concesión antigua, y NORTE ${ }^{473}$ no creía en su supresión, ni en su transformación en participación de beneficios. La compañía asume que si una disposición oficial la impusiera, NORTE la cumpliría y su personal la acataría, aunque cree que provocaría un estado de descontento y perturbación moral que la empresa cree que debe ser evitada. NORTE confirma que en los últimos años el personal ha reiterado peticiones de nuevas pagas extraordinarias a las que NORTE respondió que no estaba en condiciones de concederlo.

A juicio de NORTE ${ }^{474}$, el reparto de una suma fija, cierta, cualquiera que sea el resultado de la explotación, cobrada siempre en la misma fecha es preferible para los trabajadores que una participación en los beneficios que pueden en algún momento no existir. Este argumento, sorprendente, está alejado de toda deseable relación entre salarios y beneficios, y de los intereses cuantitativos de los empleados; sólo puede entenderse desde la postura de no mantener la situación para no molestar al personal.

En cuanto a las consecuencias contables de transformar la paga extraordinaria en participación de beneficios, NORTE $^{475}$ no cree que hiciese cambiar nada el saldo de la cuenta

\footnotetext{
473 AHF P-113-258-3: “Contestación de la Compañía de los Caminos de Hierro del NORTE de España al Informe redactado por la Primera Comisión investigadora de la situación económica de las empresas de ferrocarriles nombrada por Real Orden de 20 de octubre de 1923": Apartado "II. Reparos del Informe a las diversas partidas que componen las cuentas de explotación".

474 AHF P-113-258-3: "Contestación de la Compañía de los Caminos de Hierro del NORTE de España al Informe redactado por la Primera Comisión investigadora de la situación económica de las empresas de ferrocarriles nombrada por Real Orden de 20 de octubre de 1923": Apartado "II. Reparos del Informe a las diversas partidas que componen las cuentas de explotación".

475 AHF P-113-258-3: "Contestación de la Compañía de los Caminos de Hierro del NORTE de España al Informe redactado por la Primera Comisión investigadora de la situación económica de las empresas de
} 
de explotación, si la suma total repartida había de ser de un importe aproximado a la paga mensual. Es necesario recalcar el diferente significado contable que supone que una cantidad sea recogida como gastos o como reparto del resultado, porque está consensuado que la cifra del resultado del ejercicio es una medida de la evolución presente de la sociedad. El tratamiento de contabilización correcto es el de gasto como tiene presente NORTE, pero no recurriendo a un engaño de los conceptos contables como éste. La consideración como reparto y no como gasto supone que la cifra de beneficios sea mayor, y por tanto una apariencia mejor de la empresa para, por ejemplo, justificar la supresión del anticipo. Esto es lo que busca la Comisión en los argumentos posteriores.

Visto desde el momento actual, es necesario destacar que la remuneración de los trabajadores debe registrarse como gasto independientemente que sea fijo o variable en función de la cifra del resultado del ejercicio, lo único que cambia es que el primero se incluye en la regularización y el variable requiere de una regularización posterior.

2. Que en las reparaciones del material, por alargarse demasiado la vida del mismo o por no haberse podido reparar a tiempo, se producen gastos de reparación que pueden estimarse extraordinarios y que no deben cargarse a la cuenta de explotación sino a las reservas.

La empresa admite que le gustaría, y lo intenta, dar de baja todas la unidades antiguas, pero que no le es posible retirar de la circulación tantas máquinas y vagones como quisiera, "por

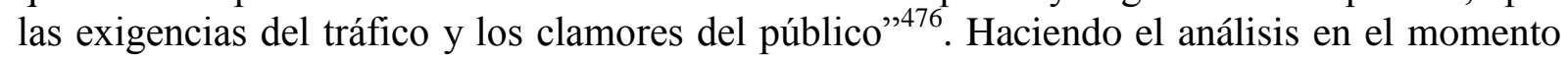
actual, está claro que si hiciera la renovación en ese momento se quedaría sin material suficiente para realizar la actividad. En verdad, hacía muchos ejercicios contables que el material era obsoleto porque no se había renovado por falta de medios. Posteriormente la renovación sí se producirá, fundamentalmente con préstamos, durante la Dictadura.

Lo que NORTE no comparte [y aquí le asiste la razón de nuevo] es que los gastos de reparación, porque los vehículos sean viejos, o porque hasta ese momento no haya habido facilidad para hacerlo, pierdan su carácter de gasto de explotación y deban imputarse a las reservas. NORTE cree que la imputación a reservas no tiene fundamento "legal ni moral alguno" ${ }^{477}$. Además, considera que las reservas, que fueron todas constituidas con beneficios no repartidos a los accionistas por voluntad de éstos, tienen todas ellas un fin especial fijado

ferrocarriles nombrada por Real Orden de 20 de octubre de 1923": Apartado "II. Reparos del Informe a las diversas partidas que componen las cuentas de explotación".

${ }^{476}$ AHF P-113-258-3: "Contestación de la Compañía de los Caminos de Hierro del NORTE de España al Informe redactado por la Primera Comisión investigadora de la situación económica de las empresas de ferrocarriles nombrada por Real Orden de 20 de octubre de 1923": Apartado "II. Reparos del Informe a las diversas partidas que componen las cuentas de explotación".

${ }^{477}$ NORTE se interroga en estos términos: “¿La reparación de un vagón nuevo es un gasto de explotación y la de uno viejo no? ¿La reparación de cincuenta vagones es gasto de explotación y la de setenta o setenta y cinco no?". (AHF P-113-258-3: "Contestación de la Compañía de los Caminos de Hierro del NORTE de España al Informe redactado por la Primera Comisión investigadora de la situación económica de las empresas de ferrocarriles nombrada por Real Orden de 20 de octubre de 1923": Apartado "II. Reparos del Informe a las diversas partidas que componen las cuentas de explotación"). 
expresamente al acordar su dotación. Según interpreta NORTE, el Informe propone imputar estos gastos al "Fondo de amortización del material motor y móvil", y para NORTE esta reserva está destinada a cubrir el quebranto que la compañía sufre al eliminar de los inventarios las unidades del material, y si se aplicaran para otro fin, además de que sería alterar el destino a ella señalado por los que dieron su dinero para constituirla, faltaría después crédito para su fin propio, "por haberlo gastado en cosa distinta a aquella a que estaba destinado" ${ }^{478}$.

Respecto a la reserva "Fondo de amortización del material motor y móvil", la compañía destaca que, en la página 100 del "Informe redactado por la Primera Comisión investigadora de la situación económica de las empresas de ferrocarriles", existe un error al afirmar que, en los años 1919-1922, NORTE realizó aportaciones a ella de parte del producto neto de explotación. NORTE aclara [y es verdad como puede observarse en sus estados financieros] que no realizó ninguna.

3. Que en los conceptos de "Transformaciones con ampliaciones" y "Renovación de vía" se comprenden sumas que deberían ser satisfechas por las reservas.

Para defender sus posiciones, NORTE expone por separado tres argumentos: (a) qué los gastos extraordinarios de la vía ("Transformaciones con ampliaciones" y "Renovación de vía") no se deben realizar sino en la cuantía que lo permita la partida corriente que se fije por este concepto, (b) qué cuando por su carácter de urgencia haya que hacerlos en cuantía superior a la señalada, deben soportarlos las reservas, y (c) qué todas las reservas deben subvenir a esta atención, cualquiera sea su origen y su destino.

a) Qué los gastos extraordinarios de la vía ("Transformaciones con ampliaciones" y "Renovación de vía") no se deben realizar sino en la cuantía que lo permita la partida corriente que se fije por este concepto.

Respecto a este punto, NORTE afirma que eso es lo que hace la compañía. Al final de cada año, NORTE establece un Presupuesto general de gastos para el año siguiente, por todos los conceptos y para todos los servicios. Al establecer el Presupuesto general se procura que el importe total de los gastos acordados sea conforme al de los ingresos presumibles, de modo que presente en su conjunto un resultado parecido al del ejercicio precedente, si éste ha sido satisfactorio. En algunos conceptos puede haber diferencias entre los gastos reales y los previstos; pero en otros, como la "Renovación de vía", por ejemplo, se fija un programa de trabajo para el año y en él NORTE se atiene exactamente al programa trazado. En "Transformaciones con ampliaciones" la compañía acuerda un crédito global, que no es de

\footnotetext{
478 AHF P-113-258-3: “Contestación de la Compañía de los Caminos de Hierro del NORTE de España al Informe redactado por la Primera Comisión investigadora de la situación económica de las empresas de ferrocarriles nombrada por Real Orden de 20 de octubre de 1923": Apartado "II. Reparos del Informe a las diversas partidas que componen las cuentas de explotación".
} 
mucha importancia, y del que generalmente no se $\operatorname{salen}^{479}$. No se producen gastos por los conceptos enunciados que no estén dentro de las previsiones del año, en las cuales se ha tenido en cuenta que no se produzca desnivel notable en el resultado general del ejercicio.

La partida "Renovación de vía" no se realiza por voluntad propia, sino por la imperiosa necesidad de sustituir el carril en los tramos de línea que están más desgastados. En los años 1919-1922, fue necesario renovar o sustituir los carriles con la misma rapidez que en 1913, pues eran mucho más frecuentes las circulaciones, más rápidos los trenes y más pesado el material, por lo que se desgasta el carril más pronto, obligando así a una renovación más intensa.

NORTE realizó estudios técnicos desde el año 1902. Estos estudios determinan que el promedio de renovación que la empresa está obligada a realizar es de 200 kilómetros al año, si se quiere conservar la vía en buen estado y evitar accidentes ${ }^{480}$. En el periodo 1902-1922, la empresa excedió la renovación que pudiera ser denominada "renovación normal".

NORTE considera que en verdad, la partida "Renovación de vía" es un gasto de conservación. Lo clasificaba como un concepto especial para ofrecer una mayor claridad en las cuentas. La empresa considera que no hay diferencia esencial entre el gasto de sustituir un carril que se rompe por accidente o por defecto de construcción, que el de sustituir otros desgastados por el uso $^{481}$. NORTE afirma que este sistema de contabilización de la partida "Renovación de vía" no lo implantó la compañía en los últimos años de su existencia, sino que lo registraba de esta manera desde su origen, siguiendo el ejemplo de todas las compañías francesas y de las más importantes de otros países, que también hacen la misma distribución que NORTE entre "Primer establecimiento" y "Explotación" de los gastos que la renovación produce ${ }^{482}$.

b) Qué cuando por su carácter de urgencia haya que hacerlos en cuantía superior a la señalada, deben soportarlos las reservas

\footnotetext{
479 En "Transformaciones con ampliaciones" la compañía acuerda un crédito global, que no es de mucha importancia, "y del que generalmente no nos salimos" (AHF P-113-258-3: "Contestación de la Compañía de los Caminos de Hierro del NORTE de España al Informe redactado por la Primera Comisión investigadora de la situación económica de las empresas de ferrocarriles nombrada por Real Orden de 20 de octubre de 1923": Apartado "II. Reparos del Informe a las diversas partidas que componen las cuentas de explotación").

480 AHF P-113-258-3: "Contestación de la Compañía de los Caminos de Hierro del NORTE de España al Informe redactado por la Primera Comisión investigadora de la situación económica de las empresas de ferrocarriles nombrada por Real Orden de 20 de octubre de 1923": Apartado "II. Reparos del Informe a las diversas partidas que componen las cuentas de explotación".

481 AHF P-113-258-3: "Contestación de la Compañía de los Caminos de Hierro del NORTE de España al Informe redactado por la Primera Comisión investigadora de la situación económica de las empresas de ferrocarriles nombrada por Real Orden de 20 de octubre de 1923": Apartado "II. Reparos del Informe a las diversas partidas que componen las cuentas de explotación".

482 AHF P-113-258-3: "Contestación de la Compañía de los Caminos de Hierro del NORTE de España al Informe redactado por la Primera Comisión investigadora de la situación económica de las empresas de ferrocarriles nombrada por Real Orden de 20 de octubre de 1923": Apartado "II. Reparos del Informe a las diversas partidas que componen las cuentas de explotación".
} 
En este punto se hallan comprendidas tres cuestiones: si el carácter de urgencia puede hacer perder a un gasto de explotación su naturaleza de tal; si se la puede también hacer perder la circunstancia de no haberse repartido los accionistas todos los beneficios de años anteriores, por espíritu de previsión; y las diferencias que puede haber en este punto entre la propiedad de una industria cualquiera y el usufructo temporal concedido a las empresas ferroviarias.

Para NORTE, no es lógico que la reconstrucción de la vía, por el desgaste propio de su uso, pueda estimarse como gasto de explotación cuando la renovación se hace dentro de lo establecido en el presupuesto del año, y no deba estimarse así cuando se hace por mayor cantidad de la prevista, a causa de la conveniencia o de la precisión de intensificarla. Lo mismo en uno que en otro caso la naturaleza del gasto es única. Podría decirse que en el segundo caso se debe hacer un presupuesto extraordinario o se debe incluir el gasto en el ejercicio siguiente, si tanto respeto se quiere tener al concepto del presupuesto aprobado; pero parece un error afirmar que en el primer caso el gasto corresponde a la cuenta de explotación y en el segundo a las reservas.

NORTE $^{483}$ argumenta que si las reservas no existieran, si los accionistas se hubieran repartido la totalidad de los beneficios, no podría negarse a los gastos de renovación de vía su verdadero y único carácter de gastos de explotación. Es más, si hubieran existido empresas que no han podido reservar beneficios porque no los han tenido, ¿dónde cargarán estos gastos de sustitución de carriles? Concluye NORTE [de forma brillante], que en las empresas, donde no han tenido beneficios o donde los han repartido todos, la renovación de la vía constituye un gasto de la explotación, y que no tiene sentido para aquellas que por espíritu de previsión o de buena gestión han reservado parte de sus beneficios repartibles, para dar mayor estimación a sus valores, esa misma atención no constituya también, como para las otras, un gasto de explotación.

El Estado desea que NORTE invierta en la renovación de la vía las reservas de la empresa. Sin embargo, NORTE ${ }^{484}$ precisa que es una concesionaria de ferrocarril, teniendo un estatus bien diferente al de una empresa privada propietaria de la vía. Aquí acierta la empresa al establecer la verdadera peculiaridad de su industria. Cualquier propietario de una empresa de cualquier otro sector posee sus bienes en pleno dominio, mientras que la concesionaria del ferrocarril sólo posee el usufructo temporal de la concesión. Los primeros pueden invertir sus reservas en la mejora de la finca, por lo que disminuye su activo en el valor del inmueble. Por el contrario, a una empresa ferroviaria no se le puede exigir que emplee sus beneficios, antiguos o modernos, en mejorar líneas que no son suyas y de las que sólo tiene un usufructo temporal, por tiempo indeterminado, pues el Estado puede rescatarlas al día siguiente de

\footnotetext{
483 AHF P-113-258-3: “Contestación de la Compañía de los Caminos de Hierro del NORTE de España al Informe redactado por la Primera Comisión investigadora de la situación económica de las empresas de ferrocarriles nombrada por Real Orden de 20 de octubre de 1923": Apartado "II. Reparos del Informe a las diversas partidas que componen las cuentas de explotación".

${ }^{484}$ AHF P-113-258-3: "Contestación de la Compañía de los Caminos de Hierro del NORTE de España al Informe redactado por la Primera Comisión investigadora de la situación económica de las empresas de ferrocarriles nombrada por Real Orden de 20 de octubre de 1923": Apartado "II. Reparos del Informe a las diversas partidas que componen las cuentas de explotación".
} 
haber incurrido en el gasto. Visto desde el siglo XXI, esta reversión es la principal razón para explicar por qué las empresas no han invertido en infraestructuras. NORTE no lo puede decir más claro.

c) Qué todas las reservas deben subvenir a esta atención, cualquiera sea su origen y su destino

Este es el punto más débil del razonamiento de NORTE. Para la empresa el Informe no está acertado porque las reservas son beneficios obtenidos por los accionistas en ejercicios anteriores y mantenidos en la compañía para fines especificados para cada uno de ellas; y no hay ninguna reserva cuyo fin sea cubrir gastos de reparación de material y de renovación de la vía. Para la empresa todas las reservas están destinadas a fines especiales diferentes de aquél, por lo que aplicarlas a cosas distintas para las que están constituidas sería alterar la finalidad de las mismas y dejarlas sin fondos para aquello que realmente constituye su objeto.

\section{“III. Previsión de los resultados del año 1923"}

En este apartado la compañía presenta una previsión de los resultados del ejercicio 1923. Se realiza una presentación en tres columnas. En la primera se incluye el plus indicado entre los gastos, como propone el Informe. En otra columna no se incorporan los gastos y el plus concedido con cargo al adelanto del Estado, es decir conforme al procedimiento contable elegido por NORTE. En la tercera columna se incluye la diferencia entre ambas - previsión de la compañía e Informe-. El detalle de las tres columnas aparece reflejado en el cuadro 16. 
Cuadro 16. Liquidación Probable del año 1923

\begin{tabular}{|l|c|c|c|}
\hline $\begin{array}{l}\text { LIQUIDACIÓN PROBABLE } \\
\text { DEL AÑO 1923 }\end{array}$ & Según el Informe & Según la compañía & $\begin{array}{c}\text { Diferencia de la } \\
\text { previsión de la } \\
\text { compañía sobre el } \\
\text { Informe }\end{array}$ \\
\hline INGRESOS & $\mathbf{3 1 2 . 0 0 0 . 0 0 0}$ & $\mathbf{3 1 4 . 0 0 0 . 0 0 0}$ & $+\mathbf{2 . 0 0 0 . 0 0 0}$ \\
\hline & & & \\
\hline Administración central & 3.003 .000 & 3.721 .000 & +718.000 \\
\hline Dirección & 2.208 .000 & 2.251 .000 & +43.000 \\
\hline Reclamación & 6.424 .000 & 6.700 .000 & +276.000 \\
\hline Tráfico & 918.000 & 909.000 & -9.000 \\
\hline Intervención & 3.852 .000 & 4.165 .000 & +313.000 \\
\hline Explotación & 49.006 .000 & 48.673 .000 & -333.000 \\
\hline Material y Tracción & 27.8487 .000 & 106.246 .000 & +1.359 .000 \\
\hline Vía y obras & 2.286 .000 & 39.199 .000 & +11.377 .000 \\
\hline $\begin{array}{l}\text { Diferencia entre los pagos } \\
\text { hechos con cargo al anticipo } \\
\text { del Estado y las sumas } \\
\text { recibidas de éste }\end{array}$ & & 5.500 .000 & +3.214 .000 \\
\hline & & & \\
\hline Pensiones & $\mathbf{2 0 0 . 4 6 6 . 0 0 0}$ & $\mathbf{2 1 7 . 3 6 4 . 0 0 0}$ & $+\mathbf{1 6 . 8 9 8 . 0 0 0}$ \\
\hline Cargas & 3.100 .000 & 3.150 .000 & +50.000 \\
\hline Total de gastos y cargas & $\mathbf{2 7 6 . 8 6 6 . 0 0 0}$ & $\mathbf{2 9 3 . 8 1 4 . 0 0 0}$ & + \\
\hline & $\mathbf{3 5 . 1 3 4 . 0 0 0}$ & $\mathbf{2 0 . 1 8 6 . 0 0 0}$ & $\mathbf{+ 1 4 . 9 4 8 . 0 0 0}$ \\
\hline Excedente & & & \\
\hline
\end{tabular}

Fuente: AHF P/113/258-3: “Contestación de la Compañía de los Caminos de Hierro del NORTE de España al Informe redactado por la Primera Comisión investigadora de la situación económica de las empresas de ferrocarriles nombrada por Real Orden de 20 de octubre de 1923": Apartado "III. Previsión de los resultados del año 1923”.

Visto desde el momento actual deben analizarse dos tipos de comentarios diferentes sobre este apartado: unos sobre la estructura y otros sobre los datos.

El primer aspecto a destacar es que la estructura del presupuesto de NORTE es mucho más adecuada que la de la Comisión. La columna de los conceptos está realizada en una única columna, siendo muy parecida a como se realiza actualmente, tras la adopción directa e indirecta de las International Financial Reporting Standards, y cómo se utilizaba en esa época en las empresas estadounidenses. El cuadro detalla los ingresos, para posteriormente incluir los gastos y cargas. Por diferencia de los segundos sobre los primeros se obtiene el excedente, término aún utilizado en el PGC de entidades no lucrativas. El cuadro de la Comisión recogía los gastos, posteriormente los ingresos, y sin diferenciar claramente -cosa que realiza la empresa de forma muy adecuada- refleja el excedente.

En segundo lugar es necesario interpretar donde se originó la diferencia de la previsión de la compañía sobre el Informe. El origen de las diferencias se encuentra en seis partidas. 
Dentro de los ingresos ofrecidos por la compañía, incluyeron dos millones de pesetas más, porque incorporaron el saldo acreedor de intereses, cambios y comisiones.

En el servicio de administración central, NORTE recogió más gastos por importe de 2.000 pesetas porque el Informe no tuvo en cuenta pagos importantes realizados en el cuarto trimestre para liquidar parte de los accidentes de Onteniente y Paredes.

En los gastos de Dirección, Reclamación, Tráfico, Intervención y Explotación, el Informe sumó a las cifras de fin de septiembre una tercera parte, y NORTE tuvo en cuenta las liquidaciones de ciertos conceptos que la empresa realizaba al fin de año: cambio de material, Caja de previsión, Almacenes, etc.

Tanto para los gastos de Material y Tracción, como los de Vía y obras, el Informe deducía, para cargarlo a las reservas, parte de los gastos de reparación de material y todos los de renovación de la vía.

Respecto a la diferencia entre los pagos hechos con cargo al anticipo del Estado y las sumas recibidas de éste, el Informe tuvo en cuenta sólo la del año 1923, mientras que NORTE recogió la totalidad de lo que el Estado debía pagar.

El Informe no tuvo en cuenta las pensiones que se pagan por años, por lo que para NORTE los gastos por pensiones son 50.000 pesetas más.

Tras analizar todos los datos anteriores, el alegato final de la compañía muestra claramente su objetivo al elaborar e incluir el cuadro en este apartado: "Si a los gastos propios de ella, se unieran los que el Estado satisface, en lugar de un excedente probable de 20.186.000 pesetas, tendríamos un déficit de 11.014.000" 485 . Por consiguiente, si el Estado resolviese cesar en el pago de los gastos que cubre el anticipo, sería procedente autorizar a la compañía para aumentar sus ingresos normales, en la cuantía precisa para compensar ese déficit, dar al capital la remuneración justa y proveer a los aumentos que pueden tener los gastos por la aplicación completa de la jornada de ocho horas, y a la elevación que habían de sufrir las cargas con las nuevas emisiones necesarias para la ejecución de nuevas obras y adquisición de material.

\section{"IV: Pronósticos para ejercicios posteriores"}

En este apartado, la empresa destacó, los optimistas pronósticos que el Informe realizó para los ejercicios de NORTE posteriores al año 1923.

\footnotetext{
485 AHF P-113-258-3: "Contestación de la Compañía de los Caminos de Hierro del NORTE de España al Informe redactado por la Primera Comisión investigadora de la situación económica de las empresas de ferrocarriles nombrada por Real Orden de 20 de octubre de 1923": Apartado "III. Previsión de los resultados del año 1923".
} 
Un aspecto a destacar es que NORTE partía del hecho de que los gastos no iban a aumentar más en el futuro, a pesar de que en ese momento había medidas legislativas previstas, y evolución previsible del mercado, que hacían pensar que algunos costes aumentarían, como por ejemplo los laborales. Así indica expresamente NORTE para Explotación, Material y Tracción, talleres y Vía y obras. Esto es especialmente destacable y chocante en los gastos de personal porque afirma que "no se prevé aumento alguno para la implantación completa de la jornada de ocho horas" ${ }^{486}$. Era prácticamente imposible que los costes laborales no aumentaran, como así fue.

\section{"V. Materialización de las reservas"}

En ese apartado, NORTE defiende su postura de realizar una operación para materializar sus reservas, "lógica y justa", en su opinión ${ }^{487}$.

El activo de una compañía de ferrocarriles se compone de dos partes:

- Líneas, Material y Mobiliario, que pertenece en nudapropiedad al Estado y de la que la empresa no tiene más que el usufructo.

- Propiedad privada, fondos de caja, cartera, etc., que pertenece a la empresa en pleno dominio.

La primera parte del activo tiene como contrapartida el "capital-acciones", las obligaciones y las subvenciones. Todos estos recursos financieros están invertidos en la adquisición o construcción de todos aquellos elementos revertibles. La segunda parte del activo procede de las cuentas acreedoras y especialmente de las reservas.

Para NORTE, las buenas prácticas contables "universalmente seguidas"488, establecen que los fondos que se inviertan en obras nuevas o en adquisición de material deben proceder de la emisión de obligaciones, "procurando siempre que el importe del activo revertible y el del pasivo consolidado sean equivalentes" "489. Esto no es siempre posible. Así ocurre cuando en un periodo no hay beneficios de la explotación o éstos son insuficientes para garantizar una

\footnotetext{
${ }^{486}$ AHF P-113-258-3: “Contestación de la Compañía de los Caminos de Hierro del NORTE de España al Informe redactado por la Primera Comisión investigadora de la situación económica de las empresas de ferrocarriles nombrada por Real Orden de 20 de octubre de 1923": Apartado "IV: Pronósticos para ejercicios posteriores".

${ }^{487}$ AHF P-113-258-3: "Contestación de la Compañía de los Caminos de Hierro del NORTE de España al Informe redactado por la Primera Comisión investigadora de la situación económica de las empresas de ferrocarriles nombrada por Real Orden de 20 de octubre de 1923": Apartado "V. Materialización de las reservas".

${ }^{488}$ AHF P-113-258-3: "Contestación de la Compañía de los Caminos de Hierro del NORTE de España al Informe redactado por la Primera Comisión investigadora de la situación económica de las empresas de ferrocarriles nombrada por Real Orden de 20 de octubre de 1923": Apartado "V. Materialización de las reservas".

${ }^{489}$ AHF P-113-258-3: "Contestación de la Compañía de los Caminos de Hierro del NORTE de España al Informe redactado por la Primera Comisión investigadora de la situación económica de las empresas de ferrocarriles nombrada por Real Orden de 20 de octubre de 1923": Apartado "V. Materialización de las reservas".
} 
nueva emisión de empréstitos, pues en ambos casos no hay posibilidades de usar el crédito y no se pueden hacer emisiones; no obstante como las obras nuevas y la adquisición de material no pueden retrasarse hasta que se realicen los empréstitos, las compañías tienen que emplear los fondos procedentes de las cuentas acreedoras y las reservas para realizar estos gastos hasta que pueda llevarse a cabo una emisión que restablezca el equilibrio antes citado.

El razonamiento anterior es el argumentado por NORTE. Si los fondos restituidos a las cuentas acreedoras y a las reservas por el activo revertible se han invertido en valores, ha sido por medida de buen gobierno, que aconseja esa inversión mejor que tenerlos en cuenta corriente. Estos valores se han dividido en dos cuentas ("Títulos a disposición" y "Valores afectos a la materialización de las reservas") por conveniencia interior de la empresa; operación por lo cual no se substraen los títulos así agrupados ni al cumplimiento de los fines especiales asignados a las reservas a que están afectos, ni a cubrir las responsabilidades generales de la compañía, lo mismo que si se hallasen en una única cuenta. La prueba de ello es que el producto anual de los mismos (intereses, etc.) se acredita, mientras se lleva a efecto su empleo, a la cuenta de explotación, en disminución de las cargas.

NORTE no observa nada censurable en su actuación. Argumenta que cuando las empresas necesitan hacer uso de su crédito, aprovechan el momento que les es más favorable para ello. Si tienen que restituir a las cuentas de tesorería los fondos que se han inmovilizado en el haber del Estado, lo hacen en el momento en que realizan la operación de crédito, que es cuando tienen posibilidades de hacerlo. "El que haya una diferencia de interés entre la deuda que emiten, con carácter de consolidada, y los valores de la deuda flotante del Estado en que invierten sus sobrantes, hasta que puedan ser necesarios para nuevas obras, condición esencial es de la distinta clase de deuda, y cosa necesaria en todas las inversiones de fondos a corto plazo" 490 .

NORTE concluye afirmando que no cree que el Informe pretenda que los fondos de reservas deban también invertirse de una manera definitiva en obras de primer establecimiento en beneficio del Estado (además de en gastos de explotación), porque esto no sería justo y además "equivaldría a un aumento de capital social, que ninguna Ley ni disposición alguna puede imponer a la Compañía"491.

\section{"VI. Examen de las conclusiones"}

Para finalizar el documento, NORTE analiza las diez conclusiones del Informe, expresando con cuáles de ellas están de acuerdo y con cuáles no:

\footnotetext{
${ }^{490}$ AHF P-113-258-3: "Contestación de la Compañía de los Caminos de Hierro del NORTE de España al Informe redactado por la Primera Comisión investigadora de la situación económica de las empresas de ferrocarriles nombrada por Real Orden de 20 de octubre de 1923": Apartado "V. Materialización de las reservas".

${ }^{491}$ AHF P-113-258-3: "Contestación de la Compañía de los Caminos de Hierro del NORTE de España al Informe redactado por la Primera Comisión investigadora de la situación económica de las empresas de ferrocarriles nombrada por Real Orden de 20 de octubre de 1923": Apartado "V. Materialización de las reservas".
} 
1. La primera conclusión del informe establece que debe mantenerse el recargo del $15 \%$ acordado por Real Decreto de 26 de diciembre de 1918, por resultar imposible su supresión. La Compañía está de acuerdo con esta medida, pero además, considera que deberían suprimirse las excepciones de su aplicación, por dar lugar a errores y trabajos complicados; además, tales excepciones "no obedecen a razón alguna"492. En nuestra opinión, esto es especialmente relevante porque en realidad la subida fue pequeña, por existir muchas tarifas especiales a las que no afectó el $15 \%$.

2. Según el Informe, la compañía está obligada a reembolsar al Estado 12.823.000 pesetas en concepto de anticipo, por calcularse que excederán los beneficios del año 1923 de los de 1913. NORTE rechaza esta segunda conclusión del Informe porque la cuenta establecida por la Comisión para llegar a este resultado [contradiciéndose a sí misma, en cuanto no comprende los pluses del Estado] disminuyó deliberadamente los gastos, poniendo a cargo de las reservas, sin más razón que porque éstas han sido contabilizadas siempre en NORTE, y también en todas las empresas similares del mundo, como gastos de explotación. En nuestra opinión, es fácil ver un argumento puramente retórico en este análisis de NORTE.

3. La tercera conclusión del Informe establece que la compañía no necesita el anticipo del Estado. NORTE no está de acuerdo con ello puesto que tal afirmación se basa en la exposición errónea de la cuenta de explotación mostrada en la conclusión anterior. En nuestra opinión, la realidad económica-financiera de los registros contables de NORTE era negativa, por lo que claramente sí la necesitaban. Lo que por otro lado ocurría era que la Hacienda no quería pagarlas.

4. La cuarta conclusión del Informe ratifica la proposición de suprimir el anticipo, lo cual queda contestado con las dos anteriores conclusiones.

5. La quinta conclusión del Informe afirma que la compañía puede vivir sin auxilio alguno, lo cual ya está contestado. NORTE comenta algo más sobre los auxilios recibidos por el Estado, en concreto sobre el recargo del $15 \%$ por las excepciones indicadas y por el cálculo de los precios a largo recorrido del 8 al $9 \%$ únicamente. Los préstamos del Estado para comprar material obligan a NORTE a pagar anualmente como cargas ${ }^{493}$, una anualidad muy superior a la que se hubiera pagado obteniendo los fondos por otros medios. Además, el anticipo de Pajares supuso una merma en ocho o diez millones de los fondos disponibles, por haberlos invertido en obras y material de electrificación, que el Estado reembolsa con grandísimo retraso.

6. La sexta conclusión del Informe es que es dudoso que la compañía pueda repartir dividendos en años sucesivos. NORTE comparte este pronóstico, añadiendo además que "se produciría cada año un déficit considerable y la completa depreciación de las acciones y la consiguiente ruina a los tenedores de las mismas"494.

\footnotetext{
492 AHF P-113-258-3: “Contestación de la Compañía de los Caminos de Hierro del NORTE de España al Informe redactado por la Primera Comisión investigadora de la situación económica de las empresas de ferrocarriles nombrada por Real Orden de 20 de octubre de 1923": Apartado "VI. Examen de las conclusiones". ${ }^{493}$ Lo reconoce el propio Informe.

494 AHF P-113-258-3: “Contestación de la Compañía de los Caminos de Hierro del NORTE de España al Informe redactado por la Primera Comisión investigadora de la situación económica de las empresas de ferrocarriles nombrada por Real Orden de 20 de octubre de 1923": Apartado "VI. Examen de las conclusiones".
} 
7. La séptima conclusión del Informe prevé la imposibilidad de NORTE para levantar los empréstitos necesarios para las nuevas obras, debido al acortamiento de los plazos de concesión. NORTE lo comparte, sobre todo si se llega a cumplir la medida establecida en el Informe de privar a la compañía de los medios necesarios para cubrir sus gastos y cargas y mantener el crédito. En nuestra opinión, nada se puede aportar sobre la prórroga de los empréstitos, pues estamos de acuerdo con el argumento en que coinciden la Comisión y la empresa. De la defensa de NORTE podemos afirmar que aquí se une cuentas en mal estado, por un lado, con que no se quiere invertir más porque está próxima la reversión, por otro. Evidentemente, a NORTE le interesa que lo haga el Estado después de la reversión.

8. En octavo lugar se propone que el Estado entregue a la compañía los fondos necesarios para las nuevas obras. NORTE lo aceptaría con dos condiciones: por un lado que se le facilite los medios de cubrir sus gastos y cargas más la remuneración debida a su capital y, por otro lado, que se reintegre los adelantos de las obras con mayor regularidad, que lo sucedido hasta ese momento con el reintegro de Pajares. En los años posteriores, será el Estado, a través de la Caja Ferroviaria, quien va a invertir, convirtiéndose el Estado en socio de las ferroviarias.

9. NORTE está de acuerdo con la novena conclusión del Informe, que fija el importe de la anualidad necesaria para amortizar en sesenta años, al 5\% de interés, un préstamo de 55.000.000 pesetas.

10. NORTE considera inteligible la décima conclusión pues hace referencia a un auxilio no comentado en ninguna parte del Informe. Lo cual es cierto. Interpreta la empresa que seguramente en la redacción preliminar del Informe habría un proyecto para incluir otro auxilio, y en la redacción definitiva no se incluyó.

\subsubsection{Informe relativo a la Compañía MZA}

a) Informe relativo a la Compañía MZA realizado por la Segunda Comisión investigadora de la situación económica de las empresas del ferrocarril

El Informe relativo a la Compañía MZA realizado por la "Segunda Comisión investigadora de la situación económica de las empresas del ferrocarril"495 está fechado en Madrid el 29 de noviembre de 1923 y firmado por el Jefe de la Segunda Comisión. Este Informe está integrado por tres componentes: ámbito de la revisión, opinión y conclusiones. No obstante, no las diferencia en párrafos distintos, ni los ubica consecutivamente, ni mucho menos les coloca los títulos de cada componente.

Respecto al ámbito de la revisión o alcance, el informe establece que "La contabilidad general adoptada por la compañía, en cuanto a la parte examinada y comprobada, es (...)". A

\footnotetext{
${ }^{495}$ El Informe relativo a la Compañía MZA realizado por la Segunda Comisión inspectora es recogido por Peña y Pérez (1940: Tomo I, 119-120). La extensión del informe de la Segunda Comisión es mucho mayor que la de la Primera, por esa razón, el apartado de este trabajo referido a la Segunda Comisión es menor. La principal razón de este hecho se deriva de que las Comisiones detectaron más irregularidades de gestión en la compañía NORTE.
} 
continuación establece que se ha realizado después de un "detenido examen del Activo y Pasivo", aunque la Comisión investigadora definió que no debía limitarse a ambas partidas sino ampliarse el estudio a las partidas que "estimen indispensable conocer a fondo para juzgar el estado económico" 496 .

Respecto a la opinión, establece que "la contabilidad de los servicios no se oponen a la claridad de la general, pero algo la complican". Más adelante indica que "la contabilidad general adoptada por la compañía (...) es buena, clara, aceptable y algunas veces previsora".

Las conclusiones son las siguientes:

1. La Comisión tenía el convencimiento adquirido con el examen, de que sería posible la reducción del número de agentes de la compañía, que llevaría a un mayor rendimiento de trabajo.

2. El personal ferroviario esta mucho más remunerado que el personal dependiente del Estado y de las demás empresas de servicios, por lo que la Comisión propone un descuento gradual de los haberes. Observa posible disminuir los gastos de personal en un $5 \%$.

3. La Comisión cree que el resto de gastos, que no son de personal, pueden disminuirse en un $10 \%$, eliminando todo "cuanto sea lujoso" y no del todo necesario.

4. El estado de las cuentas permite suponer un aumento de ingresos de siete millones de pesetas por tráfico, que producirá un aumento de beneficios de 3,36 millones.

Para complementar las conclusiones, la Segunda Comisión inspectora incluye un resumen con los efectos que tendrían las medidas propuestas, y la evolución previsible del mercado, de forma que pueda observarse el análisis cuantitativo de todos estos hechos. El resultado de la Comisión es que se produciría un aumento sobre los productos líquidos del año 1922 en 34,06 millones de pesetas. El cuadro 17 recoge el resumen cuantitativo de las recomendaciones de la Segunda Comisión.

\footnotetext{
${ }^{496}$ Además, como anejos al Informe sobre los activos y pasivos se incluirán estados diversos que muestren: los ingresos de las empresas como productos de todas clases de las líneas, los gastos de las explotaciones de las líneas, los gastos generales de Consejos de Administración y otros semejantes, los gastos que representen las cargas financieras y los gastos representativos de los dividendos repartidos a los accionistas.
} 


\section{Cuadro 17. Resumen cuantitativo de las recomendaciones de la Segunda Comisión Inspectora}

\begin{tabular}{|l|l|c|}
\hline REDUCCIONES & \multicolumn{1}{|c|}{$\begin{array}{c}\text { Expresado en } \\
\text { millones de } \\
\text { pesetas }\end{array}$} \\
\hline & $\begin{array}{l}\text { 5\% sobre los gastos de personal, mediante una gradual rebaja } \\
\text { en los haberes y reducción en el número de agentes sobre } \\
69,12\end{array}$ & 3,45 \\
\hline & Indemnizaciones por pérdidas & 8 \\
\hline & Gastos de conservación & 20 \\
\hline & $10 \%$ sobre los restantes gastos & 5,05 \\
\hline AUMENTOS & \multicolumn{1}{|l}{} & 3,36 \\
\hline & Por el tráfico & 26,2 \\
\hline & $\begin{array}{l}10 \% \text { sobre las tarifas actuales, aumentadas ya casi todas en un } \\
15 \% \text { sobre las primitivas. Sobre 262 millones }\end{array}$ & $\mathbf{6 6 , 0 6}$ \\
\hline & $\begin{array}{l}\text { Deducción del anticipo para personal y de su insuficiencia, } \\
\text { considerados como ingresos }\end{array}$ & 32 \\
\hline & Aumento sobre los productos líquidos del año 22 & $\mathbf{3 4 , 0 6}$ \\
\hline
\end{tabular}

Fuente: Elaboración propia a partir de los datos recogidos en el Informe relativo a la Compañía MZA realizado por la "Segunda Comisión investigadora de la situación económica de las empresas del ferrocarril"497

Tras las conclusiones, la Comisión realiza tres recomendaciones a la empresa.

- La Comisión entiende que el aumento de tarifas propuesto es suficiente para competir con los transportes por carretera, "dada la extensión y condiciones de las líneas que constituyen la red de MZA".

- La Comisión establece que el tanto\% de aumento de tarifas propuesto es un término medio, pues en las tarifas de viajeros, por ejemplo, convendría hacerlo variable para las distintas clases, con el fin de recargar menos a las más modestas.

- La Comisión cree que MZA debe reducir el número de billetes gratuitos y a precio reducido, concedidos a personas ajenas a la compañía.

Además de estas recomendaciones a la empresa, realiza dos recomendaciones al Estado, las cuales son muy importantes para el futuro de la auditoría y la contabilidad en España.

La Segunda Comisión recomienda la realización continuada de auditorías periódicas ${ }^{498}$, en su opinión por personal público, con estas palabras: "sería de gran conveniencia establecer, a cargo de funcionarios con los debidos conocimientos de contabilidad, una constante inspección contable acerca de las entidades ferroviarias". Los argumentos que esgrime la

\footnotetext{
${ }^{497}$ El Informe relativo a la Compañía MZA realizado por la Segunda Comisión inspectora es recogido por Peña y Pérez (1940: tomo I, 120).

${ }^{498}$ La Segunda Comisión recomienda que la contabilidad de la empresa "fuera intervenida" periódicamente por contables en ella especializados.
} 
Comisión es intentar proteger a las compañías de los grupos de presión que puedan atentar sobre el prestigio de las ferroviarias: "por la posibilidad de que las empresas disimulen en la contabilidad sus verdaderos productos o de que aumenten los gastos ... y más que nada para que a las compañías de ferrocarriles no pueda atribuírseles la realización de aquella posibilidad, garantizándolas, por tanto de inculpaciones que hacen tener recientísimas campañas relacionadas con los asuntos ferroviarios y la facilidad con que desgraciadamente acoge gran parte del ambiente público rumores contra empresas que llaman grandes y poderosas".

La Segunda Comisión recomienda la creación por parte del Estado de una ley contable específica para empresas de ferrocarril: "Convendría imponer una norma fija a la contabilidad de las compañías de ferrocarriles, porque siendo completamente discrecional actualmente la manera de cumplir el precepto legal de que todas las operaciones se reflejen en los libros, no ha encontrado la Comisión (...), la facilidad que aquella norma, de estar ya impuesta, le hubiera proporcionado".

El Informe relativo a la Compañía MZA era más limitado que el de NORTE. El realizado por la Segunda Comisión Inspectora se limitaba al balance ${ }^{499}$, no analizaba la cuenta de resultados ni las estadísticas incluidas en la memoria. Por el contrario el Informe de MZA ofrece mayores recomendaciones al Estado y a la empresa, que mientras en NORTE se limitaron a la discusión sobre las partidas contables. Lo que es indudable que Informes tan heterogéneos tienen su origen en la escasa planificación estatal de esta primera auditoría y en la inexistente coordinación entre los censores de ambas compañías.

\section{b) Observaciones de la Compañía MZA al Informe relativo a la Compañía MZA}

El Informe relativo a la Compañía MZA realizado por la Segunda Comisión Inspectora ${ }^{500}$ tuvo una repuesta escrita por parte del Director General de la Compañía MZA, fechada en Madrid el 6 de diciembre de 1923.

Las observaciones de la compañía son discordantes con las conclusiones y con las recomendaciones dirigidas a MZA, aunque coincidentes con las realizadas al Estado.

El Director General de la Compañía MZA realizó las siguientes observaciones:

- No es posible, a juicio de la Compañía, aumentar el producto líquido en 34 millones como apuntaba la Segunda Comisión Inspectora. Para ello se basa en la experiencia de las grandes compañías estadounidenses, inglesas y suizas en ese mismo año 1922. Por supuesto Maristany tenía razón, lo único que podemos interrogarnos en el momento actual es por qué el director no incluyó a las entidades francesas.

\footnotetext{
${ }^{499}$ Sabemos que el análisis se limitó al balance, pero no fueron difundidos más datos que los expresados en este trabajo sobre el modo en que fue realizado este análisis.

${ }^{500}$ Las Observaciones de la Compañía MZA al Informe relativo a la Compañía MZA realizado por la Segunda Comisión Inspectora es recogido por Peña y Pérez (1940: tomo I: 119-120).
} 
- Es insuficiente, a juicio de la compañía, el aumento de tarifas propuesto para sustituir el anticipo y resolverse el problema de la capacidad de las líneas. Este argumento es totalmente coincidente con lo afirmado por Boix en NORTE.

- MZA no confía en que se produzca una significativa disminución de gastos que según el informe puede producir la medida de reducir el número de billetes gratuitos y a precio reducido, concedidos a personas ajenas a la compañía. Es necesario estar totalmente de acuerdo con este argumento.

Por su parte, la compañía está conforme con la creación por parte del Estado de una ley contable específica para empresas de ferrocarril, y que la contabilidad de la empresa fuese intervenida por contables en ella especializados, sólo matiza que fuese lo suficientemente flexible como para que "pudieran caber sin extremada violencia las particularidades y condiciones distintas de unas y otras explotaciones".

\subsubsection{Importancia de las revisiones de los estados financieros de NORTE y MZA}

La repercusión de la creación de Comisiones investigadoras de la contabilidad a partir del Real Decreto de 20 de octubre de 1923 es máxima desde el punto de vista historiográfico, porque estas Comisiones realizaron una de las primeras auditorías externas de estados financieros en España.

Es muy difícil conocer si verdaderamente esta revisión fue la primera auditoría en España, porque, por un lado, es controvertido identificar las cualidades que debe tener una revisión de estados contables para tener la calificación de auditoría, y por otro lado, porque siempre puede aparecer una revisión nueva en otro sector, o incluso en el mismo que haga replantearnos la novedad absoluta de esta revisión.

Sin embargo, el estudio de esta revisión debe tener un papel estelar entre los incipientes esfuerzos de revisión de los estados contables, tanto por su meticulosidad, como por su calidad.

Además, la revisión gubernamental de las cuentas de las concesionarias del ferrocarril tuvo un papel político innegable. Tanto que se nos plantea el interrogante de saber si la revisión tenía una motivación de conocer la situación económico-financiera de las compañías, o si en realidad fue un instrumento político para argumentar por parte del Gobierno la necesidad de que los anticipos que el Estado estaba abonando a las compañías, dejaran de entregarse, sobre todo, por la escasez de fondos en las arcas públicas en ese momento. Nuestra opinión es que fue más un instrumento político que de validación de la situación económica, aunque su nivel de calidad, aún con deficiencias, es alto para el momento en que se realizó.

La comprobación de que la auditoría externa de las cuentas anuales nació en las empresas ferroviarias es una idea concordante con lo que había ocurrido en el Reino Unido y en Estados Unidos, aunque los métodos fueron distintos. El origen de la auditoría externa en el Reino Unido se realizó por medio de una Ley, en concreto en la Great Western Railway's Act de 
1835; en Estados Unidos el origen nació en la práctica empresarial de la década de 1850, con especial relevancia de Henry Varnum Poor; por su parte, en España tiene su origen en un Decreto legal para evaluar la viabilidad futura de las empresas ferroviarias y especialmente de las ayudas concedidas por el Estado.

Los dos informes que llevaron a cabo las Comisiones pusieron los pilares sobre la contabilidad y la auditoría futura en España ${ }^{501}$. Además, cada informe fue importante en una dimensión: el de NORTE en contabilidad, y el de MZA en la auditoría.

La "Primera Comisión investigadora de la situación económica de las empresas del ferrocarril" dedicada a NORTE es relevante por sus contenidos. En opinión de la Comisión, la situación económica y financiera de NORTE tenía una peor situación, y los criterios de contabilización tenían un número mayor de aspectos a corregir. Por esta razón, esta Comisión se centró en los aspectos formales de fondo y contenido, realizando un análisis muy detallado. Su importancia reside allí y en la constatación, por primera vez, de la importancia que tiene la creatividad contable. La Comisión puso de manifiesto, de forma explícita, el primer método de creatividad contable utilizado por parte de una empresa española y reconocido por un auditor externo: el registro de los anticipos por parte de NORTE.

Por su parte, el Informe realizado por la "Segunda Comisión investigadora de la situación económica de las empresas del ferrocarril" se detiene en aspectos formales del trabajo de la auditoría, e incluso del informe de auditoría. Esta diferente forma de actuar, respecto al informe sobre NORTE se debe a que la situación económica de MZA era más saludable y que sus registros contables eran más acertados, por lo que la Comisión no incidió tanto en evaluar su situación económico-financiera y la fiabilidad de sus registros contables. La Comisión de MZA, al contrario que hizo la Comisión que analizó NORTE, no incluyó en su informe una exposición numérica concreta sobre los datos sobre los que se realizó la revisión contable, y por esa razón, este trabajo no ha tenido la posibilidad de disponer de esa información. No obstante, los aspectos formales del trabajo de revisión y el informe fueron determinantes para el futuro de la auditoría.

El informe de la Comisión sobre MZA establece algunos componentes del alcance del trabajo de auditoría que persisten en el Informe actual, al establecer expresamente los estados financieros analizados, los ejercicios contables que son revisados y el objetivo de la revisión. Además señala, de forma separada y posterior, la opinión. En esta opinión se indican cualidades de la información contable, muy valoradas en la auditoría actual, como la claridad. También se indican actitudes de la contabilidad de la empresa analizada, como la prudencia.

El trabajo analizado culmina con una serie de recomendaciones a la gerencia, tanto de la buena gestión como de la adecuada contabilización.

\footnotetext{
${ }^{501}$ Estos informes materializaron las influencias de los países anglosajones sobre la contabilidad y la auditoría, que cómo hemos visto en el primer apartado fueron decisivas.
} 
Pero la creación de Comisiones Investigadoras de la Contabilidad de las compañías de octubre de 1923 tiene, además, una importancia máxima sobre la planificación de la contabilidad y la auditoría en España. La Segunda Comisión recomienda, y MZA está de acuerdo, en que se deberían realizar todos los años auditorías periódicas, en su opinión por personal público. De igual forma, la Segunda Comisión recomienda la creación por parte del Estado de una ley contable específica para empresas de ferrocarril, antecedente de la legislación contable obligatoria y, por ende de las adaptaciones sectoriales. En opinión de la Segunda Comisión se mejoraría el registro, tanto por su incidencia en la fiabilidad, como en la comparabilidad.

\subsubsection{Actuación del Directorio tras la auditoría}

Con la realización de la auditoría de 1923, el Directorio militar pudo diagnosticar cual era la situación económica-financiera de las compañías, permitiéndole tomar las medidas oportunas para intentar resolver el problema ferroviario, medidas que culminarían con la publicación del Estatuto Ferroviario de 1924.

El Real Decreto de 7 de noviembre de $1923^{502}$ prorrogó hasta el uno de enero de 1924 las autorizaciones concedidas en los artículos $2^{\circ}$ y $4^{\circ}$ de la Ley de Subsistencias de 11 de noviembre de 1916. El Real Decreto de 28 de diciembre de 1923, lo prorrogó hasta el uno de febrero de 1924.

Por medio de la Real Orden de 8 de noviembre de 1923, el Directorio Militar creó una Oficina de Tarifas, aneja al Consejo Superior Ferroviario, para realizar estudios sobre la explotación comercial de los ferrocarriles preparatorios de los dictámenes y propuestas que debe formular el Consejo Superior Ferroviario. El 18 de diciembre de 1923, la Oficina de Tarifas emitió su dictamen, y en consecuencia, el Consejo Superior Ferroviario elevó al Gobierno su Informe: "Informe del Consejo Superior sobre las tarifas". En ese Informe de cuatro puntos se propone (1) la adopción de un coeficiente único para todas las empresas, (2) cuando las condiciones de una o varias empresas ferroviarias no permitan obtener los rendimientos precisos con los aumentos de tarifas que se acuerden, los déficits deberán ser compensados con los excesos de otras compañías, y si tal compensación fuese insuficiente, habría que suplir lo que faltase por otros medios, como la reducción de las cargas o tributos que pesan sobre los transportes para ponerlas en condiciones de posible competencia con otros sistemas de transporte, o el auxilio directo del Estado, (3) la supresión de los pases de libre circulación y billetes a favor de personas ajenas al servicio ferroviario, así como la implantación de seguros especiales para los transportes ferroviarios y (4) las mejoras que convendría introducir en las instalaciones han de ocasionar gastos, lo cual debe traducirse en mayores percepciones para los transportes.

El 17 de diciembre de 1923 los representantes de ocho importantes bancos elevaron una instancia al presidente del Directorio Militar en relación al régimen ferroviario. Ante la posibilidad de que el Estado ejerciera su derecho de adquirir líneas mediante pago de su

\footnotetext{
${ }^{502}$ El texto del 7 de noviembre de 1923 puede observarse en: NORTE y MZA (1932: Anejo 7).
} 
importe, los representantes de la banca manifestaron su preocupación porque esa experiencia ha sido "desastrosa" en países más acostumbrados a una buena y ordenada administración. Pero aún consideran un error más grave anular el crédito de las compañías y sustituirle por el del Estado, pues este tendrá insoportables cargas que conllevaría un detrimento del sector transporte. Pero sobre todo, están preocupados de que mientras se implanta el nuevo régimen no se prive a las compañías de los recursos necesarios pues producirían la depreciación de los valores ferroviarios en 5.000 millones de pesetas, que habría de arrastrar a todos los demás títulos, haciendo perder a la opinión pública la confianza en la Banca.

El R. D. de 30 de enero de 1924 decidió la reducción progresiva del anticipo hasta la implantación del nuevo régimen ferroviario sin contrapartida. Este tex to reduce mensualmente de un modo progresivo, por doceavas partes, hasta la implantación del nuevo régimen ferroviario, los anticipos para personal que venían percibiendo las empresas, sin que dichas reducciones pudieran suponer reducción en los jornales y haberes de los obreros y agentes inferiores ferroviarios.

La cuarta disposición transitoria del Real Decreto-Ley de 12 de julio de 1924, que implantó el Estatuto Ferroviario de 1924, estableció que los anticipos, aunque reducidos, se mantendrían de forma provisional hasta que se establecieran las nuevas tarifas del período provisional $(\text { Base } 10)^{503}$. Los anticipos del Estado subsistirían reducidos en diversas proporciones, según las compañías, siendo las mayores reducciones $50 \%$ para NORTE y MZA. Al fijarse el período provisional (R. D. de 8 de agosto de 1926), cesaron totalmente los anticipos, pero las tarifas no cambiaron.

Las compañías manifestaron su decepción al examinar el Estatuto Ferroviario de 1924 pues comprobaron que no se habían tenido en cuenta por el Gobierno las peticiones dirigidas en los diferentes escritos enviados por ellas (NORTE y MZA, 1934: 69).

\subsection{Legislación Mercantil y contable aplicable a las ferroviarias}

Las empresas ferroviarias deben cumplir con la legislación mercantil sobre la construcción y explotación ferroviaria ${ }^{504}$, por un lado, y con las obligaciones contables incorporadas en la legislación mercantil aplicables a las empresas de todos los sectores, por otro.

Un aspecto interesante es comprobar el nivel de cumplimiento de las obligaciones formales de la contabilidad por parte de cada ferroviaria española. En esta línea, vamos a observar el grado de cumplimiento de los estados contables de NORTE respecto a la legalidad vigente en ese momento.

\footnotetext{
${ }^{503}$ El texto del Real Decreto-Ley de 12 de julio de 1924 puede observarse en NORTE y MZA (1932: anejo 1).

${ }^{504}$ Las ideas contenidas en cada una de las disposiciones legislativas que regularon el sector ferroviario fueron expuestas en los comentarios de las Comisiones que redactaron las dos obras que marcaron el estudio del problema ferroviario en España: "Elementos para el estudio del problema ferroviario en España" (Cambó: 19181921) y “Antecedentes y datos para el estudio del problema ferroviario" (Peña y Pérez: 1940, tomo I).
} 


\subsubsection{Legislación mercantil sobre la construcción y explotación ferroviaria}

En este apartado se repasan las legislaciones mercantiles ${ }^{505}$ que regularon la construcción y explotación del sector ferroviario que no tuvieron incidencia sobre las formalidades de los registros contables, dejando para los apartados siguientes la legislación mercantil con disposiciones concretas sobre el registro contable y su publicación ${ }^{506}$.

El ordenamiento jurídico que reguló la construcción y explotación ferroviaria durante el siglo XIX benefició más a los intereses privados de las compañías extranjeras que a los intereses generales del Estado ${ }^{507}$. En nuestra opinión, el legislador antepuso sacar a España del retraso en el establecimiento de la red ferroviaria, aunque fuese realizado por empresas con capital extranjero, o aunque la remuneración supusiera una salida de capital fuera de las fronteras españolas.

La demora en la construcción tiene su correspondencia con un retraso en la regulación legal. A continuación se analizan las principales legislaciones españolas.

La legislación mercantil sobre la construcción y explotación ferroviaria vino precedida de un Informe encargado por el gobierno a la Comisión de ingenieros de caminos (Informe Subercase) concluida el 2 de noviembre de 1844. El Informe Subercase fue presidido por su Inspector General, Juan Subercase, y elaborado también por C. Santa Cruz y José Subercase $^{508}$. Aunque no era una Ley, el Informe fue importante y decisivo ${ }^{509}$. Con dicho Informe se propuso al Gobierno la aprobación de las condiciones generales bajo las cuales se habían de autorizar la actuación de las ferroviarias. Los autores del Informe Subercase examinaron las diversas fórmulas de Derecho comparado que, hasta la fecha, se habían utilizado en la construcción de los ferrocarriles ${ }^{510}$. La Comisión tenía un gran conocimiento sobre el sector, y sobre lo que ocurría en países de nuestro entorno y Estados Unidos (Ortúñez, 2016a: 85). La experiencia acreditada de los distintos países les permitió asesorar e informar al Gobierno acerca del modelo más idóneo a seguir en España. El Informe estaba orientado hacia una construcción de los ferrocarriles por el Estado, aunque el sistema de empresa privada se eligió como un mal menor. En el Informe Subercase se pusieron las bases del futuro: ancho de vía uniforme para todo el país (seis pies castellanos, equivalentes a 1,676 metros), estructura de la red nacional, declaración del sistema ferroviario como servicio público, opción por la concesión como forma de suministrarlo, fijación de tarifas máximas

\footnotetext{
${ }^{505}$ El sistema legislativo español ha presentado habitualmente características propias del derecho continental europeo: textos largos y amplios, y regulación muy detallada y variada (Santos, 2015: 91).

506 En la Biblioteca Ferroviaria de la FFE, se conserva la colección bibliográfica más completa sobre disposiciones y normativas ferroviarias, consultable a través del portal: <www.docutren.com>

${ }^{507}$ La idea de que la legislación benefició más a los intereses privados de las compañías extranjeras que a los intereses generales del Estado es compartida por Costa (1983: 156).

${ }^{508}$ Boag (1923) calificó como "sabios ingenieros" a los tres integrantes que elaboraron el "Informe Subercase".

${ }^{509}$ Ortuño (1920a) denominó al "Informe Subercase" de "monumento al acierto". Por su parte, Wais (1987) (1974) denominó a la R.O. de 31 de diciembre de 1844 como "piedra angular de nuestra legislación ferroviaria".

${ }^{510}$ El "Informe Subercase" de 1844 se basó en los antecedentes europeos. La primera Ley de Ferrocarriles fue la belga de 1834 .
} 
por el Gobierno para evitar abusos de las compañías y establecimiento de ayudas y garantías para ellas. La construcción y gestión corría a cargo del sector privado, mientras que el Estado se reservaba la regulación de la actividad ferroviaria.

El Informe Subercase sirvió de base al Gobierno para redactar la Real Orden de 31 de diciembre de 1844, que fue la primera disposión en materia ferroviaria que se dictó en España $^{511}$. Además de establecer las reglas para el examen de admisión de las propuestas que quisieran hacerse al Gobierno sobre el establecimiento de ferrocarriles", reguló los requisitos generales para la concesión de líneas a construir y explotar mediante la aprobación de un pliego de condiciones generales y un modelo de tarifa.

La Real Orden de 31 de diciembre de 1844 impone severas obligaciones a los concesionarios. La regulación contenida en ella parte de la idea de que si el Estado concedía la construcción y explotación a las compañías privadas lo era temporalmente y por necesidades del momento, reservándose el Estado las facultades de inspección, vigilancia y reglamentación. Se recoge la figura de la reversión de las líneas férreas configurándose, en definitiva, un régimen de concesiones temporales, con la facultad de rescate anticipado. Asimismo, esta Orden no fija plazo alguno para las concesiones, dejando a cada pliego de condiciones la determinación del mismo.

La Real Orden de 1844 sigue la línea establecida en el Informe Subercase aunque introduce una modificación al mismo al incluir en su articulado la figura de las concesiones provisionales. Al Gobierno le parecieron demasiado exigentes las normas del Informe y observando cómo en la mayor parte de los países se extendían los ferrocarriles mientras que España no contaba con ninguno, quería dar amplias facilidades para que la iniciativa privada y el capital acudiesen a construirlos (Wais, 1974: 53-54). Así pues, "cuando el suscriptor o suscriptores de propuesta de camino de hierro sean sujetos de reconocido arraigo y ofrezcan además garantías que el Gobierno estima suficientes, se les concederá un término de doce o dieciocho meses para que puedan presentar los documentos y llenar las formalidades que expresan las disposiciones precedentes, con la autorización necesaria para obtener los datos precisados, reservándose entretanto la preferencia sobre otras propuestas que se refieran al mismo camino" (art. 3).

Las consecuencias de esta previsión fueron negativas ya que quedó desvirtuado el propósito contenido en el Informe Subercase de la solidez de las solicitudes para evitar el peligro de las

\footnotetext{
511 Tanto esta Real Orden de 1844 como las restantes disposiciones concernientes a los ferrocarriles que anteceden a la Ley General Ferroviaria de 3 de junio de 1855, tienen como denominador común tener un rango inferior a la categoría de Ley. Ello se debe, principalmente, a la dificultad de encaje normativo del nuevo fenómeno ferroviario. También es posible que se adoptara deliberadamente este rango secundario con objeto de facilitar una cierta discrecionalidad del poder público en la adjudicación de las ventajas de establecimiento de líneas de transporte por ferrocarril (Bermejo Vera, 1997: 221).
} 
especulaciones. En la práctica, estas concesiones provisionales se obtenían con gran facilidad y posteriormente eran cedidas para obtener ganancias por dicho traspaso ${ }^{512}$.

La Instrucción para propomover y ejecutar las obras públicas de 10 de octubre de 1845 tiene como principal finalidad unificar la normativa vigente sobre construcción. Las obras públicas pueden ser realizadas por el Estado, las Provincias y los Ayuntamientos, y a través de empresas (o concesión), contrata (art. 5), y a su vez, los empresarios pueden proponer la ejecución de cualquier obra que le interese cumpliendo una serie de requisitos (art. 8). La norma instaura un control por parte de la Administración de la construcción del proyecto si el Gobierno otorga la concesión (arts. 13-21 y 27).

La Ley de 20 de febrero de 1850 autorizaba al gobierno para hacer o rectificar concesiones provisionales, en tanto se aprobaba y sancionaba la Ley sobre ferrocarriles (Real Orden de 26 de enero de 1850: nota 16).

La Ley General de Ferrocarriles de 3 de junio de 1855, con la instrucción y pliego de condiciones que la acompañó, de 15 de febrero de 1856 , fue muy esperada ${ }^{513}$. La Ley de 3 de junio de 1855 dio una mayor intervención del Estado en la construcción y explotación de los ferrocarriles, así como en lo que se refiere a las ayudas a aportar a las empresas concesionarias. La Ley clasificó las líneas férreas en dos categorías: las de servicio general y las de servicio particular (arts. 1-3). La construcción de líneas de servicio general se podían llevar a cabo por el Estado y, en su defecto, por los particulares o compañías privadas, siendo necesaria, en el primer supuesto -para que el Gobierno pudiera iniciar la construcción- una ley; y, en el segundo, la obtención de la correspondiente concesión que, asimismo, se otorgaría por ley (arts. 4-7) ${ }^{514}$.

La Ley implantó un modelo de red ferroviaria radial, tomando como centro Madrid, copiando el preexistente de los Caminos Reales de Carlos III (art. 2). Además, asumió el control por parte del gobierno de la construcción de la red (art. 4), e incluso permite hacer un seguimiento en la red para verificar la ejecución y cumplimiento de las obras (art. 6). El Gobierno concedía a los inversores: subvenciones (art. 8), seguridad en la inversión (art. 19), y ventajas en la importación de materiales al quedar exentos de tasas de aduanas (art. 20).

\footnotetext{
${ }^{512}$ La mayor parte de estas peticiones no tenían por objeto construir ferrocarriles sino el beneficio que obtendrían con el posterior traspaso de su derecho; esta operación se repetía sucesivamente sin que las compañías alcanzaran su status legal (Tortella, 1973: 167 y 168).

${ }^{513}$ La Ley General Ferroviaria de 1855 se hizo de esperar ya que debieron transcurrir casi diez años hasta su aprobación. En este periodo se sucedieron cinco proyectos de Ley e incluso la comisión nombrada por el Gobierno para analizar el segundo de los proyectos de Ley General terminó por redactar una Ley provisional que fue aprobada el 20 de febrero de 1850. En el mes de noviembre de 1854 Luxán, el entonces ministro de Fomento del Gobierno progresista que se estableció tras la Revolución de 1854, presentó a las Cortes un nuevo proyecto de Ley General. Finalmente, la Ley General de Ferrocarriles fue aprobada y sancionada el 3 de junio de 1855 , tras la convocatoria del Congreso realizada por el Gobierno de Espartero y Leopoldo O'Donnell.

${ }^{514}$ Esta reserva del rango normativo supremo para el otorgamiento de las concesiones ferroviarias es una de las principales deficiencias técnico-jurídicas del sistema concesional, pues las leyes posteriores que otorgaban cada una de las concesiones ferroviarias, podían modificar las condiciones generales establecidas en la Ley General de 1855 .
} 
La Ley General de Ferrocarriles de 3 de junio de 1855 tenía previstas tres fórmulas para que el Estado pudiera colaborar con los particulares en la construción de líneas de servicio general: (1) ejecutando con éstos obras concretas, (2) mediante la entrega a las empresas de una parte del capital invertido en determinado período, (3) asegurando a los capitales un interés ${ }^{515}$.

Respecto a las concesiones, se dispuso que serían otorgadas mediante pública subasta, fijándose el plazo máximo de 99 años para las concesiones de líneas de servicio general (arts. 2 y 14), transcurrido el cuál el Estado obtendría la posesión de las líneas con todas sus dependencias (art. 15).

La Ley estableció una serie de ventajas en cuanto a la ocupación de terrenos y exención de impuestos y aranceles. El capital extranjero se encontraba salvaguardado por el Estado y exento de represalias, confiscaciones o embargos por causa de guerra (arts. 19 y 20). Por otra parte, también enumeraba las causas y efectos de la caducidad de las concesiones ${ }^{516}$ (arts. 2129), y con respecto a la explotación ferroviaria regulaba cuestiones relativas a las tarifas, a los servicios gratuitos que debían cumplir las empresas, al servicio telegráfico de las líneas y a medidas de vigilancia y de seguridad de la explotación (arts. 31-42).

El capital social no podrá ser inferior al coste de construcción y de los materiales de explotación. Cada una de las acciones tiene que estar desembolsadas en dos tercios ${ }^{517}$. Los accionistas no recibirán dividendos hasta que no estén totalmente desembolsados (art. 46). Por último, permite cubrir la tercera parte del capital por medio de empréstitos (art. 48).

En la práctica, la Ley de 1855 reavivó la fe de los inversores y con ello las construcciones ferroviarias se multiplicaron vertiginosamente, siendo en este periodo cuando se otorgó la concesión de la línea NORTE y MZA. La Ley tuvo como principal motivación la de buscar inversores para su desarrollo ${ }^{518}$, pero como en España no había grandes inversores, el capital que se encontró fue extranjero (Benito, 2015: 67).

\footnotetext{
515 A las empresas ferroviarias se les aseguraba un mínimo interés o un interés fijo, según se determinara en la ley de cada concesión (art. 8. 3). Estos intereses garantizados son suprimidos por la Ley de 23 de noviembre de 1877 (art. 12) pero serán reestablecidos por el art. 17 de la Ley de Presupuestos de 29 de junio de 1899. Sobre tales subvenciones se pronunció la Sentencia de la Sala $3^{\mathrm{a}}$ de 23 de junio de 1868 sobre una negativa de aumento de subvención a una compañía de ferrocarril, que se pronuncia en los siguientes términos "no tiene una Empresa derecho á pedir aumento de subvención por variación de trazado, que aprobó el Gobierno ni está en las facultades de éste otorgarlo por ser estos contratos esencialmente legislativos, según la ley general de ferrocarriles".

${ }^{516}$ Entre otras causas se prevén las siguientes: el incumplimiento de las condiciones fijadas, la falta de comienzo de las obras, la interrupción de las mismas o del servicio por culpa de la empresa, etc.

${ }_{517}$ Posteriormente, el Código de Comercio de 1885 establecerá que debe estar desembolsada en un $25 \%$.

518 Los inversores extranjeros llegaron favorecídos directa o indirectamente por medidas como la Desamortización de Madoz y la Ley de Sociedades Crediticias, y por el efecto llamada de intentar obtener un beneficio rápido.
} 
Transcurridos ocho meses desde la promulgación de la Ley de 1855, el Real Decreto de 15 de febrero de 1856 aprobó la Instrucción para su cumplimiento, así como el pliego de condiciones generales y el modelo de tarifa para las empresas concesionarias de ferrocarriles de servicio general.

En los diez años posteriores se emitieron un gran número de leyes y disposiciones administrativas sobre cuestiones ferroviarias de diversa índole: la Ley sobre Policía y Conservación de Ferrocarriles ${ }^{519}$ de 14 de noviembre de 1855; la Real Orden de 16 de julio de 1855 sobre el modo de practicar el amojonamiento y plano detallado de los ferrocarriles concluidos; la Real Orden de 4 de octubre de 1856 sobre el pago de los derechos de arancel por material ferroviario; el Real Decreto de 11 de marzo de 1857 sobre divisiones para el servicio de ferrocarriles; la Real Orden de 31 de agosto de 1862 sobre exención de derechos aduaneros al material; la Real Orden de 24 de enero de 1863 sobre destino de marcaderías y objetos olvidados; la Ley de 4 de junio de 1863 de autorización al Gobierno para uniformar las tarifas de peaje y transporte; la Real Orden de 15 de octubre de 1863 sobre las condiciones de aptitud de los guarda agujas; la Real Orden de 27 de octubre de 1863 sobre indemnización por las empresas de los efectos deteriorados o extraviados; y la Real Orden de 3 de mayo de 1865 sobre limitación de la franquicia ferroviaria.

Además de ellas, se emitieron algunas leyes sobre las inversiones, pero que tuvieron una gran influencia sobre la explotación ferroviaria. De entre todas, destaca la promulgación de la Ley de Sociedades de Crédito de 1856, que eliminaba las cortapisas existentes en cuanto a participación de las finanzas extranjeras en el sector ferroviario. Esta norma, junto a la Ley de Ferrocarriles de 1855, permitió emprender con firmeza la construcción de la red.

El Real Decreto de 14 de noviembre de $1868{ }^{520}$ abandona el monopolio del Estado en cuanto a las obras públicas, incluidas las ferroviarias. Cuando una persona o sociedad proponga construir cualquier obra de las que se consideren públicas podrá hacerlo con toda libertad y sin intervención ni control alguno por parte del Estado (art. 1). Si cumple ciertas condiciones, la empresa queda libre de proyectar, ejecutar y explotar la obra construída sin intervención alguna de los agentes administrativos. La Administración se limita a inspeccionar el cumplimiento de las contratas.

El Real Decreto creó un fondo de ayuda a las compañías ferroviarias. A ello se llegó porque el Gobierno español no encontró otra salida ante el escandaloso déficit público a que tenía que hacer frente, y al negociar con banqueros extranjeros la obtención de ayudas al Estado, los Rothschild franceses le impusieron como condición que subvencionara a las compañías ferroviarias. Así, el Decreto de 14 de noviembre de 1868 asignó el $15 \%$ del producto del empréstito a las empresas de ferrocarril. Las concesiones ferroviarias fueron otorgadas a perpetuidad y el Estado quedó privado de la posibilidad de construir y explotar ferrocarriles,

\footnotetext{
${ }^{519}$ El Reglamento de policía de los ferrocarriles que complementaría esta normativa se aprueba por Real Decreto de 8 de julio de 1859 .

${ }^{520}$ El Real Decreto de 14 de noviembre de 1868 fue elaborado por el ministro de Fomento Luis Zorrilla, sin que la Real Orden de 31 de diciembre de 1844 y la Ley de 3 de junio de 1855 quedaran formalmente derogadas.
} 
cuya puesta en funcionamiento quedó en manos de la iniciativa privada. No obstante, se preveían algunos supuestos en los que el Estado podría llegar a construir de forma directa. También se dispuso que fuese competencia de las compañías ferroviarias fijar las tarifas y peajes por la utilización de la obra viaria.

La Ley de 9 de junio de 1869 -que está basada en los principios proclamados por la doctrina del liberalismo económico- fijó las bases generales para la nueva legislación de obras públicas, rompiendo radicalmente con la línea de colaboración e intervención que había mantenido el Estado con los inversores privados hasta ese momento, y dejando al criterio de la iniciativa privada la construcción de infraestructuras relativas al transporte tales como carreteras y ferrocarriles, así como la gestión de las empresas concesionarias con total autonomía.

Respecto a las concesiones ferroviarias, la nueva norma las otorgaba a perpetuidad, quedando el Estado privado de la posibilidad de construir y explotar ferrocarriles, cuya puesta en funcionamiento quedaba a todos los efectos en manos de la iniciativa privada, permitiéndose que fuera competencia de las compañías ferroviarias fijar las tarifas y peajes por la utilización de la obra viaria: "por importantes que sean las obras públicas se paralizan con los sistemas restrictivos...cualquier persona que por sí y sin intervención del Estado adquiera los elementos indispensables para construir...un ferrocarril, puede, sin trabas, sin restricciones, sin que la Administración se interponga, llevar á cabo la empresa que imaginó". No obstante, a pesar del carácter no intervencionista de la norma, se preveían algunos supuestos en los que el Estado, por razones diversas, podría llegar a tomar la iniciativa en la construcción de forma directa.

La Ley de Bases de 1876 limita la concesión a 99 años, y concede el carácter de "imprescindibles" a las subvenciones.

La Ley General de Ferrocarriles de 23 de noviembre de 1877, y el Reglamento para su aplicación de 24 de mayo de 1878, restablecía prácticamente la situación ferroviaria anterior a la Revolución de 1868 y 1869, puesto que "reproducía la casi totalidad del articulado de la Ley de 1855" (Olmedo, 2001). El texto clasificaba a los ferrocarriles en dos tipos, por un lado, los ferrocarriles de servicio general, que se entregaban a la explotación pública para el transporte de viajeros y tráfico de mercancías y, por el otro, los ferrocarriles de servicio particular, que eran los destinados a la exclusiva explotación de una industria determinada o al uso privado.

El Capítulo Primero de la Ley de 1877 clasificaba las líneas ferroviarias de servicio general en 7 redes geográficas: Norte (12 líneas), Nordeste (34), Este (15), Mediodía (26), Oeste (11), Noroeste (14) e Islas Baleares (1).

La Ley de 1877 introdujo algunas novedades: (a) la necesaria modificación por ley del plan general ferroviario; (b) la posibilidad de que las empresas gozaran de exenciones de derechos aduaneros o de aprovechamientos de obras de uso público compatibles con el de los ferrocarriles; (c) la exigencia de garantías más severas a las compañías privadas tanto para 
solicitar como para obtener una concesión ferroviaria; y (d) la competencia del ministro de Fomento sobre cuestiones que pudieran suscitarse en relación con la construcción y explotación ferroviaria, así como las relativas a la conservación de los ferrocarriles.

La Ley de 1877 formulaba seis principios inspiradores de la nueva organización ferroviaria: 1) carácter temporal, aunque dilatado, de las concesiones, incluso en los ferrocarriles de uso particular; 2) continuidad y obligación del servicio, garantizado por la incautación y caducidad; 3) reversión de las explotaciones al Estado; 4) ausencia de monopolio que pudiera entorpecer otras nuevas concesiones; 5) facultad de autorizar y, en ciertos casos, modificar tarifas; y 6) vigilancia permanente de la autoridad competente.

Con la emisión de la Ley de 1877 se pretendía salvaguardar el interés público, el problema es que el gobierno español no cumplió lo establecido en la Ley. No cumplió con lo establecido en los arts. 36 y 51, donde se prescribía que las concesiones de ferrocarriles caducarían cuando se interrumpiera total o parcialmente el servicio público de las líneas, o cuando la compañía concesionaria fuese disuelta por resolución judicial o declarada en quiebra. Además, el artículo 23 de los pliegos de concesión establecía que la compañía estaba obligada a conservar en buen estado el camino de hierro y sus dependencias de modo que la circulación fuese fácil y segura. El artículo 24 agregaba que si no lo conservara en buen estado de servicio, el Gobierno "proveerá lo conveniente al efecto, a costa de la empresa" (ya que para eso había recibido anticipos de material). Sin embargo, en lugar de aplicar la Ley, lo impidió, garantizando el pago de los bonos. Los obligacionistas podrían haber ejecutado a las empresas que incumplieran con el pago de las cargas financieras de las obligaciones, podrían haber provocado la suspensión de pagos, concedido el estado legal de quiebra y ejecutado la caducidad de la concesión. Por el contrario, la actuación del Estado permitió que las líneas se mantuvieran en servicio a su costa ${ }^{521}$.

La Ley de Policía de Ferrocarriles de 23 de noviembre de 1877, el Reglamento para su ejecución de 8 de septiembre de 1878 y el Reglamento de Señales de 1872 regulaban con detalle todo lo referente a la conservación de la vía, servidumbres de ferrocarriles, penalidad y procedimiento de las faltas cometidas por los concesionarios o arrendatarios, delitos y faltas contra la seguridad y conservación de los ferrocarriles, formación, marcha y permanencia de trenes en las estaciones $\mathrm{y}$, derechos y obligaciones de los viajeros.

Hasta la emisión del Estatuto Ferroviario, no se emitió ninguna Ley relevante de carácter general en el siglo $\mathrm{XX}$, sin embargo, se emitieron algunas disposiciones relativas a ferrocarriles secundarios y estratégicos, que afectan a los tramos locales. La Real Orden de 13 de julio de 1904 constituyó una comisión para unificar el material de los ferrocarriles. El 30 de julio de 1904, el gobierno publicó la primera Ley de Ferrocarriles Secundarios. La Ley de Ferrocarriles Secundarios y Estratégicos de 26 de marzo de 1908, y su Reglamento para la

\footnotetext{
${ }^{521}$ La actuación del Estado permitió que las líneas se mantuvieran en servicio a costa del Estado, que las pérdidas las sufriera éste y los beneficios se los adjudiquen las compañía, pues en opinión de De Benito (1935: 151), "el aumento de dividendos y la constitución de los fondos de reserva los han logrado gracias a la aportación del Estado".
} 
ejecución de la Ley de ferrocarriles secundarios y estratégicos de 26 de marzo de 1908, obligó a domiciliarse en España a las sociedades que se constituyeran a partir de ese momento. La Ley de 23 de febrero de 1912 modificó la Ley de 1908. Y por último, el Decreto-Ley de 5 de mayo de 1926 aprobó el Plan Preferente de Ferrocarriles de urgente construcción.

El Estatuto Ferroviario de 1924 estableció por primera vez la promoción y estímulo para agrupar las líneas (Base I, ap. 2; Base VIII, ap. 1a). También reguló la inspección e intervención de la gestión técnica, económica y financiera (Base VIII, ap. 4) y la nueva intervención contable (Base XV). Dentro de la reorganización administrativa ferroviaria, el aspecto más importante es la creación de la "Caja Ferroviaria del Estado", administrada por el Consejo Superior de Ferrocarriles e intervenida directamente por el Ministerio de Hacienda. Su finalidad es la administración de los recursos necesarios para ejecutar la nueva política ferroviaria, tanto en lo referente a la adquisición de los recursos financieros como en lo referente a la inversión de aquéllos.

Posterior a nuestro periodo de estudio, es necesario destacar la Ley de Bases de Ordenación Ferroviaria y de los Transportes por Carretera, de 24 de enero, de 1941, creadora de RENFE.

Una vez analizadas todas estas regulaciones, se analiza la legislación mercantil con incidencia en la contabilidad de las compañías ferroviarias ${ }^{522}$. Los textos mercantiles que incorporan formalidades contables, y que influyen el periodo de estudio, son $^{523}$ : el Código de Comercio de 1829, el Reglamento de 17 de febrero de 1848, la Ley de 11 de julio de 1856 sobre constitución de las compañías concesionarias de ferrocarriles, el Código de Comercio de 1885, el Estatuto ferroviario de julio 1924 y el Comité ejecutivo del Consejo Superior de Ferrocarriles del 15 de enero de 1926.

\subsubsection{Código de Comercio de 1829}

Cuando se produce el nacimiento legal de las empresas concesionarias ferroviarias españolas a mediados del siglo XIX-, la normativa vigente en materia contable estaba compilada en el Código de Comercio de 1829. Este texto establece los requerimientos contables para las empresas de todos los sectores, sin especificar tratamientos particulares para las concesionarias del ferrocarril.

El Código de Comercio de 1829 implantó un importante grado de deberes para los empresarios. Supuso la generalización de la obligación de llevanza de la contabilidad para

\footnotetext{
${ }^{522}$ La normativa contable concerniente a las compañías de ferrocarriles en España fue estudiada por Montoya y Guzmán (2012).

${ }^{523}$ Anteriores a ella, dos normas fueron fundamentales para el devenir de la técnica contable en España "Pragmáticas de Castilla" de 1549/1552, donde se ordenaba llevar la contabilidad por el sistema de partida doble, y las "Ordenanzas de Bilbao" de 1737, donde se regulaba los libros de contabilidad obligatorios, sus requisitos formales y su valor probatorio, así como la obligación de preparar periódicamente un balance.
} 
todos los comerciantes -incluidas las compañías ferroviarias- susceptibles de comparación con grandes empresas industriales.

La mayoría de los artículos con incidencia en la contabilidad se encontraban en el Título $2^{\circ}$, Sección II. El artículo 32 del Código de 1829 establecía tres libros de contabilidad que debía llevar todo comerciante con carácter obligatorio: Diario, Mayor (o de cuentas corrientes) y de Inventarios; más adelante el texto incorpora un cuarto que también es obligatorio: el libro "Copiador de cartas y telegramas". El texto graduaba los distintos tipos de obligaciones en cuanto a la llevanza de la contabilidad según se tratase de comerciante al por mayor o al por menor.

Ningún apartado del Código de Comercio de 1829 hace mención expresa al método de la partida doble, ni a la obligatoriedad de uso. No obstante, como señala Fernández Peña (1991, 61), de los artículos 33 y 34 se deduce que debe utilizarse siempre:

- Artículo 33: En el libro se sentarán, día por día, y según el orden en que se vayan haciendo, todas las operaciones que haga el comerciante en su tráfico, designando el carácter y circunstancias de cada operación, y el resultado que produce a su cargo y descargo; de modo que cada partida manifieste quien sea el acreedor y quién el deudor en la negociación a que se refiere.

- Artículo 34: Las cuentas corrientes con cada objeto o persona en particular se abrirán por Debe y Ha de haber, en el libro mayor, y a cada cuenta se trasladarán por riguroso orden de fechas los asientos del diario.

El texto también se ocupa de los aspectos formales de la contabilidad. Entre éstos, destacan las siguientes:

- Artículo 36: El libro de inventarios empezará con la descripción exacta del dinero, bienes inmuebles y muebles, créditos (...) que formen el capital del comerciante. Después formará cada comerciante anualmente, y extenderá en el mismo libro el balance general (...), comprendiendo en él todos sus bienes, créditos y acciones, así como también todas sus deudas y obligaciones pendientes a la fecha del balance.

- Artículo 40: Los tres libros que se prescriben de rigurosa necesidad en el orden de la contabilidad comercial, estarán encuadernados, forrados y foliados; en cuya forma los presentará cada comerciante al tribunal de comercio de su domicilio, para que por uno de sus individuos y el escribano del mismo tribunal, se rubriquen (sin exigirse derechos algunos por el escribano) todas sus hojas, y se ponga en la primera una nota con fecha, firmada por ambos, del número de hojas que contiene el libro.

- Artículo 41: En el orden de llevar los libros de contabilidad mercantil se prohíbe: $1^{\circ}$. Alterar en los asientos el orden progresivo de fechas y operaciones (...). $2^{\circ}$. Dejar blancos ni huecos, pues todas sus partidas se han de suceder unas a otras (...). $3^{\circ}$. Hacer interlineaciones, raspaduras ni enmiendas, sino que todas las equivocaciones y omisiones que se cometan se han de salvar por medio de un nuevo asiento hecho en la fecha en que se advierta la omisión o el error. $4^{\circ}$. Tachar asiento alguno. $5^{\circ}$ Mutilar alguna parte del libro. 
En el Código de Comercio de 1829, la contabilidad se entendía secreta (artículo 49), aunque se concretaban tres supuestos en que podía ser levantada tal obligación: juicios de sucesión universal, liquidación de compañía y quiebra (artículo 50). Los libros contables debían llevarse con los requisitos exigidos para que pudieran tener valor en juicio, siendo probablemente esto último el verdadero acicate del comerciante para procurar una ordenada llevanza de la contabilidad, si bien se establecían sanciones pecuniarias por la inobservancia u ocultación de la contabilidad.

El Código de Comercio de 1829 fue objeto de diversas propuestas de modificación, aunque finalmente tan sólo fue reformado en cuatro ocasiones. En 1868 se suprimió la jurisdicción especial de los Tribunales de Comercio. En segundo lugar, las sanciones de tipo pecuniario establecidas por la inobservancia u ocultación de la contabilidad, fueron eliminadas ${ }^{524}$ por el Proyecto de reforma de Código de 1829 publicado en 1869. En 1878, se cambió la legislación en materia de quiebras. Por último, el Proyecto para la reforma del Código de Comercio de 1829, publicado en 1882, recogía la enumeración definitiva de los libros de contabilidad que necesariamente debía llevar el comerciante: Inventarios y Balances ${ }^{525}$, Diario, Mayor y los demás que ordenaran las leyes. El Código de Comercio de 1829 fue finalmente derogado por el Código de Comercio de 1885.

\subsubsection{Reglamento de 17 de febrero de 1848}

En cuanto a la obligación de publicar información contable y los requisitos de su presentación, el Reglamento de 17 de febrero de 1848 que desarrolla la Ley sobre compañías mercantiles por acciones de 28 de enero de 1848, recoge por primera vez la obligación de publicar los balances. Tal y como indica el artículo 34: "anualmente formalizarán las compañías mercantiles por acciones un balance general de su situación, en que se comprenderán todas las operaciones practicadas en el año, sus resultados y el estado de su activo y pasivo. Estos balances, autorizados por los administradores de la compañía bajo su responsabilidad directa y personal, y después de reconocidos y aprobados en junta general de accionistas, se remitirán al jefe político de la provincia, quien dispondrá su comprobación, y hallándose exactos y conformes con los libros de la compañía, se imprimirán y publicarán en el Boletín oficial de la provincia, comunicándose asimismo al Tribunal de Comercio del territorio".

La obligación de publicación del artículo 34 del Reglamento de 17 de febrero de 1848 no se desarrolló en cuanto al formato, contenido y valoración de la información a presentar, lo que dificultó la homogeneidad de los documentos y, por consiguiente, su comparabilidad.

\footnotetext{
${ }^{524}$ Tampoco el Código de 1885 recogió las sanciones de tipo pecuniario por la inobservancia u ocultación de la contabilidad.

${ }^{525}$ En el Proyecto para la reforma del Código de Comercio de 1829, publicado en 1882, se observa una posición preeminente del primero de ellos (Libro de Inventarios y Balances) con relación al resto de libros contables. Esta opinión es compartida por Bernal (2000: 173-201).
} 


\subsubsection{Ley de 11 de julio de 1856 sobre constitución de las compañías concesionarias de ferrocarriles}

La Ley de 11 de julio de 1856 sobre constitución de las compañías concesionarias de ferrocarriles es una Ley específica del sector ferroviario. En su artículo 11 se recoge que las compañías estarán obligadas a presentar al Gobierno, por medio del gobernador civil, un balance demostrativo y calificado de todo su haber activo y pasivo, que se publicara en la Gaceta; y siempre que el Gobierno lo pidiere remitirán por el mismo conducto estados que den pleno conocimiento de sus operaciones, así como las demás noticias y detalles relativos a los gastos e ingresos de la empresa. El Gobierno podrá además examinar, siempre que lo estime conveniente, la contabilidad y administración de las compañías, y comprobar sus existencias, nombrando a este efecto delegados retribuidos por las mismas sociedades, a quienes sus respectivos directores-gerentes o administradores tendrán obligación de presentar cuantos libros, datos, valores y documentos les fueren por estos pedidos y existieren $\mathrm{o}$ debiesen existir en sus oficinas ${ }^{526}$.

Aunque fue la primera legislación que obligó a presentar los estados financieros, no se emitió, paralelamente, una regulación que dispusiera las directrices oportunas sobre cómo elaborar y presentar dicha información contable, es decir, no se especificaron, aspectos tan relevantes para la homogeneidad de los documentos contables como los requisitos de presentación, contenido y formato, los criterios de valoración, y la delimitación temporal.

Aunque la publicidad de los estados contables era obligatoria, un estudio de Bernal (2004: 77) sobre los estados contables publicados en la Gaceta de Madrid entre los años 1857 y 1862, concluye que no se llegaron a publicar los documentos de las principales compañías ferroviarias españolas.

Las denominaciones más utilizadas en los diferentes documentos publicados son: balance de cuentas, balance de la sociedad, inventario-balance, balance general, balance general de situación y resultado de operaciones y balance general de activo y pasivo. Con respecto a las partes del balance, se denominan activo-pasivo, acreedores-deudores o capital activo-capital pasivo. Algunos de estos estados incluyen «notas» que desarrollan la información y algunos incorporan una cuenta de «Ganancias y Pérdidas». En algunos casos, estos estados contables representan datos de una fecha concreta, y en otros comprenden un determinado periodo ${ }^{527}$.

Importantes para las ferroviarias son también dos leyes posteriores: la Ley de Roforma de la Ley de Sociedades Anónimas de 12 de octubre de 1869, y el Real Decreto de 19 de

\footnotetext{
${ }^{526}$ Posteriormente, en el artículo 14 de la Real Orden de 12 de diciembre de 1857, se estableció que el Gobierno Civil exigirá copia de los balances generales comprobándolos con los libros de contabilidad. Cfr. Real Orden de 12 de diciembre de 1857 y Reglamento para el ejercicio de las funciones que corresponden á los gobernadores de provincia y delegados especiales del Gobierno cerca de las compañías mercantiles por acciones de 12 de diciembre de 1857.

${ }^{527}$ Estos datos son obtenidos del estudio de Bernal (2004: 78).
} 
noviembre de 1875 referente al aumento de capital, acciones y modificación de los Estatutos (Gaceta 20 y 24 de noviembre de 1875).

\subsubsection{Código de Comercio de 1885}

El Código de Comercio de 1885 entró en vigor el día 1 de enero de 1886, derogando el Código de Comercio de 1829.

Al contrario que el texto de 1829, el Código de Comercio de 1885 sí dedica una parte de su articulado al tratamiento específico de las concesionarias del ferrocarril. A esto hay que añadir las especificaciones generales para constitución y funcionamiento que tiene prevista la legislación mercantil a todas las sociedades anónimas.

Mercantilmente, la forma societaria utilizada para la constitución de las compañías ferroviarias fue la sociedad anónima, por ser el medio más adecuado para facilitar la reunión del capital social y las operaciones financieras sucesivas. La sociedad concesionaria se constituía como cualquier sociedad anónima de la época, ante notario, adoptando los puntos que correspondían a la concesión de la línea ferroviaria (Montoya, 2010: 122) (Montoya y Guzmán, 2012: 9).

El Código de Comercio de 1885 (artículo 119) señalaba que "toda compañía de comercio, antes de dar principio a sus operaciones, deberá hacer constar su constitución, pactos, y condiciones, en escritura pública que se presentará para su inscripción en el Registro Mercantil". Posteriormente, dicho texto normativo (artículo 122) hacía referencia expresa a los distintos tipos de sociedades mercantiles, mencionando al referirse a sociedades anónimas lo siguiente: "Las anónimas, en que formando el fondo común los asociados por partes o porciones ciertas, figuradas por acciones (...), encargan su manejo a mandatarios o administradores que representen a la compañía bajo una denominación apropiada al objeto o empresa a que destine sus fondos".

En relación a la constitución de la compañía, el Código de Comercio de 1885 (artículo 185) señalaba que el capital social de las compañías ferroviarias debía estar totalmente suscrito y realizado al menos en su $25 \%$, siendo sus títulos nominativos hasta tanto no se hubiesen desembolsado en un 50\% de su nominal. En cuanto la financiación del importe total de la construcción de la línea, éste debía ser soportado al menos en el 50\% del total por el capital social y las subvenciones recibidas en su caso para tal fin.

El Código de Comercio de 1885 dedicaba una parte de su articulado al tratamiento específico de las concesionarias del ferrocarril, en concreto la Sección IX, del Libro Segundo de su Título I (artículos 184 a 192) con la denominación "Compañías de Ferrocarriles y demás Obras Públicas". En ella se especifica tanto la regulación mercantil de su financiación, venta de los derechos de concesión y fusión de estas empresas, como las formalidades contables que hay que cumplir. 
Respecto a la financiación de este tipo de empresas, se hacía referencia a su capital social y a las subvenciones estatales, supeditando la constitución de las sociedades ferroviarias a la completa suscripción del capital y a su realización en una cuarta parte del mismo (artículo 185). El mismo artículo establece que "El capital social de las compañías, unido a la subvención, si la hubiere, representará por lo menos la mitad del importe del presupuesto total de la obra". Además, también se abordaban los asuntos referentes a la emisión y amortización de obligaciones.

Por otro lado, regulaba la posibilidad de vender, ceder y traspasar sus derechos de concesión y su posible fusión con otras empresas del ramo (arts. 186 a 189), para lo cual se exigía tres requisitos:

- El consentimiento unánime de los socios, a menos que en los estatutos se hubiesen establecido otras reglas para alterar el objeto social.

- El consentimiento de todos los acreedores, si bien éste no era necesario cuando se respetasen las garantías e hipotecas, conservando los acreedores la integridad de sus respectivos derechos.

- La autorización del Gobierno en los casos de que la empresa gozase de subvención directa del Estado, o hubiese sido concedida por una ley u otra disposición gubernativa.

El Código de Comercio de 1885 recogía referencia expresa a la información contable concreta que las compañías de ferrocarriles debían suministrar. Se obligaba a clasificar sus operaciones en dos grandes apartados: por un lado, construcción de las vías férreas y demás obras públicas de cualquier clase y, por el otro, explotación de las mismas, bien a perpetuidad o durante el plazo señalado en la concesión (artículo 184).

Desde el punto de vista del registro contable para todo tipo de empresas, el Código de Comercio de 1885 exigía a todos los comerciantes la confección de un balance general al final de cada año. Este requerimiento implicaba un mayor esfuerzo para los minoristas que hasta entonces sólo tenían obligación de confeccionarlo cada tres años. Por otro lado, se permitía a todo tipo de sociedades la anotación en un único asiento del producto de todas las ventas diarias al contado, cuando anteriormente dicha posibilidad sólo era aplicable para los comerciantes al por menor.

El Título III del Libro Primero (artículos 33 a 49) del Código de Comercio de 1885 establece que los comerciantes debían llevar necesariamente un libro de Inventarios y Balance, un libro Diario, un libro Mayor, un Copiador de cartas y telegramas y otros que pudieran ordenar las leyes especiales en los distintos sectores económicos. Además, las sociedades mercantiles entre las que se encontraban las ferroviarias- debían cumplimentar adicionalmente un libro de Actas, donde se hicieran constar todos los acuerdos tomados por las Juntas Generales de socios y los Consejos de Administración (artículo 33).

En cuanto al método de contabilidad que se debía utilizar, el Código de Comercio parecía reconocer la existencia de distintas alternativas al recoger textualmente la frase "según el 
sistema de contabilidad que se adopte" en su artículo 34. Sin embargo, el propio artículo 38, al referirse al Libro Diario señalaba que "seguirán después día por día todas sus operaciones, expresando cada asiento el cargo y el descargo de las respectivas cuentas", por lo que esta forma de expresión venía a descartar la utilización del método de "partida simple" en favor de la "partida doble", extremo que se confirma atendiendo al contenido del artículo 40 que señalaba textualmente lo siguiente: "las cuentas con cada objeto o persona se abrirán además por Debe y Haber en el libro Mayor".

El comerciante podía llevar personalmente la contabilidad, o bien delegar en personas expresamente autorizadas para ello (artículo 35), presumiéndose concedida tal autorización, salvo prueba en contrario ${ }^{528}$.

Los libros contables podrían ser legalizados a instancia de parte, aunque la normativa no obligaba a ello. Para la legalización de los libros contables, éstos debían estar debidamente encuadernados, forrados y foliados, y presentados al Juez municipal ${ }^{529}$ del distrito donde tuviera su establecimiento mercantil la compañía, a efectos de que en el primer folio de cada uno de ellos inscribiese una nota firmada de los folios que tuviere el libro, estampando además en todas las hojas el sello del Juzgado municipal que lo diligenciaba (artículo 36).

El texto disponía el contenido de cada uno de los diferentes libros obligatorios en los siguientes términos:

1. Libro de Inventarios y Balances (artículo 37). Este libro debía comenzar con el inventario elaborado por el comerciante en el momento de dar comienzo a sus operaciones, conteniendo la relación exacta del dinero, valores, créditos, efectos al cobro, bienes muebles e inmuebles, mercaderías y efectos de todas clases,

\footnotetext{
${ }^{528}$ La delegación en la llevanza de la contabilidad fue un tema controvertido en la época, tal como lo evidencia Oliver (1897, Tomo I, 13-14): "si la conciencia del comerciante debe hallarse en los libros, y el Juez debe estar seguro de encontrarla en ellos; si los interesados en los negocios, liquidaciones y participaciones de una casa comercial, necesitan hallar en los libros la verdadera historia de todas las operaciones de la misma; si en el comercio de buena fe, el hombre honrado y probo, en sus malos o desgraciados negocios, tiene el escudo de su dignidad, en medio de la mayor desdicha, en los libros, por ellos se han de ilustrar sus acreedores, por ellos se ha de calificar la quiebra, por ellos en fin, sabe el comerciante sus pérdidas y sus ganancias, y determina la conducta que ha de seguir para lo sucesivo. Pues si tanta importancia tienen los libros de comercio, ¿cómo el legislador no ha significado de un modo concluyente que estos no puede llevarlos cualquier mancebo a falta del comerciante?". En el párrafo transcrito parece reclamarse de alguna manera la necesidad de conocimientos técnicos para la llevanza de los libros contables con objeto de que la contabilidad pudiera cumplir su fin último, de tal forma que "....con personalidad propia el tenedor de libros y responsabilidad personal por los asientos que hiciera, sería un valladar siempre en el que fraude o mala fe se estrellarían, y debe tenerse en cuenta que en muchos casos los asuntos comerciales y de crédito son verdaderamente de orden público".

${ }^{529}$ La R.O. de 29 de diciembre de 1885 disponía que la legalización de los libros comerciales, dado el pequeño trabajo que imponía, se haría por los Jueces municipales, sin recibir por ello derecho alguno. Posteriormente, la R.O. de 27 de noviembre de 1912 decretaba que los Jueces municipales entregasen un recibo al presentante los libros, con indicación de la fecha y hora de la recepción y del plazo que, según el trabajo pendiente de la oficina, había de tardar en despacharse, fijando a su vez que este plazo no podría ser superior a veinte días hábiles, y que el despacho de los libros se haría por riguroso orden de presentación, sin que por los encargados de realizarla y bajo la responsabilidad a que hubiere lugar, pudieran ser pospuestas unas solicitudes a otras.
} 
apreciados en su valor real y que constituían su Activo. Además, en el mismo debía de inscribirse la relación exacta de sus deudas y toda clase de obligaciones pendientes, y que formaban su Pasivo. Por diferencia entre el Activo y el Pasivo, se fijaba el Capital con el que iniciaba sus operaciones. Posteriormente y de forma anual, el comerciante debía extender en el mismo libro el balance general de los negocios, con los pormenores antes indicados, y de acuerdo con los asientos procedentes del Libro Diario, sin reserva ni omisión alguna, bajo su firma y responsabilidad $^{530}$.

2. Libro Diario (artículo 38). La primera partida de este libro debía ser el resultado del inventario inscrito en el Libro de Inventario y Balances, dividido en una o varias cuentas consecutivas. Posteriormente seguirían día por día todas las operaciones llevadas a cabo por el comerciante, expresando en cada asiento el cargo y descargo de las respectivas cuentas. En el caso en que las operaciones fueran numerosas, cualquiera que fuese su importancia, o cuando hubiesen tenido lugar fuera del domicilio, podían anotarse en un único asiento las que se referían a cada cuenta y día, pero guardando el mismo orden. Asimismo, también debían anotarse en la fecha en que se retirase de caja las cantidades que el comerciante destinaba a sus gastos domésticos, llevándose a una cuenta especial que para su control se abría en el Libro Mayor.

3. Libro Mayor (artículo 39). Este libro se debía abrir por Debe y Haber las cuentas con cada objeto o persona en particular, trasladando al mismo por orden riguroso de fechas los asientos del Libro Diario referentes a ellas.

4. Libro de Actas (artículo 40). Este libro debía contener los acuerdos que se tomaban por las compañías en juntas o por sus administradores, expresando la fecha, los asistentes, los votos emitidos y cualquier otra información que condujese al exacto conocimiento de lo acordado, debiendo estar debidamente firmada cada acta por gerentes, directores o administradores que estuvieran encargados de la gestión de la sociedad, o los determinados por sus estatutos o bases que la rigiesen.

5. Libro copiador de cartas y telegramas (artículo 41). En este libro debían ser trascritas, integra y sucesivamente, por orden de fechas, incluidas la antefirma y firma, todas las cartas que el comerciante escribiese relativas a su tráfico mercantil, así como los despachos telegráficos que hubiese expedido. En cuanto a las cartas y despachos telegráficos recibidos, solo se observaba la obligación de conservarlas cuidadosamente en legajos de forma ordenada (artículo 42).

\footnotetext{
${ }^{530}$ En opinión de Bernal (2000), en el Código de Comercio de 1885 podía observarse una posición preeminente del primer libro (Libro de Inventarios y Balances) con relación al resto.
} 
Respecto a la ejecución material de la contabilidad de la compañía, el Código de Comercio establecía (artículo 43) criterios generales para su presentación, indicando que los comerciantes debían llevar sus libros con claridad, por orden de fechas, sin blancos, interpolaciones, raspaduras ni tachaduras, y sin presentar señales de haber sido alterados sustituyendo o arrancando los folios o de cualquier otra manera. A propósito de los errores $\mathrm{u}$ omisiones en que hubieran incurrido, los mismos debían ser salvados a continuación e inmediatamente de ser advertidos, explicando en qué consistían y extendiendo en el concepto como se debía de haber presentado el correspondiente apunte, añadiendo además, cuando hubiese transcurrido cierto tiempo desde la comisión del error u omisión, una nota al margen del apunte erróneo precisando que había sido corregido.

Además, el Código de Comercio de 1885 exigía publicar anualmente en la Gaceta, el balance detallado de su situación económica (artículo 157).

Por último, se establecía la obligación de conservar toda la documentación contable durante el periodo de tiempo que durase el negocio y hasta cinco años después de haberlo liquidado (artículo 49).

\subsubsection{Estatuto ferroviario de julio 1924}

El Proyecto de "Nuevo régimen ferroviario de 14 de enero de 1924", en su Base decimoquinta "Contabilidad de las empresas", establece la primera regulación, aunque sea no definitiva, sobre la contabilidad ferroviaria. En él aparece que, por disposiciones especiales, y a propuesta del Consejo Superior de Ferrocarriles, se establecerán las reglas de contabilidad, que deberán ser rigurosamente guardadas, a fin de que se mantenga en todo tiempo, distinta y clara, la "cuenta y razón" 531 de ingresos y gastos concernientes a los ferrocarriles, y también para preservar de eventualidades, complicaciones y anormalidades el servicio financiero de los mismos. La base añade que "las empresas que en la actualidad llevan la contabilidad de sus ferrocarriles mezclada con la correspondiente a otras industrias, la modificaran a partir del 1 de enero de 1924, para que se pueda apreciar, con absoluta independencia, todo el detalle económico referente al transporte ferroviario que tengan concedido" (Proyecto de "Nuevo régimen ferroviario de 14 de enero de 1924: Base decimoquinta).

Esta previsión quedó recogida en el Estatuto ferroviario de 12 de julio de 1924. En su Preámbulo, el Estatuto ferroviario regula una pinceladas del futuro de la contabilidad, mientras que el grueso de los contenidos contables queda regulado en la Base decimoquinta "Contabilidad de las empresas".

El Preámbulo establece que el Consejo Superior va a tener, a partir de ese momento, "la alta inspección de la explotación comercial, de la contabilidad, de la unificación del material y agrupación de líneas".

\footnotetext{
${ }^{531}$ El término “cuenta y razón” es un sinónimo de contabilidad.
} 
La Base decimoquinta "Contabilidad de las empresas" del Estatuto ferroviario establece que "A propuesta del Consejo Superior de Ferrocarriles, se establecerán las reglas de contabilidad a las que deben ajustarse las empresas acogidas a éste régimen, con el fin de establecer en todo tiempo, en forma clara y exacta", la cuenta y razón de ingresos y gastos "correspondientes a las respectivas explotaciones ferroviarias, con separación de las relativas a los bienes de las empresas no incluidos en el valor del establecimiento de las mismas" (subrayado nuestro para señalar las novedades respecto al texto incluido en el Proyecto de "Nuevo régimen ferroviario de 14 de enero de $1924 ")^{532}$.

La Base decimoquinta del Estatuto ferroviario establece que la Sección permanente encargada de la gestión de la Caja Ferroviaria, se llamará "de Contabilidad y Caja”, adscribiéndose a la misma una oficina, a la que se hallarán afectos funcionarios del Cuerpo de Contabilidad del Estado. Esta Sección estudiará, formulará y propondrá al Consejo las reglas y normas y ejercerá la correspondiente intervención en las contabilidades de las empresas, para recabar el cumplimiento de las normas antes citadas.

Para asegurar la eficacia en la implantación de dichas reglas, el Consejo Superior de Ferrocarriles acordará la adopción por todas las empresas de una clasificación uniforme de sus ingresos, gastos y cargas de manera que cada uno de los conceptos parciales comprendidos en estos tres epígrafes se correspondan exactamente en las contabilidades de aquéllas, a fin de facilitar la implantación de las medidas de carácter general que puedan ser necesarias y evitar las dificultades a que daría lugar la diversidad de criterio en las referidas clasificaciones.

De igual forma, deberán sujetarse todas las empresas a las normas que dicte el Consejo Superior de Ferrocarriles, a propuesta de la Sección de Contabilidad y Caja, para la distinción y determinación de los gastos de primer establecimiento y de explotación, así como para acomodar a modelos uniformes los balances anuales, las estadísticas del tráfico y los demás datos de carácter general requeridos por la aplicación del Régimen ferroviario.

\subsubsection{Normas del Comité ejecutivo del Consejo Superior de Ferrocarriles de 15 de enero de 1926}

El Comité ejecutivo del Consejo Superior de Ferrocarriles estableció, el 15 de enero de 1926, unas normas referentes al cómputo de los gastos de obras y adquisiciones de material, para los casos en que las primeras fuesen inferiores a 3.000 pesetas y las segundas no excediesen de

\footnotetext{
532 “A propuesta del Consejo Superior de Ferrocarriles, se establecerán las reglas generales de contabilidad que se estimen precisas y a las que deberán ajustarse las empresas acogidas a este régimen, con el fin de establecer en todo tiempo, en forma clara y exacta, la cuenta y razón de los ingresos y gastos correspondientes a las respectivas explotaciones ferroviarias, con separación de las relativas a los bienes de las empresas no incluidos en el valor del establecimiento de las mismas. Estas reglas deberán detallar las normas precisas para el debido cumplimiento de los preceptos consignados en las Bases anteriores, tanto por lo que afecta a la fijación de los valores y capitales definidos en la Base novena, como por lo que se refiere a la recopilación de los datos en que han de basarse los cálculos y revisiones de las tarifas, a la distribución de los productos de las mismas, a las disposiciones contenidas en la Base decimotercera para determinadas concesiones y a la fijación en su caso de las anualidades de rescate" (Estatuto ferroviario de 12 de julio de 1924: Base decimoquinta).
} 
10.000 pesetas. Se aplicaban a créditos especiales, que trimestralmente debían cancelarse, al aprobar el gasto el Consejo Superior.

Cómo ese procedimiento motivaba que no se pudiesen liquidar dichos gastos de una forma normal, el citado Comité dictó nuevas reglas e instrucciones para dar uniformidad a la contabilidad de los gastos que, por su carácter especial, fuera difícil distinguir si correspondían a primer establecimiento o debían llevarse a la cuenta de explotación.

Las normas eran cuatro.

Regla 1. Se considerarán comprendidos en los gastos imputables a la cuenta de explotación de las compañías adheridas al nuevo régimen ferroviario establecido por el R.D., de 12 de julio de 1924, los que a continuación se enumeran, agrupándolos al efecto en un capítulo especial con el epígrafe de "Gastos complementarios de la explotación" a que se cargarán los ocasionados:

a) Por la adquisición de las instalaciones y elementos que se detallan a continuación, cuando sean en aumento sobre los existentes:

*Efectos y enseres constitutivos del "Pequeño material", como son: básculas corrientes, gálibos, taquilleros, etiqueteros, carretillas, faroles, cocinas, banderines, relojes, toldos, prolongas y similares.

* Mobiliario usual y útiles y efectos de la limpieza de las estaciones, de los dormitorios del personal de trenes y de las dependencias análogas.

* Herramientas, útiles y enseres corrientes de las brigadas de las vía, de los recorridos, del material móvil, del telégrafo y del teléfono, del personal de maniobras, carga y descarga y transbordo de equipajes y mercancías y de las carboneras.

* Enseres y aparatos complementarios para las instalaciones de alumbrado, calefacción, aseo y desinfección de coches y vagones, oficinas, almacenes, talleres, estaciones, dormitorios, refectorios, dispensarios, escuelas, etc.

* Pequeñas máquinas útiles para los talleres de los Depósitos y Reservas de Tracción, de los Recorridos del Material Móvil, del Telégrafo, del Teléfono, del Pequeño material y de la Vía.

* Cualquier otro elemento análogo a los anteriores en cuanto a su destino y valor.

b) Por la ejecución de las obras accesorias de las explanaciones, como son: recortes y muretes de revestimiento de taludes, revestimientos y rastrillos de cunetas, obras de saneamiento de terraplenes, trincheras y túneles; zampados y rastrillos de defensa de fundaciones de las obras de fábrica, apertura de pozos y obras para captación y conducción de aguas para casillas y otros edificios, reformas y mejoras de detalle en la disposición interior de los citados edificios, prolongación y transformación de vías, andenes y obras análogas, en cuanto a su destino y valor.

Las adquisiciones y las obras que han de estimarse comprendidas en los apartados A y B quedarán limitadas, en cuanto a su importancia y cuantía, por las cantidades que se citan en la regla $4^{\mathrm{a}}$.

Regla 2. El importe total que habría de consignarse en los presupuestos anuales de explotación de las compañías para esos "Gastos complementarios" no excederá del 1\% sobre el primer 
millón de pesetas de productos brutos, y del $2 \%$ de los productos brutos restantes, pudiendo las compañías ampliar en sus presupuestos las consignaciones que resultan de aplicar estos coeficientes hasta llegar al promedio del importe que invirtieron en dichos gastos durante el trienio 1923-1925.

Regla 3. Cuando las adquisiciones y obras imputadas a "Gastos complementarios" excedieran del importe que resulte de la aplicación de los coeficientes señalados, para invertir en los mismos nuevas cantidades, hasta el límite que marque lo que pudiera corresponder con arreglo al trienio 1923-1925, había que pedir autorización al Comité ejecutivo para poder seguir imputando gastos a dicha cuenta.

Regla 4. El importe parcial de las obras y materiales con cargo al presupuesto anual de "Gastos complementarios" no puede exceder de: 500 pesetas para las compañías cuyos productos brutos anuales sean inferiores a un millón, de 5.000 pesetas para las compañías cuyos productos brutos excedan del millón y no lleguen a 100 millones y de 10.000 pesetas para aquellas en que se exceda de los 100 millones de productos brutos. NORTE se encontraba en el tercer caso.

Consecuentemente con estas normas, la Dirección de NORTE dio orden a las Divisiones y Servicios de que las obras y adquisiciones de material cuyo importe exceda de 10.000 pesetas se hicieran con cargo a la Caja Ferroviaria, y las de menor importe, con cargo a los gastos de explotación, aún cuando sean en aumento sobre los existentes, creándose en el presupuesto de cada División un nuevo capítulo "bis", con el epígrafe "Gastos complementarios de explotación" y cargándose a él los gastos menores de 10.000 pesetas ocasionados por adquisición o ejecución de obras.

\subsection{Regulación interna de las compañías}

El presente apartado analiza los procedimientos contables aplicados por el sector ferroviario en España a lo largo del primer cuarto del siglo XX, con especial referencia a las reglamentaciones emitidas por las propias compañías -especialmente NORTE y MZA-, ante la parquedad de la legislación aplicable, recogida de forma prácticamente exclusiva en el Código de Comercio de 1885.

Las compañías ferroviarias tuvieron que editar regulaciones de cuño propio debido a la escasa legislación aplicable durante el periodo de tiempo objeto de estudio. Esta normativa interna caracteriza el modelo contable particular de cada compañía.

Por tanto, además de la regulación legal del sector, es necesario analizar la regulación que voluntariamente realizan las empresas para solventar las lagunas e indeterminaciones de las leyes. Para ello es necesario centrarse en la reglamentación interna de las empresas para instaurar un medio de contabilización homogénea, tanto desde el punto de vista espacial, como temporal. 
Las compañías tuvieron que emitir una regulación interna de los procesos de información contable porque el Código de Comercio de 1885 era muy escueto en materia contable. Este texto se limitaba a especificar los libros obligatorios que debían llevar los comerciantes, enumerando algunas pautas generales a tener en cuenta a la hora de su formulación, sin que en ningún caso recogiese un desarrollo exhaustivo en cuanto a la normalización contable aplicable, como posteriormente ha ocurrido en España desde el año 1973 con la puesta en práctica de los distintos planes generales de contabilidad y sus adaptaciones sectoriales.

Por ello, las compañías ferroviarias tuvieron la necesidad de emitir sus propios reglamentos con la intención de establecer de forma uniforme los principios contables de aplicación, así como las instrucciones necesarias para poder llevar a cabo la actividad contable en cada compañía.

El esfuerzo autoregulador llevado a cabo por las compañías completó la escasez normativa en materia contable del Código de Comercio de 1885. La valoración positiva de dicha autoregulación permite afirmar que a través de la regulación contable de las compañías ferroviarias "se contribuyó a un avance del progreso científico de la disciplina contable" (Montoya y Guzmán, 2012: 39).

Las regulaciones internas de las compañías mejoraron la información contable, tanto en el ámbito del detalle de los ingresos y gastos de la explotación, como en lo concerniente a las principales rúbricas del balance de las compañías.

No obstante, la información contable de estas empresas presentaba dos problemas. En primer lugar, existe gran diversidad en la presentación de la información que hace difícil la lectura de dicho estado contable, cuestión derivada, sin duda, de la inexistencia de una regulación normativa general. El segundo problema es que existen en ellos algunas inconsistencias conceptuales, especialmente en determinadas rúbricas del Pasivo del Balance, y así se confunde en determinados casos el concepto de reserva tradicional con el de cuentas de compensación (amortizaciones del inmovilizado), mientras que en otros casos no figuran con título adecuado dentro de la rúbrica correspondiente de acuerdo a su naturaleza (obligaciones amortizadas) ${ }^{533}$.

Siempre cumpliendo lo establecido normativamente en el Código de Comercio y demás legislación mercantil, era una práctica generalizada que cada compañía ferroviaria tuviera establecido un sistema particular de clasificación de sus productos y gastos, así como un reglamento en el que se consignaban sus principios uniformes de contabilidad. Cada empresa se regía por su propio reglamento, no obstante todos obedecían a un mismo fin, por lo que los reglamentos de contabilidad fueran similares en todas las compañías. Normalmente las diferencias existentes eran de orden secundario determinadas por las especiales necesidades de cada empresa y por el sistema con el que organizaban sus múltiples servicios ${ }^{534}$.

\footnotetext{
${ }^{533}$ Este segundo problema fue analizado por Montoya y Guzmán (2012: 39).

${ }^{534}$ El contenido de los reglamentos de contabilidad general están recogidos por Garcés (1869).
} 
Las dos grandes compañías del sector, NORTE y MZA, fueron las que emitieron unos reglamentos más completos y detallados, siendo "copiados en la mayoría de las ocasiones por otras compañías más pequeñas" (Montoya y Guzmán, 2012: 8). Este apartado analiza el desarrollo de los procesos contables y los pormenores de la teneduría de libros en el sector ferroviario mediante el análisis de los reglamentos e instrucciones dictados por las propias empresas en el ámbito de sus competencias ${ }^{535}$, con especial referencia a los publicados por NORTE y MZA, por su importancia dentro del sector, que sin duda contribuyeron intrínsecamente a un avance del progreso científico de la disciplina contable ${ }^{536}$.

Entre la sociedades que ofrecen una autoregulación más completa se encuentran el FerroCarril de Córdoba a Málaga (1863a; 1863b; 1863c; 1865), la Compañía de los Ferrocarriles de Tarragona a Barcelona y a Francia (1868; 1876a; 1876b; 1881; 1887a; 1887b; 1887c; 1887d; 1887e), la Compañía de Explotación de los Ferrocarriles de Madrid a Cáceres y Portugal y del Oeste de España $(1897 ; 1918 ; 1927)$ y la Compañía Nacional de los Ferrocarriles del Oeste de España (1929a; 1929b, 1929c; 1929d; 1933). Otras sociedades presentan algunas regulaciones interesantes, entre ellas, la realizada por la Compañía de los Caminos de Hierro de Barcelona a Francia por Figueras (1866), la Compañía del Ferrocarril de Tarragona a Martorell y Barcelona (1872), la Compañía del Ferrocarril de Alcoy a Gandía y Puerto de Gandía (1892a; 1892b), la Compañía del Ferrocarril de Argamasilla-Tomelloso (1919) y la Compañía del Ferro-carril de Medina del Campo a Salamanca (1923).

La regulación interna más importante es la de MZA, y dentro de esta empresa es necesario diferenciar los Reglamentos para la contabilidad financiera y los establecidos para la contabilidad de gestión, siendo su máxima expresión la gestión de los talleres.

\subsubsection{Reglamentos de contabilidad financiera de MZA}

MZA aplica, además de la legislación vigente, los manuales de procedimiento interno elaborados por la compañía. El primero de ellos son los Estatutos de 1857. El mismo año ya emitió el "Reglamento de Contabilidad de 3 de diciembre de 1857"537 para autoregular los procedimientos de contabilidad para los primeros años de funcionamiento.

Cuatro años más tarde, MZA (1861b) emitió el documento "Instrucción para la contabilidad", que supone unas normas de régimen interno para el control contable en la construcción de ferrocarriles (escrito aún en español y francés).

\footnotetext{
535 Los criterios y contenidos de los reglamentos de contabilidad general aplicados por las compañías de ferrocarriles en España fueron estudiados contemporáneamente por Garcés $(1869$; 1882) y, más adelante por Montoya y Guzmán (2012).

${ }^{536}$ La preocupación mostrada por el sector ferroviario respecto a la normalización contable ha sido considerada por algunos investigadores como el inicio de la denominada contabilidad moderna (Valdaliso López, 2000).

${ }^{537}$ El "Reglamento de Contabilidad de 3 de diciembre de 1857" estuvo vigente entre 1857 y 1889 ; fue derogado por el artículo 58 del "Reglamento Especial del Servicio de la Contabilidad General” de 1889.
} 
Más adelante, MZA (1863) emitió el documento "Résumé des ordres de service et circulaires de l'Ingenieur en chef de la construction indiquant celles de leurs dispositions restant en viguer au 5 novembre 1863", que es una recopilación del conjunto de normativa en vigor referente a personal, materiales, obras y contabilidad, acompañada de la regulación interna de la empresa elaborada para interpretar estas normas.

El documento interno de la compañía denominado "Clasificación de los Gastos de Explotación y Construcción” de 1886 regulaba la presentación de los gastos en el Informe Anual de MZA. Este documento presenta, tanto para los gastos de explotación como de construcción, una distribución por capítulos y, a su vez, con más detalle, de éstos por artículos, a modo de «cuadro de cuentas». La utilidad del documento radica en que, al generarse un gasto, debe ser clasificado en una de las divisiones proporcionadas por éste, asignándolo al capítulo y artículo correspondiente. La existencia de documentos internos de clasificación de gastos permitía incrementar un elevado grado de uniformidad. Utilizarlos en la elaboración de las Cuentas Anuales supuso generar información contable homogénea, al menos en cuanto a presentación y estructura, permitiendo su comparación entre diferentes periodos. Pero en concreto, la aplicación de este documento en la clasificación de los gastos permitió la homogeneidad temporal, y no solo en términos de criterios de clasificación por naturaleza, sino también de funcionalidad.

El "Reglamento especial del Servicio de la Contabilidad General" (MZA, 1889, 1-11) fue el documento más importante para autoregular la contabilidad financiera. En los 58 artículos que lo componen, se establece el funcionamiento del Servicio de Contabilidad de la compañía, que queda dividido en Contabilidad General y Servicio de Caja y Pagaduría. El título primero dedicado a la Contabilidad General establece que el objeto del servicio es el control de los productos de los gastos, de los recursos y compromisos de la compañía, regula sus funciones y su organización administrativa. El título segundo del Reglamento está dedicado al Servicio de Caja y Pagaduría, que se subdivide en Caja Central, Caja sucursal en Sevilla y Pagaduría, cuya organización y funcionamiento se describe pormenorizadamente.

Por lo que se refiere a los presupuestos, las directrices marcadas por el Reglamento Provisional para la Contabilidad de los Servicios de la Red Antigua, aprobado en 1908, son recogidas por primera vez en el presupuesto para el año 1910. Los gastos constituyen el eje central del nuevo Reglamento que anuló todas las disposiciones anteriores no coincidentes. Su finalidad era, como reza el artículo $1^{\circ}$, clasificar, ordenar, justificar y fiscalizar todos los gastos en los que incurriera la compañía, para, de este modo, realizar los pagos pertinentes y conocer los costes reales incurridos. 


\subsubsection{Reglamentos de contabilidad de gestión de MZA (Talleres)}

Dos son los principales documentos emitidos por MZA para alcanzar una contabilización homogénea $^{538}$ en sus talleres. El primer documento es el artículo 44 (denominado "Contabilidad de los Talleres") del Reglamento Provisional para Contabilidad de los Servicios de la Red Antigua (MZA, 1908) ${ }^{539}$, que, sin grandes alteraciones, se mantuvo hasta el final de la compañía en 1941. El segundo es el Informe para el director general con el título "coste de los trabajos realizados en el taller central de vía y obra" realizado, por el ingeniero del material fijo, el 31 de diciembre de 1922.

\subsubsection{Reglamento Provisional para Contabilidad de los Servicios de la Red Antigua de 1908}

Antes de describir las formas contables, el texto enumera los distintos tipos de instalaciones:

- "Los generales de Madrid y Barcelona-Clot, afectos al Servicio de Material y Tracción". Se trataba de los conocidos Talleres Generales, grandes establecimientos donde se realizaban las grandes reparaciones del material rodante (motor y remolcado). Los Talleres Generales de Madrid estaban situados junto a la estación de Atocha, entre las vías y el arroyo Carcabón. El número de empleados superó el millar.

- "Los de los Depósitos de máquinas adscritas al propio Servicio, con sus correspondientes Reservas y Recorridos". En los quince Depósitos, esparcidos por toda la red, se llevaban a cabo las reparaciones ordinarias de las máquinas, y en los quince de los Recorridos las del material remolcado, preferentemente vagones.

- "El central de Vía y Obras establecido en Madrid", también conocido como Taller de Puentes, dedicado a la reparación del material fijo como la vía y las obras de fábrica (estaciones). Desde 1924 se situó en Villaverde y dispuso de instalaciones y equipamiento modélicos. En sus momentos de máximo esplendor ocupó más de doscientos empleados.

- "Los que existen en Madrid para las atenciones del pequeño Material, del Telégrafo y de la Electricidad, anejos a las Inspecciones del Servicio del Movimiento". Eran instalaciones humildes, con un número de empleados muy reducido y un nivel de actividad fluctuante. Dependían del servicio de Explotación o Movimiento y en ellos se construían y reparaban básculas, grúas, cajas de fondos, muebles, lonas y demás pequeños accesorios; se hacían aparatos y accesorios de alumbrado (oficinas, trenes, estaciones), aparatos de calefacción y material eléctrico (carros transbordadores) y aparatos telegráficos y telefónicos y relojes.

- El de Litografía, anejo a los Almacenes Generales, también situado en Madrid.

\footnotetext{
${ }^{538}$ Pocos son los trabajos sobre la contabilidad de los talleres, a pesar de que los Talleres Generales de Atocha y el Taller Central de Villaverde, fueron, hasta fechas avanzadas, la industria más relevante de Madrid (Martínez Vara y de los Cobos: 2007a).

539 Aunque la obra lleva por título Reglamento Provisional para Contabilidad de los Servicios de la Red Antigua", en realidad se refiere a los talleres de toda la red, Antigua y Catalana, como se puede comprobar en la relación de los mismos que se ofrece en el cuadro 1 del texto.
} 
El artículo 44 del "Reglamento Provisional para Contabilidad de los Servicios de la Red Antigua" clasifica los gastos motivados por el funcionamiento de los Talleres en:

1. Gastos generales correspondientes al personal de vigilancia, administración y dirección, al entretenimiento de las máquinas, útiles y herramientas, y al consumo de fuerza motriz, combustible, engrases, alumbrado, objetos de dibujo y escritorio, etc.

2. Gastos correspondientes a la inversión o consumo de las materias empleadas en los diversos trabajos que se ejecuten.

3. Gastos correspondientes a la mano de obra invertida en los trabajos.

El aspecto más significativo y valioso de este sistema contable es la clasificación detallada de los gastos, establecida a partir de la página 61 del citado documento. La clasificación detallada de los gastos de talleres se realiza por medio de la apertura de cuentas especiales para cada uno de los trabajos que en aquellos se ejecuten. Para la designación abreviada de cada cuenta se emplean cuatro cifras separadas por trazos inclinados. La primera cifra indica el Taller en que se abre la cuenta. La segunda refleja el servicio, División o entidad deudora. La tercera señala el número de cada cuenta especial, número que para cada Servicio corresponde a un determinado concepto o género del gasto o trabajo, en correspondencia con la clasificación reglamentaria de los gastos de cada Servicio. La cuarta refleja el número de orden que en cada clase especial de cuentas corresponda sucesivamente a los pedidos.

A continuación se describen los códigos de cada una de las cifras. Para mostrarlo, con una mayor claridad, se ha dispuesto una secuencia ordenada de las cifras en cuadros, por lo que se advierte que no responde a la disposición originaria de la información.

La primera cifra, indicadora del Taller acreedor, debe ser elegida entre las establecidas en el cuadro número 18. 
Cuadro 18. Códigos de la primera cifra

\begin{tabular}{||l|l|}
\hline \multicolumn{2}{|l|}{ Primera cifra } \\
\hline \hline Talleres generales afectos al servicio de material y tracción \\
\hline \hline 1. Madrid & \\
2. Barcelona-Clot & Red Catalana \\
\hline \hline Talleres de los depósitos de máquinas afectos al propio servicio \\
\hline \hline Red Antigua & 25. Mora \\
\hline 10. Zaragoza & 26. Villanueva \\
11. Aranda & 27. Barcelona (Pueblo Nuevo) \\
12. Madrid & 28. Portbou \\
13. Alcázar & \\
14. Albacete & \\
15. Murcia & \\
16. Alicante & \\
17. Ciudad Real & \\
18. Córdoba & \\
19. Sevilla & \\
20. Mérida & \\
\hline \hline
\end{tabular}

Fuente: Elaboración propia

La segunda cifra, indicadora de la entidad deudora, debe ser elegida entre las recogidas en el cuadro número 19. 


\section{Cuadro 20. Códigos de la segunda cifra}

\section{Segunda cifra}

Trabajos ejecutados por cuenta de la Compañía a cargo

5. Del Servicio de Material y Tracción

31. Del Servicio de Vía y Obras

45. Del Servicio de Movimiento

46. De la inspección del Pequeño Material

55. De la inspección de Electricidad

65. De la inspección de Telégrafos

75. De la división de Almacenes

80. De la Dirección

81. Del Servicio Comercial

82. De la División de Reclamaciones

83. Del Servicio de Contabilidad General

84. Del Servicio de Intervención y Estadística

85. Del Servicio de lo Contencioso

86. Del Servicio Sanitario

87. Del Servicio de las Minas

Trabajos efectuados por cuenta de entidades y particulares directamente relacionados con los Servicios de la Compañía

100. De la Dirección General de Correos

101. De la Dirección de Obras Públicas

102. De la Casa Real

103. De la Fábrica de la Moneda y Timbre

110. De la Compañía Internacional de coches-camas

111. Del Ferrocarril de Alcantarilla a Lorca

112. Del Ferrocarril de Soria

113. De las Minas de Puertollano

120. De las Compañía Gaditana de Minas

121. De la Sociedad de Gasificación Industrial

122. De la Sociedad Transportes de vagones de Irún

123. De la Sociedad La Unión de Alicante

124. De la Sociedad Deutsch y Compañía

125. De la Sociedad Loidi y Zuloica

126. De la Sociedad Bodegas Bilbaínas

131. De Don Giacomo Grigolon

132. De Don H. Guillot, de San Sebastián

133. De Don Tomás Santo Domingo, de Valladolid

134. Del Señor Marqués de Mudela

136. De los Señores Fourcade, Gutubay y Compañía

137. De los Señores Muniesa y Horta

Fuente: Elaboración propia

La tercera cifra, indicadora de la cuenta especial, debe ser elegida entre las alternativas recogidas en el cuadro número 21 . 


\section{Cuadro 21. Códigos de la tercera cifra}

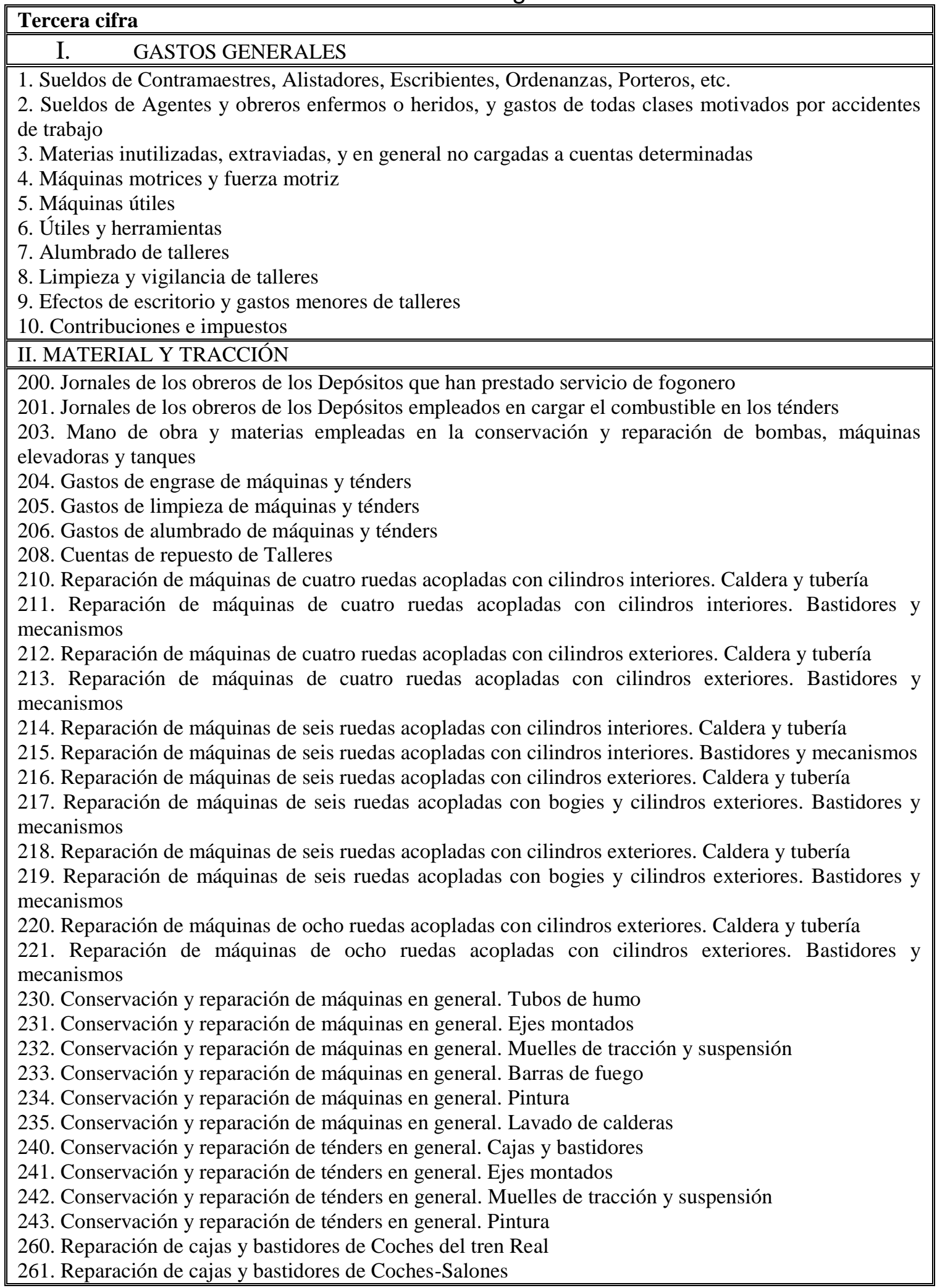


262. Reparación de cajas y bastidores de Coches de lujo

263. Reparación de cajas y bastidores de Coches ordinarios

264. Reparación de cajas y bastidores de Furgones

265. Reparación de cajas y bastidores de Vagones

266. Reparación de cajas y bastidores de Vagones cisternas

267. Reparación de cajas y bastidores de Grúas móviles

270. Reparación de coches, furgones y vagones en general. Frenos

271. Reparación de coches, furgones y vagones en general. Ejes montados

272. Reparación de coches, furgones y vagones en general. Cajas de engrase

273. Reparación de coches, furgones y vagones en general. Muelles de suspensión y tracción

274. Reparación de coches, furgones y vagones en general. Guarnecido de coches

280. Conservación de coches, furgones y vagones. Pintura de coches

281. Conservación de coches, furgones y vagones. Pintura de vagones y furgones

282. Conservación de coches, furgones y vagones. Limpieza

283. Conservación de coches, furgones y vagones. Guarnecido

284. Conservación de coches, furgones y vagones. Conservación en general

285. Conservación de aparatos de calefacción de coches y furgones

287. Engrase de coches, furgones y vagones

290. Reparación de averías causadas por accidentes. Máquinas. Averías pequeñas

291. Reparación de averías causadas por accidentes. Máquinas. Averías de importancia

292. Reparación de averías causadas por accidentes. Coches, furgones y vagones. Averías pequeñas

293. Reparación de averías causadas por accidentes. Coches. Averías de importancia

294. Reparación de averías causadas por accidentes. Vagones y furgones

296. Conservación y reparación de puentes giratorios

297. Gastos de la fundición de Hierro

298. Gastos de la fundición de Cobre

III. SERVICIO DE VÍA Y OBRAS

300. Gastos de creosotaje de traviesas y largueros. Mano de obra

301. Gastos de creosotaje de traviesas y largueros. Combustible

302. Gastos de creosotaje de traviesas y largueros. Engrases de máquinas

303. Gastos de creosotaje de traviesas y largueros. Alquiler, entretenimiento y reparación de bombas, calderas y demás aparatos de maquinaria

304. Creosotaje de traviesas y largueros por contrata

305. Repuestos del Taller Central de Servicio

306. Reparación de puentes

307. Refuerzos de puentes

309. Reparación de armaduras, cubiertas y marquesinas

310. Reparación de placas giratorias

311. Reparación de carros transbordadores

312. Reparación y construcción de agujas

313. Reparación y construcción de cruceros y corazones

314. Reparación y construcción de cajas de maniobra

320. Construcción de transmisiones ordinarias

321. Construcción de transmisiones concentradas

330. Reparación de aparatos y transmisiones de enclavamientos

331. Construcción de enclavamientos

340. Reparación de aparatos de señales

341. Construcción de aparatos de señales

342. Construcción y reparación de accesorios para transmisiones de señales

IV. SERVICIO DE MOVIMIENTO. PEQUEÑO MATERIAL

401. Oficinas Centrales. Construcción y reparación de los aparatos de alumbrado

402. Oficinas Centrales. Construcción y reparación del mobiliario 
405. Trenes. Construcciones y reparación de los aparatos de alumbrado

406. Trenes. Construcciones y reparación del mobiliario de dormitorios de conductores y guardafrenos

407. Trenes. Construcciones y reparación de prolongas y cadenas

408. Trenes. Construcciones y reparación de lonas y toldos

410. Estaciones. Construcción y reparación de aparatos de alumbrado

411. Estaciones. Construcción y reparación de aparatos de calefacción

412. Estaciones. Construcción y reparación de mobiliario

413. Estaciones. Construcción y reparación de básculas

414. Estaciones. Construcción y reparación de grúas fijas

420. Fabricación y reparación de efectos de carpintería y ferretería

421. Fabricación y reparación de efectos de hojalatería

422. Fabricación y reparación de efectos de pintura y varios

425. Repuestos del taller

V. SERVICIO DE MOVIMIENTO. ELECTRICIDAD

501. Oficinas Centrales. Conservación y reparación de los aparatos de alumbrado

502. Oficinas Centrales. Conservación y reparación de los aparatos de calefacción y ventilación

505. Trenes. Conservación y reparación de aparatos y accesorios de alumbrado

510. Estaciones. Conservación y reparación de aparatos y accesorios de alumbrado eléctrico de las estaciones de servicio común

511. Estaciones. Conservación y reparación de aparatos y accesorios de alumbrado eléctrico de la estación de Madrid

512. Estaciones. Conservación y reparación de aparatos y accesorios de alumbrado eléctrico de la estación de Alcázar

513. Estaciones. Conservación y reparación de aparatos y accesorios de alumbrado eléctrico de la estación de Sevilla

515. Estaciones. Conservación y reparación de aparatos de calefacción y ventilación de la estación de Madrid

518. Estaciones. Conservación y reparación del material eléctrico de carros transbordadores

520. Aparatos de medición y ensayo

525. Repuesto del taller

VI. SERVICIO DE MOVIMIENTO. TELÉGRAFO

601. Construcción de aparatos telegráficos

605. Construcción de aparatos telefónicos

610. Reparación de relojes

615. Fabricación y reparación de accesorios

620. Fabricación y reparación de aparatos de ensayos

625. Repuesto del taller

\section{Fuente: Elaboración propia}

La cuarta cifra es la indicadora del número de orden del pedido. Para ello se empleará la numeración correlativa (renovándola anualmente), con arreglo al orden cronológico de los pedidos respectivos, para poder evaluar separadamente los precios líquidos ${ }^{540}$ de cada uno de aquéllos, aunque correspondan al mismo Servicio o entidad deudora, y a gastos o trabajos de igual índole.

\footnotetext{
${ }^{540}$ La conceptualización y forma de calcular los precios líquidos están definidos en las páginas 68-70 del documento analizado.
} 
El procedimiento de registro es claro y sistemático. Sin embargo, el procedimiento se complica con los casos especiales de simplificación de anotaciones. Los procedimientos de simplificación son tres, todos ellos descritos en el apartado i) situados en la página 66 del documento.

La primera simplificación consiste en la eliminación de la primera cifra en algunas circunstancias. En las anotaciones de cuentas, estampadas en las hojas de tareas que se formalicen en cada taller, se suprimirá la primera cifra indicadora del taller acreedor, por suplirla con suficiente claridad el encabezamiento del estado.

La segunda simplificación consiste en la supresión de la tercera cifra en algunos casos. Se eliminará la tercera cifra en todas las anotaciones de las cuentas relativas a trabajos ejecutados por cuenta de entidades y particulares relacionados con el Servicio de la Compañía, relativos por lo general a las reparaciones del material móvil de propiedad de los mismos que circule por las líneas de la compañía, por puntualizarse claramente esta designación en los respectivos pedidos y no interesar a las Contabilidad de los servicios, la estadística detallada de los diferentes precios relativos a dichas cuentas.

La tercera y última simplificación consiste en eliminar la última cifra cuando concurran determinadas circunstancias. Salvo en casos excepcionales, que señalaría la respectiva Jefatura del Servicio, se prescindirá de la última cifra en las anotaciones de cuentas correspondientes a trabajos propios del Servicio a que pertenezca el Taller, por agruparse generalmente en las respectivas estadísticas los gastos consiguientes, según clasificaciones relacionadas con las terceras cifras de estas cuentas, sin detallar los importes parciales de cada trabajo.

Cuando en virtud de las prescripciones de las tres simplificaciones se suprima alguna cifra en las anotaciones de las cuentas, se indicará la supresión conservando todos los trazos de separación de las cuatro cifras reglamentarias.

A continuación el documento establece una ejemplificación de anotaciones: apartado j) situados en la página 66 del documento analizado con la denominación "Ejemplos de anotaciones". Uno de ellos es la cuenta 1/5/241, que corresponde a los trabajos ejecutados por los Talleres Generales de Madrid, con cargo al Servicio de Material y Tracción, para la reparación de Ejes montados de ténders. La cuenta 40/80/402/6 corresponde a los trabajos ejecutados por los Talleres del Pequeño Material, con cargo a la dirección, por la Reparación del Mobiliario de Oficinas, según el pedido número 6 de los realizados al citado Taller por el expresado Servicio. La cuenta 1/75/341/3 corresponde a los trabajos ejecutados por los talleres Generales de Madrid, con cargo a Almacenes Generales, por la Construcción de aparatos de Señales, según el pedido número 3 de los realizados al citado Taller por la expresada División. La cuenta 16/123//4 corresponde a los trabajos ejecutados por el Taller de Depósito de Alicante, con cargo a la Sociedad La Unión de dicha ciudad, según el pedido número 4 de la misma. Por último, exponemos la cuenta 50/1/7/2 corresponde a los trabajos 
ejecutados por el Taller de Electricidad, con cargo a los talleres Generales de Madrid, para el alumbrado de los mismos según el pedido número 2.

El sistema de codificación es muy sistemático, dando unos resultados informativos satisfactorios; sin embargo el sistema de simplificación no parece estar a la altura. En primer lugar, con estas simplificaciones no se realiza una anotación mucho más abreviada, por lo que no parece muy relevante su utilización. Pero al contrario, su inclusión sí puede minorar el carácter informativo de las anotaciones, al convertir unos datos tan claros, como los que ofrece la codificación, en unos datos relativamente oscuros.

Para argumentar lo anterior, se analiza con detalle el apartado j) del documento: "Ejemplos de anotaciones". En concreto, los ejemplos de simplificación de los trabajos ejecutados por los Talleres generales de Barcelona-Clot por pago de jornales a obreros enfermos $(2 / 0 / 2 / 0$ sin simplificar) y los del Taller de Telégrafos por la adquisición de útiles y herramientas (60/0/6/0 sin simplificar) son difícil de entender. Para el primero, el ejemplo de simplificación lleva a designarlo como (2/2//), lo cual puede provocar dudas para el usuario de los registros contables sobre si son los dos primeros campos los que tienen valor y los dos segundos campos son los que no lo tienen, o son el primero y el tercero de los datos los que tienen valor. Respecto al segundo ejemplo (/60/6/), puede provocar dudas al usuario sobre si los dos campos con valor son el segundo y tercero, y no el primero y el tercero.

Todas estas dudas informativas al usuario, unidas al escaso valor de abreviación de estas medidas de "simplificación", permiten afirmar lo inapropiado de las medidas de simplificación. El hecho de que las simplificaciones compliquen la dimensión informativa de los apuntes, es muy relevante ya que esta información debería ser analizada por los niveles jerárquicos superiores y por otros departamentos de la organización, tanto por ser un medio para evaluar la gestión como por ser un medio de control interno.

En definitiva, la utilidad de registro de la contabilidad quedó perfectamente satisfecha con las normas de codificación, mientras que no se alcanza el mismo grado de satisfacción en la dimensión informativa de los apuntes con las normas de simplificación.

\subsubsection{Informe para el director general con el título "coste de los trabajos realizados en el taller central de vía y obra" realizado por el ingeniero del material fijo, el 31 de diciembre de 1922}

El informe tenía una doble finalidad. La primera era justificar la viabilidad económica del taller "Central de Vía y Obra" frente las alternativas concretas de externalización. La segunda era argumentar la necesidad de no reducir la capacidad operativa del taller (incluso en algunos grupos aumentar) en el inminente traslado a la nueva ubicación de Villaverde Bajo, reubicación provocada por el estrangulamiento de las instalaciones en las que estaba situada en ese momento la planta, entre la estación de Atocha y los talleres "Generales de Material y Tracción”, que le impedía aumentar el nivel de producción. 
El informe agrupa una serie de datos, que posteriormente son analizados y comentados, para terminar ofreciendo una serie de conclusiones. Los datos tienen dos tipos de naturalezas, por un lado, reflejar el precio medio de cada uno de los años de actividad, por el otro, realizar una comparación de los trabajos, clasificados por grupo de actividad, entre los realizados por el taller y sus competidores privados.

En primer lugar, el informe realiza una desagregación temporal por años de los trabajadores y toneladas producidas para detallar los precios medios para cada año. Los datos de cada año aparecen desagregados por los operarios que han sido utilizados, a su vez dividiéndolos entre fijos y suplementarios (temporales). También aparecen detallados el número de toneladas producidas en cada año, separando las producidas en total en el taller, y en términos unitarios por cada trabajador.

En segundo lugar, el informe analiza los datos de los diferentes trabajos agrupados en tres grupos: (1) cambios y aparatos de vía, (2) cubiertas y estructuras metálicas y (3) puentes metálicos. Para los tres grupos se analizan detalladamente el coste unitario de cada trabajo realizado. Buscando realizar una comparación interempresarial, algunos de los trabajos realizados por el taller son acompañados por el mismo detalle para el coste del trabajo si es realizado fuera del taller, en una empresa privada ("industria particular" en denominación del Informe). El coste unitario de cada trabajo no está expresado únicamente en términos absolutos y finales, sino que aparece detallado por el coste unitario, y dentro de este total se especifica el coste de sus cuatro componentes principales: materiales, mano de obra, sobrecargo de la mano de obra y gastos generales.

El Informe obtiene unas conclusiones, diferenciando los comportamientos dentro de los tres principales grupos de trabajo que realiza el Taller.

Los grupos de "cambios y aparatos de vía" y "puentes metálicos" son claramente rentables económicamente, por encima del $20 \%$ de rentabilidad respecto a la industria particular. Ante esta clara rentabilidad, el informe propone aumentar la actividad en estos dos grupos. Esta decisión estaría apoyada, además de en la clara ventaja de rentabilidad respecto a la competencia, en que permitiría mantener personal cualificado para solventar necesidades de carácter urgente. El informe argumenta que, en estas situaciones, el personal propio realizaría el trabajo de mejor modo que la industria privada, ya que ésta no dejaría trabajos pendientes con otros clientes, ni tendría personal especializado de incorporación inmediata. Realmente el informe va más allá, pues recomienda aumentar el peso relativo de ambos grupos, pero selectivamente, es decir, retirar a la industria particular los pedidos más rentables, trasladándola los menos rentables. El aumento de capacidad es concordante con el aumento de instalaciones, previsto en ese momento, al ser trasladadas a Villaverde Bajo.

Para el segundo grupo de actividades, "cubiertas y estructuras", la rentabilidad no es mucho mayor que las de la industria, por lo que las recomendaciones son distintas. El informe constata que existe una crisis de trabajo en el sector, que permite obtener unos precios competitivos en las externalizaciones. Pero aún con estos precios, las rentabilidades son 
similares a los de esas empresas, de tal forma que el informe establece que la reparación de este grupo de actividades sería neutral, es decir, no supondría ni grandes rentabilidades ni perjuicio alguno.

En nuestra opinión, el elaborador del informe, adecuadamente, tuvo en consideración algunos aspectos que son básicos para ofrecer un documento que sirva para tomar las decisiones de producto y precio que pretende.

- El informe es consciente de que, sobre la decisión de externalizar o no una parte de la producción, es necesario valorar el precio pero también la calidad del producto. Así lo hace al estimar que, en los casos que recomienda aumentar la producción, no sólo existen razones de precio (páginas 9 y 12), sino también se detallan experiencias donde el taller resolvió las contingencias más rápido y mejor que la industria particular (páginas $16 \mathrm{y}$ 17). Además, el informe destaca los aspectos comparativamente positivos que tendría la fabricación en taller: el control de la calidad de los productos, el convencimiento de que el taller especializará los talleres y operarios que considere necesario, cosa que raramente realizará la industria particular, el problema de los pedidos muy especializados o en los que hace mucho tiempo que no se manufacturan, donde la industria particular, con toda seguridad, no tendrá recursos especializados $\mathrm{y}$, por último, la posibilidad de evitar discusiones con defectos y plazos de entrega.

- El informe también analiza cual, de todas las posibles externalizaciones, es una empresa más fiable (La Maquinaria Terrestre y Marítima).

- El informe tiene en cuenta la economía de escala en su análisis, al afirmar que al aumentar la producción de productos similares “(...) podrán repartirse ciertos gastos de importancia casi uniforme, entre mayor número de unidades de peso, por lo que casi siempre ocurre, los costes unitarios de obras de importancia serían menores" (página 18).

- El informe es consciente de que la inversión, el desarrollo y la innovación continuada son el futuro del sector al afirmar que “(...) sería muy conveniente, no sólo aumentar, sino a la vez trasformar algunos medios de producción existentes, a las máquinas y perfeccionamientos modernos" (página 22).

- El informe valora positivamente la importancia del capital humano, es más, ante la decisión de aumentar la fabricación, uno de los argumentos es que así existirá en todo momento suficiente personal apto para atender cualquier necesidad de carácter urgente y 
perentorio. Además, es consciente que la externalización supondría que la industria particular no tendría personal especializado que, por el contrario, sí tendría una fabricación propia en el taller.

- El informe basa su estrategia en un aspecto fundamental, el aprovechamiento de poder seleccionar los proyectos más rentables, dejando a la industria los que en cada momento menos interesen.

- La decisión de aumentar la capacidad de trabajo es consistente con el nivel estructural, ya que el taller proyectado en Villaverde Bajo estaba preparado para alcanzar más de las 1.300-1.400 recomendadas en el informe, en concreto, 2.000 toneladas anuales.

Sin embargo, aunque los aspectos generales son correctos, y puede considerarse como un análisis acertado, el elaborador del informe no tuvo en cuenta algunos aspectos particulares necesarios para la toma de decisiones eficiente:

- El informe compara la empresa únicamente con algunos trabajos de la industria particular; no realiza una comparación detallada de todos, lo cual puede hacer suponer que, por intereses particulares, el elaborador del informe eligió comparar los que ofrezcan una rentabilidad diferencial mayor.

- El elaborador del informe advierte, adecuadamente, la crisis que presentaba en ese momento la industria particular. El informe observaba la debilidad principal, ya que, tras la crisis, las empresas particulares solicitarían mayores retribuciones. Sin embargo, no tiene en cuenta un componente de debilidad secundaria, ya que los proveedores de materiales, en momentos de crisis, ofrecen precios ajustados porque saben que la lucha competencial de la industria se repercute al mercado de proveedores. Mientras que la recesión acontezca, los proveedores contendrán sus precios, pero cuando la situación mejore solicitarán tarifas mayores, que incrementarán los costes de producción de la industria particular, y en el caso de fabricación propia, también en el taller.

- El informe no advierte que si el taller aumenta su capacidad, ofreciendo a la industria particular menos trabajos, y además los menos rentables, los proveedores ofrecerán mejores condiciones y precios al taller, al aumentar el peso del taller en el mercado. 
- El informe no incorpora entre su estrategia aprovechar su poder de negociador frente a los proveedores y empresas del sector.

- El informe no tiene en cuenta las consecuencias negativas monetarias derivadas de externalizar los trabajos urgentes. En estas situaciones, la industria particular estarán motivados para aumentar el precio de los trabajos, ya que su poder de negociación aumenta ante las necesidades urgentes. Sí valora, por el contrario, que ante estos trabajos urgentes la industria particular daría preferencia temporal a la finalización a los clientes que ya tuviera comprometidos.

- El informe no termina de establecer claramente una estrategia general para el largo plazo, se centra fundamentalmente en los aspectos de corto/medio plazo. Dentro de ella destaca el silencio ante las actuaciones que debe tener el taller cuando acontezca, antes o después, la salida de la crisis de las empresas de la industria particular.

- Los datos ofrecidos en la comparación son parciales al ofrecer únicamente los costes de los productos. Al no tener información de las afectaciones e imputaciones, ni tampoco la cuenta de resultados, es imposible saber si el taller incorporó como costes del periodo a componentes que deberían ser incluidos como costes del producto.

- El documento no tiene en cuenta que para tomar una decisión de producto, se manejan dos escenarios diferentes dependiendo de que la empresa se encuentre en plena capacidad o no. Suponemos que en el momento de elaborar el informe no estaba en plena capacidad, pero que con las recomendaciones se propone alcanzarlas, eso sí sólo en los grupos de "cambios y aparatos de vía" y "puentes metálicos". Esta idea puede observarse en la página 11 del informe: “(...) opino que para esta clase de trabajos (...) se debe encargar al taller de la compañía el mayor número de aparatos y elementos posibles, para que siempre que su capacidad de trabajo lo permita, realizar los encargos que, de otro modo, se harían a la industria particular".

- La información sobre los costes es incompleta, y esta limitación impide tomar las decisiones sobre precio y producto adecuadas. El informe proporciona información sobre el coste completo (full costing) de los productos pero no desarrolla un análisis de costes variables (direct costing). La información ofrecida por el taller para el análisis es la de los costes completos sin diferenciar, en ningún momento, la parte variable y la parte fija para cada uno de las componentes. Esta limitación impide tomar las decisiones en función del 
margen de contribución, esencial para todas las decisiones, pero sobre todo para las que deben decidir sobre fabricar un producto dentro de la compañía o encargarla a otra fuera de su ámbito.

- La decisión respecto al segundo grupo, quizá sea acertada, pero para llegar a ella, el informe ha utilizado herramientas equivocadas, al no tener en cuenta el margen de contribución, el sistema de costes variables y la capacidad productiva de la compañía. Con las herramientas utilizadas, la decisión de producir o no, se solventa con que es neutral desde el punto de vista económico, pero que por garantizar la calidad y que exista en todo momento suficiente personal apto para atender cualquier necesidad de carácter urgente y perentorio, es mejor fabricarla. Este análisis con las herramientas adecuadas puede sugerir otra estrategia, que además podría estar apoyada por las incertidumbres que se atisban cuando el sector salga de la crisis en la que está inmerso.

\subsubsection{Unificación de contabilidad entre NORTE y MZA}

La Comisión Mixta creada entre NORTE y MZA, el 27 de junio de 1906, decidió unificar la contabilidad para facilitar la recíproca intervención entre ambas empresas. A partir de esa fecha, la regulación interna de MZA tiende a coincidir con la de NORTE. La cual queda expuesta en el capítulo cinco.

\subsection{Práctica contable propuesta por los expertos}

La contabilidad de las compañías ferroviarias ha tenido mucha importancia en el desarrollo de la práctica y el pensamiento contable (Boockholdt, 1977: 9-28).

En el siglo XIX, las ferroviarias españolas utilizaron los criterios de registro de las ferroviarias francesas, sobre todo "porque lo impusieron los inversores franceses" (Broder: 2012). Con el paso del tiempo los gerentes españoles, los contables de las empresas ferroviarias y los contables generalistas empezaron a realizar estudios y ensayos, que desarrollaron una doctrina propia española para los registros contables de las empresas ferroviarias. Los textos son variados en presentación, origen y publicación.

\subsubsection{Fuentes de la doctrina contable española}

En este apartado se repasa el origen de la práctica contable española en los diferentes tipos de textos existentes.

Por un lado están los libros que ofrecen información sobre el servicio y explotación de los ferrocarriles en general, que establecen un apartado o tema sobre la contabilidad. Schillings (1853, 121-171) escribió un manual de divulgación para el personal ferroviario sobre el 
servicio de explotación del ferrocarril. Los contenidos de los capítulos son: personal; conservación y vigilancia de la vía; tracción, material y señales; gran velocidad: servicio de los viajeros y estaciones principales e intermedias; organización de la circulación y composición de los trenes: casos de peligro, llegada de los trenes a su destino; poca velocidad: servicio de transporte de mercancías; y el último contabilidad. De la misma forma, Matallana (1863; 1867; 1873) escribió tres libros dedicados al personal subalterno, en los cuales se analizan los siguientes aspectos: organización del Servicio de Vía y Obras; documentación de la Contabilidad de la vía; funciones que tiene que realizar el personal subalterno para que la empresa cumpla con sus formalidades contables; sección técnica; vigilancia de la vía; modelos de impresos; e índices legales de las disposiciones al respecto. Rahola (1914-1923) emitió el "Tratado de ferrocarriles", el más importante manual básico sobre ferrocarriles; cada tomo está dedicado a un punto básico para el conocimiento técnico del ferrocarril, estando gran parte del tomo $\mathrm{V}$ dedicado a la contabilidad.

En segundo lugar, los manuales de contabilidad general para todo tipo de empresas y sectores que incluían un capítulo específico para describir la contabilidad de las empresas ferroviarias, siendo las más importantes los trabajos de Torrents y Monner (1885: 531) Martínez Pérez (1910: 205-208) y De Aragón (1942: Libro noveno y 497-514).

En tercer lugar, hay que valorar los manuales de contabilidad ferroviaria en la época de las concesionarias ferroviarias privadas entre los que destacan Imedio Díaz $(1934)^{541}$ e Imedio Díaz y Fraisero (1934) ${ }^{542}$. Ambos son auténticos manuales de la aplicación práctica de los conocimientos contables a los ferrocarriles. En ellos se analizan la constitución de una empresa ferroviaria, la contabilidad de la emisión de acciones y del pago de cupones, cuenta de gastos del primer establecimiento y deuda ferroviaria.

Del mismo modo, existieron los textos que analizaban la información contable de las estaciones de las empresas ferroviarias. Muñoz Mosquera (1884, 1-449) realizó un libro que consta de dos secciones: la primera dedicada a la contabilidad de estaciones, y la segunda a la parte técnica de movimiento (circulación de trenes...).

También hubo libros especializados en la contabilidad ferroviaria sectorial, por ejemplo la militar de Díaz Reynes (1881, 1-354).

Además, existen manuales de preparación para el ingreso en la compañía NORTE, donde siempre uno de los temas era la contabilidad. Estos manuales fueron realizados por la propia empresa $^{543}$ y por personas independientes ${ }^{544}$. Para el examen de empleados sencillos había un

\footnotetext{
${ }^{541}$ Este autor es Joaquín Imedio Díaz, Interventor del Estado en la Explotación de Ferrocarriles, director de la revista Caminos de Hierro. No debe confundirse con su hermano Alfonso Imedio Díaz, Interventor del Estado en ferrocarriles, agregado al Servicio Comercial de la Compañía de MZA y director técnico de la Revista Caminos de Hierro; ni con Antonio L. Imedio Moreno Interventor del Estado en la Explotación de Ferrocarriles.

${ }^{542}$ El primero de los autores es el anteriormente citado Joaquín Imedio Díaz. El otro es Carlos Fraisero García, encargado de la Sección de Contabilidad del Correo Central (Dirección General Comunicaciones).

${ }^{543}$ NORTE (1921b: 1-188; 1921c: 1-8; 1921d: 1-8).
} 
tema sobre contabilidad ferroviaria (Moragas, 1914, 1-43) (NORTE, 1921c: 1-8). Para el examen de empleado principal había tres grandes grupos: Organización y funcionamiento de la compañía; Contabilidad de estaciones y Tarificación ferroviaria (NORTE, 1921b: 1-188). Para la preparación a las oposiciones de ingreso en el cuerpo administrativo de ferrocarriles, se incluían muchos temas administrativos y mercantiles y de contabilidad (Urbina y Calatañazor, 1889: 1-275). Para la superación de los exámenes para la Inspección administrativa y mercantil de ferrocarriles, el temario se componía de temas generales de aritmética, contabilidad y derecho mercantil (Luque y Pallardo, 1888: 1-532). El mayor peso de la contabilidad se encontraba en el programa para el ingreso en la Sección de contabilidad (oficinas) (E.R. y G.F.V.: 1914) (Ruiz: 1916) (Ruiz y Vega, 1921: 1-19). Posteriormente destaca los apuntes de contabilidad mercantil y modelos del rayado de libros, adaptados a los distintos programas de las oposiciones para empleados de la compañia NORTE (González Castro: 1922) (Cintora y Riñón: 1926).

También existían manuales de preparación de los exámenes en otras empresas, como MZA. El "Programa para exámenes de factores. Contabilidad en las estaciones" de MZA estaba integrado por 54 cuestiones sobre materia de contabilidad en las estaciones (MZA, 1913: 13).

También existieron manuales preparatorios para la superación del examen de ingreso en cualquier compañía de ferrocarriles (Santapau y Merenciano, 1916: 1-192).

De la misma forma, existieron temarios para el acceso a los puestos estatales, como por ejemplo el del Interventor del Estado en la Explotación de Ferrocarriles. Este temario constaba de una parte técnica (vía, material, explotación técnica) y comercial (explotación, tarifas, contabilidad, derecho mercantil y administrativo). Algunos textos preparaban la parte contable (Melendez, 1908: 1-419) (Martínez Saénz De Merino, 1921: 1-127) (Ramón; Campos y Santo: 1921).

Además, son relevantes los apuntes sobre obras públicas para los estudiantes de la Escuela de Ingenieros de Caminos, donde aparecen nociones de contabilidad. Así puede verse en los apuntes para la clase de legislación, administración y contabilidad de las obras públicas ${ }^{545}$.

Por último, existieron informes periciales de la contabilidad donde se ofrecían una opinión tras estudiar los libros y documentos justificativos de las cuentas de la construcción de la línea ${ }^{546}$.

\footnotetext{
${ }^{544}$ Luque y Pallardo (1888: 1-532), Urbina y Calatañazor (1889: 1-275), Moragas (1914: 1-43), Ruiz (1916), Ruiz y Vega (1921: 1-19) y González Castro (1922).

${ }^{545}$ Anónimo (1890): Apuntes para la clase de legislación, administración y contabilidad de las obras públicas. Curso de 1889-90, Madrid: M. Alarcón.

${ }_{546}$ Anónimo (1897: 1-10): Informe de los peritos contables nombrados por el Juzgado de Primera Instancia del Distrito de la Audiencia para examinar la contabilidad y documentación referentes a las obras hechas por Don Francisco de Paula Retortillo en el Ferrocarril de Mérida a Sevilla: balance de 1887 y estado de comprobación de saldos. Madrid: Imprenta de Evaristo Martínez.
} 
Del conjunto de todas estas fuentes podemos extraer unas recomendaciones sobre los registros contables, tanto de teneduría, como de presentación de los estados financieros, y de estadísticas. Esto supone una doctrina contable ferroviaria en España independientemente de la que se realizaba en otros países. A continuación analizamos sus principales contenidos.

\subsubsection{Teneduría propuesta por la doctrina}

En este tipo de compañías es muy importante la distribución de funciones para el registro adecuado de las operaciones, pues era muy distinto al de empresas de otros sectores. El personal de cada uno de los Servicios que componen las empresas ferroviarias, tiene, entre su dedicación, unas funciones a realizar para que la empresa obtenga el sistema de información contable (Matallana, 1863; 1867; 1873).

En las empresas ferroviarias es relativamente sencilla la gestión del "tenedor de libros", limitada a registrar periódicamente en los libros Diario y Mayor los resultados del tráfico. Sin embargo, la labor del jefe de contabilidad ${ }^{547}$ era más difícil, compleja y delicada, y sobre todo "tenía más responsabilidad" (Montoya, 2010: 109), pues estaba obligado a llevar bajo su dirección la intervención y estadística, así como a examinar, compulsar y comprobar hasta en sus menores detalles las distintas partidas y conceptos que componían el tráfico diario de la línea, "debiendo clasificarlas y agruparlas convenientemente después para formar el estado resumido que debía pasar a la teneduría y posteriormente a conformar los asientos contables que forman los libros de contabilidad" (Oliver: 1885).

La contabilidad de cada Sección da a conocer sus resultados en un periodo -generalmente cada mes- a la Sección de Contabilidad general por medio de informes ("Estados" en denominación de la compañías). Estos "Estados" son los documentos que utiliza esta Sección para incorporar su contabilidad a la general (Martínez Pérez: 1910: 206).

El servicio combinado de una línea, cuando enlaza o empalma con otras de distintas empresas, forzosamente da lugar a cargos o abonos de compañía a compañía, según resulta de sus liquidaciones, que se practican generalmente cada diez días, o al final de mes en ferrocarriles de poca importancia (Torrents y Monner, 1885: 530-532).

Las estaciones de una vía férrea liquidan generalmente todos los días con la Intervención, la cual revisa minuciosamente las cuentas que le remiten con sus comprobantes, pasándolos después a la Sección de Estadística (Torrents y Monner, 1885: 531).

Para tener una idea completa de la explotación de las empresas concesionarias ferroviarias es necesario dividir su ciclo productivo en cuatro fases o periodos: la concesión de la línea, que

\footnotetext{
${ }^{547}$ La responsabilidad de los "jefes de contabilidad" se pone de manifiesto en la Instrucción General $n^{\circ} 1$ sobre la organización de los Servicios de la Compañía NORTE.
} 
llevaba aparejada la previa o paralela constitución de la sociedad que debía regentar la línea, la posterior construcción de la línea férrea, y su definitiva explotación ${ }^{548}$.

Las distintas fases del negocio de los ferrocarriles condicionaban en cada caso la contabilidad de la compañía. Considerando las especiales características del sector, la contabilidad se adaptaba a las cuatro fases que caracterizaban este tipo de negocios (Concesión, Constitución, Construcción de la línea y Explotación), alcanzando un mayor desarrollo en la última etapa.

Las actividades de constitución de la sociedad ferroviaria y de solicitud de la concesión, pueden coincidir en el tiempo, o puede existir una constitución anterior.

\subsubsection{Constitución de la sociedad mercantil}

La primera tarea de las personas que pretendían explotar una línea de ferrocarriles normalmente un grupo de financieros- es la constitución de la sociedad. Para ello se precisa reunir capitales suficientes para su realización. Estos capitales, tratándose de un negocio de esta índole, habían de ser necesariamente cuantiosos, puesto que, tanto las instalaciones y obras, como la adquisición de material, suponen la inversión de grandes sumas.

La nueva sociedad procedía a la apertura de los cinco libros obligatorios oficiales exigidos por la normativa mercantil vigente: libro de Inventarios y Balance, libro Diario, libro Mayor, libro de Actas y, por último, Copiador de cartas y telegramas.

En el Libro Diario se registran los asientos correspondientes a su constitución, para lo cual era necesario abrir la cuenta de "Gastos de constitución de la sociedad", en la que se recogían a través de divisionarias (Administración, comisiones, gastos generales, etc.) los ocasionados con tal motivo.

Una cuestión a resolver en la constitución de la sociedad anónima, desde el punto de vista contable, es la valoración de la emisión de las acciones, puesto que se reconocía la posibilidad de su emisión a la par, sobre la par y bajo la par. El primer supuesto no ofrece duda alguna en cuanto a su contabilización, similar a la que se practica hoy en día. Sin embargo, sí existen diferencias sustantivas en los otros dos citados. Cuando la emisión era sobre la par, "supuesto bastante poco frecuente" (Montoya y Guzmán, 2012: 9), la prima de emisión se percibía al tiempo de cancelar el último dividendo pasivo, registrándose posteriormente en la cuenta de pérdidas y ganancias como si de un ingreso más del periodo se tratase, sin que dicha partida figurase en balance como hoy en día ocurre. En cuanto al caso de emisión de acciones bajo la

\footnotetext{
${ }^{548}$ En las empresas del ferrocarril se distingue el periodo de "concesión", que concluye al constituir por escritura pública la sociedad, y el de "construcción", que termina cuando se da principio a la "explotación" (Torrents y Monner, 1885: 531). De Aragón (1942: 500) recoge estas tres fases, con la denominación "periodos"; la denominación que las concede son Período de concesión y constitución, Periodo de construcción y Periodo de explotación.
} 
par -actualmente prohibido por nuestra legislación mercantil ${ }^{549}$-, se permitía a condición de que al saldar el último dividendo pasivo se registrase la diferencia entre el valor nominal y el efectivo recibido en una cuenta denominada "prima de reembolso", que posteriormente debía traspasar su saldo a la cuenta de "Gastos de Primer Establecimiento"; en este supuesto se proponía un tratamiento asimétrico respecto del caso de emisión sobre la par, al no quedar afectado el resultado del ejercicio, dado que "quedaba prohibido traspasar el saldo de la cuenta de prima de reembolso a la cuenta de pérdidas y ganancias" (Montoya y Guzmán, 2012: 13).

\subsubsection{Obtención de la concesión administrativa}

De forma paralela a su constitución, se solicitaba la concesión de la línea ferroviaria al Ministerio de Obras Públicas, para que una vez obtenida pudiese iniciarse la construcción de la línea.

En la solicitud de la concesión debía quedar argumentado que se intentaba establecer la explotación de un ferrocarril en una de las regiones estratégicas de comercio que careciera de comunicaciones eficaces. De esta forma, los organizadores de la compañía realizaban las gestiones con el Estado, intentando que favoreciera y ayudara al proyecto, incidiendo en que el proyecto aportara utilidad al conjunto del país ${ }^{550}$.

Para conseguir la aprobación estatal, la empresa debía planificar, incluso antes de la constitución, tanto las posibilidades del negocio, como la cuantía aproximada de capitales que se precisan y las posibilidades económicas del proyecto. Esta planificación debía ser realizada por medio de un cuerpo técnico especializado, compuesto de financieros e ingenieros. Los ingenieros, por medio de la cartografía del territorio, estudiaban los accidentes del terreno, lo que les dará una idea aproximada del coste de las obras. Los financieros enfocaban el problema desde el punto de vista comercial, estudiando las posibilidades económicas de las regiones por donde iba a atravesar el ferrocarril. Ambos tipo de profesionales emitirán sendos informes.

Cuando el proyecto era aceptado por los organismos técnicos asesores del Estado, éste se encargaba de facilitar la labor de los promotores en sus distintos aspectos. Los organismos técnicos del Estado cederán su cartografía detallada que facilitara la labor de los ingenieros. Apoyándose en ella, los ingenieros comenzarán a desarrollar el proyecto del trazado de la empresa, sirviendo como referencia las zonas que hay que comunicar, previamente fijadas por

\footnotetext{
${ }^{549}$ El artículo 59.2 del RD-Legislativo 1/2010, de 2 de julio, por el que se aprueba el Texto Refundido de la Ley de Sociedades de Capital señala que "no podrán crearse participaciones o emitirse acciones por una cifra inferior a la de su valor nominal".

${ }^{550}$ NORTE realizó esta justificación. En un documento (Chemin de Fer du Nord de L'Espagne, 1858: 1-27) señala las características de las líneas de la compañía NORTE; empezando por la fecha de las concesiones describe, a través de un análisis de los Estatutos, la formación de la sociedad y las características del trazado. En el documento, se justifica la importancia de la construcción de estas líneas, basándose en la riqueza agrícola y mineral de las zonas que atraviesa, incluyendo una breve previsión de resultados que apoya la importancia de esta nueva vía de comunicación, y por tanto de la compañía del NORTE, para el desarrollo peninsular.
} 
los financieros. La labor de los financieros sería la de gestionar la concesión de los terrenos necesarios para el establecimiento de las estaciones y depósitos, los permisos para el paso de la vía, la expropiación forzosa de los terrenos por ser considerados por el Estado obras de utilidad pública, y el cálculo del justiprecio de los terrenos.

La redacción y aprobación definitiva del proyecto ponía punto final al periodo de constitución y daba comienzo a los trabajos de construcción.

Contablemente los gastos que se generaban en este periodo eran bastante notables y diversos, registrándose a través de cuentas divisionarias con títulos al efecto (personal, material, instrumentos, viajes, imprevistos...) que traspasaban su saldo a la cuenta "Gastos de Estudio y Concesión",551.

La cuenta "Gastos de Estudio y Concesión" se saldaba, bien al finalizar la fase de construcción de la línea o al cierre de cada ejercicio económico, con cargo a la cuenta denominada "Construcción de la vía” (Montoya y Guzmán, 2012: 13).

La cuenta "Gastos de Estudio y Concesión", junto a la de "Gastos de constitución de la sociedad", formaban el saldo de la cuenta nueva titulada "Gastos de Primer Establecimiento". Esta última cuenta estaba destinada a registrar operaciones de relevancia a lo largo de la vida la sociedad ferroviaria, tales como adquisiciones de terrenos, obras e instalaciones, material fijo y móvil, etc., por lo que fue una de las más importantes de la contabilidad del sector ferroviario, pudiendo afirmarse que "la misma representaba el inventario de los bienes que una compañía debía revertir al Estado de acuerdo a las cláusulas del contrato de concesión" (Imedio Díaz, 1934: 44).

La cuenta "Gastos de primer establecimiento" [formados por las cuentas "Gastos de constitución de la sociedad" y "Gastos de estudio y concesión"] eran anticipados por un intermediario financiero o un particular, sin que se hubieran creado las cuentas de "Acciones", "Capital" y "Caja". El registro que realizaban las ferroviarias era el siguiente: cargo de la cuenta "Gastos de constitución de la sociedad" con abono de la cuenta "Varios"; igualmente, cargo de la cuenta "Gastos de estudio y concesión" con abono de la cuenta "Varios".

Este es el origen de la distinción actual de las cuentas de constitución y de primer establecimiento, pues ellas fueron las que por primera vez en España diferenciaron ambos conceptos. Las ferroviarias españolas diferenciaban dentro de los "Gastos de primer establecimiento" dos cuentas: "Gastos de constitución" y "Gastos de estudio y Concesión".

Un aspecto fundamental para la teneduría de libros de las ferroviarias fue la diferenciación entre gastos de "primer de establecimiento" y "cuenta de explotación"

\footnotetext{
${ }^{551}$ La cuenta "Gastos de Estudio y Concesión" es denominada "Proyecto" por Oliver (1885: 42).
} 
La cuenta de "Gastos de primer establecimiento" comprende las cuentas de las líneas en explotación y las de en estudio y proyecto; se las adeuda de los gastos de adquisición de las compradas y de las cantidades invertidas en las construidas a que se refiere el capítulo de "Gastos generales", dividido en Gastos anteriores a la constitución, Administración, Personal central, Gastos de la administración central, intereses de obligaciones e Intereses varios, y el capítulo de "Gastos de construcción", que comprende: Dirección, Adquisición de terrenos y alquileres, Explanaciones, Obras de arte, materiales de vía, Balastaje y asientos de la vía, Construcción de edificios, Empalizadas, barreras y accesorios, Telégrafos, material fijo, útiles y herramientas, Material móvil y Pequeño material y muebles (Martínez Pérez, 1910: 207).

La cuenta "Gastos de primer establecimiento" no es objeto de abono salvo en el momento de terminar la concesión, cuando el Estado se incaute de la línea y de su explotación, que se acreditará del valor de las líneas, material móvil y de todos los inmuebles destinados al servicio de transportes, con adeudo a las cuentas de "Reservas especiales", o a las que correspondan los valores recibidos por el importe en que fueron enajenadas las líneas. "Es, por tanto, necesario que la administración de estas empresas cuide de que, para que cuando llegue el momento en que el estado se subrogue en los derechos de la empresa, hayan sido amortizadas las acciones y obligaciones emitidas por la compañía" (Martínez Pérez, 1910: 207).

Por su parte, la "Cuenta de Explotación” recibe en su haber los ingresos del tráfico, según las tarifas de aplicación y las especiales, clasificados en "Gran velocidad", que se divide en Viajeros, Equipajes y perros, Valores, encargos y comestibles, Coches correos en los trenes, Carruajes, ganados y transportes fúnebres, Diversos, almacenajes y repesos, y en "Pequeña velocidad", que comprende los Transportes de mercancías, Carruajes, Ganados y Varios. También se abona a esta cuenta cualquier otro ingreso fuera del tráfico que recaude. La suma de estos ingresos constituye el total del tráfico. Por el otro lado, son objeto de adeudo a la "Cuenta de Explotación", los conceptos siguientes: "Administración central y dirección", que comprende las dietas del Consejo, personal administrativo y gastos de las oficinas, "Servicios de la explotación", por los sueldos del personal afectos al servicio de tráfico y los gastos de estas oficinas, "Movimiento", que incluye los haberes del personal y los gastos de este servicio, "Material y tracción", por los haberes de los empleados de esta sección, materiales consumidos por las máquinas y conservación del material móvil, y por último, "Gastos generales", por todos los servicios y los extraordinarios y complementarios que se originen (Martínez Pérez, 1910: 207).

La suma que arrojen estos diferentes conceptos constituye el total de gastos, así que la diferencia entre el total de productos y el total de gastos representará el producto neto de la explotación, con el que se ha de atender a las cargas por intereses y amortización de las obligaciones, y los gastos que ocasionen los servicios de banca y los de vigilancia del Gobierno, que se adeudarán a la cuenta de explotación. El saldo de esta cuenta representará el producto líquido, si la suma del haber fuera mayor que la del debe, o el quebranto, en el caso contrario, que se abonará o cargará a la cuenta de "Ganancias o pérdidas" (Martínez Pérez, 1910: 208). 
Las subvenciones concedidas por el Estado para la construcción de las líneas, se adeudan a la cuenta de "Subvenciones a cobrar", con abono a la de "Subvenciones", acreditándose a la primera, como adeudo a "Caja" del importe de las subvenciones cobradas. La cuenta de "Subvenciones" no será adeudada más que del importe de la que renuncie la compañía, que se acreditará a la de "Subvenciones a cobrar" (Martínez Pérez, 1910: 208).

\subsubsection{Periodo de construcción de la línea ferroviaria}

Constituida la nueva sociedad ferroviaria y obtenida la concesión, en la siguiente fase se debía proceder a la construcción de las vías férreas.

Las obras necesarias para el establecimiento de la explotación ferroviaria eran muchas y costosas, y su realización duraba bastante tiempo. La explanación del camino donde iba a ser colocada la vía requería de cuantiosos gastos de movimientos de tierras; los obstáculos que ofrecían las montañas por donde tenían que pasar los caminos debían de ser vencidos por perforaciones; y con frecuencia debían de ser salvados los barrancos o el paso de los ríos mediante puentes. Cuando se habían explanado los caminos, se daba comienzo al tendido de la línea, a la construcción de edificios para las estaciones, a las obras de señales y enclavamientos, a los edificios para los depósitos y a las barreras para los pasos a nivel.

La construcción de las vías férreas podía abordarse desde una doble perspectiva, según que la compañía optase por el denominado criterio de "administración", es decir, si la propia sociedad la encargada de la obra de forma directa, o bien se utilizase el criterio de "destajo", en el caso de subcontratar las obras a terceras empresas. El hecho de seguir uno u otro método no afectaba de forma significativa al sistema de llevar la contabilidad. Sin embargo, el registro sí era distinto si utilizaba para ello libros auxiliares o no.

\subsection{Registro de la construcción con libros auxiliares}

Al comienzo de esta etapa era preciso la apertura de los cinco libros oficiales de la empresa (Inventarios y Balance, Diario, Mayor, Copiador de cartas y telegramas y libro de Actas), pero también de los libros auxiliares (Construcciones, Acopios, de Caja, Proveedores u Órdenes de pago), que permitan el registro de las facturas que han de ser pagadas a consecuencia de los materiales que vayan adquiriéndose.

Las cuentas que componían los libros oficiales eran susceptibles de desglose a diferentes niveles en función de los criterios establecidos por cada compañía, lo que suponía la necesidad de que existieran libros auxiliares donde constaban de forma minuciosa el detalle de las partidas totales que periódicamente se pasaban a los Libros Diario y Mayor. 
Los libros auxiliares que ofrecen mayor importancia son los de "Acopios" y "Construcciones" 552 , que permiten llevar las cuentas detalladas de los materiales que se vayan adquiriendo para ser invertidos en las construcciones.

El libro de "Acopios" se abría, o bien en forma de fichero, por artículos, o bien como libro encuadernado, destinando una hoja a cada artículo de los que se precisen adquirir, para hacer constar en él las adquisiciones y las salidas con destino a las obras y conocer en todo momento la existencia de los mismos ${ }^{553}$.

El libro de "Construcciones" se abría por las obras que se fuesen realizando, con objeto de agrupar en cada una de ellas los diferentes gastos invertidos, los cuales sumados darán el importe total de cada obra tan pronto como se terminen. Dentro de estas obras era conveniente hacer una clasificación de los gastos para facilitar después a la contabilidad central su acertada clasificación en los asientos. De Aragón (1942: 502) propone clasificar los gastos en Jornales, Materiales y Gastos Generales. El mismo autor describe un modelo de libro de Construcciones, donde puede apreciarse la manera de anotar los gastos invertidos en las distintas obras ejecutadas (ver cuadro 22).

Cuadro 22. Modelo de libro de Construcciones

\begin{tabular}{|c|c|c|c|c|c|c|c|}
\hline \multirow{2}{*}{$\begin{array}{l}\begin{array}{l}\text { Obra } \\
\text { número }\end{array} \\
\text { Fechas }\end{array}$} & \multicolumn{7}{|c|}{ CONSTRUCCIÓN DE LA VÍA } \\
\hline & Conceptos & Jornales & Materiales & $\begin{array}{l}\text { Gastos } \\
\text { generales }\end{array}$ & TOTAL & $\begin{array}{l}\text { Material } \\
\text { devuelto al } \\
\text { almacén }\end{array}$ & $\begin{array}{l}\text { Total } \\
\text { por mes }\end{array}$ \\
\hline & Sumas anteriores & & & & & & \\
\hline & $\begin{array}{l}\text { Jornales de eventuales } \\
\text { Industria de Cementos, } \\
\text { Su factura } \\
\text { Factura de La } \\
\text { Metalúrgica, por } \\
\text { viguería de hierro, } \\
\text { herramientas y útiles } \\
\text { Fuerza eléctrica }\end{array}$ & & & & & & \\
\hline & Suma hasta fin de mes & & & & & & \\
\hline
\end{tabular}

Fuente: De Aragón (1942: 503)

\footnotetext{
${ }^{552}$ Estas denominaciones de los libros han sido tomadas de De Aragón (1942: 502).

${ }^{553}$ De Aragón (1942: 502) denomina al libro de "Acopios" como "de Almacén".
} 
Establecido el registro de las obras por medio de los libros auxiliares, no era necesario realizar diariamente en el Libro Diario una relación detallada de la aplicación de los pagos que la caja realizaba por cuenta de estas construcciones. De Aragón (1942: 504) describe un asiento tipo en el libro Diario por pagos realizados en el día con cargo a las diferentes obras, según se detalla en el libro auxiliar correspondiente (ver cuadro 23).

Cuadro 23. Asiento en el libro Diario por pagos realizados en el día con cargo a las diferentes obras, según se detalla en el libro auxiliar correspondiente

\begin{tabular}{|l|l|l|}
\hline DEBE & Fecha de asiento & HABER \\
\hline & $\begin{array}{l}\text { Construcciones (por jornales) } \\
\text { Acopios (por facturas de materiales de construcción con detalle } \\
\text { en el libro auxiliar) } \\
\text { a Construcciones }\end{array}$ & \\
\hline
\end{tabular}

Fuente: De Aragón (1942: 504)

La salida de materiales que el almacén proporcione para las obras se irá anotando en los estados semanales que éste facilite a la contabilidad, o diariamente, cuando se trate de cantidades considerables. El asiento correspondiente se realizará con cargo a la cuenta de Construcciones (ver cuadro 24).

Cuadro 24. Asiento por pagos realizados en el día con cargo a las diferentes obras, según se detalla en el libro auxiliar correspondiente

\begin{tabular}{|l|l|l|}
\hline DEBE & Fecha de asiento & HABER \\
\hline & $\begin{array}{l}\text { Construcciones (por ladrillos y cementos facilitados por el } \\
\text { almacén para la realización de obras) } \\
\text { Construcciones (por herramientas facilitas por el almacén) } \\
\text { a Acopios }\end{array}$ & \\
\hline
\end{tabular}

Fuente: De Aragón (1942: 504)

Terminadas las obras, y totalizados los gastos que se han producido en cada una, se iban registrando en el Libro Diario mediante asientos con cargo a la cuenta que debían registrar el valor de la obra realizada y abono a la de Construcciones.

Estos asientos se iban registrando paulatinamente a medida que las obras se fuesen terminando, con lo cual, al final del periodo se encontrará la cuenta "Construcciones" saldada, y las que representan bienes con un saldo deudor igual al importe del valor de las obras.

Para completar todo lo anterior, De Aragón (1942: 504-506) realizó un listado de las posibles obras realizadas (diecinueve) y su manera de aplicar el importe a sus respectivas cuentas (doce). 
Las diecinueve posibles obras son las siguientes:

- Obra número 1. Estudios y trabajos técnicos.

- Obra número 2. Instrumentos

- Obra número 3. Herramientas y útiles para obras

- Obra número 4. Terraplenes

- Obra número 5. Desviación de corrientes ocasionales

- Obra número 6. Afianzamiento de taludes

- Obra número 7. Expropiación de terrenos

- Obra número 8. Pasos bajo la vía

- Obra número 9. Puentes y alcantarillas

- Obra número 10. Traviesas y vulcanización de las mismas.

- Obra número 11. Tendido de la vía

- Obra número 12. Plataformas giratorias

- Obra número 13. Locomotoras

- Obra número 14. Coches y vagones

- Obra número 15. Edificios para muelles y estaciones

- Obra número 16. Depósitos de agua

- Obra número 17. Aparatos e instalaciones telegráficas

- Obra número 18. Señales y enclavamientos

- Obra número 19. Rieles.

Existían algunas obras que debían ser comprendidas en la misma cuenta para incorporarlas mejor a las cuentas del balance. Así sucedía con las obras relativas a los "Instrumentos", "Herramientas" y "Terraplenes", "Desviación de corrientes ocasionales" y "Afianzamiento de taludes", que son en realidad trabajos ejecutados para los mismos fines y que deben ser reunidas en Terraplenes. La obra número 8 "Pasos bajo la vía", carece de una clasificación adecuada en el balance, por lo que debe ser llevada a la cuenta del balance "Material y Construcción de la vía", del mismo modo que la número 11, que se refiere a la construcción de la misma.

Por su parte, la obra número 9 "Puentes y Alcantarillas", comprende dos conceptos que en la contabilidad deben ir separados, porque permitiría conocer su valor para futuras estimaciones; para saber el importe de cada uno se puede recurrir al libro auxiliar donde se encuentraban detalles para poder realizar la separación.

La obra número 12 "Plataformas giratorias", debía ir unida a la 19 de "Rieles", por ser ésa la denominación de Material móvil, que es el título de la cuenta en el balance. Las números 15 y 16 deben reunirse en la cuenta del balance "Estaciones y Dependencias", y con ellas la número 18 por carecer de ordenación más adecuada en el balance.

Las doce cuentas que propuso el autor son: 
1. Estudios y trabajos técnicos. Sueldos, jornales, dietas y demás gastos efectuados en los trabajos de levantamientos topográficos, los cuales se hallaban representados por los proyectos y planos almacenados en los archivos de la empresa como resultados de los mismos.

2. Útiles y herramientas. Valor de las obras realizadas (comprende las obras número 2 y 3 ).

3. Obras de explanación. Valor de los trabajos realizados para la construcción del camino (incluye las obras número 4, 5 y 6).

4. Derechos de la vía y terrenos para depósitos. Indemnizaciones pagadas a los propietarios de terrenos para la construcción (recoge las obras número 7).

5. Material y construcción de la vía. Obras realizadas con motivo de la construcción de la vía (comprende las obras número 8 y 11).

6. Puentes. Valor de los puentes de hierro y hormigón construidos para el tendido de la vía.

7. Alcantarillas. Valor de las obras de alcantarillado necesarias para dar el paso a los torrentes ocasionales.

8. Traviesas. Valor de las traviesas empleadas en la construcción del camino y vulcanización de las mismas.

9. Rieles y placas de unión. Valor de los rieles y placas que componen el camino (comprende las obras número 12 y 19).

10. Material móvil. Valor del material móvil adquirido para la explotación (incluye las obras número 13 y 14).

11. Estaciones y dependencias. Valor de los edificios para estaciones y dependencias (recoge las obras número 15, 16 y 17).

12. Telégrafos. Valor de las instalaciones telegráficas (comprende las obras número 17).

Terminadas las obras se generaba un asiento contable en el Libro Diario para registrar el valor de la obra realizada y abono a la de Construcciones (ver cuadro 25). 


\section{Cuadro 25. Asiento de traspaso a sus cuentas respectivas del valor de las obras realizadas para la construcción de la vía ${ }^{55}$}

\begin{tabular}{|l|l|l|}
\hline DEBE & Fecha de asiento & HABER \\
\hline & Estudios y trabajos técnicos & \\
Útiles y herramientas & \\
Obras de explanación & \\
Derechos de la vía y terrenos para depósitos & Material y construcción de la vía & \\
& Puentes & \\
Alcantarillas & \\
& Traviesas & \\
& Rieles y placas de unión & \\
Material móvil & Estaciones y dependencias & \\
& Telégrafos & \\
& a Construcciones & \\
\hline
\end{tabular}

Fuente: De Aragón (1942: 505-506)

\subsection{Registro de la Construcción sin libros auxiliares}

Al comienzo de esta etapa se abrían de forma generalizada una serie de cuentas, que al final de la construcción se debían resumir en una única, que permitiese conocer el coste total de la línea construida. Las cuentas son: Construcción de la vía, Expropiaciones, Material fijo, Material móvil y Gastos generales (Oliver, 1885, 43).

Los principales motivos de cargo de las cuentas referidas son las siguientes:

- Construcción de la vía. En esta cuenta se cargaban los jornales y todas las partidas que afectasen al coste de la construcción de vías, tales como puentes, cunetas, desmontes, terraplenes, túneles, estaciones, casetas, cercados, pasos a nivel y servicios telegráficos. Además, también se registraban en esta partida las herramientas, útiles y otros efectos que fuesen necesarios para tal fin. La administración de las partidas relativas a esta cuenta correspondía al ingeniero jefe, quién recibía periódicamente la información pormenorizada de las cuentas de la construcción en curso, bien a través de los destajistas a los que se les había encomendado la obra, o por medio de los capataces en el caso de realizar la compañía las obras directamente, de forma que una

\footnotetext{
${ }^{554}$ Este asiento se ha realizado suponiendo que fuese una sóla la línea que la empresa pretende explotar. Cuando son varias, la contabilidad central se abre de forma que cada línea refleje en ella las operaciones de una explotación independiente. Esto motiva que se lleve una contabilidad por separado para cada línea, considerando a la principal con el establecimiento central de la compañía y obrando las demás, en sus relaciones con ella, como si se tratase de explotaciones diferentes. Este sistema requiere, por tanto, la implantación de un negociado de contabilidad para cada línea. Esta contabilidad secundaria desarrollaría el asiento de la terminación de las obras del modo análogo a la anterior, con la única variación de que la cuenta "Construcciones" se llamará en sus libros "Establecimiento Central".
} 
vez revisadas y admitidas las mismas, daba orden de expedir un certificado, en virtud del cual recibían de la dirección un libramiento contra la caja de la empresa.

- Expropiaciones. A través de esta cuenta se registraban los importes derivados de las adquisiciones de los terrenos necesarios para el desarrollo de la línea ferroviaria en construcción.

- Material fijo. Mediante esta cuenta se reflejaba el coste de los raíles, traviesas, grapones, discos, bridas, tornillos, agujas y demás elementos que formaban dicho material.

- Material móvil. En esta rúbrica se adeudaba el coste de locomotoras, ténderes, coches, vagones y demás vehículos que la compañía tenía adquiridos hasta emprender la explotación de la línea en construcción.

- Gastos generales: Esta cuenta se componía de las partidas de gastos de personal y de oficina, así como los demás que no se pudieran aplicar a alguna de las cuentas anteriores, tales como alquileres, viajes, anuncios o gastos judiciales.

Además de las cuentas mencionadas, cuando una empresa de ferrocarriles adquiría materiales para la construcción (cal, ladrillos, cimiento, etc.), con objeto de suministrarlos posteriormente a los destajistas o capataces, se debía abrir adicionalmente la cuenta "Materiales para construcción", que se cargaba por el coste de los materiales y se abonaba con el de los entregados o suministrados, saldándose en su momento con cargo a la cuenta "Construcción de la vía” (Montoya y Guzmán, 2012: 9).

Finalizado el periodo de construcción, las cuentas mencionadas se saldaban con cargo a otra llamada "Coste del camino XXXX" u otro título análogo, o bien realizando un cargo a la cuenta "Gastos de Primer Establecimiento", siendo en ese instante cuando el ingeniero jefe practicaba una liquidación general para determinar el coste de cada una de las obras emprendidas, de forma que fuera factible conocer pormenorizadamente la valoración de los elementos construidos tales como puentes, cunetas y estaciones, y que contablemente debería coincidir con el Debe de la cuenta antes mencionada (Montoya y Guzmán, 2012: 9).

\subsubsection{Financiación de la construcción}

En aquellos casos en los que la línea ferroviaria estuviera subvencionada por el Estado se debía abrir la cuenta titulada "Subvención", a la que se irían abonando las cantidades percibidas.

Por otro lado, para realizar la construcción de la vía férrea, la mayor parte de las compañías necesitaban el endeudamiento mediante la emisión de empréstitos, operación autorizada por el Código de Comercio (artículo 186), que textualmente indicaba que tales empresas podían “(...) emitir obligaciones al portador o nominativas, libremente y sin más limitaciones que las consignadas en este Código y las que establezcan en sus respectivos estatutos".

Las emisiones debían estar inscritas en el Registro Mercantil de la provincia, y si eran hipotecarias, también debían registrarse en los respectivos registros de la propiedad, 
regulándose además, que las emisiones más antiguas tenían preferencia en el pago de cupón y amortización de los títulos respecto de las más modernas.

El artículo 187 del Código de Comercio establecía que en los casos de concesiones temporales subvencionadas por el Estado, las obligaciones de la compañía ferroviaria deberían estar totalmente amortizadas dentro del plazo de la concesión, de tal forma que el Estado debía recibir la obra libre de todo gravamen al finalizar el periodo concesional.

Hasta 1924, los empréstitos se emitieron sin autorización gubernamental. Sin embargo, por medio del RD-Ley de 12 de julio de 1924, el Gobierno, ante la difícil situación que atravesaban las compañías férreas, instituyó el denominado "Nuevo Régimen Ferroviario", haciéndose cargo del coste de la construcción de nuevas líneas férreas y de la adquisición de material, con la intención de evitar una subida de tarifas inviable en aquellos momentos, estableciendo la necesidad de solicitar autorización para la emisión de obligaciones (Base $1^{\mathrm{a}}$, apdos. $3^{\circ}$ y $6^{\circ}$ ).

Desde el punto de vista de técnica contable, una vez acordada por el Consejo de Administración de la compañía la emisión del empréstito (también denominado "capitalobligaciones"), se procedía a su registro contable a través de la cuenta "Obligaciones de la emisión XXX". Los títulos podían ser emitidos a par, sobre la par y bajo la par. A diferencia de las acciones, la emisión de empréstitos podía ser suscrita parcialmente. En los casos de existencia de primas de emisión y/o reembolso, según se tratase de emisiones sobre la par o bajo la par, el tratamiento contable era similar respecto de la emisión de acciones, si bien no se precisaba el destino del saldo de la cuenta "prima de reembolso", que supuestamente debería de cancelarse con cargo a la cuenta de pérdidas y ganancias en coherencia con el tratamiento dado a la cuenta "prima de emisión", que se saldaba con un abono a la cuenta de resultados.

\subsubsection{Periodo de explotación de la concesión}

Concluido el periodo de construcción de la línea férrea y de todas sus instalaciones, así como la compra de todo el material móvil necesario para su puesta en servicio, se iniciaba la cuarta fase relativa a su explotación.

La "contabilidad central" reunía los datos suministrados por los servicios, a partir de los cuales se registraban las distintas operaciones, cuyo resumen se ponía de manifiesto a través de la "Cuenta General de la Explotación", que no incluía las denominadas "cargas de explotación", reflejando por tanto el citado estado contable los ingresos y gastos derivados exclusivamente de la explotación del negocio (Joaquín Imedio Díaz, 1934: 62).

El ciclo general contable de las compañías ferroviarias se organizaba a partir de la operatoria realizada por las estaciones, dado que era en dichos centros donde se producía la práctica totalidad de los ingresos de la empresa. 


\subsubsection{Cuentas utilizadas}

Las ferroviarias necesitaban un gran número de cuentas para organizar toda la información que necesitan, tanto para ofrecerlas a usuarios externos, como para la gestión de la propia empresa $^{555}$

En el cuadro 26 se recogen las dieciséis principales cuentas que solían intervenir específicamente en la contabilidad general de ferrocarriles.

555 Esta afirmación no es compartida por toda la doctrina, pues de Aragón (1942: 497) establece erróneamente que "las empresas de transportes no son empresas fabriles y no requiere, por tanto, el complicado sistema de cuentas que para el registro de tan diversas operaciones es necesario". 


\section{Cuadro 26. Cuentas de los ferrocarriles españoles}

\begin{tabular}{|c|c|c|}
\hline CUENTA & PERIODO & MOVIMIENTO DE LA CUENTA \\
\hline Proyecto & $\begin{array}{l}\text { Periodo de } \\
\text { concesión }\end{array}$ & $\begin{array}{l}\text { Se carga del importe de los planos, viajes, memorias y cuantos gastos ocasione la } \\
\text { concesión. En su día se saldará con la cuenta "Construcción" }\end{array}$ \\
\hline $\begin{array}{l}\text { Gastos de } \\
\text { instalación }\end{array}$ & $\begin{array}{l}\text { Periodo de } \\
\text { concesión }\end{array}$ & $\begin{array}{l}\text { Se adeuda del coste de la escritura de constitución de la compañía, tiraje y timbre de las } \\
\text { acciones, etc. Se abona cada año del tanto } \% \text { de amortización que pasa a figurar en el debe } \\
\text { de la cuenta de PPyGG }\end{array}$ \\
\hline $\begin{array}{l}\text { Construcción de la } \\
\text { vía }\end{array}$ & $\begin{array}{l}\text { Periodo de } \\
\text { construcción }\end{array}$ & $\begin{array}{l}\text { Se carga con las entidades que devengan los contratistas de las obras cuando se verifican } \\
\text { éstas por contratas, o bien del importe de los jornales y materiales invertidos, si la } \\
\text { compañía construye directamente la línea }\end{array}$ \\
\hline Expropiaciones & $\begin{array}{l}\text { Periodo de } \\
\text { construcción }\end{array}$ & $\begin{array}{l}\text { Se adeuda del importe de los terrenos que deben ocuparse abonando a las cuentas de los } \\
\text { propietarios, o bien a la de "Caja", en el caso de que se satisfaga aquel en el acto }\end{array}$ \\
\hline Material fijo & $\begin{array}{l}\text { Periodo de } \\
\text { construcción }\end{array}$ & Se carga con el coste de los raíles, traviesas, agujas, y demás que componen dicho material \\
\hline Gastos generales & $\begin{array}{l}\text { Periodo de } \\
\text { construcción }\end{array}$ & $\begin{array}{l}\text { Se adeuda de los gastos que no tienen aplicación en ninguna de las anteriores cuentas, } \\
\text { como alquileres, sueldos de los empleados de las oficinas, etc. }\end{array}$ \\
\hline $\begin{array}{l}\text { Productos de la } \\
\text { explotación }\end{array}$ & $\begin{array}{l}\text { Periodo de } \\
\text { explotación }\end{array}$ & $\begin{array}{l}\text { Se acredita del total de diario que producen las estaciones y de las cantidades que } \\
\text { corresponde percibir de otras compañías por el servicio combinado. Se adeuda de las } \\
\text { partidas que deben abonarse a las líneas con las cuales hay establecido servicio combinado }\end{array}$ \\
\hline $\begin{array}{l}\text { Gastos de la } \\
\text { explotación }\end{array}$ & $\begin{array}{l}\text { Periodo de } \\
\text { explotación }\end{array}$ & $\begin{array}{l}\text { Se carga con la suma de los gastos que ocasionan los distintos servicios que podemos } \\
\text { resumir en Administración central, movimiento, Material y tracción, y Vías y obras. } \\
\text { El detalle de dichos servicios aparecerá en los libros auxiliares }\end{array}$ \\
\hline Material móvil & $\begin{array}{l}\text { Periodo de } \\
\text { explotación }\end{array}$ & $\begin{array}{l}\text { Se adeuda del coste de las locomotoras, coches, vagones, etc., y se abona cuando se venden } \\
\text { por inservibles, o por cualquier otro motivo }\end{array}$ \\
\hline $\begin{array}{l}\text { Impuestos o canon } \\
\text { a favor del estado }\end{array}$ & $\begin{array}{l}\text { Periodo de } \\
\text { explotación }\end{array}$ & $\begin{array}{l}\text { Se abona de las cantidades a que ascienden los impuestos, según resulta de la liquidación } \\
\text { diaria del tráfico; y se adeuda cuando se satisface el importe de los mismos. }\end{array}$ \\
\hline Talleres & $\begin{array}{l}\text { Periodo de } \\
\text { explotación }\end{array}$ & $\begin{array}{l}\text { Se carga por el importe de las máquinas, utensilios, materias primas necesarias para los } \\
\text { trabajos de construcción y reparación a que se dedican. Los jefes de estas dependencias } \\
\text { presentan periódicamente sus facturas a la sección de contabilidad, la cual formula los } \\
\text { asientos abonando a la cuenta de "Talleres con cargo a Material Móvil", o los conceptos } \\
\text { que correspondan }\end{array}$ \\
\hline Almacenes & $\begin{array}{l}\text { Periodo de } \\
\text { explotación }\end{array}$ & $\begin{array}{l}\text { Se carga por el importe de los componentes para los trabajos de almacenaje. En estos } \\
\text { almacenes de material, era el jefe de suministros quién registraba en su libro auxiliar el } \\
\text { movimiento de cada uno de los almacenes de la línea. }\end{array}$ \\
\hline
\end{tabular}

Fuente: Elaboración propia con adaptación parcial de Torrents y Monner (1885: 531-532)

Para el registro contable de las operaciones derivadas de la explotación de la línea férrea, la contabilidad general distinguía las siguientes cuentas como las principales:

- Productos de la explotación.

- Gastos de la explotación.

- Cargas de la explotación. 
- Impuestos o cargas del Estado.

- Servicio combinado.

Las dos primeras rúbricas -"Productos de la explotación" y "Gastos de la explotación"recogían las principales partidas a inscribir en la "Cuenta General de Explotación" de la compañía, obteniéndose por diferencia el denominado "Producto Neto". El cociente entre gastos e ingresos recibe la denominación "coeficiente de explotación", que permitía evaluar la situación del negocio en términos relativos.

Por su parte, la rúbrica "Cargas de explotación" estaba conformada por los pagos de intereses y amortización de obligaciones, las diferencias por transacciones en moneda extranjera y la amortización del inmovilizado, entre otras. Detraído el importe de esta rúbrica del "Producto Neto" se obtenía el denominado "Producto Líquido o Excedente" que equivalía al saldo de la "Cuenta de Pérdidas y Ganancias".

Las dos últimas partidas en conjunto -"Impuestos o cargas del Estado" y "Servicio combinado"- se conocían con la denominación genérica de "Participaciones Ajenas", dado que reflejaban un pasivo exigible a favor de la Hacienda Pública y de otras compañías ferroviarias respectivamente. En éste último caso, el saldo también podía ser de naturaleza deudora según el movimiento habido en el periodo objeto de liquidación.

Además de las cuentas de gastos mencionadas, era frecuente que se abrieran otras cuentas relacionadas con la explotación del negocio ferroviario, entre las que destacan las de suministros, talleres y almacenes de la compañía.

El cuadro 27 recoge la estructura de la Cuenta General de la Explotación de acuerdo a las principales rúbricas relativas a gastos e ingresos:

Cuadro 27. Estructura de la Cuenta General de Explotación

\begin{tabular}{|l|l|}
\hline \multicolumn{2}{|c|}{} \\
\hline Gastos de explotación & Productos de explotación \\
* Administración central y Dirección & * Ingresos de tráfico: \\
* Servicios: & - Gran velocidad \\
- Servicio de material y tracción & - Pequeña velocidad \\
- Servicio de movimiento & * Ingresos varios \\
- Servicio de vía y obras & \\
- Gastos generales 556 & \\
\hline
\end{tabular}

Fuente: Montoya y Guzmán (2012: 17) con datos de Oliver (1897: 52-54)

\footnotetext{
${ }^{556}$ En esta cuenta se recogían los gastos de tipo general de todos los servicios, así como los extraordinarios o complementarios.
} 


\subsubsection{Productos de la explotación}

Los transportes que constituían el objeto de las compañías ferroviarias se dividían en dos grandes apartados (Oliver: 1885): transportes a gran velocidad y transportes a pequeña velocidad.

Los ingresos clasificados por artículos debían ser subdivididos, a su vez, en grupos de detalle, como por ejemplo, los viajeros en tarifas ordinaria o reducida, el ganado por tipos de animales (bueyes, vacas, mulas, caballos, cerdos, etc.), y especialmente las mercancías según la materia o clase de las mismas, "pudiendo llegar su clasificación hasta veinte grupos diferentes" (Joaquín Imedio Díaz, 1934, 77).

En este sentido, Joaquín Imedio Díaz (1934: 76-77) proponía la clasificación genérica por capítulos y artículos que se incluye en el cuadro 28. 
Cuadro 28. Propuesta genérica de clasificación de los ingresos de explotación de las compañías ferroviarias

\begin{tabular}{|c|c|}
\hline CAPÍTULOS & ARTÍCULOS \\
\hline Capítulo I. Viajeros & $\begin{array}{l}\text { Artículo } 1^{\circ} \text {. Primera clase } \\
\text { Artí́culo } 2^{\circ} \text {. Segunda clase } \\
\text { Artículo } 3^{\circ} \text {. Tercera clase } \\
\text { Artículo } 4^{\circ} \text {. Suplemento de lujo } \\
\text { Artículo } 5^{\circ} \text {. Billetes de andén } \\
\text { Artículo } 6^{\circ} \text {. Billetes kilométricos } \\
\text { Artí́culo } 7^{\circ} \text {. Trenes especiales } \\
\text { Artículo } 8^{\circ} \text {. Perros } \\
\text { Artículo } 9^{\circ} \text {. Equipajes } \\
\text { Artículo } 10^{\circ} \text {. Equipajes no acompañados }\end{array}$ \\
\hline Capítulo II. Gran velocidad & $\begin{array}{l}\text { Artículo } 11^{\circ} . \text { Mensajerías } \\
\text { Artículo } 12^{\circ} \text {. Ganados } \\
\text { Artí́culo } 13^{\circ} \text {. Metálico y valores } \\
\text { Artículo } 14^{\circ} \text {. Paquetes postales } \\
\text { Artículo } 15^{\circ} \text {. Encargos } \\
\text { Artículo } 16^{\circ} \text {. Carruajes } \\
\text { Artículo } 17^{\circ} \text {. Transportes fúnebres } \\
\text { Artículo } 18^{\circ} \text {. Estadías y almacenajes } \\
\text { Artí́culo } 19^{\circ} \text {. Repesos y precintos } \\
\text { Artículo } 20^{\circ} \text {. Varios }\end{array}$ \\
\hline Capítulo III. Pequeña velocidad & $\begin{array}{l}\text { Artículo } 21^{\circ} \text {. Mercancías } \\
\text { Artículo } 22^{\circ} \text {. Carruajes } \\
\text { Artículo } 23^{\circ} \text {. Ganados } \\
\text { Artículo } 24^{\circ} \text {. Material rodante extraño } \\
\text { Artículo } 25^{\circ} \text {. Estadías y almacenajes } \\
\text { Artículo } 26^{\circ} \text {. Repesos y precintos } \\
\text { Artículo } 27^{\circ} \text {. Varios }\end{array}$ \\
\hline Capítulo IV. Anejos al tráfico & $\begin{array}{l}\text { Artí́culo } 28^{\circ} \text {. Peajes } \\
\text { Artículo } 29^{\circ} \text {. Alquiler de todos } \\
\text { Artículo } 30^{\circ} \text {. Desinfectación } \\
\text { Artículo } 31^{\circ} \text {. Maniobras } \\
\text { Artículo } 32^{\circ} \text {. Reparación de embalajes } \\
\text { Artículo } 33^{\circ} \text {. Custodia } \\
\text { Artículo } 34^{\circ} \text {. Consigna y almohadas }\end{array}$ \\
\hline Capítulo V. Diversos & $\begin{array}{l}\text { Artículo } 35^{\circ} \text {. Fondas y cantinas } \\
\text { Artículo } 36^{\circ} \text {. Transportes en servicios } \\
\text { Artículo } 37^{\circ} \text {. Arrendamiento de terrenos } \\
\text { Artículo } 38^{\circ} \text {. Cambio de material } \\
\text { Artículo } 39^{\circ} \text {. Telégrafo } \\
\text { Artículo } 40^{\circ} \text {. Coches-cama } \\
\text { Artículo } 41^{\circ} \text {. Publicidad } \\
\text { Artículo } 42^{\circ} \text {. Bibliotecas } \\
\text { Artículo } 43^{\circ} \text {. Venta de materiales y sobrantes } \\
\text { Artículo } 44^{\circ} \text {. Varios }\end{array}$ \\
\hline
\end{tabular}

Fuente: Joaquín Imedio Díaz (1934: 76-77) 
Los productos de una línea ferroviaria estaban conformados por los resultados diarios que proporcionaban las estaciones y el servicio combinado, en el supuesto de que la línea tuviera enlace con otra perteneciente a otra compañía. No obstante, además de los ingresos del tráfico, existían otros de carácter "especial", que no se contabilizaban a través del Servicio de Intervención, sino directamente por la Contabilidad Central, y que podían ser de tipo recurrente o bien tener un carácter de interinidad a lo largo del ejercicio, distinguiéndose tres tipos, tal como se muestra en el cuadro 29.

\section{Cuadro 29. Tipología de ingresos de carácter especial}

\begin{tabular}{|l|l|}
\hline Relacionados con la Hacienda Pública & - Premio de cobranza \\
& - Transporte de correo \\
& - Transporte del Estado \\
\hline Ayuda del Estado & - Patra de seguro \\
& - Reservas \\
& - Anticipos \\
\hline Procedentes de Transacciones & - Subvenciones \\
& - Senta y alquiler de terrenos \\
& - Alquiler de material móvil \\
& - Intereses de cuentas y depósitos \\
\hline
\end{tabular}

Fuente: Joaquín Imedio Díaz $(1934,78)$

Entre los ingresos relacionados con la Hacienda Pública, el premio de cobranza era concedido por la Hacienda a las compañías como compensación a la recaudación de impuestos, timbres y seguro obligatorio. Por su parte, las cuotas de seguro correspondían al concierto relativo a la pensión y accidentes del personal.

Los ingresos por ayuda del Estado derivaban de las subvenciones y anticipos, así como del patrimonio privado poseído por algunas de las empresas.

Los ingresos procedentes por transacciones se nutrían de los derivados de operaciones por alquileres o ventas, así como por la colocación en entidades financieras de excesos de tesorería para evitar su improductividad.

En cuanto al cobro de los servicios en las estaciones, tanto en su servicio local como en el combinado si existía, éstos se percibían generalmente al contado por la parte correspondiente a gran velocidad, pero sin embargo, en los servicios de transporte de mercancías a pequeña velocidad, el expedidor podía pagarlas a la salida o a la llegada, y aún en el primer caso, no siempre efectuaba el pago en el momento ni en el día de su entrega en la estación de embarque. En este sentido, los portes no cobrados en el día en la estación de salida y los que tenían que recaudarse a la llegada de la mercancía a otra estación, se debían atribuir a aquella en donde había tenido lugar su embarque e imputarse a resultados de esa fecha, lo que venía a 
complicar de forma importante el proceso contable de la recaudación por transportes a pequeña velocidad.

Además, cuando como consecuencia del servicio combinado, una mercancía pasaba de una línea férrea a otra distinta, aunque los portes se hubieren cobrado a la salida y en el acto en la estación de embarque, ésta no debía considerarlos como productos obtenidos en la fecha de recepción de la mercancía, ya que esta compañía quedaba a deber de aquellos portes cobrados la cantidad que correspondía a la otra empresa con la que compartía la combinación.

Las diferentes estaciones que conformaban la línea llevaban la contabilidad en la forma prescrita por cada compañía, formulando determinados estados contables que debían informar de los productos del tráfico, y que junto con sus comprobantes y demás documentos pasaban diariamente de las estaciones a las oficinas centrales de intervención y estadística, para que después de comprobados y realizadas, en su caso, las rectificaciones pertinentes, se pudiera determinar el importe total de los ingresos de la explotación obtenidos. En este sentido, el jefe de contabilidad formulaba otro estado llamado "Liquidación de los productos del trafico del día XX”, que pasaba después al tenedor de libros para que este registrara de forma global el importe de los ingresos diarios de la explotación del negocio ferroviario.

A título de ejemplo se incluye a continuación las minuciosas instrucciones que el "Reglamento de Contabilidad de las Estaciones de la Compañía del Ferrocarril de Zaragoza a Pamplona de 1860" recogía para la confección del "Resumen de operaciones del día". El artículo 202 del citado Reglamento recoge: "Las Estaciones establecen diariamente el libro titulado Resumen de las operaciones, modelo E. núm. 17, y la hoja extracto del mismo libro, que se remite todos los días a la Intervención" 557 .

\subsubsection{Gastos de la explotación}

Bajo la rúbrica de gastos de la explotación se registran periódicamente el total de gastos derivados de los principales servicios ferroviarios, cuyo detalle solía llevarse por medio de libros auxiliares, si bien cada uno de tales servicios generalmente se subdividía en otros tantos, tal como se muestra en el cuadro 30, lo que implicaba la existencias de otros libros auxiliares adicionales, que no eran llevados por la oficina de intervención y estadística, sino por el tenedor de libros encargado de la contabilidad central, teniendo cada servicio -y hasta cada subdivisión- su propia contabilidad y documentación peculiar y diferenciada de las demás, con arreglo a los modelos adoptados por cada compañía.

${ }^{557} \mathrm{El}$ artículo 203 establece que este resumen se forma del modo siguiente:

- "En la casilla núm. 2 figurarán en su renglón especial todos los productos cobrados por la Estación en el día de la fecha.

- En el renglón del viajeros.- El total del libro, modelo E, núm. $3^{\circ}$, casilla 24, renglón Totales.

- Pases de Familia.- El total del estado, modelo E, núm. 18.

- Suplementos.- El total del estado, modelo E., núm. 5.

- Equipajes.- La suma de la casilla núm. 8 del estado modelo E, núm. 9.

- Perros.- La suma de la casilla 9 del estado, modelo E, núm. 9.” 
Generalmente los gastos de explotación se cargaban cada mes en virtud de estados que comprendían las nóminas, facturas o gastos formados separadamente por cada servicio, sin perjuicio de que durante dicho periodo se adquirieran ciertas materias necesarias para la explotación, que inmediatamente se cargaban a la cuenta de gastos correspondiente.

\section{Cuadro 30. Principales Servicios o Centros de Coste de las Compañías Ferroviarias}

\begin{tabular}{|c|c|}
\hline $\begin{array}{l}\text { Administración Central y } \\
\text { Dirección }\end{array}$ & 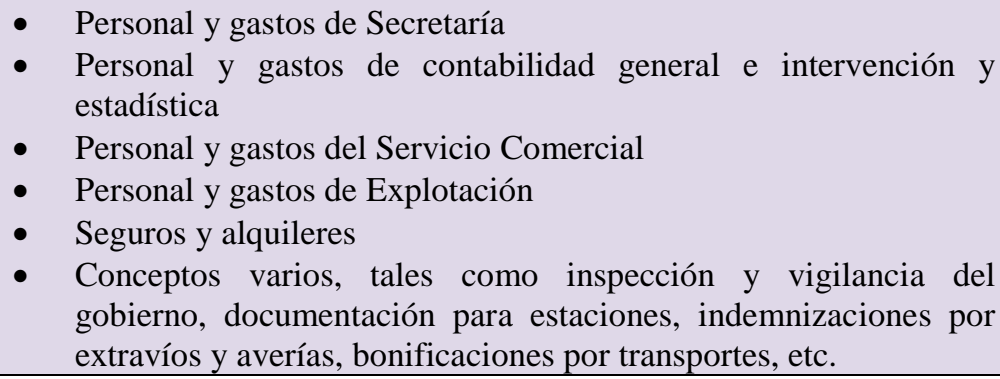 \\
\hline Servicio de Movimiento & $\begin{array}{l}\text { - } \quad \text { Personal y gastos de oficinas } \\
\text { - } \quad \text { Personal y gastos de estaciones } \\
\text { - } \quad \text { Personal y gastos de trenes } \\
\text { - } \quad \text { Personal y gastos de telégrafo }\end{array}$ \\
\hline Servicio de Material y Tracción & $\begin{array}{l}\text { - Personal y gastos de oficinas } \\
\text { - } \text { Combustibles de tracción, grasas, etc. } \\
\text { - } \quad \text { Reparación de locomotoras y ténderes } \\
\text { - } \quad \text { Reparación de coches y vagones } \\
\end{array}$ \\
\hline Servicio de vía y obras & $\begin{array}{l}\text { - } \quad \text { Personal y gastos de oficina. } \\
\text { - Personal y gastos de vigilancia de la vía } \\
\text { - } \quad \text { Personal, material y efectos para la conservación de la vía } \\
\text { - } \quad \text { Personal y gastos de obras de tierra } \\
\text { - } \quad \text { Personal y gastos de obras de arte } \\
\text { - } \quad \text { Personal y gastos de conservación de edificios }\end{array}$ \\
\hline
\end{tabular}

Fuente: Montoya y Guzmán (2012: 22) a partir de Oliver (1897)

\subsubsection{Cargas de la explotación}

Además de los gastos de explotación del negocio ferroviario, que debían figurar dentro de la "Cuenta General de la Explotación", las compañías ferroviarias cargaban separadamente al saldo del Producto neto otras partidas que no obedecían en sentido estricto a la explotación, aunque sí incidían de forma directa en el resultado del ejercicio.

En este sentido, dentro de esta rúbrica se incluían los intereses procedentes de empréstitos así como el importe de las obligaciones amortizadas, las diferencias de cambio por operaciones en moneda extranjera y la amortización del material fijo y móvil. Desde una concepción actual de la contabilidad, el resultado de la explotación quedaba desvirtuado al no considerar, por ejemplo, como gastos afectos a la misma los correspondientes a las amortizaciones del material, siendo también discutible la presentación contable de los empréstitos amortizados. 


\subsubsection{Impuestos o cargas del Estado}

La oficina de intervención y estadística determinaba el importe total de los impuestos a través del estado diario de la liquidación general del tráfico, para que el tenedor de libros los abonara en una sola partida en esta cuenta, realizándose un pago mensual con cargo a la misma en virtud de un estado que se presentaba con sujeción a lo previsto en el Reglamento definitivo para la administración y cobranza del impuesto transitorio sobre el precio según tarifa de los billetes de viajeros y de los derechos de registro sobre los transportes marítimos y terrestres que estableció la Ley del presupuesto de ingresos de 1872-73 (Oliver, 1885: 53).

\subsubsection{Servicio combinado}

De acuerdo con el movimiento ferroviario diario, la oficina de intervención y estadística determinaba la cuantía que cada día había que cargar y abonar a esta cuenta, plasmando el resultado total en el estado general diario de contabilidad o liquidación general del tráfico diario, que posteriormente era reproducido por el tenedor de libros a través de los correspondientes asientos en los Libros Diario y Mayor.

Las cantidades pendientes de liquidación por servicios combinados solían liquidarse cada diez días, siendo la compañía que explotaba mayor número de kilómetros la que dirigía a la que explotaba menos kilometraje un estado de liquidación demostrativo del saldo líquido que resultaba a su favor o en su contra, el cual pasaba a la sección especial que tenía la intervención y estadística para el servicio combinado, siendo dicha sección la encargada de liquidar diariamente el resultado del tráfico de cada una de las estaciones de la línea. Además, dicha oficina liquidadora tenía la responsabilidad de revisar el estado decenal comentado, y hallándolo conforme, el tenedor de libros cargaba o abonaba entonces el saldo resultante a la cuenta de servicio combinado, con abono o cargo a la compañía combinada que había presentado la liquidación que motivaba el asiento.

El asiento contable que se generaba en el Diario por el tráfico ferroviario del día anterior (o de un determinado periodo de tiempo concreto) tenía la estructura de cuentas que recoge el cuadro 31 .

\section{Cuadro 31. Asiento diario resumen del tráfico ferroviario}

\begin{tabular}{|l|ll|l|}
\hline DEBE & Fecha de asiento & HABER \\
\hline & Caja (1) & \\
Servicio combinado (2) & \\
Diversos por tráfico (3) & $\begin{array}{l}\text { a Producto de explotación (4) } \\
\text { a Impuestos o cargas al Estado (5) } \\
\text { a Servicio combinado (2) } \\
\text { a Diversos por tráfico (3) }\end{array}$ & \\
& \multicolumn{2}{|c|}{} & \\
& & \\
\hline
\end{tabular}

Fuente: Montoya y Guzmán (2012: 24) a partir de Oliver (1885) 
En el asiento anterior, los movimientos de las cuentas reseñadas atendían a los siguientes conceptos:

(1) Caja: remesas de efectivo realizadas por las estaciones.

(2) Servicio combinado: por el saldo resultante de la liquidación.

(3) Diversos por tráfico: por el saldo resultante de la liquidación.

(4) Productos de explotación: por los reflejados en estado de liquidación general del tráfico (diario o por el periodo seleccionado).

(5) Impuestos o cargas del Estado: por los resultantes de acuerdo al Estado de liquidación general del tráfico.

La cuenta "Diversos por tráfico" era una cuenta colectiva, que generalmente recibía para un mismo periodo cargos y abonos procedentes de las liquidaciones de las diferentes estaciones, por lo que llegado el momento de la liquidación decenal del Servicio Combinado, el estado general de liquidación reflejaba el saldo a favor o en contra de dicho servicio, que a su vez modificaba el de la liquidación practicada por Servicio Combinado ${ }^{558}$.

\subsubsection{Suministros}

Los efectos y materias primas necesarias para el adecuado funcionamiento de los distintos servicios de la compañía se solían registrar a través de la cuenta "Suministros", que a su vez era susceptible de otras subdivisiones para reflejar el movimiento de conceptos tales como billetes, carbón, combustibles, accesorios, grasas, materias textiles, etc.

En la fecha de adquisición de dichos efectos, provisionalmente se cargaban las facturas a "Suministros" con abono a "Caja" o al proveedor correspondiente, y posteriormente, en el momento de la salida de los mismos con destino a los diferentes servicios que componían los gastos de explotación, se acreditaba la citada cuenta en el importe correspondiente, practicándose generalmente un asiento con periodicidad mensual, según un estado general que se formulaba de las salidas de los efectos con el detalle de los servicios a los que afectaban.

\subsubsection{Talleres}

Para la construcción y reparación del material, en muchos casos las compañías disponían de talleres, en cuyo caso abrían una cuenta general con tal denominación, sin perjuicio de que cada taller llevaba por separado los libros auxiliares necesarios para registrar su propia contabilidad, cargando a dicha cuenta el importe de las maquinas, utensilios, materias primas y demás materiales necesarios para los trabajos a que se dedicaban, siendo los propios talleres los que periódicamente y siempre que era necesario, presentaban sus facturas a la sección de contabilidad general, intervención y estadística, secciones que una vez conformada la citada documentación,

\footnotetext{
${ }^{558}$ Oliver (1885: 55-58) muestra ejemplos de documentación relativa al control contable que se llevaba sobre las operaciones de servicio combinado. En concreto, incluye la documentación utilizada para el Estado de Liquidación de los productos del tráfico diario de la Compañía de los Ferrocarriles de Tarragona a Barcelona y Francia (Cuadro 6: paneles A, B, C y D), en el que se puede apreciar el detalle de los conceptos de débito y crédito de acuerdo a los comentarios anteriores.
} 
formulaban los oportunos asientos abonando a la cuenta "Talleres" los importes respectivos con cargo a los conceptos correspondientes.

$\mathrm{Al}$ respecto, la Compañía MZA, en el artículo 43 del "Reglamento Provisional para los servicios de la Red Antigua", de fecha 30 de noviembre de 1908, regulaba la contabilidad de los talleres, definiendo los existentes, así como los conceptos de gastos que podían generarse, que se dividían en: i) gastos generales, tales como combustibles, vigilancia, etc.; ii) consumo de materiales de los trabajos que se realizaban en las diferentes dependencias de los talleres, y iii) gastos de mano de obra directa por la intervención de los operarios contratados para realizar las tareas correspondientes. Para una mejor organización de los talleres, las tareas se documentaban en un modelo de documento para cada operación de trabajo, a partir de una clasificación específica de cada gasto que atendía a cuatro dígitos: la primera cifra indicaba el taller acreedor, las segunda cifra la entidad deudora, la tercera cifra la cuenta especial de pertenencia, y la cuarta cifra el orden de pedido en la que estaba referenciado el gasto (Villacorta y Martínez Vara: 2009).

\subsubsection{Almacenes}

En las líneas de gran recorrido, existían varios almacenes de material en distintos puntos geográficos. En estos almacenes de material, era el jefe de suministros quién registraba en su libro auxiliar el movimiento de cada uno de los almacenes de la línea, por lo que de forma general cada servicio de suministros llevaba su numeración particular.

Como en el caso de los talleres, desde el punto de vista contable la compañía MZA hacía una regulación expresa de sus movimientos de entrada y salida. Fue regulada en el artículo 45 del Reglamento Provisional para los servicios de la Red Antigua, de 30 de noviembre de 1908, en el que se manifestaba que la finalidad de todos los almacenes era mantener en perfectas condiciones el stock de todos los materiales, repuestos y objetos utilizados en el resto de servicios de la compañía, y que por diferentes motivos no se encuentran disponibles para ser adquiridos fuera de sus dependencias debido a la especificidad de los mismos por estar destinado al negocio ferroviario, además de resultar bastante menos costoso su adquisición en grandes cantidades. A efectos de gestión contable, como en los talleres, se utilizaba un código de cuatro cifras con el siguiente significado: la primera cifra estaba referida al almacén acreedor, la segunda cifra al servicio deudor, la tercera cifra al concepto de gasto y la cuarta cifra a la clase de efecto (Fidalgo y Miranda, 2006).

\subsection{Informes Anuales de las compañías ferroviarias}

El presente apartado analiza el contenido de los Informes Anuales de las compañías ferroviarias, indicando los distintos cambios acontecidos en su estructura y contenido. La información contenida en dichos balances y cuentas de resultados no ha sufrido grandes cambios hasta la participación del Estado en las compañías ferroviarias bien a través de anticipos o de la Caja Ferroviaria, momento a partir del cual la cantidad y calidad de la información ofrecida por las compañías aumentó para dar reflejo de dicha situación. 
Los Informes Anuales de las ferroviarias, al igual que los de cualquier compañía, eran documentos a través de los cuales los administradores rendían cuentas anualmente a los accionistas, representados en las asambleas generales ordinarias. Los datos contables aparecen, generalmente, resumidos en el Balance de situación de la compañía y en la Cuenta de explotación donde se incluían los ingresos y gastos del periodo. En algunos casos, además, podían recoger con mayor o menor detalle determinados datos estadísticos, normalmente relacionados con el tráfico. No sólo contenían información de tipo contable porque abundaban datos relativos al estado financiero de la sociedad, donde se exponía la situación de la sociedad a lo largo del ejercicio económico, con especial atención a los datos referidos a la explotación de las líneas y del tráfico, así como a los gastos incurridos para la construcción o reforma de sus instalaciones. Toda la información era comentada y valorada a través de diferentes apartados en los que quedaba justificada la actuación de sus gestores y la toma de decisiones ${ }^{559}$.

Estos contenidos resultan habituales (Sanz: 2000) en los Estados Financieros e Informes de Gestión que componen hoy en día la información financiera que obliga en la actualidad la Ley de Sociedades de Capital. En realidad, la documentación contemporánea no difiere en gran medida de cómo se confeccionaban los Estados Financieros a mediados del siglo XIX, en plena efervescencia capitalista, y de cuáles eran los contenidos e informaciones que se reproducían en estos documentos.

Las compañías ferroviarias de la época, como todas las empresas en la actualidad, elaboraban un Informe Anual a través de la cual el Consejo de Administración informaba a los accionistas de la marcha del negocio. Sin embargo, en la actualidad la información se suministra por imperativo legal, mientras que en el caso que en la época de las ferroviarias privadas, el Informe Anual se elaboraba únicamente para sus accionistas y sin la obligatoriedad actual.

La realización del Informe Anual no tuvo una regulación explícita hasta el PGC de 1973. Hasta ese momento, la documentación tenía un "carácter casero" (Palencia-Lefler: 2008). Sólo a partir de la promulgación de las leyes sobre sociedad anónimas y de comercio se generalizó su uso y se produjo una normalización de su contenido.

En el caso de los ferrocarriles, su regulación se establecía a cuatro niveles: en primer lugar, el código de comercio en vigor (1829 y 1885); en segundo término, la aplicación de lo regulado en las leyes sobre el régimen jurídico de las sociedades anónimas (1848 y 1856); a continuación, las referencias normativas de las leyes de ferrocarriles (1844, 1855 y 1877); y por último, los estatutos y el resto de reglas y documentos que aprobaban y actualizaban las propias compañías ferroviarias.

La legislación mercantil regulaba la inscripción de la sociedad anónima mediante una escritura de constitución, validada ante un notario, donde se articulaban unos estatutos que

\footnotetext{
${ }^{559}$ El valor de los Informes Anuales como instrumento justificativo de la toma de decisiones de la compañías ferroviarias españolas, y de la actuación de sus gestores, fue analizado por Blasco et al. (2015: 3).
} 
debían someterse a la aprobación del Gobierno y ser publicados en la Gaceta de Madrid, donde debían figurar los datos básicos, razón social y socios fundadores (Ley de sociedades de 1856: artículo 9; Gaceta de Madrid: 29 de enero de 1856).

Los estatutos de las empresas ferroviarias eran los documentos que principalmente regulaban su funcionamiento interior. En la mayoría de las sociedades, no se producían grandes variaciones tras la aprobación inicial en el momento de la constitución. Sólo en algunos casos, se variaron ligeramente los fines de la sociedad o se hicieron modificaciones en su capital social y accionariado (Blasco et al., 2015. 4). Por el contrario, sí fueron significativos los cambios derivados de las reformas políticas de la década de 1920 con la creación del Estatuto Ferroviario, lo que provocó muchas nuevas ediciones de estatutos de estas compañías.

Los estatutos de las compañías ferroviarias se parecían mucho los unos a los otros ya que respondían al modelo que se había copiado de otras sociedades anónimas extranjeras, fundamentalmente francesas. Normalmente en su Título V, los estatutos recogían artículos que regulaban la rendición de cuentas, obligando la presentación anual de cuentas y balances a los accionistas.

Desde el primer momento, los Informes Anuales constituían un documento clave para la difusión del prestigio de la empresa, de ahí que fuera especialmente importante el modo de transmitir la información, ya que podía desalentar a nuevos inversores o difundir incertidumbre entre los existentes ${ }^{560}$.

Quizá por eso, los Informes Anuales comenzaron a consolidar un formulismo o coletilla que hacía mención al carácter imperativo que originaba estos documentos. Las dos compañías ferroviarias españolas más importantes -MZA y NORTE- comenzaron a incluir este formulismo en la década de 1880, cuando ambas utilizaban en el arranque de sus Informes Anuales la frase "Según nuestros estatutos...". Esta entradilla se generalizó al comenzar el siglo XX, cuando prácticamente todas las compañías ferroviarias españolas incluían lo siguiente: “(...) según establecen nuestros estatutos en su artículo... el Consejo de Administración tiene la honra de someter a vuestra aprobación las cuentas y Balance correspondiente al ejercicio (...)".

Posteriormente, tras la incorporación a la referencia de los Estatutos, se comenzó a incluir que la información contable tenía como principales destinatarios a los accionistas. Alguna invocación a los socios fue singular como la realizada por la Compañía del Ferrocarril de Alcantarilla a Lorca, que iniciaba sus Informes Anuales del siguiente modo: "Gratísima satisfacción nos procura el deber de reunirnos por precepto estatutario en Junta General, para daros cuenta del pasado ejercicio y someter a vuestra deliberación y acuerdo la gestión de este Consejo y el Balance cerrado el 31 de diciembre último".

\footnotetext{
${ }^{560}$ Esto es observado por Gabás (1990) y Palencia-Lefler (2008).
} 
Junto a estas fórmulas se incorporó durante mucho tiempo la referencia de que la convocatoria había sido publicada en los medios oficiales habituales, como la Gaceta de Madrid o el Journal officiel de République Française, dada la mayoritaria presencia de inversores galos en algunas compañías, y la existencia de comités propios en París.

En esa búsqueda de transmitir prestigio y seguridad, encontramos algunos casos, como el de The Great Southern of Spain Railway (que explotaba en el sureste español una red de $168 \mathrm{~km}$ de Lorca a Baza y al puerto de Águilas) que utilizó durante muchos años como presentación la siguiente frase, que reflejaba la inclusión de la firma de los auditores para respaldar la veracidad de las cuentas: "El Consejo de Administración presenta las cuentas debidamente visadas, correspondientes al año que terminó en 31 de diciembre..." Esta afirmación quedaba corroborada en el propio Informe Anual con la firma de los auditores. La incorporación de la firma de los auditores no respondía a una obligación de las normas de la legislación británica sobre todo porque no estaba obligada a responder de ella- pero sí a justificar su inversión ante los accionistas y obligacionistas de las islas, de donde procedía la casi totalidad de sus inversores.

La mayoría de las empresas dividían los Informes Anuales en tres grandes apartados: a) notas introductorias, b) documentos justificativos contables y estadísticos, y c) acuerdos aprobados por la junta ${ }^{561}$.

La separación de los contenidos en estos apartados se mantuvo en los documentos elaborados por prácticamente todas las compañías ferroviarias privadas que operaron en España, si bien los contenidos en cada uno de estos apartados muestran diferencias entre las distintas empresas estudiadas.

El apartado "notas introductorias" estuvo presente en todas las compañías consultadas. En realidad es un apartado sin título, que inicia, tras la consabida entradilla, una explicación de los acontecimientos económicos y sociales de la empresa, incidiendo también de manera notable en el contexto histórico y político que afectaba a la explotación ferroviaria. A principios del siglo XX comenzaron a introducirse índices de contenidos para orientar en la lectura a los accionistas. Algunos Informes Anuales sobrepasaban el medio centenar de páginas.

Tras la presentación, se desarrollaba toda una variedad de contenidos contables y estadísticos que fue cambiando con el paso de los años. En algunas situaciones, los contenidos se eliminaron, como fue el caso del detalle de la construcción de la vía, propia de los primeros años y de la fase expansiva, y en otros se ampliaron, como descripción de la evolución del material móvil, y las relaciones con el Estado a través de las partidas registradas a cargo de anticipos y similares. También era frecuente la descripción y análisis de hechos contenciosos

\footnotetext{
561 Santos, Fidalgo y Santos (2012) ya dividieron la confección de los Informes Anuales en tres grandes apartados: a) notas introductorias, b) documentos justificativos contables y estadísticos, y c) acuerdos aprobados por la junta.
} 
relevantes en los que se vió inmersa la empresa o las políticas previsión y beneficencia que tuvo lugar.

El mayor despliegue de información se producía para explicar la evolución de los tráficos, con todo tipo de detalles, tanto en lo concerniente al volumen e ingresos, como a los gastos derivados de dicha explotación. Esta información cobró especial desarrollo con el inicio de la crisis del carbón ocasionada por la Primera Guerra Mundial, que paralizó los fletes y elevó los precios considerablemente. El caudal informativo era tal que algunas compañías optaron por publicar de forma separada sus series estadísticas ${ }^{562}$.

En tercer lugar, era coincidencia habitual en todos los Informes Anuales el registro de los acuerdos tomados por parte de la junta general que afectaba tanto a la renovación o no de los cargos de consejeros, la toma de decisiones sobre las estrategias del negocio, el establecimiento del reparto del dividendo en su caso para los accionistas y la aprobación de las cuentas de la sociedad. En estas resoluciones se puede seguir la evolución de importantes personajes políticos y empresariales que prestaron servicios en la empresa, a través de las referencias a sus nombramientos, ceses e incluso fallecimiento.

Blasco et al. (2015: 6-7) analizaron el contenido de los Informes Anuales de las compañías ferroviarias en dos periodos: 1875-1923, y 1925 en adelante.

Todos los Informes Anuales tenían muchos puntos en común, no obstante, cada compañía elaboraba su información para la difusión a los accionistas según sus propios intereses. A pesar de que los apartados para cada empresa eran distintos, a continuación se sintetizan los puntos frecuentemente utilizados por la generalidad de las sociedades.

1) Variaciones y sus causas de las diferentes magnitudes de ingresos y gastos, así como un análisis de la situación general del balance de la compañía y otros comentarios sobre cuestiones tales como la explotación de las minas de su propiedad, las instituciones de previsión y beneficencia, el canje y adhesión de acciones y obligaciones, los impuestos ingresados en el Tesoro y los beneficios obtenidos por el Estado, la liquidación del ejercicio, etc.

2) "Resoluciones de la Junta General".

3) Anejos de contabilidad y datos estadísticos, que incluía generalmente:

- El "Balance", donde se detallaba la situación de la compañía al cierre del ejercicio, sería similar al Balance de Situación que hoy día se incluye en las Cuentas Anuales. En él se mostraba -de forma agregada para toda la compañía- su estructura económico-financiera, detallando la primera en una hoja denominada Activo, y la segunda en otra llamada Pasivo.

- En las "Cuentas de Explotación" -agrupadas para el total de la compañía- aparecían los ingresos y gastos del ejercicio clasificados como de explotación. La información se mostraba en formato de cuenta, es decir en una hoja los Gastos y en otra los Ingresos. Sería un estado

\footnotetext{
562 Andaluces publicó series estadísticas propias fuera de sus Informes Anuales (véase Cuéllar y Sánchez Picón: 2008). MZA no publicó series estadísticas separadas. El conjunto estadístico histórico más importante es el de NORTE, el cual ha contado con algunos estudios de análisis importantes (véase Gómez Mendoza (1984; 1985).
} 
similar a la actual Cuenta de Pérdidas y Ganancias, pero únicamente hasta el resultado de explotación, ya que los "Gastos Financieros", "Impuestos" y otros no incluidos en esta "Cuenta de Explotación" se incluían dentro de la información referida a "Cargas de Explotación". Por tanto, el Resultado del Ejercicio se compondría únicamente por la información suministrada en la "Cuenta de Explotación" y en las "Cargas de explotación".

- En los "Gastos de Establecimiento" se mostraban los gastos de establecimiento desde la creación de la compañía hasta la fecha de cierre del ejercicio, por "línea y capitulo".

- Los "Resultados por líneas de la explotación" mostraban el resultado por "línea" indicando un mayor detalle para los ingresos.

- Otros cuadros como:

- Resultados comparativos de la explotación.

- Estadística de proyectos de primer establecimiento (aportaciones de la Caja Ferroviaria).

- Cuadro determinativo de la parte proporcional del Estado en el Capital de Establecimiento desde 1925.

4) Por último se incluían "Datos referidos al tráfico", donde se insertaba información relativa al tráfico. Dentro de ellas las más significativas son las estadísticas de los trenes-kilómetro y toneladas-kilómetro sobre toda la red ${ }^{563}$.

El mayor paso dado por el sector ferroviario en el periodo 1900-1923 era que existía el convencimiento generalizado de que en el documento, que actualmente denominamos Estados Financieros, deben incluirse al menos dos estados: balance y cuenta de pérdidas y ganancias, apareciendo esta terminología en algunas ocasiones. No obstante, la denominación no era consensuada, tanto en los documentos, como en el propio nombre del estado. Por ejemplo, De Aragón (1942: 500) denominaba "Balance" al documento que incluye tanto a "Explotación" (cuenta de pérdidas y ganancias actual) como a "Valores" (balance actual) ${ }^{564}$.

\subsubsection{El balance general de las compañías ferroviarias}

Los balances y la restante información financiera se redactaba por años naturales, imprimiéndose para ser entregada a los accionistas de la compañía y al público en general, siendo preceptivo, además, la publicación de dicho estado contable en la Gaceta de Madrid por tratarse de sociedades anónimas, de acuerdo a lo preceptuado en el artículo 157 del Código de Comercio de 1885.

Debido a la importancia a nivel informativo de este estado financiero, en el Código de Comercio de 1885 se exigía a todos los comerciantes la confección de un balance general al final de cada año. Aunque unos años antes, el Proyecto para la reforma del Código de Comercio de 1829 , publicado en 1882, recogía ya la enumeración definitiva de los libros de

\footnotetext{
${ }^{563}$ Boag (1923) se deshizo en elogios hacia los Informes Anuales de las empresas españolas del periodo 19001923.

${ }^{564}$ De Aragón (1942: 498) considera como fundamental para dividir el balance, utilizar una clasificación de las cuentas en: cuentas de explotación y cuentas de valores, pero no sólo para las ferroviarias, sino para todos los negocios industriales.
} 
contabilidad que necesariamente debía llevar el comerciante: Inventarios y Balances, Diario y Mayor.

El artículo 37 del Código de Comercio de 1885 establecía que el Libro de Inventarios y Balances debía iniciarse con el inventario del comerciante al comienzo de sus operaciones, conteniendo la relación exacta del dinero, valores, créditos, efectos al cobro, bienes muebles e inmuebles, mercaderías y efectos de todas clases, apreciados en su valor real y que constituían su Activo. Además, en el mismo debía inscribirse la relación exacta de sus deudas y toda clase de obligaciones pendientes, que formaban su Pasivo. Por tanto, se fijaba como Capital con el que iniciaba sus operaciones, la diferencia exacta entre el Activo y el Pasivo. Posteriormente y de forma anual, el comerciante debía extender en el mismo libro el balance general de los negocios, con los pormenores antes indicados, y de acuerdo con los asientos procedentes del Libro Diario, sin reserva ni omisión alguna, bajo su firma y responsabilidad.

Este documento era preceptivo para cualquier comerciante bajo la denominación de "Balance general de los negocios", de acuerdo al contenido de artículo 37 del Código de Comercio de 1885 si bien, en los Informes Anuales de las compañías del sector frecuentemente utilizaban los términos "Situación de la Compañía en XX de XXXXX de XX", o "Situación General de las Cuentas en XX de XXXXX de XX", precedida del nombre oficial de la sociedad, ubicando en la parte izquierda de dicho estado contable la estructura económica o Activo, y en la parte derecha la estructura financiera o Pasivo. Por su parte, parte de la doctrina denominaba al documento Balance como "Valores" (Joaquín Imedio Díaz, 1934: 69) (De Aragón, 1942: 500).

El balance no tenía una estructura normalizada como en la actualidad, sino que cada compañía confeccionaba dicho documento en función a su propia reglamentación, sin embargo hemos encontrado similitudes y estructuras comunes en los balances de las diferentes compañías que se repetían de forma recurrente.

De Aragón (1942: 500) divide al Balance ("Valores" para él) en Cuentas de capital ${ }^{565}$ y Cuentas de Bienes. El propio autor (De Aragón, 1942: 498) realiza la siguiente distinción de lo que él denomina "Segunda parte. Cuentas de valores":

a) CUENTAS DE CAPITAL

$1^{\circ}$ Capital. Capital social, Accionistas, Acciones Dividendos activos, Dividendos pasivos.

$2^{\circ}$ Obligaciones. Obligaciones, Servicio de obligaciones.

$3^{\text {o }}$ Reservas. Reserva estatutaria, Reserva para amortización de material, Reserva para conservación y mejora de las instalaciones, Reserva para riesgos de incendios, Reserva para previsión de créditos incobrables, Reserva para pensiones y retiros, Reserva para resultados adversos, Reservas para gastos imprevistos.

\footnotetext{
${ }^{565}$ En las cuentas de capital se incluyen además de estas un gran número de reservas establecidas para prever los distintos riesgos a los que se encuentra expuestas las empresas, con el fin de evitar trastornos en su economía.
} 


\section{b) CUENTAS DE BIENES DE LA SOCIEDAD}

$1^{\circ}$ Cuentas de Material e Instalaciones. Estudios y trabajos técnicos, Útiles y herramientas, Derechos de la vía y terrenos para depósitos, Obras de explanación, Material y construcción de la vía, Puentes, Alcantarillas, traviesas, Rieles y placas de unión, Cruzamientos y cambios, Material móvil, Estaciones y dependencias, Telégrafos, mobiliarios y enseres.

$2^{\mathbf{o}}$ Combustibles y Acopios. Almacenes generales, Combustibles y hullas, Acopios de material y tracción, Almacén de los depósitos y talleres, Trabajos en curso de ejecución en los talleres, Almacén de la vía, Talleres de la vía.

$3^{\text {o }}$ Metálico y Valores. Caja central, Bancos, Títulos depositados como garantía de préstamos.

\section{$4^{\circ}$ Deudores y Acreedores.}

a) Deudores - Fianzas y depósitos constituidos. Anticipos al personal, Deudores varios.

b) Acreedores. Depósitos en garantía, Créditos del personal, Proveedores.

Joaquín Imedio Díaz (1934: 69) definía el balance como "la expresión numérica del estado de un negocio en una época determinada, sirviendo, por consiguiente, para indicar el beneficio o pérdida obtenidos", documento por otra parte preceptivo para cualquier comerciante. En el epígrafe de Cuentas de valores se deben incluir todas las referencias al capital, a las reservas, a las obligaciones y a las cuentas de valores de activo: coste de la vía, edificaciones, estaciones, dependencias, terraplenes, puentes, alcantarillado, mobiliario y enseres, acopios, caja y bancos, deudores y acreedores.

En el cuadro 32 se muestran las principales rúbricas que generalmente se inscribían en el balance de las ferroviarias españolas.

\section{Cuadro 32. Estructura del Balance general de las compañías ferroviarias}

\begin{tabular}{|c|c|}
\hline Activo & Pasivo \\
\hline $\begin{array}{ll}\text { - } & \text { Gastos de construcción de las líneas } \\
\text { - } & \text { Coste de material móvil } \\
\text { - } & \text { Material de oficinas, herramientas } \\
\text { - } & \text { Acopios } \\
\text { - } & \text { Cartera } \\
\text { - } & \text { Cuentas deudoras } \\
\text { - } & \text { Caja y bancos } \\
\text { - } & \text { Cuentas de orden } \\
\text { - } & \text { Pérdidas y Ganancias (pérdidas) }\end{array}$ & $\begin{array}{ll}\text { - } & \text { Capital social (acciones) } \\
\text { - } & \text { Obligaciones } \\
\text { - } & \text { Subvenciones } \\
\text { - } & \text { Capital o aportación del Estado } \\
\text { - } & \text { Reservas } \\
\text { - } & \text { Cuentas acreedoras } \\
\text { - } & \text { Beneficios pendientes de reparto } \\
\text { - } & \text { Cuentas de orden } \\
\text { - } & \text { Pérdidas y Ganancias (beneficio) }\end{array}$ \\
\hline
\end{tabular}

Fuente: Elaboración propia con adaptación parcial de Joaquín Imedio Díaz (1934: 70) 


\subsubsection{Cuentas de Explotación (Cuenta de pérdidas y ganancias)}

El estado contable denominado Cuenta de Explotación representaba los resultados alcanzados por el negocio principal de la ferroviaria e informaba, por un lado, de los ingresos obtenidos por la prestación del servicio de transporte y, por otro lado, de los gastos incurridos para su desarrollo. Torrents y Monner (1885: 531) ya identificaban que en las ferroviarias, era imprescindible practicar un análisis completo de las diversas causas que producen los ingresos y ocasionan los gastos.

La Cuenta de Explotación se presentó con un formato de cuenta tradicional, es decir, en horizontal con dos columnas, situándose en el lado izquierdo los ingresos de explotación y en el lado derecho los gastos.

Los ingresos de explotación se desglosaron normalmente entre los procedentes de la gran velocidad y la pequeña velocidad, y en algunas empresas también se desglosaban los productos fuera del tráfico. Los gastos de explotación se pueden distinguir básicamente en seis conceptos, con ligeras variaciones a lo largo de los años en las diferentes compañías: I. Administración, II. Dirección y servicios generales, III. Movimiento o explotación, IV. Vía y obras, V. Material y tracción y VI. Gastos extraordinarios.

La cuenta de ingresos y gastos diseñada por Joaquín Imedio Díaz y Fraisero (1934: 121) presenta una denominación de "Cuenta de Pérdidas y Ganancias" y sus componentes "Débito" en la primera columna y "Crédito" en la segunda columna.

De Aragón (1942: 498) realiza la siguiente distinción de lo que él denomina "Primera parte. Cuentas de explotación" ${ }^{566}$ :

A) GASTOS DE EXPLOTACIÓN

$1^{\circ}$ Gastos de Dirección y Administración. Consejo de Administración, Dirección y Gerencia, División técnica, Gastos de correos, impresos y varios, Reclamaciones e investigaciones.

$2^{\circ}$ Gastos de Servicio de Tracción y Movimiento

a) Cuentas de Personal. Personal de estaciones, Personal de tracción, Personal de vigilancia del camino.

b) Cuentas de material. Combustibles para las locomotoras, Aceite para los vagones, lubricantes y trapos para locomotoras, Herramientas y útiles para el movimiento.

c) Servicio del telégrafo. Personal, material.

$3^{\circ}$ Gastos del Servicio de Conservación

a) Servicio de la vía. Rieles, bridas, balasto, eclisas, etc.

b) Conservación del Camino. Reparación de edificios, Reparación de obras de fábrica, Reparación de obras de tierra.

\footnotetext{
${ }^{566}$ En las Cuentas de explotación deben agruparse todas las destinadas a registrar gastos e ingresos de la industria, que liquidan o cierran al final del ejercicio por Pérdidas y Ganancias.
} 
c) Servicio de material móvil. Reparación de coches, Reparación de grúas, Reparación de locomotoras.

B) CARGAS DE LA EXPLOTACIÓN

$1^{\circ}$ Intereses, Amortizaciones e Impuestos. Impuestos, Intereses y amortizaciones de obligaciones, Amortización de obligaciones año XX, jubilaciones y socorros al personal.

$2^{\circ}$ Varios. Intereses, cambios y Comisiones, Intereses de obligaciones.

C) PRODUCTOS DE LA EXPLOTACIÓN

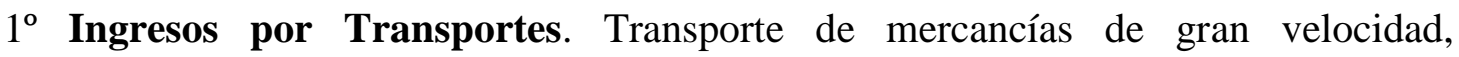
Transporte de mercancías de grande-pequeña velocidad, Transportes de mercancías de pequeña velocidad, Transportes de mercancías por tarifas especiales, Transportes de viajeros.

$2^{\circ}$ Ingresos varios. Ingresos del telégrafo por servicio particular, ingresos por derechos accesorios, Ingresos varios.

\subsubsection{Estadísticas}

Las empresas ferroviarias precisaban llevar como complemento a la contabilidad, un Servicio de estadística e información, bien organizado. Este Servicio de estadística e información es considerado de forma generalizada por la doctrina como ajeno a la contabilidad, sin embargo, para nosotros es el más claro ejemplo de la información de la contabilidad de Gestión.

Las principales estadísticas son "los servicios de billetes de mercancías y de viajeros, y los talones de mercancías transportadas" (de Aragón, 1942: 511). Para los primeros es posible observar "su número y su clasificación, permitiendo averiguar cuáles son las regiones más ricas que originan mayor porcentaje de billetes de clases más costosas" (de Aragón, 1942: 511). Para el segundo es posible observar la diversidad de artículos transportados "desde cada región y el tonelaje de los mismos" (de Aragón, 1942: 511-512).

Otros de los datos que se realizan es el relativo al rendimiento de los diversos trenes, a la capacidad de arrastre de cada máquina y al consumo de combustibles de las mismas, lo cual nos permite establecer el coste de la unidad conocida con el nombre de "tren-kilómetro, que no es otra cosa que lo que cuesta el arrastre de una tonelada por kilómetro recorrido en los distintos trenes en circulación por una línea" (de Aragón, 1942: 512).

Estos datos técnicos son decisivos para la economía de la compañía, principalmente cuando es necesario realizar un estudio para el establecimiento acertado de la tarifas de viajeros y de mercancías.

En los Informes Anuales, las empresas ferroviarias incluían muchas estadísticas e indicadores. Las más frecuentes son las siguientes (Imedio Díaz y Fraisero: 1934):

- Estado de ingresos por líneas 
- Relación de los ingresos por conceptos (viajeros, gran velocidad, pequeña velocidad y varios)

- Ingresos por conceptos y kilómetros explotados

- Unidades de tráfico explotado y conceptos

- Estadística de las diferentes mercancías transportadas (peso y producto)

- Estadística de los viajeros transportados por clases (números y productos)

- Ingresos por estaciones.

\subsection{Compañía de Caminos de Hierro del Norte de España (NORTE)}

La Compañía de los Caminos de Hierros del Norte de España fue fundada el 30 de marzo de 1858, mientras que el 29 de diciembre de 1858 se otorgó la escritura de constitución, obteniéndose la constitución definitiva y aprobación de los estatutos el 14 de enero de 1859 (Real Decreto del 14 de enero de 1859 autorizando a la constitución y aprobación de los estatutos de la Compañía de los Caminos de Hierro del Norte de España, Ministerio de Fomento. Colección Legislativa de la Deuda española / Colección de Decretos) ${ }^{567}$.

La primera asamblea general se realizó en Madrid el 19 de enero de 1859. La mayoría de los suscriptores de títulos eran extranjeros, alcanzando la inversión española tan sólo al 25\% del capital de la sociedad ${ }^{568}$.

La Compañía de los Caminos de Hierro del Norte de España debe su origen al interés de los Péreire por hacer negocios en España para lo cual crearon la Sociedad General de Crédito Mobiliario Español.

Desde su génesis, NORTE estuvo orientada a ser una de las grandes sociedades mercantiles que liderara el desarrollo del sistema de transporte terrestre español. Su estrategia empresarial inicial estuvo centrada en controlar la principal vía de comunicación con Francia ${ }^{569}$.

NORTE fue la empresa privada más importante de España, tanto por el número de sus activos, como por el número de kilómetros en explotación, o por el número de trabajadores -siendo la segunda MZA-. Dentro de las empresas europeas, NORTE pasó de ser la decimonovena empresa de Europa en el siglo XIX a ser la décima del continente a partir de 1917, siempre seguida por detrás, pero muy cerca, por MZA -esta última pasó de ser la vigésima en el siglo XIX, a ser la undécima a partir de 1917 (Carreras y Tafunell, 1993: 127-174; 1996: 77; 1997: 277-304)-.

\footnotetext{
${ }^{567}$ Los Estatutos fueron publicados por la compañía (NORTE: 1859). La edición francesa de los Estatutos de creación de la Compañía del NORTE puede observarse en NORTE (1863, 1-30). La Real Orden de 18 de diciembre de 1858 dispuso la modificación de los estatutos, lo cual se llevó a efecto el 29 de diciembre de 1858. ${ }^{568}$ Sobre la constitución y el desarrollo de NORTE, véase Wais (1974), Artola (1978) y Gómez Mendoza (1982; 1989).

${ }^{569}$ Véase la importancia de su estrategia en Bentabol et al. (2011: 15).
} 
NORTE alcanzó una enorme importancia porque durante muchos años dominaba prácticamente la mitad septentrional de la península Ibérica, incluídos sus puertos ${ }^{570}$, y su paulatino desarrollo empresarial le permitió unir Madrid con la frontera francesa y el Cantábrico.

La Compañía del NORTE se benefició de las ayudas estatales que la Dictadura de Primo de Rivera concedió a las compañías a través del Estatuto Ferroviario de 1924. Sin embargo, estas ayudas se cortaron bruscamente al proclamarse la Segunda República (Wais, 1974: 623). Durante el periodo republicano el ferrocarril en general atravesó una época de grave crisis, aunque la compañía logró mantener su independencia. NORTE desarrolló su actividad hasta 1941, cuando al igual que el resto de ferrocarriles de vía ancha, pasaría a integrarse en RENFE.

Es posible diferenciar cuatro etapas en la evolución de NORTE durante el siglo XIX ${ }^{571}$ : creación (1845-1855), construcción y puesta en servicio (1856-1873), expansión (1875-1892) y estabilización (1893-1899).

\subsubsection{Primera etapa. La creación de la compañía}

En 1843, acababan de inaugurarse los hornos de Santa Ana en Bolueta, y España aún no disponía de ninguna línea de ferrocarril. La industria siderúrgica vizcaína estaba entonces en pleno desarrollo, y necesitaba transportes fiables hacia Madrid, por lo que tenía un gran interés en la creación de un ferrocarril que la conectase a la capital. Los sucesivos gobiernos españoles firmaban sólo concesiones provisionales para su construcción, y con esta forma de "provisionalidad" es con la que el Gobierno, los municipios y las Cámaras de Comercio interesados (principalmente en Vizcaya), obtienen la autorización de construir la línea que desde entonces comenzará a llamarse "del Norte".

Entre 1845 y 1855 se realizaron varios proyectos de ferrocarril que pretendían conectar Madrid con las provincias vascas y la frontera francesa. Los proyectos estaban redactados para salir de Madrid, y tenían previsto transcurrir por Valladolid, Burgos, Bilbao, para luego continuar la costa por Deva para alcanzar la frontera francesa en Irún.

Los años trascurren sin que se realice obra alguna, hasta que se aprueba la Ley General de los Ferrocarriles de 3 de junio de 1855. Como consecuencia de la nueva Ley, el proyecto de la línea del NORTE se divide en tres tramos: (1) Madrid a Valladolid por Ávila y Medina del Campo, (2) Valladolid a Burgos y (3) Burgos a Francia por Miranda de Ebro. El último tramo evita Vizcaya, puesto que el trazado elegido pasa por Vitoria, Alsasua, Tolosa y San Sebastián.

\footnotetext{
${ }^{570}$ De la importancia de esta compañía baste mencionar su control sobre los puertos de Barcelona, Bilbao, Pasajes, Santander, Gijón, La Coruña y Vigo (Hernández Marco: 1997).

${ }^{571}$ Sobre la cronología de la apertura de líneas y la construcción ferroviaria de NORTE es fundamental la obra de Wais $(1948 ; 1974 ; 1987)$.
} 
Para obtener la línea en su integridad es necesario obtener la concesión de los tres tramos. El 14 de noviembre de 1855, los hermanos Emile e Isaac Péreire -junto con los financieros José Joaquín de Osma, Enrique O’Shea y Eugenio Duclerc- obtienen la concesión del tramo Valladolid - Burgos (Tedde, 1978, vol. II: 23). Por medio de la Ley de 11 de julio de 1856, la Sociedad de Crédito Mobiliario Español, creada por los propios hermanos Péreire, obtiene la concesión de los otros dos tramos. Mientras se pone la primera piedra en Valladolid, los Péreire también obtienen la concesión del ramal de Venta de Baños a Alar del Rey.

La entrada en el sector de los ferrocarriles de la recién creada Sociedad General de Crédito Mobiliario Español (una de las entidades de crédito nacidas de la legislación bancaria del periodo progresista) marcó un nuevo periodo para la evolución no sólo de la línea férrea Madrid-Irún, sino también de todos los transportes ferroviarios, puesto que su intervención supuso dos hechos fundamentales: en primer lugar, la conexión entre el ferrocarril y la banca, lo que iba a permitir movilizar rápidamente la gran cantidad de capital financiero necesario para la construcción y posterior puesta en servicio de las líneas férreas, y en segundo lugar, el vínculo entre el binomio ferrocarril-banca y el mercado exterior de capitales, al ser la empresa de iniciativa francesa.

\subsubsection{Segunda etapa. Construcción y puesta en servicio de la línea}

El 18 de junio de 1856, NORTE comenzó la construcción de su línea principal desde Valladolid en los dos sentidos, es decir, hacia Burgos por un lado y hacia Medina del Campo por otro. A comienzos de 1861 ya se habían terminado 360 kilómetros de su trazado total, esto es, los segmentos entre Valladolid y Medina del Campo y Valladolid a Burgos.

A partir de 1856, una pequeña colonia francesa se instala en Valladolid para comenzar los trabajos ${ }^{572}$. Esta ciudad presenta la ventaja de estar a medio camino de los extremos de la línea (Wais, 1974, Capítulo VIII). A medio plazo, está previsto instalar allí los talleres para el material rodante de la compañía y su principal depósito de locomotoras.

En 1864 NORTE culmina su etapa de formación con las líneas Madrid-Irún y Venta de Baños-Alar, alcanzando los 739,8 km, que mantuvo sin cambios hasta 1874. El proceso fue todo lo acelerado que la Ley General de 1855 preveía. La conexión de la línea de NORTE con el extremo sur de las líneas de Midi "Compagnie des Chemins de Fer du Midi e du Canal Latéral à la Garonne" (que pertenece también a los hermanos Péreire) se realiza en Irún y Hendaya.

El cuadro 33 muestra la entrada en servicio de los distintos tramos de NORTE en la etapa de construcción.

\footnotetext{
572 Compagnie des Chemins de Fer du Nord de l'Espagne, Procès verbaux des séances tenues par la reunión de Paris: $18-I V-1856$.
} 
Cuadro 33. Entrada en servicio de los distintos tramos de NORTE (1856-1873)

\begin{tabular}{|c|c|c|}
\hline Fecha & Sección & Longitud $(\mathrm{km})$ \\
\hline 1 de agosto de 1860 & Venta de Baños-Alar del Rey & 90,772 \\
\hline 1 de agosto de 1860 & Valladolid-Venta de Baños & 36,749 \\
\hline 15 de septiembre de 1860 & Medina del Campo-Valladolid & 42,211 \\
\hline 25 de noviembre de 1860 & Sanchidrián-Medina del Campo & 55,326 \\
\hline 25 de noviembre de 1860 & Venta de Baños-Burgos & 84,325 \\
\hline 25 de julio de 1861 & Burgos-Quintanapalla & 16,286 \\
\hline 9 de agosto de 1861 & Madrid-El Escorial $^{573}$ & 50,295 \\
\hline 13 de abril de 1862 & Miranda de Ebro-Olazagutía & 74,743 \\
\hline 26 de julio de 1862 & Quintanapalla-Miranda de Ebro & 73,010 \\
\hline 4 de marzo de 1863 & Ávila-Sanchidrián & 30,415 \\
\hline 1 de julio de 1863 & El Escorial-Ávila & 70,276 \\
\hline 1 de septiembre de 1863 & Beasain-San Sebastián & 41,402 \\
\hline 1 de octubre de 1863 & Madrid (Atocha)-Madrid (Príncipe Pío) (Cinturón) & 7,968 \\
\hline 18 de octubre de 1863 & San Sebastián-Irún & 16,872 \\
\hline 22 de abril de 1864 & Irún-Hendaya (Francia) & 1,704 \\
\hline 20 de agosto de 1864 & Olazagutía-Beasain & 47,472 \\
\hline SUMA & & 739,826 \\
\hline
\end{tabular}

Fuente: Elaboración propia a partir de datos de NORTE (1940), Wais (1974) y Gómez Mendoza (1989)

\subsubsection{Tercera etapa. Expansión}

En Francia y otras partes de Europa las compañías de los hermanos Péreire se enfrentan a problemas en la década de 1860. Igualmente, los inicios de NORTE son duros. En la parte septentrional de la red, las guerras carlistas empeoran una situación ya de por sí precaria. La situación mejora a partir de los años 70 del siglo XIX; las guerras carlistas terminan, y el Gobierno concede algunas subvenciones por las destrucciones sufridas. En 1874, la Sociedad del Crédito Mobiliario Español cede a NORTE las minas de carbón de Barruelo por tres millones de francos. En 1876, la compañía comienza a sustituir carriles de hierro por carriles de acero. Además, la compañía empieza a abastecerse con proveedores españoles, principalmente de empresas vascas y catalanas.

A partir de 1874 comienza la expansión de la compañía -quizás por sentirse menos dependiente de París (Wais, 1987, vol. I: 193)-, que se realiza en dos subetapas: en la primera etapa, hasta 1889, la sociedad amplió su red hacia Cataluña y el Noroeste, dotándola de una transversalidad de la que carecía, lo que supuso triplicar su red inicial, mientras que en la segunda etapa (1890-1892) se produce un fenómeno expansionista más agresivo al adquirir líneas en territorio de MZA.

\footnotetext{
${ }^{573}$ El Director de NORTE Aubert (1861: 1-20) “crítica al funcionamiento del Crédito Moviliario (sic) Español y por tanto a la Sociedad del Camino de Hierro del NORTE" por la demora en la puesta en funcionamiento de la línea Madrid-Escorial así como por la mala calidad de las instalaciones hasta el momento realizadas (pendientes, desmontes, mala calidad del balasto utilizado...).
} 
NORTE inició su estrategia de expansión el 31 de enero de 1874 con la adquisición de la Nueva Compañía del Ferrocarril de Alar del Rey a Santander por la suma de 92.702.000 reales. Esta primera anexión responde a una estricta lógica porque en adelante la compañía puede encaminar sus suministros exteriores en las vías propias hasta Santander.

En 1878 compró las líneas de Alsasua a Barcelona de la "Compañía de los Ferrocarriles de Zaragoza a Pamplona y Barcelona" (ZPB) y de Castejón a Bilbao de la "Compañía del Ferrocarril de Tudela a Bilbao". Ambas son estratégicamente muy importantes. La anexión de ZPB, el 13 de febrero de 1878, permite alcanzar el Mediterráneo y casi duplica la longitud de las líneas explotadas. La anexión de la "Compañía del Ferrocarril de Tudela a Bilbao", el 28 de marzo de 1878, permite acceder al gran puerto de Vizcaya. NORTE es ahora una gran red y cree necesario poseer una gran estación en Madrid. En 1878 se inician los trabajos de construcción de la nueva estación de Príncipe Pío que se inaugurará el 16 de julio de 1882.

El 24 de mayo de 1881, NORTE adquiere la concesión de la línea en vía métrica de Villalba a El Berrocal. Poco después, el 11 de agosto de 1881, la compañía obtiene la concesión de la línea Segovia-Medina que ofrece una alternativa a la línea principal sobre una parte de su trazado meridional.

En 1884 adquiere el ferrocarril de Medina-Segovia y consiguió la concesión de la SegoviaVillalba. El 14 de agosto de 1884 absorbió la pequeña Compañía de los Ferrocarriles de Lérida a Reus y Tarragona que permite consolidar las posiciones de la compañía en Cataluña.

El 1885, compró las líneas de la Compañía de los Caminos de Hierro de Asturias, Galicia y León y la de Lérida a Tarragona de la Compañía de los Ferrocarriles de Lérida a Reus y Tarragona. La compra de la Compañía de los Ferrocarriles de Asturias, Galicia y León, el 1 de mayo de 1885, abre nuevas salidas a estas provincias hasta entonces ignoradas por NORTE.

En 1886 adquirió el ferrocarril Villalba-San Juan. El 13 de octubre de 1886, el Crédito General de Ferrocarriles cede la concesión de la línea de San Juan de Nieva a Villabona de Asturias.

El 31 de diciembre de 1887, NORTE absorbe las líneas de la Minas de San Juan de las Abadesas y la de Sociedad de Ferrocarriles de San Juan de las Abadesas a Selgua.

El 1 de febrero de 1889, la línea Barbastro-Selgua se transfiere a NORTE. Con ello termina su primera etapa de expansión, que comenzó en 1874 y culmina en 1889 alcanzando los 2.061,5 km de longitud.

En la segunda etapa de expansión que comienza en 1890, se produce un fenómeno expansionista de mayor agresividad competitiva al adquirir líneas en territorio de la compañía MZA. El 27 de mayo de 1890, NORTE adquiere la concesión de la línea Soto de Rey-Ciaño. El 25 de mayo de 1891 compró la potente línea Almansa-Tarragona a la Sociedad de 
Ferrocarriles de Almansa a Valencia y Tarragona (AVT) ${ }^{574}$, permitiendo conectar el litoral levantino con el tendido ferroviario catalán ${ }^{575}$. Prosiguió su política agresiva de adquisiciones en dura competencia con MZA, adquiriendo, el 1 de enero de 1892, la pequeña Sociedad de los Caminos de Hierro del Este de España y el ferrocarril Valencia-Utiel ${ }^{576}$. Estas adquisiciones supusieron un incremento de la red de $548 \mathrm{Kms}^{577}$. Con estas anexiones concluye la fase de expansión, delimitando lo que será en adelante el territorio de la compañía. En el cuadro 34 se reflejan las anexiones realizadas por NORTE en la época de expansión.

\section{Cuadro 34. Anexiones de NORTE en la época de expansión (1874-1892)}

\begin{tabular}{|c|c|c|c|c|}
\hline & LINEA & APERTURA & ADQUISICIÓN & $\begin{array}{c}\text { LONGITUD } \\
\text { (KM) }\end{array}$ \\
\hline \multirow[t]{11}{*}{ Primera Fase } & Madrid- Irún & 1863 & - & 729 \\
\hline & Alar-Santander & 1866 & 1874 & 139 \\
\hline & Alsasua-Barcelona & 1865 & 1878 & 663 \\
\hline & Castejón- Bilbao & 1863 & 1878 & 250 \\
\hline & Medina-Segovia & 1884 & 1884 & 92 \\
\hline & Segovia-Villalba & 1888 & 1884 & 63 \\
\hline & Asturias, Galicia y León & 1884 & 1885 & 759 \\
\hline & Lérida-Tarragona & 1879 & 1885 & 103 \\
\hline & Villabona-San Juan & 1886 & 1886 & 21 \\
\hline & Abadesas - Selgua & 1880 & 1887 & 128 \\
\hline & Selgua-Barbastro & 1880 & 1889 & 19 \\
\hline \multirow{5}{*}{ Segunda Fase } & Soto de Rey - Ciaño & 1894 & 1890 & 22 \\
\hline & Almansa - Tarragona & 1878 & 1891 & 460 \\
\hline & Valencia - Utiel & 1887 & 1892 & 88 \\
\hline & Compañía del Este de España & 1872 & 1892 & 98 \\
\hline & TOTAL & & & 3.634 \\
\hline
\end{tabular}

Fuente: Elaboración propia a partir de datos de NORTE (1940), Wais (1974), Tedde (1978), Gómez Mendoza (1989), Comín, Martín, Muñoz, Vidal (1998)

Con la política de las fusiones y absorciones del siglo XIX, la compañía reforzó su posición dentro del sector, buscó una red más integrada y consiguió mejorar su escala de producción,

\footnotetext{
${ }^{574}$ La cesión es ratificada mediante Ley de 30 de julio de 1891.

575 Tedde (1978, 2 y 47-104; 1996); Comín, et al. (1998, I: 160-164).

${ }^{576}$ La "Sociedad de los Ferrocarriles de Cuenca a Valencia y Teruel" fue disuelta siendo Montero Rios, ministro de Fomento. Cambió su denominación social, el 9 de diciembre de 1886, tomando el nombre de "Caminos de Hierro del Este de España” empresa que culminó las obras el 11 de septiembre de 1887 al inaugurar los 10 kilómetros inconclusos entre Sieteaguas y Buñol. La constitución de la sociedad tuvo lugar en Valencia en la notaria de Miguel Tasso Chiva, con un capital de 10.000.000 pts en 20.000 acciones (Revista Minera, Tomo 38, año 1887).

${ }^{577}$ Datos tomados de Comín, et al. (1998: 169).
} 
aumentó el tráfico y disminuyó los costes unitarios al repartirse los fijos entre un número mayor de unidades transportadas ${ }^{578}$, lo que indirectamente favoreció a la economía española $^{579}$.

En este periodo, NORTE emprendió una estrategia de crecimiento para aprovechar las economías de escala del sector. Para su crecimiento utilizó una rápida concentración horizontal mediante la absorción de compañías más pequeñas, de esta forma, NORTE compró a muy buenos precios, ya que se aprovecharon de los apuros sufridos por muchas empresas medianas para absorberlas (Comín, et al., 1998: 149).

\subsubsection{Cuarta etapa. Estabilización}

El 3 de mayo de 1893, el Gobierno autorizó a NORTE la transferencia de la línea de Jaca (construida por la compañía por cuenta de la Sociedad Anónima Aragonesa). En el cuadro 35 se recoge las líneas que entraron en servicio en la época de estabilización (1893-1899). En 1893 NORTE compró el ferrocarril Huesca-Canfranc a la Sociedad Anónima Aragonesa; sin embargo, no se concluyó su construcción (182km) hasta 1929 a causa de la crisis.

Cuadro 35. Entrada en servicio en la época de estabilización (1893-1899)

\begin{tabular}{|l|l|l|l|}
\hline CONCESIÓN & FECHA & SECCIÓN & LONGITUD (KM) \\
\hline Jativa-Alcoy & 29 de marzo de 1893 & Jativa-Albaida & 28,9 \\
\hline. & 17 de mayo de 1894 & Albaida-Onteniente & 9,2 \\
\hline. & 15 de abril de 1904 & Onteniente-Alcoy & 25,1 \\
\hline $\begin{array}{l}\text { Soto del Rey-Ciaño Santa } \\
\text { Ana }\end{array}$ & 1 de julio de 1894 & Soto del Rey-Ciaño & 21,5 \\
\hline TOTAL & & $\mathbf{8 4 , 7}$ \\
\hline
\end{tabular}

Fuente: Elaboración propia a partir de datos de NORTE (1940), Wais (1974) y Gómez Mendoza (1989)

\subsubsection{Consecuencias de la construcción y explotación de la red durante el periodo 1845- 1899}

Al comienzo del siglo XX, NORTE se encontraba en una buena situación estratégica pero acompañada de una mala situación económica.

\footnotetext{
${ }^{578}$ Según cálculos de Tedde (1978: 2 y 95-98; 1996: 278-283), en NORTE "el índice de coste medio comenzó a caer a partir 1875. Si bien el descenso se prolonga en NORTE hasta 1930, es entre 1875 y 1895 cuando resultó más pronunciado, coincidiendo con los mayores saltos en la extensión de la red. En la medida que el coste medio descendía la empresa se aproximaba a una zona de explotación óptima.

${ }^{579}$ Los efectos sobre la economía española pueden observarse en Anés Álvarez (1978: 355-512), Gómez Mendoza (1989a: Capítulo 5) y en Comín (1999).
} 
La longitud de la vía al acabar el siglo XX era estable. NORTE vio cumplido su deseo de ocupar los principales trazados de la Península, enlazados entre sí. Poseía un largo eje EsteOeste que iba desde Vigo y La Coruña hasta Barcelona, que enlazaba en Venta de Baños con otro Norte-Sur que unió Madrid con Francia a través de Miranda de Ebro.

Aunque la construcción se había concluido con éxito, la situación económico financiera de la empresa no era a final del siglo XIX, lo que hubiera deseado NORTE. Se centró tanto en la construcción desmesurada, y en la competencia con MZA, que desantendió la rentabilidad de la empresa.

El periodo finisecular se caracterizó para NORTE en que sufrió graves dificultades económicas, sucediéndose cinco ejercicios en pérdidas (1893-1897).

Las razones de esta situación tan negativa se debe a seis factores, según afirman reiteradamente los Informes Anuales de NORTE del periodo 1891-1900 ${ }^{580}$ : la eliminación del impuesto del $10 \%$ sobre el producto de los billetes de viajeros en 1883, la insuficiente cuantificación de las subvenciones, el final del tratado con Francia en 1891, la crisis agrícola de 1892-1893 que produjo una reducción muy acusada en el comercio de los cereales y el vino, la financiación deficiente y, por último, la elevación del cambio entre la peseta y franco a partir de 1894.

Las compañías de ferrocarriles atravesaban en 1866 una crisis aguda. Para acudir en su auxilio, el Estado por medio del Decreto de 29 de diciembre de 1866, les cedió el impuesto del 10\% establecido por la Ley de Hacienda de 25 de junio de 1864 sobre el producto de los billetes de viajeros, a fin de que pudieran aplicarlo al pago de los intereses y a la amortización de las obligaciones que las compañías habían emitido o que emitieran después (NORTE, 1893: 13). Este impuesto que, según los términos del Decreto de 1866, tenía carácter permanente, fue abolido en 1883 con gran perjuicio para las compañías. La supresión del impuesto supuso una disminución de 2.4000 .000 pesetas en sus recaudaciones netas anuales (NORTE, 1893: 14).

La derogación anticipada de la subvención fue uno de los aspectos más determinantes para NORTE. Por un lado, para fijar la subvención que debía concederse a las compañías de ferrocarriles, el Gobierno mando valorar el coste probable de construcción de las líneas. Esta valoración fue muy inferior al coste efectivo de los caminos ${ }^{581}$, fundamentalmente por las contingencias imprevistas que se presentaron en la construcción. En 1854, el coste se fijó en 1.296.196.306 pesetas para los 7.798 kilómetros que se proyectó construir en el conjunto de todas las ferroviarias (NORTE, 1893: 5). Para la línea Madrid-Irún el coste probable era $153.369,672$ pesetas y resultó después que el gasto efectivo fue de $346.592,458$, lo que supuso una diferencia de más de 193.222,786 (NORTE, 1893: 6). El Estado tenía previsto conceder una subvención del $42 \%$ de la valoración, sin embargo a NORTE le concedió un 17\%,

\footnotetext{
${ }^{580}$ NORTE $(1892 ; 1893 ; 1894 ; 1895 ; 1896 ; 1897 ; 1897 ; 1898 ; 1899 ; 1900 ; 1901)$.

${ }^{581}$ El hecho de que la valoración fuese muy inferior al coste efectivo de los caminos, había ocurrido en todos los países (NORTE, 1893: 5).
} 
cantidad que parecía a la empresa "exigua si se tiene en cuenta que la compañía no es más que usufructuaria del camino y que este debe pasar a ser propiedad del Estado al expirar la concesión, en cuya época el valor del camino será muy superior a su primitivo coste por las considerables ampliaciones y mejoras que en él se están realizando constantemente" (NORTE, 1893: 6$)^{582}$.

La elevación del cambio entre la peseta y franco a partir de 1894, fue el otro problema importante, porque el franco era la moneda con que NORTE amortizaba las obligaciones e intereses de su abultada deuda contraída en esta divisa para realizar sus anexiones.

Cuando el gobierno español promulgó la Ley de 1855, la unidad monetaria era el real de vellón. En ese momento la pieza de 20 reales valía 5 francos, 26 céntimos y 4 milésimas. Sobre este tipo monetario fueron reguladas las tarifas del ferrocarril, y con arreglo a la misma base emitieron las compañías, con la aprobación del gobierno español, acciones y obligaciones de 1.900 reales, equivalentes a 500 francos. En ese momento se daba comúnmente el nombre de pesetas a las piezas de 4 reales que estaba en circulación. Por Decreto de 19 de octubre de 1868 el gobierno español declaró que desde el 1 de enero de 1870 la unidad monetaria sería la peseta, moneda efectiva equivalente a 100 céntimos. La peseta objeto de dicho Decreto valía 5\% menos que la antigua peseta convencional de cuatro reales. Esta depreciación de la moneda supuso una pérdida efectiva de 5\% sobre las recaudaciones. Para NORTE representó una pérdida anual de más de dos millones de pesetas (NORTE, 1893: 19). El Estado no las compensó, a pesar de que dio la razón a las ferroviarias la Comisión que nombró el Gobierno por Decretos de 7 y 15 de noviembre de 1868 para examinar los medios de hacer prosperar las empresas de ferrocarriles, o ahorrarles gastos y disminuirles trabas administrativas.

Las compañías recaudaban en pesetas el importe de sus percepciones, y debían pagar en francos en el extranjero los intereses y la amortización de la mayor parte de sus obligaciones. Por lo tanto, para procurarse francos tuvieron que hacerlo con la pérdida del cambio entre el valor variable de ambas monedas, que llegó a ser en 1892 hasta un $21 \%$, esto es que para cada 100 francos remitidos a Paris las compañías tuvieron que pagar 121 pesetas. A NORTE (1893: 21) este hecho le produjo un aumento de los gastos de $2,17 \%$ en $1888,3,65 \%$ en 1889 , 4,51\% en $1890,7 \%$ en 1891 y $17 \%$ en 1892.

A partir de 1894, la situación de NORTE era angustiosa porque debía pagar los intereses de sus empréstitos y amortizar las obligaciones de las compañías ferroviarias incorporadas. Ante una inminente suspensión de pagos, tuvo que recurrir a soluciones bancarias adversas, a un polémico convenio con los obligacionistas y a suspender la concesión de dividendos a obligacionistas en un prolongado periodo (1891-1907). La ausencia de reparto de

\footnotetext{
${ }^{582}$ La empresa calculó en 3,21\% la rentabilidad del Estado por las subvenciones entregadas a las ferroviarias en el quinquenio 1887-1891, mientras que las acciones de la compañía habían tenido un interés medio de 2,21\% al año para el mismo periodo (NORTE, 1893: 6).
} 
remuneración a las acciones a partir de 1891, originó una bajada importante en sus valores ${ }^{583}$, tanto en el mercado español como en el extranjero (NORTE, 1893:21).

${ }^{583}$ En 1892 los valores de los ferrocarriles españoles, junto con los del propio Estado español, eran los únicos que cotizaban en bolsas de valores fuera de España. 


\section{CAPÍTULO CUARTO.- MODELO ORGANIZATIVO DE NORTE}

La organización, estructura organizativa y jerárquica de la entidad define, por un lado el centro de decisión, y por otro condiciona los canales informativos, entre los que se encuentra el modelo contable de forma que satisfaga las necesidades informativas de los usuarios y los requerimientos normativos.

Un elemento imprescindible para analizar la empresa NORTE es conocer la estructura de su organización y gestión. Es fundamental identificar cual era el proceso de toma de decisiones y en qué Secciones se dividía la empresa ${ }^{584}$.

\subsection{Toma de decisiones}

La composición del accionariado y del Consejo de Administración constituye la estructura de toma de decisiones formal de la empresa NORTE. No obstante, el Consejo de Administración no tiene apenas poder real de decisión dentro de la organización. Es más bien un reflejo del poder político que había en el país en cada momento -por eso iban y venían los Consejeros- y un enlace con otras empresas -tanto suministradoras como posibles aliadas-.

La toma de decisiones real se encuentra diluida en una serie de organismos distintos: los diferentes Comités y Comisiones que coexistieron en NORTE. Y dentro de esta estructura real, la figura más relevante era el Director general de NORTE ya que de él dependían la gestión y toma de decisiones cotidianas que llevaba a cabo el personal ejecutivo asalariado ${ }^{585}$; siempre vigilado estrechamente por el administrador delegado, que era el enlace con el Consejo de Administración.

El cuadro 36 recoge las etapas en la evolución del proceso de toma de decisiones de la compañía.

\footnotetext{
${ }^{584}$ En el lenguaje ferroviario de la época el término "Sección" se utiliza para hacer referencia a los tramos en que puede dividirse una línea de ferrocarril. El mismo término también es utilizado para hacer referencia a los departamentos funcionales en los que se organiza la compañía. El origen de esta acepción se encuentra en la contabilidad de costes francesa, donde nace el "Sistema de Costes por Secciones".

${ }^{585}$ Bien es cierto que ningún Director de NORTE tuvo tanto poder como Maristany en MZA, donde el Consejo de Administración siempre terminaba diciendo que hacían lo que dijera Maristany.
} 


\section{Cuadro 36. Etapas en la evolución del proceso de toma de decisiones de NORTE}

\begin{tabular}{|l|l|}
\hline PERIODO & HECHOS RELEVANTES EN EL PROCESO DE TOMA DE DECISIONES \\
\hline $1858-1859$ & $\begin{array}{l}\text { Empresa constructora } \\
\text { Dos organismos de dirección de NORTE: Comités de París y Comité de Madrid }\end{array}$ \\
\hline $1859-1863$ & $\begin{array}{l}\text { El Comité de Paris es el principal centro de toma decisiones de NORTE } \\
\text { Tres organismos de dirección de NORTE: Comité de Madrid, Comité de París y Comité } \\
\text { Ejecutivo }\end{array}$ \\
\hline $1864-1892$ & $\begin{array}{l}\text { El Comité de Paris es el principal centro de toma decisiones de NORTE } \\
\text { Tres organismos de dirección de NORTE: Comité de Madrid, Comité de París y Comité } \\
\text { Ejecutivo } \\
\text { Comité Ejecutivo independiente del Comité de Madrid }\end{array}$ \\
\hline $1893-1905$ & $\begin{array}{l}\text { El Comité de Paris es el principal centro de toma decisiones de NORTE } \\
\text { Cuatro organismos de dirección de NORTE: Comité de Madrid, Comité de París, Comité } \\
\text { de Barcelona y Comité Ejecutivo } \\
\text { Comité Ejecutivo independiente del Comité de Madrid }\end{array}$ \\
\hline $1906-1917$ & $\begin{array}{l}\text { La toma de decisiones se traslada a un organismo externo a la estructura organizativa de } \\
\text { NORTE: la Comisión Mixta. } \\
\text { Cinco organismos de dirección de NORTE: Comisión Mixta, Comité de Madrid, Comité } \\
\text { de París, Comité de Barcelona y Comité Ejecutivo }\end{array}$ \\
\hline $1924-1941$ & $\begin{array}{l}\text { La toma de decisiones se mantiene en un organismo externo a la estructura organizativa de } \\
\text { NORTE: la Comisión Mixta. } \\
\text { Cuatro organismos de dirección de NORTE: Comisión Mixta, Comité de Madrid, Comité } \\
\text { de París y Comité de Barcelona } \\
\text { El Comité de Madrid es el principal centro de toma decisiones de NORTE, en detrimento } \\
\text { del Comité de París } \\
\text { Comité de Madrid y Comité Ejecutivo se fusionan. El presidente del Consejo presidió } \\
\text { ambos Comités } \\
\text { Comité de Madrid 15 miembros y Comité de Barcelona } 7 \text { miembros } \\
\text { de París y Comité de Barcelona } \\
\text { El Comité de Madrid es el principal centro de toma decisiones de NORTE } \\
\text { Comité de Dirección y Comité Financiero }\end{array}$ \\
\hline 1918 -
\end{tabular}

Fuente: Elaboración propia 
Hasta 1859, la empresa es meramente constructora y su estructura se confecciona con un escalón superior en la que se sitúan los Comités de Madrid y de París. Aunque en teoría tenían las mismas atribuciones y colaboran en las decisiones a adoptar, la construcción del tramo Madrid-Irún se maneja en realidad desde París, donde se encuentran los hermanos Péreire, Calderón, Abaroa, Bixio, Brouckère, Delessert, Galliera, Salvador, Seillière y otros administradores importantes de la firma. Isaac Péreire se encarga como vicepresidente de coordinar la actuación de ambos Comités. Cualquier decisión debe ser adoptada de común acuerdo por los administradores de las dos capitales, pero siempre está presente en las discusiones la sensación de que la toma de decisiones es llevada realmente desde París.

A raíz de 1859, en la que se constituye NORTE, las atribuciones de ambos Comités quedan perfectamente definidas estatutariamente. Madrid delega en los administradores de París el cuidado de dirigir la construcción y organizar la ejecución de los trabajos, incluída la designación del director y principales ingenieros encargados de los mismos. Los presupuestos y créditos generales serán concedidos por el Consejo de Administración a propuesta del Comité de París. En Madrid tan sólo se tomarán las medidas oportunas para movilizar los recursos una vez que se les notifique. La contabilidad de la empresa será llevada conjuntamente en las dos capitales, París tiene especial cuidado de hacer llegar puntualmente a Madrid copia de los recibos por los pagos efectuados en Francia a cargo de la compañía (Cordero y Menéndez, 1978, 213).

El Comité de Madrid tiene la misión de velar porque se asegure en España el cumplimiento de las decisiones del Consejo de Administración, encargándose de las gestiones que sean precisas ante el Ministerio de Fomento y el Gobierno español, y de resolver los asuntos judiciales que se presenten a la compañía en España ${ }^{586}$. Además, también tiene el encargo de arreglar las cuestiones relativas a la expropiación de terrenos ${ }^{587}$.

El modelo de organización y gestión de NORTE es chandleriano, pero no puro, sino influenciado por las ferroviarias francesas y por los conflictos regionalistas de nuestro país. En efecto, el diseño organizativo de NORTE tenía rasgos de la moderna estructura de Chandler, pero con unas peculiaridades: por un lado, derivación concreta de la estructura chandleriana denominada departamental francés, y por otra está integrado por un Consejo de Administración -sin poder real-, el Comité de Dirección de París -que era el que realmente ostentaba el poder ejecutivo de las empresas- y dos Comités más - uno en Madrid y otro en Barcelona- supeditados al anterior.

Dado que sus características productivas dependían de la implementación de sistemas novedosos, el ferrocarril estadounidense tuvo que dotarse de un nuevo tipo de organización que fuese capaz de resolver las complejas exigencias que comportaba. Así surgió la moderna

\footnotetext{
${ }^{586}$ Compagnie des Chemins de Fer du Nord de l’Espagne, Procès verbaux des séances tenues par la reunión de Paris: 8-II-1859.

${ }^{587}$ Compagnie des Chemins de Fer du Nord de l'Espagne, Procès verbaux des séances tenues par la reunión de Paris: 3-XI-1857.
} 
empresa corporativa, que, como explicó Chandler (1977), representó un avance cualitativo de la empresa capitalista. La estructura organizativa chandleriana se conformaba por una distribución jerarquizada en la cual el presidente y el consejo de administración se encontraban en la cúspide, mientras la base se hacía cada vez más ancha según se distribuían y subdividían las competencias. Del Consejo de Administración y del presidente dependía el gerente o director general, y éste, a su vez, tenía responsabilidad sobre los jefes de sección, que disponían de un variado número de trabajadores a su servicio (Vidal y Ortúñez: 2002).

Para controlar estructuras empresariales de tanta envergadura, y con una división del trabajo tan compleja, NORTE, al igual que las grandes ferroviarias españolas adoptó el modelo francés de gestión de empresas (Comín, et al., 1998: I, 150), un modelo organizativo muy burocratizado caracterizado por los principios de centralización, jerarquía, formalización y especialización. Tal sistema constituyó un método altamente efectivo de organizar a un gran número de personas y una forma muy eficiente de afrontar los requisitos administrativos de los sistemas sociales a gran escala. El reclutamiento de personal, la promoción y, en general, las reglas que definen las trayectorias laborales se configuraron de forma similar a como se hizo en las grandes redes francesas y, en general, europeas, esto es, sobre la base del mérito, la capacidad y la subordinación de los trabajadores a los objetivos de la empresa.

El diseño organizativo tuvo que ser el de las ferroviarias francesas porque el país vecino fue el principal proveedor de capital financiero ${ }^{588}$, de tecnología, de capital humano productivo cualificado y de puestos directivos y administrativos; sobre todo al principio cuando nada de esto existía en España (de los Cobos y Martínez Vara, 2009: 2).

Los primeros gerentes de NORTE fueron abrumadoramente extranjeros (Vidal: 1999), preferentemente ingenieros galos, si bien no tardaron en incorporarse españoles, aunque dentro de una oferta muy limitada debido a la escasez de centros de esta formación, a los que se fueron agregando contables provenientes de las Escuelas de Comercio y juristas. El primer español que accedió a la Dirección de NORTE fue Boix en 1908, los once anteriores habían sido franceses ${ }^{589}$. Es de destacar la clara motivación del Comité de Paris y de los accionistas franceses en que se mantuviera a los Directores de origen francés. Ridícula parece la interpretación que se dio a mediados del siglo XX a la decisión de las empresas, tan arduos debates internos, de mantener a Directores de origen galo: "Todos los Directores habían sido franceses por razón de costumbre, que el Estado español no quiso contrariar" (García Venero, 1948: 355).

El diseño organizativo de NORTE era el departamental francés. El sistema departamental es una forma centralizada de organización; los diversos agentes están especializados en los

\footnotetext{
${ }^{588}$ El capital social de las ferroviarias españolas era mayoritariamente de origen galo (Castro, 2007: 81-118). Hasta 1900 se invirtieron en los ferrocarriles españoles 2400 millones de pesetas, de los que 1.400 millones de pesetas era de origen francés (Tedde, 1991, tomo I: 305). En concreto, en el momento de su constitución NORTE y MZA era mayoritariamente de capital francés.

${ }^{589}$ Lo mismo ocurrió en MZA hasta la llegada de Maristany, también en 1908, con la excepción de Cipriano Segundo Montesinos y Estrada, nombrado director de MZA en 1869.
} 
trabajos de su departamento. El principio de especialización inherente a este sistema -dice Fenelon (1934)- es bueno, pero tiene el peligro de que la centralización pueda ser excesiva y los empleados acaben con una responsabilidad muy limitada ${ }^{590}$.

El concreto diseño organizativo era el departamental francés de NORTE estaba integrado por el Consejo de Administración, bastante protocolario (Carón: 1997), y el Comité de Dirección, que era el que realmente ostentaba el poder ejecutivo de las empresas. NORTE tuvo tres comités, uno en París (el que ratificaba las decisiones de fondo), el otro en Madrid, y, desde fines del siglo XIX, un tercero en Barcelona; el segundo y tercero supeditados al primero.

Por debajo del Consejo de Administración se situaba el Director General, encargado de ejecutar las decisiones tomadas por los órganos superiores, de coordinar las secciones de la compañía y de servir como canal de comunicación entre el Consejo de Administración y estas secciones ${ }^{591}$.

El Director general era la figura más relevante de la empresa ya que de él dependían la gestión y toma de decisiones cotidianas que llevaba a cabo el personal ejecutivo asalariado, siempre vigilado por el administrador delegado, que era el enlace con el Consejo de Administración.

Debido al importante volumen de capital francés que se invierte, NORTE creó un Comité en territorio francés que tenían reservada la competencia de resolver sobre ciertas funciones encomendadas al Consejo de Administración según los Estatutos.

NORTE reparte la toma de decisiones importantes- como la adquisición de inmovilizados, nuevas construcciones y temas financieros- entre dos Comités, uno en París y otro en Madrid $^{592}$. En una primera época, las decisiones importantes las tomaba el Comité de París ${ }^{593}$.Con el paso de los años, algunas de estas funciones fueron traspasadas al de Madrid, aunque en apariencia se mantuvieran en el Comité de París.

El Comité Ejecutivo - llamado también Comité de Dirección - estaba integrado por el Director general y dos Administradores (también podrían ser denominados Consejeros, pero en las Actas del Consejo de Administración prefieren aquella denominación).

El Comité de Madrid se componía de un presidente y cuatro vicepresidentes: con tres en representación de accionistas de Madrid, uno de Barcelona y uno de París. Los

\footnotetext{
${ }^{590}$ Sobre los peligros de la centralización excesiva de este modelo y de que los empleados acaben con una responsabilidad muy limitada, observese los certeros trabajos de Vidal (1996 y 1999).

${ }_{591}$ Matallana (1873: prefacio) realizó una excepcional exposición del diseño funcional de las compañías.

${ }^{592}$ En Biarritz se reunieron los Comités de París y Madrid, para tratar tres temas: Examen y preparación de las "Cuentas y situación financiera de la Compañía" correspondiente al ejercicio de 1903, Previsión de gastos ordinarios para el ejercicio 1904 y examen de los medios convenientes para que las relaciones entre los Comités de París y Madrid sean más continúas y activas, y se obtenga la más rápida preparación y resolución de los asuntos que han de serles sometidos (Acta ${ }^{\circ} 696$ del Libro de actas del Consejo de Administración de NORTE: 30 de enero de 1904).

${ }^{593}$ NORTE. Actas Comité de Madrid, 19 de mayo de 1881.
} 
administradores se repartían a partes iguales: cinco en representación de los accionistas del País Vasco y cinco de Madrid. En el Comité de Barcelona la representación era mayoritaria de Cataluña: cuatro de siete administradores, uno de la región valenciana y dos de Madrid.

El Comité de Barcelona se creó en 1893, añadiéndose a los que ya funcionaban en Madrid y París. El Comité de Barcelona se crea para dar respuesta a un cambio geográfico en el accionariado, pues Cataluña se convirtió en el mercado hegemónico en el origen de las acciones, desde fines del siglo XIX. Ante esta falta de poder, en 1905, un grupo de presión catalán hizo un llamamiento en la prensa de Barcelona para hacer frente común en la junta de accionistas $^{594}$. El 8 de junio de 1905 se celebró una Junta General de Accionistas de NORTE, donde se evidenciaron las diferencias en el nivel de descentralización de las líneas de la región catalana ${ }^{595}$, entre el Comité de Madrid y Barcelona ${ }^{596}$. El Comité de Barcelona nunca tuvo capacidad ejecutiva. Lo que sí se consiguió es que el Comité de Barcelona fuese adquiriendo progresivamente mucha mayor capacidad de decisión y de influencia en el proceso de toma de decisiones en la compañía ${ }^{597}$, al mismo tiempo que se trató de reducir el número de administradores en Madrid, equilibrando la representación según las distintas procedencias de los accionistas ${ }^{598}$.

A partir del 1 de junio de 1908 funcionó una Dirección consultiva compuesta de dos miembros, cuya residencia será la misma del Comité de París ${ }^{599}$. Las atribuciones de esta Dirección consultiva consistirán en cooperar con la Dirección de Madrid en su gestión para la buena marcha de la sociedad. Para ello existirá una correspondencia entre la Dirección de Madrid y la Dirección consultiva para que ambas estén al corriente de todos los asuntos que interesen a la compañía, intentándose dar, salvo en caso de urgencia, conocimiento de las propuestas antes de someterlas a los Comités. Las relaciones entre la Dirección de Madrid y la Dirección consultiva se harán más directas, por medio de viajes, para que puedan estudiar sobre el terreno, las medidas técnicas, financieras y administrativas, los programas de obras que deban ejecutarse, el material que debe adquirirse y en general todas las cuestiones relativas a la marcha y funcionamiento de la compañía. La Dirección consultiva en París estará compuesta por Mauricio Péreire y León Waldmann.

\footnotetext{
${ }^{594}$ Cfr. "La próxima Junta del NORTE", Gaceta de los Caminos de Hierro, 1905, p. 221.

595 Las exigencias del Comité de Barcelona eran constantes. Una carta oficial del Comité de Barcelona, firmada por el Señor Girona, propone cumplir los deseos de la "región catalana", sobre la necesidad de establecer un servicio directo de viajeros entre Barcelona, San Sebastián y la frontera francesa; el Director contesta que el servicio está sometido a estudio en la Dirección general de Correos, y que cree que pronto podrá darse satisfacción a "Cataluña" (Acta n ${ }^{\circ} 674$ del Libro de actas del Consejo de Administración de NORTE: 21 de marzo de 1902).

${ }^{596}$ MZA concedió un nivel de descentralización mayor a su división en Cataluña. MZA al fusionarse con TBF mantuvo una gestión descentralizada entre la Red Antigua y la Red Catalana, con dos Comités que disponían de competencias sobre sus ámbitos de actuación.

597 No ocurrió lo mismo en MZA, donde el accionariado catalán no conseguiría demasiada capacidad de maniobra, como señala Ortúñez (1997).

${ }^{598}$ Esto se convirtió en regla durante la década de 1920, al consolidarse el control de NORTE por parte de los bancos y del accionariado catalán y vasco (Vidal, 1999: 635).

${ }^{599}$ Los honorarios de la Dirección consultiva serán de 40.000 pesetas anuales a distribuir entre los dos miembros de la misma, a parte de los gastos de viaje que serán a cargo de la compañía.
} 
Desde enero de 1918, quedaron delimitadas las competencias entre el Comité de Madrid, integrado por sólo 15 miembros, y el de Barcelona, compuesto por siete ${ }^{600}$ Entre ambos aprobaban las decisiones de mayor relevancia a propuesta del Comité de Dirección — también llamado Ejecutivo - integrado por el director general y dos administradores que llevaban la gestión desde Madrid, cabeza de la explotación de la red.

En enero de 1918, tras la dimisión del cargo de presidente del Comité de Madrid que desempeñaba Antonio Borregón y a propuesta del presidente del Consejo de Administración Faustino Rodríguez San Pedro ${ }^{601}$ - se fusionaron ambas presidencias, que habían funcionado de forma autónoma desde 1864. Desde ese momento, el "Comité de Madrid de NORTE" era conocido también como "Comité Ejecutivo" o "Comité de Dirección". La unificación de ambas presidencias vino provocada por la entrada de los bancos en el capital social (Vidal Olivares, 1999: 638), pues ellos creían que así tendrían un mayor control de la explotación en momentos de dificultades en la compañía.

Por su parte, el Comité de París fue cediendo competencias y su papel se fue reduciendo a la representación del capital social en los mercados financieros europeos, pero sin demasiada capacidad de decisión (Comín, et al., 1998: 187). Esto es un gran cambio porque desde los orígenes de NORTE, el Comité de Paris había tenido gran capacidad de decisión.

Desde su origen hasta 1920 las decisiones importantes de NORTE las tomaba, o al menos las refrendaba el Comité de París ${ }^{602}$, aunque por supuesto, las opiniones de los Directores y administradores del Comité de Madrid eran tenidas en cuenta. Esto ocurrió así hasta la década de 1920, cuando el Comité de París fue cediendo competencias y su papel se fue reduciendo a la representación del capital social en los mercados financieros europeos, pero sin demasiada capacidad de decisión.

Coincidiendo con la españolización de los Directivos y del capital, y en parte como resultado de la aplicación del Estatuto ferroviario de 1924, los miembros de los Consejos de Administración de NORTE se especializaron mucho más, creándose Comités de dirección y

\footnotetext{
${ }^{600}$ Para la composición de los Consejos de Administración véase NORTE (1940) y el Universal Directory of Railways Official and Railway Year Book, London: The Directory Publishing Company Limited, 1890-1937.

${ }^{601}$ Faustino Rodríguez-San Pedro Díaz-Argüelles, el más importante presidente del Consejo de Administración de los Ferrocarriles del Norte, tuvo una gran importancia en la política española. Diputado por Alicante en las elecciones de 1884. En 1899 pasó al Senado como senador vitalicio, llegando a ser vicepresidente de dicha cámara. Posteriormente se convirtió en alcalde de Madrid. Fue ministro de Hacienda entre el 25 de marzo y el 20 de julio de 1903 en el gabinete Silvela. Entre el 5 de diciembre de 1903 y el 16 de diciembre de 1904, fue ministro de Estado en un gobierno Maura. Entre el 25 de enero de 1907 y el 21 de octubre de 1909, fue ministro de Instrucción Pública y Bellas Artes en el conocido como "gobierno largo" de Maura. Fue profesor de la Universidad Central de Madrid, académico de la Real Academia de Ciencias Morales y Políticas, presidente de la Unión Ibero-Americana. Como curiosidad podemos afirmar que es bisabuelo del exvicepresidente del gobierno y expresidente del Fondo Monetario Internacional Rodrigo Rato.

${ }^{602}$ El Comité de París era el reflejo de los capitales franceses atraídos a la compañía por James Rothschild. La distinción de un Consejo de Administración y un Comité de París ya se había producido en ferroviarias italianas con capital francés.
} 
financieros; de este modo los administradores estaban más vinculados a la tarea de gestión profesional que a la mera representación de las acciones que poseían o que representaban. La empresa ya venía experimentando este comportamiento desde los inicios del siglo, pero fue más notable durante los años de la dictadura del general Primo de Rivera. En MZA el cambio fue anterior, se produjo en los años 1917 y 1918.

Desde que la creación de la Comisión Mixta en 1906, la toma de decisiones se toma en este organismo por lo que la esfera de poder se traslada a un organismo ajeno a la estructura organizativa de NORTE.

El 27 de junio de 1906, NORTE y MZA tomaron un acuerdo que se mantuvo hasta 1925, cuando dejó de estar vigente. El contrato, denominado de "Sindicatura general de productos", regulaba el transporte combinado de ambas empresas. El acuerdo se basaba en crear un fondo común para los ingresos procedentes del tráfico en sus redes combinadas ${ }^{603}$. El aspecto más importante del nuevo pacto consistió en la creación de una Comisión Mixta de las dos compañías para efectuar un seguimiento del Convenio. Desde su constitución, la Comisión Mixta gobernó conjuntamente NORTE y MZA. Desde que se creó la Comisión Mixta, es posible hablar de un duopolio en el ferrocarril español. Además de las tarifas nacionales, también las compañías comenzaron a plantear acuerdos en sus relaciones internacionales, a medida que aumentaron los vínculos con los mercados exteriores, especialmente los de Europa central y Portugal (Vidal, 1995a; 1995b).

A partir de la creación de la Comisión Mixta, existieron cuatro organismos de dirección simultáneamente: Comité de Madrid, Comité de París, Comité de Barcelona y Comisión $\operatorname{Mixta}^{604}$.

Desde la constitución de la Comisión Mixta, el gobierno de la compañía se delegaba en un organismo externo a ella, que establecía sus líneas estratégicas, aunque sus organismos internos llevaran a cabo el gobierno diario de la compañía. Como ejemplo podemos encontrar que en 1908, el II Congreso de Economía Nacional impulsó una Asamblea Ferroviaria, en la que no quisieron participar ni NORTE ni MZA. Las pequeñas compañías explicitaron que la nacionalización de todo el sistema ferroviario era la única solución a su estado general de quiebra. Las dos empresas no participaron porque sus intereses estaban muy alejados de los de las pequeñas. Seguramente su motivación era intentar unir toda la red, pero no sustituyendo las empresas por el Estado, sino mantener unas únicas empresas privadas, ellas mismas. En este Congreso tomaron una decisión conjunta, con los mismos argumentos, tomando una posición de fuerza común.

NORTE y MZA también tuvieron una estrategia común frente al ministro de Fomento y el resto de compañías. Esto puede observarse el 28 de noviembre de 1919 cuando NORTE solicito al gobierno de una elevación de tarifas del 50\%, aunque NORTE creía que era necesario un 53\% (Acta ${ }^{\circ} 897$ del Libro de actas del Consejo de Administración de NORTE:

\footnotetext{
${ }^{603}$ Proyecto definitivo del contrato firmado por MZA y NORTE el 17 de mayo de 1906.

${ }^{604}$ Acta ${ }^{\text {o }} 760$ del Libro de actas del Consejo de Administración de NORTE: 30 de abril de 1909.
} 
28 de noviembre de 1919, Apartado II) y el 12 de junio de 1920 cuando se realizó una nueva solicitud de elevación de tarifas (Acta no 906 del Libro de actas del Consejo de Administración de NORTE: 12 de junio de 1920, Apartado III). Estas dos solicitudes realizadas al presidente del Consejo de Ministros fueron realizadas simultáneamente en las juntas generales de accionistas de NORTE y MZA.

Por otro lado, ante el Problema Ferroviario, NORTE y MZA tuvieron una estrategia común frente al ministro de Fomento (Acta $\mathrm{n}^{\circ} 917$ del Libro de actas del Consejo de Administración de NORTE: 10 de mayo de1921, Apartado III.5).

\subsection{Accionariado}

\section{Cuadro 37. Etapas en la evolución del accionariado de NORTE}

\begin{tabular}{|c|c|c|c|}
\hline & $\begin{array}{l}\text { Denominación } \\
\text { de la etapa }\end{array}$ & Periodo & Accionariado \\
\hline 1 & Capital inicial & $1858-1873$ & $\begin{array}{l}\text { Mayoría de capital social francés y belga } \\
\text { Péreire control absoluto. Ligera disminución del accionariado Péreire } \\
\text { desde } 1870\end{array}$ \\
\hline 2 & $\begin{array}{l}\text { Primera } \\
\text { españolización } \\
\text { del capital }\end{array}$ & $1874-1879$ & $\begin{array}{l}\text { Progresivo aumento del capital español, sobre todo vasco y catalán } \\
\text { (primero el catalán) }\end{array}$ \\
\hline 3 & $\begin{array}{l}\text { Primera } \\
\text { bancarización } \\
\text { del capital }\end{array}$ & $1880-1884$ & $\begin{array}{l}\text { Mayoría del capital social español, sobre todo de bancos. } \\
\text { Preferentemente capitales catalanes y vascos. } \\
\text { Profundización de la disminución del accionariado Péreire }\end{array}$ \\
\hline 4 & $\begin{array}{l}\text { Crisis bancaria } \\
\text { y bursátil }\end{array}$ & $1885-1886$ & Disminución del capital catalán \\
\hline 5 & Crisis financiera & $1887-1892$ & $\begin{array}{l}\text { Disminución capital de la familia Comillas; aumento del capital de las } \\
\text { empresas de su grupo y asociados }\end{array}$ \\
\hline 6 & $\begin{array}{l}\text { Atomización del } \\
\text { accionariado }\end{array}$ & 1893-1899 & $\begin{array}{l}\text { Pérdida de poder de los grandes tenedores de acciones. Atomización del } \\
\text { accionariado } \\
\text { Pérdida de poder del grupo del Marqués de Comillas } \\
\text { Aumento de poder de los Péreire }\end{array}$ \\
\hline 7 & $\begin{array}{l}\text { Segunda } \\
\text { españolización y } \\
\text { bancarización } \\
\text { del capital }\end{array}$ & $1900-1941$ & $\begin{array}{l}\text { Importancia de los intereses industriales en el accionariado } \\
\text { Mayor peso de la banca privada española } \\
\text { Españolización del accionariado, sobre todo vasco y catalán (más el } \\
\text { vasco) } \\
\text { Enfrentamientos entre el capital social francés y español }\end{array}$ \\
\hline
\end{tabular}

Fuente: Elaboración propia 
El cuadro 37 recoge las etapas en la evolución del accionariado de NORTE. El primer rasgo característico del accionariado de NORTE su progresiva españolización, sobre todo del País Vasco y Cataluña, del accionariado. Desde la mayoritaria participación del capital francés en sus primeros años de funcionamiento, la presencia de tenedores de acciones españoles fue acrecentándose progresivamente. Desde el punto de vista de la distribución geográfica, existieron dos oleadas en la "españolización del capital" 605 de la mayor empresa española: la primera -incipiente- en el periodo 1874-1879, y la segunda -definitiva- en el siglo XX (19001941).

Pero esta españolización no sólo debe estudiarse desde el punto de vista de una distribución geográfica, sino también desde una distribución funcional, pues se produjo un proceso claro de bancarización. Realmente en el periodo 1880-1884 se produjo la primera oleada de bancarización que luego tuvo dos réplicas: en la I Guerra Mundial y en el periodo 1930-1941. Por tanto, la empresa NORTE evolucionó desde una mayoritaria participación de capital francés en sus primeros años de existencia, a un capital social mayoritario de bancos españoles, preferentemente de capital catalán (el más importante en el siglo XIX), y de origen vasco (el más importante en el siglo XX).

Tras destacar los dos rasgos fundamentales, es posible observar siete etapas en la evolución temporal del accionariado.

La Compañía de los Caminos de Hierro del NORTE de España se creó oficialmente en Madrid el 29 de diciembre de 1858. El diseño original de la compañía estaba pensado para que las decisiones del gobierno de la empresa fuesen tomadas por la Junta General de Accionistas. Cada anuncio de la convocatoria de la Junta General de Accionistas era publicada en la Gaceta de Madrid y en varios periódicos ${ }^{606}$. La primera Asamblea General de la nueva compañía tuvo lugar en Madrid el 19 de enero de 1859.

En el momento de su constitución, el capital era de 380 millones de reales, formado por 200.000 acciones de 1.900 reales de valor nominal.

Como puede observarse en el cuadro 38, en ese momento NORTE tenía la mayoría de capital foráneo: aproximadamente el $70 \%$ de su capital fundacional estuvo en manos de extranjeros $^{607}$, franceses y belgas especialmente ${ }^{608}$.

\footnotetext{
${ }^{605}$ La consideración de este hecho como "nacionalización del capital de la mayor empresa española" fue realizada por Vidal (1999: 656). Parece más adecuado el término "españolización", para no confundirlo con el proceso de titularización de la compañía por parte del Estado, que podría denominarse "nacionalización".

${ }^{606}$ Acta n $^{\circ} 785$ del Libro de actas del Consejo de Administración de NORTE: 17 de marzo de 1911, Apartado III.

${ }^{607}$ Tedde (1978, II: 27), Wais (1987: 185-186) y Comín, et al. (1998: 182) asumían que el capital español era menor al $25 \%$.

${ }^{608}$ Véase la lista de reparto de acciones de NORTE según la escritura realizada el 29 de diciembre de 1858 en Madrid. Ella fue reproducida por Tedde (1978: 27).
} 
Cuadro 38. Porcentaje sobre el total de las acciones de NORTE presentes y representadas

\begin{tabular}{|c|c|c|c|}
\hline Reparto de las Acciones de NORTE & $\begin{array}{c}\text { Porcentaje en } \\
\text { la constitución } \\
1858 \\
\end{array}$ & $\begin{array}{l}\text { Porcentaje } \\
\text { en } 1901\end{array}$ & $\begin{array}{c}\text { Porcentaje } \\
\text { en } 1924\end{array}$ \\
\hline Sociedad General de Crédito Mobiliario Español & $26,4 \%$ & $0,6 \%$ & - \\
\hline Le Crédit Mobilier Français & $14,7 \%$ & $29 \%$ & - \\
\hline La Société Générale Belge & $10 \%$ & - & - \\
\hline Familia Péreire $^{609}$ & $8 \%$ & $23 \%$ & $1,8 \%$ \\
\hline Duque de Galliera & $7 \%$ & - & - \\
\hline Baron Seillières & $7 \%$ & - & - \\
\hline Banco de Bélgica & $5 \%$ & - & - \\
\hline Fould y Cia. & $4 \%$ & - & - \\
\hline J. J. de Uribarren y Cia. & $4 \%$ & - & - \\
\hline Carlos Calderón & $1,8 \%$ & - & - \\
\hline Marqués de Comillas & - & $5 \%$ & $0,8 \%$ \\
\hline Crédito Mercantil & - & $4 \%$ & - \\
\hline Banco Hispano Colonial & - & $4 \%$ & $1,7 \%$ \\
\hline Banco Urquijo (Marqués de Urquijo) & - & $2 \%$ & $10,6 \%$ \\
\hline Ferrer y Capella & - & $2 \%$ & - \\
\hline L. de Larramundi & - & $1,5 \%$ & - \\
\hline Leonardo Echevarría & - & $1,2 \%$ & - \\
\hline Banca Arnus y Garí & - & $12 \%$ & $12,5 \%$ \\
\hline Manuel Girona & - & $0,4 \%$ & - \\
\hline Banco de Vizcaya & - & - & $9 \%$ \\
\hline Ignacio Coll y Portabella & - & - & $6,1 \%$ \\
\hline Banco de Bilbao & - & - & $5,7 \%$ \\
\hline Banco Hispano Americano & - & - & $4,9 \%$ \\
\hline Banco Español de Crédito & - & - & $4,8 \%$ \\
\hline Ramón de la Sota y Aburto & - & - & $3,3 \%$ \\
\hline José Joaquín de Ampuero & - & - & $2,6 \%$ \\
\hline Julio de Arteche & - & - & $2,5 \%$ \\
\hline Domingo de Epalza & - & - & $2,5 \%$ \\
\hline Enrique de Zarate & - & - & $2,5 \%$ \\
\hline Juan Sánchez de León & - & - & $1,1 \%$ \\
\hline Banco Marsanz & - & - & $1,1 \%$ \\
\hline Banco Central de Madrid & - & - & $0,9 \%$ \\
\hline Compañía General de Tabacos de Filipinas & - & - & $0,7 \%$ \\
\hline Banco Sainz & - & - & $0,6 \%$ \\
\hline Banco de Santander & - & - & $0,4 \%$ \\
\hline Banco Mercantil de Santander & - & - & $0,4 \%$ \\
\hline \multirow[t]{2}{*}{ Otros minoritarios individuales } & $12,1 \%$ & $15,3 \%$ & $23,5 \%$ \\
\hline & $100 \%$ & $100 \%$ & $100 \%$ \\
\hline
\end{tabular}

Fuente: Elaboración propia a partir de Archivo de Protocolos de Madrid, escritura de 29 de diciembre de 1858, firmado por el notario Antonio V. Banco Vaamonde ${ }^{610}$

${ }^{609}$ Emile, Isaac y Eugenio en 1858; Viuda de Isaac, Emile y Gustave en 1901; Maurice en 1924. 
Hasta 1873 el accionariado de NORTE permanece estable, salvo una ligera disminución del peso de las acciones de la familia Péreire y un progresivo aumento del accionariado español $^{611}$.

NORTE no amplió apenas su capital inicial, pues cuando necesito recursos acudió a la financiación ajena, generalmente obligaciones. Los mínimos resultados contables hacían poco atractivas las ampliaciones de capital para los inversores, por lo que la compañía recurrió a obligaciones hipotecarias, más fáciles de colocar porque los inversores potenciales preferían esos títulos, al implicar menores riesgos. A cambio, la compañía incurrió en altos costes financieros puesto que la remuneración a los obligacionistas que consumieron gran parte de los ingresos generados por la explotación.

Aunque el capital no cambió cuantitativamente, cualitativamente sí varió, y es un aspecto fundamental para entender las modificaciones acontecidas en la dirección, organización, toma de decisiones y gestión de la compañía.

Tras la mayoritaria participación del capital francés en sus primeros años de vida, la presencia de tenedores de acciones españoles fue acrecentándose. El periodo 1874-1879 supone la primera etapa de "españolización del capital", eso sí incipiente, del accionariado de NORTE su progresiva españolización, sobre todo del País Vasco y Cataluña.

En el periodo 1874-1879 se produjo un importante cambio en la estructura del capital accionarial de la compañía ${ }^{612}$. Tras la incorporación de la línea de Alar del Rey a Santander en 1874, la fusión con la Compañía de Zaragoza a Pamplona y Barcelona ${ }^{613}$ en 1878, y la adquisición del ferrocarril de Tudela a Bilbao ${ }^{614}$ en 1879 , los inversores catalanes y vascos dispusieron a partir de entonces de mayor presencia en el capital de NORTE. Esta mayor presencia de capital vasco y catalán en el capital de NORTE se tradujo en un aumento de las presiones dentro del Consejo de Administración para variar estrategias y modificar la política de explotación general seguida hasta ese momento por la compañía. No obstante, las presiones no dieron muchos resultados.

Las absorciones de ferrocarriles y los consiguientes movimientos internos provocados entre los accionistas supusieron el acceso de nuevos propietarios. El resultado fue que en el periodo 1880-1884 se produjo una disminución del peso de las acciones de la familia Péreire y un

\footnotetext{
${ }^{610}$ Archivos de NORTE, Junta General de Accionistas de 25 de mayo de 1901, Caja 57; Archivos de NORTE, Junta General de Accionistas de 4 de octubre de 1924, Caja 68. Esta documentación es citada por Tedde (1978, Vol. II: 27).

${ }^{611}$ AHF, Archivos de NORTE, Caja 57.

${ }^{612}$ Este cambio de la estructura de capital fue puesto de relieve por Vidal Olivares (1997: 54).

${ }^{613}$ La Compañía de Zaragoza a Pamplona y Barcelona es fruto de la fusión de las de Barcelona a Zaragoza, en quiebra en 1866, y de Zaragoza a Pamplona. La primera de ellas, íntegramente de capital catalán.

${ }^{614}$ La construcción del ferrocarril de Tudela a Bilbao se había iniciado en 1856, a partir de una iniciativa de la Junta de Comercio de Vizcaya y con el apoyo explícito del Banco de Bilbao, creado simultáneamente. Sobre estos aspectos véase Ormaechea (1989: 3-42).
} 
progresivo aumento del accionariado español — aunque el Crédito General de Ferrocarriles aumentase su participación hasta un $85 \%^{615}$ - en un contexto de reducción temporal del total de acciones en circulación ${ }^{616}$. En este periodo, los cambios en la composición del capital de NORTE fueron muy relevantes. La suma de las acciones en manos de españoles se acercaba a las tres cuartas partes del capital de la compañía, que suponía una ruptura con la hegemonía francesa, vigente desde la fundación de la sociedad (Vidal, 1997: 65-66).

En el periodo 1880-1884 se produjo la primera oleada de bancarización. La empresa NORTE evolucionó desde una mayoritaria participación de capital francés en sus primeros años de existencia, a un capital social mayoritario de bancos españoles, preferentemente de capital catalán, pero sobre todo de origen vasco (Vidal, 1999: 7). Esta bancarización tuvo repercusiones importantes. En primer término, sobre la conformación de su Consejo de Administración -por tanto, en la estrategia global de la compañía-, y en segundo lugar, sobre la organización y gestión de la propia empresa. La entrada de nuevos administradores, coincidiendo con cambios profundos en la propiedad, como fueron los que tuvieron lugar en la década de 1880 (y posteriormente durante el primer tercio del siglo XX), condujo a una mayor profesionalización del órgano representante de la propiedad. Este movimiento, a su vez, conllevó la optimización progresiva de los recursos humanos que dirigían la compañía ferroviaria: la nueva propiedad estableció el reclutamiento de directivos más aptos y eficientes, entrenados en el negocio del transporte ferroviario y con capacidad para liderar el sector, a fin de obtener mejoras en los resultados. Aunque las medidas no tuvieron reflejo en la cuenta de explotación.

El periodo 1885-1886 se caracterizó por la considerable reducción del predominio catalán en el accionariado, provocado por la crisis bancaria y el consiguiente descalabro bursátil que sufrieron las acciones y otras formas de participación, sobre todo en el mercado de Barcelona.

Hasta entonces los bancos catalanes y los ahorradores individuales catalanes ${ }^{617}$, habían participado masivamente en operaciones bursátiles. Las bancas Arnús, Marsans, Garriga Nogués o Vidal-Cuadras fueron las que con mayor interés centraron su atención en la inversión en valores ferroviarios, así como los grupos financieros que nacieron al calor de la «fiebre financiera» de 1881-1882: Banco de Valls, de Tarrasa o de Sabadell. Por su parte, los bancos con mayor calado, como el Hispano Colonial o el Crédito Mercantil, se especializaron en la financiación industrial y en operaciones a largo plazo, preferentemente con el sector público y la compra de valores ferroviarios y de empresas marítimas ${ }^{618}$. La crisis acabó con

\footnotetext{
${ }^{615}$ El grupo financiero catalán Crédito General de Ferrocarriles, vinculado al Marqués de Comillas, amplio su cartera accionarial de NORTE gracias a su participación en el ferrocarril de Alsasua a Barcelona, que fue adquirido en 1878, pero sobre todo, con las anexiones por NORTE del San Juan de las Abadesas a Barcelona en 1880 y del Villabona a San Juan de Nieva en 1886.

${ }^{616}$ Estos datos proceden de las listas de accionistas asistentes y representados en la Junta de 1874, procedentes de la Fundación de los Ferrocarriles Españoles, Archivos de NORTE, Caja 57. Las analizó con mucho detalle Vidal (1999).

${ }^{617}$ De forma muy notable los empresarios del textil catalán como los Güell (Cabana, 1993: vol. 2).

${ }^{618} \mathrm{La}$ inversión de los intermediarios financieros en la compra de valores ferroviarios y de las empresas marítimas de esa época puede observarse en Sudriá (1982: 152). Para analizar la banca y el mercado de capitales
} 
una parte importante de la especulación desatada entonces, así como con la corriente inversora, que en Cataluña se había dirigido desde la agricultura hasta el crecimiento urbano, el comercio y, especialmente, la banca y los ferrocarriles (Pascual, 1991: 351-378) (Tafunell, 1991: 390-391) (Sudriá, 1994: 191-205).

En el periodo 1887-1892 se produjo una crisis financiera. En NORTE este periodo se caracteriza por la progresiva pérdida de participación que Claudio López Brú, segundo Marqués de Comillas, tuvo en el capital de NORTE. A la muerte de Antonio López y López (1817-1883), Primer Marqués de Comillas, éste tenía casi el 18\% del capital de NORTE. La participación del heredero Claudio López Brú en NORTE cayó al 11\% en 1887, el 7'3\% en 1890 y al 5\% en 1901. La pérdida de participación accionarial personal del heredero Claudio López Brú, segundo Marqués de Comillas, se fue compensando con la participación de las empresas participadas por su grupo, especialmente a través del Crédito Mercantil, el Banco Hispano Colonial y el Crédito General de Ferrocarriles ${ }^{619}$, así como con el aumento de participación de algunos de los banqueros particulares que estuvieron muy próximos a la estrategia empresarial de la familia López, tales como los hermanos Güell, Manuel Girona o José Carreras y Xuriach.

Las crisis financieras de los años ochenta golpearon con fuerza a las empresas vinculadas a los ferrocarriles y, entre ellas, las que formaban parte del entorno de Comillas. Así, el Crédito General de Ferrocarriles se liquidaba en 1890, dejando en suspenso muchas de las obras ferroviarias para las que había obtenido las correspondientes concesiones ${ }^{620}$.

El periodo 1893-1899 se caracteriza por una atomización del accionariado, un aumento de poder de los Péreire y una pérdida de poder del grupo Comillas. A pesar de la integración de la compañía de Barcelona a San Juan de las Abadesas y de la de Almansa a Valencia y Tarragona, en 1893, se produjo un retroceso en el accionariado de la compañía NORTE de los grandes tenedores de acciones, produciéndose un reparto de títulos entre residentes españoles y franceses, recuperando la familia Péreire el protagonismo anterior a las fusiones de finales de 1870 y confirmándose el ligero retroceso del grupo del Marqués de Comillas.

El retorno al protagonismo del grupo familiar de los Péreire en el accionariado de NORTE se explica por el aumento en su participación -ya sea directamente ${ }^{621}$ o con los intereses que representaban- en las ampliaciones de capital que se produjeron en la década de 1890. La depreciación que sufrió la peseta respecto al franco francés, y la caída de las cotizaciones de

en Cataluña durante el último tercio del siglo XIX, véase Tafunell (1991: 379-421). Para la estrategia seguida por los dos bancos citados dentro del grupo empresarial de su propietario, el Marqués de Comillas. Consultar Rodrigo y Alharilla (1996: 144-172).

${ }^{619}$ El Crédito General de Ferrocarriles había sido una de las sociedades financieras creadas por Antonio López y López, primer Marqués de Comillas. Con ella pretendió ampliar su influencia en el ámbito de los ferrocarriles (Rodrigo y Alharilla, 1996: 178-179; 1998: 97-99; 1999).

${ }^{620}$ Entre ellos, el ferrocarril de Alicante a Alcoy (Vidal Olivares, 1991: 162-163). Sobre las crisis financieras de la década de 1880, Tedde (1974, I: 283-286).

${ }^{621}$ En 1881 fallece Isaac Péreire. Sus acciones pasaron a manos de su viuda, de su hermano Emile y su hijo Gustave. 
los valores ferroviarios españoles en el mercado español y en el de París, permitió a los Péreire la compra a muy buenos precios, de títulos que iban a ser remunerados en francos, beneficiándose de la prima de cambio (Comín, et al., 1998: 185). La evolución de las acciones y las obligaciones en el mercado de París reflejaba la caída de las cotizaciones de los valores ferroviarios españoles, y en este contexto la adquisición a la baja de títulos que iban a ser remunerados con prima en el tipo de cambio constituía un buen negocio para los inversores que ya contaban con participación en el capital de la compañía NORTE ${ }^{622}$. La depreciación de la peseta provocó la exigencia de los obligacionistas de cobro de sus intereses en francos y no en pesetas como pretendía la compañía (Gómez Mendoza, 1989: 75-76). El grupo francés estaba en mejores condiciones que el accionariado español para realizar estas operaciones, lo cual explicaría que Comillas no sólo no comprase acciones nuevas — pues le resultarían más caras por la diferencia entre la peseta y el franco-, sino que disminuyera su participación ante la bajada que estaban experimentando las cotizaciones durante los años noventa en París ${ }^{623}$. La caída de cotizaciones permitió a los Péreire mantener el control de NORTE, mientras que Comillas salía del negocio ferroviario.

El periodo 1900-1929 se caracterizó por la irrupción de la nueva banca mixta española y los intereses puramente financiero-industriales en el accionariado ${ }^{624}$. Si bien la banca estuvo presente en NORTE desde su fundación, con banqueros individuales y con las sociedades de crédito, los cambios acaecidos en el sistema financiero español y el tránsito hacia la organización de un mercado de capitales más regulado después de la crisis de mediados de 1880 se reflejaron en su estructura del capital. El cambio de siglo provocó el surgimiento y la consolidación de una banca mixta, la cual tuvo entre sus objetivos la participación en el sector industrial y el ferroviario.

La segunda oleada- esta mucho más amplia que la primera- de bancarización de la estructura del capital de NORTE se produjo a partir de $1914^{625}$. La definitiva segunda etapa de españolización del capital de NORTE ${ }^{626}$, de principios de siglo coincidió con procesos

\footnotetext{
${ }^{622}$ La evolución de las cotizaciones de los valores de las compañías NORTE y MZA durante los años noventa, puede verse en Tedde (1978, II: 43-46).

${ }^{623}$ Este hecho también ocurría en España como demuestra Montero (1994: 87-91) al analizar las cotizaciones de los valores ferroviarios de las obligaciones del ferrocarril de Tudela a Bilbao en la Bolsa de Bilbao a lo largo de la década de 1890.

${ }^{624}$ La bancarización de NORTE comenzó con el nombramiento como Administrador de Conde de Serra. Hasta entonces la financiación había sido fundamentalmente originada por el capital de la familia francesa Péreire y la catalana Comillas. Desde ahora comenzará un proceso según el cual tiene más peso en la financiación las entidades bancarias españolas, sobre todo las situadas en las vascongadas. En la Memoria de 1906 aparece que para sustituir la vacante dejada por el fallecimiento de Manuel Girona, el Consejo propone nombrar al Sr Conde de Serra, Consejero de varias entidades bancarias "cuyo concurso nos será de gran utilidad dada su reconocida competencia" (NORTE: 1907: 34).

${ }^{625}$ Para Vidal Olivares (1999: 634) la bancarización se agudizó en los años de la I Guerra Mundial.

${ }^{626}$ Para poder concurrir en la Junta General de Accionistas de 1907 se presentan 226.092 acciones, de las cuales serán 13.770 acciones en Madrid, 60.867 en Barcelona y 151.455 en Bilbao (Acta $\mathrm{n}^{\circ} 736$ del Libro de actas del Consejo de Administración de NORTE: 30 de abril de 1907).
} 
similares en los grandes ferrocarriles españoles, incluido $\mathrm{MZA}^{627}$. La necesidad de renovar el material móvil y el de tracción ${ }^{628}$ a consecuencia de la brusca alteración de las condiciones de explotación durante la coyuntura bélica y la pérdida de protagonismo de los accionistas franceses, propiciaron la entrada de la gran banca española en NORTE (Vidal Olivares, 1999: 634).

En 1917, año en que termina la I Guerra Mundial, existían dos rasgos distintivos: mayor peso de la banca privada en la estructura del capital de NORTE y que Cataluña y el País Vasco se convirtieron en los mercados hegemónicos en el origen de las acciones. En primer lugar, los intereses directos de intermediarios financieros suman 42,7\%, destacando el Banco de Bilbao con 24,5\%, Banca Arnús y Garí con un 4,9\%, el Banco Español de Crédito con 3,4\% y el Banco de Vizcaya con un $3,2 \%$, frente al $12,8 \%$ de capital de la familia Péreire ${ }^{629}$. En segundo lugar, el origen de los depósitos fue Barcelona con el 39\% y Bilbao el 32, seguidas de París y Madrid con el 14,9 y el 13,7\%, respectivamente ${ }^{630}$.

El accionariado vasco supero al catalán progresivamente, pero cuando definitivamente quedó clara su fortaleza fue en 1919. La Junta General Ordinaria celebrada el 17 de mayo de 1919 despertó cierta expectación ${ }^{631}$ a causa de la actitud de los accionistas bilbaínos, cuya representación ostentaron los señores Santiago Ugarte, Victor Chavarri, Julio Arteche, Julio Hernández, Federico Echevarría, Domingo Epalza, Tomás de Urquijo y los señores Zárate y otros que ostentaban la representación de la Cámara de Comercio de Bilbao. De las 237.827 acciones representadas, el grupo bilbaíno ostentaba la representación de aproximadamente 100.000 de ellas. Este grupo tenía tanto poder que llegó a impugnar el Informe Anual presentado por el Consejo. La mayor importancia del capital vasco sobre el catalán en esos años tuvo su reflejo en una variación en la gestión de la compañía. En 1919 la Cámara de Comercio de Bilbao realizó gestiones ante NORTE, para que se aumentaran los servicios de trenes hasta Bilbao, destacando su presidente Tomás Urquijo, que se había firmado la escritura de cesión por parte de la Cámara de Comercio de Bilbao a la Compañía de los Caminos de Hierro del NORTE de España, de los terrenos adquiridos por la corporación vizcaína destinados a la nueva estación de mercancías, cuya construcción se llevaría a cabo con un anticipo reintegrable de los Bancos de Bilbao y de Vizcaya ${ }^{632}$.

\footnotetext{
${ }^{627}$ Eduardo Maristany, director de MZA, en el marco de la Conferencia Ferroviaria de 1905, afirmaba que en ese año la mitad del capital invertido en el sector era de procedencia nacional. (Maristany: 1905). Parte de esta españolización en el capital, en la Junta General de Accionistas y Consejo de Administración, fue utilizada como un sistema de defensa-justificación ante el poder político.

${ }^{628}$ Sobre el despegue de la industria de construcción de material ferroviario durante la I Guerra Mundial véase Cayón y Muñoz (1998).

${ }^{629}$ AHF Archivos de NORTE, Caja 62. Acciones presentadas en la Junta General de Accionistas del 12 de mayo de 1917.

${ }^{630}$ AHF Archivos de NORTE, Caja 62. Acciones presentadas en la Junta General de Accionistas del 12 de mayo de 1917. Gran parte de los intereses catalanes aparecen agrupados en la cartera de Ignacio Coll y Portabella que representaba el 13\% del capital y el de Conde de Torroella de Montgrí con el 3,1\% del capital.

${ }^{631}$ Gaceta de los Caminos de Hierro, 24 de mayo de 1919.

${ }^{632}$ Gaceta de los Caminos de Hierro, 24 de octubre de 1919.
} 
En 1924, alrededor del $45 \%$ de las acciones se encontraban bajo el control directo de instituciones financieras, especialmente las de capital vasco, y en menor medida, por las catalanas. El capital francés prácticamente se retiró, dejando el protagonismo fundamental al capital español. Este proceso de españolización del capital, ya era importante a comienzos del siglo, pero tras la Gran Guerra y durante la década de 1920 fue prácticamente total. En ello se traslucía el proceso de intervención creciente del Estado, que buscaba aumentar la participación del capital nacional en las principales compañías, así como tratar de provocar la fusión de las grandes empresas de ferrocarril (como hubiera sido normal entre NORTE y MZA). Este movimiento no era sino el reflejo de las tendencias existentes en los sistemas ferroviarios de Inglaterra o Francia ${ }^{633}$.

Haciendo un inciso, es posible afirmar que durante todo el periodo 1900-1924, las relaciones entre el capital español y francés en NORTE fueron malas. Desde la muerte del primer Marqués de Comillas, A. López López en 1883, fueron frecuentes los enfrentamientos entre el capital francés de los Péreire y el español de los Comillas. Los principales enfrentamientos se produjeron por la adquisición-construcción de líneas, por el nombramiento de directores y por la gestión de estos directores. En primer lugar, se produjeron divergencias a propósito de la adquisición de las compañías Asturias-Galicia-León, el fracaso de los proyectos de la línea Valladolid-Ariza y el intento fallido de hacerse con el ferrocarril de Tarragona a Barcelona y Francia (de los Cobos y Martínez Vara, 2009: 6). En segundo lugar, uno de los enfrentamientos más importante fue el que se produjo entre el Comité de París y el Marqués de Comillas, en representación del Comité de Barcelona, a propósito del nombramiento como Director General de Aubert propuesto por el Comité de París en 1901 tras la jubilación de Barat. Para sustituir a Aubert, NORTE manejó la idea de incorporar a Eduardo Maristany. La prensa se hizo eco de estos planes de NORTE para incorporar a Eduardo Maristany (Revista Minera, Metalúrgica y de Ingeniería. "Cambios de dirección en los ferrocarriles del Norte". 1904, p. 98). Por último, las divergencias se hicieron más acentuadas por el gravísimo accidente de Torremontalvo (junio de 1903), hecho que cuestionó la obsoleta forma de explotación de NORTE. Este incidente llevó a la dimisión del director Aubert en 1904.

El periodo 1930-1941, representa la agudización de la etapa de españolización y bancarización del capital ${ }^{634}$, sobre todo por los vascos, ya que "el capital de NORTE era dominado por los Bancos de Bilbao y de Vizcaya" (Wais, 1987: 257). El aumento del poder de la banca respecto a los años veinte era de cinco puntos porcentuales, ya que se había pasado del $44 \%$ en 1924 al $49 \%$ en vísperas del estallido de la Guerra Civil. Durante la década de 1930, el peso del capital vasco seguía siendo el más alto, ya que el $45 \%$ de los accionistas habían depositado sus acciones en el País Vasco; Cataluña seguía manteniendo el segundo lugar, con el 26\%, mientras que Madrid alcanzaba el 14\%.

\footnotetext{
${ }^{633}$ Este proceso ha sido resaltado por Gourvish (1980) y Caron (1973).

${ }^{634} \mathrm{La}$ idea de que en los años treinta el proceso de bancarización alcanzó su punto álgido es compartida por Vidal Olivares (1999: 638).
} 
Durante la década de 1930, el deterioro de los resultados de la explotación ${ }^{635}$, tras los beneficios de la década precedente, propició una profundización de la toma de participaciones de la banca con la crisis económica, en gran parte debido a que los pequeños accionistas deshicieron sus posiciones por la mala coyuntura económica que atravesó la II República.

Los ferrocarriles no habían mejorado ni sus infraestructuras ni su material móvil durante la década de 1930, pensando que los auxilios del Estado, que ya venían disfrutando desde el final de la Gran Guerra y con el Estatuto de 1924, vendrían a solucionar los problemas de gestión, financiación, así como el deterioro de la calidad de explotación.

Influyó también la cercanía del final de las concesiones para algunas de las grandes compañías. El estallido de la Guerra Civil adelantaría el resultado, y en 1941 la Ley de Ordenación Ferroviaria, que establecía los mecanismos de rescate previos a la nacionalización de la red y a la creación del organismo público RENFE, estimó una valoración de las compañías que excedía ampliamente el precio de mercado de las sociedades ferroviarias a comienzos de 1940. El rescate final aprobado por el régimen franquista y el pago a las compañías se hizo ${ }^{636}$, respetando los intereses financieros, que eran los que mayoritariamente predominaban en las compañías.

La composición del accionariado de NORTE y de su evolución a lo largo de la vida de la compañía tuvo influencia sobre las modificaciones experimentadas en los Consejos de Administración; a su vez, estas modificaciones tienen repercusiones sobre la gestión y la evolución estratégica de la empresa, en particular en la configuración de su estructura organizativa interna.

\footnotetext{
${ }^{635}$ La disminución de los ingresos por tráfico de NORTE a comienzos de los treinta fue de un 4,9\%, mientras que los salarios y otros beneficios sociales habían aumentado como consecuencia de las medidas tomadas por los primeros gobiernos de la II República. La compañía comenzó a experimentar serios apuros financieros, más graves a partir de 1934 (Tedde, 1978: 226-231).

${ }^{636}$ Los cálculos realizados por la comisión que estudió conjuntamente el demérito, esto es las pérdidas ocasionadas por la Guerra Civil y el retraso de la conservación, mostraban cómo el Estado franquista buscaba exonerar a las compañías de su responsabilidad por la mala gestión entre 1930 y 1936. De este modo, la nacionalización trataba de cargar el erario público con sobreprecios, indemnizando a los accionistas y obligacionistas por encima del valor real de sus propiedades. Sin duda, la gran banca, propietaria mayoritaria de las compañías NORTE y MZA, presionó para conseguir estos objetivos en un contexto muy favorable, como fueron los inicios de la dictadura de Franco (Muñoz, 1995: 50-80). Para Ortúñez (1999a: 511) al régimen de Franco no le quedó más remedio que asumir la nacionalización para garantizar el funcionamiento del sistema ferroviario.
} 


\subsection{Consejo de Administración}

\subsubsection{Actas del Consejo de Administración}

El Código de Comercio de 1885 estableció, como uno de los cuatro libros contables que necesariamente deben llevar los comerciantes, el libro de Actas, donde se deberían hacer constar todos los acuerdos tomados por las Juntas Generales de socios y los Consejos de Administración (artículo 33). Este libro debía contener los acuerdos que se tomaban por las compañías en juntas o por sus administradores, expresando la fecha, los asistentes, los votos emitidos y cualquier otra información que condujese al exacto conocimiento de lo acordado, debiendo estar debidamente firmada cada acta por gerentes, directores o administradores que estuvieran encargados de la gestión de la sociedad, o los determinados por sus estatutos o bases que la rigiesen (artículo 40).

En las Sesiones del Consejo de Administración de NORTE tenían derecho de asistir, y así lo hicieron en algún momento: presidente, administradores, secretario del consejo, director de la compañía, subdirectores de la compañía y miembros de la Dirección Consultiva (mientras que existió 1908-1914).

En 1908, el Consejo aprobó que las Sesiones ordinarias del Consejo se celebrarán en una fecha fija: el último viernes de cada mes, y si dicho día fuese festivo, el día hábil inmediatamente anterior (Acta $\mathrm{n}^{\mathrm{o}} 746$ del Libro de actas del Consejo de Administración de NORTE: 28 de febrero de 1908).

En cada una de las Sesiones del Consejo de Administración de NORTE se elabora un Acta. La estructura y contenidos del Acta van modificándose, ampliando cada vez más su contenido.

Hasta 1909, en cada Acta se aprueban siete documentos: Acta de la Sesión del Comité de Madrid, Acta de la Sesión del Comité de París, Acta de la Sesión del Comité de Barcelona, Acta de la Sesión del Comisión Mixta, Situación de Caja, Boletín de Recaudaciones y el Estado de Saldos de reparto del fondo común con MZA.

El Acta del Consejo de Administración refleja los acuerdos de este organismo, pero además da conocimiento de los cuatro documentos que permiten el gobierno de la organización (Acta de la Sesión del Comité de Madrid, Acta de la Sesión del Comité de París, Acta de la Sesión del Comité de Barcelona y Acta de la Sesión del Comisión Mixta), y los tres que ayudan a gestionar la empresa (Situación de Caja, Boletín de Recaudaciones y el Estado de Saldos de reparto del fondo común con MZA). Esto se hace cada vez con una estructura más ordenada y con unos mayores contenidos. 
El Acta del Consejo de Administración de NORTE de 30 de abril de 1909 presenta una gran novedad respecto a la exposición del documento. Por primera vez aparece ordenado con unos números romanos, que a su vez está dividido en número árabes. Esto permitirá citar los puntos que forman el documento (Acta $\mathrm{n}^{\mathbf{0}} 760$ del Libro de actas del Consejo de Administración de NORTE: 30 de abril de 1909).

A partir del 11 de junio de 1912, hay otra novedad respecto al contenido. El Acta de las Sesiones del Consejo de Administración aprueba ocho documentos: Acta de la Sesión del Comité de Madrid, Acta de la Sesión del Comité de París, Acta de la Sesión del Comité de Barcelona, Acta de la Sesión del Comisión Mixta, Situación de Caja, Cuenta general (de los productos y gastos de la explotación), Fondo Común (saldo del reparto de productos del fondo común con MZA), Productos (Boletín diario provisional de las recaudaciones) (Acta $\mathrm{n}^{\circ}$ 801 del Libro de actas del Consejo de Administración de NORTE: 11 de junio de 1912).

El cuadro 39 recoge la estructura de los Libros de Actas del Consejo de Administración de la compañía NORTE en el periodo 1906-1924. 
Cuadro 39. Estructura de los Libros de Actas del Consejo de Administración de NORTE en el periodo 1906-1924

\begin{tabular}{|l|}
\hline Número de Acta y fecha \\
\hline Enumeración de los presentes \\
Presidente \\
Miembros del Consejo presentes \\
Otros asistentes no miembros del Consejo (normalmente Director y Secretario General) \\
\hline I. Lectura del Acta Anterior \\
\hline II. Se da conocimiento de asuntos y documentos \\
Bienvenida a nuevos administradores \\
Actas del Comité de Madrid \\
Actas del Comité de Barcelona \\
Actas del Comité de París \\
Actas de la Comisión Mixta con MZA \\
Reales Decretos relacionados con la situación económica general y ferroviaria en particular \\
Situación de Caja \\
Reecaudaciones \\
Productos contabilizados en el último mes \\
Cuentas generales de explotación del último mes (indicando el importe total y la diferencia \\
con el año anterior) \\
Fondo Común con la compañía MZA en cada una de las decenas de cada mes \\
Domiciliación de Valores \\
Depósitos de títulos de la compañía \\
\hline III. Acuerdos tomados en la Sesión del Consejo \\
Obras de renovación y mejoras \\
Plazas convocadas \\
\hline IV. Nombramientos \\
Se levanta la Sesión \\
Firma del presidente del Consejo y un Administrador \\
\hline
\end{tabular}

Fuente: Elaboración propia

El nombramiento de los administradores de la compañía es complejo: lo propone el presidente, de conformidad con el Comité de Madrid, París y Barcelona, y el Consejo lo aprueba (Acta $\mathrm{n}^{\circ} 748$ del Libro de actas del Consejo de Administración de NORTE: 24 de abril de 1908). 
En NORTE fue tradición incorporar a los Directores generales de la empresa al Consejo de Administración, con la intención de beneficiarse de sus conocimientos de la sociedad, del que habían adquirido sobre las compañías competidoras y del que poseían sobre el sector ferroviario y de transporte en general $^{637}$.

\subsubsection{Componentes del Consejo de Administración}

Es posible distinguir varios períodos en la conformación de la estructura y composición de los miembros del Consejo de Administración de NORTE. Las distintas fases vienen a coincidir con los movimientos operados en la propiedad accionarial (cuadro 40). A su vez, el Consejo tendrá influencia directa en la estructura organizativa y contratación de Directores y demás personal.

\section{Cuadro 40. Etapas en la evolución del Consejo de Administración de NORTE}

\begin{tabular}{|l|l|l|}
\hline $\begin{array}{l}\text { Étapa } \\
\text { Periodo }\end{array}$ & Consejo de Administración & $\begin{array}{l}\text { Etapas del accionariado con la } \\
\text { que está relacionada }\end{array}$ \\
\hline $\begin{array}{l}\text { Primer } \\
\mathbf{1 8 5 8 - 1 8 7 3}\end{array}$ & $\begin{array}{l}\text { Primera etapa } \\
\text { Mayoría administradores } \\
\text { franceses y belgas fueron muy importantes }\end{array}$ & Incremento del número de administradores, llegando a \\
\hline $\begin{array}{l}\text { Segundo } \\
\mathbf{1 8 7 4 - 1 8 9 2}\end{array}$ & $\begin{array}{l}\text { Segunda, tercera, cuarta y quinta } \\
\text { etapa } \\
\text { Gran influencia de los accionistas catalanes y vascos }\end{array}$ & \\
\hline $\begin{array}{l}\text { Tercero } \\
\mathbf{1 8 9 3 - 1 8 9 9}\end{array}$ & $\begin{array}{l}\text { Presiones para buscar las alianzas con MZA } \\
\text { Mayor profesionalidad de los administradores }\end{array}$ & Sexta etapa \\
\hline $\begin{array}{l}\text { Cuarto } \\
\mathbf{1 9 0 0 - 1 9 4 1}\end{array}$ & $\begin{array}{l}\text { Reducción progresiva del número de administradores } \\
\text { cfr. cuadro 46) }\end{array}$ & Séptima etapa \\
& $\begin{array}{l}\text { Mayor profesionalidad de los administradores } \\
\text { Comité Ejecutivo más especializado y con más } \\
\text { vicepresidentes }\end{array}$ & \\
\hline
\end{tabular}

Fuente: Elaboración propia

${ }^{637}$ Para la composición de los Consejos de Administración véase The Directory Publishing Company Limited (1937) y NORTE (1940). 
En el apartado anterior se analizó la composición de su accionariado y de su evolución a lo largo de la vida comercial de la compañía. En el actual subapartado se analizan las modificaciones experimentadas en los Consejos de Administración ${ }^{638}$.

El Consejo de Administración de NORTE siempre fue representativo del órgano representante de la propiedad. Los dos rasgos más importantes del Consejo de Administración de NORTE es que estaba muy vinculado con los poderes económicos de la época, pero también estaba muy relacionado con los poderes políticos.

Cuando NORTE se constituyó en 1858, se fijaron en 22 el número de miembros del Consejo de Administración, elegidos por la Junta General de Accionistas.

Desde el principio estuvieron integrados por una mayoría de administradores nacionales, aunque el número de consejeros no nacionales era muy importante. Sobre todo en los primeros Consejos de Administración, donde hubo una presencia abrumadora de administradores no nacionales (recordemos que entre el $67-70 \%$ de su capital fundacional estaba en manos de franceses y belgas). No hubo un número de consejeros no nacionales mayor porque la Ley obligaba una mayoría cuantificada de administradores nacionales (Comín, et al., 1998: 182).

Los administradores españoles -que eran la mayoría- accedieron al Consejo representando a los bancos propietarios de la mayoría de las acciones, en su mayor parte vinculados al Crédito Mobiliario Español o al Crédit Mobilier Françáis ${ }^{639}$.

Hasta 1874, como el accionariado de NORTE permanece estable, también se estabiliza el Consejo de Administración, tanto en número como en composición. El Consejo de Administración no experimentó grandes cambios ni en cuanto al equilibrio interno de la propiedad de las acciones ni a la incorporación de miembros significativos. En esta etapa NORTE mantuvo entre sus administradores las conexiones con el llamado lobby colonial y con el ala moderada del liberalismo español, "para dar cabida tanto a los intereses de la burguesía harinera castellana y cántabra como a los artífices de la legislación ferroviaria durante el Sexenio revolucionario y la Restauración" (Vidal, 1997: 53; 1999: 629).

El primer gran cambio se produce al integrar tres administradores más a partir de 1874 a consecuencia de la incorporación de la línea de Alar del Rey a Santander.

En el año 1878 se produjo la fusión de la Compañía Zaragoza-Pamplona y Barcelona ${ }^{640}$ y la adquisición del ferrocarril de Tudela a Bilbao. Este proceso de fusiones y adquisiciones se

\footnotetext{
${ }^{638}$ Para la composición de los Consejos de Administración véase The Directory Publishing Company Limited (1937) y NORTE (1940).

${ }^{639}$ Sobre la fundación y actividades de esta sociedad financiera surgida con la legislación de sociedades de crédito del bienio progresista durante los años sesenta del siglo XIX véase Tortella (1982: 68-73).

${ }^{640}$ La Compañía de Zaragoza a Pamplona y Barcelona es fruto de la fusión de las de Barcelona a Zaragoza, en quiebra en 1866, y de Zaragoza a Pamplona. La primera de ellas, íntegramente de capital catalán.
} 
tradujo en una ampliación del número de administradores, llegando hasta 41, previa modificación de los Estatutos. Entre los nuevos administradores nombrados se encuentran el Marqués de Salamanca $^{641}$, Antonio López López, F. Sepúlveda, F. Rodríguez San Pedro, E. Güell y M. Girona (NORTE, 1940: 639-640).

No hubo movimiento en el número de administradores hasta 1893. En la etapa 1893-1899 los inversores catalanes y vascos dispusieron de mayor presencia en el capital de NORTE, lo que supuso a su vez en una mayor presencia en el Consejo de Administración de NORTE. Esto se tradujo en el comienzo de un proceso de aumento de las presiones dentro del Consejo de Administración para variar estrategias y modificar la política de explotación general seguida hasta ese momento por la compañía ferroviaria. El cambio de estrategia se manifestó en intentar tejer alianzas con las grandes compañías, sobre todo con MZA, en materia de $\operatorname{tarifas}^{642}$.

La integración de la compañía de Barcelona a San Juan de las Abadesas y de la de Almansa a Valencia y Tarragona, en 1893 supuso la incorporación de cinco administradores más, para representar los intereses de los accionistas valencianos.

El Consejo de Administración es un reflejo del poder de los accionistas y de los diferentes intereses que confluyen en los diferentes Comités, a su vez, el Consejo de Administración tiene influencia directa sobre el diseño organizativo de la empresa y la contratación de los directores de la compañía. Por un lado, el protagonismo creciente de la banca española en el accionariado de NORTE, acentuado desde comienzos del siglo XX, supuso un mayor grado de profesionalidad de los Consejos de Administración, al reducirse el número de consejeros y aumentar el peso de los profesionales de la gestión. Por otro lado, los ingenieros y directores generales de la explotación fueron incorporándose desde los años 1890, pero sobre todo, después de 1900: los casos de Jean Barat y Félix Boix, directores generales a finales del siglo XIX y durante el primer tercio del XX, constituyen dos ejemplos de la nueva situación.

Durante el periodo 1900-1941, el Consejo de Administración fue reduciendo su tamaño y especializando las funciones de sus administradores, como muestra el aumento de tres vicepresidencias y la creación del Comité de Barcelona. También se institucionalizó la gestión de NORTE con el establecimiento de la Comisión de Dirección o Ejecutiva. Estas reformas mejoraron la organización y facilitaron la fluidez de las órdenes y de la información corporativa entre el Consejo de Administración, la dirección y las distintas unidades productivas (Comín, et al., 1998: 188). El esquema organizativo de NORTE se hizo más

\footnotetext{
${ }^{641}$ José María de Salamanca y Mayol (Málaga, 23/05/1811-Madrid, 21/01/1883) fue una destacada figura aristócrata y un importante hombre de negocios, en la época de Isabel II. Sus inversiones fueron muy significativas en sectores como el ferroviario, la construcción, la banca o la inversión bursátil. Con respecto a MZA, antes de su constitución, el Marqués de Salamanca ya era concesionario de la línea ferroviaria MadridAlicante. Compatibilizó ser Consejero de NORTE y MZA.

${ }^{642}$ "En la misma línea de tratar de modificar las estrategias anteriores se tejieron alianzas más consistentes con las grandes compañías en competencia - sobre todo con MZA - en materia de tarifas, y al mismo tiempo se planteó la compra y ampliación de la red con algunas líneas importantes, como las de Lérida a Tarragona y las de Asturias, León y Galicia, entre otras" (Vidal Olivares, 1997: 64).
} 
complejo, acercándose ligeramente a las estructuras multidivisionales típicas de las grandes compañías estadounidenses y europeas, pero sin aplicarlo completamente. Este proceso, que coincidió con la españolización del capital, fue impulsado por los directivos que se habían ido formando en la propia empresa ferroviaria.

En 1905 se reorganiza el Consejo de Administración renombrando el cargo de Secretario, pasando a denominarse Secretario del Consejo, y lo que es más importante, reorganiza la Dirección y oficinas centrales estableciendo un orden jerárquico distinto que los años anteriores.

La reducción del número de consejeros atenuó parte de las críticas que recibían las ferroviarias, pues existía una corriente de opinión que consideraba que el número de consejeros de estas empresas era desproporcionadamente grande, de tal forma que "por mucho dinero que ganasen las ferroviarias siempre sería insuficiente para nutrir los bolsillos de tantos consejeros" (Ramos Oliveira: 1935). Este argumento puede ser cierto, pero lo que no es riguroso era la afirmación del mismo autor de que el poder e influencia de los administradores era enorme. Realmente era la ferroviaria la que buscaba a los administradores para fidelizar un poder político o el de una empresa suministradora o aliada, y eran los administradores los que aceptaban, de buen grado, por considerarse elegidos al recibir una alta remuneración.

NORTE participaba en el capital de empresas industriales españolas, directa o indirectamente, especialmente en el sector de la siderurgia y en las empresas de fabricación de material móvil. Esta participación interempresarial de acciones produjo -o al menos coincidió en el tiempouna estrecha relación entre las empresas, y sus proveedoras y clientes, por medio de los consejeros. Muchos consejeros de NORTE eran a su vez consejeros en otras empresas, varias de ellas industriales suministradoras.

Sin ir más lejos, durante la gestión de Barat como Directivo, y después como Director de NORTE, fue miembro del Consejo de Administración de la empresa "Altos Hornos de Vizcaya”, empresa con la que NORTE tuvo lazos importantes como suministradora.

La existencia de una gran cantidad de Consejos, Direcciones y altos puestos de responsabilidad permitió a algún consejero formar parte con simultaneidad de puestos en diversas empresas, acumulando retribuciones. Don Estanislao de Urquijo y Usía, tercer Marques de Urquijo, participó simultáneamente en el Consejo de Administración de 34 empresas, tanto ferroviarias como no ferroviarias (De Benito, 1935: 100); entre ellas, NORTE, Ferrocarriles de Carreño, Ferrocarril de Bilbao a Portugalete, Ferrocarril de Tánger a Fez, Ferrocarril Central de Aragón, Minas de Barruelo, Banco Hipotecario y Sociedad Inmobiliaria Valenciana ${ }^{643}$. Entre su influencia destaca que fue uno de los fundadores y principales accionistas de Altos Hornos de Vizcaya y de la Sociedad Española de Construcciones Metálicas, ambas proveedoras de NORTE.

\footnotetext{
${ }^{643}$ Los Anuarios financieros de los Bancos suministran información sobre ello.
} 
Esto fue así hasta el 9 de septiembre de 1932. La República aprobó la Ley de Incompatibilidades, que impedía a los administradores de las compañías acogidas al Estatuto de 1924 figurar en el Consejo de Administración si éstos tenían simultáneamente intereses en más de tres compañías ferroviarias o en empresas suministradoras de material móvil o fijo. A consecuencia de ello, doce consejeros de NORTE abandonaron el Consejo de Administración en mayo de 1933.

\subsubsection{Presidente del Consejo de Administración}

El cuadro 41 resume las etapas en la evolución de la Presidencia del Consejo de Administración de NORTE.

Cuadro 41. Etapas en la evolución de la Presidencia del Consejo de Administración de NORTE

\begin{tabular}{|l|l|}
\hline Periodo & Presidente \\
\hline $\mathbf{1 8 5 8 - 1 8 6 5}$ & $\begin{array}{l}\text { Presidente Carlos Manuel Calderón } \\
\text { Influencia de banqueros españoles, políticos, gestores del Estado y gestores del } \\
\text { ferrocarril }\end{array}$ \\
\hline $\mathbf{1 8 8 5 - 1 9 1 0}$ & $\begin{array}{l}\text { Presidente Francisco Serrano } \\
\text { Influencia del poder político } \\
\text { Presidente: Sagasta, Antonio Borregón y Rodríguez San Pedro nombramiento del } \\
\text { Influencia del poder político } \\
\text { Influencia del capital catalán } \\
\text { Equilibrio entre Régimen de Restauración y el segundo Marqués de Comillas }\end{array}$ \\
\hline $\mathbf{1 9 1 1 - 1 9 1 9}$ & $\begin{array}{l}\text { Antonio Borregón y Rodríguez San Pedro } \\
\text { Gran influencia del capital bancario vasco } \\
\text { Influencia del capital catalán y de los obligacionistas de Alar }\end{array}$ \\
\hline $\mathbf{1 9 2 0 - 1 9 3 5}$ & $\begin{array}{l}\text { Alonso Martínez } \\
\text { Profesionalización del Consejo de Administración }\end{array}$ \\
\hline
\end{tabular}

Fuente: Elaboración propia

El análisis de la estructura y composición de los miembros del Consejo de Administración de NORTE, debe completarse con la enumeración de cada una de las personas que han ocupado 
la presidencia del Consejo de Administración. Utilizar este cargo como indicador fue la norma en el estudio de la mayor parte de las compañías europeas (Carón: 1973) (Hughes: 1992) (Merger: 1992).

En el periodo 1858-1865 los presidentes eran banqueros españoles. La primera presidencia del Consejo de Administración recayó en Carlos Manuel Calderón (1858-1865), banquero del Crédito Mobiliario Español. Por su parte, las vicepresidencias fueron desempeñadas por Ignacio Olea, también del Crédito Mobiliario Español, e Isaac Péreire, conocido empresario de ferrocarriles, gas y minas en Francia. Además de los banqueros profesionales, españoles y extranjeros, el primer Consejo de Administración incluyó políticos bien relacionados con los círculos del poder y parlamentarios — Luis González Bravo-, así como profesionales con experiencia en la gestión administrativa del Estado, como Fermín Lasala ${ }^{644}$.

Con los problemas financieros surgidos a mediados de 1860 se recurrió para la Presidencia a un político de primera fila como el general Francisco Serrano y Domínguez, Duque de la Torre, con el objetivo de conseguir suficientes apoyos por parte del Estado. Este político, con mayor o menor intermitencia, se mantuvo como presidente entre 1866 y 1884. Su figura representaba el equilibrio perfecto entre el capital francés, la conexión colonial a través del negocio de los exportadores de harinas a las Antillas, materializado por la entrada de los obligacionistas del ferrocarril de Alar del Rey a Santander y los orígenes del sistema político de la Restauración canovista.

Las relaciones con el núcleo de los exportadores de harinas a las Antillas estaban representados por Serrano, ya que había sido capitán general de Cuba (1859-1862). También con el Marqués de Manzanedo, banquero vinculado a los negocios coloniales, y muy especialmente por su sustituto en el Consejo de Administración de NORTE: Manuel Gutiérrez de la Concha, Marqués de la Habana. Este último había sido capitán general y gobernador de la isla de Cuba en 1851-1852 y 1854-1859; ministro de Ultramar en 1864 y presidente del Consejo de Ministros en 1868 (Vidal Olivares, 1997: 53).

A partir de 1885 la importante presencia de capital catalán inaugura una nueva etapa en la que políticos de primera fila en el régimen de la Restauración, como Práxedes Mateo Sagasta, compartieron la presidencia del Consejo de Administración de NORTE en Madrid con hombres (tales como Faustino Rodríguez San Pedro) al servicio de Claudio López Brú, Segundo Marqués de Comillas, que presidia el Comité de Barcelona desde la década de 1880.

Durante el primer tercio del siglo XX se mantuvo la influencia del capital catalán y de los obligacionistas del ferrocarril de Alar, lo cual fue completado a partir de 1911 por la entrada del capital bancario vasco. Antonio Borregón y Rodríguez San Pedro se mantuvieron como máximos representantes hasta 1920.

\footnotetext{
${ }^{644}$ La relación completa de los componentes del primer Consejo de Administración de la compañía NORTE se puede encontrar en NORTE (1940: 633-634).
} 
En el periodo 1920-1935 presidiría el Consejo de Administración el Marqués de Alonso Martínez. Este periodo y este personaje representaba la culminación de la profesionalización de la empresa. El liberal Manuel Alonso Martínez había sido ministro de Hacienda en 18551856 en el gobierno de O'Donnell-Espartero y redactor de las disposiciones administrativas sobre ferrocarriles.

El cuadro 42 analiza los presidentes del Consejo de Administración de NORTE en el periodo 1900-1923. En esa época exisieron numerosas variaciones provocadas de las entradas y salidas de Faustino Rodríguez San Pedro de NORTE.

\section{Cuadro 42. Presidentes del Consejo de Administración de NORTE en el periodo 1900-1923}

\begin{tabular}{|l|l|}
\hline EJERCICIO CONTABLE & PRESIDENTE \\
\hline $1900-1901$ & Faustino Rodríguez San Pedro \\
\hline $1902-1903$ & Antonio Borregón \\
\hline $1904-1905$ & Faustino Rodríguez San Pedro \\
\hline $1906-1908$ & Antonio Borregón \\
\hline $1909-1918$ & Faustino Rodríguez San Pedro \\
\hline $1919-1923$ & Marqués de Alonso Martínez \\
\hline
\end{tabular}

Fuente: Elaboración propia

El libro de Actas de los Consejos de administración va recogiendo los cambios producidos en los cargos de Administradores en el periodo 1900-1924. Para analizar los nombramientos, dimisiones, ceses y fallecimientos de los administradores resultan valiosos, además de los libros de Actas, la documentación relativa a las juntas de accionistas y los expedientes de altos cargos de NORTE custodiados en el AHF. También en el Archivo del Ministerio de Hacienda se conservan Libros de actas y de juntas de accionistas de diferentes compañías privadas. Incluidos en la serie de la "Secretaría General de la Dirección NORTE" están los 128 expedientes sobre personal de altos cargos donde se hace referencia a los nombramientos, dimisiones, ceses y fallecimientos de los administradores de esta compañía entre 1859 y $1937^{645}$.

En 1902, Práxedes Mateo Sagasta vuelve a ser administración de NORTE, tras su renuncia anterior (Acta $\mathrm{n}^{\circ} 683$ del Libro de actas del Consejo de Administración de NORTE: 29 de diciembre de 1902), al año siguiente, en 1903, fallece (Acta $n^{\circ} 684$ del Libro de actas del Consejo de Administración de NORTE: 17 de enero de 1903).

Ante la renuncia de Faustino Rodríguez San Pedro en 1902, el Consejo nombra como Administrador a Estanislao de Urquijo, "cuyo conocimientos especiales en asuntos

\footnotetext{
${ }^{645}$ Vidal analizó las características y la evolución de los directivos de esta compañía a través de 33 expedientes, donde se recoge información de los cargos ocupados en el escalafón de personal, formación, procedencia u ocupaciones anteriores -si las hubiere-, salarios, jubilación y, ocasionalmente, correspondencia entre los diversos comités de la compañía en torno a nombramientos y ascensos (Vidal, 1997: 72-75).
} 
industriales y financieros ofrecen segura y lisonjera garantía de acierto". Además el Consejo acuerda que el nuevo administrador forme parte del "Comité ejecutivo de Madrid" (Acta $\mathrm{n}^{\circ}$ 700 del Libro de actas del Consejo de Administración de NORTE: 13 de mayo de 1904).

En 1904, Faustino Rodríguez San Pedro deja su puesto en el Ministerio, por lo que es propuesto Administrador de NORTE, en el puesto vacante de Sagasta, así como en el de presidente del Consejo de Administración (Acta $n^{\circ} 711$ del Libro de actas del Consejo de Administración de NORTE: 31 de marzo de 1905). Toma posesión el 10 de abril de 1905, depositando en las Cajas del Banco Español de Crédito 100 acciones de NORTE totalmente liberadas, para cumplir lo establecido en los Estatutos en lo que corresponde a la garantía del cargo de administrador (Carta del 2 de abril de 1905 de Faustino Rodríguez San Pedro dirigida al vicepresidente del Consejo) (Acta $\mathrm{n}^{\circ} 712$ del Libro de actas del Consejo de Administración de NORTE: 10 de abril de 1905).

En 1906, el presidente propone a Conde Foy para el puesto de administrador que deja por defunción Mauricio Bixio; el Consejo lo aprobó (Acta n 724 del Libro de actas del Consejo de Administración de NORTE: 30 de abril de 1906).

El mismo año, con arreglo al artículo 15 de los Estatutos, se reelige a los cargos del Consejo: presidente Faustino Rodríguez San Pedro y vicepresidentes Emilio Péreire, Marqués de Comillas, Antonio Borregón y Marqués de Luque (Acta n 726 del Libro de actas del Consejo de Administración de NORTE: 20 de mayo de 1906).

El presidente, por indicación de los Administradores de Barcelona, propuso para ocupar la vacante de Administrador por el fallecimiento de Manuel Girona, al Marqués de Robert ${ }^{646}$, "persona completísima en asuntos financieros y que goza de gran prestigio e importante posición en Barcelona" (Acta $\mathrm{n}^{\mathrm{0}} 727$ del Libro de actas del Consejo de Administración de NORTE: 15 de junio de 1906).

El mismo año, Francisco Rodríguez San Pedro vuelve a dimitir como Administración y presidente del Consejo de NORTE, porque por tercera vez es llamado a formar parte de un Ministerio, esta vez de Instrucción Pública (Acta $n^{\circ} 733$ del Libro de actas del Consejo de Administración de NORTE: 28 de enero de 1907).

En 1908, NORTE reelige como vicepresidentes del Consejo a Emilio Péreire, Marqués de Comillas, Borregón y Marqués de Luque, y miembros del Comité ejecutivo a Borregón, Marqués de Luque, Ibarra, Estibans y Urquijo (Acta n 750 del Libro de actas del Consejo de Administración de NORTE: 7 de mayo de 1908).

A propuesta del presidente, y de conformidad con el Comité de Madrid, París y Barcelona, el Consejo aprueba nombrar administradores de la compañía a Joaquín López Dóriga y Ruiz de

\footnotetext{
${ }^{646}$ Posteriormente, el Marqués de Robert manifiesta, ante el Comité de Barcelona, que desea figurar como Conde de Serra (Acta $n^{\circ} 730$ del Libro de actas del Consejo de Administración de NORTE: 20 de octubre de 1906).
} 
la Escalera, y a Manuel Arús y Fortuny, en las vacantes ocurridas por el fallecimiento del Marqués de Viena de la Sierra y José M. Semprún (Acta $n^{\circ} 748$ del Libro de actas del Consejo de Administración de NORTE: 24 de abril de 1908).

Los administradores difuntos reciben el dinero de los depósitos en garantía de su gestión cuando el Consejo lo apruebe y se hayan aprobadas las cuentas del ejercicio anterior, así ocurre con Marqués de Viesca de la Sierra, José María Semprún y Santos de Joasa (Acta ${ }^{\circ}$ 750 del Libro de actas del Consejo de Administración de NORTE: 7 de mayo de 1908).

Fallece el administrador de la compañía Manuel Estibans Goizueta (Acta $n^{\circ} 755$ del Libro de actas del Consejo de Administración de NORTE: 27 de noviembre de 1908).

El Consejo de NORTE aprobó la propuesta del Comité que acordó designar al administrador de la Compañía José Antonio de Ibarra para que sustituyera al difunto Manuel Estibans en la Comisión Mixta a partir del 29 de noviembre de 1908 (Acta ${ }^{\circ} 755$ del Libro de actas del Consejo de Administración de NORTE: 27 de noviembre de 1908).

Fallece el administrador Marqués de Luque. El presidente propuso para el cargo de los administradores de la compañía, de acuerdo con los Comités de París y Barcelona, a Federico Rivero O`Neale -para sustituir a Estibans- y Marqués de Alonso Martínez -para sustituir a Icasa- (Acta $\mathrm{n}^{\mathrm{o}} 756$ del Libro de actas del Consejo de Administración de NORTE: 29 de diciembre de 1908).

En 1909, el presidente da cuenta del acuerdo tomados por los Comités de Madrid, París y Barcelona para nombrar a Rafael Bernar y Llacer (Conde de Bernar) para el cargo de administrador, vacante por el fallecimiento del Marqués de Luque; el Comité acuerda dicho nombramiento (Acta $\mathrm{n}^{\mathrm{o}} 760$ del Libro de actas del Consejo de Administración de NORTE: 30 de abril de 1909).

Tras haber cesado las circunstancias que obligaron a su dimisión, Faustino Rodríguez San Pedro es reelegido administrador de NORTE y presidente de su Consejo de Administración. Esta decisión fue acordada por los Comités de Madrid, París y Barcelona, y aprobada por el Consejo (Acta $\mathrm{n}^{\mathrm{o}} 769$ del Libro de actas del Consejo de Administración de NORTE: 27 de noviembre de 1909, Apartado III).

En 19010, muere el administrador de la Compañía Antonio Borrel (Acta n 773 del Libro de actas del Consejo de Administración de NORTE: 31 de marzo de 1910, Apartado II).

El 12 de mayo de 1910, el 12 de mayo de 1911 y el 13 de mayo de 1912, son reelegidos Faustino Rodríguez San Pedro como presidente y Emilio Péreire, Marqués de Comillas y Antonio Borregón como vicepresidentes (Acta $n^{\circ} 776$ del Libro de actas del Consejo de Administración de NORTE: 12 de mayo de 1910, Apartado II) (Acta ${ }^{\circ} 788$ del Libro de actas del Consejo de Administración de NORTE: 12 de mayo de 1911, Apartado II) (Acta $\mathrm{n}^{\circ} 880$ 
del Libro de actas del Consejo de Administración de NORTE: 13 de mayo de 1912, Apartado II).

En 1910 fallece la Viuda de Isaac Péreire, en ese momento su hijo Gustavo Péreire era administrador de la Compañía, y Emilio Péreire vicepresidente (Acta $\mathrm{n}^{\circ} 777$ del Libro de actas del Consejo de Administración de NORTE: 6 de junio de 1910, Apartado II).

El Consejo nombró a Ignacio Coll y Portabella como administrador, que era uno de los principales accionistas de la compañía, afecto al Comité de Barcelona, tras el fallecimiento de Antonio Borrel (Acta $\mathrm{n}^{\circ} 777$ del Libro de actas del Consejo de Administración de NORTE: 6 de junio de 1910, Apartado III). Ignacio Coll y Portabella acepta el cargo por medio de una carta al Consejo fechada el 11 de junio de 1910.

El Consejo nombró a Fernando León y Castillo, Marqués de Mumi, como administrador, tras la vacante de Jean Barat (Acta $\mathrm{n}^{\mathbf{0}} 779$ del Libro de actas del Consejo de Administración de NORTE: 31 de septiembre de 1910, Apartado III). El Marqués de Mumi acepta el cargo por medio de una carta al Consejo fechada el 4 de octubre de 1910.

En 1911, tras la muerte del administrador Joaquín López Dáriga y Ruiz de la Escalera (Acta n 790 del Libro de actas del Consejo de Administración de NORTE: 1 de julio de 1911, Apartado II) el Consejo nombró en su puesto, a propuesta del presidente, a Eduardo Cobian y Roffignac para el cargo de Administrador de la Compañía (Acta ${ }^{\circ} 794$ del Libro de actas del Consejo de Administración de NORTE: 23 de diciembre de 1911, Apartado III.3).

El 23 de diciembre de 1911, el Consejo de Administración designó al Marqués de Alonso Martínez, Administrador de la Compañía, para formar parte del Comité de Madrid (Acta $\mathrm{n}^{\circ}$ 794 del Libro de actas del Consejo de Administración de NORTE: 23 de diciembre de 1911, Apartado III.2). Esta decisión fue aprobada por el Comité de París el 27 de enero de 1912 (Acta del Libro de actas del Comité de París: 27 de enero de 1912).

El 28 de febrero de 1913, el Consejo de Administración designó a Mauricio Péreire, presidente del Comité de París, para desempeñar el cargo de vicepresidente del Consejo, vacante por la defunción de su padre Emilio Péreire (Acta ${ }^{\circ} 809$ del Libro de actas del Consejo de Administración de NORTE: 28 de febrero de 1913, Apartado IV).

El 23 de abril de 1913, el Consejo de Administración nombró a Emiliano Ruiz Valarino para el cargo de administrador de la compañía, para sustituir al fallecido Federico Rivero O`Neal (Acta ${ }^{\circ} 811$ del Libro de actas del Consejo de Administración de NORTE: 23 de abril de 1913, Apartado III).

El 23 de abril de 1913, el Consejo de Administración suprime a partir del 1 de mayo de 1914, la Dirección Consultiva, que fue nombrada por el propio Consejo de Administración el 7 de mayo de 1908. Esta decisión se tomó con motivo del fallecimiento de León Waldmann y del pase a la Presidencia del Comité de París de Mauricio Péreire. En lugar de la Dirección Consultiva se crea en el Comité de París una Comisión Consultiva especial formada por el 
presidente de dicho Comité y por otro Administrador del mismo (Acta $\mathrm{n}^{\circ} 811$ del Libro de actas del Consejo de Administración de NORTE: 23 de abril de 1913, Apartado III).

El mismo año, el Comité de París envió una carta al Consejo de Administración fechada el 15 de mayo de 1913 donde manifiesta el nombramiento del Administrador Marqués de Alonso Martínez para el cargo de vicepresidente del Consejo (Acta ${ }^{\circ} 814$ del Libro de actas del Consejo de Administración de NORTE: 3 de junio de 1913, Apartado II).

El Comité de París envió una carta al Consejo de Administración fechada el 15 de mayo de 1913 donde manifiesta el nombramiento del administrador Emiliano Ruiz Valarino para formar parte del Comité de Madrid (Acta $\mathrm{n}^{\circ} 814$ del Libro de actas del Consejo de Administración de NORTE: 3 de junio de 1913, Apartado II).

El 20 de julio de 1916, el Consejo de Administración da conocimiento del nombramiento del Conde de Sert y Conde de Gamazo, afectos al Comité de Barcelona, para el cargo de administrador de NORTE. (Acta ${ }^{\circ} 811$ del Libro de actas del Consejo de Administración de NORTE: 20 de julio de 1916, Apartado II). Estos nombramientos se hicieron para sustituir a los fallecidos Manuel Arnús y José Carreras. (Carta del Comité de Barcelona al Consejo de Administración: 11 de mayo de 1916) (Carta del Comité de París al Consejo de Administración: 13 de mayo de 1916).

El 23 de febrero de 1917, el Consejo de Administración nombró a José Luís Villabaso para el cargo de administrador de la compañía, para sustituir al fallecido Ricardo de Arellano (Acta n ${ }^{\circ} 860$ del Libro de actas del Consejo de Administración de NORTE: 23 de febrero de 1917, Apartado IV).

El 2 de julio de 1917, el Consejo de Administración nombró de nuevo, tras cesar las causas que motivaron sus dimisiones de 27 de abril de 1917, como administradores de la compañía a Eduardo Cobián Roffignac y a Emiliano Ruiz Valarino (Acta ${ }^{\circ} 866$ del Libro de actas del Consejo de Administración de NORTE: 2 de julio de 1917, Apartado V).

En 1919 comienza la pérdida del poder predominante de la banca vasca, y eso se observa en el nombramiento de los administradores. En este año se nombraron tres nuevos administradores: José Joaquín de Ampuero, Tomás Urquijo y Carlos Prado. Estos nombramientos no fueron los que propusieron el grupo de Bilbao por medio del Señor Ampuero. El presidente del Consejo de Administración Rodríguez San Pedro se acogió a un defecto de forma para no realizado (Acta $n^{\circ} 894$ del Libro de actas del Consejo de Administración de NORTE: 12 de julio de 1919, Apartado II).

El 29 de septiembre de 1919, el Consejo de Administración nombró de nuevo, tras cesar las causas que motivaron su dimisión anterior, al Conde de Gamazo para el cargo de 
Administrador de la compañía (Acta n ${ }^{\circ} 895$ del Libro de actas del Consejo de Administración de NORTE: 29 de septiembre de 1919, Apartado IV).

El 30 de octubre de 1919, el Consejo de Administración nombró a Enrique de Zárate y Gastón Guiot para el cargo de Administrador de la compañía, para sustituir a los fallecidos José Luís de Villabaso y Agustín Bestel (Acta n 896 del Libro de actas del Consejo de Administración de NORTE: 30 de octubre de 1919, Apartado III).

El 30 de marzo de 1920, el Consejo de Administración nombró al Marqués de Alonso Martínez como presidente del Comité de Madrid, al Marqués de Urquijo como vicepresidente del Consejo, a Valentino Corbeña, José Joquín Ampuero y Tomás de Urquijo como miembros del Comité de Madrid, y finalmente, a Felix Boix, como administrador y simultaneamente para formar parte del Comité de Madrid (Acta n 902 del Libro de actas del Consejo de Administración de NORTE: 30 de marzo de 1920, Apartado II).

El 26 de abril de 1920, el Consejo de Administración nombró a Joaquín Ampuero para el cargo de Administrador de la compañía, para sustituir al dimitido Conde de Bernat (Acta ${ }^{\circ}$ 903 del Libro de actas del Consejo de Administración de NORTE: 26 de abril de 1920, Apartado III).

El 26 de abril de 1920, el Consejo, oyendo los requerimientos de los Comités, decidió crear un nuevo cargo, denominado Delegado del Consejo cerca de la Dirección. En ese primer momento decidieron designar para dicho cargo al presidente del Consejo Marqués de Alonso Martínez (Acta n ${ }^{\circ} 903$ del Libro de actas del Consejo de Administración de NORTE: 26 de abril de 1920, Apartado III).

El Consejo nombró a Boix como Administrador-Director (Acta n ${ }^{\circ} 906$ del Libro de actas del Consejo de Administración de NORTE: 12 de junio de 1920, Apartado III).

El 29 de octubre de 1920 se incorporan como administradores los señores Soto y Arteche (Acta n 906 del Libro de actas del Consejo de Administración de NORTE: 29 de octubre de 1920, Apartado I).

De igual forma, el 29 de octubre de 1921 se incorporan como administradores los señores Valentín Ruiz Senén y Juan Sanchez de León e Igual (Acta ${ }^{\circ} 915$ del Libro de actas del Consejo de Administración de NORTE: 29 de octubre de 1921, Apartado I).

Para observar la relación entre el accionariado y la composición del Consejo de Administración, y el nombramiento del presidente del Consejo, y a su vez, la consiguiente relación de todo ello con la contratación de directores y subdirectores el mejor ejemplo es López Brú (1855-1925), segundo Marqués de Comillas. 
Hasta la década de 1880 el Consejo de Administración tenía una elevada presencia de extranjeros, preferentemente franceses, y los directores, responsables de la transmisión y ejecución de las órdenes emanadas de él, también fueron franceses. La llegada de Barat a la dirección en 1881, que duró hasta 1901 produjo un incremento del número de ejecutivos españoles. Desde entonces, los inversores españoles van a disponer de una mayor presencia en el Consejo de Administración. Entre ellos destaca C. López Brú (1855-1925) segundo Marqués de Comillas por la participación accionarial que concentraba, en su persona y el capital participado por su grupo, más del $40 \%$ del accionariado.

C. López Brú (segundo Marqués de Comillas) tenía una concepción de la empresa tradicional, familiar e impregnada de la filosofía católica (de los Cobos y Martínez Vara, 2009: 7). Tuvo gran ascendiente personal sobre los gestores de las empresas de su propiedad o en las participadas por el grupo, lo que le permitió influir poderosamente en sus decisiones, incluso por encima de lo que representaba su propiedad. Esto ocurrió en NORTE, donde al finalizar la I Guerra Mundial, poco quedaba del interés ferroviario del grupo Comillas, sin embargo, todo parece indicar "que pocas decisiones se tomaban sin su consentimiento, directamente o a través de sus poderosos hombres cercanos a sus efectos, muy en particular el ubicuo y todopoderoso maurista F. Rodríguez San Pedro" (de los Cobos y Martínez Vara, 2009: 7), asiduo presidente del Consejo de Administración de NORTE y hombre de confianza de López Brú. El destino de Faustino Rodríguez San Pedro estuvo siempre ligado a los marqueses de Comillas con quienes compartía el mismo celo apostólico empresarial (Fontela, 2005: 154).

La elección de hombres de confianza como Rodríguez San Pedro es coherente con la forma de gobernar los negocios de López Brú. Su pretensión era basarse en un cuadro burocrático compuesto de hombres de máxima confianza (administradores), cuya lealtad se valoraba más que el conocimiento y habilidades de los expertos técnicos (gerentes profesionales). Esta práctica es errónea para dirigir grandes empresas.

Rodríguez San Pedro era asturiano y se trasladó muy joven a Madrid, estableciendo un bufete desde el que se vinculará a las élites políticas y empresariales del país. Ingresó en el Consejo de Administración de NORTE en 1878, cuando tuvo lugar la fusión de NORTE con el ferrocarril Zaragoza-Pamplona-Barcelona. En 1894 alcanza la presidencia del Consejo de Administración de NORTE. Fue alcalde de Madrid y ocupó tres carteras ministeriales (Hacienda, Estado e Instrucción Pública) en los gobiernos de Maura.

Cada vez que Rodríguez San Pedro fue llamado por la Corona para ser ministro, dimitía de Administrador de NORTE, vicepresidente de NORTE y presidente del Comité de Madrid, para volver a ser reincorporado cuando cesaban sus funciones (Acta $\mathrm{n}^{\circ} 686$ del Libro de actas del Consejo de Administración de NORTE: 31 de marzo de 1903).

En 1932, la II República aprobó la Ley de Incompatibilidades (9 de septiembre de 1932), que impedía a los administradores de las compañías acogidas al Estatuto de 1924 figurar en los Consejos de Administración si éstos tenían simultáneamente intereses en más de tres compañías ferroviarias o en empresas suministradoras de material móvil o fijo. A 
consecuencia de ello, 12 administradores de NORTE abandonaron el Consejo de Administración en mayo de 1933.

\subsection{Directores}

Desde el punto de vista de la gestión, el elemento clave de esta estructura empresarial eran los directivos, quienes mantuvieron una alta movilidad en sus puestos.

NORTE utiliza el concepto "Directores de la Compañía" para denominar al conjunto de personas integrado por el Director, el Director adjunto y los Subdirectores (Acta $\mathrm{n}^{\mathrm{o}} 727$ del Libro de actas del Consejo de Administración de NORTE: 15 de junio de 1906). Este término "Directores de la Compañía" es asimilable al moderno de "Directivo" (executive o manager en inglés) que recoge a todos los miembros de la dirección.

Para analizar los nombramientos, dimisiones, ceses y fallecimientos de los directores resultan valiosos los libros de Actas de los Consejos de administración, la documentación relativa a las juntas de accionistas y los expedientes de altos cargos de NORTE custodiados en el AHF. También en el Archivo del Ministerio de Hacienda se conservan Libros de actas y de juntas de accionistas de diferentes compañías privadas ${ }^{647}$.

Siendo una compañía extranjera, y dada la inexperiencia en la materia de los ingenieros y técnicos españoles, la construcción y posterior explotación de las líneas fue dirigida, por expertos extranjeros: ingenieros franceses traídos de las sociedades matrices del país vecino. La cabeza de la gestión de NORTE se organizó en una Dirección General que fue ocupada al principio por un francés.

A finales del siglo XIX hubo un progresivo aumento del accionariado español dejando sentir un creciente interés por el reclutamiento de altos ejecutivos hispanos con preferencia a los extranjeros, que desde los comienzos de la compañía habían acaparado los puestos directivos. A pesar de la mayor relevancia de los accionistas españoles en el Consejo de NORTE, los administradores de París mantuvieron el nombramiento de directores franceses hasta 1908.

La trayectoria seguida por NORTE en la contratación de sus directivos no fue diferente a la mostrada por la mayor parte de las empresas ferroviarias europeas. Los puestos directivos fueron desempeñados por aquellos que habían participado en la fase inicial de la construcción de la compañía, y posteriormente en la puesta en marcha de la explotación, pero a medida que se fue necesitando ampliar la plantilla debido al aumento del tráfico y de la extensión de la red, se fueron jerarquizando los puestos directivos de acuerdo con un organigrama general (Vidal, 1999: 649).

\footnotetext{
${ }^{647}$ Vidal (1997: 72-75) analizó las características y la evolución de los directivos de esta compañía a través de 33 expedientes, donde se recoge información de los cargos ocupados en el escalafón de personal, formación, procedencia u ocupaciones anteriores -si las hubiere-, salarios, jubilación y, ocasionalmente, correspondencia entre los diversos comités de la compañía en torno a nombramientos y ascensos.
} 
En los primeros años de explotación los altos directivos de NORTE estuvieron mejor pagados que los de MZA, siendo además más numerosos y con una jerarquía algo más escalonada que MZA (Saénz Ridruejo, 1990: 366). Los directores gozaban de una indemnización por objetivos que, eventualmente, podía venir acompañada de gratificaciones. También se fue introduciendo otras ventajas como los complementos para vivienda, especialmente desde fines del siglo XIX, así como el abono de las remuneraciones en francos, cuando la depreciación de la peseta afectó a los directivos de origen francés. Durante el siglo XX se mantuvo, en términos generales, la mayor remuneración de los ejecutivos de NORTE sobre la competencia $^{648}$.

La política salarial de NORTE siguió el principio de sueldos diferentes para cargos similares, en función de la trayectoria profesional anterior para cada directivo, para retener a sus propios ingenieros formados en la empresa y para contratar personal competente en el mercado (Comín, Martín, Muñoz, Vidal, 1998: 190).

NORTE, mucho más que MZA, utilizó la maniobra de contratar especialistas procedentes de otras empresas ferroviarias. En general, los directivos que provenían de otras compañías percibieron en NORTE mayores salarios y ascendieron más rápidamente en el escalafón de la compañía, que los que desarrollaron su carrera siempre en NORTE (Vidal, 1999: 650). A esto hay que añadir los directivos que entraban a trabajar en NORTE derivados de los procesos de fusión y absorción de otras ferroviarias.

En consonancia con la composición de la propiedad de la compañía, NORTE trazó sus planes de puesta en marcha de la construcción y posterior explotación de las líneas sobre la base de un cuerpo de directivos franceses, con formación en ingeniería, traídos de las sociedades matrices.

El procedimiento de nombramiento de los cargos está plenamente establecido. La designación de los subjefes de explotación la realiza el Consejo, a propuesta del Comitét ${ }^{649}$.

Como aparece en el cuadro 43, en el periodo 1858-1880 los directores se dedicaban fundamentalmente a la construcción. A partir de 1881, coincidiendo con el nombramiento de Barat, el director, no sólo se dedica a la construcción, sino que empieza a dedicarse a la gestión. A partir de 1908 los directores se dedicaban fundamentalmente a la gestión.

\footnotetext{
${ }^{648}$ Según los datos recopilados por E. P. Juez Gonzalo (1992: 198-304), los salarios de director, directores adjuntos, subdirectores e ingeniero jefe de División y Servicio eran algo mayores en NORTE que en MZA. Vidal Olivares (1997: 88) resalta que en NORTE los directores franceses de comienzos del XX, León Waldman y Bachy, disfrutaron de mayores salarios (56.000 pesetas cada uno) que el propio Barat, quien al jubilarse en 1901 percibía 50.000 anuales. Este era el mismo salario que tenía- en 1908- Maristany cuando se hizo cargo de la Dirección General de MZA.

${ }^{649}$ Acta n 746 del Libro de actas del Consejo de Administración de NORTE: 28 de febrero de 1908.
} 


\section{Cuadro 43. Evolución de los directores de NORTE}

\begin{tabular}{|l|l|}
\hline Periodo & Dirección \\
\hline $\mathbf{1 8 5 8 - 1 8 8 0}$ & Directores franceses \\
& Dedicados a la construcción \\
\hline $\mathbf{1 8 8 1 - 1 9 0 7}$ & Directores franceses \\
& Dedicados a la construcción y a la gestión simultaneamente \\
\hline $\mathbf{1 9 0 8 - 1 9 4 1}$ & $\begin{array}{l}\text { Directores españoles } \\
\end{array}$ \\
& Dedicados a la gestión \\
\hline
\end{tabular}

Fuente: Elaboración propia

Como aparece en el cuadro 44, hasta el 1 de junio de 1908 todos los directores de NORTE fueron de nacionalidad francesa, a partir de esa fecha todos son españoles.

La formación de los directores franceses era la usual de los ingenieros franceses, por lo que estuvieron más preocupados por la construcción de la infraestructura, las anexiones de nuevas líneas y por los aspectos técnicos de la explotación, que por la gestión empresarial del negocio. La gestión cotidiana de la explotación fue encomendada a cuadros medios, en su mayor parte jóvenes franceses reclutados desde 1860; éstos fueron escalando posiciones y especializándose en la gestión comercial, realizando un aprendizaje fundamentalmente práctico.

Gran parte de estos directores habían trabajado en las compañías galas vinculadas a los hermanos Péreire, tales como el ferrocarril de Saint Germain. Más tarde se trasladaron a España, para consolidar su carrera profesional y aplicar sus conocimientos. Después se trasladaron de nuevo a Francia para terminar su carrera en los ferrocarriles franceses (Ribeill, 1993: 299-334). Este comportamiento provocó que entre 1860 y 1881 la permanencia media en el cargo de director fuese de tan sólo tres años.

\section{Cuadro 44. Directores Generales de NORTE}

\begin{tabular}{|l|l|}
\hline Nombre del Director & Fecha de nombramiento \\
\hline León Lalanne & Director general de la Construcción \\
\hline Carlos Fournier & Desde 1 de agosto de 1860 \\
\hline R. Desorgeries & Desde 13 de noviembre de 1860 \\
\hline Gustavo Noblemaire & Desde 15 de noviembre de 1866 \\
\hline Eduardo Pirel & Desde 15 de agosto de 1869 \\
\hline Napoleón Lionnet & Desde 6 de diciembre de 1876 \\
\hline Carlos Guillaume & Desde 1 de octubre de 1878 \\
\hline Jean Barat & Desde 20 de febrero de 1881 \\
\hline
\end{tabular}




\begin{tabular}{|l|l|}
\hline Clemente Aubert & Desde 1 de mayo de 1901 \\
\hline Gustavo Bachy & Desde 25 de mayo de 1904 \\
\hline León Waldmann & Desde 23 de diciembre de 1906 \\
\hline Felix Boix & Desde 1 de junio de 1908 hasta 31 de diciembre de 1918 \\
\hline Sin Director & Desde 1 de enero de 1919 hasta 14 de julio de 1920 \\
\hline Felix Boix & Desde 14 de julio de 1920 \\
\hline José Moreno & Desde 27 de mayo de 1932 \\
\hline Enrique Grasset & Desde 31 de mayo de 1934 \\
\hline Javier Marquina & Desde 5 de junio de 1939 \\
\hline
\end{tabular}

Fuente elaboración propia a partir de los datos de NORTE (1940, tomo II: 41)

En consonancia con la estructura del capital, la compañía se organizó sobre la base de un cuerpo técnico integrado por ingenieros franceses, traídos de las sociedades matrices, bajo la Dirección General de un profesional, también francés (Vidal, 1999: 628). No es extraño que hasta los años 1880 hubiera en los consejos de administración una elevada presencia de extranjeros, preferentemente franceses, y que los directores, responsables de la transmisión y ejecución de las órdenes emanadas de él, también fueron franceses.

El primer director relevante fue G. Noblemaire quien, a instancias de los Péreire, dirigió la compañía entre 1866 y 1869, un momento especialmente complicado, cuando los resultados de la explotación eran negativos (aparte de las cargas financieras) y la compañía se vio obligada a suspender los intereses de su deuda (Broder, 2000: 80-81).

En el terreno social, el joven Noblemaire trató de llevar a la práctica las enseñazas recibidas de su maestro en l'Ecole Polytechnique Frédéric Le Play. Basándose en sus observaciones sobre la realidad social, Le Play constataba en Les Ouvriers européens que las grandes sociedades por acciones, dados sus enormes recursos económicos, podían disponer de los gerentes más eminentes (de los Cobos y Martínez Vara, 2009: 6). Además, fue el primero en percatarse del conflicto existente entre dos racionalidades. De un lado, la de los gerentes, poseedores de los conocimientos técnicos, pero sin la legitimidad tradicional -autoridad, en términos weberianos- para administrar la propiedad. Del otro, la de los consejeros y las asambleas de accionistas, que, según él, a menudo destruían la iniciativa y limitaban libertad de los nuevos ejecutivos. Creía Le Play que el empresario-heroico, aquel que conseguía innovar en los negocios, adquiría una legitimidad carismática y debería ser, por tanto, quien administrase la empresa de forma tradicional, esto es, siguiendo la triada de valores PadrePatrón-Patria. Tales son los roles que, a su juicio, deberían asumir los gerentes de las grandes corporaciones como los ferrocarriles (de los Cobos y Martínez Vara, 2009: 6).

Varias de las ideas de Le Play en relación con la paz, la estabilidad y el progreso social encontraron buena acogida en diversos campos. En España, y pese al breve espacio de tiempo que dirigió NORTE, fue Noblemaire impulsó toda una serie de iniciativas en la línea leplayana: la construcción de escuelas para los hijos de los empleados, la dotación de 
bibliotecas, centros de recreo, el establecimiento del economato de Valladolid o la creación de la caja de préstamos de la compañía (Noblemaire, 1905: 74). También, NORTE fue pionera en España en el establecimiento de una caja de pensiones. Años después, en 1882, Noblemaire accedió a la dirección de la Compagnie de Paris a Lyon et a la Méditerranée, la mayor ferroviaria francesa donde refinará el sistema de patronazgo como política de gestión de la mano de obra.

Jean Barat y Priou fue director general entre el 20 de febrero de 1881 y el 30 de abril de $1901^{650}$, conviritiéndose en el más importante de la primera época en NORTE. El francés Barat nacio en Oloron Sainte Marie (Aquitaine) en la frontera pirenaica franco-española ${ }^{651}$. Fue el principal valedor de la construcción del paso fronterizo con Francia por Canfranc, ya que ese paso requería la construcción del tramo Canfranc y se ciudad natal Oloron-SainteMarie, tanto que en la primera reunión del Comité de Dirección de NORTE en la que participó, siete días después de su nombramiento, ya se trato el interés de la Dirección por esa línea ${ }^{652}$.

Vino a España a trabajar como inspector telegráfico en la recién fundada NORTE, cuando tenía 37 años, y se jubiló en 1901 como Director general de la compañía con 65 años ${ }^{653}$. Tras su retiro, Barat ingreso en el Consejo de Administración de NORTE en el que permaneció hasta $1909^{654}$.

Barat fue un hombre muy considerado por los hermanos Péreire, pragmático, de habilidad contrastada y reconocido prestigio. En los primeros años de la dirección de Barat se produjo, de un lado, un cambio fundamental en la estructura de la propiedad de la empresa como efecto de las fusiones y adquisiciones (Vidal: 1999) y, del otro, un incremento del número de ejecutivos españoles.

Barat dirigió y coordinó los procesos de fusión y adquisición, desarrolló alguna política financiera novedosa, pero además realizó propuestas que terminaron en acuerdos para aprovechar sinergias con la competencia.

\footnotetext{
${ }^{650} \mathrm{El}$ nombramiento como director de NORTE fue realizado el 21 de enero de 1881 (Chemin de fer du Nord de l'Espagne. Procès verbaux des séances tenues a la reunión de parís, 21 janvier 1881).

${ }^{651}$ La biografía de Barat fue estudiada por Wais (1987: 196). La historia profesional de Barat desde sus inicios hasta su entrada en la Compañía del NORTE puede verse en Apuntes biográficos referentes al Excmo. Sr. D. Juan Barat, antiguo Director de la Compañía de los Caminos de Hierro del NORTE de España. Madrid: Imprenta Central de los Ferrocarriles, 1906, 1-58. El libro incluye un anexo "Respuesta al cuestionario adoptado en Francia por el Consejo Superior del Comercio y de la Industria en su sesión de 18 de diciembre de 1889" en la que el Barat responde a una serie de preguntas relativas a la industria y al comercio en España.

${ }^{652}$ NORTE. Actas Comité de Madrid, 28 de enero de 1881.

${ }^{653}$ En los ferrocarriles británicos y franceses, la edad de retiro era de 65 años. En las compañías del resto de Europa lo usual era que el retiro se hiciera en esa edad. También era constumbre que el sueldo disfrutado durante los últimos años se consolidase como pensión de retiro (Gourvish, y Ribeill, 1993; 1987).

654 “Excmo Sr. D. Juan Barat", Gaceta de los Caminos de Hierro, 1915, pp. 338-339.
} 
Desde que era el subdirector de NORTE coordinó la fusión de NORTE con la línea de Alar a Santander en 1874 y las adquisiciones de las líneas Bilbaro a Castejón en 1878 y de Barcelona a Alsasua en 1881. Posteriormente como Director se adquirieron las líneas de Palencia a Coruña, de León a Gijón y de Oviedo a Trubia (731 milómetros), de Lérida a Tarragona (103 kilómetros), de Barcelona a San Juan de las Abadesas (112 kilómetros), de Almansa a Valencia y Tarragona y sus ramales (542 kilómetros) y de Valencia a Utiel (88 kilómetros). Una de las razones de su gran motivación para adquirir y fusionar líneas era que tenía un incentivo de 432 pesetas $/ \mathrm{km}$, que en algún momento fue percibido en francos franceses (Comín, et al., 1989: 189). Parte de esa remuneración no se le abonó, lo que provocó su salida del Consejo de Administración de NORTE en $1909^{655}$.

Además, organizó el arreglo financiero de la compañía tras los descalabros experimentados en los años de la crisis de 1866. Fue entonces cuando llevó a cabo la propuesta de restructuración de las obligaciones en circulación, proponiendo su sustitución por unas nuevas en condiciones favorables para todas las partes.

Pero lo más destacable es que durante su gestión en NORTE fue el artífice de las relaciones comerciales con los competidores, especialmente en lo que se refiere a convenios de tarifas con MZA entre 1870 y 1896. Como jefe comercial planteó, en 1870, un nuevo convenio de tarifas con MZA basado en el abono de una cantidad alzada, pagadera por años, en lugar del proyecto de sindicatura de productos o de porcentaje por tonelada propuesto por el entonces director Noblemaire. La habilidad desarrollada por Barat en las negociaciones para establecer el primer convenio de tarifas con MZA, le llevaron al nombramiento como subdirector de NORTE. Desde este cargo continuó llevando el peso de la estrategia comercial de la compañía, que hasta entonces tan buenos resultados estaba dando. Barat, como subdirector, planteó el acuerdo formal más importante con MZA: el convenio para la división del tráfico entre las dos redes bajo la base y el principio de la distancia más corta.

Barat supo moverse entre los dos grupos de poder de NORTE en ese momento. A pesar de que era un hombre de confianza del Comité de París, Barat participaba en las sociedades impulsadas por el otro grupo de accionistas de NORTE, encabezado por el Marqués de Comillas (Altos hornos y fábricas de hierro y acero de Bilbao, Altos Hornos de Vizcaya Crédito general de ferrocarriles, Duro Felguera, Material para ferrocarriles y construcciones y Sociedad Hullera Española), de la que obtuvo suculentos beneficios (Rodrigo Alharilla: 1999) (Vidal: 1999). Durante la gestión de Barat como Director de NORTE, fue miembro del Consejo de Administración de la empresa "Altos Hornos de Vizcaya", empresa con la que NORTE tuvo lazos importantes como suministradora ${ }^{656}$.

No obstante, sobre la gestión de Barat hubo dos aspectos negativos. No realizó ninguna innovación respecto al management digna de mención. Su concepción del negocio ferroviario

\footnotetext{
655 FFE. Norte. Archivos de personal, Expedientes personales, leg. 122.

${ }^{656}$ Incluso, cuando le sorprendió la dolencia que le llevó a la muerte, se disponía a asistir al Consejo y Junta General de los Altos hornos de Bilbao, de cuya sociedad era administrador fundador (ABC, 18 de mayo de 1917 : $15)$.
} 
se centraba en la maximización de los ingresos, pues consideraba que los resultados de explotación sólo mejorarían aumentando el tráfico, con la incorporación de nuevos flujos de mercancías y viajeros. Barat nunca puso el acento en la reducción de costes, al contrario que estaban haciendo los directivos estadounidenses y británicos en esa época. Esto sin duda fue provocado por su formación autodidacta, y por su clara vinculación con la escuela francesa de dirección de la empresa, derivada por sus años de aprendizaje en compañías francesas antes de entrar a trabajar en NORTE.

La mala situación de NORTE se achaca al problema ferroviario. La principal razón de la mala situación de la compañía fue la estructura de la masa de pasivo, y su consiguiente estructura de costes. Quizás el origen de la mala situación fue la política expansionista que llevó la empresa. La obsesión de sus directores, sobre todo de Barat, era la de crecer fuese como fuese. Esto podría ser debido a intentar ganar una carrera de continuas fusiones y adquisiciones con el resto de empresas, sobre todo con MZA, pues las líneas que no anexionara NORTE lo haría MZA. Cabe la duda de si la indiscriminada adquisición de empresas tuvo su verdadero origen en las comisiones que recibían los altos cargos de NORTE -incluido el propio Barat- cuando incorporaban compañías a NORTE.

Tras la destitución de Barat, ocuparon el cargo de director de NORTE, tres franceses. Esto provocó que durante el periodo 1900-1906 hubiera un movimiento de protesta por los nombramientos de directivos franceses, que, además, no habían trabajado nunca antes en NORTE. Las protestas venían de los trabajadores, de los cronistas de la época, del poder político, pero sobre todo desde dentro del accionariado.

Entre las opiniones que lamentaban la plaga de franceses ocupando puestos de responsabilidad a comienzo del siglo XX; destacan las críticas vertidas por un antiguo empleado de NORTE, cuando ya estaba jubilado, García Vázquez (1905; 1906a; 1906b).

Las críticas sobre la masiva ocupación de ingenieros franceses no sólo ocurría en NORTE, también en el resto de empresas ferroviarias españolas ${ }^{657}$ y europeas ${ }^{658}$.

En 1900, Sánchez de Toca presentó el primer proyecto de intervención estatal sobre los ferrocarriles. El ministro publicó varios decretos que, emitidos como medidas voluntarias, pretendía autorizar al gobierno a realizar una auténtica reforma de las bases de la política ferroviaria, con vistas a su nacionalización. Entre sus medidas destaca que autorizaba al Gobierno a imponer a las compañías ferroviarias determinado material para las líneas que se consideraban deficitarias en oferta de transporte, medidas de nacionalización de los cargos de las compañías y la exigencia de que el abono de intereses y dividendos se hiciera en pesetas. Tras cinco meses todas su propuestas fueron derogadas por el Consejo de Estado y no llegaron a entrar en vigor, salvo el decreto de naturalización de cargos, que exigió que dos

\footnotetext{
${ }^{657}$ Se lamentaba Boag (1923) de la situación, que él definía como que era un "plaga de franceses ocupando sin merecerlo puestos de responsabilidad", en el resto de empresas ferroviarias españolas.

${ }^{658}$ No sólo en España ocurrió esto. Anteriormente, en Italia los primeros managers de los años 1840 habían sido mayoritariamente franceses.
} 
tercios de los consejeros, el director y los jefes de servicio de las compañías ferroviarias fueran españoles y tuvieran fijada su residencia en España. Las grandes compañías retrasaron ocho años su puesta en marcha hasta 1908, cuando fueron nombrados Boix y Maristany en NORTE y MZA respectivamente.

La tensión entre el capital francés y español de NORTE por la nacionalización de los directores de la compañía quedó patente en el periodo 1900-1906 (Vidal: 1999).

A pesar del aumento del capital español en el Consejo de Administración de NORTE, las direcciones generales seguían recayendo en franceses pese a la oposición de cualificados administradores. NORTE mantuvo a directores franceses por varias razones: mayor peso de los accionistas franceses, la voluntad del Comité de París, así como la menor influencia de los directivos españoles en la alta dirección (Vidal Olivares, 1999: 647).

El 8 de junio de 1905 se celebró la Junta General de Accionistas de NORTE. Allí se evidenció por primera vez que los miembros del Comité de Madrid tomaron el mando decididamente de la compañía en detrimento de la mayoría francesa.

Los inversores españoles (fundamentalmente catalanes y vascos) no siempre mantuvieron relaciones armónicas con el capital francés. Desde la muerte del primer marqués, A. López López, fueron frecuentes los roces entre el capital francés de los Péreire y el español de los Comillas. Se enfrentaron a propósito de la adquisición de la Compañía de Asturias-GaliciaLeón, la creación del Crédito General de Ferrocarriles, el fracaso de los proyectos de expansión de NORTE como la construcción de la línea Valladolid-Ariza, el intento fallido de hacerse con la Compañía del Ferrocarril de Tarragona a Barcelona y Francia (TBF) o del dominio casi absoluto de la red ibérica bajo el nombre de Gran Central Español. Las divergencias alcanzaron su cenit en la llamada crisis de los cambios (1894-1904) y por el gravísimo accidente de Torremontalvo (junio de 1903), hecho que cuestionó la obsoleta forma de explotación de NORTE. Las críticas sobre la gestión de la compañía desembocaron en la dimisión del director C. Aubert en 1904. Su relevo por otro directivo francés, G. Bachy, que incorporó en puestos de confianza a técnicos de su nacionalidad, no allanó las cosas, pues buena parte de los administradores y la opinión pública, alentados desde el propio Consejo de Administración, demandaban la "españolización” de la compañía.

Los inversores españoles van a disponer a partir de entonces de mayor presencia en el Consejo de Administración ${ }^{659}$. Entre ellos destaca C. López Brú (1855-1925) segundo marqués de Comillas por la participación en el capital que concentraba en su persona y su grupo (más del 40\% del accionariado). Comillas, un hombre de profundas convicciones religiosas, promotor en sus empresas de asociaciones y organizaciones de obreros cristianos

\footnotetext{
${ }^{659}$ Con motivo de la fusión con la Compañía de los Ferrocarriles de Zaragoza a Pamplona y Barcelona (1878) y previa modificación del artículo correspondiente de los Estatutos, se incrementó en 10 el número de consejeros, quedando 36 en total. Entre los nombrados se encuentran el Marqués de Salamanca, Antonio López López, F. Sepúlveda, F. Rodríguez San Pedro, E. Güell y M. Girona (NORTE, 1940: I: 639-640).
} 
como freno del movimiento socialista, cuyos principios, en particular el código de familia cristiana, trató de infiltrar en todas sus empresas (de los Cobos y Martínez Vara, 2009: 8). Para el Marqués, cada empresa era como una familia (la identificación leplayana patrón-padre alcanza su máxima expresión) donde cada miembro debía ocupar su puesto, su círculo, sin salirse de él. El marqués siempre tuvo gran ascendiente personal sobre los gestores de las empresas de su propiedad o en las participadas por el grupo, lo que le permitió influir poderosamente en sus decisiones, incluso por encima de lo que representaba su propiedad. Pocas fueron las decisiones tomadas sin su consentimiento, directamente o a través de sus poderosos hombres muy cercanos a sus afectos, muy en particular el ubicuo y todopoderoso maurista F. Rodríguez San Pedro, asiduo presidente del Consejo de Administración (de los Cobos y Martínez Vara, 2009: 9).

Jean Barat, ejerció de director entre 1881 y 1901. Tras 1901, le sucedieron otros tres directores franceses (Aubert, Bachy y Waldmann). El sucesor de Barat, Clement Aubert ejerció poco más de dos años y medio como director de la compañía. Las críticas sobre su gestión motivaron su renuncia en febrero de 1904 y su relevo por otro gerente francés: Gustave Bachy, que falleció en noviembre de 1906. El tercer director de este tiempo fue Léon Waldmann, que estuvo en la dirección hasta que el 1 de junio de 1908 ocupó el puesto, por primera vez, un español: Felix Boix.

Clemente Aubert, un ingeniero francés con experiencia en compañías del vecino país, fue propuesto en 1901 para la Dirección General por el Comité de París. En esa época, el Comité de Barcelona manifestó su deseo de españolizar, tanto el puesto de Dirección General, como la del resto de Directivos (y en general los empleados de altos puestos). El Marqués de Comillas, en representación del Comité de Barcelona, se opuso explícitamente al nombramiento de Aubert, proponiendo un director de nacionalidad española y que en todo caso el propuesto por el Comité de París actuase como director adjunto ${ }^{660}$.

Para reemplazar a Aubert, el Consejo, de acuerdo con los Comités de París y Madrid, nombra a Bachy como director de NORTE en mayo de 1904. El Ingeniero de Puentes y Calzadas Gustave Bachy y Rey procedía de la Dirección de los Ferrocarriles Argelinos, que eran propiedad de la compañía francesa Compañía de París a Lyon y el Mediterráneo (P.L.M), una de las grandes del ferrocarril francés ${ }^{661}$.

En 1905, Bachy comenzó a reclutar alto personal de confianza, encontrando cierta oposición dentro de los accionistas españoles. Tal fue el caso de D. P. Gravier, quien fue nombrado

\footnotetext{
${ }^{660}$ En el Consejo de Administración de Madrid en 1901 queda reflejado que: «El señor Presidente manifestó que tenía encargo del señor Marqués de Comillas [hace referencia a Claudio López Bru, segundo Marqués de Comillas] para expresar que, en su opinión, convendría que el cargo de director de la Compañía recayese en una persona de nacionalidad española, basando esta opinión en razones de sentido general, sin, que por su parte, tuviese persona que indicar para el expresado puesto, y que satisfecha esa condición de nacionalidad para el director de la Compañía, no encontraría nada que oponer a la designación de Mr. Aubert si fuese como adjunto a la Dirección, inspector de todos los servicios ni otro cargo en que pudieran utilizarse sus aptitudes o especiales conocimientos.

661 Acta $\mathrm{n}^{\circ} 701$ del Libro de actas del Consejo de Administración de NORTE: 25 de mayo de 1904
} 
subdirector de NORTE en febrero de 1905. Hasta ese momento había sido ingeniero jefe del Material y Tracción en la Real Compañía Portuguesa de Ferrocarriles. Tampoco había tenido anteriormente vinculación contractual con NORTE.

A la muerte de Bachy, el presidente del Comité de Madrid y París propuso al Consejo el nombramiento de León Waldmann para ocupar el puesto de Director de la Compañía, concediéndole el mismo sueldo de 56.000 pesetas anuales ${ }^{662}$. El Consejo aprobó por unanimidad este nombramiento por "su calidad de Ingeniero consultor del Comité de París, y por la experiencia adquirida por él durante su gestión como Director adjunto al lado de Barat" "663. Cuando dejó de ser Director en diciembre de 1906, fue nombrado Director consultivo, cargo que ocupó hasta su muerte en $1909^{664}$.

Lo importante no era que Aubert, Bachy y Waldmann no fueran españoles, lo grave es que nunca habían tenido ninguna vinculación con la empresa española NORTE, por tanto, no conocían ni el entorno económico español, ni la estructura organizativa ni el proceso productivo de la compañía NORTE ${ }^{665}$.

Cuando León Waldmann dimite como Director de la Compañía, el Consejo se propuso la reorganización de la Dirección de la Compañía, de acuerdo con lo convenido por los Comités de Madrid y París. El cargo de Director de la compañía será desempeñado en Madrid por Félix Boix, en ese momento ocupaba el cargo de Director adjunto ${ }^{666}$. El Ingeniero de Caminos Boix se mantuvo en el cargo de Director General de NORTE hasta julio de 1932, salvo una baja temporal en el período que transcurrió entre el 1 de enero de 1919 y el 14 de julio de 1920, en que la compañía estuvo sin director ${ }^{667}$.

El acceso de los ingenieros españoles a la Dirección General de NORTE se mantuvo a partir del nombramiento de Félix Boix y Merino ${ }^{668}$ el 1 de junio de 1908. Boix nacido en Barcelona

${ }^{662}$ Sesión del Comité de Paris 1-3 de diciembre de 1905 y Sesión del Comité de Madrid 1-3 de diciembre de 1905.

${ }^{663}$ Acta $n^{\circ} 720$ del Libro de actas del Consejo de Administración de NORTE: 23 de diciembre de 1905.

${ }^{664}$ Acta $n^{\circ} 770$ del Libro de actas del Consejo de Administración de NORTE: 31 de diciembre de 1909, Apartado II.

${ }^{665}$ La excepción fue L. Waldman, quien ya había trabajado con Barat como adjunto a la dirección varios años, aunque después de su retiro pasase al Consejo de Administración, en representación del Comité de París, en calidad de ingeniero consultor, mostrando su vinculación al entorno de los intereses de la familia Péreire.

${ }^{666} \mathrm{La}$ remuneración de Boix como Director de NORTE será de 50.000 pesetas al año, asignándole además 10.000 pesetas en concepto de gastos de residencia (Acta $\mathrm{n}^{\circ} 750$ del Libro de actas del Consejo de Administración de NORTE: 7 de mayo de 1908). El sueldo del Director Boix aumenta en 10.000 pesetas desde el 1 de enero de 1911 (Acta $\mathrm{n}^{\mathrm{o}} 782$ del Libro de actas del Consejo de Administración de NORTE: 22 de diciembre de 1910, Apartado IV).

${ }^{667}$ AHF, E-0124-004 Expediente del nombramiento y fallecimiento del administrador Félix Boix y Merino.

${ }^{668} \mathrm{Su}$ nombramiento venía precedido de una unanimidad dentro de NORTE: "actualmente desempeña el cargo de Director Técnico de la Sociedad explotadora de la red en Madrid a Cáceres y Portugal, y que por su notoria reputación e indiscutibles antecedentes de inteligencia y laboriosidad, ofrecía seguras y lisonjeras garantías para la buena marcha de los servicios que le habían de ser encomendados" (Acta n 699 del Libro de actas del Consejo de Administración de NORTE: 15 de abril de 1904). 
en 1858, era Ingeniero de Caminos, Canales y Puertos. Su padre, Elzeario Boix Llovateras, también ingeniero de Caminos (Sáenz Ridruejo, 1990: 366), vino a Madrid a trabajar en el Canal de Isabel II. Más tarde, Felix Boix se trasladó a Madrid, y trabajó en la misma empresa durante el tiempo que estuvo en un intermedio laboral en NORTE, entre julio de 1919 y enero de 1920.

Boix entró como directivo en la Compañía ferroviaria de Madrid a Cáceres y Portugal (MCP) en 1895, cuando la sociedad estaba realizando una modificación de su estructura administrativa. Hasta ese momento la estructura de MCP estaba constituida por una única persona; además este director era siempre francés, derivado de que el capital era predominantemente francés. A partir de 1895, la toma de decisiones se confía a un Comité Directivo compuesto por tres miembros, de los cuales ejercía la presidencia el encargado de los Servicios Administrativos y Económicos, Alfredo Loewy, y a las otras dos personas el resto de Servicios: a uno los de Explotación y a otro los Técnicos, cargo para el que fue nombrado Félix Boix. Con este nombramiento se convierte en el primer directivo que tenía origen español. A los cinco años MCP realiza otra transformación de sus estructuras organizativas, el Comité Directivo se convierte en un Dirección bipartita, ejercida por el Director Administrativo -Loewy- persona de confianza del capital francés, y un Director Técnico -Boix-. En 1904 dimite de MCP para pasar a NORTE (Wais, 1962: 859). Cuando ingresó en NORTE en 1904, la compañía se encontraba reclutando directivos tras el retiro de Barat. El cargó que ocupó fue el de subdirector. El mismo 1904, Boix fue nombrado Director adjunto de Waldmann. El 1908 se produce su nombramiento como Director de NORTE. El año 1919, diferencias de criterio con el presidente del Consejo de Administración motivan un corto eclipse ferroviario de Boix. Deja NORTE pasando a ser Director del Canal de Isabel II. En junio de 1920, vuelve a NORTE, con el cargo de Administrador-Director. Muere en ese cargo el 11 de mayo de $1932^{669}$. Dejó una huella enorme, tanto en la gestión de la principal empresa española de la época como en la actividad cultural de la capital de España ${ }^{670}$.

La entrada de Boix en NORTE estuvo unida a la de Javier Sanz y Larrumbe y Jorge Burgaleta y Caballero. En 1904, Waldman manifiestó querer dejar el cargo de Director. En ese momento el Comité de París y el Consejo planean reorganizar el alto personal de la compañía, creando un puesto de Director adjunto y dos cargos de Subdirectores. El presidente comenzó las gestiones para buscar un Director adjunto, que le sustituyera sin que se resentiera la explotación y la organización tras su marcha. De acuerdo con los Comités de París, Madrid y Barcelona, el presidente propuso a Felix Boix y Merino. El Consejo aprueba a Boix en el puesto y además, faculta al Comité de Madrid para que fije el sueldo anual de Boix, consultando en la parte necesaria a los Comités de París y Barcelona. Respecto a los dos

\footnotetext{
${ }^{669}$ La prensa de la época recogió de forma destacada su muerte (ABC 13 de mayo de 1932, p. 8).

${ }^{670}$ Félix Boix fue aficionado y coleccionista de Bellas Artes, además, de conferenciante y escritor sobre temas de pintura y dibujo. Ingreso en la Real Academia de Bellas Artes de San Fernando el 8 de noviembre de 1925. El Museo Municipal de Madrid tiene su origen en la Exposición «El Antiguo Madrid», organizada por la Sociedad Española de Amigos del Arte, que presidía Boix, gran entusiasta y entendido tanto en obras de arte como en lo referente a la historia de Madrid. Esta Exposición, inaugurada a fines del año 1926, se prolongó durante todo 1927, con un enorme éxito, pero el Museo no quedó constituido como tal hasta 1929. La dimensión artística de Boix fue puesta de manifiesta por Wais (1962: 858-862).
} 
Subdirectores el Consejo aprueba la creación de los dos cargos y las personas elegidas (que no se incorporan en ese momento sino cuando se reestructure la organización de los Servicios). Las personas elegidas ${ }^{671}$ son Javier Sanz y Larrumbe ${ }^{672}$ y Jorge Burgaleta y Caballero $^{673}$.

Con Boix se acabaron las protestas por la nacionalidad de los directores. No sólo fue el primer director español de NORTE, sino que además, pobló de españoles los mandos de la empresa. El nombramiento de Boix "revela el aumento de la influencia del capital español",674 y es un claro indicio de la españolización de la empresa (Reparaz: 1932).

Boix se rodeó de personas de su confianza (Wais: 1962; 1963), que mayoritariamente eran jóvenes ingenieros de caminos e ingenieros industriales, formados en el recién creado ICAI (Instituto Católico de Artes e Industrias) de la Universidad propiciada por el Marqués de Comillas. Entre 1908 y 1914 la compañía vive un momento relativamente dulce.

A principios de 1919, NORTE llevó a cabo una profunda remodelación de su equipo directivo, cesó en su cargo el Director Felix Boix, y los subdirectores Enrique Stevenin ${ }^{675}$ y Javier Sanz. En el intervalo que NORTE estuvo sin director entre los dos periodos en que lo fue Boix, la gestión correría interinamente a cargo del Marqués de Alonso Martínez, que además de administrador de la compañía, formaba parte de su Consejo ${ }^{676}$. En febrero de 1919 pasó al cargo de subdirector de la compañía Eduardo Garre Rex, que había desempeñado hasta la fecha la Jefatura de Contabilidad Central y Caja, en cambio el puesto de director no había sido cubierto todavía, pasando Luis Olanda ${ }^{677}$ de subdirector a Director Adjunto ${ }^{678}$.

\footnotetext{
${ }^{671}$ Acta n ${ }^{\circ} 699$ del Libro de actas del Consejo de Administración de NORTE: 15 de abril de 1904.

${ }^{672}$ Javier Sanz y Larrumbe era Inspector General de primera clase del Cuerpo de Ingenieros de Caminos, Canales y Puertos, y en ese momento estaba al servicio de NORTE como ingeniero agregado a la Dirección (Acta $n^{\circ} 699$ del Libro de actas del Consejo de Administración de NORTE: 15 de abril de 1904).

${ }^{673}$ Jorge Burgaleta y Caballero era Ingeniero Industrial y desempeñaba en NORTE el puesto de Ingeniero Jefe de la Tercera División, teniendo a su cargo todo lo referente a Material Móvil, Tracción y Almacenes. "Es notoria su competencia en todo cuanto se refiere a su actual servicio en nuestra Compañía, así como en todo lo referente a Explotación" (Acta n 699 del Libro de actas del Consejo de Administración de NORTE: 15 de abril de 1904). Cuando era un joven ingeniero participó en la electrificación de la rampa de Pajares. Junto con Viani escribió el libro sobre Conveniencia y posibilidad de electrificar los ferrocarriles españoles (Viani y Burgaleta: 1919).

${ }^{674}$ Gaceta de los Caminos de Hierro, 14 de mayo de 1908.

${ }^{675}$ Anteriormente, el Consejo había acordado la readmisión en el cargo de Subdirector del Ingeniero Stevenin con un sueldo anual de 25.000 pesetas (Acta $n^{\circ} 739$ del Libro de actas del Consejo de Administración de NORTE: 31 de mayo de 1907).

${ }^{676}$ Gaceta de los Caminos de Hierro, 1 de enero de 1919.

${ }^{677}$ El ingeniero de caminos Luis Olanda y Benito fue contratado, a fines de 1904, como ingeniero jefe agregado a la Dirección con treinta y siete años. Su experiencia previa en el sector procedía de haber trabajado en dos compañías de ferrocarriles: la de Zafra a Huelva y la Compañía de los Ferrocarriles del Sur de España. El 23 de diciembre de 1911 NORTE crea una nueva plaza de Subdirector, la cual es ocupado por Luis Olanda y Benito con un sueldo de 20.000 pesetas al año a partir del 1 de enero de 1912 (Acta n 794 del Libro de actas del Consejo de Administración de NORTE: 23 de diciembre de 1911, Apartado III.4). En 1919 era nombrado director adjunto, con un sueldo anual de 30.000 pesetas, que le fueron aumentadas, en 1920, a 40.000. Se jubiló en 1932. Este fue uno de los ejemplos que utilizó Vidal Olivares (1997: 88) para aseverar que los directivos que
} 
Durante los años de gestión en la dirección de Boix, el mando general continuó en manos de estrechos colaboradores suyos como fueron José Moreno Osorio ${ }^{679}$, Enrique Grasset y Javier Marquina. Todos ellos administraron la compañía durante la II República, la Guerra Civil y los primeros años del franquismo.

Las diferencias salariales y de trayectoria profesional entre ejecutivos dentro de la empresa se acentuaron cuando los efectos de la Guerra Mundial se dejaron sentir en la escasez de material y se tuvieron que reclutar especialistas procedentes de otras compañías a fin de reorganizar el servicio de tracción, sacar el máximo rendimiento a los talleres de reparación de locomotoras y vagones, e incrementar la productividad del parque móvil de NORTE. Así, en 1917, cuando la tercera parte de las locomotoras del parque de la compañía estaban inmovilizadas por estar sometidas a reparaciones de gran envergadura, se recurrió a la contratación de un ingeniero

provenían de otras compañías percibieron mayores salarios y ascendieron más rápidamente en el escalafón de NORTE. Para compararlo muestra los datos del ingeniero jefe agregado a la Dirección (igual cargo) el ingeniero de caminos Pedro Pablo de Alarcón y Contreras se mantuvo hasta 1919. Al año siguiente fue nombrado ingeniero jefe de Explotación, con 16.500 pesetas anuales, jubilándose en 1932 en el mismo puesto.

${ }^{678}$ Gaceta de los Caminos de Hierro, 1 de enero de 1919.

${ }^{679}$ José Moreno Ossorio (1869 - 1963), IV Conde de Fontao. concluye la carrera de Ingeniería de Caminos, Canales y Puertos en 1895. Ingresa en julio de dicho año en la Compañía de los Caminos de Hierro del Sur de España como Jefe de Sección de Vía y Obras. En 1905 comienza a trabajar en NORTE. En 1908 es nombrado Ingeniero jefe de la Explotación (Acta n 746 del Libro de actas del Consejo de Administración de NORTE: 28 de febrero de 1908) y en 1921 Subdirector.

Moreno Osorio fue uno de los grandes artífices de la electrificación del ferrocarril en España. El año en el que accede a la Subdirección del NORTE inicia, de forma totalmente novedosa, la electrificación de algunas líneas ferroviarias. La primera línea en sufrir esta transformación es la que une Busdongo a Ujo en la línea León-Gijón. Esta obra se lleva a cabo gracias a la concesión de un préstamo reintegrable a la Compañía del NORTE arbitrado por una ley del ministro de Fomento Cambó. Un año después -en 1922- Moreno Osorio realiza un viaje a Estados Unidos donde estudia la implantación en ese país de los ferrocarriles equipados con tracción eléctrica por corriente continua a alta tensión, lo que supondrá el primer intento de traer a España esta tecnología a fin de efectuar la electrificación de la línea de Pajares, que se abre en 1924.

Bajo su dirección se realizan, con posterioridad, los estudios y trabajos de las electrificaciones de las líneas Barcelona- Manresa- San Juan de las Abadesas y Alsasua-Irún inauguradas respectivamente en 1926 y 1929.

En 1928 se inician los estudios para la línea Ávila-Segovia. En virtud de estos méritos, durante la Dictadura de Primo de Rivera, se le designa primer Presidente de la Comisión Oficial de Electrificación. En 1928-1930 es sucesivamente nombrado consejero de las empresas de Ferrocarriles del Oeste de España (compañía estatal creada en 1928 en vista del gran déficit de la compañía concesionaria Madrid-Cáceres-Portugal y Oeste de España), de la Compañía del Central de Aragón, de la de Bilbao a Portugalete, de la Compañía de La Cruz de Minas y fundición de plomo de Linares, de Tramisa, de la Linarense de Electricidad y de Flamma Carbo.

Ya bajo la República, en 1932, asciende a Director General de la Compañía del NORTE. Desde 1932 desempeñó también el cargo de miembro de la Comisión Permanente de la Asociación Internacional del Congreso de los Ferrocarriles (AICF), lo que le llevaría a representar a España en las reuniones de Bruselas que se celebraron con carácter anual y donde se discutirían aspectos importantes sobre el desarrollo de los ferrocarriles europeos. También ese año dirige la electrificación de la línea Bilbao-Portugalete.

El 28 de junio de 1936, pocos días antes de iniciarse la Guerra Civil Española, es designado Presidente del Consejo de Administración de la Compañía del NORTE (ABC, 28 de junio de 1936, p. 17).

Tras la guerra, en 1942, Moreno Osorio se integra en el primer Consejo de Administración de la recién creada RENFE como Vicepresidente (ABC, 22 de abril de 1947, p.17), cargo que ocupará hasta el 30 de mayo de 1950. En 1955 es nombrado Presidente Honorario de RENFE (ABC, 10 de diciembre de 1955, p. 83). 
industrial que hasta el momento era jefe de Tracción en MZA: Federico de Vargas y Soto. Francisco Rahola, hasta entonces Jefe de Tracción de NORTE, había fallecido y el Comité de Dirección no quería recurrir al subjefe Paul Normand como sustituto. Esto dio paso a un enfrentamiento entre el Comité de Dirección y el Consejo de Administración de Madrid, por una parte, con el de París por otra, ya que este último defendía la sucesión de Rahola por el francés Normand, oponiéndose a Vargas por su juventud, inexperiencia y falta de conocimiento del funcionamiento de NORTE. Boix y el presidente del Comité de Dirección Borregón, defendieron el reclutamiento de Vargas por su competencia, su formación y habilidad desempeñadas en la compañía rival ${ }^{680}$. El enfrentamiento cabe incluirlo en el contexto más amplio de la pugna que, al menos desde 1885 , se venía experimentando entre los directivos españoles y los franceses que constituían el reflejo de los cambios en la estructura de capital de NORTE. Finalmente se aprobaría el nombramiento de Vargas en 1917. Boix volvía a imponer su criterio.

El Consejo aprueba la jubilación de Boix el 29 de noviembre de 1918 (Acta $\mathrm{n}^{\circ} 885$ del Libro de actas del Consejo de Administración de NORTE: 29 de noviembre de 1918, Apartado II) (Gaceta de los Caminos de Hierro, 24 de abril de 1919). F. Rodríguez San Pedro, continuó como presidente del Consejo de Administración, poco tiempo pues, año y medio después, es reemplazado por el liberal Alonso Martínez, retornado con él F. Boix, quien desde ese momento no sólo será director sino también consejero, tras cambios importantes en la estructura de la propiedad de la empresa.

Hay un consenso en la literatura ferroviaria española (de los Cobos y Martínez Vara, 2009: 2) en señalar que las retribuciones y las condiciones de trabajo de NORTE eran mejores a las de MZA; sin embargo, la conflictividad laboral del ferrocarril tuvo su centro en NORTE. Esta situación sólo se puede explicar por la diferencia en los estilos de dirección de F. Boix y Merino y E. Maristany y Gibert, directores de NORTE el primero y de MZA el segundo.

Hubo entre Boix y Maristany coincidencias lógicas en no pocas cuestiones básicas, pero diferían en muchos asuntos importantes como el referido específicamente a la diagnosis de la conflictividad laboral y la manera de abordarla. Dos formas de gestión -dentro, eso sí, de la lógica empresarial capitalista- a las que, obviamente, no fueron indiferentes los Consejos de administración de sendas compañías, donde -y estos es el factor de divergencia importantehabía prohombres vinculados a grupos de interés económico y político diferentes (de los Cobos y Martínez Vara, 2009: 4).

NORTE y MZA estuvieron dirigidas por dos de los más prestigiosos ingenieros de caminos, Boix y Maristany ${ }^{681}$, oriundos de Barcelona y con una fuerte personalidad, cercana en la

\footnotetext{
${ }^{680}$ En 1917 Boix y el presidente del Comité de Dirección Borregón, criticaban a Normand porque «... el señor Normand, que no es ingeniero ni tiene título técnico, carece de autoridad para imponerse al personal a sus órdenes» (Carta del director de NORTE, Félix Boix, al presidente del Comité de Dirección de NORTE, A. Borregón. AHF, Expediente de Federico Vargas de Soto, Leg. 126).

${ }^{681}$ En 1885 ingresó en la compañía de los ferrocarriles de Tarragona a Barcelona y Francia (TBF) el ingeniero de caminos Eduardo Maristany Gibert (1855-1941), nieto de Manuel Gibert, que fue presidente de la primitiva
} 
inflexibilidad. Hicieron la carrera prácticamente al mismo tiempo, su formación fue similar y accedieron a la dirección en el mismo año (1908). Por otro lado, las dos compañías nacieron, en los mismos años (MZA en 1857 y NORTE 1858), ligada la primera a los Rotchschild, que siempre mantuvieron su presencia activa a través del Comité de París, y la segunda a los Péreire. Ambas compañías repartiron la toma de decisiones importantes entre dos Comités, uno en París y otro en Madrid; además crearon un Comité de Barcelona.

NORTE y MZA tenían enfoques muy distintos, que generaron culturas de empresas muy diferentes. Maristany ${ }^{682}$ aludió con frecuencia a la diferente cultura corporativa de las compañías (AHF S-36-97).

NORTE concede más poder al Consejo, mientras que MZA concede más poder a la Dirección. En los primeros años de mandato de Boix en NORTE y Maristany en MZA, podemos observar una línea jerárquica distinta entre ambas compañías. En ambas la toma de decisiones residía en el Consejo de Administración, sin embargo, en MZA este organismo otorgó a Maristany y su staff gran libertad de acción. Sin embargo, durante el primer mandato de Boix en NORTE se podía entrever (de los Cobos y Martínez Vara, 2009: 1) la alargada sombra de C. López Brú, segundo Marqués de Comillas, exteriorizada en la figura de F. Rodríguez San Pedro, presidente del Consejo de Administración y hombre de confianza de López Brú.

Aunque hubo coincidencias en ciertas prácticas de NORTE y MZA, los métodos de gestión de una y otra ferroviaria difirieron profundamente. Se trataba de dos grupos financieros con enfoques muy distintos, que generaron, como no podía ser de otro modo, culturas de empresa diferentes. La gestión en NORTE se mantuvo más apegada al viejo paternalismo leplayano, aderezado con el catolicismo social de los Comillas, mientras que MZA siguió la línea más sobria del ideario liberal (de los Cobos y Martínez Vara, 2009: 21). El ideario tuvo su reflejo

compañía de Mataró. Es necesario señalar que muere cuando RENFE absorbe "su" MZA. Cuando llega Maristany a TBF en 1855, TBF se hallaba enfrascado en la construcción de una línea directa de Barcelona a Zaragoza, por una ruta situada mucho más al sur que la que la Compañía del NORTE explotaba vía Lleida y Manresa. La nueva línea del TBF, que pasaba por Caspe, utilizaba entre Zaragoza y la Puebla de Híjar el trazado del entonces abortado proyecto de ferrocarril de Zaragoza al Mediterráneo, para discurrir entre la Puebla de Híjar y el nudo de Reus por un trazado de construcción 100\% nueva. Maristany llegó a TBF en el momento en que sus conocimientos eran más necesarios, pues la divisoria entre la cuenca hidrográfica del Ebro y la de la costa catalana tenía que ser salvada por medio del túnel de la Argentera, de 4044 metros de longitud. En 1885, Maristany encontró las obras del túnel paralizadas por las dificultades del terreno, no obstante supo terminarlas con acierto.

${ }^{682}$ En 1885 ingresó en la compañía de los ferrocarriles de Tarragona a Barcelona y Francia (TBF) el ingeniero de caminos Eduardo Maristany Gibert (1855-1941), nieto de Manuel Gibert, que fue presidente de la primitiva compañía de Mataró. Es necesario señalar que muere cuando RENFE absorbe "su” MZA. Cuando llega Maristany a TBF en 1855, TBF se hallaba enfrascado en la construcción de una línea directa de Barcelona a Zaragoza, por una ruta situada mucho más al sur que la que la Compañía del NORTE explotaba vía Lleida y Manresa. La nueva línea del TBF, que pasaba por Caspe, utilizaba entre Zaragoza y la Puebla de Híjar el trazado del entonces abortado proyecto de ferrocarril de Zaragoza al Mediterráneo, para discurrir entre la Puebla de Hijar y el nudo de Reus por un trazado de construcción 100\% nueva. Maristany llegó a TBF en el momento en que sus conocimientos eran más necesarios, pues la divisoria entre la cuenca hidrográfica del Ebro y la de la costa catalana tenía que ser salvada por medio del túnel de la Argentera, de 4044 metros de longitud. En 1885, Maristany encontró las obras del túnel paralizadas por las dificultades del terreno, no obstante supo terminarlas con acierto. 
en la gestión profesional de empresa de Maristany, y una visión paternalista arcaica, en la que se construía viviendas y parroquias para los empleados de Boix.

Hasta nuestros días ha llegado la idea de que Boix tuvo una acertada gestión de Boix ${ }^{683}$, o que incluso fue un buen gestor. Sin embargo, la gestión de Boix ante las reivindicaciones laborales de los empleados ferroviarios fue muy deficiente. Mientras que en MZA, Maristany supo interpretar correctamente el fenómeno sindicalista dentro del sistema capitalista, Boix se enfrentó con mano dura a ellos, sin duda pensando que sus condiciones eran muy buenas -lo cual era verdad-, y que su forma rígida de administrar, siendo intransigente con los sindicatos, era la adecuada. El peor pecado de Boix fue que en 1918 despidió a 5.000 empleados cualificados de NORTE, introduciendo para sustituirlo personas sin formación. Esto supuso una pérdida de capital humano, y una evidente descapitalización.

Los trabajadores de NORTE tenían muchos conflictos con la compañía, realizando algunas huelgas y amenazando con la realización de otras. La empresa gestionó incorrectamente estos conflictos al amenazar con despidos masivos en los talleres de Valladolid y en las minas de Barruelo y Surroca. El origen de estos conflictos es que gestionaba peor su capital humano.

Cómo las retribuciones de los trabajadores de NORTE eran mayores que las de MZA, no tiene sentido pensar que las huelgas eran por retribución ni por las condiciones laborales. Si a lo anterior unimos que el número de trabajadores de NORTE era mayor al de MZA, esto sólo puede significar que NORTE gestionaba peor su capital humano, de forma que era menos eficiente y productivo. El reflejo de ello era que los trabajadores eran demasiados para el volumen del tráfico de la empresa, y estaban pagados por encima de la competencia.

Sin embargo, también podría verse desde otro punto de vista, pagaba más a sus trabajadores para reducir la posibilidad de conflictos, sabiendo la mala gestión en el capital humano.

Pero todo esto pudo cambiar porque NORTE manejó seriamente la idea de contratar a Eduardo Maristany como Director General de la compañía para sustituir a Aubert. Algunos accionistas de NORTE, representantes del grupo de Bilbao, ofreció el puesto de Director de NORTE a Maristany. La prensa se hizo de estos planes de NORTE para incorporar a Eduardo Maristany en 1904 (Revista Minera, Metalúrgica y de Ingeniería. "Cambios de dirección en los ferrocarriles del Norte". 1904, p. 98). Si esto se hubiera producido, Maristany hubiera incorporado su pensamiento en NORTE, y MZA hubiera tenido que hacerse con los servicios de otro Directivo, ¿quizás Boix? (no deja de ser un contrafactual).

El aspecto más determinante para esta investigación es la escasa formación económica de los directores. De lo que sabemos sobre las biografías de los directivos ferroviarios (Ortúñez, 1999.a: 139), la dirección recaía de manera habitual en ingenieros con poca formación económica. Éstos estaban perfectamente capacitados para organizar la producción, pero

${ }^{683}$ El principal defensor de esta idea es Wais (1962), el comentario es originado, en parte, porque es amigo de Boix. 
carecían de formación económica. Situación provocada en parte por la escasez de estudios de gestión en facultades universitarias españolas.

\subsection{Resto de trabajadores}

Hasta la aparición de NORTE y del resto de las grandes ferroviarias, ninguna otra empresa había tenido que seleccionar y dirigir un número tan elevado y diversificado de empleados.

NORTE fue incrementando con rapidez sus efectivos humanos, pasando a disponer entre empleados fijos, de plantilla y eventuales alrededor de los 40.000 trabajadores en la década de los años treinta. La productividad del trabajo en NORTE, medida por el valor del producto bruto por kilómetro y agente, era la mayor de las compañías ferroviarias españolas con la excepción del período de la Gran Guerra en que MZA y Andaluces la superaron ampliamente (Juez Gonzalo, 1992: 113). El empleo y gasto de personal en la compañía ferroviaria NORTE fue estudiado con detalle por Martínez Vara (2003a).

En el periodo estudiado estaban perfectamente establecidos en NORTE, los salarios y retribuciones de los empleados, los medios de promoción interna, de promoción y los documentos de seguridad en el trabajo y para los clientes.

A continuación analizamos el reclutamiento, política salarial, promoción, ventajas concedidas a los empleados, y control de los trabajadores establecido por NORTE.

En los primeros momentos la elección del personal idóneo y fiable no resultó sencilla pues, salvo el trabajo en talleres (ajustadores, torneros, carpinteros...) y oficinas (administrativos y personal subalterno), se trataba de profesiones totalmente nuevas: maquinistas, fogoneros, jefes de estación, guardagujas... Los candidatos seleccionados solían proceder del artesanado urbano, industria rural y campesinado ${ }^{684}$. Para la realización de la actividad, estos nuevos operarios precisaban de una formación que NORTE se la suministró, formal o informalmente.

Para minimizar los costes asociados con el reclutamiento de la clase idónea de trabajadores y con la formación adecuada, una vez acabada la red y normalizada ya la explotación, NORTE comenzó a aplicar, desde fechas tempranas, la lógica de los mercados internos, aspecto éste donde la dirección de los ferrocarriles resultó pionera ${ }^{685}$. Mediante este sistema intentaban, una vez contratados los trabajadores con el perfil más adecuado, garantizar el control a través de un amplio equipo de vigilancia y, sobre todo, retener los servicios de los que habían recibido de la empresa formación específica y habían acumulado más experiencia y destreza en el oficio ${ }^{686}$.

\footnotetext{
${ }^{684}$ Este proceso había ocurrido igual en Inglaterra (Kingsford, 1970: 1-12) y Francia (Revue d'histoire des chemins de fer, 2000: $\mathrm{n}^{\circ} 22$ ).

${ }^{685} \mathrm{La}$ lógica de los mercados internos es analizada por Savage (2000: 70). A principios del siglo XX, las principales ferroviarias británicas no sólo tenían establecidos mercados internos, sino que eran, en expresión de Howlett (2000), sus más firmes adeptas dentro del país.

${ }^{686}$ Fitzgerald (1999) y Ribeill (1998).
} 
De este modo consiguieron relaciones laborales estables y seguridad frente a las incertidumbres, se aseguraron la rentabilidad de la inversión realizada en formación y, mediante la identificación con la empresa, buscaron neutralizar el avance sindical $^{687}$, lo que era fundamental en empresas de servicios públicos muy vulnerables a los paros ${ }^{688}$, aunque NORTE no siempre consiguió ${ }^{689}$.

NORTE tenía perfectamente establecido los criterios de fijación salarial, así quedó constancia en las decisiones del Consejo de Administración del periodo analizado ${ }^{690}$.

La promoción en NORTE se regía por el principio de antigüedad. Incluso para los puestos de mayor responsabilidad, se prefería, siempre que fuera posible, el personal de la casa. Regía, pues, la lógica de lo que hoy denominamos mercados internos.

En general, preferían cubrir las vacantes por medio de la promoción interna, esto es, con trabajadores eficientes, disciplinados y situados en la clasificación inmediatamente inferior dentro de la "línea de progresión", a los que, de este modo, se reconocían sus méritos, diligencia y disponibilidad o, lo que es lo mismo, su aptitud y lealtad ${ }^{691}$, siempre que cumplieran con las reglas formales diseñadas por la empresa y los candidatos reunieran las condiciones $^{692}$.

\footnotetext{
${ }^{687} \mathrm{El}$ análisis de la actuación de los sindicatos de empresas ferroviarias en la época es analizado por Plaza (2012; 2006; 2004).

${ }^{688}$ La conflictividad laboral en el sector ferroviario puede observarse en Juez $(1983 ; 1992 ; 1999 ; 2000 ; 2001)$.

${ }^{689}$ En septiembre de 1912 se declaró una huelga en la red catalana de MZA y parcialmente extendida a las líneas catalanas de NORTE. El Consejo de Administración tenía mucho miedo de que se extendiera la huelga al grueso de la red de NORTE (Acta ${ }^{\circ} 803$ del Libro de actas del Consejo de Administración de NORTE: 28 de septiembre de 1912, Apartado III).

${ }^{690}$ El Consejo aprueba el Proyecto de Orden de Dirección número 34, de 24 de mayo de 1904, se aumenta a 80, 100 y 120 pesetas anuales a los empleados que tienen 4, 5 y 6 hijos (Acta $\mathrm{n}^{\circ} 781$ del Libro de actas del Consejo de Administración de NORTE: 25 de noviembre de 1910, Apartado II.4). El Consejo modifica la Instrucción General número 2 aumenta las indemnizaciones de los gastos de viaje de los agentes, principalmente del personal de Trenes y Tracción, pasando de ser 2.233 .872 pesetas a 2.628.342 pesetas (Acta $\mathrm{n}^{\circ} 782$ del Libro de actas del Consejo de Administración de NORTE: 22 de diciembre de 1910, Apartado IV). El Consejo fijó los sueldos para el año 1911 en 265.109, con aumento de 62.349 pesetas sobre el año anterior (Acta n ${ }^{\circ} 783$ del Libro de actas del Consejo de Administración de NORTE: 28 de enero de 1911, Apartado IV). El Consejo fijó los sueldos para el año 1912 en 313.216, con aumento de 47.107 pesetas sobre el año anterior (Acta no 795 del Libro de actas del Consejo de Administración de NORTE: 27 de enero de 1912, Apartado III).

${ }^{691}$ Cada compañía ferroviaria estableció su propio mercado interno, lo que, como indica Howlett (2000), les permitió reducir costes de transacción, planificar a largo plazo y eludir las crecientes amenazas de los sindicatos.

${ }^{692}$ La posibilidad de trepar por las escaleras ocupacionales indujo al empleado a permanecer en la compañía porque su salario mejoraba con la antigüedad y porque, si la abandonaba, perdía todos los derechos laborales acumulados, aunque entrara a trabajar en otra ferroviaria.
} 
No obstante, a pesar de que normalmente se promocionaba internamente, NORTE no tuvo problemas a la hora de reclutar trabajadores, lo cual era una prueba irrefutable del buen trato que dispensaba ${ }^{693}$.

NORTE estableció tanto la incorporación de empleados del exterior, como procedimientos establecidos para la promoción interna, el mejor ejemplo es la política realizada simultáneamente en 1911. Por un lado, el Consejo aprobó la inclusión en la plantilla de 7 agentes auxiliares cuyo sueldo asciende a 9.150 pesetas al año (Acta $\mathrm{n}^{\circ} 783$ del Libro de actas del Consejo de Administración de NORTE: 28 de enero de 1911, Apartado IV). Por otro lado, el 2 de junio de 1911 el Consejo aprobó la proposición de la Dirección de proceso para la provisión de plazas de "empleados principales" y "empleados sencillos" en las oficinas de todas la red ferroviaria de NORTE. Dicha provisión de plazas se hará por concurso, ante un tribunal de exámenes. La edad para la admisión de plazas de "empleados sencillos" será de 18 a 24 años, y de 21 a 35 para las de "empleados principales"; si el solicitante es agente de la compañía no habrá límite de edad. Para determinados puestos de oficinas, especialmente en los Servicios de Intervención y Tráfico, podrán ser nombrados empleados sencillos o principales que tengan esos conocimientos por ser trabajadores de las estaciones de la red por medio de exámenes especiales (Acta $\mathrm{n}^{\circ} 789$ del Libro de actas del Consejo de Administración de NORTE: 2 de junio de 1911, Apartado III).

NORTE retuvo y controló los servicios de su fuerza de trabajo porque, además de "formar un gran mercado interno" ${ }^{\circ 94}$, sus directivos supieron establecer también innovadores y sofisticados programas de bienestar social que acabaron por reforzar a aquel al generar conductas colaboradoras con las empresas. Los gestores de NORTE se percataron de que tan importante como la disciplina era disponer de un eficiente sistema de incentivos extrasalariales ${ }^{695}$ con los que ganar la colaboración y lealtad de los empleados, especialmente de los más difíciles de reemplazar ${ }^{696}$.

Una parte del personal activo fijo recibía, además del salario, otras muchas prestaciones extrasalariales, bien como retribución directa por trabajos realizados (horas extraordinarias, destajos, primas diversas); o bien como consecuencia de la implantación de instituciones de carácter benéfico. Es necesario destacar las ventajas especiales de carácter benéfico que disfrutaban los empleados ferroviarios de NORTE, entre ellos destacan: empleo fijo, billetes gratuitos, escuelas para los hijos de ferroviarios, gratificaciones, uniformes, economatos, alquiler de viviendas de las compañías, socorros, seguros de enfermedad, asistencia médicosanitaria y pensiones.

\footnotetext{
${ }^{693}$ La relación entre la idea de que la facilidad de reclutar trabajadores estaba directamente relacionado con el buen trato que dispensaban las ferroviarias fue anteriomente establecida por Boag (1923).

${ }^{694}$ Esto es explicado por Fitzgerald (1988: 20-32).

${ }^{695}$ Martinez Vara (2003a).

${ }^{696}$ La importancia de un eficiente sistema de incentivos extrasalariales para garantizarse la colaboración y lealtad de los empleados es analizada por Savage (1988).
} 
La más importante institución benéfica fue el sistema de pensiones, implantada por NORTE desde fechas muy tempranas, mucho antes de que fuera práctica habitual en España. La Dirección de NORTE elaboró en 1912 un proyecto de Reglamento para la concesión de pensiones de retiro a todo el personal de la compañía, incluso el personal fijo jornalero. Este proyecto es aprobado por los Comités de Madrid (Acta Comité de Madrid: 13 de julio de 1912), París (Acta Comité de París: 26 de junio de 1912) y Barcelona (Acta Comité de Barcelona: 30 de julio de 1912) y presentado al Consejo (Acta $\mathrm{n}^{\circ} 803$ del Libro de actas del Consejo de Administración de NORTE: 28 de septiembre de 1912, Apartado III.10).

Frente a estas ventajas ofrecidas por NORTE, la realidad de esa época se caracterizaba por los siguientes aspectos: $1^{\circ}$ ) el empleo temporal era aún muy importante; $2^{\circ}$ ) que muchas de las "prestaciones" eran concesiones muy recientes, conseguidas tras no pocos enfrentamientos con la dirección; $3^{\circ}$ ) que no todos los trabajadores de la misma empresa tenían derecho a ellas; y $4^{\circ}$ ) que no eran aún pocas las compañías donde no estaban reconocidas o su ejercicio era muy pobre.

Los gestores de las ferroviarias españolas, incluída NORTE, se quejaban reiteradamente del fuerte encarecimiento de los costes labores a partir del fin de las hostilidades y desde luego no exageraban cuando consideraban "privilegiadas" las condiciones de la profesión ferroviaria regularidad salarial, estabilidad en el empleo y posibilidades de promoción- en comparación con otros sectores económicos. Los costes laborales estaban creciendo pero también las empresas ferroviarias funcionaban a media capacidad ${ }^{697}$.

NORTE impuso un control férreo a los empleados, por medio de la emisión y cumplimiento de documentos internos. El trabajo seguro y bien realizado dependía de que cada empleado cumpliera de forma estricta con las funciones que se le habían asignado ${ }^{698}$, lo que requería disponer de una disciplina espartana y de una estrecha vigilancia para su cumplimiento. El control sobre los empleados se realizaba con la emisión de documentos y la vigilancia de su cumplimiento. La Instrucción General número 2 regula el régimen interno de los agentes (Acta $n^{\circ} 782$ del Libro de actas del Consejo de Administración de NORTE: 22 de diciembre de 1910, Apartado IV).

Uno de los principales activos de la empresa NORTE, aunque también fuente de muchísimos problemas, fue su capital humano. Dentro de los trabajadores de la compañía, destacan algunos:

- Aranceta, Pedro Agustín de. Ingeniero mecánico de la división de ferrocarriles del NORTE. Ingeniero Industrial del Real Instituto de Madrid, Caballero Comendador y Gran Cruz de Isabel la Católica.

- Armenta, Alfredo. Empleado en el Servicio del Movimiento de los Ferrocarriles del NORTE. vicepresidente de la Asociación General de Empleados y Obreros de Ferrocarriles de España.

\footnotetext{
${ }^{697}$ Imedio (1935: 72) apuntó que las empresas ferroviarias funcionaban a media capacidad.

${ }^{698}$ La idea de que el trabajo seguro dependía de que cada empleado cumpliera de forma estricta con las funciones que se le habían asignado, está tomada de Lummis (1996: 6-67).
} 
- Díez Aguasal, Florencio. Empleado en la Intervención del Ferrocarril del NORTE. Abogado de los Ilustres Colegios de Madrid y Santander.

- Flobert. Ingeniero Jefe de Material y Tracción NORTE.

- Forcano Catalán, Alfredo. Agente de investigación en el Servicio de Reclamaciones de la Compañía de NORTE.

- García-Lomas, José María. Ingeniero agregado de la Dirección de NORTE.

- Gómez Alonso, Salvador. Jefe del Servicio Contencioso de NORTE.

- Hurtado de Urtasún, Alfredo. Subalterno de la División Administrativa de NORTE.

- Martín-Gamero, Andrés. Jefe de Sección de lo Contencioso de NORTE. Abogado del Ilustre Colegio de Madrid.

- Serna Rebollo, Jesús. Empleado en el Servicio de Reclamaciones de NORTE. Profesor de la clase de telégrafos en la Academia de la Asociación General de Empleados y Obreros de los Ferrocarriles de España.

- Torre, Enrique de la. Primero fue agente comercial principal en NORTE, más tarde fue empleado del servicio de Intervención y Estadística de NORTE, en 1924 es nombrado subdirector del servicio de Tráfico de NORTE y posteriormente fue nombrado por el Jefe de la sección de tasas en la intervención y estadística de NORTE $^{699}$. Fuera de la compañía fue el creador y director del Anuario de Ferrocarriles, que comenzó a publicarse en 1893 cuando ya se había diseñado la red y estaban construidas las principales arterias. Posteriormente se hizo cargo de la dirección técnica del semanario Gaceta de los Caminos de Hierro. En 1905 era secretario de la Asociación General del Empleados y Obreros de los Ferrocarriles. Intervino en la Asamblea Nacional de Ferrocarriles de 1919, en la mesa dedicada a las relaciones laborales.

- Viani Caballero, Mario. Ingeniero principal de Material y Tracción de NORTE. Inspector de Material Móvil en NORTE. Ingeniero industrial.

- Wais, Francisco. Ingeniero de NORTE. Ingeniero de Caminos.

- Zurdo Olivares, Luis. Maquinista de NORTE.

De los 34 directivos de NORTE cuya trayectoria profesional conocemos, la mayor parte eran ingenieros de caminos. Los ingenieros industriales fueron minoría, aunque desde $1900 \mathrm{su}$ número aumentó sensiblemente, porque salían mas graduados de las Escuelas Industriales, porque se funda el ICAI en 1908 (Instituto Católico de Artes e Industrias) y porque el trabajo de la Administración comienza a saturarse.

\subsection{Estructura organizativa}

El cuadro 45 recoge las etapas en la evolución de la estructura organizativa de NORTE.

${ }^{699}$ Gaceta de los Caminos de Hierro, 1 de junio de 1924, p. 182. 


\section{Cuadro 45. Etapas en la evolución de la estructura organizativa de NORTE}

\begin{tabular}{|c|c|}
\hline PERIODO & ESTRUCTURA ORGANIZATIVA \\
\hline $1858-1865$ & $\begin{array}{l}\text { Modelo de gestión francés } \\
\text { Dirección en París }\end{array}$ \\
\hline $1866-1872$ & $\begin{array}{l}\text { Modelo de gestión francés } \\
\text { Dirección en Madrid } \\
\text { Sistema de servicios diferenciados }\end{array}$ \\
\hline $1873-1884$ & $\begin{array}{l}\text { Modelo de gestión francés } \\
\text { Dirección en Madrid } \\
\text { Cuatro Servicios: Administración central, Explotación, Material y tracción y Vías } \\
\text { Una única División: Vía y Obras }\end{array}$ \\
\hline $1885-1887$ & $\begin{array}{l}\text { Barat } \\
\text { Modelo de gestión francés } \\
\text { Dirección en Madrid } \\
\text { Cinco Servicios: Administración central, Explotación, Material y tracción, Vías e } \\
\text { Intervención y estadística } \\
\text { Una única División: Vía y Obras }\end{array}$ \\
\hline $1888-1891$ & $\begin{array}{l}\text { Barat } \\
\text { Modelo de gestión francés } \\
\text { Dirección en Madrid } \\
\text { Diez Servicios: Administración central, Tráfico, Movimiento, Tracción, Material y } \\
\text { tracción, Vías, Intervención y estadística, Contencioso, Contabilidad central, } \\
\text { Reclamaciones e investigaciones. } \\
\text { Una única División: Vía y Obras }\end{array}$ \\
\hline $1892-1899$ & $\begin{array}{l}\text { Barat } \\
\text { Modelo de gestión francés } \\
\text { En 1892, Barat elaboró Ordenes y Circulares que regulaba la compañía } \\
\text { Ocho Servicios: Administración central, Tráfico, Movimiento, Tracción, Contencioso, } \\
\text { Intervención, Reclamaciones e investigaciones }\end{array}$ \\
\hline $1900-1907$ & $\begin{array}{l}\text { Instrucción General número } 1 \\
\text { En 1904, Bachy elaboró nueva regulación } \\
\text { Cuatro Servicios: Administración y dirección, Explotación, Material y tracción y Vía y }\end{array}$ \\
\hline
\end{tabular}




\begin{tabular}{|l|l|}
\hline & $\begin{array}{l}\text { obras. } \\
\text { Junto a ellos se encontraban tres adjuntos a las dirección: Contencioso, Sanitario e } \\
\text { Intervención }\end{array}$ \\
\hline $1908-1914$ & $\begin{array}{l}\text { Boix } 1909 \text { modificación de los artículos 2, } 7 \text { y 11 de la Instrucción General número 1 } \\
\text { Acercamiento a algunos aspectos del Modelo Multidivisional (sin aplicarlo) }\end{array}$ \\
& $\begin{array}{l}\text { En 1908 cuatro Divisiones: Contabilidad y reclamaciones, Explotación, Material y } \\
\text { tracción y Vía y obras. Desde 1909 son cinco, pues se añade una División más: } \\
\text { Comercial } \\
\text { Dirección Consultiva }\end{array}$ \\
\hline $1915-1933$ & $\begin{array}{l}\text { Acercamiento a algunos aspectos del Modelo Multidivisional (sin aplicarlo) } \\
\text { División Servicio eléctrico con independencia de la gestión de sus directivos }\end{array}$ \\
\hline $\begin{array}{l}\text { Administrador-Delegado, con funciones de enlace entre el Comité Ejecutivo de la } \\
\text { Compañía, el Consejo de Administración y la Dirección }\end{array}$ \\
$\begin{array}{l}\text { Se crearon Subdirecciones que agrupaban a dos o más Divisiones y algunos servicios. } \\
\text { Las Subdirecciones fueron cuatro: de Asuntos Generales (personal, jurados mixtos, } \\
\text { servicio contencioso y sanitario), Comercial (explotación, movimiento, comercial y } \\
\text { reclamaciones), Técnica (material y tracción, vía y obras, servicio eléctrico) y } \\
\text { Administrativa (contabilidad central, intervención, caja central) }\end{array}$ \\
\hline
\end{tabular}

\section{Fuente: Elaboración propia}

La estructura de NORTE tiene relación con la etapa de construcción en la que se encuentra la empresa.

En la primera etapa de la construcción y puesta en servicio entre 1858-1865, las órdenes llegaban de París donde residía el Director General del proyecto, el ingeniero León Lalanne. En Valladolid residía el ingeniero N. Fournier, el cual garantizaba la transmisión de las instrucciones tomadas en Francia.

A partir de 1866 la toma de decisiones cambia geográficamente. Como la construcción de la vía no se realizó con los resultados esperados, la compañía tomó dos medidas en ese año: cambio de director y traslado de la dirección a Madrid. La construcción de la línea del NORTE costó el doble de la suma inicialmente prevista. Además, el tráfico se desarrollaba lentamente; a veces por errores de la propia compañía, como por ejemplo cuando en Castilla no construyó carreteras de acceso a las principales estaciones. Por estos errores se nombró a un nuevo Director en 1866, Gustave Noblemaire ${ }^{700}$. La Dirección de la red también fue trasladada a Madrid en 1866, lo que proporcionaba más autonomía. La compañía será menos

\footnotetext{
${ }^{700}$ El paso de Gustave Noblemaire por NORTE fue efímero pues abandonó el cargo al cabo de dos años por otro puesto en la Compagnie des Chemins de fer de Paris à Lyon et à la Méditerranée.
} 
dependiente de París, coincidiendo con una etapa de mejora en la situación económica en España.

El acercamiento de la toma de decisiones a España no se derivó de una estrategia empresarial planificada de NORTE, sino que tuvo su origen en presiones periodísticas -que incluso llegaron a los tribunales-, y por disputas judiciales. Por un lado, un columnista del periódico político "La Verdad", llamado Timoner (1864: 1-15), que a su vez era contratista de obras, publicó en ese periódico un artículo el 25 de abril de 1862. En el artículo se consideraba nula la autorización dada por el Estado a NORTE, argumentando que la empresa incumplía lo prescrito en la ley de 28 de enero de 1848 relativa a sociedades mercantiles por acciones (artículo 11). El asepecto controvertido aparecía en el contenido del pliego de condiciones para la contratación de las obras, donde recogía que las contiendas judiciales se resolverán por los Tribunales franceses (artículo 41). Timoner (1865, 1-31) expuso su litigio contra NORTE, elevando al ministro una exposición de hechos, con la cual pretendía anular la concesión otorgada a la Compañía por incumplimiento de la ley general de sociedades anónimas por acciones. El autor consideraba que la organización de la compañía, con un Comité en Paris de amplios y absolutos poderes, varía la naturaleza y el domicilio legal, lo cual no había sido propuesto ni consentido por el gobierno. En este caso, según el artículo11 de la citada Ley, toda alteración o reforma en los estatutos y reglamentos que no obtenga la aprobación del gobierno será ilegal y anulará por sí la autorización en virtud de la cual existe la compañía. La Sentencia fue favorable al demandante ${ }^{701}$. Por otro lado, con motivo de un juicio ordinario, se planteó el problema de la jurisdicción nacional, que según diversos autores fue conculcada por NORTE. López de Lara $(1865,1-40)$ defendió que la empresa estaba domiciliada por la ley y estatutos en Madrid, por lo que no tiene sentido que las principales cuestiones judiciales procedentes de sus grandes contratas, sean dirimidas en la jurisdicción especial del Tribunal del Sena y la Corte Imperial de París, en vez del fuero ordinario español. Todas estas presiones periodísticas y judiciales fueron la verdadera razón de la traslación de poder a Madrid.

Aparte de la Dirección General, NORTE disponía de varios “departamentos" ("Servicios” en denominación de la compañía). La dirección de los Servicios, y por lo general también los puestos de mayor responsabilidad, recaía en ingenieros, que habían comenzado su carrera dentro de la Administración, en la propia Dirección de Obras Públicas o en las jefaturas provinciales dependientes de ella, sin llegar a desligarse de ella totalmente ${ }^{702}$.

La actividad ferroviaria coordina distintos Servicios, cada uno de los cuales aporta su especificidad a un complejo mecanismo técnico y humano. Aunque NORTE presenta diferencias en la definición del número y nomenclatura de los Servicios, propias de su evolución en la estructura organizativa a lo largo del tiempo, puede identificarse un patrón común a todas las etapas. Había tres grandes Servicios: Vía y obras, Movimiento, y Material y

\footnotetext{
${ }^{701}$ Posteriormente, NORTE planteó un pleito por injurias y calumnias contra Timoner (Timoner, 1864: 1-15).

702 Boag (1923) veía acertado que se contrataran únicamente a ingenieros en aquellas tareas donde los conocimientos técnicos eran una condición obligada, pero, dada su formación británica, no entendía que se les prefiriera también para otras más en consonancia con otro tipo de perfil como el servicio comercial.
} 
tracción; y varios pequeños: Talleres, Contabilidad y caja, Intervención y estadística, Almacenes, Contencioso, Sanitario, Comercial, y Eléctrico.

Disponer la circulación de los trenes implica básicamente tres requerimientos: el rail, el material rodante y el personal especializado o capital humano. Del primero se ocupa el "Servicio de Vía y Obras" ${ }^{703}$. Contar con el material móvil necesario y ordenar de forma eficiente y puntual los vehículos (locomotoras, coches, furgones para el correo y vagones) es cometido del "Servicio de Material y Tracción". Cuando ya está determinada la infraestructura, el "Servicio de Explotación o Movimiento" se ocupa de generar el transporte, esto es, de disponer y coordinar la conducción y circulación de los trenes y de establecer las relaciones mercantiles con los clientes directamente o a través de agencias comerciales. Existen otras necesidades, menos obvias, pero también imprescindibles para que el tren alcance su destino, que afectan asimismo al conjunto de todos los servicios, y en especial de los tres mencionados. Una de ellas, es la que se refiere al mantenimiento del material, fijo y móvil. La actividad ferroviaria, por sus propias características, necesita una gran variedad de instalaciones de mantenimiento, con funciones, medios y dotaciones diferentes, a todas las cuales, y con independencia del servicio del que dependan, se las denomina "Servicio de Talleres".

En 1873, NORTE elabora un documento en el que divide la empresa en cuatro Servicios: Administración central, Explotación, Material y tracción y Vías ${ }^{704}$.

Jean Barat (Director de NORTE en el periodo 1881-1901) se mostró muy hábil en el diseño de estrategias comerciales y en el establecimiento de relaciones con las otras grandes empresas ferroviarias. Sin embargo, la gestión de Barat al frente de NORTE muestra una escasa originalidad desde el punto de vista de la innovación como manager. Su concepción del negocio ferroviario no iba más allá de la consideración de los resultados de la explotación: éstos mejorarían si se conseguía aumentar el tráfico y/o atraer flujos nuevos de mercancías y pasajeros. Sin embargo, no puso el acento en la gestión de los costes, aspecto en los que los directivos estadounidenses y británicos habían sido auténticos expertos e innovadores ${ }^{705}$. Salvo las iniciativas puestas en marcha para la retirada y sustitución de antiguas obligaciones de NORTE durante los difíciles años 1864-1868, tampoco se prodigó en conocimientos financieros demasiado novedosos relativos a la marcha de la compañía, especialmente durante los apuros de liquidez de la década de los años 1890 (Vidal, 1997: 84). Debido a sus primeros años de aprendizaje en la compañía francesa de Nord y su posterior entrada en NORTE, su trayectoria viene a subrayar su vinculación a la escuela francesa en lo que se refiere al estilo de dirección y a su impronta como gestor de la empresa. El número de directivos franceses

\footnotetext{
${ }^{703}$ Matallana (1873) realizó una detallada exposición de los requerimientos del Servicio de Vía y Obras.

704 El documento es W-33-132. Compañía de los Caminos de Hierro del Norte de España, "Informe sobre contabilidad", 30 de abril de 1873, Madrid: Norte. En este documento los documentos de planificación y organización todavía son elaborados en francés.

${ }^{705}$ Al final del siglo XIX y primer cuarto del siglo XX ya es posible encontrar empresas españolas de otros sectores con una contabilidad de gestión desarrollada. Ello puede observarse en Donoso et. al. (2006: 42-67).
} 
importantes era abrumador, lo cual contrastaba con el aumento del peso que en el accionariado comenzaban a tener los accionistas españoles ${ }^{706}$.

En 1885 se refuerza el Servicio de explotación y se incorpora como nuevo Servicio el Servicio de Intervención y estadística. A partir de ese momento, el Servicio de explotación tenía como cometido mover los trenes. Requería un gran número de empleados: jefes de estación, factores, telegrafistas, guardagujas y conductores de tren (NORTE, 1885a, 1-578). El Servicio de Intervención y estadística tiene por objeto la comprobación de las recaudaciones de cualquier servicio, el examen de tasas, la liquidación de cuentas con deudores o acreedores, la vigilancia de la contabilidad de las estaciones, formación de estadísticas y de mandatos de pago y, por último, fabricación de billetes (NORTE, 1885a, 1578).

Si se comparan los diversos esquemas de organización que fue adoptando la compañía se observará que cuando NORTE incorporó en 1891 su última gran empresa ferroviaria (AVTAlmansa a Valencia y Tarragona) todavía no se acercaba a un organigrama multidivisional. Hasta ese momento la compañía se había desarrollado sobre la base de un sistema de Servicios diferenciados: Contencioso, Contabilidad central, Tráfico, Intervención y estadística, Movimiento, Reclamaciones e investigaciones y Tracción.

El uno de enero de 1892, Barat elaboró un gran número de Órdenes y Circulares que mejoraron la regulación interna de NORTE.

En 1893, cuando se incorporó la línea Huesca-Canfranc, únicamente existía una División: la de Vía y Obras. Esto supone que la compañía seguía manteniendo esencialmente un esquema todavía constructor más que de gestión enfocada hacia la explotación comercial, a pesar de que el recurso a la ampliación de los diferentes servicios fuese el utilizado para ir descentralizando las funciones y conseguir adaptarse a los requerimientos de una explotación más compleja. Cada uno de los Servicios en los que se dividía la compañía se fue independizando administrativamente, a medida que la compañía iba creciendo en sus necesidades de administración del trabajo interno generado por la gestión (Comín, et al., 1998: 187).

\footnotetext{
${ }^{706}$ En 1908, el administrador, y antiguo Director de la compañía, Barat, envió dos documentos al Consejo. En uno presenta la renuncia del cargo de administrador de la empresa. En el otro solicita del Consejo el abono de determinadas cantidades en concepto de retribución por servicios prestados al conseguir la fusión de varias líneas. El Consejo acordó que se sometieran a los Comités de París y Barcelona y lo comunicasen al Consejo antes del día 5 o 6 de mayo de 1908 en el que se reunirá de nuevo (Acta n 748 del Libro de actas del Consejo de Administración de NORTE: 24 de abril de 1908). El Comité de París envía una carta al Consejo el 30 de abril de 1908 en el que se afirma que debe ser aceptada la dimisión. Asimismo, el Comité de Barcelona envía una carta al Consejo el 28 de abril de 1908, en la que se afirma que el Consejo no debería acceder a las peticiones de Barat, por estimar que, tanto los servicios ordinarios como extraordinarios que prestó a la compañía están plenamente retribuidos. El Presidente del Comité ejecutivo acepta la renuncia y deniega el abono de dinero solicitado (Acta n 749 del Libro de actas del Consejo de Administración de NORTE: 6 de mayo de 1908).
} 
NORTE siguió manteniendo el modelo francés de gestión y organización cuando alcanzó su madurez como empresa en el primer tercio del siglo $\mathrm{XX}$ : es decir, sólo algunas áreas alcanzaron un cierto grado de autonomía de objetivos, organización interna autónoma y capacidad para disponer de presupuesto propio. Esto fue así únicamente en la División de Material y Tracción, ya que desde 1914-1918 la electrificación y el proceso de cambio tecnológico del material móvil de la compañía aceleraron la relativa independencia de gestión de esta División y la de sus directivos responsables. En NORTE no hubo nunca un esquema multidivisional típicamente estadounidense, como prácticamente en ninguno de los países europeos; más bien el esquema de organización fue mixto, claramente desarrollado e inspirado por los directivos de formación francesa, aunque modificado y adaptado posteriormente a las particularidades del mercado de transporte ferroviario español.

En 1900 la gestión de NORTE tenía solamente cuatro unidades de decisión: Consejo de Administración, Comité de Barcelona, Comité de Paris, y por último, Dirección y oficinas centrales. La decisión es más geográfica que funcional. La primera innovación, y la más importante, es la creación del Comité Ejecutivo. Este organismo aparece en 1901, dando un paso de gigante en la organización y profesionalización de la empresa. El primer Comité estaba compuesto por un vicepresidente, Faustino Rodríguez San Pedro, y dos Administradores. La segunda gran novedad se produjo en la Dirección y oficinas centrales; en 1904 NORTE pasa de tener un Director y un Subdirector, a tener un Director Consultor Honorario, un Subdirector Honorario, un Director de la Compañía, un Director Adjunto y dos Subdirectores. Con las dos medidas se identifica un traslado de poder de los Consejos al Comité Ejecutivo, y de los accionistas a la Dirección, que toma cada vez más poder ${ }^{707}$.

En 1900, la compañía publicó la "Instrucción general número 1 sobre la organización de los servicios de la compañía" (NORTE, 1900: 1-49). En ese año, tanto el organigrama como el procedimiento de toma de decisiones estaba perfectamente explicitado por escrito. El organigrama estaba basado en cuatro Servicios o Divisiones: Administración y dirección, Explotación, Material y tracción y Vía y obras. Junto a ellos se encontraban tres Servicios adjuntos a las dirección: Contencioso, Sanitario e Intervención.

Los procedimientos de toma de decisiones también estaban establecidos. Los agentes principales de la compañía elevaban informes a la jefatura de los cuatro Servicios. Por otra parte, los responsables a los adjuntos se reunían todas las semanas con el director en la "Conferencia Semanal de la Dirección"; este grupo remitía sus trabajos al Comité de Madrid, donde cada quincena se adoptaban los acuerdos más importantes. El Consejo de Administración estaba formado por cuatro miembros: Faustino Rodríguez San Pedro, que ejercía de presidente, Antonio Borregón, Manuel Estibaus y Federico Luque; además asistían a las deliberación, a título de invitados, el director de la compañía Clément Aubert y el Secretario de la compañía Méndez Vigo. El Consejo de Administración elevaba sus decisiones al Comité de Administración que ratificaba los acuerdos tomados en las instancias

\footnotetext{
${ }^{707}$ El estudio de los intereses de directivos y propietarios fue analizado por los estudiosos de la Teoría de la Agencia (Jensen y Meckling: 1976) (Smith y Watts: 1982) (Jensen, 1983; 323) (Healy: 1985) (Watts y Zimmerman, 1986; 1979).
} 
anteriores. El Comité de Paris intervenía cuando había que adoptar decisiones importantes, sobre la construcción de líneas, anexiones de otras compañías, asuntos financieros, importantes compras de material o nombrar al director de la compañía. El proceso concluía con la celebración de la Junta General de Accionistas a mitad del año para debatirse los asuntos acaecidos en el año anterior.

El 31 de diciembre de 1904, Bachy revisó por completo el sistema interno de NORTE en una extensa colección de Órdenes y Circulares que anulaban las emitidas por Barat en 1892 (NORTE: 1904b).

Por lo que se refiere a los organigramas de gestión, desde 1908, NORTE se encaminó progresivamente hacia una organización en la que se introdujeron algunos elementos típicos de los esquemas organizativos de tipo multidivisional ${ }^{708}$ (aunque nunca lo aplico completamente), a medida que aumentó la cantidad de personal de plantilla y paralelamente la gestión se hizo más compleja por el tamaño y la extensión de la red, tal y como se desprende de los organigramas.

En la primera época de NORTE, el diseño organizativo adoptado fue, como no podía ser de otro modo, el importado de las ferroviarias francesas, lo que no ha de sorprender pues el país vecino fue el principal proveedor de capital financiero, y por derivación, también del tecnológico y humano más cualificado, sobre todo al principio, cuando nada de esto existía aquí (de los Cobos y Martínez Vara, 2009: 3). Pero este modelo fue cambiando.

NORTE evolucionó de un Modelo francés (management desarrollado por los gestores franceses y utilizado por ellos hasta 1900), en el que el Director General tenía un poder excesivo, a una modernización de las estructuras organizativas, como las que tenían las grandes ferroviarias estadounidenses y del resto de Europa. Esto fue realizado, sobre todo en la época en la que el Director General de NORTE era Boix (1908-1932). Hasta su llegada, el origen de su capital era francés, por lo que el management desarrollado por los gestores franceses era el que se venía utilizando en aquel país. En esta época el Director general acumuló un poder excesivo, sin permitir demasiadas posibilidades de participación en la toma de decisiones a los cargos medios y altos. Esto fue así hasta que Boix asumió la Dirección General en 1908. Bajo el mandato de Boix mejoraron algunos de los objetivos comerciales planteados, fundamentalmente importante fue la incorporación de jóvenes ingenieros de variada formación y la modificación del organigramas de gestión. El creciente poder de los directivos, similar a lo que ocurría en Estados Unidos y en el resto de las compañías europeas, se notó en NORTE a partir de 1908. La empresa comenzó a mostrar los rasgos y

\footnotetext{
708 Las modificaciones en el organigrama de la empresa ferroviaria progresivamente se fueron acercando someramente al modelo multidivisional que caracteriza la época de madurez de la mayor parte de las compañías ferroviarias del mundo durante el primer tercio del siglo XX. Con excepciones, tales como la compañía de capital estadounidense Ferrocarril Central Mexicano, que sufrió un proceso involucionista en su camino hacia el desarrollo de un esquema organizativo multidivisional entre 1880 y 1907 ; véanse los estudios de S. Kuntz (1995, 1996 y 1997).
} 
características de las grandes compañías corporativas y como tal se comportaba en su trayectoria y en sus objetivos.

Boix imprimió un cambio profundo en los esquemas de organización de la compañía al acercar la compañía a unas formas más corporativas, en las que algunos de los elementos del sistema multidivisional se fueron abriendo paso, aunque fue un mínimo acercamiento sin que se pueda afirmar que se aplicó un modelo multidivisional. Las razones por las que al final NORTE no aplicó un modelo multidivisional deben encontrarse en Boix: por un lado él no creía en la cesión de la toma de decisiones descentralizada, y por otro él no tuvo contacto con países en los que estaban aplicándolo en ese momento, al contrario que le ocurrió a MZA, cuando Maristany realizó sus viajes por Estados Unidos.

En todo caso, Boix fue el artífice y responsable de la transición de NORTE desde un esquema constructor a un esquema organizativo más desarrollado, al imprimir un nuevo rumbo a la compañía, abandonando el esquema de inspiración francesa, deudor todavía de la fase inicial de construcción y adaptando el organigrama de NORTE al objetivo de rentabilizar la empresa mediante una explotación más eficiente (Vidal, 1999: 656). A lo largo de los años de gestión de Boix en NORTE lo más sobresaliente fue el acceso a los puestos directivos de ingenieros de caminos. Boix se apoyó en ellos para modificar el organigrama de funcionamiento de la compañía y mejorar la eficiencia del sistema de explotación de la empresa ${ }^{709}$.

Hasta la llegada de Boix, los diferentes Servicios se habían ido ampliando para descentralizar las funciones y adaptarse a los requerimientos de una gestión más compleja. Con él comenzó a adoptarse una modificación más profunda. Comenzó sustituyendo el esquema de departamentos por el de Divisiones (aunque manteniendo en todo el periodo la denominación de Servicios), y terminó aplicando un sistema con algún elemento del modelo multidivisional, basado en Divisiones descentralizadas y con cierta capacidad de decisión y coordinada por un Comité de Dirección. La estructura establecida partía del principio de la autonomía divisional, al frente del cual figuraba un responsable que coordinaba funciones y decisiones emanadas de la Dirección general. Las Divisiones que instauró Boix en los primeros años desde su nombramiento en 1908 fueron cuatro: primera, que abarcaba Contabilidad y reclamaciones; segunda, incluía Explotación; tercera. Material y tracción; y cuarta, Vía y obras. En el nuevo esquema se agrupaban en una división los antiguos Servicios de lo Contencioso, Contabilidad central y Reclamaciones e investigación en una única división Contabilidad y reclamaciones.

En 1909 se añadió una División especial -Comercial-, que supondría tener a partir de ese momento cinco unidades de gestión. El 1 de julio de 1909, el Consejo aprobó la propuesta de la Dirección de 14 de junio de 1909, aprobada por el Comité en Sesión de 18 de junio de 1919, por la que se modifica los artículos 2, 7 y 11 de la "Instrucción General número 1". Según este acuerdo, se creó una nueva División, denominada "División Comercial", bajo las órdenes de un Jefe. Dicha División comprenderá los Servicios del Tráfico y de la Intervención

\footnotetext{
${ }^{709}$ Francisco Wais (1987, I: 197) subraya que este proceso de incorporación de ingenieros al staff directivos de NORTE fue un gran apoyo a los cambios que Boix fue introduciendo paulatinamente en NORTE.
} 
y Estadística, pasando a depender del primero las Secciones de Detasas y de Estadística comercial, que hasta esa fecha había pertenecido al segundo ${ }^{710}$.

En 1914 se creó el Servicio Eléctrico, dependiente de Explotación, y en 1915 se potenció la División de Material tras los años de la guerra mundial y el ingreso de NORTE en el Estatuto Ferroviario. El nuevo esquema de Divisiones fue ampliándose desde 1914-1915, alcanzando su mayor exponente a partir de 1925, año en que las dependencias subordinadas a cada una de las Divisiones fueron creciendo, incrementándose el número de directivos, tanto los de alta responsabilidad como, especialmente, los cargos medios.

Desde 1917, la compañía comienza un nuevo proceso de reestructuración. Se crean más subdirecciones, directores adjuntos o agregados y personal consultivo. La promoción hacia estos cargos se realizaba desde las filas de los jefes del Servicio de Contabilidad y sobre todo de los jefes de División, casi siempre procedentes del área de Explotación y Vía y Obras, los cuales eran ingenieros solventes y con años de experiencia en la empresa. De esta forma, los rasgos que presenta la trayectoria formativa de ejecutivos y de organización de NORTE vienen a coincidir con los de las grandes compañías ferroviarias europeas ${ }^{711}$. NORTE tuvo, sin embargo, sus propios ritmos de crecimiento y de adaptación a entornos institucionales y económicos.

Como puede observarse en el cuadro 46, la estructura organizativa y de gestión de NORTE va perfilándose para alcanzar una mayor profesionalización.

El número de administradores en los Consejos y Comités va aumentando según transcurren los años. El Consejo de Administración mantiene la denominación de sdministradores para el grueso de sus miembros; por el contrario, el Comité de Barcelona, el Comité de Paris y el Comité Ejecutivo mantuvieron su denominación de administradores hasta 1920, año en el que sus componentes mayoritarios pasan a denominarse vocales.

Esta reestructuración de 1920 es la más importante porque planifica una reorganización funcional, de cargos y de estructura. En los años anteriores, la estructura se estaba volviendo obsoleta, con cargos sin funciones establecidas, y con más cargos honoríficos de los necesarios. Esta situación fue solventada a corto plazo dejando de cubrir muchos cargos, aunque estuvieran establecidos en los organigramas. La empresa dejó sin cubrir el Jefe de lo Contencioso entre el año 1915 y 1918, el presidente del Comité Ejecutivo en los años 1918 y 1919, el Director en el año 1919 y dos vocales del Comité de Barcelona en el año 1920.

Los Ingenieros pasan a tomar cada vez más protagonismo. Ocupan la mayoría de los puestos de dirección, pero además se crean puestos específicos para ellos. En 1900 sólo había un Consultor en el Comité de Paris, en 1905 se crea un puesto de Inspector principal en la Dirección, en 1908 el de Inspector general de los servicios administrativos y financieros en la

\footnotetext{
${ }^{710}$ Acta $\mathrm{n}^{\mathrm{o}} 765$ del Libro de actas del Consejo de Administración de NORTE: 1 de julio de 1909: Apartado III.

711 "NORTE no fue una excepción en el panorama del sector, mostrando las mismas características generales que se han advertido en otras empresas de similar tamaño" (Vidal, 1998: 98).
} 
Dirección. En 1909, el de Ingeniero de material en el Comité de Paris, junto con dos ingenieros jefes (adjunto y agregado) en la Dirección. En 1910 se creó el puesto de Ingeniero Consultor en el Comité de Paris. En 1913 se creó el puesto de Ingeniero Consultor de minas agregado en la Dirección.

En la década de 1930 las características descritas en este último esquema se consolidaron. NORTE llevo a cabo una reorganización de los altos cargos en $1934^{712}$, de forma que estableció los perfiles propios de una gran empresa corporativa, en línea con las grandes compañías manufactureras y ferroviarias de los países más industrializados de la Europa occidental. La reorganización de 1934 en NORTE consistió en el nombramiento de un administrador-delegado, que actuaría de enlace entre el Comité Ejecutivo de la Compañía, el Consejo de Administración y la Dirección. Además, se crearon subdirecciones diversas que agrupaban a dos o más Divisiones y algunos servicios. Estas últimas fueron: Subdirección de Asuntos Generales (personal, jurados mixtos, servicio contencioso y sanitario), Subdirección Comercial (explotación, movimiento, comercial y reclamaciones), Subdirección técnica (material y tracción, vía y obras, servicio eléctrico) y Subdirección administrativa (contabilidad central, intervención, caja central).

Además de los ejecutivos de gestión cabría también añadir que algunos directivos de NORTE ascendieron en el escalafón de la compañía no a través de su formación y su trabajo desempeñado en el organigrama de la empresa, sino por acceso al Consejo de Administración a través de la Secretaría General. Se trataba de personal sin formación técnica, pero que alcanzó remuneraciones que estaban por encima de la mayoría del personal más cualificado. Joaquín Fesser y Fesser (1856-1918) ${ }^{713}$ y Ventura González de la Cruz (1870-1933) fueron los Secretarios generales del Consejo de Administración.

La profesionalización de la empresa, se había ido apuntando desde la última década del siglo XIX pero tuvo su total consecución ccuando Alonso Martínez presidió el Consejo de Administración en el periodo 1920-1935.

Esta profesionalización en la gestión se realizó a través de los Comités. La profesionalización realizada bajo la gestión de Marqués de Alonso Martínez tiene las siguientes características:

- El Consejo de Administración fue reduciendo su tamaño al compás de la profesionalización y de los movimientos internos producidos por los cambios en la estructura de la propiedad accionarial.

- El Comité ejecutivo amplía su tamaño, aumentando el número de vicepresidencias. En ese momento estaba integrado por cuatro administradores y el director general.

- El Comité ejecutivo reforzó su papel en el día a día de la empresa ferroviaria.

\footnotetext{
${ }^{712}$ Cada una de estas subdirecciones estaría desempeñada por los hasta entonces directores adjuntos o los subdirectores, que eran: F. de Vargas, F. P. Villamil, A. Rene Flobert y Ángel Vara y López de la Llave. AHF, Archivos de NORTE, Personal, Leg. 126.

${ }^{713}$ Joaquín Fesser y Fesser que desempeñaba el cargo de agente Comercial del Servicio de Tráfico, fue nombrado- el 1 de febrero de 1905- Secretario del Consejo, con un sueldo anual de 6.000 pesetas (Acta $\mathrm{n}^{\circ} 709$ del Libro de actas del Consejo de Administración de NORTE: 28 de enero de 1905).
} 
- El Comité ejecutivo tendió a una mayor especialización, tratando de imprimir mayor eficiencia en la gestión y procurando mayor fluidez en la información corporativa entre Consejo de Administración y Dirección.

La profesionalización caminó de forma simultánea a la diversificación del accionariado, a la entrada del capital catalán y vasco, a la españolización del capital y a la consecución de una cierta madurez en la explotación comercial de la compañía. A este último proceso contribuyeron también los directivos, los cuales se fueron formando al compás de la consolidación de la empresa ferroviaria y de la mayor complejidad de su esquema de organización corporativa.

\section{Cuadro 46. Estructura organizativa de NORTE en el periodo 1900-1924}

\begin{tabular}{|c|c|c|}
\hline $\begin{array}{l}\text { Ejercicio } \\
\text { económico }\end{array}$ & Estructura organizativa & Integrantes \\
\hline \multirow[t]{5}{*}{1900} & Consejo de Administración & $\begin{array}{l}\text { 1 Presidente } \\
1 \text { Vicepresidente } \\
11 \text { Administradores } \\
1 \text { Secretario } \\
\end{array}$ \\
\hline & Comité Ejecutivo & - \\
\hline & Comité de Barcelona & $\begin{array}{l}1 \text { Presidente } \\
5 \text { Administradores } \\
1 \text { Secretario }\end{array}$ \\
\hline & Comité de Paris & $\begin{array}{l}\text { 1 Presidente } \\
7 \text { Administradores } \\
1 \text { Ingeniero Consultor } \\
1 \text { Secretario }\end{array}$ \\
\hline & Dirección y oficinas centrales & $\begin{array}{l}1 \text { Director } \\
1 \text { Subdirector }\end{array}$ \\
\hline \multirow[t]{5}{*}{1901} & Consejo de Administración & $\begin{array}{l}\text { 1 Presidente (existe el cargo pero nadie lo ocupa) } \\
1 \text { Vicepresidente } \\
11 \text { Administradores } \\
1 \text { Secretario }\end{array}$ \\
\hline & Comité Ejecutivo & $\begin{array}{l}1 \text { Vicepresidente } \\
2 \text { Administradores }\end{array}$ \\
\hline & Comité de Barcelona & $\begin{array}{l}1 \text { Presidente } \\
5 \text { Administradores } \\
1 \text { Secretario } \\
\end{array}$ \\
\hline & Comité de Paris & $\begin{array}{l}\text { 1 Presidente } \\
7 \text { Administradores } \\
1 \text { Ingeniero Consultor } \\
1 \text { Secretario }\end{array}$ \\
\hline & Dirección y oficinas centrales & $\begin{array}{l}1 \text { Director } \\
1 \text { Subdirector }\end{array}$ \\
\hline \multirow[t]{5}{*}{1902} & Consejo de Administración & $\begin{array}{l}\text { 1 Presidente (existe el cargo pero nadie lo ocupa) } \\
1 \text { Vicepresidente } \\
12 \text { Administradores } \\
1 \text { Secretario }\end{array}$ \\
\hline & Comité Ejecutivo & $\begin{array}{l}1 \text { Vicepresidente } \\
3 \text { Administradores }\end{array}$ \\
\hline & Comité de Barcelona & $\begin{array}{l}1 \text { Presidente } \\
5 \text { Administradores } \\
1 \text { Secretario } \\
\end{array}$ \\
\hline & Comité de Paris & $\begin{array}{l}1 \text { Presidente } \\
7 \text { Administradores } \\
1 \text { Ingeniero Consultor } \\
1 \text { Secretario } \\
\end{array}$ \\
\hline & Dirección y oficinas centrales & 1 Director \\
\hline
\end{tabular}




\begin{tabular}{|c|c|c|}
\hline & & 1 Subdirector \\
\hline \multirow[t]{5}{*}{1903} & Consejo de Administración & $\begin{array}{l}1 \text { Presidente (existe el cargo pero nadie lo ocupa) } \\
4 \text { Vicepresidente } \\
11 \text { Administradores } \\
1 \text { Secretario }\end{array}$ \\
\hline & Comité Ejecutivo & $\begin{array}{l}1 \text { Vicepresidente } \\
2 \text { Administradores }\end{array}$ \\
\hline & Comité de Barcelona & $\begin{array}{l}1 \text { Presidente } \\
5 \text { Administradores } \\
1 \text { Secretario }\end{array}$ \\
\hline & Comité de Paris & $\begin{array}{l}1 \text { Presidente } \\
9 \text { Administradores } \\
1 \text { Ingeniero Consultor } \\
1 \text { Secretario }\end{array}$ \\
\hline & Dirección y oficinas centrales & $\begin{array}{l}1 \text { Director } \\
1 \text { Subdirector }\end{array}$ \\
\hline \multirow[t]{5}{*}{1904} & Consejo de Administración & $\begin{array}{l}1 \text { Presidente (existe el cargo pero nadie lo ocupa) } \\
4 \text { Vicepresidente } \\
12 \text { Administradores } \\
1 \text { Secretario }\end{array}$ \\
\hline & Comité Ejecutivo & $\begin{array}{l}1 \text { Vicepresidente } \\
3 \text { Administradores }\end{array}$ \\
\hline & Comité de Barcelona & $\begin{array}{l}1 \text { Presidente } \\
5 \text { Administradores } \\
1 \text { Secretario }\end{array}$ \\
\hline & Comité de Paris & $\begin{array}{l}1 \text { Presidente } \\
9 \text { Administradores } \\
1 \text { Ingeniero Consultor } \\
1 \text { Secretario } \\
\end{array}$ \\
\hline & Dirección y oficinas centrales & $\begin{array}{l}\text { 1 Director Consultor Honorario } \\
1 \text { Subdirector Honorario } \\
1 \text { Director de la Compañía } \\
1 \text { Director Adjunto } \\
2 \text { Subdirectores }\end{array}$ \\
\hline \multirow[t]{5}{*}{1905} & Consejo de Administración & $\begin{array}{l}1 \text { Presidente } \\
4 \text { Vicepresidente } \\
12 \text { Administradores } \\
1 \text { Secretario del Consejo }\end{array}$ \\
\hline & Comité Ejecutivo & $\begin{array}{l}1 \text { Presidente } \\
4 \text { Administradores }\end{array}$ \\
\hline & Comité de Barcelona & $\begin{array}{l}1 \text { Presidente } \\
5 \text { Administradores } \\
1 \text { Secretario } \\
\end{array}$ \\
\hline & Comité de Paris & $\begin{array}{l}1 \text { Presidente } \\
9 \text { Administradores } \\
1 \text { Ingeniero Consultor } \\
1 \text { Secretario }\end{array}$ \\
\hline & Dirección y oficinas centrales & $\begin{array}{l}1 \text { Director de la Compañía } \\
1 \text { Director Adjunto } \\
2 \text { Subdirectores } \\
1 \text { Director Honorario Consultor } \\
1 \text { Subdirector Honorario } \\
1 \text { Inspector Principal agregado }\end{array}$ \\
\hline \multirow[t]{4}{*}{1906} & Consejo de Administración & $\begin{array}{l}1 \text { Presidente } \\
4 \text { Vicepresidentes } \\
11 \text { Administradores } \\
1 \text { Secretario del Consejo }\end{array}$ \\
\hline & Comité Ejecutivo & $\begin{array}{l}1 \text { Presidente } \\
4 \text { Administradores }\end{array}$ \\
\hline & Comité de Barcelona & $\begin{array}{l}1 \text { Presidente } \\
4 \text { Administradores } \\
1 \text { Secretario }\end{array}$ \\
\hline & Comité de Paris & $\begin{array}{l}1 \text { Presidente } \\
8 \text { Administradores } \\
1 \text { Ingeniero Consultor }\end{array}$ \\
\hline
\end{tabular}




\begin{tabular}{|c|c|c|}
\hline & & $\begin{array}{l}\text { 1 Secretario } \\
1 \text { Ingeniero de Material } \\
1 \text { Jefe de Contabilidad }\end{array}$ \\
\hline & Dirección y oficinas centrales & $\begin{array}{l}1 \text { Director de la compañía } \\
1 \text { Director Adjunto } \\
1 \text { Subdirector } \\
1 \text { Director Honorario Consultor } \\
\text { 1 Ingeniero Consultor } \\
1 \text { Inspector principal fuera de clase, agregado }\end{array}$ \\
\hline \multirow[t]{5}{*}{1907} & Consejo de Administración & $\begin{array}{l}1 \text { Presidente } \\
4 \text { Vicepresidentes } \\
11 \text { Administradores } \\
1 \text { Secretario del Consejo }\end{array}$ \\
\hline & Comité Ejecutivo & $\begin{array}{l}1 \text { Presidente } \\
4 \text { Administradores }\end{array}$ \\
\hline & Comité de Barcelona & $\begin{array}{l}1 \text { Presidente } \\
5 \text { Administradores } \\
1 \text { Secretario }\end{array}$ \\
\hline & Comité de Paris & $\begin{array}{l}1 \text { Presidente } \\
9 \text { Administradores } \\
1 \text { Ingeniero Consultor } \\
1 \text { Secretario } \\
1 \text { Ingeniero de Material } \\
1 \text { Jefe de Contabilidad } \\
1 \text { Jefe de lo Contencioso }\end{array}$ \\
\hline & Dirección y oficinas centrales & $\begin{array}{l}1 \text { Director de la compañía } \\
1 \text { Director Adjunto } \\
1 \text { Subdirector } \\
1 \text { Director Honorario Consultor } \\
1 \text { Ingeniero Consultor } \\
1 \text { Inspector principal fuera de clase, agregado }\end{array}$ \\
\hline \multirow[t]{5}{*}{1908} & Consejo de Administración & $\begin{array}{l}1 \text { Presidente } \\
4 \text { Vicepresidentes } \\
8 \text { Administradores } \\
1 \text { Secretario del Consejo }\end{array}$ \\
\hline & Comité Ejecutivo & $\begin{array}{l}\text { 1 Presidente } \\
4 \text { Administradores }\end{array}$ \\
\hline & Comité de Barcelona & $\begin{array}{l}1 \text { Presidente } \\
5 \text { Administradores } \\
1 \text { Secretario } \\
\end{array}$ \\
\hline & Comité de Paris & $\begin{array}{l}1 \text { Presidente } \\
9 \text { Administradores } \\
1 \text { Secretario } \\
1 \text { Ingeniero de Material } \\
1 \text { Jefe de Contabilidad } \\
1 \text { Jefe de lo Contencioso } \\
1 \text { Inspector general de los servicios administrativos y financieros }\end{array}$ \\
\hline & Dirección y oficinas centrales & $\begin{array}{l}1 \text { Director de la compañía } \\
1 \text { Director Adjunto } \\
2 \text { Subdirectores } \\
1 \text { Director Honorario Consultor } \\
1 \text { Ingeniero Consultor } \\
1 \text { Inspector principal fuera de clase, agregado }\end{array}$ \\
\hline \multirow[t]{4}{*}{1909} & Consejo de Administración & $\begin{array}{l}1 \text { Presidente } \\
3 \text { Vicepresidentes } \\
10 \text { Administradores } \\
1 \text { Secretario del Consejo }\end{array}$ \\
\hline & Comité Ejecutivo & $\begin{array}{l}1 \text { Presidente } \\
3 \text { Administradores }\end{array}$ \\
\hline & Comité de Barcelona & $\begin{array}{l}1 \text { Presidente } \\
6 \text { Administradores } \\
1 \text { Secretario } \\
\end{array}$ \\
\hline & Comité de Paris & $\begin{array}{l}1 \text { Presidente } \\
9 \text { Administradores } \\
1 \text { Secretario general e Inspector general de los servicios administrativos y financieros }\end{array}$ \\
\hline
\end{tabular}




\begin{tabular}{|c|c|c|}
\hline & & $\begin{array}{l}1 \text { Secretario del Comité } \\
1 \text { Ingeniero de Material } \\
1 \text { Jefe de lo Contencioso } \\
1 \text { Jefe de Contabilidad } \\
2 \text { Directores Consultivos }\end{array}$ \\
\hline & Dirección y oficinas centrales & $\begin{array}{l}1 \text { Director de la compañía } \\
2 \text { Subdirectores } \\
1 \text { Director Honorario Consultor } \\
1 \text { Ingeniero Jefe adjunto } \\
1 \text { Ingeniero Jefe agregado }\end{array}$ \\
\hline \multirow[t]{5}{*}{1910} & Consejo de Administración & $\begin{array}{l}1 \text { Presidente } \\
3 \text { Vicepresidentes } \\
10 \text { Administradores } \\
1 \text { Secretario del Consejo }\end{array}$ \\
\hline & Comité Ejecutivo & $\begin{array}{l}\text { 1 Presidente } \\
3 \text { Administradores }\end{array}$ \\
\hline & Comité de Barcelona & $\begin{array}{l}1 \text { Presidente } \\
5 \text { Administradores } \\
1 \text { Secretario } \\
\end{array}$ \\
\hline & Comité de Paris & $\begin{array}{l}1 \text { Presidente } \\
9 \text { Administradores } \\
1 \text { Secretario general e Inspector general de los servicios administrativos y financieros } \\
1 \text { Secretario del Comité } \\
1 \text { Ingeniero de Material } \\
1 \text { Jefe de lo Contencioso } \\
1 \text { Jefe de Contabilidad } \\
1 \text { Director Consultivo } \\
1 \text { Ingeniero Consultor }\end{array}$ \\
\hline & Dirección y oficinas centrales & $\begin{array}{l}1 \text { Director de la compañía } \\
2 \text { Subdirectores } \\
1 \text { Director Honorario Consultor } \\
1 \text { Ingeniero Jefe adjunto } \\
2 \text { Ingenieros Jefes agregados }\end{array}$ \\
\hline \multirow[t]{5}{*}{1911} & Consejo de Administración & $\begin{array}{l}1 \text { Presidente } \\
3 \text { Vicepresidentes } \\
10 \text { Administradores } \\
1 \text { Secretario del Consejo }\end{array}$ \\
\hline & Comité Ejecutivo & $\begin{array}{l}1 \text { Presidente } \\
3 \text { Administradores }\end{array}$ \\
\hline & Comité de Barcelona & $\begin{array}{l}1 \text { Presidente } \\
6 \text { Administradores } \\
1 \text { Secretario }\end{array}$ \\
\hline & Comité de Paris & $\begin{array}{l}1 \text { Presidente } \\
9 \text { Administradores } \\
1 \text { Secretario general e Inspector general de los servicios administrativos y financieros } \\
1 \text { Secretario del Comité } \\
1 \text { Ingeniero de Material } \\
1 \text { Jefe de lo Contencioso } \\
1 \text { Jefe de Contabilidad } \\
1 \text { Director Consultivo } \\
1 \text { Ingeniero Consultor }\end{array}$ \\
\hline & Dirección y oficinas centrales & $\begin{array}{l}1 \text { Director de la compañía } \\
2 \text { Subdirectores } \\
1 \text { Director Honorario Consultor } \\
1 \text { Ingeniero Jefe adjunto } \\
2 \text { Ingenieros Jefes agregados }\end{array}$ \\
\hline \multirow[t]{3}{*}{1912} & Consejo de Administración & $\begin{array}{l}1 \text { Presidente } \\
3 \text { Vicepresidentes } \\
11 \text { Administradores } \\
1 \text { Secretario del Consejo } \\
1 \text { Secretario Adjunto }\end{array}$ \\
\hline & Comité Ejecutivo & $\begin{array}{l}1 \text { Presidente } \\
3 \text { Administradores }\end{array}$ \\
\hline & Comité de Barcelona & $\begin{array}{l}1 \text { Presidente } \\
6 \text { Administradores }\end{array}$ \\
\hline
\end{tabular}




\begin{tabular}{|c|c|c|}
\hline & & 1 Secretario \\
\hline & Comité de Paris & $\begin{array}{l}\text { 1 Presidente } \\
9 \text { Administradores } \\
1 \text { Secretario general e Inspector general de los servicios administrativos y financieros } \\
1 \text { Secretario del Comité } \\
1 \text { Secretario Adjunto } \\
1 \text { Ingeniero de Material } \\
1 \text { Jefe de lo Contencioso } \\
1 \text { Jefe de Contabilidad } \\
1 \text { Director Consultivo } \\
1 \text { Ingeniero Consultor }\end{array}$ \\
\hline & Dirección y oficinas centrales & $\begin{array}{l}1 \text { Director de la compañía } \\
3 \text { Subdirectores } \\
1 \text { Director Honorario Consultor } \\
2 \text { Ingenieros Jefes agregados }\end{array}$ \\
\hline \multirow[t]{5}{*}{1913} & Consejo de Administración & $\begin{array}{l}1 \text { Presidente } \\
3 \text { Vicepresidentes } \\
13 \text { Administradores } \\
1 \text { Secretario del Consejo } \\
1 \text { Secretario Adjunto }\end{array}$ \\
\hline & Comité Ejecutivo & $\begin{array}{l}1 \text { Presidente } \\
1 \text { Vicepresidente } \\
3 \text { Administradores } \\
\end{array}$ \\
\hline & Comité de Barcelona & $\begin{array}{l}1 \text { Presidente } \\
6 \text { Administradores } \\
1 \text { Secretario }\end{array}$ \\
\hline & Comité de Paris & $\begin{array}{l}1 \text { Presidente } \\
1 \text { Vicepresidente } \\
7 \text { Administradores } \\
1 \text { Ingeniero Consultor } \\
1 \text { Secretario general e Inspector general de los servicios administrativos y financieros } \\
1 \text { Secretario Adjunto } \\
1 \text { Ingeniero de Material } \\
1 \text { Jefe de lo Contencioso } \\
1 \text { Jefe de Contabilidad } \\
1 \text { Director Consultivo } \\
1 \text { Ingeniero Consultor }\end{array}$ \\
\hline & Dirección y oficinas centrales & $\begin{array}{l}1 \text { Director de la compañía } \\
3 \text { Subdirectores } \\
1 \text { Director Honorario Consultor } \\
2 \text { Ingenieros Jefes agregados } \\
1 \text { Ingeniero Consultor de minas agregado } \\
\end{array}$ \\
\hline \multirow[t]{5}{*}{1914} & Consejo de Administración & $\begin{array}{l}\text { 1 Presidente } \\
4 \text { Vicepresidentes } \\
10 \text { Administradores } \\
1 \text { Secretario del Consejo } \\
1 \text { Secretario Adjunto }\end{array}$ \\
\hline & Comité Ejecutivo & $\begin{array}{l}1 \text { Presidente } \\
4 \text { Administradores }\end{array}$ \\
\hline & Comité de Barcelona & $\begin{array}{l}1 \text { Presidente } \\
6 \text { Administradores } \\
1 \text { Secretario }\end{array}$ \\
\hline & Comité de Paris & $\begin{array}{l}\text { 1 Presidente } \\
1 \text { Vicepresidente } \\
7 \text { Administradores } \\
1 \text { Ingeniero Consultor } \\
1 \text { Secretario general e Inspector general de los servicios administrativos y financieros } \\
1 \text { Secretario Adjunto } \\
1 \text { Ingeniero de Material } \\
1 \text { Jefe de lo Contencioso } \\
1 \text { Jefe de Contabilidad } \\
1 \text { Director Consultivo } \\
1 \text { Ingeniero Consultor }\end{array}$ \\
\hline & Dirección y oficinas centrales & $\begin{array}{l}1 \text { Director de la compañía } \\
3 \text { Subdirectores } \\
1 \text { Director Honorario Consultor }\end{array}$ \\
\hline
\end{tabular}




\begin{tabular}{|c|c|c|}
\hline & & $\begin{array}{l}2 \text { Ingenieros Jefes agregados } \\
1 \text { Ingeniero Consultor de minas agregado }\end{array}$ \\
\hline \multirow[t]{5}{*}{1915} & Consejo de Administración & $\begin{array}{l}1 \text { Presidente } \\
4 \text { Vicepresidentes } \\
10 \text { Administradores } \\
1 \text { Secretario del Consejo } \\
1 \text { Secretario Adjunto }\end{array}$ \\
\hline & Comité Ejecutivo & $\begin{array}{l}1 \text { Presidente } \\
4 \text { Administradores }\end{array}$ \\
\hline & Comité de Barcelona & $\begin{array}{l}1 \text { Presidente } \\
5 \text { Administradores } \\
1 \text { Secretario }\end{array}$ \\
\hline & Comité de Paris & $\begin{array}{l}1 \text { Presidente } \\
1 \text { Vicepresidente } \\
7 \text { Administradores } \\
1 \text { Ingeniero Consultor } \\
1 \text { Secretario general e Inspector general de los servicios administrativos y financieros } \\
1 \text { Secretario Adjunto } \\
1 \text { Ingeniero de Material } \\
1 \text { Jefe de lo Contencioso (existe el cargo pero nadie lo ocupa) } \\
1 \text { Jefe de Contabilidad } \\
1 \text { Director Consultivo } \\
1 \text { Ingeniero Consultor }\end{array}$ \\
\hline & Dirección y oficinas centrales & $\begin{array}{l}1 \text { Director de la compañía } \\
3 \text { Subdirectores } \\
1 \text { Director Honorario Consultor } \\
2 \text { Ingenieros Jefes agregados } \\
1 \text { Ingeniero Consultor de minas agregado }\end{array}$ \\
\hline \multirow[t]{5}{*}{1916} & Consejo de Administración & $\begin{array}{l}1 \text { Presidente } \\
4 \text { Vicepresidentes } \\
10 \text { Administradores } \\
1 \text { Secretario del Consejo } \\
1 \text { Secretario Adjunto }\end{array}$ \\
\hline & Comité Ejecutivo & $\begin{array}{l}1 \text { Presidente } \\
4 \text { Administradores }\end{array}$ \\
\hline & Comité de Barcelona & $\begin{array}{l}1 \text { Presidente } \\
5 \text { Administradores } \\
1 \text { Secretario }\end{array}$ \\
\hline & Comité de Paris & $\begin{array}{l}1 \text { Presidente } \\
1 \text { Vicepresidente } \\
4 \text { Administradores } \\
1 \text { Secretario del Comité } \\
1 \text { Ingeniero Consultor } \\
1 \text { Secretario general e Inspector general de los servicios administrativos y financieros } \\
1 \text { Secretario Adjunto } \\
1 \text { Ingeniero de Material } \\
1 \text { Jefe de la Secretaría } \\
1 \text { Jefe de lo Contencioso (existe el cargo pero nadie lo ocupa) } \\
1 \text { Jefe de Contabilidad } \\
1 \text { Director Consultivo } \\
1 \text { Ingeniero Consultor }\end{array}$ \\
\hline & Dirección y oficinas centrales & $\begin{array}{l}1 \text { Director de la compañía } \\
3 \text { Subdirectores } \\
1 \text { Director Honorario Consultor } \\
2 \text { Ingenieros Jefes agregados } \\
1 \text { Ingeniero Consultor de minas agregado }\end{array}$ \\
\hline \multirow[t]{3}{*}{1917} & Consejo de Administración & $\begin{array}{l}1 \text { Presidente } \\
4 \text { Vicepresidentes } \\
7 \text { Administradores } \\
1 \text { Secretario del Consejo } \\
1 \text { Secretario Adjunto }\end{array}$ \\
\hline & Comité Ejecutivo & $\begin{array}{l}1 \text { Presidente } \\
3 \text { Administradores }\end{array}$ \\
\hline & Comité de Barcelona & $\begin{array}{l}1 \text { Presidente } \\
6 \text { Administradores } \\
1 \text { Secretario }\end{array}$ \\
\hline
\end{tabular}




\begin{tabular}{|c|c|c|}
\hline & Comité de Paris & $\begin{array}{l}\text { 1 Presidente } \\
1 \text { Vicepresidente } \\
7 \text { Administradores } \\
1 \text { Secretario del Comité } \\
1 \text { Ingeniero Consultor } \\
1 \text { Secretario general e Inspector general de los servicios administrativos y financieros } \\
1 \text { Secretario Adjunto } \\
1 \text { Ingeniero de Material } \\
1 \text { Jefe de la Secretaría } \\
1 \text { Jefe de lo Contencioso (existe el cargo pero nadie lo ocupa) } \\
1 \text { Jefe de Contabilidad } \\
1 \text { Director Consultivo } \\
1 \text { Ingeniero Consultor }\end{array}$ \\
\hline & Dirección y oficinas centrales & $\begin{array}{l}\text { 1 Director de la compañía } \\
3 \text { Subdirectores } \\
1 \text { Director Honorario Consultor } \\
2 \text { Ingenieros Jefes agregados } \\
1 \text { Ingeniero Consultor de minas agregado }\end{array}$ \\
\hline \multirow[t]{5}{*}{1918} & Consejo de Administración & $\begin{array}{l}1 \text { Presidente } \\
3 \text { Vicepresidentes } \\
9 \text { Administradores } \\
1 \text { Secretario del Consejo }\end{array}$ \\
\hline & Comité Ejecutivo & $\begin{array}{l}\text { 1 Presidente (existe el cargo pero nadie lo ocupa) } \\
4 \text { Administradores }\end{array}$ \\
\hline & Comité de Barcelona & $\begin{array}{l}1 \text { Presidente } \\
5 \text { Administradores } \\
1 \text { Secretario }\end{array}$ \\
\hline & Comité de Paris & $\begin{array}{l}\text { 1 Presidente } \\
1 \text { Vicepresidente } \\
6 \text { Administradores } \\
1 \text { Secretario del Comité } \\
1 \text { Ingeniero Consultor } \\
1 \text { Secretario general e Inspector general de los servicios administrativos y financieros } \\
1 \text { Secretario Adjunto } \\
1 \text { Ingeniero de Material } \\
1 \text { Jefe de la Secretaría } \\
1 \text { Jefe de lo Contencioso (existe el cargo pero nadie lo ocupa) } \\
1 \text { Jefe de Contabilidad } \\
1 \text { Director Consultivo } \\
1 \text { Ingeniero Consultor }\end{array}$ \\
\hline & Dirección y oficinas centrales & $\begin{array}{l}\text { 1 Director de la compañía } \\
3 \text { Subdirectores } \\
1 \text { Director Honorario Consultor } \\
1 \text { Ingeniero Jefe agregado } \\
1 \text { Ingeniero Consultor de minas agregado }\end{array}$ \\
\hline \multirow[t]{4}{*}{1919} & Consejo de Administración & $\begin{array}{l}1 \text { Presidente } \\
3 \text { Vicepresidentes } \\
11 \text { Administradores } \\
1 \text { Secretario del Consejo }\end{array}$ \\
\hline & Comité Ejecutivo & $\begin{array}{l}1 \text { Presidente (existe el cargo pero nadie lo ocupa) } \\
4 \text { Administradores }\end{array}$ \\
\hline & Comité de Barcelona & $\begin{array}{l}1 \text { Presidente } \\
4 \text { Administradores } \\
1 \text { Secretario }\end{array}$ \\
\hline & Comité de Paris & $\begin{array}{l}1 \text { Presidente } \\
1 \text { Vicepresidente } \\
5 \text { Administradores } \\
1 \text { Secretario del Comité } \\
1 \text { Ingeniero Consultor } \\
1 \text { Secretario general e Inspector general de los servicios administrativos y financieros } \\
1 \text { Secretario Adjunto } \\
1 \text { Ingeniero de Material } \\
1 \text { Jefe de la Secretaría } \\
1 \text { Jefe de lo Contencioso } \\
1 \text { Jefe de Contabilidad } \\
1 \text { Director Consultivo }\end{array}$ \\
\hline
\end{tabular}




\begin{tabular}{|c|c|c|}
\hline & & 1 Ingeniero Consultor \\
\hline & Dirección y oficinas centrales & $\begin{array}{l}1 \text { Director de la compañía (existe el cargo pero nadie lo ocupa) } \\
1 \text { Subdirector } \\
1 \text { Director Honorario Consultor } \\
2 \text { Ingeniero Jefe agregado } \\
1 \text { Ingeniero agregado } \\
1 \text { Ingeniero Consultor de minas agregado }\end{array}$ \\
\hline \multirow[t]{5}{*}{1920} & Consejo de Administración & $\begin{array}{l}1 \text { Presidente Honorario } \\
1 \text { Presidente } \\
4 \text { Vicepresidentes } \\
21 \text { Administradores } \\
1 \text { Secretario General de la Compañía }\end{array}$ \\
\hline & Comité Ejecutivo & $\begin{array}{l}1 \text { Presidente } \\
6 \text { Vocales } \\
1 \text { Secretario } \\
\end{array}$ \\
\hline & Comité de Barcelona & $\begin{array}{l}1 \text { Presidente } \\
6 \text { Vocales (dos de ellos no están ocupados) } \\
1 \text { Secretario }\end{array}$ \\
\hline & Comité de Paris & $\begin{array}{l}1 \text { Presidente } \\
1 \text { Vicepresidente } \\
6 \text { Vocales } \\
1 \text { Secretario General } \\
1 \text { Secretario Adjunto }\end{array}$ \\
\hline & Dirección y oficinas centrales & $\begin{array}{l}1 \text { Administración-Director de la compañía } \\
1 \text { Director Adjunto } \\
3 \text { Subdirectores } \\
1 \text { Director Honorario Consultor } \\
1 \text { Ingeniero Jefe agregado } \\
1 \text { Ingeniero agregado } \\
1 \text { Ingeniero Consultor de minas agregado }\end{array}$ \\
\hline \multirow[t]{5}{*}{1921} & Consejo de Administración & $\begin{array}{l}1 \text { Presidente Honorario } \\
1 \text { Presidente } \\
4 \text { Vicepresidentes } \\
25 \text { Administradores } \\
1 \text { Secretario General de la Compañía }\end{array}$ \\
\hline & Comité Ejecutivo & $\begin{array}{l}1 \text { Presidente } \\
6 \text { Vocales } \\
1 \text { Secretario } \\
\end{array}$ \\
\hline & Comité de Barcelona & $\begin{array}{l}1 \text { Presidente } \\
6 \text { Vocales } \\
1 \text { Secretario } \\
\end{array}$ \\
\hline & Comité de Paris & $\begin{array}{l}1 \text { Presidente } \\
1 \text { Vicepresidente } \\
8 \text { Vocales } \\
1 \text { Secretario General } \\
1 \text { Secretario Adjunto } \\
\end{array}$ \\
\hline & Dirección y oficinas centrales & $\begin{array}{l}1 \text { Administración-Director de la compañía } \\
1 \text { Director Adjunto } \\
3 \text { Subdirectores } \\
1 \text { Director Honorario Consultor } \\
2 \text { Ingenieros Jefes agregados } \\
1 \text { Ingeniero agregado } \\
1 \text { Ingeniero Consultor de minas agregado }\end{array}$ \\
\hline \multirow[t]{4}{*}{1922} & Consejo de Administración & $\begin{array}{l}1 \text { Presidente Honorario } \\
1 \text { Presidente } \\
4 \text { Vicepresidentes } \\
22 \text { Administradores } \\
1 \text { Secretario General de la Compañía } \\
\end{array}$ \\
\hline & Comité Ejecutivo & $\begin{array}{l}1 \text { Presidente } \\
6 \text { Vocales } \\
1 \text { Secretario } \\
\end{array}$ \\
\hline & Comité de Barcelona & $\begin{array}{l}1 \text { Presidente } \\
6 \text { Vocales } \\
1 \text { Secretario }\end{array}$ \\
\hline & Comité de Paris & 1 Presidente \\
\hline
\end{tabular}




\begin{tabular}{|c|c|c|}
\hline & & $\begin{array}{l}1 \text { Vicepresidente } \\
7 \text { Vocales } \\
1 \text { Secretario General } \\
1 \text { Secretario Adjunto } \\
\end{array}$ \\
\hline & Dirección y oficinas centrales & $\begin{array}{l}1 \text { Administración-Director de la compañía } \\
1 \text { Director Adjunto } \\
3 \text { Subdirectores } \\
1 \text { Director Honorario Consultor } \\
2 \text { Ingenieros Jefes agregados } \\
1 \text { Ingeniero agregado } \\
1 \text { Ingeniero Consultor de minas agregado }\end{array}$ \\
\hline \multirow[t]{5}{*}{1923} & Consejo de Administración & $\begin{array}{l}\text { 1 Presidente Honorario } \\
1 \text { Presidente } \\
4 \text { Vicepresidentes } \\
21 \text { Administradores } \\
1 \text { Secretario General de la Compañía }\end{array}$ \\
\hline & Comité Ejecutivo & $\begin{array}{l}1 \text { Presidente } \\
5 \text { Vocales } \\
1 \text { Secretario }\end{array}$ \\
\hline & Comité de Barcelona & $\begin{array}{l}1 \text { Presidente } \\
6 \text { Vocales } \\
1 \text { Secretario } \\
\end{array}$ \\
\hline & Comité de Paris & $\begin{array}{l}1 \text { Presidente } \\
1 \text { Vicepresidente } \\
7 \text { Vocales } \\
1 \text { Secretario General } \\
1 \text { Secretario Adjunto } \\
\end{array}$ \\
\hline & Dirección y oficinas centrales & $\begin{array}{l}1 \text { Administración-Director de la compañía } \\
1 \text { Director Adjunto } \\
3 \text { Subdirectores } \\
1 \text { Director Honorario Consultor } \\
2 \text { Ingenieros Jefes agregados } \\
1 \text { Ingeniero agregado } \\
1 \text { Ingeniero Consultor de minas agregado }\end{array}$ \\
\hline
\end{tabular}

Fuente: Elaboración propia a partir de los datos del Anuario de la Torre (1892-1935) $)^{714}$

${ }^{714}$ Los datos del cuadro se han obtenido del Anuario de la Torre (1892-1935): año 1900: pp. 61-79; año 1901: pp. 34-50; año 1902: pp. 9-29; año 1903: pp. 9-29; año 1904: pp. 9-29; año 1905: pp. 9-29; año 1906: pp. 9-30; año 1907: pp. 63-86; año 1908: pp. 63-86; año 1909: pp. 63-86; año 1910: pp. 63-87; año 1911: pp. 63-86; año 1912: pp. 63-86; año 1913: pp. 63-90; año 1914: pp. 63-90; año 1915: pp. 63-90; año 1916: pp. 63-90; año 1917: pp. 63-90; año 1918: pp. 65-82; año 1919: pp. 65-82; año 1920: pp. 65-82; año 1921: pp. 65-82; año 1922: pp. 65-84; año 1923: pp. 65-84. 


\section{CAPÍTULO CINCO.- SISTEMA DE INFORMACIÓN CONTABLE DE NORTE}

El ferrocarril es uno de los sectores más estudiados tradicionalmente por la investigación histórica, tanto en España como en el resto de los países desarrollados, motivado por el importante papel desempeñado en el progreso económico ${ }^{715}$. Dentro del estudio de la historia económica del ferrocarril, llama la atención la escasez de investigaciones realizadas sobre los registros contables, lo cual es fundamental pues la contabilidad moderna apareció en las compañías ferroviarias.

En este apartado se pretende responder a dos interrogantes sobre el diseño del modelo contable de NORTE: si es representativo del proceso productivo y si es útil para analizar la situación económica y financiera de la compañía. Para la realización de este tipo de análisis se han estudiado diferentes aspectos, como son: documentos previos, presentación, contenido y formato de la información contable periódica, principios de contabilidad generalmente aceptados, comparabilidad de las cifras, información por segmentos de negocio, de actividad o geográficos, y la capacidad de evaluar de forma adecuada las características clave de la información económico-financiera de la compañía.

El sistema contable implantado en NORTE presenta un alto grado de sofisticación ${ }^{716}$. Cumple con las dos visiones de la Contabilidad Directiva: cumplimiento de las -escasas- leyes contables y mercantiles, pero también adecuación a la regulación interna de la compañía.

La Contabilidad Directiva está formada por dos tipos de información. El primero es el Informe Anual -Memoria en denominación de la propia empresa-, constituido por la información periódica que ofrece la empresa al final de cada periodo contable, ya sea porque le obliga una legislación o un acuerdo interno de la Junta general de la empresa. En el caso específico de NORTE estos contenidos se encuentran en los Informes Anuales de NORTE de los años 1858 a 1943 (con la única excepción del año 1940); esta es la información principal, con mucha menos relevancia se sitúa la información preparatoria para elaborarla. El segundo es la información interna manejada de forma continuada por la empresa para tomar adecuadas decisiones de gestión. En el caso concreto de NORTE esta información está materializada en los informes periódicos que ofrece el Consejo de Administración.

A su vez, en los Informes Anuales de NORTE se incluyen dos tipos de datos. Unos que tienen como principales usuarios a los externos -fundamentalmente acreedores y accionistas-, tanto presentes como potenciales. Esta información es la precursora de la contabilidad normalizada actual. En el Informe Anual también se encuentran datos que tienen como destinatarios a los usuarios internos -gestores y administradores-. Estos datos son una mínima parte de la información que manejan los gestores de la empresa para tomar decisiones. Estos contenidos

\footnotetext{
${ }^{715}$ Una buena puesta al día de la historiografía aparece en Muñoz y Vidal (2001).

${ }^{716}$ El sistema contable de NORTE fue analizado a por Montoya Chinchilla (2011) y Montoya y Guzmán (2012; 2011a; 2011b).
} 
del Informe Anual que tienen como objetivo satisfacer a los usuarios internos, junto con la totalidad de información interna que manejan los gestores para la toma de decisiones de gestión y administración de la compañía, son los precursores de la actual Contabilidad Interna o de Gestión.

La dualidad de contenidos que integran la contabilidad externa es bien entendida por las concesionarias privadas del ferrocarril. Aunque la toma de decisiones de gestión y administración es el objetivo fundamental de la Contabilidad de Gestión, también juega un papel importante para la Contabilidad Financiera ${ }^{717}$.

\subsection{Regulación contable interna}

La primera regulación interna de NORTE, elaborada por ella para ser utilizada exclusivamente por ella, son los Estatutos. Los Estatutos de NORTE presentan tres versiones: iniciales $^{718}$, su versión francesa ${ }^{719}$, y el texto legal que modifica la edición anterior de estatutos de la compañía ${ }^{720}$. El texto realiza la regulación completa de la compañía, por lo que se ocupa de una forma muy superficial de la autoregulación contable.

Por su parte, la primera regulación interna de NORTE, elaborada por ella para ser utilizada exclusivamente por ella sobre una materia específicamente contable, es un documento elaborado el 30 de octubre de $1872^{721}$ para realizar el reparto de los gastos de la explotación entre las diferentes líneas de la red.

La segunda autoregulación contable versa sobre el mismo asunto, pues se realiza una revisión sobre el reparto de los gastos de la explotación entre las diferentes líneas de la red en otro documento fechado el 21 de septiembre de $1878^{722}$.

También NORTE utilizó como regulación interna un documento realizado conjuntamente con otras compañías: la "Clasificación general de mercancías" "723. Esta regulación consta de un cuadro utilizado por ocho compañías ferroviarias (NORTE, de Segovia a Medina del Campo, de Alar San Quirce a Santander, de Castejón a Bilbao, de Zaragoza a Alsasua y Barcelona, de

\footnotetext{
717 Boyns y Edwards (1996: 46). La contabilidad externa juega un papel importante en tres parcelas de la dirección de empresas: la toma de decisiones, la planificación y el control (Arnold y Hope, 1983: 356).

${ }^{718}$ NORTE (1859).

${ }^{719}$ NORTE (1863).

${ }^{720}$ NORTE (1874).

${ }^{721}$ W-52-1 Regla de contabilidad $n^{\circ} 8$ nueva, Proporción en que los servicios de la compañía deben repartir los gastos de la explotación entre las líneas que forman la red, Compañía de los Caminos de Hierro del Norte de España, 30 de octubre de 1872.

${ }^{722}$ W-52-1 Regla para el reparto de los gastos de la explotación entre las diferentes líneas de la red en la Compañía de los Caminos de Hierro del Norte de España, 21 de septiembre de 1878.

${ }^{723}$ Compañías de los Caminos de Hierro del Norte, de Segovia a Medina del Campo De Alar San Quirce a Santander de Castejón a Bilbao de Zaragoza a Alsasua y Barcelona de Tardienta a Huesca de Selgua a Barbastro y de Lérida a Reus y Tarragona. Clasificación general de mercancías, pp. 1-56.
} 
Tardienta a Huesca, de Selgua a Barbastro y de Lérida a Reus y Tarragona) para conocer a qué grupo de mercancía, que determina tarifa, corresponde el producto a transportar. La importancia de este documento es máxima porque permite observar el control indirecto de NORTE sobre todas estas líneas sobre las que la empresa tenía influencia; aunque jurídicamente tenían personalidad jurídica independiente en ese momento, en los años posteriores todas ellas se integrarían en la unidad jurídica NORTE.

Posteriormente, NORTE realizó regulaciones internas sobre muchos aspectos ${ }^{724}$, que tenían repercusión sobre la contabilidad:

- Seguridad (NORTE, 1862, 1-36).

- Entretenimiento corriente de los coches y vagones, y de todas las reparaciones que no necesitan la entrada de los vehículos en los talleres (NORTE, 1874a: 1-28).

- Deberes económicos frente a los trabajadores; en concreto, recompensas, castigos, gratificaciones, fianzas, embargos, indemnizaciones, gastos de viaje o residencia y normas básicas para la creación de las Cajas de Previsión y Retiro (NORTE, 1878a: 132).

- Diferenciación entre los gastos de primer establecimiento, por un lado, y los ingresos y gastos de la explotación, por otro (NORTE, 1878b, 1-39).

- Organización de los suministros (NORTE, 1880: 1-15).

- Organización interna de los almacenes generales y sus relaciones con los diferentes servicios de la compañía (NORTE, 1880: apéndice $n^{\circ} 2$ ).

- Organización interna de las máquinas-herramientas, herramientas de mayor cuantía, herramientas de mano, muebles, objetos de pequeño material (NORTE, 1880: apéndice $\mathrm{n}^{\mathrm{o}} 2$ ).

- Formalidades y operaciones prescritas para el adeudo y tránsito de mercancías, así como para su consignación y reexpedición (NORTE, 1881a: 1-4).

- Instrucción especial para la contabilidad de las agencias de aduanas (NORTE, 1881a: apéndice).

- Instrucción específica para la contabilidad de la agencia de Hendaya (NORTE, 1881a: apéndice).

- Órdenes de servicio, circulares y avisos relacionados con el Servicio de la Intervención y Estadística (NORTE, 1881b: 104).

- Reglamento para la vigilancia y conservación de la vía (NORTE: 1882c).

- Definición de los jefes de estación como aquellos agentes encargados de la dirección de las estaciones, establecimiento de sus funciones relativas a la explotación y movimiento, pues se encargaban de la composición, entrada y salida de trenes; intervención y contabilidad de estaciones y reclamaciones (NORTE, 1882a: 1-78; 1885b: 1-38).

- Funciones de los inspectores de explotación (NORTE, 1882b: 1-20).

\footnotetext{
$\overline{724}$ Las regulaciones internas de la contabilidad hasta el año 1924 fueron analizadas por Forcano (1924, 1-416), donde se recoge una recopilación de las circulares de la compañía sobre viajeros, mercancías, contabilidad, paquetes postales, reclamaciones. Forcano era agente de investigación en el Servicio de Reclamaciones de NORTE.
} 
- Mantenimiento del material ferroviario, principalmente locomotoras y material remolcado (NORTE, 1883: 1-108).

- Funciones del Servicio de Intervención y Estadística, entre las que se encuentra la vigilancia de la contabilidad de las estaciones, elaboración de estadísticas y de mandatos de pago (NORTE, 1885a: 1-578).

- Instrucción General número 9 sobre la Intervención y Contabilidad de la Percepción (NORTE, 1885c: 1-55; 1885d: 1-55).

- Instrucciones relativas al Servicio de Intervención en Ruta, que tiene por objeto asegurarse de que todos los viajeros vayan provistos de sus billetes; cumplimentar reglas sobre circulación gratuita de los trenes; exigir el pago de averías o deterioros causados por viajeros; vigilar el servicio de los agentes del tren etc. (NORTE, 1891: 1110).

Todos estos documentos emitidos en el siglo XIX tenían relación con la contabilidad. A principios del siglo XX NORTE publicó tres documentos (NORTE: 1900; 1904; 1907b) ${ }^{725}$ que tuvieron gran importancia para el sistema de información contable, en ellos se definía respectivamente la estructura contable de la organización, la ordenación de ingresos y gastos, y las funciones de cada puesto.

La Instrucción General Número 1 sobre la Organización de los Servicios de la Compañía de los Caminos de Hierro del NORTE de España, publicada el 30 de septiembre de 1900, especificaba las actividades relacionadas con la contabilidad de la compañía (NORTE, 1900; apartado $\left.8^{\circ}\right)^{726}$.

La Contabilidad Central estabá encomendada a un agente que llevaba el título de Jefe de la Contabilidad Central. Su misión consistirá en dirigir la Contabilidad Central, las contabilidades especiales de las cuatro Divisiones ${ }^{727}$, la de las Minas y de las Agencias de

\footnotetext{
${ }^{725}$ Durante el siglo XX, la compañía emitió otros documentos menos importantes, con influencia directa sobre la contabilidad, que tenían relación sobre algunos aspectos: personal de los Servicios (NORTE: 1900d), meritorios de estaciones (NORTE: 1900e), guardagujas (NORTE: 1910b), personal (NORTE: 1912b), pensiones de retiro de viudedad y orfandad (NORTE: 1912c), Servicio Sanitario (NORTE: 1916c) personal (NORTE: 1916b) y personal administrativo (NORTE: 1918b).

${ }^{726}$ Con este documento podemos observar los esfuerzos de NORTE para autoregular su actividad contable, pero la compañía realizó autoregulaciones en otras materias en ese mismo año para comenzar el siglo con un soporte documental que mejorara su gestión. NORTE (1900: 1-162) emitió la "Instrucción general número 3 sobre el Servicio Sanitario de la Compañía", por la que se realiza una Descripción del Servicio Sanitario de la Compañía: organización, atribuciones de los médicos, reconocimientos y asistencia a los empleados, accidentes y suministro de medicamentos. Entre los apéndices destaca la designación del material destinado al Servicio Sanitario y su distribución en los trenes y estaciones; enfermedades y deformidades que incapacitan para el ingreso en la compañía; cartilla sanitaria con preceptos para conservar la salud. Igualmente, en abril de ese mismo año, NORTE (1900b) publicó los baremos para la aplicación de las Tarifas Generales de Viajeros.

${ }^{727} \mathrm{La}$ Instrucción reconocía la existencia de las siguientes divisiones, todas ellas bajo las órdenes del Director de la Compañía: $1^{\text {a }}$ División. Servicio Central de Dirección; $2^{\mathrm{a}}$ División. De Explotación; $3^{\mathrm{a}}$ División. De Material, Tracción y Almacenes generales; $4^{\mathrm{a}}$ División. De Vía y Obra.
} 
Aduanas, el Servicio de Títulos y de la Caja Central, y la centralización de la Contabilidad del Servicio de la Cobranza.

El documento establece que la Contabilidad Central y las Contabilidades especiales debían registrar todas las cuentas y operaciones de la compañía, con arreglo a los Reglamentos de Contabilidad, al igual que la teneduría de libros auxiliares de gastos y productos de las Divisiones. De igual forma se ocupaba de vigilar e intervenir las operaciones de la Sección de Títulos y Cupones, las operaciones de la Caja Central y las de la Contabilidad de la Intervención de la Cobranza. Además, debe proceder junto con el agente encargado de la Intervención de Gastos al arqueo de la Caja Central, con arreglo a las instrucciones dictadas sobre el particular.

La Contabilidad Central suministrará a los Servicios que constituyen las diferentes Divisiones los datos que necesiten sobre los gastos de sus respectivos Servicios, y les enviará un estado mensual de los gastos, dentro del plazo determinado.

La Instrucción detalla los objetivos de la Caja Central, la Intervención de Gastos y la Intervención de la Cobranza y Estadística:

- La Caja Central estará a cargo de un agente que llevará el título de Cajero Central. Será su cometido: pagar los sueldos y salarios del personal de la Compañía y efectuar los pagos y cobros de todas clases que deban hacerse en virtud de documentos extendidos conforme a los Reglamentos de la compañía (NORTE, 1900: apartado $9^{\circ}$ ).

- Sobre la Intervención de gastos, la Instrucción General $n^{\circ} 1$ indicaba que el examen, comprobación e intervención de los libramientos y documentos de pago, estará a cargo de un agente que llevará el título de Ordenador de Pagos. Cuidará de que los documentos de gastos y libramientos que se expidan se inscriban en los registros especiales establecidos al efecto. No cursará ningún documento de pago sin haberse cerciorado previamente de que el gasto a que aquél se contrae ha sido autorizado por la superioridad en la forma reglamentaria. Concurrirá con el Jefe de la Contabilidad Central al arqueo de los fondos de la Caja Central (NORTE, 1900: apartado 10²).

- En cuanto a la Intervención de la Cobranza y Estadística, la Instrucción General $\mathrm{n}^{\mathbf{0}} 1$ señalaba que la contabilidad de los ingresos de la explotación y la comprobación de las operaciones de las estaciones, de los despachos centrales y de las percepciones suplementarias en los trenes, estarán encomendadas a un agente que se titulará Jefe de la Intervención y de la Estadística. Tendrá a su cargo la recepción y clasificación de los billetes de viajeros y la de los documentos de contabilidad enviados diariamente por las estaciones, los despachos centrales y los Interventores de ruta; la comprobación y rectificación, si ha lugar, de todas las tasas aplicadas; la intervención de cobros y pagos; el establecimiento del crédito y débito en las estaciones y despachos centrales; el resumen de los productos de la explotación; las cuentas corrientes con las compañías de ferrocarriles que están en relaciones de tráfico 
combinado, con las Administraciones Públicas, etc.; las cuentas del impuesto para el Tesoro; el servicio de paquetes postales; la telegrafía privada; la rebaja de tasa; la contabilidad de los portes en servicio combinado y sindicado, así como la de los reembolsos; la teneduría, por partida doble, de la contabilidad de los ingresos de todas clases; la estadística de los transportes y productos de todas clases; el establecimiento de los productos por líneas y la intervención de los trenes en ruta (NORTE, 1900: apartado $11^{\circ}$ ).

En segundo lugar, NORTE publicó en 1904 un documento titulado "Clasificación de Ingresos y Gastos de la Explotación" (NORTE, 1904c: 1-17), que incluye una Tabla de clasificación de los ingresos y gastos de explotación de la compañía. Respecto a los ingresos proponía el detalle por capítulos y artículos que se recoge en el cuadro 47.

\section{Cuadro 47. Clasificación de los ingresos de explotación de NORTE}

\begin{tabular}{|c|c|}
\hline Transportes en gran velocidad & $\begin{array}{l}\text { Artículo } 1^{\circ} \text {. Viajeros } \\
\text { Artículo } 2^{\circ} \text {. Equipajes y perros } \\
\text { Artículo } 3^{\circ} \text {. Mensajería y mercancías a gran velocidad } \\
\text { Artículo } 4^{\circ} \text {. Coches y sillas correos } \\
\text { Artículo } 5^{\circ} \text {. Caballos y mulas } \\
\text { Artículo } 6^{\circ} \text {. Almacenaje y productos diversos }\end{array}$ \\
\hline Transportes en pequeña velocidad & $\begin{array}{l}\text { Artículo } 1^{\circ} \text {. Mercancías a pequeña velocidad } \\
\text { Artículo } 2^{\circ} \text {. Carruajes y ganados de todas clases } \\
\text { Artículo } 3^{\circ} \text {. Almacenaje y productos diversos }\end{array}$ \\
\hline Capítulo III. Ingresos diversos & $\begin{array}{l}\text { Artículo } 1^{\circ} \text {. Arrendamientos de fondas, cantinas, puesto de agua, } \\
\text { despachos y librerías } \\
\text { Artículo } 2^{\circ} \text {. Productos de forraje, mondas y corta de árboles } \\
\text { Artículo } 3^{\circ} \text {. Arrendamientos de terrenos y propiedades diversas } \\
\text { Artículo } 4^{\circ} \text {. Venta de papeles desechados } \\
\text { Artículo } 5^{\circ} \text {. Alquiler de material } \\
\text { Artículo } 6^{\circ} \text {. Productos del correo } \\
\text { Artículo } 7^{\circ} \text {. Productos de la telegrafía privada } \\
\text { Artículo } 8^{\circ} \text {. Productos diversos }\end{array}$ \\
\hline
\end{tabular}

Fuente: Clasificación ingresos y gastos de explotación de NORTE (1904c)

El cuadro 48 recoge el detalle por capítulos y artículos de los gastos de explotación de NORTE. 


\section{Cuadro 48. Clasificación de los gastos de explotación de NORTE}

\begin{tabular}{|c|c|}
\hline $\begin{array}{r}\text { Capítulo I. } \\
\text { Administración Central }\end{array}$ & $\begin{array}{l}\text { Artículo } 1^{\circ} \text {. Honorarios y dietas de los Administradores } \\
\text { Artículo } 2^{\circ} \text {. Personal de la administración central } \\
\text { Artículo } 3^{\circ} \text {. Seguros, contribuciones y alquileres } \\
\text { Artículo } 4^{\circ} \text {. Gastos generales } \\
\text { Artículo } 5^{\circ} \text {. Gastos de intervención, de vigilancia y de policía por el } \\
\text { Gobierno } \\
\text { Artículo } 6^{\circ} \text {. Administración de los bienes de la compañía }\end{array}$ \\
\hline $\begin{array}{r}\text { Capítulo II. } \\
\text { Dirección de la Compañía }\end{array}$ & $\begin{array}{l}\text { Artículo } 1^{\circ} . \text { Personal de todos los servicios de la dirección } \\
\text { Artículo } 2^{\circ} \text {. de oficina y accesorios } \\
\text { Artículo } 3^{\circ} \text {. Impresos } \\
\text { Artículo } 4^{\circ} . \text { Vestuario de los servicios centrales }\end{array}$ \\
\hline $\begin{array}{l}\text { Capítulo III. } \\
\text { Explotación }\end{array}$ & $\begin{array}{l}\text { Artículo } 1^{\circ} \text {. Servicio Central de la Dirección y del Movimiento de las } \\
\text { Demarcaciones y de las Inspecciones } \\
\text { Artículo } 2^{\circ} \text {. Trenes } \\
\text { Artículo } 3^{\circ} \text {. Estaciones } \\
\text { Artículo } 4^{\circ} \text {. Tráfico } \\
\text { Artículo } 5^{\circ} \text {. Reclamaciones e investigaciones } \\
\text { Artículo } 6^{\circ} \text {. Intervención de la cobranza }\end{array}$ \\
\hline $\begin{array}{r}\text { Capítulo IV. Material y } \\
\text { tracción }\end{array}$ & $\begin{array}{l}\text { Artículo } 1^{\circ} \text {. Servicio Central } \\
\text { Artículo } 2^{\circ} \text {. Personal del servicio de tracción } \\
\text { Artículo } 3^{\circ} \text {. Material del servicio de tracción } \\
\text { Artículo } 4^{\circ} \text {. Reparación del material de tracción en los talleres } \\
\text { Artículo } 5^{\circ} \text {. Reparación del material de transporte en talleres y } \\
\text { puestos de recorrido }\end{array}$ \\
\hline Capítulo V. Vía & $\begin{array}{l}\text { Artículo } 1^{\circ} \text {. Servicios Centrales de la División, de las } \\
\text { circunscripciones y de las Secciones } \\
\text { Artículo } 2^{\circ} \text {. Vigilancia de la vía } \\
\text { Artículo } 3^{\circ} \text {. Conservación de la vía propiamente dicha (mano de obra } \\
\text { y materiales) } \\
\text { Artículo } 4^{\circ} \text {. Conservación de los edificios } \\
\text { Artículo } 5^{\circ} \text {. Gastos extraordinarios, que incluía renovación de la vía y } \\
\text { balasto, grandes reparaciones, transformaciones e instalaciones } \\
\text { suprimidas }\end{array}$ \\
\hline
\end{tabular}

Fuente: Clasificación ingresos y gastos de explotación de la Compañía NORTE (1904c)

El Producto Neto de la explotación del negocio ferroviario se obtenía por diferencia entre los ingresos y gastos de explotación descritos, importes que aparecían en la "Cuenta General de la Explotación”. Sin embargo, las compañías ferroviarias cargaban separadamente al saldo del Producto neto otras partidas que no obedecían en sentido estricto a la explotación, aunque sí incidían de forma directa en el resultado del ejercicio, entre las que se incluían los intereses procedentes de empréstitos, el importe de las amortizaciones de obligaciones, las diferencias de cambio por operaciones en moneda extranjera y la amortización del material fijo y móvil.

En 1907, la compañía emitió un libro dirigido a los futuros factores de estación (NORTE, 1907b). El libro se iniciaba con una definición del cargo y sus funciones, para luego, en catorce artículos, describir todos los aspectos que les iban a ser de utilidad para el desempeño de la labor: servicio de viajeros (billetes y tarifas especiales), equipajes, mercancías 
(expediciones y llegadas), paquetes postales, telegrafía, rectificaciones de tasas, recaudaciones suplementarias, impuestos y timbre, operaciones contables y estadísticas y, por último, varios (NORTE, 1907b: 1-153).

\subsection{Documentos contables distintos del Informe Anual}

NORTE publica cuatro tipos de información contable. La fundamental es la que se generaba cada año al final del ejercicio y que era depositada y publicada: el Informe Anual. Pero, además, NORTE proporcionaba tres tipos de información contable: (i) una información preparatoria para conseguirlo, (ii) una información contable contemporánea al Informe Anual pero de exclusivo uso interno y (iii) una información contable posterior al Informe Anual que servía como medidor de la situación económico financiera y como revisión de los estados financieros.

Los documentos preliminares estaban escritos, en un primer momento en idioma francés, mientras que el Informe Anual, la contemporánea y la posterior lo estaban en castellano.

La información previa -preparatoria para elaborar los estados financieros- estaba compuesta por cinco tipos de documentos realizados por los contables de la empresa antes de realizar los estados financieros $^{728}$. El primer tipo de documento es un cuadro de doble entrada en el que las columnas son las diferentes líneas de la empresa y las filas son cada una de las partidas del balance. El segundo tipo de documento es un cuadro financiero para cada una de las emisiones de empréstitos, al que le acompaña toda la información de las series, intereses, amortización del principal, y una información en formato literal que complementa todo lo anterior. El tercer tipo de documento está compuesto por los cuadros de amortización financiera de los empréstitos. El cuarto tipo es una enumeración de cada uno de los activos no corrientes de la organización. El quinto documento es un cuadro donde se recoge toda la información sobre las acciones y obligaciones emitidas por la sociedad.

En segundo lugar, NORTE manejaba una información contemporánea al Informe Anual compuesta por seis estados financieros independientes y diferentes de él.

El primero es denominado "Balance del libro mayor a fecha XXX". Es similar al balance de comprobación actual ${ }^{729}$, pues incluye partidas de activo, pasivo, patrimonio neto, gastos e ingresos. El cuadro 49 muestra el Balance del libro mayor elaborado por la empresa NORTE en el ejercicio contable 1922.

\footnotetext{
${ }^{728}$ AHF, W-51-8 Estudio sobre el ejercicio de 1903 de la Compañía de los Caminos de Hierro del Norte de España, 12 de noviembre de 1904. Este documento aún se elaboraba en la sede de París, por lo que estaba elaborado en francés.

${ }^{729}$ AHF, W-38-13 “Balance del libro mayor a 31 de diciembre de 1904. Contabilidad Central” Compañía de los Caminos de Hierro del Norte de España, 30 de mayo de 1905. AHF, W-43-6 "Balance del libro mayor en 31 de diciembre de 1922. Antes de cerrar las cuentas de explotación, 30 de mayo de 1923.
} 
Cuadro 49. Balance del libro mayor elaborado por la empresa NORTE en el ejercicio 1922

\begin{tabular}{|l|l|l|l|l|}
\hline Designación de las cuentas & \multicolumn{2}{|c|}{ Sumas } & \multicolumn{2}{c|}{ Saldos } \\
\hline & Debe & Haber & Debito & Crédito \\
\hline & & & & \\
& & & & \\
\hline
\end{tabular}

Fuente: Elaboración propia a partir de los datos de NORTE $^{730}$

El segundo es denominado por NORTE como "Situación de la compañía a 31 de diciembre de 1904. Contabilidad Central" "731. En él se especifican los saldos de los componentes de activos, pasivos y partidas de patrimonio neto.

El tercer documento fue denominado por NORTE "Cuenta general de los productos y gastos de la explotación de diciembre de 19x1 comparada con igual mes de 19x0", en el que se incluyen los ingresos y gastos separados en dos cuentas, expresadas en tres columnas: año 2, año 1 y las diferencias entre ambas. En las filas de los ingresos, cada uno de los ingresos están divididos en Viajeros, Gran velocidad, Pequeña velocidad, Productos fuera del tráfico y Diversos; al final de las filas se incluye un resumen de cada uno de estos componentes. En las filas de los gastos, éstos se ordenan en función del centro de costes (Administración central, Dirección, Explotación, Material y tracción y Vía y obras) y dentro de él se separan por su naturaleza. Por ejemplo, el centro de costes Administración Central, se divide en "Administración central (personal)", en segundo lugar "Seguros, alquileres, etc." y por último "Gastos generales".

El cuadro 50 muestra la Cuenta general de los productos y gastos de la explotación de diciembre de 1922 comparada con igual mes de 1921 elaborado por la empresa NORTE.

\footnotetext{
730 AHF, W-43-6 "Balance del libro mayor en 31 de diciembre de 1922. Antes de cerrar las cuentas de explotación, 30 de mayo de 1923.

${ }^{731}$ AHF, W-38-13 "Situación de la compañía a 31 de diciembre de 1904. Contabilidad Central" Compañía de los Caminos de Hierro del Norte de España, 30 de mayo de 1905 [en francés].
} 
Cuadro 50. Cuenta general de los productos y gastos de la explotación de diciembre de 1922 comparada con igual mes de 1921 elaborada por la empresa NORTE

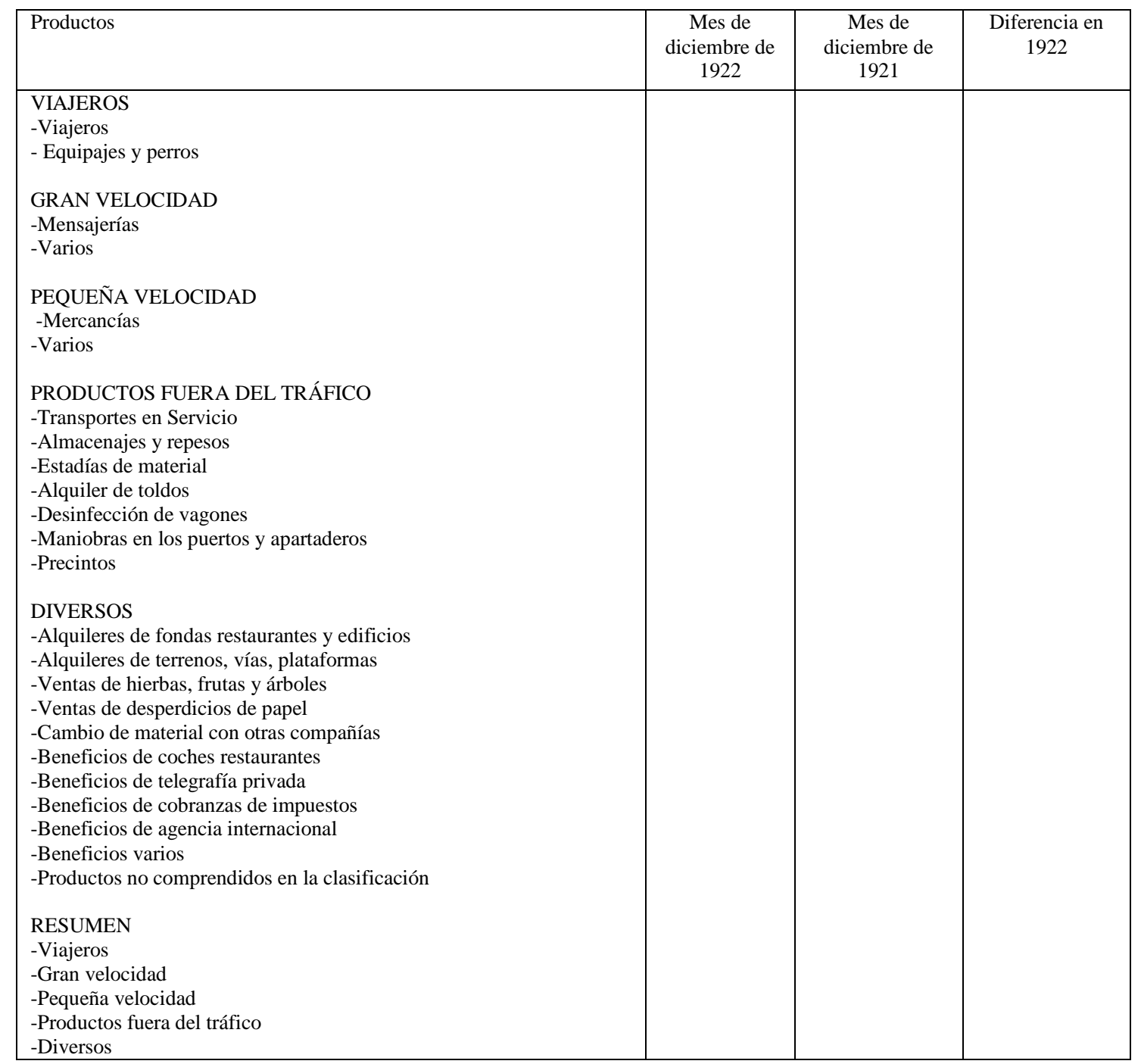




\begin{tabular}{|c|c|c|c|}
\hline Gastos & $\begin{array}{l}\text { Mes de diciembre de } \\
1922\end{array}$ & $\begin{array}{ll}\text { Mes } & \text { de } \\
\text { diciembre } & \text { de } \\
1921 & \end{array}$ & $\begin{array}{l}\text { Diferencia } \\
\text { en } 1922\end{array}$ \\
\hline $\begin{array}{l}\text { ADMINISTRACIÓN CENTRAL } \\
\text { Administración central (personal) } \\
\text { - Personal superior de la administración central } \\
\text { - Personal técnico de París y de las Secretarías del Consejo y de los } \\
\text { Comités } \\
\text {-Servicios de lo contencioso de París } \\
\text { - Servicio de contabilidad en París } \\
\text {-Porteros, ordenanzas y dependientes del Consejo y de los Comités } \\
\text { Seguros, alquileres, etc. } \\
\text {-Gastos por incendios } \\
\text {-Gastos diversos } \\
\text {-Alquileres de oficinas de la Administración Central } \\
\text {-Reparaciones de los locales de la Administración Central } \\
\text {-Reparaciones y renovación del mobiliario y objetos inventariados } \\
\text { de Administración Central } \\
\text { Gastos generales } \\
\text {-Gastos de oficina y diversos } \\
\text {-Impresos } \\
\text {-Vestuario } \\
\text {-Encabezamiento en la Administración del timbre en Francia } \\
\text {-Gastos judiciales, multas } \\
\text {-Socorros, setos de beneficiencia, pensiones, indemnizaciones, etc. a } \\
\text { personas extrañas a la compañía } \\
\text {-Gastos de representación y generales diversos } \\
\text {-Pensiones de retiro } \\
\text {-Subvenciones }\end{array}$ & & & \\
\hline
\end{tabular}

Fuente: Elaboración propia a partir de los datos de NORTE $^{732}$

El cuarto estado financiero es la "Cuenta general de los productos y gastos de la explotación desde el 1 de enero a fin de diciembre del año 19XX" en la que se incluyen los saldos de los ingresos y gastos al principio del ejercicio, al final del ejercicio y la diferencia entre ambos ${ }^{733}$.

El quinto documento se denomina "Contabilidad de ingresos", donde se exponen las cuentas en tres columnas: débitos, créditos y saldos. Dentro de los dos primeros se diferencian los saldos anteriores, del mes y total. La última columna diferencia entre saldos deudores y acreedores. Así puede observarse en el cuadro 51.

\footnotetext{
${ }^{732}$ AHF, W-43-8 “Cuenta general de los productos y gastos de la explotación de diciembre de 1922 comparada con igual mes de 1921”, Contabilidad central, 30 de mayo de 1923.

${ }^{733}$ AHF, W-43-6 "Cuenta general de los productos y gastos de la explotación desde el 1 de enero a fin de diciembre del año 1922”, Contabilidad central, 30 de mayo de 1923.
} 


\section{Cuadro 51. Contabilidad de ingresos elaborado por la empresa NORTE en el ejercicio 1922}

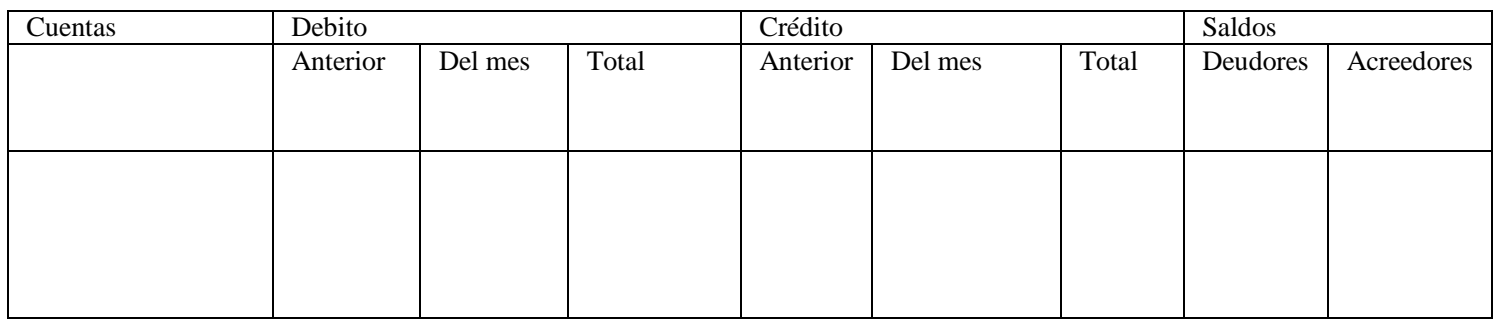

Fuente: Elaboración propia a partir de los datos de NORTE ${ }^{734}$

Por último, NORTE manejaba una información posterior al Informe anual, compuesta por los informes de la empresa en contestación a los discursos pronunciados por los socios en la junta general de accionistas.

Los más destacados son los realizados por Boix en contestación al accionista Burgaleta ${ }^{735}$ en 1923 por las siguientes motivaciones:

- Aumento injustificado de 220.000 pesetas de gastos de explotación si se tiene en cuenta la disminución del combustible $\mathrm{f}^{736}$

- Mala utilización de las máquinas ${ }^{737}$

- Imperfección con que técnicamente se lleva el Servicio de explotación, lo que condujo a resultados desastrosos en el Servicio de Material y Tracción ${ }^{738}$.

- Gastos inútiles, por ejemplo, la adjudicación de los concursos de combustibles ${ }^{739}$.

- Irregularidades de gestión, como el escándalo producido porque NORTE mezcló el plomo y el estaño ${ }^{740}$.

\footnotetext{
${ }^{734}$ AHF, W-43-6 “Contabilidad de ingresos” División comercial, Intervención, 30 de mayo de 1923.

${ }^{735}$ NORTE (1923b: 1-48).

${ }^{736}$ AHF, S-15-44bis. Discurso pronunciado por el accionista Burgaleta en la junta general celebrada el 19 de mayo de 1923: formuladas por encargo del Consejo de Administración y acordada por este su publicación, Compañía de los Caminos de Hierro del Norte de España, 19 de mayo de 1923, Madrid: Norte, p. 4.

${ }^{737}$ AHF, S-15-44bis. Discurso pronunciado por el accionista Burgaleta en la junta general celebrada el 19 de mayo de 1923: formuladas por encargo del Consejo de Administración y acordada por este su publicación, Compañía de los Caminos de Hierro del Norte de España, 19 de mayo de 1923, Madrid: Norte, p. 8.

${ }^{738}$ AHF, S-15-44bis. Discurso pronunciado por el accionista Burgaleta en la junta general celebrada el 19 de mayo de 1923: formuladas por encargo del Consejo de Administración y acordada por este su publicación, Compañía de los Caminos de Hierro del Norte de España, 19 de mayo de 1923, Madrid: Norte, p. 4.

739 AHF, S-15-44bis. Discurso pronunciado por el accionista Burgaleta en la junta general celebrada el 19 de mayo de 1923: formuladas por encargo del Consejo de Administración y acordada por este su publicación, Compañía de los Caminos de Hierro del Norte de España, 19 de mayo de 1923, Madrid: Norte, p. 11.

${ }^{740}$ AHF, S-15-44bis. Discurso pronunciado por el accionista Burgaleta en la junta general celebrada el 19 de mayo de 1923: formuladas por encargo del Consejo de Administración y acordada por este su publicación, Compañía de los Caminos de Hierro del Norte de España, 19 de mayo de 1923, Madrid: Norte, p. 11. Boix le contestó que aunque este hecho realmente se produjo de forma puntual, esto no volvió a ocurrir como se pudo comprobar con los análisis al Laboratorio de la Escuela de Minas (NORTE, 1923b: 46).
} 
- Erorres de gestión como no haberse preocupado de reducir el peso muerto (vagones) por tonelada útil ${ }^{741}$.

\subsection{Contenidos del Informe Anual}

La confección de los balances y restante información financiera de NORTE se redactaba por años naturales, imprimiéndose para ser entregada a los accionistas de la compañía y al público en general, siendo preceptivo, además, la publicación de dicho estado contable en la Gaceta de Madrid por tratarse de sociedades anónimas, de acuerdo a lo establecido en el artículo 157 del Código de Comercio de 1885.

La información periódica ${ }^{742}$ fue elaborada por la sociedad en todos los ejercicios contables de la vida de la compañía. Actualmente lo denominaríamos Informe Anual, aunque no recibió tal denominación en ningún momento. La denominación concedida por el Consejo de Administración de NORTE hasta 1904 era: "Junta General de Accionistas. Memoria del Consejo de Administración. Resoluciones de la Junta". A partir de 1905, NORTE concedió a este documento la denominación "Memoria del Consejo de Administración leída y aprobada por la Junta General Ordinaria de Accionistas. Resoluciones de la Junta",743.

La estructuración y procedimiento de esta información era la siguiente: el organismo "Consejo de Administración" elaboraba dos documentos, "Memoria del Consejo de Administración" y "Cuentas del ejercicio", en el periodo de tiempo que va del cierre del ejercicio del año anterior a la fecha de celebración de la Junta General de Accionistas. Ambos documentos eran presentados al organismo "Junta General de Accionistas" en la fecha de celebración de la Junta para su aprobación. El día de celebración de la Junta, este organismo debatía sobre la marcha de la sociedad; al final del debate se emitía el tercer documento: "Resoluciones de la Junta General". En este documento se incluía toda la información que había aprobado o desaprobado la Junta General de Accionistas. Tras su aprobación, el documento era publicado posteriormente junto a una batería de datos estadísticos.

El Informe Anual de la Compañía NORTE incluía cuatro documentos ${ }^{744}$ :

1) La Memoria del ejercicio propiamente dicha, donde se explicaban las variaciones y sus causas de las diferentes magnitudes de ingresos y gastos, así como un análisis de la situación general del balance de la compañía y otros comentarios sobre cuestiones tales como la explotación de las minas de su propiedad, las instituciones de previsión y beneficencia, el

\footnotetext{
${ }^{741}$ AHF, S-15-44bis. Discurso pronunciado por el accionista Burgaleta en la junta general celebrada el 19 de mayo de 1923: formuladas por encargo del Consejo de Administración y acordada por este su publicación, Compañía de los Caminos de Hierro del Norte de España, 19 de mayo de 1923, Madrid: Norte, p. 12.

${ }^{742}$ Los primeros que analizaron los contenidos del Informe Anual fueron Bentabol et al. (2011: 15).

${ }^{743}$ Acta $\mathrm{n}^{\circ} 727$ del Libro de actas del Consejo de Administración de NORTE: 15 de junio de 1906.

${ }^{744}$ Estos componentes son inconfundibles. Para disipar las posibles dudas sobre el número de los componentes sólo es necesario observar el primer punto de las "Resoluciones de la Junta General" de cada ejercicio contable: "La Junta General aprueba en todas sus partes la Memoria del Consejo de Administración , así como las cuentas del ejercicio". Vid. Informes Anuales de cada ejercicio, por ejemplo la del año 1900 (NORTE, 1901: 39).
} 
canje y adhesión de acciones y obligaciones, los impuestos ingresados en el Tesoro y los beneficios obtenidos por el Estado, la liquidación del ejercicio, etc.

2) Las "Resoluciones de la Junta General", que recogía los acuerdos aprobados o desaprobados por la Junta General de Accionistas.

3) Las "Cuentas del ejercicio", que incluían:

- La Situación de la compañía al cierre, incluyendo un estado contable similar al que hoy en día se conoce como Balance de Situación, en el que se mostraba de forma agregada para toda la compañía el detalle de su estructura económica y financiera.

- La Cuentas de Pérdidas y Ganancias, agrupadas para el total de la compañía y desglosadas por líneas, donde aparecían todos los ingresos y gastos del ejercicio diferenciados entre "de explotación" y "otros", mostrándose en formato de cuenta.

4) "Datos estadísticos", donde se insertaba abundante información, normalmente detallada por líneas.

El cuadro 52 muestra los componentes del Informe Anual del Consejo de Administración de NORTE en el periodo 1900-1926, incluyendo la denominación, fecha de celebración, presidente y extensión de cada uno de los componentes. 


\section{Cuadro 52. Componentes del Informe Anual del Consejo de Administración de NORTE 1900-1926}

\begin{tabular}{|c|c|c|c|c|c|c|}
\hline $\begin{array}{l}\text { EJERCICIO } \\
\text { CONTABLE }\end{array}$ & DENOMINACIÓN & $\begin{array}{l}\text { FECHA DE } \\
\text { CELEBRACIÓN } \\
\text { DE LA JUNTA }\end{array}$ & PRESIDENTE & $\begin{array}{l}\text { PÁGINAS } \\
\text { DE LA } \\
\text { MEMORIA }\end{array}$ & $\begin{array}{l}\text { PÁGINAS DE LA } \\
\text { RESOLUCIONES } \\
\text { DE LA JUNTA } \\
\text { GENERAL }\end{array}$ & $\begin{array}{l}\text { PÁGINAS DE } \\
\text { LAS } \\
\text { CUENTAS } \\
\text { DEL } \\
\text { EJERCICIO }\end{array}$ \\
\hline 1900 & $\begin{array}{l}\text { Junta General de Accionistas. } \\
\text { Memoria del Consejo de } \\
\text { Administración. Resoluciones de la } \\
\text { Junta }\end{array}$ & $\begin{array}{l}25 \text { de mayo } \\
\text { de } 1901\end{array}$ & $\begin{array}{l}\text { Faustino } \\
\text { Rodríguez } \\
\text { San Pedro }\end{array}$ & $1-38$ & 39 & $41-135$ \\
\hline 1901 & $\begin{array}{l}\text { Junta General de Accionistas. } \\
\text { Memoria del Consejo de } \\
\text { Administración. Resoluciones de la } \\
\text { Junta }\end{array}$ & $\begin{array}{l}3 \text { de junio de } \\
1902\end{array}$ & $\begin{array}{l}\text { Faustino } \\
\text { Rodríguez } \\
\text { San Pedro }\end{array}$ & $1-40$ & 41 & $43-139$ \\
\hline 1902 & $\begin{array}{l}\text { Junta General de Accionistas. } \\
\text { Memoria del Consejo de } \\
\text { Administración. Resoluciones de la } \\
\text { Junta }\end{array}$ & $\begin{array}{l}30 \text { de mayo } \\
\text { de } 1903\end{array}$ & $\begin{array}{l}\text { Antonio } \\
\text { Borregón }\end{array}$ & $1-41$ & $43-44$ & $45-137$ \\
\hline 1903 & $\begin{array}{l}\text { Junta General de Accionistas. } \\
\text { Memoria del Consejo de } \\
\text { Administración. Resoluciones de la } \\
\text { Junta }\end{array}$ & $\begin{array}{l}26 \text { de mayo } \\
\text { de } 1904\end{array}$ & $\begin{array}{l}\text { Antonio } \\
\text { Borregón }\end{array}$ & $1-43$ & 44 & $45-138$ \\
\hline 1904 & $\begin{array}{l}\text { Junta General de Accionistas. } \\
\text { Memoria del Consejo de } \\
\text { Administración. Resoluciones de la } \\
\text { Junta }\end{array}$ & $\begin{array}{l}8 \text { de junio de } \\
1905\end{array}$ & $\begin{array}{l}\text { Faustino } \\
\text { Rodríguez } \\
\text { San Pedro }\end{array}$ & $1-43$ & 44 & $45-138$ \\
\hline 1905 & $\begin{array}{l}\text { Memoria del Consejo de } \\
\text { Administración leída y aprobada } \\
\text { por la Junta General Ordinaria de } \\
\text { Accionistas. Resoluciones de la } \\
\text { Junta }\end{array}$ & $\begin{array}{l}20 \text { de mayo } \\
\text { de } 1906\end{array}$ & $\begin{array}{l}\text { Faustino } \\
\text { Rodríguez } \\
\text { San Pedro }\end{array}$ & $1-35$ & 36 & $38-117$ \\
\hline 1906 & $\begin{array}{l}\text { Memoria del Consejo de } \\
\text { Administración leída y aprobada } \\
\text { por la Junta General Ordinaria de } \\
\text { Accionistas. Resoluciones de la } \\
\text { Junta }\end{array}$ & $\begin{array}{l}11 \text { de mayo } \\
\text { de } 1907\end{array}$ & $\begin{array}{l}\text { Antonio } \\
\text { Borregón }\end{array}$ & $1-34$ & 35 & $36-115$ \\
\hline 1907 & $\begin{array}{l}\text { Memoria del Consejo de } \\
\text { Administración leída y aprobada } \\
\text { por la Junta General Ordinaria de } \\
\text { Accionistas. Resoluciones de la } \\
\text { Junta }\end{array}$ & $\begin{array}{l}7 \text { de mayo de } \\
1908\end{array}$ & $\begin{array}{l}\text { Antonio } \\
\text { Borregón }\end{array}$ & $1-31$ & 32 & $34-114$ \\
\hline 1908 & $\begin{array}{l}\text { Memoria del Consejo de } \\
\text { Administración leída y aprobada } \\
\text { por la Junta General Ordinaria de } \\
\text { Accionistas. Resoluciones de la } \\
\text { Junta }\end{array}$ & $\begin{array}{l}17 \text { de mayo } \\
\text { de } 1909\end{array}$ & $\begin{array}{l}\text { Antonio } \\
\text { Borregón }\end{array}$ & $1-31$ & $33-34$ & $36-115$ \\
\hline 1909 & 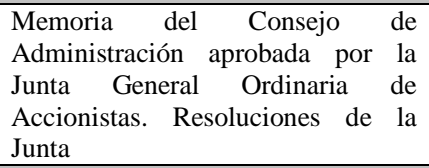 & $\begin{array}{l}12 \text { de mayo } \\
\text { de } 1910\end{array}$ & $\begin{array}{l}\text { Faustino } \\
\text { Rodríguez } \\
\text { San Pedro }\end{array}$ & $1-30$ & $31-33$ & $34-113$ \\
\hline 1910 & 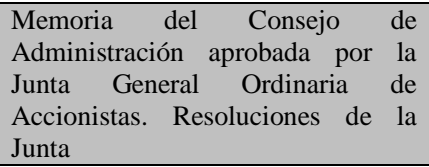 & $\begin{array}{l}12 \text { de mayo } \\
\text { de } 1910\end{array}$ & $\begin{array}{l}\text { Faustino } \\
\text { Rodríguez } \\
\text { San Pedro }\end{array}$ & $1-33$ & $34-37$ & $38-117$ \\
\hline 1911 & $\begin{array}{lll}\text { Memoria del Consejo } & \text { de } \\
\text { Administración aprobada por } & \text { la } \\
\text { Junta General Ordinaria } & \text { de } \\
\text { Accionistas. Resoluciones de } & \text { la } \\
\text { Junta. Ejercicio de } 1911 & \\
\end{array}$ & $\begin{array}{l}13 \text { de mayo } \\
\text { de } 1912\end{array}$ & $\begin{array}{l}\text { Faustino } \\
\text { Rodríguez } \\
\text { San Pedro }\end{array}$ & $1-33$ & $34-35$ & $36-115$ \\
\hline 1912 & 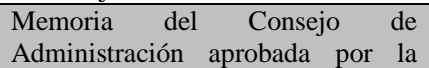 & $\begin{array}{l}4 \text { de mayo de } \\
1913\end{array}$ & $\begin{array}{l}\text { Faustino } \\
\text { Rodríguez }\end{array}$ & $1-34$ & $35-37$ & $38-125$ \\
\hline
\end{tabular}




\begin{tabular}{|c|c|c|c|c|c|c|}
\hline & $\begin{array}{l}\text { Junta General Ordinaria de } \\
\text { Accionistas. Resoluciones de la } \\
\text { Junta. Ejercicio de } 1912\end{array}$ & & San Pedro & & & \\
\hline 1913 & 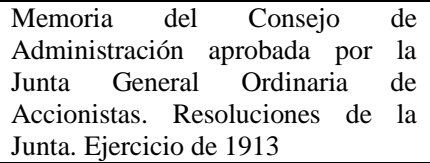 & $\begin{array}{l}3 \text { de mayo de } \\
1914\end{array}$ & $\begin{array}{l}\text { Faustino } \\
\text { Rodríguez } \\
\text { San Pedro }\end{array}$ & $1-34$ & $35-37$ & $38-119$ \\
\hline 1914 & 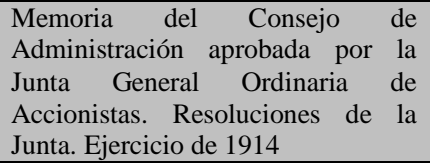 & $\begin{array}{l}8 \text { de mayo de } \\
1915\end{array}$ & $\begin{array}{l}\text { Faustino } \\
\text { Rodríguez } \\
\text { San Pedro }\end{array}$ & $1-34$ & $35-37$ & $38-119$ \\
\hline 1915 & 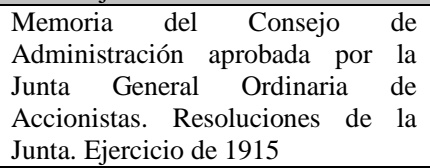 & $\begin{array}{l}6 \text { de mayo de } \\
1916\end{array}$ & $\begin{array}{l}\text { Faustino } \\
\text { Rodríguez } \\
\text { San Pedro }\end{array}$ & $1-34$ & $35-37$ & $38-120$ \\
\hline 1916 & 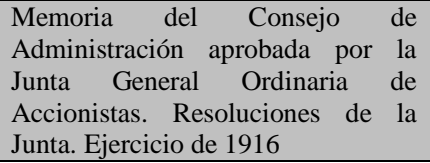 & $\begin{array}{l}12 \text { de mayo } \\
\text { de } 1917\end{array}$ & $\begin{array}{l}\text { Faustino } \\
\text { Rodríguez } \\
\text { San Pedro }\end{array}$ & $1-37$ & $38-41$ & $42-125$ \\
\hline 1917 & 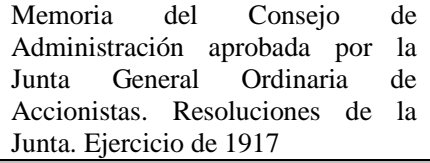 & $\begin{array}{l}18 \text { de mayo } \\
\text { de } 1918\end{array}$ & $\begin{array}{l}\text { Faustino } \\
\text { Rodríguez } \\
\text { San Pedro }\end{array}$ & $1-38$ & $39-41$ & $42-124$ \\
\hline 1918 & 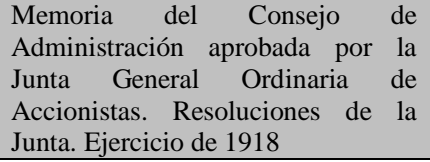 & $\begin{array}{l}17 \text { de mayo } \\
\text { de } 1919\end{array}$ & $\begin{array}{l}\text { Faustino } \\
\text { Rodríguez } \\
\text { San Pedro }\end{array}$ & $1-35$ & $36-37$ & $42-120$ \\
\hline 1919 & $\begin{array}{llr}\text { Memoria del Consejo } & \text { de } \\
\text { Administración aprobada por } & \text { la } \\
\text { Junta General Ordinaria } & \text { de } \\
\text { Accionistas. Resoluciones de } & \text { la } \\
\text { Junta. Ejercicio de } 1919 & \\
\end{array}$ & $\begin{array}{l}22 \text { de mayo } \\
\text { de } 1920\end{array}$ & $\begin{array}{l}\text { Marqués de } \\
\text { Alonso } \\
\text { Martínez }\end{array}$ & $1-36$ & $37-39$ & $40-121$ \\
\hline 1920 & $\begin{array}{l}\text { Memoria del Consejo } \\
\text { Administración aprobada por } \\
\text { Junta General Ordinaria } \\
\text { Accionistas. Resoluciones de } \\
\text { Junta. Ejercicio de } 1920\end{array}$ & $\begin{array}{l}30 \text { de mayo } \\
\text { de } 1921\end{array}$ & $\begin{array}{l}\text { Marqués de } \\
\text { Alonso } \\
\text { Martínez }\end{array}$ & $1-36$ & $37-39$ & $40-121$ \\
\hline 1921 & 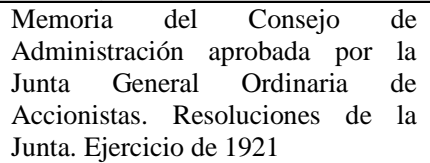 & $\begin{array}{l}27 \text { de mayo } \\
\text { de } 1922\end{array}$ & $\begin{array}{l}\text { Marqués de } \\
\text { Alonso } \\
\text { Martínez }\end{array}$ & $1-38$ & $39-41$ & $42-120$ \\
\hline 1922 & 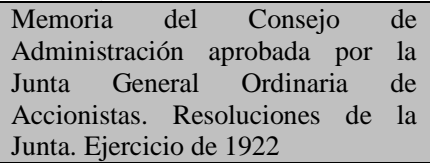 & $\begin{array}{l}19 \text { de mayo } \\
\text { de } 1923\end{array}$ & $\begin{array}{l}\text { Marqués de } \\
\text { Alonso } \\
\text { Martínez }\end{array}$ & $1-37$ & $38-39$ & $40-140$ \\
\hline 1923 & $\begin{array}{l}\text { Memoria que el Consejo de } \\
\text { Administración presenta a la Junta } \\
\text { General Ordinaria de Accionistas. } \\
\text { Proyecto de Resoluciones de la } \\
\text { Junta. Ejercicio de } 1922\end{array}$ & $\begin{array}{l}24 \text { de mayo } \\
\text { de } 1924\end{array}$ & $\begin{array}{l}\text { Marqués de } \\
\text { Alonso } \\
\text { Martínez }\end{array}$ & $1-37$ & $38-41$ & $42-120$ \\
\hline
\end{tabular}

Fuente elaboración propia 


\subsubsection{Memoria del Consejo de Administración}

\subsubsection{1. "Memoria del Consejo de Administración" de los ejercicios contables 1900-1904}

La "Memoria del Consejo de Administración" presenta varios formatos, que son analizados en los subapartados siguientes.

La "Memoria del Consejo de Administración" de las ejercicios contables 1900-1904 está formada por cinco componentes: Red de la Compañía, Carta del presidente del Consejo de Administración, Resultados generales del ejercicio (que a su vez se dividen en diez, Explotación, Construcción, Instalaciones nuevas y obras de conclusión definitiva, Renovación de la vía, Material móvil, Establecimientos de previsión, Minas, Líneas, Situación general y resumen de cuentas de la explotación), Administradores y Asuntos varios.

En el componente "Red de la Compañía" se informa de los kilómetros de longitud en explotación, y en construcción o a construir, al cierre de cada ejercicio contable ${ }^{745}$. La Memoria de 1903 cambia la denominación de este primer elemento de la Memoria a "Extensión de la red".

En la "Carta del presidente del Consejo de Administración" "746 éste se dirige a la Junta General de Accionistas para informarla que había sido convocada en virtud del artículo 26 de los Estatutos de la compañía ${ }^{747}$, con la intención de deliberar sobre las cuentas del ejercicio analizado $^{748}$. Además, se la informa que tiene tres encargos: someter al examen de la aprobación de las cuentas ${ }^{749}$, proceder al reemplazo y renovación de los Administradores que terminan su cometido al cierre del ejercicio contable ${ }^{750}$ y deliberar sobre las modificaciones de los estatutos ${ }^{751}$.

El apartado "Resultados generales del ejercicio ${ }^{752}$ se divide en diez documentos: Explotación, Construcción, Instalaciones nuevas y obras de conclusión definitiva, Renovación de la vía,

\footnotetext{
${ }^{745}$ NORTE (1901: 2) (1902: 2) (1903:2) (1904:2) (1905: 2).

${ }^{746}$ La denominación "Carta del Presidente del Consejo de Administración" no aparece como tal en la Memoria. No obstante el encabezamiento inicial del documentos que incluye la expresión "Señores:" y la gran similitud con el documento "Carta del Presidente" con el que comienzan los Informes Anuales actuales, permite incluir ese término.

${ }^{747}$ NORTE (1901: 2) (1902: 2) (1903: 2) (1904:3) (1905: 3).

${ }^{748}$ NORTE (1901: 3) (1902: 3) (1903: 3) (1904:3) (1905: 3).

${ }^{749}$ NORTE (1901: 3) (1902: 3) (1903:3) (1904:3) (1905: 3).

${ }^{750}$ NORTE (1901: 2) (1902: 2) (1903:2) (1904:3) (1905: 3).

${ }^{751}$ La Carta del Presidente de la Memoria de NORTE de 1901 incluye que la Junta debe "deliberar sobre las modificaciones que corresponde hacer en los estatutos a consecuencia del contrato celebrado por la Comisión liquidadora del ferrocarril y minas de San Juan de las Abadesas en 24 de mayo de 1899, y acuerdos tomados sobre él por las Juntas Generales de 4 de julio de 1899 y 25 de mayo de 1901" (NORTE, 1902: 3).

${ }^{752}$ En las Memorias de los años 1900-1904, el apartado "Resultados generales del ejercicio" no aparece como el resto de apartados en mayúsculas, centrado y en negrita. Sin embargo, lo hemos identificado porque el último párrafo de la Carta del Presidente siempre indica que "comenzaremos por exponer los resultados generales del ejercicio de que se trata" (NORTE, 1900:3; 1901: 3; 1902: 2; 1903:2; 1904:3; 1905: 3).
} 
Material móvil, Establecimientos de previsión, Minas, Líneas, Situación general y resumen de cuentas de la explotación.

El subapartado "Explotación" sintetiza los ingresos y gastos de cada ejercicio contable y las cantidades ingresadas por la compañía en las Cajas del Estado en concepto de impuestos sobre viajeros y mercancías. Además, resume los resultados de explotación del año y sus componentes, ingresos y gastos de explotación; distinguiendo en totales y por kilómetro; y diferenciando también en valores absolutos y por incrementos respecto al año precedente. Además, detalla cada uno de los ingresos por naturaleza de los transportes ${ }^{753}$.

En el subapartado "Construcción" se resume las líneas que están en construcción, indicando los túneles, cimientos de puentes y las obras que se están realizando ${ }^{754}$.

En el subapartado "Instalaciones nuevas y obras de conclusión definitiva", se resumen los trabajos que se han realizado durante el ejercicio contable. La información está dividida para cada una de las líneas, y dentro de ellas, diferenciando las que se producen en las vías y en las estaciones $^{755}$.

En el subapartado "Renovación de la vía se resume los kilómetros realizados y mejorados en cada una de las Líneas que forman la empresa ${ }^{756}$.

El subapartado "Material móvil"757 recoge las existencias de locomotoras, coches de viajeros y vagones de todas clases. Además, se indica la reparación de las máquinas realizadas en los diferentes talleres. De igual forma, se presenta la información sobre las reparaciones de coches y vagones. Asimismo, se ofrece información sobre las mejoras realizadas en las máquinas, ténders, coches furgonetas y vagones. Por último, se indica el número de obreros empleados en los talleres, y que parte se utiliza en la conservación y limpieza del material móvil $^{758}$.

El subapartado "Establecimientos de previsión" incluye diversas informaciones de tipo social. Por un lado, indica el importe de la venta de artículos de consumo, fundamentalmente comestibles, a precio reducido al personal de la compañía. Por otro lado, indica información

\footnotetext{
${ }^{753}$ NORTE (1901: 4-14) (1902: 4-14) (1903: 3-14) (1904: 3-14) (1905: 3-14).

${ }^{754}$ NORTE (1901: 14) (1902: 14) (1903: 15) (1904: 14) (1905: 15).

${ }^{755}$ NORTE (1901: 14-18) (1902: 14-18) (1903: 15-18) (1904: 14-17) (1905: 14-17).

${ }^{756}$ NORTE (1901: 18-20) (1902: 18-19) (1903: 18-19) (1904: 18) (1905: 18).

757 De los diferentes manuales de contabilidad sobre la industria ferroviaria podemos afirmar que por material móvil se incluye un concepto más amplio: locomotoras diésel y eléctricas, automotores, vehículos para mantenimiento de vías y servicios similares, coches de viajeros, equipajes, coches correo y demás, vagones cisterna y carga, contenedores, bogies y biselas, ejes, ruedas y sus partes, ganchos y demás sistemas de enganche, topes, etc., cajas de engrase y sus partes, carrocerías y sus partes, chasis y sus partes y otros componentes de material rodante.

${ }^{758}$ NORTE (1901: 20-21) (1902: 19-20) (1903: 19-20) (1904: 19) (1905: 18-19).
} 
sobre los saldos y socorros concedidos con la Caja de Previsión ${ }^{759}$, y el resto de ventajas concedidas a empleados como los saldos por las pensiones de retiro, socorros, medicinas, médicos, vestuario y escuelas ${ }^{760}$.

El subapartado "Minas" sólo aparece en los ejercicios económicos en los que NORTE explota algunas minas. Cuando es incluido, recoge información sobre la hulla extraída y sobre el número de empleados dedicados a cada una de las minas ${ }^{761}$.

En el subapartado "Líneas" se recoge la información sobre los gastos e ingresos de cada una de las líneas que forman la compañía ${ }^{762}$. En las Memorias de 1903 y 1904, este subapartado "Líneas" cambia su nombre pasando a denominarse "Resultados de las cuentas de explotación" 763 .

El subapartado "Situación general" resume el importe y variaciones de los activos y pasivos de la sociedad ${ }^{764}$.

El subapartado "Resumen de cuentas de la explotación" indica la cuenta general de la explotación en el conjunto de líneas explotadas por la Compañía diferenciando entre ingresos de explotación, productos varios y gastos de explotación ${ }^{765}$.

En el apartado "Administradores" se recogen información relevante sobre las altas y bajas dentro del colectivo. Por un lado, se hace recordatorio de los administradores fallecidos en el ejercicio económico. Del mismo modo se menciona a los administradores jubilados y los que dejan la compañía por otros motivos. Por otro lado, se enumeran los administradores cuyo mandato expira en ese ejercicio que termina y son reelegibles. Para todos ellos, el presidente del Consejo de Administración propone unos candidatos, e indica a la Junta su deseo de que sean ratificados por ella ${ }^{766}$.

En el apartado "Asuntos varios" aparece el resto de información que el presidente del Consejo de Administración desea transmitir a los accionistas, entre ella, la más frecuente, es la que se refiere a los tipos de cambio $^{767}$, a la depreciación de la moneda ${ }^{768}$, a la tributación ${ }^{769}$, a los

\footnotetext{
${ }^{759}$ La Caja de Previsión fue fundada en 1879. Tenía por objeto asegurar a los empleados y obreros enfermos o heridos una asignación igual a la mitad del sueldo o jornal durante el tiempo de su enfermedad, para los gastos de entierro y conceder socorros a las viudas y a los hijos de empleados y obreros que fallecen. Esta Caja se sostiene por el importe mensual de una retención del medio al uno\% de los sueldos y salarios del personal, con el importe de las multas y con el producto líquido de la venta de billetes de andén (NORTE, 1901: 23).

${ }^{760}$ NORTE (1901: 21-23) (1902: 20-22) (1903: 20-22) (1904: 20-21) (1905: 20-21).

${ }^{761}$ En concreto, las Memorias informan sobre las Minas de Barruelo (NORTE, 1901: 23) (1902: 22) (1903: 22) (1904: 21-22) (1905: 22-23) y Surroca (NORTE, 1902: 22) (1903: 22-23) (1904: 22-23) (1905: 22-23).

${ }^{762}$ NORTE (1901: 22-31) (1902: 22-30) (1903: 23-30).

${ }^{763}$ NORTE (1904a: 23-31) (1905: 23-29).

${ }^{764}$ NORTE (1901: 31-37) (1902: 30-36) (1903: 33-37) (1904: 32-38) (1905: 29-38).

${ }^{765}$ NORTE (1901: 37) (1902: 37) (1903: 37-39) (1904: 38-39) (1905: 38-39).

${ }^{766}$ NORTE (1901: 38) (1902: 38) (1903: 39) (1904: 40) (1905: 40).

${ }^{767}$ NORTE (1901: 35) (1902: 39) (1903: 40) (1904: 41) (1905: 41).

${ }^{768}$ NORTE (1901: 35) (1902: 39) (1903: 40) (1904: 41) (1905: 41).
} 
dividendos $^{770}$, a la Comisión liquidadora ${ }^{771}$, a los Proyectos de convenios con los obligacionistas $^{772}$, al canje de acciones y participaciones ${ }^{773}$ y a la modificación de los estatutos $^{774}$. Este apartado está formado por un número variable de párrafos, todos ellos referenciados y ordenados por números romanos; para complementarlos se incluyen algunos cuadros explicativos y aclaratorios.

\subsubsection{2. "Memoria del Consejo de Administración” del ejercicio contable 1905}

Existe un segundo formato de presentación de la Memoria. A partir del ejercicio contable 1905, se modifica la estructura de la Memoria para incorporar seis novedades, que deben ser consideradas como mejoras.

Una de las principales novedades es que a partir de ese momento se introduce un índice ("Índice General") en los Informes Anuales, favoreciendo la comprensión de los títulos que lo forman.

Otra importante novedad es que establece un número mayor de títulos, lo que permite exponer mejor la información, ofreciendo una información al usuario más clara y ordenada.

La información aparece ordenada: los títulos por números romanos y los subtítulos por letras mayúsculas.

Además, la Carta del presidente establece un resumen sobre la evolución de la sociedad antes del "Resumen general de las cuentas de explotación".

Este formato trae uno de los avances más importantes a la hora de elaborar los estados financieros: la inclusión de la información sobre los saldos en el ejercicio pretérito. Hasta ese momento, salvo en contadas ocasiones en las estadísticas, sólo se encontraban los datos del

\footnotetext{
${ }^{769}$ NORTE (1901: 35-36) (1902: 39-40) (1903: 40-41) (1904: 41-42) (1905: 41-42).

${ }^{770}$ NORTE (1901: 35-36) (1902: 39-40) (1903: 41) (1904: 42) (1905: 42).

${ }^{771}$ NORTE (1901: 36).

${ }^{772}$ NORTE (1901: 36-37) (1902: 40).

773 NORTE (1904a: 42) (1905: 42). La operación a la que se refiere la Memoria de 1903 y 1904 es el canje de acciones y participaciones de San Juan de las Abadesas por acciones de NORTE.

${ }^{774}$ En concreto, la modificación de los Estatutos para fijar el capital social por consecuencia del contrato celebrado con la Comisión liquidadora del ferrocarril y Minas de San Juan de las Abadesas en 24 de mayo de 1899, y acuerdos tomados sobre él por las Juntas Generales de 4 de julio de 1899 y 25 de mayo de 1901, establece que se entreguen a los accionistas de dicha línea y a la citada Comisión 26.000 acciones NORTE en títulos definitivos. Como esto implica una modificación del capital, el tercer párrafo de las Resoluciones de la junta General expresa la nueva redacción de capital social (NORTE, 1902: 40). De la misma forma en la Memoria de 1902 aparece que, de conformidad con lo acordado en la Junta general de Accionistas del 3 de junio de 1902, se llevó a cabo el 25 de junio la escritura de fijación del capital de la compañía en 245.100 .000 pesetas, representado por 516.000 acciones de 475 pesetas completamente liberadas. En el mismo documento aparece que el 1 de julio de 1902 se han emitido 26.000 acciones para su entrega a la Comisión liquidadora y a las accionistas de la Sociedad Ferrocarril y Minas de San Juan de las Abadesas; quedan por canjear 4.967 acciones de las 26.000 emitidas (NORTE, 1903: 41-42).
} 
ejercicio corriente que estaba siendo analizado. Sin embargo, en este formato se incluyen por primera vez de forma regular los saldos del ejercicio pretérito junto a los del ejercicio corriente. Esto -que se generaliza en el apartado I. "Resumen general de las cuentas de explotación" (NORTE, 1906: 6)- acerca sobremanera a los Estados financieros del Plan General Contable de 2007, y las International Financial Reporting Standards, donde se obliga a incorporar los datos del ejercicio anterior en todos los puntos de la Memoria. Además, NORTE incorpora una mejora que las empresas actuales no realizan; la gran finalidad de incorporar los datos pretéritos y actuales es observar las diferencias, y NORTE no lo deja implícito para que el usuario lo calcule, sino que realiza los cálculos de las diferencias situándolos en una columna adjunta, incorporando a cada dato el signo positivo o negativo antes de la diferencia calculada para hacerlo más visual. No obstante, la información comparativa es mejorable, NORTE no lo hace para todos los puntos de la Memoria. Además incorpora primero el saldo del año anterior, es decir lo expone con un criterio temporal, cuando lo adecuado, es colocar primero el dato del año analizado, para incluir posteriormente el pretérito.

La otra gran novedad de la Memoria del periodo 1905 es que recoge una redacción mucho más amplia que en los anteriores ejercicios contables. No sólo se incorpora un resumen en la Carta del presidente, sino que, a lo largo de toda la Memoria, se incluyen informaciones que aclaran y complementan los saldos numéricos incluidos en los cuadros estadísticos y en el lenguaje matemático ofrecido a los usuarios del Informe Anual. Y esta debe ser la finalidad de la Memoria.

La "Memoria del Consejo de Administración" del ejercicio contable 1905 está formada por nueve componentes: Longitud de las líneas (kilómetros) ${ }^{775}$, I. Resumen general de las cuentas de explotación ${ }^{776}$, (que a su vez se dividen en tres: A. Ingresos del Tráfico, B. Gastos de la explotación y C. Cargas de la explotación) II. Situación general, III. Explotación de minas, IV. Instituciones de previsión y de beneficencia, V. Canjes y adhesión de acciones y obligaciones, VI. Impuestos ingresados en el Tesoro y beneficios obtenidos por el mismo, VII. Asuntos varios y VIII. Dirección y Consejo de administración ${ }^{777}$. En el Índice general no aparece, entre los contenidos, la Carta del presidente del Consejo de Administración, sin embargo, aparece después del apartado Longitud de las líneas (kilómetros).

En el apartado "Longitud de las líneas (kilómetros)" se informa de los kilómetros de longitud en explotación, y en construcción o a construir, al cierre de cada ejercicio contable ${ }^{778}$.

\footnotetext{
${ }^{775}$ Este subapartado, que es recogido sin número romano, sustituye a la "Red de la Compañía" del quinquenio 1900-1904. No obstante, aunque en el Índice general se la denomina I. Longitud de las líneas (kilómetros), a la hora de desarrollarlo continúa denominándola Red de la Compañía.

${ }^{776}$ Este subapartado sustituye a la "Resultados generales del ejercicio" del quinquenio 1900-1904, que aunque no aparecía con este título o encabezamiento, aparecía con esa denominación de forma implícita en la "Carta del Presidente del Consejo de Administración".

${ }^{777}$ Este subapartado sustituye a la "Administradores" del quinquenio 1900-1904.

${ }^{778}$ NORTE (1906: 4).
} 
En la "Carta del presidente del Consejo de Administración",779, éste se dirige a la Junta General de Accionistas para comunicarla que ha sido convocada en virtud del artículo 26 de los estatutos de la Compañía ${ }^{780}$. Además, se la informa que tiene tres encargos: someter al examen de la aprobación de las cuentas ${ }^{781}$, proceder al reemplazo y renovación de los Administradores que terminan su cometido al cierre del ejercicio contable ${ }^{782}$ y examinar los demás asuntos que han de ser objeto de la deliberación de la Junta ${ }^{783}$. La Carta del presidente de la Memoria de 1905 introdujo un breve y general comentario sobre la evolución que había llevado la empresa en el año analizado. Este comentario, incluido al final de la carta del presidente, permite acercarla al documento "Carta del presidente" con el que comienzan los Informes Anuales del siglo XXI. La introducción de este párrafo es de la máxima importancia porque incluye también en formato literal la información que complementa a los estados financieros, cuando hasta ese momento era exclusivamente matemática. A partir de ese momento, los Informes Anuales son muy semejantes a los utilizados en España desde 2007 con la aplicación de las International Financial Reporting Standards al ordenamiento jurídico español, cuando se incorporó el ECPN y el EFE, y la utilización del EPG en cascada unicolumnar. Esto supone que el PGC 1973 y el PGC 1990 no mejoraron ostensiblemente la información ofrecida por las ferroviarias de 1900-1923. NORTE presentaba los dos estados financieros principales, ordenados en dos columnas, acompañadas de una información literal y matemática que explicaban los saldos allí contenidos; además ofrecían una mayor información para mejorar la utilidad de los usuarios. Otro aspecto positivo de la nueva estructura informativa es que, por primera vez, la Memoria ofrece información de la estrategia futura de la sociedad ${ }^{784}$.

El apartado I. Resumen general de las cuentas de explotación ${ }^{785}$ recoge los ingresos y gastos de cada ejercicio contable y las cantidades ingresadas por la compañía en las Cajas del Estado en concepto de impuestos sobre viajeros y mercancías. El apartado "I. Resumen general de las cuentas de explotación" se divide en tres subapartados: A. Ingresos del Tráfico, B. Gastos de la explotación y C. Cargas de la explotación. Antes de analizar cada uno de estos subapartados la empresa incluye un cuadro resumen donde se recogen los saldos de los ingresos del tráfico y los gastos de la explotación (y por diferencia de ambas el Margen denominado "Producto neto") y las cargas de la explotación, donde se diferencian los

\footnotetext{
${ }^{779}$ La denominación "Carta del Presidente del Consejo de Administración” no aparece como tal en el Índice general. No obstante el encabezamiento inicial del documentos incluye la expresión "Señores:". Notar que este documento presenta una gran similitud con el documento "Carta del Presidente" con el que comienzan los Informes Anuales actuales.

${ }^{780}$ NORTE (1906: 5).

${ }^{781}$ NORTE (1906: 5).

${ }^{782}$ NORTE (1906: 5).

${ }^{783}$ NORTE (1906: 5)

${ }^{784}$ En el apartado "VII. Asuntos varios" de la Memoria de 1905 aparece que "con la amortización de agosto de 1906 terminan para ello los efectos del convenio con los obligacionistas aprobado en la junta general de 31 de mayo de 1900 y sancionado judicialmente en 9 de agosto de 1901; por consecuencia, habrá de volverse a amortizar las obligaciones por sorteo desde el 1 de octubre, cesando las compras en Bolsa, hasta entonces autorizadas" (NORTE, 1906: 33).

${ }^{785}$ Este subapartado sustituye al denominado "Explotación" incluido en el informe anual del quinquenio 19001904.
} 
intereses y amortización de las obligaciones ${ }^{786}$, Intereses, cambios y comisiones, Accidentes $^{787}$ y Amortización ${ }^{788}$. El subapartado “A. Ingresos del Tráfico" incluye los ingresos totales y por kilómetro, a continuación se expresa los ingresos del tráfico de cada una de las líneas. Posteriormente se incluyen los ingresos del tráfico de cada una de las clases: Viajeros, Gran velocidad, Pequeña velocidad y Varios ${ }^{789}$. El subapartado "B. Gastos de la explotación" incluye los gastos totales y por kilómetro, a continuación se expresa los gastos del tráfico de cada una de las líneas. Posteriormente se incluyen los ingresos del tráfico de cada una de las clases: Viajeros, Gran velocidad, Pequeña velocidad y Varios. Además, incorpora la información de los ingresos y gastos relacionados con el recorrido de trenes; entre ellos destacan los ingresos y gastos por kilómetro de tren. De la misma forma, se presenta la información sobre los kilómetros explotados, entre ella la longitud explotada, Ingresos por kilómetro explotado, Gastos por kilómetro explotado y la Relación entre el gasto y el ingreso ${ }^{790}$. El subapartado “C. Cargas de la explotación” incluye los Intereses de las obligaciones, Amortización de las obligaciones, Amortización de material, Intereses, cambios y comisiones ${ }^{791}$.

En el apartado "II. Situación general" se recoge el importe y variaciones de los activos y pasivos de la sociedad respecto al año anterior y, lo que es más importante, intenta dar algunas explicaciones de cada uno de los conceptos ${ }^{792}$. Las partidas del activo sobre las que ofrece más información, son la Construcción de las líneas y sus dependencias, Minas, Material móvil, Caja y banqueros, cuentas deudoras ${ }^{793}$ y Cuentas de orden ${ }^{794}$. En el pasivo destaca la interpretación sobre los saldos de las Obligaciones, Subvenciones, Cuentas acreedoras, Reservas, Excedente de productos de ejercicios anteriores y Cuentas de orden.

El apartado "III. Explotación de las minas" sólo se incluye en los ejercicios económicos en los que NORTE explota algunas minas. Cuando aparece, recoge información sobre la hulla

\footnotetext{
${ }^{786}$ La Memoria de 1905 incluye en este subapartado tres conceptos: Intereses, Amortizaciones y Amortización de bonos sin interés de Asturias, Galicia y León (NORTE, 1906: 6).

${ }^{787}$ La Memoria de 1905 incluye en este subapartado los accidentes en Puente Montalbo y Cercedilla (NORTE, 1906: 6).

${ }^{788}$ La Memoria de 1905 incluye, dentro de las cargas de explotación, la Amortización de 0,4\% de material motor y móvil (NORTE, 1906: 6). Es el primer ejercicio contable en el que se ofrece información sobre la amortización registrada.

${ }^{789}$ NORTE (1906: 6-9).

${ }^{790}$ NORTE (1906: 10-15).

${ }^{791}$ NORTE (1906: 16).

${ }^{792}$ NORTE (1906: 17-25).

793 Entre las "Cuentas Deudoras" figuraban las destinadas a reflejar las fianzas y depósitos entregados, así como las cuentas de deudores varios y las correspondientes al Servicio Combinado.

${ }^{794}$ Las "Cuentas de orden" aparecían en el activo, estando compensada esta rúbrica por otra de igual título y saldo en la masa de Pasivo. Su función era meramente informativa no tenía influencia alguna en el valor patrimonial de la compañía. Puede ser un anticipo del estado, sin interés, para abono de haberes al personal. También recogían información relativa a valores en custodia y otros valores pertenecientes al patrimonio privado de la empresa. Imedio Díaz y Fraisero (1934: 125) opinaban que "Si las cuentas de orden tienen grandes sumas pueden encubrir la verdadera situación económico-financiera de la empresa".
} 
extraída y sobre el número de empleados dedicados a cada una de las minas y sobre los cánones y gravámenes de cada una de las explotaciones ${ }^{795}$.

En el apartado "IV. Instituciones de previsión y de beneficencia" se ofrece diversas informaciones de tipo social. Por un lado indica el importe de la venta de artículos de consumo, fundamentalmente comestibles, a precio reducido al personal de la compañía. Por otro lado, aparece información sobre los saldos y socorros concedidos con la Caja de Previsión, y el resto de ventajas concedidas a empleados como los saldos por las pensiones de retiro, socorros, medicinas, médicos, vestuario y escuelas ${ }^{796}$.

El apartado "V. Canjes y adhesión de acciones y obligaciones" ofrece información sobre la situación en ese momento de los canjes y adhesiones de acciones y obligaciones ${ }^{797}$.

El apartado "VI. Impuestos ingresados en el Tesoro y beneficios obtenidos por el mismo" recoge información sobre lo recaudado para el Tesoro y los beneficios obtenidos por el Estado durante el ejercicio económico. Ello es expuesto tanto por el número de unidades monetarias totales como por kilómetro. Además, se informa sobre los dividendos que representan las sumas recaudadas por la compañía e ingresadas en el Tesoro ${ }^{798}$.

En el apartado "VII. Asuntos varios" aparece el resto de información que el presidente del Consejo de Administración desea transmitir a los accionistas, entre ella, la más frecuente, es la que se refiere a cómo la empresa interpreta que se ha obtenido el excedente (beneficio) ${ }^{799}$, evaluación previsible del excedente ${ }^{800}$, convenio con los obligacionistas $^{801}$, a los dividendos ${ }^{802}$, emisión de obligaciones ${ }^{803}$, a las relaciones con las demás compañías de ferrocarriles $^{804}$ y la solicitud a la Junta para que conceda autorización para formalizar

\footnotetext{
795 En concreto, las Memorias en este periodo informan sobre las Minas de Barruelo (NORTE, 1906: 26) y Surroca (NORTE, 1906: 26-27).

${ }^{796}$ NORTE (1906: 20-21).

${ }^{797}$ En concreto, la Memoria de 1905 informa sobre el Canje de las obligaciones de Zaragoza a Barcelona y de Zaragoza a Pamplona (NORTE, 1906: 30), la Adhesión de las acciones de Lérida a Reus y Tarragona (NORTE, 1906: 30) y el Canje de acciones y participaciones de San Juan de las Abadesas por acciones de NORTE (NORTE, 1906: 30-31).

${ }^{798}$ NORTE (1906: 31).

${ }^{799}$ En el apartado "VII. Asuntos varios" de la Memoria de 1905 aparece que se ha llegado al excedente por disminución de los gastos, no por aumento de ingresos (NORTE, 1906: 33).

${ }^{800}$ NORTE (1906: 33).

${ }^{801}$ En el apartado "VII. Asuntos varios" de la Memoria de 1905 aparece que "con la amortización de agosto de 1906 terminan para ello los efectos del convenio con los obligacionistas aprobado en la junta general de 31 de mayo de 1900 y sancionado judicialmente en 9 de agosto de 1901; por consecuencia, habrá de volverse a amortizar las obligaciones por sorteo desde el 1 de octubre, cesando las compras en Bolsa, hasta entonces autorizadas" (NORTE, 1906: 33).

${ }^{802}$ NORTE (1906: 33).

${ }^{803}$ NORTE (1906: 36).

${ }^{804}$ En la Memoria de 1905 aparece que "Durante el ejercicio de 1905 nuestras relaciones con las demás compañías de ferrocarriles se han mantenido en los mismos términos de cordialidad que en los anteriores, proponiéndose estrechar aún más la comunidad de intereses que nos liga con la de Madrid a Zaragoza y a
} 


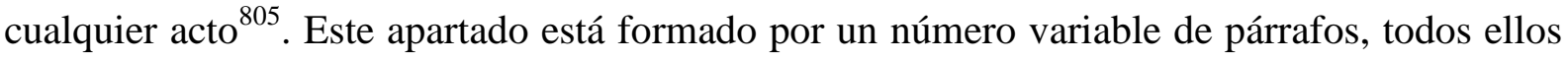
referenciados y ordenados por números romanos; además para complementarlos, se incluyen algunos cuadros explicativos y aclaratorios.

Por último, al igual que vimos en el periodo 1900-1904, en el apartado "VIII. Dirección y Consejo de administración" 806 se recuerda a los administradores fallecidos en el ejercicio económico. Igualmente se hace mención de los administradores jubilados y los que dejan la compañía por otros motivos. Por otro lado, se enumeran los administradores cuyo mandato expira en el ejercicio que termina, y son reelegibles. Para todos ellos, el presidente del Consejo de Administración propone unos candidatos e indica a la Junta su deseo de que sean ratificados por ella ${ }^{807}$.

\subsubsection{3. "Memoria del Consejo de Administración" de los ejercicios contables 1906}

La "Memoria del Consejo de Administración" del ejercicio contable 1906 está formada por nueve componentes: Longitud de las líneas (kilómetros), I. Resumen general de las cuentas de explotación (que a su vez se dividen en cuatro: A. Ingresos del Tráfico, B. Ingresos varios, C. Gastos de la explotación, D. Cargas de la Explotación), II. Situación general, III. Explotación de minas, IV. Instituciones de previsión y de beneficencia, V. Canjes y adhesión de acciones y obligaciones, VI. Impuestos ingresados en el Tesoro y beneficios obtenidos por el mismo, VII. Asuntos varios y VIII. Dirección y Consejo de administración ${ }^{808}$. Aunque en el Índice general no aparece entre los contenidos la Carta del presidente del Consejo de Administración, sin embargo, aparece después del apartado I. Longitud de las líneas (kilómetros).

Igual que en el ejercicio contable anterior, en la "Longitud de las líneas (kilómetros)" se informa de los kilómetros de longitud en explotación, y en construcción o a construir, al cierre de cada ejercicio contable ${ }^{809}$.

En la "Carta del presidente del Consejo de Administración",810, éste se dirige a la Junta General de Accionistas para informarla que ha sido convocada en virtud del artículo 26 de los estatutos de la compañía NORTE (1907: 5). Además, se la informa que tiene tres encargos: someter al examen de la aprobación de las cuentas ${ }^{811}$, proceder al reemplazo y renovación de

Alicante; propósito que, al realizarse, permitirá mejorar y perfeccionar los servicios en beneficio del público, reportando al mismo tiempo positivas ventajas a las dos compañías" (NORTE, 1906: 34).

${ }^{805}$ NORTE (1906: 34).

${ }^{806}$ El apartado "VIII. Dirección y Consejo de Administración " sustituye al apartado "Administradores" del formato de los informes anuales del quinquenio 1900-1904.

${ }^{807}$ NORTE (1906: 40).

${ }^{808}$ NORTE (1907: 4-31).

${ }^{809}$ NORTE (1907: 4).

${ }^{810}$ La denominación "Carta del Presidente del Consejo de Administración” no aparece como tal en el Índice general. No obstante, el encabezamiento inicial del documento incluye la expresión "Señores:". Este documento presenta una gran similitud con el documento "Carta del Presidente" con el que comienzan los Informes Anuales actuales.

${ }^{811}$ NORTE (1907: 5). 
los Administradores que terminan su cometido al cierre del ejercicio contable ${ }^{812}$ y examinar los demás asuntos que han de ser objeto de la deliberación de la Junta ${ }^{813}$. Dos son las principales novedades del documento: una en la evaluación de la situación económicofinanciera y otra sobre la presentación de las cuentas. En primer lugar, si la Carta del presidente de la Memoria de 1905 introdujo un breve y general comentario sobre la evolución que había llevado la empresa en el año analizado, la gran novedad de la Memoria del año 1906 es que esa breve nota se amplía, dando detalles sobre los gastos e ingresos de explotación, y el excedente, y concediendo una explicación de la evolución. Evidentemente esta explicación es sesgada, pero es posible afirmar que es el antecedente del Informe de Gestión de la empresa, que actualmente se incluye en los Informes Anuales elaborados con la normativa PGC 2007 e International Financial Reporting Standards. La segunda novedad es aún más importante si cabe, pues es una de las primeras situaciones en las que una empresa española ofrece información sobre la modificación de los criterios de presentación de una partida. Esto se materializa en que una cantidad de dinero es traspasada de los gastos de explotación a las cargas a partir de este ejercicio económico, y esto se ha realizado avisándolo en este documento y justificándolo ${ }^{814}$.

El apartado I. "Resumen general de las cuentas de explotación" sintetiza los ingresos y gastos de cada ejercicio contable y las cantidades ingresadas por la compañía en las Cajas del Estado en concepto de impuestos sobre viajeros y mercancías ${ }^{815}$. El apartado "I. Resumen general de las cuentas de explotación" se divide en cuatro subapartados: A. Ingresos del Tráfico, B. Ingresos varios, C. Gastos de la explotación, D. Cargas de la Explotación. Antes que pasar a informar sobre cada uno de estos subapartados se incluye un cuadro resumen donde se recogen los saldos de los ingresos del tráfico, de los ingresos varios, la suma de todos los ingresos, a partir de ellos los gastos de la explotación (y por diferencia con la suma de los ingresos el margen denominado "Producto neto") y las cargas de la explotación, donde se diferencian los intereses y amortización de las obligaciones ${ }^{816}$, Intereses, cambios y comisiones, Accidentes ${ }^{817}$, Amortización ${ }^{818}$, encabezamiento con la administración del timbre en Francia y ejercicios cerrados (saldos de la cuenta). El subapartado "A. Ingresos del Tráfico" incluye los ingresos totales y por kilómetro, a continuación se expresa los ingresos del tráfico de cada una de las líneas. Posteriormente se indican los ingresos del tráfico de cada una de las clases: Viajeros, Gran velocidad, Pequeña velocidad y Varios ${ }^{819}$. El subapartado

\footnotetext{
${ }^{812}$ NORTE (1907: 5).

${ }^{813}$ NORTE (1907: 5).

${ }^{814}$ En la Carta del Presidente aparece que "hemos creído que por su naturaleza debían formar parte de las cargas" (NORTE, 1907: 5).

815 NORTE (1907: 6-16).

${ }^{816}$ La Memoria de 1906 incluye en este subapartado tres conceptos: Intereses, Amortizaciones y Amortización de bonos sin interés de Asturias, Galicia y León (NORTE, 1907: 6).

${ }^{817}$ La Memoria de 1906 incluye en este subapartado los accidentes en Puente Montalbo y Cercedilla (NORTE, 1907: 6)

${ }^{818}$ La Memoria de 1906 incluye, dentro de las cargas de explotación, la Amortización de 5\% de material motor y móvil (NORTE, 1907: 6).

${ }^{819}$ NORTE (1907: 6-9).
} 
"B. Ingresos varios" recoge los saldos de los ingresos distintos al tráfico ${ }^{820}$. El subapartado "C. Gastos de la explotación" incluye los gastos totales y por kilómetro, a continuación se indican los gastos del tráfico de cada una de las líneas. Posteriormente se incluyen los gastos del tráfico de cada una de las clases: Viajeros, Gran velocidad, Pequeña velocidad y Varios. Además, incluye información de los ingresos y gastos relacionados con el recorrido de trenes; entre ellos destacan los ingresos y gastos por kilómetro de tren. De la misma forma, se presenta la información sobre los kilómetros explotados, en concreto Longitud explotada, Ingresos por kilómetro explotado, Gastos por kilómetro explotado y la Relación entre el gasto y el ingreso ${ }^{821}$. El subapartado "D. Cargas de la explotación" incluye los Intereses de las obligaciones, Amortización de las obligaciones, Amortización de material, Intereses, cambios y comisiones ${ }^{822}$. La novedad más representativa del año 1906 es que establece los datos del año presente, los del año anterior, y la diferencia entre ambos ${ }^{823}$.

El apartado "II. Situación general" recoge el importe y variaciones de los activos y pasivos de la sociedad respecto al año anterior y, lo que es más importante, intenta dar algunas explicaciones de cada uno de ellos ${ }^{824}$. Dentro del activo ofrece información, sobre todo, acerca de la Construcción de las líneas y sus dependencias, Minas, Material móvil, Caja y banqueros, cuentas deudoras y Cuentas de orden. En el pasivo destaca la exposición sobre los saldos de las Obligaciones, Subvenciones, Cuentas acreedoras, Reservas, Excedente de productos de ejercicios anteriores y Cuentas de orden.

El apartado "III. Explotación de las minas" sólo se incluye en los ejercicios económicos en los que NORTE explota algunas minas. Cuando aparecen, recoge información sobre la hulla extraída y sobre el número de empleados dedicados a cada una de las minas y sobre los cánones y gravámenes de cada una de las explotaciones ${ }^{825}$.

Por su parte, en el apartado "IV. Instituciones de previsión y de beneficencia" se recogen diversos contenidos de tipo social. Por un lado, el importe de la venta de artículos de consumo, fundamentalmente comestibles, a precio reducido al personal de la compañía. Por otro lado, información sobre los saldos y socorros concedidos con la Caja de Previsión, y el resto de ventajas concedidas a empleados como los saldos por las pensiones de retiro, socorros, medicinas, médicos, vestuario y escuelas ${ }^{826}$.

En el apartado "V. Canjes y adhesión de acciones y obligaciones" se ofrece información sobre la situación en ese momento de los canjes y adhesiones de acciones y obligaciones ${ }^{827}$.

\footnotetext{
${ }^{820}$ NORTE (1907: 9).

${ }^{821}$ NORTE (1907: 9-15).

${ }^{822}$ NORTE (1907: 15).

${ }^{823}$ NORTE (1907: 6-16).

${ }^{824}$ NORTE (1907: 17-25).

${ }^{825}$ En concreto, las Memorias en este periodo informan sobre las Minas de Barruelo (NORTE, 1907: 26) y Surroca (NORTE, 1907: 26-28).

${ }^{826}$ NORTE (1907: 28).

${ }^{827}$ En concreto, las Memorias en este periodo informan sobre el Canje de las obligaciones de Zaragoza a Barcelona y de Zaragoza a Pamplona (NORTE, 1907: 30), la Adhesión de las acciones de Lérida a Reus y
} 
El apartado "VI. Impuestos ingresados en el Tesoro y beneficios obtenidos por el mismo" ofrece información sobre lo recaudado para el Tesoro y los beneficios que el Estado obtuvo durante el ejercicio económico. Ello es expuesto tanto por el número de unidades monetarias totales como por kilómetro. Además, se informa sobre los dividendos que representa las sumas recaudadas por la compañía e ingresadas en el Tesoro ${ }^{828}$.

En el apartado "VII. Asuntos varios" aparece el resto de información que el presidente del Consejo de Administración desea transmitir a los accionistas, entre ella, la más frecuente, es la que se refiere a cómo la empresa interpreta que se ha obtenido el excedente (beneficio) ${ }^{829}$, evaluación previsible del excedente ${ }^{830}$, información sobre los créditos incobrables ${ }^{831}$, sobre los deterioros de valor ${ }^{832}$, adquisición en Bolsa de las obligaciones para cumplir el convenio con los obligacionistas ${ }^{833}$, evolución de las obras pendientes ${ }^{834}$, cambios en los registros contables $^{835}$, las relaciones con las demás compañías de ferrocarriles ${ }^{836}$ y la solicitud a la

Tarragona (NORTE, 1907: 30) y el Canje de acciones y participaciones de San Juan de las Abadesas por acciones de NORTE (NORTE, 1907: 30-31).

${ }^{828}$ NORTE (1907: 31).

${ }^{829}$ NORTE (1907: 32).

${ }^{830}$ NORTE (1907: 32).

${ }^{831}$ La Memoria de 1906 incluye por primera vez una cuenta denominada "Ejercicios cerrados" deudora de una suma importante por créditos incobrables. Este es el primer registro de una evaluación de las pérdidas por créditos incobrables en la historia de NORTE. Este aspecto es recogido en el apartado "VII. Asuntos varios" de la Memoria del Informe Anual de NORTE de 1906 (NORTE, 1907: 32).

${ }^{832}$ Para evitar el efecto de los créditos incobrables sobre los resultados definitivos de los ejercicios venideros, el Consejo (NORTE, 1907: 32) propone a la junta la creación de un fondo de previsión. El primer ejercicio que se creó es en este 1906. El importe inicial en ese ejercicio contable es de 200.000 pesetas. Este es el primer registro de un deterioro de valor por método indirecto en la historia de NORTE.

${ }^{833}$ En el apartado "VII. Asuntos varios" de la Memoria de 1906 aparece que ha concluido la compra en Bolsa de las obligaciones a que se refiere el Convenio de octubre de 1906 (NORTE, 1907: 32).

${ }^{834}$ En la Memoria de 1906 aparece que están casi terminadas las obras del ramal de enlace con el Ferrocarril Cantábrico en la estación de Torrelavega (NORTE, 1907: 32).

${ }^{835}$ En la Memoria de 1906, NORTE ofrece información sobre dos posibles cambios contables que el Consejo propone a la Junta para su ratificación. En primer lugar, el Consejo (NORTE, 1907: 32) observó que las condiciones del comercio y de la industria habían variado, NORTE necesitaba proceder al ensanche de estaciones, a la prolongación de vías de maniobras y apartaderos, a comprar material. De la misma forma, el desarrollo del tráfico y los progresos de la industria requieren trenes de gran número de vagones y el empleo de locomotoras más pesadas, así como de mayor velocidad; por ello NORTE necesitaba reconstruir o modificar los puentes metálicos y el refuerzo de la vía. Todos estos gastos hasta el ejercicio 1906 habían sido registrados como gastos de explotación. La propuesta del Consejo es que estos gastos sean registrados como gastos extraordinarios, pues vienen a recargar algunos ejercicios de manera anormal. El segundo cambio propuesto es la constitución de un fondo para realizar obras de mejora y "al cual quedaría afecto el saldo del excedente de los productos del presente ejercicio, deducción hecha del impuesto sobre utilidades que corresponda" (NORTE, 1907: 32). A dicho fondo de mejora se imputarían los gastos extraordinarios. De esta forma los gastos de explotación estarían exclusivamente limitados a los gastos corrientes. La dotación de este fondo supone tomar una medida contable en virtud de una "prudencia" tomada en consideración por la empresa, e incluso explicitada como la motivación de la medida (NORTE, 1907: 32).

${ }^{836}$ En la Memoria de 1906 aparece que desde el ejercicio de 1905 existen unas excelentes relaciones entre MZA y NORTE. Relaciones que han dado como resultado un completo acuerdo entre ambas compañías. NORTE (1907: 33) pensaba que este acuerdo daría como resultado una mayor rapidez en los transportes, una 
Junta para que conceda autorización para formalizar cualquier acto ${ }^{837}$. Este apartado está formado por un número variables de párrafos, todos ellos referenciados y ordenados por números romanos, aunque para complementarlos se incluyen algunos cuadros explicativos y aclaratorios.

Por último, en el apartado "VIII. Dirección y Consejo de administración" se hace recordatorio de los administradores fallecidos en el ejercicio económico, los jubilados y los que dejan la compañía por otros motivos ${ }^{838}$. Por otro lado, se enumeran los administradores cuyo mandato expira en ese ejercicio que termina y son reelegibles. Para todos ellos, el presidente del Consejo de Administración propone unos candidatos, e indica a la Junta su deseo de que sean ratificados por ella ${ }^{839}$.

\subsubsection{4. "Memoria del Consejo de Administración" de los ejercicios contables 1907-1911}

La "Memoria del Consejo de Administración” del ejercicio contable 1907 está formada por nueve componentes: Longitud de las líneas (kilómetros), I. Resumen general de las cuentas de explotación (que a su vez se dividen en cuatro: A. Ingresos del Tráfico, B. Ingresos varios, C. Gastos de la explotación, D. Cargas de la Explotación), II. Situación general, III. Explotación de minas, IV. Instituciones de previsión y de beneficencia, V. Canjes y adhesión de acciones y obligaciones, VI. Impuestos ingresados en el Tesoro y beneficios obtenidos por el Estado, VII. Liquidación del ejercicio y VIII. Consejo de administración ${ }^{840}$. Aunque en el Índice general no aparece entre los contenidos la Carta del presidente del Consejo de Administración, sin embargo, aparece después del apartado I. Longitud de las líneas (kilómetros).

En la "I. Longitud de las líneas (kilómetros)" se informa de los kilómetros de longitud en explotación, y en construcción o a construir, al cierre de cada ejercicio contable ${ }^{841}$.

En la "Carta del presidente del Consejo de Administración" "842, éste se dirige a la Junta General de Accionistas para informarla que ha sido convocada en virtud del artículo 26 de los estatutos de la Compañía ${ }^{843}$. Además, se la informa que tiene tres encargos: someter al

simplificación de las tarifas y, sobre todo, las compañías obtendrán la apreciable ventaja de no tener que preocuparse de las diferentes direcciones que pudiera tomar el tráfico.

${ }^{837}$ NORTE (1907: 33).

${ }^{838}$ En la Memoria de 1906 aparece que Faustino Rodríguez San Pedro había presentado la dimisión del cargo de Presidente del Consejo y Administrador de NORTE, por haber sido nombrado ministro de la Corona (NORTE, 1907: 34).

${ }^{839}$ NORTE (1907: 34).

${ }^{840}$ NORTE (1908: 4-31) (1909: 4-31)(1910:4-31)(1911:4-31)(1912: 4-31).

${ }^{841}$ NORTE (1908: 4) (1909: 4) (1910: 4) (1911: 4) (1912: 4).

${ }^{842}$ Tampoco aquí la denominación "Carta del Presidente del Consejo de Administración” aparece como tal en el Índice general. No obstante, el encabezamiento inicial del documento incluye la expresión "Señores:". Como hemos dicho anteriormente este documento presenta una gran similitud con la "Carta del Presidente" con el que se inician los Informes Anuales actuales.

${ }^{843}$ NORTE (1908: 5) (1909: 5) (1910: 5) (1911: 5) (1912: 5). 
examen de la aprobación de las cuentas ${ }^{844}$, proceder al reemplazo y renovación de los Administradores que terminan su cometido al cierre del ejercicio contable ${ }^{845}$ y examinar los demás asuntos que han de ser objeto de la deliberación de la Junta ${ }^{846}$. La principal novedad del documento es sobre la presentación de las cuentas. La empresa continúa incluyendo información en el mismo sentido que en la Memoria de 1906, ofreciendo información sobre la modificación de los criterios de presentación de una partida. Esto se materializa en que una cantidad de dinero es traspasada de los gastos de explotación a las cargas a partir de este ejercicio económico, y esto se ha realizado avisándolo en este documento y justificándolo ${ }^{847}$. En el ejercicio 1907 amplía la información ofreciendo una evaluación de la gestión. Incluye los siguientes contenidos: que cesó el artículo $5^{\circ}$ del Convenio de 31 de mayo de 1900, que tras dieciséis años de vicisitudes diversas, por fin se propone la distribución de un dividendo de 10 pesetas por acción, que se dote una parte importante del beneficio a reservas, "inspirándose en consideraciones de prudente previsión", interpretación de los aumentos de ingresos, gastos y resultados del ejercicio, que la falta de estabilidad del tipo de cambio puede ocasionar desagradables sorpresas y, por último, que quedan importantes y costosos trabajos de mejora ${ }^{848}$.

El apartado I. "Resumen general de las cuentas de explotación" sintetiza los ingresos y gastos de cada ejercicio contable y las cantidades ingresadas por la compañía en las Cajas del Estado en concepto de impuestos sobre viajeros y mercancías ${ }^{849}$. El apartado "I. Resumen general de las cuentas de explotación" se divide en cuatro subapartados: A. Ingresos del Tráfico, B. Ingresos varios, C. Gastos de la explotación, D. Cargas de la Explotación. Antes que pasar a informar sobre cada uno de estos subapartados se incluye un cuadro resumen donde se recogen los saldos de los ingresos del tráfico, de los ingresos varios, la suma de todos los ingresos, a partir de ellos los gastos de la explotación (y por diferencia con la suma de los ingresos el Margen denominado "Producto neto") y las cargas de la explotación, donde se diferencian los intereses y amortización de las obligaciones, Intereses, cambios y comisiones, Accidentes, Amortización ${ }^{850}$, encabezamiento con la administración del timbre en Francia y ejercicios cerrados (saldos de la cuenta). El subapartado "A. Ingresos del Tráfico" incluye los ingresos totales y por kilómetro, a continuación se expresa los ingresos del tráfico de cada una de las líneas. Posteriormente se indican los ingresos del tráfico de cada una de las clases: Viajeros, Gran velocidad, Pequeña velocidad y Varios ${ }^{851}$. El subapartado "B. Ingresos varios" recoge los saldos de los ingresos distintos al tráfico ${ }^{852}$. El subapartado "C. Gastos de la explotación" incluye los gastos totales y por kilómetro, a continuación se indican los gastos

\footnotetext{
${ }^{844}$ NORTE (1908: 5) (1909: 5) (1910: 5) (1911: 5) (1912: 5).

${ }^{845}$ NORTE (1908: 5) (1909: 5) (1910: 5) (1911: 5) (1912: 5).

${ }^{846}$ NORTE (1908: 5) (1909: 5) (1910: 5) (1911: 5) (1912: 5).

${ }^{847}$ En la Carta del Presidente aparece que "hemos creído que por su naturaleza debían formar parte de las cargas" (NORTE, 1908: 5; 1909:5; 1910:5; 1911:5; 1912:5).

${ }^{848}$ NORTE (1908: 5-6) (1909: 5-6) (1910: 5-6) (1911: 5-6) (1912: 5-6).

${ }^{849}$ NORTE (1908: 6-16) (1909: 6-16) (1910: 6-16) (1911: 6-16) (1912: 6-16).

${ }^{850}$ La Memoria de 1907 incluye, dentro de las cargas de explotación, la Amortización de 5\% de material motor y móvil (NORTE, 1908: 6; 1909:6; 1910:6; 1911:6; 1912:6).

${ }^{851}$ NORTE (1908: 6-9) (1909: 6-9) (1910: 6-9) (1911: 6-9) (1912: 6-9).

${ }^{852}$ NORTE (1908: 9) (1909: 9) (1910: 9) (1911:9) (1912:9).
} 
del tráfico de cada una de las líneas. Posteriormente se incluyen los gastos del tráfico de cada una de las clases: Viajeros, Gran velocidad, Pequeña velocidad y Varios. Además, incluye información de los ingresos y gastos relacionados con el recorrido de trenes; entre ellos destacan los ingresos y gastos por kilómetro de tren. De la misma forma, se presenta la información sobre los kilómetros explotados, entre ella la longitud explotada, Ingresos por kilómetro explotado, Gastos por kilómetro explotado y la Relación entre el gasto y el ingreso ${ }^{853}$. El subapartado "D. Cargas de la explotación" incluye los Intereses de las obligaciones, Amortización de las obligaciones, Amortización de material, Intereses, cambios y comisiones ${ }^{854}$. La empresa muestra los datos del año presente, los del año anterior, y la diferencia entre ambos ${ }^{855}$.

El apartado "II. Situación general" recoge el importe y variaciones de los activos y pasivos de la sociedad respecto al año anterior $\mathrm{y}$, lo que es más importante, intenta dar algunas explicaciones de cada uno de ellos ${ }^{856}$. Dentro del activo ofrece información, sobre todo, acerca de la Construcción de las líneas y sus dependencias, Minas, Material móvil, Caja y banqueros, cuentas deudoras y Cuentas de orden. En el pasivo destaca la exposición sobre los saldos de las Obligaciones, Subvenciones, Cuentas acreedoras, Reservas, Excedente de productos de ejercicios anteriores y Cuentas de orden.

El apartado "III. Explotación de las minas" sólo se incluye en los ejercicios económicos en los que NORTE explota algunas minas. Cuando aparecen, recoge información sobre la hulla extraída y sobre el número de empleados dedicados a cada una de las minas y sobre los cánones y gravámenes de cada una de las explotaciones ${ }^{857}$.

El apartado "IV. Instituciones de previsión y de beneficencia" sintetiza diversas informaciones de tipo social. Por un lado, indica el importe de la venta de artículos de consumo, fundamentalmente comestibles, a precio reducido al personal de la compañía. Por el otro lado, se indica información sobre los saldos y socorros concedidos con la Caja de Previsión, y el resto de ventajas concedidas a empleados como los saldos por las pensiones de retiro, socorros, medicinas, médicos, vestuario y escuelas ${ }^{858}$.

En el apartado "V. Canjes y adhesión de acciones y obligaciones" se recoge información sobre la situación en ese momento de los canjes y adhesiones de acciones y obligaciones ${ }^{859}$.

\footnotetext{
${ }^{853}$ NORTE (1908: 9-16) (1909: 9-16) (1910: 9-16) (1911: 9-16) (1912: 9-16).

${ }^{854}$ NORTE (1908: 15) (1909: 15) (1910: 15) (1911: 15) (1912: 15).

${ }^{855}$ NORTE (1908: 6-16) (1909: 6-16) (1910: 6-16) (1911: 6-16) (1912: 6-16).

${ }^{856}$ NORTE (1908: 17-25) (1909: 17-25) (1910: 17-25) (1911: 17-25) (1912: 17-25).

${ }^{857}$ En concreto, las Memorias en este periodo informan sobre las Minas de Barruelo (NORTE, 1908: 24) y Surroca (NORTE, 1908: 24-25) (1909: 24-25) (1910: 24-25) (1911: 24-25) (1912: 24-25).

${ }^{858}$ NORTE (1908: 26-27) (1909: 26-27) (1910: 26-27) (1911: 26-27) (1912: 26-27).

${ }^{859}$ En concreto, las Memorias en este periodo informan sobre el Canje de las obligaciones de Zaragoza a Barcelona y de Zaragoza a Pamplona (NORTE, 1908: 28; 1909: 28; 1910: 28; 1911: 28; 1912: 28), la Adhesión de las acciones de Lérida a Reus y Tarragona (NORTE, 1908: 28; 1909: 28; 1910: 28; 1911: 28; 1912: 28) y el Canje de acciones y participaciones de San Juan de las Abadesas por acciones de NORTE (NORTE, 1908: 28; 1909: 28; 1910: 28; 1911: 28; 1912: 28).
} 
El apartado "VI. Impuestos ingresados en el Tesoro y beneficios obtenidos por el Estado" "860 ofrece información sobre el importe recaudado para el Tesoro y los ingresos obtenidos por el Estado durante el ejercicio económico. Ello es expuesto por el número de unidades monetarias totales y por kilómetro. Además, se informa sobre los dividendos que representa las sumas recaudadas por la compañía e ingresadas en el Tesoro ${ }^{861}$.

El apartado "VII. Liquidación del ejercicio" $" 862$ aparece el resto de información que el presidente del Consejo de Administración desea transmitir a los accionistas, entre ella, la más frecuente, es la que se refiere a cómo la empresa interpreta que se ha obtenido el excedente (beneficio) ${ }^{863}$ y evaluación previsible del excedente ${ }^{864}$.

Por último, en el apartado "VIII. Consejo de administración" se hace mención y recordatorio de los administradores fallecidos en el ejercicio económico, de los administradores jubilados y de los que dejan la compañía por otros motivos. Por otro lado, se enumeran los administradores cuyo mandato expira en ese ejercicio que termina y son reelegibles. Para todos ellos, el presidente del Consejo de Administración propone unos candidatos, e indica a la Junta su deseo de que sean ratificados por ella ${ }^{865}$.

La Memoria de 1908 intenta ofrecer una información más desagregada pasando de VIII títulos a IX, pero termina siendo un mayor número de títulos que de contenidos. En 1909 vuelve al número de títulos de 1907. Las Memorias de 1909, 1910 y 1911 son idénticas a la de 1907 con la única variación que agrupa en un único apartado (V.) la conversión de obligaciones y el canje y adhesión de acciones y obligaciones ${ }^{866}$.

\subsubsection{5. "Memoria del Consejo de Administración" de los ejercicios contables 1912-1918}

La Memoria de 1912 es la primera que incorpora anejos. Este primer ejercicio incorpora tres, que son la normativa interna de la sociedad. A partir de ese ejercicio, en la Memoria de los años 1913, 1914, 1915, 1916, 1917 y 1918, los anejos se siguen exponiendo pero los contenidos son distintos; se expone un único anejo que expone los beneficios que obtiene el Estado de la actividad de NORTE.

\footnotetext{
${ }^{860}$ En el ejercicio 1907 se denomina "VI. Impuestos ingresados en el Tesoro y beneficios obtenidos por el Estado", mientras que en el ejercicio 1906 se denominaba "VI. Impuestos ingresados en el Tesoro y beneficios obtenidos por el mismo" Cfr. NORTE (1907: 31) y NORTE (1908: 29).

${ }^{861}$ NORTE (1907: 31) (1908: 29).

${ }^{862}$ Este apartado "VII. Liquidación del ejercicio" del ejercicio 1907 sustituye al apartado "VII. Asuntos varios" del ejercicio 1906, ofreciendo una información más reducida en el primero (NORTE, 1907: 35; 1908: 34).

${ }^{863}$ NORTE (1908:30) (1909:30) (1910:30) (1911:30) (1912:30).

${ }^{864}$ NORTE (1908:30) (1909:30) (1910:30) (1911:30) (1912:30).

${ }^{865}$ NORTE (1908:34) (1909:34) (1910:34) (1911:34) (1912:34).

${ }^{866}$ NORTE (1908: 26-27) (1909: 26-27) (1910: 26-27) (1911: 26-27) (1912: 26-27).
} 


\subsubsection{6. "Memoria del Consejo de Administración" de los ejercicios contables 1919-1920}

La Memoria de 1919 es la primera firmada por el nuevo presidente del Consejo de Administración Marqués de Alonso Martínez. La novedad más importante es que comienza por incorporar una pagina (NORTE, 1920: 3) en la que indica el nombre del presidente del Consejo de Administración, los cuatro vicepresidentes y los veintiún administradores, lo cual supone el primer organigrama oficial expuesto en la información contable actual por el Consejo de Administración de una empresa en España.

\subsubsection{7. "Memoria del Consejo de Administración" de los ejercicios contables 1921-1923}

La gran novedad de la Memoria de 1921-1923 es que incorpora una mayor información en forma de Anejos y de gráficos.

La primera novedad del ejercicio contable 1921 era la inclusión de un anejo en el que la compañía ofrece información sobre los beneficios que obtiene el Estado por la actividad de NORTE: "Beneficios obtenidos por el Estado, de las líneas que explota NORTE, durante los años 1880 a 1921 ". El principal objetivo de esta medida era presionar al gobierno de turno sobre las necesidades de la industria ferroviaria en general y de la empresa en particular. La segunda novedad es la inclusión de un gráfico denominado "Representativo del valor absoluto de los conceptos de gastos de la explotación y de cargas de la explotación en relación con la cifra total de ingresos de explotación. Sin plus del Estado y con plus del Estado".

En el ejercicio contable 1922 se incluyen dos Anejos y un gráfico. El primer anejo es "Beneficios obtenidos por el Estado, de las líneas que explota NORTE, durante los años 1880 a 1922". El segundo es la "Carta en francés a los accionistas de NORTE sobre la promulgación del Decreto Ley de 12 de julio, que establece un nuevo régimen de los ferrocarriles". El Gráfico incluido es "Representativo del valor absoluto de los conceptos de gastos de la explotación y de cargas de la explotación en relación con la cifra total de ingresos de explotación. Sin plus del Estado y con plus del Estado".

En el ejercicio contable 1923 se incluye un anejo donde se ofrece información sobre los beneficios que obtiene el Estado por la actividad de NORTE: "Beneficios obtenidos por el Estado, de las líneas que explota NORTE, durante los años 1880 a 1923”.

El cuadro 53 muestra los contenidos de la Memoria de NORTE en el periodo 1900-1923. 


\section{Cuadro 53. Contenidos de la Memoria de NORTE 1900-1923}

\begin{tabular}{|c|c|}
\hline $\begin{array}{l}\text { EJERCICIO } \\
\text { CONTABLE }\end{array}$ & COMPONENTES DE LA MEMORIA \\
\hline 1900 & $\begin{array}{l}\text { Red de la Compañía } \\
\text { Carta del presidente } \\
\text { Resultados generales del ejercicio } \\
\text { (Explotación, Construcción, Instalaciones nuevas y obras de conclusión definitiva, Renovación de la vía, Material } \\
\text { móvil, Establecimientos de previsión, Minas, Líneas, Situación general y resumen de cuentas de la explotación) } \\
\text { Administradores } \\
\text { Asuntos varios }\end{array}$ \\
\hline 1901 & $\begin{array}{l}\text { Red de la Compañ́a } \\
\text { Carta del presidente } \\
\text { Resultados generales del ejercicio } \\
\text { (Explotación, Construcción, Instalaciones nuevas y obras de conclusión definitiva, Renovación de la vía, Material } \\
\text { móvil, Establecimientos de previsión, Minas, Líneas, Situación general y resumen de cuentas de la explotación) } \\
\text { Administradores } \\
\text { Asuntos varios }\end{array}$ \\
\hline 1902 & $\begin{array}{l}\text { Red de la Compañía } \\
\text { Carta del presidente } \\
\text { Resultados generales del ejercicio } \\
\text { (Explotación, Construcción, Instalaciones nuevas y obras de conclusión definitiva, Renovación de la vía, Material } \\
\text { móvil, Establecimientos de previsión, Minas, Líneas, Situación general y resumen de cuentas de la explotación) } \\
\text { Administradores } \\
\text { Asuntos varios }\end{array}$ \\
\hline 1903 & $\begin{array}{l}\text { Red de la Compañía } \\
\text { Carta del presidente } \\
\text { Resultados generales del ejercicio } \\
\text { (Explotación, Construcción, Instalaciones nuevas y obras de conclusión definitiva, Renovación de la vía, Material } \\
\text { móvil, Establecimientos de previsión, Minas, Líneas, Situación general y resumen de cuentas de la explotación) } \\
\text { Administradores } \\
\text { Asuntos varios }\end{array}$ \\
\hline 1904 & $\begin{array}{l}\text { Red de la Compañía } \\
\text { Carta del presidente } \\
\text { Resultados generales del ejercicio } \\
\text { (Explotación, Construcción, Instalaciones nuevas y obras de conclusión definitiva, Renovación de la vía, Material } \\
\text { móvil, Establecimientos de previsión, Minas, Líneas, Situación general y resumen de cuentas de la explotación) } \\
\text { Administradores } \\
\text { Asuntos varios }\end{array}$ \\
\hline 1905 & $\begin{array}{l}\text { Longitud de las líneas (kilómetros) } \\
\text { Carta del presidente } \\
\text { I. Resumen general de las cuentas de explotación } \\
\text { A. Ingresos del Tráfico }\end{array}$ \\
\hline
\end{tabular}




\begin{tabular}{|c|c|}
\hline & $\begin{array}{l}\text { B. Gastos de la explotación } \\
\text { C. Cargas de la Explotación } \\
\text { II. Situación general } \\
\text { III. Explotación de las Minas } \\
\text { IV. Institución de previsión y de beneficencia } \\
\text { V. Canjes y adhesión de acciones y obligaciones } \\
\text { VI. Impuestos ingresados en el Tesoro y beneficios obtenidos por el mismo } \\
\text { VII. Asuntos varios } \\
\text { VIII. Dirección y Consejo de Administración } \\
\text { Resoluciones de la Junta General } \\
\text { Situación de la Compañía } \\
\text { Cuentas de la Explotación de cada una de las líneas que forman la red de la compañía } \\
\text { Cuenta general de la explotación del conjunto de las líneas }\end{array}$ \\
\hline 1906 & $\begin{array}{l}\text { Longitud de las líneas (kilómetros) } \\
\text { Carta del presidente } \\
\text { I. Resumen general de las cuentas de explotación } \\
\text { A. Ingresos del Tráfico } \\
\text { B. Ingresos varios } \\
\text { C. Gastos de la explotación } \\
\text { D. Cargas de la Explotación } \\
\text { II. Situación general } \\
\text { III. Explotación de las Minas } \\
\text { IV. Institución de previsión y de beneficencia } \\
\text { V. Canjes y adhesión de acciones y obligaciones } \\
\text { VI. Impuestos ingresados en el Tesoro y beneficios obtenidos por el mismo } \\
\text { VII. Asuntos varios } \\
\text { VIII. Dirección y Consejo de Administración } \\
\text { Resoluciones de la Junta General } \\
\text { Situación de la Compañía } \\
\text { Cuentas de la Explotación de cada una de las líneas que forman la red de la compañía } \\
\text { Cuenta general de la explotación del conjunto de las líneas }\end{array}$ \\
\hline 1907 & $\begin{array}{l}\text { Longitud de las líneas (kilómetros) } \\
\text { Carta del presidente } \\
\text { I. Resumen general de las cuentas de explotación } \\
\text { A. Ingresos del Tráfico } \\
\text { B. Ingresos varios } \\
\text { C. Gastos de la explotación } \\
\text { D. Cargas de la Explotación } \\
\text { II. Situación general } \\
\text { III. Explotación de las Minas } \\
\text { IV. Institución de previsión y de beneficencia } \\
\text { V. Canje y adhesión de acciones y obligaciones } \\
\text { VI. Impuestos ingresados en el Tesoro y beneficios obtenidos por el Estado } \\
\text { VII. Liquidación del ejercicio } \\
\text { VIII. Consejo de Administración } \\
\text { Resoluciones de la Junta General } \\
\text { Situación de la Compañía } \\
\text { Cuentas de la Explotación de cada una de las líneas que forman la red de la compañía } \\
\text { Cuenta general de la explotación del conjunto de las líneas }\end{array}$ \\
\hline 1908 & Longitud de las líneas (kilómetros) \\
\hline
\end{tabular}


Carta del presidente

I. Resumen general de las cuentas de explotación

A. Ingresos del Tráfico

B. Ingresos varios

C. Gastos de la explotación

D. Cargas de la Explotación

II. Situación general

III. Explotación de las Minas

IV. Institución de previsión y de beneficencia

V. Canje y adhesión de acciones y obligaciones

VI. Conversión de obligaciones

VII. Impuestos ingresados en el Tesoro y beneficios obtenidos por el Estado

VIII. Liquidación del ejercicio

IX. Consejo de Administración

Resoluciones de la Junta General

Situación de la Compañía

Cuentas de la Explotación de cada una de las líneas que forman la red de la compañía

Cuenta general de la explotación del conjunto de las líneas

\begin{tabular}{|c|c|}
\hline 1909 & $\begin{array}{l}\text { Longitud de las líneas (kilómetros) } \\
\text { Carta del presidente } \\
\text { I. Resumen general de las cuentas de explotación } \\
\text { A. Ingresos del Tráfico } \\
\text { B. Ingresos varios } \\
\text { C. Gastos de la explotación } \\
\text { D. Cargas de la Explotación } \\
\text { II. Situación general } \\
\text { III. Explotación de las Minas } \\
\text { IV. Institución de previsión y de beneficencia } \\
\text { V. Conversión de obligaciones y canje y adhesión de acciones y obligaciones } \\
\text { VI. Impuestos ingresados en el Tesoro y beneficios obtenidos por el Estado } \\
\text { VII. Liquidación del ejercicio } \\
\text { VIII. Consejo de Administración } \\
\text { Resoluciones de la Junta General } \\
\text { Situación de la Compañía } \\
\text { Cuentas de la Explotación de cada una de las líneas que forman la red de la compañía } \\
\text { Cuenta general de la explotación del conjunto de las líneas }\end{array}$ \\
\hline 1910 & $\begin{array}{l}\text { Longitud de las líneas (kilómetros) } \\
\text { Carta del presidente } \\
\text { I. Resumen general de las cuentas de explotación } \\
\text { A. Ingresos del Tráfico } \\
\text { B. Ingresos varios } \\
\text { C. Gastos de la explotación } \\
\text { D. Cargas de la Explotación } \\
\text { E.F.G. Excedente de productos } \\
\text { II. Situación general } \\
\text { III. Explotación de las Minas } \\
\text { IV. Situación de previsión y de beneficencia } \\
\text { V. Canje y adhesión de acciones y obligaciones } \\
\text { VI. Conversión de obligaciones } \\
\text { VII. Impuestos ingresados en el Tesoro y beneficios obtenidos por el Estado } \\
\text { VIII. Liquidación del ejercicio } \\
\text { IX. Consejo de Administración }\end{array}$ \\
\hline
\end{tabular}




\begin{tabular}{|c|c|}
\hline & $\begin{array}{l}\text { Resoluciones de la Junta General } \\
\text { Situación de la Compañía } \\
\text { Cuentas de la Explotación de cada una de las líneas que forman la red de la compañía } \\
\text { Cuenta general de la explotación del conjunto de las líneas }\end{array}$ \\
\hline 1911 & $\begin{array}{l}\text { Longitud de las líneas (kilómetros) } \\
\text { Carta del presidente } \\
\text { I. Resumen general de las cuentas de explotación } \\
\text { A. Ingresos del Tráfico } \\
\text { B. Ingresos varios } \\
\text { C. Gastos de la explotación } \\
\text { D. Cargas de la Explotación } \\
\text { E.F.G. Excedente de productos } \\
\text { II. Situación general } \\
\text { III. Explotación de las Minas } \\
\text { IV. Institución de previsión y de beneficencia } \\
\text { V. Canje y adhesión de acciones y obligaciones } \\
\text { VI. Impuestos ingresados en el Tesoro y beneficios obtenidos por el Estado } \\
\text { VII. Liquidación del ejercicio } \\
\text { VIII. Consejo de Administración } \\
\text { Resoluciones de la Junta General } \\
\text { Situación de la Compañía } \\
\text { Cuentas de la Explotación de cada una de las líneas que forman la red de la compañía } \\
\text { Cuenta general de la explotación del conjunto de las líneas }\end{array}$ \\
\hline 1912 & $\begin{array}{l}\text { Longitud de las líneas (kilómetros) } \\
\text { Carta del presidente } \\
\text { I. Resumen general de las cuentas de explotación } \\
\text { A. Ingresos del Tráfico } \\
\text { B. Ingresos varios } \\
\text { C. Gastos de la explotación } \\
\text { D. Cargas de la Explotación } \\
\text { E.F.G. Excedente de productos } \\
\text { II. Situación general } \\
\text { III. Explotación de las Minas } \\
\text { IV. Institución de previsión y de beneficencia } \\
\text { V. Canje y adhesión de acciones y obligaciones } \\
\text { VI. Impuestos ingresados en el Tesoro y beneficios obtenidos por el Estado } \\
\text { VII. Liquidación del ejercicio } \\
\text { VIII. Consejo de Administración } \\
\text { Resoluciones de la Junta General } \\
\text { Situación de la Compañía } \\
\text { Cuentas de la Explotación de cada una de las líneas que forman la red de la compañía } \\
\text { Cuenta general de la explotación del conjunto de las líneas } \\
\text { Anejos: } \\
\text { Orden de Dirección no } 103: \text { "Reglamento para la concesión de pensiones de retiro, viudedad y orfandad", Madrid, } 1 \\
\text { de noviembre de } 1912 \\
\text { Orden de Dirección no } 104: \text { "Supresión del descuento al personal como contribución a la Caja de Previsión", } \\
\text { Madrid, } 24 \text { de diciembre de } 1912\end{array}$ \\
\hline
\end{tabular}




\begin{tabular}{|c|c|}
\hline & $\begin{array}{l}\text { Orden de Dirección no } 105 \text { : "Supresión y devolución de fianzas a los agentes comprendidos en el artículo } 50 \text { de la } \\
\text { Instrucción General n } 2^{\circ} \text { ", Madrid, } 24 \text { de diciembre de } 1912\end{array}$ \\
\hline 1913 & $\begin{array}{l}\text { Extensión de la red } \\
\text { Carta del presidente } \\
\text { I. Resumen general de las cuentas de explotación } \\
\text { A. Ingresos del Tráfico } \\
\text { B. Ingresos varios } \\
\text { C. Gastos de la explotación } \\
\text { D. Cargas de la Explotación } \\
\text { E.F.G. Excedente de productos } \\
\text { II. Situación general } \\
\text { III. Explotación de las Minas } \\
\text { IV. Institución de previsión y de beneficencia } \\
\text { V. Canje y adhesión de acciones y obligaciones } \\
\text { VI. Impuestos ingresados en el Tesoro y beneficios obtenidos por el Estado } \\
\text { VII. Liquidación del ejercicio } \\
\text { VIII. Consejo de Administración } \\
\text { Resoluciones de la Junta General } \\
\text { Situación de la Compañía } \\
\text { Cuentas de la Explotación de cada una de las líneas que forman la red de la compañía } \\
\text { Cuenta general de la explotación del conjunto de las líneas } \\
\text { Anejo: } \\
\text { Beneficios obtenidos por el Estado, de las líneas que explota NORTE, durante los años } 1893 \text { a } 1913\end{array}$ \\
\hline 1914 & $\begin{array}{l}\text { Extensión de la red } \\
\text { Carta del presidente } \\
\text { I. Resumen general de las cuentas de explotación } \\
\text { A. Ingresos del Tráfico } \\
\text { B. Ingresos varios } \\
\text { C. Gastos de la explotación } \\
\text { D. Pensiones al personal } \\
\text { E. Cargas de la Explotación } \\
\text { F.G.H. Excedente de productos } \\
\text { II. Situación general } \\
\text { III. Explotación de las Minas } \\
\text { IV. Institución de previsión y de beneficencia } \\
\text { V. Canje y adhesión de acciones y obligaciones } \\
\text { VI. Impuestos ingresados en el Tesoro y beneficios obtenidos por el Estado } \\
\text { VII. Liquidación del ejercicio } \\
\text { VIII. Consejo de Administración } \\
\text { Resoluciones de la Junta General } \\
\text { Situación de la Compañía } \\
\text { Cuentas de la Explotación de cada una de las líneas que forman la red de la compañía } \\
\text { Cuenta general de la explotación del conjunto de las líneas } \\
\text { Anejo: } \\
\text { Beneficios obtenidos por el Estado, de las líneas que explota NORTE, durante los años } 1880 \text { a } 1914\end{array}$ \\
\hline 1915 & $\begin{array}{l}\text { Extensión de la red } \\
\text { Carta del presidente } \\
\text { I. Resumen general de las cuentas de explotación } \\
\text { A. Ingresos del Tráfico } \\
\text { B. Ingresos varios }\end{array}$ \\
\hline
\end{tabular}




\begin{tabular}{|c|c|}
\hline & $\begin{array}{l}\text { C. Gastos de la explotación } \\
\text { D. Pensiones al personal } \\
\text { E. Cargas de la Explotación } \\
\text { F.G.H. Excedente de productos } \\
\text { II. Situación general } \\
\text { III. Explotación de las Minas } \\
\text { IV. Institución de previsión y de beneficencia } \\
\text { V. Canje y adhesión de acciones y obligaciones } \\
\text { VI. Impuestos ingresados en el Tesoro y beneficios obtenidos por el Estado } \\
\text { VII. Liquidación del ejercicio } \\
\text { VIII. Consejo de Administración } \\
\text { Resoluciones de la Junta General } \\
\text { Situación de la Compañía } \\
\text { Cuentas de la Explotación de cada una de las líneas que forman la red de la compañía } \\
\text { Cuenta general de la explotación del conjunto de las líneas } \\
\text { Anejo: } \\
\text { Beneficios obtenidos por el Estado, de las líneas que explota NORTE, durante los años } 1880 \text { a } 1915\end{array}$ \\
\hline 1916 & $\begin{array}{l}\text { Extensión de la red } \\
\text { Carta del presidente } \\
\text { I. Resumen general de las cuentas de explotación } \\
\text { A. Ingresos del Tráfico } \\
\text { B. Ingresos varios } \\
\text { C. Gastos de la explotación } \\
\text { D. Pensiones al personal } \\
\text { E. Cargas de la Explotación } \\
\text { F.G.H. Excedente de productos } \\
\text { II. Situación general } \\
\text { III. Explotación de las Minas } \\
\text { IV. Institución de previsión y de beneficencia } \\
\text { V. Canje y adhesión de acciones y obligaciones } \\
\text { VI. Impuestos ingresados en el Tesoro y beneficios obtenidos por el Estado } \\
\text { VII. Liquidación del ejercicio } \\
\text { VIII. Emisión de obligaciones } \\
\text { IX. Domiciliación en España de los valores de la compañía pagaderos en moneda nacional o extranjera } \\
\text { X. Consejo de Administración } \\
\text { Resoluciones de la Junta General } \\
\text { Situación de la Compañía } \\
\text { Cuentas de la Explotación de cada una de las líneas que forman la red de la compañía } \\
\text { Cuenta general de la explotación del conjunto de las líneas } \\
\text { Anejo } \\
\text { Beneficios obtenidos por el Estado, de las líneas que explota NORTE, durante los años } 1880 \text { a } 1917\end{array}$ \\
\hline 1917 & $\begin{array}{l}\text { Extensión de la red } \\
\text { Carta del presidente } \\
\text { I. Resumen general de las cuentas de explotación } \\
\text { A. Ingresos del Tráfico } \\
\text { B. Ingresos varios } \\
\text { C. Gastos de la explotación } \\
\text { D. Pensiones al personal } \\
\text { E. Cargas de la Explotación } \\
\text { F.G.H. Excedente de productos } \\
\text { II. Situación general }\end{array}$ \\
\hline
\end{tabular}




\begin{tabular}{|c|c|}
\hline & $\begin{array}{l}\text { III. Explotación de las Minas } \\
\text { IV. Institución de previsión y de beneficencia } \\
\text { V. Canje y adhesión de acciones y obligaciones } \\
\text { VI. Impuestos ingresados en el Tesoro y beneficios obtenidos por el Estado } \\
\text { VII. Liquidación del ejercicio } \\
\text { VIII. Emisión de obligaciones } \\
\text { IX. Domiciliación en España de los valores de la compañía pagaderos en moneda nacional o extranjera } \\
\text { X. Consejo de Administración } \\
\text { Resoluciones de la Junta General } \\
\text { Situación de la Compañía } \\
\text { Cuentas de la Explotación de cada una de las líneas que forman la red de la compañía } \\
\text { Cuenta general de la explotación del conjunto de las líneas } \\
\text { Anejo: } \\
\text { Beneficios obtenidos por el Estado, de las líneas que explota NORTE, durante los años } 1880 \text { a } 1917\end{array}$ \\
\hline 1918 & $\begin{array}{l}\text { Extensión de la red } \\
\text { Carta del presidente } \\
\text { I. Resumen general de las cuentas de explotación } \\
\text { A. Ingresos del Tráfico } \\
\text { B. Ingresos varios } \\
\text { C. Gastos de la explotación } \\
\text { D. Pensiones al personal } \\
\text { E. Cargas de la Explotación } \\
\text { F.G.H. Insuficiencia de productos } \\
\text { II. Situación general } \\
\text { III. Explotación de las Minas } \\
\text { IV. Institución de previsión y de beneficencia } \\
\text { V. Canje y adhesión de acciones y obligaciones } \\
\text { VI. Impuestos ingresados en el Tesoro y beneficios obtenidos por el Estado } \\
\text { VII. Liquidación del ejercicio } \\
\text { VIII. Asuntos varios } \\
\text { IX. Consejo de Administración } \\
\text { Resoluciones de la Junta General } \\
\text { Situación de la Compañía } \\
\text { Cuentas de la Explotación de cada una de las líneas que forman la red de la compañía } \\
\text { Cuenta general de la explotación del conjunto de las líneas } \\
\text { Anejo: } \\
\text { Beneficios obtenidos por el Estado, de las líneas que explota NORTE, durante los años } 1880 \text { a } 1918\end{array}$ \\
\hline 1919 & $\begin{array}{l}\text { Extensión de la red } \\
\text { Carta del presidente } \\
\text { I. Resumen general de las cuentas de explotación } \\
\text { A. Ingresos del Tráfico } \\
\text { B. Ingresos varios } \\
\text { C. Gastos de la explotación } \\
\text { D. Pensiones al personal } \\
\text { E. Cargas de la Explotación } \\
\text { F.G.H. Excedente de productos } \\
\text { II. Situación general } \\
\text { III. Explotación de las Minas } \\
\text { IV. Institución de previsión y de beneficencia } \\
\text { V. Canje y adhesión de acciones y obligaciones } \\
\text { VI. Impuestos ingresados en el Tesoro y beneficios obtenidos por el Estado } \\
\text { VII. Liquidación del ejercicio }\end{array}$ \\
\hline
\end{tabular}




\begin{tabular}{|c|c|}
\hline & $\begin{array}{l}\text { VIII. Domiciliación en España de los valores de la compañía pagaderos en moneda nacional o extranjera } \\
\text { IX. Consejo de Administración } \\
\text { Resoluciones de la Junta General } \\
\text { Situación de la Compañía } \\
\text { Cuentas de la Explotación de cada una de las líneas que forman la red de la compañía } \\
\text { Cuenta general de la explotación del conjunto de las líneas } \\
\text { Anejo: } \\
\text { Beneficios obtenidos por el Estado, de las líneas que explota NORTE, durante los años } 1880 \text { a } 1919\end{array}$ \\
\hline 1920 & $\begin{array}{l}\text { Extensión de la red } \\
\text { Carta del presidente } \\
\text { I. Resumen general de las cuentas de explotación } \\
\text { A. Ingresos del Tráfico } \\
\text { B. Ingresos varios } \\
\text { C. Gastos de la explotación } \\
\text { D. Pensiones al personal } \\
\text { E. Cargas de la Explotación } \\
\text { F. Excedente de productos } \\
\text { II. Situación general } \\
\text { III. Explotación de las Minas } \\
\text { IV. Institución de previsión y de beneficencia } \\
\text { V. Canje y adhesión de acciones y obligaciones } \\
\text { VI. Impuestos ingresados en el Tesoro y beneficios obtenidos por el Estado } \\
\text { VII. Liquidación del ejercicio } \\
\text { VIII. Domiciliación en España de los valores de la compañía pagaderos en moneda nacional o extranjera } \\
\text { IX. Consejo de Administración } \\
\text { Resoluciones de la Junta General } \\
\text { Situación de la Compañía } \\
\text { Cuentas de la Explotación de cada una de las líneas que forman la red de la compañía } \\
\text { Cuenta general de la explotación del conjunto de las líneas } \\
\text { Anejo: } \\
\text { Beneficios obtenidos por el Estado, de las líneas que explota NORTE, durante los años } 1880 \text { a } 1920\end{array}$ \\
\hline 1921 & $\begin{array}{l}\text { Extensión de la red } \\
\text { Carta del presidente } \\
\text { I. Resumen general de las cuentas de explotación } \\
\text { A. Ingresos del Tráfico } \\
\text { B. Ingresos varios } \\
\text { C. Gastos de la explotación } \\
\text { D. Pensiones al personal } \\
\text { E. Cargas de la Explotación } \\
\text { F. Excedente de productos } \\
\text { II. Situación general } \\
\text { III. Explotación de las Minas } \\
\text { IV. Institución de previsión y de beneficencia } \\
\text { V. Canje y adhesión de acciones y obligaciones } \\
\text { VI. Impuestos ingresados en el Tesoro y beneficios obtenidos por el Estado } \\
\text { VII. Liquidación del ejercicio } \\
\text { VIII. Domiciliación en España de los valores de la compañía pagaderos en moneda nacional o extranjera } \\
\text { IX. Consejo de Administración } \\
\text { Resoluciones de la Junta General } \\
\text { Situación de la Compañía }\end{array}$ \\
\hline
\end{tabular}




\begin{tabular}{|c|c|}
\hline & $\begin{array}{l}\text { Cuentas de la Explotación de cada una de las líneas que forman la red de la compañía } \\
\text { Cuenta general de la explotación del conjunto de las líneas } \\
\text { Anejo: } \\
\text { Beneficios obtenidos por el Estado, de las líneas que explota NORTE, durante los años } 1880 \text { a } 1921 \\
\text { Gráfico: } \\
\text { Representativo del valor absoluto de los conceptos de gastos de la explotación y de cargas de la explotación en } \\
\text { relación con la cifra total de ingresos de explotación. Sin plus del Estado y con plus del Estado }\end{array}$ \\
\hline 1922 & $\begin{array}{l}\text { Extensión de la red } \\
\text { Carta del presidente } \\
\text { I. Resumen general de las cuentas de explotación } \\
\text { A. Ingresos del Tráfico } \\
\text { B. Ingresos varios } \\
\text { C. Gastos de la explotación } \\
\text { D. Pensiones al personal } \\
\text { E. Cargas de la Explotación } \\
\text { F. Excedente de productos } \\
\text { II. Situación general } \\
\text { III. Explotación de las Minas } \\
\text { IV. Institución de previsión y de beneficencia } \\
\text { V. Domiciliación en España de los valores de la compañía pagaderos en moneda nacional o extranjera } \\
\text { VI. Impuestos ingresados en el Tesoro y beneficios obtenidos por el Estado } \\
\text { VII. Liquidación del ejercicio } \\
\text { VIII. Cesión de los terrenos sobrantes de la antigua estación de Valencia } \\
\text { IX. Consejo de Administración } \\
\text { Resoluciones de la Junta General } \\
\text { Situación de la Compañía } \\
\text { Cuentas de la Explotación de cada una de las líneas que forman la red de la compañía } \\
\text { Cuenta general de la explotación del conjunto de las líneas } \\
\text { Anejo: } \\
\text { Beneficios obtenidos por el Estado, de las líneas que explota NORTE, durante los años } 1880 \text { a } 1922 \\
\text { Carta en francés a los accionistas de NORTE soblre la propmulgación del Decreto Ley de } 12 \text { de julio, que establece } \\
\text { un nuevo régimen de los ferrocarriles } \\
\text { Gráfico: } \\
\text { Representativo del valor absoluto de los conceptos de gastos de la explotación y de cargas de la explotación en } \\
\text { relación con la cifra total de ingresos de explotación. Sin plus del Estado y con plus del Estado }\end{array}$ \\
\hline 1923 & $\begin{array}{l}\text { Extensión de la red } \\
\text { Carta del presidente } \\
\text { I. Resumen general de las cuentas de explotación } \\
\text { A. Ingresos del Tráfico } \\
\text { B. Ingresos varios } \\
\text { C. Gastos de la explotación } \\
\text { D. Pensiones al personal } \\
\text { E. Diferenciaen los pagos hechos con cargo al anticipo del Estado } \\
\text { F. Cargas de la Explotación } \\
\text { G. Excedente de productos } \\
\text { II. Situación general } \\
\text { III. Explotación de las Minas } \\
\text { IV. Institución de previsión y de beneficencia } \\
\text { V. Domiciliación en España de los valores de la compañía pagaderos en moneda nacional o extranjera } \\
\text { VI. Impuestos ingresados en el Tesoro y beneficios obtenidos por el Estado } \\
\text { VII. Liquidación del ejercicio }\end{array}$ \\
\hline
\end{tabular}




\begin{tabular}{|l|l|}
\hline & $\begin{array}{l}\text { VIII. Emisión de obligaciones } \\
\text { IX. Consejo de Administración } \\
\text { Proyecto de Resoluciones de la Junta General } \\
\text { Situación de la Compañía } \\
\text { Cuentas de la Explotación de cada una de las líneas que forman la red de la compañía } \\
\text { Cuenta general de la explotación del conjunto de las líneas } \\
\text { Anejo: } \\
\text { Beneficios obtenidos por el Estado, de las líneas que explota NORTE, durante los años } 1880 \text { a } 1923\end{array}$ \\
\hline
\end{tabular}

Fuente elaboración propia

\subsubsection{Proyecto de Resoluciones de la Junta General}

Hasta la Memoria de 1920, la denominación de este apartado era "Resoluciones de la Junta General". A partir de la Memoria de 1921 se denominó "Proyecto de Resoluciones de la Junta General"'.

Las "Resoluciones de la Junta General", y posteriormente el "Proyecto de Resoluciones de la Junta General", está formada por un número variable de párrafos, todos ellos referenciados y ordenados por números romanos. La información que contiene es muy homogénea pues en ella se recogen los posibles acuerdos que han de ser aprobados o desaprobados por la Junta General de Accionistas. El primer punto es siempre la aprobación de la Memoria del Consejo de Administración y de las Cuentas del ejercicio anterior ${ }^{867}$. El segundo es el nombramiento y reelección de administradores ${ }^{868}$. El tercero, si es que existe, ofrece información sobre los acuerdos tomados por la Junta General para las modificaciones de los Estatutos ${ }^{869}$. El último párrafo es la confirmación de las autorizaciones de la Junta al Consejo del periodo contable anterior y las autorizaciones para el próximo ejercicio ${ }^{870}$. Respecto a las autorizaciones de la

${ }^{867}$ NORTE (1901: 39; 1902: 40; 1903: 43; 1904:44; 1905:44; 1906: 36; 1907:34; 1908: 33-34; 1909: 31-33; 1910: 34; 1911: 34; 1912: 35; 1913: 35; 1914: 35; 1915: 35; 1916: 38; 1917: 39; 1918: 36; 1919: 37; 1920: 37; 1921: $39 ; 1922: 38 ; 1923: 38 ; 1924: 38)$.

${ }^{868}$ NORTE (1901: 39; 1902: 40; 1903: 43; 1904:44; 1905:44; 1906: 36; 1907:34; 1908: 33-34; 1909: 31-33; 1910: 34-37; 1911: 34-35; 1912: 35-37; 1913: 35-37; 1914: 35-37; 1915: 35-37; 1916: 38-41; 1917: 39-41; 1918: 36-37; 1919: 37-39; 1920: 37-39; 1921: 39-41; 1922: 38-39; 1923: 38-41; 1924: 38-41).

${ }^{869}$ En concreto, la modificación de los estatutos para fijar el capital social por consecuencia del contrato celebrado con la Comisión liquidadora del ferrocarril y Minas de San Juan de las Abadesas en 24 de mayo de 1899, y acuerdos tomados sobre él por las Juntas Generales de 4 de julio de 1899 y 25 de mayo de 1901, procede que se entreguen a los accionistas de dicha línea y a la citada Comisión 26.000 acciones NORTE en títulos definitivos; y cómo esto implica una modificación del capital. A continuación la Memoria expresa la nueva redacción de capital social (NORTE, 1901: 40). En la Memoria de 1903 aparece que la Junta autoriza al Consejo a proceder a la conversión de las obligaciones 5 y $6 \%$ actualmente en circulación. La Junta autoriza, además, al Consejo a emitir nuevas obligaciones. El número total de los títulos no excederá de 150.000. Las obligaciones serán reembolsables a la par durante el periodo de concesión de las líneas sobre las cuales serán especialmente emitidas. El Consejo fijará todas las demás condiciones de la emisión (NORTE, 1903: 44).

${ }^{870}$ NORTE (1901: 39; 1902: 40; 1903: 43; 1904:44; 1905:44; 1906: 36; 1907:34; 1908: 34; 1909: 33; $1910: 37$; 1911: 35; 1912: 37; 1913: 37; 1914: 37; 1915: 37; 1916: 41; 1917: 41; 1918: 37; 1919: 39; 1920: 39; 1921: 41; 1922: 39; 1923: 41; 1924: 41). 
Junta, desde el ejercicio contable 1918 se produce un gran refuerzo del poder del Consejo. Hasta 1918 en este apartado simplemente se confirmaba sus autorizaciones anteriores y autorizaba nuevamente al Consejo para celebrar los contratos u obtener las concesiones que considere necesarios. A partir de 1918 se amplían las atribuciones del Consejo, pues se recoge que la Junta confirma sus autorizaciones anteriores y autoriza nuevamente al Consejo para celebrar los contratos u obtener las concesiones que considere necesarios. Asimismo, autoriza al Consejo a realizar enajenaciones, permutas, cesiones, aportaciones o cualquier disposición de bienes muebles o inmuebles, aunque superen el límite establecido en el artículo 19. Por último, el quinto párrafo, si existe, establece que la Junta, a propuesta de algún accionista, agradece por su labor al Consejo de Administración, a la dirección y al personal.

El cuadro 54 describe los Componentes de las resoluciones de la junta general- Proyecto de resoluciones de la junta general de cada uno de los ejercicios económicos. 


\section{Cuadro 54. Componentes de las "Resoluciones de la junta general" - "Proyecto de resoluciones de la junta general"}

\begin{tabular}{|c|c|}
\hline & COMPONENTES DE LAS RESOLUCIONES DE LA JUNTA GENERAL \\
\hline 1900 & $\begin{array}{l}\text { I. Aprobación de la Memoria del Consejo de Administración y de las Cuentas del ejercicio } \\
\text { II. Nombramiento como administrador de Jean Barat y reelección del Marqués de Comillas, Semprúm, Mir y } \\
\text { Pestel } \\
\text { III. La Junta confirma sus autorizaciones anteriores y autoriza nuevamente al Consejo para celebrar los } \\
\text { contratos u obtener las concesiones que considere necesarios. Además autoriza a verificar el canje de las } \\
26.000 \text { acciones que deben ser entregadas conforme al artículo } 4 \text { del contrato celebrado con la Comisión } \\
\text { liquidadora del ferrocarril y minas de San Juan de las Abadesas el } 24 \text { de mayo de } 1899 \text {, ya sea creando } 26.000 \\
\text { acciones nuevas o de otra forma. }\end{array}$ \\
\hline 1901 & $\begin{array}{l}\text { I. Aprobación de la Memoria del Consejo de Administración y de las Cuentas del ejercicio } \\
\text { II. Reelige a los administradores que cesaban en sus funciones Moreno Campos, Maycas y Jean Barat } \\
\text { III. Modificación de los estatutos para fijar el capital social por consecuencia del contrato celebrado con la } \\
\text { Comisión liquidadora del ferrocarril y Minas de San Juan de las Abadesas en } 24 \text { de mayo de } 1899 \text {, y acuerdos } \\
\text { tomados sobre él por las Juntas Generales de } 4 \text { de julio de } 1899 \text { y } 25 \text { de mayo de } 1901 \text {. En virtud de ese } \\
\text { contrato se deben entregar } 26.000 \text { acciones NORTE en títulos definitivos; como esto implica una modificación } \\
\text { del capital, a continuación, el tercer párrafo incluye la nueva redacción de capital social. } \\
\text { IV. La Junta confirma sus autorizaciones anteriores y autoriza nuevamente al Consejo para celebrar los } \\
\text { contratos u obtener las concesiones que considere necesarios. }\end{array}$ \\
\hline 1902 & $\begin{array}{l}\text { I. Aprobación de la Memoria del Consejo de Administración y de las Cuentas del ejercicio } \\
\text { II. Reelige a los administradores que cesaban en sus funciones por cinco años: Estiabus, Isasa, Péreire (G), } \\
\text { Bixio, Güell y Bacigalupi, Girona, Carreras y Xuriach, Borrell y Folch y Barón de Satrústegui. } \\
\text { III. La Junta general autoriza a la a la conversión de las del } 5 \text { y } 6 \% \text { que estaban en circulación. } \\
\text { La Junta autoriza, además, al Consejo a emitir nuevas obligaciones. Estas obligaciones tendrán un valor } \\
\text { nominal de } 500 \text { pesetas. Estas obligaciones devengarán un importe fijado por el Consejo. El número total de } \\
\text { títulos no excederá de } 150.000 \text {. Estas obligaciones serán reembolsables a la par durante el periodo de } \\
\text { concesión de las líneas sobre las cuales serán especialmente emitidas. El Consejo fijará todas las demás } \\
\text { condiciones especiales de la emisión. } \\
\text { IV. La Junta confirma sus autorizaciones anteriores y autoriza nuevamente al Consejo para celebrar los } \\
\text { contratos u obtener las concesiones que considere necesarios. }\end{array}$ \\
\hline 1903 & $\begin{array}{l}\text { I. Aprobación de la Memoria del Consejo de Administración y de las Cuentas del ejercicio } \\
\text { II. Condolencias por la muerte del vicepresidente Faustino Rodríguez San Pedro. Nombramiento como } \\
\text { Administrados de Estanislao de Urquijo. Reelige a los administradores que cesaban en sus funciones por cinco } \\
\text { años: Péreire (Emile), Angulo, Marques de Luque, Borregón, Zabala, Ibarra, Marques de Viesca y Arellano. } \\
\text { III. La Junta confirma sus autorizaciones anteriores y autoriza nuevamente al Consejo para celebrar los } \\
\text { contratos u obtener las concesiones que considere necesarios. }\end{array}$ \\
\hline 1904 & $\begin{array}{l}\text { Aprobación de la Memoria del Consejo de Administración y de las Cuentas del ejercicio } \\
\text { Nombramiento como Administrador a Faustino Rodríguez San Pedro. Reelige a los administradores que } \\
\text { aban en sus funciones por cinco años: Alberto Ellissen y Enrique Rouen, } \\
\text { La Junta confirma sus autorizaciones anteriores y autoriza nuevamente al Consejo para celebrar los } \\
\text { atratos u obtener las concesiones que considere necesarios. }\end{array}$ \\
\hline 1905 & $\begin{array}{l}\text { I. Aprobación de la Memoria del Consejo de Administración y de las Cuentas del ejercicio } \\
\text { II. Nombramiento como Administrador a Conde Foy. Reelige a los administradores que cesaban en sus } \\
\text { funciones por cinco años: Marqués de Comillas, Semprún, Mir y Pestel. } \\
\text { III. La Junta confirma sus autorizaciones anteriores y autoriza nuevamente al Consejo para celebrar los } \\
\text { contratos u obtener las concesiones que considere necesarios. }\end{array}$ \\
\hline 1906 & $\begin{array}{l}\text { I. Aprobación de la Memoria del Consejo de Administración y de las Cuentas del ejercicio } \\
\text { II. Nombramiento como Administrador a Conde de Serra }{ }^{871} \text {. Reelige a los administradores que cesaban en sus } \\
\text { funciones por cinco años: Moreno Campo, Maycas, Barat, Pererire (M) y Ellissen (R). }\end{array}$ \\
\hline
\end{tabular}

${ }^{871}$ El nombramiento como Administrador de Conde de Serra tiene una importancia máxima porque con él comienza la bancarización de NORTE. Hasta entonces la financiación había sido fundamentalmente originada por el capital de la familia francesa Péreire y la catalana Comillas. Desde ahora comenzará un proceso según el 


\begin{tabular}{|c|c|}
\hline & $\begin{array}{l}\text { III. La Junta confirma sus autorizaciones anteriores y autoriza nuevamente al Consejo para celebrar los } \\
\text { contratos u obtener las concesiones que considere necesarios. }\end{array}$ \\
\hline 1907 & $\begin{array}{l}\text { I. Aprobación de la Memoria del Consejo de Administración y de las Cuentas del ejercicio } \\
\text { II. Nombramiento como Administrador a Joaquín López-Dóriga y Manuel Arnús, tras el fallecimiento del } \\
\text { Marqués de Viesca de la Sierrra y José María Semprún. Reelige a los administradores que cesaban en sus } \\
\text { funciones por cinco años: Manuel Estibaus, Gustavo Péreire, Eusebio Güell, José Carreras, Antonio Borrell, } \\
\text { Barón de Satrústegui, Conde de Serra y Conde Foy. } \\
\text { III.La Junta confirma sus autorizaciones anteriores y autoriza nuevamente al Consejo para celebrar los } \\
\text { contratos u obtener las concesiones que considere necesarios. } \\
\text { IV. La Junta, a propuesta del accionista Barbey, da un voto de gracias al Consejo de Administración, a la } \\
\text { dirección y al personal, por su labor. }\end{array}$ \\
\hline 1908 & $\begin{array}{l}\text { I. Aprobación de la Memoria del Consejo de Administración y de las Cuentas del ejercicio } \\
\text { II. Nombramiento como Administrador a Federico Rivero y O`Neale, Vicente Alonso Martínez (Marqués de } \\
\text { Alonso Martínez) y Rafael Bernar (Conde de Bernar). Reelige a los administradores que cesaban en sus } \\
\text { funciones por cinco años: Emilio Péreire, Rafael Angulo, Antonio Borregón, Martín de Zavala, José Antonio } \\
\text { de Ibarra, Ricardo de Arellano, Estanislao de Urquijo y Joaquín López-Dóriga. } \\
\text { III. La Junta autoriza al Consejo para realizar la conversión de las obligaciones } 5 \% \text { de interés que tiene en } \\
\text { circulación con garantía de las líneas de Villalba a Segovia y de Almansa a Valencia y Tarragona. } \\
\text { IV. La Junta confirma sus autorizaciones anteriores y autoriza nuevamente al Consejo para celebrar los } \\
\text { contratos u obtener las concesiones que considere necesarios. } \\
\text { V. La Junta, a propuesta del accionista Barbey, da un voto de gracias al Consejo de Administración, a la } \\
\text { dirección y al personal, por su labor. }\end{array}$ \\
\hline 1909 & $\begin{array}{l}\text { I. Aprobación de la Memoria del Consejo de Administración y de las Cuentas del ejercicio } \\
\text { II. Nombramiento como Administrador a Faustino Rodríguez San Pedro. Reelige a los administradores que } \\
\text { cesaban en sus funciones por cinco años, Alberto Ellissen y Enrique Rouen. } \\
\text { III. La Junta confirma sus autorizaciones anteriores y autoriza nuevamente al Consejo para celebrar los } \\
\text { contratos u obtener las concesiones que considere necesarios. } \\
\text { IV. La Junta, a propuesta de los accionistas Barbey y Conde del Moral de Calatrava, da un voto de gracias al } \\
\text { Consejo de Administración, a la dirección y al personal, por su labor. }\end{array}$ \\
\hline 1910 & $\begin{array}{l}\text { I. Aprobación de la Memoria del Consejo de Administración y de las Cuentas del ejercicio } \\
\text { II. Nombramiento como Administrador a Fernando León y Castillo, Ignacio Coll y Portabella, en sustitución } \\
\text { de Jean Barat dimitido y Antonio Borell fallecido. Reelige a los administradores que cesaban en sus funciones } \\
\text { por cinco años: Marqués de Comillas, Manuel Arnús, Eugenio Mir y A. Pestel. } \\
\text { III. Ratificar y ampliar la autorización que tenía conferida al Consejo, para realizar la conversión de las } \\
\text { obligaciones de } 1^{\mathrm{a}} \text { y } 2^{\mathrm{a}} \text { serie, con } 5 \text { por } 100 \text { de interés, que la compañía tiene emitidos con garantía de la línea } \\
\text { de Tudela a Bilbao, mediante la emisión de obligaciones de } 4 \text { por } 100 \text { de interés con garantía de la misma } \\
\text { línea. } \\
\text { IV. La Junta confirma sus autorizaciones anteriores y autoriza nuevamente al Consejo para celebrar los } \\
\text { contratos u obtener las concesiones que considere necesarios. } \\
\text { V. La Junta, a propuesta de los accionistas Barbey, da un voto de gracias al Consejo de Administración, a la } \\
\text { dirección y al personal, por su labor. }\end{array}$ \\
\hline 1911 & $\begin{array}{l}\text { I. Aprobación de la Memoria del Consejo de Administración y de las Cuentas del ejercicio } \\
\text { II. Nombramiento como Administrador a Eduardo Cobián y Roffignac, en sustitución de Joaquín López } \\
\text { Dóriga y Ruiz de la Escalera fallecido. Reelige a los administradores que cesaban en sus funciones por cinco } \\
\text { años: Francisco Moreno Campo, José Maycas, Fernando León y Castillo, Mauricio Péreire y Roberto Ellissen. } \\
\text { III. La Junta confirma sus autorizaciones anteriores y autoriza nuevamente al Consejo para celebrar los } \\
\text { contratos u obtener las concesiones que considere necesarios. } \\
\text { IV. La Junta, a propuesta de los accionistas Barbey, da un voto de gracias al Consejo de Administración, a la } \\
\text { dirección y al personal, por su labor. }\end{array}$ \\
\hline 1912 & $\begin{array}{l}\text { I. Aprobación de la Memoria del Consejo de Administración y de las Cuentas del ejercicio } \\
\text { II. Nombramiento como Administrador a Federivo Rivero O`Neale, en sustitución de Emilio Péreire y } \\
\text { Trinitario Ruiz Valarino fallecidos. Reelige a los administradores que cesaban en sus funciones por cinco } \\
\text { años: Gustavo Péreire, Eusebio Güell, José Carreras, Ignacio Coll, Barón de Satrústegui, Conde de Serra, }\end{array}$ \\
\hline
\end{tabular}

cual tiene más peso en la financiación las entidades bancarias españolas, sobre todo las situadas en las vascongadas. En la Memoria de 1906 aparece que el Consejo propone nombrar al Sr Conde de Serra, Consejero a su vez de varias entidades bancarias "cuyo concurso nos será de gran utilidad dada su reconocida competencia" (NORTE: 1907: 34). Con ello, NORTE buscaba una financiación futura más ventajosa. 


\begin{tabular}{|c|c|}
\hline & $\begin{array}{l}\text { Conde Foy y Trinitario Ruiz Valarino. } \\
\text { III. La Junta autoriza al Consejo a crear y emitir nuevas obligaciones hasta } 150.000 .000 \text { de pesetas nominales } \\
\text { IV. La Junta confirma sus autorizaciones anteriores y autoriza nuevamente al Consejo para celebrar los } \\
\text { contratos u obtener las concesiones que considere necesarios. } \\
\text { V. La Junta, a propuesta de los accionistas Barbey, da un voto de gracias al Consejo de Administración, a la } \\
\text { dirección y al personal, por su labor. }\end{array}$ \\
\hline 1913 & $\begin{array}{l}\text { I. Aprobación de la Memoria del Consejo de Administración, las Cuentas del ejercicio y la aplicación del } \\
\text { excedente de productos en la forma propuesta por el Consejo } \\
\text { II. Reelige a los administradores que cesaban en sus funciones por cinco años: Rafael Angulo, Antonio } \\
\text { Borregón, Martín de Zavala, José A. de Ibarra, Ricardo de Arellano, Marqués de Bolarque, Eduardo Cobián, } \\
\text { Conde de Bernar y Marqués de Alonso Martínez. } \\
\text { III. La Junta confirma sus autorizaciones anteriores y autoriza nuevamente al Consejo para celebrar los } \\
\text { contratos u obtener las concesiones que considere necesarios. } \\
\text { V. La Junta da un voto de gracias al Consejo de Administración, a la dirección y al personal, por su labor. }\end{array}$ \\
\hline 1914 & $\begin{array}{l}\text { I. Aprobación de la Memoria del Consejo de Administración, las Cuentas del ejercicio y la aplicación del } \\
\text { excedente de productos en la forma propuesta por el Consejo } \\
\text { II. Reelige a los administradores que cesaban en sus funciones por cinco años: Faustino Rodríguez San Pedro, } \\
\text { Alberto Ellissen y Enrique Rouen. } \\
\text { III. La Junta confirma sus autorizaciones anteriores y autoriza nuevamente al Consejo para celebrar los } \\
\text { contratos u obtener las concesiones que considere necesarios. } \\
\text { V. La Junta da un voto de gracias al Consejo de Administración, a la dirección y al personal, por su labor. }\end{array}$ \\
\hline 1915 & $\begin{array}{l}\text { I. Aprobación de la Memoria del Consejo de Administración, las Cuentas del ejercicio y la aplicación del } \\
\text { excedente de productos en la forma propuesta por el Consejo } \\
\text { II. Reelige a los administradores que cesaban en sus funciones por cinco años: Marqués de Comillas, Eugenio } \\
\text { Mir y Agustín Pestel. } \\
\text { III. La Junta confirma sus autorizaciones anteriores y autoriza nuevamente al Consejo para celebrar los } \\
\text { contratos u obtener las concesiones que considere necesarios. } \\
\text { V. La Junta da un voto de gracias al Consejo de Administración, a la dirección y al personal, por su labor. }\end{array}$ \\
\hline 1916 & $\begin{array}{l}\text { I. Aprobación de la Memoria del Consejo de Administración, las Cuentas del ejercicio y la aplicación del } \\
\text { excedente de productos en la forma propuesta por el Consejo } \\
\text { II. Autorización para convertir en títulos pagaderos únicamente en España y en pesetas, los que tenía en } \\
\text { circulación pagaderos en pesetas o moneda extranjera } \\
\text { III. Nombramiento como Administrador a Conde de Sert y Juan Luis Villabaso, en sustitución de José } \\
\text { Carreras y Ricardo de Arellano, dimitidos y Conde de Gamazo por el fallecido Manuel Arnús. Reelige a los } \\
\text { administradores que cesaban en sus funciones por cinco años: Francisco Moreno Campos, José Maycas, } \\
\text { Mauricio Péreire y Roberto Ellisen. } \\
\text { IV. La Junta confirma sus autorizaciones anteriores y autoriza nuevamente al Consejo para celebrar los } \\
\text { contratos u obtener las concesiones que considere necesarios. } \\
\text { V. La Junta da un voto de gracias al Consejo de Administración, a la dirección y al personal. }\end{array}$ \\
\hline 1917 & $\begin{array}{l}\text { I. Aprobación de la Memoria del Consejo de Administración, las Cuentas del ejercicio y su liquidación en la } \\
\text { forma propuesta por el Consejo } \\
\text { II. Nombramiento de Valentín Gorbeña en sustitución del fallecido Marqués de Muni. Reelige a los } \\
\text { administradores que cesaban en sus funciones por cinco años: Gustavo Péreire, Conde Güell, Conde de Sert, } \\
\text { Ignacion Coll, Barón de Satrústegui, Conde de Serra, Conde Foy y Trinitario Ruiz Valarino. } \\
\text { III. La Junta confirma sus autorizaciones anteriores y autoriza nuevamente al Consejo para celebrar los } \\
\text { contratos u obtener las concesiones que considere necesarios. } \\
\text { Asimismo autoriza al Consejo a celebrar los contratos de suministro, o realizar las adquisiciones de bienes } \\
\text { muebles o inmuebles. }\end{array}$ \\
\hline 1918 & $\begin{array}{l}\text { I. Aprobación de la Memoria del Consejo de Administración, las Cuentas del ejercicio y su liquidación en la } \\
\text { forma propuesta por el Consejo } \\
\text { II. Reelige a los administradores que cesaban en sus funciones por cinco años: Marqués de Caviedes, Antonio } \\
\text { Borregón, Martín de Zavala, Jose A. de Ibarra, José Luis de Villabaso, Marqués de urquijo, Conde de Bernar, } \\
\text { Marqués de Alonso Martínez. } \\
\text { III. La Junta confirma sus autorizaciones anteriores y autoriza nuevamente al Consejo para celebrar los } \\
\text { contratos u obtener las concesiones que considere necesarios. } \\
\text { Asimismo autoriza al Consejo a celebrar los contratos de suministro, o realizar las adquisiciones de bienes } \\
\text { muebles o inmuebles. }\end{array}$ \\
\hline 1919 & $\begin{array}{l}\text { I. Aprobación de la Memoria del Consejo de Administración, las Cuentas del ejercicio y su liquidación en la } \\
\text { forma propuesta por el Consejo }\end{array}$ \\
\hline
\end{tabular}




\begin{tabular}{|c|c|}
\hline & $\begin{array}{l}\text { II. Ratifica a los administradores Conde de Gamazo, José Joaquín de Ampuero, Carlos de Prado, Tomás } \\
\text { Urquijo, Gaston Guiot, Enrique de Zárate y Félix Boix. Reelige a los administradores que cesaban en sus } \\
\text { funciones por cinco años: Félix Boix y Alberto Ellisen. } \\
\text { III. La Junta confirma sus autorizaciones anteriores y autoriza nuevamente al Consejo para celebrar los } \\
\text { contratos u obtener las concesiones que considere necesarios. } \\
\text { Asimismo autoriza al Consejo a realizar enajenaciones, permutas, cesiones, aportaciones o cualquier } \\
\text { disposición de bienes muebles o inmuebles, aunque superen el límite establecido en el artículo } 19 \text {. } \\
\text { GRAN REFUERZO DEL PODER DEL CONSEJO }\end{array}$ \\
\hline 1920 & $\begin{array}{l}\text { I. Aprobación de la Memoria del Consejo de Administración, las Cuentas del ejercicio y la aplicación del } \\
\text { excedente de productos en la forma propuesta por el Consejo } \\
\text { II. Ratifica a los administradores Julio de Arteche, Ramón de Sota, Valentín Ruíz Senén y Juan Suan Sánchez } \\
\text { de León. Reelige a los administradores que cesaban en sus funciones por cinco años: Marqué de Comillas, } \\
\text { Eugenio Mir y Gaston Guiot. } \\
\text { III. La Junta confirma sus autorizaciones anteriores y autoriza nuevamente al Consejo para celebrar los } \\
\text { contratos u obtener las concesiones que considere necesarios. } \\
\text { Asimismo autoriza al Consejo a realizar enajenaciones, permutas, cesiones, aportaciones o cualquier } \\
\text { disposición de bienes muebles o inmuebles, aunque superen el límite establecido en el artículo } 19 \text {. } \\
\text { GRAN REFUERZO DEL PODER DEL CONSEJO } \\
\text { IV. La Junta da un voto de gracias al Consejo de Administración, a la dirección y al personal. }\end{array}$ \\
\hline 1921 & $\begin{array}{l}\text { I. Aprobación de la Memoria del Consejo de Administración, las Cuentas del ejercicio y la aplicación del } \\
\text { excedente de productos en la forma propuesta por el Consejo } \\
\text { II. Reelige a los administradores que cesaban en sus funciones Mauricio Péreire, Roberto Ellissen y Conde de } \\
\text { Gamazo. } \\
\text { III. La Junta confirma sus autorizaciones anteriores y autoriza nuevamente al Consejo para celebrar los } \\
\text { contratos u obtener las concesiones que considere necesarios. } \\
\text { Asimismo autoriza al Consejo a realizar enajenaciones, permutas, cesiones, aportaciones o cualquier } \\
\text { disposición de bienes muebles o inmuebles, aunque superen el límite establecido en el artículo } 19 \text { de los } \\
\text { Estatutos. } \\
\text { GRAN REFUERZO DEL PODER DEL CONSEJO }\end{array}$ \\
\hline 1922 & $\begin{array}{l}\text { I. Aprobación de la Memoria del Consejo de Administración, las Cuentas del ejercicio y la aplicación del } \\
\text { excedente de productos en la forma propuesta por el Consejo } \\
\text { II. Reelige a los administradores que cesaban en sus funciones Gustavo Péreire, Ignacio Coll, Barñin de } \\
\text { Satrústegui, Conde de Torroella de Montgrí, Conde de Foy, Trinitario Ruiz Valarino, Valentín Gorbeña, } \\
\text { Valentín Ruiz Senén y Juan Sánchez León. } \\
\text { III. La Junta confirma sus autorizaciones anteriores y autoriza nuevamente al Consejo para celebrar los } \\
\text { contratos u obtener las concesiones que considere necesarios. } \\
\text { Asimismo autoriza al Consejo a realizar enajenaciones, permutas, cesiones, aportaciones o cualquier } \\
\text { disposición de bienes muebles o inmuebles, aunque superen el límite establecido en el artículo } 19 \text { de los } \\
\text { Estatutos. } \\
\text { GRAN REFUERZO DEL PODER DEL CONSEJO }\end{array}$ \\
\hline 1923 & $\begin{array}{l}\text { I. Aprobación de la Memoria del Consejo de Administración, las Cuentas del ejercicio y la aplicación del } \\
\text { excedente de productos en la forma propuesta por el Consejo } \\
\text { II. La Junta confirma los nombramientos de Antonio Borregón, José Joaquín de Ampuero, Tomás Urquijo, } \\
\text { Ramón de Sota, Venancio de Echevarría y Domingo de Epalza. } \\
\text { Igualmente, reelige a los administradores que cesaban en sus funciones Marqués de Caviedes, Martín de } \\
\text { Zavala, José A. de Ibarra, marqués de Urquijo, Marqués de Alonso Martínez, Enrique de Zárate y Julio de } \\
\text { Arteche. } \\
\text { III. La Junta confirma sus autorizaciones anteriores y autoriza nuevamente al Consejo para celebrar los } \\
\text { contratos u obtener las concesiones que considere necesarios. } \\
\text { Asimismo autoriza al Consejo a realizar enajenaciones, permutas, cesiones, aportaciones o cualquier } \\
\text { disposición de bienes muebles o inmuebles, aunque superen el límite establecido en el artículo } 19 \text { de los } \\
\text { Estatutos. } \\
\text { GRAN REFUERZO DEL PODER DEL CONSEJO }\end{array}$ \\
\hline
\end{tabular}

Fuente: Elaboración propia 


\subsubsection{Cuentas del ejercicio}

El estado financiero "Cuentas del ejercicio" está integrado por tres documentos: "Situación de la Compañía", "Cuenta de explotación” y "Datos estadísticos".

La "Situación de la Compañía" -denominado "Balance" a partir de 1923- es un único cuadro que está dividido en dos columnas: Activo y Pasivo"

La "Cuenta de explotación" está formada por un gran número de cuadros que pueden ser agrupados en: numerosos cuadros que recogen las "Cuentas de la Explotación de cada una de las líneas que forman la red de la compañía” para, a continuación, incorporar un cuadro denominado "Cuenta general de la explotación del conjunto de las líneas", que es el resumen de todos los anteriores. Toda esta información está recogida en forma de cuadros, todos ellos divididos en dos columnas: Gastos y Productos. Las "Cuentas de la Explotación de cada una de las líneas que forman la red de la compañía" recogen un cuadro por cada una de las líneas de NORTE al cierre del ejercicio. Al final de ellas, como agrupación de todos los cuadros anteriores, se establece un cuadro que representa la "Cuenta general de la explotación del conjunto de las líneas" ${ }^{\prime 873}$.

El documento "Datos estadísticos" está compuesto por cuadros, todos ellos referenciados y ordenados por números romanos. El número de cuadros ${ }^{874}$ incorporados fue de veinte hasta 1906 y de dieciocho en el periodo 1907-1923. El cuadro 55 recoge cada componente de las cuentas de cada ejercicio contable en el periodo 1900-1923.

\footnotetext{
${ }^{872}$ NORTE (1901: 42-43; 1902: 44-45; 1903: 46-47; 1904: 46-47; 1905: 46-47; 1906: 39-41; 1907: 37-38; 1908: 35-36; 1909: 37-38; 1910: 35-36; 1911: 39-40;1912: 37-38; 1913: 39-40; 1914: 39-40: 1915: 39-40; 1916: 3940; 1917: 43-44; 1918: 43-44; 1919: 43-44; 1920: 41-42; 1921: 41-42; 1922: 43-44; 1923: 41-42; 1924: 43-44). ${ }^{873}$ NORTE (1901: 44-69; 1902: 46-69; 1903: 48-71; 1904: 48-71; 1905: 48-71; 1906: 42-69; 1907: 39-65; 1908: 37-63; 1909: 39-65; 1910: 37-63; 1911: 41-65;1912: 39-63; 1913: 41-65; 1914: 41-65: 1915: 41-66; 1916: 4165; 1917: 45-70; 1918: 45-70; 1919: 45-70; 1920: 43-68; 1921: 43-69; 1922: 45-70; 1923: 43-69; 1924: 45-70).

${ }^{874}$ NORTE (1901: 71-135; 1902: 71-139; 1903: 73-137; 1904: 73-138; 1905: 73-138; 1906: 71-117; 1907: 67115; 1908: 65-114; 1909: 67-115; 1910: 65-113; 1911: 67-117;1912: 65-115; 1913: 67-125; 1914: 67-119: 1915: 67-119; 1916: 67-120; 1917: 72-125; 1918: 72-124; 1919: 72-120; 1920: 71-121; 1921: 71-121; 1922: 72-120; 1923: 71-140; 1924: 71-120).
} 
Cuadro 55. Componentes de las cuentas de cada ejercicio en el periodo 1900-1923

\begin{tabular}{|c|c|}
\hline $\begin{array}{l}\text { EJERCICIO } \\
\text { CONTABLE }\end{array}$ & COMPONENTES DE LAS CUENTAS DEL EJERCICIO \\
\hline 1900 & $\begin{array}{l}\text { Situación (Activo y Pasivo) } \\
\text { Cuenta de explotación (Gastos y Productos) de cada una de las Líneas de NORTE } \\
\text { Datos estadísticos: } \\
\text { I. Pormenores de los ingresos } \\
\text { II. Ingresos por kilómetro explotado } \\
\text { III. Gastos por kilómetro explotado } \\
\text { IV. Recorrido de los trenes } \\
\text { V. Gastos por kilómetro de recorrido de los trenes } \\
\text { VI. Transportes y productos de viajeros } \\
\text { VII: Viajeros por clases } \\
\text { VIII. Resultados comparados de la explotación } \\
\text { IX. Productos por estaciones de importancia } \\
\text { X. Peso y producto de las mercancías por naturaleza } \\
\text { XI. Material móvil de la compañía del NORTE existente y su recorrido } \\
\text { XII. Composición de los trenes en la red } \\
\text { XIII. Trabajo de los trenes en el transporte de viajeros } \\
\text { XIV Trabajo de los trenes en el transporte de mercancías } \\
\text { XV. Trabajo de los coches } \\
\text { XVI. Trabajo de los vagones } \\
\text { XVII. Trabajo de las máquinas } \\
\text { XVIII. Gastos de material y tracción } \\
\text { XIX Gastos de material y tracción desde el punto de vista del trabajo útil } \\
\text { XX. Gastos de vía y obras }\end{array}$ \\
\hline 1901 & $\begin{array}{l}\text { Situación (Activo y Pasivo) } \\
\text { Cuenta de explotación (Gastos y Productos) de cada una de las Líneas de NORTE } \\
\text { Datos estadísticos: } \\
\text { I. Pormenores de los ingresos } \\
\text { II. Ingresos por kilómetro explotado } \\
\text { III. Gastos por kilómetro explotado } \\
\text { IV. Recorrido de los trenes } \\
\text { V. Gastos por kilómetro de recorrido de los trenes } \\
\text { VI. Transportes y productos de viajeros } \\
\text { VII: Viajeros por clases } \\
\text { VIII. Resultados comparados de la explotación } \\
\text { IX. Productos por estaciones de importancia } \\
\text { X. Peso y producto de las mercancías por naturaleza } \\
\text { XI. Material móvil de la compañía del NORTE existente y su recorrido } \\
\text { XII. Composición de los trenes en la red } \\
\text { XIII. Trabajo de los trenes en el transporte de viajeros } \\
\text { XIV Trabajo de los trenes en el transporte de mercancías } \\
\text { XV. Trabajo de los coches } \\
\text { XVI. Trabajo de los vagones } \\
\text { XVII. Trabajo de las máquinas } \\
\text { XVIII. Gastos de material y tracción }\end{array}$ \\
\hline
\end{tabular}




\begin{tabular}{|c|c|}
\hline & $\begin{array}{l}\text { XIX Gastos de material y tracción desde el punto de vista del trabajo útil } \\
\text { XX. Gastos de vía y obras }\end{array}$ \\
\hline 1902 & $\begin{array}{l}\text { Situación (Activo y Pasivo) } \\
\text { Cuenta de explotación (Gastos y Productos) de cada una de las Líneas de NORTE } \\
\text { Datos estadísticos: } \\
\text { I. Pormenores de los ingresos } \\
\text { II. Ingresos por kilómetro explotado } \\
\text { III. Gastos por kilómetro explotado } \\
\text { IV. Recorrido de los trenes } \\
\text { V. Gastos por kilómetro de recorrido de los trenes } \\
\text { VI. Transportes y productos de viajeros } \\
\text { VII: Viajeros por clases } \\
\text { VIII. Resultados comparados de la explotación } \\
\text { IX. Productos por estaciones de importancia } \\
\text { X. Peso y producto de las mercancías por naturaleza } \\
\text { XI. Material móvil de la compañía del NORTE existente y su recorrido } \\
\text { XII. Composición de los trenes en la red } \\
\text { XIII. Trabajo de los trenes en el transporte de viajeros } \\
\text { XIV Trabajo de los trenes en el transporte de mercancías } \\
\text { XV. Trabajo de los coches } \\
\text { XVI. Trabajo de los vagones } \\
\text { XVII. Trabajo de las máquinas } \\
\text { XVIII. Gastos de material y tracción } \\
\text { XIX Gastos de material y tracción desde el punto de vista del trabajo útil } \\
\text { XX. Gastos de vía y obras }\end{array}$ \\
\hline 1903 & $\begin{array}{l}\text { Situación (Activo y Pasivo) } \\
\text { Cuenta de explotación (Gastos y Productos) de cada una de las Líneas de NORTE } \\
\text { Datos estadísticos: } \\
\text { I. Pormenores de los ingresos } \\
\text { II. Ingresos por kilómetro explotado } \\
\text { III. Gastos por kilómetro explotado } \\
\text { IV. Recorrido de los trenes } \\
\text { V. Gastos por kilómetro de recorrido de los trenes } \\
\text { VI. Transportes y productos de viajeros } \\
\text { VII: Viajeros por clases } \\
\text { VIII. Resultados comparados de la explotación } \\
\text { IX. Productos por estaciones de importancia } \\
\text { X. Peso y producto de las mercancías por naturaleza } \\
\text { XI. Material móvil de la compañía del NORTE existente y su recorrido } \\
\text { XII. Composición de los trenes en la red } \\
\text { XIII. Trabajo de los trenes en el transporte de viajeros } \\
\text { XIV Trabajo de los trenes en el transporte de mercancías } \\
\text { XV. Trabajo de los coches } \\
\text { XVI. Trabajo de los vagones } \\
\text { XVII. Trabajo de las máquinas } \\
\text { XVIII. Gastos de material y tracción } \\
\text { XIX Gastos de material y tracción desde el punto de vista del trabajo útil } \\
\text { XX. Gastos de vía y obras }\end{array}$ \\
\hline 1904 & Situación (Activo y Pasivo) \\
\hline
\end{tabular}




\begin{tabular}{|c|c|}
\hline & $\begin{array}{l}\text { Cuenta de explotación (Gastos y Productos) de cada una de las Líneas de NORTE } \\
\text { Datos estadísticos: } \\
\text { I. Pormenores de los ingresos } \\
\text { II. Ingresos por kilómetro explotado } \\
\text { III. Gastos por kilómetro explotado } \\
\text { IV. Recorrido de los trenes } \\
\text { V. Gastos por kilómetro de recorrido de los trenes } \\
\text { VI. Transportes y productos de viajeros } \\
\text { VII: Viajeros por clases } \\
\text { VIII. Resultados comparados de la explotación } \\
\text { IX. Productos por estaciones de importancia } \\
\text { X. Peso y producto de las mercancías por naturaleza } \\
\text { XI. Material móvil de la compañía del NORTE existente y su recorrido } \\
\text { XII. Composición de los trenes en la red } \\
\text { XIII. Trabajo de los trenes en el transporte de viajeros } \\
\text { XIV Trabajo de los trenes en el transporte de mercancías } \\
\text { XV. Trabajo de los coches } \\
\text { XVI. Trabajo de los vagones } \\
\text { XVII. Trabajo de las máquinas } \\
\text { XVIII. Gastos de material y tracción } \\
\text { XIX Gastos de material y tracción desde el punto de vista del trabajo útil } \\
\text { XX. Gastos de vía y obras }\end{array}$ \\
\hline 1905 & $\begin{array}{l}\text { Situación (Activo y Pasivo) } \\
\text { Cuenta de explotación (Gastos y Productos) de cada una de las Líneas de NORTE } \\
\text { Datos estadísticos: } \\
\text { I. Pormenores de los ingresos } \\
\text { II. Ingresos por kilómetro explotado } \\
\text { III. Gastos por kilómetro explotado } \\
\text { IV. Recorrido de los trenes } \\
\text { V. Gastos por kilómetro de recorrido de los trenes } \\
\text { VI. Transportes y productos de viajeros } \\
\text { VII: Viajeros por clases } \\
\text { VIII. Resultados comparados de la explotación } \\
\text { IX. Productos por estaciones de importancia } \\
\text { X. Peso y producto de las mercancías por naturaleza } \\
\text { XI. Material móvil de la compañía del NORTE existente y su recorrido } \\
\text { XII. Composición de los trenes en la red } \\
\text { XIII. Trabajo de los trenes en el transporte de viajeros } \\
\text { XIV Trabajo de los trenes en el transporte de mercancías } \\
\text { XV. Trabajo de los coches } \\
\text { XVI. Trabajo de los vagones } \\
\text { XVII. Trabajo de las máquinas } \\
\text { XVIII. Gastos de material y tracción } \\
\text { XIX Gastos de material y tracción desde el punto de vista del trabajo útil } \\
\text { XX. Gastos de vía y obras }\end{array}$ \\
\hline 1906 & $\begin{array}{l}\text { Situación (Activo y Pasivo) } \\
\text { Cuenta de explotación (Gastos y Productos) de cada una de las Líneas de NORTE }\end{array}$ \\
\hline
\end{tabular}




\begin{tabular}{|c|c|}
\hline & $\begin{array}{l}\text { Datos estadísticos: } \\
\text { I. Pormenores de los ingresos, } \\
\text { II. Ingresos por kilómetro explotado } \\
\text { III. Gastos por kilómetro explotado } \\
\text { IV. Recorrido de los trenes } \\
\text { V. Gastos por kilómetro de recorrido de los trenes } \\
\text { VI. Transportes y productos de viajeros } \\
\text { VII: Viajeros por clases } \\
\text { VIII. Resultados comparados de la explotación } \\
\text { IX. Productos por estaciones de importancia } \\
\text { X. Peso y producto de las mercancías por naturaleza } \\
\text { XI. Material móvil de la compañía del NORTE existente y su recorrido } \\
\text { XII. Composición de los trenes en la red } \\
\text { XIII. Trabajo de los trenes en el transporte de viajeros } \\
\text { XIV Trabajo de los trenes en el transporte de mercancías } \\
\text { XV. Trabajo de los coches } \\
\text { XVI. Trabajo de los vagones } \\
\text { XVII. Trabajo de las máquinas } \\
\text { XVIII. Gastos de material y tracción } \\
\text { XIX Gastos de material y tracción desde el punto de vista del trabajo útil } \\
\text { XX. Gastos de vía y obras) }\end{array}$ \\
\hline 1907 & $\begin{array}{l}\text { Situación (Activo y Pasivo) } \\
\text { Cuenta de explotación (Gastos y Productos) de cada una de las Líneas de NORTE } \\
\text { Datos estadísticos } \\
\text { I. Pormenores de los ingresos } \\
\text { II. Ingresos por kilómetro explotado } \\
\text { III. Gastos por kilómetro explotado } \\
\text { IV. Recorrido de los trenes } \\
\text { V. Gastos por kilómetro de recorrido de los trenes } \\
\text { VI. Transportes y productos de viajeros } \\
\text { VII. Viajeros por clases } \\
\text { VIII. Resultados comparados de la explotación } \\
\text { IX. Productos por estaciones de importancia } \\
\text { X. Peso y producto de las mercancías por naturaleza } \\
\text { XI. Material móvil de la compañía del NORTE existente y su recorrido } \\
\text { XII. Composición de los trenes en la red } \\
\text { XIII. Trabajo de los trenes en el transporte de viajeros } \\
\text { XIV Trabajo de los trenes en el transporte de mercancías } \\
\text { XV. Trabajo de las máquinas } \\
\text { XVI. Gastos del Material y de la Tracción } \\
\text { XVII. Gastos del Material y Tracción } \\
\text { XVIII Gastos de Vía y Obras (Conservación) }\end{array}$ \\
\hline 1908 & $\begin{array}{l}\text { Situación (Activo y Pasivo) } \\
\text { Cuenta de explotación (Gastos y Productos) de cada una de las Líneas de NORTE } \\
\text { Datos estadísticos: } \\
\text { I. Pormenores de los ingresos } \\
\text { II. Ingresos por kilómetro explotado } \\
\text { III. Gastos por kilómetro explotado } \\
\text { IV. Recorrido de los trenes }\end{array}$ \\
\hline
\end{tabular}




\begin{tabular}{|c|c|}
\hline & $\begin{array}{l}\text { V. Gastos por kilómetro de recorrido de los trenes } \\
\text { VI. Transportes y productos de viajeros } \\
\text { VII. Viajeros por clases } \\
\text { VIII. Resultados comparados de la explotación } \\
\text { IX. Productos por estaciones de importancia } \\
\text { X. Peso y producto de las mercancías por naturaleza } \\
\text { XI. Material móvil de la compañía del NORTE existente y su recorrido } \\
\text { XII. Composición de los trenes en la red } \\
\text { XIII. Trabajo de los trenes en el transporte de viajeros } \\
\text { XIV Trabajo de los trenes en el transporte de mercancías } \\
\text { XV. Trabajo de las máquinas } \\
\text { XVI. Gastos del Material y de la Tracción } \\
\text { XVII. Gastos del Material y Tracción } \\
\text { XVIII Gastos de Vía y Obras (Conservación) }\end{array}$ \\
\hline 1909 & $\begin{array}{l}\text { Situación (Activo y Pasivo) } \\
\text { Cuenta de explotación (Gastos y Productos) de cada una de las Líneas de NORTE } \\
\text { Datos estadísticos: } \\
\text { I. Pormenores de los ingresos } \\
\text { II. Ingresos por kilómetro explotado } \\
\text { III. Gastos por kilómetro explotado } \\
\text { IV. Recorrido de los trenes } \\
\text { V. Gastos por kilómetro de recorrido de los trenes } \\
\text { VI. Transportes y productos de viajeros } \\
\text { VII. Viajeros por clases } \\
\text { VIII. Resultados comparados de la explotación } \\
\text { IX. Productos por estaciones de importancia } \\
\text { X. Peso y producto de las mercancías por naturaleza } \\
\text { XI. Material móvil de la compañía del NORTE existente y su recorrido } \\
\text { XII. Composición de los trenes en la red } \\
\text { XIII. Trabajo de los trenes en el transporte de viajeros } \\
\text { XIV Trabajo de los trenes en el transporte de mercancías } \\
\text { XV. Trabajo de las máquinas } \\
\text { XVI. Gastos del Material y de la Tracción } \\
\text { XVII. Gastos del Material y Tracción } \\
\text { XVIII Gastos de Vía y Obras (Conservación) }\end{array}$ \\
\hline 1910 & $\begin{array}{l}\text { Situación (Activo y Pasivo) } \\
\text { Cuenta de explotación (Gastos y Productos) de cada una de las Líneas de NORTE } \\
\text { Datos estadísticos: } \\
\text { I. Pormenores de los ingresos } \\
\text { II. Ingresos por kilómetro explotado } \\
\text { III. Gastos por kilómetro explotado } \\
\text { IV. Recorrido de los trenes } \\
\text { V. Gastos por kilómetro de recorrido de los trenes } \\
\text { VI. Transportes y productos de viajeros } \\
\text { VII. Viajeros por clases } \\
\text { VIII. Resultados comparados de la explotación } \\
\text { IX. Productos por estaciones de importancia } \\
\text { X. Peso y producto de las mercancías por naturaleza } \\
\text { XI. Material móvil de la compañía del NORTE existente y su recorrido }\end{array}$ \\
\hline
\end{tabular}




\begin{tabular}{|c|c|}
\hline & $\begin{array}{l}\text { XII. Composición de los trenes en la red } \\
\text { XIII. Trabajo de los trenes en el transporte de viajeros } \\
\text { XIV Trabajo de los trenes en el transporte de mercancías } \\
\text { XV. Trabajo de las máquinas } \\
\text { XVI. Gastos del Material y de la Tracción } \\
\text { XVII. Gastos del Material y Tracción } \\
\text { XVIII Gastos de Vía y Obras (Conservación) }\end{array}$ \\
\hline 1911 & $\begin{array}{l}\text { Situación (Activo y Pasivo) } \\
\text { Cuenta de explotación (Gastos y Productos) de cada una de las Líneas de NORTE } \\
\text { Datos estadísticos: } \\
\text { I. Pormenores de los ingresos } \\
\text { II. Ingresos por kilómetro explotado } \\
\text { III. Gastos por kilómetro explotado } \\
\text { IV. Recorrido de los trenes } \\
\text { V. Gastos por kilómetro de recorrido de los trenes } \\
\text { VI. Transportes y productos de viajeros } \\
\text { VII. Viajeros por clases } \\
\text { VIII. Resultados comparados de la explotación } \\
\text { IX. Productos y Gastos por estaciones de importancia } \\
\text { X. Peso y producto de las mercancías por naturaleza } \\
\text { XI. Material móvil de la compañía del NORTE existente y su recorrido } \\
\text { XII. Composición de los trenes en la red } \\
\text { XIII. Trabajo de los trenes en el transporte de viajeros } \\
\text { XIV Trabajo de los trenes en el transporte de mercancías } \\
\text { XV. Trabajo de las máquinas } \\
\text { XVI. Gastos del Material y de la Tracción } \\
\text { XVII. Gastos del Material y Tracción } \\
\text { XVIII Gastos de Vía y Obras (Conservación) }\end{array}$ \\
\hline 1912 & $\begin{array}{l}\text { Situación (Activo y Pasivo) } \\
\text { Cuenta de explotación (Gastos y Productos) de cada una de las Líneas de NORTE } \\
\text { Datos estadísticos: } \\
\text { I. Pormenores de los ingresos } \\
\text { II. Ingresos por kilómetro explotado } \\
\text { III. Gastos por kilómetro explotado } \\
\text { IV. Recorrido de los trenes } \\
\text { V. Gastos por kilómetro de recorrido de los trenes } \\
\text { VI. Transportes y productos de viajeros } \\
\text { VII. Viajeros por clases } \\
\text { VIII. Resultados comparados de la explotación } \\
\text { IX. Productos y Gastos por estaciones de importancia } \\
\text { X. Peso y producto de las mercancías por naturaleza } \\
\text { XI. Material móvil de la compañía del NORTE existente y su recorrido } \\
\text { XII. Composición de los trenes en la red } \\
\text { XIII. Trabajo de los trenes en el transporte de viajeros } \\
\text { XIV Trabajo de los trenes en el transporte de mercancías } \\
\text { XV. Trabajo de las máquinas } \\
\text { XVI. Gastos del Material y de la Tracción } \\
\text { XVII. Gastos del Material y Tracción } \\
\text { XVIII Gastos de Vía y Obras (Conservación) }\end{array}$ \\
\hline
\end{tabular}




\begin{tabular}{|c|c|}
\hline 1913 & $\begin{array}{l}\text { Situación (Activo y Pasivo) } \\
\text { Cuenta de explotación (Gastos y Productos) de cada una de las Líneas de NORTE } \\
\text { Datos estadísticos: } \\
\text { I. Pormenores de los ingresos } \\
\text { II. Ingresos por kilómetro explotado } \\
\text { III. Gastos por kilómetro explotado } \\
\text { IV. Recorrido de los trenes } \\
\text { V. Gastos por kilómetro de recorrido de los trenes } \\
\text { VI. Transportes y productos de viajeros } \\
\text { VII. Viajeros por clases } \\
\text { VIII. Resultados comparados de la explotación } \\
\text { IX. Productos y Gastos por estaciones de importancia } \\
\text { X. Peso y producto de las mercancías por naturaleza } \\
\text { XI. Material móvil de la compañía del NORTE existente y su recorrido } \\
\text { XII. Composición de los trenes en la red } \\
\text { XIII. Trabajo de los trenes en el transporte de viajeros } \\
\text { XIV Trabajo de los trenes en el transporte de mercancías } \\
\text { XV. Trabajo de las máquinas } \\
\text { XVI. Gastos del Material y de la Tracción } \\
\text { XVII. Gastos del Material y Tracción } \\
\text { XVIII Gastos de Vía y Obras (Conservación) }\end{array}$ \\
\hline 1914 & $\begin{array}{l}\text { Situación (Activo y Pasivo) } \\
\text { Cuenta de explotación (Gastos y Productos) de cada una de las Líneas de NORTE } \\
\text { Datos estadísticos: } \\
\text { I. Pormenores de los ingresos } \\
\text { II. Ingresos por kilómetro explotado } \\
\text { III. Gastos por kilómetro explotado } \\
\text { IV. Recorrido de los trenes } \\
\text { V. Gastos por kilómetro de recorrido de los trenes } \\
\text { VI. Transportes y productos de viajeros } \\
\text { VII. Viajeros por clases } \\
\text { VIII. Resultados comparados de la explotación } \\
\text { IX. Productos y Gastos por estaciones de importancia } \\
\text { X. Peso y producto de las mercancías por naturaleza } \\
\text { XI. Material móvil de la compañía del NORTE existente y su recorrido } \\
\text { XII. Composición de los trenes en la red } \\
\text { XIII. Trabajo de los trenes en el transporte de viajeros } \\
\text { XIV Trabajo de los trenes en el transporte de mercancías } \\
\text { XV. Trabajo de las máquinas } \\
\text { XVI. Gastos del Material y de la Tracción } \\
\text { XVII. Gastos del Material y Tracción } \\
\text { XVIII Gastos de Vía y Obras (Conservación) }\end{array}$ \\
\hline 1915 & $\begin{array}{l}\text { Situación (Activo y Pasivo) } \\
\text { Cuenta de explotación (Gastos y Productos) de cada una de las Líneas de NORTE } \\
\text { Datos estadísticos: } \\
\text { I. Pormenores de los ingresos } \\
\text { II. Ingresos por kilómetro explotado }\end{array}$ \\
\hline
\end{tabular}




\begin{tabular}{|c|c|}
\hline & $\begin{array}{l}\text { III. Gastos por kilómetro explotado } \\
\text { IV. Recorrido de los trenes } \\
\text { V. Gastos por kilómetro de recorrido de los trenes } \\
\text { VI. Transportes y productos de viajeros } \\
\text { VII. Viajeros por clases } \\
\text { VIII. Resultados comparados de la explotación } \\
\text { IX. Productos y Gastos por estaciones de importancia } \\
\text { X. Peso y producto de las mercancías por naturaleza } \\
\text { XI. Material móvil de la compañía del NORTE existente y su recorrido } \\
\text { XII. Composición de los trenes en la red } \\
\text { XIII. Trabajo de los trenes en el transporte de viajeros } \\
\text { XIV Trabajo de los trenes en el transporte de mercancías } \\
\text { XV. Trabajo de las máquinas } \\
\text { XVI. Gastos del Material y de la Tracción } \\
\text { XVII. Gastos del Material y Tracción } \\
\text { XVIII Gastos de Vía y Obras (Conservación) }\end{array}$ \\
\hline 1916 & $\begin{array}{l}\text { Situación (Activo y Pasivo) } \\
\text { Cuenta de explotación (Gastos y Productos) de cada una de las Líneas de NORTE } \\
\text { Datos estadísticos: } \\
\text { I. Pormenores de los ingresos } \\
\text { II. Ingresos por kilómetro explotado } \\
\text { III. Gastos por kilómetro explotado } \\
\text { IV. Recorrido de los trenes } \\
\text { V. Gastos por kilómetro de recorrido de los trenes } \\
\text { VI. Transportes y productos de viajeros } \\
\text { VII. Viajeros por clases } \\
\text { VIII. Resultados comparados de la explotación } \\
\text { IX. Productos y Gastos por estaciones de importancia } \\
\text { X. Peso y producto de las mercancías por naturaleza } \\
\text { XI. Material móvil de la compañía del NORTE existente y su recorrido } \\
\text { XII. Composición de los trenes en la red } \\
\text { XIII. Trabajo de los trenes en el transporte de viajeros } \\
\text { XIV Trabajo de los trenes en el transporte de mercancías } \\
\text { XV. Trabajo de las máquinas } \\
\text { XVI. Gastos del Material y de la Tracción } \\
\text { XVII. Gastos del Material y Tracción } \\
\text { XVIII Gastos de Vía y Obras (Conservación) }\end{array}$ \\
\hline 1917 & $\begin{array}{l}\text { Situación (Activo y Pasivo) } \\
\text { Cuenta de explotación (Gastos y Productos) de cada una de las Líneas de NORTE } \\
\text { Datos estadísticos: } \\
\text { I. Pormenores de los ingresos } \\
\text { II. Ingresos por kilómetro explotado } \\
\text { III. Gastos por kilómetro explotado } \\
\text { IV. Recorrido de los trenes } \\
\text { V. Gastos por kilómetro de recorrido de los trenes } \\
\text { VI. Transportes y productos de viajeros } \\
\text { VII. Viajeros por clases } \\
\text { VIII. Resultados comparados de la explotación } \\
\text { IX. Productos y Gastos por estaciones de importancia }\end{array}$ \\
\hline
\end{tabular}




\begin{tabular}{|c|c|}
\hline & $\begin{array}{l}\text { X. Peso y producto de las mercancías por naturaleza } \\
\text { XI. Material móvil de la compañía del NORTE existente y su recorrido } \\
\text { XII. Composición de los trenes en la red } \\
\text { XIII. Trabajo de los trenes en el transporte de viajeros } \\
\text { XIV Trabajo de los trenes en el transporte de mercancías } \\
\text { XV. Trabajo de las máquinas } \\
\text { XVI. Gastos del Material y de la Tracción } \\
\text { XVII. Gastos del Material y Tracción } \\
\text { XVIII Gastos de Vía y Obras (Conservación) }\end{array}$ \\
\hline 1918 & $\begin{array}{l}\text { Situación (Activo y Pasivo) } \\
\text { Cuenta de explotación (Gastos y Productos) de cada una de las Líneas de NORTE } \\
\text { Datos estadísticos: } \\
\text { I. Pormenores de los ingresos } \\
\text { II. Ingresos por kilómetro explotado } \\
\text { III. Gastos por kilómetro explotado } \\
\text { IV. Recorrido de los trenes } \\
\text { V. Gastos por kilómetro de recorrido de los trenes } \\
\text { VI. Transportes y productos de viajeros } \\
\text { VII. Viajeros por clases } \\
\text { VIII. Resultados comparados de la explotación } \\
\text { IX. Productos y Gastos por estaciones de importancia } \\
\text { X. Peso y producto de las mercancías por naturaleza } \\
\text { XI. Material móvil de la compañía del NORTE existente y su recorrido } \\
\text { XII. Composición de los trenes en la red } \\
\text { XIII. Trabajo de los trenes en el transporte de viajeros } \\
\text { XIV Trabajo de los trenes en el transporte de mercancías } \\
\text { XV. Trabajo de las máquinas } \\
\text { XVI. Gastos del Material y de la Tracción } \\
\text { XVII. Gastos del Material y Tracción } \\
\text { XVIII Gastos de Vía y Obras (Conservación) }\end{array}$ \\
\hline 1919 & $\begin{array}{l}\text { Situación (Activo y Pasivo) } \\
\text { Cuenta de explotación (Gastos y Productos) de cada una de las Líneas de NORTE } \\
\text { Datos estadísticos: } \\
\text { I. Pormenores de los ingresos } \\
\text { II. Ingresos por kilómetro explotado } \\
\text { III. Gastos por kilómetro explotado } \\
\text { IV. Recorrido de los trenes } \\
\text { V. Gastos por kilómetro de recorrido de los trenes } \\
\text { VI. Transportes y productos de viajeros } \\
\text { VII. Viajeros por clases } \\
\text { VIII. Resultados comparados de la explotación } \\
\text { IX. Productos y Gastos por estaciones de importancia } \\
\text { X. Peso y producto de las mercancías por naturaleza } \\
\text { XI. Material móvil de la compañía del NORTE existente y su recorrido } \\
\text { XII. Composición de los trenes en la red } \\
\text { XIII. Trabajo de los trenes en el transporte de viajeros } \\
\text { XIV Trabajo de los trenes en el transporte de mercancías } \\
\text { XV. Trabajo de las máquinas } \\
\text { XVI. Gastos del Material y de la Tracción }\end{array}$ \\
\hline
\end{tabular}




\begin{tabular}{|c|c|}
\hline & $\begin{array}{l}\text { XVII. Gastos del Material y Tracción } \\
\text { XVIII Gastos de Vía y Obras (Conservación) }\end{array}$ \\
\hline 1920 & $\begin{array}{l}\text { Situación (Activo y Pasivo) } \\
\text { Cuenta de explotación (Gastos y Productos) de cada una de las Líneas de NORTE } \\
\text { Datos estadísticos: } \\
\text { I. Pormenores de los ingresos } \\
\text { II. Ingresos por kilómetro explotado } \\
\text { III. Gastos por kilómetro explotado } \\
\text { IV. Recorrido de los trenes } \\
\text { V. Gastos por kilómetro de recorrido de los trenes } \\
\text { VI. Transportes y productos de viajeros } \\
\text { VII. Viajeros por clases } \\
\text { VIII. Resultados comparados de la explotación } \\
\text { IX. Productos y Gastos por estaciones de importancia } \\
\text { X. Peso y producto de las mercancías por naturaleza } \\
\text { XI. Material móvil de la compañía del NORTE existente y su recorrido } \\
\text { XII. Composición de los trenes en la red } \\
\text { XIII. Trabajo de los trenes en el transporte de viajeros } \\
\text { XIV Trabajo de los trenes en el transporte de mercancías } \\
\text { XV. Trabajo de las máquinas } \\
\text { XVI. Gastos del Material y de la Tracción } \\
\text { XVII. Gastos del Material y Tracción } \\
\text { XVIII Gastos de Vía y Obras (Conservación) }\end{array}$ \\
\hline 1921 & $\begin{array}{l}\text { Situación (Activo y Pasivo) } \\
\text { Cuenta de explotación (Gastos y Productos) de cada una de las Líneas de NORTE } \\
\text { Datos estadísticos: } \\
\text { I. Pormenores de los ingresos } \\
\text { II. Ingresos por kilómetro explotado } \\
\text { III. Gastos por kilómetro explotado } \\
\text { IV. Recorrido de los trenes } \\
\text { V. Gastos por kilómetro de recorrido de los trenes } \\
\text { VI. Transportes y productos de viajeros } \\
\text { VII. Viajeros por clases } \\
\text { VIII. Resultados comparados de la explotación } \\
\text { IX. Productos y Gastos por estaciones de importancia } \\
\text { X. Peso y producto de las mercancías por naturaleza } \\
\text { XI. Material móvil de la compañía del NORTE existente y su recorrido } \\
\text { XII. Composición de los trenes en la red } \\
\text { XIII. Trabajo de los trenes en el transporte de viajeros } \\
\text { XIV Trabajo de los trenes en el transporte de mercancías } \\
\text { XV. Trabajo de las máquinas } \\
\text { XVI. Gastos del Material y de la Tracción } \\
\text { XVII. Gastos del Material y Tracción } \\
\text { XVIII Gastos de Vía y Obras (Conservación) }\end{array}$ \\
\hline 1922 & $\begin{array}{l}\text { Situación (Activo y Pasivo) } \\
\text { Cuenta de explotación (Gastos y Productos) de cada una de las Líneas de NORTE } \\
\text { Datos estadísticos: }\end{array}$ \\
\hline
\end{tabular}




\begin{tabular}{|l|l|}
\hline & I. Pormenores de los ingresos \\
II. Ingresos por kilómetro explotado \\
III. Gastos por kilómetro explotado \\
IV. Recorrido de los trenes \\
V. Gastos por kilómetro de recorrido de los trenes \\
VI. Transportes y productos de viajeros \\
VII. Viajeros por clases \\
VIII. Resultados comparados de la explotación \\
IX. Productos y Gastos por estaciones de importancia \\
X. Peso y producto de las mercancías por naturaleza \\
XI. Material móvil de la compañía del NORTE existente y su recorrido \\
XII. Composición de los trenes en la red \\
XIII. Trabajo de los trenes en el transporte de viajeros \\
XIV Trabajo de los trenes en el transporte de mercancías \\
XV. Trabajo de las máquinas \\
XVI. Gastos del Material y de la Tracción \\
XVII. Gastos del Material y Tracción \\
XVIII Gastos de Vía y Obras -Conservación \\
Balance (Activo y Pasivo) \\
Cuenta de explotación (Gastos y Productos) de cada una de las Líneas de NORTE \\
Datos estadísticos: \\
I. Pormenores de los ingresos \\
II. Ingresos por kilómetro explotado \\
III. Gastos por kilómetro explotado \\
IV. Recorrido de los trenes \\
V. Gastos por kilómetro de recorrido de los trenes \\
VI. Transportes y productos de viajeros \\
VII. Viajeros por clases \\
VIII. Resultados comparados de la explotación \\
IX. Productos y Gastos por estaciones de importancia \\
X. Peso y producto de las mercancías por naturaleza \\
XI. Material móvil de la compañía del NORTE existente y su recorrido \\
XII. Composición de los trenes en la red \\
XIII. Trabajo de los trenes en el transporte de viajeros \\
XIV Trabajo de los trenes en el transporte de mercancías \\
XV. Trabajo de las máquinas \\
XVI. Gastos del Material y de la Tracción \\
XVII. Gastos del Material y Tracción \\
XVIII Gastos de Vía y Obras -Conservación \\
\hline
\end{tabular}

Fuente: Elaboración propia 


\subsubsection{Situación de la Compañía - Balance}

La Situación de la Compañía elaborada por NORTE presentaba seis formatos distintos de presentación. Estos seis modelos son relativamente estables y uniformes a lo largo del tiempo.

La Situación de la Compañía de $1900^{875}$ y $1901^{876}$ está presentada en dos columnas: activos y pasivos. Los activos están divididos en siete títulos: Construcción del camino y sus dependencias, Minas, Material móvil, Mobiliario, material inventariado y acopios ${ }^{877}$, Caja y banqueros, Cuentas deudoras ${ }^{878}$ y Cuentas de orden. Los pasivos están divididos en seis títulos: Capital social, Obligaciones ${ }^{879}$, Subvenciones, Cuentas acreedoras, Reservas y Cuentas de orden.

En 1902 cambia el nombre del título que refleja la aportación de los accionistas. Se abandona la denominación "Capital Social", más actual y adecuada, y comienza a utilizarse la denominación “Acciones”. Así, la Situación de la Compañía de $1902^{880} 1903^{881}$ y $1904^{882}$ está presentada en dos columnas: activos y pasivos. Los activos están divididos en siete títulos: Construcción del camino y sus dependencias, Minas, Material móvil, Mobiliario, material inventariado y acopios, Caja y banqueros, Cuentas deudoras y Cuentas de orden. Por su parte, los pasivos están divididos en seis títulos: Acciones, Obligaciones, Subvenciones, Cuentas acreedoras, Reservas y Cuentas de orden.

En 1905 cambia el nombre del título que refleja la "Construcción del camino y sus dependencias" por la "Construcción de las líneas y sus dependencias". Así, la Situación de la Compañía de $1905^{883}, 1906^{884}, 1907^{885}, 1908^{886}, 1909^{887}, 1910^{888}$ y $1911^{889}$ está dividida en dos columnas: activos y pasivos. Los activos están divididos en siete títulos: Construcción de la línea y sus dependencias, Minas, Material móvil, Mobiliario, material inventariado y acopios, Caja y banqueros, Cuentas deudoras y Cuentas de orden. Los pasivos están divididos

\footnotetext{
${ }^{875}$ NORTE (1901: 42-43).

${ }^{876}$ NORTE (1902: 43-45).

${ }^{877}$ La rúbrica Acopios recogía las existencias de los diferentes almacenes de las compañías, así como las correspondientes a combustibles y repuestos.

${ }^{878}$ En cuanto a las "Cuentas Deudoras", figuraban entre ellas las destinadas a reflejar las fianzas y depósitos entregados, así como las cuentas de deudores varios y las correspondientes al Servicio Combinado.

${ }^{879}$ Los empréstitos figuraban en el Balance con detalle de las diferentes emisiones realizadas respecto de las líneas de la compañía a las que financiaban, diferenciando, además, entre las obligaciones pendientes de amortizar y las ya amortizadas.

${ }^{880}$ NORTE (1903: 46-47).

${ }^{881}$ NORTE (1904a: 46-47).

${ }^{882}$ NORTE (1905: 46-47).

${ }^{883}$ NORTE (1906: 39-40).

${ }^{884}$ NORTE (1907: 39-40).

${ }^{885}$ NORTE (1908: 34-35).

${ }^{886}$ NORTE (1909: 36-37).

${ }^{887}$ NORTE (1910: 34-35).

${ }^{888}$ NORTE (1911: 38-39).

${ }^{889}$ NORTE (1912: 36-37).
} 
en seis títulos: Acciones, Obligaciones, Subvenciones, Cuentas acreedoras, Reservas y Cuentas de orden.

El año 1912 presenta tres novedades en el activo: desaparece el título de "Minas", estando incluídas en el título "Propiedades de la compañía". En ese mismo año el antiguo título "Caja y banqueros" se incluye en el nuevo "Metálico y valores". "Acopios" se incorpora como un título independiente, dejando de estar en el título "Mobiliario, material inventariado y acopios". Por su parte, las novedades en el pasivo son dos: se intercambia el orden de las "Reservas" y las "Cuentas acreedoras" y, lo más importante, se incorpora el título "Resultados obtenidos por la aplicación del artículo $3^{\circ}$ del Convenio de 31 de mayo de 1900". Así, la Situación de la Compañía de $1912^{890}, 1913^{891}, 1914^{892}, 1915^{893}, 1916^{894}, 1917^{895}$, $1918^{896}, 1919^{897}$ y $1920^{898}$ está presentada en dos columnas: activos y pasivos. Los activos están divididos en ocho títulos: Construcción de la línea y sus dependencias, Material móvil, Propiedades de la compañía, Mobiliario y material inventariado, Acopios, Metálico y valores Cuentas deudoras y Cuentas de orden. Los pasivos están divididos en siete títulos: Acciones, Obligaciones, Subvenciones, Resultados obtenidos por la aplicación del artículo $3^{\circ}$ del Convenio de 31 de mayo de 1900, Reservas, Cuentas acreedoras y Cuentas de orden.

En 1921 hay un único cambio por la modificación en la ubicación del activo: Propiedades de la compañía pasa a situarse después del Mobiliario y material inventariado. Así, la Situación de la Compañía de $1921^{899}$ y $1922^{900}$ está presentada en dos columnas: activos y pasivos. Los activos están divididos en ocho títulos: Construcción de la línea y sus dependencias, Material móvil, Mobiliario y material inventariado, Propiedades de la compañía, Acopios, Metálico y valores, Cuentas deudoras y Cuentas de orden. Los pasivos están divididos en siete títulos: Acciones, Obligaciones, Subvenciones, Resultados obtenidos por la aplicación del artículo $3^{\circ}$ del Convenio de 31 de mayo de 1900, Reservas, Cuentas acreedoras y Cuentas de orden.

En 1923 el cambio es fundamental porque el Documento "Situación de la Compañía" pasa a denominarse "Balance", nomenclatura que no se abandonará hasta el final de la vida de la compañía. Además, en el pasivo se incorpora un nuevo título: Emisiones de obligaciones totalmente amortizadas. El Balance de la Compañía de 1923 está dividida en dos columnas: activos y pasivos $^{901}$. Los activos están divididos en ocho títulos: Construcción de la línea y sus dependencias, Material móvil, Mobiliario y material inventariado, Propiedades de la

\footnotetext{
${ }^{890}$ NORTE (1913: 38-39).

${ }^{891}$ NORTE (1914: 38-39).

${ }^{892}$ NORTE (1915: 38-39).

${ }^{893}$ NORTE (1916: 38-39).

${ }^{894}$ NORTE (1917: 42-43).

${ }^{895}$ NORTE (1918: 42-43).

${ }^{896}$ NORTE (1919: 42-43).

${ }^{897}$ NORTE (1920: 42-43).

${ }^{898}$ NORTE (1921: 40-41).

${ }^{899}$ NORTE (1922: 42-43).

${ }^{900}$ NORTE (1923: 40-41).

${ }^{901}$ NORTE (1924: 42-43).
} 
compañía, Acopios, Metálico y valores Cuentas deudoras y Cuentas de orden. Los pasivos están divididos en ocho títulos: Acciones, Obligaciones, Subvenciones, Emisiones de obligaciones totalmente amortizadas, Resultados obtenidos por la aplicación del artículo $3^{\circ}$ del Convenio de 31 de mayo de 1900, Reservas, Cuentas acreedoras y Cuentas de orden.

\subsection{Examen de las partidas integrantes del Activo hasta 1924}

En este apartado se analiza el contenido de cada título del activo en el periodo 1900-1924 ${ }^{902}$, para poder comprender los componentes del capital económico de NORTE.

La partida "Construcción de las líneas y de sus dependencias" constituye la primera partida del balance en todos los ejercicios del periodo. Hasta el Informe Anual del 1905 se denomina "Construcción del camino". Incluye el valor real de las líneas, apartaderos y estaciones que forman las líneas que constituyen la red de NORTE, incrementado dicho valor con los intereses de sus acciones y obligaciones, cambios y comisiones satisfechos durante el tiempo de la construcción, gastos del servicio central de la Dirección y de la inspección y vigilancia del Gobierno durante el mismo periodo y los trabajos y conclusiones de obra a partir de 1870 .

La partida "Material Móvil” representa el valor según inventario del precio de adquisición del material existente al cierre del ejercicio de: locomotoras, herramientas de locomotoras, coches para viajeros y vagones de todas clases.

La partida "Mobiliario y material inventariado" refleja el mobiliario de las oficinas centrales y de las estaciones de la red, la importante partida de toldos para cubrir las mercancías, así como las herramientas necesarias en las estaciones para el servicio.

La partida "Propiedades de la Compañía" representa el valor de los edificios y terrenos adquiridos por la compañía para sus instalaciones fuera de las líneas que explota, y que ella considera como un empleo seguro de sus recursos. Dentro de ellas, los conceptos principales que incluyó la empresa son el valor de los edificios para oficinas en Madrid (Paseo del Rey), los terrenos de la antigua estación de Valencia y de las instalaciones, terrenos, edificios, pertenencias, fábricas de cemento, salto de agua, alumbrado eléctrico, carbón y esquistos retirados del coste del ferrocarril asignado a las Minas de Barruelo y de Surroca. En 1922 la partida "Propiedades de la Compañía" sufrió una importante reducción del valor, pero únicamente fue por una reclasificación de las cuentas; las partidas de las Minas de carbón de Barruelo y de los terrenos de la antigua estación de Valencia fueron aportados a Sociedades

\footnotetext{
${ }^{902}$ La "Primera Comisión investigadora de la situación económica de las empresas del ferrocarril" elaboró, el 29 de noviembre de 1923, el "Examen del activo y pasivo del balance de la Compañía de los Caminos de Hierro del NORTE de España del años 1922”, cumpliendo lo dispuesto en el artículo 4 del Real Decreto de 20 de octubre de 1922. Este fue el primer documento que analizó detalladamente los contenidos de cada una de las partidas del activo y pasivo de NORTE (AHF P-113-258-1: "Memoria sobre la situación económica de la Compañía de los Caminos de Hierro del NORTE de España”, Primera Comisión investigadora de la situación económica de las empresas de ferrocarriles, 29 de noviembre de 1923).
} 
constituidas para su explotación, ingresando en la cartera de la compañía acciones representativas de sus aportaciones.

En 1875, NORTE adquirió la propiedad de las minas de Barruelo al comprarlas por 11.590 .000 reales al "Crédito Moviliario ${ }^{903}$ Español". Desde entonces la compañía las explotaba directamente por medio de su Servicio de Material y Tracción. Los trabajadores de la mina suponían, para NORTE, muchos quebraderos de cabeza porque tenían los beneficios de tipo minero (jornadas de siete horas, y pluses de producción) y de tipo ferroviario (mensualidades, pases y billetes). Por esta razón, NORTE realizó una segregación de las minas, constituyendo el 19 de enero de 1922 una empresa independiente para la explotación de las mismas: la Sociedad Minas de Barruelo. En la escritura de cesión aparece que las Sociedad Minas de Barruelo debería entregar a NORTE ocho millones de pesetas en acciones de la primera, cuyo capital era de diez millones. Además, la Sociedad Minas de Barruelo estaba obligado a entregar a NORTE la totalidad de los carbones producidas por ella. Por su parte, la Sociedad Minas de Barruelo estaba obligado a mantener al personal que había prestado servicio a NORTE, y además, mantener las ventajas que tenían en esta sociedad.

Desde el balance de 1922, la cuenta Minas de Barruelo dejó de formar parte del epígrafe "Propiedades de la Compañía", siendo remplazadas por valores mobiliarios que figuraban en la cartera. El valor por el que figuraban las Minas de Barruelo en el activo de 1921 de NORTE, último balance en que aparecen, fue de 7.229.919,71 pesetas. En el periodo 18751885 , el valor del balance de esta cuenta fue de 2.897 .500 pesetas. En los años 1886-1893 el valor era de 3.596 .000 pesetas. En los balances de 1894 y 1895 desaparecen del activo tales minas, pues en 1894, para atender a las necesidades de la Tesorería, se enajenaron por 3.500.000 pesetas, con pacto expreso de ser revertidas a NORTE, en el plazo de diez años, mediante el pago de diez anualidades de 350.000 pesetas cada una, plazo reducible a voluntad de la compañía. Durante este periodo de tiempo, NORTE formalizó otro contrato, este de arrendamiento operativo sobre las minas, lo que permitió conservar la explotación de las mismas. En el ejercicio contable 1896 se anuló el contrato originario, volviendo a figurar las minas en el activo de NORTE por los 3.596.000 de pesetas a las que estaban valoradas en el año 1893. Hasta ese momento los beneficios eran considerados por NORTE como un ingreso fuera de explotación; a partir de ese momento, los beneficios se dedicaron a amortizar las obras de instalación y utensilios de las mismas, y a disminuir el valor del activo, que llegó a tener en el balance de 1903, un saldo de 1.109.296,90 pesetas. Desde 1903 empieza a aumentar el activo, hasta llegar en 1921 al valor citado de 7.299.919,71 pesetas, por acumulaciones anuales de diferentes cantidades que representaban las obras de mejora y nuevas instalaciones realizadas en las minas, y además, porque en 1910 se aumentó el activo en 1.593.905,3 pesetas por haberse rescatado el 98,13\% del censo que pesaba sobre gran parte de las concesiones de las minas, que venían obligando al pago de 1,875 pesetas por toneladas extraída, a la casa Collantes, antigua poseedora de gran parte de las concesiones. En el año 1917, y hasta su venta, vuelven a figurar como ingresos fuera de la explotación los beneficios

\footnotetext{
903 Ortografía de la época.
} 
de las minas, que llegaron a ser de $1.010 .118,1$ pesetas en el año 1921 , que como hemos escrito, fue el último en el que las Minas de Barruelo figuran en el balance de NORTE.

En 1922, NORTE cedió a una sociedad especial, la "Sociedad Inmobiliaria Valenciana", de los terrenos sobrantes del derribo de la antigua estación de Valencia ${ }^{904}$. Según la escritura de 5 de julio de 1922, NORTE aportó los terrenos que resultaron sobrantes de la antigua estación de Valencia a la "Sociedad Inmobiliaria Valenciana". El capital de esta empresa era de 5 millones de pesetas, de 500 pesetas de valor nominal cada una. Las 10.000 acciones se repartieron en partes iguales entre NORTE que aportó 5.000 acciones, y 3.500 bonos al $4 \%$ también de valor nominal de 500 pesetas, y entre los Bancos Bilbao, Urquijo y Vizcaya. El importe con que esos terrenos valencianos ${ }^{905}$ figuraban en el activo del balance del año 1920, era de 2.051.882,37 pesetas, que es la cantidad que figuró como "Baja" en el activo de la línea de Almansa a Valencia y Tarragona en el balance de 1921, y que pasó a figurar en el concepto de "Propiedades de la Compañía", de donde desapareció en el balance de 1922 por la cesión.

Por su parte, dentro del activo corriente aparece la partida "Acopios", que recogía las existencias de los diferentes almacenes de las compañías, así como las correspondientes a combustibles y repuestos. La partida "Acopios" se descompone en ocho conceptos: "Almacén general", "Combustibles", "Acopios de material y tracción", "Almacenes de los depósitos y talleres", "Trabajos en curso de ejecución en los talleres", "Almacén de la vía", "Taller de la vía" y "Almacenes de los servicios".

La subpartida "Almacén general" integra las existencias en el almacén principal de Valladolid, talleres, depósito y recorrido de las líneas. El inventario de NORTE del ejercicio 1922 dividía el "Almacén general" en los siguientes efectos:

- Metales en bruto.

- Maderas.

- Mobiliario para oficinas y estaciones.

- Herramientas y máquinas obreras.

- Uniformes.

- Quincalla, lampistería, cristales, pinturas, esponjas, cepillos, etc.

- Piezas de máquinas y ténders.

- Piezas de coches y vagones.

- Guarniciones de carruajes, cueros, pieles, toldos, correas y cordelería.

- Traviesas y longrinas.

- Pequeño material de vía, aparatos y piezas de recambio, bombas y material telegráfico.

- Aceites, sebos y demás substancias para el engrase.

- Combustible, estufas y accesorios.

- Materias viejas y varios.

\footnotetext{
${ }^{904}$ La motivación "para desglosarlos de NORTE” era poder realizar una "venta más racional” (NORTE, 1940: 251).

${ }^{905}$ Estos terrenos fueron declarados sobrantes de la explotación por Real Orden de 6 de abril de 1920.
} 
La prestación del servicio de transporte de viajeros y de mercancías requiere de proveerse de combustibles para mover sus elementos de transporte (hulla, aceites, grasas, fuerza eléctrica, etc.), pero no destinados a la elaboración, sino al consumo. Para reflejarlo, la subpartida "Combustibles" representa el valor de carbón y leña existente en los depósitos de las estaciones para el suministro, durante noventa días aproximadamente, de las máquinas y calefacción de trenes, estaciones y oficinas.

La subpartida "Acopios de material y tracción" se descompone en Piezas de recambio para máquinas, Materiales para composición de vehículos y Materiales en los talleres, depósitos y recorrido.

La subpartida "Almacenes de los depósitos y talleres" se divide en tres: Acopio en los talleres de máquinas de Valladolid, Acopio en los talleres de coches de Valladolid y Acopio en los talleres San Andrés.

Igualmente, la subpartida "Trabajos en curso de ejecución en los talleres" se descompone en tres: Acopio en los talleres de máquinas de Valladolid, Acopio en los talleres de coches de Valladolid y Acopio en los talleres San Andrés.

La subpartida "Almacén de la vía" representa el valor de los materiales situados en toda la extensión de las líneas. El inventario de NORTE dividía la subpartida "Almacén de la vía" en nueve clases: Carriles, Pequeño material, Traviesas, Longrinas, Aparatos fijos, Telégrafo, Hierro viejo, Diversos y Material de enclavamiento.

La subpartida "Taller de la vía" comprende el valor a formalizar en cuenta de los materiales y mano de obra de trabajos en curso de ejecución a la fecha del balance.

La subpartida "Almacenes de los servicios" incluye los acopios y carbones de las Minas propiedad de la compañía, antes de ser incorporados en 1922 a empresas individualizadas.

También dentro del activo corriente, la partida "Metálico y valores" se descompone en cuatro conceptos: "Caja y banqueros", "Banco de Barcelona", "Títulos a disposición" y "Valores afectos a la materialización de las reservas".

La cifra de la subpartida "Caja y banqueros" se distribuía entre los saldos que presentan la Caja central de la compañía, las seis pagadurías, y los principales bancos de Madrid, Barcelona, Bilbao, Valladolid y Santander, en España, y Londres, París y Bruselas, en el extranjero.

La subpartida "Banco de Barcelona" representa la cifra existente en la cuenta corriente de dicha entidad en el momento de declarar su suspensión de pagos en $1920^{906}$.

\footnotetext{
${ }^{906}$ El Banco de Barcelona fue fundado en 1845. Nació bajo el impulso del burgués Manuel Girona i Agrafel, que tanta importancia tuvo en NORTE. Desapareció en 1920 con una sonada quiebra que se sustanció por la Ley de
} 
La subpartida "Títulos a disposición" representa la cifra de valores figurados por su valor efectivo. Los de mayor valor son cuatro:

- Obligaciones del Tesoro depositadas en el Banco de España en garantía de la cuenta de crédito.

- Obligaciones especiales de NORTE 6\% para la venta.

- Diferencia de precios en los bonos de Asturias, Galicia y León afectos a las reservas.

- Varios valores en cartera.

La subpartida "Valores afectos a la materialización de las reservas" está constituida por el valor efectivo de valores del Estado, en su mayor parte destinados a representar materialmente, y en forma fácilmente realizable, el importe de las reservas que se detallan en el pasivo. Los valores al cierre del ejercicio de 1922, son los siguientes:

- Obligaciones del tesoro, $5 \%$.

- Deuda interior, $4 \%$.

- Cédulas hipotecarias, $4 \%$.

- Cédulas hipotecarias, $5 \%$.

- Acciones de la Sociedad Inmobiliaria Valenciana.

- Bonos de aportación a la Sociedad Inmobiliaria Valenciana.

- Acciones de la Maquinista Terrestre y Marítima ${ }^{907}$.

- Acciones de la Sociedad Anónima "Minas de Barruelo".

- Bonos sin interés de Asturias, Galicia y León.

- Obligaciones especiales NORTE, $6 \%$.

Por su parte, la partida "Cuentas deudoras" se descompone en cuatro conceptos: "Intervención de la cobranza", "Fianzas y depósitos constituidos en las Cajas del Estado", "Deudores varios" y "Cantidades a cobrar del Estado para completar el anticipo de personal".

La subpartida "Intervención de la cobranza" representa el saldo deudor del conjunto de las partidas siguientes:

- Estaciones.

- Compañías combinadas.

- Cuentas del Estado por transporte y aduanas.

- Agencias de aduanas.

- Básculas automáticas y alquiler de almohadas.

- Reembolso.

- Billetes kilométricos.

Suspensión de Pagos de 1922, hecha a medida del problema del Banco de Barcelona. La Ley de Suspensión de Pagos de 1922 fue diseñada por Francisco Cambó, ministro de Fomento, y José Bertrán y Musitu, ministro de Gracia y Justicia (solamente fue ministro 5 semanas, para sacar adelante la ley); la Ley estuvo en vigor hasta 2004.

907 La Maquinista Terrestre y Marítima, fundada en 1856, estaba dedicada a construcciones mecánicas y metálicas (ABC, 7 de octubre de 1921, p. 6). 
- Automóviles, exceso de almacenaje y fianzas para vagones.

- Detasas por cuenta ajena.

- Cantidades en litigio con compañías combinadas.

- Varios.

- Remesas de las estaciones en comisión.

La subpartida "Fianzas y depósitos constituidos en las Cajas del Estado" representa las sumas depositadas en las Cajas del Estado como garantía de concesiones y litigios y para poder alzarse con acuerdos administrativos, por multas y liquidación del impuesto de utilidades (Ley de Utilidades de 27 de marzo de 1900; Gaceta del 28 de marzo de 1900).

La subpartida "Deudores varios" representa los saldos deudores de las cuentas siguientes:

- Gastos a formalizar con cargo a primer establecimiento y explotación.

- Compañías combinadas.

- Gastos de domiciliación de obligaciones a formalizar.

- Gastos de emisión de obligaciones a 6\% a formalizar.

- Anticipos al personal.

- Cooperativa de Funcionarios del NORTE.

- Anticipo del Estado de diciembre (cobrado en enero).

- Primas de cobranza por el impuesto de transportes pendientes.

- Intereses sobre valores en cartera del ejercicio que se cierra a cobrar en el año siguiente.

- Pagos por impuestos extranjeros a reintegrar por los accionistas.

- Diversos corresponsales.

La subpartida "Cantidades a cobrar del Estado para completar el anticipo de personal" representa el exceso de lo pagado al personal por el plus concedido por la compañía a sus empleados en base del anticipo del Estado, para suplir insuficiencias de recursos. Según los argumentos de la empresa, en realidad representa una suma a formalizar con cargo a la cuenta de explotación, por carecer de fundamento el concepto de deudor en que figura el Estado, por no haber surgido la insuficiencia de medios económicos que hubiese justificado la reclamación que esta cifra quiere hacer constar.

Las "Cuentas de orden" recogían información relativa a valores en custodia, estando compensada esta rúbrica por otra de igual título y saldo en la masa de pasivo, por lo que su función era meramente informativa, sin que tuviera influencia alguna sobre el valor patrimonial de la compañía. La partida "Cuentas de orden" se descompone en dos conceptos: "Cantidades satisfechas al personal por cuenta del Estado" y "Valores nominales".

La subpartida "Cantidades satisfechas al personal por cuenta del Estado" representa la contrapartida de la cuenta del pasivo por los anticipos hechos por el Estado para pago del personal. La compañía mantiene el criterio de conservar este gasto, no como una necesidad de 
la explotación, sino como un auxilio que puede modificar los haberes del personal cuando el auxilio cese.

La subpartida "Valores nominales" representa los saldos de las cuentas corrientes con los bancos por valores depositados en sus cajas y los que tiene en Caja la compañía por depósitos constituidos, siendo la contrapartida de las cantidades del pasivo representativa de tales obligaciones.

\subsection{Examen de las partidas integrantes del Activo a partir de 1924}

A partir de 1924 se continuan empleando de las cuentas y títulos utilizados hasta entonces, pero, al ser una información claramente dinámica, también se realizaron nuevas clasificaciones y se utilizaron algunos títulos nuevos. En este apartado se analiza el contenido de cada título del activo para los ejercicios contables posteriores al $1924^{908}$ para poder ser comparadas con las partidas del intervalo de estudio de esta investigación. Es necesario destacar que desde julio de 1924 se produce una asociación con el Estado, y que muchas cuentas reflejan esta relación tan trascendental.

A partir de 1924, existieron nuevos títulos de activo. El principal es el "Gasto de la construcción y del material", que puede ser clasificado, según su naturaleza, en cuatro partidas: "Construcción de las líneas y sus dependencias", "Material Móvil", "Cuenta de material destruido" y "Material inventariado, mobiliario, herramientas, etc."

El "Gasto de la construcción y del material" también puede descomponerse en dos conceptos: "Gastado por la compañía", que incluye los anticipos por ser dinero tomado a préstamo por la empresa y que lo paga con intereses y "Aportado por la Caja Ferroviaria o el Estado"; la diferencia entre la aportación verdadera del Estado y el saldo de la cuenta "Aportado por la Caja Ferroviaria o el Estado" está reflejado en la cuenta "Diferencia de material destruido".

La partida Cartera de activo de NORTE estuvo integrada por "Títulos a disposición", "Valores afectos a la materialización de las reservas", "Valores afectos al fondo de previsión especial disponible (R. O. de 4 de mayo de 1927)" y "Fianzas y depósitos constituidos en las Cajas del Estado".

La partida de "Caja y Banqueros" -que representa el dinero en metálico y valores- está compuesta por cuatro subpartidas: "Saldo de la cuenta de caja", "Saldo de cuentas corrientes en bancos", "Remesas de las Pagadurías en camino" y "Remesas de las estaciones en camino".

\footnotetext{
${ }^{908}$ Estas cuentas son descritas por la propia sociedad (NORTE, 1940: 461-578). Véase también un análisis comparativo de las cuentas de personal de NORTE en Martínez Vara (2003a: 362).
} 
El "Saldo de la cuenta de caja" refleja la existencia de dinero en la caja Central y en las siete Pagadurías al fin del ejercicio, descontando el metálico afecto a Materialización de reservas y al fondo de previsión especial disponible.

El "Saldo de cuentas corrientes en bancos" es el saldo de cuentas corrientes en las Centrales y Sucursales de los Bancos de España, Vizcaya, Bilbao, Internacional de Industria y comercio, Previsores del Porvenir y Castilla, Santander y Mercantil, Arnús Garí, Hispano Colonial, Magín Valls y Paris et des Pays Bas.

La subpartida "Remesas de las Pagadurías en camino" incluye los ingresos realizados por las estaciones durante los últimos días de diciembre del año en los bancos y que, por no figurarlos hasta enero del año siguiente, se registran provisionalmente a esta cuenta.

La subpartida "Remesas de las estaciones en camino" representa el importe de las recaudaciones de estaciones enviadas a las pagadurías en los últimos días de diciembre de cada año y que no figura en los ingresos en Caja hasta los primeros días de enero.

Entre las "Cuentas deudoras" se encuentran cinco epígrafes: "Intervención de la cobranza, cuenta corriente", "Fianzas y depósitos constituidos en las Cajas del Estado", "Atrasos por exceso de la jornada de ocho horas", "Quebranto de emisión de obligaciones" y "Deudores varios".

En la subpartida "Intervención de la cobranza, cuenta corriente" figuran varias partidas correspondientes a diferentes conceptos del servicio de Intervención, siendo la más importante de ellas la de "Transportes por cuentas del Estado". En esta última aparecen cantidades que se adeudan a la compañía por el Estado, por ser facturas de transporte de cadáveres -como el de la Infanta Pilar-, de viajes -como los de Martínez Campos-, de repatriados -como los de Cuba y Filipinas-, de correspondencia pública, etc.

El epígrafe "Fianzas y depósitos constituidos en las Cajas del Estado" estaba constituido por un conjunto de otras muchas cuentas pertenecientes a cinco grupos. En el primero figurarán las fianzas para recursos, contra liquidaciones sobre beneficios y utilidades y para reclamaciones contra ayuntamientos. Las del segundo están formadas por el depósito efectuado para la concesión del ferrocarril de San Martín de Provensals a Llerona, en sustitución al que tenía constituido la Sociedad Catalana de Crédito, primitiva concesionaria de tal línea. En el tercer grupo se incluyen los depósitos y fianzas consignadas en la Caja General a disposición de distintos juzgados para garantizar las responsabilidades civiles de la compañía que puedan derivarse en las causas seguidas contra agentes por accidentes (guardabarreras, por arrollamiento de carros y automóviles, maquinistas por accidentes, choques, etc.). En las del cuarto grupo se figuran los libramientos a favor de Procuradores para entablar recursos contra reclamaciones, principalmente de obreros, pero también de otros sujetos; los de fianzas por teléfonos; restos de fianzas abandonadas por contratistas y suministradores. Para concluir, en el quinto grupo están incluidos los depósitos constituidos por la compañía en la "Cámara acorazada de Barcelona", y de los que sólo se exige en los 
centros oficiales, como fianzas para determinados asuntos, el resguardo acreditativo de que la compañía tiene hecho en sus Cajas el oportuno depósito. Los valores que constituyen las fianzas y los depósitos estaban sometidos, además de a las contingencias de su valor intrínseco, a las consecuencias de los expedientes o reclamaciones por los que se hallan depositados.

La subpartida "Atrasos por exceso de la jornada de ocho horas" incluye la parte de los atrasos que había que cargar a la explotación en anualidades, que se efectuaba el rembolso de las sumas recibidas para su pago.

La partida "Quebranto de emisión de obligaciones" recoge todos los quebrantos o pérdidas sufridos por la compañía en las diversas emisiones de sus obligaciones.

La subpartida "Deudores varios" está formada por los siguientes conceptos:

- "Deudores varios de Divisiones y Servicios".

- "Anticipos a varios".

- "Anticipos al personal".

- "Reclamaciones e investigaciones".

- "Deudores por uniforme".

- "Servicio de almacenes".

- "Operaciones a liquidar".

- "Compañías combinadas".

- "Haberes del personal comprendido en el Decreto de 4 de julio de 1931”.

- "Sociedad Inmobiliaria Valenciana".

- "Economato: cuenta general".

- "Barruelo: Cuenta de adquisición de Surroca".

- "Barrruelo: Cuenta de crédito".

- "Delegación de las Compañías en el Consejo Superior de Ferrocarriles".

- "Descuento a los obligacionistas por arbitrio municipal".

- "Parte del empréstito Alar para horas extraordinarias".

- "Cuenta de crédito sin interés del Central de Aragón".

- "Deudores varios".

- "Mitad insuficiencia de la línea Puigcerdá a cargo del Estado".

- "Gastos de emisión de bonos de tesorería".

La subpartida "Deudores varios de Divisiones y Servicios" incluye las partidas pendientes de regularización o cobro en las distintas Divisiones o Servicios de la compañía.

La subpartida "Anticipos a varios" recoge los anticipos realizados por Caja a diferentes oficinas o Servicios de la compañía.

La subpartida "Anticipos al personal" recoge los anticipos realizados por Caja a los trabajadores de NORTE. 
La subpartida "Reclamaciones e investigaciones" incluye los libramientos expedidos a favor de procuradores y particulares para el pago del principal en los pleitos promovidos contra la compañía por reclamaciones.

La subpartida "Deudores por uniforme" recoge los derechos de cobro por la ropa de trabajo.

La subpartida "Servicio de almacenes" incluye cantidades pendientes de cobrar a la compañía por transporte y desembolsos de almacenes y compradores de material.

La subpartida "Operaciones a liquidar" importa los débitos por operaciones al cierre de un ejercicio contable, a regularizar en el siguiente ejercicio.

La subpartida "Compañías combinadas" recoge los saldos deudores de los Servicios combinados con otras compañías.

En la subcuenta "Haberes del personal comprendido en el Decreto de 4 de julio de 1931" se incluyen los derechos de cobro -no cobrados al cierre del ejercicio- correspondientes al personal regulado en el Decreto de 4 de julio de 1931.

La subpartida "Sociedad Inmobiliaria Valenciana" hace referencia a la venta a la inmobiliaria por NORTE de 8.412 obligaciones de Utiel -primera hipoteca- a 35 pesetas cada una, según acuerdo del Consejo de Administración, de 30 de diciembre de 1925.

La subpartida "Economato: cuenta general" recoge las cantidades que debe el economato a la compañía por mobiliario, enseres, mercaderías, portes y otros conceptos. Los derechos de cobro se refieren a documentos a pagar, impuestos para el tesoro, acreedores por ventas a plazos y otros conceptos.

La subpartida "Barruelo: Cuenta de adquisición de Surroca" incluye los derechos de cobro derivados de la cesión de las Minas de Surroca. Por medio de la escritura otorgada en Madrid en 18 de febrero de 1926, se hizo cesión de las Minas de Surroca, por NORTE a Barruelo, creándose y entregándose a NORTE 244 bonos de adquisición, de 5.000 pesetas cada uno. En total fueron 1.220.000 pesetas en que se valoraron las concesiones (muebles e inmuebles de Surroca). Los bonos habían de amortizarse anualmente con los beneficios que producían las propias minas de Surroca.

La subpartida "Barrruelo; Cuenta de crédito" recoge el saldo del derecho de cobro existente al cierre del ejercicio contable por el crédito concedido por NORTE a la empresa Barruelo. Según el acuerdo del Comité ejecutivo de la Compañía, de 7 de septiembre de 1932, se concedió un crédito de 5 millones de pesetas, con el interés legal del 5\% anual, liquidable por trimestres, a la Sociedad Barruelo por ejecución de obras en las minas. 
La subpartida "Delegación de las Compañías en el Consejo Superior de Ferrocarriles" incluye los pagos realizados por el Servicio de Caja de NORTE por documentos de la Delegación. Los créditos fueron por la participación en los gastos de la oficina de Barcelona y de participación en los gastos del Tribunal Central del Trabajo Ferroviario.

El importe en el Balance del epígrafe "Descuento a los obligacionistas por arbitrio municipal" refleja la diferencia entre el importe satisfecho por la compañía y lo descontado por cupones de vencimiento. Se refiere al importe satisfecho por NORTE durante un ejercicio contable a diversos ayuntamientos por arbitrio municipal en cupones y obligaciones, que procede descontar a los tenedores durante el ejercicio siguiente, y lo pendiente de descuento del ejercicio contable que se cierra, como consecuencia de haberse suspendido la amortización de obligaciones.

La subpartida "Parte del empréstito Alar para horas extraordinarias" recoge la cantidad ya amortizada de la parte del empréstito Alar-Santander que se afectó al pago de los atrasos de la implantación de la jornada de ocho horas.

La cifra que recoge la subpartida "Cuenta de crédito sin interés del Central de Aragón" es el importe de la cuenta de crédito abierta por NORTE en el Banco de España de Madrid con garantía de obligaciones propiedad de NORTE de la emisión del Central de Aragón 6\%, año 1931, por un importe de 10 millones la cuenta, siendo de 25 la garantía. Dicha cuenta fue cedida sin interés al Central de Aragón.

La subpartida "Deudores varios" estuvo integrada en el periodo 1924-1941 por importes sobre ayuntamientos, diferencias de cambio sobre francos percibidos en Irún por cuenta de la Compañía Midi, empresas anunciadoras, empresas de alquiler de almohadas, CAMPSA, Gas Madrid, Ministerio de Fomento, Pescaderías Coruñesas, Hullera Española, sumas por cobrar de la Caja Ferroviaria por mobiliario, máquinas, herramientas y por obras menores de primer establecimiento.

La subpartida "Mitad insuficiencia de la línea Puigcerdá a cargo del Estado" recoge los derechos de cobro por la explotación de la línea. El Estado, según el contrato establecido en 2 de septiembre de 1929, debe satisfacer la mitad de la insuficiencia habida en la explotación de la línea.

El saldo de la subpartida "Gastos de emisión de bonos de tesorería" corresponde a los conceptos de propaganda, firma de títulos y comisiones a favor de bancos, derivados de la emisión de 25 millones de bonos de tesorería.

\subsection{Examen de las partidas integrantes del Pasivo hasta 1924}

La partida "Acciones" representa el valor nominal de las acciones que constituyen el capital social de la compañía. Esta partida se constituyó a medida que la ampliación de las 
concesiones y adquisiciones de líneas lo hacía necesario. El cuadro 56 muestra las acciones emitidas por NORTE al cierre del ejercicio 1923. Todas estas acciones tienen un valor nominal de 475 pesetas o 500 francos, por lo que no se emitieron diferentes series de acciones.

Cuadro 56. Acciones emitidas por NORTE al cierre del ejercicio 1923

\begin{tabular}{|l|c|c|c|}
\hline \multicolumn{1}{|c|}{ FECHA DE EMISIÓN } & $\begin{array}{c}\text { NÚMERO DE } \\
\text { ACCIONES }\end{array}$ & $\begin{array}{c}\text { VALOR NOMINAL } \\
\text { DE CADA ACCIÓN }\end{array}$ & $\begin{array}{c}\text { VALOR NOMINAL } \\
\text { DE LA EMISIÓN }\end{array}$ \\
\hline $\mathbf{2 7}$ de enero de 1859 & 200.000 & 475 & 95.000 .000 \\
\hline $\mathbf{1 5}$ de marzo de 1878 & 100.000 & 475 & 47.500 .000 \\
\hline $\mathbf{1}$ de julio de 1882 & 50.000 & 475 & 23.750 .000 \\
\hline 30 de abril de 1890 & 40.000 & 475 & 19.000 .000 \\
\hline 30 de abril de 1891 & 100.000 & 475 & 47.500 .000 \\
\hline 25 de junio de 1902 & 26.000 & 475 & 12.350 .000 \\
\hline $\begin{array}{l}\text { Total acciones emitidas al } \\
\text { cierre de 1923 }\end{array}$ & $\mathbf{6 1 6 . 0 0 0}$ & & $\mathbf{2 4 5 . 1 0 0 . 0 0 0}$ \\
\hline
\end{tabular}

Fuente: Elaboración propia

La clasificación de la cuenta "Acciones" diferencia entre amortizadas y pendientes de amortizar; y en el supuesto que tengan garantías, debe diferenciarse según el nivel de garantía que concedan.

Las "Subvenciones" están clasificadas según lo establecido en los "Informes de la Comisión investigadora de la compañía del NORTE de 29 de noviembre de 1923", cumpliendo lo dispuesto en el artículo 4 del Real Decreto de 20 de octubre de 1922.

En cuanto al capítulo de "Reservas", si bien en cualquier compañía mercantil era común constituir un fondo para cubrir futuras inversiones, propiciando así la autofinanciación de la empresa, en las compañías de ferrocarriles era de obligatoria dotación con el fin de amortizar las acciones en que se dividía el capital antes de dar cumplimiento al compromiso de reversión de los activos de la línea férrea al Estado cuando la concesión era de carácter temporal.

Como aspecto negativo debemos señalar que en esta rúbrica de Reservas se incluían algunas cuentas que no obedecían a la naturaleza de reservas en sentido estricto, como era el caso de los fondos de amortización y la dotación de provisiones para obras de mejora. Podemos afirmar que ambas partidas estaban indebidamente incluidas dentro de este apartado. Además, ninguna de estas dos partidas se reflejaba como gastos de la explotación. Si unimos este hecho a lo comentado para el caso de la amortización de obligaciones, también podemos afirmar que existía una cierta confusión en cuanto a la presentación de la información financiera dentro de la masa de Pasivo. 
Lo que más destaca positivamente de la estructura del pasivo NORTE es que establece un régimen de disponibilidad de reservas, distinguiendo tres partidas: disponibles, indisponibles y parcialmente disponibles.

La partida "Reservas" se descompone en nueve conceptos: "Resultados obtenidos por la aplicación del artículo tercero del Convenio de 31 de mayo de 1900", "Reserva especial estipulada por el artículo quinto del Convenio de 31 de mayo de 1900" "Reserva de previsión", "Fondo para amortización de material" "Reserva para gastos de conservación extraordinaria y mejora de instalaciones", "Reserva de seguro para incendios", "Fondo de previsión para créditos incobrables y reclamaciones en litigio", "Pensiones de retiro" y "Reservas diversas".

La reserva "Resultados obtenidos por la aplicación del artículo $3^{\circ}$ del Convenio de 31 de mayo de 1900" aparece por primera vez en el pasivo de NORTE en 1902. El artículo $3^{\circ}$ del Convenio de 31 de mayo de 1900 -que entró en vigor el 8 de agosto de 1901- facultó al Consejo de la compañía para comprar en Bolsa durante cinco años, a contar desde 1 de julio de 1900, un número de títulos fijados en los cuadros de amortización. En el Convenio aparecía establecido que era obligatorio que el resultado que resulte de la diferencia entre el importe de la amortización a la par, de 500 francos, y el gasto efectivo de las compras, se destinara a completar la reserva especial prevista en el artículo $5^{\circ}$ (12 millones de pesetas). Además, estaba establecido que el sobrante se aplicará a la constitución de una segunda reserva para nuevas obras y adquisición de materia móvil.

La subpartida "Reserva especial estipulada por el artículo quinto del Convenio de 31 de mayo de 1900" responde al compromiso contraído por la compañía con sus obligacionistas en virtud del Convenio aprobado por los Tribunales el 9 de agosto de 1901, y cuyo artículo $5^{\circ}$ disponía que se destinase una suma de doce millones de pesetas afecta exclusivamente a completar hasta su total pago el cumplimiento del servicio de cupones y de la amortización de los Títulos u obligaciones pagaderos en el extranjero. Aparece por primera vez en el balance de 1901 con un valor de 12 millones, sin que hubiera existido variación posterior durante el periodo analizado. En ese momento recoge el traspasado de la cuenta "Remanente de los productos de 1899", que figuraban como "Cantidades en litigio", sin haber tenido necesidad de ser completada esta reserva con las compras en bolsa establecidas en el artículo $5^{\circ}$ del Convenio.

La "Reserva de previsión" se dotó para protegerse de cualquier eventualidad que se produjeran en las costosas obras de mejora y adquisición de toda clase de material previstas por NORTE. Se constituyó en cumplimiento del artículo 34 de los Estatutos de la compañía, y se destinaba a gastos imprevistos, pudiendo aplicarse, según el artículo 35 de los Estatutos, a completar el fondo de amortización de las acciones, caso de que en uno o más años, los productos líquidos de la empresa fueran insuficientes para asegurar el reembolso de los mismos. 
La subpartida "Fondo de reserva para la amortización de material" se dividía en dos conceptos: para material fijo ${ }^{909}$ y para material motor y móvil. Aparece como reservas desde 1911, habiendo sido incluida hasta esa fecha dentro de las "Cuentas acreedoras". Se basaba en un acuerdo del Consejo de Administración ${ }^{910}$, aunque en tal acuerdo sólo se autorizaba que se consignase en el grupo de reservas la cifra de la cuenta que viene figurando en el grupo de "Cuentas acreedoras", con la asignación de "Reservas para amortización de material". No obstante, a partir de 1912, se aumenta su dotación con una nueva función con aplicación a estas cuentas; se carga el valor de los materiales que desaparecen por el uso, a fin de conservar las instalaciones de Primer establecimiento con el valor que tiene en el Balance. Por lo que a material fijo se refiere, estas aplicaciones no se realizan, pues se llevan a cuenta de explotación los gastos procedentes de las renovaciones de vías. En material motor y móvil también resulta exigua la cantidad aplicada, por lo que son las grandes reparaciones de material las que alargan la vida de máquinas, coches y vagones.

La constitución de la subpartida "Reserva para gastos de conservación extraordinaria y mejora de instalaciones" tiene su origen en el acuerdo de la Junta General de Accionistas de 11 de mayo de 1907. Su objetivo era exclusivamente la mejora y conservación de instalaciones. Fue constituida con parte del excedente de productos de 1906, y se hicieron aplicaciones a ella, principalmente, para costear la sustitución y refuerzo de puentes. Las aplicaciones fueron suspendidas a partir del ejercicio 1919 porque se satisfacían estos gastos con cargo a la cuenta de explotación, detrayendo el saldo de las mismas.

La subpartida "Reserva de seguro para incendios" estaba constituída para hacer frente a las pérdidas que pueden ocasionar los siniestros cuya importancia exceda de las coberturas contratadas con las compañías aseguradoras de incendios. La subpartida "Reserva para seguros de incendios" aparece registrada como reserva desde 1886, habiendo sido incluida hasta esa fecha dentro de las "Cuentas acreedoras".

La subpartida "Fondo de previsión para créditos incobrables y reclamaciones en litigio" aparece por primera vez en el balance de 1911. Su importancia se deriva de que es considerada por la compañía como imprescindible en una "administración bien ordenada como la de NORTE" $" 911$.

La subpartida "Pensiones de retiro" se dotaba para realizar el pago de las pensiones de las familias de sus agentes. El 25 de junio de 1873, NORTE tomó el acuerdo de crear una "Caja de Retiros para el Personal" con cargo a los productos de la explotación. La cantidad se fijó en el $5 \%$ de los haberes del personal, con cuyo capital, incrementado con los intereses, atendería la compañía a las exigencias de los retiros, destinando el sobrante a aumentar el saldo del año siguiente. "Fue un acto espontaneo de NORTE" (NORTE, 1940: 386), en un periodo anterior al

\footnotetext{
${ }^{909}$ En el material fijo se incluyen los siguientes conceptos: carriles, agujas, puntas de corazón y otros elementos para cruces, cambios de vías y desvíos, contracarriles y cremalleras, traviesas, piezas para la colocación y unión o fijación de carriles.

910 Acta 773 Consejo de Administración de NORTE, 31 de mayo de 1910.

911 Acta 773 Consejo de Adinistración de NORTE, 31 de mayo de 19010.
} 
sindicalismo y al auge de las cuestiones obreras. Como existía una desproporción entre los ingresos de dicha Caja de Retiros (5\% del sueldo de los agentes) y los gastos (las pensiones), el saldo fue aumentando considerablemente hasta llegar en 1898 a 10.601.702,52 pesetas. Desde 1898 hasta 1932, el importe que figura en el balance permaneció invariable, porque NORTE consideró que este saldo "era suficiente para atender cualquier eventualidad como garantía de las pensiones de retiro" (NORTE, 1940: 386). Por tanto, hasta 1932 figuró en el pasivo de NORTE la reserva de pensiones de retiro por importe de 10.601.703,52 pesetas. Desde 1933 se englobó esta cuenta, junto a otras en la de "Reservas constituidas con anterior al ingreso en el Régimen ferroviario". Esta dotación es un ejemplo por el que podemos afirmar que NORTE no sólo realizó los registros contables para cumplir con el objetivo legal, y formal, sino que desde el principio de su existencia realizó apuntes contables para mejorar el sistema de información, sin que estuviese obligado a ello por ninguna legislación. Esta dotación fue un acto espontáneo de la compañía, en un periodo anterior al sindicalismo y al auge de las cuestiones obreras.

Por último, la subpartida "Reservas diversas" estaba constituida por las siguientes tres cuentas: "Crédito abierto para mejora de las líneas de Alsasua, Zaragoza y Barcelona", "Reserva para resultados eventuales de Asturias, Galicia y León" y "Reserva para gastos imprevistos".

La partida "Cuentas acreedoras" se descompone en trece conceptos: "Fianzas", "Cupones y obligaciones a pagar", "Accionistas (acreedores de bonos de liquidación de Asturias, Galicia y León)", "Acreedores varios", "Excedentes de productos de la explotación", "Dividendos acordados pendientes de reparto", "Cupones y obligaciones a pagar", "Obligaciones amortizadas y prescritas de vencimiento pasado", "Intereses corridos sobre cupones y anualidades por vencer", "Bonos complementarios de intereses y amortización rembolsables a la aprobación del Convenio de 31 de mayo de 1900", "Diferencia de precio sobre acciones no adheridas de Lérida, Reus y Tarragona" y "Comisión permanente de obligacionistas de Tudela a Bilbao".

La subpartida "Fianzas" incluye las cantidades depositadas en metálico por los expedidores de mercancías a porte debido, que por su índole, puedan sufrir deterioro y ser rechazadas, o no retiradas, por los receptores sin satisfacer los portes. La partida "Fianzas" estaba constituida por dos partidas: "Fianzas definitivas, en metálico" y "Fianzas provisionales, en metálico". Ambas representan las fianzas que los mozos del exterior -proveedores y contratistas- tenían depositadas en la Cajas de la compañía para responder de los suministros a efectuar, de los trabajos a realizar o de la función a desempeñar.

La subpartida "Accionistas (acreedores de bonos de liquidación de Asturias, Galicia y León)" representa el derecho de los accionistas poseedores de las acciones números 1 a 350.000, a canjear el cupón número sesenta por $1 / 25$ de bono de los creados al incorporarse definitivamente a la red de NORTE las líneas de Asturias, Galicia y León, para liquidar las cuentas existentes en aquella fecha entre las dos empresas. 
La cifra que figuraba en la subpartida "Acreedores varios" representaba el saldo acreedor de treinta y dos cuentas representativas de impuestos para el Tesoro devengados a la fecha del balance, y libramientos pendientes de pago por los distintos servicios de la explotación y almacenes. La existencia de dichos saldos tiene su origen en la imposibilidad de formalizar los gastos en la fecha de cierre.

La subpartida "Excedentes de productos de la explotación" representa los beneficios cuya aplicación o reparto no ha sido dispuesto por la Junta General de accionistas a fecha de cierre.

La partida "Dividendos acordados pendientes de reparto" representaba el dividendo acordado por la Junta con cargo a los beneficios del año anterior, que todavía no ha sido satisfecho a los accionistas.

La partida "Cupones y obligaciones a pagar" estaba formada por nueve conceptos:

- Cupones vencidos por pagar.

- Obligaciones amortizadas por rembolsar.

- Cupones vencidos sobre valores en custodia.

- Obligaciones amortizadas sobre valores en custodia.

- Obligaciones amortizadas y prescritas, de vencimiento pasado.

- Intereses corridos sobre cupones y anualidades por vencer.

- Bonos complementarios de intereses y amortización rembolsables a la aprobación del Convenio de 31 de mayo de 1900".

- Diferencia de precio sobre acciones no adheridas de Lérida, Reus y Tarragona.

- Comisión permanente de obligacionistas de Tudela a Bilbao.

La subpartida "Obligaciones amortizadas y prescritas de vencimiento pasado" incluía las obligaciones prescritas para su rembolso, pero que la compañía, a pesar de transcurrir el plazo marcado por la Ley para la prescripción, las incluía en sus cuentas, "y aún haciendo pagos sobre ellas, cuando sus tenedores alegan ciertos derechos para el cobro" (NORTE, 1940: 548).

La subpartida "Intereses corridos sobre cupones y anualidades por vencer" se refiere a los intereses de las distintas emisiones, "de vencimientos muy variables, que van corridos a fecha de balance” (NORTE, 1940: 548).

La subpartida "Bonos complementarios de intereses y amortización rembolsables a la aprobación del Convenio de 31 de mayo de 1900" se deriva del citado Convenio, que entró en vigor el 8 de agosto de 1901 -fecha de su aprobación-, aunque sus efectos se retrotraían al 30 de junio de 1900. En el periodo de tiempo entre ambas fechas, el reembolso de los títulos amortizados y el pago de los intereses correspondientes a los vencimientos se hacían en metálico. La diferencia entre el importe que se pagaba y el valor que se reconocía a los títulos y cupones, por el artículo 2 del Convenio de 31 de mayo de 1900, se liquidaba entregando unos bonos que podían ser efectivos después de aprobarse el Convenio. La partida "Bonos complementarios de intereses y amortización rembolsables a la aprobación del Convenio de 31 de mayo de 1900" recogía la diferencia entre estos dos importes. A partir del 8 de agosto 
de 1901 se fueron presentando al cobro los bonos, produciéndose desde entonces el cargo cada vez que se efectuaban pagos de esta clase.

La subpartida "Diferencia de precio sobre acciones no adheridas de Lérida, Reus y Tarragona" procede de la fusión de con esta línea (L. R. T.). Las condiciones por las que NORTE entró a tomar posesión de aquella línea fueron: reconocer todo su valor (475 pesetas) a las antiguas acciones y ofrecer a los titulares de las acciones que se adhirieran al Convenio que NORTE celebró con L. T. R., un interés fijo, un plazo de amortización y el derecho de reembolso a razón de 500 pesetas o francos. De esta forma, las acciones adheridas quedaban convertidas en obligaciones de NORTE, y las no adheridas eran consideradas como acciones especiales de NORTE, cuyo derecho se limitaba a los resultados de la línea L. T. R.

Para determinar el coste de la línea L.R.T. se abonó a la cuenta de su primer establecimiento el importe de las 50.000 acciones que las reconocía al adherirse con crédito a Acciones de L. R. T.

Para las acciones adheridas el asiento a realizar es el siguiente:

\begin{tabular}{lll|l}
$500 \quad$ pesetas & DEBE & HABER & \\
$\begin{array}{l}\text { por acción }\end{array}$ & & Acciones de L. R. T. & $\begin{array}{l}500 \text { pesetas por } \\
\text { acción }\end{array}$
\end{tabular}

Para las acciones no adheridas el asiento a realizar es el siguiente:

\begin{tabular}{|c|l|l|}
$\begin{array}{c}500 \text { pesetas } \\
\text { por acción }\end{array}$ & $\begin{array}{l}\text { DEBE } \\
\text { establecimiento }\end{array}$ & Acciones de L. R. T. \\
& $\begin{array}{l}\text { Diferencia de precio sobre acciones no } \\
\text { adheridas de L. R. T. }\end{array}$ & $\begin{array}{l}475 \text { pesetas por } \\
\text { acción } \\
25 \text { pesetas por } \\
\text { acción }\end{array}$ \\
\hline
\end{tabular}

A medida que se iban adhiriendo las acciones, se procedía a establecer el siguiente asiento:

\begin{tabular}{lll|l} 
& DEBE & HABER & \\
$25 \quad$ pesetas & Diferencia de precio sobre acciones no & Acciones de L. R. T. & $\begin{array}{l}25 \text { pesetas por } \\
\text { acción }\end{array}$ \\
por acción & adheridas de L. R. T.
\end{tabular}

La subpartida "Comisión permanente de obligacionistas de Tudela a Bilbao" se deriva de la conversión en obligaciones de la tercera serie de las acciones de la Compañía de Tudela a Bilbao. Como consecuencia de la conversión, las acciones quedaron anuladas, y los antiguos accionistas se constituyeron en Comisión permanente de obligacionistas de tercera serie de Tudela a Bilbao, encargada de la liquidación de la compañía. De los fondos disponibles que resultan en la liquidación, se destinaba una cantidad $(0,25$ pesetas por título) para satisfacer parte del impuesto que devengan los cupones de dichas obligaciones. Las sumas que entrega la Comisión por este concepto (créditos) y lo que NORTE paga a los obligacionistas (débitos) 
se registran en la cuenta "Comisión permanente de obligacionistas de Tudela a Bilbao", que da un saldo acreedor.

Por último, la partida "Cuentas de orden" se descompone en dos conceptos: "Anticipos del Estado para complemento de haberes" y "Valores nominales".

La cifra de la subpartida "Anticipos del Estado para complemento de haberes" representaba la obligación contraída por la compañía para con el Estado de reintegrarle su importe cuando los beneficios excedan del importe de los beneficios obtenidos en 1913.

La subpartida "Valores nominales" es la contrapartida de la cuenta de activo de mismo nombre. Representaba el valor de los efectos en cartera y de los depositados en los bancos para su custodia o en garantía de cuentas de crédito.

\subsection{Examen de las partidas integrantes del Pasivo a partir de 1924}

A partir de 1924 se continuan empleando la mayoría de cuentas y títulos utilizados hasta entonces, pero también se incorporaron algunos nuevos. En este apartado se analiza el contenido de cada nuevo título del pasivo para los ejercicios contables posteriores al $1924^{912}$, fecha trascendental porque desde julio de 1924 se produce una asociación con el Estado.

La partida “Aportación del Estado conforme al R.D. de 12 de julio de 1924" tiene su origen en la entrada de la Compañía en el Régimen ferroviario que estableció el Real Decreto-Ley de 12 de julio de 1924. Su planteamiento, incidencia, tramitación y determinación de los conceptos del valor real del establecimiento y del capital real del concesionario fue transcendental. El Real Decreto-Ley de 12 de julio de 1924 planteaba a las compañías ferroviarias la cuestión de decidir si iban o no a solicitar su ingreso en el régimen ferroviario, acogiéndose a los beneficios de la Caja Ferroviaria, o prescindiendo de los mismos. Al igual que todas las compañías, si NORTE no se acogía se le suprimiría tanto el recargo del $15 \%$ en las tarifas como los anticipos para pagos de una parte de los haberes del personal. En ese caso no podría contar, por tanto, con más ingresos que los procedentes de la aplicación de las tarifas, "insuficientemente remuneradas" (NORTE, 1940: 515) según la compañía. Si, por el contrario, NORTE se acogía, tendría que aceptar las obligaciones y limitaciones que le imponía el nuevo régimen ferroviario, perdiendo su libertad de acción, al entrar en "una verdadera asociación con el Estado" (NORTE, 1940: 515). La Junta general extraordinaria de accionistas de NORTE de 4 de octubre de 1924 acordó el ingreso de la compañía en el nuevo régimen ferroviario, solicitándolo el 10 de octubre de 1924.

La partida "Diferencia de material destruido" estaba relacionada con las partidas "Aportado por la Caja Ferroviaria o el Estado" y con la de "Acopios". El "Gasto de la construcción y del material" se descomponía en dos conceptos: "Gastado por la compañía", que incluía los

\footnotetext{
${ }^{912}$ Estas cuentas son descritas por la propia sociedad en NORTE (1940: 461-578). Véase también un análisis comparativo de las cuentas de personal de NORTE en Martínez Vara (2003a: 362).
} 
anticipos de dinero tomado a préstamo por la empresa y que lo pagaba con intereses y "Aportado por la Caja Ferroviaria o el Estado"; la diferencia entre la aportación verdadera del Estado y el saldo de la cuenta "Aportado por la Caja Ferroviaria o el Estado" estaba reflejado en la cuenta "Diferencia de material destruido". Igualmente, la partida "Diferencia de material destruido" estaba relacionada con la de "Acopios". Cuando la empresa compraba un elemento de activo no corriente con cargo a la aportación del Estado por un importe, por ejemplo un vagón de 1.000 pesetas, NORTE registraba un activo en la cuenta "Material móvil" de 1.000 pesetas y un pasivo en la cuenta "Aportación del Estado" por el mismo importe. Si en un choque se destruía el vagón, se debía dar de baja la cuenta "Material móvil" por 1.000 pesetas, dando de alta por el mismo el importe la cuenta "Material destruido"; la cuenta de pasivo "Aportación del Estado" se mantiene invariable. Si este vagón destruido se recogen piezas utilizables, por valor de 50 pesetas y la compañía, en vez de ponerlas a disposición del Estado (devolvérselas, porque del Estado son), las ingresa en el parque de Acopios, entonces el registro debe ser un aumento de la cuantía de "Acopios" en 50 pesetas, disminuyéndolas en la cuenta del "Material destruido"; tras todos estos movimientos la cuenta de pasivo "Aportación del Estado" se mantenía invariable.

A partir del año 1933, NORTE agrupó en una partida, denominada "Reservas constituidas con anterioridad al ingreso de la compañía en el actual régimen ferroviario", el saldo de todas las cuentas de reservas incluidas en los balances anteriores al balance 1932. Estas reservas existentes hasta el año 1932 eran las siguientes: "Reserva especial estipulada en el artículo $5^{\circ}$ del convenio de 31 de mayo de 1900", "Fondo de reserva para la amortización del material", "Reserva para gastos de conservación y mejora de las instalaciones", "Reserva para seguros de incendios", "Fondo de previsión para créditos incobrables y reclamaciones en litigio" y "Reserva de previsión".

Igualmente, en esta cuenta recién creada, NORTE incluyó algunas partidas que habían sido registradas hasta entonces como pasivo. Hasta 1932, la cuenta "Caja de Retiros para el Personal" figuró en el pasivo de NORTE, por un importe de 10.601.703,52 pesetas estando dotada para garantizar las pensiones de retiro. Desde 1933 se englobó esta cuenta con otras varias en la de "Reservas constituidas con anterior al ingreso en el Régimen ferroviario".

La Junta General de Accionistas de NORTE, de 21 de mayo de 1927 acordó destinar -del beneficio del año 1926- una reserva denominada "Fondo de previsión especial disponible conforme a la R.O. de 4 de mayo de 1927", dedicada especialmente a la regularización de dividendos y a hacer frente a cualquier contingencia que pudiera reflejarse en los resultados de la explotación de la red. La R.O. de 4 de mayo de 1927 estableció que la disposición relativa a la inmovilización de las reservas a la que se refería la R. O. de 27 de junio de 1925, afectaba únicamente a aquellas que las compañías tenían constituidas en la fecha de su ingreso en el nuevo Régimen ferroviario, pero no a las que constituyeran posteriormente. Las que se constituyeran posteriormente, tienen el origen en la dotación voluntaria de una parte de los resultados positivos, por los que las compañías podrían disponer libre y voluntariamente para aplicarlos a los fines que desearan. Por el contrario, las reservas a las que se refería la R. 
O. de 27 de junio de 1925 -las que tenían constituidas en la fecha de su ingreso en el nuevo Régimen ferroviario- eran indisponibles.

En la partida "Acreedores varios" se recogen diecisiete subpartidas:

- Impuestos del Tesoro sobre acciones y obligaciones.

- Servicio de Almacenes, cuenta corriente.

- Deudores varios de Divisiones y Servicios.

- Créditos del personal.

- Acreedores varios por retenciones judiciales.

- Impuesto de utilidades sobre sueldos.

- Ferrocarril de Mediodía de Francia (Midi).

- Haberes del personal comprendido en el Decreto de 4 de julio de 1931.

- Compañías combinadas.

- Libramientos de la explotación.

- Documentos establecidos en favor del personal comprendido en el Decreto de 4 de julio de 1931.

- S.A. Minas de Barruelo, cuenta corriente.

- Reconstitución de la reserva Este-Norte.

- Impuesto del 1,3\% sobre pagos de la Caja Ferroviaria.

- Banco de España de Madrid, cuenta de crédito nº 22.410.

- Mutualidad N. M. B.

- Acreedores varios.

La subpartida "Impuestos del Tesoro sobre acciones y obligaciones" recogía las cantidades que al final del ejercicio se debían entregar a Hacienda por impuesto de utilidades -de beneficios- sobre importe de cupones por regularización de derechos reales.

La subpartida "Servicio de Almacenes, cuenta corriente" estaba originada casi en su totalidad por la diferencia de inventario.

La subpartida "Deudores varios de Divisiones y Servicios" tenía su origen, en su mayor parte, en cantidades pendientes de formalización.

La subpartida "Créditos del personal" estaba compuesta por cantidades que no se habían abonado al personal y que quedaban pendientes al final del ejercicio. Ellas corresponden a "Personal comprendido en el Decreto de 4 de julio de 1931" y, en mayor medida, a "Personal de la compañía".

La subpartida "Acreedores varios por retenciones judiciales" incluía las cantidades retenidas por orden judicial a los agentes, y que, al final del ejercicio contable, no se habían entregado a sus acreedores. 
La subpartida "Impuesto de utilidades sobre sueldos" recogía las cantidades descontadas al personal por tributos relacionados con sus sueldos y que estaban pendientes de entregar a Hacienda.

La subpartida "Ferrocarril de Mediodía de Francia (Midi)" era el resultado de las operaciones derivadas de la relación con la ferroviaria francesa Midi por compartir las fronteras de Irún y Canfranc. Tiene su origen en las liquidaciones del servicio combinado, los gastos de entretenimiento de vía y la energía eléctrica consumida con arreglo a los Convenios establecidos. Los gastos de entretenimiento de vías estaban regulados por el artículo 24 del Convenio de 8 de abril de 1864 entre Francia y España. En el citado artículo 24 aparece que "cada una de las empresas (NORTE y Midi) abonará a la otra el 6\% anual de la mitad del capital invertido en la construcción de la parte de camino de hierro comprendida entre la aguja de entrada en la estación y el estribo del puente de Bidasoa más próximo a dichas agujas" (este puente fue construido por cuenta de las dos empresas). Cada empresa aplicará sus tarifas propias a la línea que en la parte internacional le corresponda, sin que estas tarifas puedan en ningún caso exceder en el territorio del otro país del máximo concedido a la empresa extranjera en su respectivo contrato; percibirá los ingresos y cubrirá los gastos de tracción y explotación correspondiente a dicha línea. En este Convenio aparece especificado que NORTE será la encargada de las operaciones de conservar, reparar y vigilar la vía en la parte internacional. La de Midi de Francia le facilitará materiales para su vía. El coste de la mano de obra, de la conservación, reparación y vigilancia de las dos líneas se dividirá entre ambas empresas a prorrata kilométrica.

Por medio del Decreto de 4 de julio de 1931, el Estado obligó a NORTE a readmitir al personal despedido en huelgas anteriores, corriendo a cargo del Estado las sumas a pagar, bien sea, en unos casos, entregándoles una cantidad total como liquidación, en otros, admitiéndoles al trabajo y pagándoles sus sueldos o jornales, y en otros, jubilándoles. La subpartida "Haberes del personal comprendido en el Decreto de 4 de julio de 1931" refleja estas deudas por las cantidades pendientes de pagar.

La subpartida "Compañías combinadas" recoge las cantidades pendientes de pagar a otras empresas por servicio combinado de transporte.

La subpartida "Libramientos de la explotación" incorpora las cantidades a que ascienden los libramientos extendidos y formalizados por las distintas Divisiones y Servicios.

Como de todo lo que se deriva del cumplimiento del Decreto de 4 de julio de 1931 se lleva contabilización aparte, la partida "Documentos establecidos en favor del personal comprendido en el Decreto de 4 de julio de 1931" recoge las cantidades a que ascienden los libramientos extendidos y formalizados referidos exclusivamente a este personal.

La Sociedad Minas de Barruelo fue constituida el 19 de enero de 1922 como empresa independiente para explotar unas minas que hasta ese momento eran explotadas directamente por NORTE. Desde su constitución, las acciones de la Sociedad Minas de Barruelo estuvieron 
en su totalidad en poder de NORTE. Por esta razón, NORTE llevaba cuenta de los gastos, suplidos y suministros. La partida "S.A. Minas de Barruelo, cuenta corriente" recoge las deudas de NORTE con ella.

La subpartida "Reconstitución de la reserva Este-Norte" tenía su origen en el ejercicio económico 1923, cuando se traspasó su saldo de la antigua cuenta "Comisión liquidadora del Ferrocarril del Este". Esta cuenta junto con las seiscientos sesenta y ocho obligaciones de primera hipoteca de Utiel, que también se entregaron, constituía parte de la reserva que estipulaba el artículo $5^{\circ}$ del contrato de NORTE con la Compañía del Este y del artículo $9^{\circ}$ del Convenio de la Compañía del Este con sus acreedores.

El saldo acreedor de la subpartida "Impuesto del 1,3\% sobre pagos de la Caja Ferroviaria" correspondía a operaciones pendientes de regularización por la División de Vía y Obras.

La subpartida "Banco de España de Madrid, cuenta de crédito n 22.410" reflejaba el saldo de la cuenta de crédito número 22.410 abierta por NORTE en el Banco de España de Madrid. Esta cuenta fue abierta para hacer frente a las necesidades del Ferrocarril Central de Aragón, propiedad en su totalidad de NORTE. El importe inicial fue de 10 millones de pesetas, garantizado con una emisión de obligaciones por importe de 25 millones del Central de Aragón.

La Mutualidad N. M. B. (NORTE, MZA y Barruelo) se formó para asegurar el riesgo de incapacidad permanente o muerte, hacía la distribución anual entre las tres entidades de lo que a cada una corresponde pagar por sus accidentes propios. La cuenta "Mutualidad N. M. B." aparece en el pasivo de NORTE por la diferencia entre los créditos y débitos. En cada ejercicio contable aparecían como créditos en la "Mutualidad N. M. B." el importe de la aportación por accidentes y el de la aportación de la parte que a NORTE le corresponde en la formación del fondo de reserva exigido para la Mutualidad por la Caja de Seguros.

La subpartida "Acreedores varios" incluye, en sus diferentes momentos de la vida de NORTE, dieciocho cuentas que aparecieron en el pasivo de la empresa:

- “Asociación General de Empleados y Obreros de F. C.” representaba las cantidades a que asciendían los descuentos realizados por NORTE a los empleados y obreros, para su entrega a este organismo, actuando la compañía como banquero para ellas, sin lucro alguno y, prestándoles por tanto un servicio.

- "Caja de Socorros Mutuos de los interventores en ruta" recogía las cantidades a que ascendían los descuentos realizados por NORTE a los interventores en ruta, para su entrega al organismo, actuando la compañía como banquero para ellas, sin lucro alguno y, prestándoles únicamente un servicio.

- "La Unión, Sociedad de Maquinistas y Fogoneros" representaba las cantidades a que ascendían los descuentos hechos por NORTE a los maquinistas y fogoneros, para su entrega a las Sociedades, actuando la compañía como banquero para ellas, sin lucro alguno $\mathrm{y}$, prestándoles únicamente un servicio. 
- "La Maquinista Terrestre Marítima, Sociedad de Socorros y Retiros de Maquinistas y Fogoneros" incorpora las cantidades a que ascienden los descuentos hechos por NORTE a los maquinistas y fogoneros, para su entrega a los organismos, actuando la compañía como banquero para ellas, sin lucro alguno y, prestándoles únicamente un servicio.

- "Depósitos hechos para la construcción de apartaderos de diversas entidades".

- "Pago de cupones y reembolso de títulos amortizados con varios bancos".

- La cuenta "Cantidades a pagar por domiciliación de valores" recogía las comisiones que se pagaban a la presentación de títulos a domiciliar.

- La cuenta "Compañía de coches-camas" se abonaba por las averías en su material y algunos transportes, y se cargaba por el importe de alumbrado, suministros de carbón y reparaciones de vehículos.

- La cuenta "Cantidades pendientes de entrega a accionistas de la antigua Sociedad de Almansa" reflejaba el reembolso de obligaciones y cupones de acciones que no se habían hecho efectivas después del convenio con la empresa Almansa-ValenciaTarragona.

- La cuenta "Fianzas y sumas en concepto de penalidad" recogía las fianzas y depósitos de pasivo.

- "Depósitos constituidos en garantía de cupones que faltaban a títulos renovados".

- El importe de la cuenta "Intereses y reembolso de títulos depositados por fianzas" reflejaba el saldo a favor de varios depositantes por el valor de cupones vencidos y títulos amortizados que no les habían sido pagados.

- "Pensionistas (créditos atrasados)".

- El importe de la cuenta "Pagos en París a clasificar" recogía los documentos de pago expedidos por el Comité de París, a abonar en francos.

- La cuenta "Comisión liquidadora de la Caja de Socorros y Ahorros de Agentes ferroviarios" recogía el importe de recibos pendientes de pago a los agentes de la compañía que se hallaban en servicio a 30 de junio de 1926 y que correspondían al reparto de los 12 millones que establecía el R. D. de 13 de abril de 1927.

- La cuenta "Seguro obligatorio ferroviario" reflejaba la cantidad a liquidar con la Comisaría del Seguro obligatorio por el concepto de "billetes de funcionarios de la compañía y sus familiares" (NORTE, 1940: 387).

- La cuenta "Carnet ferroviario" representaba lo descontado al personal por este concepto y pendiente de pago a la Asociación.

- "Tasa del 3\% sobre tarifas ferroviarias".

Desde las cuentas anuales de 1929 aparecía en el pasivo la cuenta "Anticipo reintegrable entregado por la Caja Ferroviaria". Como consecuencia del Convenio Internacional de Washington -ratificado provisionalmente en España por el R.D. de 24 de mayo de 1918- se dictó el R.D. de 3 de abril de 1919, fijando en ocho horas diarias, o cuarenta y ocho semanales, la jornada máxima legal en toda clase de trabajos a partir del 1 de octubre de 1919. Las bases generales para la implantación de la jornada de ocho horas en ferrocarriles se establecieron en la R.O. de 17 de octubre de 1921. El pago de los atrasos se regularon por medio del Decreto-ley de 
13 de abril de 1927, y posteriormente por medio del R.D. de 2 de mayo de 1928. En este último aparecía que las compañías ingresarían el importe total de sus atrasos en metálico, pudiendo acudir a la Caja Ferroviaria para que ésta les anticipase los importes. Por este hecho se registraba un pasivo por el anticipo reintegrable entregado por la Caja Ferroviaria, integrado por el capital más los intereses.

A partir de 1924, NORTE incluía dentro de las Cuentas de orden dos novedades, siempre teniendo en cuenta que la partida principal continúa siendo el "Anticipo del Estado para complemento de haberes". La primera novedad es que se incluía una nueva subpartida "Cantidades recibidas del Estado para obras de enlaces ferroviarios". La segunda es que se incluía un número mayor de componentes en la subpartida "Valores nominales".

La cifra que figura en la cuenta "Cantidades recibidas del Estado para obras de enlaces ferroviarios" se refería exclusivamente, al importe de las obras ejecutadas en Barcelona para supresión de pasos a nivel en la calle Meridiana en la línea Barcelona-Zaragoza.

Dentro de los "Valores nominales" se incluían los siguientes ocho conceptos:

- "Fianzas de los señores administradores".

- La cuenta "Fianzas definitivas en valores" recogía el saldo acreedor que representaba el valor nominal de los títulos depositados en NORTE en concepto de fianzas.

- La cuenta "Fianzas provisionales en valores" incluía el saldo acreedor que representaba el valor nominal de los títulos depositados en las Cajas de NORTE para formar parte en concursos.

- La cuenta "Depositantes" recogía los depósitos que los particulares tenían efectuados en las Cajas de NORTE y en la Cámara Acorazada de Barcelona.

- La cuenta "Valor nominal de los títulos en cartera" recogía los valores depositados en bancos, propiedad de la compañía.

- El saldo de la cuenta "Valores para entregar a antiguos accionistas de AlmansaValencia-Tarragona" representaba el valor nominal de acciones de NORTE que estaban depositadas en el Banco Español de Crédito, a disposición de los poseedores de las acciones de la antigua Compañía de Almansa.

- La cuenta "Obligaciones de antiguos empleados fallecidos o ausentes" recogía las fianzas de empleados que, por una u otra causa, no habían sido devueltas todavía.

- La cuenta "Ferrocarril Central de Aragón, cuenta de títulos depositados en garantía". era una cuenta de pasivo que estaba garantizando una cuenta de activo. La cuenta de crédito abierta por NORTE en el Banco de España de Madrid por un importe de 10 millones de pesetas a disposición del Central de Aragón estaba garantizada por 25 millones de obligaciones del 6\% del Central de Aragón, propiedad del NORTE.

- La cuenta "Pagarés por introducción de material" representaba el importe de los pagarés suscritos por la compañía en concepto de derechos de introducción de material y que se hallan pendientes de cancelación en varias aduanas. 


\subsubsection{Cuentas de explotación}

Las Cuentas de Explotación de NORTE tenían formatos distintos de presentación. A pesar de ello, existen aspectos comunes de todo el periodo 1900-1923. El primero es que estaba expresado en dos columnas: la primera, denominada Gastos, y la segunda, Productos. El segundo aspecto común es que en los Gastos se incluía el Saldo deudor de la cuenta de "Ejercicios cerrados", y en Productos se registraba el Saldo acredor de la cuenta de "Ejercicios cerrados". El tercero es que la diferencia entre gastos e ingresos de cada línea se registraba siempre como Insuficiencia de Productos, en la columna de los Productos, si los gastos eran mayores que los ingresos; y Exceso de productos, en la columna de los Gastos, si los gastos eran menores que los ingresos.

Es posible identificar nueve formatos de presentación. Las Cuentas de Explotación del periodo 1900-1904 ${ }^{913}$ estaban formadas por dos columnas. La primera, denominada Gastos, estaba dividida en dos títulos: Gastos de explotación (dividido a su vez en Administración central, Dirección, Explotación, Material y tracción y Vía y obras) y Cargas de la explotación (dividido a su vez en dos subapartados Intereses y amortización de las obligaciones e Intereses, cambios y comisiones). La segunda columna, denominada Productos, se dividía en dos títulos: Productos de la explotación (que a su vez se dividía en tres subtítulos: Transportes a gran velocidad, Transportes a pequeña velocidad y Productos diversos) y Productos de fuera de la explotación ${ }^{914}$ (donde se incluían una gran cantidad de conceptos, entre otros, Intereses y beneficios en la venta de valores, Anualidad de San Juan de las Abadesas, Anualidad de Valencia a Utiel, Intereses, cambio sobre pagos en el extranjero y comisiones, y Productos varios fuera de la explotación).

La Cuenta de Explotación del ejercicio contable 1905 introdujo dos novedades fundamentales para el desarrollo de la información contable (NORTE, 1906: 40-63). La primera es que dentro del nuevo apartado "Tráfico" se incluían las Reclamaciones e investigaciones y la intervención de la cobranza. La segunda novedad es que dentro de los "Intereses y amortización de las obligaciones" -componente único de las Cargas de la explotación- se incluían los intereses de los empréstitos, la amortización de los empréstitos, los intereses, cambio sobre pagos en el extranjero y comisiones, los accidentes ${ }^{915}$ y la amortización ${ }^{916}$. Estos dos últimos conceptos tienen la máxima importancia. La relevancia de los accidentes parte de que supone que se incorporan por primera vez los gastos excepcionales; pero además se incorporan como gastos ordinarios (como en la actualidad) no como extraordinarios. Es posible inferir que los accidentes ocurren y ocurrirán, y que deben estar previstos dentro de unos niveles; este razonamiento supuso una madurez en la gestión. La amortización es relevante porque supone registrar por primera vez la dotación por deterioro de valor ordinario

\footnotetext{
${ }^{913}$ NORTE (1901: 44-69; 1902: 46-69; 1902: 47-70; 1903:47-70; 1904: 48-71; 1905: 48-71).

${ }^{914}$ No existe ningún título denominado "Productos de fuera de la explotación", no obstante, lo inferimos porque el resto de los componentes están dentro de una semisuma cuyo título es Productos de la Explotación.

${ }^{915}$ En la Memoria de 1905 se cita, por ejemplo, el accidente en Cercedilla (NORTE, 1906: 40).

${ }^{916}$ En la Memoria del ejercicio contable de 1905, la dotación de la amortización es del 0,4\% de material motor y de transporte (NORTE, 1906: 40).
} 
definitivo por uso, desuso u obsolescencia. Y este es un reflejo de una madurez en la contabilidad.

Por lo demás, el documento continúa formado por dos columnas. La primera, denominada Gastos, estaba dividida en dos títulos: Gastos de explotación (dividido a su vez en Administración central, Dirección, Explotación, Trafico, Material y tracción y Vía y obras) y Cargas de la explotación (constituido íntegramente en un apartado Intereses y amortización de las obligaciones). La segunda columna, denominada Productos, se dividía en dos títulos Productos de la explotación (que a su vez se dividía en tres subtítulos: Transportes a gran velocidad, Transportes a pequeña velocidad y Productos diversos) y Productos de fuera de la explotación $^{917}$ (donde se incluían, entre otros, Intereses, cambio sobre pagos en el extranjero y comisiones).

La Cuenta de Explotación del ejercicio contable 1906 introdujo una novedad al incluir por primera vez una cuenta denominada "Ejercicios cerrados", dentro de las cargas de la explotación, para incorporar los créditos incobrables. Este es el primer registro de las pérdidas por créditos incobrables en la historia de NORTE (NORTE, 1907: 40). La Cuenta de Explotación del ejercicio 1906 estaba formada por dos columnas (NORTE, 1907: 40-63). La primera -denominada Gastos- estaba dividida en dos títulos: Gastos de explotación (dividido a su vez en Administración central, Dirección, Explotación, Trafico, Material y tracción y Vía y obras) y Cargas de la explotación (constituido íntegramente en un apartado Intereses y amortización de las obligaciones, donde se incluían los intereses de los empréstitos, la amortización de los empréstitos, los intereses, el cambio sobre pagos en el extranjero y comisiones, los accidentes ${ }^{918}$, la amortización ${ }^{919}$ y los créditos incobrables). La segunda columna -denominada Productos- se dividía en dos títulos Productos de la explotación (que a su vez se dividía en tres subtítulos: Transportes a gran velocidad, Transportes a pequeña velocidad y Productos diversos) y Productos de fuera de la explotación ${ }^{920}$ (donde se incluían, entre otros, Intereses, cambio sobre pagos en el extranjero y comisiones).

Las Cuentas de Explotación del periodo 1907-1911 únicamente tuvo ligeras novedades de presentación sobre las Cargas de explotación, que se dividían en tres epígrafes. El principal impacto es que desaparecen los créditos incobrables de los gastos. Las Cuentas de Explotación de los ejercicios $1907^{921}, 1908^{922}, 1909^{923}, 1910^{924}$ y $1911^{925}$ estaban formadas

\footnotetext{
${ }^{917}$ No existe ningún título denominado "Productos de fuera de la explotación", no obstante, lo inferimos porque el resto de los componentes están dentro de una semisuma cuyo título es Productos de la Explotación.

${ }^{918}$ En la Memoria del ejercicio 1996 se cita, por ejemplo, el accidente en Cercedilla (NORTE, 1907: 40).

${ }^{919}$ En la Memoria de 1906, la dotación de la amortización es del 5\% de material motor y de transporte (NORTE, 1907: 40).

${ }^{920}$ No existe ningún título denominado "Productos de fuera de la explotación", no obstante, lo inferimos porque el resto de los componentes están dentro de una semisuma cuyo título es Productos de la Explotación.

${ }^{921}$ NORTE (1908: 36-57).

922 NORTE (1909: 38-60).

${ }^{923}$ NORTE (1910: 36-58).

${ }^{924}$ NORTE (1911: 36-63).

${ }^{925}$ NORTE (1912: 38-61).
} 
por dos columnas. La primera, denominada Gastos, estaba dividida en dos títulos: Gastos de explotación (dividido a su vez en Administración central, Dirección, Explotación, Trafico, Material y tracción y Vía y obras) y Cargas de la explotación (constituida por cuatro apartados Intereses y amortización de las obligaciones, Intereses, cambio sobre pagos en el extranjero y comisiones, Amortización del $5 \%$ de material ${ }^{926}$ y Encabezamiento con la Administración del Timbre en Francia). La segunda columna, denominada Productos, se dividía en dos títulos: Productos de la explotación (que a su vez se dividía en tres subtítulos: Transportes a gran velocidad, Transportes a pequeña velocidad y Productos diversos) y Productos de fuera de la explotación ${ }^{927}$ (donde se incluían entre otros, el Premio de cobranza sobre pagos al Tesoro, Intereses cambios y comisiones, y la anualidad de Valencia a Utiel).

En la partida "Premio de cobranza sobre pagos al Tesoro" se incluían las cantidades obtenidas por la compañía como premio o prima por las sumas que en calidad de impuestos recaudaba para el Estado. Las cantidades son las siguientes: el 1\% sobre las utilidades de los sueldos, el $1 \%$ sobre el impuesto de transportes, el 1,5\% sobre el impuesto de Timbre o el $4 \%$ sobre lo cobrado por el seguro de viajeros (NORTE, 1940: 374).

Las Cuentas de Explotación del ejercicio 1912 desagregaba más la información, pues dividía los Gastos de explotación en ocho epígrafes. Además realizaba un cambio de nomenclatura en el último apartado de la Cargas de la Explotación, pasando a denominarse "Servicio de valores en el extranjero"928, en vez de "Encabezamiento con la Administración del Timbre en Francia”. Por último, establece unos nuevos porcentajes de amortización. Las Cuentas de Explotación del ejercicio 1912 están formadas por dos columnas (NORTE, 1913: 38-63). La primera -denominada Gastos- está clasificado en dos títulos: Gastos de explotación (dividido a su vez en Administración central, Dirección, Reclamaciones e investigaciones, Trafico, Intervención de la cobranza, Explotación, Material y tracción, y Vía y obras) y Cargas de la explotación (constituido por cuatros apartados Intereses y amortización de las obligaciones, Intereses, cambio sobre pagos en el extranjero y comisiones ${ }^{929}$ y Servicio de valores en el extranjero). La segunda columna -denominada Productos- se dividía en dos títulos Productos de la explotación (que a su vez se divide en tres subtítulos: Transportes a gran velocidad, Transportes a pequeña velocidad y Productos diversos) y Productos de fuera de la

\footnotetext{
${ }^{926}$ Los dos conceptos Intereses, cambio sobre pagos en el extranjero y comisiones, por un lado, y Amortización del 5\% de material, por otro, están dentro de una misma semisuma. Los consideramos apartados distintos por ser conceptos diferentes. Al igual que en la Memoria de 1906, la dotación de la amortización es del 5\% de material motor y de transporte. Cfr. NORTE (1908: 36-57) (1909: 38-60) (1910: 36-58) (1911: 36-58) (1912: 38-61) (1913: 38-63).

${ }^{927}$ No existe ningún título denominado "Productos de fuera de la explotación", no obstante, lo inferimos porque el resto de los componentes están dentro de una semisuma cuyo título es Productos de la Explotación.

${ }^{928}$ Los importes de la cuenta "Servicio de valores en el extranjero" estaba integrado por las cantidades pagadas a la Hacienda francesa por cuenta de las obligaciones allí situadas.

${ }^{929}$ Los dos conceptos Intereses, cambio sobre pagos en el extranjero y comisiones, por un lado, y Amortización del 5\% de material, por otro, pasan a estar en 2012 claramente separados y diferenciados, dejando de estar en la misma semisuma, por ser conceptos diferentes. La Amortización de material en la Memoria de 2012 del 3\% del Material fijo y 5\% del Material motor y móvil (NORTE, 1913: 38-63). Desde la Memoria de 1906, y hasta la del 2011, la dotación de la amortización era del 5\% de material motor y de transporte. Cfr. NORTE (1908: 36-57; 1909: 38-60; 1910: 36-58; 1911: 36-58; 1912: 38-61).
} 
explotación ${ }^{930}$ (donde se incluía entre otros los Intereses, cambios sobre pagos en el extranjero y comisiones, Productos varios fuera de la explotación).

Las Cuentas de Explotación del periodo 1913-1916 presentaba como novedad que dividían los gastos en tres títulos, introduciendo las pensiones pagadas al personal. Además, vuelve a variar los porcentajes de amortización. Por último, establece una nueva ordenación y denominación de los componentes de las cargas de explotación; el cambio de nomenclatura es que el "Servicio de valores en el extranjero" pasa a denominarse "Gastos de Servicio de valores en el extranjero". Pero lo más significativo es que, por primera vez, se modifica la clasificación de los productos. Las Cuentas de Explotación de los ejercicios $1913^{931}, 1914^{932}$, $1915^{933}$ y $1916^{934}$ estaban formadas por dos columnas. La primera -denominada Gastosestaba dividida en tres títulos: Gastos de explotación (dividido a su vez en Administración central, Dirección, Reclamaciones e investigaciones, Trafico, Intervención de la cobranza, Explotación, Material y tracción, y Vía y obras), Pensiones pagadas al personal y Cargas de la explotación (constituido por cuatros apartados: Intereses y amortización de las obligaciones, Amortización de material ${ }^{935}$, Intereses, cambio sobre pagos en el extranjero y comisiones, y Gastos de Servicio de valores en el extranjero). La segunda columna -denominada Productosse dividía en dos títulos: Productos de la explotación (que a su vez se divide en cinco títulos: Viajeros, Transportes a gran velocidad, Transportes a pequeña velocidad, Productos fuera del tráfico e Ingresos diversos) y Productos de fuera de la explotación ${ }^{936}$ (donde se incluyen, entre otras, Intereses, cambios y comisiones).

Las Cuentas de Explotación del periodo contable 1917-1921 tienen como novedad que desaparecen dos títulos de las Cargas de explotación: tanto la de "Intereses, cambio sobre pagos en el extranjero" como la de amortización. Las Cuentas de Explotación de los ejercicios $1917^{937}, 1918^{938}, 1919^{939}, 1920^{940}$ y $1921^{941}$ estaban formadas por dos columnas. La primera -

\footnotetext{
${ }^{930}$ No existe ningún título denominado "Productos de fuera de la explotación", no obstante, lo inferimos porque el resto de los componentes están dentro de una semisuma cuyo título es Productos de la Explotación.

${ }^{931}$ NORTE (1914: 38-65).

${ }^{932}$ NORTE (1915: 40-64).

${ }^{933}$ NORTE (1916: 40-64).

${ }^{934}$ NORTE (1917: 44-68).

${ }^{935}$ La Amortización de material es a partir de la Memoria de 1916 del 1\% del Material fijo y 3\% del Material motor y móvil (NORTE, 1917: 44-68). La Amortización de material de la Memoria de 2015 del 1,5\% del Material fijo y 4\% del Material motor y móvil (NORTE, 1916: 40-64). La Amortización de material de la Memoria de 2014 del 1,25\% del Material fijo y 2,5\% del Material motor y móvil (NORTE, 1915: 40-64). La Amortización de material de la Memoria de 2013 del 1,25\% del Material fijo y 5\% del Material motor y móvil (NORTE, 1914: 38-65). La Amortización de material en la Memoria de 2012 del 3\% del Material fijo y 5\% del Material motor y móvil (NORTE, 1913: 38-63). Desde la Memoria de 1906, y hasta la del 2011, la dotación de la amortización era del 5\% de material motor y de transporte. Cfr. NORTE (1908: 36-57) (1909: 38-60) (1910: 36-58) (1911: 36-58) (1912: 38-61).

${ }^{936}$ No existe ningún título denominado "Productos de fuera de la explotación", no obstante, lo inferimos porque el resto de los componentes están dentro de una semisuma cuyo título es Productos de la Explotación.

${ }^{937}$ NORTE (1918: 44-68).

${ }^{938}$ NORTE (1919: 38-64).

${ }^{939}$ NORTE (1920: 42-66).

${ }^{940}$ NORTE (1921: 42-66).
} 
denominada Gastos- estaba dividida en tres títulos: Gastos de explotación (clasificado a su vez en Administración central, Dirección, Reclamaciones e investigaciones, Trafico, Intervención de la cobranza, Explotación, Material y tracción, y Vía y obras), Pensiones pagadas al personal y Cargas de la explotación (constituido por dos apartados Intereses y amortización de las obligaciones y Gastos de Servicio de valores en el extranjero). La segunda columna -denominada Productos- se dividía en dos títulos: Productos de la explotación (que a su vez se dividía en cinco títulos: Viajeros, Transportes a gran velocidad, Transportes a pequeña velocidad, Productos fuera del tráfico e Ingresos diversos) y Productos de fuera de la explotación ${ }^{942}$ (donde se incluían, entre otras, Intereses, cambios y comisiones, Anualidad de Valencia a Utiel y Premio de cobranza sobre pagos al Tesoro).

El documento Cuentas de Explotación del ejercicio 1922 tiene como novedad que introdujo un nuevo concepto en las Cargas de explotación: Intereses y amortización de los anticipos reintegrables para la adquisición de material. La cuenta "Anticipos reintegrables para la adquisición de material" estaba originada y realizada conforme una regulación estatal. El R.D. de 15 de octubre de 1920 autorizaba la concesión a las compañías de anticipos reintegrables en veinte anualidades consecutivas, calculadas con interés del 5\%, destinadas exclusivamente a la adquisición de material de motor y móvil.

Las Cuentas de Explotación del ejercicio 1922 estaban formadas por dos columnas (NORTE, 1923: 42-66). La primera -denominada Gastos- estaba dividida en tres títulos: Gastos de explotación (dividido a su vez en Administración central, Dirección, Reclamaciones e investigaciones, Trafico, Intervención de la cobranza, Explotación, Material y tracción, y Vía y obras), Pensiones pagadas al personal y Cargas de la explotación (constituido por tres apartados Intereses y amortización de las obligaciones, Intereses y amortización de los anticipos reintegrables para la adquisición de material y Gastos de Servicio de valores en el extranjero). La segunda columna -denominada Productos- se clasificaba en dos títulos: Productos de la explotación (que a su vez se dividía en cinco títulos: Viajeros, Transportes a gran velocidad, Transportes a pequeña velocidad, Productos fuera del tráfico e Ingresos diversos) y Productos de fuera de la explotación ${ }^{943}$ (donde se incluían, entre otras, Intereses, cambios y comisiones, Anualidad de Valencia a Utiel y Premio de cobranza sobre pagos al Tesoro).

Las Cuentas de Explotación del ejercicio 1923 tiene como novedad que introdujo un nuevo concepto en las Cargas de explotación: Diferencia en los pagos efectuados al personal con cargo al anticipo del Estado. Las Cuentas de Explotación del ejercicio 1923 estaban formadas por dos columnas (NORTE, 1924: 44-67). La primera, denominada Gastos, estaba dividida en tres títulos: Gastos de explotación (subdividido a su vez en Administración central, Dirección, Reclamaciones e investigaciones, Trafico, Intervención de la cobranza, Explotación, Material

\footnotetext{
${ }^{941}$ NORTE (1922: 44-68).

${ }^{942}$ No existe ningún título denominado "Productos de fuera de la explotación", no obstante, lo inferimos porque el resto de los componentes están dentro de una semisuma cuyo título es Productos de la Explotación.

${ }^{943}$ No existe ningún título denominado "Productos de fuera de la explotación", no obstante, lo inferimos porque el resto de los componentes están dentro de una semisuma cuyo título es Productos de la Explotación.
} 
y tracción, y Vía y obras), Pensiones pagadas al personal y Cargas de la explotación (constituido por tres apartados Intereses y amortización de las obligaciones ${ }^{944}$, Intereses y amortización de los anticipos reintegrables para la adquisición de material y Gastos de Servicio de valores en el extranjero). La segunda columna, denominada Productos, se dividía en dos títulos Productos de la explotación (que a su vez se subdividía en cinco títulos: Viajeros, Transportes a gran velocidad, Transportes a pequeña velocidad, Productos fuera del tráfico e Ingresos diversos) y Productos de fuera de la explotación ${ }^{945}$ (donde se incluían, entre otras, Intereses, cambios y comisiones, Anualidad de Valencia a Utiel y Premio de cobranza sobre pagos al Tesoro).

La clasificación de los gastos de explotación de NORTE en el periodo 1900-1923 es acertada y adecuada, porque muestra con detalle la actividad de la empresa. Esta afirmación es nuestra, pero está apoyada incluso por la opinión del Estado. En la introducción de la "Memoria sobre la situación económica de la Compañía de los Caminos de Hierro del NORTE de España" "946 que analizó las cuentas del periodo 1913-1919 a 1922 y los primeros meses de 1923-valoró como acertada la clasificación de los gastos de explotación de NORTE.

Los ingresos de explotación son prácticamente los únicos que consiguen las compañías. Así puede constatarse en NORTE (Capítulo V), pues dicha partida suponía, de media, porcentajes superiores al 96,5\% del total de ingresos. Sin embargo, es distinto el caso de los gastos de explotación, los cuales se sitúan en la horquilla del $43 \%$ al $77 \%$ del total en el periodo examinado ${ }^{947}$.

Los ingresos de explotación eran los derivados de los servicios diarios prestados por las estaciones y del servicio combinado que tuviera la línea. Las diferentes estaciones que conformaban la línea llevaban la contabilidad en la forma prescrita por la regulación contable interna de la compañía, formulando determinados estados contables que debían informar de los productos del tráfico, que junto con sus comprobantes y demás documentos pasaban diariamente de las estaciones a las oficinas centrales de intervención y estadística, para que, después de comprobados minuciosamente todos los valores y realizadas las rectificaciones

\footnotetext{
${ }^{944}$ NORTE no registra la amortización del material en la Memoria de 1917 (NORTE, 1918: 44-68) ni 1918 (NORTE, 1919: 38-64), ni 1919 (NORTE, 1920: 42-66), ni 1920 (NORTE, 1921: 42-66), ni 1921 (NORTE, 1922: 44-68), ni 1922 (NORTE, 1923: 42-66) ni 1923 (NORTE, 1924: 44-67). La Amortización de material de la Memoria de 2016 es del 1\% del Material fijo y 3\% del Material motor y móvil (NORTE, 1917: 44-68). La Amortización de material de la Memoria de 2015 del 1,5\% del Material fijo y 4\% del Material motor y móvil (NORTE, 1916: 40-64). La Amortización de material de la Memoria de 2014 del 1,25\% del Material fijo y 2,5\% del Material motor y móvil (NORTE, 1915: 40-64). La Amortización de material de la Memoria de 2013 del 1,25\% del Material fijo y 5\% del Material motor y móvil (NORTE, 1914: 38-65). La Amortización de material en la Memoria de 2012 del 3\% del Material fijo y 5\% del Material motor y móvil (NORTE, 1913: 38-63). Desde la Memoria de 1906, y hasta la del 2011, la dotación de la amortización era del 5\% de material motor y de transporte. Cfr. NORTE (1908: 36-57) (1909: 38-60) (1910: 36-58) (1911: 36-58) (1912: 38-61).

${ }^{945}$ No existe ningún título denominado "Productos de fuera de la explotación", no obstante, lo inferimos porque el resto de los componentes están dentro de una semisuma cuyo título es Productos de la Explotación.

${ }^{946}$ Emitida por la "Primera Comisión investigadora de la situación económica de las empresas del ferrocarril" el 29 de noviembre de 1923.

${ }^{947}$ Este análisis está apoyado en el trabajo de Montoya (2011: 166).
} 
pertinentes, se pudiera determinar el importe total de los ingresos de la explotación obtenidos. Así, el jefe de contabilidad formulaba otro estado llamado "Liquidación de los productos del tráfico del día XX", que pasaba después al tenedor de libros para que éste registrara de forma global el importe de los ingresos diarios de la explotación del negocio ferroviario ${ }^{948}$.

El "Producto Neto de la Explotación" del negocio ferroviario se obtenía por diferencia entre los ingresos y gastos de explotación descritos, cuya expresión se ponía de manifiesto mediante la redacción de la denominada "Cuenta General de la Explotación". Sin embargo, las compañías ferroviarias cargaban separadamente al saldo del Producto Neto otras partidas que no obedecían en sentido estricto a la explotación, aunque sí incidían de forma directa en el resultado del ejercicio, entre las que se incluían los intereses procedentes de empréstitos, el importe de las amortizaciones de obligaciones, las diferencias de cambio por operaciones en moneda extranjera y la amortización del material fijo y móvil (Montoya y Guzmán, 2011: 117).

En el periodo estudiado 1900-1923, los ingresos se incrementaron en un valor medio de un 4,6\% anual $^{949}$, alcanzando su valor máximo en el año 1919 como consecuencia, entre otras razones, del incremento de tarifas del $15 \%$ aprobado por el Gobierno. Sin embargo, a este buen comportamiento de los ingresos le acompañó un mayor incremento de los gastos, creciendo en promedio a una tasa del 6,7\% y llegando a su máximo del 35\% en 1918. Este incremento de los gastos de explotación fue especialmente brusco en la época del problema ferroviario, con un incremento medio del $14 \%$ de 1914 a 1920, destacando especialmente el incremento del gasto en combustible, que llegó a alcanzar un 360\% a lo largo de los seis años, con medias anuales del $24 \%$, mientras que los gastos de personal lo hacían en el $97 \%$, con una media anual del $10 \%$.

En cuanto a los resultados obtenidos por la compañía en los primeros quince años del periodo evaluado, estos no presentaron grandes fluctuaciones, manteniendo un nivel muy cercano a cero, si bien arrojando escasas pérdidas en 1904 y crecientes beneficios en los siguientes años.

En resumen, se puede concluir que durante el tortuoso periodo en el que se produjo el problema ferroviario se consiguió el aumento de los ingresos de explotación de NORTE en una media anual del 8,6\%, debido básicamente al incremento del transporte de todas las partidas (viajeros y mercancías), a lo que se unió la fuerte subida de las tarifas aprobadas en diciembre de 1918 (con efectos en el ejercicio 1919), si bien estos incrementos no pudieron compensar la espectacular subida de los gastos de explotación, protagonizada fundamentalmente por los combustibles y los gastos de personal, que se incrementaron un $14,1 \%{ }^{950}$.

\footnotetext{
${ }^{948}$ El análisis de la documentación contable intermedia es analizada con detalle en el trabajo de Montoya y Guzmán (2011: 116).

${ }^{949}$ Dato obtenido de Montoya y Guzmán (2011: 146).

${ }^{950}$ Este análisis de este periodo está inmejorablmenet analizado por Montoya y Guzmán (2011: 117).
} 
Para realizar una comparación con los datos analizados, se incluye la estructura de la Cuenta General de explotación de los años 1925 y 1935. La Cuenta General de Explotación de 1925 estaba formada por dos columnas. La primera -denominada Gastos- estaba dividida en cuatro títulos: Administración Central y Dirección (con una subdivisión a su vez en tres ítems: Tráfico, Movimiento y Eléctrico), Vía y obras, Material y tracción y Gastos generales. La segunda -denominada Productos- se dividía en dos títulos: Ingresos del tráfico (con una subdivisión a su vez en dos ítems: Gran velocidad y Pequeña velocidad) e Ingresos varios.

Para formar indicadores de gestión, y para calcular el gasto total del Servicio, NORTE incorpora en la cuenta "Gastos generales" los saldos de los siguientes servicios: Administración central y dirección, Reclamación, Intervención, Comercial, Eléctrico, Explotación, Material y tracción y Vías y obras. La partida negativa del Servicio Comercial se debe a un ingreso, cobrado de otras compañías, por gastos que la de NORTE había anticipado, en años anteriores, "para la instalación de algunas Juntas de Detasa" (NORTE, 1940: 380).

La Cuenta General de Explotación de 1935 estaba formada por dos columnas. La primera denominada Gastos- estaba dividida en doce títulos: Administración Central, Dirección, Reclamaciones e investigaciones, intervención de la cobranza, Comercial, Eléctrico, Explotación, Material y tracción, Vía y obras, Gastos generales de explotación, Pensiones pagadas al personal y Cargas de explotación. La segunda -denominada Productos- se dividía en cinco títulos: Viajeros, Transportes a gran velocidad, Transportes a pequeña velocidad, Productos fuera del tráfico e Ingresos diversos.

En el año 1927 se produce un cambio de asignación al Servicio "Administración central y dirección". A partir de esa fecha se incorporan las cantidades satisfechas al personal por complemento de haberes (pluses). Hasta ese momento se habían registrado a cargo del anticipo del Estado, y figuraban por separado en ejercicios anteriores.

\subsubsection{Datos estadísticos}

Es posible diferenciar los conceptos propios de Estadística y los de Contabilidad. Ambos conceptos deben complementarse en su tarea informativa de la dirección de la empresa. La contabilidad constituye el instrumento de medida que valora los hechos económicos de la empresa para conocer la situación económica de la misma. La estadística tiene un contenido más amplio y extenso que la simple representación de datos numéricos de fenómenos económicos en cuadros y gráficos ${ }^{951}$.

El documento "Datos estadísticos", incluído en los Informes Anuales de NORTE del periodo 1900-1923, estaba compuesto por veinte cuadros, todos ellos referenciados y ordenados por números romanos.

I. Pormenores de los ingresos.

\footnotetext{
${ }^{951}$ Para la distinción entre contabilidad y estadística puede observarse lo establecido en Goxens (1970: 15-26).
} 
II. Ingresos por kilómetro explotado.

III. Gastos por kilómetro explotado ${ }^{952}$.

IV. Recorrido de los trenes.

V. Gastos por kilómetro de recorrido de los trenes.

VI. Transportes y productos de viajeros.

VII. Viajeros por clases.

VIII. Resultados comparados de la explotación.

IX. Productos por estaciones de importancia.

$\mathrm{X}$. Peso y producto de las mercancías por naturaleza.

XI. Material móvil de la compañía del NORTE existente y su recorrido.

XII. Composición de los trenes en la red.

XIII. Trabajo de los trenes en el transporte de viajeros.

XIV. Trabajo de los trenes en el transporte de mercancías.

$\mathrm{XV}$. Trabajo de los coches.

XVI. Trabajo de los vagones.

XVII. Trabajo de las máquinas.

XVIII. Gastos de Material y Tracción.

XIX. Gastos de Material y Tracción desde el punto de vista del trabajo útil.

XX. Gastos de Vía y Obras.

Los indicadores son muy numerosos, pero no son una recopilación de datos sin orden ni sentido, sino que la empresa elige los indicadores que considera más adecuados para constituir con ellos una acertada herramienta con la que observar la esencia del proceso productivo. Por ejemplo, la fluctuación del "Número absoluto de viajeros" nada indica por sí sólo, pues para la empresa es muy diferente un viaje de un viajero de 40 kilómetros o de 500 kilómetros. Por esta razón, NORTE agregó a este dato el "Recorrido medio por viajero" y el eficaz indicador "Número de viajeros-kilómetro". Para NORTE (1940: 353), el número de viajeros-kilómetro es el indicador "verdaderamente importante" para apreciar el tráfico de viajeros.

\subsection{Indicadores que acompañan a los Informes Anuales}

Durante todo el periodo analizado, NORTE utilizaba indicadores para que la ayudasen a la gestión de los usuarios internos, es decir son de consumo interno. Los Informes Anuales no deberían incluir ningún tipo de indicador para la gestión. No obstante, la compañía ofrece indicadores en la información periódica externa -Informes Anuales- para intentar ayudar simultáneamente a los usuarios externos e internos.

\footnotetext{
${ }^{952}$ Reparaz (1934) escribió que a las ferroviarias les interesa mucho conocer la parte de capital invertida en gastos totales de establecimiento por cada kilómetro de vía en explotación, porque permite una apreciación sobre la riqueza o pobreza de las instalaciones.
} 
Estos indicadores estaban salpicados dentro del Informe Anual. Al no estar recogidos en un apartado específico, consideramos que no fueron incluídos por NORTE como un componente del Informe Anual.

Es posible identificar tres periodos distintos en la presentación de indicadores en el Informe Anual de NORTE.

En el quinquenio 1900-1904, NORTE estableció periódicamente en los Informes Anuales los siguientes indicadores que reflejan su gestión:

- "Relación entre el gasto y el producto". Este indicador aparecía en el apartado I. "Pormenores de los ingresos", en la información estadística de los Informes anuales ${ }^{953}$. Además, este indicador también acompaña a la "Cuenta de explotación"

- "Gasto por kilómetro explotado". Este indicador estaba situado en el apartado II. "Ingreso por kilómetro explotado" en la información estadística de los Informes anuales 955 .

- "Ingreso por kilómetro explotado". Este indicador aparecía en el apartado III. "Gasto por kilómetro explotado", en la información estadística de los Informes anuales ${ }^{956}$.

- "Relación del gasto con el ingreso". Este indicador, expresado en porcentaje, estaba recogido en el apartado IX. "Productos por estaciones de importancia" en la información estadística de los Informes anuales ${ }^{957}$.

- Transporte medio anual de los coches. Estaba calculado como cociente entre el numerador "recorrido kilométrico correspondiente a los asientos ocupados", y el denominador "Término medio de los coches empleados excluidos los coches correos del Estado". El indicador estaba recogido en el apartado XV. "Trabajo de los coches" en la información estadística de los Informes anuales ${ }^{958}$.

- Recorrido medio anual de los coches. Estaba calculado como cociente entre el numerador "Recorrido total" y el denominador "Término medio de los coches empleados excluidos los coches correos del Estado". Este indicador aparecía en el apartado XV. "Trabajo de los coches" en la información estadística de los Informes anuales ${ }^{959}$.

- "Trabajo medio anual de los vagones". Estaba calculado como cociente del numerador "Trabajo medio", y el denominador "Término medio de los vagones empleados". Este indicador está recogido en el apartado XVI. "Trabajo de los vagones" en la información estadística de los Informes anuales ${ }^{960}$.

- "Recorrido medio anual de los vagones". Estaba calculado como cociente entre el numerador "Recorrido total de los vagones remolcados", y el denominador "Término

\footnotetext{
${ }^{953}$ NORTE (1901: 72-77; 1902: 74-79; 1903: 74-79; 1904: 74-79; 1905: 74-79; 1906: 74-79).

${ }^{954}$ NORTE (1901: 44-69; 1902: 46-69; 1903: 47-70; 1904: 48-71; 1905: 48-71; 1906: 40-63).

${ }^{955}$ NORTE (1901: 78-79; 1902: 80-83; 1903: 80-83; 1904: 80-83; 1905: 80-83; 1906: 80-83).

${ }^{956}$ NORTE (1901: 80-81; 1902: 84-85; 1903: 84-85; 1904: 84-85; 1905: 84-85; 1906: 84-85).

${ }^{957}$ NORTE (1901: 69; 1902: 75; 1903: 73; 1904: 104; 1905: 104; 1906: 104).

${ }^{958}$ NORTE (1901: 129; 1902: 133; 1903: 131; 1904: 131; 1905: 131; 1906: 131).

${ }^{959}$ NORTE (1901: 129; 1902: 133; 1903: 131; 1904: 131; 1905: 131; 1906: 131).

${ }^{960}$ NORTE (1901: 130; 1902: 134; 1903: 132; 1904: 132; 1905: 132; 1906: 132).
} 
medio de los vagones empleados". Este indicador estaba recogido en el apartado XVI. "Trabajo de los vagones", en la información estadística de los Informes anuales ${ }^{961}$.

En el periodo 1905-1920 y 1922, NORTE recoge los siguientes indicadores que reflejan su gestión en los Informes Anuales:

- Ingresos por kilómetro explotado ${ }^{962}$.

- Gastos por kilómetro explotado ${ }^{963}$.

- Relación entre el gasto y el ingreso ${ }^{964}$.

- Relación entre el gasto y el ingreso de la explotación. Este indicador estaba ubicado en el apartado I. "Pormenores de los ingresos" en la información estadística de los Informes Anuales ${ }^{965}$. Pero además, también estaba ubicado acompañando a la "Cuenta de explotación" 966.

- Circulación diaria, es decir, el número de trenes que han circulado en un día y por kilómetro ${ }^{967}$.

- Ingreso por kilómetro recorrido ${ }^{968}$.

- Recorrido medio de una tonelada ${ }^{969}$.

- Recorrido medio de un viajero ${ }^{970}$.

- Relación entre el recorrido de los vagones vacíos y el de los remolcados ${ }^{971}$.

\footnotetext{
${ }^{961}$ NORTE (1901: 130; 1902: 134; 1903: 132; 1904: 132; 1905: 132; 1906: 132).
}

${ }^{962}$ NORTE (1906: 76; 1907: 76: 1908: 72; 1909: 74-81; 1910: 72-73; 1911: 74-77; 1912: 74-77; 1913: 78-83; 1914: 78-83; 1915: 78-83; 1916: 82-87; 1917: 82-87; 1918: 80-85; 1919: 80-85; 1920: 80-85; 1921: 80-85; 1923: 80-85).

${ }^{963}$ NORTE (1906: 72-75; 1907: 68-73; 1908: 68-71; 1909: 69-70; 1910: 68-71; 1911: 68-71; 1912: 70-73; 1913: 70-73; 1914: 68-77; 1915: 68-77; 1916: 78-81; 1917: 78-81; 1918: 76-79; 1919: 76-79; 1920: 76-79; 1921: 7679; 1923: 76-79).

${ }^{964}$ NORTE (1906: 15; 1907: 14; 1908: 14; 1909: 40-61; 1910: 62-67; 1911: 62-67; 1912: 69-74; 1913: 69-74; 1914: 69-74; 1915: 69-74; 1916: 72-77; 1917: 72-77; 1918: 76-79; 1919: 76-79; 1920: 76-79; 1921: 76-79; 1923: 76-79).

${ }^{965}$ NORTE (1906: 37; 1907: 70; 1908: 62; 1909: 64-67; 1910: 72-73; 1911: 74-77; 1912: 74-77; 1913: 78-83; 1914: 78-83; 1915: 78-83; 1916: 82-87; 1917: 82-87; 1918: 44-68; 1919: 44-68; 1920: 44-68; 1921: 44-68; 1923: 44-68).

${ }^{966}$ NORTE (1906: 40-63; 1907: 40-63; 1908: 40-63; 1909: 40-63; 1910: 38-58; 1911: 38-58; 1912: 38-61; 1913: 38-61; 1914: 40-64; 1915: 40-64; 1916: 40-64; 1917: 44-68; 1918: 86-87; 1919: 86-87; 1920: 86-87; 1921: 8687; 1923: 86-87).

${ }^{967}$ NORTE (1906: 79-80; 1907: 79-80; 1908: 79-80; 1909: 79-80; 1910: 76-77; 1911: 76-77; 1912: 78-79; 1913: 78-79; 1914: 78-79; 1915: 82-83; 1916: 82-83; 1917: 82-83; 1918: 86-87; 1919: 86-87; 1920: 86-87; 1921: 8687; 1923: 86-87).

${ }^{968}$ NORTE (1906: 80-81; 1907: 80-81; 1908: 76-79; 1909: 76-79; 1910: 76-77; 1911: 76-77; 1912: 78-79; 1913: 78-79; 1914: 78-79; 1915: 82-83; 1916: 82-83; 1917: 82-83; 1918: 86-87; 1919: 86-87; 1920: 86-87; 1921: 8687; 1923: 86-87).

${ }^{969}$ NORTE (1906: 86-91; 1907: 86-91; 1908: 86-91; 1909: 86-91; 1910: 84-87; 1911: 84-87; 1912: 80-86; 1913 : 80-86; 1914: 88-89; 1915: 88-89; 1916: 88-89; 1917: 88-89; 1910: 84-87; 1911: 84-87; 1912: 80-86; 1913: 8086; 1914: 88-89; 1915: 88-89; 1916: 88-89; 1917: 88-89; 1918: 86-87; 1919: 86-87; 1920: 86-87; 1921: 86-87; 1923: 86-87).

${ }^{970}$ NORTE (1906: 86-91; 1907: 86-91; 1908: 86-91; 1909: 86-91; 1910: 84-87; 1911: 84-87; 1912: 80-86; 1913: 80-86; 1914: 88-89; 1915: 88-89; 1916: 88-89; 1917: 88-89; 1918: 86-87; 1919: 86-87; 1920: 86-87; 1921: 8687; 1923: 86-87). 
- Término medio de las toneladas transportadas por vagón cargado y kilómetro ${ }^{972}$.

- "Trabajo medio anual de los vagones". Este indicador estaba calculado como cociente entre el numerador "Trabajo medio", y el denominador "Término medio de los vagones empleados". Este indicador estaba ubicado en el apartado XVI. "Trabajo de los vagones", en la información estadística de los Informes anuales ${ }^{973}$.

- "Recorrido medio anual de los vagones". Era calculado como cociente del numerador Recorrido total de los vagones remolcados, y el denominador término medio de los vagones empleados. Este indicador estaba recogido en el apartado XVI. "Trabajo de los vagones" en la información estadística de los Informes anuales ${ }^{974}$.

- Trabajo útil", calculado como las Toneladas útiles transportadas a un kilómetro de distancia $^{975}$.

- "Toneladas totales", calculadas como el Peso útil y Peso muerto transportado a un kilómetro comprendido el peso de los motores ${ }^{976}$.

- "Relación entre el trabajo útil y el peso muerto", calculada por el cociente entre el "Trabajo útil" y la "Circulación de los vehículos" (Peso muerto) ${ }^{977}$.

- "Relación entre el trabajo útil y el peso arrastrado", calculada por el cociente entre el Trabajo útil y el Total de peso arrastrado (el Total de peso arrastrado es la suma del “Trabajo útil" y la "Circulación de los vehículos") 978 .

- "Relación entre el trabajo útil y el trabajo total", calculada por el cociente entre el "Trabajo útil" y el "Trabajo total" (el Trabajo total es la suma del Total de peso arrastrado y la Circulación de las máquinas) ${ }^{979}$.

\footnotetext{
${ }^{971}$ NORTE (1906: 110; 1907: 86-91; 1908: 86-91; 1909: 86-91; 1910: 84-87; 1911: 84-87; 1912: 80-86; 1913: 80-86; 1914: 88-89; 1915: 88-89; 1916: 88-89; 1917: 88-89; 1918: 86-87; 1919: 86-87; 1920: 86-87; 1921: 8687; 1923: 86-87).

${ }^{972}$ NORTE (1906: 110; 1907: 112; 1908: 112; 1909: 110; 1910: 84-87; 1911: 84-87; 1912: 80-86; 1913: 80-86; 1914: 88-89; 1915: 88-89; 1916: 88-89; 1917: 88-89; 1918: 86-87; 1919: 86-87; 1920: 86-87; 1921: 86-87; 1923: 86-87).
}

${ }^{973}$ NORTE (1906: 111; 1907: 112; 1908: 112; 1909: 110; 1910: 84-87; 1911: 84-87; 1912: 80-86; 1913: 80-86; 1914: 88-89; 1915: 88-89; 1916: 88-89; 1917: 88-89; 1918: 86-87; 1919: 86-87; 1920: 86-87; 1921: 86-87; 1923: 86-87).

${ }^{974}$ NORTE (1906: 111; 1907: 112; 1908: 112; 1909: 110; 1910: 84-87; 1911: 84-87; 1912: 80-86; 1913: 80-86; 1914: 88-89; 1915: 88-89; 1916: 88-89; 1917: 88-89; 1918: 86-87; 1919: 86-87; 1920: 86-87; 1921: 86-87; 1923: 86-87).

${ }^{975}$ NORTE (1906: 116; 1907: 112; 1908: 112; 1909: 110; 1910: 76-77; 1911: 76-77; 1912: 78-79; 1913: 78-79; 1914: 78-79; 1915: 82-83; 1916: 82-83; 1917: 82-83; 1918: 82-83; 1919: 82-83; 1920: 82-83; 1921: 82-83; 1923: 82-83).

${ }^{976}$ NORTE (1906: 116; 1907: 116; 1908: 116; 1909: 116; 1910: 108-109; 1911: 108-109; 1912: 110-111; 1913 : 110-111; 1914: 114-115; 1915: 114-115; 1916: 118-119; 1917: 118-119; 1918: 116-117; 1919: 116-117; 1920: 116-117; 1921: 116-117; 1923: 116-117).

${ }^{977}$ NORTE (1906: 111; 1907: 112; 1908: 112; 1909: 110; 1910: 108-109; 1911: 108-109; 1912: 110-111; 1913 : 110-111; 1914: 114-115; 1915: 114-115; 1916: 118-119; 1917: 118-119; 1918: 116-117; 1919: 116-117; 1920: 116-117; 1921: 116-117; 1923: 116-117).

${ }^{978}$ NORTE (1906: 111; 1907: 112; 1908: 112; 1909: 110; 1910: 108-109; 1911: 108-109; 1912: 110-111; 1913: 110-111; 1914: 114-115; 1915: 114-115; 1916: 118-119; 1917: 118-119; 1918: 116-117; 1919: 116-117; 1920: 116-117; 1921: 116-117; 1923: 116-117). 
- Consumo de combustible por kilómetro recorrido por los trenes ${ }^{980}$.

- Consumo de combustible por kilómetro recorrido por las máquinas ${ }^{981}$.

- Consumo por tonelada kilométrica de trabajo útil ${ }^{982}$.

- Consumo por tonelada kilométrica de trabajo total ${ }^{983}$.

- Gasto por kilómetro explotado ${ }^{984}$.

- Gasto por kilómetro de tren ${ }^{985}$.

- Recorrido medio de una tonelada ${ }^{986}$.

- Recorrido medio de un viajero ${ }^{987}$.

- Número de toneladas de excesos de equipaje de mensajerías, metálico, animales y coches expedidos en el año ${ }^{988}$.

- Número de toneladas de excesos de equipaje de mensajerías, metálico, animales y coches expedidos por día ${ }^{989}$.

- Número de toneladas para el comercio expedidos al año ${ }^{990}$.

${ }^{979}$ NORTE (1906: 111; 1907: 112; 1908: 112; 1909: 110; 1910: 108-109; 1911: 108-109; 1912: 110-111; 1913: 110-111; 1914: 114-115; 1915: 114-115; 1916: 118-119; 1917: 118-119; 1918: 116-117; 1919: 116-117; 1920: 116-117; 1921: 116-117; 1923: 116-117).

${ }^{980}$ NORTE (1906: 116; 1907: 116; 1908: 112; 1909: 110; 1910: 108-109; 1911: 108-109; 1912: 110-111; 1913 : 110-111; 1914: 114-115; 1915: 114-115; 1916: 118-119; 1917: 118-119).

${ }^{981}$ NORTE (1906: 116; 1907: 116; 1908: 112; 1909: 110; 1910: 108-109; 1911: 108-109; 1912: 110-111; 1913: 110-111; 1914: 114-115; 1915: 114-115; 1916: 118-119; 1917: 118-119; 1918: 116-117; 1919: 116-117; 1920: 116-117; 1921: 116-117; 1923: 116-117).

${ }_{982}$ NORTE (1906: 116; 1907: 116; 1908: 112; 1909: 110; 1910: 108-109; 1911: 108-109; 1912: 110-111; 1913: 110-111; 1914: 114-115; 1915: 114-115; 1916: 118-119; 1917: 118-119; 1918: 116-117; 1919: 116-117; 1920: 116-117; 1921: 116-117; 1923: 116-117).

${ }_{983}$ NORTE (1906: 116; 1907: 116; 1908: 112; 1909: 110; 1910: 108-109; 1911: 108-109; 1912: 110-111; 1913 : 110-111; 1914: 114-115; 1915: 114-115; 1916: 118-119; 1917: 118-119; 1918: 116-117; 1919: 116-117; 1920 : 116-117; 1921: 116-117; 1923: 116-117).

${ }^{984}$ NORTE (1906: 116; 1907: 116; 1908: 112; 1909: 110; 1910: 108-109; 1911: 108-109; 1912: 110-111; 1913: 110-111; 1914: 114-115; 1915: 114-115; 1916: 118-119; 1917: 118-119; 1918: 116-117; 1919: 116-117; 1920: 116-117; 1921: 116-117; 1923: 116-117).

${ }^{985}$ NORTE (1906: 116; 1907: 116; 1908: 112; 1909: 110; 1910: 108-109; 1911: 108-109; 1912: 110-111; 1913: 110-111; 1914: 114-115; 1915: 114-115; 1916: 118-119; 1917: 118-119; 1918: 116-117; 1919: 116-117; 1920: 116-117; 1921: 116-117; 1923: 116-117).

${ }^{986}$ NORTE (1906: 84-85; 1907: 84-85; 1908: 84-85; 1909: 84-85; 1910: 80-86; 1911: 80-86; 1912: 80-86; 1913 : 92-97; 1914: 92-97; 1915: 92-97; 1916: 92-97; 1917: 92-97; 1918: 120-121; 1919: 120-121; 1920: 120-121; 1921: 120-121; 1923: 120-121).

987 NORTE (1906: 84-85; 1907: 84-85; 1908: 84-85; 1909: 84-85; 1910: 80-86; 1911: 80-86; 1912: 80-86; 1913 : 92-97; 1914: 92-97; 1915: 92-97; 1916: 92-97; 1917: 92-97; 1918: 120-121; 1919: 120-121; 1920: 120-121; 1921: 120-121; 1923: 120-121).

${ }^{988}$ NORTE (1906: 84-85; 1907: 84-85; 1908: 84-85; 1909: 84-85; 1910: 80-86; 1911: 80-86; 1912: 80-86; 1913 : 92-97; 1914: 92-97; 1915: 92-97; 1916: 92-97; 1917: 92-97; 1918: 120-121; 1919: 120-121; 1920: 120-121; 1921: 120-121; 1923: 120-121).

${ }^{989}$ NORTE (1906: 84-85; 1907: 84-85; 1908: 84-85; 1909: 84-85; 1910: 80-86; 1911: 80-86; 1912: 80-86; 1913 : 92-97; 1914: 92-97; 1915: 92-97; 1916: 92-97; 1917: 92-97; 1918: 120-121; 1919: 120-121; 1920: 120-121; 1921: 120-121; 1923: 120-121).

${ }_{990}$ NORTE (1906: 84-85; 1907: 84-85; 1908: 84-85; 1909: 84-85; 1910: 80-86; 1911: 80-86; 1912: 80-86; 1913 : 92-97; 1914: 92-97; 1915: 92-97; 1916: 92-97; 1917: 92-97; 1918: 120-121; 1919: 120-121; 1920: 120-121; 1921: 120-121; 1923: 120-121). 
- Número de toneladas para el comercio expedidos al día ${ }^{991}$.

- Número de toneladas para el comercio transitadas en el año ${ }^{992}$.

- Número de toneladas para el comercio transitadas a un kilómetro ${ }^{993}$.

Nótese que estableció algunos indicadores distintos a los del periodo anterior, pero además cambió la denominación de otros.

En los ejercicios contables 1921 y 1923, NORTE no incluyó los indicadores de gestión en su Informe Anual. Esto no sólo no es una mala práctica, sino que debe ser entendida como una medida deseable porque separa la contabilidad normalizada de la contabilidad de gestión. El único indicador que incluye es la "Relación entre el gasto y el ingreso" que acompaña a la "Cuenta de explotación" $"$ "994.

Al observar la gran cantidad de indicadores de gestión mostrados en los diferentes Informes Anuales a lo largo de todo el periodo de estudio 1900-1923, es posible afirmar que la diferencia entre la contabilidad interna y externa no está lo suficientemente perfilada, lo cual tiene todo el sentido al ser tan escasa la normalización contable.

\subsection{Valoración crítica del Informe Anual}

La elaboración del Informe Anual de NORTE era responsabilidad de la Dirección General. Los Informes Anuales debían estar sometidos a aprobación por la Junta General de Accionistas y remitidas a la Delegación de Gobierno para su inspección. Por último, constituían un fundamento esencial para la toma de decisiones en las reuniones del Consejo de Administración.

NORTE debía publicitar su información contable por tres razones. La primera era la necesidad de informar a los accionistas y acreedores de la compañía sobre la gestión, dado que habían aportado recursos, a fin de analizar su estabilidad y solvencia. La segunda era la necesidad de informar de la gestión de las subvenciones recibidas ya que era habitual que parte de los fondos fuesen públicos, de forma que, disponer de información sobre cómo se habían gestionado suponía cumplir con el principio de transparencia, lo que requería publicar los estados contables. La tercera se basaba en que como el ferrocarril era un bien de interés común para la sociedad española, la Ley reservaba al Estado la posibilidad de fijar las tarifas de precios con el fin de que no fueran abusivas para el público. La intervención del Estado

\footnotetext{
${ }^{991}$ NORTE (1906: 84-85; 1907: 84-85; 1908: 84-85; 1909: 84-85; 1910: 80-86; 1911: 80-86; 1912: 80-86; 1913 : 92-97; 1914: 92-97; 1915: 92-97; 1916: 92-97; 1917: 92-97; 1918: 120-121; 1919: 120-121; 1920: 120-121; 1921: 120-121; 1923: 120-121).

992 NORTE (1906: 84-85; 1907: 84-85; 1908: 84-85; 1909: 84-85; 1910: 80-86; 1911: 80-86; 1912: 80-86; 1913 : 92-97; 1914: 92-97; 1915: 92-97; 1916: 92-97; 1917: 92-97; 1918: 120-121; 1919: 120-121; 1920: 120-121; 1921: 120-121; 1923: 120-121).

${ }^{993}$ NORTE (1906: 84-85; 1907: 84-85; 1908: 84-85; 1909: 84-85; 1910: 80-86; 1911: 80-86; 1912: 80-86; 1913 : 92-97; 1914: 92-97; 1915: 92-97; 1916: 92-97; 1917: 92-97; 1918: 120-121; 1919: 120-121; 1920: 120-121; 1921: 120-121; 1923: 120-121).

${ }^{994}$ NORTE (1922: 40-64; 1924: 44-68).
} 
suponía comprobar que, con las tarifas fijadas, los capitalistas recuperaban la inversión efectuada más un interés adicional que les garantizara un mínimo de rentabilidad.

Por consiguiente, estos documentos -de elaboración y publicidad obligatoria- fueron utilizados para analizar la situación financiera de la compañía, y para argumentar la toma de decisiones.

\subsubsection{Aspectos positivos del Informe Anual}

El Informe Anual de NORTE constituía una fuente de información completa, comparable, relevante, útil, además eran capaces de representar cuantitativa y cualitativamente el proceso productivo.

La información que reunían los estados contables era completa, porque recogía las operaciones del ejercicio entero.

Los Informes Anuales sirven para la rendición de cuentas y para la toma de decisiones. A medida que pasan los ejercicios los documentos son más precisos en cuanto a la información que ofrece.

NORTE presentaba la construcción de los ferrocarriles como un activo de la compañía. Activar los costes de producción de la infraestructura, implicaba valorar este inmovilizado y reconocerlo como un bien, suministrando al destinatario de la información contable una visión más completa.

La compañía cumplía con los principales criterios de valoración y principios de contabilidad generalmente aceptados. NORTE cumplió con la hipótesis básica de devengo y de empresa en funcionamiento, porque registró los gastos e ingresos tan pronto iban siendo conocidos, y además, la empresa tuvo previsiones de futuro, por ejemplo cuando reflejaba las diferentes dotaciones, como los fondos para "Cajas de Previsión y Retiro". De la inclusión de determinadas partidas en el Balance, se deducía el cumplimiento del principio de devengo, pues la corriente monetaria y financiera se registró de forma independientemente, lo que constituía una aproximación más exacta a la situación real de la compañía.

Además del devengo y de la empresa en funcionamiento, NORTE realizaba sus registros contables en función de la hipótesis de prudencia. La primera vez que NORTE enunció el principio de prudencia fue en las cuentas del ejercicio 1907 donde afirmó que, tras dieciséis años de vicisitudes diversas, por fin se propone la distribución de un dividendo de 10 pesetas por acción; pero además se dotó una parte importante del beneficio a reservas, "inspirándose en consideraciones de prudente previsión" (NORTE, 1908: 5-6). La compañía dotó cinco reservas basadas en la prudencia: "Cajas de Previsión y Retiro", "Reserva para previsión de créditos incobrables", "Fondo de previsión para créditos incobrables y reclamaciones en litigio", "Fondo de previsión especial disponible conforme a la R.O. de 4 de mayo de 1927" y "Reserva de previsión". La subpartida "Fondo de previsión para créditos incobrables y 
reclamaciones en litigio" es considerada por la empresa como imprescindible en una "administración bien ordenada como la de NORTE"995. El "Fondo de previsión especial disponible conforme a la R.O. de 4 de mayo de 1927" está dotado para hacer frente a cualquier contingencia que pudiera reflejarse en los resultados de la explotación de la red. La "Reserva de previsión" se dotó para protegerse de cualquier eventualidad o gastos imprevistos que se produjeran en las obras de mejora y adquisición de toda clase de material previstas por NORTE. La dotación del fondo de obras de mejora (NORTE, 1907: 32) supuso tomar una medida contable en virtud de una "prudencia" tomada en consideración por la empresa ${ }^{996}$.

Homogeneizar es el requisito previo que debe cumplir la información contable, pues es susceptible de ser comparada. Sin esta condición es posible que las conclusiones alcanzadas no sean válidas. Una de las intenciones del trabajo es averiguar si estos estados contables eran, o no, comparables, tanto en la forma como en el fondo.

Los documentos analizados son comparables, puesto que su estructura de presentación y contenido no varía de forma significativa. No sólo esta cuestión de forma ayuda a la homogeneización, sino que, en cuanto al fondo, los criterios de valoración y principios de contabilidad generalmente aceptados parecen mantenerse uniformes para estos años.

A pesar de no disponer de regulación aplicable en la elaboración de los estados contables emitidos por el sector ferroviario, a fin de homogeneizar la información contable que suministran sus estados contables, la normativa interna de NORTE intenta responder a la necesidad de que estos sean comparables. Para ello proporciona, a través de la "Clasificación de los Gastos de Explotación y Construcción" de 1886, una distribución de éstos por divisiones y subdivisiones, es decir, capítulos y artículos, de forma que, utilizando este documento, la estructura en que se clasifican los gastos permanece constante, lo cual genera un grado de homogeneidad suficiente en los estados contables que permite la comparación entre la información contable de distintos periodos y no sólo en términos de criterios de clasificación por naturaleza, sino también, de funcionalidad.

Hasta 1924, las empresas ferroviarias homogeneizaron voluntariamente su registro y presentación de los ingresos y gastos con su propia regulación. Desde la implantación del Estatuto ferroviario en 1924, el Consejo Superior de Ferrocarriles acordó la adopción por todas las empresas de una clasificación uniforme de sus ingresos, gastos y cargas de manera que cada uno de los conceptos se correspondan exactamente en las contabilidades de aquéllas, a fin de facilitar la implantación de las medidas de carácter general que puedan ser necesarias y evitar las dificultades a que daría lugar la diversidad de criterio en las referidas clasificaciones. Esta homogenización fue trascendental, porque desde ese momento existía una legislación que obligaba a registrar y presentar los gastos e ingresos.

Además, la inclusión de información segmentada fue de gran utilidad, y constituyó uno de los grandes avances para su época. El suministro de información segmentada que presentaban los

\footnotetext{
995 Acta 773 Consejo de Administración de NORTE, 31 de mayo de 1910.

${ }^{996}$ La empresa explicita como la motivación de la dotación de este fondo la "prudencia" (NORTE, 1907: 33).
} 
estados contables de NORTE, proporcionaban datos por tipo de actividad y área geográfica. $\mathrm{Su}$ inclusión era relevante porque permitía asociar riesgos y rentabilidades con mayor precisión, lo que favorecería una gestión más eficiente de cada segmento.

Por último, los documentos contables del Informe Anual ofrecían información de los resultados de la compañía, de forma que permitía analizar la situación de la compañía en términos de rentabilidad, y además, esto lo hacía sobre las dos fases en que se organizaba su actividad: construcción y explotación. Eran capaces de representar cuantitativa y cualitativamente el proceso productivo, vinculando cada fase de su actividad a una cuenta de resultados, en la que se detallaba el origen y el destino de los fondos.

\subsubsection{Cumplimiento de la legislación mercantil y contable}

Durante el periodo 1900-1923, NORTE cumplió escrupulosamente con lo establecido en el Código de Comercio de 1885 respecto a la teneduría de libros contables. NORTE clasificaba sus operaciones en dos grandes apartados: por un lado, construcción de las vías férreas y demás obras públicas de cualquier clase y, por el otro, explotación de las mismas, bien a perpetuidad o durante el plazo señalado en la concesión (artículo 184). Además, llevaba el libro de Inventarios y Balance, el libro Diario, el libro Mayor y el libro de Copiador de cartas y telegramas según establecían los artículos 33 a 49. Además, cumplimentó adecuadamente el libro de Actas, donde se hicieron constar todos los acuerdos tomados por las Juntas Generales de socios y los Consejos de Administración (artículo 33). Por otro lado, realizó todos sus registros contables en función del método de partida doble según establece el artículo 38 y 40. Por último, respecto a la ejecución material de la contabilidad, el artículo 43 del Código de Comercio establecía los criterios generales para su presentación, indicando que "los comerciantes debían llevar sus libros con claridad, por orden de fechas, sin blancos, interpolaciones, raspaduras ni tachaduras, y sin presentar señales de haber sido alterados sustituyendo o arrancando los folios o de cualquier otra manera", lo cual fue cumplido por NORTE.

El Estatuto ferroviario reguló con mucha profundidad los requerimientos contables de las concesionarias y, lo que es más importante, regula la vigilancia de su cumplimiento. Los registros contables de NORTE cumplieron perfectamente lo establecido en materia contable en el Estatuto Ferroviario. Por un lado, llevó el Libro de Inventarios y Balances (artículo 37), diferenciando con la relación del dinero, valores, créditos, efectos al cobro, bienes muebles e inmuebles, mercaderías y efectos de todas clases, apreciados en su valor real y que constituían su Activo, con la relación exacta de sus deudas y toda clase de obligaciones pendientes que formaban su Pasivo, y por diferencia entre el Activo y el Pasivo, se fijaba el Capital con el que iniciaba sus operaciones. Además, el Libro Diario (artículo 38) registró día a día todas las operaciones llevadas a cabo por el comerciante, expresando en cada asiento el cargo y descargo de las respectivas cuentas. También llevó correctamente el Libro Mayor (artículo 39) estableciendo cuentas con cada objeto o persona en particular, trasladando al mismo por orden riguroso de fechas los asientos del Libro Diario referentes a ellas. Además, estableció el Libro de Actas (artículo 40), conteniendo los acuerdos que se tomaban por las compañías en 
juntas o por sus administradores, expresando la fecha, los asistentes y los votos emitidos. Cada una de las actas estuvo firmada por los gerentes, directores o administradores, encargados de la gestión de la sociedad. Por último, NORTE incluyó, por orden de fechas, en el Libro copiador de cartas y telegramas (artículo 41) todas las cartas que escribió relativas a su tráfico mercantil, así como los despachos telegráficos expedidos.

Y más adelante, NORTE también cumplió lo establecido en el Comité ejecutivo del Consejo Superior de Ferrocarriles del 15 de enero de 1926. Antes de que se creara el Estatuto, la Compañía NORTE cargaba los gastos de poca importancia en una cuenta que llamaba de "Pequeño material", y las de obras de primer establecimiento iban a su cuenta correspondiente, por pequeñas que fueran. Cuando NORTE se adaptó al Estatuto Ferroviario empezó a registrar la cuenta "Gastos complementarios de explotación" según lo establecía el Comité ejecutivo del Consejo Superior de Ferrocarriles.

\subsubsection{Validación del paradigma}

El siglo XIX es el periodo en el que hubo un "cambio de énfasis desde el registro de las transacciones (record keeping) hacia el reporting financiero" (Edwards: 1989: 8). A esto se le denominó cambio de paradigma porque la contabilidad evolucionó de un mero sistema de registro a una herramienta de rendición de cuentas. Este cambio de paradigma está relacionado con la evolución de la economía capitalista, donde se produjo una separación de la gestión y la propiedad de la empresa. Con ello, la contabilidad se convirtió en un mecanismo para informar a los inversores sobre la marcha de su negocio.

Tanto en la transicción hacia el capitalismo financiero, como en el cambio de paradigma producido en el siglo XIX, tuvieron gran importancia las empresas ferroviarias. El camino hacia el capitalismo financiero se caracterizó por la creciente importancia de las grandes empresas -sobre todo las del ferrocarril-, las cuales necesitaban obtener importantes capitales a través de los mercados para financiar su actividad. En este sentido, en las empresas de ferrocarriles "la información financiera se necesitaba en una escala anteriormente impredecible, para poder comprobar que el proyecto planificado estaba correctamente concebido, para realizar un seguimiento de los costes durante la etapa de construcción, y para informar de los resultados (a los accionistas) cuando la línea estaba operativa" (Edwards, 1989: 13).

NORTE estaba en un claro proceso de capitalismo financiero, es más fue una de las primeras empresas españolas en las que claramente se produjo la separación entre gestión y propiedad. Pero, además, NORTE fue una de las pioneras en adoptar el cambio del paradigma de la contabilidad que se produjo en el siglo XIX, pasando de ser un mero sistema de registro a una herramienta de rendición de cuentas. La mejor prueba del cambio del paradigma es que los Informes Anuales de la empresa en el periodo 1900-1923 estaban ya enfocados a los accionistas, a los que expresamente estaban dirigidos los Informes Anuales (cada componente comienza con "Señores Accionistas"). 
Por otro lado, la contabilización de NORTE en el periodo 1900-1923 está caracterizada por un entorno de cambios en la práctica, filosofía y teoría contable, pero siempre fiel a la corriente francesa de pensamiento contable.

Los criterios de contabilización utilizados por NORTE en el siglo XIX son los que utilizaban en los años anteriores las ferroviarias francesas. Esto tiene todo el sentido porque el capital, los directivos y los planificadores financieros de las ferroviarias españolas eran galos. NORTE afirma que su sistema de contabilización fue implantado siguiendo el ejemplo de todas las compañías francesas ${ }^{997}$. Pero no sólo eso, los usos y costumbres contables de los primeros años se fueron perpetuando a lo largo del siglo XX en NORTE ${ }^{998}$.

El pensamiento contable de Francia, tuvo una gran influencia en Europa durante el siglo XIX. En ese momento, los contables franceses -como Hubert (1854), Cosack (1904) y Cordonnier (1924: 5-62)- fueron los que más importancia tuvieron en el diseño del sistema contable. Sin embargo, durante el primer cuarto del siglo XX, la contabilidad francesa dejó de tener su posición de privilegio. Las nuevas ideas, que nacieron en Italia y Alemania, se centraron en que la cuestión más importante que tenía que atender la contabilidad era la determinación del beneficio, es decir, "averiguar cúanto había ganado o perdido la empresa durante el ejercicio contable" (Zappa, 1927; 1962). En el mismo sentido, Schmalenbach (1919; 1922) pensaba que la cuestión más importante al final del ejercicio era la determinación de los resultados anuales; de acuerdo con esta idea, no debía prestarse tanta atención al volumen y a la estructura del patrimonio de la empresa mostrada en el balance estatico (balance tradicional), sino más bien al balance dinámico (la cuenta de resultados). Esta visión fue tomada por la doctrina española en el segundo cuarto del siglo XX; Imedio (1934: 69) definía el balance como "la expresión numérica del estado de un negocio en una época determinada, sirviendo, para indicar el beneficio o pérdida obtenidos".

Los criterios de contabilización utilizados por NORTE no fueron permeables al pensamiento procedente de Italia y Alemania en el primer cuarto del siglo XX, sino que se mantuvo cercano al pensamiento contable francés que venía utilizando desde el origen. Por ejemplo, durante el periodo 1900-1923, NORTE consideró al balance como el estado contable fundamental.

\footnotetext{
${ }^{997}$ NORTE afirma que "este sistema de contabilización lo implantó la compañía siguiendo el ejemplo de todas las compañías francesas y de las más importantes de otros países, que también hacen la misma distribución que NORTE entre Primer establecimiento y Explotación”. AHF P-113-258-3: "Contestación de la Compañía de los Caminos de Hierro del NORTE de España al Informe redactado por la Primera Comisión investigadora de la situación económica de las empresas de ferrocarriles nombrada por Real Orden de 20 de octubre de 1923": Apartado "II. Reparos del Informe a las diversas partidas que componen las cuentas de explotación".

${ }^{998}$ NORTE afirma en 1923 que este sistema de contabilización no lo implantó la compañía en los últimos años de su existencia, sino que lo registró de esta manera desde su origen". AHF P-113-258-3: "Contestación de la Compañía de los Caminos de Hierro del NORTE de España al Informe redactado por la Primera Comisión investigadora de la situación económica de las empresas de ferrocarriles nombrada por Real Orden de 20 de octubre de 1923": Apartado "II. Reparos del Informe a las diversas partidas que componen las cuentas de explotación".
} 
Al contrario, que la estructura organizativa de NORTE, que sí se abrío a las nuevas formas organizativas de Estados Unidos; en materia contable la compañía permaneció fiel a la filosofía francesa que tuvo desde el origen.

\subsubsection{Aspectos negativos del Informe Anual}

Los aspectos negativos más sobresalientes de la contabilidad de NORTE son: ausencia de clara separación entre contabilidad financiera y de gestión, presentación inadecuada para el análisis, problemas de comparabilidad temporal y espacial, y la utilización incipiente de manipulación de los estados financieros.

\subsubsection{Escasa separación entre contabilidad financiera y de gestión}

Los estados contables de NORTE respondían tanto a necesidades de información internas como externas, lo cual proporciona una fuente de información común.

El nivel de desglose que presentaban los estados contables -sobre todo en la Cuenta de Explotación- era excesivo para la rendición de cuentas. En la Cuenta de Explotación de NORTE el criterio de clasificación utilizado en las partidas de gastos proporciona información bajo una doble perspectiva -funcional y por naturaleza-, lo que suponía informar de los costes generados por cada departamento en que se organizaba la compañía. Esto resultaba innecesario dado que el usuario externo de la información contable no tenía capacidad de gestionar y controlar el gasto que cada unidad producía. Por ello, y dado que el único órgano que tenía tales competencias era el Consejo de Administración, suponía ofrecer una información necesaria y suficiente para la toma de decisiones y/o rendición de cuentas en el ámbito interno, pero excesiva e innecesaria para la rendición de cuentas en el ámbito externo. La concesión de exceso de información tenía otro problema añadido, pues ofrecía unos datos a la competencia que permitían conocer datos sensibles de NORTE, por ejemplo la cantidad que cobraba de media un agente o comisionista o a cuánto habían costado los suministros. Estos datos permitían conocer datos vitales para conocer las ventajas competitivas del negocio y que, más bien, debería estar dentro de la esfera del secreto empresarial.

Ambas consideraciones deben ser analizadas desde un concepto más amplio, porque son cruciales para observar el devenir del sistema de información contable. En esta época, NORTE no diferenciaba convenientemente las dos dimensiones de la contabilidad directiva, pues incorporaba en un mismo informe, por un lado, los contenidos de la contabilidad financiera, cuyos destinatarios eran los accionistas y el resto de los usarios externos de la empresa, y por otro, los contenidos de la contabilidad externa, que sólo debían conocer los gerentes.

El primer signo inequívoco de la separación entre contabilidad de gestión y contabilidad financiera es la no divulgación del presupuesto en los años 1910-1919, quedando exclusivamente para el consumo interno. 


\subsubsection{Presentación inadecuada para el análisis}

Por otro lado, el Balance (o "Situación de la Compañía" en terminología de NORTE los primeros años) no presentaba una ordenación de las partidas en función del proceso de conversión en liquidez o de su vencimiento, lo que imposibilita examinar la capacidad de solvencia de la empresa ${ }^{999}$.

Además, existía una confusión en la presentación de la información financiera dentro de la masa de Pasivo, principalmente en el capítulo de "Reservas", por la amortización de obligaciones y por la dotación de provisiones para obras de mejora.

Si bien en cualquier compañía mercantil era común constituir un fondo, propiciando la autofinanciación de la empresa, en las compañías de ferrocarriles debía ser de obligado cumplimiento con el fin de amortizar las acciones en que se dividía el capital antes de que llegase el momento de la reversión de los activos de la línea férrea al Estado cuando la concesión era de carácter temporal. Además, en esta rúbrica se incluían algunas cuentas que no obedecían a la naturaleza de reservas en sentido estricto, como era el caso de los fondos de amortización de obligaciones, que no se reflejaban como gastos de explotación y siendo además indebidamente incluidos dentro de este apartado, al igual que en el caso de la dotación de provisiones para obras de mejora.

NORTE, al igual que el resto de las compañías no creó una rúbrica específica para "Reserva por obligaciones amortizadas", lo cierto es que contablemente las detraían del Producto Neto como componente de las denominadas "Cargas de Explotación", por lo que en este sentido se sumaba una financiación propia (obligaciones amortizadas) con una ajena (obligaciones pendientes de amortizar) en aras de conocer la situación global de la financiación de la partida de "Gastos de Primer Establecimiento".

\subsubsection{Deficiencias en la comparación espacial y temporal}

Un sistema contable relevante y fiable requiere de una información comparable, tanto espacial como temporalmente. La espacial es la que posibilita confrontar datos entre diferentes empresas, mientras la temporal es la que permite la comparación entre los distintos ejercicios económicos de una misma entidad.

\footnotetext{
${ }^{999}$ Sin embargo, en el mismo periodo de estudio, la compañía Andaluces sí tenía fijado un criterio para facilitar su interpretación y homologación. En el activo normalmente se ordenaban los elementos en función de su liquidez, es decir en función de la facilidad que tiene un bien para convertirse en dinero; el dinero depositado en la caja es el bien más líquido que hay. Por su parte, el pasivo se solía ordenar en función del estado financiero, un elemento será más exigible cuanto menor sea el plazo en que vence (Blasco, 2015: 13). El capital es el elemento menos exigible, mientras que las deudas con proveedores suelen ser exigibles a muy corto plazo.
} 
En cuanto a la comparación de cifras contables entre ejercicios, NORTE siempre valoró como una medida muy positiva la inclusión de los datos comparativos del ejercicio actual y el precedente. La empresa recogía todos los datos del año presente y del anterior en la información adicional (documento similar a la Memoria actual), y las diferencias entre ambos, desde el ejercicio contable de 1902; en los periodos anteriores sólo lo incluía en cuatro cuadros: Gastos de la explotación ${ }^{1000}$, Recorrido de los trenes ${ }^{1001}$, Gastos por kilómetros explotados ${ }^{1002}$ y Gastos por kilómetros de tren ${ }^{1003}$. No obstante, en ningún ejercicio contable del periodo de estudio recogió esta información comparativa en el Balance y Cuenta de resultados. Incluirlo en los estados financieros principales sería, sin duda, de mucha utilidad como referente para valorar los cambios más significativos que pudieran haber ocurrido en las partidas. Aunque la información comparable no fue incluída en los estados financieros principales de los Informes Anuales periódicos, sí fue recogida en los estados financieros principales incluidos en un documento recopilatorio confeccionado puntualmenteen un momento posterior. NORTE (1940) sí realizó la exposición de datos de varios años en los estados contables principales en la recopilación puntual que realiza sobre ella misma en 1940, donde se incluyeron cuadros comparativos de los principales datos contables. Esta exposición es muy meritoria, porque para realizar esta comparación fue necesario realizar una conciliación para hacer completamente compatible la heterogenea información suministrada en los estados contables de diferentes ejercicios económicos.

En segundo lugar, respecto a la comparación de cifras contables entre compañías del sector, no existía en la época, normativa o regulación que dispusiera de criterios de presentación y publicación de la información contable por parte de las compañías, que eran los sujetos obligados. Dado que cada compañía tenía su propia normativa interna, reglamentos internos de funcionamiento sobre la contabilidad y clasificaciones de los gastos de explotación y construcción es inevitable la existencia de diferencias en cuanto a los formatos y contenidos de los estados contables de cada ferroviaria, dificultando o incluso imposibilitando, la comparación entre estas compañías pertenecientes al mismo sector.

Analizando el detalle, podemos encontrar unas partidas en concreto donde se observa la diferencia de contabilización de NORTE con MZA o con otras sociedades.

Al contrario que NORTE, MZA reflejaba a través de la estructura del balance la diferencia de las dos actividades fundamentales desarrolladas: por un lado, la construcción de la infraestructura y por otro la explotación del servicio de transporte ferroviario. Esta diferenciación se puso de manifiesto contablemente a través de la publicación de documentos independientes: con un enfoque patrimonialista, en la Cuenta de Establecimiento MZA recogía los costes de construcción de las líneas ferroviarias y sus infraestructuras, y las fuentes de financiación aplicadas; y por otro, con un enfoque económico en la Cuenta de

\footnotetext{
${ }_{1000}$ NORTE $(1900 ; 11 ; 1901 ; 11 ; 1902 ; 11)$.

${ }^{1001}$ NORTE $(1900 ; 12 ; 1901 ; 12 ; 1902 ; 12)$.

${ }^{1002}$ NORTE $(1900 ; 13 ; 1901 ; 13 ; 1902 ; 13)$.

${ }^{1003}$ NORTE $(1900 ; 13 ; 1901 ; 13 ; 1902 ; 13)$.
} 
Explotación, MZA recogía los ingresos y gastos generados a partir de la actividad de prestación del servicio de transporte ferroviario ${ }^{1004}$.

La principal rúbrica del Activo era la del inmovilizado, representada por las cuentas del "coste de la construcción de las líneas" así como por las de "material móvil y de oficinas". NORTE registraba todas estas partidas por separado, mientras que MZA las incluían dentro de una rúbrica general denominada "Gastos de primer establecimiento".

Independiente de su forma de presentación, el inmovilizado se identificaba con el valor real del capital del concesionario, pudiendo figurar por su valor neto contable, o bien a precio de adquisición, siendo en este último caso necesario crear en el Pasivo del balance la rúbrica de "Fondo de Amortización", que, sin embargo, se situaba dentro del epígrafe "Reservas", aunque por su naturaleza no atendiese al concepto genérico del tal rúbrica ${ }^{1005}$.

MZA incluía en el balance una rúbrica adicional titulada "Deudores al capital" para incluir las cantidades pendiente de cobro relacionadas con obligaciones en cartera, subvenciones o dividendos pasivos; esta rúbrica tenía su correspondencia en la masa de Pasivo respecto de la cuenta de capital social, subvenciones recibidas y "capital-obligaciones" por las emisiones de empréstitos realizadas.

Mientras que MZA y NORTE utilizaban un único epígrafe, muchas ferroviarias españolas distinguían entre dos partidas: "Caja y Bancos" y "Cartera". La rúbrica de "Caja y Bancos" recogía la tesorería al cierre del ejercicio, mientras que la de "Cartera" registraba los valores propiedad de la compañía depositados en bancos, en algunos casos afectos a fondos de previsión con contrapartida en el Pasivo, así como a "títulos no emitidos y conservados". En este último caso, su valor debía compensar la cuenta de capital que figuraba en el Pasivo, de donde Joaquín Imedio Díaz (1934: 72) dedujo que en este tipo de compañías estaba permitida la emisión de acciones que no obedecían a una verdadera aportación patrimonial, si bien, también se solía incluir este concepto en la cuenta "Deudores de capital". Mientras que la mayoría de ferroviarias incluían dos títulos diferenciados -"Caja y Bancos" y "Cartera"-, la Compañía NORTE las recogía en un epígrafe único titulado "Metálico y Valores", mientras que MZA utilizaba la denominación de "Caja y Cartera".

También en el pasivo hubo aspectos mejorables en la contabilización de NORTE. Cuando el Estado participaba en la explotación del negocio junto con la compañía bajo la figura del consorcio, era frecuente entre las ferroviarias españolas incluir dentro del Pasivo la rúbrica titulada "Capital del Estado", debiéndose detallar separadamente a través de cuentas divisionarias su aportación, así como los anticipos de material, préstamos al personal, y cualquier otra partida relevante derivada de tal acuerdo. NORTE no incluyó esta partida.

\footnotetext{
${ }^{1004}$ La contabilización de MZA en este tema fue analizado por Benito Barroso (2015: 264).

1005 "Los inmovilizados pueden figurar por su valor actual o por su precio de adquisición. En este último caso aparecerá en el pasivo un fondo de amortización” (Joaquín Imedio Díaz y Fraisero, 1934: 124 y 125).
} 
Finalmente, en el apartado "Cuentas Acreedoras" figuraban las fianzas depositadas, los libramientos pendientes de pago y los acreedores diversos de la compañía, incluyéndose en algunas ocasiones en esta rúbrica las "Cuenta de Orden", en cuyo caso aparecían en el Activo del Balance dentro de la rúbrica de "Cuentas Deudoras", tratamiento este último que aplicaba la Compañía MZA, a diferencia de la Compañía NORTE, que ubicada la rúbrica de "Cuentas de orden" al final del Balance.

\subsubsection{Manipulación de la información financiera}

Las dudas sobre si la información contable de las empresas refleja su verdadera situación económica es un tema de debate y reflexión actual, pero ya preocupaba en la sociedad española desde la creación de las grandes compañías privadas. El objetivo de este apartado es analizar si NORTE realizó manipulación de la información contable en el periodo 1900-1923. Ello se hará por medio, por un lado, del análisis de las intenciones de sus directivos a través de la documentación existente sobre la correspondencia postal entre ellos y, por otro lado, por la observación de la influencia de cada medida de manipulación sobre los registros contables por medio del análisis conjunto tanto de la información contable oficial como de los datos de gestión que manejaba la gerencia.

La correspondencia postal entre los directivos de las sociedades es fundamental para intentar atisbar las intenciones de las compañías. El estudio de toda esta información ha sido posible gracias a la legislación mercantil. El Código de Comercio de 1829 (artículo 32) y el Código de Comercio de 1885 (artículo 41) establecieron, como uno de los cuatro libros contables que necesariamente deben llevar los comerciantes, un libro "Copiador de cartas y telegramas". En este debían ser trascritas, integra y sucesivamente, por orden de fechas, incluidas la antefirma y firma, todas las cartas que el comerciante escribiese relativas a su tráfico mercantil, así como los despachos telegráficos que hubiese expedido.

Antes de analizar el caso de NORTE, es necesario definir correctamente el concepto de manipulación contable. Las reconocidas definiciones de Griffiths (1988), Jameson (1988), Naser (1993:2) y Naser y Pendlebury (1993) describen la manipulación contable como la transformación de las cifras reales de la contabilidad financiera buscando alcanzar lo que se desea, aprovechando la normativa existente o ignorándola. Esta visión debe mejorarse porque supone que existen unos datos reales y objetivos de la empresa, cuando este hecho no puede ser aceptable ya que la elaboración de la información será siempre subjetiva.

Las definiciones de manipulación contable más aceptadas en la actualidad huyen de la consideración de unos valores absolutos como ciertos, reales u objetivos. La manipulación contable se define como "una intervención en el proceso de elaboración de la información financiera y contable, con el objetivo de obtener algún beneficio propio" (Schipper, 1989: 92) haciendo uso de la "discrecionalidad y subjetividad de las normas" (Healy y Whalen, 1999: 365-383). 
De este nuevo concepto se deriva que la manipulación contable requiere dos requisitos. El primero es que sea consciente y voluntario; por lo tanto no entraría en el concepto una alteración de datos realizada sin que exista voluntad. La segunda es que intente alcanzar un objetivo determinado; por lo que no entraría en el concepto si la alteración no es premeditada para alcanzar una finalidad. Estos dos requisitos complican sobremanera el análisis para afirmar si una política contable de una organización fue una manipulación contable o no, pues requiere identificar la voluntariedad por un lado, y la realización de la alteración de los datos para alcanzar una finalidad determinada por otro. La evaluación de ambas medidas únicamente se puede alcanzar por métodos indirectos como el análisis de las intenciones por medio de la comunicación interempresarial y personal de los gestores de la organización. Los métodos directos de análisis de los estados financieros permitirán observar la política contable, pero nunca las intenciones de los gestores de una organización.

Dentro de la manipulación contable, la doctrina internacional incluye consensuadamente (Elvira y Amat, 2008: 50-51) dos hechos: contabilidad creativa y gestión del beneficio contable. La contabilidad creativa recoge el conjunto de medidas cuyo objetivo es afectar al balance de situación. La gestión del beneficio contable (earnings management) "es la habilidad de incrementar o reducir el beneficio actual y futuro" (Copeland, 1968: 101). Dentro de la gestión del beneficio contable es posible identificar dos conceptos: alisamiento de los resultados (income smoothing) y la depresión del resultado para reducir los beneficios actuales para incrementar los futuros (big bath).

No obstante, esta acertada definición y clasificación se ha quedado obsoleta frente a una cambiante evolución del mercado. Estos conceptos no son adecuados, por limitados, porque tan importante como la elaboración de los datos contables es la presentación de los mismos. Por tanto, es necesario ampliar, tanto el concepto, como la clasificación de la manipulación contable, para adecuarlos al entorno económico actual.

Pero, además, el concepto de contabilidad creativa debe modificarse para adaptarse al nuevo paradigma de la contabilidad financiera. La consideración de la contabilidad creativa como conjunto de medidas cuyo objetivo es alterar el balance de situación era propia de un entorno de la contabilidad en la que este documento era el único que era ofrecido a los usuarios. Sin embargo, en la actualidad el emisor del Informe Anual ofrece información en el Balance, pero también en el Estado de Pérdidas y Ganancias, en el Estado de Cambios en el Patrimonio Neto, en el Estado de Flujos de Efectivo y en la Memoria. La contabilidad creativa debe incluir la alteración en el registro y/o valoración de los elementos recogidos en cualquiera de los cinco documentos.

La propuesta de definición de esta investigación es la siguiente. La manipulación contable es cualquier modificación consciente tanto del registro, como de la valoración o la presentación de la información financiera y contable, con el objetivo de obtener alguna finalidad particular, haciendo uso de la discrecionalidad y subjetividad de las normas o de la ausencia de regulación, pero siempre sin incumplir las leyes. 
De este nuevo concepto se deriva que la manipulación contable requiere dos requisitos. El primero es que sea consciente y voluntario; por lo que no entraría en el concepto una alteración de datos realizada sin que exista voluntad. La segunda es que intente alcanzar un objetivo determinado (las motivaciones pueden ser muy variadas: llegar a alcanzar un bonus, pagar menos impuestos; mejorar la imagen, estabilizar los resultados, repartir más o menos dividendos, etc.); por lo tanto, no entraría en el concepto una alteración que no fuese premeditada para alcanzar una finalidad.

Dentro de la manipulación contable, es posible identificar dos conceptos: manipulación en la elaboración de la información y manipulación en su presentación.

La contabilización de un elemento de los estados financieros es un proceso que consta de tres funciones: registro, valoración y presentación. La manipulación en la elaboración de la información contable consiste en la modificación del registro y/o valoración de los activos, pasivos, netos, gastos o ingresos.

La manipulación en la elaboración de la información contable está compuesta por la contabilidad creativa y la gestión del beneficio contable. La gestión del beneficio contable es la habilidad de incrementar o reducir la cifra del resultado contable, tanto actual como futuro. La contabilidad creativa es el conjunto de medidas cuyo objetivo es alterar la estructura del Balance, Estado de Pérdidas y Ganancias, Estado de Cambios en el Patrimonio Neto, Estado de Flujos de Efectivo y Memoria. La contabilidad creativa debe incluir la alteración en el registro y/o valoración de los elementos recogidos en cualquiera de los cinco documentos, salvo las modificaciones para obtener una cifra distinta del resultado contable. Si se modifican los datos del Estado de Pérdidas y Ganancias pero no la cifra del resultado, estamos ante una política de contabilidad creativa, mientras que si altera la cifra del resultado contable es un procedimiento de gestión del beneficio contable.

Por su parte, la manipulación en la presentación de la información contable es toda la alteración de la información contable fuera de la modificación del registro y/o valoración, es decir la alteración en la exposición de los activos, pasivos, netos, gastos o ingresos. Esto incluye toda alteración de los elementos, de los subtotales, de los índices o de las ratios, en el momento de ofrecérselo al usuario.

La manipulación en la presentación de la información contable puede producirse en el momento de la elaboración de los Informes Anuales, pero también en un momento posterior a la publicación de los Informes Anuales.

La manipulación en la presentación de la información contable producida en el momento de la elaboración de los Informes Anuales supone que los elementos han sido registrados y valorados sin ánimo de ser alterados, pero su presentación en los estados financieros ha sido modificada para hacer creer al usuario que aparentemente la empresa tiene más o menos solvencia, rentabilidad o liquidez. 
La manipulación en la presentación de la información contable tras la elaboración de los Informes Anuales puede deberse a dos situaciones. La primera que se produzca en otros canales distintos al Informe Anual (en anuarios recopilatorios de la información contable, en bases de datos informatizadas, en la página web de la compañía, en informaciones trimestrales o semestrales no obligatorias por internet, etc.). La segunda es que se produzca la alteración de la información en el momento de ser ofrecida para otras finalidades específicas (como la información ofrecida a autoridades regulatorias bursátiles, financieras o de seguros).

En el cuadro 57 aparece la clasificación de todos los procedimientos de manipulación contable que pueden producirse en cualquier empresa de cualquier momento.

\section{Cuadro 57. Clasificación de la manipulación contable}

\begin{tabular}{|c|c|c|}
\hline \multirow{3}{*}{$\begin{array}{l}\text { Manipulación } \\
\text { contable }\end{array}$} & $\begin{array}{lll}\text { Manipulación en } & \text { la } \\
\text { elaboración } & \text { de } & \text { la } \\
\text { información } & & \end{array}$ & Gestión del beneficio contable \\
\hline & \multirow{2}{*}{$\begin{array}{l}\text { Manipulación en la } \\
\text { presentación de la } \\
\text { información contable }\end{array}$} & $\begin{array}{l}\text { Alteración en la presentación del } \\
\text { Informe Anual }\end{array}$ \\
\hline & & $\begin{array}{l}\text { Alteración en la presentación fuera } \\
\text { del Informe Anual } \\
\text { - Canales distintos } \\
\text { - Finalidades específicas }\end{array}$ \\
\hline
\end{tabular}

Fuente: Elaboración propia

En los próximos apartados se analizan los medios de manipulación de la información financiera utilizados por NORTE en el periodo 1900-1924, identificando cuáles ofrecían una información más atractiva y cuáles menos aparente ${ }^{1006}$.

En el cuadro 58 se recogen los procedimientos de manipulación de la información financiera de NORTE en el periodo 1900-1924, diferenciando entre los que se producen en la elaboración de la información financiera y en su presentación.

Dentro de los procedimientos de manipulación en la elaboración de la información financiera, NORTE realizó prácticas de contabilidad creativa sobre dos partidas, eso sí poco importantes cuantitativamente: creación de fondos de mejora y anticipo para la implantación de la jornada de ocho horas. Es necesario destacar que los tres procedimientos de contabilidad creativa se

\footnotetext{
1006 Glynn (1984: 109) describe cómo las ferroviarias británicas del siglo XIX presentaban estados financieros mal redactados, incompletos e incomprensibles; pero además, con ellos los administradores o directores de forma deliberada trataban de distorsionar su presentación, entre otros, frente a los inversores. Sin embargo, no tenemos trabajos sobre manipulaciones contables en empresas ferroviarias españolas.
} 
realizaron sobre un mismo documento, la cuenta de resultados; si la contabilidad creativa se redujera al balance, ninguna de estas políticas se incluiría en el concepto de manipulación contable. Por su parte, NORTE utilizó procedimientos de gestión de la cifra del resultado contable sobre ocho partidas: los gastos de primer establecimiento, la amortización contable, el deterioro de valor, el fondo para compensar el acuerdo de 4 de enero de 1896, los ingresos de transporte en servicio, los anticipos reintegrables para compensar las subidas retributivas, la política de dotación y aplicación de reservas y, por ultimo, el registro ineficiente de partidas de la cuenta de explotación. Sobre todas estas medidas es posible identificar el efecto sobre la cifra de resultados

Respecto a la manipulación de la información financiera en el proceso de presentación, pueden identificarse los que producen una alteración en la presentación en las diferentes fuentes de información y los que suponen una alteración en la presentación de las ratios (coste por kilómetro y coeficiente de explotación). El único procedimiento que no utilizó NORTE fue la presentación fuera del Informe Anual, ya fuese por canales distintos o por finalidades específicas.

Cuadro 58. Partidas en los que NORTE aplicó procedimientos de manipulación de la información contable en 1900-1924

\begin{tabular}{|c|c|c|c|}
\hline \multirow{13}{*}{$\begin{array}{l}\text { Manipulación } \\
\text { contable }\end{array}$} & \multirow{10}{*}{$\begin{array}{l}\text { Manipulación } \\
\text { en la } \\
\text { elaboración de } \\
\text { la información }\end{array}$} & \multirow{2}{*}{$\begin{array}{l}\text { Contabilidad } \\
\text { creativa }\end{array}$} & Creación de fondos de mejora \\
\hline & & & $\begin{array}{l}\text { Anticipo para la implantación de la } \\
\text { jornada de ocho horas }\end{array}$ \\
\hline & & \multirow{8}{*}{$\begin{array}{l}\text { Gestión de la } \\
\text { cifra del resultado } \\
\text { contable }\end{array}$} & Gastos de primer establecimiento \\
\hline & & & Amortización contable \\
\hline & & & Deterioro de valor \\
\hline & & & $\begin{array}{l}\text { Fondo para compensar el acuerdo de } \\
4 \text { de enero de } 1896\end{array}$ \\
\hline & & & Ingresos de transporte en servicio \\
\hline & & & $\begin{array}{l}\text { Anticipos reintegrables para } \\
\text { compensar las subidas retributivas }\end{array}$ \\
\hline & & & $\begin{array}{l}\text { Política de dotación y aplicación de } \\
\text { reservas }\end{array}$ \\
\hline & & & Partidas de la cuenta de explotación \\
\hline & \multirow{3}{*}{$\begin{array}{l}\text { Manipulación } \\
\text { en la } \\
\text { presentación } \\
\text { de la } \\
\text { información }\end{array}$} & \multirow{3}{*}{$\begin{array}{l}\text { Alteración en la } \\
\text { presentación del } \\
\text { Informe Anual }\end{array}$} & $\begin{array}{l}\text { Alteración de presentación en las } \\
\text { diferentes fuentes de información }\end{array}$ \\
\hline & & & Ratio coste por kilómetro \\
\hline & & & Ratio coeficiente de explotación \\
\hline
\end{tabular}

Fuente: Elaboración propia 


\subsubsection{Procedimientos de manipulación financiera en la elaboración: Contabilidad creativa}

\section{a) Creación de fondo de obras de mejora}

Los gastos extraordinarios de NORTE incluyen tres conceptos ${ }^{1007}$. Primeramente, los de obras motivadas por causas imprevistas (como inundaciones, descarrilamientos, incendios, etc.), cuyo objeto es volver las cosas a su ser y estado anterior. En segundo lugar, los de las obras motivadas con ocasión de transformaciones que, sin representar ampliación de lo existente, mejoran su función. Por último, la parte imputable a la cuenta de explotación de las transformaciones, que al mismo tiempo sustituían a las ya existentes, y se consideraban convenientes para conseguir ampliaciones o mejoras.

El primer concepto es el único que debería estar incluido en los gastos excepcionales. Los gastos producidos en el segundo y tercer concepto deberían tener cabida en los gastos de explotación. Este artificio permite quitar parte de los gastos de explotación ubicándolos en los gastos extraordinarios. Aunque este hecho no supone una variación de la cifra de gastos, y por ende de la cifra de resultado contable, es una alteración del registro encuadrada como una política de manipulación contable ${ }^{1008}$.

Esto ocurre durante todo el periodo, pero en el apartado "VII. Asuntos varios" de la Memoria del Informe Anual de 1906, NORTE (1907: 32) ofrece información sobre un posible cambio contable que el Consejo propone a la Junta para su ratificación. La propuesta es la constitución de un fondo para realizar obras de mejora, al cual se imputarían los gastos extraordinarios. De esta forma los gastos de explotación estarían exclusivamente limitados a los gastos corrientes. La dotación de este fondo supone una dotación novedosa basada en la hipótesis contable de prudencia, e incluso la "prudencia" es explicitada por la empresa como la motivación de la medida (NORTE, 1907: 33).

En el documento, NORTE ofrece información sobre un posible cambio contable que el Consejo propone a la Junta para su ratificación. El Consejo observó que las condiciones del comercio y de la industria habían variado; NORTE (1907: 33) necesitaba proceder al ensanche de estaciones, a la prolongación de vías de maniobras y apartaderos, y a comprar material. De la misma forma, el desarrollo del tráfico y los progresos de la industria requerían trenes con un número mayor de vagones y el empleo de locomotoras más pesadas y de mayor velocidad; por ello la empresa necesitaba reconstruir los puentes metálicos y reforzar las vías. Hasta el ejercicio 1906, todos estos gastos habían sido contabilizados como gastos de explotación. El Consejo proponía que estos gastos fuesen registrados como gastos extraordinarios, argumentando que venían a recargar algunos ejercicios de manera anormal.

\footnotetext{
1007 AHF P-113-258-1: "Memoria sobre la situación económica de la Compañía de los Caminos de Hierro del NORTE de España", Primera Comisión investigadora de la situación económica de las empresas de ferrocarriles, 29 de noviembre de 1923.

${ }^{1008} \mathrm{Al}$ igual que la del Anticipo para la implantación de la jornada laboral de ocho horas.
} 
Pero el Consejo iba va más allá, pues proponía la constitución de un fondo para realizar obras de mejora y "al cual quedaría afecto el saldo del excedente de los productos del presente ejercicio, deducción hecha del impuesto sobre utilidades que corresponda" (NORTE, 1907: 32). A dicho fondo de mejora se imputarían los gastos extraordinarios. De esta forma, los gastos de explotación estarían exclusivamente limitados a los gastos corrientes.

b) Anticipo para la implantación de la jornada laboral de ocho horas

Por medio del R.D. de 13 de abril de 1927 y 2 de mayo de 1928, la Caja Ferroviaria anticipó más de 14 millones de pesetas para la implantación de la jornada laboral de ocho horas (NORTE, 1940: II, cuadro 23). Este anticipo del Gobierno debería ser devuelto en 20 anualidades con un $5 \%$ de interés.

NORTE no contabilizó como costes de la explotación los anticipos para la implantación de la jornada de ocho horas, aunque sí las incluyó en el gasto total. La partida debería haber sido incluída en los gastos de explotación. Este artificio contable permitió reducir parte de los gastos de explotación ubicándolos en los gastos extraordinarios. Este hecho no supuso una variación de la cifra de gastos, y por ende de la cifra de resultado contable, sin embargo, muestra una alteración en la presentación del Estado de Pérdidas y Ganancias. Esta maniobra es una alteración del registro encuadrada como una política de manipulación contable.

\subsubsection{Procedimientos de manipulación financiera en la elaboración: Manipulación de la cifra de beneficios}

\section{a) Gastos de primer establecimiento}

Heredada de las prácticas contables francesas, NORTE tenía establecido un criterio para el reparto de las obras en las vías y edificios al servicio de la explotación, de forma que determinasen las cantidades que debían cargarse a la cuenta de primer establecimiento aumentando la cifra de activo de la compañía- y las que debían considerarse como gastos de explotación.

Para repartir los gastos que se originan con las obras que sin aumentar el valor anterior de la instalación, son necesarias para la mejora o ampliación de servicios o locales, excepto en los de renovación de vía, NORTE utilizaba el siguiente criterio: "llevar a la partida de gastos de primer establecimiento los que corresponden al aumento y dejar en los de explotación los de renovación o sustitución de lo ya existente"1009. La política de NORTE en este sentido debe ser alabada, en primer lugar, por el mero hecho de tenerla establecida y explicitada en la empresa, y en segundo lugar porque parece una medida sensata y razonable.

1009 AHF P-113-258-1: "Memoria sobre la situación económica de la Compañía de los Caminos de Hierro del NORTE de España", Primera Comisión investigadora de la situación económica de las empresas de ferrocarriles, 29 de noviembre de 1923: Apartado "Personal". 
Los dirigentes de NORTE actuaron casi siempre en función de este criterio a lo largo del periodo estudiado, siendo un criterio asumido en la toma de decisiones de gestión. La utilización de este criterio fue publicitado al exterior de la empresa, de forma que puede afirmarse que era conocido por la opinión pública y por el Estado.

Aunque este criterio sea la guía de actuación de NORTE, lo cual es positivo, la aplicación del criterio a algunos casos concretos puede ser interpretada como una práctica de manipulación de la información contable. En primer lugar, NORTE no lo aplicó en algunas situaciones para intentar obtener una cifra de resultados más adecuada. Por ejemplo, en 1905 el presidente de NORTE afirmó que propondría al Consejo la concesión de créditos necesarios para las obras de ampliación de las estaciones madrileñas de Príncipe Pío y el Paseo Imperial, "que debieran ir a la cuenta de Primer establecimiento,... no cabiendo respecto de estos gastos guardar las reglas ni seguir el criterio que es indispensable aplicar a los asuntos ordinarios de la explotación, propios del Presupuesto anual'1010.

En segundo lugar, en diversos ejercicios contables, la empresa NORTE aplicó este criterio, pero lo utilizó para obtener unos resultados del ejercicio mayores o menores en función de los intereses particulares de la dirección en cada momento. Por ejemplo, en 1923, la compañía realizó un reparto de los gastos de renovación de vía o sustitución del carril de 32 kilos y medio por el de 43 kilos, entre gastos de primer establecimiento e imputables a la explotación, con un criterio dudoso ${ }^{1011}$. NORTE tomó como base el gasto total de la renovación y llevó a gastos de primer establecimiento el valor del exceso de peso del carril nuevo sobre el antiguo y el de traviesas que en mayor número exija aquél para su asiento, baja del resto que resulta el valor de los carriles viejos y material que se puede utilizar según su estado de conservación y lleva al gasto de explotación este segundo resto. En esta forma que lo hace la compañía, y siendo de su exclusiva iniciativa la mayor o menor extensión de la línea a renovar cada año, puede activarlo o suspenderlo, según convenga a sus intereses, y llevar los gastos de explotación a términos que le permitan el excedente de productos en la cuenta más conveniente a sus planes.

Otro ejemplo es el que se produjo con los "Gastos de domiciliación de valores", pero en este caso con la clara motivación de disminuir los gastos y aumentar los activos empresariales. Dentro de las cargas de explotación se encuentran los "Gastos de domiciliación de valores", que tuvo mucha transcendencia en el proceso de nacionalización del capital de NORTE. Por cada título a domiciliar que presentaban los banqueros, NORTE les abonaba 2 pesetas (una por los derechos de intervención y otra por comisión de mediación). Cuando era la banca extranjera la que los presentaba, se le abonaba, por giro postal, una peseta por título $\mathrm{y}$, además, había que pagar 0,5 pesetas a la Junta Sindical de Bolsa, por su mediación de oficio. Si los títulos los presentaban particulares, se abonaba a la Junta Sindical las mismas 0,5 pesetas. Las partidas

\footnotetext{
${ }^{1010}$ Acta n 719 del Libro de actas del Consejo de Administración de NORTE: 27 de noviembre de 1905.

1011 Así también lo cree la Comisión que realiza en 1923 una revisión contable de NORTE, pues no está de acuerdo con este criterio de reparto (AHF P-113-258-1: "Memoria sobre la situación económica de la Compañía de los Caminos de Hierro del NORTE de España", Primera Comisión investigadora de la situación económica de las empresas de ferrocarriles, 29 de noviembre de 1923: Apartado "Vía y obra").
} 
"Gastos de domiciliación de valores de la Compañía" y "Gastos de domiciliación de emisiones de obligaciones Valencianas NORTE" tuvieron mucha repercusión en el documento denominado "Ingreso en el régimen ferroviario establecido en 12 de julio de 1924, de varias compañías, y entre ellas las del NORTE y MZA"1012. En la "Evaluación Provisional de Capitales" de este documento, para calcular el Valor del Establecimiento, se propone que ambas partidas deben deducirse de las partidas del activo, tanto por no tener el concepto de gastos de emisión, que el Estatuto autoriza a deducir del producto de los empréstitos, como por no poderse considerar como gastos de primer establecimiento.

En estas tres excepciones es posible observar la voluntariedad de la medida -aunque no la finalidad-, y también atisbar el efecto sobre la cifra de resultados, pues la primera disminuye los gastos y las dos siguientes los aumenta. Sin embargo, no es posible afirmar que existe manipulación contable porque no hemos podido obtener pruebas documentales de la motivación que tenía la gerencia al utilizar estos excepcionales criterios contables.

\section{b) Amortización contable de activos no corrientes}

Las empresas, también las ferroviarias, han utilizado dos conceptos de amortización: el financiero y el contable. La amortización financiera es utilizada desde el origen de las compañías ferroviarias con la amortización de empréstitos y de acciones, y más adelante con la amortización de anticipos reintegrables. NORTE registró el concepto financiero de amortización de deudas en la Cuenta General de la Explotación, y más concretamente en la rúbrica "Cargas de la Explotación", dentro del título de las dos siguientes cuentas: "Interés y amortización de las obligaciones"1013 y "Amortización de bonos sin interés de Asturias, Galicia y León". Por su parte, este apartado se centra en el concepto contable de la amortización por ser susceptible de ser una herramienta de manipulación de la información financiera.

Antes de analizar el registro de amortización contable de la compañía, es necesario observar la regulación legal de la época, lo cual servirá para conocer su nivel de cumplimiento. La Ley sobre las Utilidades de la Riqueza Mobiliaria de 27 de marzo de 1900 (Gaceta de Madrid del 28 de marzo de 1900) -denominada Ley Villaverde- fue la primera en sentar las bases para la consideración fiscal de la amortización. Aunque en dicha Ley no se hacía referencia concreta a la amortización, sí se tipificaban las tarifas sobre la riqueza mobiliaria ${ }^{1014}$, así como se sometían a las sociedades a un gravamen del $12 \%$.

\footnotetext{
${ }^{1012}$ Real Orden de 29 de diciembre de 1925, disponiendo el ingreso en el Régimen fe-rroviario establecido por Real Decreto-ley de 12 de julio de 1924, de las Compañías de ferrocarriles que figuran en la relación que se inserta.

${ }^{1013}$ La partida "Cargas financieras. Interés y amortización de las obligaciones" que figura en la cuenta de explotación, incluía el importe abonado por las emisiones de empréstitos recogidos en el pasivo, las cuales son amortizadas por el método francés. El ingreso de las compañías en el régimen ferroviario el año 1925 paralizó la emisión de obligaciones por la compañía, pues los gastos de primer establecimiento, a que se destinaban, los sufragaba la Caja Ferroviaria y, después, el Estado (NORTE, 1940: 398).

${ }^{1014}$ Bentabol et al. (2011: 22) analizaron la evolución histórica de la amortización. Para ellos, las connotaciones del concepto de amortización se podrían clasificar dependiendo del tipo de empresas. En el caso de las empresas
} 
La primera referencia específica a la amortización contable apareció en el artículo 50 del Real Decreto de 17 de septiembre en aplicación de la Ley de Utilidades (Gaceta de Madrid de 23 de Septiembre de 1906). Este Real Decreto introdujo dos novedades relevantes. Por una parte, recogió por primera vez el cálculo de la cuota de amortización por medio de coeficientes, antecedente de los que rigen en la actualidad, estableciéndose el porcentaje máximo de amortización del 5\%. Por otra parte, estableció el coste histórico o coste de producción del elemento como base para el cálculo de la amortización. A partir de ese momento, la depreciación de los activos no corrientes materiales e inmateriales quedaba reflejada en la normativa legal a través de la tributación de los beneficios y, de esta forma, al reconocerse la amortización como partida deducible de los ingresos gravables, se incentivaba su cálculo y registro por parte de la empresa.

El artículo 3 de la Ley de 29 de abril de 1920 (Gaceta de Madrid, no 121 de 30 de abril de 1920) estableció dos hitos de considerable importancia respecto de la amortización. En primer lugar, consagró los principios de efectividad y contabilización, que a partir de dicha fecha se reiteraron en leyes posteriores. Desde ese momento, ambos requisitos deben calificarse como condiciones "sine qua non" para la admisión como gasto deducible de la amortización. Con la efectividad se quería indicar que la amortización debía ser la valoración de la pérdida de valor real sufrida por el inmovilizado durante el ejercicio económico. El otro requisito exigido era el de la contabilización de la depreciación, que estaba limitado en esta Ley al procedimiento directo. En segundo lugar se eliminó el límite máximo del 5\% establecido en el Real Decreto de 1906, dejando cierta libertad para amortizar siempre que se cumplieran los referidos principios, es decir, que la amortización fuese efectiva y estuviera contabilizada.

El artículo 4 del Real Decreto de 22 de septiembre de 1922 admitió la contabilización de las amortizaciones, tanto por el procedimiento directo, como por el indirecto.

La Base octava del "Estatuto ferroviario 1924" estableció que a los inmuebles y material fijo y móvil cedidos por el Estado, no se les aplicará coeficiente alguno de amortización.

Una vez analizada la regulación legal, observamos la práctica seguida por las empresas. Los procesos de amortización se introdujeron en el modelo contable tradicional en el siglo XX con la creación de las grandes compañías, fundamentalmente "las del sector del ferrocarril y mineras" (Benito, 2015: 205). El concepto de amortización es el registro sistemático de corrección de valor desde que el activo esta en condiciones de uso, es decir se contabiliza a lo

industriales, que llevaban una contabilidad de costes desarrollada, la amortización se considera un elemento formativo del coste del producto o servicio y, en consecuencia, una necesidad para la adecuada determinación de dicho coste. En el caso de las empresas comerciales y de servicios, en las que la información que se requiere es puramente de carácter financiero, la amortización se considera como garantía del mantenimiento del capital y criterio de valoración de los elementos del activo, contabilizando la misma como gasto o componente negativo de la cuenta de resultados. 
largo de la vida útil ${ }^{1015}$. NORTE fue pionero en el registro de la amortización contable en España.

Anteriormente, en el periodo 1886-1889, MZA realizó un proceso contable con ciertas similitudes a la amortización pero que es un concepto distinto; nos referimos a la corrección de valor después de su vida útil, es decir se registraba cuando el activo dejaba de estar en condiciones de funcionar. Ese concepto nunca debe ser considerado como amortización, sino corrección de valor después de su vida útil. No obstante, MZA la definió como "amortización" "1016, y en verdad es un proceso similar pues en la Junta General de Accionistas se asignaba con la calificación "fuera de servicio" o "fuera de uso", y a partir de ese momento se imputaba a la cuenta de Explotación, repartiéndola en cuatro años. Este proceso ha sido calificado como que "no comprende una fase de dotación, sino más bien un proceso de saneamiento de las cuentas" (Benito, 2015: 208). Es necesario especificar que, en ese momento (Fidalgo et al.: 2015), en Francia -la inspiradora de la práctica contable ferroviaria española-, estaban prohibidas las depreciaciones sistemáticas. El proceso de imputación de coste por el deterioro del inmovilizado "fuera de uso" con cargo a Explotación, se hizo sin alteración del inventario en la Cuenta de Establecimiento, como hubiese sido lo lógico en la práctica contable de MZA, si hubiese sido una amortización contable sistematica para corregir el uso, desuso u obsolescencia.

El cuadro 59 establece las diferencias entre el registro, mal llamado de amortización, de MZA en el periodo 1886-1889 y el registro de amortización contable de NORTE en el periodo 1900-1924.

Cuadro 59. Práctica contable de la corrección de valor de MZA en el periodo 18861889 y NORTE en 1900-1924

\begin{tabular}{|l|l|}
\hline Corrección de valor MZA 1886-1889 & Amortización NORTE 1900-1924 \\
\hline $\begin{array}{l}\text { Activos registrados en la Cuenta de } \\
\text { establecimiento }\end{array}$ & $\begin{array}{l}\text { Activos registrados en cuentas individuales } \\
\text { de activo }\end{array}$ \\
\hline Saneamiento & Dotación sistemática \\
\hline $\begin{array}{l}\text { Comienza el registro cuando deja de estar en } \\
\text { condiciones de funcionar }\end{array}$ & $\begin{array}{l}\text { Comienza el registro en el momento en que } \\
\text { comienza a estar en condiciones de funcionar }\end{array}$ \\
\hline No intenta corregir la obsolescencia y el uso & Intenta corregir la obsolescencia y el uso \\
\hline
\end{tabular}

Fuente: Elaboración propia

\footnotetext{
1015 Sobre la cualidad más importante, que la dotación sea sistemática acontece desde final del siglo XVIII, y con mayor frecuencia a principios del siglo XIX; los países que primero comenzaron a consolidar una depreciación sistemática se debió a que se establecieron Leyes que lo promovieron: Francia (1807) y Alemania (1884). Esto puede ser observado en Benito $(2015,214)$.

${ }^{1016}$ Informe Anual de MZA 1886, Notas Memoria, página 5.
} 
Bélgica fue el primer país del continente europeo donde se implantó el sistema ferroviario (año 1835), y también fue el primero donde se estableció la amortización contable. Lardner (1850: 62) describe el diferente tratamiento que establecían las ferroviaras belgas sobre el deterioro para el material móvil y para el desgaste de las vías. Las ferroviarias belgas consideraban que sobre las locomotoras no se necesitaba la dotación de ningún fondo, porque "con el progreso natural de las reparaciones y renovaciones en el material móvil de las compañías ferroviarias, no existe deterior gradual" (Lardner, 1850: 62). Por el contrario, las traviesas se deterioraban y requerían la reinstalación (en el caso belga de un $8 \%$ de media), y por ello, se deberían realizar dotaciones anuales a un fondo de reserva.

La generalización del registro de la amortización en el Reino Unido fue muy posterior. Sólo tras la entrada en vigor de The Railway Companies (Accounts and Returns) Act 1911 se contabilizó masivamente (Edwards, 1986a: 262) la provisión anual de fondos de amortización para cargar las renovaciones y sustituciones.

Para analizar la amortización de NORTE en su totalidad es necesario observar siete dimensiones: tratamiento contable, denominación, reflejo en el Informe Anual, coeficientes, cuantía, método de contabilización y vinculación de la dotación con la cifra de resultados del ejercicio.

El Informe Anual de NORTE incluye el término amortización contable en dos ubicaciones distintas $^{1017}$, como resulta natural por la aplicación de la partida doble:

a. En la Cuenta General de la Explotación, y más concretamente en la rúbrica de "Cargas de la Explotación", dentro del título de la cuenta "Amortización de material, fijo y móvil".

b. En el Pasivo del Balance de Situación, en concreto en el título de la rúbrica "Fondo para amortización del material fijo y móvil”.

La empresa no reconoció, en ningún ejercicio del periodo analizado, cuenta compensadora de activo alguna, porque en ningún texto legal se obligaba a hacerlo. NORTE realizaba una interpretación de la amortización desde el punto de vista de la contabilidad financiera no desde la contabilidad de gestión. A pesar de ser una empresa dedicada a la explotación de infraestructuras por medio de la prestación del servicio de transporte ferroviario, la amortización no constituía un elemento formativo del coste de dicho servicio, sino que se consideraba únicamente como un gasto dentro de la Cuenta de Pérdidas y Ganancias ${ }^{1018}$. En la Cuenta de Resultados no se incorporó en la rúbrica de Gastos de Explotación, sino en la denominada "Cargas de Explotación". Además de la dotación a la amortización de determinados elementos de activo, el epígrafe "Cargas de Explotación" incorporaba gastos

\footnotetext{
${ }^{1017}$ NORTE (1904: 6; 1905; 6; 1906: 6; 1907: 6; 1908: 6; 1909: 6; 1910: 6; 1911: 6; 1912: 6; 1913: 6; 1914: 6; 1915: 5; 1917: 6; 1918: 6; 1919: 6; 1920: 6; 1921: 6; 1922: 6; 1923: 6; 1924: 6).

${ }^{1018}$ Esto puede observarse en la documentación de NORTE (1904: 6; 1905; 6; 1906: 6; 1907: 6; 1908: 6; 1909 : 6; 1910: 6; 1911: 6; 1912: 6; 1913: 6; 1914: 6; 1915: 5; 1917: 6; 1918: 6; 1919: 6; 1920: 6; 1921: 6; 1922:6; 1923: 6; 1924: 6).
} 
tales como los derivados de intereses de obligaciones, depreciaciones de la moneda, gastos extraordinarios, e incluso la amortización de las obligaciones y bonos.

Por otro lado, NORTE consideraba a los fondos de amortización como una reserva. Esta consideración era concedida por la propia empresa: "La compañía viene aplicando esta reserva la amortización del material de tracción y transporte que se da de baja por inútil en la parte que resta entre el valor en que figura en el inventario y lo que de él se puede utilizar" 1019 .

Desde el comienzo del registro de la amortización (Lardner, 1850: 62), algunas compañías ferroviarias tuvieron la necesidad de diferenciar los elementos del material móvil, por un lado, y los componentes de vías y raíles como elementos de mayor permanencia, por otro. Así lo hizo NORTE, variando a lo largo del tiempo la denominación concedida a cada uno de los dos componentes de los bienes amortizables -“amortización de material" en denominación de la empresa-. Hasta 1912, NORTE consideraba bienes amortizables al material motor y móvil; a partir de esa fecha también valoraba y registraba amortización sobre el material fijo. Teniendo en cuenta esto, la denominación de los primeros elementos varió en dos ocasiones. En los Informes Anuales de los ejercicios contables 1903-1906, NORTE utilizó la denominación "Material motor y de transporte" 1020 para designar a la "amortización de material". En los ejercicios contables del periodo 1907-1911 utilizó exclusivamente la genérica denominación "Material"1021. A partir del ejercicio 1912 la "amortización de material" pasó a aparecer separada en dos conceptos: "Material fijo" y "Material motor y móvil" ${ }^{1022}$.

Respecto a la inclusión de la información en el Informe Anual, observamos que se informa tanto en el "Resumen General de las cuentas de explotación", como en la propia "Cuenta de explotación". El Informe Anual de 1903 de NORTE es el primero en el que se registra la amortización -aunque no amplía información sobre ella- pues incluye, dentro de las cargas de explotación, la amortización del material motor y móvil. Por su parte, el Informe Anual de 1905 es el primero en el que se ofrece información sobre la amortización registrada; en este ejercicio se especifica que, dentro de las cargas de explotación, se recoge la amortización de 0,4\% de material motor y móvil. El Informe Anual de 1906 establece por primera vez los datos comparativos con los del ejercicio anterior. La última gran novedad se produce a partir del Informe Anual de 1912, donde se empieza a realizar una separación de la amortización de Material, motor y móvil por un lado, y de Material fijo por otro.

1019 AHF P-113-258-1: "Memoria sobre la situación económica de la Compañía de los Caminos de Hierro del NORTE de España", Primera Comisión investigadora de la situación económica de las empresas de ferrocarriles, 29 de noviembre de 1923.

${ }^{1020}$ NORTE (1904: 39; 1905: 16; 1906: 16; 1907: 16).

${ }^{1021}$ NORTE (1908: 16; 1909: 16; 1910: 16; 1911: 16; 1912: 16).

${ }^{1022}$ NORTE (1913: 16; 1914: 16; 1915: 16; 1916: 16; 1917: 16; 1918: 16; 1919: 16; 1920: 16; 1921: 16; 1922 : 16; 1923: 16; 1924: 16). 
El apartado "I. Resumen general de las cuentas de explotación" del ejercicio 1905 de NORTE recoge los ingresos y gastos de cada ejercicio contable y las cantidades ingresadas por la compañía en las Cajas del Estado en concepto de impuestos sobre viajeros y mercancías. El apartado "I. Resumen general de las cuentas de explotación" se divide en tres subapartados: A. Ingresos del Tráfico, B. Gastos de la explotación y C. Cargas de la explotación. Antes de analizar cada uno de estos subapartados la empresa incluye un cuadro resumen donde se recogen los saldos de los ingresos del tráfico y los gastos de la explotación (y por diferencia de ambas el Margen denominado "Producto neto") y las cargas de la explotación, donde se diferencian los intereses y amortización de las obligaciones, Intereses, cambios y comisiones, Accidentes y Amortización. Respecto a este último apartado, la Memoria de 1905 incluye, dentro de las cargas de explotación, la Amortización de 0,4\% de material motor y móvil (NORTE, 1906: 6). Es el primer ejercicio contable en el que se ofrece información sobre la amortización registrada.

La Cuenta de Explotación del ejercicio contable $1905^{1023}$ introduce una novedad fundamental para el desarrollo de la información contable. Dentro de los "Intereses y amortización de las obligaciones" -componente único de las Cargas de la explotación- se incluyen los intereses de los empréstitos, la amortización de los empréstitos, los intereses, cambio sobre pagos en el extranjero y comisiones, los accidentes y la amortización ${ }^{1024}$. La amortización es relevante porque supone registrar por primera vez la dotación por deterioro de valor ordinario definitivo por uso, desuso u obsolescencia. Y este es un reflejo de una madurez en la contabilidad.

El apartado I. "Resumen general de las cuentas de explotación" del ejercicio 1906 de NORTE sintetiza los ingresos y gastos de cada ejercicio contable y las cantidades ingresadas por la compañía en las Cajas del Estado en concepto de impuestos sobre viajeros y mercancías (NORTE, 1907: 6-16). El apartado "I. Resumen general de las cuentas de explotación" se divide en cuatro subapartados: A. Ingresos del Tráfico, B. Ingresos varios, C. Gastos de la explotación, D. Cargas de la Explotación. Antes que pasar a informar sobre cada uno de estos subapartados se incluye un cuadro resumen donde se recogen los saldos de los ingresos del tráfico, de los ingresos varios, la suma de todos los ingresos, a partir de ellos los gastos de la explotación (y por diferencia con la suma de los ingresos el margen denominado "Producto neto") y las cargas de la explotación, donde se identifican por separado los intereses y amortización de las obligaciones, Intereses, cambios y comisiones, Accidentes, Amortización, encabezamiento con la administración del timbre en Francia y ejercicios cerrados (saldos de la cuenta). El Informe Anual de 1906 incluye, dentro de las cargas de explotación, la Amortización de 5\% de material motor y móvil (NORTE, 1907: 6). La novedad más representativa del ejercicio es que establece tres tipos de datos: los del año presente, los del año anterior, y la diferencia entre ambos (NORTE, 1907: 6-16).

La Cuenta de Explotación del ejercicio contable 1906 está formada por dos columnas (NORTE, 1907: 40-63). La primera -denominada Gastos- está dividida en dos títulos: Gastos

\footnotetext{
${ }^{1023}$ NORTE (1906: 40-63).

${ }^{1024}$ Esta es la amortización contable; la amortización financiera se sitúa en el mismo apartado. En la Memoria de 1905, la dotación de la amortización contable es del 0,4\% de material motor y de transporte (NORTE, 1906: 40).
} 
de explotación (dividido a su vez en Administración central, Dirección, Explotación, Trafico, Material y tracción y Vía y obras) y Cargas de la explotación (constituido íntegramente en un apartado Intereses y amortización de las obligaciones, donde se incluyen los intereses de los empréstitos, la amortización de los empréstitos, los intereses, cambio sobre pagos en el extranjero y comisiones, los accidentes ${ }^{1025}$, la amortización ${ }^{1026}$ y los créditos incobrables). La segunda columna -denominada Productos- se divide en dos títulos sola línea (que a su vez se divide en tres subtítulos: Transportes a gran velocidad, Transportes a pequeña velocidad y Productos diversos) y Productos de fuera de la explotación ${ }^{1027}$ (donde se incluyen, entre otros, Intereses, cambio sobre pagos en el extranjero y comisiones).

El apartado I. "Resumen general de las cuentas de explotación" de los ejercicios 1907-1911 incluye, dentro de las cargas de explotación, la Amortización de 5\% de material motor y móvil ${ }^{1028}$.

Las Cuentas de Explotación del periodo 1907-1911 están formadas por dos columnas. La primera, denominada Gastos, está dividida en dos títulos: Gastos de explotación (dividido a su vez en Administración central, Dirección, Explotación, Trafico, Material y tracción y Vía y obras) y Cargas de la explotación (constituido por cuatro apartados Intereses y amortización de las obligaciones, Intereses, cambio sobre pagos en el extranjero y comisiones, Amortización del 5\% de material ${ }^{1029}$ y Encabezamiento con la Administración del Timbre en Francia). La segunda columna, denominada Productos, se divide en dos títulos: Productos de la explotación (que a su vez se divide en tres subtítulos: Transportes a gran velocidad, Transportes a pequeña velocidad y Productos diversos) y Productos de fuera de la explotación.

Desde el ejercicio 1911 se produce una modificación en la presentación. La subpartida "Fondo de reserva para la amortización de material" se dividía en dos conceptos: para material fijo ${ }^{1030}$ y para material motor y móvil. Aparece en los balances desde 1911, en calidad de reservas, habiendo sido incluida hasta esa fecha dentro de las "Cuentas acreedoras". Esta novedad se basó en un acuerdo del Consejo de Administración ${ }^{1031}$, aunque en tal acuerdo sólo se autorizaba que se consignase en el grupo de reservas la cifra de la

\footnotetext{
1025 En la Memoria de 1905 y 1996, por ejemplo, se cita el accidente en Cercedilla (NORTE, 1907: 40).

1026 En la Memoria de 1906, la dotación de la amortización es del 5\% de material motor y de transporte (NORTE, 1907: 40).

${ }^{1027}$ No existe ningún título denominado "Productos de fuera de la explotación", no obstante, lo inferimos porque el resto de los componentes están dentro de una semisuma cuyo título es Productos de la Explotación.

${ }^{1028}$ NORTE (1908: 6; 1909: 6; 1910: 6; 1911: 6; 1912: 6).

${ }^{1029}$ Los dos conceptos Intereses, cambio sobre pagos en el extranjero y comisiones, por un lado, y Amortización del 5\% de material, por otro, están dentro de una misma semisuma. Los consideramos apartados distintos por ser conceptos diferentes. Al igual que en el Informe Anual de 1906, la dotación de la amortización es del 5\% de material motor y de transporte. Cfr. NORTE (1908: 36-57) (1909: 38-60) (1910: 36-58) (1911: 36-58) (1912: 3861) (1913: 38-63).

${ }^{1030}$ En el material fijo se incluyen los siguientes conceptos: carriles, agujas, puntas de corazón y otros elementos para cruces, cambios de vías y desvíos, contracarriles y cremalleras, traviesas, piezas para la colocación y unión o fijación de carriles.

${ }^{1031}$ Acta 773 Consejo de Administración de NORTE, 31 de mayo de 1910.
} 
cuenta que venía figurando en el grupo de "Cuentas acreedoras", con la asignación de "Reservas para amortización de material". No obstante, a partir de 1912, se aumenta su dotación con una nueva función con aplicación a estas cuentas; se carga el valor de los materiales que desaparecen por el uso, a fin de conservar las instalaciones de Primer establecimiento con el valor que tiene en el Balance. Por lo que a material fijo se refiere, estas aplicaciones no se realizan, pues se llevan a cuenta de explotación los gastos procedentes de las renovaciones de vías. En Material motor y móvil también resulta exigua la cantidad aplicada, por lo que las grandes reparaciones de material alargan la vida de máquinas, coches y vagones.

En las Cuentas de Explotación del ejercicio 1912 se establecieron unos nuevos porcentajes de amortización. Los dos conceptos Intereses, cambio sobre pagos en el extranjero y comisiones, por un lado, y Amortización del 5\% de material, por otro, pasan a estar en 1912 claramente separados y diferenciados, dejando de estar en la misma semisuma, por ser conceptos diferentes. La Amortización de material recogida en el Informe Anual de 1912 fue del 3\% para el Material fijo y 5\% para el Material motor y móvil. (NORTE, 1913: 38-63). En los Informes Anuales desde 1906, y hasta la del 1911, la dotación de la amortización fue del 5\% de material motor y de transporte ${ }^{1032}$.

La amortización del periodo 1913-1916 permanece con una exposición estable, variando únicamente por los porcentajes.

Las Cuentas de Explotación del periodo contable 1917-1923 tienen como novedad que desaparece el título de amortización. NORTE no registra la amortización del material en el Informe Anual de 1917 (NORTE, 1918: 44-68) ni de 1918 (NORTE, 1919: 38-64), ni de 1919 (NORTE, 1920: 42-66), ni de 1920 (NORTE, 1921: 42-66), ni de 1921 (NORTE, 1922: 4468), ni de 1922 (NORTE, 1923: 42-66) ni de 1923 (NORTE, 1924: 44-67). Esta política será concordante con el futuro legislativo. La Base octava del "Estatuto ferroviario de 1924" establece que a los inmuebles y material fijo y móvil cedidos por el Estado, no se les aplicará coeficiente alguno de amortización, por demérito de tiempo y servicio sobre los inmovilizados.

Por lo que respecta a los coeficientes de amortización aplicables desde el punto de vista legislativo, el Real Decreto de 1906 estableció un porcentaje máximo de amortización del 5\% anual, que posteriormente la Ley de 1920 eliminó, permitiendo cierta libertad para amortizar, siempre que se cumpliesen los principios de efectividad y contabilización.

Para el cálculo de la dotación anual, NORTE siempre respetó el límite máximo del 5\% establecido por el Real Decreto de 1906, durante todo el periodo examinado. El porcentaje aplicado por la compañía a la amortización del material móvil, con anterioridad a la publicación del Real Decreto de 1906, fue sensiblemente inferior al 5\%, ciñéndose a dicho porcentaje desde entonces y hasta 1913, fecha a partir de la cual disminuyó el tipo utilizado.

${ }^{1032}$ Cfr. NORTE (1908: 36-57; 1909: 38-60; 1910: 36-58; 1911: 36-58; 1912: 38-61). 
En cuanto al material fijo, los tipos aplicados para su amortización fueron sensiblemente inferiores a los utilizados para el material móvil y, por tanto, por debajo del máximo permitido.

La Memoria de 1903 incluía, dentro de las cargas de explotación, la amortización de 1\% del Material motor y de transporte (NORTE, 1904: 6). Es el primer ejercicio contable en el que se registró la amortización, aunque no se detallará información sobre ella ${ }^{1033}$.

El Informe Anual de 1905 incluyó, dentro de las cargas de explotación, la amortización de 0,4\% del Material motor y de transporte (NORTE, 1906: 6). Es el primer ejercicio contable en el que se ofrece información detallada sobre la amortización registrada ${ }^{1034}$.

El Informe Anual del periodo 1906-1911 incluyó, dentro de las cargas de explotación, la Amortización de $5 \%{ }^{1035}$. En el año 1906 se aplica ese porcentaje sobre el material, que se denomina amortización del Material motor y de transporte ${ }^{1036}$. En los años $1907^{1037}, 1908^{1038}$, $1909^{1039}, 1910^{1040}$ y $1911^{1041}$ el mismo porcentaje se aplica sobre el Material.

\footnotetext{
${ }^{1033}$ En el año 1903 no se utilizaba aún la denominación Material móvil, sino que se incluía en un apartado denominado "Material motor y de transporte" dentro de las "Cargas de la explotación". "Se dota una amortización del 1\% sobre el material motor y de transporte" (NORTE, 1904: 39).

${ }^{1034}$ En el ejercicio 1905 la información de la amortización se incluye en el subapartado "Amortización de material" del apartado "C. Cargas de la explotación" del apartado "I. Resumen general de las cuentas de explotación" (NORTE, 1906: 16). Dentro del apartado "Amortización de material" se especifica que el porcentaje del $0,4 \%$ se debe a la amortización de Material motor y de transporte.

${ }_{1035}$ NORTE (1906: 6; 1907: 6; 1908: 6; 1909: 6; 1910: 6; 1911: 6; 1912: 6; 1913: 6; 1914: 6).

${ }^{1036}$ En el ejercicio 1906 la información de la amortización se incluye en el subapartado "Amortización de material" del apartado "D. Cargas de la explotación" del apartado "I. Resumen general de las cuentas de explotación" (NORTE, 1907: 16). Dentro del apartado "Amortización de material" se especifica que el porcentaje del 5\% se debe a la amortización de Material motor y de transporte.

${ }^{1037}$ En el ejercicio 1907 la información de la amortización se incluye en el subapartado "Amortización de material" del apartado "D. Cargas de la explotación" del apartado "I. Resumen general de las cuentas de explotación" (NORTE, 1908: 17).

${ }^{1038}$ En el ejercicio 1908 la información de la amortización se incluye en el subapartado "Amortización de material" del apartado "D. Cargas de la explotación" del apartado "I. Resumen general de las cuentas de explotación" (NORTE, 1909: 16).

${ }^{1039}$ En el año 1909 la información de la amortización se incluye en el subapartado "Amortización de material" del apartado "D. Cargas de la explotación" del apartado "I. Resumen general de las cuentas de explotación" (NORTE, 1910: 15).

${ }^{1040}$ En el año 1910 la información de la amortización se incluye en el subapartado "Amortización de material" del apartado "D. Cargas de la explotación" del apartado "I. Resumen general de las cuentas de explotación" (NORTE, 1911: 15).

${ }^{1041}$ En el año 1911 la información de la amortización se incluye en el subapartado "Amortización de material" del apartado "D. Cargas de la explotación" del apartado "I. Resumen general de las cuentas de explotación" (NORTE, 1912: 15).
} 
En los ejercicios contables $1912^{1042}$ y $1913^{1043}$, se dotó un 5\% sobre el Material motor y móvil, pero un porcentaje menor sobre el material fijo: 3,5\% para 1912 y 1,3\% para 1913.

En los años posteriores, $1914^{1044}, 1915^{1045}$ y $1916^{1046}$, sin razón ni justificación declarada, se registró unos niveles de amortización menores, lo que supuso un menor gasto, y un mayor beneficio. En el periodo 1917-1924 no se registró la amortización.

El detalle de los tipos aplicados para cada una de las categorías de activos puede observarse $^{1047}$ en el cuadro 60 .

${ }^{1042}$ En el año 1912 la información de la amortización se incluye en el subapartado "Amortización de material" del apartado "D. Cargas de la explotación" del apartado "I. Resumen general de las cuentas de explotación" (NORTE, 1913: 16).

${ }^{1043}$ En el ejercicio 1913 la información de la amortización se incluye en el subapartado "Amortización de material" del apartado "E. Cargas de la explotación" del apartado "I. Resumen general de las cuentas de explotación" (NORTE, 1914: 18).

${ }^{1044}$ En el ejercicio 1914 la información de la amortización se incluye en el subapartado "Amortización de material" del apartado "E. Cargas de la explotación" del apartado "I. Resumen general de las cuentas de explotación" (NORTE, 1915: 18).

${ }^{1045}$ En el ejercicio 1915 la información de la amortización se incluye en el subapartado "Amortización de material" del apartado "E. Cargas de la explotación" del apartado "I. Resumen general de las cuentas de explotación" (NORTE, 1916: 18).

${ }^{1046}$ En el ejercicio 1916 la información de la amortización se incluye en el subapartado "Amortización de material" del apartado "E. Cargas de la explotación" del apartado "I. Resumen general de las cuentas de explotación" (NORTE, 1917: 18).

${ }^{1047}$ Cabe precisar que, tal como era habitual en dicha época según los manuales consultados, el sistema de amortización utilizado es no financiero, y así, al principio del periodo considerado la amortización se efectúa en cuotas constantes, variando según determinadas circunstancias (Bentabol et al., 2011: 20). 


\section{Cuadro 60. Coeficientes de amortización}

\begin{tabular}{|c|c|c|}
\hline Ejercicio contable & $\begin{array}{c}\text { Amortización de } \\
\text { Material motor y de } \\
\text { transporte }\end{array}$ & \\
\hline 1900 & --- & \\
\hline 1901 & --- & \\
\hline 1902 & --- & \\
\hline 1903 & $1 \%$ & \\
\hline 1904 & --- & \\
\hline 1905 & $0,4 \%$ & \\
\hline 1906 & $5 \%$ & \\
\hline Ejercicio contable & $\begin{array}{c}\text { Amortización de } \\
\text { Material }\end{array}$ & \\
\hline 1907 & $5 \%$ & \\
\hline 1908 & $5 \%$ & \\
\hline 1909 & $5 \%$ & \\
\hline 1910 & $5 \%$ & \\
\hline 1911 & $5 \%$ & \\
\hline Ejercicio contable & $\begin{array}{c}\text { Material motor y } \\
\text { móvil }\end{array}$ & Material fijo \\
\hline 1912 & $5 \%$ & $3,5 \%$ \\
\hline 1913 & $5 \%$ & $1,3 \%$ \\
\hline 1914 & $2,5 \%$ & $1,25 \%$ \\
\hline 1915 & $4 \%$ & $1,5 \%$ \\
\hline 1916 & $3 \%$ & $1 \%$ \\
\hline 1917 & --- & --- \\
\hline 1918 & --- & --- \\
\hline 1919 & --- & --- \\
\hline 1920 & --- & --- \\
\hline 1921 & --- & --- \\
\hline 1922 & --- & --- \\
\hline 1923 & --- & --- \\
\hline 1924 & --- & --- \\
\hline
\end{tabular}

Fuente: Elaboración propia

NORTE registró la amortización contable sobre dos tipos de activos: Material móvil o rodante y Material fijo. En NORTE se amortizaron sólo los elementos directamente relacionados con la producción, primero el Material motor y móvil desde 1903 y, más tarde, el Material fijo a partir de 1912. En el periodo estudiado, la compañía amortizó el Material móvil o rodante en todos los ejercicios desde 1903, con la única excepción de los ejercicios en el que la sociedad obtuvo pérdidas. Respecto al material fijo, 1912 es el primer ejercicio en el que se tiene constancia de la amortización de este tipo de inmovilizado, que se mantiene hasta 1916, año en el que se interrumpe dicha política junto con la del material móvil, motivado por la aparición de la fase inicial del problema ferroviario en sentido estricto, que llevó a la sociedad a diversos ejercicios consecutivos de pérdidas. 
De la aplicación de los porcentajes de amortización señalados sobre los valores de coste del material que figuraban en los Balances de la compañía, se obtenía la amortización del ejercicio, que se explicitaba en la Cuenta de Resultados, dentro de la rúbrica "Cargas de la Explotación”. Los importes consignados para cada ejercicio se incluyen en el cuadro 61.

Cuadro 61. Cuantía de la amortización practicada por tipología de elementos

\begin{tabular}{|c|c|c|c|}
\hline Año & $\begin{array}{c}\text { Total } \\
\text { Amortización }\end{array}$ & $\begin{array}{c}\text { Amortización de } \\
\text { Material motor y de } \\
\text { transporte }\end{array}$ & \\
\hline \multicolumn{3}{|l|}{1900} & \\
\hline \multicolumn{3}{|l|}{1901} & \\
\hline \multicolumn{3}{|l|}{1902} & \\
\hline 1903 & $981.156,94$ & $981.156,94$ & \\
\hline 1904 & --- & --- & \\
\hline 1905 & $410.490,40$ & $410.490,40$ & \\
\hline 1906 & $5.169 .296,88$ & $5.169 .296,88$ & \\
\hline $\begin{array}{l}\text { Ejercicio } \\
\text { contable }\end{array}$ & $\begin{array}{c}\text { Total } \\
\text { Amortización }\end{array}$ & $\begin{array}{c}\text { Amortización de } \\
\text { Material }\end{array}$ & \\
\hline 1907 & $5.346 .527,00$ & $5.346 .527,00$ & \\
\hline 1908 & $5.602 .951,25$ & $5.602 .951,25$ & \\
\hline 1909 & $5.931 .068,42$ & $5.931 .068,42$ & \\
\hline 1910 & $6.186 .055,22$ & $6.186 .055,22$ & \\
\hline 1911 & $6.512 .965,56$ & $6.512 .965,56$ & \\
\hline $\begin{array}{l}\text { Ejercicio } \\
\text { contable }\end{array}$ & $\begin{array}{c}\text { Total } \\
\text { Amortización }\end{array}$ & $\begin{array}{c}\text { Amortización de } \\
\text { Material motor y } \\
\text { móvil }\end{array}$ & $\begin{array}{c}\text { Amortización de } \\
\text { Material fijo }\end{array}$ \\
\hline 1912 & $11.459 .766,20$ & $6.871 .286,21$ & $4.588 .479,99$ \\
\hline 1913 & $9.340 .360,77$ & $7.606 .088,78$ & $1.734 .271,99$ \\
\hline 1914 & $5.901 .344,53$ & $4.129 .872,41$ & $1.771 .472,12$ \\
\hline 1915 & $8.909 .527,14$ & $6.769 .414,08$ & $2.140 .113,06$ \\
\hline 1916 & $6.501 .378,67$ & $5.067 .498,30$ & $1.433 .880,37$ \\
\hline 1917 & --- & --- & --- \\
\hline 1918 & --- & --- & --- \\
\hline 1919 & --- & --- & --- \\
\hline 1920 & --- & --- & --- \\
\hline 1921 & --- & --- & --- \\
\hline 1922 & --- & --- & --- \\
\hline 1923 & --- & --- & --- \\
\hline 1924 & ---- & ---- & --- \\
\hline
\end{tabular}

Fuente: Elaboración propia

En cuanto al método de contabilización (directo e indirecto), hasta 1910 NORTE utilizó el método directo, adoptándose desde 1911 el método indirecto, que sería el admitido 
fiscalmente por el Real Decreto de 1922 (Gaceta de Madrid no 252, de 19 de octubre de 1922).

NORTE incumplió la legislación contable durante once ejercicios contables consecutivos. Hasta la promulgación del Real Decreto de 1922, el método indirecto no era admitido fiscalmente por la legislación, aunque, sin embargo, fue el elegido por la compañía NORTE para el reflejo de la amortización a partir de 1911, tal como se constata al tener el gasto por tal concepto como contrapartida una cuenta incluida en el pasivo del Balance titulada "Fondo de amortización para el Material fijo y móvil", que compensaba los valores de los elementos amortizados que se mostraban en el activo ${ }^{1048}$. Con anterioridad a 1911, el método utilizado fue el directo, ya que no aparecía en el Pasivo la cuenta señalada anteriormente, ni tampoco en el Activo se recogía cuenta alguna compensadora del valor de los inmovilizados.

El importe del saldo de la cuenta de Pasivo "Fondo para amortizaciones de material", utilizada por la compañía NORTE para adoptar el método indirecto aparece en el cuadro 62.

1048 Bentabol et al. (2011) escribió que el reflejo de la "Amortización del material” en el pasivo del Balance implica la utilización del método indirecto de reflejo de dicha amortización, pese a no ser un criterio fiscalmente admitido por la normativa de la época. 


\section{Cuadro 62. Saldo de la cuenta de pasivo Fondo de Amortización}

\begin{tabular}{|c|c|c|c|}
\hline Ejercicio contable & $\begin{array}{l}\text { Total Fondo de } \\
\text { Amortización }\end{array}$ & $\begin{array}{ll}\text { Amortización } & \text { de } \\
\text { Material motor y de } \\
\text { transporte }\end{array}$ & \\
\hline 1900 & - & - & \\
\hline 1901 & - & - & \\
\hline 1902 & - & - & \\
\hline 1903 & - & - & \\
\hline 1904 & - & - & \\
\hline 1905 & - & - & \\
\hline 1906 & - & - & \\
\hline Ejercicio contable & $\begin{array}{l}\text { Total Fondo de } \\
\text { Amortización }\end{array}$ & $\begin{array}{ll}\text { Amortización } & \text { de } \\
\text { Material } & \\
\end{array}$ & \\
\hline 1907 & - & - & \\
\hline 1908 & - & - & \\
\hline 1909 & - & - & \\
\hline 1910 & - & - & \\
\hline 1911 & $37.003 .904,47$ & $37.003 .904,47$ & \\
\hline Ejercicio contable & $\begin{array}{l}\text { Total Fondo de } \\
\text { Amortización }\end{array}$ & $\begin{array}{l}\text { Amortización de } \\
\text { Material motor y móvil }\end{array}$ & Material fijo \\
\hline 1912 & $47.958 .748,20$ & $43.370 .268,21$ & $4.588 .479,99$ \\
\hline 1913 & $56.589 .494,94$ & $50.266 .742,96$ & $6.322 .751,98$ \\
\hline 1914 & $62.423 .277,31$ & $54.329 .053,21$ & $8.094 .224,10$ \\
\hline 1915 & $70.954 .551,27$ & $60.720 .214,11$ & $10.234 .337,16$ \\
\hline 1916 & $77.071 .502,73$ & $65.403 .285,20$ & $11.668 .217,53$ \\
\hline 1917 & $76.312 .219,09$ & $64.644 .001,56$ & $11.668 .217,53$ \\
\hline 1918 & $75.262 .143,68$ & $63.593 .926,15$ & $11.668 .217,53$ \\
\hline 1919 & $75.095 .678,74$ & $63.427 .461,21$ & $11.668 .217,53$ \\
\hline 1920 & $75.040 .300,24$ & $63.372 .082,71$ & $11.668 .217,53$ \\
\hline 1921 & $74.308 .056,34$ & $62.639 .839,11$ & $11.668 .217,23$ \\
\hline 1922 & $73.720 .675,32$ & $62.052 .458,09$ & $11.668 .217,23$ \\
\hline 1923 & $71.802 .186,46$ & $60.133 .969,23$ & $11.668 .217,23$ \\
\hline 1924 & $66.713 .380,85$ & $55.045 .163,62$ & $11.668 .217,23$ \\
\hline
\end{tabular}

Fuente: Elaboración propia por adaptación parcial de Bentabol et al. (2011: 20)

Un aspecto a averiguar es cómo se condicionó la amortización a la obtención de benefícios suficientes y/o a los requerimientos del Consejo de Administración. El criterio aplicado por el Consejo de Administración de la compañía fue registrar la amortización en función de la cifra de resultados, obviándose dicho criterio en los años que registraron pérdidas, tal como puede constatarse en el periodo comprendido entre los ejercicios 1903 a 1918. Como se puede observar en el cuadro 63, durante el periodo 1903-1918 únicamente se reflejó el coste de la amortización en aquellos ejercicios que obtuvieron beneficios contables, no en los que tuvieron pérdidas ${ }^{1049}$. A pesar de tener beneficios contables, la partida de amortización se

${ }^{1049}$ Este criterio puede observarse en la información elaborada por la propia empresa. AHF P-113-258-1: "Memoria sobre la situación económica de la Compañía de los Caminos de Hierro del NORTE de España", 
suprimió en los años 1919-1924. Durante el periodo 1903-1918, en los ejercicios contables en los que sí se contabilizó la amortización, este concepto supone entre un $42 \%$ y un $188 \%$ del beneficio obtenido. En el periodo 1900-1902, no se registró amortización, aunque NORTE sí obtuvo beneficios.

Cuadro 63. Porcentaje de la amortización sobre Beneficio

\begin{tabular}{|l|l|l|l|}
\hline $\begin{array}{l}\text { Ejercicio } \\
\text { contable }\end{array}$ & $\begin{array}{l}\text { Resultado del } \\
\text { ejercicio }\end{array}$ & Amortización & \% Amort/Rdo \\
\hline $\mathbf{1 9 0 0}$ & $251.836,21$ & --- & --- \\
\hline $\mathbf{1 9 0 1}$ & $179.995,36$ & --- & --- \\
\hline $\mathbf{1 9 0 2}$ & $938.099,00$ & --- & --- \\
\hline $\mathbf{1 9 0 3}$ & $1.579 .951,85$ & $981.156,94$ & $62,10 \%$ \\
\hline $\mathbf{1 9 0 4}$ & $-2.616 .392,61$ & --- & --- \\
\hline $\mathbf{1 9 0 5}$ & $265.955,72$ & $410.490,40$ & $154,35 \%$ \\
\hline $\mathbf{1 9 0 6}$ & $2.747 .648,23$ & $5.169 .296,88$ & $188,14 \%$ \\
\hline $\mathbf{1 9 0 7}$ & $9.578 .062,76$ & $5.346 .527,00$ & $55,82 \%$ \\
\hline $\mathbf{1 9 0 8}$ & $9.953 .401,59$ & $5.602 .951,25$ & $56,29 \%$ \\
\hline $\mathbf{1 9 0 9}$ & $10.175 .500,36$ & $5.931 .068,42$ & $58,29 \%$ \\
\hline $\mathbf{1 9 1 0}$ & $14.130 .258,80$ & $6.186 .055,22$ & $43,78 \%$ \\
\hline $\mathbf{1 9 1 1}$ & $15.539 .305,95$ & $6.512 .965,56$ & $41,91 \%$ \\
\hline $\mathbf{1 9 1 2}$ & $16.331 .273,79$ & $11.459 .766,20$ & $70,17 \%$ \\
\hline $\mathbf{1 9 1 3}$ & $13.360 .479,61$ & $9.340 .360,77$ & $69,91 \%$ \\
\hline $\mathbf{1 9 1 4}$ & $8.004 .557,29$ & $5.901 .344,53$ & $73,72 \%$ \\
\hline $\mathbf{1 9 1 5}$ & $11.073 .219,71$ & $8.909 .527,14$ & $80,46 \%$ \\
\hline $\mathbf{1 9 1 6}$ & $10.278 .445,81$ & $6.501 .378,67$ & $63,25 \%$ \\
\hline $\mathbf{1 9 1 7}$ & $-1.005 .482,65$ & --- & --- \\
\hline $\mathbf{1 9 1 8}$ & $-20.410 .083,05$ & --- & --- \\
\hline $\mathbf{1 9 1 9}$ & $9.843 .752,11$ & --- & --- \\
\hline $\mathbf{1 9 2 0}$ & $22.066 .691,77$ & --- & --- \\
\hline $\mathbf{1 9 2 1}$ & $20.698 .287,27$ & --- & --- \\
\hline $\mathbf{1 9 2 2}$ & $22.034 .466,49$ & --- & --- \\
\hline $\mathbf{1 9 2 3}$ & $22.316 .878,94$ & --- & --- \\
\hline $\mathbf{1 9 2 4}$ & $22.614 .662,41$ & --- & \\
\hline & & & \\
\hline
\end{tabular}

Fuente: Bentabol et al. (2011: 18)

La dotación de la amortización de NORTE puede dividirse en tres periodos. De 1900-1902 no se dotó amortización ni con beneficios ni con pérdidas. Entre 1903-1916 sólo se dotó en ejercicios contables con beneficios, no en los que tienen pérdidas. Entre 1917-1924 no se amortizó ni con beneficios ni con pérdidas. Con estos datos, es posible inferir que NORTE no

Primera Comisión investigadora de la situación económica de las empresas de ferrocarriles, 29 de noviembre de 1923. 
tuvo motivación continuada uniforme de creatividad contable con la amortización. $\mathrm{O}$ al menos no es posible encontrar un patrón de conducta sobre esta creatividad contable.

Sin embargo, sí es posible identificar un proceso de atenuación de las pérdidas. Si existían pérdidas en el periodo 1903-1916, la sociedad no registraba la amortización para que los resultados contables no fueran excesivamente negativos. Por el contrario, en los ejercicios contables con beneficios, la empresa sí la registraba buscando la representatividad de la valoración y una prudencia valorativa. Esto supone desnaturalizar el concepto de la amortización como corrección sistemática del valor, lo que nos hace evaluar como poco madura la contabilización de NORTE en el proceso de registro de la amortización.

Por todo ello, no es posible encontrar la voluntariedad y finalidad expresa, necesarias para identificar una manipulación contable en el proceso de registro de la amortización. Esto es destacable porque es el principal medio de creatividad temporal contable con el que NORTE podía de forma sencilla alterar la apariencia de las cuentas -mucho más en un entorno de escasa regulación legislativa como la del periodo analizado-, seguramente por la escasa experiencia en su utilización (recordemos que era los primeros años en los que la empresa aplicaba la amortización). Además, no tenemos pruebas documentales de la voluntariedad de estas acciones de registro y valoración.

\section{c) Deterioro de valor}

El Informe Anual de 1906 incluye una cuenta denominada "Ejercicios cerrados", deudora de una suma importante por créditos incobrables. Para "evitar en los sucesivo la influencia de hechos de esta naturaleza sobre los resultados definitivos de los ejercicios venideros", el Consejo propone a la Junta la creación de un fondo de previsión. El importe inicial en el ejercicio contable 1906 fue de 200.000 pesetas. Este es el primer registro de un deterioro de valor, por el método indirecto, en la historia de NORTE.

Esta partida incluida en el apartado "VII. Asuntos varios" de la Memoria del Informe Anual de NORTE de 1906 supone una dotación novedosa basada en la hipótesis contable de prudencia. La medida disminuye el beneficio del ejercicio, al dotar una mayor cantidad de gastos respecto a los ejercicios precedentes. Es posible que la constitución de este fondo tuviera como motivación intentar conceder unos menores beneficios, quizás para no repartir dividendos $\mathrm{o}$, con más probabilidad, para ofrecer una imagen más negativa de la que pudiera tener sin realizar estas acciones. Sin embargo, no tenemos pruebas documentales de la voluntariedad y búsqueda de la finalidad de estas medidas.

\section{d) Política de dotación y aplicación de reservas}

Los Estatutos de NORTE concedían al Consejo la facultad de constituir reservas. Su creación era una medida de prudencia empresarial, que debe ser valorada como una práctica contable positiva. No obstante, es posible identificar cuatro situaciones en la que se produjo una manipulación de la información contable con las reservas. En las cuatro situaciones puede 
observarse una manipulación contable en el momento de la dotación, porque se carga la cuenta de resultados y se abona la cuenta de reservas. Pero, además, en el tercer y cuarto caso se produce una manipulación contable adicional en la aplicación de la reserva. En la aplicación se carga las reservas y se abona la cuenta de tesorería o la disminución de activo o aumento de pasivo, sin que se registre un gasto en la cuenta de resultados. Por lo tanto, si no hay gasto, hay un aumento de beneficio artificial, y por tanto, una mejor apariencia de la situación real en los años en que se aplica.

La manipulación de la información financiera adicional se produjo en todos los casos salvo en aquellos en que se dotó una reserva y luego se aplicó sin relacionarse con una salida presente o futura de recursos; bien porque no se produjo nunca el hecho por el que se constituyó, como en el primer caso, o porque se desestimó el hecho por el que se fundó, como en el segundo.

Primeramente, en el Informe Anual de NORTE de 1910-1913 ${ }^{1050}$ aparece que el Consejo constituyó una "Reserva de previsión" por 2.000 .000 pesetas en cada ejercicio. Esta dotación coincide con otra dotación de la "Reserva para gastos de conservación extraordinaria y mejora de instalaciones", que representa un exceso de celo con el conservadurismo.

En segundo lugar, NORTE constituyó una reserva denominada "Fondo de previsión para créditos incobrables y reclamaciones en litigio" en las juntas generales de mayo de 1907, 1908 y 1909 por dos conceptos. Por un lado, se dotó 53.462,08 pesetas por las cantidades que -en opinión de NORTE- "debían ser satisfechas por el Estado, por transporte de coches celulares vacios". En 1914, la empresa renuncia al cobro por haber sido resuelta desfavorablemente la reclamación realizada (NORTE, 1915; 25). Por otro lado, se dotó 1.051.703,91 pesetas por cantidades reclamadas por la Hacienda con origen en utilidades sobre beneficios en las provincias Vascongadas y Navarra por el concierto económico de ellas. En 1918 se liquida esa suma por haber sido resuelta la reclamación (NORTE, 1919; 24).

Sin embargo, sí constituyen políticas de manipulación contable adicional en la aplicación los dos siguientes casos porque se evita el registro de un gasto; cuando se produce la reparación, como en el tercer caso, o cuando se produce la reconstrucción de inmuebles por un incendio, como en el cuarto caso.

El tercer lugar, la Compañía NORTE dotó a partir del año 1906 y hasta 1913, con cargo a beneficios, la denominada "Reserva para gastos de conservación extraordinaria y mejora de instalaciones". Debería de haberse modificado la denominación y la clasificación. Por una parte, la denominación de esta rúbrica debería estar referida, con exclusividad, a la mejora de instalaciones ${ }^{1051}$; por otra parte debería clasificarse en cualquier caso dentro de la reservas de libre disposición de la sociedad. Los movimientos de la mencionada reserva se pueden apreciar en el cuadro 64.

\footnotetext{
${ }^{1050}$ NORTE (1911: 6; 1912: 6; 1913: 7; 1914: 25).

${ }^{1051}$ Esta opinión fue aportada por Bentabol et al. (2011: 18).
} 


\section{Cuadro 64. Reserva para gastos de conservación extraordinaria y mejora de instalaciones}

\begin{tabular}{|l|c|c|c|}
\hline Año & Dotaciones & Aplicaciones & Saldo \\
\hline 1900 & --- & --- & --- \\
\hline 1901 & --- & --- & -- \\
\hline 1902 & --- & --- & --- \\
\hline 1903 & --- & --- & --- \\
\hline 1904 & --- & --- & --- \\
\hline 1905 & --- & --- & --- \\
\hline 1906 & --- & --- & $2.048 .856,67$ \\
\hline 1907 & $2.337 .383,53$ & $288.526,86$ & $3.035 .472,26$ \\
\hline 1908 & $2.000 .000,00$ & $1.013 .384,41$ & $2.838 .771,51$ \\
\hline 1909 & $1.500 .000,00$ & $1.696 .700,75$ & $2.829 .874,85$ \\
\hline 1910 & $1.500 .000,00$ & $1.508 .896,66$ & $2.747 .237,96$ \\
\hline 1911 & $1.500 .000,00$ & $1.582 .636,89$ & $3.768 .469,77$ \\
\hline 1912 & $1.500 .000,00$ & $478.768,19$ & $4.172 .485,38$ \\
\hline 1913 & $500.000,00$ & $95.984,39$ & $4.110 .451,52$ \\
\hline 1914 & --- & $62.033,86$ & $4.094 .924,85$ \\
\hline 1915 & --- & $15.526,67$ & $4.060 .707,53$ \\
\hline 1916 & --- & $34.217,32$ & $3.973 .715,08$ \\
\hline 1917 & --- & $86.992,45$ & $3.797 .973,30$ \\
\hline 1918 & --- & $175.741,78$ & $3.527 .605,01$ \\
\hline 1919 & --- & $270.368,29$ & $3.527 .052,61$ \\
\hline 1920 & --- & 552,40 & $3.527 .052,61$ \\
\hline 1921 & --- & --- & $3.527 .052,61$ \\
\hline 1922 & --- & --- & $3.526 .772,31$ \\
\hline 1923 & --- & $280,615,20$ & $3.506 .157,11$ \\
\hline 1924 & --- & &
\end{tabular}

Fuente: Bentabol et al. (2011: 19)

El saldo de la reserva superó los cuatro millones en los ejercicios contables 1913-1916, siendo los saldos más altos de todo el periodo.

El cuarto caso se produjo cuando NORTE dotó la "Reserva de seguros para incendios". En el periodo de estudio tiene dos dotaciones. La primera se había dotado en años anteriores, apareciendo en el balance de 1900 por un importe de 1.049.715,53 pesetas, y se aplicó en el año 1906 por 32.674 pesetas por el incendio del 23 de julio de 1906 en el Depósito de máquinas de la estación de Madrid. La segunda se produjo en el Informe Anual de 1915-1916 para la reconstrucción de la cubierta del Depósito de Caja, destruida por un incendio el 8 de febrero de 1914. El importe dotado es de 745,98 pesetas en 1915, 12.447,57 en 1916 y $14.173,83$ en 1917. Esta partida no tuvo aplicación en el periodo analizado.

En la dotación y aplicación de la reserva no ha sido posible comprobar la voluntariedad ni la búsqueda de la finalidad de la manipulación de la información contable. 


\section{e). Contabilización deficiente de partidas de la Cuenta de explotación}

\section{e.1) Apartaderos y vías}

La partida "Intereses, cambios y comisiones" de la Cuenta de explotación está formada por los conceptos siguientes:

- Comisiones a favor de los banqueros por cupones y obligaciones pagados, cheques, transferencia, ingresos de estaciones y de Bancos

- Derechos de custodia

- Apartaderos y vías

- Gastos e intereses de las tres cuentas de crédito abiertas en el Banco de España de Madrid

- Varios, por diferencia de liquidación de utilidades, de Derechos Reales, de timbre de negociación.

La subpartida "Apartaderos y vías" presenta una clara alteración contable desde 1874, pues debería ser contabilizado como un ingreso para la compañía. No obstante, el razonamiento para incluirlo como un cargo pretende ser justificado por NORTE de la siguiente forma: "en su haber se abona lo ingresado en las estaciones por la ocupación de terrenos correspondientes a diversas líneas, en concepto de intereses de capital empleado en las instalaciones de apartaderos y vías" (NORTE, 1940: 375).

\section{e.2) Insuficiencia de productos}

La partida "insuficiencia de productos" recoge la insuficiencia que resultó de la explotación del conjunto de las líneas que forman la red; no obstante, la insuficiencia real ${ }^{1052}$ de la compañía sólo es el importe que figura en el balance, pues en el importe señalado en la cuenta de explotación hay que descontar la parte que le corresponde soportar al Estado y que éste debe abonar a NORTE.

\section{e.3) Gastos de administración de la línea Valencia a Utiel}

La existencia de la partida "Anualidad de Valencia a Utiel" es sospechosa de crear un artificio contable. La adquisición de la línea de Valencia a Utiel celebrada en diciembre de 1892, crea un Convenio entre las compañías de NORTE y la del Este. En el artículo 8 del Convenio se establece que "NORTE explotará la línea de Valencia a Utiel mediante el rembolso de los gastos y cargas efectivas y de los de cambios, comisiones e impuestos y una suma fija anual de 400 pesetas por kilómetro para los gastos de administración y dirección”. El producto neto, es decir, los productos líquidos de la explotación, deducidos los gastos anteriores serán aplicados, en primer término, al pago de los intereses y de la amortización de las obligaciones de rédito fijo garantizadas por NORTE. Los excedentes de productos netos se aplicarán (1) a la formación del fondo de reserva y (2) al pago de la amortización y de los intereses de las

1052 “Insuficiencia verdad” en denominación de la compañía (NORTE, 1940: 377). 
obligaciones de rédito variable, si hubiese sobrante; y el remanente sobrante, si lo hubiese, se abonará a la Comisión liquidadora de la Compañía del Este de España, para que lo reparta a las acciones de la misma.

La Comisión liquidadora de la Compañía del Este de España se crea para vigilar el cumplimiento del contrato. Mientras subsista el contrato, tienen que figurar como ingreso para NORTE los gastos de administración y dirección de la línea de Utiel. No obstante, NORTE no registra estos ingresos.

\section{e.4) Cupones de las obligaciones de la línea Valencia a Utiel}

En la partida de la cuenta de explotación de NORTE "Productos varios fuera de la explotación" se incluyen parte de los productos de la línea Valencia-Utiel. En concreto, los cupones de las obligaciones que quedan en dicha línea de primera hipoteca, domiciliados, pertenecientes al depósito efectuado de NORTE al verificarse la fusión con la de Este ${ }^{1053}$. En el artículo 5 del Convenio de NORTE con la Compañía del Este de 1892 aparece que la empresa de Utiel tenía 39.846 obligaciones en aquel momento, y ellas son sustituidas por 26.564 (dos terceras partes) de rédito fijo del $3 \%$ con cargo del NORTE y por 13.282 (una tercera parte) de rédito variable.

De estas 13.282 obligaciones, 154 se cambian por las amortizadas y no rembolsadas de las de rédito fijo, 1.550 para entregar a acreedores de la Compañía del Este en pago de sus créditos y 6.000 para ser entregadas a la Compañía del NORTE por la Comisión liquidadora del Este para ir terminando la línea. Estos son los cupones de las obligaciones existentes en la partida "Productos varios fuera de la explotación" en los ejercicios contables posteriores.

Siempre que subsistan las obligaciones de rédito variable (solamente se amortizaron un número pequeño de títulos de los 13.282 creados), es obligatorio llevar esta cuenta. Es posible identificar una gran carga de alteración contable en esta partida porque NORTE no los contabiliza como ingresos.

Aunque tengamos sospechas de alteración contable en las cuatro partidas de la cuenta de explotación analizadas, no debe considerarse manipulación contable, porque no hemos podido contrastar la voluntariedad y finalidad de las medidas.

\section{f) Fondo para compensar el acuerdo de 4 de enero de 1896}

En los años anteriores a 1896, el sector ferroviario cumplía perfectamente las condiciones de una estructura oligopolística. En algunos tramos, los viajeros podían elegir entre varias líneas de NORTE y MZA, por esta razón ambas empresas pugnaban por atraer a los usuarios a sus líneas.

${ }^{1053}$ NORTE (1940: 374). 
En este contexto, NORTE y MZA firmaron en 1896 un convenio sobre reparto de tráficos (MZA: 1896b), que tuvo una duración de diez años. El pacto por el principio de la distancia más corta de 1875 se había ido al traste por un duro enfrentamiento entre MZA y NORTE por el tráfico entre Castilla y Cataluña a propósito de la apertura de la línea de Valladolid a Ariza y la variante de Caspe. Esta línea ponía a MZA en contacto directo con Barcelona y Zaragoza. De los peligros de este hecho se dieron cuenta en seguida los dirigentes de NORTE: "la compañía de Alicante, unida así en Zaragoza con la de Tarragona a Barcelona y Francia, estableció un sinnúmero de tarifas, vía Caspe, con precios más reducidos que los que regían anteriormente en combinación con la línea de NORTE, desviando de esta última entre Zaragoza y Barcelona, vía Manresa, el tráfico de viajeros y mercancías que la utilizaban" ${ }^{1054}$. La pugna de tarifas fue muy dura ${ }^{1055}$ y Barat planteó a MZA un entendimiento en diciembre de 1894 que no fue aprobado, lo cual ahondó en la «guerra» de tarifas hasta que, finalmente, se firmó el acuerdo, el 4 de enero de $1896^{1056}$.

El acuerdo de 4 de enero de $1896^{1057}$ terminó con el enfrentamiento de tarifas con MZA. Según este acuerdo, se aplicaban precios totales iguales al transporte en tres tramos: entre Barcelona y Zaragoza, entre Zaragoza y Valladolid y entre Lérida y Barcelona (por Manresa y Picamoixons). En estos tramos existía la posibilidad de recorrerlos por las líneas de las dos compañías implicadas, dejando a los clientes la posibilidad de elegir la vía que más le conviniera. Las recaudaciones del tráfico de dichas líneas formarían un fondo común entre MZA, NORTE y TBF (Tarragona, Barcelona y Francia) ${ }^{1058}$ que se repartirían entre ellas, tras haber deducido los gastos, aplicando unos coeficientes de reparto.

El pacto de reparto de tráfico de 1896 se saldó con una cuantiosa suma a liquidar por NORTE a MZA, pero ello se debió en parte a la mala negociación de NORTE. Esta última consumía más carbón por kilómetro que MZA, porque su trazado tenía más rampas y curvas. Analizando el coeficiente virtual de las redes, calculado por el cociente entre la longitud virtual (distancia entre dos puntos si el trazado careciese de pendientes y curvas) y la longitud real de las líneas, es posible observar que el coeficiente para NORTE era mayor que para $\mathrm{MZA}^{1059}$. Este hecho era importante porque el acuerdo de 1896 estableció una caja común de

\footnotetext{
${ }^{1054}$ Carta enviada por J. Barat el 4 de abril de 1908 al presidente del Consejo de Administración de NORTE, realizando una exposición de las indemnizaciones que la compañía le debía, p. 14.

${ }^{1055}$ La pugna de tarifas fue muy dura especialmente en lo que se refiere al trigo y las harinas, así como también a los vinos; véase Sanz (1985) y Gómez Mendoza (1984).

${ }^{1056}$ La firma del acuerdo de 1896 fue propiciado y presentado por el propio Barat, y firmado por Sagasta y Elduayen por NORTE, el Marqués de Urquijo y Baüer por MZA y Planas por TBF (Tarragona, Barcelona y Francia).

${ }^{1057}$ Este acuerdo para circular por la vía más corta es derivado del acuerdo de 1875 , aunque este acuerdo inicial de 1875 tenía por objeto el trayecto hacia el puerto de Bilbao.

${ }^{1058}$ El 1 de enero de 1898 MZA absorbió la "Compañía de Tarragona a Barcelona y Francia" (TBF), denominada desde entonces "Red Catalana de MZA", que explotaba 723 kilómetros.

1059 Según los datos de García Raja (2006), NORTE consumía más carbón por kilómetro, tenía más rampas y curvas y tenía un peor coeficiente virtual de las redes, en general, pero esto fue decisivo en el trazado catalán. La Compañía de los Ferrocarriles de Tarragona a Barcelona y a Francia (TBF) construyó una mejor línea directa de Zaragoza a Barcelona por Caspe que la antigua línea de Zaragoza a Barcelona por Lérida de la Compañía NORTE; la de MZA tenía una menor distancia (345,507 kilómetros respecto a los 365,706 kilómetros) y lo que
} 
ingresos a la que se restaba un gasto de tracción igual a las dos compañías $(0,02$ pesetas/tonelada/kilómetro) sin distinguir las diferencias de trazado de cada red. Para que el acuerdo hubiese sido equitativo, NORTE debería haber introducido algún tipo de corrección, que no favoreciese a MZA, la compañía de longitudes virtuales más benévolas. Si se hubiera realizado la medida correctora, la suma a liquidar por NORTE a MZA hubiera sido menor.

Contablemente, NORTE dotaba un fondo de reserva para cuentas que debían ajustarse al final del ejercicio. Este fondo tenía su origen en detasas ${ }^{1060}$ por tarifas y liquidaciones a otras compañías, entre ellas las compensaciones a pagar a MZA por el acuerdo. Las detasas se generaban al rectificar los portes pagados a las empresas que aseguraban al ferrocarril un determinado tonelaje de carga a lo largo de un periodo. En contrapartida, esas empresas recibían una tarifa especial, cuya diferencia monetaria respecto a los que se acogían a la tarifa oficial de la compañía se devolvía a los beneficiados al finalizar el año.

Entre 1899-1903, la cuenta de ajuste con MZA presentó un saldo deudor de 6.474.693,64 pesetas, dato que denotaba que el acuerdo negociado por Barat no era favorable para NORTE. Ésta debía pagar a MZA por los ajustes derivados de circular por la vía más corta. En 1895 MZA había conseguido un tejido viario con mayor potencialidad estratégica: dominaba el trayecto Valladolid-Ariza -lo que suponía el transporte de cereales de la meseta castellana a Cataluña- y el trayecto Zaragoza-Barcelona, vía Caspe. Uno de los aspectos más estratégicos que poseía NORTE era la posibilidad de circular entre las dos principales ciudades españolas; sin embargo, desde la vigencia del acuerdo de 1896, NORTE debió abonar a MZA una gran cantidad de dinero debido a que el camino más corto era el de MZA. Para realizar el camino entre Madrid y Barcelona se podía circular vía Lleida (NORTE) o Caspe (MZA). Como había que circular por la vía más corta, NORTE debía pagar a MZA en virtud de que se circulaba por su vía y con su tracción. El acuerdo de Barat con MZA produjo una desventaja para NORTE, lo cual la situó en un plano de desventaja respecto a MZA que se mantuvo en el tiempo.

En este periodo $1899-1903$ se dedicaron 5.978.553 pesetas para compensar al alto personal y al afecto a la compañía ${ }^{1061}$. Esto supuso una consolidación de la práctica de repartir altas primas entre determinado personal que se mantuvo en el tiempo en los años posteriores. En concreto, los altos directivos en ese periodo tenían una alta remuneración ${ }^{1062}$, a la cual se

es más importante, una longitud virtual más favorable que NORTE (640,18 kilómetros respecto a los 1.045,599 kilómetros).

${ }^{1060}$ Detasa -rebaja de tasa- es la rectificación de importes pagados en los ferrocarriles cuando se hace en ellos una rebaja para devolver el exceso de lo cobrado.

1061 AHF W-80-1, Resumen de los ingresos del tráfico de las líneas que explotan actualmente las Compañías de NORTE y de Madrid a Zaragoza y Alicante. 27 de febrero de 1905.

${ }^{1062}$ El 22 julio de 1889, el Consejo acordó entregar las primas por buenos servicios en el año 1898. Al "Personal superior", que son 52 agentes, 163.770 pesetas, al de la "Secretaría del Consejo", compuesto de 7 agentes, 5.606,55 pesetas, al personal de "Oficinas, Almacenes y Minas", compuesto de 1.268 agentes, 442.917,26 y al de "Estaciones" compuesto de 1.624 agentes, 375.460,04 pesetas (Acta n 646 del Libro de actas del Consejo de Administración de NORTE: 22 julio de 1889). 
unían unas exageradas gratificaciones especiales a Barat ${ }^{1063}$. El origen de estos altos sueldos se debe a que era el final de mandato de Barat, alabado como buen gestor, pero visto con el tiempo, antecesor de los contratos millonarios de directivos al autoimponerse una indemnización y pensión fuera de toda lógica. La obtención de una alta remuneración por parte de él debía ir acompañada de un reparto al resto de sus directivos para evitar su rechazo, y las consiguientes discripancias y tensiones en la cúpula directiva. Era un momento en el que, hasta que llegó Boix a NORTE, los directores eran todos franceses, con un alto prestigio -aunque quizás no merecido- de buenos gestores entre los trabajadores de la empresa.

En el mismo periodo en que los altos directivos recibían tanto dinero, simultaneamente la empresa tenía cinco años de datos contables negativos. Para poder pagar estas cantidades se buscaron soluciones complejas, desatendiendo la compra de materiales y el mantenimiento del mismo y sus instalaciones.

Ambos hechos fueron conocidos por MZA diez años más tarde de que comenzaran a realizarse las dotaciones del fondo, en enero de 1906, dentro de las conversaciones entre ambas compañías que culminaron con el contrato de sindicatura general del tráfico.

El 27 de enero de 1906, Felix Boix -director adjunto de NORTE- confesó a Maristany ${ }^{1064}$, director de la Red Catalana de MZA, que desde 1896 -año del acuerdo- la compañía retiraba semanalmente una parte de la recaudación para formar un fondo de reserva que había llegado a ser de cuatro o cinco millones de pesetas al año ${ }^{1065}$, dedicado a distintas cuentas que requerían ser ajustadas al final del ejercicio. Boix no fue responsable porque la medida no la

El 30 junio de 1900, El consejo acordó entregar las primas por buenos servicios en el año 1898. Esta vez no se desglosa por categorías. Únicamente aparece que se concede a 3.089 agentes, 1.196.300,57 pesetas (Acta $n^{\circ} 657$ del Libro de actas del Consejo de Administración de NORTE: 30 junio de 1900).

El 22 junio de 1901, El consejo acordó entregar las primas por buenos servicios en el año 1900. A Barat Director 12.500 pesetas, al "Personal superior", que son 77 agentes, 145.787,5 pesetas, al personal de "Oficinas, Almacenes y Minas", compuesto de 1.376 agentes, 505.817,24 y al de "Estaciones" compuesto de 1.789 agentes, 469.609,11 pesetas (Acta $\mathrm{n}^{\circ} 667$ del Libro de actas del Consejo de Administración de NORTE: 22 junio de 1901).

El 9 julio de 1902, El consejo acordó entregar las primas por buenos servicios en el año 1901. A Aubert Director $17.479,5$ pesetas, al "Personal superior", que son 61 agentes, 100.803,97 pesetas, al personal de "Oficinas, Almacenes y Minas", compuesto de 1.368 agentes, 504.514,73 pesetas y al de "Estaciones" compuesto de 1844 agentes, 474.217,49 pesetas (Acta n 679 del Libro de actas del Consejo de Administración de NORTE: 9 julio de 1902).

${ }^{1063}$ El 15 de diciembre de 1898 , El consejo acordó entregar a Barat 250.000 por sus "extraordinarios y especiales servicios" en función de las primas anuales al personal de la compañía (Acta n 637 del Libro de actas del Consejo de Administración de NORTE: 15 de diciembre de 1898). El 31 de octubre de 1901, el Consejo acuerda establecer una gratificación especial a Barat de 100.000 pesetas (Acta $n^{\circ} 668$ del Libro de actas del Consejo de Administración de NORTE: 31 de octubre de 1901).

1064 Esa confesión se enmarca dentro de un clima de gran complicidad en la que se estaba planeando el oligopolio definitivo entre ambas de 1906.

1065 "Informe Notas sobre las conversaciones sostenidas entre NORTE y MZA". Maristany 31 de enero de 1906. Documento incluido en AHF S-80-1, Expediente de estudio y tramitación del contrato de sindicatura general del tráfico. 
tomó él; la instauración de la medida denota que la gestión de Barat y sus predecesores fue bastante negativa.

Esta alteración de la contabilidad distorsionaba profundamente los cálculos de ingresos sobre los que se negociaba la renovación del acuerdo de tráficos entre las dos compañías.

Eduardo Maristany reflexionaba sobre ello, afirmando que esa alteración de la contabilidad se había realizado "para que no se viera por accionistas y obligacionistas que, mientras estos cobraban su cupón con pérdida y aquellos no cobraban dividendo alguno, se repartía a los empleados las primas referidas" $"$.

Por tanto, en esta medida sí hemos encontrado la voluntariedad y la búsqueda de la finalidad de la manipulación de la información contable.

\section{g) Manipulación para incrementar artificialmente los ingresos de transporte en servicio}

Los componentes del apartado "Transporte en servicio" (o Transporte interno dentro de la compañía) eran los requeridos para satisfacer las necesidades de los distintos Servicios o Divisiones en las que se organizaba la compañía. Desde principios de 1905, con objeto de presentar una subida de ingresos, NORTE ${ }^{1067}$ recurrió a la manipulación contable de duplicar los ingresos en concepto de "Transporte en servicio". Por cada tonelada y kilómetro 0,03 pesetas con un mínimo de 0,25 pesetas por expedición.

El precio de "Transporte en servicio" era una convención ${ }^{1068}$, en el caso de NORTE era invariable desde 1883. Contablemente se imputaba como un ingreso, siendo su contrapartida un cargo de los servicios que demandaban estos transportes, porque ocasionaban un gasto. El coste estimado debía ser muy inferior al coste real; de otro modo produciría una notable alteración de la contabilidad entre un ingreso, que no podía materializarse monetariamente, y un gasto que era real y cierto. La empresa facturaba anualmente numerosas expediciones. Aunque las tarifas aplicadas a esta clase de transportes eran reducidas, el ingreso ficticio era grande. El importe estaba establecido en 0,03 pesetas por cada tonelada y kilómetro, con un mínimo de 0,25 pesetas por cada expedición, en vez de 0,015 pesetas por cada tonelada y kilómetro.

\footnotetext{
1066 “Informe Notas sobre las conversaciones sostenidas entre NORTE y MZA”. Maristany 31 de enero de 1906. Documento incluido en AHF S-80-1, Expediente de estudio y tramitación del contrato de sindicatura general del tráfico.

${ }^{1067}$ Orden de dirección $n^{\circ}$ 51. Tarifa interior aplicable a los transporte hechos para el servicio de la compañía entre las estaciones de la Red del NORTE de 1905. Anterior tarifa servicio distribuida por Circular $\mathrm{n}^{\circ} 65$ del Servicio de Tráfico de 26 de diciembre de 1883.

${ }^{1068}$ Para el análisis, es fundamental identificar que el precio de "transporte en servicio" era una convención. No todos los autores lo reconocen, por ejemplo no lo contempla Gómez Mendoza (1982; 1983: 148-169; 1989a; 1989b: 269 - 323; 1991: 177 - 204; 1998: 1 - 17; 1999).
} 
Era un ingreso ficticio, porque no era ingresado, ni se podía ingresar en caja, y por tanto, más que productos eran gastos que se cargaban a la cuenta de los servicios de la compañía que ordenaba las expediciones ${ }^{1069}$.

Esta práctica de creatividad contable realizada por NORTE en sus cuentas, desde principio de 1905, permitió mostrar una recuperación de los ingresos en las declaraciones semanales que realizaba la compañía. Derivado de ello, el Banco Español de Crédito pudo emitir para NORTE 80.000 obligaciones de 500 pesetas al $86 \%$ de su valor y con un interés del $4 \%$.

Esta manipulación fue filtrada a Baüer, presidente del Comité de Madrid de MZA, por la familia Urquijo -que participaba simultáneamente en el accionariado de NORTE y MZA-: "Seguro que le habrá chocado a usted el aumento de recaudación que acusa el NORTE este año (...) le participo que este aumento es ficticio y es debido a que desde el 1 de enero los transportes en servicio se facturan a tres céntimos en vez de 1,5 céntimos; esto ha producido un aumento de ingresos de 260.000 pesetas y como el aumento total es menor que dicha cantidad, resulta que NORTE está en baja real. Estos Señores han apelado a este medio para preparar su emisión de obligaciones" ${ }^{, 070}$.

Por tanto, en esta medida está comprobada la voluntariedad y la búsqueda de la finalidad de la manipulación de la información contable.

h) Alteración del tratamiento de los anticipos reintegrables para compensar las subidas retributivas

Entre 1920 y 1926, el Estado adelantó a las ferroviarias unas cantidades fijas para que éstas pudieran hacer frente a los incrementos de las remuneraciones y a la adquisición de material $^{1071}$. El reflejo contable de este hecho económico en NORTE fue distinto en los años 1920-1922 y en el periodo 1923-1926.

\footnotetext{
${ }^{1069}$ García Vázquez (1906a), antiguo empleado de NORTE, ya jubilado, explicaba la manipulación contable: "Se facturan anualmente numerosas expediciones denominadas del servicio interior de la compañía, si bien es verdad que las tarifas aplicadas a esta clases de transportes es sumamente reducida, no es lo menos que el ficticio producto se eleva a muchos miles de pesetas. Este producto es ficticio, imaginario para los efectos de las entidades accionistas y obligacionistas, puesto que no ha ingresado, ni puede ingresar en caja, y por tanto, más que productos son gastos que se cargan a la cuenta de los servicios de la compañía que ordena aquéllas expediciones".

${ }^{1070}$ Carta de Baüer a Maristany, 23 de febrero de 1905, AHF S-103.

${ }^{1071}$ Se otorgaron por la R.O. de 23 de marzo de 1920, confirmada por la del 10 de abril de 1920, y desaparecieron en 1926. Fueron pagadas directamente desde el Presupuesto (Comín, et al., 1998: I, 307) y supusieron a la empresa algo más de 158 millones de pesetas (Informes Anuales, 1920-1926). El Gobierno determinó anticipar a las compañías, con carácter reintegrable, las "cantidades a que ascendieran durante un mes los haberes ofrecidos al personal (NORTE, 1940: I, 238) (Peña y Pérez, 1940: tomo I. 20). Con cargo a este anticipo, se concedió al personal un segundo plus a añadir al anterior, subsistiendo, además, a cuenta de las propias reservas de la Compañía, la mensualidad de abril, "calculada sobre la base de los sueldos matrices" más los dos pluses (NORTE, 1940: I, 429; 1921). Sumadas las tres rúbricas, el incremento efectivo de los haberes con referencia a 1913 se situó entre un $133 \%$ para los sueldos inferiores a 1.500 pesetas o 4 pesetas de jornal diario $-75.22 \%$ de todo el empleo- y un $75 \%$ para los 89 operarios más elevados (AHF: C/58/4).
} 
En el periodo 1920-1922, NORTE no contabilizó como gasto los anticipos reintegrables para compensar las subidas retributivas ${ }^{1072}$. Es posible afirmar que NORTE realizó una inadecuada contabilización del anticipo del Estado ya que no lo registró como un gasto de personal. El objetivo de esta medida era que las cuentas de NORTE tuvieran unos gastos menores a los que acontecían realmente en cada periodo.

Este método de creatividad contable fue comunicado a NORTE, por la "Primera Comisión investigadora de la situación económica de las empresas del ferrocarril", en el documento que recogía las conclusiones de la revisión de las cuentas de la compañía realizada en $1923^{1073}$.

NORTE excluía de los gastos, los realizados con cargo al anticipo que recibe del Estado para pago de su personal ${ }^{1074}$. NORTE se consideraba como una mandataria del Estado, por lo que los incluía en el activo y pasivo de sus balances. Es decir, NORTE se limitó a hacer figurar los anticipos del personal en el activo y pasivo, como si la empresa fuera mera intermediaria entre el Estado y el personal ${ }^{1075}$.

Este razonamiento contable no tiene ningún tipo de justificación ${ }^{1076}$, pues el Estado anticipó esta cantidad porque NORTE había manifestado la necesidad de aumentar sus sueldos o jornales, para posteriormente reconocer claramente que no podía realizar este incremento del pago al personal sin aumentar las tarifas. Procediese el dinero del Estado o de NORTE, es indudable que esta partida debe incrementar la cuantía de los gastos de explotación. Al no tener este hecho registrado, se produjo una cifra de resultado contable menor, y derivado de

\footnotetext{
1072 AHF, C/113/258; Peña y Pérez (1940, tomo I: 20-21); Artola (1978, 1: 422-423) y Comín, et al. (1998: 292293).

${ }^{1073}$ La Comisión encargada de analizar NORTE ("Primera Comisión investigadora de la situación económica de las empresas del ferrocarril") emitió, el 29 de noviembre de 1923, la "Memoria sobre la situación económica de la Compañía de los Caminos de Hierro del Norte de España". En el apartado que analizaba la Cuenta de la explotación, la Comisión analizó la inadecuada [en su opinión] contabilización del anticipo del Estado ya que NORTE no lo registraba como un gasto de personal. El objetivo de esta medida era que las cuentas de NORTE tuvieran unos gastos de explotación menores a los que acontecían realmente en cada periodo ("Primera Comisión investigadora de la situación económica de las empresas del ferrocarril", emitida el 29 de noviembre de 1923: Apartado "Personal").

1074 La Segunda Comisión comenzó su informe señalando que comprendía las razones que llevaron a la Administración a autorizar los anticipos de personal, pero creía, sin embargo, que le faltó "previsión" al conceder un montante "excesivo" (AHF P/113/257-4).

1075 La Primera Comisión investigadora de la situación económica de las empresas del ferrocarril resultó muy crítica con la forma de contabilizar los anticipos del personal de NORTE, pues, a su entender, se limitó "a hacerlo figurar en el activo y pasivo de sus balances", como si la empresa fuera -se dice en las Memorias- "mera intermediaria entre el Estado y el personal" (NORTE, 1923: 8-9).

${ }^{1076}$ Este razonamiento incumple la hipótesis de entidad. La hipótesis de entidad considera la sociedad como una unidad con realidad propia, independiente, autónoma, distinta y separada de los sujetos con los que se relaciona: administradores, promotores, fundadores, propietarios, acreedores y trabajadores. La hipótesis de entidad no ha sido expresamente incluida en ningún ordenamiento europeo. En la legislación contable española también existe una formulación implícita de la hipótesis, pues se confiere a la sociedad el objeto de la contabilidad y, además, se define una cuenta (titular de explotación) para establecer la relación entre el propietario y la empresa.
} 
ello una descapitalización de la empresa porque se distribuyeron unos beneficios que no existieron en realidad ${ }^{1077}$.

Políticos de la época, como Maura, afirmaron que el tratamiento debería ser registrarlo como un gasto de explotación ${ }^{1078}$.

En los cuadros 65 y 66 se comparan, por un lado, los resultados de explotación de NORTE sin incluir el anticipo como gasto y, por el otro, los resultados de NORTE si se hubiesen registrado como gastos los anticipos del Estado; ambos para los años 1921 y 1922.

Cuadro 65. Comparación de los resultados de explotación y los resultados reales de NORTE del año 1921

\begin{tabular}{|l|c|l|c|}
\hline \multicolumn{2}{|c|}{ SEGÚN LA COMPAÑÍA } & \multicolumn{1}{c|}{$\begin{array}{c}\text { CONTABILIZACIÓN DEL ANTICIPO } \\
\text { COMO GASTO }\end{array}$} \\
\hline Ingresos & $287.829 .205,5$ & Ingresos & $287.829 .205,5$ \\
\hline Gastos de explotación & $267.130 .918,23$ & Gastos de explotación & 298.750 .918 \\
\hline $\begin{array}{l}\text { EXCEDENTE DE } \\
\text { PRODUCTOS }\end{array}$ & $20.698 .287,27$ & $\begin{array}{l}\text { INSUFICIENCIA DE } \\
\text { PRODUCTOS }\end{array}$ & $10.921 .712,5$ \\
\hline
\end{tabular}

Fuente: Primera Comisión investigadora de la situación económica de las empresas del ferrocarril $^{1079}$

Cuadro 66. Comparación de los resultados de explotación y los resultados reales de NORTE del año 1922

\begin{tabular}{|l|c|l|c|}
\hline \multicolumn{2}{|c|}{ SEGÚN LA COMPAÑíA } & \multicolumn{2}{c|}{$\begin{array}{c}\text { CONTABILIZACIÓN DEL ANTICIPO } \\
\text { COMO GASTO }\end{array}$} \\
\hline Ingresos & $300.078 .833,95$ & Ingresos & $300.078 .833,95$ \\
\hline Gastos de explotación & $278.044 .373,46$ & Gastos de explotación & $309.244 .373,46$ \\
\hline $\begin{array}{l}\text { EXCEDENTE DE } \\
\text { PRODUCTOS }\end{array}$ & $22.034 .460,46$ & $\begin{array}{l}\text { INSUFICIENCIA DE } \\
\text { PRODUCTOS }\end{array}$ & $9.165 .539,51$ \\
\hline
\end{tabular}

Fuente: Primera Comisión investigadora de la situación económica de las empresas del ferrocarril $^{1080}$

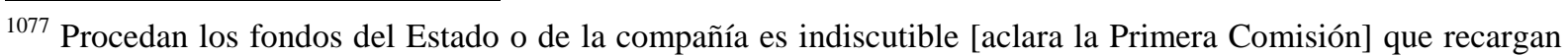
los gastos de explotación y "al no tenerlo en cuenta (...) lleva a resultados erróneos y a una distribución y aplicación de beneficios que no existen en la realidad (AHF P-113-258-1).

${ }^{1078}$ En sus intervenciones en el Congreso los días 15,16 y 17 de junio de 1921, mientras que se debatía el Proyecto de Ley Cierva y su propuesta de Consorcio, Maura afirmó que sería improcedente considerar como si fuesen gastos de establecimiento los anticipos del personal ya consumidos en la explotación.

1079 "Primera Comisión investigadora de la situación económica de las empresas del ferrocarril", emitida el 29 de noviembre de 1923: Apartado "Personal".

1080 "Primera Comisión investigadora de la situación económica de las empresas del ferrocarril", emitida el 29 de noviembre de 1923: Apartado "Personal".
} 
Como se puede observar en los dos cuadros anteriores, con la contabilización adecuada de estas partidas, NORTE no hubiera tenido resultados positivos de explotación, sino negativos. Por lo que nunca podría haber distribuido dividendos. Sin embargo, la empresa repartió dividendos correspondientes a beneficios no obtenidos, lo que provocó una cierta descapitalización de la empresa, al conceder dinero a los accionistas en mayor medida de lo que les debería haber correspondido, lo cual supuso una minoración de las garantías de cobro de los acreedores.

Los resultados recogidos en los Informes Anuales de la empresa permitieron al Consejo de Administración de la compañía aumentar sus fondos de reserva en siete y diez millones de pesetas en cada uno de los años y repartir un dividendo del 5\% a sus accionistas. Si NORTE hubiese registrado como gastos los anticipos del Estado, no hubiera podido realizar la distribución. Incluso, en los años posteriores la política de reparto debería haber sido más prudente, pues no hubiera podido ser explicado con argumentos convincentes que quien no tiene dinero suficiente para atender los gastos corrientes del ejercicio y tiene que recibirlo de una entidad externa, pueda repartir dividendos a los accionistas. Además, era difícil de explicar que una empresa que recibiera préstamos del Estado, pudiera ofrecer mayores retribuciones a los accionistas que los que abona el Estado, siendo este el que se los facilita. Este argumento fue puesto de manifiesto por la Primera Comisión ${ }^{1081}$.

Por su parte, entre 1923 y 1926, NORTE recibió menos de lo que sufragó por tal concepto, por lo que la empresa hubo de hacerse cargo de la diferencia, esperando que le fuera devuelta. Esta partida de diferencias, aunque no se registró dentro de los costes de explotación, sí se incluyó como gasto. Su consideración como gasto es el tratamiento correcto, pero, aún así, en este periodo también se realizaron prácticas de creatividad contable, porque su registro como gasto fue realizado por NORTE en dos apartados distintos. En la compilación de Marquina (NORTE, 1940: I, 431), NORTE incluyó estas partidas dentro del "cajón de sastre" que es la rúbrica "Varios" (NORTE, 1940: II, Cuadro 23). Por el contrario, los Informes Anuales de NORTE en los periodos 1923-1926 las sitúan con entidad propia en los resúmenes de las cuentas de explotación bajo el epígrafe "Diferencia entre las sumas satisfechas al personal en concepto de anticipo del Estado y las sumas recibidas de éste con ese objeto".

Una vez observado el tratamiento contable ofrecido por NORTE, es necesario indagar sobre el correcto criterio de contabilización que debería haber utilizado la empresa para contabilizar el principal y las cuentas accesorias que se registran cada año para anotar la remuneración de los trabajadores.

En el momento de la concesión del anticipo, la operación debería haberse registrado como deuda. Es una deuda porque desde que se concedieron estos anticipos habrían de ser

\footnotetext{
${ }^{1081}$ La Primera Comisión concluye que no puede admitirse en buena lógica que "quien no tiene fondos suficientes para atender a los gastos corrientes del año y ha de recibirlo de una entidad extraña reparta, en cambio, un dividendo del 5\% y, además, incremente sus fondos de reserva" ("Primera Comisión investigadora de la situación económica de las empresas del ferrocarril". AHF P-113-258-1: "Memoria sobre la situación económica de la Compañía NORTE”). Véase también en Peña y Pérez (1940, tomo I, 89-109).
} 
devueltos. Según admitían las propias concesionarias, el Estado les concedió "sencillamente un préstamo" (NORTE y MZA, 1932: anejo 14). En concreto, era una deuda asimilable a una subvención o donación reintegrable: pasivo exigible que puede convertirse en pasivo no exigible si se cumplen una serie de condiciones. NORTE razonó incorrectamente esta primera parte del análisis al entender que "podía considerarse como subvención o donación" (Peña y Pérez, 1940: tomo I: 110-119), es decir un pasivo no exigible (no reintegrable). La postura de NORTE no es concordante con lo manifestado dos años antes por la misma empresa, cuando afirmó en 1921 que "constituyen una deuda que, no obstante, su carácter eventual (...), puede llegar a ser exigible" (Gaceta de los Caminos de Hierro, 1921: 296). El tratamiento adecuado de la operación es considerarlo que su naturaleza es la de pasivo exigible, aunque tenga la capacidad de ser convertible en pasivo no exigible. Algo parecido ocurre con una subvención reintegrable: el anticipo debe registrarse como deuda, y sólo si en un momento futuro se condona la deuda por parte del Estado, se registraría como pasivo no exigible. Esta naturaleza es independiente de que el anticipo no llegue a ser devuelto nunca al Estado o, incluso, de que la empresa no tenga intención de devolvérselo al Estado. Por esta razón, no tiene sentido lo observado en las intervenciones realizadas en el Congreso de los Diputados los días 15, 16 y 17 de junio de 1921, cuando se debatía el Proyecto de Ley Cierva y su propuesta de Consorcio, pues Maura no admitía que se considerase la aportación del Estado al Consorcio como anticipos que devengaran el 5\% de interés, pues no las entregaba con ánimo de que le devolvieran el dinero y, por tanto, no había anticipo. Aquí es donde es posible encontrar la finalidad de la política de manipulación de la información financiera. El reparto de dividendos es una consecuencia de la consideración del anticipo. La finalidad de no considerarlo como deuda es intentar no devolvérsela, pues realmente NORTE, como el resto de ferroviarias no tenía intención de devolver el dinero al Estado.

Respecto a la remuneración periódica de los trabajadores, indefectiblemente debe contabilizarse como un gasto. Esto fue analizado correctamente por la Comisión que revisó las cuentas de NORTE, quien afirmó que "proceda el dinero del Estado o de la Compañía es indiscutible que recarga el gasto de explotación"1082. Al "no tenerlo en cuenta (...) lleva a resultados erróneos y [a una] distribución y aplicación de beneficios que no existen en la realidad"1083. NORTE realizó una interpretación equivocada al considerar que "debía considerarse como subvención o donación, pero nunca como gasto" (Peña y Pérez, 1940: tomo I, 110-119). La postura de NORTE, difícil de asumir, era sostenida desde dos años antes en público. NORTE afirmaba en 1921 que, "aunque constituyen una deuda, no se contabilizan (...) entre los gastos" (Gaceta de los Caminos de Hierro, 1921: 296). La postura de NORTE contrasta con la sostenida por la misma empresa tres años en la información privada. NORTE sí tuvo en cuenta el anticipo en su información interna en carta remitida por Boix a Maristany el 24 de junio de 1920. En esa carta le adjuntaba un avance de las cuentas de explotación, donde sí aparecía el asiento de devolución del anticipo ${ }^{1084}$. Con la contabilización correcta, las

\footnotetext{
1082 "Primera Comisión investigadora de la situación económica de las empresas del ferrocarril”), emitida el 29 de noviembre de 1923: Apartado "Personal".

1083 "Primera Comisión investigadora de la situación económica de las empresas del ferrocarril"), emitida el 29 de noviembre de 1923: Apartado "Personal" (Peña y Pérez, 1940: tomo I: 110-119).

${ }^{1084}$ AHF P/65/82-1. Carta de F. Boix a E. Maristany el 24 de junio de 1920.
} 
aparentes pérdidas contables de la empresa hubieran sido beneficios. Queda contrastada la voluntariedad de la medida porque en su información fuera del Informe Anual sí lo incluía.

Por todo ello, en esta medida sí está comprobaba la voluntariedad y la búsqueda de la finalidad de la manipulación de la información contable.

\subsubsection{Evaluación de la manipulación de la información contable con gestión del resultado}

Las meras suposiciones de manipulación contable observadas en los efectos que presenta en los Informes Anuales de NORTE son opinables, sin embargo, al contrastar estos datos con la correspondencia comercial y personal, sí se tiene constancia de que NORTE realizó una manipulación de la información financiera sobre tres partidas -Fondos para compensar el acuerdo de 4 de enero de 1896, Ingresos por transportes de servicio y anticipo de personal-, porque en ellas están perfectamente identificadas la voluntariedad y la finalidad que buscaba la gerencia al realizarla.

Una vez analizadas todas las políticas contables que modifican el resultado, estén comprobadas o no que fueron manipulaciones de la información financiera, es necesario identificar el efecto de cada uno de los métodos que modifican la cifra de beneficios, con la intención de encontrar un patrón permanente en los procedimientos.

En el cuadro 67 se manifiestan los procedimientos de manipulación contable que afectan al beneficio de NORTE en cada uno de los años del periodo 1900-1923, indicando los que son neutrales para el beneficio (0), alteran el beneficio aumentándolo (+) o alteran el beneficio disminuyéndolo (-). 


\section{Cuadro 67. Procedimientos de manipulación de la información contable que afectan al resultado de NORTE 1900-1923}

\begin{tabular}{|c|c|c|c|c|c|c|c|c|}
\hline & \multicolumn{5}{|c|}{ MEDIDAS SOSPECHOSAS DE MANIPULACIÓN } & \multicolumn{3}{|c|}{$\begin{array}{c}\text { MEDIDAS EN LAS QUE ESTA } \\
\text { CONTRASTADA LA MANIPULACIÓN }\end{array}$} \\
\hline $\begin{array}{l}\text { Ejercicio } \\
\text { contable }\end{array}$ & $\begin{array}{c}\text { Gastos primer } \\
\text { establecimiento }\end{array}$ & Amortización & $\begin{array}{l}\text { Deterioro de } \\
\text { valor }\end{array}$ & Reservas & $\begin{array}{c}\text { Cuenta de } \\
\text { explotación }\end{array}$ & $\begin{array}{c}\text { Fondo } \\
\text { compensación } \\
\text { acuerdo } 4 \text { enero } \\
1896\end{array}$ & $\begin{array}{c}\text { Ingreso } \\
\text { transporte } \\
\text { servicio }\end{array}$ & $\begin{array}{c}\text { Anticipo de } \\
\text { personal }\end{array}$ \\
\hline 1900 & 0 & + & 0 & 0 & - & - & 0 & 0 \\
\hline 1901 & 0 & + & 0 & 0 & - & - & 0 & 0 \\
\hline 1902 & 0 & + & 0 & 0 & - & - & 0 & 0 \\
\hline 1903 & 0 & - & 0 & 0 & - & - & 0 & 0 \\
\hline 1904 & 0 & + & 0 & 0 & - & - & 0 & 0 \\
\hline 1905 & + & - & 0 & + & - & - & + & 0 \\
\hline 1906 & 0 & - & - & + & - & - & + & 0 \\
\hline 1907 & 0 & - & - & - & - & 0 & 0 & 0 \\
\hline 1908 & 0 & - & - & - & - & 0 & 0 & 0 \\
\hline 1909 & 0 & - & - & - & - & 0 & 0 & 0 \\
\hline 1910 & 0 & - & - & - & - & 0 & 0 & 0 \\
\hline 1911 & 0 & - & - & - & - & 0 & 0 & 0 \\
\hline 1912 & 0 & - & - & - & - & 0 & 0 & 0 \\
\hline 1913 & 0 & - & - & - & - & 0 & 0 & 0 \\
\hline 1914 & 0 & - & - & + & - & 0 & 0 & 0 \\
\hline 1915 & 0 & - & - & + & - & 0 & 0 & 0 \\
\hline 1916 & 0 & - & - & + & - & 0 & 0 & 0 \\
\hline 1917 & 0 & + & - & + & - & 0 & 0 & 0 \\
\hline 1918 & 0 & + & - & + & - & 0 & 0 & 0 \\
\hline 1919 & 0 & + & - & + & - & 0 & 0 & 0 \\
\hline 1920 & 0 & + & - & + & - & 0 & 0 & - \\
\hline 1921 & 0 & + & - & 0 & - & 0 & 0 & - \\
\hline 1922 & 0 & + & - & + & - & 0 & 0 & - \\
\hline 1923 & + & + & - & + & - & 0 & 0 & 0 \\
\hline
\end{tabular}

Fuente: Elaboración propia

No es posible inferir una política programada permanente de alteración del resultado en una única dirección. No obstante, sí es posible encontrar un patrón de conducta sobre la manipulación de la información financiera, porque mayoritariamente NORTE intenta ofrecer un resultado contable menor al real con la alteración de las prácticas contables.

NORTE es una de las primeras empresas españolas en planificar unos procedimientos continuados de manipulación de la información financiera. A lo largo del periodo 1900-1923, la empresa intentó ofrecer de forma sistemáticas unos menores beneficios de los que hubiera registrado sin realizar ciertas maniobras contables. La motivación principal de la compañía no era ahorrarse impuestos, ni evitar el reparto de dividendos, sino mostrar una imagen más desfavorable de la que hubiera tenido sin realizar estas maniobras contables, para forzar una mayor ayuda estatal. Hasta el año 1920, la principal finalidad era mostrar una información que concediera argumentos a los que abogaban por un aumento de tarifas por parte del Estado; a partir de 1920, momento en el que el Estado concede a las compañías ferroviarias anticipos de personal y material, pretendía ofrecer una información financiera que perpetuara la concesión del anticipo por parte del Estado.

La aseveración de que la empresa intentó ofrecer de forma sistemáticas unos menores beneficios de los que hubiera registrado sin realizar ciertas maniobras contables, se argumenta 
por las actuaciones de la empresa NORTE -su política contable- a pesar de que la propia compañía expone explícitamente lo contrario, al afirmar que tiene una motivación fundamental de incluir pocos gastos. NORTE afirmó que: "La cuenta de explotación ha sido formulada con el prejuicio de aligerar los gastos, para que de la cuenta resulte que la compañía puede cubrir todas sus atenciones sin necesidad del anticipo del Estado, con la derivación consiguiente de que no necesita tampoco para ello elevación alguna de tarifas"1085. La afirmación de la empresa no concuerda con su actuación contable porque su política contable no intenta reducir los gastos. Y es lógico, porque para la empresa lo fundamental era la elevación de las tarifas y/o la renovación de la concesión del anticipo del Estado.

La estrategia elegida por NORTE es parte del juego de la compañía con el Estado para presionarle por medio de la exposición de una situación económico-financiera aparentemente peor, y así provocar un aumento de tarifas y/o la concesión de subvenciones y anticipos.

Realmente la actuación contable de NORTE tenía un doble juego: en unos ejercicios la interesó mejorar su apariencia y en otros empeorarla. Aunque en la mayoría de los años de la vida de la empresa la motivación era disminuir artificialmente el beneficio por un aumento motivado de los gastos, también la compañía actuó en el sentido contrario puntualmente. Los aumentos puntuales de beneficios se produjeron en los años 1905 y 1906 - cómo hemos visto en el cuadro 67- porque en ellos coincidió la necesidad de emitir empréstitos y las negociaciones para un posible acuerdo comercial entre NORTE y MZA. En 1905 comenzó a realizar una manipulación para incrementar artificialmente los ingresos de transporte en servicio. Esta práctica de manipulación de la información contable de las cuentas de NORTE permitió que el Banco Español de Crédito pudiera emitir para NORTE 80.000 obligaciones de 500 pesetas al $86 \%$ de su valor y con un interés del $4 \%$, que de otro modo, hubiera sido más difícil. De la misma forma, también tenía motivación para mejorar la apariencia cuando se encontraba en un proceso de negociación de un posible acuerdo comercial con MZA. En una reunión celebrada entre MZA y NORTE el 31 de enero de 1906, dentro de las conversaciones entre ambas compañías que culminaron con el contrato de sindicatura general del tráfico del 27 de junio de 1906, los representantes de NORTE (Borregón, Boix, Estibaus, Ibarra, Urquijo y Waldmann) confesaron a los de MZA (Baïer y Maristany) que los ingresos declarados en las Memorias de NORTE eran inferiores a los reales ${ }^{1086}$.

La manipulación dual de NORTE era consecuencia de la existencia del controvertido e inestable entorno al que se enfrentaba. Por un lado, puntualmente necesitaba la obtención de recursos del mercado de capitales, ya sea por medio de préstamos de intermediarios financieros, pero sobre todo por la emisión de empréstitos que colocar. Para esas situaciones puntuales, NORTE quería dar una situación de solvencia, por lo que realizaba un maquillaje contable en sentido de mejorar su apariencia económico-financiera. Por otro lado, para

\footnotetext{
1085 AHF P-113-258-3: “Contestación de la Compañía de los Caminos de Hierro del NORTE de España al Informe redactado por la Primera Comisión investigadora de la situación económica de las empresas de ferrocarriles nombrada por Real Orden de 20 de octubre de 1923": Apartado "II. Reparos del Informe a las diversas partidas que componen las cuentas de explotación".

${ }^{1086}$ AHF S-80-1, Expediente de estudio y tramitación del contrato de sindicatura general del tráfico.
} 
desarrollar ordinariamente su proceso productivo necesitaba los anticipos del personal por parte del Estado, por lo que continuadamente ofrecía unos resultados económicos inferiores a los que tendría sin manipulación de la información contable, para forzar que el Estado mantuviera la concesión de los anticipos o realizara el ansiado aumento de tarifas.

Además de ello, existieron algunas prácticas sospechas no contrastadas en las que no podemos afirmar que existió manipulación de la información financiera. No podemos afirmar que exista manipulación, pero sí alteración de los resultados contables; sin embargo, aunque no hemos comprobado su motivación y voluntariedad, podemos sospechar que obedecían más a la ausencia de una normativa concreta sobre el modo de realizar la contabilidad, y a un desconocimiento del modo correcto de registrarlo. Esto se produce en cinco casos: gastos de establecimiento, amortización, deterioro de valor, fondo de obras y mejoras y, por último, diversas partidas de gastos de explotación.

\subsubsection{Procedimientos de manipulación financiera en la presentación}

\section{a) Alteraciones de presentación en las diferentes fuentes de información}

NORTE presenta su propia información directamente -con datos elaborados por NORTE y también presentados por ella misma- por dos medios: en los Informes Anuales presentados por el Consejo de Administración cada año, y en los documentos que agregan información de varios años -como el de Marquina- publicados excepcionalmente por la compañía; pero además, también ofrece sus datos indirectamente -con datos suministrados por NORTE pero agrupados por otro organismo- en documentos externos que también acumulan varios ejercicios contables, siendo el más relevante el documento Antecedentes y datos para el estudio del problema ferroviario de la Junta Superior de Ferrocarriles. Las tres fuentes presentan los datos de diferente forma, lo que puede dar lugar a equívocos. Salvo que se quiera ocultar algún dato o alterar la apariencia de la información, no se entiende porqué es diferente el modo en que se presentó la misma información contable de NORTE en las tres fuentes principales de análisis: Informes Anuales de NORTE ${ }^{1087}$, Antecedentes y datos para el estudio del problema ferroviario de la Junta Superior de Ferrocarriles ${ }^{1088}$ y compilación de Marquina $^{1089}$.

Las diferencias entre los citados textos se producen sobre tres partidas: los ingresos fuera del tráfico, los gastos de explotación y las cargas financieras.

Por el lado de los ingresos, el grueso de ellos provenía del tráfico y sobre ellos existe total coincidencia. Las diferencias se producen al contabilizar los ingresos fuera del tráfico, reflejados en los "Ingresos por intereses y comisiones" de la Junta Superior de

\footnotetext{
1087 NORTE $(1901 ; 1902 ; 1903 ; 1904 ; 1905 ; 1906 ; 1907 ; 1908 ; 1909 ; 1910 ; 1911 ; 1912 ; 1913 ; 1914 ; 1915 ;$ $1916 ; 1917 ; 1918 ; 1919 ; 1920 ; 1921 ; 1922 ; 1923 ; 1924)$.

1088 Peña y Pérez (1940: tomo IV, Cuadro 1-B, columna f).

${ }^{1089}$ NORTE (1940).
} 
Ferrocarriles ${ }^{1090}$ y en la columna "Varios" de Marquina ${ }^{1091}$. Ambas series coinciden, excepto en los ejercicios económicos 1924, 1925 y 1927. Existen errores para estos años en una de las dos fuentes. La misma información aparece en los Informes Anuales, pero desagregada en dos componentes: "ingresos varios" (se refiere a los "ingresos fuera de la explotación") e "intereses, cambios y comisiones". De la suma de ambos se obtiene una nueva serie que es idéntica a la de la Junta Superior de Ferrocarriles ${ }^{1092}$ y también a la de Marquina ${ }^{1093}$, excepto en los citados años. Aunque el propio Marquina advierte que "aún cuando la forma en que se presentan parece no encajar en la cuenta de explotación, formulada en las Memorias, los datos son iguales" 1094 , es evidente que los correspondientes a esos años no coinciden. En Marquina ${ }^{1095}$ la columna de "Varios" incluye los productos fuera del tráfico (almacenajes y repesas, estadías de material, alquiler de toldos, precintos, etc.), los productos diversos (alquileres de fondas y edificios, ventas de frutas, telegrafía privada, cobranza de impuestos, coches camas, etc.), y los ingresos producidos por billetes de anden, paralizaciones etc., que algunas campañas llevan solamente a la cuenta de Pensiones ${ }^{1096}$.

La presentación de los gastos de la explotación también varía de una fuente a otra. Las serie "Gastos de la explotación" de Marquina ${ }^{1097}$ coincide con la partida homónima de los Informes Anuales, y con la de la Junta Superior de Ferrocarriles "Gastos de personal, materias y diversos"1098 hasta 1922. Ninguna de las tres contempla los anticipos (1920-1926) entregados por el Estado para la mejora de los haberes del personal. No obstante, la Junta Superior de Ferrocarriles ${ }^{1099}$ sí incluye, aunque no lo explicite: (a) la diferencia entre lo aportado por el Estado, que fue menos de lo que correspondía entregar al personal por los anticipos de haberes de personal (1923-1926), y (b) los anticipos por los atrasos en la aplicación de la jornada de ocho horas (1928-1935). Por ello las cifras son más elevadas entre 1923 y 1935. Los Informes Anuales de NORTE y Marquina ${ }^{1100}$ también recogen las dos rúbricas, pero las sitúan en lugares distintos dentro de las cuentas de explotación. En ambas constituyen apartados propios "diferencia entre las sumas satisfechas al personal en concepto de anticipo del Estado y las recibidas de este con este objeto" y "cantidades a cargo de la Compañía en concepto de atrasos de la jornada de ocho horas". El matiz entre ambas fuentes es que

\footnotetext{
${ }^{1090}$ Peña y Pérez (1940: tomo I, Cuadro 1-B, columna f).

${ }^{1091}$ NORTE (1940, II: 12, Cuadro 1A).

1092 Peña y Pérez (1940: tomo IV).

${ }^{1093}$ NORTE (1940, II: 2).

${ }^{1094}$ NORTE (1940: I, 369).

1095 NORTE (1940, II: 2).

${ }^{1096}$ Marquina tiene establecidos por escrito claramente los conceptos que utiliza. Producto bruto total= Producto de viajeros de Gran Velocidad + Producto de mercancías de Gran Velocidad + Producto de mercancías de pequeña Velocidad + Varios. Productos de viajeros se refiere a productos de $1^{\mathrm{a}}, 2^{\mathrm{a}}$ y $3^{\mathrm{a}}$ clase. Productos de mercancías de Gran Velocidad incluye equipajes, perros, mensajerías, valores y todos los productos de Gran Velocidad, excepto viajeros. Productos de mercancías de Pequeña Velocidad incluye toda clase de mercancías en Pequeña Velocidad (coches, ganado, etc.) y transportes en servicios (NORTE, 1940, II: 2).

${ }^{1097}$ NORTE (1940: II, Cuadro 21).

1098 Peña y Pérez (1940: tomo IV: Cuadro 1-B, Columna h).

1099 Peña y Pérez (1940: tomo IV).

${ }^{1100}$ NORTE (1940).
} 
Marquina $^{1101}$ incluye las dos partidas en la columna de "Varios", junto a "pérdidas en cambios, comisiones, derechos de timbre".

Con respecto a las cargas financieras, la serie de Marquina ${ }^{1102}$ comprende únicamente intereses y amortización de las obligaciones. A las cifras de Marquina, Antecedentes y datos para el estudio del problema ferroviario de la Junta Superior de Ferrocarriles ${ }^{1103}$ añade los bonos de Asturias, Galicia y León, que Marquina no contempla y que acaban en 1924, y, desde 1922, los intereses y amortización de los anticipos del Estado para la adquisición de material, que Marquina ofrece como serie independiente en la relación de gastos totales ${ }^{1104}$ junto a las pensiones, atrasos por la jornada de ocho horas y el cajón de sastre "Varios". La información contenida en los Informes Anuales es más pormenorizada; a las anteriores partidas -intereses y amortización de las obligaciones, sin excluir los bonos de Galicia, Asturias y León, e intereses y amortización de los anticipos- agregan: ejercicios cerrados (saldo deudor o acreedor), gasto de valores en el extranjero y gasto de domiciliación de valores. A la suma resultante le restan el montante de los "Intereses, cambios y comisiones". El resultado de todo ello es una serie ligeramente diferente a la del Antecedentes y datos para el estudio del problema ferroviario de la Junta Superior de Ferrocarriles ${ }^{1105}$. Si se suman las "Cargas financieras" "1106 y las cifras correspondientes a "perdidas en cambios, comisiones, derechos de timbre, etc."1107 de la Junta Superior de Ferrocarriles, se obtienen los valores recogidos en Marquina ${ }^{1108}$. Por supuesto, la serie de gastos y cargas totales es la misma en las tres fuentes.

Además, también se producía una diferente exposición de los mismos datos cuando los datos son mostrados por la propia empresa o por la empresa conjuntamente con su competidor. Según lo establecido por NORTE (1940: 226), su gasto de combustible pasara de 19 millones en 1913 a 75 millones en 1918, mientras que según lo expresado conjuntamente por ambas compañías (NORTE y MZA, 1932: 14), el gasto de combustible de NORTE en 1913 fue de 16 millones, pasando a ser en 1919 de cerca de 69 millones. Esto supone que la empresa, en el año 1940, registró unos gastos de combustible en los años 1913 y 1919, mayores a los que había mostrado junto a MZA ocho años antes.

b) Manipulación de la ratio coste por kilómetro

La ratio coste por kilómetro servía a la empresa para conocer la racionalización de los gastos. La empresa lo calculaba por el cociente entre los viajeros y mercancías transportados a un kilómetro entre los gastos totales de explotación.

\footnotetext{
${ }^{1101}$ NORTE (1940: II, Cuadros 23).

1102 NORTE (1940: II, Cuadros 22 y 23).

${ }^{1103}$ Peña y Pérez (1940: tomo IV, Cuadro 1-B, Columna n).

${ }^{1104}$ NORTE (1940: tomo II, Cuadro 23).

${ }^{1105}$ Peña y Pérez (1940: tomo IV).

${ }^{1106}$ Peña y Pérez (1940: tomo IV, Cuadro 1-B, Columna n).

1107 Peña y Pérez (1940: tomo IV, Cuadro 1-B, Columna k).

${ }^{1108}$ NORTE (1940: II).
} 
Entre los indicadores utilizados respecto a los gastos de explotación, NORTE concede la máxima importancia a los Gastos de explotación por kilómetro explotado, calculado como Gastos de explotación / kilómetro explotado. Son incluidos tanto en la información periódica recogida por la empresa (Marquina) ${ }^{1109}$, como en el apartado II. "Ingreso por kilómetro explotado" en la información estadística de los Informes Anuales ${ }^{1110}$.

La motivación principal de alterar esta ratio era que, en muchos datos, NORTE sufría una situación peor respecto a MZA, lo que la perjudicaba en el proceso de obtención de recursos de mercado de capitales y en la situación relativa frente a MZA para la negociación de acuerdos y para la posible fusión entre ambas entidades. Las ratios que presentaban una mayor diferencia entre NORTE y MZA se situaban en el apartado de "Material y tracción". NORTE consumía más carbón por kilómetro, porque tenía más rampas y curvas. Analizando el coeficiente virtual de las redes, calculado por el cociente entre la longitud virtual y la longitud real de las líneas, es posible observar que el coeficiente para NORTE era mayor que para MZA. Por tanto, NORTE consumía más carbón por kilómetro ${ }^{1111}$.

En los Informes Anuales aparecían los datos oficiales de la compañía, es decir los que NORTE quería ofrecer a accionistas y acreedores. Según el Informe Anual de la empresa en 1901 (NORTE, 1902: 12), los datos eran 0,02936 para MZA y 0,03588 para NORTE. Esto suponía que NORTE mostraba que era el 122\% del de MZA (0,03588/0,02936=1,22207084).

Frente a estos datos, MZA y NORTE manejaban otra información interna, que reflejaba datos bien distintos. Según ellos, el coste por kilómetro en 1901 era en MZA de 0,0289, mientras que para NORTE era de $0,03427^{1112}$. Esto suponía que NORTE en realidad sabía que era el $118 \%$ del de MZA $(0,03427 / 0,0289=1,18581315)$

De esta forma, NORTE intentaba mostrar un coste por kilómetro más bajo que el real lo que le situaba en una situación aparentemente mejor.

c) Manipulación de la ratio coeficiente de explotación

El Coeficiente de explotación es la proporción de ingresos absorbidos por los gastos de explotación. Era calculado por NORTE como Gastos de la explotación / Ingresos de la explotación. La compañía lo consideraba como el indicador de gestión más importante "aún cuando el conocimiento de este coeficiente no es suficiente para juzgar la marcha de la empresa,

\footnotetext{
1109 NORTE (1940: tomo II, 35).

${ }^{1110}$ NORTE (1901: 71-135; 1902: 71-139; 1903: 73-137; 1904: 73-138; 1905: 73-138; 1906: 71-117; $1907: 67-$ 115; 1908: 65-114; 1909: 67-115; 1910: 65-113; 1911: 67-117;1912: 65-115; 1913: 67-125; 1914: 67-119: 1915: 67-119; 1916: 67-120; 1917: 72-125; 1918: 72-124; 1919: 72-120; 1920: 71-121; 1921: 71-121; 1922: 72-120; 1923: 71-140; 1924: 71-120).

${ }^{1111}$ Según los datos de García Raja (2006), NORTE consumía más carbón por kilómetro, tenía más rampas y curvas y tenía un peor coeficiente virtual de las redes, en general, pero esto fue decisivo en el trazado catalán.

1112 "Resumen de los ingresos del tráfico de las líneas que explotan actualmente las Compañías del NORTE y de Madrid a Zaragoza y Alicante. 27 de febrero de 1905". Documento incluido en AHF W-80-1.
} 
pues no tiene en cuenta las cargas financieras, entre otras cosas, es un índice muy acusado de la marcha de la explotación” (NORTE, 1940: 384).

No sólo NORTE lo consideraba la principal medida de comparación interempresarial, también la doctrina de la época (André, 1919: 375-376) y el resto de ferroviarias (NORTE y MZA, 1933: 143).

Pues bien, el coeficiente de explotación en el ejercicio contable 1901, conforme a los datos internos de la compañía era de 44,51\% ${ }^{1113}$, mientras que el Informe Anual de NORTE (1902) publicado a los usuarios externos indicaba que en el mismo año 1901 era de 49,62\%.

Con esta medida, NORTE intentaba mostrar un coeficiente de explotación más bajo que el real lo que le situaba en una situación aparentemente mejor frente al mercado, usuarios externos de la información financiera, y su posible aliado o competidor MZA.

\subsection{Sistema de información de gestión}

El sistema de información de gestión de NORTE utiliza los dos medios de planificación y control: los indicadores y los presupuestos.

\subsubsection{Indicadores de gestión}

NORTE maneja una información muy amplia y, además, la analiza y expone de forma muy sistemática, disgregada por años. La empresa no sólo ofrece mucha información, sino que la procesa de tres modos: estableciendo porcentajes, diferencias y actualización de valores.

Los datos internos que manejaba NORTE fueron recogidos en informes firmados por la Dirección. Gran parte de esta información, además, fue incluida en los documentos recopilatorios que realizó NORTE (1940).

A continuación se analiza la exposición de la información, y su procesamiento en la elaboración de series e índices ${ }^{1114}$.

Respecto al tráfico de viajeros, establece una distribución de viajeros por clase $\left(1^{\mathrm{a}}, 2^{\mathrm{a}}\right.$ y $\left.3^{\mathrm{a}}\right)$ y por precio (a precio entero, a precio reducido y kilométricos), y esto se realiza por año, por día y expresado en tanto\% (NORTE, 1940, tomo II: 8-12) ${ }^{1115}$.

\footnotetext{
1113 "Resumen de los ingresos del tráfico de las líneas que explotan actualmente las Compañías del NORTE y de Madrid a Zaragoza y Alicante. 27 de febrero de 1905". Documento incluido en AHF W-80-1.

1114 A efectos de poder realizar una comparación, establecemos los indicadores de gestión de su máximo competidor. MZA (1933: 279) establece seis principales índices para reflejar su gestión: Gastos de personal, Gastos de carbón, otras materias e indemnizaciones, Gastos totales de explotación, Gasto total por kilómetrotren, Peso de carbón consumido por tonelada-kilómetro bruta y Carga media de los trenes.

${ }^{1115}$ La doctrina (Gual, 1950: 409) establecía los siguientes indicadores para observar las estadísticas del tráfico:

- Kilómetro de tren, como referencia a los costes de explotación y modo de medir la densidad del servicio

- Carga bruta y neta de los trenes
} 
El transporte de viajeros presenta una distinción de los datos al tráfico y a sus productos en Gran velocidad y Pequeña velocidad (NORTE, 1940, tomo II: 6-13). En Gran velocidad se divide y detalla a su vez en Productos (a su vez en Totales y Por kilómetro), Equipajes y perros (a su vez en Número de toneladas de equipajes, Número de perros y Productos de equipajes y de perros), Mensajerías y valores (a su vez en Kilos de mensajerías, Valores en pesetas y Productos de mensajerías y valores), Coches (a su vez en Número y productos), Caballos (a su vez en Número y productos) y Varios (Productos). En Pequeña velocidad se divide y detalla en Productos (a su vez en Totales y Por kilómetro), Mercancías (a su vez en Totales y Por kilómetro), Transportes en servicio (a su vez en Totales y Por kilómetro), Coches (a su vez en Número y productos), Animales (a su vez en Número y productos) y Varios (Productos).

Respecto al tráfico de mercancías, NORTE (1940, tomo II: 18) también realiza una distinción en Gran velocidad y Pequeña velocidad. En cada una de ellas expone el número de toneladas expedidas para el comercio en el año y en cada uno de los días y el número de productos de cada mercancía.

Las toneladas kilométricas tienen un papel fundamental, al expresar su valor para el total de la Gran velocidad y Pequeña velocidad. A su vez en la Gran velocidad, NORTE (1940, tomo II: 19-20) divide la información de las toneladas kilométricas para Equipajes, Excesos de equipajes, perros, mensajerías y metálico, Caballos y mulas, Coches y Total. La Pequeña velocidad se divide en Mercancías para el comercio, Mercancías para el servicio, Coches y ganado y Total.

Respecto a los ingresos, NORTE (1940, tomo II: 20-25) identifica entre Productos varios y Productos de la explotación. En los Productos de la explotación se distingue entre los productos de la explotación (Totales y Por kilómetro), Ingresos de viajeros (Totales, Por kilómetro y En porcentaje), Ingresos de gran velocidad (Totales, Por kilómetro y En porcentaje), Ingresos de pequeña velocidad de mercancías, varios y transportes en servicio (Totales, Por kilómetro y En porcentaje), Ingresos de pequeña velocidad de caballos, coches y animales (Totales, Por kilómetro y En porcentaje) e Ingresos de productos fuera de tráfico e ingresos diversos (Totales, Por kilómetro y En porcentaje).

La información sobre los gastos es cuantiosa y muy fraccionada. La primera división de los gastos se realiza en cuatro títulos: de explotación, de las pensiones, cargas financieras y varios.

- Toneladas kilómetro y viajeros kilómetro, para identificar la densidad del tráfico

- Toneladas kilómetro por horas máquina, para conocer el trabajo rentable ejecutado

- Carga por vagón y por coche, como control de las operaciones de carga

- Composición y carga máxima de los trenes, según las líneas y los tipos de vagones. 
Los Gastos de explotación se clasifican en nueve Departamentos (Divisiones en denominación de NORTE): Gastos de Administración Central, Dirección, Reclamaciones, Comercial, Intervención de la cobranza, Servicio eléctrico, Explotación, Material y tracción, Vía y obras (NORTE, 1940, tomo II: 22-38). Los Gastos de Administración Central se subdividen en Honorarios y dietas de los trabajadores, Personal, Seguros, alquileres, etc., Gastos generales, Gastos de intervención, vigilancia y política por el gobierno, Administración de propiedades de la compañía y Total. Los Gastos de explotación de Dirección se subdividen en Dirección, Gastos complementarios y Total. Los Gastos de Reclamaciones se dividen en Gastos complementarios, Indemnizaciones pagadas por el servicio y Totales. La División de Explotación se clasifica en Servicios centrales, Trenes, Estaciones, Gastos generales y Total. Los Gastos de explotación de Material y tracción se dividen en Servicio central, Personal de tracción, Material de tracción, Reparación del material de tracción en talleres, Reparación del material de transporte en talleres y recorridos, Gastos complementarios y Total. Por último, Vía y obras se divide en Servicio central, Vigilancia de la vía, Conservación de la vía, Conservación de edificios, Gastos extraordinarios, Peaje a la compañía MZA, Gastos complementarios, Totales.

Además de lo anterior, los gastos de explotación de Material y tracción tienen una segunda clasificación (NORTE, 1940, tomo II: 55-56). Los gastos de Tracción tienen una división adicional entre Gastos Generales, Maquinistas y fogoneros, Personal en los depósitos y en las subestaciones, Engrase, limpieza y alumbrado de máquinas, gastos diversos de los depósitos, Alimentación de agua, Combustibles y energía eléctrica y Total. La información sobre los gastos de Material se divide en Maquinaria y ténderes, Coches y vagones, Engrase de vehículos y Total. Relacionado con todo lo anterior, la empresa maneja información sobre los Gastos por kilómetro de tren.

Los Gastos de las pensiones son ofrecidos en una cuenta independiente desde 1912. Desde 1874 a 1911 no figuraba el gasto de las pensiones en cuenta separada, sino que su importe se incluía en "Intereses, cambios y comisiones" y "Administración Central".

En las cargas financieras se diferencian los Intereses, Amortización, Obligaciones, Crédito Moviliario ${ }^{1116}$ Español, Obligaciones amortizables y Totales (NORTE, 1940, tomo II: 8-36).

La mayor cantidad de información que procesa NORTE (1940, tomo II: 39-47) es sobre el número de trenes y recorridos totales. Expone el Número de trenes para el público, especificando los que son de Viajeros, de Mercancías, Mixtos y Totales. También expone los Recorridos kilométricos de los trenes, diferenciando entre de Viajeros, de Mercancías, Mixtos, Trabajos, Totales, de Vapor y Eléctricos. También se maneja información sobre el Número de locomotoras (indicando si son de Vapor, Eléctricas y Totales), Número de coches y Número de vagones. Además se detalla minuciosamente el recorrido kilométrico de los vehículos y composición media de los trenes, diferenciando todos ellos entre Coches y Vagones y, a su vez, cada uno de ellos, Viajeros, Mixtos, Mercancías, Total y Por coche y Por

$\overline{{ }^{1116} \text { Según la ortografía de la época. }}$ 
vagón. La exposición continúa con el Recorrido de los de viajeros, Recorrido de los mixtos, Número de viajeros transportados a un kilómetro, Recorrido de los enganchados a los trenes, Asientos ofrecidos por kilómetro, Número de viajeros transportados por kilómetro y coche, Número de coches en circulación y Transporte medio anual.

En la información sobre los datos relativos a trenes, destaca el detalle de los ingresos y gastos por kilómetro de tren. La información culmina con el detalle del Producto líquido, calculado como diferencia entre los Ingresos totales y los Gastos totales. Los gastos están sistemáticamente divididos según su naturaleza en: Administración y Dirección, Reclamaciones, Comercial, Intervención de la cobranza, Explotación, Material y tracción de vapor, Material y tracción eléctrico, Vía y obras y Gastos generales (NORTE, 1940, tomo II: 41).

Especial importancia tiene el reflejo de la información sobre el Número de toneladas transportadas por cada kilómetro, dividido en Viajeros, Mixtos, Mercancías y Total, y el Número de toneladas transportadas por cada tren y kilómetro, dividido en Viajeros, Mixtos, Mercancías y Total.

Respecto al trabajo de los vagones en el transporte de mercancías, NORTE (1940, tomo II: 49) maneja información sobre el Recorrido kilométrico de la totalidad de los vagones, diferenciando entre el Recorrido kilométrico de los vagones cargados y el Recorrido kilométrico de los vagones vacíos y trabajos. La compañía concede mucha importancia a los indicadores Término medio de las toneladas transportadas por vagón cargado y kilómetro, el Término medio de las toneladas transportadas por vagón empleado y kilómetro, el Número de vagones empleados, el Número de toneladas kilométricas por vagón empleado y el Recorrido medio anual (medido en kilómetros) por vagón empleado.

Sobre las toneladas kilométricas, NORTE (1940, tomo II: 50) diferencia entre las producidas en la Gran velocidad y la Pequeña velocidad. La empresa realiza una distinción de elementos, sobre las toneladas kilométricas, con una denominación muy específica: Total de Grande y Pequeña velocidad (Trabajo útil), Circulación de vehículos (Peso muerto), Total de peso arrastrado (Trabajo útil + Peso muerto), Circulación de máquinas (Peso muerto ${ }^{1117}$ ) y Total del peso circulado (Circulación de máquinas + Peso muerto ${ }^{118}$ ).

Sobre Recorridos y toneladas arrastradas, NORTE (1940, tomo II: 52) diferenció los Kilómetros de tren, Kilómetros de máquina, Trabajo útil (toneladas kilométricas) y Toneladas kilométricas totales, y dentro de cada una de ellas distingue entre los correspondientes al Vapor, Eléctricos y Totales.

NORTE (1940, tomo II: 54), como no podía ser de otro modo, concede una importancia capital al consumo de carbón. Sobre este tema expone información sobre el Consumo total,

\footnotetext{
${ }^{1117}$ NORTE (tomo II, 51) denomina "Peso muerto a dos conceptos distintos": Circulación de vehículos y a la Circulación de máquinas.

${ }^{1118}$ Este Peso muerto se refiere a la Circulación de máquinas.
} 
Precio medio por tonelada, Miles de pesetas gastadas en carbón para las máquinas, Kilogramos gastados por kilómetro de tren, Kilogramos gastados por kilómetro de máquina, Kilogramos gastados por tonelada kilométrica de trabajo útil y Kilogramos gastados por tonelada kilométrica de trabajo total.

Con la misma finalidad, NORTE (1940, tomo II: 57) utiliza información sobre los datos del Consumo de energía eléctrica, y lo hace exponiendo el Consumo de energía eléctrica, Precio medio del kilovatio hora, Consumo de energía eléctrica por kilómetro de tren, Consumo de energía eléctrica por kilómetro de máquina, Consumo de energía eléctrica por tonelada kilométrica de trabajo útil, Consumo de energía eléctrica por tonelada kilométrica de trabajo total y Consumo medio por tonelada kilométrica remolcada.

Respecto al número y coste de personal, NORTE (1940, tomo II: 58) maneja información sobre el total de personal, tanto en número como en coste, distinguiendo entre jubilados y trabajadores, y dentro de estos últimos diferenciando entre agentes, plantilla y jornal. Además, también maneja información del porcentaje que representa sobre el total gastado por la compañía el gasto del personal activo; del mismo modo sobre el gasto de personal jubilado; y por último sobre el gasto de personal total. Relacionado con lo anterior, la empresa NORTE (1940, tomo II: 62) detalla pormenorizadamente cada uno de los emolumentos y beneficios varios otorgados al personal de la compañía.

NORTE (1940, tomo II: 60-61) utiliza información sobre el total de las sumas invertidas en "Obras de beneficencia y Previsión", desglosadas en Caja de previsión a cuenta de personal, Caja de previsión a cuenta de la compañía, Socorros, Numerosa familia, Médicos, Medicinas, aparatos ortopédicos, Vestuario, Enseñanza, subvenciones y centros instructivos, Importe de las pensiones. Además, maneja dos porcentajes relacionados: Tanto\% que representa el gasto en beneficencia y previsión sobre el gasto total y Tanto $\%$ del gasto en beneficencia y previsión sobre el ingreso.

Además, a partir del año 1906 -comienzo de la Sindicatura con MZA- y hasta su nacionalización, incorpora índices con Base 100, para establecerlo como evaluador de la gestión. La compañía utiliza las siguientes medidas expresadas, con relación a la de 1906, que se toma como 100:

- Variación de la base de percepción en viajeros (NORTE, 1940, tomo II: 13).

- Variación de la base de percepción de mercancías por tonelada kilométrica (NORTE, 1940, tomo II: 18).

- Variación de los ingresos totales (NORTE, 1940, tomo II: 23).

- Variación del coeficiente de explotación (NORTE, 1940, tomo II: 35).

- Variación de los gastos totales (NORTE, 1940, tomo II: 37).

- Número de agentes, plantilla y jornal (NORTE, 1940, tomo II: 58).

- Importe pagado a los trabajadores (NORTE, 1940, tomo II: 58).

- Importe pagado por agente (NORTE, 1940, tomo II: 58). 
La compañía evalúa su actividad con varios indicadores que aparecen sintetizados en los cuadros del 68 a 76. Los indicadores son muy amplios y diversos. Sólo echamos en falta dos de los utilizados actualmente ${ }^{1119}$. Uno es el aprovechamiento, que es la relación entre los viajeros kilómetro y las plazas kilómetro. El otro es la velocidad media de los trenes.

Cuadro 68. Indicadores utilizados por NORTE respecto al número de viajeros del tráfico de viajeros

\begin{tabular}{|l|l|}
\hline INDICADOR & FORMA DE CALCULARLO \\
\hline Número total de viajeros-kilómetros & Número total de viajeros / kilómetros explotados \\
\hline Número total de toneladas - kilométricas & $\begin{array}{l}\text { Número total de toneladas transportadas / kilómetros } \\
\text { explotados }\end{array}$ \\
\hline $\begin{array}{l}\text { Número total de viajeros-kilómetros de } \\
\text { viajeros a precio entero }\end{array}$ & $\begin{array}{l}\text { Número total de viajeros a precio entero / kilómetros } \\
\text { explotados }\end{array}$ \\
\hline $\begin{array}{l}\text { Número total de viajeros-kilómetros de } \\
\text { viajeros a precio reducido }\end{array}$ & $\begin{array}{l}\text { Número total de viajeros a precio reducido / kilómetros } \\
\text { explotados }\end{array}$ \\
\hline $\begin{array}{l}\text { Número total de viajeros-kilómetros de } \\
\text { viajeros a precio kilométrico }\end{array}$ & $\begin{array}{l}\text { Número total de viajeros a precio kilométrico / } \\
\text { kilómetros explotados }\end{array}$ \\
\hline $\begin{array}{l}\text { Recorrido medio de un viajero } \\
\text { Recorrido medio de un viajero a precio } \\
\text { entero }\end{array}$ & $\begin{array}{l}\text { Número total de viajeros-kilómetros / número total de } \\
\text { viajeros a precio entero }\end{array}$ \\
\hline $\begin{array}{l}\text { Recorrido medio de un viajero a precio } \\
\text { reducido }\end{array}$ & $\begin{array}{l}\text { Número total de viajeros-kilómetros / número total de } \\
\text { viajeros a precio reducido }\end{array}$ \\
\hline $\begin{array}{l}\text { Recorrido medio de un viajero a precio } \\
\text { kilométricos }\end{array}$ & $\begin{array}{l}\text { Número total de viajeros-kilómetros / número total de } \\
\text { viajeros a precio kilométricos }\end{array}$ \\
\hline
\end{tabular}

Fuente: Elaboración propia a partir de los datos de NORTE (1940: tomo II, 10)

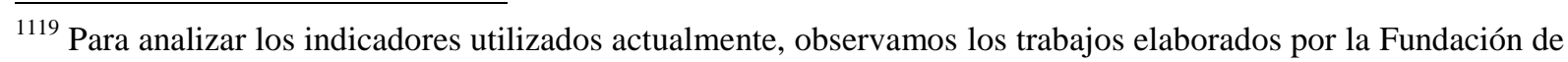
Ferrocarriles Españoles (2011). 
Cuadro 69. Indicadores utilizados por NORTE respecto a los productos del tráfico de viajeros (ingresos)

\begin{tabular}{|l|l|}
\hline INDICADOR & FORMA DE CALCULARLO \\
\hline Producto medio por viajero & Producto de viajeros / número de viajeros \\
\hline Producto medio por viajero primera clase & $\begin{array}{l}\text { Producto de viajeros / número de viajeros de primera } \\
\text { clase }\end{array}$ \\
\hline Producto medio por viajero segunda clase & $\begin{array}{l}\text { Producto de viajeros / número de viajeros de segunda } \\
\text { clase }\end{array}$ \\
\hline Producto medio por viajero tercera clase & $\begin{array}{l}\text { Producto de viajeros / número de viajeros de tercera } \\
\text { clase }\end{array}$ \\
\hline Precio del producto medio a precio entero & $\begin{array}{l}\text { Producto de viajeros a precio entero / número total de } \\
\text { viajeros a precio entero }\end{array}$ \\
\hline $\begin{array}{l}\text { Precio del producto medio a precio } \\
\text { reducido }\end{array}$ & $\begin{array}{l}\text { Producto de viajeros a precio reducido / número total de } \\
\text { viajeros a precio reducido }\end{array}$ \\
\hline $\begin{array}{l}\text { Precio del producto medio a precio } \\
\text { kilométricos }\end{array}$ & $\begin{array}{l}\text { Producto de viajeros a precio kilométricos / número total } \\
\text { de viajeros a precio kilométricos }\end{array}$ \\
\hline Producto medio por viajero - kilómetro & Producto medio por viajero / kilómetros explotados \\
\hline $\begin{array}{l}\text { Producto medio por viajero - kilómetro a } \\
\text { precio entero }\end{array}$ & $\begin{array}{l}\text { Producto medio por viajero a precio entero / kilómetros } \\
\text { explotados }\end{array}$ \\
\hline $\begin{array}{l}\text { Producto medio por viajero - kilómetro a } \\
\text { precio reducido }\end{array}$ & $\begin{array}{l}\text { Producto medio por viajero a precio reducido / } \\
\text { kilómetros explotados }\end{array}$ \\
\hline $\begin{array}{l}\text { Producto medio por viajero - kilómetro a } \\
\text { precio kilométricos }\end{array}$ & $\begin{array}{l}\text { Producto medio por viajero a precio kilométricos / } \\
\text { kilómetros explotados }\end{array}$ \\
\hline
\end{tabular}

Fuente: Elaboración propia a partir de los datos de NORTE (1940: tomo II, 13)

Cuadro 70. Indicadores utilizados por NORTE respecto al tráfico de mercancías

\begin{tabular}{|l|l|}
\hline INDICADOR & FORMA DE CALCULARLO \\
\hline Recorrido medio de la tonelada & $\begin{array}{l}\text { Número total de toneladas-kilómetros / número total de } \\
\text { toneladas }\end{array}$ \\
\hline Producto medio de una tonelada & $\begin{array}{l}\text { Producto total / Número de toneladas expedidas para el } \\
\text { comercio }\end{array}$ \\
\hline Media de una tonelada kilómetro & $\begin{array}{l}\text { Número total de toneladas-kilómetros / Número de } \\
\text { toneladas expedidas para el comercio }\end{array}$ \\
\hline
\end{tabular}

Fuente: Elaboración propia a partir de los datos de NORTE (1940: tomo II, 18) 
Cuadro 71. Indicadores utilizados por NORTE respecto a los gastos de explotación

\begin{tabular}{|l|l|}
\hline INDICADOR & FORMA DE CALCULARLO \\
\hline $\begin{array}{l}\text { Ingresos de explotación por kilómetro } \\
\text { explotado }\end{array}$ & Ingresos de explotación / kilómetro explotado \\
\hline $\begin{array}{l}\text { Gastos de explotación por kilómetro } \\
\text { explotado }\end{array}$ & Gastos de explotación / kilómetro explotado \\
\hline Ingresos neto por kilómetro explotado & Ingresos neto / kilómetro explotado \\
\hline Coeficiente de explotación & Gastos de la explotación / Ingresos de la explotación \\
\hline
\end{tabular}

Fuente: Elaboración propia a partir de los datos de NORTE (1940: tomo II, 35)

Cuadro 72. Indicadores utilizados por NORTE respecto a los gastos unitarios y agentes unitarios

\begin{tabular}{|c|c|}
\hline INDICADOR & FORMA DE CALCULARLO \\
\hline Unidades de tráfico & $\begin{array}{l}\text { Toneladas kilométricas (G. y } \quad \text { P. } \quad \text { V.) }+ \text { Viajeros } \\
\text { Kilómetro }\end{array}$ \\
\hline Toneladas kilométricas de viajeros & Viajeros kilómetro x 0,07 (T) \\
\hline Toneladas Kilométricas totales & $\begin{array}{l}\text { Toneladas kilométricas (G. y P. V.) + Unidades de } \\
\text { tráfico }\end{array}$ \\
\hline Gasto por kilómetro de tren & Gasto total / Kilómetros de tren \\
\hline Gasto por mil unidades de tráfico & Gasto total / Unidades de tráfico \\
\hline Gasto por kilómetro de Red & Gasto total / Kilómetros de red \\
\hline $\begin{array}{l}\text { Gasto por mil toneladas kilométricas } \\
\text { totales (Viajeros y mercancías) }\end{array}$ & Gasto total x 1.000 / Toneladas kilométricas totales \\
\hline Agentes por kilómetro de red & Número total de agentes / Kilómetros de red \\
\hline Agentes por mil kilómetros de tren & Número total de agentes x 1.000 / Kilómetros de tren \\
\hline Agentes por millón de unidades de tráfico & $\begin{array}{l}\text { Número total de agentes } \mathrm{x} 1.000 .000 / \text { Unidades de } \\
\text { tráfico }\end{array}$ \\
\hline
\end{tabular}

Fuente: Elaboración propia a partir de los datos de NORTE (1940: tomo II, 48, 49, 59 y 60)

Cuadro 73. Indicadores utilizados por NORTE respecto a las reclamaciones. Antecedente del Capital Intelectual

\section{INDICADOR}

Tanto por mil que representan sobre los ingresos, los pagos hechos por indemnizaciones

\section{FORMA DE CALCULARLO}

Pagos realizados por indemnizaciones por reclamaciones x 1.000 / Ingresos totales

Fuente: Elaboración propia a partir de los datos de NORTE (1940: tomo II, 48-49) 
Cuadro 74. Indicadores utilizados por NORTE respecto al número de trenes y recorridos totales

\begin{tabular}{|l|l|}
\hline INDICADOR & FORMA DE CALCULARLO \\
\hline Circulación diaria & Número de trenes por día y kilómetro \\
\hline $\begin{array}{l}\text { Relación de los asientos ocupados a los } \\
\text { ofrecidos }\end{array}$ & $\begin{array}{l}\text { Número de viajeros transportados a un kilómetro / } \\
\text { Asientos ofrecidos por kilómetro }\end{array}$ \\
\hline
\end{tabular}

Fuente: Elaboración propia a partir de los datos de NORTE (1940: tomo II, 39)

Cuadro 75. Indicadores utilizados por NORTE respecto al número de trenes y recorridos totales

\begin{tabular}{|l|l|l|}
\hline INDICADOR & FORMA DE CALCULARLO \\
\hline $\begin{array}{l}\text { Relación entre el recorrido de los vacíos y y } \\
\text { el de los remolcados }\end{array}$ & $\begin{array}{l}\text { Recorrido kilométrico de los vagones vacíos / } \\
\text { (Recorrido kilométrico de los vagones vacíos + } \\
\text { Recorrido kilométrico de los vagones cargados) }\end{array}$ \\
\hline
\end{tabular}

Fuente: Elaboración propia a partir de los datos de NORTE (1940: tomo II, 49)

Cuadro 76. Indicadores utilizados por NORTE respecto al trabajo de las máquinas (Toneladas kilométricas)

\begin{tabular}{|l|l|}
\hline INDICADOR & FORMA DE CALCULARLO \\
\hline $\begin{array}{l}\text { Relación entre el trabajo útil y el peso } \\
\text { muerto }\end{array}$ & $\begin{array}{l}\text { Total de grande y pequeña velocidad (Trabajo útil) / } \\
\text { Circulación de vehículos (Peso muerto) }\end{array}$ \\
\hline $\begin{array}{l}\text { Relación entre el trabajo útil y el peso } \\
\text { arrastrado }\end{array}$ & $\begin{array}{l}\text { Total de grande y pequeña velocidad (Trabajo útil) / } \\
\text { Total de peso arrastrado }\end{array}$ \\
\hline $\begin{array}{l}\text { Relación entre el trabajo útil y el peso } \\
\text { total circulado }\end{array}$ & $\begin{array}{l}\text { Total de grande y pequeña velocidad (Trabajo útil) / } \\
\text { Total de peso circulado }\end{array}$ \\
\hline
\end{tabular}

Fuente: Elaboración propia a partir de los datos de NORTE (1940: tomo II, 51)

Los indicadores anteriores son incluídos en la información interna manejada en cada ejercicio contable y, además, simultáneamente en la Información excepcional, no periódica que NORTE ofrece a sus usuarios internos y externos. Pero, por otro lado, existen indicadores que son mostrados exclusivamente en la voluminosa recopilación publicada en 1940:

- Número absoluto de viajeros (NORTE, 1940: 356).

- Número total de viajeros-kilómetros (NORTE, 1940: 357).

- Recorrido medio de un viajero (NORTE, 1940: 357).

- Recorrido medio de un viajero con billete kilométrico (NORTE, 1940: 357).

\footnotetext{
${ }^{1120}$ Este indicador es de máxima importancia, porque supone una de las primeras aproximaciones al cálculo de los recursos ociosos.

${ }^{1121}$ Este indicador es de máxima importancia, porque supone una de las primeras aproximaciones al cálculo de los recursos ociosos.
} 
- Productos totales de los viajeros (primera clase, segunda clase, tercera clase, suplementarias) (NORTE, 1940: 357).

- Productos totales de los viajeros (a precio entero, a precio reducido y kilométricos) (NORTE, 1940: 357).

- Recaudación media por viajero (NORTE, 1940: 358).

- Base media, es decir, el producto medio por viajero-kilómetro (NORTE, 1940: 356).

- Recorrido medio de una tonelada (NORTE, 1940: 367).

- Productos totales de pequeña velocidad (NORTE, 1940: 367).

- Productos de explotación (Viajeros, Gran velocidad, Pequeña velocidad y Fuera del tráfico), expresado en unidades monetarias y porcentaje (NORTE: 1940: 371).

- Coeficiente de explotación. Comparación entre los ingresos y los gastos de explotación. NORTE lo consideraba como un indicador de gestión "Aún cuando el conocimiento de este coeficiente no es suficiente para juzgar la marcha de la empresa, pues no tiene en cuenta las cargas financieras, entre otras cosas, es un índice muy acusado de la marcha de la explotación" (NORTE, 1940: 384). La validez de este coeficiente como herramienta de gestión está en entredicho. Jiménez Ontiveros (1930) advirtió que el coeficiente de explotación no tiene valor científico, porque siendo la expresión de una relación entre gastos e ingresos, "indica solamente la marcha a posteriori de las explotaciones, pero no permite una investigación a fondo de las causas que influyen en los resultados económicos de la industria". Aunque esto es cierto, y no sirva para tomar decisiones de gestión como utiliza NORTE, es válido para un análisis como el que se realiza en esta investigación para analizar a posteriori el sector ferroviario y las compañías que en él actuaban.

Otras veces los datos ofrecidos en los informes internos de la dirección son presentados de forma distinta al modo en que están expuestos en la documentación periódica. Para calcular los indicadores de gestión, NORTE (1940: 369) agrupa en el epígrafe "Productos fuera del tráfico" las siguientes partidas que aparecían en el Informe Anual de NORTE:

- Transporte en servicio.

- Almacenajes y repesos.

- Estadías de material.

- Alquiler de toldos.

- Desinfección de vagones.

- Maniobras en los puertos.

- Precintos.

- Peaje.

- Varios.

Del mismo modo, para calcular los indicadores de gestión, NORTE (1940: 370) agrupa en el epígrafe "Ingresos diversos" las siguientes partidas que aparecían en el Informe Anual de NORTE:

- Alquiler de fondas, edificios, etc.

- Arrendamientos de terrenos. 
- Ventas de hierbas y frutos.

- Venta de papel.

- Cambio de material.

- Coches restaurantes.

- Telegrafía privada.

- Cobranza de impuestos.

- Agencia Internacional.

- Varios.

- Productos no clasificados.

\subsubsection{Presupuestos}

NORTE tiene una adecuada política de elaboración de presupuestos y control de sus desviaciones. Esto lo hace para todas y cada una de las líneas que formaban la red. Pero no se circunscribe exclusivamente a las líneas, NORTE también establece presupuestos para las estaciones $^{1122}$.

\subsubsection{Procedimiento}

NORTE relata cómo tenía perfectamente establecido el modo de confeccionar los presupuestos $^{1123}$. Al final de cada año, NORTE establecía un Presupuesto general de gastos para el año siguiente, por todos los conceptos y para todos los servicios. Al establecer el Presupuesto general se procuraba que el importe total de los gastos acordado fuese conforme al de los ingresos presumibles, de modo que presentara en su conjunto un resultado parecido al del ejercicio precedente, si éste había sido satisfactorio.

Además, NORTE también tenía establecido el procedimiento para resolver aspectos de algunas partidas concretas ${ }^{1124}$. En algunos conceptos podía haber diferencias entre los gastos reales y los previstos; pero en otros, como la "Renovación de vía" por ejemplo, se fijaba un programa de trabajo para el año y NORTE se atendía exactamente al programa trazado. En "Transformaciones con ampliaciones" la compañía acuerda "un crédito global, que no es de mucha importancia, y del cual generalmente no se salía. No se incurrían en gastos por los

\footnotetext{
${ }^{1122}$ NORTE llevó a cabo el estudio de una estación de mercancías en Bilbao; el ingeniero de NORTE, Grassent, redactaría el presupuesto correspondiente y formuló el proyecto (Gaceta de los Caminos de Hierro, 8 de junio de 1917).

${ }_{1123}$ AHF P-113-258-3: "Contestación de la Compañía de los Caminos de Hierro del NORTE de España al Informe redactado por la Primera Comisión investigadora de la situación económica de las empresas de ferrocarriles nombrada por Real Orden de 20 de octubre de 1923": Apartado "II. Reparos del Informe a las diversas partidas que componen las cuentas de explotación".

${ }_{1124}$ AHF P-113-258-3: "Contestación de la Compañía de los Caminos de Hierro del NORTE de España al Informe redactado por la Primera Comisión investigadora de la situación económica de las empresas de ferrocarriles nombrada por Real Orden de 20 de octubre de 1923": Apartado "II. Reparos del Informe a las diversas partidas que componen las cuentas de explotación".
} 
conceptos enunciados que no estén dentro de las previsiones del año, en las cuales se tenía en cuenta que no se produjera desnivel notable en el resultado general del ejercicio" ${ }^{\prime 125}$.

La estructura del documento donde se recoge el presupuesto de NORTE ${ }^{1126}$ es mucho más adecuada y con un valor informativo mayor que el realizado por las empresas contemporáneas a ella. La información está expresada en una única columna, siendo muy parecida a cómo se utilizaba en esa época en las empresas estadounidenses, y cómo se realiza actualmente, tras la adopción directa e indirecta de las International Financial Reporting Standards. El documento detalla los ingresos, para posteriormente incluir los gastos y cargas. Por diferencia de los segundos sobre los primeros se obtiene el excedente ${ }^{1127}$, término aún utilizado en el Plan General Contable de Entidades no Lucrativas. Especialmente acertada es la presentación del excedente por comparación de ingresos y gastos. Para identificar las bondades y la adecuación del presupuesto, podemos comparar el presupuesto con un documento realizado por un ente externo a la compañía: el "Informe redactado por la Primera Comisión investigadora de la situación económica de las empresas de ferrocarriles nombrada por Real Orden de 20 de octubre de 1923". Un cuadro realizado por el Informe, muy similar al de los presupuestos de NORTE, recogía los gastos, posteriormente los ingresos y sin diferenciar claramente (cosa que NORTE realiza de forma muy adecuada) refleja el excedente ${ }^{1128}$.

\subsubsection{Contenidos}

Los presupuestos son realizados desde el inicio de su actividad, pero van mejorando cada año. Los realizados en 1901 son los primeros que presentan un valor predictivo alto. El presupuesto de 1901 es el primero que ofrece ordenadamente las cuatro partidas: ingresos, gastos, producto líquido y relación entre los gastos e ingresos ${ }^{1129}$.

El Consejo de NORTE aprobó el proyecto de presupuestos de ingresos y gastos de explotación de todas las líneas de la compañía para el 1901, fijando los primeros en

\footnotetext{
1125 AHF P-113-258-3: “Contestación de la Compañía de los Caminos de Hierro del NORTE de España al Informe redactado por la Primera Comisión investigadora de la situación económica de las empresas de ferrocarriles nombrada por Real Orden de 20 de octubre de 1923": Apartado "II. Reparos del Informe a las diversas partidas que componen las cuentas de explotación".

1126 AHF P-113-258-3: “Contestación de la Compañía de los Caminos de Hierro del NORTE de España al Informe redactado por la Primera Comisión investigadora de la situación económica de las empresas de ferrocarriles nombrada por Real Orden de 20 de octubre de 1923": Apartado "III. Previsión de los resultados del año 1923".

1127 AHF P-113-258-3: “Contestación de la Compañía de los Caminos de Hierro del NORTE de España al Informe redactado por la Primera Comisión investigadora de la situación económica de las empresas de ferrocarriles nombrada por Real Orden de 20 de octubre de 1923": Apartado "III. Previsión de los resultados del año 1923".

${ }^{1128}$ Cfr. AHF P-113-258-1: "Memoria sobre la situación económica de la Compañía de los Caminos de Hierro del NORTE de España", Primera Comisión investigadora de la situación económica de las empresas de ferrocarriles, 29 de noviembre de 1923, y AHF P-113-258-3: "Contestación de la Compañía de los Caminos de Hierro del NORTE de España al Informe redactado por la Primera Comisión investigadora de la situación económica de las empresas de ferrocarriles nombrada por Real Orden de 20 de octubre de 1923".

${ }^{1129}$ Acta no 664 del Libro de actas del Consejo de Administración de NORTE: 11 de abril de 1901.
} 
106.000.000 de pesetas y los segundos en 45.221.000, dejando un producto líquido de 60.779.000, siendo la relación entre los gastos e ingresos de 42,66\%. Estos son los primeros presupuestos que aparecen ordenados y completos, pues recoge los datos de toda la red y los clasifica en función de las cuatro partidas: ingresos, gastos, producto líquido y relación entre los gastos e ingresos. Los del año 1900 indicaban únicamente tres partidas (ingresos, gastos, producto líquido), y además no de toda la red, sino que se exceptuan las de San Juan de las Abadesas y la de Valencia a Utiel ${ }^{1130}$.

De la misma forma, el Consejo aprobó el proyecto de presupuestos de ingresos y gastos de explotación de todas las líneas de la compañía para el 1902, estableciendo los ingresos de explotación en 110.000.000 de pesetas y los gastos de explotación en 52.348.790, dejando un producto líquido de 57.651.790, siendo la relación entre los gastos e ingresos de $47,58 \%{ }^{1131}$. El presupuesto de 1902 es el primero que establece un presupuesto diferenciado para las Minas de Surroca por un lado y para las de Barruelo por otro, de forma que NORTE planifica los ingresos y gastos que se obtendrán de cada uno de ellas ${ }^{1132}$.

Para el 1903, el Consejo de NORTE aprobó el proyecto de presupuestos de ingresos y gastos de explotación de todas las líneas, fijando los ingresos de explotación en 118.000.000 pesetas y los gastos de explotación en 51.770.000, dejando un producto líquido de 66.230.000, siendo la relación entre los gastos e ingresos de $43,87 \%^{1133}$. Para este año los gastos son los siguientes (en pesetas): Administración Central 2.973.690, Dirección 2.321.000, Explotación 14.355.900, Material y Tracción 19.499.530 y Vía y Obras 12.641.900. El presupuesto de 1903 es el primero que además de los datos anteriores ofrece una estimación de los posibles gastos en función de sus divisiones ${ }^{1134}$. El sistema de presupuestos es lo suficientemente importante como para tomar decisiones de planificación y control en el año 1903. El Director de NORTE mandó una carta al Comité sobre la situación financiera probable de NORTE el 1 de octubre de 1903, de lo que resulta una insuficiencia económica aproximada de 3.400.000 pesetas. El Consejo acuerda ampliar el anticipo con el Banco Español de Crédito que se había firmado anteriormente y del cual se precisaba un preaviso de un mes para ampliarlo en cinco millones de pesetas $^{1135}$.

En Biarritz se reunieron los Comités de París y Madrid, para tratar varios temas, entre ellos: Examen y preparación de las "Cuentas y situación financiera de la Compañía" correspondiente al ejercicio de 1903 y Previsión de gastos ordinarios para el ejercicio 1904 y examen de los medios convenientes para que las relaciones entre los Comités de París ${ }^{1136}$.

\footnotetext{
${ }^{1130}$ Acta $^{\circ} 652$ del Libro de actas del Consejo de Administración de NORTE: 30 de marzo de 1900.

${ }^{1131}$ Acta n $^{\circ} 674$ del Libro de actas del Consejo de Administración de NORTE: 21 de marzo de 1902.

${ }^{1132}$ Acta n $^{\circ} 674$ del Libro de actas del Consejo de Administración de NORTE: 21 de marzo de 1902.

${ }^{1133}$ Acta $^{\circ} 687$ del Libro de actas del Consejo de Administración de NORTE: 25 de abril de 1903.

${ }^{1134}$ Acta $n^{\circ} 687$ del Libro de actas del Consejo de Administración de NORTE: 25 de abril de 1903.

${ }^{1135}$ Acta n $^{\circ} 692$ del Libro de actas del Consejo de Administración de NORTE: 30 de septiembre de 1903.

${ }^{1136}$ Acta no 696 del Libro de actas del Consejo de Administración de NORTE: 30 de enero de 1904.
} 
El Consejo de NORTE aprobó el proyecto de presupuestos de ingresos y gastos de explotación de todas las líneas de la compañía para el 1904, fijando los ingresos de explotación en 120.000.000 de pesetas y los gastos de explotación en 53.715.845, dejando un producto líquido de 66.284 .155 , siendo la relación entre los gastos e ingresos de $44,76 \%{ }^{1137}$.

Los presupuestos para el ejercicio 1904 presentan una novedad en el procedimiento de su realización, aunque el documento elaborado ofreció menos información y desglose ${ }^{1138}$. Fue confeccionado en un evento en Biarritz en la que se reunieron los Comités de París y Madrid, para, entre otros temas tratar la previsión de gastos ordinarios para el ejercicio $1904^{1139}$. No obstante, aunque el procedimiento fue el adecuado, la información es menor pues el presupuesto de 1904 dejó de ofrecer una estimación de los posibles gastos en función de sus divisiones $^{1140}$, lo cual supone un retroceso en las mejoras.

El Consejo de NORTE aprobó los presupuestos de ingresos y gastos de explotación de todas las líneas de la compañía para el 1905, de los que se había ocupado el Comité en su Sesión de 26 de abril de $1905^{1141}$. La empresa fijó los ingresos de explotación en 120.000 .000 de pesetas y los gastos de explotación en 59.400.455, dejando un producto líquido de 60.599.545, siendo la relación entre los gastos e ingresos de $49,5 \%{ }^{1142}$. El presupuesto de 1905 no ofreció una estimación de los posibles gastos en función de sus divisiones, pero incorpora un dato más que complementaba los gastos como es el "Recorrido de trenes de viajeros y mercancías", que en ese año es de 18.100.000 kilómetros ${ }^{1143}$.

Además, el presupuesto de 1905 avanza en la mejora de la temporalidad del presupuesto. El Comité propuso que la presentación de los presupuestos del año 1906 se realizara antes del 1 de noviembre de 1905, "a fin de que puedan estudiarse oportunamente por los Comités, ser examinados por el Consejo antes del 20 de diciembre de 1905 y empezar a regir el 1 de enero de 1906"1144. Posteriormente, el presidente indicó a los Administradores y al Director la conveniencia de que los presupuestos del año 1906 estuviesen antes que en los años anteriores "para que sean examinados en tiempo oportuno por los Comités de Madrid, París y Barcelona y sometidos en tiempo hábil para ser aprobados antes del 1 de enero a la deliberación del Consejo" $" 1145$.

\footnotetext{
${ }^{1137}$ Acta $\mathrm{n}^{\circ} 701$ del Libro de actas del Consejo de Administración de NORTE: 25 de mayo de 1904.

${ }^{1138}$ Acta n $^{\circ} 701$ del Libro de actas del Consejo de Administración de NORTE: 25 de mayo de 1904.

${ }^{1139}$ En Biarritz se reunieron los Comités de París y Madrid, para tratar tres temas: Examen y preparación de las "Cuentas y situación financiera de la Compañía" correspondiente al ejercicio de 1903, Previsión de gastos ordinarios para el ejercicio 1904 y examen de los medios convenientes para que las relaciones entre los Comités de París y Madrid sean más continúas y activas, y se obtenga la más rápida preparación y resolución de los asuntos que han de serles sometidos (Acta ${ }^{\circ} 696$ del Libro de actas del Consejo de Administración de NORTE: 30 de enero de 1904).

${ }_{1140}$ Acta $^{\circ} 700$ del Libro de actas del Consejo de Administración de NORTE: 13 de mayo de 1904.

${ }^{1141}$ Acta n $^{\circ} 713$ del Libro de actas del Consejo de Administración de NORTE: 15 de mayo de 1905.

${ }^{1142}$ Acta $^{\circ} 713$ del Libro de actas del Consejo de Administración de NORTE: 15 de mayo de 1905.

${ }^{1143}$ Acta $^{\circ} 713$ del Libro de actas del Consejo de Administración de NORTE: 15 de mayo de 1905.

${ }^{1144}$ Sesión del Comité de Madrid de 7 de julio de 1905. Acta $\mathrm{n}^{\circ} 717$ del Libro de actas del Consejo de Administración de NORTE: 21 de septiembre de 1905.

${ }^{1145}$ Acta ${ }^{\circ} 718$ del Libro de actas del Consejo de Administración de NORTE: 28 de octubre de 1905.
} 
Los trámites para la elaboración de los presupuestos eran complejos y tenían que pasar por diversas estancias (el Comité los elabora y el Consejo los aprueba), cada una con unos plazos y procedimientos distintos. Por esta razón, la fecha de elaboración de los presupuestos se demoró en el tiempo, siendo los plazos de finalización en el periodo 1901-1905 de abril, marzo, abril mayo y mayo respectivamente. Esto suponía que los administradores tenían los presupuestos totalmente desfasados durante tres, cuatro o incluso cinco meses. Esto fue subsanado en los presupuestos de 1906. El Comité propuso que la presentación de los presupuestos del año 1906 se realizase antes del 1 de noviembre de 1905, "a fin de que puedan estudiarse oportunamente por los Comités, ser examinados por el Consejo antes del 20 de diciembre de 1905 y empezar a regir el 1 de enero de 1906" ${ }^{1146}$. Posteriormente, el presidente indicó a los Administradores y al Director la conveniencia de que los presupuestos del año 1906 estén antes que en los años anteriores "para que sean examinados en tiempo oportuno por los Comités de Madrid, París y Barcelona y sometidos en tiempo hábil para ser aprobados antes del 1 de enero a la deliberación del Consejo" ${ }^{1147}$. Más adelante el presidente intenta mejorar el procedimiento de elaboración de los presupuestos. Por un lado, reitera la necesidad de que los Presupuestos de 1906 estén concluídos antes de que hubieran de comenzar a regir. Por el otro, creía necesario que el Consejo debía acordar, en cumplimiento de los Estatutos y de los Reglamentos de los Comités que se remitan a estos, "copias íntegras de los mismos a efectos de que puedan hacer las observaciones que entiendan oportunas sobre ellas"1148.

A pesar de los esfuerzos del presidente, el Presupuesto del año 1906 vuelve a realizarse con retraso: el 30 de abril de 1906. El Consejo aprueba el proyecto de presupuestos de ingresos y gastos de explotación de todas las líneas de la compañía para el 1906, donde se fijan los ingresos de explotación en 119.850.000 de pesetas y los gastos de explotación en 57.452.558 para un recorrido de trenes de 17.500 .000 kilómetros, dejando un producto líquido de 62.397.442 pesetas. Como las cargas de explotación ascienden a 56.892 .000 pesetas, resulta un excedente de 5.505.442 pesetas, siendo la relación entre los gastos e ingresos de $47,93 \%{ }^{1149}$. La novedad del Presupuesto del año 1906 es que incorpora una división más, al restar al producto líquido, las cargas de la explotación, resultando el excedente ${ }^{1150}$.

En la noche del 26 de diciembre de 1906, la Dirección de NORTE remitió los Presupuestos para el año 1907, no sólo del general de la explotación sino también de las Minas de Barruelo y Surroca ${ }^{1151}$.

\footnotetext{
1146 Sesión del Comité de Madrid de 7 de julio de 1905. Acta $n^{\circ} 717$ del Libro de actas del Consejo de Administración de NORTE: 21 de septiembre de 1905.

1147 Acta $n^{\circ} 718$ del Libro de actas del Consejo de Administración de NORTE: 28 de octubre de 1905.

${ }^{1148}$ Acta $\mathrm{n}^{\mathbf{0}} 719$ del Libro de actas del Consejo de Administración de NORTE: 27 de noviembre de 1905.

1149 Acta $n^{\mathbf{0}} 724$ del Libro de actas del Consejo de Administración de NORTE: 30 de abril de 1906.

${ }^{1150}$ Acta $n^{\mathbf{0}} 724$ del Libro de actas del Consejo de Administración de NORTE: 30 de abril de 1906.

${ }^{1151}$ Acta $\mathrm{n}^{\mathrm{o}} 732$ del Libro de actas del Consejo de Administración de NORTE: 27 de diciembre de 1906.
} 
El presupuesto del año 1907 se realiza en un momento más adecuado: el 28 de enero de 1907. El Consejo aprueba los ingresos de explotación en 121.000.000 de pesetas, los productos varios en 200.000 pesetas, lo que da un total de 121.200.000. Los gastos de explotación son fijados en 56.481.220, dejando un producto líquido de 64.718 .780 pesetas. Como las cargas de explotación ascienden a 54.667.859 pesetas, resulta un excedente de productos de 10.050.921 pesetas ${ }^{152}$. Estos presupuestos no incluyen dos datos que recogían los presupuestos anteriores: el recorrido de trenes y la relación entre los gastos e ingresos. No vuelven a parecer en los años posteriores. Por el contrario, sí que indican los beneficios previstos para las Minas de Barruelo $(120.461,8)$ y para las Minas de Surroca (17.090).

El presupuesto de 1908 era el primero que se consigue realizar en el año anterior al de referencia. En él no se incluyen los datos previstos de las respectivas Minas ${ }^{1153}$. El Consejo aprueba el presupuesto de ingresos y gastos de la explotación para el año 1908, del conjunto de líneas, estimando los Ingresos de explotación en 125.800.000 más los Productos varios 200.000, que sumaban un Total de ingresos de 125.000.000 pesetas; los gastos de explotación previstos eran 36.484.680 pesetas, lo que daba un Producto líquido de 69.515.320. Como las cargas de explotación eran 56.187.122 pesetas, el Excedente de productos previsto fue de 19.328.198 pesetas $^{1154}$. En la misma fecha, el 31 de diciembre de 1907, el Consejo aprueba un aumento de sueldos para el año 1908 de 319.402, de los cuales corresponden 268.718 para ascensos y 50.684 a regularizaciones ${ }^{1155}$. Con estas dos decisiones se alcanza un hecho fundamental porque por primera vez NORTE consigue presentar el presupuesto antes de que termine el año, aunque sea el último día, la previsión de los ingresos y gastos de la explotación y el aumento de sueldos que se producirá en el año siguiente. Estas dos medidas son un claro avance en la planificación.

El Consejo aprueba, el 25 de marzo de 1909, el presupuesto de ingresos y gastos de explotación para el año 1909. Los ingresos de explotación son 131.000.000 y productos varios son 300.000 , lo que da un ingreso total de 131.300.000 pesetas. Los gastos de explotación ascienden a 58.288.280, lo que da un producto líquido de 72.911.720. Las cargas de explotación son 56.352.991, por lo que el excedente de productos son 16.558.729 $9^{1156}$. Este presupuesto se vuelve a aprobar muy entrado el año, a finales de marzo. Eso sí, vuelve a incluir los presupuestos de las Minas de Barruelo y Surroca ${ }^{157}$.

El presupuesto para 1910 es aprobado por el Consejo el 31 de diciembre de $1909^{1158}$. Pero estas cantidades pasan a ser de consumo interno, sin que se ofrezcan los datos al exterior, ni en el Informe Anual, ni en las Actas del Consejo de Administración, ni en cualquier otro Comité o Consejo. La no divulgación del presupuesto al exterior será una medida tomada por

\footnotetext{
${ }^{1152}$ Acta $\mathrm{n}^{\mathrm{o}} 733$ del Libro de actas del Consejo de Administración de NORTE: 28 de enero de 1907.

${ }^{1153}$ Acta n $^{\circ} 744$ del Libro de actas del Consejo de Administración de NORTE: 31 de diciembre de 1907.

${ }^{1154}$ Acta n $^{\circ} 744$ del Libro de actas del Consejo de Administración de NORTE: 31 de diciembre de 1907.

${ }^{1155}$ Acta n $^{\circ} 744$ del Libro de actas del Consejo de Administración de NORTE: 31 de diciembre de 1907.

${ }^{1156}$ Acta no 759 del Libro de actas del Consejo de Administración de NORTE: 25 de marzo de 1909.

1157 Acta no 759 del Libro de actas del Consejo de Administración de NORTE: 25 de marzo de 1909.

1158 Acta no 770 del Libro de actas del Consejo de Administración de NORTE: 31 de diciembre de 1909, Apartado V.
} 
NORTE en los años 1910-1919. Es difícil de suponer las razones porque deja de ofrecerse masivamente esta información: es el año en que Barat sale del Consejo de Administración de NORTE, y es en el que comienza el sindicalismo ferroviario a tener fuerza y comenzar sus reclamaciones. Quizás la compañía considera que la información podría ser un arma para los sindicatos en las negociaciones. Visto de otro modo, puede ser considerado como un avance porque es un signo inequívoco de la separación entre contabilidad de gestión y contabilidad financiera.

El presupuesto de ingresos, gastos y cargas de la explotación para el año 1911 es examinado por el Consejo el 22 de diciembre de $1910^{1159}$. Sin embargo, en esa reunión se solicita una extensa información al Director, sobre las causas de las diferencias con las del año anterior y del 1909; además se les solicita que realicen una serie de modificaciones. En la siguiente Sesión, el 28 de enero de 1911, los presupuestos del 1911 quedan aprobados ${ }^{1160}$.

El presupuesto de 1912 es aprobado el 23 de diciembre de 1911. Son aprobados a expensas de las observaciones que su examen pueda sugerir a los Comités de París y Barcelona ${ }^{1161}$. Los presupuestos son acompañados de una nota explicativa del Director.

El presupuesto de 1913 es aprobado el 21 de diciembre de 1912. Son aprobados a expensas de las observaciones que su examen pueda sugerir en los Comités de París y Barcelona ${ }^{1162}$. Los presupuestos también son acompañados de una nota explicativa del Director.

El presupuesto de 1914 es aprobado el 27 de diciembre de 1912. En esa fecha los presupuestos también son acompañados de una nota explicativa del Director. En este presupuesto aparece una anotación que será repetida en los documentos hasta el año 1920, en el que el procedimiento varirará: "Son aprobados a expensas de las observaciones que su examen pueda sugerir en los Comités de París y Barcelona" $" 163$.

El presupuesto de 1915 es aprobado el 31 de diciembre de 1914. En esa fecha, los presupuestos también son acompañados de una nota explicativa del Director; en ella el Director dio explicaciones acerca de las líneas generales de dicho presupuesto, haciendo ver la forzosa indeterminación de las mismas y la imposibilidad de establecer previsión de las

\footnotetext{
1159 Acta $\mathrm{n}^{\mathrm{o}} 782$ del Libro de actas del Consejo de Administración de NORTE: 22 de diciembre de 1910, Apartado III.

${ }^{1160}$ Acta $\mathrm{n}^{\circ} 783$ del Libro de actas del Consejo de Administración de NORTE: 28 de enero de 1911, Apartado IV.

1161 Acta $\mathrm{n}^{\text {o }} 794$ del Libro de actas del Consejo de Administración de NORTE: 23 de diciembre de 1911, Apartado III.1.

${ }^{1162}$ Acta $n^{\circ} 807$ del Libro de actas del Consejo de Administración de NORTE: 21 de diciembre de 1912 , Apartado 8. Ninguno de los dos Comités expresó ningún reparo ni comentario (Acta $\mathrm{n}^{\circ} 808$ del Libro de actas del Consejo de Administración de NORTE: 31 de enero de 1913, Apartado 8).

1163 Acta no 819 del Libro de actas del Consejo de Administración de NORTE: 27 de diciembre de 1913, Apartado 8. Ninguno de los dos Comités expresó ningún reparo ni comentario (Acta $\mathrm{n}^{\circ} 820$ del Libro de actas del Consejo de Administración de NORTE: 27 de enero de 1914, Apartado 9).
} 
cifras, por las condiciones de excepcional incertidumbre de la situación de tráfico y mercados $^{1164}$.

El presupuesto de 1916 es aprobado el 21 de diciembre de 1915. En esa fecha los presupuestos son muy pobres, no se emiten cifras ni comentario alguno; se limita a incluir que son aprobados a expensas de las observaciones que su examen pueda sugerir en los Comités de París y Barcelona, y que van acompañados de una nota explicativa del Director ${ }^{1165}$.

El presupuesto de 1917 es aprobado el 28 de diciembre de 1916. El presupuesto fue acompañado por una memoria explicativa de las principales cifras contenidas, y un cuaderno en el que se detallan las cargas de la explotación por series y vencimientos ${ }^{1166}$.

El presupuesto de 1918 es aprobado el 27 de diciembre de 1917. Lo más significativo fue las tensas deliberaciones en el proceso de elaboración de los presupuestos, con continuos reproches al gobierno por la negativa a elevar las tarifas ${ }^{1167}$.

El 20 de diciembre de 1918 es aprobado el presupuesto de 1919, a expensas de las observaciones que su examen pueda sugerir en los Comités de París y Barcelona ${ }^{168}$. No aparece comentario explicativo del Director ${ }^{1169}$.

El presupuesto de 1920 es aprobado el 29 de diciembre de 1919, a expensas de las observaciones que su examen pueda sugerir en los Comités de París. El de Barcelona ya había dado su aprobación ${ }^{1170}$. El presupuesto de 1920 vuelve a ofrecerse públicamente, e incluso mejorado. Ahora no sólo se ofrecen los datos presupuestados para 1920, sino que también se comparan con los resultados probables de 1919, indicando si la diferencia es positiva o negativa. Esta incorporación supone un avance enorme. Estos presupuestos tomaban expresamente en cuenta las repercusiones de la jornada de ocho horas, aunque sabemos por

${ }^{1164}$ Tras estos comentarios, el Consejo acuerda aprobarlos a expensas de las observaciones que su examen pueda sugerir en los Comités de París y Barcelona. Acta $n^{\circ} 832$ del Libro de actas del Consejo de Administración de NORTE: 31 de diciembre de 1914, Apartado 8. Ninguno de los dos Comités expresó ningún reparo ni comentario (Acta $n^{\circ} 820$ del Libro de actas del Consejo de Administración de NORTE: 29 de enero de 1915, Apartado 9).

1165 Acta ${ }^{\circ} 844$ del Libro de actas del Consejo de Administración de NORTE: 21 de diciembre de 1915, Apartado III.

${ }_{1166}$ Acta $\mathrm{n}^{\circ} 858$ del Libro de actas del Consejo de Administración de NORTE: 28 de diciembre de 1916, Apartado 8 .

${ }^{1167}$ Acta n 871 del Libro de actas del Consejo de Administración de NORTE: 21 de diciembre de 1917, Apartado 8. En este documento también aparece que son aprobados a expensas de las observaciones que su examen pueda sugerir en los Comités de París y Barcelona

${ }^{1168}$ Los presupuestos fueron enviados al Comité de Barcelona el 20 de diciembre de 1918, el cual lo aprueba sin reparos el 24 de enero de 1919 (Acta n 887 del Libro de actas del Consejo de Administración de NORTE: 24 de enero de 1919, Apartado 5).

1169 Acta no 886 del Libro de actas del Consejo de Administración de NORTE: 20 de diciembre de 1918, Apartado 5.

${ }^{1170}$ Acta $\mathrm{n}^{\text {o }} 898$ del Libro de actas del Consejo de Administración de NORTE: 29 de diciembre de 1919, Apartado III.3. 
una consulta del Barón de Satrústegui que se realiza parcialmente, al personal afecto a determinados Servicios, en lo que expresamente obliga la Ley ${ }^{1171}$. En estos presupuestos de 1920 queda claro lo que opina el Consejo de ellos "son una base para que las Divisiones y Servicios puedan ajustar los diferentes conceptos de gastos a cifras conocidas, sin perjuicio de aumentar las de aquellos que resulten insuficientemente dotados"1172. Entrando al detalle de los presupuestos de 1920, es posible destacar que incorpora el producto líquido, por diferencia entre el producto neto y las pensiones de retiro. Los datos del presupuesto de 1920 aparecen en el cuadro 77.

Cuadro 77. Diferencia entre el presupuesto de 1920 y los resultados probables de 1919

\begin{tabular}{|l|l|l|l|}
\hline & $\begin{array}{l}\text { PRESUPUESTO PARA } \\
\text { en pesetas }\end{array}$ & $\begin{array}{l}\text { RESULTADOS } \\
\text { PROBABLES DE 1919 }\end{array}$ & $\begin{array}{l}\text { DIFERENCIA ENTRE } \\
\text { EL PRESUPUESTO } \\
\text { DE 1920 Y LOS } \\
\text { RESULTADOS } \\
\text { PROBABLES DE 1919 }\end{array}$ \\
\hline INGRESOS & 268.245 .200 & 268.229 .930 & +15.270 \\
\hline GASTOS & 194.537 .561 & 198.291 .839 & -3.754 .278 \\
\hline PRODUCTO NETO & 73.707 .639 & 69.938 .091 & +3.769 .548 \\
\hline $\begin{array}{l}\text { PENSIONES DE } \\
\text { RETIRO }\end{array}$ & 2.600 .000 & 2.350 .000 & +250.000 \\
\hline PRODUCTO LÍQUIDO & 71.707 .639 & 67.588 .091 & +3.519 .548 \\
\hline $\begin{array}{l}\text { CARGAS } \\
\text { FINANCIERAS }\end{array}$ & $60.952 .125,02$ & $59.669 .761,07$ & $+1.312 .363,95$ \\
\hline $\begin{array}{l}\text { EXCEDENTE DE } \\
\text { PRODUCTOS }\end{array}$ & $10.125 .518,98$ & $7.918 .329,93$ & $+2.207 .184,05$ \\
\hline
\end{tabular}

\section{Fuente: NORTE ${ }^{1173}$}

El presupuesto de 1921 es aprobado el 21 de enero de $1921^{1174}$, a expensas de las observaciones que su examen pueda sugerir en los Comités de París y Barcelona. El presupuesto fue acompañado por una memoria explicativa de las principales cifras contenidas, y un cuaderno en el que se detallan las cargas de la explotación por series y vencimientos. En este presupuesto NORTE continúa con la adecuada actuación de ofrecer los datos presupuestados para 1921 junto con los resultados probables de 1920, indicando si la diferencia es positiva o negativa. Los presupuestos también incorporan el producto líquido, por diferencia entre el producto neto y las pensiones de retiro. Los datos del presupuesto de 1921 aparecen en el cuadro 78.

\footnotetext{
${ }^{1171}$ Acta n 899 del Libro de actas del Consejo de Administración de NORTE: 29 de enero de 1920, Apartado I.

${ }^{1172}$ Acta ${ }^{\circ} 899$ del Libro de actas del Consejo de Administración de NORTE: 29 de enero de 1920, Apartado I.

${ }^{1173}$ Acta $\mathrm{n}^{\circ} 898$ del Libro de actas del Consejo de Administración de NORTE: 29 de diciembre de 1919, Apartado III.3.

${ }^{1174}$ Acta n ${ }^{\circ} 913$ del Libro de actas del Consejo de Administración de NORTE: 29 de enero de 1921, Apartado III.
} 
Cuadro 78. Diferencia entre el presupuesto de 1921 y los resultados probables de 1920

\begin{tabular}{|l|l|l|l|}
\hline & \multicolumn{1}{|c|}{$\begin{array}{c}\text { PRESUPUESTO PARA } \\
\text { en pesetas }\end{array}$} & $\begin{array}{c}\text { RESULTADOS } \\
\text { PROBABLES DE 1920 }\end{array}$ & $\begin{array}{l}\text { DIFERENCIA ENTRE } \\
\text { EL PRESUPUESTO } \\
\text { DE 1921 Y LOS } \\
\text { RESULTADOS } \\
\text { PROBABLES DE 1920 }\end{array}$ \\
\hline INGRESOS & 280.985 .000 & 278.583 .700 & +2.401 .300 \\
\hline GASTOS & 201.904 .970 & 192.567 .530 & +9.337 .440 \\
\hline PRODUCTO NETO & 79.080 .030 & 86.016 .170 & -6.936 .140 \\
\hline $\begin{array}{l}\text { PENSIONES DE } \\
\text { RETIRO }\end{array}$ & 3.000 .000 & 2.750 .000 & + ael 250.000 \\
\hline PRODUCTO LÍQUIDO & 76.080 .030 & 83.266 .170 & -7.186 .140 \\
\hline $\begin{array}{l}\text { CARGAS } \\
\text { FINANCIERAS }\end{array}$ & $59.941 .674,10$ & $59.682 .125,02$ & $+259.549,06$ \\
\hline $\begin{array}{l}\text { EXCEDENTE DE } \\
\text { PRODUCTOS }\end{array}$ & $16.138 .355,90$ & $27.584 .044,98$ & $-7.445 .689,08$ \\
\hline
\end{tabular}

Fuente: NORTE ${ }^{1175}$

El presupuesto de 1922 es aprobado el 24 de marzo de $1922^{1176}$, a expensas de las observaciones que su examen pueda sugerir en los Comités de París y Barcelona. El presupuesto fue acompañado por una memoria explicativa de las principales cifras contenidas, y un cuaderno en el que se detallan las cargas de la explotación por series y vencimientos. NORTE continúa con la maniobra adecuada de ofrecer los datos presupuestados para 1922, junto con los resultados efectivos (no probables como hasta ese momento) de 1921, indicando si la diferencia es positiva o negativa. Los presupuestos incorporan el producto líquido, pero por primera vez, se calcula por diferencia entre el ingreso y los gastos. A la diferencia entre el producto líquido y las pensiones de retiro, se le denomina "Producto líquido deducidas las pensiones". El margen "Excedentes de productos" se calcula por diferencia entre "Producto líquido deducidas las pensiones" y las cargas financieras. Los datos del presupuesto de 1922 aparecen en el cuadro 79.

\footnotetext{
${ }^{1175}$ Acta $n^{\circ} 913$ del Libro de actas del Consejo de Administración de NORTE: 29 de enero de 1921, Apartado III.

${ }^{1176}$ Acta $n^{\circ} 930$ del Libro de actas del Consejo de Administración de NORTE: 24 de marzo de 1922, Apartado III.6.
} 
Cuadro 79. Diferencia entre el presupuesto de 1922 y los resultados probables de 1921

\begin{tabular}{|l|c|c|c|}
\hline en pesetas & $\begin{array}{c}\text { PRESUPUESTO PARA } \\
\mathbf{1 9 2 2}\end{array}$ & $\begin{array}{c}\text { RESULTADOS } \\
\text { EFECTIVOS DE 1921 }\end{array}$ & $\begin{array}{c}\text { DIFERENCIA ENTRE } \\
\text { EL PRESUPUESTO } \\
\text { DE 1922 Y LOS } \\
\text { RESULTADOS } \\
\text { EFECTIVOS DE 1921 }\end{array}$ \\
\hline INGRESOS & 286.059 .466 & $286.061 .112,69$ & $-1.6486,69$ \\
\hline GASTOS & 196.847 .930 & $202.010 .152,65$ & $-5.162 .222,65$ \\
\hline PRODUCTO LÍQUIDO & 89.211 .536 & $84.050 .960,04$ & $+5.160 .575,96$ \\
\hline $\begin{array}{l}\text { PENSIONES DE } \\
\text { RETIRO }\end{array}$ & 3.000 .000 & $2.485 .509,12$ & $+514.490,88$ \\
\hline $\begin{array}{l}\text { PRODUCTO LÍQUIDO } \\
\text { DEDUCIDAS LAS } \\
\begin{array}{l}\text { PENSIONES DE } \\
\text { RETIRO }\end{array}\end{array}$ & 86.211 .536 & $81.565 .450,92$ & $+4.646 .085,08$ \\
\hline $\begin{array}{l}\text { CARGAS } \\
\text { FINANCIERAS }\end{array}$ & $62.266 .683,71$ & & $+1.399 .500,06$ \\
\hline $\begin{array}{l}\text { EXCEDENTES DE } \\
\text { PRODUCTOS }\end{array}$ & $23.944 .872,29$ & $20.698 .287,27$ & $+3.246 .585,02$ \\
\hline
\end{tabular}

Fuente: NORTE ${ }^{1177}$

El presupuesto de 1923 es aprobado el 16 de febrero de $1923^{1178}$, a expensas de las observaciones que su examen pueda sugerir en los Comités de París y Barcelona. El presupuesto fue acompañado por una memoria explicativa de las principales cifras contenidas, y un cuaderno en el que se detallan las cargas de la explotación por series y vencimientos. NORTE continúa ofreciendo los datos presupuestados para 1923 junto con los resultados efectivos de 1922, indicando si la diferencia es positiva o negativa. Los problemas de comparación entre los presupuestos de los diferentes ejercicios económicos aumentan aún más, pues vuelve a modificar los márgenes de comparación en los documentos presupuestarios. Los presupuestos incorporan el producto neto, pero por primera vez, se calcula por diferencia entre el ingreso y los gastos. El producto líquido se calcula por diferencia entre el producto líquido y las pensiones de retiro. Por último, el margen "Excedentes de productos" se calcula por diferencia entre "Producto líquido" y las cargas financieras. Los principales datos del presupuesto de 1923 aparecen en el cuadro 80.

\footnotetext{
${ }^{1177}$ Acta $\mathrm{n}^{\circ} 930$ del Libro de actas del Consejo de Administración de NORTE: 24 de marzo de 1922, Apartado III.6.

${ }^{1178}$ Acta n ${ }^{\circ} 942$ del Libro de actas del Consejo de Administración de NORTE: 16 de febrero de 1923, Apartado III.4.
} 
Cuadro 80. Diferencia entre el presupuesto de 1923 y los resultados probables de 1922

\begin{tabular}{|l|c|c|c|}
\hline en pesetas & $\begin{array}{c}\text { PRESUPUESTO PARA } \\
\mathbf{1 9 2 3}\end{array}$ & $\begin{array}{c}\text { RESULTADOS } \\
\text { EFECTIVOS DE 1922 }\end{array}$ & $\begin{array}{c}\text { DIFERENCIA ENTRE } \\
\text { EL PRESUPUESTO } \\
\text { DE 1923 Y LOS } \\
\text { RESULTADOS } \\
\text { EFECTIVOS DE 1922 }\end{array}$ \\
\hline INGRESOS & 298.345 .450 & 293.820 .450 & +4.525 .000 \\
\hline GASTOS & 205.552 .700 & 202.163 .250 & +3.369 .450 \\
\hline PRODUCTO NETO & 92.792 .750 & 91.637 .200 & +1.155 .550 \\
\hline $\begin{array}{l}\text { PENSIONES DE } \\
\text { RETIRO }\end{array}$ & 3.250 .000 & 3.000 .000 & +250.000 \\
\hline PRODUCTO LÍQUIDO & 89.542 .750 & 88.637 .200 & +905.550 \\
\hline $\begin{array}{l}\text { CARGAS } \\
\text { FINANCIERAS }\end{array}$ & 67.764 .500 & 67.172 .500 & +592.000 \\
\hline $\begin{array}{l}\text { EXCEDENTES DE } \\
\text { PRODUCTOS }\end{array}$ & 21.778 .250 & 21.464 .700 & +313.550 \\
\hline
\end{tabular}

Fuente: NORTE ${ }^{1179}$

Existió un profundo problema de comparabilidad entre los diferentes ejercicios económicos. Por un lado, porque durante un largo periodo (1910-1919) no fueron públicos. Por el otro porque modificaron constantemente los indicadores en que se ofrecía la información.

En el periodo 1900-1907, los presupuestos se realizan cuando ya habían transcurrido tres meses de ejercicio económico. Para el periodo 1907-1923, NORTE pretende corregir esta actitud aprobándolos en el ejercicio contable anterior, aunque sin conseguirlo en cinco ejercicios (1909, 1911, 1921, 1922 y 1923). Sin embargo, en 1923, la empresa se permitía alardear por tener la buena práctica de confeccionar los presupuestos, y aprobarlos en el Consejo, en el ejercicio contable anterior: "Al final de cada año, NORTE establece un Presupuesto general de gastos para el año siguiente, por todos los conceptos y para todos los servicios" $" 1180$.

\footnotetext{
${ }^{1179}$ Acta $^{\circ} 942$ del Libro de actas del Consejo de Administración de NORTE: 16 de febrero de 1923, Apartado III.4.

${ }_{1180}$ AHF P-113-258-3: "Contestación de la Compañía de los Caminos de Hierro del NORTE de España al Informe redactado por la Primera Comisión investigadora de la situación económica de las empresas de ferrocarriles nombrada por Real Orden de 20 de octubre de 1923": Apartado "II. Reparos del Informe a las diversas partidas que componen las cuentas de explotación”.
} 


\subsection{Valoración crítica del sistema de contabilidad de gestión}

\subsubsection{No aplicación del modelo de costes variables}

NORTE elaboró un sistema de costes desde su constitución. La empresa consideró desde bien pronto que el control de los costes tenía mucha utilidad, e intentó tomar las decisiones en función de este sistema. No obstante, nunca estableció un sistema de costes adecuado para la toma de decisiones, porque se fundamentó exclusivamente en el full costing.

Desde el comienzo de su vida, NORTE utilizó un sistema de costes para tomar sus decisiones. La primera vez de la que tenemos constancia fue en 1862, cuandoNORTE firmó un contrato con la empresa francesa MM Gouin et Cie, para la construcción del tramo de la línea MadridIrún, comprendido entre las estaciones de Olazagoitia y Beasaín. El contrato firmado en ese año estipulaba unas cantidades estimadas de acuerdo a los informes de los ingenieros. Sin embargo, el importe final fue superior a lo pactado, por lo que la empresa francesa demandó el pago de esas diferencias económicas. Para aportar las pruebas necesarias, NORTE (1867) presentó el informe detallado de los costes suplementarios que supuso la construcción de obras no programadas inicialmente -túneles, viaductos y ramales- detallando el importe y el modo en que había calculado los costes.

En el periodo 1881-1900, NORTE -dirigida por Barat- se centró en una estrategia de expansionar la red y mejorar los ingresos, pero su control sobre los costes era escaso (Vidal Olivares: 1999) (Vidal y Ortúñez: 2002). Por el contrario, desde 1900 sí que existió un control sobre los costes, realizando un adecuado cálculo de los costes y de su planificación, con unos presupuestos útiles y detallados. Es posible afirmar que desde ese momento se utiliza el sistema de costes para tomar sus decisiones.

Eso sí, el sistema de información de costes en NORTE era incompleto, y esta limitación impidió tomar las decisiones sobre precio y producto adecuadas. El informe proporcionaba información sobre el coste completo (full costing) de los productos, pero no desarrolló un análisis de costes variables (direct costing). La información ofrecida para el análisis es la de los costes completos sin diferenciar, en ningún momento, la parte variable y la parte fija para cada uno de las componentes. Esta limitación impidió a NORTE tomar las decisiones en función del margen de contribución, esencial para la toma de decisiones.

El núcleo central de la gestión de empresas está en la toma de decisiones. La buena o mala situación de la empresa dependerá, en gran medida, de la calidad de las decisiones tomadas por la sociedad. Los factores claves para la calidad de la toma de decisiones son dos: la calidad de la información y la calidad de los instrumentos de análisis. Dentro de este último podemos afirmar que existen dos herramientas para procesar la información y tomar la decisión adecuada: análisis diferencial y margen de contribución. Ambas están basadas en el método de asignación de costes de los costes variables, método que tiene la necesidad de discriminar los costes variables y los costes fijos para calcular el coste del producto. 
La separación de los costes en función de su formación, como elemento fundamental de gestión, fue ya utilizada desde 1894, por Hockpiuson, y posteriormente Steinmetz, para la industria eléctrica (Jiménez Ontiveros, 1940: 173). En breve, también la industria ferroviaria, comenzó a realizar la distinción de los costes en constantes con la producción y variables con ella, como elemento fundamental para la planificación y el control. Sin embargo, NORTE no realizó tal distinción.

El punto de partida del modelo de costes variables es intentar mejorar el proceso de toma de decisiones. El modelo de costes variables aparece porque el análisis de la rentabilidad basado en el modelo de costes completos presentaba un escaso valor predictivo que podría llevar a planificaciones defectuosas. Frente a esta situación era necesaria una técnica que permitiera reflejar los aspectos de las decisiones de gestión a corto plazo (precios de venta, volúmenes de producción y venta, eliminación de un producto o línea de productos, etc.).

El Modelo de Costes Variables ${ }^{181}$ es un método contable y de información financiera que carga únicamente los costes variables de fabricación al inventario de productos y trata los costes fijos de fabricación como gastos del período en que han tenido lugar los costes fijos.

Este método debe ser comparado con el método tradicional, denominado "Full costing", "Modelo de coste integral" o "Modelo de coste completo". En el Modelo de coste completo el producto absorbe todos los costes de producción, de forma que el coste de fabricar una unidad de producto incluye, por tanto, no sólo los costes variables de producción (materiales directos, mano de obra directa y gastos generales variables de fábrica), sino también los gastos generales fijos de fábrica.

Según el modelo de costes variables, los costes por gastos generales fijos de fábrica se cargan a gastos en el período en el que tienen lugar, sin añadir ninguno de ellos a las existencias. Por el contrario, con el modelo de coste integral, los costes por gastos generales fijos de fábrica se añaden a las existencias.

La principal ventaja del Modelo de costes variables es que refleja mejor el fenómeno económico real y reconoce directamente el margen de contribución. El principal argumento a favor del Modelo de Costes Variables es que proporciona mucho más rápidamente información sobre la variabilidad de costes a corto plazo al incluir la información en la cuenta de explotación.

\footnotetext{
${ }^{1181}$ La denominación tradicional de este sistema, "Modelo de costes directos" o "Direct costing", es confusa y puede llevar a equívoco, pues los costes son directos cuando pueden ser atribuidos clara y convincentemente a unidades específicas de producto o a segmentos específicos de la actividad de la empresa. La denominación más adecuada es "Modelo de Costes Variables", si bien el nombre modelo de costes directos está ampliamente difundido en la práctica contable.
} 
La cuenta de explotación del Modelo de costes completos presenta únicamente un margen bruto, al que afectan los costes fijos y es menos útil, para que la dirección tome decisiones a corto plazo.

La cuenta de explotación con el Modelo de costes variables muestra el margen de contribución. El margen de contribución es el beneficio diferencial de producir una unidad más. Su cálculo se realiza por la diferencia entre los ingresos por ventas y los costes variables para obtenerlos. El margen de contribución no es una variable absoluta ya que para calcularla es imprescindible establecerlo y referirlo a un nivel de producción determinado.

El margen de contribución es un instrumento fundamental para que la dirección tome las decisiones a corto plazo, pues ayuda a centrar la atención de los directivos en las oportunidades de modificar la combinación de los productos que fabrican y venden, de cambiar los precios de venta y de cambiar la cuantía de los gastos en actividades de venta.

La importancia del margen de contribución se deriva de que es un indicador estratégico, ya que refleja el beneficio adicional de vender una unidad más; por lo que permite ayudar en la toma de decisiones de corto plazo de fabricación y distribución de la empresa. La información sobre los márgenes de contribución suele ayudar a la dirección a decidir sobre la conveniencia de fabricar o no un determinado producto o una línea de productos, así como la cantidad de producción; el precio de venta que conviene establecer; cuánto invertir en la gestión comercial, etc. A corto plazo, será rentable producir y vender un producto si el precio de venta previsto es mayor que los costes variables (es decir, si existe margen de contribución positivo), incluso cuando el precio de venta no cubra los costes completos.

Del mismo modo, las ratios de los márgenes de contribución proporcionan una información útil acerca de los productos que la empresa debe promocionar (es decir, los productos con ratios de contribución altos) y aquellos otros que no debe hacerlo (normalmente, los que tienen ratios de contribución bajos). También indican qué productos pueden soportar costes adicionales de promoción de ventas y en qué medida.

Cuando el establecimiento de los precios de venta de los productos depende de fuerzas de mercado externas (es decir, cuando la firma tiene una influencia relativamente baja en los precios), la información sobre el margen de contribución unitario y la ratio muestra en qué medida pueden adaptarse los costes de fabricación del producto para mejorar su rentabilidad. Por ejemplo, si es posible reducir los costes unitarios variables sustituyendo el material o la mano de obra por una calidad y precio inferiores.

La cuenta de explotación del Modelo de costes variables refleja directamente el margen de contribución, que consiste en la diferencia entre los ingresos por ventas y los costes variables de fabricación, venta y administración.

La cuenta de explotación, según el modelo de coste integral no refleja el margen de contribución. En cambio, muestra el margen bruto que resulta de restar todos los componentes 
del coste de los productos vendidos (costes de fabricación variables y fijos) del ingreso por ventas. El margen de contribución y el margen bruto son dos conceptos complementarios porque son indicadores de diferentes aspectos. El margen de contribución positivo o negativo expresa si se debe de fabricar o no el producto a corto plazo, pero no nos dice nada de su viabilidad a largo plazo. En cambio, el beneficio indica si el producto ofrece problemas o no, pero no es una cifra adecuada para tomar la decisión de interrumpir o continuar su fabricación en el corto plazo.

Pues bien, NORTE valoró positivamente la distinción entre costes fijos y variables, pero no utilizó el Modelo de costes variables para tomar decisiones.

\subsubsection{El retraso en el desarrollo de la contabilidad de gestión dificultó la aplicación del modelo multidivisional}

Las empresas ferroviarias estadounidenses establecieron un modelo multidivisional porque no podían ser gestionadas desde un único centro de decisión, por lo que era necesario distribuir responsabilidades entre los directivos de las distintas divisiones. La única forma de asegurar que la marcha de cada división fuese acorde con los objetivos de la empresa, era que se establecieran sistemas de contabilidad de gestión a través de los cuales la empresa matriz transmitiera cada directriz a las divisiones.

Aunque NORTE se hubiera planteado aplicar un sistema multidivisional -cosa que nunca hizo-, su retraso en la aplicación del sistema de contabilidad de gestión hubiera dificultado su implantación en la organización. 


\section{CAPÍTULO SEXTO.- ACUERDOS DE OLIGOPOLIO Y FUSIÓN ENTRE NORTE Y MZA}

\subsection{Principal competidor de NORTE: MZA}

La Compañía de los Ferrocarriles de Madrid a Zaragoza y Alicante (MZA) ${ }^{1182}$ fue, junto a NORTE, una de las dos grandes compañías del sector en España, hasta que se produjo su absorción estatal por RENFE en 1941.

MZA inició su actividad con la construcción de pequeñas líneas, las cuales por fusiones sucesivas fueron constituyendo redes de mayor importancia. Su momento álgido fue en 1931, cuando explotaba casi 3.670 kilómetros de red.

El origen de la red lo constituyó la construcción del ferrocarril de Madrid a Aranjuez, de 49 kilómetros de longitud ${ }^{1183}$. Esta línea fue solicitada en 1844 por Don José de Salamanca -el Marqués de Salamanca- siendo concedida el 6 de abril de 1845, comenzando las obras el 4 de mayo de 1846 e inagurado el 9 de febrero de 1851 (MZA, 1933: 5) ${ }^{1184}$.

En la década de 1840 existieron numerosos e importantes proyectos que pretendían unir las capitales de provincia del país por ferrocarril. Uno de ellos fue propuesto en 1845, bajo la recomendación del Embajador de España en Londres ${ }^{1185}$ y con el apoyo de varios bancos, para la concesión por parte del Estado de una línea que conectase Madrid con Zaragoza, y que desde ahí tendiese sendas conexiones a Pamplona y Barcelona. Pero este proyecto prematuro fue abandonado por varias razones, entre ellas por excesivamente ambicioso. La idea de unir Madrid con Zaragoza no cayó, sin embargo, en el olvido; la línea fue declarada de interés general por el Estado, y su construcción como prioritaria, a partir de 1851.

José de Salamanca, propietario del Ferrocarril de Madrid a Aranjuez, ve una gran oportunidad de negocio, por lo que se pone en contacto con los Rothschild para proponerles una concesión común y la fusión con su compañía, parcialmente en explotación, con la intención de construir la línea hacia el Mediterráneo. Pero no fue el único, pues para la construcción de la línea a

\footnotetext{
${ }^{1182}$ La doctrina ha estudiado diversos aspectos de MZA: los costes laborales (Martínez Vara: 2001), el servicio de vía y obras (Letón y Machuca: 2001), los costes laborales (Martínez Vara: 2004), los salarios y programas de Bienestar Industrial (Martínez Vara: 2006), el sistema contable en sus inicios (Fidalgo y Miranda: 2006), el sistema contable de los Talleres Ferroviarios (Villacorta y Martínez Vara: 2009), la estructura organizativa en el sistema de información contable (Santos; Santos y Fidalgo: 2011b), la representatividad de las cifras contables (Santos; Santos y Fidalgo: 2011a) y la construcción de la infraestructura ferroviaria (Santos; Fidalgo y Santos: 2012).

${ }^{1183}$ La construcción de esta línea fue analizada por Castañeda (1946: 66-71).

${ }^{1184}$ El 9 de marzo de 1855 se otorgó una concesión por 99 años para la línea de Madrid a Aranjuez y Almansa a Don José de Salamanca. Esta línea inicial se fue ampliando: el 3 de octubre de 1852 queda aprobada la concesión del ramal de Almansa a Alicante y el 15 de enero de 1856 la línea de Madrid a Zaragoza (MZA, 1933: 6-10).

${ }^{1185}$ Los pasos previos del Embajador de España Jackson para la concesión por parte del Estado en 1845 fueron analizados por Wais (1974: 728).
} 
Zaragoza existieron cinco proposiciones formales: Crédito Mobiliario Español (Hermanos Péreire), José Campo y Mateu, Grupo del Chemin de Fer du Grand Central, José de Salamanca y Sociedad Española Mercantil e Industrial (Rothschild).

La adjudicación de la línea se realizó el 24 de febrero de 1856 a los Rothschild ${ }^{1186}$. Las razones de esta elección fueron que requerían menos subvenciones al Estado, y que obtuvieron un acuerdo con el Marqués de Salamanca y el Grupo del Chemin de Fer du Grand Central. La nueva compañía iba a estar formada por el Conde de Morny -propietario del Chemin de Fer du Grand Central-, Weisweller y Baüer ${ }^{187}$-representantes de los Rothschild-, y José de Salamanca -que aportó la línea de Alicante-. El primer objetivo de la compañía fue enlazar el ferrocarril a la red del Chemin de Fer du Grand Central francés.

La empresa fue creada oficialmente el 31 de diciembre de $1856^{1188}$, con la denominación Compañía de los Ferrocarriles de los Pirineos a Zaragoza y el Mediterráneo. Diez días más tarde, el 10 de enero de 1857, cambio de nombre pasando a denominarse "Compañía de los Ferrocarriles de Madrid a Zaragoza y a Alicante" (MZA) ${ }^{1189}$.

El capital social se fijó en 456 millones de reales (120 millones de francos), repartidos en 240.000 acciones de 1.900 reales (500 francos) cada una. Estas 240.000 acciones eran participadas en 110.000 por el Conde de Morny, Chateleus, G. Delahuete y Conde Le-Hon, 66.000 acciones por los hermanos Rothschild y 64.000 títulos por la Sociedad Española Mercantil e Industrial.

El Consejo de Administración se reúne por primera vez el 16 de enero de 1857. En este acto, fue elegido presidente Alejandro Mon y Menéndez (que fue presidente del Consejo de Ministros de España en el periodo 1/3/1864 a 13/9/1864). El Comité central de dirección se estableció en la ciudad de París.

La línea de Madrid a Almansa se amplió con la sección hasta Alicante, la cual fue inaugurada en mayo de 1858. Poco después, en diciembre de 1858, la compañía realizó su primera anexión, la Compañía del Ferrocarril de Castillejo a Toledo, cuyo propietario era el Marqués de Salamanca.

MZA disponía en la estación de Atocha en Madrid. El anteproyecto de la línea de Zaragoza, preveía la construcción de otra estación madrileña, cerca de la Puerta de Recoletos (la actual plaza de Cibeles), pero la compañía prefirió no construir una nueva estación madrileña, por lo que los trabajos de la línea de Aragón comenzaron desde Atocha.

\footnotetext{
${ }^{1186}$ La Ley de 1855 ofreció condiciones muy favorables para animar a posibles concesionarios.

${ }^{1187}$ Gustavo Baïer fue posteriormente Presidente del Consejo de Dirección de MZA.

${ }^{1188}$ El 31 de diciembre de 1856 se eleva a definitiva la escritura provisional de MZA fechada el 27 de septiembre de 1856 (Real Decreto del 26 de enero de 1857, autorizando a la constitución definitiva de la Compañía de ferrocarriles de Madrid a Zaragoza y Alicante, Ministerio de Fomento. Colección Legislativa de la Deuda Española / Colección de Decretos).

${ }^{1189}$ Sus estatutos pueden encontrarse en MZA (1857, 1-32).
} 
El 8 de abril de 1859 tuvo lugar la adjudicación de la línea de Alcázar de San Juan. Para acudir a ella, Baüer y José de Salamanca decidieron utilizar los servicios de un rico propietario local para que actuara de testaferro: el marqués de Villamediana. Este consiguió la concesión frente al banquero Guilhou. El 20 de abril, la concesión se transfirió como estaba pactado a MZA.

Por medio de la Ley de 30 de marzo de 1859 se decidió la creación de una nueva línea de Andalucía, de Manzanares a Málaga y Granada; interesado por los dos primeros tramos de esta línea, MZA obtiene la concesión el 20 de octubre de 1860.

El 8 de noviembre de 1859, José de Salamanca obtuvo la concesión de una línea ferrocarril de Albacete a Cartagena; la transferencia de esta línea a MZA fue autorizada por Real Decreto del 30 de abril de 1860 .

En 1861, MZA firmó un acuerdo con la Compañía del Ferrocarril de Zaragoza a Pamplona, para ofrecer un servicio Madrid-París, vía Tudela, Pamplona y Bayona de 54 horas de duración, diseñado para competir con NORTE.

En mayo de 1863 se completó la línea Madrid-Zaragoza. Los primeros años de explotación fueron difíciles, en ellos los primeros directores franceses de la compañía pretendían mejorar el rendimiento y lograr beneficios. En 1865, la compañía comienza a tener serias dificultades financieras, que son empeoradas por la competencia salvaje realizada contra NORTE, dificultades que se agudizaron en 1868. El director de MZA Cipriano Segundo Montesinos y Estrada logró rectificar la situación salvando la compañía: firmó un acuerdo sobre la distribución del tráfico con NORTE en 1870, mejoró la marcha de los trenes, y a partir de 1871 hizo sustituir los viejos carriles de hierro por acero. Estas medidas dieron rápidamente resultados y en 1873, fue posible distribuir un dividendo a los accionistas. MZA dispuso entonces de una red de una longitud de 1.428 kilómetros, preparada para ser ampliada.

La revolución de 1868 y la crisis financiera de la compañía habían llevado a los dirigentes a no pedir nuevas concesiones. En 1875, pasadas las mayores dificultades, MZA entró en una nueva fase de expansión; ésta se realizó mediante rescate y fusión con compañías prexistentes, y permitió agregar a la red de MZA aproximadamente $1.189 \mathrm{~km}$ de líneas ya existentes ${ }^{1190}$. El 5 de octubre de 1875, MZA adquirió la Compañía del Ferrocarril de Córdoba a Sevilla y sus 132 kilómetros de líneas ya en explotación así como la línea de las Minas de la Reunión a Villanueva del Río. En 1877, MZA adquiere la Compañía de los Ferrocarriles de Sevilla a Huelva. Esta adquisición supone 111 kilómetros de líneas aún en construcción, y que no se terminarán hasta 1880. Los dirigentes de MZA, que ya controlaba una serie de puertos mediterráneos, pensaban que un puerto en el Atlántico permitiría aumentar el tráfico de la red abriendo comunicación sobre nuevos países.

La absorción de la Compañía de Caminos de Hierro de Ciudad Real a Badajoz -el 8 de abril de 1880- permite aumentar la red en 510 kilómetros y sobre todo disponer de una salida hacia

${ }^{1190}$ Datos tomados de Wais (1974). 
Portugal. Esta política de fusiones/anexiones es completada con el rescate de la Compañía del Ferrocarril de Mérida a Sevilla en 1880, y de la concesión de la línea de Aranjuez a Cuenca, el 18 de noviembre de 1884 .

En sus primeros treinta años (1856-1886), MZA consiguió el primer gran objetivo: extenderse por el cuadrante sudoccidental (Alicante, Córdoba, Extremadura, Huelva y Sevilla). El 1 de enero de 1898 alcanzó el segundo objetivo: conectar con Francia al absorber la "Compañía de Tarragona a Barcelona y Francia" (TBF), denominada desde entonces "Red Catalana de MZA", que había suspendido pagos y explotaba 723 kilómetros. TBF había sido constituida por sucesivas fusiones de las pequeñas compañías explotadoras de las diversas líneas que llegaron a integrarla. Esta línea partió de la primera línea explotada en España, la de Barcelona a Mataró.

Por tanto, MZA fue constituida como una enorme empresa derivada de las concesiones (cuadro 81) y adquisiciones (cuadro 82) que se fueron incorporando sucesivamente a la línea de Madrid a Aranjuez. Dentro de este proceso fue fundamental la absorción de la "Compañía de Tarragona a Barcelona y Francia” (TBF), que permitió la ansiada conexión con Francia (cuadro 83). 


\section{Cuadro 81. Cronología de la entrada en servicio de los tramos de MZA}

\begin{tabular}{|c|c|c|c|}
\hline Concesión & Fecha & Sección & $\begin{array}{l}\text { Longitud } \\
(\mathrm{km})\end{array}$ \\
\hline Madrid-Aranjuez & 10 de febrero de 1851 & Madrid- Aranjuez & 49 \\
\hline $\begin{array}{llll}\text { Madrid } & \text { á } & \text { Aranjuez } & \text { y } \\
\text { Almansa } & & & \\
\end{array}$ & 12 de septiembre de 1853 & Aranjuez-Tembleque & 49 \\
\hline $\begin{array}{llll}\text { Madrid á } & \text { Aranjuez } & \text { y } \\
\text { Almansa } & & & \end{array}$ & 20 de junio de 1854 & Tembleque-Alcázar & 52,6 \\
\hline $\begin{array}{llll}\text { Madrid } & \text { á } & \text { Aranjuez } & \text { y } \\
\text { Almansa } & & & \\
\end{array}$ & 18 de marzo de 1855 & Alcázar-Albacete & 128 \\
\hline Constitución MZA & 31 de diciembre de 1856 & - & - \\
\hline Madrid-Almansa-Alicante & 17 de noviembre de 1857 & Albacete-Almansa & 79,5 \\
\hline Madrid-Almansa-Alicante & 15 de marzo de 1858 & Almansa-Alicante & 96,5 \\
\hline Madrid-Zaragoza & 3 de mayo de 1859 & Madrid-Guadalajara & 56,8 \\
\hline Madrid-Zaragoza & 5 de octubre de 1860 & Guadalajara-Jadraque & 43,3 \\
\hline Madrid-Zaragoza & 1 de octubre de 1861 & Zaragoza-Casetas & 13,1 \\
\hline Madrid-Zaragoza & 2 de julio de 1862 & Jadraque-Medinaceli & 61,7 \\
\hline Madrid-Zaragoza & 4 de febrero de 1863 & Medinaceli-Alhama & 53,3 \\
\hline Madrid-Zaragoza & 25 de mayo de 1863 & Alhama-Grisén & 96,2 \\
\hline Madrid-Zaragoza & 10 de agosto de 1864 & Grisén-Casetas & 13,1 \\
\hline Madrid-Zaragoza & 1 de octubre de 1864 & $\begin{array}{l}\text { Casetas-Zaragoza (Campo } \\
\text { Sepulcro) }\end{array}$ & 13,0 \\
\hline Alcázar-Ciudad Real & 1 de julio de 1860 & Alcázar-Manzanares & 49,2 \\
\hline Alcázar-Ciudad Real & 1 de octubre de 1860 & Manzanares-Daimiel & 21,4 \\
\hline Alcázar-Ciudad Real & 21 de enero de 1861 & Daimiel-Almagro & 21,3 \\
\hline Alcázar-Ciudad Real & 14 de marzo de 1861 & Almagro-Ciudad Real & 22,2 \\
\hline Albacete-Cartagena & 1 de febrero de 1863 & Murcia-Cartagena & 65,1 \\
\hline Albacete-Cartagena & 18 de enero de 1864 & Chinchilla-Hellín & 49,7 \\
\hline Albacete-Cartagena & 8 de octubre de 1864 & Cieza-Murcia & 49,3 \\
\hline Albacete-Cartagena & 8 de octubre de 1864 & Hellín-Agramón & 19,6 \\
\hline Albacete-Cartagena & 9 de marzo de 1865 & Albacete-Chinchilla & 19,1 \\
\hline Albacete-Cartagena & 27 de marzo de 1865 & Cieza-Calasparra & 24,9 \\
\hline Albacete-Cartagena & 27 de abril de 1865 & Agramón-Calasparra & 17,8 \\
\hline Albacete-Cartagena & 2 de mayo de 1891 & $\begin{array}{l}\text { Cartagena-Muelles del } \\
\text { Levante }\end{array}$ & 0,7 \\
\hline Albacete-Cartagena & 2 de mayo de 1892 & $\begin{array}{ll}\text { Costa } & \text { Levante-Puerto } \\
\text { Cartagena } & \end{array}$ & 0,7 \\
\hline Manzanares - Córdoba & 21 de abril de 1862 & Manzanares-Santa Cruz & 35 \\
\hline Manzanares - Córdoba & 25 de mayo de 1865 & $\begin{array}{l}\text { Santa Cruz-Venta de } \\
\text { Cárdenas }\end{array}$ & 30 \\
\hline Manzanares - Córdoba & 8 de julio de 1866 & $\begin{array}{l}\text { Venta de Cárdenas a } \\
\text { Vilches }\end{array}$ & 38 \\
\hline Manzanares - Córdoba & 15 de septiembre de 1866 & Vilches-Córdoba & 141 \\
\hline
\end{tabular}

Fuente: Elaboración propia a partir de MZA (1933: 5-33) 
Cuadro 82. Líneas anexionadas por MZA

\begin{tabular}{|l|l|}
\hline $\begin{array}{l}\text { Fecha de anexión } \\
\text { (o Fusión TBF) }\end{array}$ & Secciones \\
\hline $\mathbf{2 1}$ diciembre 1858 & Castillejo á Toledo \\
\hline $\mathbf{1 8}$ abril 1859 & Alcázar á Ciudad Real \\
\hline $\mathbf{2 0}$ octubre 1860 & Manzanares á Córdoba \\
\hline $\mathbf{3 0}$ abril 1860 & Albacete (Chinchilla) á Cartagena \\
\hline $\mathbf{5}$ octubre 1865 & Córdoba á Sevilla \\
\hline $\mathbf{5}$ diciembre de 1867 & Puente de Aljucen á Cáceres \\
\hline $\mathbf{2 2}$ enero de 1879 & Vadollano á Linares \\
\hline $\mathbf{1 0}$ diciembre 1879 & Linares a Los Salidos \\
\hline $\mathbf{8}$ abril 1880 & Madrid (Delicias) Ciudad Real \\
\hline $\mathbf{8}$ abril 1880 & Ciudad Real á Badajoz (C.R.B.) \\
\hline $\mathbf{8}$ abril 1880 & Ramal Almorchón á Bélmez (C.R.B) \\
\hline $\mathbf{8}$ abril 1880 & Madrid (Delicias) Ciudad Real \\
\hline $\mathbf{1 5}$ marzo 1880 & Sevilla á Huelva \\
\hline $\mathbf{1 7}$ enero 1881 & Mérida á Sevilla \\
\hline $\mathbf{1 3}$ septiembre $\mathbf{1 8 8 4}$ & Aranjuez á Cuenca \\
\hline $\mathbf{1 5}$ mayo 1891 & Tarragona á Barcelona y Francia (TBF) \\
\hline $\mathbf{1}$ enero 1895 & Valladolid á Ariza \\
\hline $\mathbf{1 5}$ de enero de 1914 & Argamasilla (Cinco Casas) á Tomelloso \\
\hline
\end{tabular}

Fuente: Elaboración propia a partir de MZA (1933: 5-33) 
Cuadro 83. Cronología de la entrada en servicio de los tramos de Red Catalana de MZA

\begin{tabular}{|c|c|c|c|}
\hline Concesión & Fecha & Sección & $\begin{array}{l}\text { Longitud } \\
(\mathrm{km})\end{array}$ \\
\hline Barcelona- Mataró & 28 octubre 1848 & Barcelona- Mataró & 28,459 \\
\hline Mataró-Arenys de Mar & 10 enero 1857 & Mataró-Arenys de Mar & 9,729 \\
\hline $\begin{array}{l}\text { Arenys de Mar-Rambla de Santa } \\
\text { Coloma de Farnés }\end{array}$ & 3 diciembre 1859 & Arenys de Mar-Tordera & 27,971 \\
\hline $\begin{array}{l}\text { Arenys de Mar-Rambla de Santa } \\
\text { Coloma de Farnés }\end{array}$ & 17 marzo 1862 & $\begin{array}{l}\text { Tordera-Rambla de Santa } \\
\text { Coloma de Farnés }\end{array}$ & 9,415 \\
\hline Barcelona-Granollers & 23 julio 1854 & Barcelona-Granollers & 29,527 \\
\hline $\begin{array}{l}\text { Granollers- } \begin{array}{c}\text { Rambla de } \\
\text { Coloma de Farnés }\end{array} \\
\text { Santa } \\
\end{array}$ & 1 septiembre 1860 & $\begin{array}{l}\text { Granollers- Rambla de Santa } \\
\text { Coloma de Farnés }\end{array}$ & 39,781 \\
\hline $\begin{array}{l}\text { Rambla de Santa Coloma de } \\
\text { Farnés-Gerona }\end{array}$ & 3 marzo 1862 & $\begin{array}{l}\text { Rambla de Santa Coloma de } \\
\text { Farnés-Gerona }\end{array}$ & 29,827 \\
\hline Gerona-Figueras & 28 octubre 1877 & Gerona-Figueras & 41,286 \\
\hline Figueras-Frontera francesa & 20 enero 1878 & Figueras-Frontera francesa & 27,185 \\
\hline Martorell-Barcelona & 26 noviembre 1854 & Molins de Rey-Barcelona & 17,663 \\
\hline Martorell-Barcelona & 10 noviembre 1856 & Corominas-Molins de Rey & 10,816 \\
\hline Martorell-Barcelona & 23 junio 1859 & Martorell-Corominas & 1,3 \\
\hline Tarragona-Martorell & 15 abril 1865 & Tarragona-Martorell & 73,708 \\
\hline Enlace por la calle de Aragón & 25 octubre 1882 & Enlace por la calle de Aragón & 3,65 \\
\hline Valls-Villanueva y Barcelona & 29 diciembre 1881 & Villanueva-Barcelona & 42,6 \\
\hline Valls-Villanueva y Barcelona & 16 abril 1882 & Calafell-Villanueva & 13,68 \\
\hline Valls-Villanueva y Barcelona & 31 enero 1883 & Valls-Calafell & 33,99 \\
\hline Valls-Villanueva y Barcelona & 1 junio 1883 & Picamoixóns-Valls & 5,2 \\
\hline Valls-Villanueva y Barcelona & 7 marzo 1885 & $\begin{array}{lll}\text { Estación de enlace- } \\
\text { Picamoixóns }\end{array}$ & 1,13 \\
\hline Valls-Villanueva y Barcelona & 15 junio 1887 & Prat a la Bordeta (enlace) & 4,244 \\
\hline Zaragoza-Valezafán & 15 junio 1874 & Zaragoza-Fuentes & 23,775 \\
\hline Zaragoza-Valezafán & 12 febrero 1877 & Fuentes-Pina & 6,654 \\
\hline Zaragoza-Valezafán & 1 diciembre 1878 & Pina-La Zaida & 21,189 \\
\hline Zaragoza-Valezafán & 10 junio 1879 & La Zaida-Puebla de Hijar & 15,830 \\
\hline Zaragoza-Valezafán & 9 julio 1894 & Ramal de enlace en Zaragoza & 4,205 \\
\hline Valdezafán-Samper & 27 junio 1894 & La Puebla de Hijar-Samper & 9,401 \\
\hline Samper-Roda & 17 julio 1884 & Reus-Roda & 31,255 \\
\hline Samper-Roda & 7 diciembre 1890 & Marsá (Falset) - Reus & 28,2 \\
\hline Samper-Roda & 8 abril 1891 & Mora- Marsá (Falset) & 20,12 \\
\hline Samper-Roda & 24 enero 1892 & Fayón-Mora & 39,137 \\
\hline Samper-Roda & 22 noviembre 1893 & Caspe-Fayón & 39,095 \\
\hline Samper-Roda & 1 julio 1894 & Samper-Caspe & 30,704 \\
\hline
\end{tabular}

Fuente: Elaboración propia a partir de MZA (1933: 45) 


\subsubsection{Estructura organizativa MZA}

Según los primeros Estatutos de MZA, una alta participación en el capital social correspondía a la Sociedad Española Mercantil e Industrial (SEMI), que en gran parte era propiedad de la familia Rothschild. Con ello, el control de la compañía estaba en manos de los Rothschild junto a otros accionistas franceses (Tedde, 1978: 20).

En su origen, el Consejo de Administración estaba constituido por veinte miembros (MZA, 1857: art. 18) quienes debían ser nombrados por los accionistas (MZA, 1857: art. 26).

En el momento de su constitución, MZA estaba dividida en cuatro Secciones: “Administración Central”, "Explotación”, “Tracción y Material” y "Vía y Obras”.

La posición dominante de NORTE y MZA fue conseguida por medio de un continuado proceso de fusión o absorción, de sociedades pequeñas (integración horizontal), un proceso lógico dentro de las grandes empresas que tuvo su momento álgido con la adquisición del Almansa-Valencia-Tarragona (AVT) por parte de NORTE (1889) y del Tarragona-BarcelonaFrancia (TBF) por parte de MZA (1898). Ambos procesos fueron distintos; AVT se integró totalmente en NORTE, mientas que la Red Catalana de MZA conservó la autonomía de los servicios frente a lo que se llamará desde entonces Red Antigua, excepto el de Material y Tracción. Esta autonomía de los servicios es un ejemplo de organización multidivisional ${ }^{1191}$, cosa que nunca tuvo NORTE.

En el contrato de fusión MZA-TBF, se estipuló que habría un periodo previo de cooperación entre las empresas, por el que MZA construiría los 254 kilómetros de la línea de Valladolid a Ariza, para establecer una "cabeza de puente" en Castilla la Vieja, "feudo" tradicional de NORTE. A su vez, TBF finalizaría la línea directa de Caspe. Cuando se cumplieran tres años desde la entrada en funcionamiento del Valladolid-Ariza, la burocracia de TBF se integraría definitivamente en la de MZA. Como fue imposible unificar las costumbres, sistemas de señalización y gálibos de cargamento de las dos empresas, las vías de MZA situadas al este de la ciudad de Zaragoza pasaron a denominarse "Red Catalana", mientras que las situadas al occidente fueron denominadas "Red Antigua". Realmente la empresa resultante no fue diseñada para ser multidivisional para ser más competitiva, sino que lo fue por las reticencias culturales de TBF.

MZA adoptó, en el caso de TBF, el criterio de las compañías estadounidenses de mantener la identidad de la compañía absorbida. La red Antigua y la red Catalana de MZA proponían las tarifas en su ámbito y administraba los fondos, las acciones y las obligaciones. También llevaban contabilidades independientes, excepto en los Servicios de Material y Tracción y de Contabilidad Central (AHF S-001-008).

\footnotetext{
${ }^{1191}$ Esta organización multidivisional fue considerada años después por Maristany (1905: 270) como uno de los puntos fuertes de MZA.
} 


\subsubsection{Sistema Contable de MZA}

La estructura organizativa de MZA condicionó el modelo contable implantado. La incidencia de la estructura organizativa en el modelo contable se evidencia a través de la observación de la clasificación que se realizó de las partidas de gastos en la Cuenta de Explotación, ya que muestra una ordenación de los mismos tanto por naturaleza como por función, siendo esta última coincidente con las divisiones de la estructura organizativa de MZA (Santos et al.; 2011b: 83-98). La doble clasificación que en ella se hace de los gastos -por naturaleza y por función-, permite a MZA disponer de información financiera con una doble perspectiva, siendo éste el punto de partida de su evolución hacia una contabilidad de costes.

Aunque MZA se constituyó el 31 de diciembre de 1856, el primer Informe Anual corresponde al periodo de 10 de julio a 31 de diciembre de 1856, limitándose a la explotación de la línea de Madrid a Albacete aportada a la constitución de MZA. En el primer balance se mostraba que para los 278 kilómetros de explotación se alcanzó un coeficiente de explotación de 92,68\%, y no se repartió ningún dividendo a las acciones (MZA, 1933: 11).

El segundo Informe Anual de la compañía está fechado el 31 de diciembre de 1857, con la sección Albacete a Almansa ya inaugurada. En el balance aparece el mismo capital junto con 17.544 obligaciones de 950 reales cada una. El nominal del empréstito era de 1.900 reales, estando capitalizadas al 6\%, tipo legal que los Estatutos atribuían igualmente a las acciones. El coeficiente de explotación en 1857 fue de 95,5\%.

Durante el siglo XIX, MZA elaboró una información contable completa. Las Cuentas Anuales estaban compuestas por la Cuenta de Establecimiento, la Cuenta de Explotación y la Situación General de las Cuentas.

MZA se obligaba a cerrar su ejercicio a 31 de diciembre y presentar los Estados financieros de la compañía, anualmente, para su aprobación ante la Junta General de Accionistas. Esta obligación estaba expresada en el artículo 47 de los Estatutos (MZA: 1857).

Como respuesta a esta obligación, se redactaban los Informes Anuales. En los primeros ejercicios económicos, en realidad, consistían en la redacción de unas Notas explicativas a las que se anexaban los documentos justificativos y los acuerdos aprobados por los accionistas.

Las Notas presentaban una estructura dividida en apartados. En cada uno de estos se explicaban los datos obtenidos por la compañía, complementando o aclarando la información de los documentos justificativos anexados.

En los Informes Anuales se pueden distinguir tres grandes apartados ${ }^{1192}$ :

- Notas: detalle explicativo que complementa los documentos justificativos.

- Documentos justificativos:

${ }^{1192}$ El sistema contable de MZA en los dos primeros años de existencia fue analizado por Santos et al. (2011a: 745-785). 
- Documentos contables: 1) Cuenta de Establecimiento, 2) Cuenta de Explotación y 3) Situación General de las Cuentas, y

- Detalles estadísticos del tráfico.

- Acuerdos aprobados por los accionistas (este documento era incorporado tras la celebración de la Junta General de Accionistas).

El contenido de cada apartado es el siguiente:

i. En la "Situación financiera" se informaba del origen de los fondos que se destinaron a la financiación de la construcción de las líneas, en concreto la empresa recogía información sobre la composición y variación del capital social, capital social efectivo (desembolsado), dividendos pasivos exigidos y no exigidos, y emisión de obligaciones.

ii. En la "Cuenta de Establecimiento y Situación General de las Cuentas" se detallaban los aspectos más relevantes de estos documentos acerca de los recursos y empleos asociados a la construcción de la vía (Cuenta de Establecimiento) y acerca de los saldos deudores y acreedores de la compañía (Situación General de las Cuentas).

iii. En la "Cuenta de Explotación" se informaba de los resultados de la actividad de explotación del ferrocarril, de los pronósticos sobre resultados esperados por la apertura de nuevas secciones y de los hechos relevantes que pudieran haber afectado a los resultados obtenidos (por ejemplo, precios del combustible, consumos de materias primas o gastos de tracción por término medio).

iv. En la "Situación de los trabajos o estado de las obras" se informaba sobre la evolución y situación de las obras construidas hasta el momento y las necesidades de realizar obras de mejora sobre esta infraestructura. También se detallan las necesidades de recursos móviles y fijos que se requerían para prestar un servicio óptimo.

v. En "Material y útiles" se informaba detalladamente del número y valor de las locomotoras, coches y vagones que se habían adquirido, diferenciando entre los que ya se habían recibido y los que estaban pendientes. Dentro de este apartado se desglosaban los datos por tramos de construcción de cada una de las líneas, detallando para cada uno su estado y evolución.

vi. Dentro de las "Consideraciones Generales" se informaban de los próximos proyectos de conexión en el largo plazo con lugares de importancia estratégica, y de las proposiciones que el Consejo de Administración debía someter a la aprobación de la JGA.

En los primeros años de vida de MZA, la "Cuenta de Establecimiento" mostraba los resultados de la gestión de la actividad de construcción (Santos et al., 2011a: 745-785). Se presentaba dividido en dos bloques: a la derecha, el "Capital"; y, a la izquierda, los "Gastos". $\mathrm{El}$ primero informaba de las diferentes fuentes de financiación de las que se disponía (capital social desembolsado y obligaciones emitidas, entre otros), y el segundo detallaba los gastos asociados a esta actividad, imputándolos a la línea ferroviaria que los hubiese ocasionado. El bloque de los Gastos se estructuraba en tres apartados: "Gastos Generales" (donde se recogían los gastos de administración y los anteriores a la constitución de la compañía), "Construcción" (donde aparece el detalle de los gastos inherentes a la construcción del tendido viario, las estaciones, el material móvil y las obras de arte) y "Ferrocarril de XXX" (que recogía la adquisición a terceros de cada una de las líneas por la compañía). El bloque de 
los Gastos cumplía con las directrices marcadas por el documento interno de la compañía, denominado "Clasificación de los Gastos de Explotación y Construcción” de 1886.

La "Cuenta de Explotación" mostraba los resultados obtenidos por el negocio principal de la compañía: la prestación del servicio de transporte. Se presentaba dividida en dos bloques: a la derecha, los "Gastos"; y, a la izquierda, los "Productos". El primero de los bloques informaba de los Gastos incurridos en la actividad principal y, el segundo de los bloques, detallaba los Productos generados (tanto dentro del tráfico como fuera de éste). El detalle del bloque de los Gastos cumplía, al igual que la Cuenta de Establecimiento, con las directrices marcadas por el documento interno de la compañía, denominado "Clasificación de los Gastos de Explotación y Construcción" de 1886. El resultado global de la actividad se presentaba por diferencia entre los recursos generados por la explotación comercial del ferrocarril y los gastos necesarios para su desarrollo. La diferencia entre los bloques figuraba como exceso o defecto de productos sobre gastos.

Así llegó la contabilidad de la empresa al final del siglo XIX. MZA cambió el sistema contable a principios del siglo XX. La finalidad y dimensión del cambio de sistema contable aparece recogido en la "Nota para el Consejo" del "Presupuesto de la Red Antigua para 1911", incluido en el Libro de presupuestos $\mathrm{n}^{\circ} 45$ de MZA. Los cambios tienen dos orígenes ${ }^{1193}$ : la continuación de la reforma y reorganización de los Servicios comenzadas en 1909 (supresión del Servicio de la Contabilidad de los Servicios y aplicación del Reglamento provisional de contabilidad en cada uno de los Servicios), y la implantación de lo acordado en la Reunión de París de abril de 1909, que fue adoptado por la empresa a partir del año 1910.

\subsection{Comparación económico-financiera entre MZA y NORTE}

De entre todas las compañías españolas de ferrocarril, sobresalieron NORTE y MZA, las cuales llegaron a tener, entre las dos, cerca del $60 \%$ de todo el tendido de vía ancha. Ambas compañías se constituyeron como sociedades anónimas en un intervalo de dos años de diferencia $^{1194}$. A los tres años de su constitución, NORTE ya había emitido obligaciones que superaban el valor del capital social desembolsado, mientras que MZA realizó su primer empréstito a los cinco años de su fundación.

En la figura 1 se recoge la longitud de las líneas de ambas compañías en kilómetros. En ella puede observarse cómo hubo una fase de impulso inicial de la construcción de la vía, a la que le siguió otra de profunda crisis, no reanudándose la construcción hasta mediada la década de

\footnotetext{
${ }^{1193}$ Véase Archivo Histórico Ferroviario, Libro de Presupuestos de la Red Antigua para 1911, $\mathrm{n}^{\text {o }}$ 45, fols. 1-5: "Nota para la Dirección".

${ }^{1194}$ MZA se constituyó el 31 de diciembre de 1856 (R.D: del 26 de enero de 1857 autorizando a la constitución definitiva de la Compañía de Ferrocarriles de Madrid a Zaragoza y Alicante, Ministerio de Fomento. Vid. Colección Legislativa de la Deuda española / Colección de Decretos). NORTE quedó inscrita el 29 de diciembre de 1858, obteniéndose la constitución definitiva y aprobación de los estatutos el 14 de enero de 1859 (R.D: del 14 de enero de 1859 autorizando a la constitución y aprobación de los estatutos de la Compañía de los Caminos de Hierro del Norte de España, Ministerio de Fomento (Colección Legislativa de la Deuda española / Colección de Decretos).
} 
$1870^{1195}$. A partir de ese momento, NORTE y MZA entraron en una competencia continua, donde a la compra o anexión de una compañía la otra respondía con una adquisición o fusión que no sólo corrigiese esa situación sino que la superase. Así fue hasta el final del siglo XIX, donde se estabilizó el número de kilómetros de cada compañía. Dentro de las nuevas construcciones, la más importante fue la línea Valladolid-Ariza (1895) con la que MZA pretendía capturar parte del tráfico cerealista de Castilla-León. Al finalizar el siglo XIX, y una vez concluida la mayor parte de las fusiones y absorciones, cada una de las dos grandes controlaban un tercio del tendido ferroviario total; en concreto, en el año 1898, NORTE poseía 3.552 kilómetros y MZA 3.650 (una vez integrada TBF). Entre las dos ocupaban tres cuartos del empleo del sector (Ballesteros y Martínez Vara: 2001a).

En 1900, la red ferroviaria española divide el mapa central y meridional de la Península entre las dos grandes compañías. NORTE posee el eje Madrid-Santander, y partiendo de este, en Venta de Baños el eje que llega hasta Barcelona, con ramificaciones hasta Bilbao, Irún, Pamplona, Zaragoza, Tarragona, Granollers y San Juan de las Abadesas. Por su parte, MZA explota el eje Madrid-Port Bou, pasando por Zaragoza, Tarragona, Barcelona y Gerona, además del eje Ariza-Valladolid.

En 1917, NORTE y MZA ocupaban, por la cuantía de sus activos, el primero y segundo lugar dentro del ranking empresarial español (Carreras y Tafunell, 1996).

La existencia de economías de escala generó de forma natural una tendencia a la concentración de empresas y un funcionamiento cercano al régimen de monopolio. En parte, las dos compañías tuvieron la posición preeminente en el mercado que le permitió llegar a formar un oligopolio, porque fueron las que tuvieron acceso más directo al mercado de capitales francés.

Tal posición hegemónica dentro del negocio ferroviario español se mantuvo hasta su nacionalización en 1941, lo que no fue acompañado de resultados contables satisfactorios.

\footnotetext{
1195 Tortella (1994: 109) advierte que este segundo impulso se llevo a cabo bajo el signo de la concentración.
} 
Figura 1. Longitud de líneas de NORTE y MZA en kilómetros

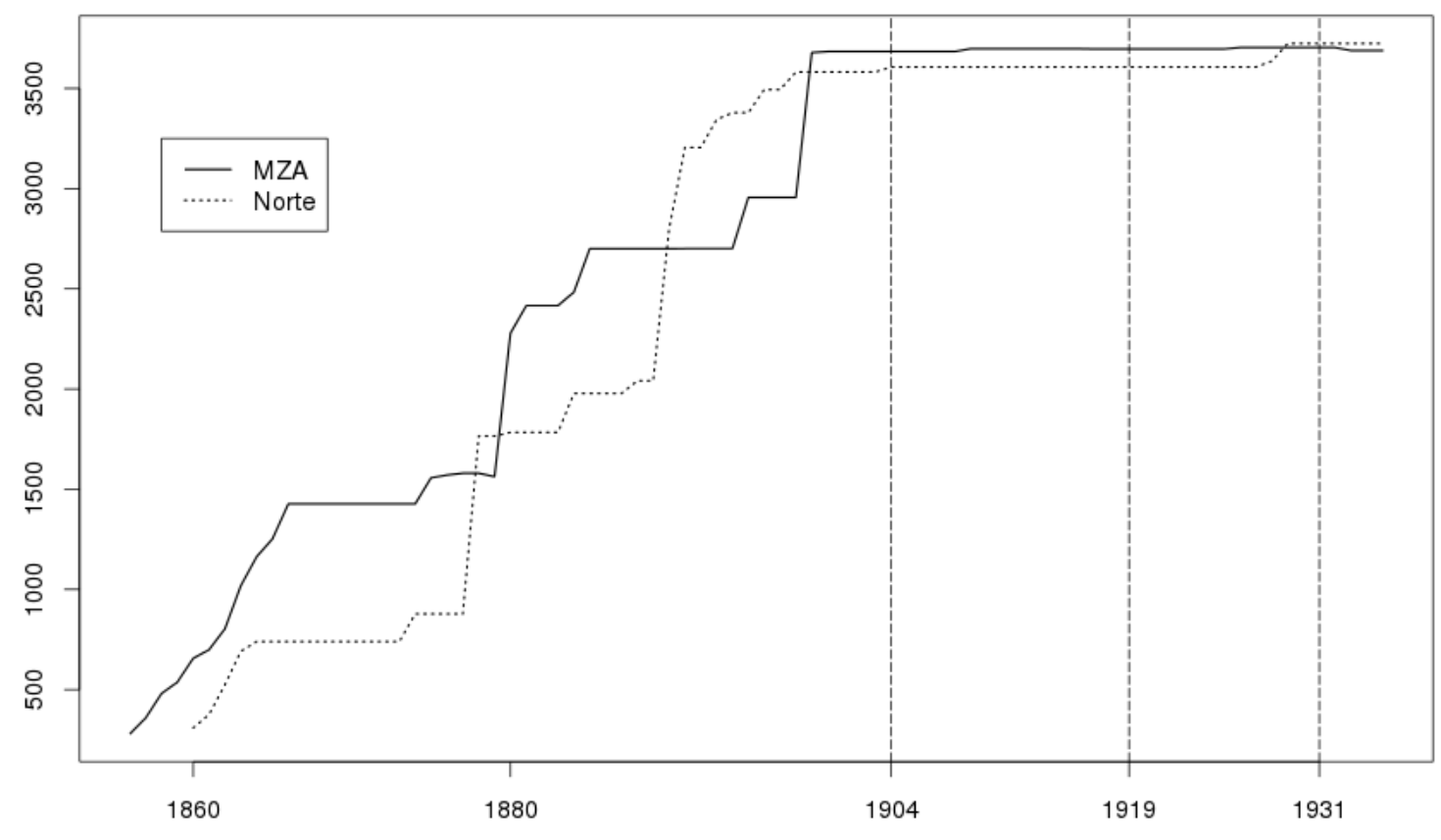

Fuente: Elaboración propia

En las figuras 2 y 3 se muestran el número de viajeros netos y las toneladas netas transportadas en millones de pesetas. En ellas podemos observar cómo, a finales de siglo XIX, NORTE dominaba en ambos apartados, aspecto corregido por MZA a principios de siglo cuando empezaron a alternarse. Hasta 1919, la evolución de ambas era muy similar, no obstante, a partir de ese momento se observa una cierta especialización, MZA transporta más viajeros y NORTE transporta más mercancías.

Dado el tamaño y la localización de su red, era natural que NORTE se especializase en el transporte de mercancías (llegaron a generar 2/3 de los ingresos a partir de 1896) en pequeña velocidad, que incluye el tráfico de carga en general y el transporte de ganado ${ }^{1196}$.

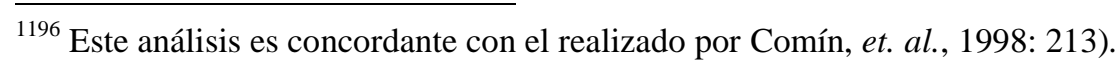


Figura 2. Viajeros netos transportados de NORTE y MZA en millones de pesetas

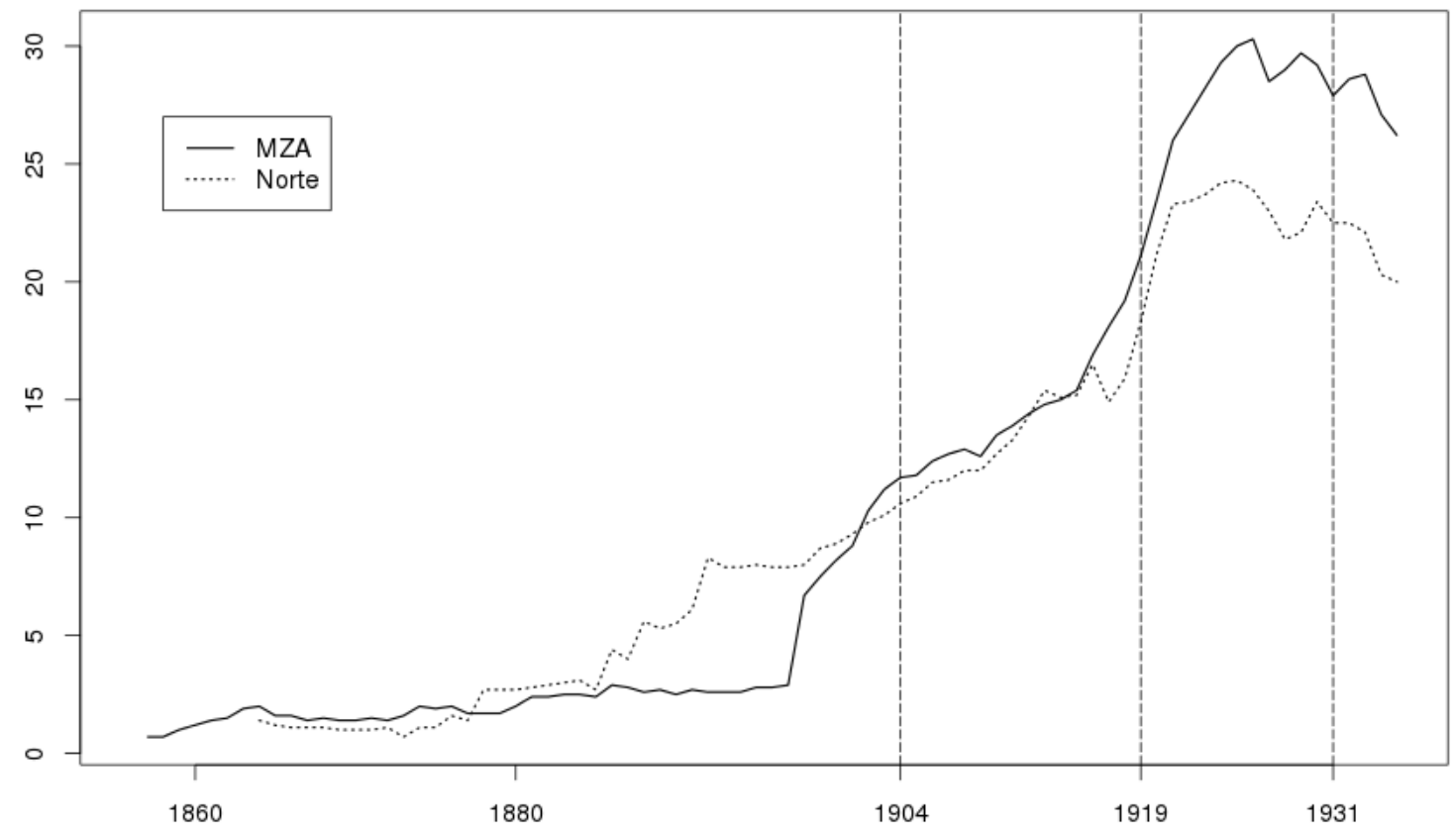

Fuente: Elaboración propia 
Figura 3. Toneladas netas transportadas de NORTE y MZA en millones de pesetas

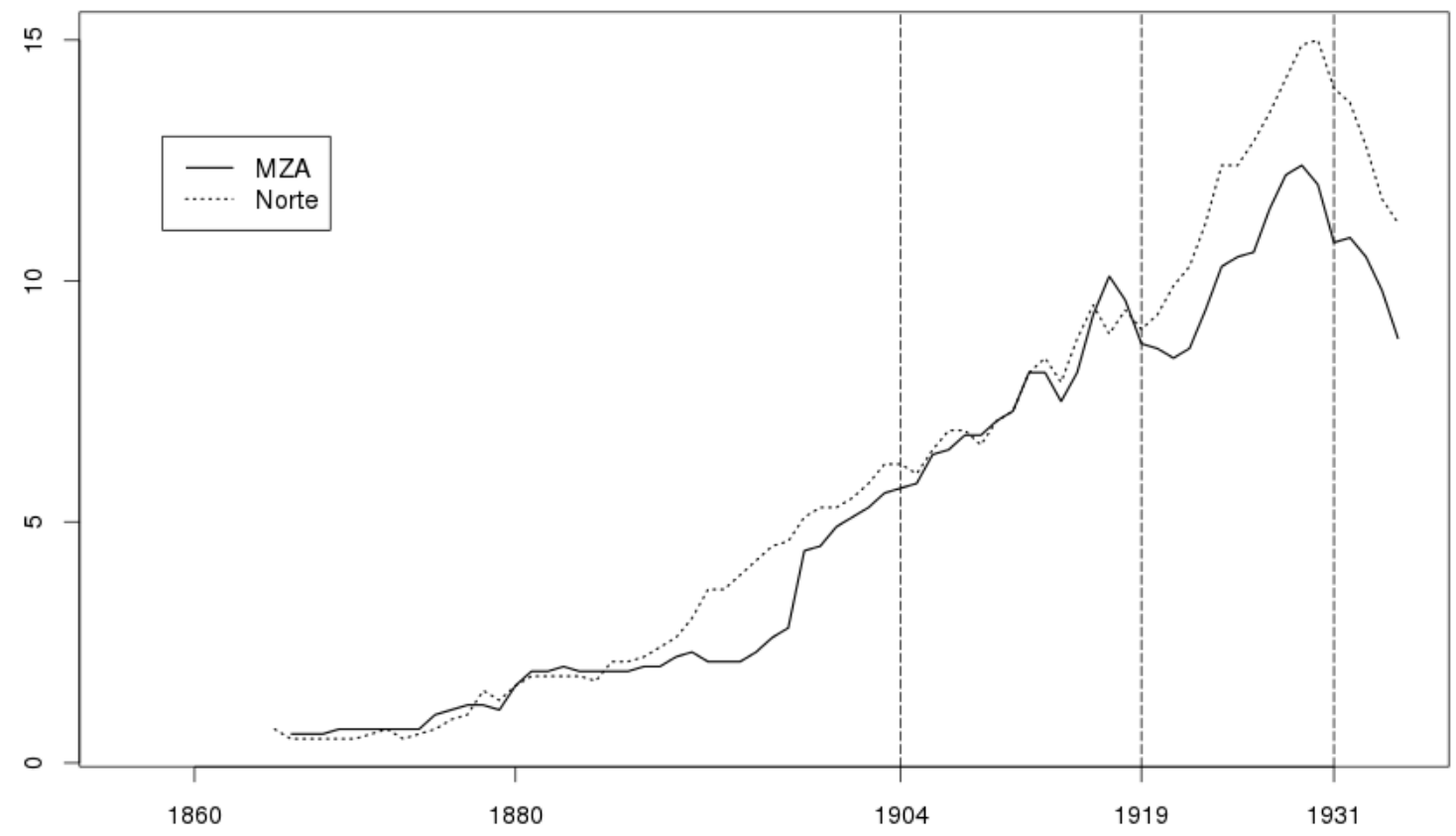

Fuente: Elaboración propia 
Esto es concordante con las figuras 4 y 5 que reflejan las ratios viajeros por kilómetro y toneladas por kilómetro.

Las dos grandes compañías compartían el rasgo común de que los ingresos procedían más del transporte de mercancías que de la movilización de viajeros.

Hasta 1898, en NORTE ambos ratios mostraron una evolución en escalera cuyos peldaños coincidían con la absorción de líneas. Una vez producida la adquisición de las diferentes compañías, aumentaban las ratios, permaneciendo estancado hasta la siguiente absorción, como muestran los periodos 1880-1887, 1888-1890 y 1892-1898. Después del año 1893 no hubo absorciones, y el ratio viajeros por kilómetro tuvo una expansión ininterrumpida que duraría hasta 1930 en la que la compañía explotó sus líneas a pleno rendimiento.

Las ratios de MZA reflejan la expansión del periodo 1870-1881, así como las secuelas de la depresión agraria iniciada en 1882, especialmente sobre los transportes de mercancías. Entre 1898 y 1920 crecieron las ratios de viajeros y mercancías, contribuyendo a los mayores ingresos de MZA.

Durante las dos primeras décadas del siglo XX se transportaron más productos a mayores tarifas, lo que permitió una mayor rentabilidad. Las ratios viajeros por kilómetro de NORTE fueron mejores que los de MZA hasta 1919, momento en que la tendencia se invierte. Por su parte, el rátio de toneladas por kilómetro es favorable para NORTE, excepto en el intervalo 1916-1919. 
Figura 4. Ratio Viajeros por Kilómetros de NORTE y MZA

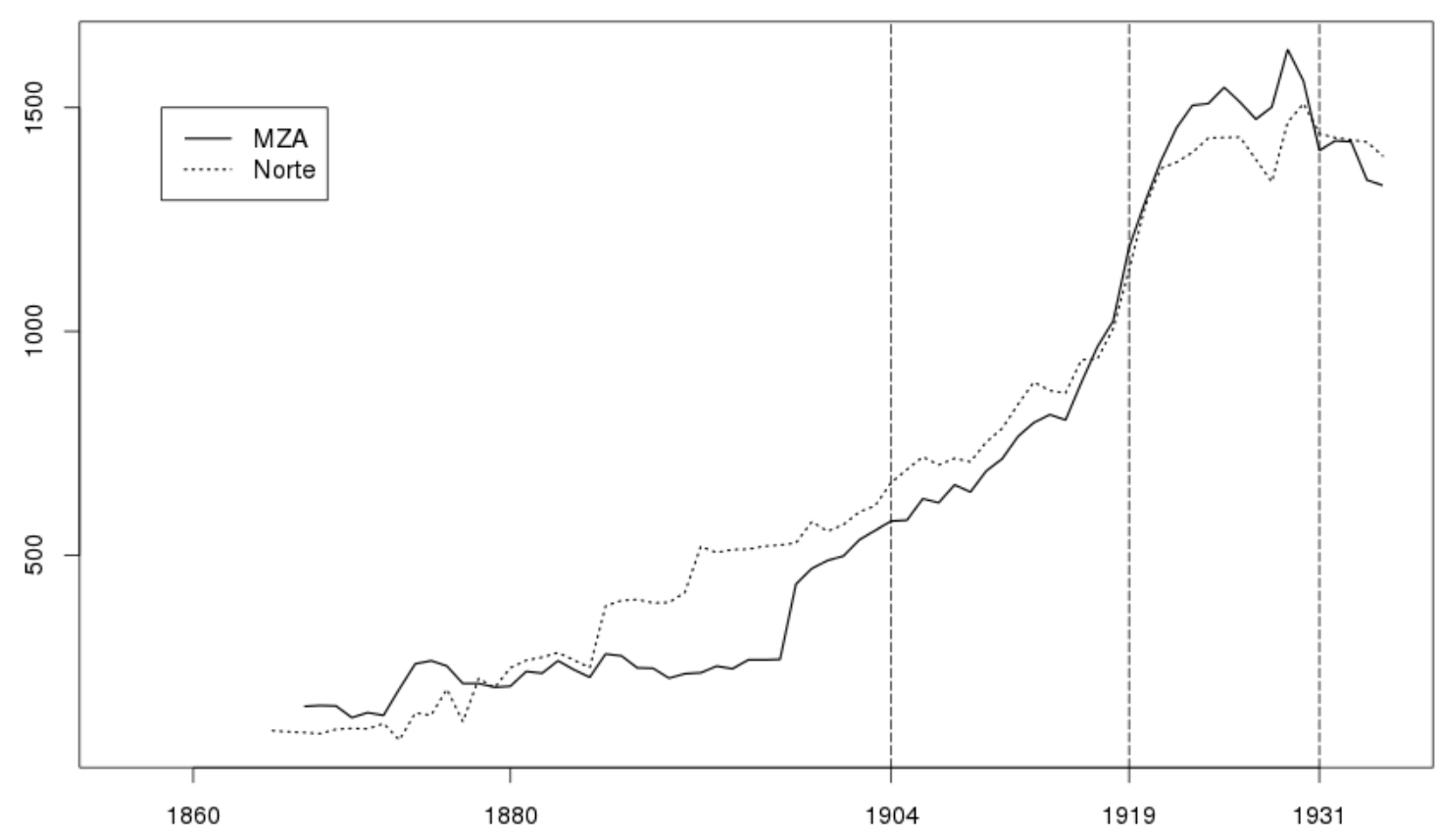

Fuente: Elaboración propia 
Figura 5. Ratio Toneladas por Kilómetros de NORTE y MZA

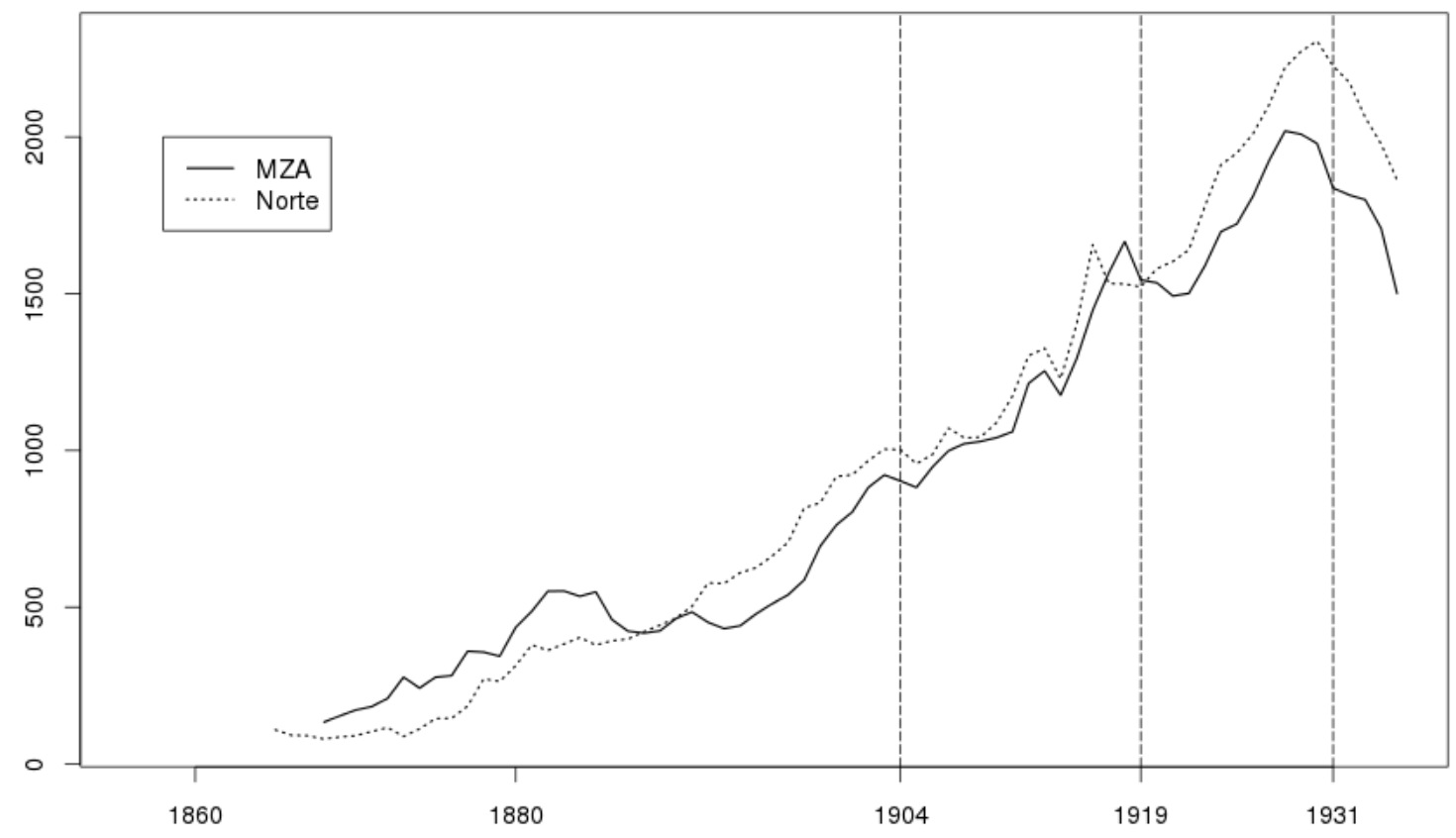

Fuente: Elaboración propia 
En las figuras 6 y 7 se recogen respectivamente los ingresos y gastos de explotación en millones de pesetas. NORTE presentó más gastos e ingresos que MZA, salvo en dos periodos: en el inicio de su actividad y en el periodo 1920-1924, donde los ingresos y gastos fueron idénticos o incluso un poco mayores para MZA.

La estructura de gastos de ambas empresas se caracterizaba por su alto nivel de costes fijos, debido a las enormes inversiones a muy largo plazo que exigía la industria.

La política de tarifas de ambas compañías era la típica de las empresas con fuerte poder de mercado, es decir, trasladaban a los precios todos los incrementos de los costes de producción (Comín, et. al., 1998: 150). Las dos compañías cobraron las tarifas más altas permitidas por los pliegos de condiciones aprobados en las leyes estatales. En sus inicios ambas mantuvieron precios elevados, hasta 1870 MZA y hasta 1878 NORTE.

Los precios medios del transporte de NORTE fueron mucho más elevados que los de MZA. Los directivos de NORTE justificaron sus altos precios con el argumento de que la Guerra Carlista había destruido su material fijo y móvil situado en el País Vasco; según ellos, como el Estado no les compensó por estas pérdidas, la compañía tuvo que resarcirse manteniendo las tarifas altas (Comín, et. al., 1998: 219).

Las altas tarifas tienen su origen en que no existía un mercado competitivo, pues hasta que no ampliaron sus líneas más allá de los troncos originales, ambas tenían monopolios locales. Una vez que el proceso de integración vertical comenzó a generar un duopolio nacional, las dos compañías ya tenían opción a competir. Sin embargo, optaron por no hacerlo y realizar acuerdos para la fijación de las tarifas y el reparto de los tráficos.

Ambas compañías respetaron sus acuerdos tarifarios desde 1870, establecidos en función de sus costes medios. El pacto de 1895 entre NORTE y MZA para repartirse el tráfico y unificar tarifas permitió la recuperación de los ingresos por transporte de mercancías de ambas compañías.

Los ingresos de NORTE estuvieron influenciados por la absorción de líneas, por la coyuntura económica y por la política de tarifas seguida por la compañía. En 1878 se produjo las conexiones con las líneas de Bilbao a Tudela y de Barcelona a Zaragoza y Pamplona, que elevaron considerablemente los tráficos, al añadir el tronco principal Madrid-Irún con el eje que conectaba el País Vasco con Aragón y Cataluña. A partir de 1881, los tráficos se estancaron por la crisis económica iniciada en 1882. Desde 1885 los ingresos de NORTE se recuperaron por la adquisición el año anterior de las líneas del Ferrocarril Reus-Lérida y los Ferrocarriles de Asturias a Galicia y León. A partir de 1896 se volvieron a incrementar los ingresos por la integración de las líneas de San Juan de las Abadesas, de la Huesca-Canfranc, y del entramado ferroviario valenciano. El gráfico de los ingresos refleja las dos crisis agrícolas de los periodos 1881-1885 y 1892-1895. 
Los ingresos por viajeros de MZA permanecieron estancados entre 1876 y 1898 hasta la compra de TBF en 1899, con una leve recuperación en 1891.

La I Guerra Mundial produjo un aumento en los costes de explotación, tantos fijos como variables, lo que supuso una elevación de tarifas, pero de forma paralela entre ambas compañías pues ya se encontraban dentro del marco de colaboración de la Sindicatura de Tráficos de 1906.

Figura 6. Ingresos de explotación de NORTE y MZA en millones de pesetas

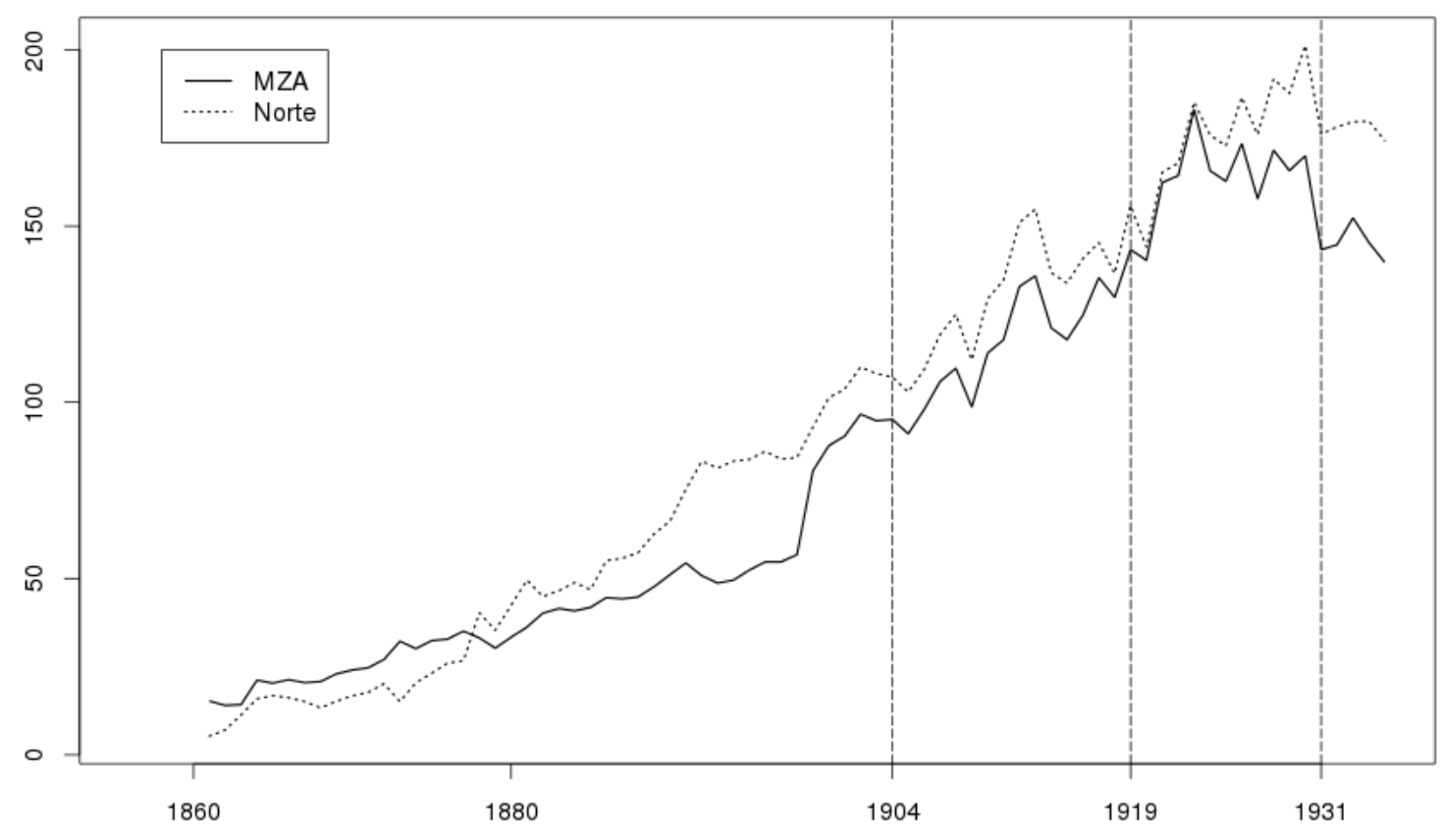

Fuente: Elaboración propia 
Figura 7. Gastos de explotación de NORTE y MZA en millones de pesetas

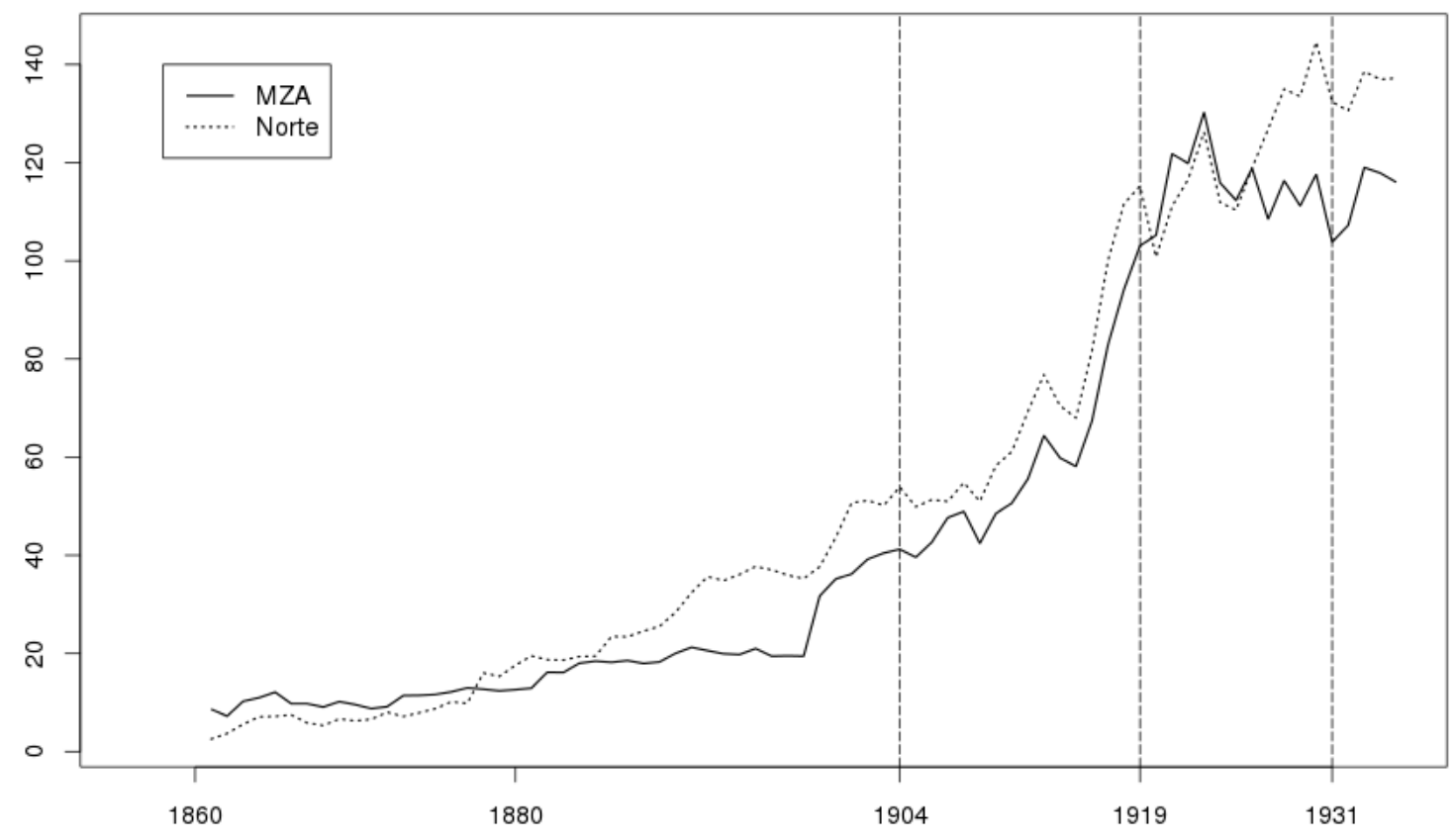

Fuente: Elaboración propia 
Las figuras 8, 9 y 10 reflejan la tendencia de los ingresos de explotación, gastos de explotación y cargas financieras respectivamente. Las tendencias de estas variables están calculadas usando medias móviles, para alisar los valores reales y dejar más clara su evolución.

Los gastos de explotación de ambas compañías presentan una tendencia similar, aunque sus fluctuaciones a corto plazo no coincidan. A una relativa estabilidad entre 1866 y 1898, le siguió un notable crecimiento entre 1898 y 1915, que se acentuó desde este último año.

En el apartado Material y tracción había una importante diferencia entre las dos empresas. NORTE consumía más carbón por kilómetro, porque tenía más rampas y curvas que atravesar. Analizando el coeficiente virtual de las redes (calculado por el cociente entre la longitud virtual y la longitud real de las líneas), se observa que el coeficiente para NORTE era mayor que para MZA. Como NORTE tenía más rampas y curvas en general, consumía más carbón por kilómetro ${ }^{1197}$. Esto fue decisivo en el trazado catalán. La Compañía de los Ferrocarriles de Tarragona a Barcelona y a Francia (TBF) construyó una mejor línea directa de Zaragoza a Barcelona por Caspe que la antigua línea de Zaragoza a Barcelona por Lérida de NORTE; la de MZA tenía una menor distancia (345,507 kilómetros respecto a los 365,706 kilómetros) y lo que es más importante, una longitud virtual más favorable que NORTE (640,18 kilómetros respecto a los 1.045,599 kilómetros).

Los gastos en vía y obras también eran superiores en NORTE, debido al perfil más duro de sus trazados. La mayoría de los grandes pasos montañosos de España (Bárcena, Guadarrama, Orduña, Pajares y Torre del Bierzo) estaban a cargo de NORTE. Estos trazados requerían más dinero para renovar el material de la vía, desgastado por la acción de las continuas frenadas para retener a los trenes en las bajadas y por el costoso mantenimiento del mayor número de túneles y puentes necesitados (Grandes Compagnies Espagnoles de Chemins de Fer: 1903).

El periodo 1900-1923 fue para NORTE y MZA un periodo de crecimiento económico. Entre 1906 y 1912, particularmente, los excedentes aumentan con regularidad, continuando a nivel alto entre 1912 y 1919, salvo las excepciones de 1917 y 1918 (en estos años se produce un encarecimiento de las materias primas y un incremento de la presión de los trabajadores por mejorar su remuneración). En 1919, MZA y NORTE vuelven a tener beneficios por el aumento de las tarifas ferroviarias por parte del sector público, y el incremento de la demanda exterior en los años de la I Guerra Mundial. La recuperación del transporte tiene sus principales figuras en la línea Madrid-Irún en NORTE, y los aumentos de ingresos experimentados por las líneas catalanas de MZA.

Entre 1900 y 1919 se produce un aumento de los costes de explotación. Esto se debió fundamentalmente a la subida de precios de toda la economía española, a partir sobre todo, de la década de 1910, y agudizada después por la I Guerra Mundial. Pero también se explica por el aumento del tráfico que obligaba a renovar el material móvil, dotando a los trenes de

\footnotetext{
${ }^{1197}$ Según recoge García Raja (2006), NORTE tenía más rampas y curvas y tenía un peor coeficiente virtual de las redes.
} 
máquinas más potentes y rápidas, a fortalecer la vía (cambiando los carriles viejos por otros con mayor resistencia ante volúmenes crecientes de carga) y a asumir mayores incrementos en los costes de mano de obra y de materias primas, sobre todo de carbón ${ }^{1198}$.

Respecto a las cargas financieras, la tendencia fue alcista en ambas compañías hasta el intento de fusión de 1919. La tendencia fue mayor en MZA, salvo en el periodo comprendido desde su constitución hasta el acuerdo de 1880.

Figura 8. Tendencia de ingresos de explotación de NORTE y MZA

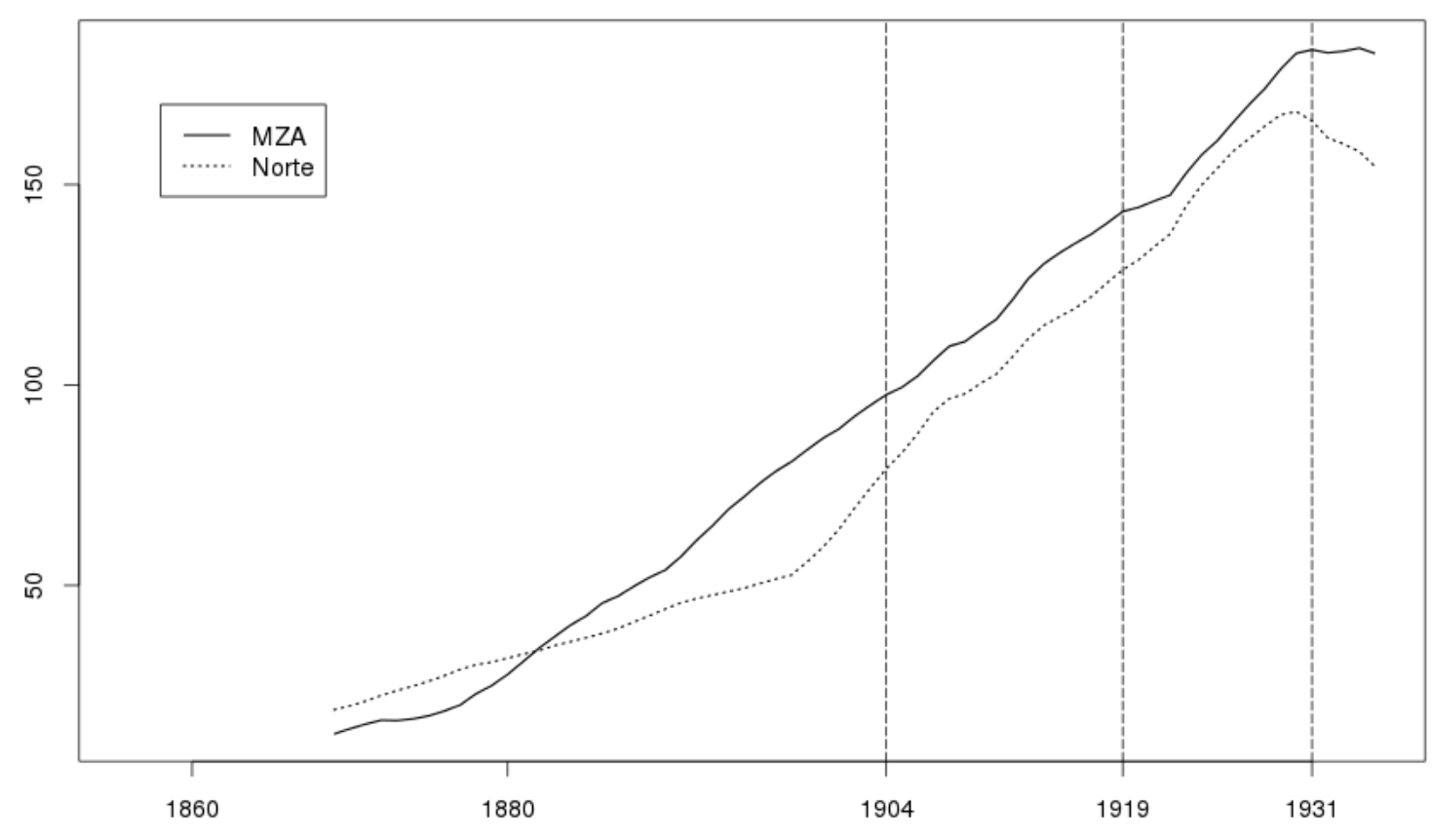

Fuente: Elaboración propia

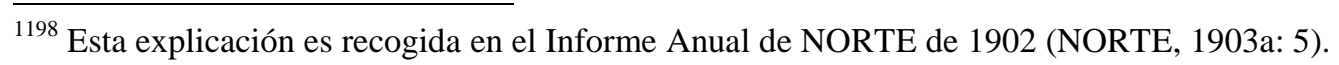


Figura 9. Tendencia de gastos de explotación de NORTE y MZA

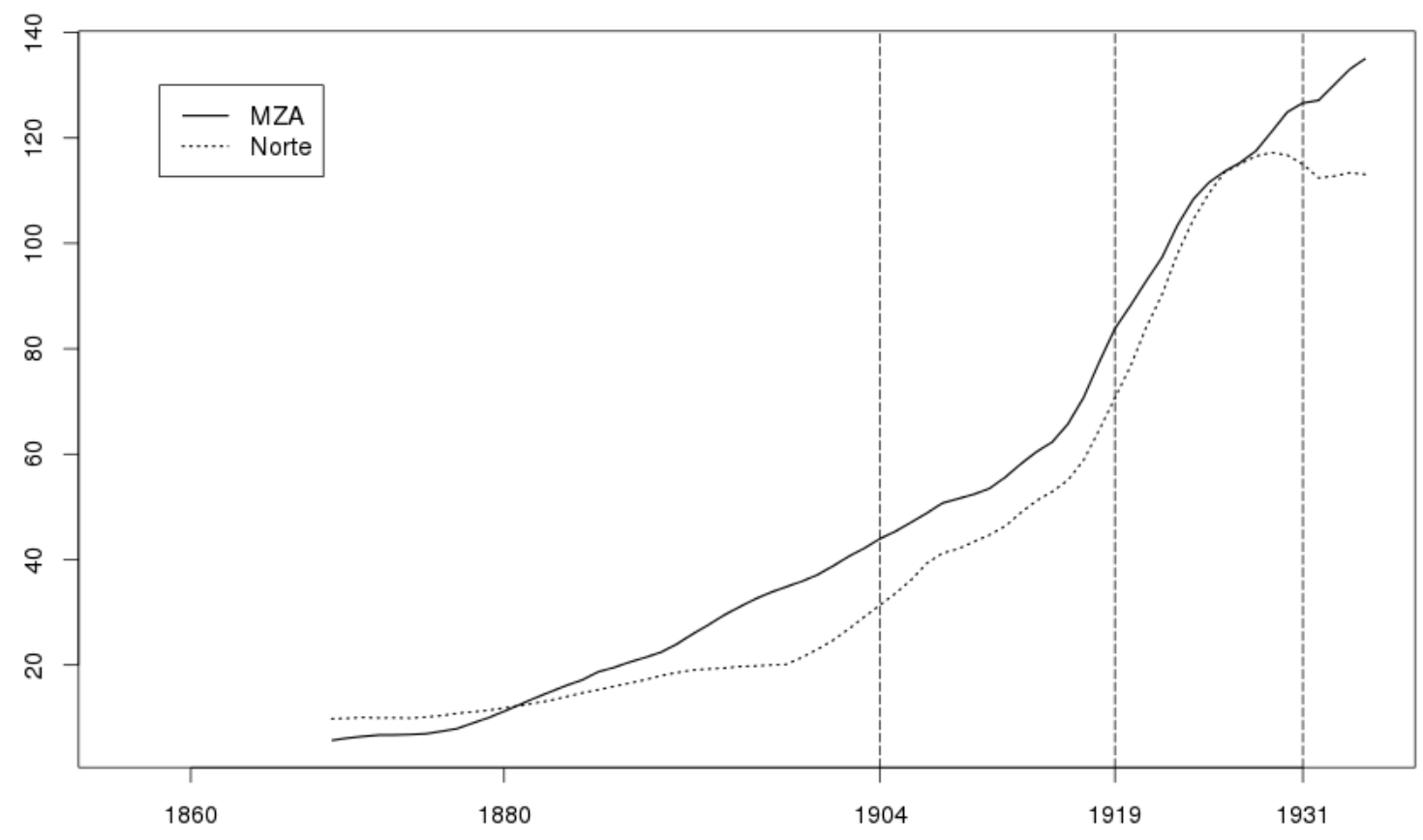

Fuente: Elaboración propia 
Figura 10. Tendencia cargas financieras de NORTE y MZA

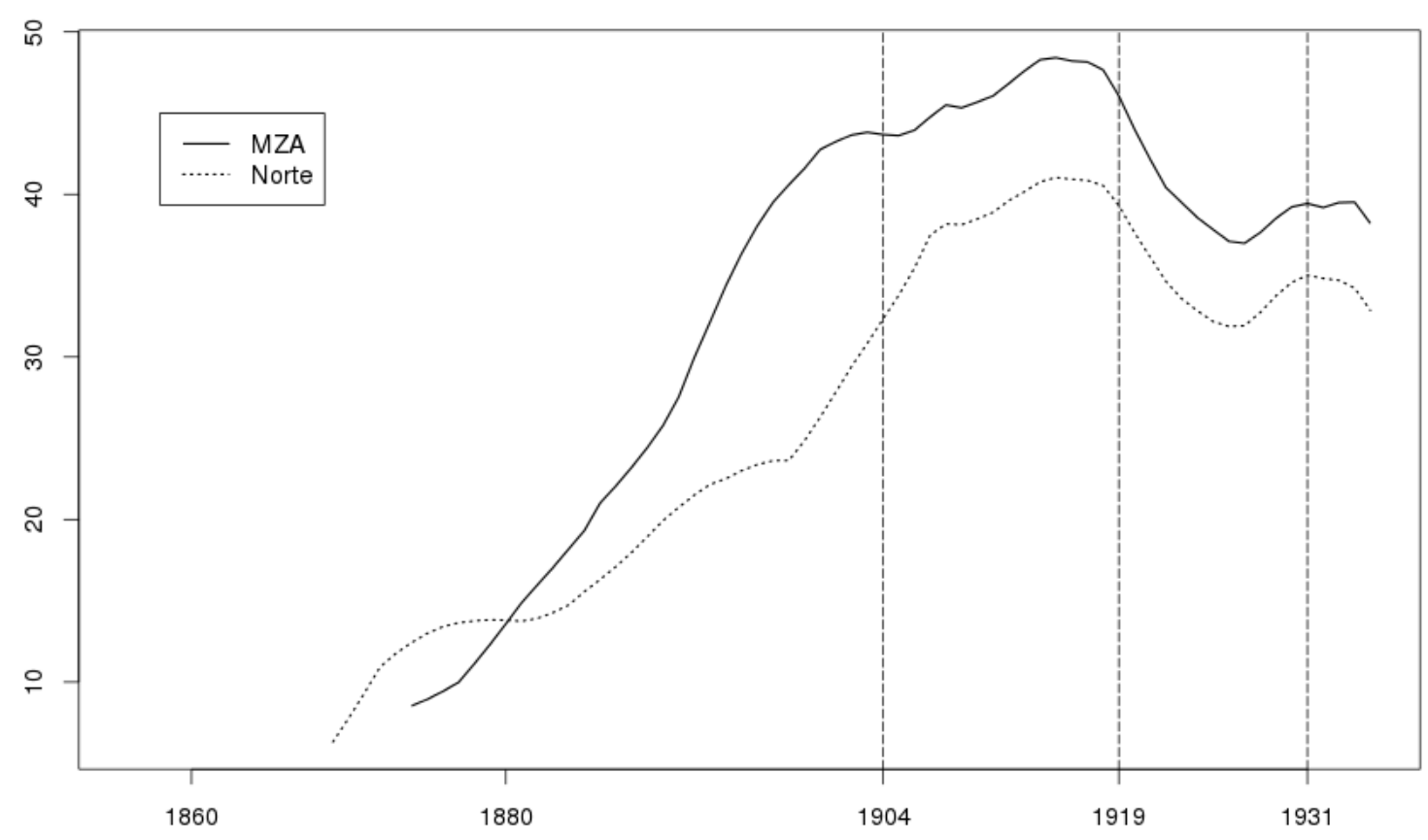

Fuente: Elaboración propia 
En la figura 11 se recoge el resultado contable final en millones de pesetas. Ambas compañías estuvieron intercambiando sus posiciones de preminencia. Las mayores diferencias se produjeron en el periodo 1900-1919, donde el resultado de MZA fue mucho mejor. El periodo en el que se produjeron las mayores diferencias a favor de NORTE fue en la década de 1880.

Hasta 1866, NORTE obtuvo beneficios porque no tuvo que amortizar obligaciones. Sin embargo, entre 1866 y 1871 las cargas financieras y el estancamiento de los ingresos de explotación provocaron pérdidas. Desde principios de 1870, la economía entró en una etapa expansiva (Tedde, 1978: 140) (Carreras, 1990), lo que permitió que, a partir de 1874, NORTE volviese a obtener resultados positivos. La época de beneficios se prolongó hasta 1891. Los ejercicios con mayores beneficios son los comprendidos entre 1882 y 1886 , debido a que los ingresos pasaron de 40 a más de 60 millones de pesetas. La década de 1890 trajo pérdidas contables de nuevo, provocadas por el estancamiento de sus tráficos y el crecimiento de los gastos, sobre todo los financieros. Esa década fue mala para la economía española pues, aunque comenzó la recuperación de la agricultura, la guerra de Cuba tuvo efectos negativos (Comín, et. al., 1998: 205). La demanda de servicios ferroviarios no aumentó tanto como la empresa había previsto, sin embargo, los gastos financieros se duplicaron entre 1883 y 1900 , pasando de 24,4 a 48,2 millones de pesetas, provocados por la amortización e intereses de empréstitos emitidos para financiar la adquisición de líneas (Tedde, 1978: 162-165). A final del siglo XIX, NORTE necesitaba dinero y ni los bancos les concedían préstamos, ni los accionistas querían acudir a una ampliación de capital. La empresa intento acudir al Estado, sin embargo, la Hacienda Pública no le prestó ayuda porque estaba comprometida para hacer frente a la deuda pública y a la guerra de Cuba. La opción que tomó la compañía fue pactar una reestructuración financiera con los accionistas y obligacionistas en 1895: los primeros renunciaron a percibir dividendos durante tres años y los segundos aceptaron cobrar los intereses en pesetas, en vez de en francos, durante ese mismo periodo. Además, para obtener liquidez, se emitieron obligaciones del ferrocarril de Villaba a Segovia.

En las décadas de 1890 y 1900 los resultados consolidados de NORTE fueron positivos, o no tan negativos, gracias a que las líneas secundarias Almansa-Barcelona, Tudela-Bilbao y Asturias-Galicia-León tuvieron altas rentabilidades. Por el contrario, su línea principal Madrid-Irún experimentó pérdidas porque soportaba unos costes financieros proporcionalmente mayores al resto de líneas. En las décadas de 1910 y 1920 mejoró la posición de la línea principal al haber amortizado parte de su deuda (Tedde, 1978: 175).

NORTE tuvo que esperar hasta 1907 para que los resultados totales fuesen positivos, pues tuvo pérdidas doce ejercicios consecutivos, entre 1895 y 1907. Por el contrario, MZA tuvo resultados positivos desde 1900, porque su fusión con TBF permitió aumentar los tráficos y contener los gastos de explotación y financieros. Los ingresos de NORTE crecieron hasta 1916, pero muy lentamente.

Por su parte, MZA tuvo beneficios hasta 1860, luego se estancó durante tres años, para caer posteriormente hasta 1866. A continuación se produjo una recuperación hasta 1875. A partir 
de 1875, MZA entró en la fase de expansión de sus redes, mediante la construcción de líneas nuevas, y la adquisición de compañías ya operativas. Este aumento de la red duplicó los ingresos, que pasaron de 32 millones de pesetas en 1874 a más de 60 en 1898. Con la adquisición de TBF por parte de MZA en 1899, la red se extendió a Cataluña, lo que posibilitó duplicar los ingresos de MZA, al pasar de 100 a rebasar ampliamente los 200 milones de pesetas entre 1900 y 1919. Desde 1916 se produjo un aumento de los gastos de explotación que comenzó a empeorar los resultados. A diferencia de NORTE, que tuvo pérdidas en muchos periodos, MZA sólo tuvo pérdidas contables a partir de 1931.

Hasta 1904, NORTE tuvo una rentabilidad menor respecto a MZA. Por su parte, NORTE experimentó una recuperación evidente en el periodo 1905-1916.

El resultado de explotación de ambas sociedades creció relativamente poco entre 1914 y 1919. El gran aumento del transporte en los años de la I Guerra Mundial no supuso resultados contables positivos en los mismos niveles de crecimiento para MZA y NORTE; incluso registraron beneficios inferiores en términos absolutos a los de los primeros años de la década de 1910. 
Figura 11. Resultado contable final de NORTE y MZA en millones de pesetas

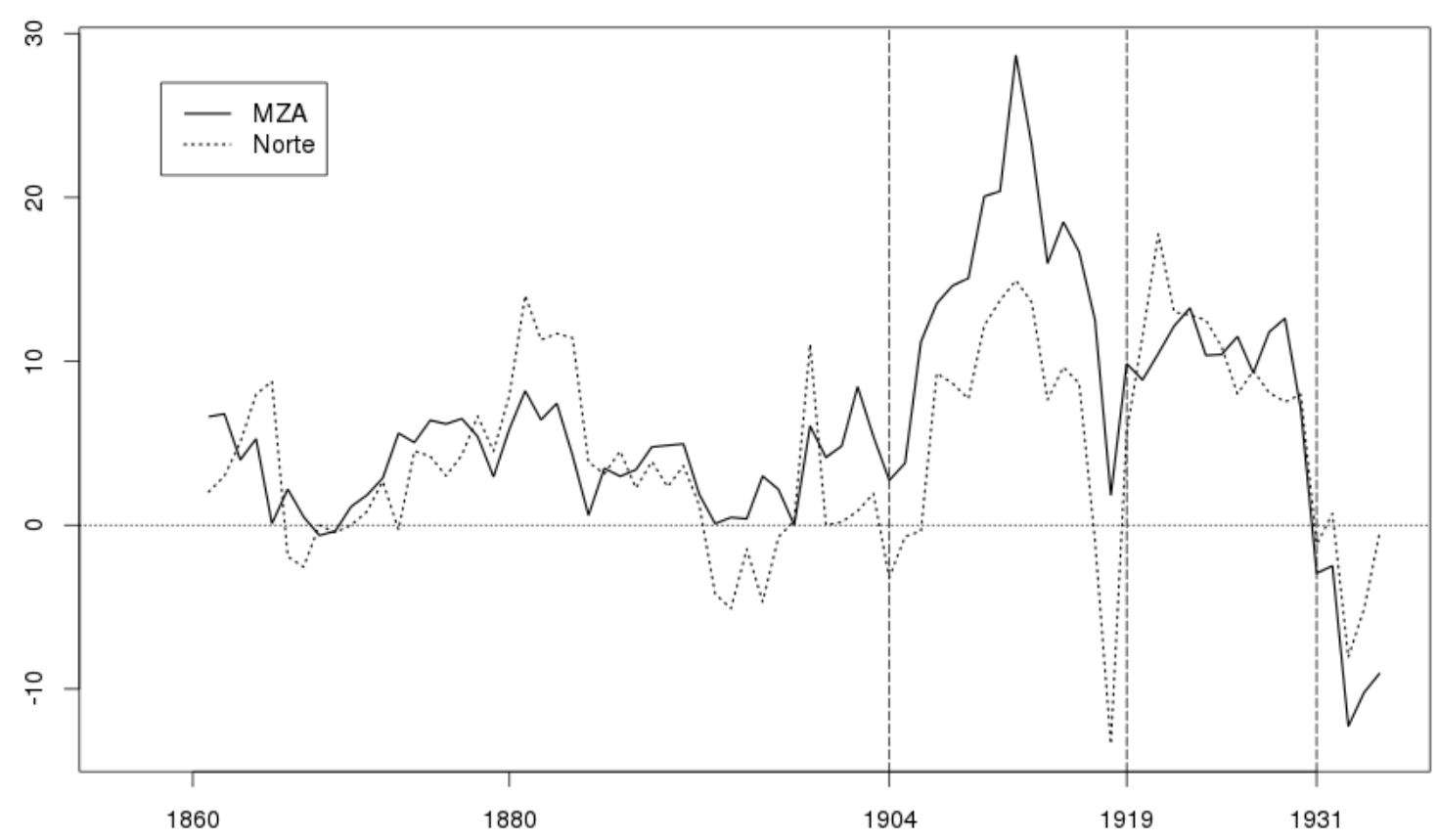

Fuente: Elaboración propia 
En la figura 12 se recogen las cargas financieras en millones de pesetas. En ella puede observarse como las cargas financieras de NORTE empezaron siendo menores, pero en la década de 1870 superaron a las de MZA y así se mantuvieron hasta la desaparición de las compañías. La incorporación de la red catalana no llegó a equiparar los gastos financieros de las dos grandes compañías, que para MZA suponían 10 millones de pesetas menos al año que para NORTE.

Figura 12. Cargas financieras de NORTE y MZA en millones de pesetas

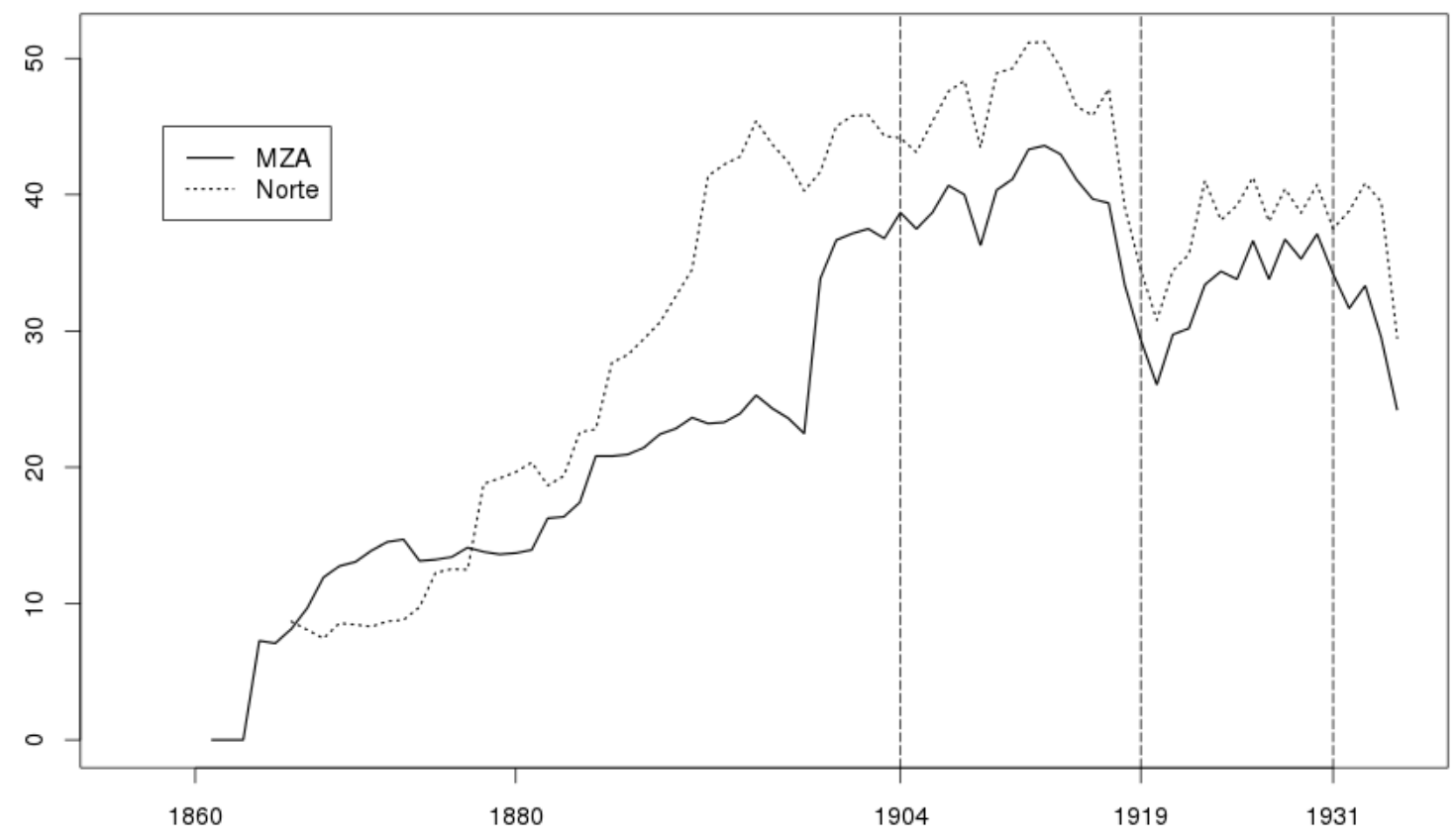

Fuente: Elaboración propia 
En el cuadro 84 aparecen las tendencias lineales en el periodo 1900-1924 para las variables en las que la tendencia no es lineal. Las tendencias están calculadas por mínimos cuadrados ordinarios (OLS) para cada variable y compañía, y las tendencias por mínimos cuadrados generalizados (GLS) de las diferencias entre las compañías junto con su significatividad. No tiene sentido calcular la significatividad con OLS ya que en una serie temporal los residuos están correlacionados y eso falsearía los intervalos de confianza.

Cuadro 84. Tendencias lineales de las variables más representativas de NORTE y MZA en el periodo 1900-1924

\begin{tabular}{|c|c|c|c|c|c|c|c|}
\hline & & \multicolumn{2}{|l|}{ OLS } & & \multicolumn{3}{|l|}{ GLS } \\
\hline & & intercepto & pendiente & & intercepto & & pendiente \\
\hline \multirow[t]{2}{*}{ Viajeros netos } & NORTE & -1177.535 & 0.623 & \multirow{2}{*}{$\begin{array}{l}\text { Diferencia } \\
\text { NORTE-MZA }\end{array}$} & \multirow{2}{*}{$\begin{array}{l}459.867 \\
(290.807)\end{array}$} & \multirow{2}{*}{\multicolumn{2}{|c|}{$\begin{array}{l}-0.2417 \\
(0.1469)\end{array}$}} \\
\hline & MZA & -1488.825 & 0.787 & & & & \\
\hline \multirow{2}{*}{$\begin{array}{l}\text { Toneladas } \\
\text { netas }\end{array}$} & NORTE & -461.346 & 0.245 & \multirow{2}{*}{$\begin{array}{l}\text { Diferencia } \\
\text { NORTE-MZA }\end{array}$} & \multirow{2}{*}{\multicolumn{2}{|c|}{$\begin{array}{l}-134.183 \\
(204.986)\end{array}$}} & \multirow{2}{*}{$\begin{array}{l}0.070 \\
(0.094)\end{array}$} \\
\hline & MZA & -384.436 & 0.205 & & & & \\
\hline \multirow{2}{*}{$\begin{array}{l}\text { Ingresos } \\
\text { explotación }\end{array}$} & NORTE & -5758.191 & 3.081 & \multirow{2}{*}{$\begin{array}{l}\text { Diferencia } \\
\text { NORTE-MZA }\end{array}$} & \multirow{2}{*}{\multicolumn{2}{|c|}{$\begin{array}{l}456.257 \\
(553.513)\end{array}$}} & \multirow{2}{*}{$\begin{array}{l}-0.232 \\
(0.289)\end{array}$} \\
\hline & MZA & -6432.687 & 3.428 & & & & \\
\hline \multirow{2}{*}{$\begin{array}{l}\text { Gastos } \\
\text { explotación }\end{array}$} & NORTE & -6529.245 & 3.454 & \multirow{2}{*}{$\begin{array}{l}\text { Diferencia } \\
\text { NORTE-MZA }\end{array}$} & \multirow{2}{*}{\multicolumn{2}{|c|}{$\begin{array}{l}987.348 \\
(1146.768)\end{array}$}} & \multirow{2}{*}{$\begin{array}{l}-0.513 \\
(0.599)\end{array}$} \\
\hline & MZA & -7492.808 & 3.954 & & & & \\
\hline \multirow{2}{*}{$\begin{array}{l}\text { Viajeros } \\
\text { por km. }\end{array}$} & NORTE & -68107.467 & 36.089 & \multirow{2}{*}{$\begin{array}{l}\text { Diferencia } \\
\text { NORTE-MZA }\end{array}$} & \multirow{2}{*}{$\begin{array}{l}11696.637 \\
(6772.671)\end{array}$} & \multirow{2}{*}{+} & \multirow{2}{*}{$\begin{array}{l}-6.109+ \\
(3.542)\end{array}$} \\
\hline & MZA & -81173.175 & 42.905 & & & & \\
\hline \multirow{2}{*}{$\begin{array}{l}\text { Toneladas por } \\
\mathrm{km} \text {. }\end{array}$} & NORTE & -74551.963 & 39.665 & \multirow{2}{*}{$\begin{array}{l}\text { Diferencia } \\
\text { NORTE-MZA }\end{array}$} & \multirow{2}{*}{\multicolumn{2}{|c|}{$\begin{array}{l}-2521.509 \\
(10509.836)\end{array}$}} & \multirow{2}{*}{$\begin{array}{l}1.370 \\
(5.497)\end{array}$} \\
\hline & MZA & -73795.618 & 39.228 & & & & \\
\hline
\end{tabular}

Fuente: Elaboración propia

Los valores de los coeficientes calculados con OLS permiten identificar cómo se comportan las series en el intervalo 1900-1924. Puede observarse que en general son muy parecidas. Respecto a los valores calculados con GLS debajo de cada valor aparece entre paréntesis el error estándar, que permite observar si hay diferencias significativas entre NORTE y MZA. De ello se infiere que no hay diferencias significativas, salvo para los viajeros por $\mathrm{km}$, en donde las diferencias son marginalmente significativas (con un nivel de significatividad del $10 \%)$. 
En líneas generales se observa que ambas empresas evolucionan de forma similar. La principal diferencia consiste en que NORTE está más endeudada y tiene menos beneficios que MZA. También se observa que, a partir de 1920, MZA transporta más viajeros y NORTE transporta más mercancías.

\subsection{Relación competencial entre MZA y NORTE}

Desde los primeros intentos de ordenación ferroviaria, los gobiernos españoles creían que la mejor alternativa para los intereses nacionales era que las líneas ferroviarias se reuniesen en pocas compañías ${ }^{1199}$. Pero, además, las características de la industria ferroviaria española favorecían la agrupación empresarial, o al menos la alianza entre compañías.

Frecuentemente, las ferroviarias españolas buscaron apoyos entre ellas para aunar esfuerzos, normalmente contra el Estado ${ }^{1200}$. Así lo hicieron las tres empresas ferroviarias más importantes en algunas ocasiones ${ }^{1201}$, y con mucha mayor frecuencia y relevancia las dos grandes.

Las prácticas estratégicas de actuación conjunta entre NORTE y MZA se iniciaron en sus procesos de absorción del periodo 1874-1896 (Vidal Olivares, 1999: 643). Los principales acuerdos fueron tomados sobre las tarifas nacionales, no obstante también las compañías comenzaron a plantear acuerdos en sus relaciones internacionales, a medida que aumentaron los vínculos con los mercados exteriores, especialmente los de Europa occidental y los de Portugal (Vidal Olivares, 1995a).

NORTE y MZA tuvieron un acercamiento y colaboración profunda que estuvo, incluso, cerca de llevarlas a la fusión. Una de las posibilidades de las dos grandes empresas de capital francés para mejorar su situación económica era fortalecer su posición frente al gobierno y frente al mercado por la vía de la fusión. Con ella se pretendían lograr, entre otros objetivos, la reducción de los costes de explotación. Las dos grandes siempre tuvieron presente la fusión, aunque no se llegó a ejecutar nunca. Hubo tres momentos de especiales dificultades económicas de la explotación, en los que la fusión estuvo cerca de producirse, aunque nunca se consumó: en 1904, 1919 y 1931. Además de estos intentos, hubo cuatro fechas en las que no se optó por la fusión, sino que se tomaron otros caminos de acercamiento entre ambas empresas: los acuerdos comerciales para actuar como oligopolio entre MZA y NORTE de

\footnotetext{
${ }^{1199}$ Así incluso lo expresaron el Presidente del Consejo de Ministros de España Ramón María Narváez y su ministro de Fomento Manuel de Orovio (Wais, 1948: 115).

${ }^{1200}$ Muchos son los ejemplos de estas alianzas: NORTE y MZA (1934; 1933; 1932; 1916; 1915; 1902), NORTE, MZA, Andaluces y MCP $(1922 ; 1919)$ y NORTE, MZA, Andaluces, MCP y Oeste (1907: 1-31).

${ }^{1201}$ La primera posición conjunta relevante de las tres grandes -NORTE, MZA y Andaluces- fue la reclamación de la Federación Nacional de los Ferroviarios Españoles derivadas del Primer Congreso ferroviario de junio de 1912. Las características de esta alianza pueden observarse en Carta de Federación Nacional de los Ferroviarios Españoles al Director de la Compañía de Ferrocarriles Andaluces: 20 julio de 1912. Carta del Presidente del Consejo de Administración de la Compañía de Ferrocarriles Andaluces al Consejo de Administración de NORTE: 26 de julio de 1912. Acta no 803 del Libro de actas del Consejo de Administración de NORTE: 28 de septiembre de 1912, Apartado III.9.
} 
1870, 1875, 1896 y, el más importante (Sindicatura), de 1906. Además de ello, en 1923, la Dictadura de Primo de Rivera promocionó el establecimiento de un oligopolio de tres empresas entre MZA, NORTE y Andaluces; ante las dificultades de llevarlo a cabo propuso la fusión entre las tres principales ferroviarias. El cuadro 85 recoge el tipo de vinculación entre NORTE y MZA.

Cuadro 85. Tipo de vinculación entre NORTE y MZA

\begin{tabular}{|l|l|l|}
\hline FECHA & \multicolumn{1}{|c|}{ TIPO DE ACUERDO } & \multicolumn{1}{|c|}{$\begin{array}{c}\text { EMPRESAS } \\
\text { PARTICIPANTES }\end{array}$} \\
\hline 1870 & Acuerdo de oligopolio. Convenio de tarifas & MZA y NORTE \\
\hline 1875 & Acuerdo de oligopolio. Convenio de distancia más corta & MZA y NORTE \\
\hline 1896 & Acuerdo de oligopolio. Convenio de reparto de tráfico & TBF, MZA y NORTE \\
\hline 1904 & Intento de fusión & MZA y NORTE \\
\hline 1906 & Acuerdo de oligopolio. Sindicatura & MZA y NORTE \\
\hline 1919 & Intento de fusión & MZA y NORTE \\
\hline 1923 & Establecimiento de un oligopolio. Posterior propuesta de fusión & MZA, NORTE y Andaluces \\
\hline 1931 & Intento de fusión & MZA y NORTE \\
\hline
\end{tabular}

Fuente: Elaboración propia

En los intentos de fusión de 1904, 1919 y 1931, la iniciativa partió de NORTE y la negativa de MZA, es decir NORTE proponía las fusiones que no culminaron por indecisión de MZA. En la misma línea, los acuerdos de oligopolio de 1870, 1875, 1896 y 1906 fueron propuestos por NORTE y se llevaron a cabo porque MZA sí aceptó. Por su parte, el oligopolio de tres empresas entre MZA, NORTE y Andaluces y la posterior fusión de 1923, no partió de ninguna ferroviaria, sino que fue primeramente propuesta por el Estado, y posteriormente matizada por el propio Estado; en este caso, la negativa a la propuesta de oligopolio partió de NORTE, y la negativa a la fusión vino de las tres empresas, sobre todo porque nunca llegaron las prometidas ventajas económicas y fiscales para fomentar la fusión.

Para realizar la búsqueda de las razones por las que la fusión no terminó culminando, es necesario recurrir al análisis de una serie de fuentes:

1. Estados Financieros de NORTE y MZA.

2. Estatutos de NORTE y MZA.

3. Correspondencia escrita entre los directivos de NORTE y MZA, y los de cada uno de ellos con su respectiva casa matriz.

4. Documentos internos entre los diferentes empleados de NORTE y MZA.

\subsection{Enfrentamiento inicial de MZA-NORTE}

Las luchas comerciales, productivas y estratégicas de NORTE y MZA, produjeron un inicial escenario de lucha competitiva muy enraizada ${ }^{1202}$.

${ }^{1202}$ Este escenario fue analizado por Tedde (1978: 71-80). 
La historia de la competencia empresarial entre ambas puede dividirse en tres etapas. Entre 1855-1873 eran dos de las compañías de mayor envergadura financiera y distributiva, pero con parecido comportamiento en el mercado que otras sociedades ferroviarias españolas. Entre 1874 y 1905, la estrategia expansionista de las dos sociedades llegó a plantear abiertamente un conflicto comercial entre ambas para controlar el tráfico. A partir de 1906, NORTE y MZA consagran un régimen de duopolio con reparto de beneficios, y comienza un proceso de integración entre ambas compañías.

En la primera etapa se produjeron movimientos competenciales y litigios por medio de empresas satélites, controladas por ellas y que posteriormente se integrarían en los dos gigantes ferroviarios españoles. Las más importantes se produjeron en la provincia de Barcelona. En 1885, existió una reivindicación de la Compañía del Norte de Barcelona a Granollers $^{1203}$ (posteriormente de MZA) en contra de la Compañía del Ferrocarril de Barcelona a Zaragoza (posteriormente de NORTE) debido a la rivalidad surgida entre ambas $^{1204}$

El periodo en el que MZA y NORTE compitieron más duramente fue 1874-1896. NORTE llevó a cabo una estrategia de absorciones y fusiones con la intención de realizar una ofensiva para mejorar su posición frente a $\mathrm{MZA}^{1205}$ en el mercado ferroviario español. Tanto la integración del ferrocarril de Alar a Santander en 1874, como la incorporación a la explotación de la Compañía de Zaragoza a Pamplona y Barcelona en 1878, y la del ferrocarril de Tudela-Bilbao en 1879, tenían como finalidad cerrar espacios en el País Vasco para intentar dominar el tráfico en la zona.

El siguiente movimiento estratégico de NORTE fue la apertura de influencia hacía la fachada mediterránea, donde dominaba MZA. Ambos colosos disputaban por integrarse a la rentable Compañía de Almansa a Valencia y Tarragona, propiedad del grupo del financiero y banquero valenciano José Campo. Aunque las dos compañías estaban interesadas en hacerse con su control, hasta el fallecimiento de Campo en 1890 no comenzaron las negociaciones.

\footnotetext{
${ }^{1203}$ Camino de Hierro del Norte (1851): Estatutos y reglamento de la Sociedad Anónima titulada Camino de Hierro del Norte correspondiente a la sección de Barcelona a Granollers autorizada por Real Decreto de 30 de julio de 1851, Barcelona: Imprenta de Pons y Cía. El objeto de esta sociedad era la construcción y aprovechamiento del ferrocarril de Barcelona a Granollers, pudiendo hacer las adquisiciones necesarias para las obras y demás servicios del camino. Inicialmente denominado Camino de Hierro del Norte, irá modificando su nombre según vaya prolongándose hasta Gerona (FFCC de Barcelona a Granollers). En 1862, al unirse con el Camino de Hierro de Barcelona a Mataró, pasa a denominarse empresa de los Caminos de Hierro de Barcelona a Gerona. Los estatutos fundacionales son modificados en 1858 y 1862.

${ }^{1204}$ La Compañía del Ferrocarril de Barcelona a Zaragoza sostenía que tenía el derecho a prolongar la línea que, arrancando en Sabadell terminara en Moncada y desde este punto prolongar hasta Barcelona. Por el contrario, la Compañía del Ferrocarril de Barcelona a Granollers defendía el derecho a impedir esta prolongación y a obligar a dicha línea a que siguiera empalmando en Moncada con su ferrocarril. Esta compañía alegaba que además había sido construida sin subvenciones, por lo cual no era lícito interceptarle lucros que le corresponderían por afluencias naturales de la línea y que se favorezca en contra una empresa subvencionada (Camino de Hierro del Norte (1855: 1-23).

${ }^{1205}$ Esta finalidad fue observada por Vidal Olivares (1997: 52).
} 
Finalmente, NORTE la adquirió en 1891. Con la adquisición de la Compañía de Almansa a Valencia y Tarragona, NORTE asestó un duro golpe a MZA, pues se introdujo de lleno en un mercado mediterráneo en el que hasta entonces MZA había actuado como monopolista. La estrategia agresiva de NORTE en Levante continuó con la adquisición en 1892 de la Compañía del Este de España ${ }^{1206}$ y del ferrocarril Valencia-Utiel.

Como respuesta a estos movimientos de NORTE, MZA construyó en 1895 la línea de Ariza, que permitían a sus trenes penetrar en el corazón del imperio castellano de NORTE. Esta rivalidad supuso una guerra de tarifas entre ambas compañías ${ }^{1207}$.

Posteriormente, las guerras se atenuaron tanto que se buscaron acuerdos tarifarios y competenciales, pero incluso entre medias de ellos, hasta 1906, las luchas reaparecían en momentos puntuales, como en la construcción de los pasos fronterizos, que se detalla a continuación.

Antes de acometerse la unión de Madrid por Francia a través de Valladolid, se publicó un texto (Los Aragoneses a la Nación Española: 1853) que postulaba el trazado del ferrocarril a Francia por Zaragoza por su menor longitud, el carácter estratégico militar de la capital aragonesa, la facilidad del terreno y por sus menores costes de establecimiento.

Esto tuvo su continuación con las tres motivaciones de NORTE para construir el paso fronterizo con Francia por Canfranc. La primera era que ese paso se haría con la construcción del tramo entre Canfranc y Oloron-Sainte-Marie (Aquitaine), siendo esta última la ciudad natal de Juan Barat y Priou. Este fue su principal valedor desde que fue nombrado director de NORTE el 21 de enero de $1881^{1208}$. En la primera reunión del Comité de Dirección de NORTE en la que participó, siete días después de su nombramiento, ya se trató el interés de la Dirección por esa línea ${ }^{1209}$. Ese interés se trasladó al Comité de París de NORTE, que era la instancia competente para resolver sobre nuevas construcciones y temas financieros. La medida que tomaron los Péreire fue la de entorpecer la construcción de cualquier ferrocarril franco-español, excepto el elegido por Barat ${ }^{1210}$. Sin embargo, cuando se jubiló Barat el 30 de abril de 1901, le relevó Theophile Delcassé, diputado por Foix, que se propuso fomentar los ferrocarriles en su Departamento cada vez que asistía a la Comisión de Ferrocarriles de la Asamblea Republicana (de los Cobos y Martínez Vara, 2012: 14). La segunda motivación con origen en NORTE fue el fuerte apoyo de Louis Barthou, diputado por Oloron, que accedería a la cartera de obras Públicas de la República en 1894. La tercera motivación fue que Aragón había sido leal a la causa libreal en la III Guerra Carlista contra los rebeldes (Cataluña y el

\footnotetext{
${ }^{1206}$ La "Sociedad de los Ferrocarriles de Cuenca a Valencia y Teruel" fue disuelta siendo Montero Rios, ministro de Fomento. Cambió su denominación social, el 9 de diciembre de 1886, tomando el nombre de "Caminos de Hierro del Este de España”, empresa que culminó las obras el 11 de septiembre de 1887 al inaugurar los 10 kilómetros inconclusos entre Sieteaguas y Buñol. La constitución de la sociedad tuvo lugar en Valencia con un capital de 10.000.000 pts en 20.000 acciones (Revista Minera, Tomo 38, año 1887).

${ }^{1207}$ La guerra de tarifas entre MZA y NORTE fue estudiada por Gómez Mendoza (1982: 5; 1989a: 62).

${ }^{1208}$ Chemin de fer du Nord de l'Espagne. Procès verbaux des séances tenues a la reunion de Paris, 21 janvier 1881.

${ }^{1209}$ NORTE. Actas Comité de Madrid, 28 de enero de 1881.

${ }^{1210}$ NORTE. Actas Comité de Madrid, 19 de mayo de 1881.
} 
Pais Vasco), y NORTE tenía muchos lazos con el gobierno liberal (Sagasta, Tomás Ibarrola, el General Serrano y Manuel Alonso Martínez). Con la construcción de este trazado se favorecía tanto a NORTE como a Aragón.

El paso de Canfranc tuvo problemas técnicos. La línea Huesca-Jaca se levantó con un presupuesto muy bajo, y al poco de su apertura se produjeron frecuentes corrimientos de tierras, desprendimientos y otros accidentes. Además, las curvas de 300 metros del Canfranc no eran aptas para las grandes velocidades que precisaba el ferrocarril directo de Madrid a París. Pero la principal razón para que el paso de Canfranc no triunfase era que los Péreire tomaron la decisión de construir los trazados de ambos lados transfronterizos con NORTE y Midi, pero sin contar con los gobiernos de los dos países que debían sufragar el paso subterráneo de los Pirineos (de los Cobos y Martínez Vara, 2012: 15). Seguramente no buscaron más apoyos políticos porque confiaron en los estrechos lazos que ya tenían entre sus empresas y ambos gobiernos. El proyecto fue definitivamente aparcado con la entrada en vigor de la Sindicatura de junio de 1906.

Mientras los Péreire eligieron el paso a Francia por San Sebastián y su puerto, los Rothschild optaron por el trayecto más directo, el paso navarro de los Alduides, en sintonía con la Compagnie du Grand Central (CGC), con la que tenía estrechas relaciones, y en cuyo poder estaba la concesión de la línea más directa a París por Limoges y Agen.

También hubo un intento de la Compañía del Ferrocarril de Zaragoza a Pamplona, para crear un acceso a Francia por los Alduides ${ }^{1211}$. Esta compañía fue creada en 1859 por el Marqués de Salamanca (Compagnie de Chemin de fer de Saragosse a Pampelune: 1861). Este proyecto necesitaba la cooperación de la Compagnie de París-Orleans para construir el tramo francés de Limoges a Agen. Y este tramo no se realizó en esa época. La Compañía del Ferrocarril de Zaragoza a Pamplona (ZP) se fusionó en 1864 con la Compañía de Barcelona a Zaragoza convirtiéndose en la Compañía del Ferrocarril de Zaragoza a Pamplona y Barcelona (ZPB). Como consecuencia de la fusión ZPB dispondrá del ramal de Tardienta a Huesca, con la posibilidad de ser prolongado a Canfranc, Oloron y Pau. Esta opción es descartada por ZPB, retomando el estudio del acceso a Francia por los Alduides (Compagnie de Chemin de fer de Saragosse a Pampelune et Barcelone: 1865). Además, el paso de Alduides resultaba problemático por las asperezas del terreno ${ }^{1212}$.

Sin embargo, ambos proyectos tardaron en realizarse, lo que supuso que se terminara la conexión ferroviaria entre Madrid y París por Hendaya e Irún. De esta forma el servicio en Francia estaría asegurado por la Midi, y en España por NORTE. En ambas sociedades, los Péreire tenían la mayoría del capital social.

\footnotetext{
${ }^{1211}$ Este acceso fue estudiado con mucha profundidad por Larrinaga (2002).

1212 Rapport de la Commission d'enquête chargée de donner son avis sur le projet d'établissement d'un chemin de fer de Bayonne en Espagne par la vallée de la Nive et les Aldudes (1857), Bayonne, Imprimerie de Veuve Lamaignère née Teulières.
} 


\subsection{Convenio de tarifas MZA-NORTE en 1870}

En algunas ocasiones, NORTE y MZA aparcaron su antigua y dura competencia, concluyendo pactos para obtener mejores rendimientos de las explotaciones ${ }^{1213}$. Los pactos interempresariales estuvieron favorecidos por las características de la industria de las concesionarias del ferrocarril, propia de una estructura oligopolística: homogeneidad del producto, pocos productores, existencia de barreras de entrada y control de mercado ${ }^{1214}$. Los miembros de un oligopolio son susceptibles de establecer acuerdos entre ellos para proceder al reparto del mercado y para mantener un sistema común de tarifas. La finalidad de los pactos de los oligopolios era intentar incrementar los beneficios conjuntos de los socios porque, al menos en teoría, estos beneficios serán siempre superiores a la suma de los beneficios individuales de cada empresa si éstas deciden operar en condiciones libres.

En 1865, MZA y NORTE comenzaron a tener serias dificultades financieras, que fueron empeoradas por la lucha salvaje llevada entre ellas. Estas dificultades se agudizaron con la Revolución de 1868, que provocó el exilio de la Reina Isabel II y significó el comienzo del Sexenio revolucionario. Durante este periodo, la crisis ferroviaria se agudizó, provocando la quiebra y desaparición de numerosas compañías. MZA y NORTE lograron resistir las adversidades de esta época, aprovechando la quiebra de las pequeñas empresas para ir expandiendo sus negocios y crecer en tamaño (Wais, 1974: 192) hasta convertirse en las dos mayores empresas ferroviarias del país. En gran parte, NORTE y MZA salvaron la situación por haber firmado el acuerdo sobre la distribución del tráfico de 1870. Este convenio se consumó porque MZA quiso, pues en NORTE siempre desearon alcanzar este tipo de acuerdos. Y ahora podemos afirmar que MZA tomó la decisión correcta porque el acuerdo le salvó de esa gran crisis, tanto que la permitión dar incluso dividendos en el año 1873.

Las posturas entre MZA y NORTE se fueron acercando paulatinamente, aunque se puede observar un salto en su evolución con la actuación de Barat en NORTE.

Jean Barat ${ }^{1215}$ fue director general entre el 20 de febrero de 1881 y el 30 de abril de 1901. Barat dirigió y coordinó los procesos de fusión y adquisición con las diversas empresas. En los años anteriores a 1870, organizó la estructura financiera de NORTE tras los descalabros experimentados en los años de la crisis de 1868, llevando a cabo una restructuración de las obligaciones en circulación. Además, durante su gestión en NORTE, fue el artífice de las relaciones comerciales con los competidores, especialmente en lo que se refiere a convenios de tarifas con MZA en 1870 y en 1896, y el de la distancia más corta de 1875.

Como jefe comercial, en 1870, Barat planteó el convenio de tarifas con MZA basado en el abono de una cantidad alzada, pagadera por años, en lugar del proyecto de sindicatura de

\footnotetext{
1213 Más adelante las compañías los acuerdos se tomaron también para competir contra las líneas de transportes por carretera (García Venero, 1948: 353).

1214 Sherer (1978) estableció, como características propias de un oligopolio: la homogeneidad del producto, el corto número de productores, la existencia de barreras de entrada y el control de mercado.

$1215 \mathrm{Su}$ biografía fue estudiada por Wais (1987: 196).
} 
productos o de porcentaje por tonelada propuesto por el entonces Director Noblemaire. Este convenio puso fin a la lucha empresarial que NORTE y MZA venían soportando, por el tráfico desde Bilbao y Alsasua a Madrid y hacia otros destinos meridionales a través del empalme de Casetas, en Zaragoza - punto de entronque con las líneas de MZA- (Vidal Olivares, 1999: 643). Este acuerdo fue planteado por Barat pero el que estaba en peor situación era MZA, que por eso aceptó.

\subsection{Acuerdo de la distancia más corta MZA-NORTE de 1875}

La habilidad desarrollada por Barat en las negociaciones para establecer el primer convenio de tarifas con MZA, le llevó a ser nombrado subdirector de NORTE. Desde este cargo continuó llevando el peso de la estrategia comercial de la compañía, que estaba dando buenos resultados. Barat, como subdirector, planteó un acuerdo decisivo con MZA: el convenio para la división del tráfico entre las dos redes bajo la base y el principio de la distancia más corta.

El principal desencadenante de este nuevo acuerdo entre ambas fue la maniobra de MZA, cambiando su política estratégica hacía una aptitud más colaboradora. El segundo desencadenante fue el fallecimiento de Émile Péreire ${ }^{1216}$ en enero de 1875 , que facilitó el acuerdo tan sólo mes y medio después.

Tras la crisis financiera de 1865-1869, MZA cambió su estrategia. A partir de ese momento no pidió nuevas concesiones, sino que su expansión se realizó por medio del rescate y fusión con compañías prexistentes. Además, buscó alianzas y acuerdos con NORTE lo que supuso una forma de reconciliarse con ella. El 5 de octubre de 1875, MZA adquirió la Compañía del Ferrocarril de Córdoba a Sevilla y sus 132 kilómetros de líneas ya en explotación así como la línea de las minas de la Reunión a Villanueva del Río. A cambio, MZA permitió la anexión de la Compañía de los Ferrocarriles de Zaragoza a Pamplona y Barcelona (ZPB) por NORTE (Cameron, 1961: 253). La fusión entre NORTE y ZPB pudo realizarse en 1874, pero el acuerdo no se alcanzó porque eran contrarios los socios catalanes, predominantes en el Consejo de ZPB, y porque había dos administradores -Ros Olano y Llorente- que lo eran simultáneamente de ZPB y MZA ${ }^{1217}$. Pero todo esto cambió tras el acuerdo de $1875^{1218}$.

Las empresas habían mantenido sus alianzas pero tuvieron un encontronazo por fuertes litigios por las cargas entre el puerto de Bilbao y Madrid. Para solventarlo, el 8 de marzo de 1875, NORTE y MZA acordaron repartirse los tráficos en esas líneas por medio del principio de que circularían por la "más corta distancia". Por el acuerdo se estableció que las mercancías debían circular como norma por la línea que demostrase menor kilometraje entre

\footnotetext{
${ }^{1216}$ Rondo E. Cameron (1961) comparte la opinión que la muerte de Émile Péreire facilitó el acercamiento entre las dos grandes ferroviarias españolas.

1217 Cartas de Bauer 6-8-1874; 9-8-1874 y 21-8-1874. Archivos Rothschild London. Estas cartas fueron estudiadas por López Morell (2005: 292).

${ }^{1218}$ Más adelante, NORTE llegó al acuerdo con MZA, lo que permitió la fusión de NORTE con ZPB, que se hizo efectiva el 13 de febrero de 1878.
} 
origen y destino $^{1219}$, de esta forma, siempre que un tráfico debiese circular por uno o por los dos ferrocarriles, lo haría por el camino más corto en kilómetros ${ }^{1220}$.

Gracias al acuerdo, MZA y NORTE establecieron una zona de influencia para cada una de ellas, se aseguraron el tráfico de su área $\mathrm{y}$, al no establecerse competencia entre ellas, pudieron, además, aplicar tarifas elevadas.

\subsection{Convenio de reparto de tráfico NORTE-MZA-TBF en 1896}

El acuerdo para circular por la vía más corta de 1896 fue derivado del acuerdo de 1875 . El objeto inicial del acuerdo por el principio de la distancia más corta de 1875 tenía por objeto el trayecto hacia el puerto de Bilbao, y se fue al traste por un enfrentamiento entre MZA y NORTE por el tráfico entre Castilla y Cataluña a propósito de la apertura de la línea de Valladolid a Ariza y la variante de Caspe. Esta línea ponía a MZA en contacto directo con Barcelona y Zaragoza: "la compañía de Alicante, unida así en Zaragoza con la de Tarragona a Barcelona y Francia, estableció un sinnúmero de tarifas, vía Caspe, con precios más reducidos que los que regían anteriormente en combinación con la línea de NORTE, desviando de esta última entre Zaragoza y Barcelona, vía Manresa, el tráfico de viajeros y mercancías que la utilizaban"1221. La pugna de tarifas fue dura ${ }^{1222}$, por lo que Barat planteó a MZA un entendimiento en diciembre de 1894 que no fue aprobado, lo cual ahondó en la "guerra de tarifas" hasta que, finalmente, el 4 de enero de 1896, se firmó un acuerdo parecido al que había presentado Barat ${ }^{1223}$.

El convenio sobre reparto de tráficos, firmado el 4 de enero de 1896, por MZA, NORTE y TBF (Tarragona, Barcelona y Francia) ${ }^{1224}$, tuvo una duración de diez años (MZA, 1896a: 4). Este acuerdo es "un convenio que pone término a las rivalidades y que concilia los intereses de las tres compañías” (MZA, 1896b: 4).

Según este acuerdo se aplicaron precios totales iguales al transporte en tres tramos: entre Barcelona y Zaragoza, entre Zaragoza y Valladolid y entre Lérida y Barcelona (por Manresa y Picamoixons). Hasta ese momento existía la posibilidad de recorrer esos tramos por las líneas de las dos compañías, dejando a los clientes la capacidad de elegir la vía. Las recaudaciones

\footnotetext{
${ }^{1219}$ Una estrategia similar había sido tomada en 1863 entre Midi, Paris a Lyon et a la Méditerranée y Po (Caron: 1997).

${ }^{1220}$ Este acuerdo fue analizado por Gómez Mendoza (1989a: 59), Comín, et al. (1998, vol. I: 216) y LópezMorrel (2005: 478).

${ }^{1221}$ Carta enviada por J. Barat el 4 de abril de 1908 al presidente del Consejo de Administración de NORTE (p. 14), realizando una exposición de las indemnizaciones que la compañía le debía.

${ }^{1222}$ En concreto la pugna de tarifas fue muy dura en lo que se refiere al trigo, las harinas y los vinos (Sanz: 1985) (Gómez Mendoza: 1984).

${ }^{1223}$ La firma del acuerdo de 1896 fue propiciado por Barat, y firmado por Sagasta y Elduayen por NORTE, el Marqués de Urquijo y Baüer por MZA y Planas por TBF (Tarragona, Barcelona y Francia).

${ }^{1224}$ El 1 de enero de 1898 MZA absorbió la "Compañía de Tarragona a Barcelona y Francia" (TBF), denominada desde entonces "Red Catalana de MZA", que había suspendido pagos y explotaba 723 kilómetros.
} 
del tráfico de dichas líneas formarían un fondo común entre MZA, NORTE y TBF que se repartiría entre ellas tras haber deducido los gastos y aplicando coeficientes de reparto.

En la vigencia de este acuerdo de 1896, existieron más ejemplos en la colaboración NORTE y MZA. Los dos más importantes se produjeron en 1902. Una carta oficial del Comité de Barcelona de NORTE, firmada por el Señor Girona, propuso la construcción de una estación común entre NORTE y MZA ${ }^{1225}$; el presidente de NORTE decidió incluirla en el acta del Consejo $^{1226}$. De la misma forma, NORTE y MZA (1902: 1-16) publicaron el documento "Contrato y reglamento celebrados entre la Compañía de los Caminos de Hierro del Norte y la de los Ferrocarriles de Madrid a Zaragoza y a Alicante para el cambio de material". En él se recogían las condiciones establecidas entre ambas compañías para regular la circulación de material de una compañía en las líneas de la otra. En el contrato se fijaban los transbordos que debía hacer cada coche o furgón, recargos por coches de lujo y alquiler de material con precios especiales. Los vagones de mercancías no estaban sujetos a transbordo y circularían libremente si estaban en buenas condiciones, siendo utilizados a su regreso por la compañía por cuya línea circulan. Además, el contrato especificaba el establecimiento de saldos, compensaciones, devoluciones y registros.

\subsection{Intento de fusión NORTE-MZA de 1904}

En el periodo 1900-1903, NORTE tuvo malos resultados contables (2,5 millones de pérdidas); en esta situación económica-financiera, no podía encontrar subscriptores para la voluminosa emisión de obligaciones que seguía sin poder realizarse. Por otro lado, existía un evidente convencimiento de que el servicio que ofrecía NORTE era malo. Además, padecía una fuerte conflictividad laboral. Ante este entorno económico, productivo y laboral, e impulsado por las motivaciones interesadas de sus administradores, NORTE difundió la eminente fusión de NORTE y MZA, que nunca llegó a producirse. La difusión se realizó por artículos en la prensa $^{1227}$ y en la documentación contable de la compañía ${ }^{1228}$.

El intento de fusión de 1904 estaba motivado tanto por la mala situación de NORTE en materia (1) económica, (2) operativa y (3) laboral, como por los movimientos estratégicos de los directivos que la gobernaban, (4) unos por acercarse a otras empresas, principalmente suministradoras de NORTE, (5) otros para acercarse a MZA, y (6) por último, otros para acercarse al Estado.

A pesar de todos estos aspectos a favor, la fusión no culminó. La principal razón por la que no se llevó a cabo la fusión fue que NORTE tenía poco prestigio entre los altos representantes de MZA, e incluso los representantes de MZA consideraban que NORTE estaba deficientemente gestionada.

\footnotetext{
1225 Gaceta de los Caminos de Hierro, 16 de febrero de 1908.

${ }^{1226}$ Acta ${ }^{\circ} 674$ del Libro de actas del Consejo de Administración de NORTE: 21 de marzo de 1902.

1227 "La fusión de los ferrocarriles del NORTE y Mediodía de España", Revista Minera Metalúrgica y de Ingeniería, 1904, p. 521. "Rumor sin fundamento", Gaceta de los Caminos de Hierro, 1904, pp. 459-460.

${ }^{1228}$ Los posibles acuerdos de fusión quedaron reflejados en los Informes Anuales de NORTE (1903; 1904).
} 


\subsubsection{Factores favorables a la fusión}

\subsubsection{Mala situación económico-financiera de NORTE}

La situación económica de NORTE en el periodo 1900-1904 era mala en relación a MZA. La situación de la compañía puede observarse en las figuras 2-12. La compañía venía de seis ejercicios económicos con pérdidas (1894-1899), y de un prolongado periodo de suspensión del pago de dividendos, pues estuvo sin repartir remuneración a los accionistas desde 1892 hasta 1906. Su mala situación se complicó por la depreciación de la peseta respecto al franco la moneda con la que la compañía debía amortizar las obligaciones y pagar los intereses de su enorme deuda contraída en esta divisa para realizar sus anexiones-, por la crisis agrícola que desplomó el tráfico interior de vinos y cereales, y la brusca caída de los intercambios entre los dos países por efecto de la alteración en el tipo de cambio.

En 1901, NORTE era la primera ferroviaria en ingresos 112,2 millones de pesetas, seguida de MZA con 95,4 millones (Figura 7. Ingresos), aunque los gastos eran mucho mayores, tanto que el resultado del ejercicio de MZA era superior, 5,1 millones de pesetas, al de NORTE, 0,7 millones (Figura 11. Resultados contables). El principal indicador de la gestión en esa época era el coeficiente de explotación (relación entre ingresos y gastos); en 1901 el coeficiente de explotación de NORTE era 49,62\% y el de MZA 40,06\%. Durante el siglo XIX y los primeros años del siglo XX, NORTE y MZA consiguieron mantener unos coeficientes de explotación muy bajos, "al ofrecer unos servicios de muy baja calidad" (Herranz, 2008: 204).

Al finalizar el ejercicio contable 1903, NORTE tenía 2,5 millones de pérdidas (Figura 11. Resultados contables), frente a los constantes beneficios contables de MZA, la cual sólo tuvo pérdidas a partir de 1931. Destacan las diferencias en los gastos de financiación -incluido los gastos de depreciación de la moneda- pues NORTE tuvo 57,6 millones de pesetas en 1901, 61,1 en 1902 y 60,3 en 1903, mientras que MZA tuvo 52,1 millones de pesetas en 1901, 51,6 en 1902 y 53,3 en 1903 .

Como el empréstito emitido por NORTE no terminaba de suscribirse, buscó otras fuentes de financiación. La Junta General de Accionistas del 3 de junio de 1902, acordó elevar el capital social a 245.100.000, mediante la conversión de las 42.000 acciones y 44.704 participaciones ("títulos de participación") de la Línea de San Juan de las Abadesas por 26.000 acciones NORTE $^{1229}$.

Como NORTE continuaba con problemas para obtener financiación, unida a su mala situación económica y a la asusencia de reparto de dividendos, intentaba no competir con MZA y buscaba acuerdos tarifarios e incluso intentos de fusión.

\footnotetext{
${ }^{1229}$ Acta n $^{\text {o }} 678$ del Libro de actas del Consejo de Administración de NORTE: 16 de junio de 1902.
} 


\subsubsection{Mala situación operativa de NORTE}

Desde final de siglo, pero sobre todo desde 1903, todo el sector -incluído MZA- conocía las deficiencias operativas de NORTE. Desde 1900, NORTE estaba en una mala situación en cuanto a seguridad, prestigio y relaciones con el Estado que se materializaron en numerosas incidencias en la explotación.

En el periodo 1900-1902, las vías de NORTE estaban en mal estado. Hubo muchos retrasos, muchos incidentes en el tráfico e incluso bastantes colisiones, que provocaron que hubiera que satisfacer cuantiosas multas al Estado. Pero la situación empeoró en 1903.

El 27 de junio de 1903 se produjo un descarrilamiento en el kilómetro 105 de la línea de Tudela a Bilbao, en el que murieron 47 personas, en Torre Montalvo (en el puente denominado Montalvo sobre el rio Najerilla) ${ }^{1230}$. Para estudiar el accidente se nombró una Comisión especial compuesta por tres ingenieros, cuyo informe mostraba las graves deficiencias atribuidas a NORTE ${ }^{1231}$.

El suceso llevó a intervenir a la Dirección General de Obras Públicas con tres disposiciones. En primer lugar, el Real Decreto de 6 de julio de 1903 nombró una Junta inspectora de las líneas ferroviarias en explotación en España. Por otro lado, la Real Orden de 31 de julio de 1903 fue encargada de revisar las condiciones de capacidad, aptitud y trabajo del personal de ferrocarriles ${ }^{1232}$. Por último, el 13 de agosto de 1903, el director de Obras Públicas presentó una propuesta para organizar los servicios ferroviarios y aumentar la seguridad en la explotación. Las tres actuaciones del Estado estaban dirigidas a todas las ferroviarias, pero tenían una relación directa con las deficiencias de seguridad cometidas por NORTE. Por un lado, en la Exposición de Motivos de la Real Orden de 31 de julio de 1903 se mencionaba explícitamente el accidente del puente de Torre Montalvo. Por el otro, tras la propuesta del 13 de agosto de 1903, el ministro de Obras Públicas Rafael Gasset citó al Director de NORTE, Aubert, para manifestarle que "no podía tolerar por más tiempo las graves y repetidas faltas que se observan diariamente en la marcha de los trenes (...), y que si no lo resolvía brevemente, llevaría el asunto al Consejo de Ministros, para que adoptase una resolución enérgica contra la compañía [NORTE]"1233.

${ }^{1230}$ Carta del Director al Consejo de Administración de NORTE: 28 de junio de 1903; Carta del Director al Consejo de Administración de NORTE: 29 de junio de 1903; Carta del Director al Consejo de Administración de NORTE: 30 de junio de 1903; Acta nº 690 del Libro de actas del Consejo de Administración de NORTE: 30 de junio de 1903.

1231 "El descarrilamiento en el puente de Torre Montalvo", Revista de obras Públicas, 1903, pp. 449-458.

1232 En la Exposición de Motivos se considera al factor humano como parte de los elementos de la seguridad ferroviaria, pues considera que "la fatiga fisiológica y moral del obrero sometido a las más altas presiones del trabajo" puede ocasionar en un instante "la mayor de la catástrofes" (Exposición de Motivos de la Real Orden de 31 de julio de 1903).

${ }^{1233}$ Carta de la dirección de 24 de septiembre de 1903 al Comité de Madrid de NORTE, Actas del Comité de Madrid de NORTE, 30 de septiembre de 1903. 
Pero, además, el Estado emitió la Real Orden de 1 de octubre de 1903, que ya no iba destinada genéricamente a todas las ferroviarias, sino que estaba dirigida expresa y concretamente a NORTE. Esta Real Orden pretendía incidir sobre NORTE para acabar con los continuos retrasos. Estos retrasos eran causados -así pensaba los interlocutores del Ministerio- por un material de tracción y rodante insuficiente y sometido a un trabajo excesivo, sin las debidas reparaciones ${ }^{1234}$.

También existieron numerosas quejas formuladas por diferentes entidades respecto al servicio, tanto de viajeros como de mercancías, en la sección entre Manresa y Barcelona ${ }^{1235}$.

Del mismo modo existían grandes retrasos en las estaciones de Madrid, tanto en Príncipe Pío como en el Paseo Imperial ${ }^{1236}$. El Director creía que los retrasos eran causados por las vías de las dos estaciones ${ }^{1237}$.

A pesar de la búsqueda del favor político, no fue posible esconder las reclamaciones que debía pagar NORTE por las reiteradas incidencias en la explotación. Este es el mayor indicio del deficiente servicio que prestaba. Por incidencias en la explotación, NORTE tuvo que pagar en 1903 cerca de 1.500 .000 pesetas, el 1,27\% de los productos (ingresos) de la compañía ${ }^{1238}$.

\subsubsection{Mala situación laboral de NORTE}

Los incidentes, retrasos y colisiones hicieron que NORTE tuviera que satisfacer cuantiosas multas al Estado en 1900-1903. Ante ello, la dirección comenzó a imponer castigos al personal de trenes y estaciones, porque entendió que había existido una falta de celo ${ }^{1239}$. Esto produjo descontento entre los trabajadores por la dimensión de los castigos. En febrero de 1902 hubo una huelga en los talleres de San Andrés de Barcelona. A final de octubre de 1902 se produjo otra huelga en las minas de Barruelo y en los talleres de Valladolid.

\footnotetext{
${ }^{1234}$ Real Orden de 1 de octubre de 1903 del Ministerio de Agricultura, Industria, Comercio y Obras Públicas.

1235 Comité de París de 17 de enero de 1903; Comité de Barcelona de 31 de enero de 1903; Comité de Barcelona de 19 de febrero de 1903; Acta nº 686 del Libro de actas del Consejo de Administración de NORTE: 31 de marzo de 1903.

${ }^{1236}$ Los retrasos en las estaciones de Madrid fueron constatados por José Maycas e informados al Director y al Presidente de NORTE; ambos se pronunciaron sobre este problema (Acta ${ }^{\circ} 719$ del Libro de actas del Consejo de Administración de NORTE: 27 de noviembre de 1905).

${ }^{1237}$ El Presidente de NORTE afirma que no tendría reparos en proponer al Consejo la concesión de créditos que fuesen necesarios para las obras o ampliaciones dirigidas a mejorar las estaciones madrileñas de Príncipe Pío el Paseo Imperial, "que debieran ir a la cuenta de Primer establecimiento... no cabiendo respecto de estos gastos, guardar las reglas ni seguir el criterio que es indispensable aplicar a los asuntos ordinarios de la explotación, propios del Presupuesto anual" (Acta n 719 del Libro de actas del Consejo de Administración de NORTE: 27 de noviembre de 1905).

1238 “Las tarifas del ferrocarril del NORTE”, Revista Minera Metalúrgica y de Ingeniería, 1904, pp. 298-299.

1239 Actas del Comité de Madrid de NORTE (1902).
} 


\subsubsection{Acercamiento a MZA}

En la Junta General de Accionistas de NORTE, celebrada el 8 de junio de 1905 (NORTE: 1905), se evidenció por primera vez, que los miembros del Comité de Madrid tomaron el mando de la compañía en detrimento de la mayoría francesa. Este hecho fue determinante pues los miembros del Comité de Madrid -al contrario de la mayoría francesa ${ }^{1240}$ - eran partidarios del acercamiento con $\mathrm{MZA}^{1241}$.

Existieron cuatro figuras claves para el acercamiento a MZA: Antonio Borregón, Estanislao Urquijo Ussía, Eduardo Maristany y Amós Salvador.

El 26 de mayo de 1904, Antonio Borregón fue nombrado presidente del Comité de Madrid de NORTE. Él había obtenido el título de Ingeniero de Caminos en la promoción de 1860, siendo compañero de pupitre del futuro presidente del Consejo de Dirección de MZA, Miguel Martínez Campos. Durante 1885 y 1886, participó en la Comisión de frenos y campañas impulsada por el Estado para estudiar los elementos de seguridad, compartiendo sus trabajos con Maristany, que representaba a la Red Catalana de $\mathrm{MZA}^{1242}$. Durante las conversaciones entre Borregón y Maristany de 1905 quedó claro que el primero deseaba la fusión entre MZA y NORTE: "Ahora más que nunca es necesario, a mi juicio, la unión entre las dos compañías"1243.

En la misma fecha, el 26 de mayo de 1904, Estanislao Urquijo Ussía ${ }^{1244}$ fue nombrado miembro del Consejo de Administración de NORTE. La principal intención de este nombramiento fue reducir la separación entre NORTE y MZA. Estanislao Urquijo era familiar y compañero de negocios de Manuel Allendesalazar, Consejero de $\mathrm{MZA}^{1245}$. Además de los lazos familiares y de negocios particulares, existía una motivación financiera directa, porque Estanislao Urquijo entró en NORTE en el momento de su fundación, y además, desde 1904 tenía un importante paquete de acciones de MZA. La influencia más importante se

\footnotetext{
1240 Seguramente, la mayoría francesa no deseaba una unión con MZA por razones históricas, emanadas de la rivalidad que siempre existió entre las familias francesas que constituyeron MZA y NORTE.

1241 “Junta de los accionista de la Compañía de NORTE", Gaceta de los Caminos de Hierro, 1905, pp. $267-268$.

${ }^{1242}$ La relación de Antonio Borregón hacia Maristany era de profunda admiración, tanto sobre su actividad gerencial, como sobre su recopilación "La conferencia ferroviaria" (Carta de Borregón a Maristany el 9 de noviembre de 1905. AHF S-103-4).

${ }^{1243}$ Carta de Borregón a Maristany el 9 de noviembre de 1905. AHF S-103-4.

1244 Estanislao de Urquijo Ussía, tercer marqués de Urquijo (y simultáneamente primer Marqués de Bolarque), nació en 1872 en Madrid, Fue director del Banco Urquijo (fundado en 1918 y convertido en los años veinte en uno de los seis grandes bancos españoles). Fue -como su padre y abuelo- diputado y senador. Ocupó cargos importantes en los bancos Urquijo, Hipotecario de España, de Crédito Industrial, en sociedades inmobiliarias y numerosas empresas ferroviarias, petrolíferas, portuarias, de construcción naval, eléctricas y mineras, de toda España. En política fue diputado a Cortes por Amurrio y senador por Álava. Fue nombrado Grande de España en 1918, Gentil Hombre de Cámara del Rey Alfonso XIII, Gran Cruz de Isabel la Católica, oficial de la Legión de Honor, Comendador de la Legión de Honor y miembro del Real Cuerpo de Caballeros Hijosdalgo de la Nobleza de Madrid. Se casó en 1898 con María del Pilar de Landecho y Allendesalazar, Marquesa de Cábrega e hija del arquitecto Luis de Landecho y Jordán de Urríes e Isabel de Allendesalazar y Muñoz de Salazar.

${ }^{1245}$ Y simultáneamente ministro de Agricultura, Industria, Comercio y Obras Públicas en los años 1903 y 1904.
} 
derivaba de sus lazos familiares; si analizamos en conjunto la casa de los Urquijo, se observa que su padre, Juan Manuel de Urquijo Urrutia ${ }^{1246}$, el segundo Marqués de Urquijo, era Consejero de MZA, y probablemente la información del Comité de Madrid de NORTE y del Consejo de MZA fluía abundantemente entre padre e hijo. La actuación de Estanislao Urquijo fue decisiva pues era realmente al que más le urgía la unión entre las dos compañías, primero porque ya tenía intereses económicos directos en forma de participación en el capital social de ambos, pero también porque los últimos movimientos estratégicos dentro de NORTE les habían hecho perder posición relativa. Desde 1902 los intereses de los Péreire y del Marqués de Comillas parecían estar más cercanos, marginando a los de Estanislao Urquijo. Existen tres manifestaciones de la perdida de poder de los Urquijo en NORTE. En primer lugar, en la Junta de Accionista de 30 de mayo de 1903 no se presentaron ni directa ni indirectamente los Péreire ni el Marqués de Comillas. En segundo lugar, en el objetivo fundacional del Banco Español de Crédito se intuía que el objetivo de la entidad financiera era facilitar la obtención del beneficio para alcanzar la armonía entre los dos grupos que tradicionalmente habían participado en NORTE, los Péreire y Comillas, dejando en un segundo plano los intereses de los Urquijo y de otros inversores. Y por último, la emisión del empréstito de NORTE de 1905 fue realizada por el Banco Español de Crédito excluyendo de la misma al grupo financiero de los Urquijo, lo que produjo malestar en la esta familia. Este malestar fue claramente expresado en la correspondencia entre Maristany y Baüer ${ }^{1247}$.

Maristany tenía cierta sintonía profesional con NORTE. Cuando dimitió Aubert del puesto de director de NORTE en febrero de 1904, se manejaron cinco nombres para sustituirle: Alzola, Borregón, Gorbeña, Polack y el propio Maristany ${ }^{1248}$. Esto supone, no sólo que su labor era bien vista por los responsables de NORTE, sino que no veían descabellado que él pudiera aceptar el cargo. En una hipotética fusión, Maristany creía -con razón- que tenía muchas posibilidades de alcanzar un puesto de dirección muy relevante. Sin embargo, no aceptó el cargo, es más, no tenemos pruebas de que tan siquiera se lo planteara. Cuando no fue posible la incorporación de Maristany como Director de NORTE en 1904, los representantes del grupo de Bilbao, alentaron un proceso de fusión con MZA, en parte porque asumieron que NORTE tenía una dinámica competencial perdedora contra MZA, pero también para así podrían beneficiarse indirectamente de la gestión y el carisma de Maristany.

El exministro Amós Salvador, sobrino de Sagasta, era Consejero de MZA. A pesar de ello, colaboró con NORTE para proteger los intereses de la compañía en el conflicto judicial tras la catástrofe del puente de Torre de Montalvo ${ }^{1249}$.

\footnotetext{
${ }^{1246}$ Juan Manuel de Urquijo Urrutia, fue el segundo marqués de Urquijo desde la muerte de su tío Estanislao. Fue diputado a Cortes por Álava, senador vitalicio y recibió de Alfonso XIII el Collar de Carlos III. Murió en Madrid en 1914. En 1843, se casó en Llodio (Álava) en 1862 con María Dolores de Ussía Aldama, hermana del primer marqués de Aldama, de importante familia de financieros y condes de los Gaitanes.

${ }^{1247}$ Carta de Baüer a Maristany, 23 de febrero de 1905, AHF S-103.

${ }^{1248}$ La prensa informó de estos planes de NORTE para incorporar a Eduardo Maristany. Puede observarse en Revista Minera, Metalúrgica y de Ingeniería ("Cambios de dirección en los ferrocarriles del Norte". 1904, p. 98) y Gaceta de los Caminos de Hierro ("La dirección de la Compañía de Norte", 1904: 75 y 89).

${ }^{1249}$ Actas del Comité de Madrid de NORTE, 13 de mayo de 1904.
} 
Además, las relaciones de altos representantes de NORTE y MZA en terceras empresas eran frecuentes. Por ejemplo, la empresa "Gasificación industrial" fue creada a iniciativa de Estanislao Urquijo Ussía, miembro del Consejo de Administración de NORTE. En esta empresa participaron: José Antonio Ibarra y Conde de Benar -Consejeros de NORTE-, Eduardo Dato, Amós Salvador, Manuel Allendesalazar -Consejeros de MZA-, Gustavo Baüer - presidente del Consejo de Dirección de MZA- y Nathan Süss- Director de MZA.

\subsubsection{Acercamiento al poder político}

Frecuentemente, los directivos lo eran simultáneamente de múltiples empresas, de forma que su poder e influencia era cada vez mayor. Las empresas pretendían que los Consejos de Administración estuvieran bien representados por los políticos más relevantes de todas las orientaciones, y los políticos acudían solicitos porque recibían una alta remuneración por ello. Además, el poder de los directivos de las grandes ferroviarias tenía influencia sobre la política de los gobiernos; la clase política primaba el sistema de directivos porque, posteriormente, en muchos casos los políticos iban a ser consejeros de las principales compañías.

La dirección de los Servicios, y por lo general también los puestos de mayor responsabilidad, recaían en ingenieros, que habían comenzado su carrera dentro de la Administración, en la propia Dirección de Obras Públicas o en las Jefaturas Provinciales dependientes de ella, lo que producía frecuentes relaciones entre los intereses públicos y privados.

Las conexiones de las compañías ferroviarias con todo el poder -ejecutivo y legislativo sobre todo- fueron en todo momento muy estrechas. Desde la misma creación de las compañías, en los Consejos de Administración de las compañías se sentaron tres presidentes del Consejo de Ministros, trece ministros de Hacienda y nueve de Fomento. Pero, las relaciones no fueron sólo con ministros, sino que también fueron innumerables las relaciones con senadores y diputados. Muchos de ellos dispusieron, con antelación, de información privilegiada e influyeron en la elaboración de las normativas que afectarían a las ferroviarias ${ }^{1250}$.

La opinión pública española recelaba de la veracidad de los resultados contables de las concesionarias, de los que eran beneficiados muchos políticos situados en los consejos de administración, de los que se intuía que favorecían los intereses ferroviarios. La persistencia de las grandes fortunas relacionadas con el ferrocarril no hubiese sido posible sin la vinculación privilegiada con la clase política, que concedía privilegios, exenciones y monopolios.

NORTE tenía entre uno de sus objetivos acercarse al poder político, para intentar mejorar sus relaciones con él. Este objetivo era básico para la compañía, mucho más cuando en mente tenían la intención de fusionarse con MZA, lo que sólo podría hacerse con el beneplácito de la clase política dirigente.

\footnotetext{
${ }^{1250}$ Todo este análisis es realizado por de los Cobos y Martínez Vara (2009: 4).
} 
Existió una tupida tela de araña entre los grupos de poder (aristócratas -principalmente Alba y Medinaceli-, terratenientes, empresarios y banqueros) y la clase política. Entre los políticos que tuvieron gran importancia en NORTE, destacan el presidente del Consejo de Ministros de España en el periodo 6 de marzo de 1901 al 6 de diciembre de 1902, Práxedes Mateo Sagasta, Comillas, Manzanedo, Urquijo y, por supuesto, el ministro de Hacienda y posteriormente de Estado, Rodríguez San Pedro. MZA también tuvo buenos contactos con los ministros de Agricultura, Obras Públicas, Agricultura, Industria y Comercio, José Canalejas, Amos Salvador y el Conde de Romanones. Entre los políticos que tuvieron gran relación con otras compañías ferroviarias destacan Elduayen, Larios, Rivas y Veragua.

La búsqueda de favor político se realizó principalmente sobre la concesión y construcción de las líneas, aunque también sobre el pronunciamiento favorable ante la gestión de accidentes. Por ejemplo, el 20 de noviembre de $1903^{1251}$ hubo un choque con cinco víctimas en la estación de Cercedilla. NORTE quedó exenta gracias a los contactos y buenas relaciones de personas que trabajaban o colaboraban conjuntamente con NORTE y el Estado ${ }^{1252}$.

La importancia de tener diputados influyentes en las empresas ferroviarias se puso de manifiesto (García Venero, 1948: 238-245) en la disputa periodística ${ }^{1253}$, empresarial y parlamentaria $^{1254}$ del trazado de los Alduides. MZA quería la salida de Alduides, pero el presidente O’Donnell negó la petición porque convertiría a Bayona en el centro del comercio hacia España, en detrimento de las ciudades españolas, y en especial de San Sebastián. NORTE no era partidario de la construcción de la salida de Alduides porque comprometía la construcción de la línea de la compañía NORTE por San Sebastián.

La influencia de NORTE sobre políticos de la época no estaba relacionada con un único partido, sino que se encontraba en ambas corrientes de pensamiento político, buscando la influencia de ministros, exministros y políticos de diferentes rangos, tanto liberales como conservadores.

El conservador Faustino Rodríguez San Pedro, que alternaba cargos en NORTE con altas responsabilidades del Estado (en 1903 era ministro), cuidaba los intereses de la compañía ${ }^{1255}$.

El liberal Amós Salvador, sobrino de Sagasta, que había sido ministro ${ }^{1256}$, fue encomendado por NORTE para proteger los intereses de la compañía en el conflicto judicial tras la catástrofe del puente de Torre de Montalvo ${ }^{1257}$.

\footnotetext{
${ }^{1251}$ Mientras que se realizaban aún las diligencias judiciales sobre la catástrofe del puente de Torre Montalvo.

1252 “Intervención del Diputado Nougués. Congreso de los diputados Torres Montalvo. Sesión de 12 de marzo de 1904”, Revista e Obras Públicas, 1904, pp. 169-171.

1253 El debate periodístico no fue sólo nacional, sino también internacional. Entre los medios hubo, muchos franceses evidentemente, pero tambié de otros países, como por ejemplo, existieron varios artículos de The Times (García Venero, 1948: 240).

${ }^{1254}$ Los diputados vascos fueron los que tuvieron la más enérgica oposición.

${ }^{1255}$ Faustino Rodríguez San Pedro "protegía convenientemente a la compañía". Así lo atestigua la "Intervención del Diputado Nougués. Congreso de los diputados Torres Montalvo. Sesión de 12 de marzo de 1904”, Revista e Obras Públicas, 1904, pp. 169-171.
} 
La creación del Banco Español de Crédito en 1903 tenía la intención inicial de facilitar la emisión de empréstitos que necesitaba NORTE. Aprovechando esta situación, la ferroviaria quiso incorporar en el Consejo del Banco a destacados hombres públicos (el Conde de Mejorada Gonzalo Figueroa, el Duque de Seo de Urgel, Manuel González-Longoria y Raimundo Fernández de Villaverde) para que con sus decisiones ayudaran a la compañía en la tarea legislativa de ambas cámaras.

Estanislao Urquijo Ussía, tercer Marques de Urquijo, fue nombrado, el 26 de mayo de 1904, miembro del Consejo de Administración de NORTE. Evidentemente este puesto estaba más que justificado porque la familia Urquijo tenía un gran número de acciones en NORTE, y era normal que tuviera un asiento en el Consejo de Administración. Pero tenía otra motivación: reducir las diferencias entre NORTE y el gobierno. Estanislao Urquijo era familiar y compañero de negocios de Manuel Allendesalazar ${ }^{1258}$. Durante años, las tensiones de NORTE con Fomento fueron constantes, sin embargo, estas se redujeron el 31 de diciembre de 1909, cuando comenzó su actividad como ministro de Fomento Manuel Allendesalazar.

A comienzos de siglo, hubo frecuentes denuncias sobre la comunión de intereses entre concesionarias y políticos en periódicos como El Heraldo de Madrid, La Justicia, El Liberal o Vida Nueva. La más importante fue la realizada por J. J. Morato: "Las leyes no suelen regir para las compañías; los encargados de hacerlas o de ejecutarlas tienen el doble cargo de legisladores y de gobernantes y de consejeros de las grandes empresas" ${ }^{\text {"259 }}$.

Además, la influencia política trajo consigo la corrupción. Entre los políticos y personajes públicos relacionados con NORTE, que tuvieron escándalos de corrupción destacaron María Cristina de Borbón, José de Salamanca y Francisco Serrano. María Cristina de Borbón, la última esposa de Fernando VII, comenzó a patrocinar gran parte de los negocios empresariales (como el ferrocarril) emergentes en España, de los cuales cobraba jugosas comisiones, que aumentaron su enorme fortuna; fue exiliada de España en 1840. José de Salamanca llegó a tener la mayor fortuna de España, levantada entre otras cosas, a base de pelotazos urbanísticos, especulaciones ventajistas en la Bolsa y tráfico de influencias gracias a sus contactos en la Corte. Francisco Serrano, en plena Guerra Carlista, y ante la proclamación de Alfonso XII como rey de España, huyó a Francia llevándose consigo todo el dinero que le había confiado el rey para pagar al ejército.

\footnotetext{
${ }^{1256}$ Y simultáneamente es Consejero de MZA.

1257 El liberal Amós Salvador fue encomendado por NORTE "para ir a Logroño a enterarse del sumario y preparar las pruebas para destruir los indicios, que según la Audiencia existían" (Actas del Comité de Madrid de NORTE, 13 de mayo de 1904).

1258 También Consejero de MZA.

${ }^{1259}$ El Heraldo de Madrid, 29 de junio de 1903.
} 


\subsubsection{Factores que impidieron la fusión}

La principal razón por la que no se llevó a cabo la fusión fue que NORTE tenía muy poco prestigio entre los altos representantes de MZA.

Los representantes de MZA tenían mal concepto de NORTE, tanto de su servicio y gestión, como de su contabilidad. Este hecho es tan relevante que desbarata todos los aspectos positivos que lo aconsejarían.

En el informe de Víctor Giol, jefe de tráfico de MZA, se concluye que: "NORTE presta un muy mal servicio en las líneas de Almansa a Valencia y Tarragona"1260.

MZA estaba mejor gestionada, con un capital organizativo muy desarrollado, centrado en un gran líder como era Maristany. NORTE tenía el Consejo dividido, con empleados poco eficientes, y con un director como Boix, considerado por la cúpula de MZA, como mal gerente

NORTE realizó unas manipulaciones contables desde el ejercicio 1905. Ello llegó a conocimiento de MZA, por una filtración de la familia Urquijo -que participaba simultáneamente en NORTE y MZA- al presidente del Comité de Madrid de MZA Baüer ${ }^{1261}$.

Además, MZA había sufrido un gran desgaste por la fusión de la Red Catalana, lo que era un gran freno a una posible fusión con otra empresa.

Por todo ello, es posible concluir que, aunque quizás se dejó querer, MZA nunca se planteó en serio la fusión con NORTE.

\subsection{Convenio "Sindicatura general de productos" NORTE-MZA: Comisión Mixta de 1906}

Con el acuerdo de 1870 se inició una fase de entendimiento entre NORTE y MZA; el acuerdo de 1870 fue renovado en 1896, y posteriormente sustituido por otro, el más importante, en 1906.

En el Informe Anual de 1905, NORTE (1906: 34) explica que "durante el ejercicio de 1905 nuestras relaciones con las demás compañías de ferrocarriles se han mantenido en los mismos términos de cordialidad que en los anteriores, proponiéndose estrechar aún más la comunidad de intereses que nos liga con la de Madrid a Zaragoza y a Alicante; propósito que, al realizarse, permitirá mejorar y perfeccionar los servicios en beneficio del público, reportando al mismo tiempo positivas ventajas a las dos compañías". En el Informe Anual de 1906 de

\footnotetext{
1260 "Ferrocarril de Ripoll a Ax les Thermes. Conveniencia de la adquisición o arrendamiento de las líneas de San Juan y de AVT con sus afluentes", Informe de Víctor Giol. Jefe de Servicio Comercial. Barcelona 8 de diciembre de 1904. Documento incluido en AHF, S-103.

${ }^{1261}$ Carta de Baüer a Maristany, 23 de febrero de 1905, AHF S-103.
} 
NORTE (1907: 33) aparece que "desde el ejercicio de 1905 existen unas excelentes relaciones entre MZA y NORTE; relaciones que han dado como resultado un completo acuerdo entre ambas compañías". En el mismo documento, la empresa afirmaba que este acuerdo daría como resultado una mayor rapidez en los transportes, una simplificación de las tarifas y, sobre todo, las compañías obtendrían la apreciable ventaja de no tener que preocuparse de las diferentes direcciones que pudiera tomar el tráfico.

El acuerdo entre NORTE y MZA, denominado de "Sindicatura general de productos", se tomó el 27 de junio de $1906^{1262}$, cuando MZA ya había absorbido totalmente a TBF ${ }^{1263}$. En ese momento se estableció una duración de 25 años, desde el 1 de enero de 1907 hasta el 31 de diciembre de 1931. El convenio sería denunciable por cualquiera de las dos compañías con una antelación de dos años. El contrato se mantuvo hasta 1925, cuando dejó de estar vigente.

El Consejo de NORTE designó a los administradores Borregón y Estibans para que firmasen el Convenio en representación de la compañía, así como para formar parte de la Comisión establecida en el artículo 14 del Convenio, "encargada de asegurar el leal cumplimiento de lo pactado", y a Estibans para que formase parte de la Comisión Mixta para el examen de tarifas a que se refiere el artículo 6 el Convenio ${ }^{1264}$. Por su parte, el Consejo de MZA nombró a Bauer y Maristany para suscribir del Convenio de reparto de productos y formar parte de las Comisiones mixtas a las que se refiere el artículo 6, relativo a las tarifas (para el que se destina a Maristany), y el artículo 14, relativo a las medidas para asegurar el cumplimiento del Convenio (para el que se destina a Bauer y Maristany) ${ }^{1265}$.

El objeto del contrato "Sindicatura general de productos" era regular el transporte combinado de ambas empresas. El acuerdo se basaba en crear un fondo común para los ingresos procedentes del tráfico en sus redes combinadas. Era un contrato público, tanto que en ocasiones el Estado tuvo que dirimir entre las partes, para reconocer deudas. El contrato pretendía buscar, para el transporte de mercancías, la ruta que resultase más económica con arreglo a las tarifas legalmente establecidas, siempre que existiera esa posibilidad.

El aspecto más importante del nuevo pacto (art. 6) consistió en la creación de una Comisión Mixta de las dos compañías para efectuar un seguimiento del Convenio. La Comisión Mixta entre NORTE y MZA se encargaría de resolver la política general de transporte combinado,

\footnotetext{
${ }^{1262}$ El Proyecto del contrato fue firmado por MZA y NORTE el 17 de mayo de 1906.

${ }^{1263}$ Un aspecto fundamental para entender porqué se tomó este acuerdo, fue un viaje a Estados Unidos realizado por Maristany. A su vuelta, escribió que en Estados Unidos, tras muchos años de competencia y de guerra de tarifas, las compañías "han preferido finalmente la coalición entre compañías a la competencia; cada día son menos frecuentes las guerras de tarifas y más permanentes las Asociaciones o los Sindicatos de tráfico" (Maristany, 1906: 28).

${ }^{1264}$ Acta $\mathrm{n}^{\mathbf{0}} 727$ del Libro de actas del Consejo de Administración de NORTE: 15 de junio de 1906.

1265 Todo esto queda reflejado en una carta enviada por el Presidente de MZA al Consejo de NORTE (Acta $n^{\circ}$ 728 del Libro de actas del Consejo de Administración de NORTE: 2 de julio de 1906).
} 
de llegar a acuerdos para el transporte de mercancías específicas, establecer las tarifas nacionales y plantear acuerdos en sus relaciones internacionales ${ }^{1266}$.

El proyecto de Convenio con MZA para la repartición de los productos del tráfico correspondientes a ambas redes fue aprobado por el Comité de Madrid de NORTE y posteriormente remitido al Comité de Barcelona de NORTE por carta el 26 de mayo de 1906. El Comité de Barcelona de NORTE escribió una carta, el 12 de junio de 1906, al Consejo en el que comunicaba la aprobación del proyecto de Convenio ${ }^{1267}$. Con ello el proyecto de Convenio con MZA fue aprobado por los Comités de Madrid, París y Barcelona de NORTE.

El 27 de junio de 1906 se reunieron Bauer y Maristany por MZA, y Borregón y Estibans por NORTE, para firmar el Convenio ${ }^{1268}$, con el objeto de repartir entre ambas empresas los productos provenientes del tráfico de las dos redes, ateniéndose a un coeficiente basado en la proporción de los productos brutos obtenido en los años 1901-1905, ambos inclusive, de cada una de las empresas.

La primera sesión de la Comisión Mixta NORTE-MZA se celebró en el salón del Consejo de NORTE el 30 de junio de $1906^{1269}$. A partir de ese momento la Comisión Mixta gobernó conjuntamente NORTE y MZA. La Comisión Mixta supuso, en la práctica, una manifestación del grado de acuerdo a que habían llegado las dos grandes compañías, que ya funcionaban de facto como un oligopolio (es posible hablar de un duopolio en el ferrocarril español).

Los asistentes a esa primera sesión fueron Bauer, Maristany (MZA), Borregón y Estibans (NORTE), los Directores generales de ambas compañías (Suss por NORTE y Waldman por MZA) y los Jefes de Servicios de la Intervención de NORTE, de MZA y de la red Catalana. En esta reunión se examinaron los trabajos preliminares para la fijación del coeficiente a que se refiere el artículo 2 del Convenio, discutiendo minuciosamente todas las partidas que pudieran ofrecer alguna duda.

Los presentes se comprometieron a realizar una nueva reunión, el 10 de octubre de 1906, para examinar los trabajos definitivos realizados por las Intervenciones para la fijación del coeficiente de reparto ${ }^{1270}$. Un signo de la importancia de los registros contables en la historia ferroviaria es que este coeficiente de reparto de productos se hace en función de los datos incluidos en el Informe Anual del año anterior.

\footnotetext{
1266 Ambas compañías comenzaron a plantear acuerdos en sus relaciones internacionales, a medida que aumentaron los vínculos con los mercados exteriores, especialmente los de Europa central y Portugal. Los vínculos de la Comisión Mixta NORTE-MZA con los mercados exteriores fueron analizados por Vidal Olivares (1995a; 1995b).

${ }^{1267}$ Sesión del Comité de Barcelona: 12 de junio de 1906 y Acta $n^{\circ} 727$ del Libro de Actas del Consejo de Administración de NORTE: 15 de junio de 1906.

${ }^{1268}$ Acta ${ }^{\circ} 728$ del Libro de actas del Consejo de Administración de NORTE: 2 de julio de 1906.

1269 AHF L 0454-0458, Actas de la Comisión Mixta entre MZA y NORTE (1906-1918).

${ }^{1270}$ Acta $^{\mathrm{o}} 728$ del Libro de actas del Consejo de Administración de NORTE: 2 de julio de 1906.
} 
En la reunión de 10 de octubre de 1906, Borregón comunicó al Consejo de NORTE que después de varias reuniones de la Comisión Mixta, los servicios de Intervención de MZA y NORTE acordaron la distribución de los productos, único aspecto que faltaba por determinar. Hasta ese momento existía una diferencia, entre las partes, sobre el producto neto de la explotación, donde se manifestaba un $42 \%$ para MZA y un $58 \%$ para NORTE ${ }^{1271}$. El acuerdo final ratificado por los Comités y Consejos de ambas empresas fue de 46,588\% para MZA y $53,412 \%$ para NORTE ${ }^{1272}$.

El 20 de noviembre de 1906, el presidente del Consejo de MZA dirigió una carta al presidente de NORTE en la que comunicaba que en la Sesión del Consejo de MZA de 12 de octubre de 1906, se había aprobado el coeficiente de productos entre ambas compañías ${ }^{1273}$.

En este proceso se observa cómo el Convenio es aprobado primero por NORTE, que es la que parece más interesada de las dos. Además, en la negociación tuvo que ceder una parte de su porcentaje inicial. Ambos hechos tienen sentido si se analiza la situación económica de NORTE, pues estaba en crisis. En las figuras 1 y 5 podemos observar que NORTE tenía menos viajeros netos y peores resultados contables que MZA, y más cargas financieras que ella. Tan mala era la situación que, a principios de 1906, el director de NORTE, Gustave Bachy, había presentado un plan de ajuste de los efectivos de la plantilla y sus sueldos ${ }^{1274}$.

Las tarifas y combinaciones se adoptarán de común acuerdo. Ambas compañías acordaron que las nuevas tarifas, y las combinadas, fueran prorrateadas por kilómetros. Igual criterio se aplicaría a los billetes extraordinarios aplicados a ferias, fiestas, baños y otros eventos. Así como a la emisión de billetes de favor, de libre circulación, de caridad o de empleados y sus familias. Incluso en el caso de que surgiese otra empresa competidora, ambas sociedades considerarían sus sedes como una sola. En el caso de anexionar nuevas redes o subarrendar tráficos, ambas compañías lo comunicarían, siempre que desvirtuaran o modificaran las corrientes de tráfico establecidas a la firma del convenio.

La Comisión mixta, compuesta por consejeros delegados y directores de las compañías, debía aprobar los proyectos de nuevas tarifas. La gestión de actuaciones comerciales complementarias de las compañías MZA y NORTE, llevó a ambas compañías a adoptar criterios de gestión de tráficos que conjugaran sus intereses. Se sindicaron los repartos de los productos procedentes del tráfico, mediante la creación de un fondo común, donde se aportarían los productos netos de la aplicación de las tarifas, excluyendo cualquier otro ingreso ajeno a este concepto. Los productos que procedan de la aplicación de las tarifas para el público, formarían un fondo común; deducidos los gastos de transporte, calculados en un

\footnotetext{
${ }^{1271}$ Gaceta de los Caminos de Hierro, 1 de septiembre de 1906.

1272 Acta n 730 del Libro de actas del Consejo de Administración de NORTE: 20 de octubre de 1906.

${ }^{1273}$ Acta $\mathrm{n}^{\mathbf{0}} 731$ del Libro de actas del Consejo de Administración de NORTE: 29 de noviembre de 1906.

${ }^{1274}$ Informe sobre cuadros de personal del director Bachy dirigido a los Señores del Comité. Madrid 10 de enero de 1905. Documento incluido en AHF, E-118-4. Cuadros de personal 1905.
} 
$30 \%$, el producto neto se distribuirá entre ambas compañías en la proporción que resulte de los productos brutos que obtuvieron en el quinquenio 1901-1905 ${ }^{1275}$.

La Comisión Mixta realizará un examen y aprobación de proyectos de las compañías para obligar a mejorar el material fijo y móvil de un modo uniforme para que ninguna quede perjudicada y asegurar los tráficos. Esta uniformidad se extiende a los pases y billetes de gracia $^{1276}$. El hecho de que una línea quedara interrumpida por fuerza mayor, no afectaría al Convenio. Ambas compañías decidieron unificar la contabilidad para facilitar la recíproca intervención.

El acuerdo no solo benefició a las compañías, sino también al público, al aplicarse el principio obligatorio de la "distancia mínima" en los transportes, pasando a ser más rápidos y económicos. El tráfico que acuda de una a otra red se computaría como tráfico local.

El Administrador Comisionado de la Red Catalana de MZA envió una carta a la Dirección de NORTE el 27 de enero de 1907 en la que se transmite el acuerdo tomado por el Consejo de Administración de MZA, respecto al Apeadero de San Andrés de la línea de Zaragoza a Barcelona de NORTE. La Comisión Mixta accede a que NORTE construya una apeadero en la línea de Zaragoza a Barcelona, junto a San Andrés del Palomar, bajo condición de que si dejara de regir el Convenio de 27 de junio de 1906, NORTE estará obligada a satisfacer a MZA el importe del producto bruto de todos los transportes que se realizasen por medio de ese apeadero sobre las vías de NORTE entre Moncada y Barcelona, una vez deducido de dicho producto el $30 \%$ desde el día en que dejase de entrar el vigor el Convenio. El Consejo de NORTE acepta en todas las partes el acuerdo del Consejo de MZA sobre el asunto ${ }^{1277}$.

En 1917, MZA solicitó la revisión del tipo del 30\% fijado en el artículo 1 del Convenio de 1906 para el abono de los gastos ocasionados por los transportes respectivamente efectuados ${ }^{1278}$. No se aprobó por la negativa del Informe del Director de NORTE, del Informe de su Comité de París, de la Memoria de Robaglia, Ingeniero Consultor del Comité de París, y de la opinión de Coll y Portabella, representante del Comité de Barcelona ${ }^{1279}$.

\footnotetext{
${ }^{1275}$ La vigilancia del Convenio se llevaría a cabo mediante la creación de un servicio de intervención recíproca, que actuaría por meses y dentro de estos por décadas, sobre la liquidación a aplicar. Gaceta de los Caminos de Hierro, 8 de agosto de 1906.

${ }^{1276}$ ABC (18 de agosto de 1906: 5).

${ }^{1277}$ Acta $\mathrm{n}^{\circ} 733$ del Libro de actas del Consejo de Administración de NORTE: 28 de enero de 1907.

1278 Acta $n^{\circ} 870$ del Libro de actas del Consejo de Administración de NORTE: 30 de noviembre de 1917, Apartado III. Tras la solicitud de MZA, comenzó un proceso de delibreación dentro de la compañía NORTE, y una serie de comunicaciones con MZA (Acta $n^{\circ} 872$ del Libro de actas del Consejo de Administración de NORTE: 8 de enero de 1918, apartado VII). Carta del Presidente de MZA al Presidente de NORTE, fechada el 11 de marzo de 1918, y la fechada 18 de abril de 1918 (Acta $n^{\circ} 876$ del Libro de actas del Consejo de Administración de NORTE: 20 de abril de 1918, Apartado IV).

${ }^{1279}$ Carta del Presidente de NORTE al de MZA, fechada el 10 de abril de 1908 (Acta n $^{\circ} 873$ del Libro de actas del Consejo de Administración de NORTE: 22 de enero de 1918, Apartado IV).
} 
El presidente del Consejo de MZA enviaba cartas al Consejo de NORTE indicando que había aprobado todas las actas de la Comisión Mixta ${ }^{1280}$. Por su parte, el Consejo de NORTE aprobó todas las actas a excepción de las adoptadas en las Sesiones celebradas los días 13 y 14 de diciembre de 1906, refundiendo en uno sólo los artículos 4 y 6 del contrato de 27 de junio de 1906 por estimar que debe aplazarse para más adelante esta modificación del mencionado contrato ${ }^{1281}$. Esta es la primera desavenencia de la Comisión Mixta.

La entrada en vigor de la Sindicatura posibilitó que ambas compañías realizaran multitud de irregularidades ofreciendo a los remitentes, bajo mano, precios más bajos a los establecidos en las tarifas ${ }^{1282}$.

Las consecuencias de la existencia de la Comisión Mixta fueron tres: la situación económica y de gestión de NORTE mejoró, su posición común frente al Estado se fortaleció y los lazos entre las compañías fueron más fuertes para tomar posiciones comunes.

La Comisión Mixta trajo prosperidad a NORTE, porque abrió un periodo de bonanza que se prolongó hasta el comienzo de la I Guerra Mundial. Tanto es así que restituyó el dividendo a los accionistas.

En la Junta General de Accionistas de abril de 1907, los accionistas de NORTE profirieron "manifestaciones halagüeñas de los accionistas,.... en vista de la próspera situación revelada en la Memoria"1283. El mismo año, Barat felicita al Consejo y a la Dirección por "el acierto que han demostrado en la administración y gerencia de la compañía, acierto que la ha conducido a un estado de prosperidad por todos conceptos, y a una situación de bienestar en el personal, que es el medio más eficaz para la buena marcha del servicio y el buen crédito de la empresa"1284.

La situación de la caja empezó a ser bollante, lo cual hizo que quisiera mostrarla. El 28 de junio de 1907 es la primera vez que se incorpora en el Libro de Actas del Consejo de Administración de NORTE la situación de la caja de NORTE, tanto en España como en París. La situación de la caja de NORTE en España el 21 de junio de 1907 arroja las siguientes cifras: 5.318.225,24 en el Banco Español de Crédito, 54.865,93 en la Caja Central, 2.797.816,4 en el Crédito Mercantil de Barcelona y 2.000.000 en el Urquijo y Compañía. La situación de la caja de NORTE en París el 19 de junio de 1907 arroja las siguientes cifras: 7.961.039,83 en el Banco Español de Crédito en francos y 1.772.332,31 en la cuenta corriente. Respecto a los títulos a disposición, hay valores de diferentes clases, por un valor nominal de 10.490 .000 pesetas en Madrid y 2.132.877,77 en París ${ }^{1285}$.

\footnotetext{
${ }^{1280}$ Acta $\mathrm{n}^{\mathrm{0}} 734$ del Libro de actas del Consejo de Administración de NORTE: 28 de febrero de 1907.

${ }^{1281}$ Acta n 734 del Libro de actas del Consejo de Administración de NORTE: 28 de febrero de 1907.

1282 Ortúñez (1999a: 449) supone que en esas prácticas debió prodigarse más NORTE.

${ }^{1283}$ Acta n 738 del Libro de actas del Consejo de Administración de NORTE: 11 de mayo de 1907.

${ }^{1284}$ Acta $n^{\circ} 740$ del Libro de actas del Consejo de Administración de NORTE: 28 de junio de 1907.

${ }^{1285}$ Acta n 740 del Libro de actas del Consejo de Administración de NORTE: 28 de junio de 1907.
} 
Además de la prosperidad económica, el Convenio trajo más fuerza en su lucha de poder frente al Estado, sobre todo en la gestión del cobro de los créditos por transportes contra el Estado. El presidente del Consejo de Ministros consideró sus reivindicaciones como legítimas, y se comprometió a buscar los medios de atender las obligaciones y buscar los medios para evitar los retrasos en el futuro ${ }^{1286}$.

La Comisión Mixta fue creada para el "desarrollo de los intereses comunes de las dos compañías" (Acta n ${ }^{0} 781$ del Libro de actas del Consejo de Administración de NORTE: 25 de noviembre de 1910, Apartado II.4). Desde ese momento creció la colaboración con MZA, y de la cual hay muchos ejemplos.

El candidato que propone NORTE para representar a las compañías de ferrocarriles en la Comisión creada por el Ministerio de Fomento, denominada "Comisión encargada de redactar el Reglamento para la aplicación de la Ley de comunicaciones marítimas" (Real Orden 18 de mayo de 1909), está consensuado con MZA (Acta $n^{\circ} 764$ del Libro de actas del Consejo de Administración de NORTE: 23 de junio de 1909: Apartado IV). En la Sesión de 1 de julio de 1909, el presidente de NORTE da cuenta al Consejo de Administración del candidato elegido de acuerdo con el Consejo. El Candidato elegido fue Federico de Arriaga, jefe de Servicio de lo Contencioso de MZA (Acta $n^{\circ} 765$ del Libro de actas del Consejo de Administración de NORTE: 1 de julio de 1909: Apartado IV).

MZA y NORTE nombran juntos a los Delegados de la Dirección General de Correos y Telégrafos (Acta de la Comisión Mixta: 4 de octubre de 1910 y Acta n 781 del Libro de actas del Consejo de Administración de NORTE: 25 de noviembre de 1910, Apartado II.4).

\subsection{Intento de fusión NORTE-MZA de 1919}

El segundo intento de llevar a cabo una fusión se planteó en junio de 1919 (mientras la Sindicatura estaba vigente). Esta posibilidad de fusión fue la más interesante porque la de 1904 fue muy prematura y porque la de 1931 se intentó realizar cuando la nacionalización parecía inevitable.

Entre 1914 y 1919 las ferroviarias estaban inmersas en la crisis identificada como problema ferroviario estricto. La citada crisis supuso, para las compañías de ferrocarril, unas dificultades que muchas no consiguieron salvar, y las que lo lograron quedaron económicamente muy perjudicadas. En este entorno, con un futuro incierto en el que no se sabía cuándo se podría salir de la crisis, ambas compañías se plantearon sumar sus fuerzas.

La iniciativa de fusión vino de NORTE. En 1919, NORTE comenzó a remontar las dificultades económicas por las que había atravesado en los dos ejercicios anteriores. En esta situación, inició maniobras de aproximación para un entendimiento con MZA. Ortúñez (1999b: 283) considera que con este intento de fusión, NORTE "intentaba plantar más resistencia al Estado ante sus envites intervencionistas".

${ }^{1286}$ Acta ${ }^{\mathrm{o}} 724$ del Libro de actas del Consejo de Administración de NORTE: 30 de abril de 1906. 
En concreto, el intento de fusión tuvo su origen en dos de los grupos de poder de NORTE: el grupo de Bilbao en mayo de 1919, y conjuntamente Mauricio Péreire y el Marqués de Comillas en junio de 1919.

Durante la I Guerra Mundial, el capital vasco obtuvo enormes beneficios. Algunos de los más acaudalados invirtieron en ferroviarias. En el caso de NORTE, el capital estaba muy concentrado, tanto que en Bilbao se reunieron el 20,3\% (105.000/516.000) de sus acciones en 1919. Estos inversores pretendían absorber la dirección de la compañía y dar la batalla a Faustino Rodríguez San Pedro.

En los años anteriores a 1919, los Consejos de Administración de NORTE trataron de equilibrar la representación y la gestión entre personas procedentes de los principales grupos de accionistas y obligacionistas, y los profesionales de la banca y la industria ${ }^{1287}$. En esa época, el Comité de Madrid y de Barcelona de NORTE se llenó de representantes procedentes del País Vasco, tanto de la de la industria (José Antonio de Ibarra y Arregui y Martín de Zavala), como de la banca (Estanislao de Urquijo y Ussía "III Marqués de Urquijo", Joaquín de Robert y Carles "II Conde de Torroella de Montgrí" e Ignacio Coll y Portabella). Algunos de los empresarios vascos que entraron en el Consejo de NORTE eran también Consejeros de los Bancos de Bilbao y Vizcaya ${ }^{1288}$, entre los que destacan, Julio de Arteche, Ramón de la Sota $^{1289}$, Valentín Ruiz Senén, Julio Sánchez de León e Igual y Enrique Ocharán ${ }^{1290}$.

El año 1919 revistió un gran interés para la historia de NORTE ${ }^{1291}$. La empresa cambió de presidente del Consejo de Administración, Faustino Rodríguez San Pedro dejó su puesto al Marqués de Alonso Martínez; no obstante algunos accionistas (pocos en número, pero con un capital total de 105.000 acciones de NORTE), representantes del grupo de Bilbao, le habían ofrecido el puesto a Eduardo Maristany (Director general de MZA), con idea de llegar así, posteriormente, con mayor facilidad a la fusión de MZA y NORTE.

La propuesta de fusión por parte de NORTE fue realizada a Maristany. Aunque Maristany no precisara quien le había hecho tal proposición, hay que pensar en el entorno de Bilbao. Entre las personas más probables son las que salieron elegidos en la convulsa junta general de NORTE, celebrada el 17 de mayo de 1919. En la citada junta general, los "señores de Bilbao" presentaron batalla atacando duramente la gestión de Faustino Rodríguez San Pedro, calificándolo de "inepto y fracasado"; sólo consiguieron uno de los cuatro objetivos que pretendían: fueron nombrados tres consejeros de su grupo, con lo cual a partir de ese

\footnotetext{
${ }^{1287}$ Para la composición de los Consejos de Administración véase The Directory Publishing Company Limited (1937) y NORTE (1940).

${ }^{1288}$ Esto fue señalado por Comín, et al. (1998: 318).

${ }^{1289}$ Ramón de la Sota fue analizado por Torres Villanueva (1996).

1290 Enrique Ocharán Rodríguez redactaba sus artículos en la prensa firmando con los dos cargos de presidente del Banco de Vizcaya y Consejero de NORTE ("El Liberal” de Bilbao: 10 de julio de 1920).

${ }^{1291}$ Las estrategias en los movimientos de capital, directivos y negocios que se produjeron en los intentos de fusión entre MZA y NORTE fueron analizados por Ortúñez (1999b: 445-459).
} 
momento, "los de Bilbao" eran siete consejeros ${ }^{1292}$. Sin embargo, no consiguieron el resto de sus propósitos: la creación de un Comité de Bilbao, la ampliación de mayor número de Consejeros y derribar a Faustino [quien cayó poco después] con la deserción a última hora de un grupo de Barcelona y con la ausencia de Urquijo que aportaba el 1,7\% de sus acciones $(9.000 / 516.000)^{1293}$.

A los pocos días, el mismo junio de 1919, Roberto Ellisen, en nombre de Mauricio Péreire y del Marqués de Comillas, volvió a plantear a Maristany que estudiase lo conveniente que sería la fusión de las dos grandes compañías.

La posibilidad de la fusión ya estaba planteada en firme por segunda vez en un mes. La iniciativa fue tomada por NORTE y la decisión final estaba en las manos de MZA. Maristany cursó la información a una parte de los miembros de la Comisión Delegada, el presidente del Consejo, Bauer, y al Comité de París a través de Lisle (Consejero de MZA entre 1906-1934). Lisle y Bauer decidieron no aceptar la fusión, pero querían conservar buenas relaciones con NORTE, y sobre todo mantener la Sindicatura de 1906.

Sin embargo, la decisión tomada por Lisle y Bauer estuvo motivada en gran parte por los propios prejuicios de Maristany hacia la fusión con NORTE. El 30 de junio de 1919, Maristany envió una carta al Comité de París de MZA en el que argumentaba en contra de la fusión: "las entrevistas que hemos celebrado con los señores de NORTE sobre otros asuntos me han confirmado una vez más que no hay manera de entenderse con ellos. Y la última carta recibida de D. Faustino sobre los gastos de transporte ${ }^{1294}$, convencerán igualmente a usted de que no hay posibilidad de llegar a un acuerdo con dicha compañía. Considero pues que aquel asunto no debe preocuparnos más y debe ser descartado definitivamente" ${ }^{\text {1295. }}$.

\subsubsection{Factores favorables a la fusión}

\subsubsection{Acercamiento al poder político}

Las conexiones con el gobierno y con la Administración pública fueron siempre importantes, incluso tras la aprobación del Estatuto ferroviario en 1924 las compañías tuvieron que seguir cuidando sus influencias sobre el aparato del Estado.

El reconocimiento público de las relaciones entre el poder político y las ferroviarias tuvieron sus mayores manifestaciones en el momento de la concesión del anticipo a las ferroviarias.

\footnotetext{
1292 Archivo de Renfe. Caja/número 36/expediente 97 (C/36/97). Intento para llegar a una inteligencia con NORTE, junio de 1919. Carta de E. Maristany a R. Lisle del Comité de París de MZA, 3 de junio de 1919.

1293 Archivo de Renfe. Caja/número 36/expediente 97 (C/36/97). Intento para llegar a una inteligencia con NORTE, junio de 1919. Carta de E. Maristany a R. Lisle del Comité de París de MZA, 3 de junio de 1919.

${ }^{1294}$ Esta última carta recibida de Faustino Rodríguez San Pedro sobre los gastos de transporte, no aparece entre la documentación del Archivo Ferroviario.

${ }^{1295}$ Carta de E. Maristany a R. Lisle del Comité de París de MZA, 30 de junio de 1919.
} 
En la Sesión del martes 23 de marzo de 1920, Juan de la Cierva afirmó en el Congreso de los Diputados que "la opinión pública conoce bien la estrecha y constante, aunque extraña, relación que las concesionarias mantienen con los políticos y con el propio Gobierno, cuya connivencia con aquellas es evidente" ${ }^{, 1296}$.

Más dura aún fue la intervención, dos días más tarde, del diputado socialista Menéndez quien denunció la captura del Estado por el lobby ferroviario; tildó de "mercenarios" a los ministros, diputados y senadores involucrados en los negocios ferroviarios; y además, criticó duramente al gobierno y a los miembros del hemiciclo por el "descarado apoyo a las ferroviarias"1297. Pero sobre todo, lo más importante es que los nombró, indicando datos concretos como el cargo, la ferroviaria en cuestión e incluso el tipo de relaciones que existían ${ }^{1298}$.

Todos estos datos deben encuadrarse dentro de visiones parciales de políticos dentro del juego de reproches parlamentarios. Aún así la influencia de los apoyos políticos, aunque cierta y real, no fue tan grande pues nunca lograron que se aumentaran las tarifas, que era el gran anhelo de las ferroviarias (teniendo en cuenta, además, que las ferroviarias tenían razón en que el aumento de tarifas hubiese sido razonable por lo que muchas de las críticas de la opinión pública no tenían sentido). Es más, igual que parte de la clase política apoyaba a los ferrocarriles, como hemos visto, otra parte de los políticos españoles eran contrarios, y si a unos les otorgamos unos posibles beneficios económicos o sociales por defenderlos, podemos suponer que por atacarlos podrían tener beneficios similares.

El cuadro 86 recoge el nombre de los políticos que figuraban en los Consejos de Administración de las compañías ferroviarias y que se hicieron públicos en las intervenciones de los diputados Menéndez y Savorit en el Congreso de los Diputados en $1920^{1299}$ :

\footnotetext{
${ }^{1296}$ Intervención de J. de la Cierva en la Sesión celebrada en el Congreso de los Diputados el martes 23 de marzo de 1920, legislatura 1919-1920 (Diario de las Sesiones de Cortes en el Congreso de los Diputados, $\mathrm{n}^{\mathbf{o}}$ 92), pp. 5121-5122.

${ }^{1297}$ Intervención de T. Menéndez en la Sesión celebrada en el Congreso de los Diputados el jueves 25 de marzo de 1920, legislatura 1919-1920 (Diario de las Sesiones de Cortes en el Congreso de los Diputados, $\mathrm{n}^{\circ}$ 94), pp. 5331-5332.

1298 "Los intereses del país jámás podrán ser defendidos por un Parlamento que envía aquí a sus representados, a sus empleados, a sus mercenarios, para oponerse a los intereses del país y defender los intereses de las Compañías Privadas". Vid. Intervención de T. Menéndez en la Sesión celebrada en el Congreso de los Diputados el jueves 25 de marzo de 1920, legislatura 1919-1920 (Diario de las Sesiones de Cortes en el Congreso de los Diputados, no 94), pp. 5331-5332.

${ }^{1299}$ Intervención de T. Menéndez en la Sesión celebrada en el Congreso de los Diputados el jueves 25 de marzo de 1920, legislatura 1919-1920 (Diario de las Sesiones de Cortes en el Congreso de los Diputados, $\mathrm{n}^{\circ}$ 94), pp. 5331-5332.
} 


\section{Cuadro 86. Personas que compatibilizaban cargos públicos y privados en las ferroviarias en 1920}

\begin{tabular}{|c|c|}
\hline COMPAÑ́́A & CARGO EN LA FERROVIARIA Y EN LA ADMINISTRACIÓN PÚBLICA \\
\hline Andaluces & $\begin{array}{l}\text { Consejero: Sr. Marqués de Santillaná, Senador } \\
\text { Abogado consultor: D. Francisco Bergamín, Senador }\end{array}$ \\
\hline $\begin{array}{l}\text { Madrid, Cáceres } \quad \mathbf{y} \\
\text { Portugal }\end{array}$ & $\begin{array}{l}\text { Administrador: Marqués de Cortina, Senador } \\
\text { Administrador: D. Manuel Urquijo (Marqués de Urquijo), Senador } \\
\text { Administrador: Luis Urquijo, Diputado } \\
\text { Administrador: Marqués de Fontalba, Senador } \\
\text { Administrador: Gil Becerril, Senador } \\
\text { Administrador: Conde de Ganiago, Diputado } \\
\text { Administrador: Gil y Biedma, Diputado }\end{array}$ \\
\hline MZA & $\begin{array}{l}\text { Presidente del Consejo de Administración: Alvarado, Diputado } \\
\text { Consejero: José Canalejas, Presidente del Gobierno } \\
\text { Consejero: Conde de Romanones, Presidente del Gobierno } \\
\text { Consejero: Eduardo Dato, Presidente del Gobierno } \\
\text { Consejero: Conde de Bugallal, Diputado y ministro de Hacienda } \\
\text { Consejero: Amós Salvador, ministro de Hacienda e ingeniero consultor } \\
\text { Consejero: Conde de Romanones, ministro de la Guerra } \\
\text { Consejero: Marqués de Santa María de Silvela, Senador } \\
\text { Consejero: Conde de San Luis, Diputado } \\
\text { Consejero: Juan Manuel Urquijo, Senador } \\
\text { Consejero: Juan Cervantes Diputado, hermano de José María Cervantes, también Diputado } \\
\text { Secretario: Eugenio Espinosa de los Monteros, yerno de Eduardo Dato } \\
\text { Letrado: Félix Sánchez Eznarriaga, yerno de Tirso Rodríguez, Senador } \\
\text { Letrado: Tomás Silvela y Loring, Diputado } \\
\text { Empleado: Raboso, Diputado. }\end{array}$ \\
\hline $\begin{array}{l}\text { Caminos de Hierro del } \\
\text { Norte de España }\end{array}$ & $\begin{array}{l}\text { Consejero: Rodríguez San Pedro, Senador } \\
\text { Consejero: Vicente Alonso Martínez, Senador } \\
\text { Consejero: Martín Zaha1a, Senador } \\
\text { Consejero: Trinitario Ruiz Valarino. Senador } \\
\text { Consejero: Estanislao Urquijo, Senador } \\
\text { Consejero: Conde de Bernar, cuñado del Presidente del Consejo de Ministros Allendesalazar } \\
\text { Administrador: Conde de Gamazo, Senador } \\
\text { Contencioso: Cirilo Tornos, hijo del Magistrado del Supremo Tornos. }\end{array}$ \\
\hline $\begin{array}{l}\text { Medina del Campo a } \\
\text { Zamora }\end{array}$ & $\begin{array}{l}\text { Consejero: Angel Urzáiz, Diputado } \\
\text { Consejero: Angel Galarza, Senador }\end{array}$ \\
\hline Central de Aragón & $\begin{array}{l}\text { Consejero: Félix Suárez Inc1án, Diputado } \\
\text { Consejero: Conde de Albay, Senador } \\
\text { Consejero: Sánchez de Toca, Senador } \\
\text { Consejero: Marqués de Lema, Diputado y ministro de Estado }\end{array}$ \\
\hline Zafra a Huelva & Consejero: Marqués de Valdeiglesias, Senador \\
\hline $\begin{array}{l}\text { Ferrocarril de La } \\
\text { Carolina }\end{array}$ & $\begin{array}{l}\text { Consejero: Conde de Romanones, Diputado } \\
\text { Consejero: José del Prado Palacio, Diputado }\end{array}$ \\
\hline $\begin{array}{l}\text { Ferrocarril de Málaga a } \\
\text { Algeciras y Cádiz }\end{array}$ & $\begin{array}{l}\text { Consejero: Duque de Bivona, Senador } \\
\text { Consejero: Marqués de Santa María de Silvela, Senador }\end{array}$ \\
\hline $\begin{array}{l}\text { Ferrocarril de Peñarroya } \\
\text { a Fuente del Arcó y a } \\
\text { Conquista }\end{array}$ & $\begin{array}{l}\text { Consejero: Conde de Romanones, Diputado } \\
\text { Consejero: Duque de las Torres, Senador, hermano del Conde de Romanones }\end{array}$ \\
\hline Lorca a Baza & Consejero: Duque de 1as Torres (Marqués de Santillana), Senador \\
\hline $\begin{array}{l}\text { Medina del Campo a } \\
\text { Salamanca }\end{array}$ & $\begin{array}{l}\text { Vicepresidente: Conde del Moral de Calatrava, Senador, suegro de D. Miguel Maura y } \\
\text { Gamazo, Díputado }\end{array}$ \\
\hline Argamasilla a Tomelloso & $\begin{array}{l}\text { Enrique Navarro Reverter, hijo de Juan Navárro Reverter, Senador, y hermano del Diputado } \\
\text { Juan Navarro Reverter }\end{array}$ \\
\hline Bilbao a Portugalete & $\begin{array}{l}\text { Administrador: D. Manuel Urquijo (Marqués de Urquijo), Senador } \\
\text { Administrador: Juan J. Gandarias, Senador }\end{array}$ \\
\hline
\end{tabular}




\begin{tabular}{|l|l|}
\hline Ferrocarril de Soria & Duque del Infantado, Senador \\
\hline Ferrocarril Cantábrico & César de la Mora, Diputado \\
\hline Ferrocarril de Tajuña & $\begin{array}{l}\text { Duque de Pastrana, Diputado, yerno del Conde de Romanones } \\
\text { José del Prado Palacio, Diputado } \\
\text { Manuel Brocas, Diputado }\end{array}$ \\
\hline $\begin{array}{l}\text { Linea de Alicante a } \\
\text { Villajoyosa y Villajoyosa } \\
\text { a Denia }\end{array}$ & $\begin{array}{l}\text { José Francos Rodríguez, Diputado } \\
\text { Salvador Canals, Diputado y Subsecretario de la Presidencia } \\
\text { Federico Loygorri, Diputado } \\
\text { Martín Rosales, Diputado }\end{array}$ \\
\hline $\begin{array}{l}\text { Caminos de Hierro del } \\
\text { Sur de España }\end{array}$ & José Francos Rodríguez, Diputado \\
\hline $\begin{array}{l}\text { Ferrocarril de Langreo } \\
\text { Marqués de Villaviciosa, Senador } \\
\text { Conde de Mieres, Diputado } \\
\text { Jorge Silvela. Diputado } \\
\text { Germán de la Mora, yerno de Maura }\end{array}$ \\
\hline $\begin{array}{l}\text { Ferrocarril de Saldaña a } \\
\text { Gallur }\end{array}$ & Basilio Paraíso, Senador \\
\hline $\begin{array}{l}\text { Ferrocarril de Haro a } \\
\text { Ezcaray }\end{array}$ & Juan Bautista Tejada, Senador \\
\hline
\end{tabular}

Fuente: Elaboración propia a partir de la exposición de Menéndez y Savorit en el Congreso de los Diputados 1300

La respuesta de los grupos aludidos no se hizo esperar. Los consejeros de las empresas, entre los que se encontraban personalidades de la banca y la industria como los marqueses de Alonso Martínez, Comillas, Aldama y Guadalmina, los condes de Gamazo y de los Gaitanes, E. Ocharán, Alvarado, J. Alfredo Loewe, M. y T. de Urquijo, Alfredo e Ignacio Bauer y José A. Ibarra dieron a La Cierva una respuesta concisa, limitándose a recordarle que existían tribunales de justicia donde "deben discutirse y resolverse las cuestiones de esta índole"1301.

El periodo 1918-1923 coincidió con un momento particularmente tormentoso de la vida política y social de España. En los cinco años y cuatro meses que van desde el "gobierno nacional" de Maura (22 de marzo de 1918), del que fue ministro de Fomento Cambó, hasta el golpe militar de Primo de Rivera (13 de septiembre de 1923) se sucedieron doce gobiernos, numerosos ministros (la cartera de Fomento cambió 15 veces) y tres elecciones generales a Cortes, con tres parlamentos diferentes ${ }^{1302}$.

El cuadro 87 muestra la relación de las ferroviarias con el poder político en el periodo 19051923. Al lado de los presidentes y ministros relacionados con el ferrocarril, aparece entre paréntesis la empresa a la que pertenecía. Se puede observar que en casi todos los gobiernos

\footnotetext{
${ }^{1300}$ Intervención de T. Menéndez en la Sesión celebrada en el Congreso de los Diputados el jueves 25 de marzo de 1920, legislatura 1919-1920 (Diario de las Sesiones de Cortes en el Congreso de los Diputados, $\mathrm{n}^{\circ}$ 94), pp. 5331-5332. La vinculación entre los ministros y los Consejeros de las ferroviarias puede observarse en la Intervención de Savorit en la Sesión celebrada en el Congreso de los Diputados el martes 23 de marzo de 1920, legislatura 1919-1920 (Diario de las Sesiones de Cortes en el Congreso de los Diputados, no 92), p. 5232.

${ }^{1301}$ Gaceta de los Caminos de Hierro, 1 de abril de 1920.

1302 "Por reconocida que sea la capacidad y voluntad de los ministros que hayan de formular la nueva ley [Ordenación Ferroviaria], es indudable que la inestabilidad de nuestras situaciones políticas no han de permitir a ninguno de ellos dar cima a tan capital tarea" (Un ingeniero, 1923: 62).
} 
existieron relaciones del más alto nivel con las ferroviarias, independientemente del color político que tuvieran. Lo que hubo después de 1923 es una influencia más directa aún. El 13 de septiembre de 1923 comienza el Directorio Militar provisional de Miguel Primo de Rivera, mientras que el 17 de septiembre de 1923 se inicia el Segundo Directorio Militar, con una clara influencia sobre la industria ferroviaria y con una decidida motivación de resolver el problema ferroviario.

\section{Cuadro 87. Relación de las ferroviarias con el gobierno (1905-1923)}

\begin{tabular}{|c|c|c|c|c|}
\hline & PRESIDENCIA & HACIENDA & FOMENTO & OTROS MINISTROS \\
\hline 1/12/1905 & $\begin{array}{l}\text { Segismundo Moret } \\
\text { (Liberal) }\end{array}$ & Amos Salvador (MZA) & Rafael Gasset & \\
\hline 9/6/1906 & $\begin{array}{l}\text { Segismundo Moret } \\
\text { (Liberal) }\end{array}$ & Amos Salvador (MZA) & Rafael Gasset & \\
\hline $6 / 7 / 1906$ & $\begin{array}{l}\text { José López } \\
\text { Domínguez (Liberal) }\end{array}$ & Juan Navarro Reverter & - & \\
\hline 30/11/1906 & $\begin{array}{l}\text { Segismundo Moret } \\
\text { (Liberal) }\end{array}$ & Eleuterio Delgado & Rafael Gasset & \\
\hline 4/12/1906 & $\begin{array}{l}\text { Marqués de la Vega de } \\
\text { Armigo } \\
\text { (Liberal) }\end{array}$ & Juan Navarro Reverter & Francisco de Federico & \\
\hline $25 / 1 / 1907$ & Conservador & $\begin{array}{l}\text { Joaquín Osma } \\
\text { luego Cayetano Sánchez Bustillo y } \\
\text { Augusto González Besada }\end{array}$ & $\begin{array}{l}\text { Augusto González } \\
\text { Besada }\end{array}$ & $\begin{array}{l}\text { Gobernación: Juan de la } \\
\text { Cierva }\end{array}$ \\
\hline 21/10/1909 & $\begin{array}{l}\text { Segismundo Moret } \\
\text { (Liberal) }\end{array}$ & Juan Alvarado & Rafael Gasset & \\
\hline 9/2/1910 & $\begin{array}{l}\text { José Canalejas } \\
\text { (Liberal) (MZA) }\end{array}$ & $\begin{array}{l}\text { Eduardo Cobían } \\
\text { luego Tirso Rodrigáñez y luego } \\
\text { Juan Navarro Reverter }\end{array}$ & $\begin{array}{l}\text { Fermín Calbetón } \\
\text { luego Rafael Gasset }\end{array}$ & \\
\hline 15/11/1912 & $\begin{array}{l}\text { Conde de Romanones } \\
\text { (Liberal) (MZA) }\end{array}$ & Gabino Bugallal (MZA) & $\begin{array}{l}\text { Miguel Villanueva } \\
\text { luego Rafael Gasset }\end{array}$ & \\
\hline 27/10/1913 & $\begin{array}{l}\text { Eduardo Dato } \\
\text { (Conservador) (MZA) }\end{array}$ & Gabino Bugallal (MZA) & $\begin{array}{l}\text { Francisco Ugarte } \\
\text { luego Luis Espada }\end{array}$ & \\
\hline 9/12/1915 & $\begin{array}{l}\text { Conde de Romanones } \\
\text { (Liberal) (MZA) }\end{array}$ & $\begin{array}{l}\text { Ángel Urzáiz } \\
\text { luego Miguel Villanueva }\end{array}$ & $\begin{array}{l}\text { Amos Salvador (MZA) } \\
\text { luego Rafael Gasset }\end{array}$ & \\
\hline 20/4/1917 & $\begin{array}{l}\text { Manuel García Prieto } \\
\text { (Liberal Demócrata) }\end{array}$ & Santiago Alba & $\begin{array}{l}\text { Duque de Almodóvar del } \\
\text { Valle }\end{array}$ & \\
\hline 11/6/1917 & $\begin{array}{l}\text { Eduardo Dato } \\
\text { (Conservador) (MZA) }\end{array}$ & Gabino Bugallal (MZA) & Vizconde de Eza & \\
\hline 1/11/1917 & $\begin{array}{l}\text { Manuel García Prieto } \\
\text { (Liberal Demócrata) }\end{array}$ & $\begin{array}{l}\text { Juan Ventosa } \\
\text { (LLiga Regionalista) } \\
\text { luego Conde de Caralt }\end{array}$ & $\begin{array}{l}\text { Duque de Almodóvar del } \\
\text { Valle }\end{array}$ & Guerra: Juan de la Cierva \\
\hline 21/3/1918 & $\begin{array}{l}\text { Antonio Maura } \\
\text { (Conservador) }\end{array}$ & Augusto González Besada & $\begin{array}{l}\text { Francisco Cambó } \\
\text { (LLiga Regionalista) }\end{array}$ & \\
\hline 9/11/1918 & $\begin{array}{l}\text { Manuel García Prieto } \\
\text { (Liberal Demócrata) }\end{array}$ & - & $\begin{array}{l}\text { Manuel García Prieto } \\
\text { (Liberal Demócrata) }\end{array}$ & \\
\hline $5 / 12 / 1918$ & $\begin{array}{l}\text { Antonio Maura } \\
\text { (Conservador) }\end{array}$ & $\begin{array}{l}\text { Juan de la Cierva } \\
\text { (Conservador independiente) }\end{array}$ & $\begin{array}{l}\text { Ángel Ossorio Gallardo } \\
\text { (Maurista) }\end{array}$ & \\
\hline 19/7/1919 & $\begin{array}{l}\text { Joaquín Sánchez de } \\
\text { Toca } \\
\text { (Conservador) }\end{array}$ & $\begin{array}{l}\text { Gabino Bugallal } \\
\text { (Conservador) (MZA) }\end{array}$ & $\begin{array}{l}\text { Abilio Calderón } \\
\text { (Conservador) }\end{array}$ & \\
\hline $12 / 12 / 1919$ & $\begin{array}{l}\text { Manuel Allendesalazar } \\
\text { (Maurista) }\end{array}$ & $\begin{array}{l}\text { Gabino Bugallal } \\
\text { (Conservador) (MZA) }\end{array}$ & $\begin{array}{l}\text { Amalio Gimeno } \\
\text { (Liberal Demócrata) } \\
\text { luego Emilio Ortuño } \\
\text { (Conservador) }\end{array}$ & $\begin{array}{l}\text { de Estado: Marqués de Lema } \\
\text { (Central de Aragón) }\end{array}$ \\
\hline $5 / 5 / 1920$ & $\begin{array}{l}\text { Eduardo Dato } \\
\text { (Conservador) (MZA) }\end{array}$ & $\begin{array}{l}\text { Lorenzo Domínguez Pascual } \\
\text { (Conservador) }\end{array}$ & $\begin{array}{l}\text { Emilio Ortuño } \\
\text { (Conservador) }\end{array}$ & \\
\hline
\end{tabular}




\begin{tabular}{|c|c|c|c|c|}
\hline & & $\begin{array}{l}\text { luego Manuel Arguelles } \\
\text { (Conservador) }\end{array}$ & $\begin{array}{l}\text { luego L. Espada } \\
\text { (Conservador) }\end{array}$ & \\
\hline $12 / 3 / 1921$ & $\begin{array}{l}\text { Manuel Allendesalazar } \\
\text { (Maurista) }\end{array}$ & $\begin{array}{l}\text { Manuel Arguelles } \\
\text { (Conservador) } \\
\text { Luego Mariano Ordóñez } \\
\text { (Conservador) }\end{array}$ & $\begin{array}{l}\text { Juan de la Cierva } \\
\text { (Conservador } \\
\text { independiente) }\end{array}$ & \\
\hline $13 / 8 / 1921$ & $\begin{array}{l}\text { Antonio Maura } \\
\text { (Conservador) }\end{array}$ & $\begin{array}{l}\text { Francisco Cambó } \\
\text { (LLiga Regionalista) }\end{array}$ & $\begin{array}{l}\text { José Maestre } \\
\text { (Conservador } \\
\text { independiente) }\end{array}$ & $\begin{array}{l}\text { Guerra: Juan de la Cierva } \\
\text { (Conservador independiente) }\end{array}$ \\
\hline $8 / 3 / 1922$ & $\begin{array}{l}\text { José Sánchez Guerra } \\
\text { (Conservador) }\end{array}$ & $\begin{array}{l}\text { Francisco Bergamín } \\
\text { (Conservador) } \\
\text { luego Juan José Ruano } \\
\text { (Conservador) }\end{array}$ & $\begin{array}{l}\text { Manuel Arguelles } \\
\text { (Conservador) } \\
\text { luego Luis R. de Viguri } \\
\text { (Conservador) }\end{array}$ & \\
\hline $1 / 9 / 1922$ & $\begin{array}{l}\text { Manuel García Prieto } \\
\text { (Liberal Demócrata) }\end{array}$ & $\begin{array}{l}\text { Santiago Alba } \\
\text { (Izquierda Liberal) }\end{array}$ & $\begin{array}{l}\text { Luis de Armiñán } \\
\text { (Izquierda Liberal) }\end{array}$ & \\
\hline $7 / 12 / 1922$ & $\begin{array}{l}\text { Manuel García Prieto } \\
\text { (Liberal Demócrata) }\end{array}$ & $\begin{array}{l}\text { José Manuel Pedregal (Partido } \\
\text { Reformista) }\end{array}$ & $\begin{array}{l}\text { Rafael Gasset (Liberal } \\
\text { Independiente) }\end{array}$ & $\begin{array}{l}\text { Guerra: } \\
\text { Niceto Alcalá-Zamora } \\
\text { (Liberal Independiente) } \\
\text { de Estado: } \\
\text { Conde de Romanones } \\
\text { (Liberal Progresista) (MZA) }\end{array}$ \\
\hline
\end{tabular}

\section{Fuente: Elaboración propia}

Además, es posible identificar lazos familiares, de amistad y empresariales entre ellos. Dato, antes de ser presidente del Consejo de Ministros, había sido consejero y presidente del Consejo de MZA; además dejó allí a su yerno Eugenio Espinosa de los Monteros, acumulando sus votos y defendiendo sus posiones. Lo mismo ocurre con el Conde de Bugallal $^{1303}$, que además de tener una influencia directa sobre MZA, tenía una vinculación familiar muy extensa con la política española pues tenía un hermano y dos yernos Senadores. "Los directores del Banco Hipotecario y del Banco Español de Crédito son consejeros de Andaluces y verdaderos representantes del capital de esos Bancos, que tienen como consejeros y abogados a Cortina, Alvarado, Conde de Romanones, el Duque del Infantado, Rogand, Senador, etc."1304. "La Casa Pereyre, que es Norte, representa la mayoría de las acciones, y es La Unión y El Fénix Español, y ellos nombran los consejeros, que son Sánchez Guerra, Gullón, Senador; García Prieto, Senador". "Los Baüer son a M. Z. y A. lo que Pereyre al Norte, y son Peñarroya, y de esta Sociedad son consejeros Romanones y su hermano, Abogado; Pérez Oliva, Senador, y otros varios"1305.

\footnotetext{
${ }^{1303}$ Aunque no tan detallada como hemos hecho aquí, la influencia del Conde de Bugallal con MZA fue denunciada en el Congreso. Ello puede observarse en la Intervención de T. Menéndez en la Sesión celebrada en el Congreso de los Diputados el jueves 25 de marzo de 1920, legislatura 1919-1920 (Diario de las Sesiones de Cortes en el Congreso de los Diputados, $\mathrm{n}^{\circ}$ 94), pp. 5.332.

${ }^{1304}$ Intervención de T. Menéndez en la Sesión celebrada en el Congreso de los Diputados el jueves 25 de marzo de 1920, legislatura 1919-1920 (Diario de las Sesiones de Cortes en el Congreso de los Diputados, no 94), pp. 5332 .

${ }^{1305}$ Intervención de T. Menéndez en la Sesión celebrada en el Congreso de los Diputados el jueves 25 de marzo de 1920, legislatura 1919-1920 (Diario de las Sesiones de Cortes en el Congreso de los Diputados, $\mathrm{n}^{\circ}$ 94), pp. 5.332 .
} 
Esta influencia es innegable, pero puede observarse desde otro punto de vista. NORTE tenía otra motivación para realizar la fusión: intentar plantar resistencia al Estado. Para tener más poder de negociación frente al Estado, y su deseo contínuo de intervención en el sector ferroviario y su injerencia en las compañías (Ortúñez, 1999a: 283).

\subsubsection{Atenuación de las luchas históricas entre las familias francesas}

Normalmente el poder político es más cambiante que el económico, pues éste en algunos casos sobrevive a gobiernos y regímenes. Los Péreire y los Rodschild dominaban Europa, independientemente del poder político que hubiese en cada momento.

Las luchas entre la familia Péreire y la Casa Rothschild fueron constantes durante muchos años y su rivalidad empresarial se extendió a lo largo de toda Europa. Esta rivalidad tuvo una manifestación pública en España con motivo del punto terminal de la línea de Madrid a Francia $^{1306}$.

El abuelo paterno Jacobo Rodríguez Péreire había nacido en Berlanga (España), aunque su familia era portuguesa e israelita. Se trasladó a París como ministro plenipotenciario de la nación hebrea ${ }^{1307}$; fue tan importante allí, que "todos los israelitas que querían residir en París, debían solicitar autorización, escrita, concedida por él” (García Venero, 1948: 220).

El padre de los hermanos Péreire, Isaac Rodríguez Péreire, había nacido en París y murió en esta ciudad en 1806, dejando dos hijos: Emile e Isaac. Ante la muerte de Isaac padre, su hijo Emile Péreire fue protegido por James de Rothschild, del que luego sería su rival.

Los hermanos Péreire comenzaron su imperio ferroviario con la creación en 1835 de la Compagnie des Chemins de Fer Paris-Saint-Germain, y en 1836 del ferrocarril de Paris a Versalles. Posteriormente idearon que una de sus líneas, la denominada Midi, "Compagnie des Chemins de Fer du Midi e du Canal Latéral à la Garonne", estuviera unida con la compañía española NORTE por Bordeaux y Bayonne.

Los Rothschild, que dominaron las finanzas europeas desde las guerras napoleónicas, financiaron las redes ferroviarias francesas en los años 1840-1851. Entre los proyectos que financiaron está la construcción del Chemin de Fer du Nord de la France en 1845, realizada conjuntamente por los Péreire y los Rothschild. En 1852, los dos hermanos Péreire se emanciparon de la dependencia de los Rothschild ${ }^{1308}$. De esta forma, los hermanos Isaac y

\footnotetext{
1306 Esta rivalidad en España y toda europa ha sido estudiada por Ravage (1931), Cameron (1961: cap. 7), Bouvier (1967) y López Morell (2005).

${ }^{1307}$ La cuestión religiosa fue importante para la gestión personal y profesional de los Péreire (Isaac Péreire: 1879).

${ }^{1308} 1852$ fue un año clave. Luis Napoleón, que se había convertido en Presidente de la II República el año anterior, da un golpe de estado y se convierte en el Emperador del segundo Imperio con el nombre de Napoleón III. El Emperador vio en los ferrocarriles el medio esencial de producir el desarrollo económico (de los Cobos y Martínez Vara, 2012: 4). Por ello favoreción su construcción, lo que explica la febril actividad constructora que
} 
Emile Péreire, irrumpen con un proyecto independiente, y a gran escala, de ferrocarril e industria para el sur de Francia. Los Rothschild se defendieron aliándose al industrial Paulin Talabot.

La estrategia de los Péreire era más agresiva y la de los Rothschild más conservadora. Los Péreire fundaron el Crédit Mobilier Française (CMF) el 9 de septiembre de 1852, con la aprobación de Napoleón III. Su objetivo era crear una organización que captase los ahorros de la pequeña burguesía para promover empresas (de los Cobos y Martínez Vara, 2012: 4). Este fue el primer banco organizado por el sistema de compañía por acciones en Francia (dotado de un capital de 60 millones de francos), y puede considerarse como el primer banco de inversión por acciones moderno. Los Péreire desembarcaban en cada una de las naciones centroeuropeas, estableciendo en cada capital un Crédit Mobilier y una empresa ferroviaria. En todas ellas, los Rothschild perseguían a sus competidores para no perder influencia en Europa $^{1309}$.

Los hermanos Péreire acaudillaron un movimiento que pretendía emancipar a Europa de la tutela financiera de la Casa Rothschild. Incluso, los Péreire fueron vencedores en algunas disputas empresariales, como la adjudicación de las líneas ferroviarias rusas. No obstante, tras quince años de dura lucha ${ }^{1310}$, al final fueron derrotados los Péreire por Jaime y Lionel de Rothschild $^{1311}$.

Como en la mayoría de Europa, los Péreire y los Rothschild trasladaron su competencia a España. En mayo de 1853, el Crédit Mobilier Française hizo una petición para crear una filial en Madrid, para implantar en España su modelo de promoción industrial y ferroviaria, ensayado en toda Europa, pero la petición fue rechazada. En noviembre de 1855, los hermanos Péreire adelantaron al Tesoro Español 14,3 millones de francos, "como prueba de buena voluntad" (Broder, 1979: 646-647). Gracias a ello fue aceptada la creación de un Crédito Mobiliario en España, tras la presentación por el ministro de Hacienda Bruil a las Cortes de la oferta de los Péreire, el 24 de diciembre de 1855. En marzo de 1856 se crea la rama española de Crédit Mobilier Française: el Crédito Mobiliario Español $(\mathrm{CME})^{1312}$. El objetivo de este banco de inversiones era construir los ferrocarriles de Madrid a la frontera francesa para unirlos a los de la Midi, para posteriormente construir un ferrocarril de Córdoba a Sevilla para establecer un corredor Cádiz-Madrid-Bordeaux.

Cuando se admite la petición de constitución de Crédito Mobiliario, los Rothschild contratacan, dando instrucciones a sus agentes en Madrid, para que crearan una sociedad gemela a la de los Péreire. El 15 de enero de 1856, se aprueba la Sociedad Española Mercantil

involucró a los principales actores de las finanzas galas (Michel Chevalier, Gustave d’Eichtat, Charles Lambert, Henri Fournel, Paulin Talabot y por supuesto Isaac y Emile Péreire).

${ }^{1309}$ Cfr. Bouvier (1967: cap. 8) y Cameron (1961: cap. 7).

1310 "Lucha furiosa" en palabras de García Venero (1948: 244). Visto con el tiempo, los Péreire tuvieron un paso fugaz por la historia de las finanzas, mientras que los Rothschild han tenido un papel muy destacado que, aunque muy atenuado, aún perdura.

${ }^{1311}$ Eso sí, "la victoria costó a los Rothschild mucho más de lo que merecía" (Ravage: 1931).

${ }^{1312}$ Un análisis del Crédito Mobiliario Español se encuentra en Tortella (1973) y Sánchez Albornoz (1977). 
e Industrial (SEMI), con un capital de 76 millones de pesetas. El objetivo de ella es casi exclusivamente financiar MZA, inscrita en Madrid como sociedad de ferrocarriles el último día del año 1856. La estrategia de MZA era adelantar a los Péreire y unir Madrid por un lado con el Mediterraneo a través del puerto de Alicante, y por el otro con Zaragoza, una de las ciudades más ricas del noroeste peninsular y nudo de distribución entre Cataluña y el País Vasco que eran las zonas más prosperas de España en ese momento.

Los Rothschild consideraban que el negocio estaba más en la construcción que en la explotación del ferrocarril. La finalidad del desembarco del capital de los Rothschild en España no estaba tanto en la solidez y racionalidad del proyecto, sino en aumentar las posibilidades de "invadir de papel las bolsas de toda Europa" (López-Morrell, 2005: 152). Pero en todo caso, los Rothschild no tenían planeado entrar en el negocio ferroviario en España, sólo la entrada de los Péreire, precipitó su inversión en nuestro país.

Las hostilidades fueron constantes. Los Rothschild crean en Francia la Reunion Financiéré, con el objetivo de excluir del mercado financiero parisino a los Péreire, para ello aglutinó a todos los rivales de los Péreire en Francia: Blount, Davillier, Marcuard, Schneider de Creusot y Vernes (Bouvier, 1967: 174).

En parte por ello, en 1857, quiebra Crédit Mobilier Française. A partir de ese momento la actividad de los Péreire se concentró en sus compañías ferroviarias.

Con la muerte de Emile Péreire en enero de 1875, NORTE consigue desligarse de esta relación totalmente enquistada. Lo cual suponía el principal impedimento para una posible fusión con MZA. Rondo E. Cameron (1971) ya afirmó que el fallecimiento facilitó el acercamiento entre las dos grandes ferroviarias.

Desde entonces el entendimiento entre ambas fue a más, además de existir los acuerdos e intentos de fusión analizados, las dos empresas organizaron formalmente su área de influencia. NORTE cedió el ferrocarril Córdoba-Sevilla para que MZA se dedicara al sur peninsular, mientras que los Péreire recibieron en 1878 el Ferrocarril de Zaragoza a Pamplona y Barcelona (ZPB), el Tudela-Bilbao y completaron el enlace ferroviario entre Port-Bou y Cervere (de los Cobos y Martínez Vara, 2012: 7).

En el mismo sentido, existió un acercamiento entre ambos grupos porque compartían altos directivos. En 1879, accedió a la vicepresidencia de Midi, Léon Aucoc, antiguo presidente de la sección de obras Públicas del Consejo de Estado de Francia y natural de Bordeaux, localidad donde estaban radicados los Péreire. En 1880 fue nombrado consejero del Comite de Paris de MZA, como hombre de confianza plena de los Rothschild, integrando un subcomité que gobernaría MZA desde Francia. Mientras era vicepresidente de Midi ${ }^{1313}$, Léon Aucoc recibió el encargo de los Rothschild para negociar en España acuerdos de tarifas y

\footnotetext{
${ }^{1313}$ En 1990, Léon Aucoc accedió a la presidencia de Midi.
} 
fusiones ${ }^{1314}$. La convergencia de intereses entre las dos familias era coherente con el escenario del ferrocarril francés de finales de siglo, caracterizado por la no-competencia (de los Cobos y Martínez Vara, 2012: 8).

\subsubsection{Buena relación entre Boix y Maristany}

NORTE y MZA estuvieron enemistadas en origen por las dos familias francesas, pero posteriormente fueron unidos por dos Directores españoles: Boix y Maristany.

La buena relación de amistad ${ }^{1315}$ entre Boix y Maristany fue uno de los principales detonantes de los intentos de fusión de NORTE y MZA en 1919. Además, encontramos varias citas de esa época que demuestran la admiración del segundo por el primero: "Maristany decía que sólo reverenciaba en temas ferroviarios a Don Félix Boix" (García Venero, 1948: 351). Cuando este dimitió de la Dirección de NORTE (para volver al año y medio), Maristany al ser requerido para emitir una opinión sobre temas varios por el Ministerio de Fomento argüía: "He de consultar a Don Félix Boix... Necesito conocer la opinión de Don Félix Boix" (García Venero, 1948: 355).

La amistad y correspondencia profesional de los dos ingenieros, que dirigieron compañías rivales "persistió a lo largo de los años" (García Venero, 1948: 353).

La relación de amistad entre Boix y Maristany estuvo fomentada por ciertas casualidades de su perfil personal y profesional. Ambos eran oriundos de Barcelona, hicieron la carrera prácticamente al mismo tiempo y su formación fue similar. Por un lado, vivieron en épocas similares; Boix nació en Barcelona el 26/5/1858 y murió en Madrid el 11/6/1932, mientras que Maristany nació en Barcelona el 26/12/1855 y murió en la misma ciudad el 5/5/1941. Por otro lado, accedieron en el mismo año (1908) a la dirección general de las dos empresas rivales que nacieron en los mismos años (MZA en 1857 y NORTE en 1858), matrices de dos familias rivales francesas (los Rotchschild en MZA y los Péreire en NORTE) controladas por sus dos Comités de Paris.

En el periodo 1918-1919 Boix dejó la dirección de NORTE para irse a trabajar al Canal de Isabel II. Se podría interpretar como un aspecto positivo adicional para la fusión, si Boix hubiera estado dirigiendo a NORTE.

Eran dos personas con una fuerte personalidad, pero con un carácter bien distinto, que se manifestaba en la forma de dirigir su organización: NORTE con el conservador Boix y MZA

\footnotetext{
${ }^{1314}$ Chemin de fer de Madrid à Saragosse \& á Alicante, Comité de parís, Procesés verbaux, 24 octobre 1879 y 12 mars 1880 .

1315 Boix considera a Maristany como "siempre tuyo buen amigo y compañero" (P-126-273. Carta de F. Boix a Eduardo Maristany, 27 de noviembre de 1923). Por otro lado, García Venero (1948: 305) considera a Boix y Maristany como "fraternales amigos y al tiempo colegas".
} 
con el más flexible Maristany. El diferente perfil del responsable dio dos perfiles de empresas bien distintas ${ }^{1316}$.

\subsubsection{Factores que impidieron la fusión}

No obstante, pesaron más los aspectos negativos que supondría la fusión, pues ésta no se llegó a alcanzar.

\subsubsection{Saldos pendientes de NORTE a MZA}

En el planteamiento de la fusión pesó que NORTE adeudaba dinero a MZA. En el momento en que se planteó la fusión, NORTE debía algunas cantidades a MZA derivadas de la Sindicatura que se resistió a saldar dadas las dificultades de tesorería por las que atravesaba entonces.

\subsubsection{Conflictividad laboral en NORTE}

El descanso dominical quedó regulado por la Ley de 3 de marzo de 1904 y el Reglamento de 19 de abril de 1905. No obstante, en 1912, NORTE carecía aún de normas precisas sobre este particular, lo que se tradujo en condiciones de trabajo muy duras, jornadas demasiado largas y descansos reducidos, no generalizados y a menudo sin retribuir (Juez Gonzalo, 2000: 30).

Cambiar este orden de cosas supondría para las concesionarias incrementar el número de operarios -había que tener otros dispuestos para los reemplazos-, y lo que es lo mismo, aumentar "el gasto de explotación fijo y permanente" $"$. Por ello se mostraron tan reticentes para su cumplimiento.

En 1912, las cuentas de las ferroviarias españolas, "como en el resto de Europa en general" (Boag: 1912), reflejaban un estado dulce. Después de años de resultados negativos, al fin, NORTE pudo repartir dividendos, muy modestos, eso sí, debido al peso de las cargas financieras. La bonanza económica no impidió, sin embargo, que se deterioraran las relaciones laborales.

En marzo de 1912, principalmente por estos motivos salariales (Pérez Sánchez: 1992), se produjeron paros en los Talleres de reparación de material móvil y motor que NORTE poseía en Valladolid ${ }^{1318}$. En este mes, el Sindicato de NORTE de la Federación Nacional de Ferroviarios elevó sendos escritos al Gobierno y a la Dirección, figurando como primera

\footnotetext{
${ }^{1316}$ Para observar lo anterior, nada mejor que analizar la obra de Martínez; Muñoz y Ortúñez (2015: 12-38).

${ }^{1317}$ AHF, C/55/47: Descanso semanal.

${ }^{1318}$ La huelga en los Talleres de Valladolid de NORTE de 1912 fue tratada en el Consejo de Administración de NORTE en el Acta ${ }^{\circ} 797$ del Libro de actas del Consejo de Administración de NORTE: 29 de marzo de 1912: Apartado IV, y en el Acta n 798 del Libro de actas del Consejo de Administración de NORTE: 26 de abril de 1912: Apartado V.
} 
exigencia el cumplimiento de la Ley de Descanso Dominical, lo que significaba que, hasta la fecha, no se había cumplido (Juez Gonzalo, 1992: 525).

En junio de 1912 se celebró el I Congreso de la Unión Ferroviaria. En carta remitida a todas las concesionarias, el Sindicato se quejaba del bajo nivel salarial de los ferroviarios y exigía un incremento lineal del $30 \%$ de los sueldos del momento ${ }^{1319}$.

Por su parte, la empresa NORTE consideraba que en ese año cumplía con lo estipulado en el contrato y además proporcionaba a los obreros una serie de ventajas sociales como economatos, ayudas económicas y gratificaciones. Consideraba también que el malestar de la clase obrera es fruto de "doctrinas maleantes y conspiradoras y que por tanto hay que combatir dichas doctrinas" (Sanz, 1916, 1-45).

En este clima de tirantez, el 30 de octubre de 1912, Boix -como Director de NORTE- remitió a su colega Maristany (MZA) y al ministro de Fomento sendos informes, uno "sobre las peticiones formuladas por el Congreso Ferroviario" y el otro detallando las "instituciones establecidas por la Compañía a favor de su personal" (AHF, S/190/72). Estimaba Boix, que tales peticiones eran disparatadas por su elevado coste (más de 20 millones de pesetas). Estaba convencido de que el personal ferroviario, y muy en particular el de su red, estaba bien retribuido y tenía garantizado el puesto de trabajo, además de disfrutar [lo que era verdad] de otras muchas ventajas laborales desconocidas aún en la mayoría de las industrias. Según Boix, carecía de toda justificación esa manera "improcedente y arbitraria de exigir sacrificios no justificados" a una compañía que en este terreno siempre había ido por delante no sólo de todas las demás ferroviarias, sino también del propio Estado, como quedaba de manifiesto en los informes que adjuntaba. Al margen de la retórica, lo que F. Boix quería dejar bien claro era su rotunda negativa a reconocer ningún tipo de capacidad negociadora a los movimientos sindicales.

En septiembre de 1912, hubo un paro por parte de los ferroviarios de TBF (red catalana de MZA), que se vivió con gran preocupación en todo el país, pues en la globalidad de la sociedad se recelaba con que acabara convirtiéndose en una temida huelga general. El aviso de la huelga general fue brutal ${ }^{1320}$. Canalejas tuvo una enérgica actitud, incluso militarizando el sector, lo cual impidió que la huelga general se materializara, pero no pudo evitar que las ferroviarias tuvieran que hacer concesiones. NORTE hubo de incrementar el número de contratados, elevar las retribuciones de algunos colectivos, agilizar las promociones internas, mejorar las condiciones de trabajo, extender la cobertura de las instituciones de carácter benéfico-social y modificar el sistema de pensiones.

NORTE extremó su actitud contraria a las organizaciones obreras, lo que, a la larga, y en una empresa que albergaba en ese momento el sindicalismo más activo del sector, se convirtió en un factor añadido de crispación en el ciclo belicoso que comenzaba. La agresividad e

\footnotetext{
1319 Las reivindicaciones pueden observarse en el Instituto de Reformas Sociales (1913: 16-24) y Juez (1992: 854-857).

${ }^{1320}$ La expresión es de Marquina (NORTE, 1940: 215).
} 
intransigencia frente a las reivindicaciones obreras fue el peor de los caminos a seguir. Sólo así se explica el clima de confrontación permanente y la radicalización de las huelgas de 1916 y 1917 en la empresa. Los ferroviarios demandaban compensaciones que paliasen el creciente distanciamiento que, como consecuencia de la Gran Guerra, se estaba produciendo entre el coste de la vida en creciente alza y el poder adquisitivo de sus remuneraciones. La sección sindical de NORTE de la Federación Nacional de Ferroviario inició y condujo los movimientos reivindicativos. Las discrepancias entre Sindicato y la empresa ${ }^{1321}$ no se hicieron esperar y acabaron desembocando en la huelga de los días 11 y 12 de julio de 1916, resuelta, al final, gracias a la decisión arbitral del Instituto de Reformas Sociales ${ }^{1322}$. En efecto, el 10 de agosto aparecía el Decreto que refrendaba el laudo dictado por su presidente, G. de Azcárate, consistente en la concesión de una mejora salarial equivalente a una gratificación especial y la imposición del reconocimiento de las asociaciones y sindicatos libremente constituidos a las empresas de servicios públicos. Se imponía la negociación como vía adecuada para resolver los conflictos. Como los precios siguieron aumentando hasta 1920, la gratificación apenas sirvió para amortiguar la alarmante pérdida del poder adquisitivo de los salarios y de nuevo arreciaron las protestas y exigencias de los ferroviarios. Los resultados de la explotación fueron, sin embargo, negativos en los ejercicios 1917 y 1918. Aún así NORTE se vio forzada, muy a su pesar, a conceder dos nuevas gratificaciones que se sumaban a la de 1916, una en junio de 1917 y la otra en julio de 1918.

NORTE tuvo un gran protagonismo en la primera huelga general indefinida de España, proclamada el 13 de agosto de $1917^{1323}$. NORTE se negó a readmitir a los despedidos por el conflicto de la violenta huelga general de Valencia de 19 de julio de 1917, al final desconvocada. El 2 de agosto de 1917, el Sindicato de NORTE propuso a la Federación Nacional de Ferroviarios una huelga general para el día 10 de agosto de 1917. Las negociaciones entre empresas, trabajadores y gobierno fracasaron. Los representantes sindicales decidieron ir a la huelga el día 13 por un voto de diferencia ${ }^{1324}$. La empresa NORTE despidió a 6.000 operarios para reprimir la propuesta (Juez, 2001: 10-11) (Martínez Vara, 2001: 12-13).

A partir de 1917 se entró en un periodo de crisis debido al agotamiento de la guerra y a que las exportaciones generaron escasez de alimentos, sobre todo en el interior del país. La falta de alimentos produjo la crisis española de 1917 y la posterior huelga general que se produjo.

En 1918 se crea la Agrupación Federativa de los Ferroviarios del NORTE, constituida como una sociedad profesional de agentes de la compañía NORTE ${ }^{1325}$.

\footnotetext{
1321 Juez (1992: 522-563) lo explicó con detalle.

1322 Instituto de Reformas Sociales (1916).

${ }^{1323}$ En ese momento, la metalúrgica de Vizcaya se encontraba en huelga general, y en Asturias se llevaba a cabo una huelga general contra los despidos en la fábrica de pólvora de Santa Bárbara.

${ }^{1324}$ Las razones y convocatorias de la huelga general indefinida de España, puede observarse en El Socialista, 13 de agosto de 1917: pp.1-3; El País, 13 de agosto de 1917: pp.1-3.

${ }^{1325}$ La Agrupación Federativa de los Ferroviarios del NORTE estaba "desprovista de carácter político y religioso y cuya finalidad es fomentar la unión y compañerismo entre los asociados, mejorar los servicios y proponer las
} 
El 31 de diciembre de 1918, los ferroviarios de la Compañía NORTE en la región catalana realizaron una protesta (ABC, 1 de enero de 1919: p. 13).

El 5 de febrero de 1919 se inició una huelga en Barcelona que se prolongó durante 44 días, convirtiéndose en huelga general paralizando el $70 \%$ de la industria catalana y que ha pasado a la historia con el nombre de huelga de "La Canadiense" 1326 , porque se inició en solidaridad con ocho despedidos del personal de oficinas de esa compañía.

El 9 de octubre de 1919 se instauró la jornada de ocho horas ${ }^{1327}$, agravando los problemas económicos de las ferroviarias, pues supuso para las empresas un mayor incremento de los gastos de explotación.

Durante todo el periodo de análisis, la huelga tuvo menos virulencia para MZA que para NORTE, a pesar de que ésta concedía más ventajas a sus trabajadores que MZA (Peña y Pérez, 1940, tomo IV: 159). Por todo ello, era normal que una posible fusión inquietara a MZA porque consideraban que el personal de NORTE era más incomodo de dirigir que el suyo propio.

Ambas compañías tenían diferencias de salarios, pero también del resto de ventajas de que disfrutaban los trabajadores. NORTE concedía muchos más privilegios sociales que MZA, por esta razón esta empresa no veía clara una fusión pues tendría que igualar por arriba y ello significaba un considerable aumento de los costes. MZA temía, sobre todo, la desigualdad que existía entre ambas empresas respecto a la edad de jubilación y las consiguientes pensiones; mientras en NORTE los trabajadores se podían jubilar a los 55 años, en MZA no podían hacerlo hasta los 60 .

\subsubsection{Problemas derivados de la competencia entre las dos empresas}

Entre los impedimentos para no llevar a cabo la fusión destacan los problemas competenciales entre ambas empresas. Una de las primeras desavenencias entre NORTE y MZA se produjo en 1917. En ese año NORTE contrató a un ingeniero industrial que hasta el momento era jefe de Tracción en MZA: Federico de Vargas y Soto. La contratación se llevó a cabo con la firme oposición del director general de MZA, Eduardo Maristany ${ }^{1328}$.

\subsubsection{Diferencias en la estructura organizativa}

reformas necesarias para la organización de personal (Agrupación Federativa de los Ferroviarios del Norte, 1918, 1-46)

${ }^{1326}$ La Barcelona Traction, Light and Power, fue conocida popularmente como "La Canadiense". En el análisis de las acciones privilegiadas que emitió puede verse el origen y dimensión de esa empresa.

${ }_{1327}$ Tuvo efecto a partir del 1 octubre de 1919 (Real Decreto de 3 de abril de 1919).

${ }^{1328}$ Este hecho fue analizado en el capítulo 4 de esta investigación. Cfr. Carta del director de NORTE, Félix Boix, al presidente del Comité de Dirección de NORTE, A. Borregón. AHF, Expediente de Federico Vargas de Soto, Leg. 126. 
MZA fue más cuidadosa que NORTE en cuestiones referidas a la gestión y control de la empresa y en el proceso de toma de decisiones. Esto es básico para entender el diferente comportamiento de ambas en cuanto se refiere a la posible fusión ${ }^{1329}$.

Para MZA, la lealtad y compenetración absoluta entre el Consejo, la Dirección y el alto personal encargado de las Subdirecciones y jefaturas más importantes eran claves para una gestión eficiente. En opinión de MZA, la gestión adecuada del capital organizativo se vería dificultado con la fusión porque en NORTE no lo tenían resuelto, como quedó de manifiesto en la Junta General de Accionistas de 1919 (NORTE: 1920a).

\subsubsection{Motivos técnicos}

También existían otros motivos como el hecho de que era necesario unificar el sentido de la circulación en los tramos de doble vía, dado que era opuesto en ambas compañías.

\subsubsection{Presión negativa de la prensa a MZA}

Los medios de comunicación eran contrarios a la fusión, con una sobreprotección de ellos hacia MZA.

La prensa española apoyaba la estrategia de MZA frente a la de NORTE debido a la estrategia de comunicación de la primera. A principios de la segunda década del siglo XX, MZA distribuyó 32.500 pesetas entre distintos medios de comunicación para intentar tener a la prensa de su lado, frente al Estado, pero también frente a la competencia. Los medios de comunicación a los que entregó el dinero fueron, entre otros: La Época, El Mundo, El País, El Globo, El Economista, Actualidad Financiera, España Económica y Financiera (AHF, Presupuestos, L. 45 y 46).

\subsubsection{Rechazo de la clase política}

Los políticos eran contrarios a la fusión porque hubieran perdido oportunidades de acabar sus días en un buen puesto dentro del Consejo de Administración de una ferroviaria. Si existía una fusión, existía la mitad de posibilidades de colocarse en ellas.

\subsubsection{Rechazo de la opinión pública}

La opinión pública española recelaba de ambas empresas porque se pensaba que sólo respondían a sus intereses, depositados en Francia, y que bloqueaban proyectos que hubieran sido trascendentales para España (de los Cobos y Martínez Vara, 2012: 8). Pero aún recelaban más de la posibilidad de que una única empresa dominara la mayoría de la Península y que pudiera imponer discrecionalmente las tarifas que a ella les interesara.

${ }^{1329}$ Esto es ampliado en el trabajo de Vidal y Ortúñez (2002: 29-54). 


\subsubsection{Negativa situación económico-financiera de NORTE en el periodo 1914-1919}

En junio de 1919, NORTE había comenzado a remontar las dificultades por las que había atravesado en los dos años anteriores, en plena Guerra, que le llevaron a no repartir dividendos en los ejercicios 1917 y 1918. En este contexto algunos miembros de NORTE iniciaron maniobras de aproximación para un entendimiento con MZA.

Cuando NORTE se planteaba la posibilidad de la fusión, creían que una buena solución para mejorar su situación económica-financiera era realizar una reestructuración de la red que llevara aparejada la unificación de la explotación. Principalmente, estimaba que era un buen medio para aligerar costes.

Además, la mala situación económica obligaba a las grandes ferroviarias españolas a solicitar al Estado aumento de tarifas, ayudas y financiación. Los buenos resultados de estas gestiones conjuntas también atisbaron las ventajas de tener una posición fuerte entre la agrupación de compañías frente al mercado y al Estado.

Para observar los antecedentes que inciden en los directivos de MZA y NORTE para negociar la fusión, es necesario analizar la situación de las empresas en el periodo 1913-1919. El año 1913 es fundamental en la historia ferroviaria, ya que "a él se refieren varios de los decretos y disposiciones que posteriormente se publicaron" (NORTE, 1940: 11). Además, desde ese año la estrategia de las empresas de ferrocarriles varió por completo. Siguiendo lo ocurrido en los ferrocarriles franceses e ingleses, NORTE y MZA se dieron cuenta que el negocio puramente privado era inviable; a partir de aquí ambas sociedades son conscientes de que van a necesitar inexorablemente la ayuda del Estado.

\subsection{Efectos de la guerra sobre la empresa}

El intento de fusión se realiza al terminar la I Guerra Mundial, que duró entre el 20 de julio de 1914 y el 11 de noviembre de 1918.

El conflicto bélico trajo un entorno nuevo para la economía española y para el sector ferroviario. El empeoramiento en la situación económico-financiera de MZA y NORTE contrasta con una buena situación de la economía en general.

En los primeros meses de la guerra, la mayoría de efectos económicos y consecuencias sociales fueron negativos, por ejemplo la repatriación de inmigrantes aumentó el paro, y aconteció una disminución del transporte, debida a la interrupción de las comunicaciones.

Superado el impacto negativo inicial, la I Guerra Mundial produjo un auténtico despegue económico en España gracias a la declaración de neutralidad (la neutralidad en el conflicto 
benefició a la economía y causó un importante crecimiento del tráfico ${ }^{1330}$. La industria del país creció porque los países beligerantes necesitaban alimentos, armas, uniformes, metal y carbón, y la competencia extranjera casi desapareció. El crecimiento fue notable sobre todo en las industrias del sector textil catalanas, la minería del carbón asturiana, la siderurgia vasca, la agricultura de cereales castellana, la industria química, la construcción naval y la industria de armas ligeras ${ }^{1331}$.

El estallido de la Gran Guerra alteró radicalmente el panorama de las explotaciones ferroviarias y marcó un punto de inflexión en la evolución de las cuentas de MZA y NORTE. Los años que duró la Guerra fueron negativos para las concesionarias ${ }^{1332}$. Entre 1914 y 1918 los ingresos aumentaron, debido al incremento del tráfico, pero aumentaron mucho más los costes de la explotación, lo que acabó con el que había sido hasta entonces una constante en el sistema ferroviario español: costes de explotación bajos y controlados, con coeficientes muy favorables. El primero de los inputs que vio elevar su precio con la Guerra fue el carbón por el cese de las importaciones; el sucedáneo nacional era de peor calidad y más caro. También se dispararon los precios de las materias utilizadas en la explotación y los gastos de reparación. La red y el parque móvil se resintieron por la intensidad del uso y se multiplicaron los litigios contra la empresa. Pero el componente más significativo de los costes de la explotación será, desde entonces, el gasto de personal. El encarecimiento de las materias y los jornales, aumentó los gastos de establecimiento efectuados para la ampliación y mejora de las líneas. Todo esto supuso que la situación económica de MZA y NORTE empeorara en un ámbito de buenos resultados del resto de sectores. Eso a pesar de que el sector ferroviario español fue específicamente beneficiado por algunos hechos, como fue el hundimiento de barcos españoles por parte de los submarinos alemanes, lo que produjo una ventaja competitiva del transporte ferroviario sobre el marítimo.

Los datos económicos del periodo 1901-1914 fueron los mejores de la historia de NORTE, siendo el único periodo del que se puede afirmar que es un negocio saneado ${ }^{1333}$. El tráfico de NORTE, al igual que el de todas las ferroviarias, fue aumentando hasta la I Guerra Mundial de 1914. A pesar de que los sucesos de la semana trágica de Barcelona de 1909 produjeron alguna retracción, no llegó a acusarse en el resultado total hasta la segunda fase de la Guerra $^{1334}$.

1330 "Una vez que se llegó a la estabilización del conflicto, la demanda de los beligerantes significó un fuerte estímulo para la economía, reflejado en el incremento de la cartera de pedidos y en la consiguiente subida de precios" (Artola, 1978: 409).

${ }^{1331}$ La Guerra produjo un superávit de la balanza comercial y un notable incremento de los beneficios empresariales. Gracias a ello se canceló la deuda externa española y se acumuló oro en el Banco de España. Por primera vez en su historia moderna, España no estaba en déficit comercial respecto al comercio con el exterior.

${ }_{1332}$ Los años en que duró la Guerra "no constituyeron tiempos de bonanza para las concesionarias" (Gómez Mendoza, 1989a: 46).

${ }^{1333}$ NORTE (1940: 212) define el periodo 1900-1917 como el "de mayor prosperidad".

${ }^{1334}$ Ignacio Coll y Portabella, administrador de NORTE, integrante del Comité de Barcelona constata los malos datos en 1910 de los datos estadísticos de las líneas que sirven en la región catalana: Zaragoza a Barcelona, Lérida a Tarragona y Barcelona a San Juan de las Abadesas. Las causas que el aporta son la larga crisis de la industria catalana a consecuencia de la alarma producida por el terrorismo y las frecuencias de las huelgas (Acta no 780 del Libro de actas del Consejo de Administración de NORTE: 31 de octubre de 1910, Apartado III.5). 
NORTE sufrió dos fases según trascurría el conflicto. En un primer momento, una retracción del tráfico. En un segundo momento, un aumento grande de ingresos, pero acompañada de una elevación de los gastos mucho mayor.

El estallido de la guerra europea, afectó profundamente a NORTE, que sufrió una profunda recesión que duró casi un año a partir de los últimos meses de 1914. Los ingresos de la compañía en 1914 disminuyeron 8.420 .000 pesetas, respecto de los de 1913 . Por su parte, la bajada de los gastos en dicho año fue sólo de 1.230 .000 pesetas. La disminución de ingresos afectó a las inversiones en curso de toda su red. NORTE se encontraba en 1914 ejecutando obras que produjeron un aumento de 23.506 .000 pesetas en gastos de primer establecimiento.

En 1915, el movimiento de las mercancías volvió a aumentar, impulsado por la mayor actividad industrial que trajo el conflicto europeo. A la crisis de 1914, le siguió una etapa de demanda creciente de transporte en NORTE debido fundamentalmente a la mayor actividad de ciertas industrias que con motivo de la guerra intensificaron su producción y a la disminución proporcional del transporte marítimo (también el de cabotaje), que obligó a suplir esta deficiencia por medio de transportes terrestres ${ }^{1335}$.

Cuando la economía española experimentó los efectos de la crecida demanda exterior, NORTE no fue capaz de aumentar el volumen de las mercancías transportadas ${ }^{1336}$. NORTE tuvo poco margen de acción, porque la renovación de la red que se llevó a cabo en la década 1890-1900 fue insuficiente "como para que existiese en ese momento capacidad desempleada" (Artola, 1978: 409). La compañía entró en una profunda crisis, al no poder ampliar su capacidad de transporte, entre otras razones porque la guerra no les permitía la adquisición del material móvil necesario.

A esta incapacidad para aumentar el tráfico se añadió la elevación del coste de la vida ${ }^{1337}$ y del precio del carbón, NORTE -al igual que todas las ferroviarias españolas- entró en la más grave crisis de toda su existencia.

En 1915 se recuperó gran parte de los ingresos y del tráfico, pero, al mismo, tiempo, empezaba el encarecimiento de la vida y la elevación del precio del carbón. Las mismas causas que provocaron el alza del tráfico fueron las que generaron, desde 1915, un proceso

\footnotetext{
${ }^{1335}$ Las causas del aumento de la demanda aparecen reflejadas en los Informes Anuales de NORTE (1915-1918). La Guerra no produjo alteraciones de importancia en las corrientes del tráfico, pero sí provocó un incremento del volumen transportado y una alteración de las distancias recorridas, debido, en parte, a la insuficiencia del transporte.

${ }^{1336}$ Cuando la economía española experimentó la crecida demanda exterior, las compañías ferroviarias se vieron incapaces de aumentar el volumen de las mercancías transportadas, aún cuando el gobierno adoptase medidas de urgencia. Estas medidas de urgencia tomadas por el gobierno fueron "promulgadas en 1917, y se mantuvieron en vigor hasta julio de 1921" (Artola, 1978: 409).

${ }^{1337}$ El coste de la vida había pasado en el periodo 1913-1920, de 100 a 191,91 (Ballesteros: 1997).
} 
inflacionista y un inesperado alza del precio de todos los inputs de la explotación ${ }^{1338}$. Esto repercutió en los gastos de explotación pues NORTE, que no podía atender al mayor tráfico, tuvo que intensificar las obras de ampliación y mejora de las líneas y adquisición de material.

El precipitado crecimiento de los gastos no sólo neutralizó el aumento de los ingresos en 1915, sino que incluso NORTE incurrió en pérdidas en 1917 y 1918. Los directivos trataron de incrementar los ingresos, y justificaron la necesidad del incremento sobre las tarifas con numerosos estudios e informes (NORTE, 1940: I, 17), pero lograron poco, pues se encontraron siempre con la negativa de la sociedad (cámaras de comercio, círculos mercantiles, asociaciones de agricultores y ganaderos), que atribuía al precio del transporte un peso excesivo respecto del precio final de las subsistencias, y exigía un servicio más barato $^{1339}$.

Debido a que el encarecimiento de las materias primas y de los gastos de personal continuaba su marcha progresiva, las compañías ferroviarias, desde el segundo semestre de 1917, presentaron al Ministerio de Fomento para su aprobación, proyectos de nuevas tarifas especiales con precios todavía inferiores a los máximos legales autorizados en las concesiones, para sustituir a otras tarifas especiales más económicas que estaban en vigor. En lo concerniente al servicio de viajeros, se hicieron importantes supresiones, como los de los billetes de ida y vuelta, tarjetas de abono, de días festivos, de mercados etc. (NORTE, 1940: 226). Esto trajo como consecuencia que en 1918 los ingresos tuvieran un aumento de 23.332.683 pesetas, debido principalmente a las modificaciones introducidas en las tarifas especiales. No obstante, los gastos aumentaron en 43.010 .884 pesetas, siendo el $56 \%$ de dicho aumento provocado por el carbón.

A finales de 1918 las compañías, acuciadas por las reclamaciones de su personal, obtuvieron del Estado la autorización para elevar sus tarifas; el gobierno, estimada justa su petición, accedió a la elevación (Real Decreto de 26 de diciembre de 1918), aunque no en la cuantía en que habían solicitado las ferroviarias. Este recargo del $15 \%$ autorizado por el ministro Cortina permitió a NORTE "restaurar sus beneficios" (Tedde, 1978: 204-205), pero resultó insuficiente y las posteriores revisiones al alza solicitadas fundamentalmente para absorber los gastos de personal en continuo ascenso se quedaron en meros proyectos y promesas incumplidas. NORTE apuntó que "para cubrir atenciones de carácter permanente, se autorizó, como era lógico, el medio de aumentar los ingresos normales de la empresa" ${ }^{\text {"1340. }}$.

La Junta General Ordinaria celebrada el 17 de mayo de 1919 ofreció la información económica del ejercicio 1918 en el Informe Anual presentado por el Consejo, pero también

\footnotetext{
${ }^{1338}$ Este incremento en el precio de los inputs, puede observarse en el Informe Anual de 1915 (NORTE, 1916: 6).

${ }^{1339}$ Esto se producía, casi siempre, "con el beneplácito del gobierno de turno" (Comín, et al., 1998: I, 289 y 299300).

${ }^{1340}$ AHF P-113-258-3: "Contestación de la Compañía de los Caminos de Hierro del NORTE de España al Informe redactado por la Primera Comisión investigadora de la situación económica de las empresas de ferrocarriles nombrada por Real Orden de 20 de octubre de 1923": Apartado "Verdadero concepto del anticipo y correcta forma de su contabilización".
} 
comunicó los resultados del periodo 1913-1918. En este documento aparecía que los gastos de explotación del ejercicio 1918 alcanzaron 166.674 .595 pesetas, frente a un ingreso global de 203.273.276 pesetas. NORTE informó que si bien sus ingresos aumentaron en el quinquenio 1913-1918 un 31,34\%, los gastos lo hicieron en el mismo periodo, un 116,52\%, casi cuatro veces más. En ese periodo el precio del carbón aumentó un 193,89\%, y el acero un 645\% (Comunicación de NORTE en la Junta General Ordinaria celebrada el 17 de mayo de 1919).

El final de la I Guerra Mundial trajo un desequilibrio grande entre los ingresos y los gastos de NORTE, provocado por un encarecimiento de la vida -que afecto a la compañía en la adquisición de materiales-, por la implantación de la jornada de ocho horas, por la elevación de jornales y por la competencia del transporte de carretera, haciendo desaparecer el monopolio de transportes que ejercía el ferrocarril. La forma de atenuar este desequilibrio fue intentar aumentar los ingresos por medio de una elevación de las tarifas -aunque lo que consiguieron fue ayuda del Estado, en forma de anticipos-.

Los gastos totales de NORTE en 1919 experimentaron un aumento de 38.280 .530 pesetas debido al incremento de la remuneración al personal y al encarecimiento de las materias primas, sobre todo la del carbón. Desde el primer día del año 1919 regía el aumento de tarifas del $15 \%$, lo que permitió conceder al personal un aumento en sus haberes, en forma de plus, una mensualidad en abril de 15.033.585 y una segunda mensualidad en noviembre de 3.185.169 pesetas. El coste total gastado en carbón en 1919 llegó a ser cinco veces el de 1913, y el precio alcanzó la cifra de 103 pesetas por tonelada, frente a las 31 pesetas de 1919. También el consumo medio por kilómetro de máquina subió exageradamente por la mala calidad del carbón que la empresa tuvo que emplear. Los ingresos del año 1919 se incrementaron 60.619.343 pesetas, debido a la reforma de la tarificación y al aumento en el tráfico.

\subsection{Obras}

Para atender el incremento de movimientos, NORTE (1940: 11, 213 y 214) emprendió multitud de obras de mejora:

- Doble vía de algunos tramos: Madrid-El Escorial, Medina del Campo-ValladolidBurgos, Irún-Alsasua, Madrid-Pozuelo, Asasua y Beasain ${ }^{1341}$.

- Vía de Barcelona a Manresa;

- Renovación de vías (42,5 kilogramos).

- Remodelación de los nudos ferroviarios, de Lérida, Tarragona, Montcada, Venta de Baños, Zaragoza y San Andrés y el depósito de locomotoras de Madrid.

- Nueva estación de pasajeros de Valencia;

${ }^{1341}$ En septiembre de 1909 quedó inaugurada la doble vía entre Asasua y Beasain, a lo largo de sus 45 kilómetros de trayecto, en el que se habían construido 25 túneles, alguno de ellos de más de un kilómetro (Gaceta de los Caminos de Hierro: 1 de septiembre de 1909). 
- Estaciones de clasificación, alguna tan importantes como las Matas en 1909, y otras de menor importancia como las de Lérida, Miranda, Moncada, San Andrés, Tarragona, Venta de Baños y Zaragoza;

- Construcción de los dos edificios para oficinas del Paseo del Rey;

- Ampliación de instalaciones de pequeña velocidad en Barcelona:

- Aumento de material motor y móvil, con modernas unidades. A las antiguas locomotoras de escasa velocidad y potencia con altas chimeneas (por ejemplo Hernán Cortes y Echegaray) se añaden las modernas de cuatro ejes acoplados y ruedas grandes, y a los coches pequeños de dos ejes, los grandes, montados sobre carretones, que llegan a ser enteramente metálicos. Se instala el freno automático continuo por vacío, y en 1910 empiezan las instalaciones de enclavamientos de concentración de palancas, que posteriormente se generalizan;

- En el servicio de Movimiento se instauran los rápidos a Hendaya, Asturias y Santander y los trenes-tranvías en Bilbao y San Sebastián.

- Los trenes rápidos de NORTE, incorporaron en febrero de 1905 en su servicio de Madrid-Hendaya un coche salón de la Compañía Internacional de Coches Camas, ofreciéndolo a los viajeros de $1^{\mathrm{a}}$ clase con un recargo de 12 pts por el recorrido completo y de 4 pts en los tramos de Madrid-Valladolid, Valladolid-Miranda y Miranda-Hendaya. El coche, de cinco departamentos independientes, con capacidad de hasta 31 viajeros, tenía tocador, servicios eléctricos, calefacción, y salón de fumadores. Su coste fue de 80.000 francos.

- En 1907 comenzaron las obras del tramo transpirenaico por Canfranc, y el 25 de octubre de 1908 se inició la perforación del Túnel Internacional de Somport, obra que requirió cuatro años para su calado ${ }^{1342}$. A diferencia de los otros tres enclaves ferroviarios de la frontera francoespañola, en Canfranc se tomó una novedosa decisión, como fue la de que todos los trámites y transbordos se realizaran en una única estación, en vez de usar el modelo dual vigente hasta entonces en Irún-Hendaya, Port Bou-Cerbére, y Puigcerdá-La Tour de Carol. Por ello, la primera estación situada en territorio francés, la de Les Forges D’Abel, era de dimensiones sumamente pequeñas, similar a la de cualquier estación rural de Francia, mientras que en el lado español se empezó a construir, en 1916, una enorme explanación, en el paraje denominado de Los Arañones, para la Estación Internacional de Canfranc ${ }^{1343}$. El túnel

\footnotetext{
${ }^{1342}$ El tendido había sido solicitado desde muy antiguo por las Diputaciones Provinciales de Zaragoza y Huesca, si bien los pasos que se habían ido dando fueron siempre lentos. Dado el tradicional recelo hispano hacia todo lo que viniera de Francia, en 1879, el Ministerio de la Guerra inició importantes trabajos de fortificación de la zona prevista para la boca sur del túnel bajo la gran cordillera, si bien estos fortines quedaron finalizados una veintena de años antes de que realmente llegaran los obreros a instalar la vía férrea y su túnel.

El 17 de septiembre de 1862 la línea de Tardienta a Huesca fue adjudicada a Eduardo Bové, quien después la transfirió a la compañía del Ferrocarril Zaragoza-Barcelona.

En 1881 el conde de Sobradiel constituyó la Compañía Anónima Aragonesa para construir el pequeño ramal que unía Tardienta con la capital oscense. El tramo de Huesca a Jaca nació del denominado Pacto del Monasterio de Piedra, en el que se convino la anexión de la Compañía Aragonesa por parte de NORTE.

${ }^{1343}$ En torno a la estación de Canfranc surgió un poblado para alojar a los cerca de 2.000 ferroviarios, aduaneros, electricistas, etc... necesarios para el funcionamiento de las instalaciones. Destaca el descomunal edificio de viajeros, obra de Fernando Ramírez de Dampierre.
} 
de Somport sería dotado exclusivamente de ancho internacional, y la estación de Canfranc tendría un edificio de viajeros situado entre dos haces de vías, uno de ancho normal procedente de Francia y el español de vía ancha ${ }^{1344}$.

- En 1913, cuando el único combustible que utilizaba era el carbón, NORTE se planteó la electrificación de una parte de la red, pues las locomotoras eléctricas eran mucho más eficientes que las de carbón ${ }^{1345}$. Por la Real Orden de 24 de julio de 1918 se autorizó al Gobierno para concertar con NORTE la instalación de la electrificación de los 62 kilómetros de la Sección Busdongo-Ujo para atravesar el Puerto de Pajares ${ }^{1346}$, una de las secciones más duras de España ${ }^{1347}$. El 10 de agosto de 1918 se aprobó el pliego de condiciones que regulaba las relaciones entre el Estado y la compañía para esta obra, así como para las instalaciones complementarias entre Palencia y Gijón ${ }^{1348}$. Las obras correrían por cuenta del Estado, en su calidad de anticipo reintegrable, sin interés, y con un reintegro pactado conjuntamente con NORTE, con la única condición que el reintegro se debía realizar dentro del plazo de concesión de la línea. En el caso de que las líneas revirtieran al Estado antes del plazo previsto en la concesión, NORTE quedaría liberada de satisfacer al Estado las anualidades de reintegro del anticipo, subsiguientes a la fecha de la reversión anticipada. Los créditos necesarios deberían consignarse en los presupuestos generales del Estado. Los anticipos reintegrables fueron concedidos con suficiente plazo para que NORTE asumiera la mejora de la explotación y su rentabilidad le permitiera los reintegros. Los detalles de este anticipo y las cantidades invertidas aparecen en el balance del Informe Anual (NORTE: 1919). Con este anticipo se inicia un nuevo rumbo en la política ferroviaria de la compañía. Hasta entonces se había seguido, mediante el régimen de concesiones temporales adoptado en España desde mediados del siglo XIX, la política de que las empresas atendiesen con sus propios recursos sus necesidades de obras de mejoras, limitándose la función del Estado a la de inspección por tratarse de un servicio público. La I Guerra Mundial, el encarecimiento de la vida y la elevación de jornales y

\footnotetext{
${ }^{1344}$ El 18 de julio de 1928, Primo de Rivera inauguró el servicio el ferrocarril de Canfranc por la red del NORTE, dando enlace a la compañía francesa del Midi. Durante las guerras de 1936-39 y 1939-45 hubo períodos de interrupción del tráfico, y posteriormente el paso de Canfranc fue perdiendo importancia para los ferrocarriles galos, ya nacionalizados. La electrificación y el sinuoso recorrido suponían una grave carga económica, lo que llevó a que, cuando el 27 de marzo de 1970 un tren de cereal perdió el control de sus frenos y se despeñó por un abismo arrastrando consigo el puente metálico de L'Estanguet, el tráfico ferroviario quedara interrumpido hasta nuestros días por la vertiente francesa. Entonces, la línea internacional de Canfranc dejó de tener interés para la SNCF y para RENFE.

1345 Lucía Ordóñez (1926: 128-130) estimaba que la electrificación de la rampa de Pajares (Ujo-Busdongo) supondría un ahorro de más de un $60 \%$ del coste de combustible.

${ }^{1346}$ Las obras de electrificación de la rampa de Pajares, en la línea de Asturias, fueron comenzadas por el ministro Cambó. El contrato de electrificación de la rampa de Pajares se firma en 1921, y la puesta en tensión tiene lugar el 1 de enero de 1925. Los buenos resultados obtenidos en la rampa de Pajares animan a NORTE a proseguir la experiencia. En 1927, se decide electrificar los tramos de Irún a Alsasua, de Barcelona a Manresa, y Barcelona a Sant Joan de les Abadesses. Las distintas líneas seleccionadas se ponen en tensión en 1928, y, para el Irún-Alsasua, el 7 de junio de 1929. Se empieza a estudiar otra electrificación ambiciosa, la de los tramos de Madrid a Ávila y Segovia, y que NORTE nunca pudo culminar.

${ }^{1347}$ En rampa prácticamente continua de 20 milésimas, comporta cerca de 70 túneles, incluyendo el de la Perruca de $3071 \mathrm{~m}$ de longitud.

${ }^{1348}$ Gaceta de los Caminos de Hierro: 24 de enero de 1915.
} 
la competencia de la carretera, trajeron grandes dificultades para que las ferroviarias pudieran acometer las mejoras exigidas por el tráfico; derivado de ello el Gobierno empezó a prestarlas auxilios económicos. Este anticipo de Pajares fue el primero para NORTE, siendo continuado por otros ${ }^{1349}$.

\subsection{Número de viajeros}

Entre los años 1906 y 1913 hubo un aumento medio anual de 556.422 viajeros. En 1914 se produjo una pequeña contracción del tráfico, originada por la I Guerra Mundial. En 1915 y 1916 aumentó el tráfico de viajeros. En 1917 se produjo una bajada del tráfico debido a las dificultades surgidas por los viajes internacionales. A partir de ese año comienza un aumento en la elevación del tráfico (NORTE, 1940: 352). Esta elevación del tráfico coincide con el aumento de las tarifas del año 1918 (NORTE, 1940: 352).

Para apreciar el tráfico de viajeros, NORTE (1940: 353) considera como el indicador "verdaderamente importante" el número de viajeros-kilómetros. Existió una bajada en los años 1914 y 1915 en este indicador. El número de viajeros-kilómetros pasa de 719 millones en 1906 a 938 en 1917 (NORTE, 1940: 353). En 1917 hay una disminución en el número absoluto de viajeros, con un aumento medio anual. Desde 1917 existe un acusado aumento (Figura 4).

Por su parte, MZA reconoce que la explotación de la red presenta difíciles circunstancias desde 1913 (MZA, 1933: 203). El tráfico sufrió una contracción en el año 1914 como consecuencia de la I Guerra Mundial. En el periodo 1915-1918 existió un aumento anual persistente y muy acentuado (MZA, 1933: 131). Respecto al número absoluto de viajeros transportados, va creciendo a gran ritmo en el periodo 1913-1919 (MZA, 1933: 275). El aumento medio anual del recorrido total cubierto por los viajeros durante el periodo 19161918 fue de 73.600 .000 kilómetros. El máximo recorrido medio por viajero de MZA de toda la historia se da en el año 1919, con 56,2 kilómetros (MZA, 1933: 279).

\subsection{Tarifas}

Con la llegada de la primera guerra mundial, NORTE sufrió a partir de 1914 sus efectos en forma de disminución del tráfico, aumento del precio del combustible y de las barras de acero para la infraestructura de vía, unido al encarecimiento de las cargas financieras y a la imposición de encorsetadas tarifas en 1917, por efectos de la Ley de Subsistencias.

En 1917, mientras que las compañías trataban de suplir la insuficiencia de los ingresos para cubrir los gastos, el gobierno impuso a los ferrocarriles la aplicación de una tarifa para el transporte de naranja al precio de 5 céntimos por tonelada y kilómetro ${ }^{1350}$. A pesar de las

\footnotetext{
${ }^{1349}$ La importancia de las obras de la Rampa de Pajares puede observarse en Revista Minera (tomo 68, año 1917, p. 232), Gaceta de los Caminos de Hierro (24 de octubre de 1919) y en ABC (3 de septiembre de 1924: p. 6).

${ }^{1350}$ La motivación del establecimiento de la tarifa para el transporte de naranja de 1917, era, según NORTE (1940: 226), "dar atención preferente al remedio de las dificultades que atravesaban otros sectores de la economía nacional". La tarifa estuvo en vigor del 8 de mayo al 5 de agosto de 1917, y la Real Orden de 21 de
} 
protestas que desde el principio elevaron las compañías al Gobierno ${ }^{1351}$, dicha tarifa continuó con algunas pequeñas interrupciones hasta el 13 de junio de $1919^{1352}$.

Como el ejercicio contable 1918 fue negativo para las cuatro grandes compañías ferroviarias (NORTE, MZA, Andaluces y MCP), el Gobierno las invitó a exponer las medidas que, a su juicio, remediaran más eficaz y rápidamente esta situación. Las cuatro realizaron un escrito el 2 de septiembre de 1918 dirigido al Ministerio de Fomento, en el que aparecía que el único procedimiento viable para alcanzar el resultado perseguido consistía en la inmediata elevación de todos los precios, "ya fueran de tarifas máximas legales, generales o especiales, tanto en las de viajeros como en las de mercancías, mediante un recargo uniforme del $25 \%$ ".

Tanto afectó a los rendimientos de las ferroviarias que Fomento se vio obligado a autorizar un aumento de las tarifas en un $15 \%$ según el Proyecto de Ley presentado por Cambó en las Cortes Generales el 22 de octubre de 1918, Proyecto que tuvo que salir adelante por el Decreto Ley firmado por el ministro de Fomento -Marques de Cortina- el 26 de diciembre del mismo año, aduciendo las circunstancias excepcionales que afectaban a las compañías ferroviarias. Por medio del Real Decreto de 26 de diciembre de 1918, el Gobierno autorizó una elevación del 15\% sobre las tarifas en vigor el 1 de enero de 1919, pero prohibiendo aplicar aquella elevación a las tarifas especiales puestas en aplicación con posterioridad a 26 de diciembre de 1918. Esta medida fue considerada como una solución provisional, y tuvo la oposición de ciertos grupos de presión (cámaras de comercio, círculos mercantiles, Asociación de Ganaderos). El incremento de tarifas máximo del $15 \%{ }^{1353}$ permitió a las concesionarias sostener, aunque por poco tiempo, los incrementos salariales de sus empleados (Comín, et al., 1999: 288). En el caso específico de NORTE, las mejoras salariales consistieron en la concesión, a partir del 1 de enero de 1919, de un plus, que oscilaba entre el

noviembre de 1917 restablecía su vigencia hasta el 22 de mayo de 1918, plazo prorrogado posteriormente, por la Real Orden de 20 de mayo de 1918 hasta el 22 de noviembre de 1918 (ABC, 23 de noviembre de 1917, p. 15). A consecuencia de la Real Orden de 10 de diciembre de 1918, rigió nuevamente la precitada tarifa desde el 14 de diciembre de 1918 al 13 de junio de 1919.

${ }^{1351}$ Las protestas frente al Gobierno fueron generalizadas en todas las compañías ferroviarias (NORTE, 1940: 226). NORTE protestó de ello, en instancia dirigida al Ministerio de Fomento el 11 de mayo de 1917, por entender que las facultades que el Gobierno se atribuía no se ceñían a los fines perseguidos en la Ley de Subsistencias de 11 de noviembre de 1916, en la que se establecía el principio de indemnización pecuniaria concertado con las Compañías, "cuando los perjuicios que a éstas se causaran fueran tan cuantiosos y evidentes como lo eran en aquel caso". NORTE volvió a protestar en una nueva instancia de 4 de febrero de 1919, porque se "vulneraba el fin esencial y único a que pareció responder la promulgación de la Ley de Subsistencia, erróneamente interpretada por el Reglamento dictado el 24 de noviembre de 1916". Ninguno de estos escritos fue contestado por el Ministerio de Fomento.

${ }^{1352} \mathrm{Al}$ final las protestas dieron parcialmente resultado. El Ministerio de Fomento dictó la Real Orden de 24 de julio de 1923, por la que se reconocía el derecho de NORTE a percibir la cantidad de 2.364.142,33 pesetas en concepto de indemnización por los transportes de naranja realizados, de acuerdo con la tarifa reducida de 0,05 pesetas por tonelada y kilómetro. Decimos parcialmente porque este saldo nunca fue pagado por el Estado. Muy posteriormente, la Ley de 6 de mayo de 1933 dispuso la reducción del 50\% en el transporte de naranja en el interior de la Península, y practicada la liquidación de las afectadas por dicha disposición, resultaron a favor de la Compañía 710.568,59 pesetas, que liquidó el estado en diciembre de 1933 (NORTE, 1940: 228).

${ }^{1353}$ Este incremento fue prorrogado posteriormente por diferentes decretos hasta la definitiva nacionalización de 1941. 
$35 \%$ para los haberes inferiores a 1.500 pesetas de anuales, o 4 reales el jornal, y el $20 \%$ para los superiores a 6.000; persistía, además, la gratificación de abril, equivalente a una mensualidad por parte de NORTE ${ }^{1354}$.

Nuevas demandas salariales, junto al temor fundado que causaba la inminente aplicación de la jornada legal máxima, hizo ver muy pronto a las empresas que el incremento autorizado en diciembre de 1918 resultaba insuficiente o, lo que es lo mismo, que, con el nivel de subida aprobado el "ferrocarril no se bastaría a sí mismo económicamente", que era el gran objetivo perseguido. De ahí que las cuatro grandes solicitaran formalmente, con fecha 30 de noviembre de 1919, al presidente del Consejo de Ministros un nuevo aumento hasta un 50\% con efecto desde el 1 de enero de 1920.

En el año 1919 se elevaron las tarifas a nivel internacional, siendo las tarifas españolas inferiores a las de casi todas ellas ${ }^{1355}$. En Alemania se fijó un aumento del 50\%, después de aumentos recientes del $35 \%$ al $110 \%$ en el servicio de viajeros según las clases y del $60 \%$ en las mercancías. En Bélgica un 40\%. La Orden gubernamental de 27 de mayo de 1918 estadounidense elevó las tarifas de mercancías un $25 \%$ y para los viajeros un 20\%. En Francia el aumento general fue de $25 \%$ en el precio del transporte. En Inglaterra se aumentaron las tarifas de viajeros en 50\% y en menor proporción las de mercancías. En Italia hubo enormes aumentos de tarifas autorizados en julio de 1914, marzo, septiembre y diciembre de 1917 y junio de 1918 que representaron un 50\% de las tarifas de viajeros y hasta el 300\% para las mercancías. En Portugal se elevaron el 57\% en mayo de 1918 para toda clase de transporte ${ }^{1356}$.

NORTE creía que la fusión con MZA permitiría incidir con más fuerza en la decisión del Estado de elevar las tarifas.

\subsection{Resultados contables}

En el período 1900-1913, los ingresos crecieron un 43,2\% y los gastos un $31,2^{1357}$. De entre estos últimos los que más se elevaron $(39,3 \%)$ fueron los de explotación, especialmente los relacionados con el combustible y personal por ser ambos los más afectados por el incremento del tráfico. En cualquier caso, los costes laborales se mantenían aún bajos. En ese momento los costes de explotación de las ferroviarias españolas se hallaban situados entre los más bajos

\footnotetext{
${ }^{1354}$ Informe Anual de 1919 (NORTE: 1920: 5-8); Marquina (NORTE, 1940: I, 236 y 427); NORTE (1931: 8); y Peña y Pérez (1940: tomo IV, 149). La gratificación de abril fue muy criticada por la comisión investigadora de la contabilidad de NORTE de la época del Directorio Militar (Peña y Pérez, 1940: tomo I, 100-101) que no entendía cómo una empresa que requería de los anticipos del Estado podía dar una paga extraordinaria a sus empleados.

${ }^{1355}$ Eso es al menos de lo que se quejaba MZA (1933: 75).

${ }^{1356}$ Este análisis se basa en los datos aportados por MZA (1933: 204).

${ }^{1357}$ La desproporción entre el crecimiento de gastos e ingresos fue considerado por Jiménez Ontiveros (1940: 87 y 109) "la característica más temible de la explotación ferroviaria" y "una de las causas más fundamentales del llamado Problema Ferroviario".
} 
de Europa, lejos de Alemania, Austria, Francia, Inglaterra, Italia y Suiza ${ }^{1358}$. Uno de los fundamentos de la rentabilidad de las empresas y de los favorables coeficientes de explotación eran los bajos salarios. No obstante, los gestores de NORTE comenzaron a preocuparse de su tendencia alcista $\mathrm{y}$, desde entonces, trataron de controlarlos mejor.

Los ingresos aumentaron en el quinquenio 1913-1918 en un 31,34\%, debido en gran parte a que la insuficiencia del cabotaje y la elevación de los fletes provocaran que fuera por ferrocarril un tráfico que antes se hacía por vía marítima (NORTE, 1940: 229). Este transporte ferroviario proveniente del marítimo se hizo generalmente a largas distancias y a tarifas reducidas.

Los gastos en el quinquenio 1913-1918 aumentaron en un 116,52\%, es decir casi cuatro veces más que los ingresos ${ }^{1359}$. El enorme aumento de los gastos obedecía, en su mayor parte, al encarecimiento de las materias primas empleadas, especialmente el carbón, y se descomponía por conceptos en la siguiente forma: Combustibles 287,61\%, Material de vía y talleres 64,16\%, Personal 35,11\%, Cambio y alquiler del material móvil 256,33\% y Reclamaciones $319,52 \%$. En total supone un $116,52 \%$.

Los gastos de Personal de tracción se duplicaron entre 1913 y 1919 por las mejoras de sueldos y pluses ${ }^{1360}$.

El aumento de los gastos de Material de tracción de 39 millones, pasó de 18 a 81 millones en el periodo 1913-1919. El aumento brusco tuvo su origen en la subida de precio de todos los materiales y principalmente por el carbón ${ }^{1361}$.

Las cargas financieras fueron elevándose gradualmente al tener que irse reduciendo el plazo de amortización de las nuevas emisiones por acercarse a la fecha de reversión de las líneas. Las cargas financieras heredadas dentro del gasto global se redujeron de 43,01\% en 1913 a 26,52 en 1918 en MZA y de 54,32 a 25,49\% en NORTE, no obstante, en ambos casos, continuaron siendo aún decisivas.

Los gastos de Administración central y dirección se duplicaron entre 1913 y $1919^{1362}$.

\footnotetext{
${ }^{1358}$ Esta idea es ampliada por González Quijano (1916: 61). La opinión de González Quijano es corroborada por el informe de Cambó (1918: II, 143-146 y 153-155, Cuadros 54-58) donde se comparan los resultados de la explotación de NORTE y MZA, años 1901 y 1913, con los de los ferrocarriles de otros países como Francia, Inglaterra, Alemania, EE.UU. o Italia entre 1908 y 1917. Los coeficientes de explotación de las dos grandes ferroviarias españoles, NORTE (49.73\% en 1913) y MZA (47.35\% también en 1913), eran los más bajos de todos.

${ }^{1359}$ Una visión de conjunto de los costes de explotación y financieros en las dos grandes, NORTE y MZA, puede verse en Comín, et al. (1998, I, 219-225).

${ }^{1360}$ AHF P-113-258-1: "Memoria sobre la situación económica de la Compañía de los Caminos de hierro del NORTE de España", Primera Comisión investigadora de la situación económica de las empresas de ferrocarriles, 29 de noviembre de 1923.

${ }^{1361}$ AHF P-113-258-1: "Memoria sobre la situación económica de la Compañía de los Caminos de hierro del NORTE de España", Primera Comisión investigadora de la situación económica de las empresas de ferrocarriles, 29 de noviembre de 1923.
} 
Los gastos de Reclamaciones e investigaciones pasaron de un millón en 1913 a más de 9,5 millones en 1919. Este aumento es imputable a las dificultades con las que se tropezó la compañía para la explotación de las líneas a partir de 1919 "por la falta o mala calidad del carbón, deplorable estado del material de tracción y transporte, que ocasionaba continuos retrasos, inutilización y mermas o deterioro de las mercancías, que motivaron innumerables reclamaciones y gastos, tanto en los litigios como en las indemnizaciones a que la compañía se vio obligada a responder" 1363 .

Por su parte, en MZA se dispararon los costes de explotación de 1918, tanto los de materias primas, combustibles, precios de conservación y personal respecto al principio de la Guerra. Aumentaron los gastos de materias y jornales. Los precios del carbón y de las demás materias experimentaron elevaciones considerables entre los años 1913-1919 (NORTE y MZA, 1932: 13). La elevación del coste de la vida obligó a la concesión de repetidas mejoras al personal (NORTE y MZA, 1932: 14). También las cargas financieras aumentaron en gran proporción (NORTE y MZA, 1932: 13).

Respecto a los productos obtenidos en el tráfico de viajeros, los productos de MZA se redujeron ligeramente en el año 1913 y 1914, como consecuencia de bajar la base de percepción y a pesar de que se aumentó el recorrido total en kilómetros. Los productos del año 1915 bajaron respecto a 1914 en 1.500 .000 pesetas, a causa de reducirse los kilómetros recorridos y la base media de percepción. Entre 1916-1919 los productos aumentan continuamente, de acuerdo con el aumento sostenido de kilometraje.

MZA se situaba en una gravísima situación. Los gastos de personal pasan de 31,1 millones en 1913 a 46 millones en 1918, los de pensiones de 0,77 a 1,5 millones, los de carbón de 13,4 a 66,3 millones, los de otras materias -incluidas las indemnizaciones por pérdidas y averías- de 19,7 a 27 millones. Esto supone que los gastos totales sufrieron un aumento de 76 millones, mientras que los productos brutos aumentaron en 57,3 millones (los productos brutos pasaron de 136,5 millones a 193,8 millones). Por otra parte, las cargas de explotación pasaron de 48,3 millones a 50,1 millones. Como consecuencia de todo ello, se llegó a que el producto líquido en 1918 se redujo a los 2,7 millones (MZA, 1933: 151).

\subsection{Carbón}

El primero de los componentes de explotación en acusar la subida de precios de 1915 fue el carbón y, en consecuencia, el gasto en combustible. Por un lado, se produjo un mayor consumo en el servicio de material y tracción provocado por el mayor volumen transportado y

1362 AHF P-113-258-1: "Memoria sobre la situación económica de la Compañía de los Caminos de hierro del NORTE de España", Primera Comisión investigadora de la situación económica de las empresas de ferrocarriles, 29 de noviembre de 1923.

${ }^{1363}$ AHF P-113-258-1: "Memoria sobre la situación económica de la Compañía de los Caminos de hierro del NORTE de España", Primera Comisión investigadora de la situación económica de las empresas de ferrocarriles, 29 de noviembre de 1923. 
por las mayores distancias recorridas por los trenes. Por otro lado, la disminución de las importaciones durante las hostilidades y su elevado precio (en 1918 la cotización media del carbón de Cardiff y Newcastle se había multiplicado por $6,5^{1364}$ ) obligó a las empresas a utilizar preferentemente el de España, escaso, caro, y, sobre todo, de peor calidad, lo que significó mayor consumo por unidad de trabajo y kilómetro y un número creciente de averías $^{1365}$.

El carbón se pagaba antes de la guerra en Asturias a 14 pesetas por tonelada sobre vagón en la clase "menudos" y 24 pesetas por tonelada sobre vagón en la clase "briquetas", y llegó a ser después de la guerra de 68 y 100 pesetas para las dos clases citadas (NORTE y MZA, 1932: $14)$.

Aunque el precio del mercado está consensuado, lo que no lo está es el precio que pagaba la compañía, porque dependiendo de la fuente los datos son distintos para NORTE y MZA. Según lo expresado por MZA (1933: 179-180), el precio unitario del carbón pasa de 32,72 pesetas tonelada en 1913 a 138,08 pesetas en 1919, es decir, el aumento para aquel periodo es de 322\%. Según NORTE (1940: 226), el gasto de combustible de NORTE, pasó de 19 millones en 1913 a 75 millones en 1918. Según lo expresado conjuntamente por ambas compañías (NORTE y MZA, 1932: 14) el gasto de combustible en 1913 fue de 16 millones en NORTE y de 13,5 en MZA, llegará a ser en 1919 de cerca de 69 millones de NORTE y de 77 en MZA.

\subsection{Materiales de explotación y conservación}

También se dispararon muy pronto los precios de las materias utilizadas en la explotación y conservación del material rodante (lubricantes, cobre en planchas, llantas para ruedas, traviesas, carriles, etc.).

Los carriles de 196 pesetas por tonelada en 1913 pasaron a 550 en el año 1918 (NORTE y MZA, 1932: 14), los tubos de humos de 22 pesetas los cien kilos a 500 pesetas (NORTE, 1940: 226), el cobre en placas de 236 pesetas los cien kilos a 640 pesetas (NORTE y MZA, 1932: 14), y las llantas de rueda de 215 pesetas la tonelada a 700 pesetas (NORTE, 1940: 226).

Si en un primer momento de la Guerra, la empresa respondió con relativo éxito al tirón de la demanda y pudo "ofrecer dignamente los servicios requeridos" (Ortúñez: 1999a), a partir de 1916 los problemas se acumularon ${ }^{1366}$. La infraestructura (raíles, material motor y móvil), pese a haber sido en parte renovada en el período anterior, se resintió y se elevó el coste por

\footnotetext{
${ }^{1364}$ Datos tomados de Martínez Vara y de los Cobos (2007b: 321).

1365 Informe Anual de NORTE de 1917 (NORTE, 1918: 7).

${ }^{1366}$ En los Informes Anuales de esos años no sólo se hace notar la enorme elevación del precio de las materias (maderas, metales, grasas, aceites, etc.) utilizadas en la explotación y conservación del material motor y móvil y obras de fábrica y vía, sino que se lamenta su escasez e incluso "falta absoluta en alguno de ellos" (NORTE, 1916: 7; 1917: 5; 1918: 5).
} 
unidad transportada. Aumentaron los gastos en conservación y reparación del material de tracción y fijo en talleres y puestos de recorrido, de la vía y de las restantes infraestructuras, incluidos dentro de los costes de explotación (Martínez Vara y de los Cobos, 2007b: 322). De ahí los innumerables litigios a los que la empresa habrá de hacer frente; la consecuencia fue un incremento de las indemnizaciones por pérdidas, averías, retrasos y falta de mercancías, y elevación igualmente inesperada del gasto en conservación y reparación del material de tracción y fijo en talleres y puestos de recorrido, de la vía y de las restantes infraestructuras, incluidos dentro de los costes de explotación.

Concluido el conflicto bélico, NORTE se vio obligada a ampliar y renovar material, equipos e instalaciones mecánicas, hidráulicas o eléctricas -dobles y cuádruples vías, electrificación de ciertos tramos, nuevas estaciones, etc.- (Artola, 1978, I: 416).

NORTE pensaba que la fusión supondría una forma de atenuar todas estas inversiones futuras, compartiéndolas con MZA.

\subsection{Salarios}

En 1916, más tarde de las subidas del carbón y de los materiales, pero "con similar ímpetu, y mayor persistencia" (Martínez Vara, 2003a; 2005), crecieron los gastos de personal, llamados a convertirse, desde ese momento, en el tema de mayor preocupación para los gerentes. Entre 1913 y 1918 los gastos laborales crecieron un 35,11\%. En 1918, caen las partidas relativas al combustible, se mantienen aún elevadas durante tres años las de material e indemnizaciones $\mathrm{y}$, sin embargo, se disparan en los dos años siguientes las de personal.

Los gastos de personal acabaron convirtiéndose en la rúbrica mayor del gasto, fundamentalmente por dos factores interaccionados: el aumento del número de empleados y el incremento de los "emolumentos" o "ventajas" (monetarias unas; en especie las otras). El dato conjunto del empleo de NORTE y MZA pasó de 47.276 trabajadores en 1913 a 64.992 en 1923 y 75.945 en 1935 .

En 1916 se iniciaron elevaciones de sueldos y salarios en el sector, planteadas como respuesta a la espiral inflacionista, que se mantuvieron hasta 1920, en una coyuntura especialmente propicia a las reivindicaciones obreras, que llevó a la implantación de la jornada laboral de ocho horas.

Por otra parte, el aumento general del coste de la vida obligó a la empresa a conceder importantes mejoras en la remuneración de su personal, al que se le aumentó una mensualidad en 1916, dos en 1917 y tres en 1918, lo que supuso un aumento del 25\%. En 1919 se le otorgaron en forma de pluses, aumentos del 20 al 35\%, subsistiendo una gratificación equivalente a una mensualidad, manteniéndose esta situación sólo en 1919 (NORTE, 1940: 223). 
El Real Decreto de 26 de diciembre de 1918 autorizó el recargo transitorio del transporte en un $15 \%$. Ante ello, NORTE envió una Circular a sus empleados en los que se compromete a pagar a todos los agentes, cada mes de abril de cada año, una mensualidad extraordinaria (ABC, 1 de enero de 1919, p. 13).

La situación era grave para NORTE, pero se complicó extraordinariamente al entrar en vigor el Real Decreto de Presidencia del Consejo de Ministros de 3 de abril de 1919, que impuso la implantación de la jornada de ocho horas para los trabajadores industriales en general. El Decreto debía entrar en vigor a partir del 1 de octubre de ese mismo año, pero, como el propio texto legal advertía, su aplicación en el sector ferroviario presentaba "dificultades numerosísimas y de importancia extraordinaria", debido a las especiales características del servicio prestado. La complejidad del problema ${ }^{1367}$ obligó a demorar su puesta en práctica y exigió multitud de estudios e informes del Instituto de Reformas Sociales, del Comité Paritario de Ferrocarriles creado por R.D de 29 de agosto del Ministerio de Fomento ${ }^{1368}$ y de las propias concesionarias ${ }^{1369}$. Se estipuló un complicado sistema de turnos y de servicios no ordinarios ${ }^{1370}$. Quedaron excluidos provisionalmente los empleados de las estaciones de mediano y poco tráfico y una parte de los vigilantes de la vía. La consecuencia fue un incremento inmediato del salario/hora, obligando a compañías a contratar más trabajadores y más horas extraordinarias (Comín, Martín, Vidal y Muñoz, 1998: 198). NORTE, al igual que el resto de las concesionarias, notó los primeros efectos del Decreto el mismo año 1919.

MZA realizó sucesivas mejoras que se fueron concediendo al personal. Estas mejoras representaron para la compañía un desembolso de 14 millones de pesetas en el personal fijo, sin tener en cuenta las repercusiones en el temporero, como consecuencia de las gratificaciones concedidas los años 1916, 1917 y 1918. Al mismo tiempo que se mejoraba al personal, el producto líquido pasaba de 23 millones en 1913 a 2,7 millones en 1918 y el dividendo repartido a los accionistas de 24 pesetas por acción en 1913 a 5 pesetas en 1918.

NORTE consideró que la fusión podría alcanzar una situación empresarial más fuerte para hacer frente a las demandas sindicales (que MZA manejaba mejor) y a las consecuencias de leyes laborales desfavorables, principalmente la implantación de las ocho horas.

Analizando la información económica-financiera comparada, NORTE tiene unos datos peores en las ratios viajeros por kilómetro (Figura 4), resultado final en millones de pesetas (Figura 11), gastos de explotación en millones de pesetas (Figura 7), viajeros netos transportados en millones de pesetas (Figura 2), longitud de líneas en kilómetros (Figura 1) y cargas financieras en millones de pesetas (Figura 12), tendencias de gastos de explotación (Figura 9).

\footnotetext{
${ }^{1367}$ La complejidad del problema es observable en Imedio Díaz (1929) y en el Instituto de Reformas Sociales (1922).

${ }^{1368}$ Se trata de una nueva institución corporativa destinado a examinar y proponer al Gobierno las resoluciones que debían ser adoptadas, procurando armonizar las necesidades que el servicio público exige con los intereses de la clase patronal -las concesionarias- y la obrera.

1369 NORTE (1940: 388-396) y Juez (2000: 155-159).

1370 Jiménez Ontiveros (1940: 79-80) y Soto Carmona (1989: 619).
} 
Sólo NORTE aventaja a MZA en ingresos de explotación en millones de pesetas (Figura 6), tendencias de cargas financieras (Tendencia 10) y tendencias de ingresos de explotación en millones de pesetas (Figura 8). Como la situación económico-financiera de MZA era mejor, NORTE intentó la fusión para mejorar su estructura empresarial y su potencialidad futura. Circunscribiéndonos a estos datos en concreto, a MZA no le convenía que la fusión se produjese.

\subsection{Cotización de NORTE}

La cotización de los valores de los títulos-valores de NORTE no concuerda con su valor contable. NORTE suspendió el dividendo a partir de 1891 y no lo restableció hasta 1907 (NORTE, 1940: 10). Esto es derivado de la mala situación económica de NORTE y de que no podía repartirse dividendos a los accionistas hasta pasados cinco años desde la implantación del Convenio de 1900. En ese periodo, las acciones de NORTE no concedían dividendos y, sin embargo, cotizaban a tipos relativamente elevados. La falta de correlación entre valor contable y valor de cotización también lo tuvo MZA, pues los mayores niveles de cotización de ambas compañías se produjeron en los ejercicios contables 2012 y 2013.

En el año 1919 la cotización estaba disminuyendo tanto en NORTE como en MZA, aunque los valores de MZA eran mayores. Respecto a estos datos en concreto, a MZA no le convenía que la fusión se produjese, mientras que NORTE entendía que con la unificación de sus títulos, la cotización sería más estable y con más potencialidad de crecimiento.

El cuadro 88 recoge la comparación de tipo medio de cotización y dividendos de NORTE y MZA en el periodo 1900-1920. 
Cuadro 88. Comparación de tipo medio de cotización y dividendos de NORTE y MZA en el periodo 1900-1920

\begin{tabular}{|c|c|c|c|c|c|c|c|c|}
\hline \multirow[b]{2}{*}{ Año } & \multicolumn{4}{|c|}{$\begin{array}{c}\text { Compañía de los Caminos de Hierro del Norte de } \\
\text { España }\end{array}$} & \multicolumn{4}{|c|}{$\begin{array}{l}\text { Compañía de los Ferrocarriles de Madrid a Zaragoza } \\
\text { y a Alicante }\end{array}$} \\
\hline & $\begin{array}{l}\text { Tipo } \\
\text { medido de } \\
\text { cotización } \\
\text { de las } \\
\text { acciones } \\
(\%)\end{array}$ & $\begin{array}{l}\text { Dividendo } \\
\text { libre de } \\
\text { impuestos } \\
\text { (Pesetas } \\
\text { por acción) }\end{array}$ & $\begin{array}{l}\text { Dividendo } \\
\text { libre de } \\
\text { impuestos } \\
\text { (\% sobre el } \\
\text { valor } \\
\text { nominal de } \\
\text { las } \\
\text { acciones) }\end{array}$ & $\begin{array}{l}\text { Dividendo } \\
\text { libre de } \\
\text { impuestos } \\
\text { (\% sobre el } \\
\text { valor de } \\
\text { cotización } \\
\text { de las } \\
\text { acciones) }\end{array}$ & $\begin{array}{l}\text { Tipo } \\
\text { medido de } \\
\text { cotización } \\
\text { de las } \\
\text { acciones } \\
(\%)\end{array}$ & $\begin{array}{l}\text { Dividend } \\
\text { o libre de } \\
\text { impuesto } \\
\mathrm{s} \\
\text { (Pesetas } \\
\text { por } \\
\text { acción) }\end{array}$ & $\begin{array}{l}\text { Dividendo } \\
\text { libre de } \\
\text { impuestos } \\
\text { (\% sobre el } \\
\text { valor } \\
\text { nominal de } \\
\text { las } \\
\text { acciones) }\end{array}$ & $\begin{array}{l}\text { Dividendo } \\
\text { libre de } \\
\text { impuestos } \\
\text { (\% sobre el } \\
\text { valor de } \\
\text { cotización de } \\
\text { las acciones) }\end{array}$ \\
\hline 1900 & 55,67 & - & - & - & 81,835 & 9 & 1,89 & 2,31 \\
\hline 1901 & 53,23 & - & - & - & 76,34 & 6 & 1,26 & 1,65 \\
\hline 1902 & 55,48 & - & - & - & 85,025 & 12 & 2,53 & 2,97 \\
\hline 1903 & 61,71 & - & - & - & 95,39 & 8 & 1,68 & 1,76 \\
\hline 1904 & 50,34 & - & - & - & 82,74 & 5 & 1,05 & 1,27 \\
\hline 1905 & 47,60 & - & - & - & 80,81 & 8 & 1,68 & 2,08 \\
\hline 1906 & 56,16 & - & - & - & 91,41 & 15 & 3,16 & 3,45 \\
\hline 1907 & 64,26 & 10 & 2,10 & 3,27 & 93,06 & 16 & 3,37 & 3,62 \\
\hline 1908 & 72,45 & 13,19 & 2,77 & 3,83 & 94,00 & 17 & 3,58 & 3,81 \\
\hline 1909 & 79,38 & 15,09 & 3,17 & 4 & 94,03 & 18 & 3,79 & 4,03 \\
\hline 1910 & 86,02 & 17,96 & 3,78 & 4,39 & 94,64 & 20 & 4,21 & 4,05 \\
\hline 1911 & 92,50 & 19,87 & 4,18 & 4,52 & 94,45 & 21 & 4,42 & 4,68 \\
\hline 1912 & 103,83 & 22,715 & 4,78 & 4,60 & 100,74 & 24 & 5,05 & 5,01 \\
\hline 1913 & 106,02 & 22,704 & 4,78 & 4,50 & 101,67 & 24 & 5,05 & 4,97 \\
\hline 1914 & 87,07 & 14,09 & 2,97 & 3,40 & 89,51 & 15 & 3,16 & 3,53 \\
\hline 1915 & 72,35 & 17,06 & 3,59 & 4,96 & 72,85 & 18 & 3,79 & 5,20 \\
\hline 1916 & 76,88 & 14,09 & 2,97 & 3,86 & 76,36 & 17 & 3,58 & 4,69 \\
\hline 1917 & 68,59 & - & - & - & 70,49 & 12 & 2,53 & 3,58 \\
\hline 1918 & 66,28 & - & - & - & 70,94 & 5 & 1,05 & 1,48 \\
\hline 1919 & 63,46 & - & - & - & 67,12 & 15 & 3,16 & 4,70 \\
\hline 1920 & 60,26 & 14,69 & 3,09 & 5,13 & 61,86 & 15 & 3,16 & 5,10 \\
\hline Promedio & 70,45 & 8,64 & 1,81 & 2,21 & 84,537 & 14,28 & 3,007 & 3,55 \\
\hline
\end{tabular}

Fuente: Elaboración propia a partir de los datos del "Cuestionario sobre la valoración de los ferrocarriles" elaborado por el Ministro Señor La Cierva. 10 de abril de 1921: Anejo número 1 y Anejo número $2^{1371}$.

\subsection{Establecimiento de tres oligopolios en 1923. Posterior intento de fusión NORTE- MZA}

El Directorio militar intentó resolver el problema ferroviario con una serie de medidas que culminarían con la emisión del Estatuto Ferroviario de 1924.

El 8 de noviembre de 1923 se publicó el "Plan de estructuración de la red ferroviaria nacional", realizado por el teniente coronel Felix Angosto, el comandante del Estado Mayor Celedonio de la Iglesia y Gregorio Pérez Conesa en representación del Ministerio de Obras Públicas. En este Plan se realizó una división geográfica de España para estructurar la red ferroviaria nacional en tres sectores:

${ }^{1371}$ Reproducido en Peña y Pérez (1940, tomo I: 48). 
- NORTE. Desde la línea de Madrid-Plasencia-Cáceres a Portugal a la línea MadridGuadalajara-Zaragoza-Tardienta-Jaca-Canfranc, ambas excluidas.

- ESTE. Desde la línea Madrid-Guadalajara-Zaragoza-Tardienta-Jaca-Canfranc, hasta la línea Madrid-Alcázar-Chinchilla-Murcia-Cartagena, ambas incluidas (también se incluye la línea Castillejo a Toledo).

- MEDIODÍA. Desde la línea Madrid-Alcázar-Chinchilla-Murcia-Cartagena, toda ella excluida (también se excluye la línea Castillejo a Toledo), hasta la línea de MadridPlasencia-Cáceres a Portugal, toda ella incluida.

El 15 de noviembre de 1923 se elaboró un Proyecto de normas para llevar a cabo la estructuración de las líneas férreas. Las compañías concesionarias de ferrocarriles podían presentar a la aprobación del gobierno, antes del 1 de enero de 1926, planes de fusión que tendieran a constituir los tres sectores definidos en el acta de 8 de noviembre de 1923, procurando que se formasen tres empresas, cada una de las cuales resultase concesionaria del mayor número posible de las líneas comprendidas en el respectivo sector (artículo 1). El texto establece que no se permitirían planes de fusiones entre empresas de sectores distintos (artículo 4).

Por las Reales Órdenes de 27 de noviembre de 1923 y de 1 de diciembre de 1923 se remitió al Consejo Superior Ferroviario, para su Informe, el "Proyecto de estructuración de la red ferroviaria nacional". El 13 de diciembre de 1923, el Consejo Superior dictaminó el "Proyecto de estructuración de la red ferroviaria nacional" en el que se materializaba y concretaba el texto de 8 de noviembre de 1923.

El "Proyecto de estructuración de la red ferroviaria nacional" de 13 de diciembre de 1923 significaba reordenar el tráfico ferroviario en tres zonas para unificar en una única administración cada una de las principales corrientes del tráfico, mejorar estratégicamente las empresas (con medidas como unificar el material, métodos y condiciones de explotación, ofrecer mejores soluciones al establecimiento de los itinerarios de los trenes de viajeros y combinaciones de éstos, etc.), y simplificar las transmisiones reduciendo el número de empalmes.

Nunca se llegó a cumplir, aunque siempre se mantuvo la posibilidad de realizar el "Proyecto de estructuración de la red ferroviaria nacional" antes de que se efectuara la reversión de las líneas, y dentro siempre del respeto de los derechos de las empresas y de la libertad de ésas para aceptar o rechazar el procedimiento.

Las tres zonas tenían su punto de convergencia en Madrid, elegido entre otras razones, porque la estación del Norte podría servir para la línea Norte y Noroeste (Norte en denominación del acta de 8 de noviembre de 1923), la de Atocha para la línea Este y Noreste (Este en denominación del acta de 8 de noviembre de 1923) y la de Delicias para la línea del Sur (Mediodía en denominación del acta de 8 de noviembre de 1923). 
Las tres redes que comprenden el proyecto de restructuración presentan las siguientes modificaciones para las tres grandes compañías existentes en ese momento:

- La red Norte estaría constituida a base de la red de la compañía NORTE en ese momento. Se proponían segregar las prósperas líneas de la región Valenciana, desde La Encina a Tarragona, así como también la línea de Zaragoza a Barcelona. NORTE perdería también la línea de Barcelona a San Juan de las Abadesas, y con ésta y la de Huesca a Jaca, las dos comunicaciones con Francia. A cambio, a la red del Norte se agregarían líneas de tráfico tan escaso como la de Valladolid a Ariza, la de Plasencia a Astorga, Medina a Zamora y Salamanca, Salamanca a la frontera portuguesa, y alguna otra de pequeños o nulos rendimientos.

- La red del Este comprende la mayor parte de las líneas que en ese momento pertenecían a MZA, menos la de Valladolid a Ariza, que pasa a la zona Norte, y las de Madrid a Ciudad Real y Badajoz, Aljucén a Cáceres, Mérida a Sevilla y la de Alcázar a Sevilla y Huelva que irían a la zona Mediodía. A cambio se incorporarían las líneas valencianas y catalanas que se proyectaba segregar de la Compañía del NORTE y la de Calatayud-Teruel-Sagunto, explotadas en ese momento por la Compañía Central de Aragón.

- La red Mediodía comprende todas las líneas que en ese momento explotaba la Compañía de los Andaluces, más la de las de Madrid a Ciudad Real y Badajoz, Aljucén a Cáceres, Mérida a Sevilla y la de Alcázar a Sevilla y Huelva y la de Madrid a Cáceres y Valencia de Alcántara que hubieran pasado de la compañía MZA a esta zona.

Estas transformaciones requieren la desmembración de la Compañía NORTE, cambios de unas líneas por otras en la de MZA y supresión de determinadas compañías. Entre las sociedades suprimidas destacan las de Madrid a Cáceres y Portugal, Salamanca a la frontera portuguesa, Medina a Zamora y Orense a Vigo, y la Compañía Central de Aragón.

Claramente la compañía NORTE saldría perdiendo con la aplicación del Proyecto, pues la privaría de excelentes líneas dándole a cambio otras líneas poco atractivas. De ello es consciente el Proyecto, sin citar expresamente a la Compañía NORTE, considera que no aceptarían voluntariamente "la amputación de miembros sanos para reemplazarlos por otros enfermos, ni resignarse sin protesta a una disminución de su prestigio" ${ }^{1372}$.

Por tanto, NORTE sería el principal escollo para que la estructuración prevista en el Proyecto se realizase. La Real Orden previene que no todas aceptarían voluntariamente, puesto que el Proyecto "colocaría a algunas en una situación de evidente inferioridad respecto de la que actualmente se encuentran" ${ }^{1373}$. Por tanto, el Proyecto, por un lado, no obliga a las empresas a

\footnotetext{
1372،"Proyecto de estructuración de la red ferroviaria nacional”, Madrid, 13 de diciembre de 1923.

1373،"Proyecto de estructuración de la red ferroviaria nacional", Madrid, 13 de diciembre de 1923.
} 
aceptarla, y por otro, concluye unas propuestas que conscientemente sabe que son muy improbables de aplicar.

Ante la negativa casi segura de la compañía NORTE, el Informe ofrece la solución sin necesidad de realizar la reestructuración. El Informe considera que podría alcanzarse un resultado ventajoso facilitando, si se produjera la exención de toda clase de derechos e impuestos, para facilitar la fusión de redes a las que pudiera convenir por encontrarse en condiciones similares. "Posible es que así ocurriese en las dos grandes redes del NORTE y de MZA, y en tal caso la reunión del conjunto de sus líneas determinaría ventajas que se acercarían mucho a las de la red única, y al importante núcleo así formado podrían agregarse otras líneas por medio de nuevas fusiones que resultasen convenientes para todas" ("Proyecto de estructuración de la red ferroviaria nacional", Madrid, 13 de diciembre de 1923).

Así tenemos los dos objetivos del Directorio: primero una división en tres compañías, y si NORTE no quiere ${ }^{1374}$, la fusión de NORTE y MZA. La segunda era a priori una solución más sencilla, justa y ventajosa, y además tenía el apoyo del Estado.

El Proyecto establece cinco conclusiones ${ }^{1375}$ :

1) El Proyecto de estructuración de las líneas férreas es prematuro, por cuanto en el plazo que ha de transcurrir hasta las reversiones pueden producirse circunstancias que modifiquen las condiciones de explotación en ese momento.

2) Convenía que la explotación de las líneas de ancho normal fuese independiente de las de vía estrecha.

3) Cuando llegase la reversión, era preferible la red única a su división en tres redes independientes.

4) La agregación de nuevas líneas a las ya existentes no podía realizarse por desmembración de otras, por oponerse a ello la solidaridad hipotecaria y financiera, que existe entre las líneas de la misma red.

5) El Estado debía facilitar las fusiones voluntarias de las compañías concesionarias por cuantos medios oportunos, y singularmente por la exención de impuestos y derechos que gravan las fusiones, tendiéndose de este modo a la constitución de grandes redes, que habrían de proporcionar, las ventajas que se obtendrían con la explotación de la red única, de las que serían base.

El 17 de diciembre de 1923 los representantes de ocho importantes bancos elevaron una instancia al presidente del Directorio Militar en relación al régimen ferroviario. Ante la posibilidad de que el Estado ejerciera su derecho de adquirir líneas mediante pago de su importe, estaban preocupados porque la experiencia había sido "desastrosa en países más acostumbrados a una buena y ordenada administración". Pero aún consideraron un error más grave anular el crédito de las compañías y sustituirle por el del Estado, pues éste "tendría insoportables cargas que conllevarían un detrimento del sector transporte". Evidentemente, por lo que estaban más preocupados era por sus negocios de intermediación financiera. Pero

\footnotetext{
${ }^{1374}$ Sin duda no quería. De ello era consciente el legislador.

1375 "Proyecto de estructuración de la red ferroviaria nacional”, Madrid, 13 de diciembre de 1923.
} 
los representantes de la Banca también estában preocupados de que mientras se implantaba el nuevo régimen no se privará a las compañías de los recursos necesarios pues ello podría producir la depreciación de los valores ferroviarios en 5.000 millones de pesetas, que habría de arrastrar a todos los demás títulos, haciendo perder la confianza de la opinión pública en la Banca.

El 28 de diciembre de 1923, el general Mayandía dio a conocer el texto del Proyecto de nuevo régimen ferroviario preparado por la Ponencia de Ferrocarriles del Directorio Militar ${ }^{1376}$. Los principios fundamentales de ella eran los siguientes:

I. Orientación de toda la gestión ferroviaria hacia la nacionalización de los ferrocarriles.

II. Intervención del Estado, ordenando las obras y los trabajos en general, y en su caso, los rescates, para conseguir la estructuración racional de las líneas férreas.

III. Construcción de obras de ampliación y mejoras de las actuales y adquisición de material, con carácter preferente y de urgencia, y construcción de líneas nuevas y de obras ferroviarias, independientemente de las actuales concesiones, conforme lo exijan los intereses públicos.

IV. Arriendo a los concesionarios de material de toda clase y del disfrute de obras ferroviarias y de líneas de ferrocarriles propiedad del Estado.

V. Cubrir los gastos de explotación y las cargas de toda clase, con un "rédito prudencial y justo" de interés y amortización para los capitales reales de los concesionarios, y suprimir todo uso gratuito de las vía férrea que no esté justificado por razón de servicio.

VI. Emisión de una deuda especial ferroviaria, a fin de anticipar a las empresas los fondos necesarios, para realizar los planes de obras y adquisiciones anteriores.

VII. Constitución de la Caja Ferroviaria del Estado para garantizar al Estado la compensación de pérdidas y la percepción de sus intereses y amortizaciones.

VIII. Libertad de las empresas para acogerse al nuevo régimen ferroviario.

IX. Funcionamiento autónomo de las empresas, pero constantemente intervenidos en todos sus aspectos por el Estado, para garantizar los intereses públicos.

El Directorio concedió el breve plazo de cinco días hábiles para que las compañías informaran sobre el Proyecto ${ }^{1377}$. El 4 de enero de 1924, las compañías firmaron un documento muy detallado, que incluía muchas observaciones con una gran cantidad de información literal e incluso gráficos y cuadros. Estas observaciones de las compañías fueron refutadas por el teniente coronel de ingenieros, Julián Gil Clemente, con la consiguiente réplica de NORTE y MZA (1932: 50 y 54) $)^{1378}$.

\footnotetext{
${ }^{1376}$ NORTE y MZA (1932: 50) se quejaron de que la Ponencia del Directorio, comunicado a las compañías el 28 de diciembre de 1923, no tuvieron en cuenta ni su informe ni las observaciones presentadas por la Banca con referencia al aspecto financiero del problema.

${ }^{1377}$ NORTE y MZA (1932: 50) afirmaron que en la Ponencia del Directorio se aprecia la influencia del Proyecto Maura y su derivado de Arguelles, "toscamente interpretados".

1378 Julián Gil Clemente fue menospreciado por NORTE y MZA (1932: 54) por poseer el cargo de teniente coronel. Más adelante, la hija de Julián Gil Clemente, la escultora y dibujante Marga Gil Roësset, se suicidó por amor a Juan Ramón Jiménez cuando éste la rechazó. Así al menos lo contó la nieta de Gil Clemente, Marga Clark (2002).
} 
La Dictadura de Primo de Rivera articuló una malla protectora de la industria nacional (García Delgado et al., 1976: 76) (Fernández Díaz Sarabia, Pedro, 2006: 1) en la que destaca el intervencionismo estatal, el aumento de la concentración económica y la proliferación de prácticas monopolistas. La predilección por las empresas monopolísticas del dictador jerezano, provocó que apoyara un gran número de absorciones y fusiones empresariales a lo largo del Directorio Militar como la creación del monopolio de CAMPSA. También apoyó las fusiones entre empresas concesionarias del ferrocarril, por lo que se puede afirmar que las dos principales compañías de ferrocarriles españolas MZA y NORTE no se fusionaron a pesar de que tuvieron un ambiente propicio para ello.

Si hubiese durado más el Directorio militar, las probabilidades de alcanzar la fusión entre NORTE y MZA hubieran sido mayores.

\subsection{Intento de fusión NORTE-MZA de 1931}

En julio 1931 hubo otro intento de acercamiento de NORTE para efectuar la fusión, y otra vez no salió adelante porque en MZA no aceptaron. La diferencia es que por primera vez, la mayoría de MZA sí estaba de acuerdo con la fusión (Maristany por un lado, y los Rothschild por otro), y sólo una parte (Lisle del Comité de París de MZA) era contrario a ella.

La primera reunión, de carácter informativo, de esta nueva intentona de NORTE, tuvo lugar entre Boix y Maristany el día 25 de julio de $1931^{1379}$. Maristany abrió la puerta a la posibilidad de realizar un nuevo contrato de características similares a la Sindicatura de 1906. Para su concreción, los Directores de ambas empresas decidieron delegar el estudio de las cuestiones concretas en Garre, por parte de NORTE, y en Alfonso por MZA.

\subsubsection{Factores favorables a la fusión}

Existía un motivo de orden práctico. El gobierno pensaba que, si se alcanzaba la fusión, podría incorporar una nutrida representación del Estado en el nuevo Consejo de Administración.

El segundo factor estaba provocado porque a principios de 1931, el entorno económico y laboral era negativo. Existía una coyuntura económica particularmente difícil, fundamentalmente por la crisis de la explotación.

Desde el año 1920, había disminuido el tráfico de NORTE considerablemente. La cifra máxima de viajeros se produjo en 1925, pero a partir de ahí sufre un rápido descenso hasta 1935, salvo los repuntes de los años 1919 y 1930 (NORTE, 1940: 352). Desde 1917 existe un acusado aumento del número de viajeros-kilómetros de NORTE hasta 1926, con una media de crecimiento de 113 millones. Desde el año 1926 se acentúa la bajada; en el periodo 19261928 la bajada es de 50 millones de pesetas. En el año 1928 coinciden los dos mínimos en la

${ }^{1379}$ Carta que Maristany envía a Lisle el día 31 de julio de 1931. 
vida de la empresa: del número absoluto y del de viajeros-kilómetros. En los años 1929 y 1930 hay dos aumentos en este último indicador, paralelo a los del número absoluto. Desde el año 1930 el número de viajeros-kilómetros disminuye (NORTE, 1940: 353). A posteriori podemos afirmar que la situación económica de ambas compañías era muy mala, tanto que, como podemos ver en la figura 11, los resultados contables a partir de 1931 fueron siempre negativos (salvo el año 1933)

No obstante, aunque los datos de NORTE no son buenos, los de MZA son aún peores. NORTE presenta mejores datos en Ingresos de explotación (Figura 6), Toneladas netas transportadas (Figura 3), Toneladas por kilómetro (Figura 5), Tendencia de las cargas financieras (Figura 10), Tendencia de los gastos de explotación (Figura 9). Por otro lado, MZA presenta mejores niveles que NORTE en Viajeros por kilómetro (Figura 4), Gastos de explotación (Figura 7), Viajeros netos (Figura 2), Cargas financieras (Figura 12), Tendencia de ingresos de explotación (Figura 8).

MZA era consciente de esa mala situación. Maristany, en carta a Lisle fechada unos meses antes, expresaba que todavía estaba por llegar lo peor; el director de MZA le había confiado que jamás habían pasado por una situación que "ni de lejos pueda tener comparación con la actual" ${ }^{\prime 380}$.

Por otro lado, el 26 de febrero de 1931, se aprueba el "Real Decreto de la Cierva, estableciendo el jornal mínimo del personal ferroviario". En él se fija en cinco pesetas el jornal mínimo del personal masculino, además se concede un aumento de 0,5 pesetas a los trabajadores que ganaran menos de 6 pesetas $^{1381}$. En este contexto, NORTE creía que la fusión podría aliviar la situación económica, incidiendo en las legislaciones futuras con un papel conjunto más importante y aumentando la potencialidad estratégica de la nueva compañía.

En tercer lugar, existía un convencimiento de que el Estado iba a impedir que existieran personas que ocuparan simultáneamente el cargo de Consejeros en varias empresas. Hasta los años treinta, habían existido bastantes personas que lo habían simultaneado, y esta había sido una de las principales razones por las que no se había realizado una fusión anteriormente, pues estas personas no querían sacrificar el privilegio de obtener varias fuentes de financiación del cargo de administrador. Si al final -como así ocurrió- iba a ser incompatible simultanear los cargos, no importaba que ahora sí se produjera una fusión. La República aprobó la Ley de Incompatibilidades (9 de septiembre de 1932), que impedía a los administradores de las compañías acogidas al Estatuto de 1924 figurar en los Consejos de Administración si éstos tenían simultáneamente intereses en más de tres compañías ferroviarias o en empresas suministradoras de material móvil o fijo. A consecuencia de ello, doce consejeros de NORTE abandonaron el Consejo de Administración en mayo de 1933.

\footnotetext{
${ }^{1380}$ Carta de E. Maristany a R. Lisle del Comité de París de MZA, del 12 de agosto de 1931.

${ }^{1381}$ Un análisis de este Real Decreto aparece en Peña y Pérez (1940, tomo IV: 31).
} 


\subsubsection{Factores que impidieron la fusión}

En julio de 1931 se volvió a plantear la misma fusión. Ante ella, sugirieron una enorme diversidad de argumentos en contra de la fusión, la mayor parte ya se habían utilizado en 1919. Pero hubo alguna idea nueva. Como para entonces la Sindicatura ya había terminado, su fracaso por los numerosos desvíos de tráfico de que MZA acusaba a NORTE, se convirtieron en un argumento más a favor del no ${ }^{1382}$.

El intento de 1931 tardó mucho en resolverse. Las seis principales dificultades y factores que lo impidieron fueron las siguientes.

La primera es que existían dudas sobre si regían los artículos del Estatuto de 1924 sobre la exención de impuestos para fusiones entre compañías. Si no hubiera habido una exención de impuestos, estos serían tan elevados que su coste desaconsejaría la operación. Al poco tiempo, se supo que el gobierno de la República mantendría los mismos privilegios que aparecían en el Estatuto.

El segundo factor que impidió la fusión fue que ambas empresas temían por las tensiones provocadas por los diferentes derechos que poseían los trabajadores en cada una de sus empresas.

La tercera razón para desaconsejar la emisión es la desconfianza de los responsables de MZA sobre la organización, gestión y servicio de NORTE. Esta información estaba originada por el flujo de información entre los tomadores de decisión de ambas empresas, e incluso estaba apoyado porque existían personas que simultaneaban el cargo de Consejero en ambas compañías ${ }^{1383}$.

En verdad, sólo una parte de MZA abordó a fondo el tema con verdadero interés y voluntad por sacarlo adelante. Sólo los Rothschild querían la fusión; ahora de forma decidida desde la pérdida de importancia de los Péreire en NORTE. Maristany recibió una carta autógrafa de Robert de Rothschild, en la que le brindaba toda la confianza, apoyo y ánimo para que se llevara a cabo la fusión, definida como "cuestión de importancia capital""1384. Otra cosa bien distinta era la opinión de Lisle del Comité de París de MZA. El día 8 de agosto de 1931 llegó la respuesta de Lisle y en ella se decía que le parecía quimérica la fusión completa de las dos compañías y que tal y como estaban las cosas en 1931, el único refugio era el rescate rápido aplicando el Estatuto de 1924.

\footnotetext{
1382 Archivo de Renfe. Caja número 43 expediente 147 Aproximación con el NORTE, 1931. Nota para el Sr. Director Adjunto D. Eduardo Alfonso. Irregularidades en el encaminamiento del tráfico combinado entre NORTE y MZA. Crisis, guerra y nacionalización.

${ }^{1383}$ Antonio Valenciano fue simultáneamente Consejero de MZA y de la Compañía del Ferrocarril Central de Aragón, cuando fue adquirida por NORTE en 1924 por medio de una OPA.

${ }^{1384}$ Carta de Robert de Rothschild a Eduardo Maristany, 1 de agosto de 1931.
} 
En junio de 1932, se escribió un documento en las oficinas de MZA que llevaba por encabezamiento "Consideraciones preliminares sobre una posible fusión entre el NORTE y MZA". Es necesario destacar el amplio proceso para realizar la posible fusión porque el documento llevaba todavía este encabezamiento, aunque hubiera transcurrido casi un año. En el documento hay una exposición de posibles dificultades, fijándose sólo en lo negativo que plantearía ésta y apareciendo sin soluciones. Cada vez que surgía alguno de los problemas más serios, como podría ser la valoración que se haría de cada una de las acciones, la contabilidad que habría que realizar para tener en cuenta las cargas hipotecarias anteriores, se obtiene indefectiblemente como toda respuesta una frase evasiva de que se trata de un asunto muy complicado sobre el que no se atreven a dar opinión: después de un año seguían añadiendo problemas en lugar de ofrecer soluciones ${ }^{1385}$. En conclusión, todo acabó en nada solamente sirvió para que en el verano de 1933 se retomaron algunas de las cláusulas del contrato de Sindicatura sobre el tráfico combinado entre las dos redes ${ }^{1386}$.

Pero el intento de fusión realmente concluyó con el fallecimiento del director general de NORTE, Boix, en mayo de 1932, el cual había sido uno de los principales promotores de este proyecto. Este Director de NORTE tenía gran prestigio entre los dirigentes de NORTE, y sobre todo era el interlocutor natural de Maristany.

\footnotetext{
1385 Archivo de Renfe. Caja número 43 expediente 147. “Aproximación con el NORTE. 1931-1932”.

${ }^{1386}$ Carta de Indalecio Prieto a Juan Alvarado, 24 de julio de 1933.
} 


\section{CONCLUSIONES FINALES}

\section{Importancia de las ferroviarias en el desarrollo de la organización y del sistema de información contable}

En las empresas ferroviarias se originaron y desarrollaron los modernos sistemas de gestión y organización de empresas, de la gestión de los recursos humanos, de la innovación en la financiación, del sistema de información para la toma de decisiones y de la auditoría.

- Las ferroviarias fueron las primeras empresas en investigar sobre el manager científico y en profundizar sobre la búsqueda de la estructura organizativa adecuada. En Estados Unidos, las compañías alcanzaron un alto nivel de desarrollo en la implantación de un management científico a finales del siglo XIX, mientras que en Alemania, Francia e Inglaterra este proceso tuvo lugar en el primer tercio del siglo XX.

- Las ferroviarias fueron las primeras empresas en las que se pudo observar claramente que el poder dejaba de estar en manos de los accionistas para pasar a ser de los directivos.

Hasta la irrupción de las ferroviarias se aceptaba masivamente la idea de que el conjunto de accionistas-propietarios reunidos en las juntas generales de accionistas constituían la fuente de todo el poder en la sociedad anónima, que podía ser ejercido directamente, o bien delegado en otros órganos en la medida que fuese conveniente por razones prácticas. Este esquema funcional tradicional fue avasallado por la estructura empresarial de la gran sociedad anónima. La dispersión accionarial, como instrumento para la acumulación de capitales, provocó la separación entre la propiedad del capital y la gestión de la gran sociedad anónima. La dispersión del accionariado trasladó el poder de decisión del órgano tradicional de gobierno -la Junta General de Accionista- hacia el órgano de administración, formado por directivos profesionales con iniciativas e intereses particulares. Esta situación generó conflictos dentro de las organizaciones, pues existía el riesgo de que los ejecutivos orientasen las decisiones societarias en beneficio propio, antes que en el interés social.

El principal hecho económico que provocó las modificaciones en la estructura de poder de las empresas fue la relevancia que adquirió en Estados Unidos el mercado de capitales como fuente de financiación de las empresas a principios del siglo XX -sobre todo en la bolsa de New York-. La perspectiva del mercado de capitales constituyó una nueva forma de entender la empresa. El accionista de una sociedad cotizada fue considerado más como partícipe del mercado de capitales que como miembro de una agrupación de accionistas. Con la influencia del mercado bursátil se asumió que en la gran sociedad anónima el accionista clásico pasó a ser solamente un inversor, por lo que los supuestos propietarios 
de la sociedad anónima no realizaban un control suficiente sobre los ejecutivos que gestionaban la compañía.

- Las empresas ferroviarias estadounidenses y británicas fueron las primeras en financiarse con clases de acciones. La primera empresa que atisbó la utilidad de la emisión de las clases de acciones en Estados Unidos fue la Baltimore and Ohio Railroad Company, que en 1836 autorizó en sus estatutos sociales la emisión de acciones privilegiadas.

- Las empresas ferroviarias estadounidenses basaron sus registros desde el inicio en el método de la partida doble y realizaron las primeras grandes innovaciones en la técnica contable. La Boston \& Worcester Railroad ya llevaba la contabilidad por partida doble en 1831, y todas las empresas estadounidenses utilizaron ese método desde entonces.

Las ferroviarias fueron las primeras en establecer una estructura de cuentas para codificar las operaciones en la contabilidad financiera, en conceder importancia a la contabilidad de capital y en innovar sobre la contabilidad de gestión, tanto en el cálculo y análisis de los costes, como en la planificación y en el control. En 1831, la Boston \& Worcester Railroad calculaba la depreciación de sus activos no corrientes. En 1856, la Pennsylvania Railroad Company estableció el principio de prudencia valorativa y estableció la dotación de una reserva antes del reparto. En la década de 1850 comenzó en Estados Unidos el interés por la contabilidad creativa y el establecimiento de un único criterio para contabilizar la cuenta de construcción y de capital. Por su parte, los Directivos ferroviarios como Charles Ellet (en los años cuarenta del siglo XIX), Daniel C. Mc Callum (en los años cincuenta del siglo XIX) y Albert Fink y J. Edgar Thompson (en los sesenta del siglo XIX) idearon los sistemas de contabilidad y de información necesarios para controlar el movimiento de los trenes y el tráfico, dar cuenta de los fondos gestionados y determinar los beneficios y pérdidas de las diversas unidades operativas y de la empresa en su conjunto. Estos sistemas proporcionaron las técnicas básicas utilizadas para crear sus sistemas de control interno y contabilidad.

- Las ferroviarias fueron las primeras empresas en considerar que el usuario de la contabilidad no era únicamente la propiedad, sino que era el público en general.

Todo sistema contable debe definir sus usuarios principales (usuarios-objetivo) a los que pretenden satisfacer. En la época en la que no era obligatoria la publicidad masiva de la información contable, sus principales destinatarios eran la dirección de la empresa y los propietarios.

Posteriormente, coincidiendo con el comienzo del depósito de la información contable en los registros públicos, se amplió el espectro, considerando como usuario a accionistas, 
asociaciones de consumidores, asociaciones empresariales o profesionales, asociaciones vecinales, clientes, competidores, dueños, empleados, gobierno nacional, autonómico y local, inversores, ONGs, proveedores y sindicatos. Esta globalidad de usuarios es coincidente con el concepto stakeholder, término utilizado por primera vez por Freeman en 1984 para referirse a quienes pueden afectar o son afectados por las actividades de una empresa.

Las ferroviarias fueron las precursoras de la ampliación de los usuarios-objetivo del sistema de información contable, incidiendo en la importancia de que la globalidad de los usuarios conocieran la situación económico-financiera de la organización.

- En las ferroviarias estadounidenses comenzaron las discusiones públicas sobre la contabilidad creativa. Durante la década de 1850, los directivos del ferrocarril, los accionistas y los periodistas dedicaron mucho tiempo a establecer con claridad la distinción entre la cuenta de capital y la cuenta de explotación. El origen de esta discusión es que estaba consensuado que los directivos podían aparentar que obtenian unos beneficios que no estaban ganando en realidad, cargando los gastos de explotación en las cuentas de construcción. Esto lo hacían para intentar aumentar las posibilidades de la empresa de conseguir fondos para completar o continuar la construcción.

- Los auditores internos existen en las ferroviarias estadounidenses desde 1847, momento en el que Latrobe estableció en la Baltimore \& Ohio la figura de chief clerk, encargado de verificar las cuentas. Por su parte, las empresas ferroviarias estadounidenses tuvieron la necesidad de instaurar auditores externos desde la década de 1850, cincuenta años antes que lo requirieran las empresas del resto de sectores.

La contabilidad ferroviaria española tuvo un retraso considerable respecto a las ferroviarias estadounidense en estas siete innovaciones. El único aspecto en el que podemos considerarlas pioneras fue en el intento de adaptación sectorial de la contabilidad ferroviaria, con un Proyecto y una Recomendación de una Comisión Investigadora de la contabilidad de una compañía.

La base duodécima del "Proyecto de Ley sobre Transportes, Obras Públicas y Fomento de la Riqueza Nacional" de 1921, denominada "Del régimen de contabilidad", establecía que "un Real Decreto establecerá las reglas de contabilidad que deberán ser rigurosamente guardadas a fin de que se mantenga en todo tiempo distinta y clara la cuenta y razón de ingresos y gastos concernientes a ferrocarriles". Este es el primer intento (aunque no se llegó a aprobar definitivamente) de regular una adaptación sectorial en España, y se intentó para la contabilidad ferroviaria. 
Dos años más tarde, la Comisión Investigadora de la Contabilidad sobre MZA recomendó la creación por parte del Estado de una ley contable específica para empresas de ferrocarril, antecedente de la legislación contable obligatoria y, por ende, de las adaptaciones sectoriales. En opinión de la propia Comisión, con esta medida se mejoraría el registro, tanto por su incidencia en la fiabilidad, como en la comparabilidad.

\section{Importancia histórica de la empresa NORTE}

La empresa NORTE ocupó el primer puesto entre las empresas privadas españolas, por volumen de activos y personal laboral. NORTE siguió la estela de las empresas ferroviarias internacionales y fue pionera en España en siete aspectos, aunque con notable retraso respecto al momento en que se realizaron estas innovaciones internacionalmente:

- Fue pionera en la profesionalización de los sistemas de gestión y organización de empresas.

- Fue una de las primeras empresas que gestionó el capital humano de forma científica, pero seguro fue la primera que lo hizo con una masa laboral tan ingente.

- Fue una de las once primeras sociedades que diversificó su estructura financiera con clases de acciones.

- El grado de meticulosidad de sus Informes Anuales fue muy elevado.

- Fue una de las primeras empresas que registró una amortización sistemática de los activos no corrientes.

- Fue la primera empresa sobre la que tenemos constancia que se realizó una manipulación de los estados financieros.

- Sobre ella se realizó en 1923 una de las primeras auditorías externas de cuentas anuales.

\section{Organización y gestión de NORTE}

NORTE debería haber empleado mucho antes la estructura organizativa utilizada en las ferroviarias de Estados Unidos para mejorar su gestión. Sin embargo, tardó en adoptarla por tres razones. La primera es que la empresa era el resultado de múltiples fusiones y adquisiciones lo que impidió instaurar una estructura uniforme para la organización. En segundo lugar, las ideas chandlerianas estaban más divulgadas y propagadas en Estados Unidos que en España, lo que dificultaba su aplicación, pues no sólo debía ser adaptada por el nivel más alto de la empresa, sino también por los mandos intermedios y por los trabajadores de base. En tercer lugar, la empresa nació con capital y directivos franceses y, por ello, su estructura era inicialmente la departamental francesa; el capital y los directivos se fueron españolizando progresivamente lo que permitió incorporar nuevas estructuras, pero como esto sólo pudo realizarse poco a poco, no se aprovecharon las ventajas que tuvo la incorporación desde el inicio en las sociedades estadounidenses.

En la medida en que NORTE fue adoptando los modelos de gestión estadounidenses, la empresa mejoró su estructura organizativa. En la investigación se ha comprobado que existió 
una estrecha relación entre el porcentaje del capital de NORTE, el número y distribución de administradores y el nombramiento de Directores y Subdirectores.

El poder de los directores en NORTE fue muy grande, mucho más que el Consejo de Administración, que tiene una función de enlace con el poder político de cada momento y con otras empresas. Pero tanto poder no tuvo siempre su correspondencia con la honorabilidad de los directores.

Barat fue alabado como buen gestor, pero visto con el tiempo, fue el antecesor de los contratos millonarios de directivos y de la autoimposición de indemnizaciones y pensiones fuera de toda lógica. Desde 1898 y hasta que dejó de ser Director de NORTE en 1901, Barat cobró incentivos exagerados. La obtención de esta alta remuneración por parte de Barat fue acompañada de un reparto al resto de sus altos directivos para evitar su rechazo, y las consiguientes discrepancias en la cúpula directiva. En concreto, Barat dedicó casi seis millones de pesetas para recompensar al alto personal, y todo esto se producía en un periodo en el que NORTE arrastraba cinco ejercicios consecutivos de pérdidas contables.

Además antepuso sus intereses particulares a los de la compañía. Una de las razones de su gran motivación para adquirir y fusionar líneas de NORTE era que tenía un incentivo de 432 pesetas $/ \mathrm{km}$. Derivado de ello, tuvo una gran disputa con la empresa porque parte de esa remuneración no se le abonó, lo que provocó su salida del Consejo de Administración de NORTE en 1909.

\section{Soluciones a los problemas en la estructura financiera}

Existieron diferencias territoriales en la financiación de las empresas ferroviarias. Las empresas ferroviarias estadounidenses y británicas estuvieron financiadas a partes iguales con acciones y empréstitos, mientras que las sociedades de la Europa continental (Francia y España, entre otras) estuvieron financiadas mucho más por obligaciones que por acciones.

De la misma forma, también existieron diferencias dentro de la clase de empréstitos y de la estructura del capital. En Estados Unidos, casi todas las compañías ferroviarias del periodo 1900-1923 estuvieron financiadas por cuatro tipos de empréstitos: obligaciones hipotecarias, obligaciones diversas, obligaciones cuya garantía radica únicamente en el beneficio líquido y obligaciones cuya garantía única es el material móvil de las compañías; por su parte, en la Europa continental, normalmente existió un único modelo de obligaciones, bien sea de carácter personal, como en Francia, bien de carácter hipotecario, como en España.

También existieron marcadas diferencias entre las distintas zonas geográficas en el proceso de emisión de acciones. El capital social de las empresas en Estados Unidos de América y el Reino Unido de la Gran Bretaña estaba compuesto por acciones ordinarias y privilegiadas, mientras que el capital de las empresas en la Europa continental estaba formado por acciones ordinarias en casi todos los casos. La existencia de emisiones de privilegiadas, rescatables, 
preferentes y $\sin$ voto en la Europa continental fue mucho menor que en el mercado anglosajón.

Las similitudes entre la estructura financiera de las empresas francesas y españolas, y su diferenciación del modelo anglosajón y germánico, no fue casual. La mayor parte del capital de las compañías españolas tiene su origen en pudientes familias francesas, y en menor medida de Bélgica, derivado de ello, se importó tanto la forma de financiación como los instrumentos en los que se materializaron.

Las empresas ferroviarias españolas se financiaron mayoritariamente por medio de empréstitos. Aunque no es lo más común, existieron once empresas relacionadas con el sector ferroviario que emitieron acciones preferentes, privilegiadas y/o rescatables: NORTE, Compañía del ferrocarril de Madrid a Aragón, Construcciones y Ferrocarriles, SGTME, CGFC, Villena a Alcoy y Yecla, Barcelona Traction, Ferrocarril de Cataluña, MPDR, Compañía del Ferrocarril Central de Aragón y Compañía General del Ferrocarril.

Aunque la emisión con clases de acciones por parte de las ferroviarias españolas fue escasa, podría haber ayudado a resolver el problema ferroviario, porque hubiera permitido financiar a las ferroviarias con acciones en mayor porcentaje que obligaciones, protegiendo su solvencia al no obligar a entregar a los inversores su remuneración periódica.

NORTE fue una de las once únicas empresas ferroviarias españolas que utilizaron emisiones de acciones privilegiadas para financiarse, lo cual debe ser destacado por ser una de las pioneras en explorar novedosas formas de diversificar su financiación. Sin embargo, NORTE no emitió acciones rescatables, lo cual hubiera mejorado su estructura financiera porque hubiera permitido unir la obtención de fondos con las necesidades de recursos a lo largo del ciclo de construcción del tendido. No obstante, la compañía tuvo un intento de amortizar las acciones ordinarias. El presidente de la compañía dió cuenta al Consejo de la carta que le había dirigido un Administrador sometiendo a su examen un proyecto muy detallado para poder efectuar la amortización de las acciones de la compañía, de forma que quedasen totalmente reembolsadas antes de revertir al Estado las últimas líneas que hubieran de entregar. El Consejo consideró una propuesta muy interesante y acordó que pasase a estudiarla el Comité Ejecutivo, aunque nunca se aprobó.

La financiación con clases de acciones hubiera resuelto, o al menos atenuado, los cuatro principales problemas de las ferroviarias concesionarias españolas.

En primer lugar, las concesionarias españolas tenían una alta financiación con recursos ajenos, fundamentalmente obligaciones, lo que provocaba una estructura económicofinanciera caracterizada por un alto nivel de endeudamiento, y que durante largos periodos no remuneró en absoluto a sus propietarios. Ante la necesidad de captar fondos, el único camino era aumentar sus deudas, algunas bancarias, pero sobre todo por medio de empréstitos. Si las compañías hubieran utilizado acciones privilegiadas u otra clase de acciones, se registrarían en los recursos propios. De esta forma, la situación económico-financiera hubiera sido la 
misma, pero la apariencia hubiera sido la de un endeudamiento menor. Además, si la sociedad no obtuviera beneficios, la compañía no tendría la obligación de remunerar a los accionistas privilegiados.

En segundo lugar, y unido al anterior problema, la financiación con empréstitos ofrecía una remuneración alta, insostenible para las empresas a largo plazo. El inversor español estaba poco motivado en invertir en sectores de elevado riesgo, como era la construcción de vías ferroviarias, por lo que las empresas se vieron obligadas a remunerar altamente a los obligacionistas. Las concesionarias podrían haber ofertado a los mercados de capitales emisiones de acciones con ventajas distintas a la remuneración -como privilegios en el voto o en el derecho a obtener una mayor cuota de liquidación-, de forma que hubieran podido ofrecer una remuneración moderada, aunque esto hubiera supuesto alguna otra contraprestación.

En tercer lugar, los administradores de las ferroviarias estaban más motivados a emitir empréstitos que acciones para no perjudicar el control empresarial de las inversiones de los accionistas que los habían nombrado. Pero este hecho podría haberse solucionado con la emisión de acciones sin voto, pues con ellas los accionistas antiguos no disminuían el control de la empresa.

Pero, además, había otro cuarto problema: la disminución de la potencia económica de las compañías ferroviarias según se acercaba al término del usufructo. Esta peculiaridad podría haber sido solucionada con la financiación por medio de acciones rescatables que se fueran amortizando a medida que se acababa la concesión.

Por tanto, la solución a los cuatro problemas podría haber sido realizar emisiones normalizadas, pero no de empréstitos, sino de acciones con alguna diferenciación en los derechos que concedían a los titulares, respecto a los títulos ordinarios.

\section{Sistema de información contable de NORTE}

Los criterios de contabilización utilizados por NORTE no fueron permeables al pensamiento procedente de Italia y Alemania en el primer cuarto del siglo XX, sino que se mantuvo cercano al pensamiento contable francés del que se inspiró desde su constitución. Al contrario que la estructura organizativa de NORTE, que sí se abrió a las nuevas formas organizativas de Estados Unidos, en materia contable la compañía permaneció fiel a la filosofía francesa que tuvo desde el origen.

Los procedimientos contables aplicados por el sector ferroviario en España a lo largo del primer cuarto del siglo XX, estaban basados en las reglamentaciones emitidas por las propias compañías, ante la parquedad de la legislación aplicable, recogida de forma prácticamente exclusiva en el Código de Comercio de 1885. El aspecto más sobresaliente de esta Ley -que regulaba expresamente a las ferroviarias- es que el Informe Anual debía presentarse al cierre de cada año natural, y que su publicación era preceptiva en la Gaceta de Madrid. 
Los Informes Anuales de NORTE eran documentos a través de los cuales los administradores rendían cuentas a los accionistas, conteniendo datos sobre la evolución de la compañía, información de tipo contable y, una exposición de estadísticas. En el Informe Anual se exponía la situación de la sociedad a lo largo del ejercicio económico, con especial atención a los datos referidos a la explotación de las líneas y del tráfico, así como a los gastos incurridos para la construcción o reforma de sus instalaciones. Los datos contables aparecían resumidos en el balance de la compañía, junto a la cuenta de explotación, donde se incluían los ingresos y gastos del periodo. Y por último recogía datos estadísticos, principalmente relacionados con el tráfico y la empresa.

Aunque no existía apenas normalización legal, la autoregulación de NORTE en ese periodo permitió ofrecer unos Informes Anuales que son un ejemplo de cómo se debe contabilizar correctamente, así como de la rigurosidad en la elaboración de sus registros, dando como resultado una información muy detallada y cuidada, con minuciosa precisión en sus registros. $\mathrm{Ni}$ el balance ni la cuenta de explotación tuvieron una estructura rígida, derivado de que no existía una legislación que especificara el formato; sin embargo, se ha identificado una estabilidad en su estructura buscando la homogeneidad.

El modelo contable de NORTE en el periodo 1900-1923 estuvo en línea con el modelo contable de las empresas ferroviarias europeas de la época, estando caracterizado por una fuerte influencia francesa.

El PGC 1973 y el PGC 1990 (ambos con una clara influencia francesa) no mejoraron ostensiblemente la información ofrecida por la empresa en el periodo 1900-1923. Por lo que podemos afirmar que la contabilización de NORTE estuvo muy desarrollada, ya que sólo con el PGC 2007 hubo un incremento significativo de información, cuando se incorporaron nuevos modelos de valoración y dos estados financieros más (Estado de Cambios en el Patrimonio Neto y Estado de Flujos de Efectivo).

Incluso podemos encontrar muchas similitudes entre los Informes Anuales de NORTE en el periodo 1900-1923 y los utilizados en España desde 2007 con la aplicación de las International Financial Reporting Standards al ordenamiento jurídico español, cuando se generalizó el Estado de Pérdidas y Ganancias en cascada unicolumnar, la información segmentada y el incremento de los contenidos a exponer en la Memoria.

Entre los indicadores que analizan las reclamaciones, NORTE utilizaba el índice "Tanto por mil que representan sobre los ingresos, los pagos hechos por indemnizaciones", que es un antecedente de un indicador del Capital Intelectual empleado en la actualidad.

NORTE presentaba los dos estados financieros principales, Balance y Cuenta de resultados, ordenados en dos columnas. En 1905, como novedad trascendental, acompaña estos documentos con una información que explicaba los saldos allí contenidos. Estas notas deben considerarse como la primera introducción del estado contable Memoria; y es de máxima 
importancia porque incluía también en formato literal la información que complementaba a los estados financieros, cuando hasta ese momento era exclusivamente matemática. En ella, además, se ofrecía una gran cantidad de información para aumentar la utilidad de los usuarios, por ejemplo, la Memoria recoge información sobre la estrategia futura de la sociedad.

El Informe Anual de 1906 supuso grandes novedades. Por un lado, expone el antecedente del Informe de Gestión, y por el otro, ofrece información sobre la modificación de los criterios de presentación de las partidas.

En la estructura del pasivo, el Informe Anual de 1906 ya reflejaba un régimen de disponibilidad de reservas, distinguiendo tres partidas: disponibles, indisponibles y parcialmente disponibles. Aspecto muy positivo pero que, sin embargo, en la contabilidad actual o no es reflejado, o reflejado de forma más atenuada.

Dentro de la información recogida en el Informe Anual de NORTE, destacan los contenidos que reflejan la estrategia de NORTE para intentar acercarse a MZA buscando alianzas con ella, primero con acuerdos comerciales y luego intentando una fusión. En la Memoria de 1905, aparecía que NORTE se proponía estrechar aún más la comunidad de intereses que les ligaba con la de Madrid a Zaragoza y a Alicante; propósito que, al realizarse, permitiría positivas ventajas a las dos compañías. En la Memoria de 1906 de NORTE aparece que desde el ejercicio de 1905 existían unas excelentes relaciones entre MZA y NORTE; relaciones que habían dado como resultado un completo acuerdo entre ambas compañías. En el Informe Anual de 1906, NORTE afirmaba que este acuerdo daría como resultado una mayor rapidez en los transportes, una simplificación de las tarifas y, sobre todo, las compañías obtendrían la apreciable ventaja de no tener que preocuparse de las diferentes direcciones que pudiera tomar el tráfico.

En el periodo estudiado, NORTE cumplió con los principales criterios de valoración y principios de contabilidad generalmente aceptados en la actualidad. De la inclusión de determinadas partidas en el Balance, se deducía el cumplimiento del principio de devengo, donde la corriente monetaria y financiera se registraba de forma independientemente, lo que constituía una aproximación más exacta a la situación real de la compañía.

Además, NORTE realizó sus registros contables en función de la hipótesis de prudencia. Desde 1906, NORTE constituyó un fondo para realizar obras de mejora que se imputaba a los gastos extraordinarios; la dotación de este fondo supuso tomar una medida contable en virtud de una prudencia tomada en consideración por la empresa, e incluso explicitada como la motivación de la medida.

En el apartado "VII. Asuntos varios" de la Memoria del Informe Anual de 1906, NORTE estableció varias dotaciones novedosas basadas en la hipótesis contable de prudencia. La principal es que incluye una cuenta denominada "Ejercicios cerrados" deudora de la suma de créditos incobrables. Para evitar en lo sucesivo la influencia de hechos de esta naturaleza sobre los resultados definitivos de los ejercicios venideros, el Consejo propuso a la Junta la 
creación de un fondo de previsión, que supone el primer registro de un deterioro de valor por el método indirecto.

En las cuentas del ejercicio 1907, NORTE enunció expresamente el principio de prudencia al afirmar que, tras dieciséis años de vicisitudes diversas, por fin se propuso la distribución de un dividendo de 10 pesetas por acción; pero además se expresa que se dotó una parte importante del beneficio a reservas, inspirándose en consideraciones de "prudente previsión".

NORTE registra la amortización desde el ejercicio 1903 -aunque no detalla información sobre ella- pues incluye, dentro de las cargas de explotación, la amortización del 1\% de material motor y móvil. El Informe Anual de 1905 es el primero en el que se ofrece información sobre la amortización registrada, pues incluye, dentro de las cargas de explotación, la amortización de $0,4 \%$ de material motor y móvil.

\section{Manipulación de la información financiera}

NORTE es una de las primeras empresas españolas en planificar unos procedimientos continuados de manipulación de la información financiera.

En el transcurso de la investigación se ha comprobado que existieron algunas prácticas contables sospechosas - aunque no contrastadas- en las que no es posible afirmar que existió manipulación de la información financiera, porque no se ha comprobado o su motivación o su voluntariedad. Aunque no podamos afirmar que existiera manipulación por parte de NORTE, sí se produjo alteración de los resultados contables en cinco casos: gastos de establecimiento, amortización, deterioro de valor, fondo de obras y mejoras y, por último, diversas partidas de gastos de explotación. No afirmamos que exista manipulación contable en estos casos porque puede ser que obedezcan más a la ausencia de una normativa concreta sobre el modo de realizar la contabilidad, y/o a un desconocimiento del modo correcto de registrarlo.

Sin embargo, sí se han comprobado la manipulación de la información contable, tanto en la alteración del resultado de la empresa, como en la presentación.

En primer lugar, existe constancia de la manipulación de la cifra del resultado del ejercicio, al contrastar los datos de los Informes Anuales con la correspondencia comercial y personal. NORTE realizó una manipulación de la información financiera sobre tres partidas -Fondos para compensar el acuerdo de 4 de enero de 1896, Ingresos por transportes de servicio y Anticipo de personal-, porque en ellas están perfectamente identificadas la voluntariedad y la finalidad que buscaba la gerencia al realizarla.

Esta afirmación no es extrapolable a la mayoría de las empresas actuales porque únicamente se puede comprobar la voluntariedad y la finalidad de una maniobra contable cuando se posean datos extracontables, como por ejemplo en este caso con la correspondencia postal, pero nunca podremos llegar a un dictamen con datos contables exclusivamente. Y rara vez estos datos extracontables están disponibles para un observador externo. 
Una vez analizados todos los procedimientos contables que modifican el resultado de NORTE, se ha identificado el efecto de cada uno de los métodos que alteran la cifra de beneficios, con la intención de encontrar un patrón permanente. De este análisis no es posible inferir una política programada permanente de alteración del resultado en una única dirección. No obstante, es posible encontrar un patrón de conducta sobre la manipulación de la información financiera.

A lo largo del periodo 1900-1923, la empresa intentó ofrecer de forma sistemática unos menores beneficios de los que hubiera registrado sin realizar ciertas maniobras contables. La motivación principal de las ferroviarias no era ahorrarse impuestos, ni evitar el reparto de dividendos, sino mostrar una imagen más negativa de la que hubiera tenido sin realizar estas maniobras contables, para forzar una mayor ayuda estatal. Hasta el año 1920, la principal finalidad era provocar un aumento de tarifas por parte del Estado; a partir de 1920, momento en el que el Estado concede a las compañías ferroviarias anticipos de personal y material, pretendía ofrecer una información financiera que perpetuara la concesión del anticipo por parte del Estado.

La aseveración de que la empresa intentó ofrecer de forma sistemática unos menores beneficios de los que hubiera registrado sin realizar ciertas maniobras contables, se argumenta por las actuaciones de la empresa NORTE -su política contable- a pesar de que la propia compañía expone explícitamente lo contrario, al afirmar que tiene una motivación de incluir pocos gastos. NORTE afirmó que: "La cuenta de explotación ha sido formulada con el prejuicio de aligerar los gastos, para que de la cuenta resulte que la compañía puede cubrir todas sus atenciones sin necesidad del anticipo del Estado, con la derivación consiguiente de que no necesita tampoco para ello elevación alguna de tarifas". Esta afirmación de la empresa no concuerda con su actuación contable porque no intenta reducir los gastos; y es lógico, porque para la empresa lo fundamental era la elevación de las tarifas y/o la renovación de la concesión del anticipo del Estado. Sin embargo, la afirmación es lógica porque quería dejar claro que los gastos no estaban artificialmente sobredimensionados a sus usuarios, fundamentalmente a los contribuyentes en general, y gobernantes en particular.

La estrategia elegida por NORTE en la mayoría de los ejercicios económicos era reflejo de una confrontación de la compañía con el Estado para presionarle por medio de la exposición de una situación económico-financiera aparentemente peor, y así provocar un aumento de tarifas y/o la concesión de subvenciones y anticipos.

Realmente la actuación contable de NORTE tenía un doble juego: en unos ejercicios la interesó mejorar su apariencia y en otros empeorarla. Aunque en la mayoría de los años de la vida de la empresa la motivación era disminuir artificialmente el beneficio por un aumento motivado de los gastos, también la compañía actuó en el sentido contrario puntualmente. Los aumentos puntuales de beneficios se produjeron en los años 1905 y 1906 porque en ellos coincidió la necesidad de emitir empréstitos y las negociaciones para un posible acuerdo comercial entre NORTE y MZA. En 1905 comenzó a realizar una manipulación para 
incrementar artificialmente los ingresos de transporte en servicio; esta práctica de manipulación de la información contable de las cuentas de NORTE permitió que el Banco Español de Crédito pudiera emitir para la compañía 80.000 obligaciones, que de otro modo, hubiera sido más difícil. De la misma forma, también tenía motivación para mejorar la apariencia cuando se encontraba en un proceso de negociación de un posible acuerdo comercial con MZA. En una reunión celebrada entre MZA y NORTE el 31 de enero de 1906, dentro de las conversaciones entre ambas compañías que culminaron con el contrato de Sindicatura general del tráfico del 27 de junio de 1906, los representantes de NORTE (Borregón, Boix, Estibaus, Ibarra, Urquijo y Waldmann) confesaron a los de MZA (Baüer y Maristany) que los ingresos declarados en los Informes Anuales de NORTE eran inferiores a los que hubieran obtenido sin manipularlos.

La manipulación dual de NORTE era consecuencia de la existencia del controvertido e inestable entorno al que se enfrentaba la empresa. Por un lado, puntualmente necesitaba la obtención de recursos del mercado de capitales, ya sea por medio de préstamos de intermediarios financieros, pero sobre todo por la emisión de empréstitos que colocar. Igual ocurría cuando estaba en un proceso de acercamiento a MZA. Para esas situaciones puntuales, NORTE quería dar una situación de solvencia, por lo que realizaba una alteración de los registros contables en sentido de mejorar su apariencia económico-financiera. Por otro lado, para desarrollar ordinariamente su proceso productivo necesitaba los anticipos del personal por parte del Estado, por lo que continuadamente ofrecía unos resultados económicos inferiores a los que tendría sin manipulación de la información contable, para forzar que el Estado mantuviera la concesión de los anticipos o realizara el ansiado aumento de tarifas.

En segundo lugar, también está probado que existieron procedimientos de manipulación financiera en la presentación. En concreto, existieron alteraciones de presentación en la exposición de la ratio coste por kilómetro, de la ratio coeficiente de explotación y de la información en los diferentes textos que recogían la información contable de la compañía.

Con la manipulación de la ratio coste por kilómetro, NORTE intentaba mostrar un coste por kilómetro más bajo que el real, lo que la situaba en una situación aparentemente mejor.

Por su parte, con la manipulación de la ratio coeficiente de explotación, NORTE intentaba mostrar un coeficiente de explotación más bajo que el real lo que la hacía parecer mejor frente al mercado, usuarios externos de la información financiera, y su posible aliado o competidor MZA.

Respecto a las alteraciones de presentación en las diferentes fuentes de información, NORTE presentaba su propia información directamente -con datos elaborados por NORTE y también presentados por ella misma- por dos medios: en los Informes Anuales presentados por el Consejo de Administración cada año, y en los documentos que agregaban información de varios años publicados excepcionalmente por la compañía-siendo el más importante el de Marquina (1940)-; pero además, también ofrece sus datos indirectamente -con datos suministrados por NORTE pero agrupados por otro organismo- en documentos externos que 
también acumulan varios ejercicios contables, siendo el más relevante el documento Antecedentes y datos para el estudio del problema ferroviario de la Junta Superior de Ferrocarriles (1940). Las tres fuentes presentan los datos de diferente forma dando lugar a equívocos, y esto tuvo su origen en el deseo de alterar la apariencia de la información. Las diferencias entre los citados textos (Informes Anuales de NORTE, Antecedentes y datos para el estudio del problema ferroviario de la Junta Superior de Ferrocarriles y compilación de Marquina) se producen sobre tres partidas: los ingresos fuera del tráfico, los gastos de explotación y las cargas financieras.

\section{Auditoría de NORTE y MZA}

La auditoría profesionalizada y obligatoria llegó más tarde a España (1960) que a otros países. El legislador español tardó en regular la actividad para la globalidad de sectores, eso sí, en esta investigación se constata que el sector ferroviario fue el primero con antecedentes regulatorios destacables.

La auditoría externa de las cuentas anuales en España nació en las empresas ferroviarias, al igual que había ocurrido anteriormente en el Reino Unido y en Estados Unidos, aunque los métodos, pero sobre todo la motivación, es distinta. El origen de la auditoría externa en el Reino Unido se realizó por medio de una Ley -la Great Western Railway's Act de 1835-, mientras que en Estados Unidos nació de la práctica empresarial en la década de 1850, con especial relevancia de Henry Varnum Poor; ambas buscaban la revisión de los estados financieros con el objetivo de garantizar una información fiable a los usuarios. Por su parte, en España tiene su origen en un Decreto legal, y su principal motivación es evaluar la viabilidad futura de las empresas ferroviarias y especialmente de las ayudas concedidas por el Estado.

La importancia de la creación de Comisiones investigadoras de la contabilidad generadas por el Real Decreto de 20 de octubre de 1923 es máxima, porque con su aplicación se realizó una de las primeras auditorías externas de estados financieros en España.

Es difícil afirmar que esta revisión fue la primera auditoría en España porque, por un lado, es controvertido identificar las cualidades que debe tener una revisión de estados contables para tener la calificación de auditoría y, por otro lado, porque siempre puede aparecer una revisión no publicada hasta ahora en otro sector, o incluso en el mismo, que haga replantearnos la novedad absoluta de esta revisión.

De todas formas, el estudio de esta revisión debe tener un papel estelar entre los incipientes esfuerzos de revisión de los estados contables, pues su nivel de meticulosidad y calidad, aún con deficiencias, es alto, para el momento en que se realizó.

La revisión gubernamental de las cuentas de las concesionarias del ferrocarril tuvo un papel político innegable. En esta investigación se plantea el interrogante de saber si la revisión tenía una motivación de conocer la situación económico-financiera de las compañías, o si en 
realidad fue un instrumento político para argumentar por parte del Gobierno la necesidad de que los anticipos que el Estado estaba abonando a las compañías, dejara de entregarse fundamentalmente, por la escasez de fondos en las arcas públicas en ese momento-. Nuestra opinión es que fue más un instrumento político, que de validación de la situación económica.

Los dos informes que llevaron a cabo las Comisiones -la Primera para NORTE y la Segunda para MZA- fueron fundamentales para el futuro de la contabilidad y la auditoría en España.

La "Primera Comisión investigadora de la situación económica de las empresas del ferrocarril", dedicada a NORTE, refleja el alcance del trabajo de revisión, donde se incide en el principio de empresa en funcionamiento y en la fiabilidad de la información contable: "todos los documentos y libros de contabilidad que ha sido preciso consultar y comprobar para hacer un minucioso estudio del funcionamiento de la empresa, comprobando los resultados que ofrecen sus balances publicados, examinando la documentación necesaria para cerciorarse de la exactitud con que son llevados a los libros principales y adquiriendo la seguridad de que las cifras contenidas en los balances y en las cuentas generales de explotación responden a la verdad de los hechos contables".

Además, también se ocupó de los procedimientos del trabajo de auditoría, reconociendo a estas técnicas como indispensables para identificar la situación económica de la compañía en el presente y para el futuro. Por un lado, la Comisión elaboró los cuadros de vencimiento de todas las cargas de la compañía, tanto financieras como en relación con los anticipos reintegrables del Estado para adquisición de material móvil. Por otro lado, juzgando que los gastos que más influían en el resultado de explotación eran las retribuciones de los agentes, la Comisión estudió las variaciones en número y dinero que experimentó el personal de todas las clases, y las retribuciones que por todos los conceptos le correspondieron.

Asimismo, en el Informe se establecen las materias claves y partidas más sensibles de la compañía para realizar un análisis lo más adecuado posible. Dentro de los objetivos de la revisión, la Comisión observó cómo fundamental el estudio del criterio de la compañía para la clasificación de las obras en las vías y edificios al servicio de la explotación, punto esencial para determinar las cantidades que deban cargarse a la cuenta de primer establecimiento aumentando la cifra de activo de la compañía-, o que deben considerarse como gastos de explotación. La Comisión fijó su atención en la extraordinaria elevación de las cifras dedicadas por NORTE a la recomposición del material móvil y a la renovación de vías. La Comisión, tras el estudio y causas que lo motivaron, obtuvo como consecuencia la necesidad de reducir ese gasto de explotación.

Respecto a la opinión del Informe, la Comisión afirmó que del examen de las cifras se deduce "la solidez del activo de la compañía y, por tanto, la absoluta garantía del pasivo". Pero no sólo ofrece un dictamen en general, sino que se detalla un juicio sobre los criterios de contabilización de NORTE. La Comisión encontró acertada la repartición de los gastos, llevando a la partida de gastos de primer establecimiento los que corresponden a la mejora o 
ampliación de servicios o locales, y dejando en los de explotación los de renovación o sustitución de lo ya existente.

La Comisión también estudió detalladamente cada una de las partidas para identificar errores e irregularidades contables realizados por la compañía. En esta tarea, cuestionó la forma de contabilizar los anticipos y el modo de gestionar la retribución. La Comisión consideró como inadecuado el registro del anticipo del personal concedido por el Estado ya que NORTE no lo registraba como un gasto de personal; esto hacía que las cuentas de NORTE tuvieran unos gastos de explotación menores a los que "acontecían realmente en cada periodo". De la misma forma, la Comisión recriminó a NORTE haber incurrido en dos grandes defectos que elevaban en exceso los gastos de personal: tener plantillas sobredimensionadas y abonar sueldos demasiado elevados en relación con los trabajadores de otras industrias y funcionarios públicos.

Por último, la Comisión realizó una recomendación: basándose en los fines que tiene la compañía, y en el carácter reversible al Estado del activo inmovilizado, la empresa debería constituir reservas que garantizasen la amortización futura del capital.

Por su parte, el Informe realizado por la "Segunda Comisión investigadora de la situación económica de las empresas del ferrocarril" dedicada a MZA se detiene en aspectos formales del trabajo de la auditoría, e incluso del informe de auditoría. La importancia de la Comisión es que las aportaciones sobre los aspectos formales del trabajo de revisión y el informe del revisor fueron determinantes para el futuro de la auditoría.

El informe de la Comisión sobre MZA establece algunos componentes del alcance del trabajo de auditoría que persisten en los actuales informes de auditoría, al establecer expresamente los estados financieros analizados, los ejercicios contables que son revisados y el objetivo de la revisión. Además, señala, de forma separada y posterior, la opinión. En esta opinión se indican cualidades de la información contable, muy valoradas en la auditoría actual, como la claridad. También se indican actitudes de la contabilidad de la empresa analizada, como la prudencia.

El Informe culmina con una serie de recomendaciones a la gerencia, tanto de la buena gestión como de la adecuada contabilización.

Esta Comisión Investigadora de la Contabilidad tiene, además, una relevancia máxima sobre la planificación de la auditoría en España. La Segunda Comisión recomienda, y MZA está de acuerdo, que se deberían realizar todos los años auditorías periódicas, y más concretamente por personal público.

\section{Competencia entre las principales ferroviarias españolas}

Los problemas económicos de las ferroviarias tuvieron su origen en las deficiencias estructurales, pues su negocio requería de unos altos costes iniciales de puesta en marcha, con 
altas inversiones en vías y material, y altas necesidades de recursos humanos. Para compensar tantos esfuerzos económicos, el negocio requería un número elevado de viajes, ya sea de personas o de materiales. Sin embargo, la situación económica del país era mala; las empresas no encontraban la demanda suficiente para transportar sus productos; y la mayoría de las familias no tenían cultura de turismo ni el poder adquisitivo necesario para viajar frecuentemente. En este entorno desarrollaron su actividad las empresas ferroviarias en el periodo 1900-1923.

La estrategia óptima de las compañías hubiera sido la de especializarse en nichos de mercado rentable: cereales de Castilla al Mediterráneo, de la industria barcelonesa o vasca al resto de España o llevar a todo el país los productos de la huerta mediterránea. Sin embargo, el miedo a perder posición competitiva hizo que todas las empresas, en mayor o menor medida, tomaran el camino equivocado de intentar absorber a otras más pequeñas. De esta forma, las empresas concesionarias del ferrocarril en España, especialmente MZA y NORTE, llegaron a tener una estructura empresarial muy desajustada: presentaban varias líneas poco rentables, con una herencia de altos costes de construcción, con muchos empleados y, además, con mala planificación, porque la proporción de empleados contratados directamente por ellas era baja en comparación con los obtenidos por la absorción de otras compañías.

Ante la mala situación económica general del país, de las empresas y de las familias, la única manera de mejorar la cuenta de resultados era aumentar las tarifas o recibir más ayudas por la compra de material y el mantenimiento del personal. El Estado no tenía los recursos suficientes para aumentar las tarifas, y por si fuera poco existía una corriente de pensamiento social que proponía que también se eliminaran los anticipos de personal y material.

La única forma que encontraron las ferroviarias para sobrevivir era que se incrementasen las ayudas gubernamentales, aunque fuera a costa de aumentar la intervención estatal en ellas. Este parecía el único camino para el Estado y para ellas, y es el que se tomó.

No obstante, es posible que hubiera habido otra solución. Una fusión de NORTE y MZA como empresas privadas, antes de la injerencia del Estado, hubiera proporcionado a ambas la capacidad económica y financiera suficiente para sanear sus cuentas, tener la capacidad de negociación suficiente frente al Estado para negociar las ayudas y tarifas, pero incluso también para cerrar vías no rentables y centrarse en las más rentables. Pero, sobre todo, evitar la competencia entre ellas les hubiera permitido aumentar la rentabilidad porque tomarían una posición común frente al mercado.

La estructura de costes de las ferroviarias -con altas inversiones en costes fijos por la construcción de la vía y muy bajos costes variables- favorecía las guerras de precios entre ellas. Pero este no era el camino correcto. La unión frente al Estado les hubiera aupado a una mejor situación.

Entre las razones por las que la fusión no terminó de culminar, destaca la deficiente estructura de gestión de NORTE, la mala situación económico-financiera de NORTE, y la equivocada 
estrategia de ambas compañías, que no interpretaron que su principal enemigo era el Estado y el transporte por carretera, más que el resto de compañías.

Pero, sobre todo, NORTE y MZA no se fusionaron porque los directivos de cada una de las empresas consideraban que con la fusión perderían su posición económica y de poder, incluso, algunos eran consejeros de ambas, y creían que sólo cobrarían una partida de dinero y no dos como hasta el momento. Tampoco los políticos querían la fusión porque reducirían a la mitad sus retiros dorados, pues el Consejo de NORTE y MZA era un destino frecuente para ellos, tras concluir su carrera política. En el proceso negociador de los intentos de fusión se observa la diferencia de intereses entre los sujetos de ambas compañías; los Directores y los Consejeros en Madrid, en Barcelona y en París, a menudo diferían en las condiciones que tenía que tener la fusión para ser apoyada por ellos, y esto era fundamental porque la insatisfacción de los requerimientos de alguno impedía la consecución de la fusión.

No obstante, aunque no se alcanzó la fusión, durante este periodo comenzó entre ambas compañías un acercamiento estratégico y comercial que no cesó hasta su nacionalización en 1941. Lo más destacable es que, en 1906, NORTE y MZA establecieron una de las primeras joint venture entre dos empresas para dominar un sector, frente al resto de la competencia y al Estado. La relevancia del acuerdo se deriva de que, no sólo eran la unión de las dos empresas privadas más importantes de España, sino que ambas se situaban entre las quince empresas más relevantes de Europa.

\section{Paso fronterizo a Francia}

Desde 1853 existieron proyectos, documentos e intervenciones públicas en las que se defendía la necesidad de realizar el trazado del ferrocarril a Francia a través de Zaragoza, debido a su menor longitud, el carácter estratégico militar de la capital aragonesa, la facilidad del terreno y sus menores costes de establecimiento.

La empresa NORTE intentó llevar a cabo el proyecto. Sus principales impulsores fueron Barat, director de NORTE que nació en Oloron-Sainte-Marie, ciudad francesa que debía ser unida con Canfranc, y Louis Barthou, diputado francés por Oloron. El proyecto también tenía un alto interés político, pues Aragón había sido leal a la causa liberal en la III Guerra Carlista contra los rebeldes (Cataluña y el País Vasco), y, además, NORTE tenía muchos lazos con el gobierno liberal (Sagasta, Tomás Ibarrola, el General Serrano y Manuel Alonso Martínez). Con la construcción de este trazado se favorecería tanto a NORTE como a Aragón.

Sin embargo, el paso de Canfranc tuvo problemas técnicos. La línea Huesca-Jaca se levantó con un presupuesto muy bajo, y al poco de su apertura se produjeron frecuentes corrimientos de tierras, desprendimientos y otros accidentes. Además, las curvas de Canfranc no eran aptas para las grandes velocidades que precisaba un ferrocarril directo de Madrid a París. Pero la principal razón para que el paso de Canfranc no triunfase fue que los Péreire tomaron la decisión de construir los trazados de ambos lados transfronterizos exclusivamente con el acuerdo entre NORTE y Midi, pero sin contar con los gobiernos de los dos países que debían sufragar el paso subterráneo de los Pirineos. Seguramente no buscaron más apoyos políticos 
porque confiaron en los estrechos lazos que ya tenían entre sus empresas y ambos gobiernos. El proyecto fue definitivamente aparcado con la entrada en vigor de la Sindicatura de junio de 1906 entre NORTE y MZA.

La hipotética existencia en el siglo XXI de un paso por los Pirineos a través de Aragón tendría beneficios, tanto de duración de viaje, al ser un camino más directo, como de equilibrio territorial, porque se atenuarían la exageradamente alta capacidad de negociación de las comunidades autónomas vascas y catalana en el sector del transporte, y en la economía española contemporánea en general. Tanta relevancia hubiera tenido el proyecto que se ha retomado en la actualidad y está proyectado que el tramo Pau-Zaragoza por Canfranc esté operativo para el año 2024. 


\section{BASE DOCUMENTAL Y BIBLIOGRÁFICA}

\section{Expedientes de Archivo (Archivo Histórico Ferroviario)}

AHF - C-0002-004: Expedientes relativos a la estación de Salillas de Jalón en la línea de Madrid a Zaragoza

AHF- S-0055-047: Informes sobre las reclamaciones en relación con el descanso en los ferrocarriles.

AHF - D-0529-026. Expediente relativo al contrato de sindicato establecido entre las compañías de los Caminos de Hierro del Norte, de MZA y de Tarragona, Barcelona y Francia.

AHF - E - 0027 - 005. Copias de las Actas de las sesiones celebradas por el Comité de Madrid de la Compañía del Norte. Sesión nº 1402-1441.

AHF - E - 0028 - 001. Copias de las Actas de las sesiones celebradas por el Comité de Madrid de la Compañía del Norte. Sesión n 1442-1484.

AHF -E - 0028 - 002. Copias de las Actas de las sesiones celebradas por el Comité de Madrid de la Compañía del Norte. Sesión no 1485 - 1492, 1494 - 1496, 1498 - 1500, 1513 - 1518, 1520 - 1523, y 1525.

AHF - E - 0028 - 003. Copias de las Actas de las sesiones celebradas por el Comité de Madrid de la Compañía del Norte en el segundo semestre del año 1903. Sesión nº 1551-1571.

AHF - E - 0028 - 004. Copias de las Actas de las sesiones celebradas por el Comité de Madrid de la Compañía del Norte. Sesión nº 1572-1647.

AHF - E - 0029 - 001. Copias de las Actas de las sesiones celebradas por el Comité de Madrid de la Compañía del Norte. Sesión n ${ }^{\circ}$ 2099-2174.

AHF - E - 0029 - 002. Copias de las Actas de las sesiones celebradas por el Comité de Madrid de la Compañía del Norte. Sesión nº 2175-2252.

AHF - E - 0029 - 003. Copias de las Actas de las sesiones celebradas por el Comité de Madrid de la Compañía del Norte. Sesión n 2422-2502.

AHF - E - 0029 - 004. Copias de las Actas de las sesiones celebradas por el Comité de Madrid de la Compañía del Norte. Sesión nº 2503-2589

AHF - E - 0030 - 001. Copias de las Actas de las sesiones celebradas por el Comité de Madrid de la Compañía del Norte. Sesión nº 2732-2778. 
AHF - E - 0030 - 002. Copias de las Actas de las sesiones celebradas por el Comité de Madrid de la Compañía del Norte. Sesión nº 2779-2839.

AHF - E - 0030 - 003. Copias de las Actas de las sesiones celebradas por el Comité de Madrid de la Compañía del Norte. Sesión no 2841-2894.

AHF - E - 0030 - 004. Copias de las Actas de las sesiones celebradas por el Comité de Madrid de la Compañía del Norte. Sesión nº 2895-2946.

AHF - E - 0030 - 005. Copias de las Actas de las sesiones celebradas por el Comité de Madrid de la Compañía del Norte Contenido: 1. Sesión nº 2947-3005.

AHF - E - 0031 - 001. Copias de las Actas de las sesiones celebradas por el Comité de Madrid de la Compañía del Norte. Sesión no 3006-3052.

AHF - E - 0124 - 004 Expediente del nombramiento y fallecimiento del administrador Félix Boix y Merino.

AHF - L-0045 a L-0195 Libros de Presupuestos de la Red Antigua de la Compañía MZA.

AHF - L-0196 a L-0257 (años 1912-1935) Libros de Presupuestos de la Red Catalana de la Compañía MZA

AHF - L-0258 a L-0268, (año 1936) Libro de Presupuestos de la Red Antigua y Red Catalana de la Compañía MZA

AHF - L-0269 a L-0277 (años 1919-1935) Libros de resúmenes de los Presupuestos de la Red Antigua y Red Catalana de la Compañía MZA.

AHF - L-0278 a L-0283 (años 1919, 1921, 1927-1934, 1936) Libros de notas anexas a los presupuestos de la Compañía MZA

AHF - L-0356 a L-0368 Libros de Actas del Consejo de Administración de la Compañía Norte.

AHF - L-0454-0458, Actas de la Comisión Mixta entre MZA y Norte (1906-1918).

AHF - L-0790 a L-0797, (años 1919-1935) Libros de resúmenes de los Presupuestos de la Red Catalana y la Red Antigua de la Compañía MZA.

AHF - L-0798 a L-0809, (años 1910-1935) Libros de Presupuestos de la Red Antigua de la Compañía MZA. 
AHF - L-0810 a L-0815, (años 1912-1935) Libros de Presupuestos de la Red Catalana de la Compañía MZA.

AHF - L-0816 a L-0820, (años 1919, 1921, 1927-1934, 1936) Libros de notas anexas a los presupuestos de la Compañía MZA.

AHF - P-0058-035. Informes realizados para el Consejo de Ministros y Ministro de Fomento, sobre los datos que justifican la elevación de tarifas (25/12/1919 - 27/12/1919)

AHF - P-0059-045. Proyecto de ley presentado al Senado sobre un nuevo recargo del 35\% sobre determinadas tarifas $(01 / 01 / 1920$ - 31/01/1920)

AHF - P-0059-046. Expediente relativo a la discusión sobre el proyecto de ley de aumento de $35 \%$ en las tarifas en el Senado (02/01/1920 - 13/01/1920)

AHF - P-0059-061. Respuesta dada por la Compañía MZA a la solicitud del Congreso de los Diputados sobre el proyecto de ley de aumento de tarifas y la explicación de la situación de la Compañía MZA en relación con otras Compañías (14/01/1920 - 22/01/1920)

AHF - P-0059-067. Borradores sobre el proyecto de Real Decreto para el caso que el proyecto de ley de elevación de tarifas fuese concedida por este instrumento jurídico (s.f.)

AHF - P-0060-78. Expediente relativo a la elevación de tarifas ferroviarias y su tramitación legal. $(01 / 11 / 1919$ - 24/06/1920)

AHF - P-0065-082. Carta remitida por F. Boix a E. Maristany el 24 de junio de 1920.

AHF - P-0065-082. Relación de cantidades que importaron en el mes de abril las mejoras ofrecidas por la Compañías abonadas con el anticipo. (1920 marzo 27/1920 mayo 17).

AHF - P-0065-082. Diferentes extremos sometidos al Consejo de Administración en su sesión del 29 de marzo relacionados con las mejoras. (1920 marzo 29).

AHF - P-0065-082. Acuerdo tomado por el Consejo de Administración sobre las mejoras al personal. (1920 marzo 29).

AHF - P-0065-082. Declaración jurada de las mejoras concedidas del personal con anterioridad al 23 de marzo. (1920 abril 8).

AHF - P-0065-082. Oficios trasmitiendo las órdenes oportunas para la confección de las nóminas y sobre el cobro del anticipo y su devolución (1918 diciembre 29/1921 marzo 15).

AHF - P-0065-082. Forma de contabilidad del anticipo según las Compañías Norte y MZA. (1920 junio 11/1920 junio 24). 
AHF - P-0113-254. Propuestas presentadas a la ponencia de ferrocarriles del Directorio Militar, según la R.O. sobre información pública del Régimen de Ferrocarriles y correspondencia. $(05 / 10 / 1923$ - 04/12/1923)

AHF - P-0113-257-001. Reales Decretos organizando y nombrando las Comisiones. (1923 octubre 21/1923 octubre 22)

AHF - P-0113-257-002. Reales decretos sobre la entrega de anticipos para adquisición de material móvil. (1920 octubre 15/1923 noviembre 5)

AHF - P-0113-257-003. Datos económicos no entregados a las Comisiones. (1923 noviembre 28/1923 diciembre -)

AHF - P-0113-257-004. Anexos de datos económicos de 1913 a 1923: ingresos y gastos, presupuestos de obras previstas, anticipos, fondos y reservas. (1922 diciembre 31)

AHF - P-0113-257-005. Informe de la 2 Comisión investigadora sobre la Compañía MZA. (1923 noviembre 29) (2 ejemplares)

AHF - P-0113-257-006. Observaciones que a la Compañía MZA ha sugerido el informe redactado por la Comisión investigadora, rectificación a esas observaciones y datos recopilados para la réplica. (1923 noviembre 29/1923 diciembre 10) (2 ejemplares).

AHF - P-0113-258-001: "Memoria sobre la situación económica de la Compañía de los Caminos de Hierro del Norte de España", Primera Comisión investigadora de la situación económica de las empresas de ferrocarriles, 29 de noviembre de 1923.

AHF - P-0113-258-003: “Contestación de la Compañía de los Caminos de Hierro del Norte de España al Informe redactado por la Primera Comisión investigadora de la situación económica de las empresas de ferrocarriles nombrada por Real Orden de 20 de octubre de $1923 "$.

AHF - P-0126-273. Carta de Félix Boix a Eduardo Maristany agradeciéndole el envío del proyecto de Reglamento para la explotación y Policía de Ferrocarriles, redactado por éste en 1907 y adjuntándolo (27/03/1923)

AHF - S-0001-008. Informe y notas sobre el mantenimiento y perfeccionamiento de la organización actual de la Compañía M.Z.A., manteniendo su división en Red Antigua y Red Catalana (01/03/1908 - 31/03/1908)

AHF - S-0015-044bis. Presentación por Félix Boix de la Memoria de la Compañía del Norte a los Accionistas del Ejercicio 1922 y réplica de Salvador Burgaleta desaprobando la actuación. Discurso pronunciado por el accionista Burgaleta en la junta general celebrada el 19 de 
mayo de 1923: formuladas por encargo del consejo de administración y acordada por este su publicación, Compañía de los Caminos de Hierro del Norte de España, 19 de mayo de 1923, Madrid: Norte.

AHF - S-0015-044bis Rectificación del Señor Burgaleta a las palabras del Señor Boix, Junta general celebrada el 19 de mayo de 1923, Madrid: Norte.

AHF - S-0035-092. Expediente relativo a la Asamblea Nacional de Ferrocarriles organizada por acuerdo del II Congreso de Economía Nacional.

AHF - S-0036-097. Estudios sobre una posible fusión de la Compañía de MZA y la del Norte (03/06/1917 - 27/06/1919).

AHF - S-0050-016-002. "Compañía del Norte y su personal: datos y cifras que es preciso conocer para juzgar con acierto el Problema Ferroviario".

AHF - P-0058-044. Relación de opiniones y conclusiones en la Asamblea Nacional de Ferrocarriles sobre cuestiones relativas al personal, la tarificación y a la estatificación de los ferrocarriles (01/01/1918 - 31/01/1919).

AHF - S-0103-001. Carta de Baüer a Maristany, 23 de febrero de 1905.

AHF - S-0103-001. Carta de Borregón a Maristany, 9 de noviembre de 1905

AHF - S-0190-072. Peticiones de la Federación Nacional de Ferroviarios Españoles (1/7/1912 $-31 / 7 / 1912)$

AHF - S-0190-072. Documentación relativa a las cuestiones de personal y sus mejoras que deben tratarse en la Conferencia de París (1/7/1912 - 31/8/1912)

AHF - S-0190-072. Informe sobre las peticiones formuladas por el Congreso Ferroviario elaborado por la Compañía del Norte (1/10/1912 - 31/10/1912).

AHF - S-0190-072. Estudio sobre las Instituciones establecidas por la Compañía del Norte a favor del personal y mejoras que se han concedido al mismo en los últimos años (30/10/1912 $-30 / 10 / 1912)$.

AHF - W-0033-012. Compañia de los Caminos de Hierro del Norte de España, "Informe sobre contabilidad", 30 de abril de 1873, Madrid: Norte [en francés].

AHF - W-0038-013-002 "Balance del libro mayor a 31 de diciembre de 1904. Contabilidad Central" Compañía de los Caminos de Hierro del Norte de España, 30 de mayo de 1905 [en francés]. 
AHF - W-0038-013-001 "Situación de la compañía a 31 de diciembre de 1904. Contabilidad Central" Compañía de los Caminos de Hierro del Norte de España, 30 de mayo de 1905 [en francés].

AHF - W-0043-002 Memoria del presupuesto, cargas y pagos de la Compañía del Norte del año 1917 (01/01/1917 - 31/01/1918).

AHF - W-0043-003. Presupuestos, memorias, estimaciones, cargas y pagos de la Compañía del Norte en el año 1918. (18/12/1917 - 01/01/1919).

AHF - W-0043-004 Presupuesto, memoria del presupuesto, cargas y pagos de la Compañía del Norte del año 1919 (1919).

AHF - W-0043-005 Presupuesto, memoria del presupuesto, cargas y pagos de la Compañía del Norte del año 1920 (año 1920).

AHF - W-0043-006 "Balance del libro mayor en 31 de diciembre de 1922. Antes de cerrar las cuentas de explotación, 30 de mayo de 1923.

AHF - W-0043-006 "Balance del libro mayor en 31 de diciembre de 1922. Definitivo, 30 de mayo de 1923.

AHF - W-0043-006 “Contabilidad de ingresos" División comercial, Intervención, 30 de mayo de 1923.

AHF - W-0043-006 "Cuenta general de los productos y gastos de la explotación desde el 1 de enero a fin de diciembre del año 1922”, Contabilidad central, 30 de mayo de 1923.

AHF - W-0043-006 "Cuenta general de los productos y gastos de la explotación de diciembre de 1922 comparada con igual mes de 1921", Contabilidad central, 30 de mayo de 1923.

AHF - W-0051-008 Estudio sobre el ejercicio de 1903 de la Compañía de los Caminos de Hierro del Norte de España, 12 de noviembre de 1904 [en francés].

AHF - W-0052-001 Regla de contabilidad $n^{\circ} 8$ nueva, Proporción en que los servicios de la compañía deben repartir los gastos de la explotación entre las líneas que forman la red, Compañía de los Caminos de Hierro del Norte de España, 30 de octubre de 1872.

AHF - W-0052-001-001 Regla para el reparto de los gastos de la explotación entre las diferentes líneas de la red en la Compañía de los Caminos de Hierro del Norte de España, 21 de septiembre de 1878. 
AHF - W-0052-001-002. Correspondencia entre la administración y el director de la compañía. (26 de septiembre de 1878).

AHF - W-0052-004 Libro de presupuestos para el ejercicio de 1917 de la Compañía del Norte $(26 / 12 / 1916-26 / 12 / 1916)$.

AHF - W-0080-001-006. Resumen de ingresos y gastos de explotación de la Compañía del Norte y MZA (27 de febrero de 1905).

\section{Bibliografía de la época (hasta la creación de RENFE en 1941)}

ANÓNIMO (1906): Apuntes biográficos referentes al Excmo. Sr. D. Juan Barat, antiguo Director de la Compañía de los Caminos de Hierro del Norte de España. Madrid: Imprenta Central de los Ferrocarriles, 1-58.

--- (1890): Apuntes para la clase de legislación, administración y contabilidad de las obras públicas. Curso de 1889-90. Madrid: M. Alarcón.

--- (1897): Informe de los peritos contables nombrados por el Juzgado de Primera Instancia del Distrito de la Audiencia para examinar la contabilidad y documentación referentes a las obras hechas por Don Francisco de Paula Retortillo en el Ferrocarril de Mérida a Sevilla: balance de 1887 y estado de comprobación de saldos. Madrid: Imprenta de Evaristo Martínez.

AGRUPACIÓN FEDERATIVA DE LOS FERROVIARIOS DEL NORTE (1918): Estatutos y reglamento general. Madrid: Bernardo Rodríguez.

ANDRÉ, E. L. (1919) "Las tarifas ferroviarias, el régimen jurídico y la situación financiera de las compañías”. Revista Nacional de Economía, Vol. VII, n² 22, pp. 349-376.

ASAMBLEA NACIONAL DE FERROCARRILES (1918a), Asamblea Nacional de Ferrocarriles: 20 al 27 de enero de 1918. Madrid: Vicente Rico.

--- (1918b), Asamblea Nacional de Ferrocarriles (enero de 1918). Resumen de los trabajos y deliberaciones. Madrid: Vicente Rico.

AUBERT, J. (1861): Ferro-carril del Norte: el Crédito Moviliario Español ante la opinión pública. Madrid: Imprenta de Zacarías Soler.

AUERBACH, W. (1873): Das Actienwesen. Frankfurt: Sauerländer.

BALTIMORE \& OHIO RAIL-ROAD (1847a): Organization of the service of the Baltimore $\&$ Ohio Rail-Road, under the proposed new system of management. Baltimore: ed. Baltimore \& Ohio Rail-Road.

--- (1847b): Twenty firths Annual Report of the Baltimore and Ohio Railroad. Baltimore: Baltimore and Ohio Railroad Company. 
BEARLE, ADOLPH A.; MEANS, GARDINER C. (1932): The modern corporation and private property. The Mac Milliam Company, New York, 1932.

BEKKER, E. J. (1871): "Beiträge zum Aktienrecht". Zeitschriftfür das gesamteHandelsrechtundWirtschaftsrecht, $\mathrm{n}^{\circ} 16$.

BENITO, JOSÉ L. DE (1935): Compañías de Ferrocarriles en quiebra. Madrid: Biblioteca Universitaria.

BERGERMAN, M. (1928): "Voting trusts and non-voting stock". Yale Law Journal, vol. XXXVII, 1927-28, 445-467.

BOAG, GEORGE L. (1923): The Railways of Spain, London: The Railway Gazette. --- (1912): Manual of railway statistics. London, The Railway Gazette.

BURGALETA, VICENTE (1918): "Conflictos entre las empresas y los obreros ferroviarios", Asamblea Nacional de Ferrocarriles (enero de 1918). Resumen de los trabajos y deliberaciones. Madrid: V. Rico, pp. 196-215.

--- (1917): "Técnica moderna. Organización de los servicios ferroviarios. El personal", Madrid Científico; sección «El Ingeniero», $\mathrm{n}^{\circ}$ 932, 439-442. Reproducido en Gaceta de los Caminos de Hierro (1917), $\mathrm{n}^{\circ}$ 3143, 471-474.

--- (1915): “Las escuelas económicas y la economía industrial”. Madrid Científico, 853, pp. 430-434, 854, 449-453.

CAMBÓ Y BATLLE, FRANCISCO DE ASÍS (1921): El Problema Ferroviario en España. Epílogo de la obra Elementos para el estudio del problema ferroviario en España. Madrid: Instituto de Ingenieros Civiles.

--- (1918-1921): Elementos para el estudio del problema ferroviario en España, 6 volúmenes, 1918-1921. (Dir.). 6 volúmenes. Madrid: Ministerio de Fomento-Gráficas Reunidas.

CEBALLOS TERESI, J. (1917): Nuestra política ferroviaria ante la guerra y para la paz. Madrid: Imprenta de Isidoro Perales

--- (1915a): Estudios Económicos y Financieros. Parasitismo intermediario. Transporte por ferrocarril y subsistencias en Madrid. Madrid: Imprenta de Isidoro Perales.

--- (1915b): Parasitsmo intermediario. Transportes por ferrocarril y subsistencias en Madrid. Madrid: Imprenta de Isidoro Perales.

CHEMIN DE FER DU NORD DE L'ESPAGNE (1857): Recueil de pièces officielles. Paris: Imprimerie Administrative et des chemins de fer de Paul Dupont.

--- (1858): Notice et carte. Paris: Imprimerie Administrative et des chemins de fer de Paul Dupont. 
CIERVA, J. DE LA (1920a): Los ferrocarriles en España. Discursos parlamentarios de 23 y 25 de febrero de 1920.

--- (1920b): Conferencia pronunciada por el Excelentísimo Señor Don Juan de la Cierva sobre el Problema ferroviario español. Madrid: Teatro de la Comedia, 3 de julio de 1920.

CINTORA CASTILLA, A. y RIÑÓN, E. (1926): Contestaciones al programa de Contabilidad para el ingreso como empleado en la Compañía del Norte. Madrid, s.n.

CÓDIGO DE COMERCIO DE 1885 (1913): Colección Escolar de Leyes y Códigos, Madrid: Ediciones Económicas de la Revista de los Tribunales, Centro Editorial de Góngora.

COMPAÑÍA DEL FERROCARRIL DE ZARAGOZA A PAMPLONA (1860): Reglamento de Contabilidad de las Estaciones, Pamplona: Imprenta y Lit. de Darío Aguirre.

COMPAÑÍAS DE LOS CAMINOS DE HIERRO DEL NORTE, DE SEGOVIA A MEDINA DEL CAMPO DE ALAR SAN QUIRCE A SANTANDER DE CASTEJÓN A BILBAO DE ZARAGOZA A ALSASUA Y BARCELONA DE TARDIENTA A HUESCA DE SELGUA A BARBASTRO Y DE LÉRIDA A REUS Y TARRAGONA: Clasificación general de mercancías, Madrid: Imprenta Central de los Ferrocarriles (Este documento fue escrito en un momento anterior a 1885, fecha de recepción del ejemplar en la Biblioteca Nacional. No aparece fecha en el documento).

COMPAÑÍA DEL CAMINO DE HIERRO DE BARCELONA A MATARÓ (1845): Escritura de sociedad y reglamento de la compañía del Camino de Hierro de Barcelona a Mataró y vice-versa. Barcelona: Imprenta de Don Juan Oliveres.

COMPAÑÍA DEL CAMINO DE HIERRO DEL NORTE (1855): Memoria acerca del derecho que la empresa titulada Camino de Hierro del Norte, sección de Barcelona a Granollers, tiene a impedir la construcción de otra vía que saliendo de Barcelona empalme con la que va de Moncada a Sabadell. Barcelona: Imprenta de Agustín Gaspar.

--- (1851): Estatutos y reglamento de la Sociedad Anónima titulada Camino de Hierro del Norte correspondiente a la sección de Barcelona a Granollers autorizada por Real Decreto de 30 de julio de 1851, Barcelona: Imprenta de Pons y Cía.

COMPAÑÍA DE LOS FERROCARRILES DE TARRAGONA A BARCELONA Y A FRANCIA (1887a): Reglamento para la policía y vigilancia de la vía, [s.n.], Barcelona.

--- (1887b): Reglamento para los conductores de trenes, [s.n.], Barcelona.

--- (1887c): Reglamento para los guarda-agujas. Barcelona: Imp. Peninsular de Mariol y López.

--- (1887d): Reglamento para los maquinistas y fogoneros. Barcelona: Imp. Peninsular de Mariol y López.

--- (1887e): Reglamento para los revisores de billetes. Barcelona: Imp. Peninsular de Mariol y López.

--- (1881): Reglamento para los guardagujas. Barcelona: Imp. Peninsular de Mariol y López. 
--- (1876a): Instrucción para el servicio de inspectores del movimiento. Barcelona: Tip. de Narciso Ramírez y Cia.

--- (1876b): Instrucción para el servicio de los agentes comerciales. Barcelona: Imp. Peninsular de Mariol y López.

--- (1868): Reglamento del personal. Servicio de Construcción. Barcelona: Imp. Peninsular de Mariol y López.

COMPAÑÍA DE EXPLOTACIÓN DE LOS FERROCARRILES DE MADRID A CÁCERES Y PORTUGAL Y DEL OESTE DE ESPAÑA (1927): Bases y reglamento para los mozos del exterior en las estaciones. Madrid: Imp. Samarón.

--- (1918): Montepío de los agentes de la Compañía de Explotación de los Ferrocarriles de Madrid a Cáceres y Portugal y del Oeste de España: Reglamento. Madrid: Imp. Samarón.

--- (1897): Reglamento especial $n^{o}$ 10: Contabilidad de las estaciones. Madrid: Establecimiento Tipográfico de los Hijos de R. Álvarez.

COMPAÑÍA DEL FERROCARRIL DE ALCOY A GANDÍA Y PUERTO DE GANDÍA (1892a): Reglamento para los maquinistas y fogoneros. Valencia: Imp. F. Domenech.

--- (1892b): Organización de las brigadas de conservación de la vía e instrucciones para las mismas. Valencia: Imp. F. Domenech.

COMPAÑÍA DEL FERROCARRIL DE ARGAMASILLA-TOMELLOSO (1919): Reglamento para los empleados. Madrid: Imp. Hernández.

COMPAÑÍA DEL FERRO-CARRIL DE MEDINA DEL CAMPO A SALAMANCA (1923): Instrucción general núm 2. Madrid: Suc. de Rivadeneyra.

COMPAÑÍA DEL FERROCARRIL DE TARRAGONA A MARTORELL Y BARCELONA (1872): Reglamento de servicio comercial. Barcelona: Tip. Narciso Ramírez y Cia.

COMPAÑÍA DE LOS CAMINOS DE HIERRO DE BARCELONA A FRANCIA POR FIGUERAS (1866): Reglamento general núm. 6: admisión de empleados. Barcelona: Tip. Narciso Ramírez y Cia.

COMPAÑÍA NACIONAL DE LOS FERROCARRILES DEL OESTE DE ESPAÑA (1933): Bases y reglamento para los mozos del exterior en las estaciones, Santander: Tip. J. Martínez.

--- (1929a): Escalafón de maquinistas y fogoneros. Madrid: Sucesores de Rivadeneyra.

--- (1929b): Escalafón del personal administrativo de todos los servicios, cerrado en $1^{o}$ de diciembre de 1929, Suc. De Rivadeneyra, Madrid.

--- (1929c): Escalafón de personal de las brigadas de Vía y Obras. Madrid: Sucesores de Rivadeneyra.

--- (1929d): Reglamento $n^{o}$ 9: servicio sanitario. Madrid: Sucesores de Rivadeneyra. 
CONVENTION OF RAILROAD COMMISSIONERS (1879): Proceedings of the Convention of Railroad Commissioners held at Saratoga Springs, New York. june 10. New York: Convention of Railroad Commissioners.

CORDONNIER, P. (1924): "L'egalité entre actionnaires avant et depuis la Loi du 22 novembre 1913”. Journal des Sociétés, pp. 5-62.

COSACK, K. (1904): Traité de droit commercial. Paris: Léon Mis Giard et E. Brière.

DAGGET, STUART (1908): Railroad reorganization. Houghton: Mifflin and Company.

DANOS. G. (1922): Les actions a vote plural. Paris: Université de Paris, Faculté de droit.

DÍAZ REYNES, S. (1881): Guía de transportes militares por ferro-carriles. Madrid: Imprenta del Cuerpo Administrativo del Ejército.

FERRO-CARRIL DE CÓRDOBA A MÁLAGA (1865): Reglamentos para la contabilidad del material y tracción y la contabilidad de talleres. Málaga: Imprenta de Casilari.

--- (1863a): Contabilidad. Reglamento de caja y pagadores. Málaga: Imprenta de Casilari.

--- (1863b): Reglamento de contabilidad de las estaciones. Málaga: Imprenta de G. de Montes.

--- (1863c): Reglamento general de contabilidad. Málaga: Imprenta de G. de Montes.

E.R. y G.F.V. (1914): Lecciones de geografía descriptiva de España con arreglo al programa para ingreso en la Compañía de los Caminos de Hierro del Norte (Oficinas). Madrid: Imp. Central de los Ferrocarriles.

EVANS, G.H. (1931): "The early history of preferred stock in the United States, 1850-1878”. American Economic Review, 21, march, pp. 56-62.

FAUST, ALBERT BERNHARDT (1909): The German element in the United States. Boston: Houghton Mifflin Co.

FENELON, KEVIN GERAD (1934): Economía Ferroviaria. Madrid: Revista de Derecho Privado.

FINK, ALERT (1875): Cost of railroad transportation, railroad accounts and government regulation of railroad tariffs. Kentucky: Louisville.

FORCANO CATALÁN, A. (1924): Compilación-compendio, que abarca lo dispuesto acerca de la prestación de servicio en las estaciones de la Compañía de los Caminos de Hierro del Norte de España, por lo que respecta a la expendición de billetes, facturaciones, telegrafía privada, contabilidad, correspondencia, expedienteo de reclamaciones etc. y organización de la compañía. Madrid: Sucesores de Rivadeneyra. 
GAILLARD. P. E. (1938): Comment éluder la suppression des actions á vole privilégié pour la loi de 13 novembre. Paris: École.

GARCÉS BENITO, V. (1882): Apéndice Segundo a la Colección Legislativa que forma parte del Diccionario de Ferro-carriles. Madrid: Establecimiento Tipográfico de M. Minuesa de los Ríos.

--- (1869): Diccionario razonado legislativo y práctico de los ferro-carriles españoles, bajo el aspecto legal, técnico, administrativo y comercial de los mismos. Madrid: Imprenta de Campuzano Hermanos.

GARCÍA FARIA, P. (1918): “Apuntes histórico-críticos acerca de los ferrocarriles españoles”. Revista de Obras Pública, $n^{\circ} 2212$.

GARCÍA VÁZQUEZ, J. (1906a): El autoritarismo y la anarquía en los Ferrocarriles del Norte. Segunda Parte. Madrid: M. Tabarés Impresor.

--- (1906b): El autoritarismo y la anarquía en los Ferrocarriles del Norte. Tercera Parte. Madrid: Imp. Helénica de M. Millán.

--- (1905): El autoritarismo y la anarquía en los Ferrocarriles del Norte. Primera Parte, Santander: Imp. El Cantábrico.

GIBB, G. (1836): “Minutes of evidence”. Railway Accountants Committee, Q 9707.

GÓMEZ, T. (1936): Fracaso de las compañías ferroviarias: ¿Quiénes son los culpables?. Madrid: Gráfica Socialista.

GONZÁLEZ CASTRO, B. (1922): Apuntes de contabilidad mercantil y modelos del rayado de libros: Adaptación al programa de las Oposiciones para empleados de la Compañia del Norte. Valladolid: Imp. Castellana.

GONZALEZ QUIJANO, P. M. (1916): “Los ferrocarriles españoles”. Revista Nacional de Economía, n. 5, pp. 52-74.

GREENE, T. L. (1891): “Railway Accounting”. Political Science Quarterly. vol. 7. n 4, pp. 598-612.

HAINES, HENRY S. (1897): American railway management. New York: J. Wiley \& Sons.

HIGGIN, GEORGE (1886): Commercial and Industrial Spain. London: Effingham Wilson.

HUBERT, FRÉDÉRIC (1854): Traité de comptabilité du matériel des chemins der fer. Paris: Imprimerie et Librairie Centrales de Chemins de Fer- De Napoléon et Cie. 
IMEDIO DÍAZ, ANTONIO L. (1935), "El problema ferroviario español”, en Economía Española, $\mathrm{n}^{\circ} 25$.

--- (1934): Ferrocarriles. Explotación y Legislación. Madrid: Imprenta Sáez Hermanos.

--- (1928-1929): Jornada de ocho horas en los Servicios Ferroviarios y ahorro de las extraordinarias. Madrid: Talleres Poligráficos.

--- (1906): El ferrocarril por dentro. Madrid: Imprenta de El Semanario de Cabra.

IMEDIO DÍAZ, J. (1934): Contabilidad General y de Transportes Terrestres. Publicación no 2, $2^{\mathrm{a}}$ edición, Madrid: Ed. Instituto Politécnico de Ferrocarriles.

IMEDIO DÍAZ, J. y FRAISERO GARCÍA, C. (1934): Contabilidad general y de las compañías de ferrocarriles y empresas de transportes automóviles. Madrid: Talleres Poligráficos.

INSTITUTO DE REFORMAS SOCIALES (1922a): Adaptación del régimen de la jornada de ocho horas a los servicios ferroviarios: antecedentes, información recibida, labor del Instituto, resolución dictadas por el Ministerio de Fomento. Madrid, M. Minuesa de los Ríos. --- (1922b): Las huelgas de ferroviarios españoles: septiembre de 1921 - agosto de 1922, Madrid: Imp. Felipe Samarán.

--- (1913): Conflicto de obreros y empleados de las Compañías de Ferrocarriles: Septiembre Octubre 1912. Madrid: Sucesores de M. Minuesa de los Ríos.

INTERSTATE COMMERCE COMMISSION (1930): Uniform System of Accounts for Steam Railroads. Washington: Governments Printing Office.

--- (1915): Rules governing the separation of operating expenses between freight service and passenger service on large steam railways. Effective on July 1, 1915. Washington: Governments Printing Office.

--- (1914a): Classification of operating revenues and operating expenses of steam roads prescribed by the Interstate commerce commission in accordance with section 20 of the Act to regulate. Washington: Governments Printing Office.

--- (1914b): Index to the classification of operating expenses of steam roads, issued by the Interstate commerce commission. Washington: Governments Printing Office.

--- (1913): Condensed classification of operating expenses of steam roads prescribed by the Interstate commerce commission, in accordance with section 20 of the Act to regulate commerce. Washington: Governments Printing Office.

--- (1912): Form of income and profit and loss statement for steam roads as prescribed by the Interstate commerce commission in accordance with section 20 of the Act to regulate commerce. Washington: Governments Printing Office.

--- (1911): Classification of operating expenses as prescribed by the Interstate Commerce Commission in accordance with section 20 of the Act to regulate commerce. Washington: Governments Printing Office.

--- (1910): Form of general balance sheet statement as prescribed by the Interstate commerce commission for steam roads in accordance with section 20 of the Act to regulate commerce. Washington: Governments Printing Office. 
--- (1909): Classification of expenditures for road and equipment as prescribed by the Interstate commerce commission in accordance with section 20 of the Act to regulate commerce. Washington: Governments Printing Office.

--- (1908a): Supplement to the third revised issue of the classification of operating expenses as prescribed by the Interstate commerce commission for steam roads. Washington: Governments Printing Office.

--- (1908b): Classification of operating expenses as prescribed by the Interstate commerce commission for steam roads in accordance with section 20 of the Act to regulate commerce. Washington: Governments Printing Office.

--- (1907): Classification of operating revenues as prescribed by the Interstate commerce commission in accordance with section 20 of the Act to regulate commerce. Washington: Governments Printing Office.

--- (1900): Uniform system of accounts for railroad companies. Washington: Governments Printing Office.

JIMENEZ ONTIVEROS, F. (1940): Estudios económicos. Transportes por ferrocarril. Principios fundamentales de economía industrial. Política y economía ferroviaria. Electrificación de ferrocarriles-dieselización, Coordinación de transportes. Revisión de tarifas. Madrid: Gráfica Administrativa.

--- (1930): La electrificación y la explotación ferroviaria. Exposición de los principios de la ciencia de gastos industriales. Madrid: Revista de Obras Públicas.

--- (1932): Problemas de la economía nacional. El automóvil y ferrocarril. La competencia que ofrecen al ferrocarril. Los transportes mecánicos por carretera. La construcción de nuevos ferrocarriles. Madrid: Blass S.A.

--- (1924): Bases para la resolución del problema ferroviario en España: Estudio crítico legislativo. Prólogo del Excmo. Sr. D. Emilio Ortuño. Madrid: Imp. de la Ciudad Lineal.

KNIGHT, J. y LATROBE, BENJAMIN H. (1838): Report on the locomotives and the police and management of several of the principals railroads in the Northern and Middle States. Baltimore: Lucas \& Deaver.

LARDNER, DIONYSIUS (1850): Railway Economy. A treatise on the new art of transport, New York: Augustus M. Kelley Publishers.

LÓPEZ DE LARA, F. (1865): La Compañía de los Caminos de Hierro del Norte de España. Cuestión de jurisdicción nacional y de policía judicial. Consultada a la Facultad de Derecho y de Jurisprudencia Española, y sometida en incidente, en juicio ordinario, a la decisión de los Tribunales. Madrid: Imprenta de R. Vicente.

LOS ARAGONESES A LA NACIÓN ESPAÑOLA (1853): Consideraciones sobre las ventajas del ferrocarril del Norte por Zaragoza y Canfranc. Madrid: Imprenta de Antonio Gallifa. 
LUCÍA ORDÓÑEZ, P. J. (1926): "Las longitudes virtuales de los ferrocarriles con tracción a vapor y de los ferrocarriles con tracción eléctrica", Revista de Obras Públicas, 74, tomo I. 2.446 pp. $75-80 ; 2.447$ pp. 102-106; 2.448 pp. 124-130.

LUQUE, C. y PALLARDO, A. (1888): Guía-consultor de los agentes y funcionarios de todas clases de la Inspección Administrativa y Mercantil de Ferrocarriles. Madrid: Imprenta de Ramón Moreno y Ricardo Rojas.

MADARIAGA, ROGELIO (1923): "Las tarifas y el Arancel. Su influencia en la industria, el comercio y el coste de vida", en España Económica y Financiera. La Estafeta, 24 de nov, núm. 1602, pp. 1105-1106.

--- (1913): El derecho a la huelga en los obreros ferroviarios. Conducta y legislación necesarias. Artículos publicados en España Económica y Financiera. Madrid: Establecimiento Tipográfico de Fontanet.

MARISTANY, EDUARDO (1925): "Algunas indicaciones acerca del nuevo régimen ferroviario en España, Francia, Inglaterra y Estados Unidos”. Revista de Obras Públicas, 73, tomo I, n 2438, 433-439.

--- (1911): Huelgas ferroviarias. Madrid: Gregorio Juste, AHF, S/181/1.

--- (1908) La Conferencia Ferroviaria de 1905: Estudios económicos sobre la explotación comercial de los ferrocarriles españoles. 1905-1908. 6 vols., Barcelona: Imp. Henrich y Cia,

--- (1906a): "Los ferrocarriles americanos". Revista de Obras Públicas, 54, tomo I, no 1.580, 25 de enero, 2-6.

--- (1906b): "Los ferrocarriles americanos". Revista de Obras Públicas, 54, tomo I, n 1.581, $15-28$.

--- (1906c): "Los ferrocarriles americanos". Revista de Obras Públicas, 54, tomo I, no 1.583, 54-60.

--- (1905) Impresiones de un viaje por los Estados Unidos. Barcelona: Imprenta de Henrich y Cia.

MARQUINA, JAVIER (1940): Compañía de los Caminos de Hierro del Norte de España (1859-1939). Volúmenes I y II. Madrid: Espasa Calpe.

MARRACO, MANUEL (1922): "El problema ferroviario". Revista España, 29 de abril de 1922, no 318 , p. 10.

MARTÍNEZ AQUERRETA, L. J. (1908): El Estado y las Compañías Ferroviarias. Madrid: Imprenta de A. Marzo.

MARTÍNEZ PÉREZ, E. (1910): Contabilidad y teneduría de libros. Madrid: Establecimiento Tipográfico.

MARTÍNEZ RAMÍREZ, F. (1920): Una solución al problema ferroviario. Ciudad Real: Artes Gráficas. 
MARTÍNEZ SÁENZ DE MERINO, E. (1921): Nociones de contabilidad: apuntes adaptado al Programa para las oposiciones al Cuerpo de Interventores del Estado en la Explotación de Ferrocarriles. Madrid: Mario Anguiano.

MATALLANA DEL REY, M. (1863): Vocabulario descriptivo de ferrocarriles. Zaragoza: Imp. de Roque Gallifa.

--- (1867): Cartilla para los guarda-agujas y guarda-barreras de los ferrocarriles. Barcelona: Establecimiento Tipográfico de N. Ramírez y Cía.

--- (1873): Manual práctico para la conservación de las vías férreas: Compendio de todo lo necesario al personal subalterno encargado del servicio y vigilancia de las mismas obras. Barcelona: Establecimiento Tipográfico de Narciso Ramírez y Compañía.

MC CALLUM, DANIEL C. (1856): “Superintendent's Report". Annual Report New York and Erie Rail Road Company for 1855, New York: New York and Erie Rail Road.

--- (1855): “Superintendent's Report". Annual Report New York and Erie Rail Road Company for 1854, New York: New York and Erie Rail Road.

MELENDEZ POLO, F. (1908): Prontuario del Interventor del Estado en la Explotación de Ferrocarriles. Obra ajustada al testimonio de preguntas de examen exigido por el vigente programa para el ingreso en el cuerpo de la Intervención del Estado en la Explotación de Ferrocarriles. Madrid: Imprenta y Estereotipia de Ricardo Fé.

MENDIZÁBAL FERNÁNDEZ, D. (1924a) "Consecuencias que se deducen de la lectura de un balance”. Revista de Obras Públicas, n 2405, pp. 185-192.

--- (1924b): Estudios económicos: consecuencias que se deducen de la lectura de un balance. Madrid: Talleres Voluntad.

MERRICK, E. J. (1937): "Statutory developments in business corporation law 1886- 1936". Harvard Law Review, vol, L, 27-45, p. 27- 44

MORAGAS VÁZQUEZ, F. (1914): Contestaciones al programa de contabilidad para los ejercicios de oposición a empleados sencillos de la Compañía de los Caminos de Hierro del Norte. Madrid: Establecimiento Tipográfico de Antonio Marzo.

MORRIS, RAY (1920): Railroad administration. New York, London: D. Appleton.

MUÑOZ MOSQUERA, E. (1884): Compendio de las disposiciones vigentes en la Compañía de los ferro-carriles de Madrid a Zaragoza y a Alicante y reglas que deben conocer los empleados de las estaciones y trenes para el desempeño de su cargo. Madrid: Rivadeneyra.

MZA (COMPAÑÍA DE LOS FERROCARRILES DE MADRID A ZARAGOZA Y A ALICANTE) (1935): Ventajas diversas disfrutadas por el personal de los diferentes servicios en el ejercicio de 1933 (mecanografiado), Madrid. 
--- (1934): Situación del personal en la Compañía M.Z.A (1913-1933). Madrid: Sucesores de Rivadeneyra.

--- (1933): Reseña Histórica de su constitución y desarrollo. Actuación de la Compañía durante los últimos veinte años, 1913-1931. Madrid: Establecimiento Tipográfico Sucesores de Rivadeneyra.

--- (1932): El Problema Ferroviario. Estudios realizados y medidas legislativas adoptadas en España para intentar su resolución. 1918-1932, MZA, Madrid.

--- (1931): Instrucciones para la formalización por las secciones de documentos relativos a la contabilidad del servicio. Madrid: Establecimiento Tipográfico Sucesores de Rivadeneyra.

---- (1922): Parque de material de explotación. Características de los diversos tipos de locomotoras y tenders de la Cía. M.Z.A.. (Diagramas). Zaragoza. 1922.

--- (1921): Parque de material de explotación. Inventario de máquinas, ténders, coches, furgones, vagones y grúas móviles. 31 Diciembre 1920. Madrid. 1921.

--- (1920): Estadística de material de explotación. Datos estadísticos sobre la explotación. Ejercicio de 1919.

--- (1919): Estadística de material de explotación. Datos estadísticos sobre la explotación. Ejercicio de 1918.

--- (1918): Estadística de material de explotación. Datos estadísticos sobre la explotación. Ejercicio de 1917.

--- (1917): Estadística de material de explotación. Datos estadísticos sobre la explotación. Ejercicio de 1916.

--- (1916): Estadística de material de explotación. Datos estadísticos sobre la explotación. Ejercicio de 1915.

--- (1915): Estadística de material de explotación. Datos estadísticos sobre la explotación. Ejercicio de 1914.

--- (1914a): Estadística de material de explotación. Datos estadísticos sobre la explotación. Ejercicio de 1913.

--- (1914b): Junta Gral. Ordinaria de 1913. Memoria presentada por el Consejo de Administración a la Junta General de Señores Accionistas celebrada en 11 de Mayo de 1913. Madrid. 1913.

--- (1913): Programa para exámenes de factores. Contabilidad en las estaciones.

Madrid: Establecimiento Tipográfico Sucesores de Rivadeneyra.

--- (1912): Parque de material de explotación. Inventario de máquinas, tenders, coches, furgones, vagones y grúas móviles. 31 Diciembre 1911. Madrid. 1912.

--- (1910): Memoria presentada por el Consejo de Administración a la Junta General de Señores Accionistas celebrada el 15 de mayo de 1910 para el ejercicio 1909, Madrid: Imprenta Central de los Ferrocarriles.

--- (1908) Reglamento Provisional para Contabilidad de los Servicios de la Red Antigua, MZA, Madrid: Sucesores de Ribadeneyra.

--- (1906) Junta Gral. Ordinaria de 1905. Memoria presentada por el Consejo de Administración a la Junta General de Señores Accionistas celebrada en 28 de Mayo de 1905. Madrid. 1905. 
--- (1904) Junta Gral. Ordinaria de 1903. Memoria presentada por el Consejo de Administración a la Junta General de Señores Accionistas celebrada en 24 de Mayo de 1903. Madrid. 1903.

--- (1889): Reglamento especial del Servicio de la Contabilidad General. Madrid: Imprenta de Rivadeneyra.

--- (1896a): Algunos datos para juzgar acerca del Proyecto de Ley de Auxilios á las compañías de ferrocarriles. Madrid: Sucesores de Rivadeneyra.

--- (1896b): Procès, Reunión del 10 de enero de 1896.

--- (1895): Junta General de Accionistas celebrada el 26 de mayo de 1896, Memoria del Consejo de Administración del año 1895, Resoluciones de la Junta, Madrid: Sucesores de Rivadeneyra.

--- (1892): Estatutos. Estatutos de la Compañía de los Ferrocarriles de Madrid a Zaragoza y a Alicante con las modificaciones acordadas por la Junta General Extraordinaria de Accionistas de 24 de Septiembre de 1892. Madrid. 1892.

--- (1876): Estatutos. Estatutos de la Compañía de Ferrocarriles de Madrid a Zaragoza y a Alicante. Segunda edición con las modificaciones aprobadas por el Gobierno. Versailles. 1876.

--- (1861a): Résumé des ordres de service et circulaires de l'Ingenieur en chef de la construction indiquant celles de leurs dispositions restant en viguer au 5 novembre 1861, Paris.

--- (1861b): Instrucción para la contabilidad. Madrid: Sucesores de Rivadeneyra.

--- (1857): Estatutos. Madrid: Imprenta y estereotipia de M. Rivadeneyra.

NEWTON F.A.A., C.H. (1930): Railway Accounts. London: Pitman \& Sons Ltd.

NEW YORK AND ERIE RAIL ROAD COMPANY (1853): Report of the Directors of the New York and Erie Rail Road Company to the stockholders in november 1853. New York: New York and Erie Rail Road Company.

NOBLEMAIRE, GUSTAVE (1905): "Les institutions patronales dans les compagnies des chemins de fer", en NOBLEMAIRE, Gustave, Hommes et choses de Chemins de fer, Paris: Imprimerie Paul Dupont, 68-83.

NORTE (COMPAÑÍA DE LOS CAMINOS DE HIERRO DEL NORTE DE ESPAÑA) (1940): Compañía de los Caminos de Hierro del Norte de España (1859-1939). Historia, Actuación, Ingresos, Gastos y Balance, vol. I. Texto y Gráficos, 2 volúmenes. Cuadros Estadísticos, Madrid: Espasa Calpe.

--- (1938): Reglamento para los guardagujas (aprobada por Real Orden de 10 de octubre de 1881), Lit. e Imp. Roel, La Coruña.

--- (1928): Manual para la instrucción profesional de los agentes técnicos de comunicaciones eléctricas, [s.n.], Madrid, 2 vol.

--- (1927a): Junta General de Accionistas celebrada el 3 de junio de 1927, Memoria del Consejo de Administración del año 1926, Resoluciones de la Junta, Madrid: Imprenta Central de los Ferrocarriles. 
--- (1927b): Reglamento de guardas jurados, [s.n.], Madrid.

--- (1927c): Reglamento para los conductores y guardafrenos (aprobada por Real Orden de 27 de septiembre de 1881), Suc. Rivadeneyra, Madrid.

--- (1926): Junta General de Accionistas celebrada el 3 de mayo de 1926, Memoria del Consejo de Administración del año 1925, Resoluciones de la Junta, Madrid: Imprenta Central de los Ferrocarriles.

--- (1925): Junta General de Accionistas celebrada el 2 de junio de 1925, Memoria del Consejo de Administración del año 1924, Resoluciones de la Junta, Madrid: Imprenta Central de los Ferrocarriles.

--- (1924): Junta General de Accionistas celebrada el 1 de junio de 1924, Memoria del Consejo de Administración del año 1923, Resoluciones de la Junta, Madrid: Imprenta Central de los Ferrocarriles.

--- (1923a): Junta General de Accionistas celebrada el 30 de mayo de 1923, Memoria del Consejo de Administración del año 1922, Resoluciones de la Junta, Madrid: Imprenta Central de los Ferrocarriles.

--- (1923b): Observaciones al discurso pronunciado por el accionista Burgaleta en la junta general celebrada el 19 de mayo de 1923: formuladas por encargo del consejo de administración y acordada por este su publicación, Compañía de los Caminos de Hierro del Norte de España, 19 de mayo de 1923, Madrid: Norte.

--- (1922a): Junta General de Accionistas celebrada el 2 de junio de 1922, Memoria del Consejo de Administración del año 1921, Resoluciones de la Junta, Madrid: Imprenta Central de los Ferrocarriles.

--- (1922b): Materias comprendidas en el examen del empleado principal, Madrid: Imprenta Central de los Ferrocarriles.

--- (1922c): Tarifas generales para los transportes de grande y pequeña velocidad en las líneas de Madrid a Irún-Hendaya, Venta de Baños a Alar (San Quirce), Villalba a Medina del Campo por Segovia, Alar (San Quirce) a Santander, Quintanilla a Barruelo, Castejón a Bilbao, León a Gijón, Oviedo a Trubia, Palencia a Coruña, Toral de los Vados a Villafranca del Bierzo, Soto de Rey a Ciaño-Santa Ana, Villabona a San Juan de Nieva, Alsasua a Zaragoza, Zaragoza a Barcelona, Tardienta a Huesca, Selgua a Barbastro, Huesca a Jaca, Lérida a Reus y Tarragona y Tudela a Zaragoza. Edición de 1922 (esta edición reemplaza a la de 1908. Madrid: Imprenta Central de los Ferrocarriles.

--- (1921a): Junta General de Accionistas celebrada el 3 de junio de 1921, Memoria del Consejo de Administración del año 1920, Resoluciones de la Junta, Madrid: Imprenta Central de los Ferrocarriles.

--- (1921b): Materias comprendidas en el examen de empleado principal. Madrid: Imprenta Central de los Ferrocarriles.

--- (1921c): Programa de ingreso en la Compañía de los Ferrocarriles del Norte. Guadalajara: Imp. Gutenberg, librería y papelería.

--- (1921d): Programa de ingreso en la Compañía de los Ferrocarriles del Norte, Madrid: Editorial Campos.

--- (1920a): Junta General de Accionistas celebrada el 3 de junio de 1920, Memoria del Consejo de Administración del año 1919, Resoluciones de la Junta, Madrid: Imprenta Central de los Ferrocarriles. 
--- (1920b): Estatutos del Personal - proyecto preparado por la Comisión-, Imp. Central de los Ferrocarriles, Madrid.

--- (1920c): Alcance de las peticiones del personal ferroviario en relación con la compañía del Norte y datos referentes a la situación económica de ésta, Imp. E. Minuesa, Madrid.

--- (1919): Junta General de Accionistas celebrada el 3 de mayo de 1918, Memoria del Consejo de Administración del año 1918, Resoluciones de la Junta, Madrid: Imprenta Central de los Ferrocarriles.

--- (1918a): Junta General de Accionistas celebrada el 2 de junio de 1918, Memoria del Consejo de Administración del año 1917, Resoluciones de la Junta, Madrid: Imprenta Central de los Ferrocarriles.

--- (1918b): Proyecto de escalafón y otras mejoras para el personal administrativo de la Compañía de los Caminos de Hierro del Norte de España. Madrid: Imprenta Central de los Ferrocarriles.

--- (1917): Junta General de Accionistas celebrada el 1 de junio de 1916, Memoria del Consejo de Administración del año 1916, Resoluciones de la Junta, Madrid: Imprenta Central de los Ferrocarriles.

--- (1916a): Junta General de Accionistas celebrada el 2 de junio de 1916, Memoria del Consejo de Administración del año 1915, Resoluciones de la Junta, Madrid: Imprenta Central de los Ferrocarriles.

--- (1916b): La Compañía del Norte y su personal. Datos y cifras que es preciso conocer para juzgar con acierto el problema ferroviario. Madrid: Imprenta Central de los Ferrocarriles.

--- (1916c): Anexo a la Instrucción general número 3 sobre el Servicio Sanitario de la Compañía: Cuadro de las estaciones sanitarias de la red. Nombres y residencias de los médicos y farmacéuticos. Madrid: Imprenta Central de los Ferrocarriles.

--- (1915a): Junta General de Accionistas celebrada el 3 de junio de 1915, Memoria del Consejo de Administración del año 1914, Resoluciones de la Junta. Madrid: Imprenta Central de los Ferrocarriles.

--- (1915b): Reglamento para el servicio de los lampareros y vigilantes del pequeño material, Imp. Central de los Ferrocarriles, Madrid.

--- (1914): Junta General de Accionistas celebrada el 4 de mayo de 1914, Memoria del Consejo de Administración del año 1913, Resoluciones de la Junta, Madrid: Establecimiento tipográfico de Sres. de Rivadeneyra.

--- (1913): Junta General de Accionistas celebrada el 3 de junio de 1913, Memoria del Consejo de Administración del año 1912, Resoluciones de la Junta, Madrid: Imprenta Central de los Ferrocarriles.

--- (1912a): Junta General de Accionistas celebrada el 1 de junio de 1912, Memoria del Consejo de Administración del año 1911, Resoluciones de la Junta, Madrid: Imprenta Central de los Ferrocarriles.

--- (1912b): Instituciones establecidas por la Compañía de los Caminos de Hierro del Norte de España en favor de su personal y mejoras que la Compañía concedió al mismo en los últimos años. Madrid: Imprenta Central de los Ferrocarriles.

--- (1912c): Reglamento para la concesión de pensiones de retiro de viudedad y orfandad. Madrid: Imprenta Central de los Ferrocarriles. 
--- (1911): Junta General de Accionistas celebrada el 30 de mayo de 1911, Memoria del Consejo de Administración del año 1910, Resoluciones de la Junta, Madrid: Imprenta Central de los Ferrocarriles.

--- (1910a): Junta General de Accionistas celebrada el 2 de junio de 19010 Memoria del Consejo de Administración del año 1909, Resoluciones de la Junta. Madrid: Imprenta Central de los Ferrocarriles.

--- (1910b): Reglamento para los guardagujas (aprobado por real orden de 10 de octubre de 1881. Madrid: Imprenta Central de los Ferrocarriles.

--- (1909): Junta General de Accionistas celebrada el 13 de mayo de 1909, Memoria del Consejo de Administración del año 1908, Resoluciones de la Junta, Madrid: Imprenta Central de los Ferrocarriles.

--- (1908a): Junta General de Accionistas celebrada el 7 de mayo de 1908, Memoria del Consejo de Administración del año 1907, Resoluciones de la Junta, Madrid: Imprenta Central de los Ferrocarriles.

--- (1908b): Baremos para la aplicación de las Tarifas Generales de Viajeros establecidos de acuerdo con los nuevos impuestos exigidos por la Ley de 3 de agosto de 1907, inserta en la Gaceta del 9 de dicho mes y año. Edición de 1908. (Estos baremos anulan los de la edición de abril de 1900). Madrid: Imprenta Central de los Ferrocarriles, 1908.

--- (1907a): Junta General de Accionistas celebrada el 11 de mayo de 1907, Memoria del Consejo de Administración del año 1906, Resoluciones de la Junta, Madrid: Imprenta Central de los Ferrocarriles.

(1907b): Manual para meritorios de estaciones: mayo 1907. Madrid: Imprenta Central de los Ferrocarriles.

--- (1906): Junta General de Accionistas celebrada el 20 de mayo de 1906, Memoria del Consejo de Administración del año 1905 Resoluciones de la Junta, Madrid: Imprenta Central de los Ferrocarriles.

--- (1905): Junta General de Accionistas celebrada el 8 de junio de 1905, Memoria del Consejo de Administración del año 1904, Resoluciones de la Junta, Madrid: Imprenta Central de los Ferrocarriles.

--- (1904a): Junta General de Accionistas celebrada el 26 de mayo de 1904, Memoria del Consejo de Administración del año 1903, Resoluciones de la Junta, Madrid: Imprenta Central de los Ferrocarriles.

--- (1904b): Órdenes de dirección vigentes en 31 de diciembre de 1904 (Anula la Colección de Órdenes y Circulares de la Dirección, vigentes en 1 de enero de 1892). Madrid: Imprenta Central de los Ferrocarriles.

--- (1904c): Clasificación de los ingresos y gastos de la explotación, Madrid: Imprenta Central de los Ferrocarriles.

--- (1903): Junta General de Accionistas celebrada el 30 de mayo de 1903, Memoria del Consejo de Administración, Resoluciones de la Junta del año 1902, Madrid: Imprenta Central de los Ferrocarriles.

--- (1902): Junta General de Accionistas celebrada el 3 de junio de 1902, Memoria del Consejo de Administración, Resoluciones de la Junta del año 1901, Madrid: Imprenta Central de los Ferrocarriles. 
--- (1901): Junta General de Accionistas celebrada el 25 de mayo de 1901, Memoria del Consejo de Administración del año 1900, Resoluciones de la Junta, Madrid: Imprenta Central de los Ferrocarriles.

--- (1900a): Instrucción general número 3 sobre el Servicio Sanitario de la Compañía. Madrid: Imprenta Central de los Ferrocarriles.

--- (1900b): Baremos para la aplicación de las Tarifas Generales de Viajeros, abril, Madrid: Imprenta Central de los Ferrocarriles.

--- (1900c): Instrucción general número 1 sobre la organización de los servicios de la compañía. Madrid: Imprenta Central de los Ferrocarriles (encuadernado con otros documentos. FFE IIIB 0261).

--- (1900d): Instrucción General Número 2 sobre el personal de los Servicios de la Compañía. Madrid: Imp. Central de los Ferrocarriles.

--- (1900e): Manual para meritorios de estaciones. Madrid: Imp. Central de los Ferrocarriles.

--- (1893): Ferrocarriles: la Compañía de los Caminos de Hierro del Norte de España y el Estado, Madrid: Imprenta Central de los Ferrocarriles.

--- (1891): Instrucción general núm. 12 sobre el servicio de la intervención en ruta. Madrid: Imp. Central ferrocarriles.

--- (1885a): Instrucción general $n^{o} 9$ sobre la intervención y contabilidad de la percepción. Madrid, $1^{\circ}$ de mayo de 1885. Madrid: Imprenta Central de los Ferro-carriles.

--- (1885b): Instrucción para los jefes de estación y factores autorizados para alternar con los mismos con arreglo al artículo $2^{\circ}$, párrafo $3^{\circ}$ del reglamento de los jefes de estación. Madrid: Imprenta Central de los Ferro-carriles.

--- (1885c): Prescripciones de servicio anexas a la instrucción general número 9 sobre la intervención y contabilidad de la percepción. Madrid: Imp. central de los ferrocarriles.

--- (1885d): Prescripciones de servicio anexas a la instrucción general num. 9 sobre la intervención y contabilidad de la percepción, 15 de Mayo de 1885 Caminos de Hierro del Norte. $1^{a}$ División. Intervención y Estadística. Madrid: Imp. Central de los ferrocarriles.

--- (1883): Reglamento para el servicio de la conservación del material móvil. Madrid: Imprenta Central de Ferrocarriles.

--- (1882a): Reglamento para los jefes de estación aprobado por Real Orden de 29 de julio de 1882. Madrid: Establecimientos tipográfico de Manuel Minuesa.

--- (1882b): Instrucción General $n^{o} 11$ sobre las funciones de los Inspectores de la Explotación. Madrid: Establecimientos Tipográficos de Manuel Minuesa.

--- (1882c): Reglamento para la vigilancia y conservación de la vía: aprobado por Real Orden de 15 de noviembre de 1883. Madrid: Imp. Central de los Ferrocarriles.

--- (1881a): Instrucción general $n^{\circ} 13$ sobre las agencias comerciales y de aduanas. Madrid: Establecimientos Tipográficos de Manuel Minuesa.

--- (1881b): Prescripciones de servicio anexas a la instrucción general para el servicio de intervención y estadística publicada en el año 1874. Madrid: Manuel Minuesa.

---(1880): Instrucción general $n^{o}$ 5, referente a los suministros y pedidos de objetos y artículos de todas clases para las oficinas centrales, estaciones, depósitos, talleres y almacenes auxiliares; a la conservación y reparación del mobiliario y pequeño material; a los desperdicios y objetos viejos e inservibles, y a la formación de inventarios, Madrid 30 de julio de 1879. Madrid: Establecimiento Tipográfico Manuel Minuesa. 
--- (1879): Titulación oficial de la Compañía de los Caminos de Hierro del Norte de España: $1^{o}$ de enero de 1879. Madrid: Establecimiento Tipográfico de Manuel Minuesa.

--- (1878a): Instrucción general Número 2 sobre el personal de los servicios de la compañía. Madrid: Establecimiento tipográfico de Manuel Minuesa.

--- (1878b): Clasificación de los gastos de primer establecimiento y de los ingresos y gastos de la explotación. Madrid: Establecimiento tipográfico de Manuel Minuesa.

--- (1874a): Instrucción general para el servicio del recorrido. Valladolid: Imprenta de H. Rodríguez.

--- (1874b): Estatutos. Madrid: Imp. del Diario Oficial de Avisos (Texto legal que modifica edición anterior de estatutos de la compañía del Norte).

--- (1867): M. Ernest Gouin \& Cie, contre la Compagnie des Chemins de Fer du Nord de l'Espagne: rapport des arbitres. Paris.

--- (1863): Statuts. París: Imprimerie Administrative de Paul Dupont.

--- (1862): Ley de 14 de noviembre de 1855, disponiendo lo conveniente sobre la conservación de las vías férreas, y castigo de los delitos y faltas que en las mismas puedan cometerse, y Reglamento para la ejecución de dicha ley sobre la policía de los ferro-carriles. Valladolid: Imprenta de D.F.M. Perillán, 36 p.

--- (1859): Estatutos. Madrid: Imp. M. Rivadeneyra.

--- (1851): Estatutos y reglamento de la Sociedad Anónima titulada Camino de Hierro del Norte correspondiente a la sección de Barcelona a Granollers autorizada por Real Decreto de 30 de julio de 1851. Barcelona: Imprenta de Pons y Cía.

--- (1845): Prospecto: Camino de Hierro del Norte de España a Madrid. Primera sección de Avilés a León: capital Lbs Est 1.100 .000 en 55.000 acciones de lbs. 20 cada una.- rs. vn. 2.000.- frs. 500. Depósito Lbs 2 por acción.-Rs Vn 200.- Frs 50. S.1.

NORTE y MZA (COMPAÑÍA DE LOS CAMINOS DE HIERRO DEL NORTE DE ESPAÑA; COMPAÑIIA DE LOS FERROCARRILES DE MADRID A ZARAGOZA Y A ALICANTE) (1934): La ordenación ferroviaria: documentos parlamentarios, $2^{\mathrm{a}}$ ed., Madrid: Compañías de los Ferrocarriles del Norte de España y de Madrid a Zaragoza y a Alicante.

--- (1933) Problema de los Ferrocarriles: antecedentes, datos, soluciones. Madrid: Gráfica Administrativa.

--- (1932) El problema ferroviario. Estudios realizados y medidas legislativas adoptadas en España para intentar su resolución, 1918-1932. septiembre, Madrid: Gráfica Administrativa. --- (1916): Contestación a la exposición presentada al Excmo. Sr. Ministro de Fomento por la Comisión de Entidades Económicas de Zaragoza. Madrid.

--- (1915): Nota sobre la influencia que en el precio de venta de los artículos de primera necesidad que se consumen en Madrid, tienen los transportes por ferrocarril. Madrid: Imprenta Alemana.

--- (1902): Contrato y reglamento celebrados entre la Compañía de los Caminos de Hierro del Norte y la de los Ferrocarriles de Madrid a Zaragoza y a Alicante para el cambio de material. Madrid: Imprenta Central de los Ferrocarriles.

NORTE, MZA, ANDALUCES y MCP (COMPAÑIIA DE LOS CAMINOS DE HIERRO DEL NORTE DE ESPAÑA; COMPAÑIIA DE LOS FERROCARRILES DE MADRID A 
ZARAGOZA Y A ALICANTE.; COMPAÑIIA DE FERROCARRILES ANDALUCES; COMPAÑIIA DE LOS FERROCARRILES DE MADRID A CÁCERES Y PORTUGAL) (1922): Proyecto de ley de ordenación ferroviaria: Informe elevado a la Comisión Permanente de Fomento del Senado por las Compañías Ferroviarias: del Norte, de MZA, de Andaluces y de MCP, Madrid: Imp. Hijos E. Minuesa.

--- (1919): Exposición que han elevado las principales compañías ferroviarias de España al Excelentísimo Señor Presidente del Consejo de Ministros justificando la necesidad de que sea autorizado una nueva elevación general de las tarifas de transportes, 30 de noviembre de 1919, Madrid: Imp. Hijos E. Minuesa.

NORTE, MZA, ANDALUCES, MCP y OESTE (COMPAÑÍA DE LOS CAMINOS DE HIERRO DEL NORTE DE ESPAÑA; COMPAÑÍA DE LOS FERROCARRILES DE MADRID A ZARAGOZA Y A ALICANTE; COMPAÑIÍA DE FERROCARRILES ANDALUCES; COMPAÑÍA DE LOS FERROCARRILES DE MADRID A CÁCERES Y PORTUGAL Y OESTE DE ESPAÑA) (1907): Memoria referente a los créditos de las compañías de ferrocarriles contra el Estado por transportes oficiales. Madrid: Establecimiento Tipográfico Sucesores de Rivadeneyra.

OLARIAGA, LUIS (1921): La cuestión de las tarifas y el problema ferroviario español. Madrid: Nieto y Compañía.

--- (1920): “Suplemento de ciencias sociales y económicas”. El Sol, 22 de junio de 1920.

OLIVER, E. (1897): La Partida Doble. Estudios teórico-prácticos de contabilidad comercial al alcance de todos. Tomos I y II, Ed. Vda. de Luis Tasso, Barcelona.

--- (1885): El Consultor del tenedor de Libros. Estudios prácticos de contabilidad por partida doble aplicados a los principales ramos de la industria y del comercio. Tomos II, Ed. Marcelino Bordoy y Cía, Barcelona.

ORTUÑO, EMILIO (1920a): El problema ferroviario: algunas consideraciones acerca del nuevo régimen para la explotación de los ferrocarriles de servicio público. Madrid: Suc. de Rivadeneyra.

--- (1920b): Gaceta de los Caminos de Hierro, 20 de noviembre de 1920.

PAGE, EUSEBIO (1881-1883): El ferro-carril. 2 vol. Madrid: Gráficas Estrada.

PENNSYLVANIA RAILROAD COMPANY (1881): Organization for conducting the business of the Pennsylvania Railroad Company. Philadelphia: Pennsylvania Railroad Company.

--- (1873): Organization for conducting the business of the Pennsylvania Company. Philadelphia: Pennsylvania Company.

--- (1856): Tenth Annual Report(s) of the Pennsylvania Railroad Company. Philadelphia: Pennsylvania Railroad Company. 
--- (1853): Seventh Annual Report(s) of the Pennsylvania Railroad Company. Philadelphia: Pennsylvania Railroad Company.

--- (1852): Fifth Annual Report(s) of the Pennsylvania Railroad Company. Philadelphia: Pennsylvania Railroad Company.

(1851): Fourth Annual Report(s) of the Pennsylvania Railroad Company. Philadelphia: Pennsylvania Railroad Company.

PELAYO, E. (1871a): "Nota sobre la contabilidad del material de ferro-carriles durante el periodo de su construcción”. Revista de Obras Públicas, 19, tomo I (8), 95-99.

--- (1871b): "Nota sobre la contabilidad del material de ferro-carriles durante el periodo de su construcción (Conclusión)”. Revista de Obras Públicas, 19, tomo I (9), 108-109.

PEÑA BOEUF, A. y PÉREZ CONESA, G. (recop.) (1940): Antecedentes y datos para el estudio del problema ferroviario. Serie Publicaciones de la Junta Superior de Ferrocarriles, Ministerio de Obras Públicas, Madrid: Gráficas Reunidas.

PÉREIRE, ISAAC (1879): La cuestión religiosa. Traducida y precedida de una biografía del autor por José Güell y Rente, a cargo de Víctor Saiz, Madrid: Imprenta Central.

POOR, HENRY V. (1854): "New York and Erie Rail Road Company". American Railroad Journal, 27, september 2 .

POTTIER, A. (1934): Les actions a vote plural. Paris: Leur réglementation.

RAHOLA, SILVIO (1914-1923): Tratado de ferrocarriles. 6 tomos, Madrid: Establecimiento Tipográfico Sucesores de Rivedeneyra.

RAVAGE, M. E. (1931): Cinco hombres de Francfort (La historia de los Rothschild), Madrid: Espasa Calpe.

REPARAZ, FEDERICO (1934): Bases de una sana ordenación ferroviaria. Madrid: Gráfica Administrativa.

--- (1932): “Don Félix Boix”. Revista de Obras Públicas, n 2597, 233-234.

RIESSER, JACOB (1911): The German Great Banks and their concentration in connection with the economic development of Germany, Wahsington D.C.: U.S. National Monetary Commission.

RIPPLEY, WILLIAM Z. (1915): Railroads: Finance and Organization. New York: Longmans Green.

--- (1912): Railroads: Rates and Regulations. New York: Longmans, Green \& Co.

RUIZ DEL ÁRBOL, E. (1916): Lecciones de geografía de España. Ilustrados con 49 mapas con arreglo al programa para el ingreso en la Compañía de los Caminos de Hierro del Norte 
realizado por Emilio Ruiz del Árbol y Gonzalo Fernández de la Vega. Madrid: Imp. Central de los Ferrocarriles.

RUIZ DEL ÁRBOL, E. Y VEGA FERNÁNDEZ DE LA G. (1921): Contestaciones al programa para el ingreso en la Compañía de los Caminos de Hierro del Norte: contabilidad (oficinas). Madrid: Juan Pueyo.

RAMÓN HERNÁNDEZ, J.; CAMPOS GONZÁLEZ, B. y SANTO TOMÁS, A. (1921): Contestaciones al Programa de Interventores del Estado en ferrocarriles. 2 tomos. Madrid: Editorial Campos [imprenta de Cleto Vallinas].

RAMOS OLIVEIRA, A. (1935): El capitalismo español al desnudo. Madrid: E. Prieto.

SANTAPAU Y MERENCIANO, A. (1916): Manual politécnico. Apuntes de caligrafía, ortografía, gramática, aritmética y contabilidad para Academias y especialmente para el ingreso en el cuerpo de ferrocarriles. Valencia: Establecimiento Tipográfico de Manuel Pau.

SANZ, C. (1916): La cuestión social ante las compañias de ferrocarriles. Pamplona: E. Albéniz.

SCHILLINGS, ALBERTO (1853): Tratado práctico del servicio y explotación de los caminos de hierro en Francia, para conocimiento e instrucción de los empleados en los de España, y para todos los que deseen tener nociones exactas sobre este nuevo y poderoso medio de transporte. Madrid: Imprenta de Manuel Minuesa.

SCHMALENBACH EUGEN (1919): Grundlagen dynamische Bilanzlehre. Leizpig: Gloeckner.

--- (1922): Goldmarkbilanz. Leizpig: Gloeckner.

SCHMULEWITZ M. (1927): Die Verwaltungsaktie. Herrschafts, Berlin.

STUART MILL, J. (1848): Essays on Economics and Society [1824-1845]. London: Routledge \& Kegan Paul.

TAYLOR, FREDERICK WINSLOW (1911): Principles of Scientific Management, Harper \& Brothers, New York and London.

--- (1903): "Shop Management", Transactions of the American Society of Mechanical Engineers, 24: 1337-1480.

TIMONER RUIZ, M. (1865): La Compañía de los Caminos de Hierro del Norte de España ante el ministerio de la ley. Madrid: Imprenta de R. Vicente.

--- (1864). A la nación española. Situación legal de la Empresa del Ferro-carril del Norte de España. Madrid: Imprenta de Vicente y Lavajos. 
THALLER, E. (1930): "Traité elementaire de droit commercial, Paris: Arthur Rouseau.

TORRE, ENRIQUE DE LA (1892-1935): Anuario de Ferrocarriles Españoles. Madrid: Imprenta de Alrededor del Mundo.

TORRENTS Y MONNER, A. (1885): Tratado de contabilidad. Barcelona: Mariano SoláSagalés, Editor.

THE DIRECTORY PUBLISHING COMPANY LIMITED (1937): Universal Directory of Railways Officials and Railway Year Book (1890-1937). London: The Directory Publishing Company Limited.

URBINA, J.; CALATAÑAZOR, A. (1889): Elementos de aritmética, gramática, contabilidad, derecho mercantil, ferrocarriles y telégrafos con arreglo al programa de exámenes para ingreso en el Cuerpo Administrativo de Ferrocarriles. Madrid: Manuel Minuesa de los Ríos.

VAN OSS, S.F. (1893): American railroad as investment. New York-London: Effingham Wilson.

VEGA ARMENTEROS, R. (1884): Una cuestión grave. Los ferrocarriles españoles. Madrid: Imprenta de Ramón Moreno y Ricardo Rojas.

VIANI, M. Y BURGALETA, V. (1919): Conveniencia y posibilidad de electrificar los ferrocarriles españoles. Madrid: Ministerio de Fomento.

VILLIAUMÉ, NICOLAS (1864): Historia de la revolución francesa desde 1789 a 1796, 2 vols. Madrid: S. Cañizares.

--- (1862): De l'Espagne et de ses chemins de fer. Paris: Garnier Frères, Librairies Editeurs.

--- (1857): Nouveau traité d'économie politique. Deuxième édition revue et augmentée par l'auteur, Paris: A.Lacroix, Verboeckhoven \& Ce.

WEDGEWOOD, R.L. (1909): "Statistics of Railway Cost". Economic journal, nº 73, march.

WHITE JOSEPH L. (1925): Analysis of Railroad Operations, New York, Simmons Boardman Publishing Corporation.

WILSON, WILLIAN B. (2010): History of the Pennsylvania Railroad Company: With Plan of Organization, Portraits of Officials and Biographical Sketches. Volume 2. London: Nabu Press.

WOODLOCK, THOMAS F. (1940): The Anatomy of Railroad Report and Ton-Mile Cost. New York: Nelson's Wall Street Library. 
ZURDO OLIVARES, L. (1911): Veinte años de vida ferroviaria y diez y seis después. Barcelona: Henrich y Cía.

\section{Bibliografía moderna}

AGUILERA RAMOS, J. L. (1994): "Clases y series de acciones. Las acciones privilegiadas", en AA.VV., en Derecho de Sociedades Anónimas, t. 11, vol. I (Capital y acciones). Madrid.

ASSOCIATION OF AMERICAN RAILROADS (1951): Railway Statistical Manual, Accounting Classification. Washington: Association of American Railroads.

ALLIENDE, M.P. (1993): Historia del ferrocarril en Chile. Santiago: Pehuén.

ALVARADO RIQUELME, M. (1998): Orígenes e historia de la auditoría. La auditoría en España y la Unión Europea: la independencia del auditor. Tesis. Madrid: Universidad Complutense de Madrid.

ÁLVAREZ LÓPEZ, J. (1991): Auditoría Contable. Madrid: ICAC.

ANÉS ÁLVAREZ, R. (1978): "Relaciones entre el ferrocarril y la economía española, 18551935”, en Miguel Artola (dir.), Los ferrocarriles en España, 1844-1943, vol. II. Madrid: Servicio de Estudios del Banco de España.

ARAGÓN, J. DE (1942): Enciclopedia moderna de contabilidad. Madrid: M. Aguilar.

ARANA GONDRA, F. J. (1976): La censura de cuentas en las sociedades anónimas. Régimen Jurídico y fundamentos de su reforma. Madrid: Ediciones ICE.

ARNOLD, J. y HOPE, T. (1983): Accounting for Management Decisions. London: PrenticeHall.

ARTOLA, MIGUEL (1978): "La acción del Estado", M. ARTOLA (Dir.), Los ferrocarriles en España, 1844-1943, 1. El estado y los Ferrocarriles. Madrid: Banco de España, Vol. 1, pp. 409-445.

BAJAS, M.; MAZUMDAR, S.C; SARIN, A. (2002): "The cost of issuing preferred stock". Journal of Financial Research, 25 (4), 577-592.

BALLESTEROS DONCEL, E. (1999): "La concesión de anticipos sin intereses a los empleados de MZA (1857-1875)". Anuario Jurídico y Económico Escurialense, 32, pp. 1.029-1.046. 
--- (1997): "Una estimación del coste de la vida en España, 1861-1936". Revista de Historia Económica - Journal of Iberian and Latin American Economic History, Año XV, nº 2, pp. 363395.

BALLESTEROS, E.; MARTINEZ VARA, T. (2001a): "La evolución del empleo en el sector ferroviario español, 1893-1935". Revista de Historia Económica - Journal of Iberian and Latin American Economic History. n 3, pp. 636-678.

--- (2001b): "La evolución del empleo en el sector ferroviario español, 1893-1935". Comunicación presentada al II Congreso de Historia Ferroviaria. Aranjuez 7-9 de febrero 2001.

--- (2001c): "El mosaico de las profesiones ferroviarias. El caso de la compañía de Madrid a Zaragoza y a Alicante, 1857-1936", en Carlos Arenas Posadas, Antonio Florencio Puntas y Jerònima Pons Pons (ed.). Edición y Comunicación. Sevilla: Trabajo y relaciones laborales en la España Contemporánea, pp. 53-64.

BARQUÍN, R. (2016): “Castillos en el aire, caminos de hierro en España: La construcción de la red ferroviaria española". Revista de la Historia de la Economía y de la Empresa. no 10, pp. 289-317.

BARRON BASKIN, J. y MIRANTI, P.J.J. (1997): A story of corporate finance. Cambridge: Cambridge University Press.

BATARDON, L. (1970): Traité pratique des sociétés commerciales. Paris: Dunod.

BELTRÁN SÁNCHEZ, E. (1994): "Las clases de acciones como instrumento de financiación de las sociedades anónimas", en AA.VV.: Estudios de Derecho Bancario y Bursátil. Homenaje a Evelio Verdera y Tuells. tomo I. La Ley. Madrid.

BENITO BARROSO, MARÍA DE LUJÁN (2015): Expansión ferroviaria en España en el siglo XIX. Entorno económico-social y modelo contable ferroviario: MZA (1875-1900). Tesis doctoral, Madrid: Universidad Complutense.

BENTABOL MANZANARES, M. A.; GUZMÁN RAJA, I.; MONTOYA CHINCHILLA, J. L.; MORALES CAPARRÓS, M. J. (2011): "La amortización contable en España durante el primer cuarto del siglo XX (1900-1925): el caso de la Compañía de los Caminos de Hierro del Norte de España", X Congreso Internacional de la AEHE, 8, 9 y 10 de Septiembre 2011, Universidad Pablo de Olavide, Carmona (Sevilla).

BERMEJO VERA, J. (1974): Régimen jurídico del ferrocarril en España (1844-1974). Estudios específicos de Renfe. Madrid: Tecnos.

BERNAL, M. (2004): "La regulación de las sociedades anónimas y la información contable publicada en la Gaceta de Madrid a mediados del siglo XIX". Revista Española de Financiación y Contabilidad. XXXIII, ene-mar. 120, pp. 65-94. 
--- (2000): "Cambio en la regulación contable: El Código de Comercio de 1885 a través de sus proyectos". Revista Española de Financiación y Contabilidad. XXIX, 103: 173-201.

BISSARA P. (1998): "Les véritables enjeux du débat sur "Le gouvernement de l'entreprise". Revue des sociétés. $\mathrm{n}^{\mathrm{o}} 1$. janvier-mars, p. 7.

BLASCO, J. E.; CUÉLLAR, D. y MONTOYA, J. L. (2015): Una aproximación al estudio de las memorias y los balances de las antiguas compañías ferroviarias: el caso de la Compañía de los Ferrocarriles Andaluces. IX Encuentro de trabajo sobre historia de la contabilidad AECA. Cartagena.

--- (2014): "La contabilidad de la compañía de los ferrocarriles andaluces en un periodo crítico (1920-1930) y su análisis a través del Estado de Flujos Efectivo". De Computis: Revista Española de Historia de la Contabilidad. n 20. junio.

BOOCKHOLDT, J.L. (1977): "Influence of the 19th and 20th railroad accounting on the development of modern accounting theory". Accounting Historian Journal, pp. 9-28.

BOUNEAU, C. (1995): L' electrification du Grand Sud-Ouest de la fin du XIXe siécle à 1946: genèse et croissance d'un complexe énergetique. Paris: Univertité de Paris.

BOUVIER, JEAN (1967): Les Rothschild. Paris: Fayard.

BOYNS, T. Y EDWARDS, J.R. (1996). The development of accounting in mid-nineteenth century Britain: a non-disciplinary view. Accounting, Auditing \& Accountability Journal. Vol. 9 (3), pp. 40-60.

BRÄNDEL, O.C. (1992): Aktiengesetz. GroBkommentar. Berlin: Water de Gruyter.

BREALEY, RICHARD A.; MYERS, STEWART C. y MARUS, ALAN J. (1996): Fundamentals of Corporate Finance. New York: McGraw-Hill.

BRIEF, RICHARD P. (1968): "Nineteenth Century Accounting Era". Journal of Accounting Research. 3. spring, pp. 1-46.

--- (1966): “The evolution of assets accounting”. Business History Review. no 40. spring, pp. $1-32$.

BRODER, ALBERT (2012): El ferrocarril español (1854-1913), el gran negocio de los franceses. Fundación de los Ferrocarriles Españoles: Madrid.

--- (2000): Historia económica de la España contemporánea. Editions de la Universitat de Barcelona. Barcelona: Alianza Editorial.

--- (1979): "Le rôle des intérêts étrangers dans la croissance économique de 1'Espagne: 18151913”, en Pierre Villar. Etat. Enterprise et Historie. Paris: Univ. Paris. 
BROWN, RICHARD (1968): A History of Accounting and Accountants. New York: Cosimo classics.

BUSTELO, F. (1994): Historia Económica. Introducción a la historia económica mundial. Historia económica de España en los siglos XIX y XX. Madrid: Editorial Complutense.

CABANES MARTÍN, A. y LETÓN RUIZ, R. (2003): "Ferrocarriles y Tranvías: una revista técnica, una fuente de información para el estudio del ferrocarril”. III Congreso de Historia Ferroviaria. Gijón.

CAIN, T.E. (1965): Charlesworth's Company Law. $8^{\mathrm{a}}$ ed. London: Stevens.

CALVOSA, L. (1995): La clausola di riscatto nella società per azioni. Milano: Copertina.

CAMERON RONDO, E. (1961): France and the economic development of Europe, 18001914. Princeton: Princeton University Press.

CAMPOBASSO, G. F. (1993): “Glistrumenti di finanzamiento: le obbligazioni”, en Il diritto delle Societá per azioni: problemi, esperienze, progetti (dir, Abbadessa, P.; Rojo, A.), Milano, 225-285.

CAMPUZANO LAGUILLO, A.B. (2000): Las clases de acciones en la sociedad anónima. Madrid: Civitas.

CARRERAS, A. (1999), "Los ferrocarriles en Europa: algunas perspectivas históricas", en M. Muñoz Rubio, J. Sanz Fernández y J. Vidal Olivares (eds.), Siglo y medio del ferrocarril en España, 1848-1998. Madrid: Fundación de los Ferrocarriles Españoles pp. 33-54.

--- (1990): "Industrialización española: estudios de historia cuantitativa". Madrid: EspasaCalpe.

--- (1983): La producció industrial espanyola i italiana des de mitjansegle XIX fins a 1'actualitat. Doctoral thesis. Barcelona: Universitat Autònoma de Barcelona.

CARRERAS, A. y TAFUNELL, X. (1997): "Spain: Big Manufacturing Firms between State and Market, 1917-1990", in A, Chandler, F. Amatori and T. Hikino (eds.), Cambridge: Big Business and the Wealth of Nations, pp. 277-304.

--- (1996): "La gran empresa en la España contemporánea: entre el mercado y el estado", en F. Comín y P. Martin Aceña (eds.) (1996): La empresa en la historia de España, Madrid: Civitas, pp. 73-90.

--- (1993): “La gran empresa en España (1917-1974). Una primera aproximación". Revista de Historia Industrial, 3, pp. 127-175.

CASARES, A. (1973): Estudio histórico-económico de las construcciones ferroviarias españolas en el siglo XIX. Madrid: Instituto de Cooperación Iberoamericana. 
CASTAÑEDA, VICENTE (1946): Los primeros ferro-carriles españoles (Intentos y realidades). Madrid: Viuda de Estanislao Maestre.

CASTRO BALAGUER, R (2007): "Historia de una reconversión silenciosa. El capital francés en España, c. 1800-1936”. Revista de Historia Industrial, nº. 33, pp. 81-118.

CARY; COLLINS y WANSLEY (2003): "The impact of trust preferred issuance of bank default risk and cash-flow: evidence from the debt and equity markets". The Financial Review. May. vol. 38. $\mathrm{n}^{\circ}$ 2. pp. 235-249.

CARY, WILLIAM L. y EISENBERG, MELVIN A. (1995): Cases and Materials on Corporations. $7^{\mathrm{a}}$ ed. New York: Westbury.

CARON, FRANÇOIS (2005): Les grandes compagnies de chemin de fer en France. 18231937. Genève: Librairie Droz.

--- (2003): "À propos de la rationalisation du travail dans les ateliers des compagnies des chemins de fer en France, 1880-1936". Revue d' Histoire des Chemins de Fer. no 28-29, pp. 190-206.

--- (1997): Histoire des chemins de fer en France. París: Fayard Editorial.

--- (1989): "Historie économique et chemin de fer". Revue de Histoire des Chemins de Fer. no 1, pp. 19-25.

--- (1981): "Ferrocarril y crecimiento económico en Francia en el siglo XIX”, en AA.VV, Los ferrocarriles y el desarrollo económico de Europa occidental durante el siglo XIX, Madrid: Renfe, pp. 105-125.

--- (1973): Histoire de l'explotation d'un grand réseau. La compagnie de chemin de fer du Nord. Paris: Ecole Practique de Haute Etudes.

CAYÓN GARCÍA, F. y CUÉLLAR VILLAR, D. (2006): "El sindicalismo ferroviario español en democracia, 1976-2000", comunicación presentada al IV Congreso de Historia Ferroviaria, Málaga 20-22 de septiembre 2006.

CAYÓN GARCÍA, F. y MUÑOZ RUBIO, M. (2001): "El trabajo de la infraestructura en RENFE (1944-1998)", comunicación presentada al II Congreso de Historia Ferroviaria, Aranjuez 7-9 de febrero 2001.

CHANDLER, ALFRED D., JR. (1990): Scale and Scope. The Dynamics of Industrial Capitalism. Cambridge MA: Harvard University Press.

--- (1977): The Visible Hand. Cambridge MA and London. England: The Belknap Press of Cambridge.

--- (1965a): The Railroads: The Nation's First Big Business. New York: Ayer Co Pub.

--- (1965b): "The Railroads: Pioneers in modern Corporate management". Business History Review, 39, spring, pp. 16-40.

--- (1964): The Railroads. The Nation's First Big Business. Sources and Readings. New York: Harcourt. Brace \& World. 
--- (1962): Strategy and Structure: Chapters in the History of the American Industrial Enterprise. Cambridge MA: MIT Press.

--- (1956): Henry Varnum Poor, business editor, analyst and reformer. Cambridge MA: MIT Press.

--- (1954): "Patterns of railroad finance, 1830-1850". Business History Review. no 28. September, pp. 248-263.

CHAMORRO DOMÍNGUEZ, M. C. (2007): Las acciones rescatables de la sociedad anónima cotizada. Madrid: La Ley.

CHANNON, G. (1996): “A.D. Chandler's "visible hand" in transport history: a review article", en Gourvish, Terry (ed.), Railways I. Studies in Transport History. ScolarPress, pp. $153-164$

CHASTAGNARET, G. (1975): "Un ejemplo de revista científica: la Revista Minera desde 1850 a 1914", en Manuel Tuñón de Lara et al. Prensa y sociedad en España. 1820-1936. Madrid: Edicusa.

CHATFIELD, M. y VANGERMEERSCH, R. (1996): The History of Accounting. New York: Garland.

CINCOTTI, C. y NIEDDU ARRICA, F. (2003): "Le preferred shares nel diritto italiano: propietá della societá per azioni e strumenti finanziari ibridi". Giurisprudenza Commerciale, $n^{\circ} 30$.

CLARK M. (2002): Amarga luz. Barcelona: CIRCE Ediciones, S.A.

CLEVELAND, HAROLD VAN B. y HUERTAS, THOMAS F. (1985): Citibank, 1812-1970. Cambridge MA: Harvard Studies in Business History.

COBOS ARTEAGA, F. DE LOS; MARTINEZ VARA, T. (2012): "Los Péreire y las Compañías de Norte de España y Midi en la definición de las conexiones ferroviarias francoespañolas 1832-1907”. VI Congreso de Historia Ferroviaria. Vitoria.

--- (2009): "Gestión del conflicto laboral en las grandes empresas. Los modelos de la dirección de las compañías ferroviarias Norte y MZA". V Congreso de Historia Ferroviaria. Palma. 14-16 de octubre.

--- (2006): "Gran clase, tercera y trabajadores. Seguridad y clases en el ferrocarril español del siglo XIX”. IV Congreso de Historia Ferroviaria Málaga 20-22 de septiembre 2006.

--- (2007): "Lenguaje y realidad: la intervención de la contabilidad de las ferroviarias por parte de la Dictadura de Primo de Rivera". Revista de la historia de la economía y de la empresa. $\mathrm{n}^{\circ} 1$, pp. 319-339.

COCHRAN, THOMAS C. (1953): Railroad Leaders, 1845-1900: The business mind in action. Cambridge MA: Cambridge University Press. 
COLLINS, JULIE H.; SHACKELFORD, DOUGLAS A. (1992): "Foreign tax credit limitations and preferred stock issuances". Journal of Accounting Research. vol. 30, supplement, pp. 103-124.

COMÍN, F. (1999): "Los efectos económicos del ferrocarril sobre la economía española (1855-1935)" en Francisco Javier Vidal Olivares, Miguel Muñoz Rubio, Jesús Sanz Fernández (eds.), Siglo y medio del ferrocarril en España, 1848 - 1998: economía, industria y sociedad, Instituto de Cultura Juan Gil Albert, CAM y Fundación de Ferrocarriles Españoles, pp. 255-271.

COMIN, F. y MARTÍN ACEÑA, P. (1984): "La política monetaria y fiscal durante la Dictadura y la Segunda República”. Papeles de Economía Española. Vol. 20, pp. 236 - 265.

COMIN, F.; MARTIN ACEÑA, P. y MUÑOZ RUBIO, M. y VIDAL OLIVARES, J. (1998): 150 Años de Historia de los Ferrocarriles en España. Madrid: Fundación Ferrocarriles Españoles.

COPELAND, R. M. (1968): “Income smoothing”. Journal of Accounting Research, 16 (suplem), pp. 101-116.

CORDERO, R. y MENÉNDEZ, F. (1978): “El sistema ferroviario español”, en M. ARTOLA (dir.) (1978), Los ferrocarriles en España, 1844-1943. Madrid: Banco de España. Vol. 1, pp. 163-341.

COSTA, M. T. (1982): La financiación exterior del capitalismo español en el siglo XIX. Barcelona: Ediciones de la Universidad de Barcelona.

COTTON, J. (1995): “Australia: share buy-backs”. Company Lawyer. n 9, pp. 287-288.

COZIAN, M. y VIANDER, A. (1992): Droit des sociétés. Levallois: Francis Lefebvre.

CREMADES, B. (1986): “Aspectos actuales de la financiación de las empresas”, en Jornadas de estudio en torno al Derecho mercantil actual V su futuro inmediato. Pamplona, pp. 33-49.

CROMPTON, G. (1998) "Good business for the nation: the railway nationalisation issue". 1921-1947. Journal of Transport History. III. n² 20, pp. 141-159.

CUELLAR VILLAR, D. (2009): Y Stephenson dijo no: Los capitales británicos en los Ferrocarriles españoles, $N^{o} 7 / 2009$, Working Papers in Economic History, Universidad Autónoma de Madrid (Spain), Department of Economic Analysis (Economic Theory and Economic History).

--- (2007): El ferrocarril en España, siglos XIX y XX: una visión en el largo plazo, No 2007/03, Working Papers in Economic History. Universidad Autónoma de Madrid (Spain), 
Department of Economic Analysis (Economic Theory and Economic History), http://EconPapers.repec.org/RePEc:uam:wpapeh:200703.

--- (2003): Los transportes en el Sureste andaluz (1850-1950): economía, empresas y territorio. Madrid: Fundación de los Ferrocarriles Españoles.

CUESTA RUTE DE LA, J. Ma . (1973): "Clases especiales de acciones y su problemática". Revista de Derecho Financiero y de Hacienda Pública, n 106-107, julio-octubre, pp. 913928.

DEPENBROCK, H. (1975): Zur Entwicklung und Bedeutung der Vorzugsaktien in der Aktienrecechten der USA und im deutsche Aktienrechteine vergleichende Undersuchung. Westfalia: Güteslosh.

DOOD, M.; BAKER, R.J. (1951): Cases and materials on corporations. Cambridge MA: Harvard University Press.

DONALDSON, G. (1962): "In defence of preferred stock". Harvard Business Review, n’. 40, pp. 123-136.

DONOSO ANES, R.; GINER INCHAUSTI, B. y RUIZ LLOPIS, A. (2006): "La contabilidad de costes a finales del s. XIX: el caso de la empresa española Trenor y Cía. (1838-1926)", DE COMPUTIS Revista Española de Historia de la Contabilidad Spanish Journal of Accounting History, $\mathrm{n}^{\circ}$. 4 Junio, pp. 42-67.

DOOD, M.; BAKER, R.J. (1951): Cases and materials on corporations. Brooklyn: The Foundation Press.

DURÉNDEZ GÓMEZ-GUILLAMÓN, A. (2001): La auditoría de cuentas en España: un estudio empírico sobre la función, utilidad y comprensión del Informe de auditoría, Tesis doctoral. Murcia: Universidad de Murcia.

DYOS, H. J. y ALDCROFT, D. H. (1974): British transport. An economic survey from the seventeenth century to the twentieth. Hardmondsworth: Pengin Books.

EDWARDS, J. R. (1989): A history of financial accounting, London: Routledge.

-- (1986a): "Depreciation and fixed asset valuation in British Railway Company Accounts to 1911”. Accounting and Business Research, summer, pp. 251-263.

--- (1986b): Legal Regulation of British Company Accounts, 1836-1900, Vol. 1. New York: Garland.

--- (1985): "The origins and evolution of the double account system: An example of accounting innovation". Abacus, march, vol. 21, nº 1, pp. 19-43.

ELVIRA BENITO, O. y AMAT SALAS, O. (2008): "La manipulación contable: tipologías y técnicas". Partida Doble, n 203, octubre, pp. 48-59. 
ESTEBAN VELASCO G. (1999): "La renovación de la estructura de la administración en el marco del debate sobre el gobierno corporativo", en El gobierno de sociedades cotizadas.

ESTEVAN DE QUESADA, C. (2002): Tomas de control y medidas defensivas. La compra de acciones propias como defensa. Pamplona: Aranzadi.

ENGEL, E.; ERICKSON, M. y MAYDEW, E. (1999): "Debt-equity hybrid securities". Journal of Accounting Research, $\mathrm{n}^{\circ} 2$.

FARRAR, J, H. (1991): Company law. London, Edinburgh, Dublin: Farrar JH and Hannigan B, Butterworths.

FARRAR, J.H. y HANNIGAN, B.M. (1998): Farrar's Company Law, 4 a ed. London, Edinburgh, Dublin: Farrar JH and Hannigan B, Butterworths.

FERNÁNDEZ DÍAZ SARABIA, P. (2006): “Tres OPAS ferroviarias en la época del directorio militar", IV Congreso Historia Ferroviaria, 20-22 septiembre de 2006, Málaga.

FERNÁNDEZ GÓMEZ, J. A. (1996), "Prehistoria del taylorismo en España: la difusión de la organización científica del trabajo en el primer tercio de siglo", en Santiago Castillo (coord.), El trabajo a través de la Historia, Madrid: Asociación de Historia Social-Centro de Estudios Históricos de la UGT.

FERNÁNDEZ PEÑA, E. (1991): La contabilidad y sus profesionales en la España de los siglos XIX y XX. Cuadernos de Estudios Empresariales, $\mathrm{n}^{\circ} 1$.

--- (1989): "La auditoría legal en España", en La Contabilidad en Iberoamérica, Madrid: ICAC.

--- (1985): “Antigüedad de la profesión auditora en España”. Técnica Contable, noviembre, $422-430$.

FERNÁNDEZ DEL POZO, L. (2008): "El requisito de mantenimiento de la integridad del capital social tras la reforma contable (Ley 16 /2007, de 4 de julio)", $18^{\circ}$ Forum de l'auditor profesional, Sitges, 3 y 4 de julio.

--- (2003a): “Un nuevo puzzle”. Diario Cinco Días. Opinión, 15 de diciembre, p. 3.

--- (2003b): "Greenmail y amortización no paritaria de acciones y de participaciones. Un examen crítico del Estado de la Cuestión en nuestra jurisprudencia”. Revista de Derecho de Sociedades, pp. 39-80.

--- (2002): La amortización de acciones y las acciones rescatables. Madrid: Civitas.

--- (1999): "Participación de trabajadores y directivos en el capital de las sociedades anónimas, Examen de la cuestión en Derecho societario". Revista de Derecho Mercantil, no. 234, pp. 1460-1480. 
--- (1995): "Sobre la llamada reducción de capital con cargo a beneficios o reservas en las sociedades anónimas y de responsabilidad limitada". Revista de Derecho Mercantil, $\mathrm{n}^{\circ}$ 218, 1995, pp. 1393-1412.

--- (1992): El fortalecimiento de los recursos propio., Zaragoza: Marcial Pons.

--- (1990): "Las acciones rescatables o redimibles". La Ley, tomo IV, pp. 1164-1177.

FERRÁN, E. (1999): Company Law and Corporate Finance. Oxford: Oxford University Press.

FIDALGO, E.; BENITO M.L. y SANTOS-CABALGANTE, B. (2015): “A Historical challenge to the accounting technique: The railway companies' fixed assets in the $19^{\text {th }}$ century", XX Workshop on Accounting and Management Control. Memorial Raymond Konopka, IE University, January, Segovia.

FIDALGO, E. y MIRANDA, R. (2006): "El sistema contable de la compañía de ferrocarriles de MZA en sus inicios (1857-1908): un estudio introductorio", XII Encuentro de la Asociación Española de Profesiones Universitarios de Contabilidad (ASEPUC), Burgos.

FITZGERALD, ROBERT (1999): "Employment relations and industrial welfare in Britain: Business ethics versus labour markets", en Business and Economic History, nº. 28, pp. 167179.

--- (1988): British labour Management and Industrial Welfare, 1846-1939. London: Groom Helm.

FOGEL, R. W. (1964) Railroads and American Economic Growth: Essays in Econometric History. Baltimore: The John Hopkins University Press.

FONTANA, G. L. (2003) "El desarrollo económico de Europa en el siglo XIX". Historia Económica de Europa. Siglos XV-XX, Barcelona, Crítica, pp. 185-302.

FONTEla TAlín, A. (2005): Vida y tiempos de Faustino Rodríguez San Pedro (18331925). Gijón: Fundación Alvargonzález.

FRIEDMAN, L.M. (1973): A history of american law. New York: Simmons \& Schuster.

FREEMAN, R. E. (1984): Strategic Management: A Stakeholder Approach. Cambridge MA: Cambridge University Press.

FUNDACIÓN DE FERROCARRILES ESPAÑOLES (2011): Informe 2010. Observatorio del Ferrocarril en España. Documento de Trabajo Diciembre 2011, Madrid: FFE.

GASPERONI, NICOLA (1950): Las Acciones de las Sociedades Mercantiles. Madrid: Editorial Revista de Derecho Privado. 
GORDON, J. N. (1988): "Ties that bond: dual class common stock and the problem of shareholder choice". California Law Review, n 75.

GOWER'S, L.C.B. (1997): Principles of Modern Company Law. London: Davies, P.L./Prentice, D.D.

GARCÍA-CRUCES GONZÁLEZ J.A.: (2002) "Notas en torno al concepto y régimen jurídico de las acciones rescatables”, en Derecho de Sociedades. Libro Homenaje a Fernando Sánchez Calero, vol. I, Madrid: Mc Graw-Hill.

--- (2000): "El nuevo régimen de las acciones preferentes (art.50.3 LSA)", en GARCÍACRUCES GONZÁLEZ, J.A. La(s) reforma(s) de la Ley de Sociedades Anónimas, Madrid: Tecnos.

--- (1999): “Las acciones rescatables”. La Ley, 24 de mayo, pp. 1694-1702.

GARCÍA DELGADO, J. L. (1989): Santiago Alba. Un programa de reforma económica de la España del primer tercio del siglo XX. Madrid: Ministerio de Obras Públicas.

GARCÍA DELGADO, J. L., SÁNCHEZ JIMÉNEZ, J. y TUÑON DE LARA, M. (1976): Los comienzos del siglo XX. 1898-1931. Barcelona: Espasa Calpe.

GARCÍA FRONTI, I.; NAVAZO RUIZ, J. (2000): “Acciones rescatables: Aspectos legales y contables". Partida Doble. no 112. junio, pp. 4-15.

GARCÍA RAYA, J. (2006): “Cronología básica del ferrocarril español en vía ancha". IV Congreso de Historia Ferroviaria, Málaga.

GARCÍA VENERO, M. (1948): "Historia Anecdótica del Ferrocarril en España”, en Cien años de ferrocarril en España, prólogo José María F. Ladreda, Vol. I, Madrid: Imprenta Editorial Magisterio Español, 1-359.

GARRIDO GARCÍA, J. M. (1991): "Tácticas defensivas frente a ofertas de adquisición hostiles: la experiencia anglosajona". Revista de Derecho Bancario y Bursátil, 42, 355-348.

GARRIGUES, JOAQUIN (1976): Curso de Derecho Mercantil, Tomo I, $7^{\mathrm{a}}$ ed. Madrid: Silvio Aguirre Torre.

--- (1971): Hacia un nuevo Derecho Mercantil. Madrid: Silvio Aguirre Torre.

GARRIGUES, J. y URÍA, R. (1952): Comentario a la Ley de Sociedades Anónimas, T I, $1^{\text {a }}$ edición. Madrid: Uría Menéndez Abogados.

GAY DE MONTELLÁ (1948): La vida económica y financiera de las sociedades anónimas. Barcelona: Bosch Casa Editorial. 
GIRONELLA MASGRAU, E. (1978): "Nacimiento de la auditoría independiente". Técnica Contable, febrero, 61, pp. 59-66.

GIUNTINI, A. (2001) Il Paeseche si muove. Le ferrovie in Italia fra '800 e '900. Milán: GrancoAngeli.

GLYNN, J.J. (1984): "The development of British railway accounting": 1800-1911". The Accounting Historians Journal, vol. II, $\mathrm{n}^{\circ}$ 1, p.103-18.

GÓMEZ MENDOZA, A. (1999): "Motor Cars and Railways in Interwar Spain. Regulation vs Deregulation", en ANDERSON-SCOG, L. y KRANTZ, O. (edits.): Institutions in the Transport and Communications Industries. State and Private Actors in the Making of Institional Patterns, 1850-1990, Canton: Science History Publications.

--- (1998): “Along broad lines. The economic history of Spanish railways, 1873-96". Journal of Transport History. Vol. 19, pp. 1-17.

--- (1991): "Las obras públicas, 1850-1935”, in F. Comín, P. Martín Aceña (eds), Madrid: Espasa Calpe, pp.177-204.

--- (1989a): Ferrocarril, industria y mercado en la modernización de España. Madrid: Espasa Calpe.

--- (1989b): "Transportes y comunicaciones", in A. Carreras (Eds), Estadísticas Históricas de España. Siglos XIX y XX, Madrid: Fundación Banco Exterior, pp. 269-323.

--- (1985): Ferrocarril y mercado interior en España (1874-1913). Vol. II: Manufacturas textiles, materias textiles, minerales, combustibles y metales. Madrid: Servicio de Estudios del Banco de España.

--- (1984): Ferrocarril y mercado interior en España (1874-1913). Vol. I: Cereales, harinas y vinos. Madrid: Servicio de Estudios del Banco de España.

--- (1983): "Spain" In: P. O'Brien (Ed.), Railways and the economic growth of western Europe (pp. 148-169). London: McMillan.

--- (1982) Ferrocarriles y cambio económico en España (1855-1913). Un enfoque de Nueva Historia Económica. Madrid: Alianza Editorial.

GOURVISH, TERRY R. (1999): "Los ferrocarriles como medio de transporte en Gran Bretaña, 1830-1990", en Siglo y medio del ferrocarril en España, 1848 - 1998: economía, industria y sociedad; Francisco Javier Vidal Olivares (ed. lit.), Miguel Muñoz Rubio (ed. lit.), Jesús Sanz Fernández (ed. lit.), pp. 55-64.

--- (1980) Railways and the British Economy, 1830-1914, London: MacMillan.

--- (1973): "A British Business Elite: The Chief Executive Managers of the Railway Industry", Business History Review, vol. XLVIII, 3, pp. 289-316.

--- (1972): Mark Huish and the London North Western Railway. Leicester: Leicester University Press.

--- (1970): "Captain Mark Huish: a pioneer in the development of railway management". Business History, Vol. XII, no 1, pp. 46-58. 
GOWER'S, L.C.B. (1997): Principles of Modern Company Law. London: Davies, P.L./Prentice, D.D.

GOXENS DUCH, A. (1985): "Un antecedente de la auditoría de la sociedad anónima" Partida Doble, enero, 17-20.

--- (1970): Contabilidad Superior. Madrid: Ediciones Giner.

GRAVES, CARL (1981), "Applying Scientific Management Principles to Railroad Repair Shops-The Santa Fe Experience, 1904-1918”. Business and Economic History, no 10, pp. 124136.

GRIER, N. (1998): UK Company Law. Chichester: Wiley.

GRIFFITHS, I. (1988): Contabilidad Creativa. Madrid: Deusto D.L.

GRIS MARTÍNEZ, J. (2005): Ferroviarios de la línea Lorca a Baza y Águilas. Murcia: Asociación Cultural de Amigos del Ferrocarril "El Labradorcico".

--- (2003): El embarcadero del Hornillo, 1903-2003. Águilas: Asociación Cultural de Amigos del Ferrocarril "El Labradorcico".

--- (2000): Southern of Spain Railway Company Limited_(1887-1936). Ferrocarriles de Lorca a Baza y Águilas. Aguilas: Asociación Cultural Amigos del Ferrocarril "El Labradorcito de Águilas.

GROSSO, P. (1999): Categorie di azioni ed assemble speciali. Il diritto italiano nel contest comunitario. Milano: Giuffrè.

GUAL VILlalBí, P. (1950): Política de comercio y de los transportes. Libro Tercero, Barcelona: Editorial Juventud.

GUERRA MARTÍN, G. (2003): El gobierno de las sociedades cotizadas estadounidenses. Su influencia en el movimiento de reforma del Derecho europeo. Pamplona: Aranzadi.

GUILLÉN, MAURO F. (1994): Models of Management. Work, Authorithy, and Organization in a Comparative Perspective, Chicago y London. Chicago: The University of Chicago Press.

HAMILTON, ROBERT W. (1996): The Law of Corporation. St Paul, Minnesota: West Publishing Co.

HANNIGAN, B. (2003): Company Law. $4^{\mathrm{a}}$ ed., London: Edinburgh.

HARRIS, A. J. (2004): "Trust preferred securities still eligible capital treatment; new rules are a compromise". Banking law journal, vol. 121, nº 8, 688-696. 
HARTMAN, B.P.; HARPER, R.M.; KNOBLET, J.A. y RECKERS, P.M. (1997): Intermediate accounting. Cincinnati: South-Western College Publishing.

HAMEL. J.; LAGABOE. G.; JAUFFRET, A. (1980): Droit commercial. Tomo 1, vol. 2, Paris: Dalloz.

HEALY, P.M. (1985): “The effect of bonus schemes on accounting decision". Journal of Accounting and Economics. $\mathrm{n}^{\mathrm{o}} 7$.

HEALY, P.M.; WAHLEN, J.M. (1999): “A Review of the earnings management literature and its implications for standard setting”. Accounting Horizons, 13, December, 365-383.

HEIER, J. R. (2010): “Accounting for the ravages of war: Corporate reporting at a troubled American railroad during the Civil War". Accounting History. vol. 15. n 2, pp. 199-228.

--- (2009): "Building the Union Pacific Railroad: a study of mid nineteenth century railroad construction accounting and reporting practices". Accounting History Review. vol. 19. $\mathrm{n}^{\circ} 3$, pp. 327-351.

--- (2000): "The foundations of modern cost management: the life and woke of Albert Fink". Accounting History Review, vol. 19, n 3, pp. 327-351.

HERNÁNDEZ, E. (2011): "La Historia de la contabilidad en busca de su verdadera identidad", X Congreso Internacional de la Asociación Española de Historia Económica Universidad Pablo de Olavide de Sevilla, Carmona (Sevilla).

--- (1998): "La historia de la contabilidad ante el nuevo milenio", VIII Encuentro de la Asociación Española de Contabilidad y Administración de Empresas, Menorca.

--- (1996): "Merchant's organizations and accounting regulation in eighteents-century Spain: The ordinances of the Tribunal of Commerce of Bilbao". Accounting, Business and Financial History, vol. 6, 277-299.

HERRANZ, A. (2008): Infraestructuras y crecimiento económico en España, (1850-1935). Madrid: Fundación de los Ferrocarriles españoles.

--- (2004): La dotación de infraestructuras en España, (1844-1935). Madrid: Banco de España.

HOUSTON, ARTHUR L.; HOUSTON, CAROL O. (1991): "The Changing use of preferred stock", Management Accounting, December.

HOWELLS, P.; BAIN, K. (2002): The economics of money, banking and finance. $2^{\mathrm{a}}$ ed., London: Prentice Hall.

IBÁÑEZ ORTEGA, N. (2011): Gigantismo industrial. Racionalización y productivismo de entreguerras en la Ría de Bilbao. Vitoria: Catarata. 
IEA/DOE (2007): Pricing Electricity in a Competitive Environment, Background, Modeling Competitive Electricity Pricing, IEA/DOE de Estados Unidos, http://www.eia.doe.gov/emeu/pgem/electric.html, consulta realizada el 1/06/2007.

INGRAM, ROBERT W. y BALDWIN, B.A. (1998): Financial Accounting. Cincinnati, Ohio: South-western College Publishing.

INFORME OLIVENCIA. EL GOBIERNO DE LAS SOCIEDADES COTIZADAS (1998): Documento de la Comisión Especial para el estudio de un código ético de los consejos de administración de las sociedades: el gobierno de las sociedades cotizadas. 26 de febrero de 1998, Madrid.

INSTITUTO NACIONAL DE RACIONALIZACIÓN DEL TRABAJO (1962): Terminología de Organización Científica del Trabajo. Madrid: Instituto Nacional de Racionalización del Trabajo.

IRVING, ROBERT J. (1976): The Northeastern Railway Company, 1870-1914: An Economic History. Leicester: Leicester University Press.

JAMESON, M. (1988): A Practical Guide to Creative Accounting. London: Kogan Page.

JENKS, LELAND H. (1961): "Early history of a railroad organization". Business History Review. $\mathrm{n}^{\circ}$ 35. summer, pp. 163-179.

JENSEN, MICHAEL C. (1983): "Organization theory, accounting and methodology". The Accounting Review. $\mathrm{n}^{\circ}$ 58. april, pp. 319-339.

JIMÉNEZ CARABALLO, D. (2011): “Apuntes para una Historia de la Auditoría”. Revista Enlace, $\mathrm{n}^{\mathrm{o}}$ 101, vol. 17, 1-9.

JUEZ GONZALO, E. (2001): "La conflictividad laboral en las antiguas compañías de ff.cc. de España", comunicación presentada al II Congreso de Historia Ferroviaria, Aranjuez 7-9 de febrero 2001.

--- (2000): Los ferroviarios de las antiguas compañías:(una historia desconocida). Gijón: Editorial Trea.

--- (1999): “La jornada de trabajo en Ferrocarriles". II Jornadas de Historia Económica de las relaciones laborales, Universidad de Sevilla, pp. 137- 142.

--- (1992): El mundo social de los ferrocarriles españoles, 1857-1917. Madrid: Universidad Complutense.

--- (1983): Ferrocarriles y vida cotidiana: Los ferroviarios de la MZA (1857-1876). Madrid: Universidad Complutense.

KARSTEN SCHMIDT, H. C. (2004): "La Reforma alemana: Las Kontrag y Transpug de 1998 y 2002, y el Código Cromme". Revista de Derecho de Sociedades, no 22, pp. 19-34. 
KINDLEBERGER, Ch. P. (1993): A financial history of Western Europe. Oxford: Oxford University Press.

KINGSFORD, P. W. (1970): Victorian Railwaymen. The emergence and Growth of Railway Labour 1830-1870. London: Frank Cass.

KIRKLAND, E. (1948a): Men, Cities and Transportation: A Study in New England History. 1820-1900, vol I, Cambridge: Harvard University Press.

--- (1948b): Men, Cities and Transportation: A Study in New England History, 1820-1900. vol II, Cambridge: Harvard University Press.

KRAUSS, H. (1999): The California Corporation: legal aspects of organization and operation. Washington DC: Bureau of National Affairs.

KRIEBEL, M. (1963): “MehrstimmrechtsloseVorzugsaktien?”. Die Aktiengessellschaft.

KÜBLER, F. (1998): Derecho de sociedades. $5^{\mathrm{a}}$ ed. (trad. Gesellschaftrecht), Heidelberg: Fundación Cultural del Notariado.

LABRANDERO, E. (1945): "La racionalización de los trabajos de reparación de vagones". Ferrocarriles y Tranvías, n⿳0 135, pp. 478-488, n 136, 538-545.

LAMANDINI, M. (2001): Strutturafinanziaria e gobernó nellesocieta di capitali. Bologna: Il Mulino.

LARRÍNAGA RODRÍGUEZ, C. (2002): Entre Irún y los Alduides. El ferrocarril del Norte y el paso de los Pirineos a mediados del siglo XIX. Irún: Casino de Irún.

LEHMAN, K. (1964): Das Recht. Berlin: Geburtstag.

LEMARCHAND, Y. (1994): "Double entry versus charge and discharge accounting in eighteenth-century France". Accounting, Business \& Financial History, (4) 1, 119-145.

--- (1993): Du dépérissement à l'amortissement. Enquête sur l'histoire d'un concept et de sa traduction comptable. Nantes: Ouest Editions.

LETÓN, R. y MACHUCA, J. (2001): "El fondo documental del servicio de vía y obras de MZA: Una fuente primaria para la investigación", II Congreso de Historia Ferroviaria: Siglo y medio de ferrocarriles, Aranjuez, Madrid.

LEVINE, M, L. (1976): Business and the law. Minnesota: West Pub. Co.

LITTLETON, A. C. (1966): Accounting evolution to 1900. New York: Russell \& Russell. 
LÓPEZ MORELL, M. Á. (2005): La casa Rothschild en España. Madrid: Marcial Pons.

LÓPEZ PITA, A. (1995): "Evolución de los criterios de proyecto de nuevas estructuras de ferrocarril". II Congreso Internacional de Ingeniería de Proyectos, Bilbao, 2 de octubre de 2015.

LORRY, M. y WATSON, L. (2001): Company Law. London: Scholar Press.

LUMMIS, TREVOR (1994): The Labour Aristocracy, 1851-1914. London: Scholar Press.

MARTIN RODRIGUEZ, M. (2007): "La economía política en la Escuela Especial de Ingenieros de Caminos, Canales y Puertos", en Carlos de ORDUNA Y ZARAUZ, Lecciones de Economía Matemática. Madrid: Fundación de las Cajas de Ahorros.

MARTÍN RODRÍGUEZ, M. (2006): "La Economía Política en la Escuela Especial de Ingenieros de Caminos Canales y Puertos, 1855-1936”. Estudio introductorio a Orduña, Carlos, Lecciones de Economía Matemática, Madrid, Fundación de las Cajas de Ahorros, pp. 9-199.

MARTÍNEZ VARA, T. (2011): "La participación de los ingenieros españoles en los Congresos Internacionales de Ferrocarriles, 1885-1933", en Ensayos de Historia y Pensamiento Económicos En homenaje al profesor Juan Hernández Andreu (José Luis García

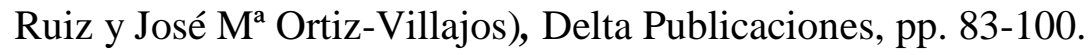

--- (2006a): "Interpreting a Data Base of Railway Workers using Optimal Scaling Techniques". Kent Business School Working Paper Series 127, pp. 1-23.

--- (2006b): "Salarios y programas de bienestar industrial en la empresa ferroviaria MZA (1915-1935)". Investigaciones de Historia Económica, 4, pp. 101-138.

---(2005) "Labour costs and the decline of the MZA Railway in Spain, 1912 to 1935". Journal of Transport History, Third Series, vol. 26, $\mathrm{n}^{\circ}$ 2, pp. 60-78.

--- (2004): "Los costes laborales y la crisis de MZA, 1913-1935. Datos y algunas reflexiones". Revista Transportes, Servicios y telecomunicaciones, $\mathrm{n}^{\circ}$ 7, pp. 103-146.

--- (2003a): "Empleo y gasto de personal en la compañía ferroviaria Norte. Una reflexión crítica sobre la obra de Marquina", en Estudios de Historia de pensamiento económico: homenaje al Profesor Francisco Bustelo García del Real, Universidad Complutense, Madrid, pp. 337-368.

--- (2003b): "Programas de bienestar industrial en la empresa ferroviaria MZA, 1915- 1935", comunicación presentada al II Congreso de Historia Ferroviaria, Aranjuez 7-9 de febrero 2001.

--- (2003c): "Los costes laborales y la crisis de MZA, 1913-1935. Datos y algunas reflexiones". TST: Revista de Historia de Transportes, Servicios y Telecomunicaciones, $\mathrm{n}^{\circ} 7$, pp. 103-146.

--- (2001): "Los costes laborales de una empresa líder: la Compañía de los ferrocarriles de Madrid a Zaragoza y a Alicante", comunicación presentada al II Congreso de Historia Ferroviaria: Siglo y medio de ferrocarriles, Aranjuez 7-9 de febrero 2001, Madrid. 
MARTÍNEZ VARA, T. y DE LOS COBOS ARTEAGA, F. (2014): "La difícil recepción de la Organización Científica del Trabajo en los ferrocarriles españoles". Revista de Historia Industrial, $\mathrm{n}^{\circ}$ 55, 2014.2, 75-102.

--- (2009): "Una mirada al pasado de la literatura ferroviaria: notas críticas sobre los textos anteriores a la nacionalización". Revista Bibliográfica de Geografía y Ciencias Sociales, Vol. XIV, $\mathrm{n}^{\circ} 834,5$ de agosto.

--- (2007a) "Taller Central de Vía y Obras". Revista de Historia [TST] Transportes, Servicios y Telecomunicaciones, $12,94-121$.

--- (2007b): "Lenguaje y realidad: la intervención de la contabilidad de los ferrocarriles por Parte de la Dictadura de Primo de Rivera". Revista de la Historia de la Economía y de la Empresa", no 1, 319-340.

MARTÍNEZ VARA, T. y RAMOS GOROSTIZA, J. L. (2015a): “La gestión científica del trabajo en los ferrocarriles españoles hasta la década de 1970: la mirada de los ingenieros". $H$ industri@. Revista de historia de la industria, los servicios y las empresas en América Latina, año 9, no 16 , primer semestre, 79-109.

--- (2015b): "Ferrocarril, capital humano y mercados internos de trabajo en España durante la época de las compañías privadas", en Revista de la Historia Económica y de la Empresa, n. 10, 2016, pp. 345-378.

MARTÍNEZ VARA, T.; MUÑOZ RUBIO, M. y ORTÚÑEZ GOICOLEA, P. P. (2015):

"Eduardo Maristany Gibert (1855-1941). Director general de MZA", Tst: Transportes, Servicios y telecomunicaciones, $\mathrm{n}^{\circ} .28, \mathrm{pp} .12-38$.

MATEO DEL PERAL, D. (1978): Los orígenes de la política ferroviaria en España, en Artola, M. (Dir): Los ferrocarriles en España, 1844/1943, Tomo 1. Madrid: Servicios de Estudios del Banco de España, 29-159.

MATTEI, U. (2003): "La riforma del diritto societario italiano. Una nuova ricezione acústica?”. Rivista del Diritto Commerciale, pp. 615 y ss.

MC CARTNEY, A. S.; ARNOLD, A. J. (2000): “George Hudson's financial reporting practices: putting the Eastern Counties Railway in Context". Accounting, Business \& Financial History, vol. 10, nº 3, 293-316.

MC GEE, ANDREWS (1999): Share Capital. London, Edinburg, Dublin: Butterworths.

MERGER, M. (1998) "Los ferrocarriles franceses desde sus orígenes a nuestros días: evolución del marco jurídico e institucional". Siglo y medio del ferrocarril en España 18481998. Economía, industria y Sociedad, Madrid: Instituto de Cultura Juan Gil Albert, CAM y Fundación de los Ferrocarriles Españoles. 
MIERZEWSKI, A. C. (1993) “The German Railway Company, 1924-1932: Between private and public enterprise. Business History Review, 67, pp. 406-438.

--- (1990) "The German National Railway between the world wars.Modernization or preparation for war?”. Journal of Transport History, III , Vol. 11, 1, pp. 40-60.

MITCHELL, L.E. (1996): "The puzzling paradox of preferred stock (and why we should care about it)". Business Lawyer, $\mathrm{n}^{\circ} 51$.

MONTENEGRO DUQUE, Á. (1991): Historia de España. Madrid: Editorial Gredos.

MONTERO, M. (1994): La Burguesía impaciente. Especulaciones e inversiones en el desarrollo empresarial de Vizcaya. Beitia, Bilbao.

MONTOYA CHINCHILLA, J. L. y GUZMÁN RAJA, I. (2012): Regulación contable del sector ferroviario español en el primer cuarto del siglo XX (1900-1925). DE COMPUTIS Revista Española de Historia de la Contabilidad Spanish Journal of Accounting History, $\mathrm{n}^{\circ}$ 17, diciembre, 1-41.

--- (2011a): La Compañía de los Caminos de Hierro del Norte de España: análisis de su cuenta de explotación (1900-1925). TST: Revista de Historia de Transportes, Servicios y Telecomunicaciones, $\mathrm{n}^{\mathrm{o}}$ 21, pp. 112-141, Madrid.

--- (2011b): "Eficiencia Técnica y Cambio Productivo en el Sector Ferroviario Español de Vía Ancha (1910-1922)". Innovar: Revista de ciencias administrativas y sociales, vol. 21, n 40, pp. 219-234.

--- (2010): El Ferrocarril de Asturias, Galicia y León (A.G.L.): un estudio de contabilidad comparado (1900-1925). Comunicación del VII Encuentro de trabajo sobre Historia de la Contabilidad, León.

MONTOYA CHINCHILLA, J. L. (2011): Contabilidad, eficiencia y cambio productivo: el caso del ferrocarril español de vía ancha (1900-1925). Tesis doctoral, Cartagena: Universidad Politécnica de Cartagena.

MONTOYA MARTIN, E. (1996): Las empresas públicas sometidas al Derecho privado. Marcial Pons, Zaragoza.

MORSE (1983): Company Law. London: Charlesworth \& Cain.

MOURGUES, N. (1996): Capitaux propres et quasi fonds propres. Paris: Economica.

MUÑOZ RUBIO, M. (2009): "La aplicación de la Ley de Responsabilidades Políticas en el ferrocarril español: un proyecto de recuperación de la memoria histórica", ponencia presentada en las Cuartas Jornadas Archivo y Memoria. La memoria de los conflictos: legados documentales para la Historia, Madrid, 19-20 febrero.

--- (1995): Renfe (1941-1991): Medio siglo de Ferrocarril público. Madrid: Ediciones Luna. 
MUÑOZ RUBIO, M. (coord.) (2005): Historia de los ferrocarriles de vía estrecha en España: una visión de conjunto. 2 Tomos, Madrid: Fundación de los Ferrocarriles Españoles (Colección de historia ferroviaria; 3-4).

MUÑOZ RUBIO, M. (ed.) (2011): “Organizaciones obreras y represión en el ferrocarril: una perspectiva internacional". Madrid: Fundación de los Ferrocarriles Españoles (Colección de Historia Ferroviaria; 8).

MUÑOZ RUBIO, M. y VIDAL OLIVARES, J. (2001) "Los ferrocarriles en la historiografía española". TST: Revista de Historia de Transportes, Servicios y Telecomunicaciones, ${ }^{\circ}$ 1, pp. 81-110.

MORRIS, S. (1973): "Stalled professionalism: The recruitment of railway officials in the United States, 1885-1940”. Business History Review, Vol. XLVII, 3, 317-334.

MORRISON ALAN D. y WILHELM WILLIAM J. (2007): Investment Banking. Institutions, Politics, and Law. Oxford: Oxford University Press.

NADAL, J. (1975) El fracaso de la revolución industrial en España. Barcelona: Ariel.

NASER, K. (1993): Creative financial Accounting: its nature and use. London: Prentice Hall.

NASER, K. y PENDLEBURY, M. (1993): Creative Financial Accounting: Its Nature And Use. London: Prentice Hall.

NIPPERDEY, T. (1996): Germany from Napoleon to Bismarck. New Jersey: Princeton University Press.

NELSON, DANIEL (1992): "Scientific Management in Retrospect", en Nelson, Daniel (ed.), A Mental Revolution. Scientific Management since Taylor, Columbus, Ohio State University Press, 5-39.

O'BRIEN, O. (1983) Railways and the Economic development of Western of Europe. London: MacMillan.

OLAVO CUNHA, P. (1993): Os direitos speciais nas sociedades anónimas: as accoes privilegiadas, Coimbra: Livraria Almedina.

OLMEDO A. (2001): Estudio histórico del ferrocarril desde la perspectiva de sus normas reguladoras. Comunicación II Congreso de Historia ferroviaria "Siglo y medio de ferrocarriles, Madrid.

ORMAECHEA, A. (1989): Ferrocarriles en Euskadi (1855-1936). Bilbao: Ferrocarriles Vascos. 
ORTÚÑEZ GOICOLEA, P. P. (2016a): “Gobernanza en la regulación del sector ferroviario español. Un análisis histórico1844-1941". Revista de historia industrial, nº 61, 79-110.

--- (2016b): "Railway Financing before Nationalization: Spain 1855-1941". Cassis, Y.; De

Luca, G.; Florio, M.: Infrastructure finance in Europe, Oxford, 218-239.

--- (2008): "Cambio político, instituciones y empresas ferroviarias en España (1918-1936)". Investigaciones en Historia Económica, otoño, número 12, 141-168.

--- (1999a): El proceso de nacionalización de los Ferrocarriles en España. Historia de las grandes compañías, 1913-1943. Tesis Doctoral, Universidad de Valladolid.

--- (1999b): "La configuración de la red nacional y las grandes compañías ferroviarias: Norte y MZA, 1913-1936", en Siglo y medio del ferrocarril en España, 1848 - 1998: economía, industria y sociedad, Francisco Javier Vidal Olivares (ed. lit.), Miguel Muñoz Rubio (ed. lit.), Jesús Sanz Fernández (ed. lit.), 1999, pp. 273-297.

--- (1993): "Los accionistas de la compañía MZA, 1913-1940". V Congreso de la Asociación de Historia Económica, vol. I, San Sebastián, pp. 203-214.

ORTÚÑEZ GOICOLEA, P. P. y VIDAL, J. (2000): "State and private companies in the Spanish Railway sector, 1848-1941", en KUIJLAARS, A.; PRUDON, K., y VISSER, J. (eds.), Business and Society, Rotterdam: Centre of Business History, pp. 123-135.

OUTSLAY, EDMUND (1992): "Discussion of foreign tax credit limitations and preferred stock issuances”. Journal Accounting Research, vol. 30, supplement, pp. 125-130.

PALENCIA-LEFLER, M. (2008): "Comunicación corporativa: Memoria Anual versus Balance Social”, ZER, 13-24, pp. 363-384.

PALMER'S (1992): Company law. I, London: Sweet \& Maxwel.

PARRA LÓPEZ, E. LA (2004): “Alfonso XIII: los intentos de renovación del sistema (190219016)”, en Javier Paredes (coord.) Historía Contemporanea del siglo XX, Barcelona: Ariel, 429-452.

PASCUAL, PERE (2000): "La gran decepción. La rentabilidad de las acciones de los ferrocarriles catalanes (1849-1943)". Revista de Historia Industrial, 17, pp. 11-59.

PATTERSON ALAN (1997): “Turning away from stock". Euromoney, December, 344, p. 137.

PAZ ARES, C. (2002): "Aproximación al estudio de los squeeze-outs en el derecho español", Actualidad Jurídica Uría \& Menéndez, núm. 3, págs. 49-67.

PENNINGTON, ROBERT R. (2001): Company Law. London: Butterworths. 
PEÑAS MOYANO, B. (2008a): Las clases de acciones como instrumentos financieros en los Derechos de sociedades británico y estadounidense. Cizur Menor (Navarra): Aranzadi.

--- (2008b): "Las categorías de acciones en el derecho societario alemán: concepto, tipología y tutela de las mismas". Revista de Derecho de Sociedades, n 30, 2008, pp. 123-162.

--- (2007): "Algunas consideraciones en relación al Derecho estadounidense de sociedades por acciones". Revista de Derecho de Sociedades, no 28, 2007, pp. 240 y ss.

PÉREZ DE LA CRUZ BLANCO, A. (1973): La reducción de capital en sociedades anónimas y de responsabilidad limitada. Zaragoza: Publicaciones del Real Colegio de España en Bolonia.

--- (1971): "Cuestiones en torno a la denominada amortización de capital", en Estudios jurídicos en homenaje a Joaquín Garrigues, Tomo III, Madrid: Editorial Tecnos.

PEREZ SÁNCHEZ, G. (1992): "Los Talleres Principales de Reparación de la Compañía del Norte en Valladolid (1861-1931)”, en Investigaciones Históricas, 12, pp. 252-283

PLATT, D.C.M. (1983): “Las finanzas extranjeras en España, 1820-1870”, en Revista de Historia Económica, nº 1, pp. 121-150.

PLAZA PLAZA, A. (2012): El sindicalismo ferroviario en España: de las sociedades mutualistas a los sindicatos de industria (1870-1936). Madrid: Fundación de los Ferrocarriles Españoles.

--- (2006): "Los orígenes del sindicalismo ferroviario en España". Comunicación presentada al IV Congreso de Historia Ferroviaria, Málaga 20-22 de septiembre 2006.

--- (2004): El Asociacionismo Ferroviario en España (1870-1917). Tesis Doctoral, Universidad Autónoma, Madrid: Departamento de Historia Contemporánea.

PISANO MASSAMORMILE, A. (2003): “Azionie dal istrumenti finanziari partecipaviti”, Rivista dele Societá, pp. 1268-1315.

POLLARD, S. (1965): The genesis of modern management: A study of the industrial revolution in Great Britain, Westminster-London: Penguin Books.

POLLINS, H. (1956): "Aspects of railway accounting before 1863" in, B. S. YAMEY, Studies in the history of Accounting (Sweet and Maxwell) A.C. Littleton, 332-55.

--- (1952a): “A note on Railway constructional costs 1825-1850", Economica, New Series, vol. $19, \mathrm{n}^{\circ} 76,395-407$.

-- (1952b): "The Finances of the Liverpool and Manchester Railway". The Economic History Review. Vol. 5, n'. 1, 90-97.

PORFIRIO CARPIO, L. (1991): Las acciones sin voto en la sociedad anónima. Madrid: La Ley-Actualidad. 
PORTER, GLENN (1999): “Los ferrocarriles en Estados Unidos, mitos y realidades”, en Siglo y medio del ferrocarril en España, 1848 - 1998: economía, industria y sociedad / Francisco Javier Vidal Olivares (ed. lit.), Miguel Muñoz Rubio (ed. lit.), Jesús Sanz Fernández (ed. lit.), pp. 105-113.

PREVITS, G. J.; SAMSON, W. D. (2000): "Exploring the contents of the Baltimore and Ohio Railroad Annual Reports: 1827-1856“. Accounting Historians Journal, vol. 27, n 1, 1-41.

RAMOS GOROSTIZA, J.L. y MARTINEZ VARA, T. (2008): Las ideas económicas de los ingenieros de caminos: la Revista de Obras Públicas (1853-1936), Investigaciones de Historia Económica, primavera, número 1, 9- 38.

RECKKINGER, G. (1983): "Vorzugsaktien in der Bundesrepublick", en Die Aktiengesellschaft, pp. 216-286.

RICHARD, J. (2006): "The victory of the Prussian railway dynamic accounting over the public finance and patrimonial accounting models (1838-1884): an early illustration of the appearance of the second stage of capitalist financial accounting and a testimony against the agency theory and the market for excuses ideologies". Université Paris Dauphine (CEREG), Cahier de recherché $n^{\circ}$ 2006-15.

RODRIGO Y ALHARILLA, M. (2007): “Los marqueses de Comillas 1817-1925: Antonio y Claudio López”, en Almodóvar Muñoz, C., Presencia de Cuba en la historiográfia española actual, pp. 141-154.

--- (1999): "La dimensión ferroviaria del holding Comillas", en M. Muñoz, J. Sanz y J Vidal Olivares (eds.). Siglo y medio de ferrocarriles en España. Economía, Industria y Sociedad, 1848-1998, Madrid: Caja de Ahorros del Mediterráneo e Instituto Juan Gil-Albert.

--- (1998): “Colonias, negocio y poder en la Restauración (1875-1898)", en J. PANIGUA y J. A. PIQUERAS, Poder económico y poder político, Valencia: Fundación Instituto de Historia Social, pp. 81-111.

--- (1996): Antonio López y López (1817-1883), Primer Marqués de Comillas. Un empresario y sus empresas, Documento de Trabajo, Fundación Empresa Pública, Programa de Historia Económica.

RODRÍGUEZ, R. (2012): "La contabilidad de la construcción de un tramo del ferrocarril de Madrid-Valladolid". VII Encuentro de trabajo sobre la Historia de la Contabilidad. Soria.

ROE, M. J. (1993): "Some differences in Corporate Structure in Germany, Japan and the United States", Yale Law Journal, june, nº 1927.

ROSS, STEPHEN A.; WESTERFIELD, RANDOLPH W. y JAFFE, JEFFREY F. (1997): Corporate Finance. New York: McGraw-Hill. 
RIBEILL, GEORGE (1993): La révolution ferroviaire. La formation des compagnies de chemins de fer en France (1823-1870). París: Belin.

--- (1989): "La société cheminote: quelques pistes pour la recherche historique". Revue histoire des chemins de fer. La histoire des chemins de fer: points de vue et perspectives, $\mathrm{n}^{\mathrm{o}} 1$, pp. 45-54.

--- (1987): "Gestion et organisation du travail dans les compagnies de chemin de fer, des origenes á 1860”. Annales ESC, septembre-octobre, 5, pp. 999-1029.

--- (1980): Le Personnel des Compannies de Chemins de fer: materiaux pour une contribution a la sociologie historique de professions, París: Centre d'enseignement et de recherches Techniques et sociétés.

RIPLEY, W.Z. (1972): Main Street and Wall Street. Kansas: M.J.

ROSSI, G. y STABILINI, A. (2003): "Virtú del mercato e scetticismo delle regole: appunti a margine della riforma del diritto societario". Rivista delle Società, pp. 1-16.

RULL SABATER, A. (1991): Diccionario sucinto de Ministros de Hacienda (s.XIX-XX). Documento 16. Madrid: Instituto de Estudios Fiscales.

SAVAGE, MIKE (2000): "Discipline, Surveillance and the "Career": Employment on Great Western Railway 1833-1914", en MCKINLAY, Alan y STARKEY, Ken (eds.), Foucault, Management theory: from Panopticon to Technologies of Self, London, Sage, pp., 65-92.

SÁENZ RIDRUEJO, F. (1990): Los ingenieros de caminos en España. Madrid: Colegio de Ingenieros de Caminos.

SAGREDO SANTOS, A. (2001): Franklin D. Roosevelt y la problemática agraria: su eco en la prensa española, 1932-1936. Tesis doctoral. Madrid: Universidad Complutense de Madrid.

SALSBURY, STEPHEN M. (1977): "Twentieth Century Railroad Managerial Practices: the case of the Pennsylvania Railroad". Research in Economic History, Jai Press, Connecticut, 43-54.

--- (1967): The state, the investor and the railroad: Boston \& Albany, 1825-1867. Cambridge, Massachusetts: Harvard University Press.

SÁNCHEZ ANDRÉS, A.: (2000): "La sociedad anónima y el mercado". Revista de Derecho de Sociedades, $\mathrm{n}^{\mathrm{o}}$ 14, pp. 13-46.

--- (1999): Sociedad anónima modelo 1988. Reforma (parcial) y crítica (total) de un texto legislativo reciente. Madrid: Mc Graw Hill.

--- (1998): "Apunte crítico sobre algunas propuestas de reforma de la Ley del Mercado de Valores dignas de comentario". Revista de Derecho Bancario y Bursátil, no 71, julioseptiembre, pp. 839-856. 
--- (1994): "La acción y los derechos del accionista", en URIA, R.; MENÉNDEZ, A.; OLIVENCIA, M.: Comentario al régimen legal de las sociedades mercantiles, t. IV, v. $1^{\circ}$, Madrid, pp. 292 y ss.

--- (1993): "Las acciones", en URÍA; MENÉNDEZ; OLIVENCIA, Comentarios al régimen legal de las sociedades mercantiles, t. IV; vol. 1, Madrid.

--- (1992): "A propósito de un caso de transformación temporal de acciones ordinarias en preferentes sin voto, con opción a recuperarlo". Revista Crítica de Derecho Inmobiliario, n ${ }^{\circ}$ 613, pp. 2495-2499.

--- (1987): “Aumento y reducción de capital”, en La Reforma del Derecho español de sociedades de capital. Madrid: Colegio Nacional de Registradores de la Propiedad y Mercantiles de España y el Notarial de Madrid en colaboración con la Universidad Complutense de Madrid.

SÁNCHEZ ALBORNOZ, N. (1977): España hace un siglo: una economía dual. Madrid: Alianza Editorial.

SÁNCHEZ-CAMPIS PELLO, C. (2012): “Agosto de 1917 Primera Huelga General indefinida". Madrid Histórico, $\mathrm{n}^{\mathrm{o}}$ 42, 48-53.

SANTOS CABALGANTE, B. (2015): La implantación del ferrocarril en España. El modelo contable y de gestión empresarial: El caso de MZA (1856-1874), Tesis doctoral, Universidad Autónoma, Madrid.

SANTOS CABALGANTE, B.; FIDALGO, E y SANTOS CEBRIÁN, M. (2014): "The origins of the spanish railroad accounting model: a qualitative study of the MZA'S operating account (1856-1874)", Revista Española de Historia de la Contabilidad "De Computis", no 21, Diciembre, pp 73- 103.

--- (2012): "Construcción de la infraestructura ferroviaria en España a través de la contabilidad: estudio histórico-contable de MZA (1856-1874)", Revista Española de Historia de la Contabilidad "De Computis", n 17, Diciembre, pp 158- 186.

SANTOS CABALGANTE, B.; SANTOS CEBRIÁN, M. y FIDALGO CERVIÑO, E. (2011a): La actividad empresarial y la representatividad de las cifras contables: el caso de MZA en sus inicios (1856-1858), en Actas II International Conference Before and after Luca Pacioli, Centro Studi Mario Pancrazi, Sansepolcro-Perugia-Florence, 17-19 junio, 2011, 745785.

--- (2011b): "Estudio de incidencias de la estructura organizativa en el sistema de información contable: el caso de MZA en el siglo XIX (bienio 1857- 1858)". International Congress on Cost Control Barcelona 2011 XII Jornada de ASEPUC de Contabilidad de Costes y de Gestión, 17-18 March: 83-98.

SANZ, C. J. (2000): "Estados contables complementarios: la memoria y el informe de gestión”. Acciones e Investigaciones Sociales, no 10, pp. 182-195. 
SANZ FERNÁNDEZ, J. (1985): "La crisis triguera finisecular: los últimos años", en AA.VV., La España de la Restauración Política, economía, legislación y cultura, Madrid, Siglo XXI, pp. 265-310.

SCHERER, F. M. (1970): Industrial market structure and economic performance. Chicago: Rand McNally \& Co.

SEIDENZAHL, FRITZ (1970): 100 Jahre Deutsche Bank, 1870-1970. Frankfort: Mit Abb.

SCHIPPER, K. (1989): “Commentary on earnings management”. Accounting Horizons, 3 (4): pp. 91-102.

SCHUIT, S. R. (1998): Corporate Law and Practice of the Netherlands, The Hague: Kluwer Law International.

SIEBEL, U.R. (1997): "Vorzugsaktien als hybride finanzierungsform und ihre grenzen", en Zeitschrift für das gesamte Handelsrecht und Wirtschaftsrecht, n' 161, pp. 642-651.

SIMMONS, P. L. (1987): "Dual class recapitalization and shareholders voting rights", Columbia Law Review, 87, pp. 106-125.

SMITH, C. y WATTS, R. (1982): "Incentive and tax effects of executive compensation plan". Australian Journal of Management, $\mathrm{n}^{\mathrm{o}}$ 7, December.

SORTER, G.H. y GANS M.S. (1974): "Opportunities and implications of the report on objetives of financial statements". Journal of Accounting Research, Studies on Financial Accounting Objetives (Suplement), 1-11.

SOTO CARMONA, Á. (1992): "La evolución salarial en el primer tercio del siglo XX: en busca de una perspectiva comparada. Los Estados Unidos, Francia y España”. Historia Social, 13, pp. 53-76.

--- (1989), El trabajo industrial en la España contemporánea (1874-1936). Madrid: Anthropos.

SUÁREZ SUÁREZ, A. S. (1991): La moderna auditoría. Un análisis conceptual y metodológico. Madrid: Mc Graw-Hill.

TAPIA HERMIDA, A.J. (1994): "Instrumentos jurídicos para la financiación de la sociedad de responsabilidad limitada", Revista de Sociedades, núm, extraordinario, 633-648.

TAFUNELL, X. (2000): "La rentabilidad financiera de la empresa española, 1880-1981: Una estimación en perspectiva sectorial”. Revista de Historia Industrial, 18, pp. 71-111. 
TEDDE DE LORCA, P. (1996) "La expansión de las grandes compañías ferroviarias españolas: Norte, MZA y Andaluces (1865-1930)", F. Comín y P. Martín Aceña (eds.), La empresa en la historia de España, Madrid: Civitas, pp. 264-301.

--- (1991): "El sector financiero", en M. Artola (dir.), Enciclopedia de Historia de España. Madrid: Alianza.

--- (1978): "Las compañías ferroviarias en España (1855-1935)", en Miguel Artola (dir.) Los ferrocarriles en España, 1844-1943, Madrid: Servicio de Estudios del Banco de España, Vol. 2, pp. 9-354.

--- (1974): «La banca privada española durante la Restauración (1974-1914)», en G. TORTELLA (dir.). La banca española durante la Restauración, vol. 1, pp. 217-245.

THOMPSON, G. L. (1991): "Myth and rationality in management decision-making: the evolution of American railroad product costing, 1870-1970", The Journal of Transport History, vol. 12, no 1, pp. 1-10.

TORRES VILLANUEVA, E. (1996): "Funciones empresariales, grupos de interés y política económica en la Restauración. El empresario vasco Ramón de la Sota”, en F. COMÍN y P. MARTÍN ACEÑA (eds.). La empresa en la Historia de España, Madrid, Civitas, pp. 423139.

TORTELLA CASARES, G. (1994): El desarrollo de la España contemporánea. Historia económica de los siglos XIX y XX. Madrid, Alianza.

--- (1973) Los orígenes del capitalismo en España. Banca, Industria y Ferrocarriles en el siglo XIX. Madrid: Tecnos.

--- (1972): "Spain 1829-1874", in R. Cameron (Eds). New York: Oxford University Press, pp.91 - 121.

TUNC, ANDRÉ (1985): Le droit American des Sociétés Anonymes. Paris: Presses Universitaires de France.

TUSELL, JAVIER (1990): Siglo XX, Madrid: Historia 16.

URWICH, LYNDALL (1943): The Elements of Administration. London: Pitman.

VALDALISO, J.M. Y LÓPEZ, S. (2000): Historia Económica de la Empresa. Barcelona: Ed. Crítica.

VAN HORNE, J.C. (1997): Financial Management and Policy. Prentice-Hall, New York.

VARGAS VARGAS, M. (1964): La sociedad anónima en el derecho anglonorteamericano, Santiago de Chile. 
VELASCO SAN PEDRO, L. A. (1986): “Sociedades anónimas: distinción entre amortización y reembolso de acciones". Cuadernos Civitas de Jurisprudencia Civil, n 11, abril-agosto, pp. 3577-3590.

VENTURA, F. (1982): "Il finanziamento delle impresa da parte deisoci”, Le societá, núm, 12, $2,1412-1414$.

VIDAL OLIVARES, J. (1999): "La estructura de la propiedad, de la organización y la gestión de una gran empresa ferroviaria: la Compañía de los Caminos de Hierro del Norte de España, 1858-1936". Revista de Historia Económica, año XVII, otoño-invierno 1999, 3, pp. 623-662.

--- (1997): La formación de los directivos en la gran empresa: El caso de la Compañía de los Ferrocarriles del Norte de España, 1858-1936. Documento de Trabajo 9702 Fundación Empresa Pública, Programa de Historia Económica, febrero, Madrid: Fundación Empresa Pública.

--- (1996): "Las compañías ferroviarias y la difusión de las modernas formas de gestión empresarial en España, 1850-1914”, en Comín, Francisco y Martín Aceña, Pablo (eds.): La empresa en la Historia de España, Madrid: Civitas pp. 285-301.

--- (1995a): «Marches nationaux ou internationaux? Les compagnies de chemins de fer en Espagne et leurs connexions intemationales avec la France et le Portugal, 1850-1914», M. Merger, A. Carreras y A. Giuntini (dir.), Les Réseaux Européens Transnationaux, xixe-xxe siécles, quels enjeux?, Nantes: Ouest Éditions, 1995, pp. 347-360.

--- (1995b): "Railway Companies and the Diffusion of Business Culture in Spain", en M. Davies, D. Wirt y F. de Goey (eds.): Conference on Business History, Rotterdam: Center of Business History-Erasmus Universiteit, pp. 275-284.

VIDAL OLIVARES, J. y ORTÚÑEZ GOICOLEA, P. P. (2002): "The internationalization of ownership of the Spanish railway Companies, 1858-1936". Business History, vol. 44, $\mathrm{n}^{\circ} 4$, 29-54.

VILLACORTA, M.A. y MARTÍNEZ VARA, T. (2009): “Aproximación al sistema contable de los Talleres Ferroviarios de MZA durante el siglo XIX”. Revista Española de Historia de la Contabilidad "De Computis", nº 11, Diciembre, pp. 116-135.

VON CAEMMERER, E. (1967): “La riforma della societá per azioni del 1965”, Rivista delle Societá, p. 167.

WAIS SAN MARTÍN, F. (1987): Historia de los ferrocarriles españoles. $3^{\mathrm{a}}$ ed. Madrid: Fundación de los Ferrocarriles Españoles.

--- (1974): Historia de los ferrocarriles españoles (1830-1914). Madrid: Editora Nacional.

--- (1962): “Don Félix Boix y Merino”. Revista de Obras Públicas, diciembre, 858-862

--- (1948): "Nacimiento, desarrollo y constitución de la red española,", en Cien años de ferrocarril en España, prólogo José María F. Ladreda, Vol. II, Madrid: Imprenta Editorial Magisterio Español, 29-192 y 241-258. 
WATTS R.; ZIMMERMAN, JEROLD L. (1986): Empirical tests of accounting choices. Positive accounting Theory. Prentice-Hall International, New Jersey.

--- (1979): "The demand for an supply of accounting theories: The market of excuses". The Accounting Review, n ${ }^{\circ}$ 2, april, 273-305.

WHITE, GERALD I.; SONDHI, ASHWIN PAUL C.; DOV, FRIED (1997): The Analysis and use of financial statements. New York: John Wiley\&Sons.

YANES YANES, P. (2004): Las acciones rescatables en la sociedad cotizada. Cizur Menor (Navarra): Thomson-Aranzadi.

--- (2002): "Notas sobre las alternativas de financiación del reembolso de acciones rescatables". Anales de la Facultad de Derecho de la Universidad de La Laguna, n 19, pp. 287 y ss.

ZAPPA, GINO (1962): L'economia delle aziende de consumo. Milano: Giuffrè.

--- (1927): Tendenze nuove negli studi di ragioneria. Milano: Giuffrè.

ZÖLLNER, W. (1984): Kolner Kommentar zum Aktiengesetz. Einleitungs-Band, Múnchen. 
